



\section{SEPULTURAS ESCAVADAS NA ROCHA DA FACHADA ATLÂNTICA DA PENÍNSULA IBÉRICA ATAS DO CONGRESSO INTERNACIONAL}

COORD.

MÁRIO JORGE BARROCA 
Título: Sepulturas Escavadas na Rocha da Fachada Atlântica da Península Ibérica: Atas do Congresso Internacional

Coordenação: Mário Jorge Barroca

Design gráfico: Helena Lobo Design | www.hldesign.pt

Capa: Sepultura escavada na rocha da necrópole da Igreja de Sendim, Tabuaço. Fotografia de Mário Barroca Edição: CITCEM - Centro de Investigação Transdisciplinar Cultura, Espaço e Memória

Via Panorâmica, s/n | 4150-564 Porto | www.citcem.org | citcem@letras.up.pt

ISBN: 978-989-8970-30-5

DOI: https://doi.org/10.21747/9789898970305/sep

Porto, novembro de 2021

Paginação: Sersilito-Empresa Gráfica, Lda. | www.sersilito.pt

Este trabalho é financiado por Fundos Nacionais através da FCT - Fundação para a Ciência e a Tecnologia, no âmbito do projeto UIDB/04059/2020. 


\title{
SUMÁRIO
}

\author{
APRESENTAÇÃO
}

Mário Jorge Barroca

Las tumbas excavadas en la roca dentro del paisaje: reflexiones a partir de un proyecto de investigación sobre el centro de la Península Ibérica

Iñaki Martín Viso

Os estudos sobre sepulturas escavadas na rocha em Portugal, trinta anos depois

Mário Jorge Barroca

O mundo dos mortos na Quinta de Crestelos: paradigma das sepulturas escavadas na rocha da necrópole Este

Alexandrina Amorim, Ana Roriz, Sérgio Simões Pereira, Zélia Rodrigues

Sepulturas escavadas na rocha no curso inferior da bacia do rio Lima - o concelho de Viana do Castelo em perspetiva

Andreia Arezes

Diferentes modelos de povoamento rural Alto-Medieval do Algarve Ocidental

Luís Miguel Cabrita

Se hace camino al andar. Sepulturas rupestres y poblamiento altomedieval en el Vale de Galegos

(Castelo de Vide, Portugal).

Fabián Cuesta-Gómez, Sara Prata

Sepulturas rupestres na igreja paroquial de Travanca (Santa Maria da Feira)

Carlos Ferreira, Linda Melo, Artur Fontinha

As sepulturas escavadas na rocha entre os rios Távora e Cabrum. Tipologias, implantação e as leituras possíveis do território

César Guedes

Las necrópolis de tumbas excavadas en la roca en Cantabria (España)

Enrique Gutiérrez Cuenca

Sepulturas escavadas na rocha do Médio Tejo: os casos de Tomar e de Ferreira do Zêzere

Sandra Lourenço, Paulo Arsénio

Sepulturas, topónimos e habitats: elementos para a compreensão do povoamento alto-medieval no município de Santa Comba Dão (Viseu)

Pedro Matos, Helena Catarino 
A necrópole rupestre de San Vitor de Barxacova (Parada de Sil, Ourense) - o descubrimento dunha nova realidade arqueolóxica na Ribeira Sacra (Galiza)

Eduardo-Breogán Nieto Muñiz

Sepulturas escavadas na rocha da região de Bragança: contributo para o estudo do povoamento medieval 313 Ana Maria da Costa Oliveira

A necrópole medieval do mosteiro de S. Miguel de Refojos, Cabeceiras de Basto

Francisco M. V. Reimão Queiroga, Cláudia Maria Martinho Lemos

Sepulturas escavadas na rocha e repovoamento medieval. O caso do concelho de Montalegre

Manuel Ramos

Do San Cibrao ao San Vítor. A necrópole de Barxacova nas fontes orais e escritas

Víctor Rodríguez Muñiz

As sepulturas escavadas na rocha do Castelo de Crestuma (Vila Nova de Gaia, Norte de Portugal):

Contextos e problemática

António Manuel S. P. Silva, Laura C. P. Sousa, Paulo A. P. Lemos, Filipe M. S. Pinto

Tumbas en piedra, tumbas de piedra. Santiago de Compostela y los rituales funerarios en la Alta Edad Media

José Suárez Otero

Sepulturas escavadas na rocha na Beira Interior durante a Alta Idade Média. Sociedades e paisagens rurais

Catarina Tente, Tomas Cordero Ruiz, João Luís Veloso

O Grupo de Sepulturas Escavadas na Rocha de Montedouro (Perafita, Matosinhos)

José Manuel Varela, Conceição Pires 


\section{APRESENTAÇÃO}

O volume que o Leitor tem entre mãos resulta, em parte, do Congresso Internacional Sepulturas Escavadas na Rocha da Fachada Atlântica da Península Ibérica, que reuniu, nos dias 19 e 20 de outubro de 2017, nas instalações da Faculdade de Letras da Universidade do Porto. A sua organização resultou de uma colaboração entre o CITCEM - Centro de Investigação Transdisciplinar Cultura, Espaço e Memória (unidade de I\&D 4059 da FCT) e o DCTP - Departamento de Ciências e Técnicas do Património da Faculdade de Letras da Universidade do Porto.

No texto de apresentação que acompanhou a convocatória do Congresso sugeriram-se algumas linhas de força para serem abordadas nos dois dias de trabalho. Recordamos, aqui, esse breve texto, que ajuda a compreender o perfil que se pretendeu imprimir a esta reunião:

As sepulturas escavadas na rocha foram uma manifestação sepulcral típica da Península Ibérica. Com efeito, apesar de se conhecerem alguns exemplos fora do espaço ibérico, é neste que se concentra a esmagadora maioria dos casos conhecidos. Durante décadas, a classificação cronológica destes sepulcros foi objeto de acesa polémica entre os arqueólogos e, embora a sua medievalidade seja hoje um dado adquirido, continuamos a lutar com dificuldades para definir os momentos de aparecimento e de extinção desta moda sepulcral. As sepulturas escavadas na rocha são, ainda, um precioso veículo para o estudo de questões que se prendem com o modelo de povoamento, com a organização eclesiástica, com a difusão da rede paroquial, com aspetos socioeconómicos e das mentalidades, etc. O Congresso de 2017 pretende ser um fórum de reflexão sobre estes e outros aspetos no que respeita às sepulturas escavadas na rocha da fachada atlântica da Península, definida aqui de uma forma ampla, abarcando o País Basco, a Cantábria, as Astúrias, a Galiza e Portugal.

Sugerem-se alguns tópicos de abordagem:

1. Sepulturas escavadas na rocha: cronologias e tipologias. Dos exemplos mais antigos, na origem de uma moda sepulcral, aos exemplos mais tardios. Diversidade tipológica e repartição espacial.

2. Sepulturas escavadas na rocha e povoamento: os cemitérios rupestres na abordagem da matriz de povoamento medieval. 
3. Sepulturas escavadas na rocha e a organização religiosa do espaço: sepulturas isoladas, agrupadas e cemitérios; a organização espacial dos cemitérios; a difusão da rede paroquial.

4. Sepulturas escavadas na rocha e outras formas de enterramento contemporâneas.

5. Sepulturas escavadas na rocha: levantamentos regionais e mapeamento de novos sítios.

A organização do congresso funcionou segundo o modelo de double blind review: todas as propostas de trabalhos, que foram submetidas na plataforma em versão anónima, foram sujeitas a um duplo referee, tendo sido atribuída uma classificação que resultou da média aritmética das classificações dadas por cada avaliador. Em função dos resultados foram admitidos ao congresso 23 comunicações e 12 posters. A estes contributos acrescente-se que, a abrir cada dia de trabalho, foi apresentada uma conferência que resultou de convite da organização: no dia 19 por nós próprios; no dia 20 por Iñaki Martín Viso. Entre conferências, comunicações e posters, participaram mais de meia centena de investigadores, de Espanha e de Portugal, que apresentaram os resultados das suas pesquisas em dois dias de estimulante debate e partilha de dados. A eles se juntaram várias dezenas de assistentes.

O processo de edição arrancou em inícios de 2019. Pensávamos que seria relativamente célere, mas a realidade esteve longe de corresponder às expetativas. Volvidos quase três anos sobre a data da reunião do Congresso, eis que, finalmente, estamos em condições de publicar as respetivas atas. Deste atraso assumimos a nossa cota-parte de responsabilidade. Em nosso abono poderíamos invocar que não foi fácil reunir textos de proveniências tão variadas, cuja redação final esteve dependente dos calendários pessoais de cada investigador, e que tiveram, depois, de ser normalizados e submetidos a novo procedimento de avaliação científica, para a respetiva edição. Mas não podemos deixar de expressar o nosso pedido de desculpas aos que responderam, de forma pronta, ao pedido de envio dos respetivos textos e que tiveram de aguardar demasiado tempo pela sua saída dos prelos. Em todo o caso, completados três anos sobre a reunião do Congresso e quase dois sobre o início do processo editorial, eis que finalmente se disponibilizam as atas desta reunião científica.

O volume que o Leitor tem nas mãos não inclui, no entanto, todas as comunicações e todos os posters que foram apresentados durante o Congresso. Lamentamos registar a impossibilidade de incluir aqui as comunicações de: 
LOBÃO, João Carlos; FERREIRA, Maria do Céu - Em torno dos espaços funerários medievais do concelho de Trancoso;

LOBÃO, João Carlos; MARQUES, António Carlos - Sepulturas escavadas na rocha do concelho de Celorico da Beira: principais conclusões dos trabalhos de inventariação e registo;

MARQUES, Jorge Adolfo Meneses - Sepulturas escavadas na rocha na região de Viseu; RUBIO DÍEZ, Rubén; CENTENO CEA, Inés Maria - Caseríos, tumbas, pastizales y huertos: la organización territorial altomedieval en el Arroyo del Mazo (Salamanca, España);

SANTOS, Maria José Ferreira dos - Sepulturas Rupestres do Concelho de Penafiel;

VALDEZ-TULLETT, Joana; NISA, João - Análise espacial das sepulturas escavadas na rocha do concelho de Nisa: Hipóteses de Interpretação;

VIEIRA, Marina - Paisagem alto medieval em contexto rural: uma perspetiva a partir dos vestígios funerários entre a Nave e rio Vouga (Viseu, Beira Alta).

De igual modo, não se incluem neste volume os posters apresentados por:

BLANCO-TORREJÓN, Laura - Las necrópolis tardoantiguas y altomedievales de Galicia (s. IV-X). Primeros resultados;

BRITO, João Cid - Sepulturas Escavadas na Rocha no Concelho de Oliveira do Hospital; LEÃO, Afonso; ESMERALDO, Ana - As sepulturas rupestres da região da Idanha; MAGUSTO, João - Sepulturas escavadas na rocha no território de Castelo de Vide: metodologias de documentação gráfica;

VALLE ABAD, Patricia; RODRIGUEZ NÓVOA, Alba Antía; DIAZ RODRIGUEZ, Mikel; FERNANDEZ FERNANDEZ, Adolfo - Contextos funerarios rupestres en el valle medio del Arnoia;

VELOSO, João Luís; CRUZ, Rosa - Sepulturas escavadas na rocha da região central da Beira Interior.

O resultado final são os 20 textos que o Leitor tem, a partir de agora, à sua disposição: 2 que resultam das conferências de abertura dos dois dias de trabalhos, 18 que espelham comunicações ou posters apresentados (e que são, aqui, alinhados por ordem alfabética do apelido do Autor ou do primeiro Autor). A qualidade dos textos reunidos neste volume deixa transparecer o sucesso de que se revestiu a organização deste Congresso que, estamos certos, será marcante para o estudo das sepulturas escavadas na rocha, uma temática que tem suscitado cada vez mais interesse junto dos Arqueólogos peninsulares que se dedicam ao estudo da Idade Média e, sobretudo, do período que se desenrolou entre a Antiguidade Tardia e a Baixa Idade Média. 
Na qualidade de Coordenador ou General Editor deste congresso não podemos deixar de expressar o nosso reconhecimento pessoal a todos os que contribuíram para a sua realização.

Uma primeira palavra de profundo reconhecimento para o CITCEM, na pessoa da sua Coordenadora Científica, Professora Doutora Amélia Polónia, que foi a entidade que permitiu que, afinal, tudo acontecesse - desde a convocatória do congresso, com a criação do seu site, passando pela realização do Congresso e culminando, agora, com a edição deste $e$-book.

Uma palavra especial de reconhecimento e gratidão para a extraordinária equipa do Secretariado do CITCEM, que na altura do Congresso era integrada pela Dr. ${ }^{a}$ Marlene Cruz, pela Dr. ${ }^{a}$ Vanessa Sousa e pelo Dr. Vasco Sistelo, contando ainda com os contributos da Dr. a Patrícia Costa e do Dr. César Guedes, que foram inexcedíveis no apoio em todas as fases da organização deste evento. Sem o seu suporte nada disto teria sido possível. Devemos, ainda, uma palavra de agradecimento à Dra. Milene dos Anjos Fernandes, pelo seu contributo na fase de revisão, paginação e edição deste e-book.

Uma palavra de reconhecimento, também, para a Reitoria da Universidade do Porto, na pessoa do Senhor Vice-Reitor Professor Doutor António Cardoso, pelo apoio financeiro concedido para a realização desta reunião científica.

O nosso reconhecimento, igualmente, ao Porto Canal, que foi Media Partner do Congresso, nomeadamente na pessoa do Dr. Joel Cleto, pela ajuda na promoção e divulgação deste encontro.

E, por fim, uma palavra de reconhecimento, enquanto General Editor deste Congresso, para os meus Colegas e Amigos que aceitaram o convite para integrar a Comissão Científica do Congresso: Andreia Arezes (FLUP/CITCEM), Helena Catarino (FLUC), José Avelino Gutiérrez González (Universidad de Oviedo), Iñaki Martín Viso (Universidad de Salamanca), Juan António Quirós Castillo (Universidad del País Vasco/Euskal Herriko Unibertsitatea), Catarina Tente (FCSH; UNL; IEM) e Teresa Soeiro (FLUP/CITCEM).

Mário Jorge Barroca

(General Editor do Congresso) 


\title{
LAS TUMBAS EXCAVADAS EN LA ROCA DENTRO DEL PAISAJE: REFLEXIONES A PARTIR DE UN PROYECTO DE INVESTIGACIÓN SOBRE EL CENTRO DE LA PENÍNSULA IBÉRICA
}

\author{
IÑAKI MARTÍN VISO*
}

\begin{abstract}
Resumen: Este trabajo es un resumen de las aportaciones realizadas sobre el análisis de los sitios con tumbas excavadas en la roca en el centro peninsular en el marco de un proyecto de investigación. A partir de una lectura crítica de los estudios previos, se efectuó una tipología de sitios, atendiendo al número y organización de las sepulturas. Estos lugares se analizaron para comprender su vinculación con los espacios domésticos y los asentamientos, así como para entender su emplazamiento en el paisaje. Como resultado de ello, se establecieron una serie de patrones, forzosamente locales, que integraron a las tumbas en la construcción de identidades locales a lo largo de la Alta Edad Media. Finalmente, la implantación del sistema parroquial supuso la desaparición de estos modelos, basados en la gestión de familias y comunidades.
\end{abstract}

Palabras clave: Tumbas excavadas en la roca; Península Ibérica; Paisaje; Comunidades; Alta Edad Media.

Abstract: This paper is a summary of the results of the analysis about rock-cut graves in Central lberia in the frame of a research project. Since a critical reading of prior studies, the first step was the creation of a typology of sites, according the number and organization of graves. Those sites were analyzed in order to understand their links to households and settlements, as well as to know better their place as part of a social landscape. As consequence, some different and local patterns were individualized, and all of them were inserted in the construction of local identities during Early Middle Ages. Finally, the formation of the parish system involved the breakdown of those patterns, which were based on familiar and communitarian management.

Keywords: Rock-cut graves; Iberian Peninsula; Landscape; Communities; Early Middle Ages.

\section{ENANOS SUBIDOS A LOMOS DE GIGANTES: UNA MIRADA SOBRE LA INVESTIGACIÓN DE LAS TUMBAS EXCAVADAS EN LA ROCA}

Las tumbas excavadas en la roca constituyen uno de los pocos elementos del paisaje rural altomedieval reconocible en el paisaje rural contemporáneo de amplias regiones de la Península Ibérica. Sin embargo, su integración en los análisis de los arqueólogos e historiadores interesados en la Alta Edad Media ha sido escasa, debido a las dificul-

\footnotetext{
* Universidad de Salamanca. Email: viso@usal.es.
} 
tades inherentes a su estudio. Es bien conocido como la mayoría de estas sepulturas aparecen prácticamente descontextualizadas con respecto a otras evidencias materiales: situadas en mitad del campo y en zonas que no se han visto afectadas por trabajos arqueológicos, resulta compleja su comprensión. Por otro lado, en amplios sectores ibéricos, estas inhumaciones no proporcionan restos de ningún tipo, bien por su reutilización en tiempos posteriores con funciones muy distintas, bien por la elección de suelos muy ácidos, en especial rocas graníticas, para la elaboración de estas sepulturas.

Más allá de estas dificultades propias de la evidencia que manejamos, subsisten otras de carácter interpretativo. Estas derivan del estudio de las tumbas desde una perspectiva exclusivamente funeraria, es decir mirando a la tumba, como ya han señalado otros investigadores ${ }^{1}$. Dado que esta se encuentra vacía, el resultado es igualmente la ausencia de toda información de calidad. Las interpretaciones dominantes hasta hace poco tiempo quedaban lastradas por esa situación, pero también por la influencia de corrientes historiográficas hoy en día ya superadas. La más completa de esas interpretaciones se la debemos a Alberto del Castillo, que en los años 60 del siglo pasado, aventuró una cronología de estas tumbas. Basándose en la presencia de un tremís de Egica (687-698) en una tumba de bañera procedente de Sant Viçenc d'Obiols y en la presencia de tumbas antropomórficas en Olérdola (Fig. 1), que corresponderían a su repoblación en el siglo X por mozárabes, planteó una evolución basada en la tipología formal de las tumbas. Las no-antropomórficas se situarían

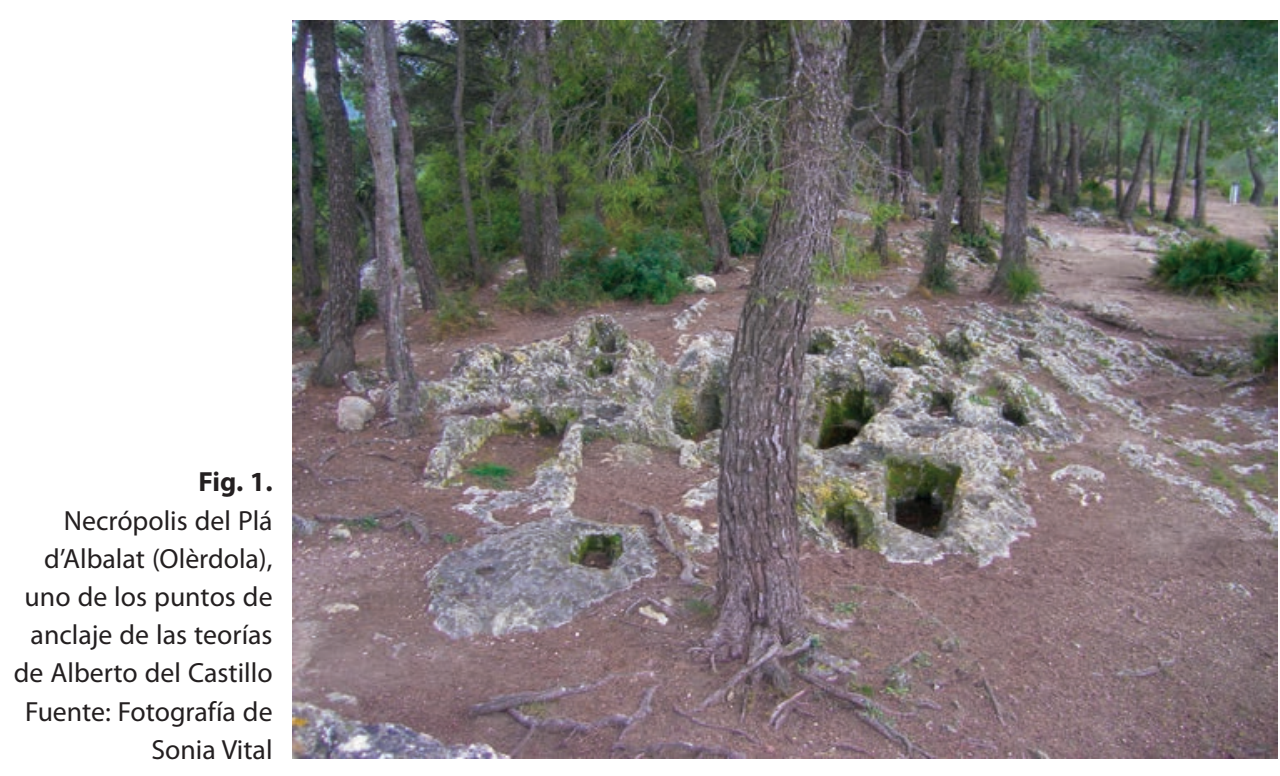

${ }^{1}$ PADILLA LAPUENTE, ÁLVARO RUEDA, 2010: 264. 
en torno a los siglos VIII-IX y las antropomorfas serían la marca de una población repobladora del siglo X. En todos los casos, se trataría de inhumaciones relacionadas con edificios eclesiásticos ${ }^{2}$. Esta explicación se hacía eco de lo que en aquel entonces era el paradigma dominante en la historiografía española, que defendía el modelo de despoblación y repoblación, incluyendo también las áreas catalanas.

Los discípulos de Alberto del Castillo continuaron su senda; en realidad, su aportación fue menor a la del maestro, ya que se limitaron a corregir aspectos muy específicos de sus teorías y a añadir algunos casos nuevos ${ }^{3}$. El problema estribaba en que ya en los años 70 las bases historiográficas sobre las que se asentaba la interpretación de Alberto del Castillo - que implicaban además una situación ancilar de la arqueología con respecto a las fuentes escritas - se deterioraron rápidamente hasta perder cualquier vigencia ${ }^{4}$. Como consecuencia, las tumbas excavadas en la roca, que solo se habían tomado en consideración para ilustrar la repoblación de espacios vacíos, no ofrecían ninguna información útil para los investigadores. Es cierto que a partir de los años ' 80 ha habido algunas aportaciones al tema en el ámbito español. Así, las reflexiones de algunos investigadores planteaban dudas acerca de la cronotipología y de la relación de estas tumbas con espacios eclesiásticos - ya que reconocían la presencia masiva de tumbas aisladas - , pero no profundizaron en esas líneas de trabajo ${ }^{5}$. El predominio investigador estuvo siempre en manos de los herederos de Alberto del Castillo. Sin duda la aportación más sobresaliente proviene de los trabajos que desde los años '90 emprendieron Jorge López Quiroga y Mónica Rodríguez Lovelle en el ámbito gallego ${ }^{6}$. Además de ofrecer una cronología más dilatada, que incluía cronologías desde el siglo VI, proponían una reinterpretación de esas evidencias en la zona entre el Miño y el Duero: serían la evidencia de una población autóctona que desde el siglo VII se habría desplazado hacia zonas marginales con respecto a los centros políticos y económicos tardorromanos - de ahí su presencia masiva en áreas de montaña - configurando comunidades unidas por lo religioso, una suerte de comunidades pseudo-fructuosianas. Estos lugares se habrían abandonado a partir de la reordenación del poblamiento en los siglos IX-X, aunque en algunos casos habrían podido perdurar gracias a su vinculación con centros de culto. Esta interpretación era crítica con el modelo despoblacionista, aunque a través de unos parámetros difíciles de comprobar. En cualquier caso, seguía defendiéndose la cronotipología como base para la datación, así como la relación con centros de

\footnotetext{
${ }^{2}$ CASTILLO, 1970, 1972.

${ }^{3}$ BIELSA, 1977; LOYOLA PEREA, 1977; ANDRIO GONZALO, 1987; LOYOLA PEREA et al., 1990; ANDRIO GONZALO et al., 1992; PADILLA LAPUENTE, 2003.

${ }^{4}$ PADILLA LAPUENTE, ÁLVARO RUEDA, 2010: 263.

${ }^{5}$ RIU, 1982; BOLÒS I MASCLANS, PAGÈS I PARETAS, 1982.

${ }^{6}$ LÓPEZ QUIROGA, RODRÍGUEZ LOVELLE, 1991, 1992, 1997; LÓPEZ QUIROGA, 2004.
} 
culto como el único elemento que permitía comprender a las tumbas en el paisaje, una relación que se ha mantenido hasta la fecha ${ }^{7}$.

La investigación portuguesa, en cambio, se dirigió por otros caminos. La débil influencia de las teorías despoblacionistas ha conllevado que las interpretaciones no hayan tomado en consideración esa variable. El estudio de Mário Barroca en los años '80 suponía una lectura muy distinta a la que se hacía en España en esos mismos momentos. En él, entre otros muchos aspectos parciales de gran interés, prestaba atención a la presencia masiva de tumbas aisladas y a su posible relación con el poblamiento rural altomedieval ${ }^{8}$. Estas líneas de trabajo son, en mi opinión, muy acertadas y he de confesar que su estudio - cuando lo leí durante mi estancia como becario posdoctoral en la Universidad de Coimbra gracias a la generosidad de la profesora Helena Catarino - me produjo un fuerte impacto. Se trataba de ideas que, de una forma u otra, yo había planteado para el caso de los espacios serranos madrileños, defendiendo igualmente el carácter disperso de los asentamientos rurales altomedievales $^{9}$. Otros trabajos sobre la zona interior de Portugal, como los elaborados por Marina Vieira ${ }^{10}$, Sandra Lourenço ${ }^{11}$ o Catarina Tente ${ }^{12}$ se encaminaban en esa misma dirección. En tales estudios, el análisis de las sepulturas se desligaba del papel de los centros eclesiásticos - pues en la mayoría de las ocasiones no había evidencias de esa relación - y de unas teorías sobre la despoblación y la repoblación que no eran operativas en el ambiente académico portugués.

Sin embargo, los trabajos sobre los asentamientos rurales en la región de Madrid y en el País Vasco pusieron de relieve desde mediados del primer decenio de este siglo el carácter concentrado de muchos asentamientos ${ }^{13}$. Por tanto, la dispersión del poblamiento rural altomedieval no debía darse como un dato sino que había de comprobarse, una situación que comprometía la ecuación entre tumbas aisladas y asentamientos dispersos, sobre todo cuando estamos hablando de un número muy bajo de inhumaciones. La publicación del trabajo de Carlos Laliena y Julián Ortega ${ }^{14}$ sobre el valle del río Martín en Aragón abrió nuevas perspectivas. Aquel estudio, basado en un sólido trabajo de prospección, relacionaba una serie de asentamientos altomedievales con las tumbas excavadas en la roca, proporcionando además dataciones que situaba a las tumbas antropomórficas en los siglos VI-VII. Estas se hallaban sobre las terrazas aluviales, con las que estaban conectadas visualmente. La interpretación de ambos investigadores

\footnotetext{
${ }^{7}$ LÓPEZ QUIROGA, GARCÍA PÉREZ, 2014.

${ }^{8}$ BARROCA, 1987, 2010-2011.

${ }^{9}$ MARTÍN VISO, 2002.

10 VIEIRA, 2004.

${ }^{11}$ LOURENÇO, 2007.

12 TENTE, 2007.

${ }^{13}$ QUIRÓS CASTILLO, 2011.

${ }^{14}$ LALIENA COBRERA, ORTEGA ORTEGA, 2005.
} 
subrayaba el uso del prestigio de los ancestros allí enterrados para la reclamación de derechos sobre el territorio. Esta interpretación rompía con los moldes explicativos hasta entonces predominantes: las tumbas se integraban en la construcción social de un paisaje complejo. La lectura de ese libro me abrió nuevos horizontes interpretativos, con los cuales pude abordar el caso de las tumbas excavadas en roca en Riba Côa ${ }^{15}$. Allí se apuntaba una nueva forma de acercarse a estas evidencias funerarias que podía ofrecer una información relevante para la comprensión de las sociedades altomedievales. Este nuevo panorama impide volver sobre la cronotipología de las sepulturas o sobre la relación con repobladores asociados a fundaciones eclesiásticas si pretendemos realizar un estudio sobre las tumbas excavadas en la roca efectivamente relevante.

Desde estos parámetros, se implementó un proyecto de investigación específico sobre el centro de la Península Ibérica, que abarcó los territorios de las provincias españolas de Ávila y Salamanca y también la región de la Beira Alta portuguesa y que se desarrolló entre los años 2011 a 2014 (Fig. 2). Los resultados de ese proyecto se han plasmado en varias publicaciones ${ }^{16}$. Aquí resumiré las propuestas que hemos

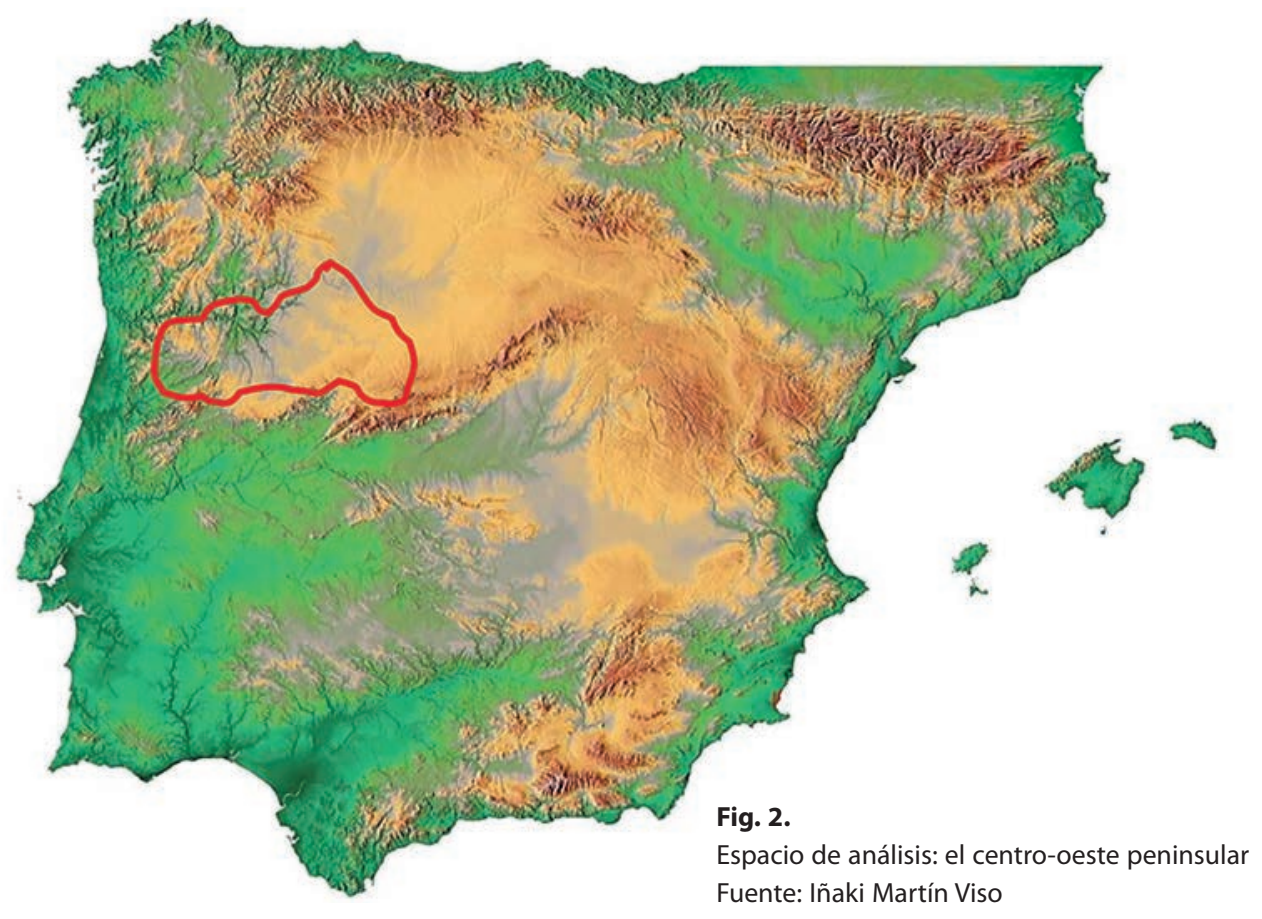

\footnotetext{
${ }^{15}$ MARTÍN VISO, 2007.

${ }^{16}$ MARTÍN VISO, 2012a, 2012b, 2014a, 2014b, 2019; BLANCO GONZALEZ, MARTÍN VISO, 2016; TENTE, 2015.
} 
realizado. Pero no se trata de ofrecer un modelo que sea aplicable a todos los casos, sino más bien de exponer una nueva forma de acercarnos a los problemas que se plantean, un cuestionario que posibilite vías sobre las que producir un conocimiento. Lo haré a través de una serie de planteamientos, que intentaré sintetizar.

\section{¿QUÉ SON LAS TUMBAS EXCAVADAS EN ROCA?}

Un primer aspecto que debe abordarse es la definición del fenómeno que estamos estudiando. El proyecto de investigación tuvo como punto de partida el reconocimiento de la extrema variabilidad de los yacimientos con tumbas excavadas en la roca. Era necesaria una tipología que sirviera como herramienta para comprender esa diversidad. A partir de la evidencia existente, se planteó una triple tipología que se basa en la articulación del espacio funerario y su relación con el paisaje ${ }^{17}$. El primer grupo, y el más frecuente, es el compuesto por tumbas aisladas o formando pequeños grupos, inferiores a 10 tumbas. El porcentaje se sitúa en un $92 \%$ en el centro-oeste peninsular. Ahora bien, este patrón podría subdividirse en dos tipos. Por un lado, aquellos formados por una tumba o por un pequeño núcleo de $2-5$ tumbas como máximo, donde puede hablarse con bastante certeza de la presencia de inhumaciones aisladas y diferenciadas (Fig. 3). En el centro-oeste peninsular este modelo es abrumadoramente mayoritario en todas las comarcas que hemos revisado. Por otro lado, los sitios que disponen de 6 a 10 tumbas suelen incluir varios pequeños núcleos o dispersarse por áreas más extensas que los formados por 1-5 tumbas. Podría tratarse de una situación semejante a la anteriormente enunciada, pero quizá sean el reflejo de áreas de inhumación más extensas. En realidad, podrían ser también el vestigio de la segunda tipología: las necrópolis rurales desordenadas o segmentadas. Se trata de espacios destinados específicamente a la inhumación, con más de 10 enterramientos, distribuidos de manera aparentemente aleatoria en tumbas, aisladas o formando pequeños núcleos. El aparente desorden probablemente provenga del hecho de que la elección concreta de cada lugar de enterramiento se llevase a cabo por las familias o individuos, pero dentro de un ámbito geográfico específico reconocido por un conjunto más amplio; estaríamos ante un modelo caracterizado por la segmentación ${ }^{18}$. El último tipo sería el de las necrópolis de tumbas agrupadas y alineadas. Poniendo de nuevo como límite inferior las 10 tumbas, se trataría de aquellos sitios en los que se detecta una fuerte agrupación de las tumbas, sin que haya núcleos aislados bien definidos. Además las sepulturas se encuentran alineadas, con una clara tendencia hacia la orientación común. Este modelo es con mucho el menos habitual, pero, como veremos, tiene un indudable interés. Estos tres grandes tipos responderían

\footnotetext{
${ }^{17}$ MARTÍN VISO, 2012a; TENTE, 2015.

${ }^{18}$ PARKER PEARSON, 1999: 12.
} 


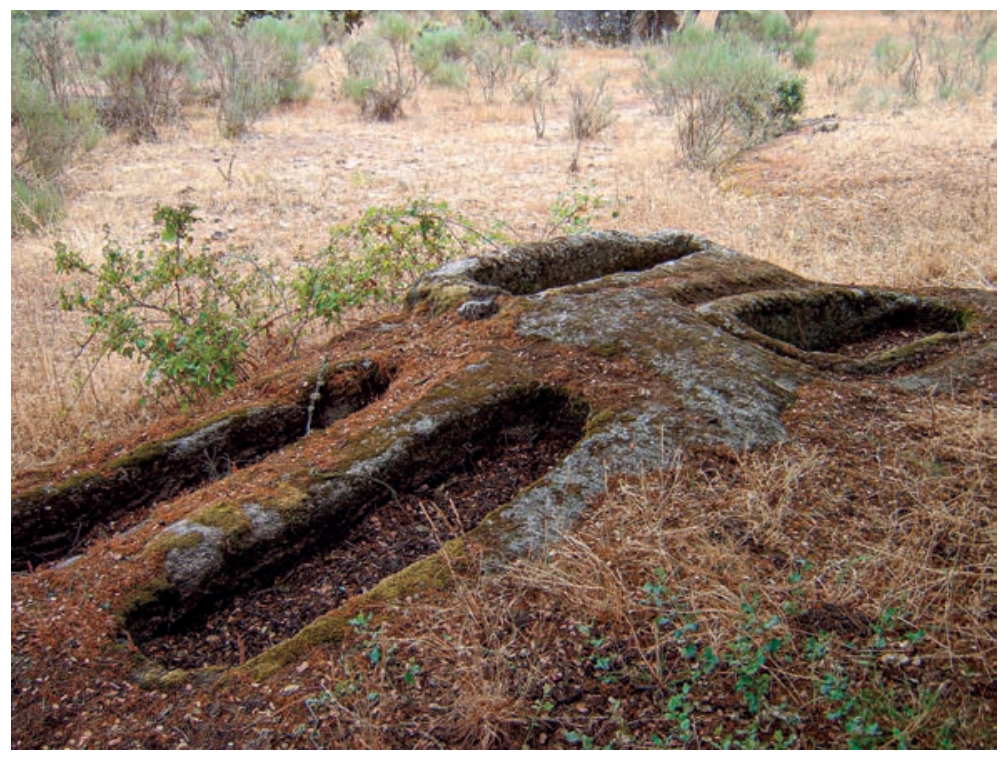

Fig. 3.

Un ejemplo de grupo de tumbas aisladas:

Álamo Blanco (Villar de Ciervo, Salamanca)

Fuente: Fotografía Iñaki Martín Viso

a iniciativas cualitativamente diferentes y darían como resultado unas "geografías funerarias ${ }^{19}$ muy distintas, como veremos más adelante. Cabe resaltar la ausencia de grandes necrópolis que dispongan de un centenar o más de enterramientos, que, en cambio, sí se documentan en otras zonas, como sucede en algunos yacimientos situados en el alto Duero ${ }^{20} \mathrm{o}$ en zonas del alto $\mathrm{Ebro}^{21}$. Se trata de lugares que se han propuesto como modélicos en la interpretación de este fenómeno ${ }^{22}$, cuando responden a una realidad regional que no debe extrapolarse necesariamente a otras áreas.

Por otro lado, este tipo de enterramientos exigía un diseño previo al fallecimiento del individuo que será enterrado. En general tienen una talla cuidadosa e implican un trabajo al menos semi-especializado. No es extraño que además se hayan elegido bolos graníticos destacados sobre el terreno, por lo que en algunos casos pueden asemejarse a una suerte de sarcófagos. Todos estos elementos contrastan con la escasa inversión en la edilicia o la pobreza de los bienes muebles en los asentamientos posromanos/altomedievales. Pueden decirse que las sepulturas, quizá con la salvedad de las necrópolis alineadas, deben comprenderse como auténticos monumentos creados por comunidades campesinas, cuyas diferencias internas se mostraban de manera más locuaz en el registro funerario.

\footnotetext{
${ }^{19}$ WILLIAMS, 2006: 191.

${ }^{20}$ PADILLA LAPUENTE, ÁLAVRO RUEDA, 2010, 2013.

${ }^{21}$ PALOMINO LÁZARO, NEGREDO GARCÍA, 2012.

${ }^{22}$ CASTILLO, 1970.
} 
Otro aspecto relevante es la cronología. Las bases sobre las que se sustentaba la propuesta cronotipológica se han revelado erróneas: el cementerio de Sant Miquel de Olérdola tiene una ocupación que puede situarse a finales del siglo VIII o comienzos del IX y la moneda de Sant Vicenç d'Obiols no puede ofrecernos una datación absoluta, sino una cronología «post quem», a partir del momento de acuñación de la pieza a finales del siglo VII. Debe tenerse en cuenta que esa evidencia debe situarse en su periodo de uso, que es a partir de esa fecha, por lo que no es necesariamente una evidencia del siglo VII, a pesar de lo que sostienen algunas interpretaciones ${ }^{23}$. En realidad, estamos ante un objeto que puede haber disfrutado de un largo tiempo de uso, con modificaciones en su significado, como ya se ha puesto de relieve en otros $\operatorname{casos}^{24}$. En cuanto a la ocupación de Olérdola, los datos actuales demuestran que esas tumbas pueden datarse ya en los siglos VIII y IX ${ }^{25}$. La cronotipología se basa en la, a mi juicio, errónea suposición de que las distintas formas corresponden a secuencias diferentes dentro de una misma línea evolutiva ${ }^{26}$, algo que en absoluto está demostrado. Es necesario establecer las bases para datar a estas tumbas en elementos mucho más sólidos, como las dataciones absolutas y la estratigrafía. Así se ha podido observar un largo lapso temporal de uso de este tipo de sepulturas, entre los siglos VI al XIII, e incluso con casos en el XV, aunque todo parece indicar que es en el periodo altomedieval cuando este tipo de enterramiento fue más utilizado ${ }^{27}$. En cualquier caso, dicha cronología - que se desliga de la diferenciación entre tumbas antropomórficas y no antropomórficas, ya que las primeras aparecen en contextos posromanos, anteriores a los siglos IX y X - está encubriendo fenómenos muy diferentes. La cuestión no es tanto datar las tumbas - siempre tendremos un margen temporal amplio - como identificar y datar aquellos procesos sociales en los que las tumbas se integraron y a los que dotaron de sentido.

En el caso del centro-oeste peninsular, las dataciones son muy escasas y se limitan a la tumba procedente de Alto da Quintinha, con una datación que se mueve entre los siglos IX y $\mathrm{X}^{28}$. Pero otras informaciones proporcionan un acercamiento a la cronología. En el caso de S. Gens, poblado de los siglos IX-X excavado por Catarina Tente, las tumbas parecen ser coetáneas a la ocupación de dicho lugar ${ }^{29}$. En cambio, los trabajos que hemos efectuado en la Dehesa de La Genestosa ${ }^{30}$ revelan un asentamiento de finales del V a mediados del VII, al que se asocia una tumba

\footnotetext{
${ }^{23}$ LÓPEZ QUIROGA, 2010: 310.

${ }^{24}$ DOMÉNECH, GUTIÉRREZ LLORET, 2006.

${ }^{25}$ MOLIST CAPELLA, BOSCH CASADEVALL, 2012.

${ }^{26}$ LÓPEZ QUIROGA, 2013.

${ }^{27}$ MARTÍN VISO, 2014a.

${ }^{28}$ NÓBREGA, NETO, TENTE, 2012.

29 TENTE, 2012; TENTE et al., 2018a.

${ }^{30}$ MARTÍN VISO et al., 2017.
} 
antropomórfica. En cambio, y como tendremos ocasión de observar, las necrópolis alineadas - cuyo contenido social es muy diferente a los casos anteriores- parecen corresponder a un periodo más tardío, posiblemente del siglo X y XI ${ }^{31}$. Y en el caso de Penedo dos Mouros, también trabajado por Catarina Tente, la tumba hallada se emplazó después de la destrucción definitiva del poblado, que debió producirse en el siglo X; aquí parece que hubo una clara intencionalidad por apropiarse de la memoria sobre este lugar ${ }^{32}$. Por consiguiente, el fenómeno de las tumbas excavadas en la roca comenzó ya en momentos muy tempranos (siglo VI), asociado ya a formas antropomórficas, y pudo perdurar al menos hasta los siglos XI y XII, pero con distintos significados. E incluso hay casos posteriores, pero para entonces esas tumbas formaban parte de cementerios parroquiales, es decir de una realidad completamente distinta de la que vemos en los siglos VI o VII.

\section{TUMBAS, ASENTAMIENTOS RURALES Y SOCIEDADES CAMPESINAS}

Un aspecto relevante es la relación de las tumbas con los asentamientos en donde habitaban las familias que enterraban a sus fallecidos en las tumbas excavadas en la roca. Aparentemente los espacios funerarios estarían desconectados de los lugares de residencia, por lo que podrían encontrarse en pleno campo, aunque dentro de un paisaje organizado. Pero puede tratarse del efecto distorsionador de la separación de la investigación sobre los espacios funerarios con respecto a la dedicada a los asentamientos. De hecho, la presencia relativamente frecuente de restos constructivos de época romana, como tégulas, cuyo uso parece dilatarse en el periodo posromano, parece ser un indicio de esa relación, aunque conviene ser cautelosos ya que son materiales descontextualizados y con una larga diacronía ${ }^{33}$.

No obstante, en el centro-oeste peninsular se observan dos ausencias claras. En primer lugar, no se detectan las sepulturas excavadas en la roca en los asentamientos rurales fortificados que surgieron en la región a partir del siglo V. Estos lugares deben relacionarse con la afirmación de poderes que articulaban el control de espacios comarcales y que estaban en manos de elites locales ${ }^{34}$. Los espacios funerarios de estos asentamientos no se conocen detalladamente, pero los datos informan de la presencia de un modelo distinto: tumbas de ejecución sencilla, agrupadas en necrópolis externas a los recintos amurallados y con ajuares en un número minoritario, pero relevante, de dichas sepulturas. Parece que en estos lugares la inversión funeraria se

\footnotetext{
${ }^{31}$ MARTÍN VISO, 2016.

32 TENTE, 2012, 2017: 218; TENTE et al., 2018b.

${ }^{33}$ TENTE, LOURENÇO, 1998.

${ }^{34}$ QUIRÓS CASTILLO, 2013; MARTÍN VISO, 2014c; VIGIL-ESCALERA GUIRADO, 2015: 151-155; TEJERIZO GARCÍA, CANOSA BETÉS, 2018.
} 
centraba en dichos ajuares y no en las propias tumbas. Podría ser la consecuencia de una cronología diferente, ya que algunos investigadores apuntan a que estos asentamientos fortificados pudieron haber sido abandonados en la segunda mitad del siglo $\mathrm{VI}^{35}$. Pero también podría ser la consecuencia de procesos sociopolíticos distintos, es decir que las tumbas excavadas en la roca surgirían en un contexto social diferente. Su existencia se relacionaría sobre todo con grupos campesinos y con las diferencias internas dentro de ellos, funcionando como una «mancha de leopardo» que mostraría la pujanza de las lógicas sociales campesinas ${ }^{36}$. La segunda ausencia es la de centros eclesiásticos asociados. En ese sentido, deben desecharse todos aquellos casos que se basan simplemente en la presencia de un hagiotopónimo, un indicio endeble; hay que tener en consideración los mecanismos de formación de los microtopónimos: la memoria de lugares sagrados pudo haber sido el fundamento para dotar a un lugar de un hagiotopónimo sin necesidad de un centro eclesiástico. Cuando hay una asociación topográfica con una determinada iglesia o ermita, un análisis más detallado pone de relieve que estamos ante fases diferentes: las zanjas de cimentación de las iglesias rompen con las tumbas o estas poseen una orientación diferente al edificio ${ }^{37}$ (Fig. 4). Aunque puede haber casos específicos en los que esta asociación se dé, las tumbas aisladas - que constituyen una apabullante mayoría de la evidencia- nunca se relacionan con esos edificios. En realidad, este patrón de enterramientos aislados y de ausencia de centros eclesiásticos un patrón predominante del periodo altomedieval, anterior a la formación de los cementerios parroquiales, cuando eran las comunidades y las familias quienes poseían el control de la gestión de los espacios funerarios ${ }^{38}$. Es cierto que todos los centros eclesiásticos disponían de áreas funerarias asociadas, pero la mayoría de esas áreas no tenían iglesias, ermitas u otro tipo de edificaciones. En cambio, para otras zonas se ha planteado una estrecha relación entre este tipo de espacios funerarios y la existencia de iglesias en el área del alto Arlanza ${ }^{39}$. Podría ser un ejemplo de una evolución regional diferente a la del centro-oeste peninsular. Sin embargo, contrasta con la evidencia europea que destaca cómo los espacios solo se pivotaron en torno a centros eclesiásticos a partir del siglo X y sobre todo con la eclosión de los cementerios parroquiales ${ }^{40}$. Por otra parte, las evidencias de esas iglesias en el alto Arlanza siguen siendo muy tenues y las cronologías tampoco están afinadas, por lo que no es posible afirmar ni que hubiera un inecclesamento altomedieval ${ }^{41}$, por

\footnotetext{
35 TEJERIZO GARCÍA, VIGIL-ESCALERA GUIRADO, 2017.

${ }^{36}$ RUBIO DÍEZ, PANIAGUA VARA, 2014; MARTÍN VISO, 2019: 135-136.

${ }^{37}$ MARTÍN VISO, 2016: 871-875.

38 ZADORA-RIO, 2003; DEVLIN, 2007; CHERRYSON, BUCKBERRY, 2010; CORLETT, POTTERTON, 2010.

${ }^{39}$ PADILLA LAPUENTE, ÁLAVRO RUEDA, 2010, 2013; LÓPEZ PÉREZ, ÀLVARO RUEDA, TRAVÉ APELLUZ, 2016.

40 ZADORA-RIO, 2003; LAUWERS, 2005; TREFFORT, 2015; THEUWS, 2018.

${ }^{41}$ LÓPEZ PÉREZ, ÁLVARO RUEDA, TRAVÉ APELLUZ, 2016.
} 


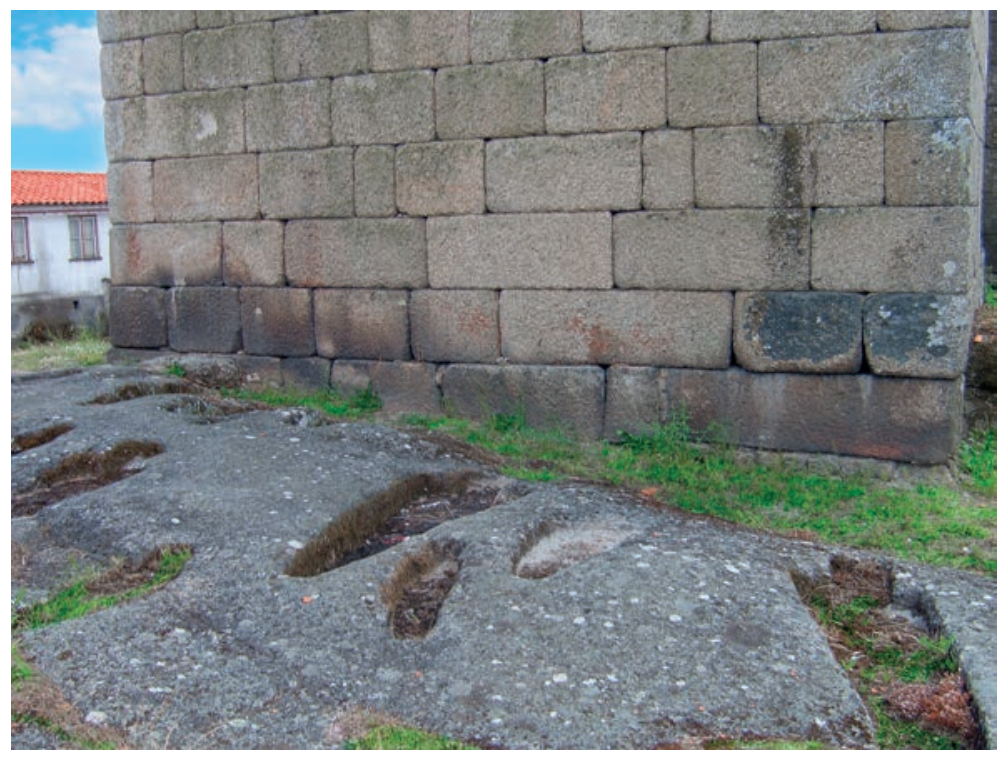

Fig. 4.

Tumbas excavadas en la roca y cimentación de la iglesia plenomedieval en Moreira de Rei

Fuente: Fotografía Iñaki Martín Viso

usar el término acuñado por Michel Lauwers ${ }^{42}$. Nada de ello desmiente la posibilidad de esa hipótesis, pero los datos existentes son poco elocuentes y, a lo sumo, podría hablarse de algún tipo de construcción eclesiástica cuya datación es insegura ${ }^{43}$, y de una relación entre estos espacios funerarios y la presencia de parroquias posteriores.

El proyecto permitió observar la relación entre tumbas y asentamientos rurales. Las intervenciones que, junto con Rubén Rubio, y con la colaboración de Inés Centeno, hemos llevado a cabo en la dehesa de La Genestosa (Casillas de Flores, provincia de Salamanca, España) así lo han corroborado. Este lugar se encuentra en el piedemonte de la Sierra de Gata, dentro de la subcomarca de El Rebollar, un área de suelos predominantemente graníticos. Se trata de un espacio articulado por el arroyo del Mazo del Prado Álvaro, un pequeño cauce fluvial que nace en la frontera con Portugal y que recorre de Oeste a Este unos 5 kilómetros. En torno a dicho arroyo se encuentran las tierras más fértiles, gracias al aporte de agua, sobre todo en los meses de primavera. A lo largo de todo el cauce se observa la presencia de más de una veintena de tumbas excavadas en la roca que se distribuyen en forma de pequeños grupos o sepulturas aisladas, sin que se configuren necrópolis propiamente dichas. Junto a estas tumbas, y a apenas unos pocos metros, situándose en lo alto del pequeño glacis que se alza sobre el arroyo, se documentan algunas edificaciones con zócalos de piedra, granito, que aún hoy son fácilmente visibles. Al menos se han podido identificar 4 núcleos

\footnotetext{
42 LAUWERS, 2005: 273.

${ }^{43}$ PADILLA LAPUENTE, ÁLAVRO RUEDA, 2013.
} 
con una cierta concentración de esas estructuras, aunque hay otras más aisladas, siempre cercanos a la presencia de esas tumbas aisladas ${ }^{44}$.

Uno de ellos es el pago de El Cañaveral, un pequeño poblado compuesto por aproximadamente una docena de edificaciones y emplazado en el glacis que domina el arroyo. Este lugar fue ocupado entre los siglos V-VII, tras una ocupación altoimperial romana previa (siglos I-II AD) y un abandono en el periodo tardorromano ${ }^{45}$. Se trata de un poblado formado por gentes campesinas, aunque hay tenues evidencias de una relación con elites, probablemente externas, como la presencia de fragmentos de pizarras numerales (Fig. 5). A 17 metros de distancia de una de las edificaciones excavadas, se halló una tumba antropomórfica excavada en la roca. Como es frecuente, carecemos de restos que permitan datar el uso de esa sepultura, pero la hipótesis más factible es que corresponda al mismo periodo de ocupación del poblado. Resulta significativa la cercanía de la sepultura a las posibles viviendas, así como el hecho de que únicamente tengamos una tumba, a pesar de documentar una docena de posibles estructuras (Fig. 6). Por otra parte, no hay ninguna evidencia de un centro de culto en el poblado. ¿Cómo es posible explicar la presencia de esta tumba? Debemos partir de un hecho claramente constatado: las tumbas son recipientes de una memoria social que utiliza a los antepasados para crear recuerdos e historias ${ }^{46}$. Por tanto, la tumba podría estar relacionada con la memoria de un antepasado convertido en ancestro, alguien cuyo prestigio se recordaba sin necesidad de una mediación eclesiástica. Situada en las cercanías del poblado, servía como punto de referencia de la comunidad que allí vivía, un marcador territorial que definía el territorio que pertenecía a esa comunidad. En toda esta zona se produjo una intensificación de la ocupación humana, reconocible en la deforestación y en la presencia de hongos coprófilos y en un incremento de las gramíneas asociadas al pasto, tal y como se detecta en los análisis paleopalinológicos ${ }^{47}$. Dada la ausencia de indicios de una presencia elitista en el poblado de El Cañaveral, puede hablarse de una colonización campesina, gracias a la cual eclosionaron nuevos asentamientos y comunidades. Las tumbas de esos ancestros habrían servido como hitos en el paisaje que servirían para reclamar derechos y legitimar el control de espacios agroganaderos en este contexto. Pero además las sepulturas habrían funcionado como un recurso de identidad de las comunidades, que se verían como los descendientes o vinculados a ese ancestro, posiblemente una memoria que fue cambiando con el tiempo. Una situación que tiene paralelos en otros ámbitos europeos, como es el caso de la Frisia altomedieval, donde las sepulturas de los ancestros parecen haber funcionado como

\footnotetext{
${ }^{44}$ MARTÍN VISO, 2019: 126-128.

${ }^{45}$ MARTÍN VISO et al., 2017.

${ }^{46}$ WILLIAMS, 2003; GILCHRIST, 2012: 14.

${ }^{47}$ MARTÍN VISO et al., 2017: 22.
} 

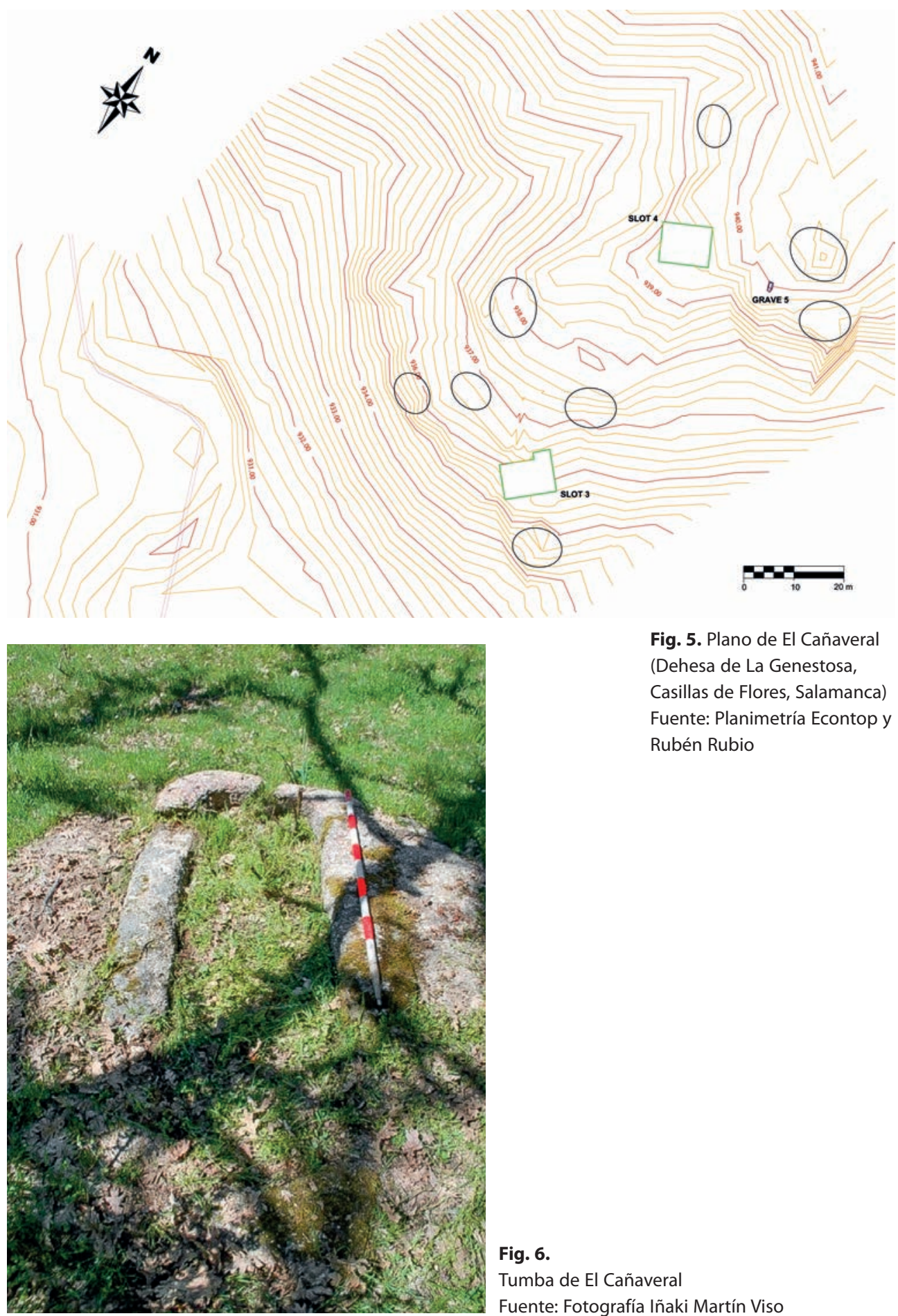

Fig. 5. Plano de El Cañaveral (Dehesa de La Genestosa, Casillas de Flores, Salamanca) Fuente: Planimetría Econtop y Rubén Rubio

Fig. 6.

Tumba de El Cañaveral

Fuente: Fotografía Iñaki Martín Viso 


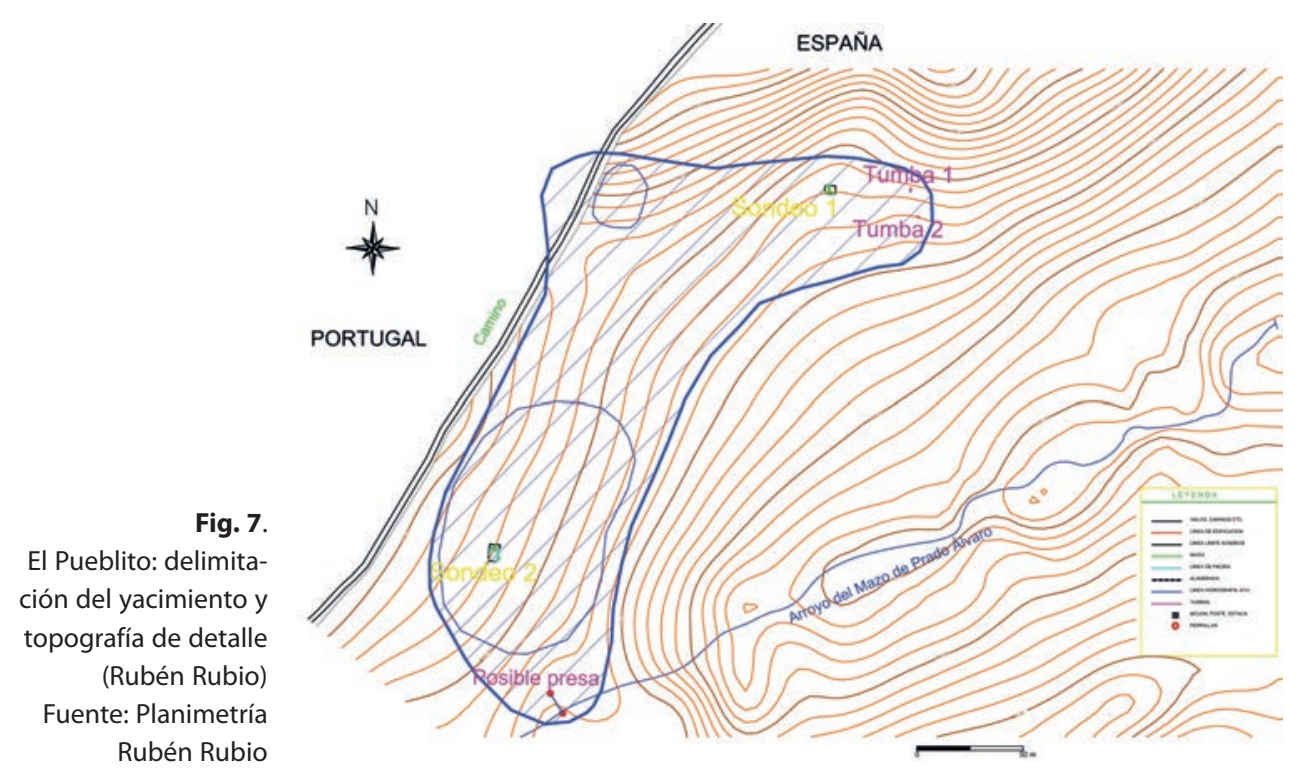

puntos de anclaje de las comunidades en un entorno de nueva ocupación hasta la construcción de iglesias ${ }^{48}$.

Este patrón parece repetirse en otros lugares que hemos identificado en la dehesa de La Genestosa. Así ocurre con El Pueblito (Fig. 7), un asentamiento semejante al de El Cañaveral, aunque las formas constructivas son algo diferentes, mientras que las producciones cerámicas recuperadas indican un abandono de todas las tradiciones productivas romanas. La datación de un hueso calcinado sobre un posible hogar nos ofrece una fecha, calibrada a 2 sigmas, entre $656-727 \mathrm{AD}$ con un $68 \%$ de probabilidad (737-769 con $27,4 \%$ de probabilidad), según análisis realizado por el Laboratorio Beta Analytic, por lo que la ocupación se situaría entre finales del siglo VII y comienzos del siglo VIII. Por tanto, nos encontraríamos con un poblado inmediatamente posterior al de El Cañaveral. A pesar de las diferencias existentes, de nuevo se han localizado un par de tumbas excavadas en la roca, una de ellas emplazada junto a un bolo granítico que puede servir como marcador en el paisaje, a escasos metros de la estructura residencial en la que se exhumó el hueso datado ${ }^{49}$. Parece, por tanto, que el patrón se reitera en la zona e incluso en momentos posteriores.

El ejemplo de La Genestosa nos muestra cómo las tumbas pueden ser un medio para visibilizar unos asentamientos construidos con técnicas sencillas y de difícil reconocimiento. El contraste entre el número de estructuras y la calidad de la edilicia frente a la escasez de tumbas excavadas en roca o el cuidado en la elaboración de las

\footnotetext{
48 THEUWS, 1999.

${ }^{49}$ RUBIO DÍEZ, MARTÍN VISO, CENTENO CEA, en prensa.
} 

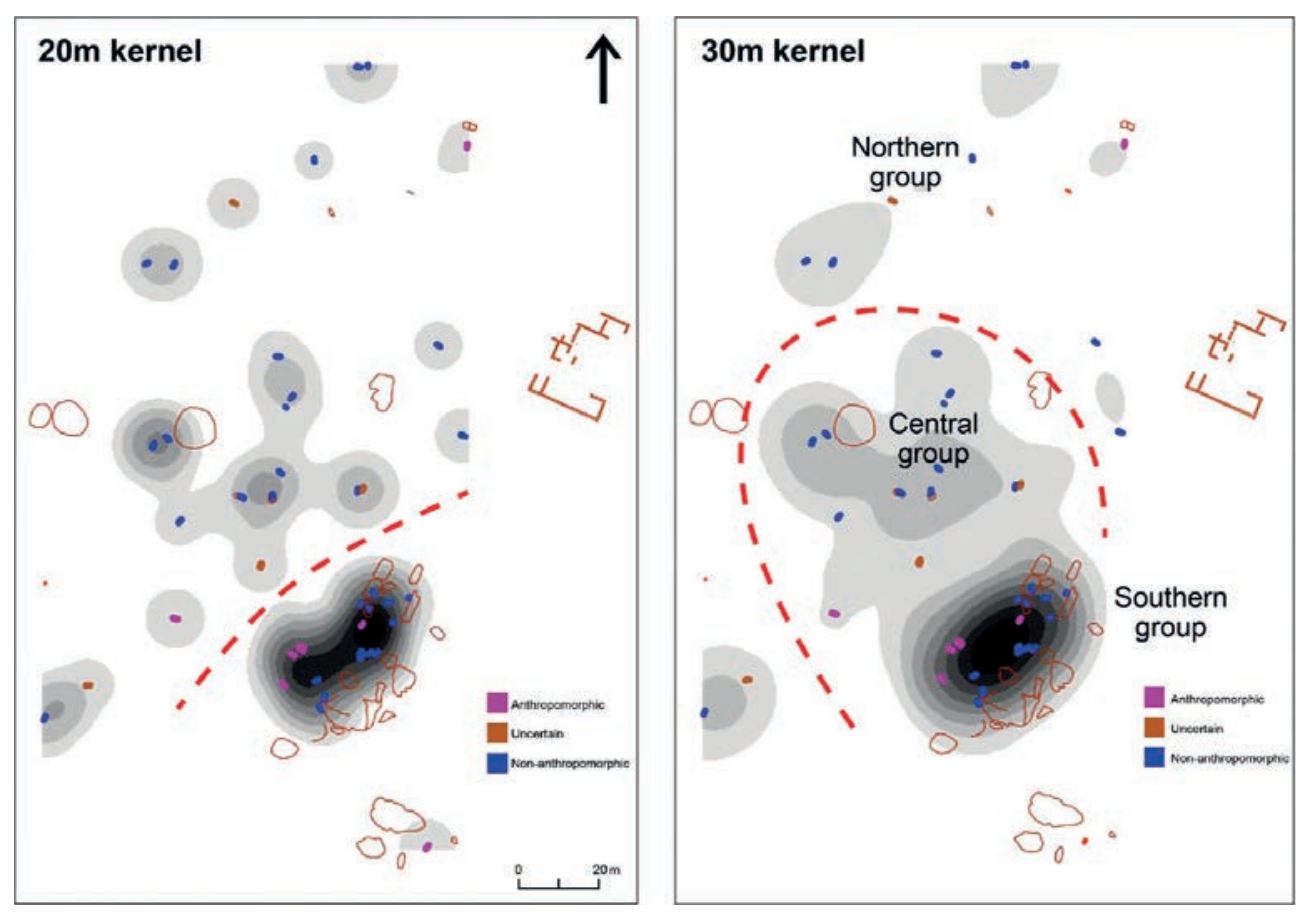

Fig. 8. Análisis de densidad Kernel sobre la necrópolis de $S$. Gens Fuente: BROOKES, TENTE, PRATA, 2017: 229

sepulturas, sería un indicador de que la mayoría de la población no se enterraba en esas sepulturas - posiblemente lo hacían en simples fosas de tierra difíciles de detectar por la acusada acidez de los suelos que habría impedido cualquier conservación $-\mathrm{y}$ que la diferenciación social en el seno de estas comunidades se plasmaba en el ámbito funerario y en la memoria. Pero en otras ocasiones, como ocurre con S. Gens (Fig. 8), el argumento quizá no sea válido, pues disponemos de una necrópolis que puede ajustarse a las dimensiones de la población del asentamiento asociado. Así sucede porque las formas de organización de los espacios funerarios son muy diversas y tiene un carácter fuertemente local. De hecho, el análisis espacial de la necrópolis ha permitido identificar un grupo de tumbas destacado, en torno a un gran bolo granítico, que reflejaría quizás las diferencias internas de la comunidad ${ }^{50}$. Se trata de un tipo de análisis de enorme interés, que abre nuevas vías de trabajo sobre una evidencia tan elusiva como las tumbas excavadas en roca. Pero, en cualquier caso, se relaciona con un asentamiento en el que se revelan aparentemente escasas evidencias de diferenciación social y que se data entre los siglos IX y X, por lo que quizás también corresponda cronológicamente a un momento diferente del que se aprecia en las tumbas del área de La Genestosa.

${ }^{50}$ BROOKES, TENTE, PRATA, 2017. 
La conclusión es que las tumbas han servido como un claro indicio a la búsqueda de los asentamientos rurales. Unos poblados, que lejos de componer un hábitat disperso, señalan la presencia de agrupaciones de unidades doméstica. El hecho de que aparezcan una o dos sepulturas tan solo se debe a que estamos ante monumentos relacionados con algunos de los miembros de esos grupos, mientras que el resto se pudo haber enterrado en fosas simples que, debido a la preponderancia de suelos graníticos, no se han conservado. Las tumbas se hallaban en las cercanías de los poblados, lo que no impide reconocer casos donde esta situación no era así y quizás se localizasen en puntos de especial significado en el paisaje sin necesidad de una inmediatez topográfica. Llama la atención que los datos hallados muestran una conexión con ocupaciones del periodo posromano, aunque este aspecto ya ha sido resaltado por otros investigadores ${ }^{51}$.

Estas experiencias se relacionan con otras que recientemente se han llevado a cabo y que se encaminan en esa misma línea. En La Cárcava de la Peladera (Hontoria, Segovia), se ha podido detectar la existencia de un pequeño espacio funerario de tumbas excavadas en la roca que se vinculaban a un asentamiento rural abierto de este mismo momento ${ }^{52}$. También los recientes trabajos sobre el yacimiento de Revenga (Burgos) parecen revelar que la extensa necrópolis se relacionaba con un asentamiento campesino que tuvo una dilatada ocupación temporal ${ }^{53}$. A pesar de que los datos son todavía algo inciertos, en especial a la hora de plantear cronologías, resultan coherentes con la idea de que las tumbas funcionan como elementos visibilizadores de un elusivo poblamiento rural. Por otro lado, la propuesta de establecer una jerarquía de asentamientos rurales mediante el recurso al número de tumbas existentes $^{54}$ no parece tener un fácil sostén por dos razones. En primer lugar, se da por sentado que todas las tumbas se corresponden a una misma fase, sin tomar en consideración que las distintas geografías funerarias podrían no ser coetáneas. En segundo lugar, estas tumbas reflejan una representación de la comunidad, pero no la comunidad en su conjunto, ya que pudo haber personas que no se inhumasen en esas tumbas, lo que, sumado a la ausencia de restos óseos, dificulta avanzar en esa idea. Además los restos exhumados hasta el momento son muy poco elocuentes y no necesariamente se relacionan con un asentamiento campesino. A pesar de todo ello, resulta aleccionador observar cómo en un caso muy anclado en las perspectivas tradicionales del fenómeno de las tumbas excavadas en la roca se están dando pasos de enorme interés. Otra zona donde se ha podido documentar una conexión entre sepulturas excavadas en la roca y asentamientos posromanos es en el concelho de

\footnotetext{
${ }^{51}$ LÓPEZ QUIROGA, GARCÍA PÉREZ, 2014: 37.

52 STRATO, 2013.

53 ÁLVARO RUEDA, TRAVÉ APELLUZ, LÓPEZ PÉREZ, 2018.

${ }^{54}$ LÓPEZ PÉREZ, ÁLVARO RUEDA, TRAVÉ APELLUZ, 2016: 179-180.
} 
Castelo de Vide (Portugal), gracias a los excelentes trabajos de Sara Prata, que han puesto de relieve la presencia no solo de poblados sino también de una importante actividad oleícola que debe situarse en ese periodo ${ }^{55}$.

En definitiva, las tumbas muestran asentamientos que ya están en funcionamiento desde los momentos posromanos, coincidiendo con el incremento de la agencia social campesina. Posiblemente sean un fenómeno que se perpetúa en el tiempo, aunque los datos sobre los siglos VIII-IX son más escasos: El Pueblito sería, por tanto, un ejemplo. Pero probablemente hay más evidencias que convendría analizar. Ahora bien, esta constatación de un fenómeno asociado a las diferencias dentro de los grupos campesinos, a la formación de nuevas identidades colectivas y a la reclamación de espacios agroganaderos no impidió la existencia de otros significados.

\section{SEPULTURAS Y CONSTRUCCIÓN SOCIAL DE LOS PAISAJES}

Una situación diferente procede de la Sierra de Ávila, un territorio de unos 700 $\mathrm{kms}^{2}$, caracterizado por la presencia de una pequeña cadena montañosa, con alturas que alcanzan los 1600 metros de altitud (aunque en esta zona la plataforma de la meseta se encuentra a 1000 metros de altitud), y que separa la cuenca sedimentaria meseteña y el valle Amblés, donde se halla la ciudad de Ávila ${ }^{56}$. En esta zona, se conocen 24 sitios con tumbas excavadas en la roca, de los cuales 8 (es decir un tercio) pueden identificarse con necrópolis desordenadas o segmentadas. Este alto porcentaje de este tipo de espacios funerarios contrasta con el predominio abrumador de las tumbas aisladas o en pequeños grupos. Se trata, por tanto, de un rasgo local que encubre un patrón diferente al que se pudo plantear en La Genestosa.

El análisis a través del SIG muestra que las zonas con tumbas aisladas y las que poseen necrópolis segmentadas tienden a diferenciarse (Mapa 1). Las primeras aparecen en las zonas del piedemonte septentrional, generalmente cerca de los cursos de agua, mientras que las segundas predominan en la zona más propiamente montañosa así como en las laderas serranas meridionales que se abren hacia el valle Amblés, es decir en áreas especialmente relevantes desde el punto de vista ganadero. Los análisis palinológicos efectuados en el Sistema Central, y en particular en sendas turberas de la Sierra de Ávila, señalan un incremento de la deforestación y de la actividad antrópica relacionada con la ganadería, aunque con una deficiente resolución temporal $^{57}$. Por tanto, parece darse una conexión entre la creación y uso de esos espacios funerarios de media montaña y un incremento de la presión ganadera, buscando

\footnotetext{
${ }^{55}$ PRATA, 2018.

56 BLANCO GONZÁLEZ, MARTÍN VISO, 2016; MARTÍN VISO, BLANCO GONZÁLEZ, 2016; MARTÍN VISO, 2019.

${ }^{57}$ ANDRADE OLALLA, RUIZ ZAPATA, DORADO, 1994: 250-254; HERNÁNDEZ BELOQUI, BURJACHS, IRIARTE CHIPAUSSO, 2013: 351.
} 


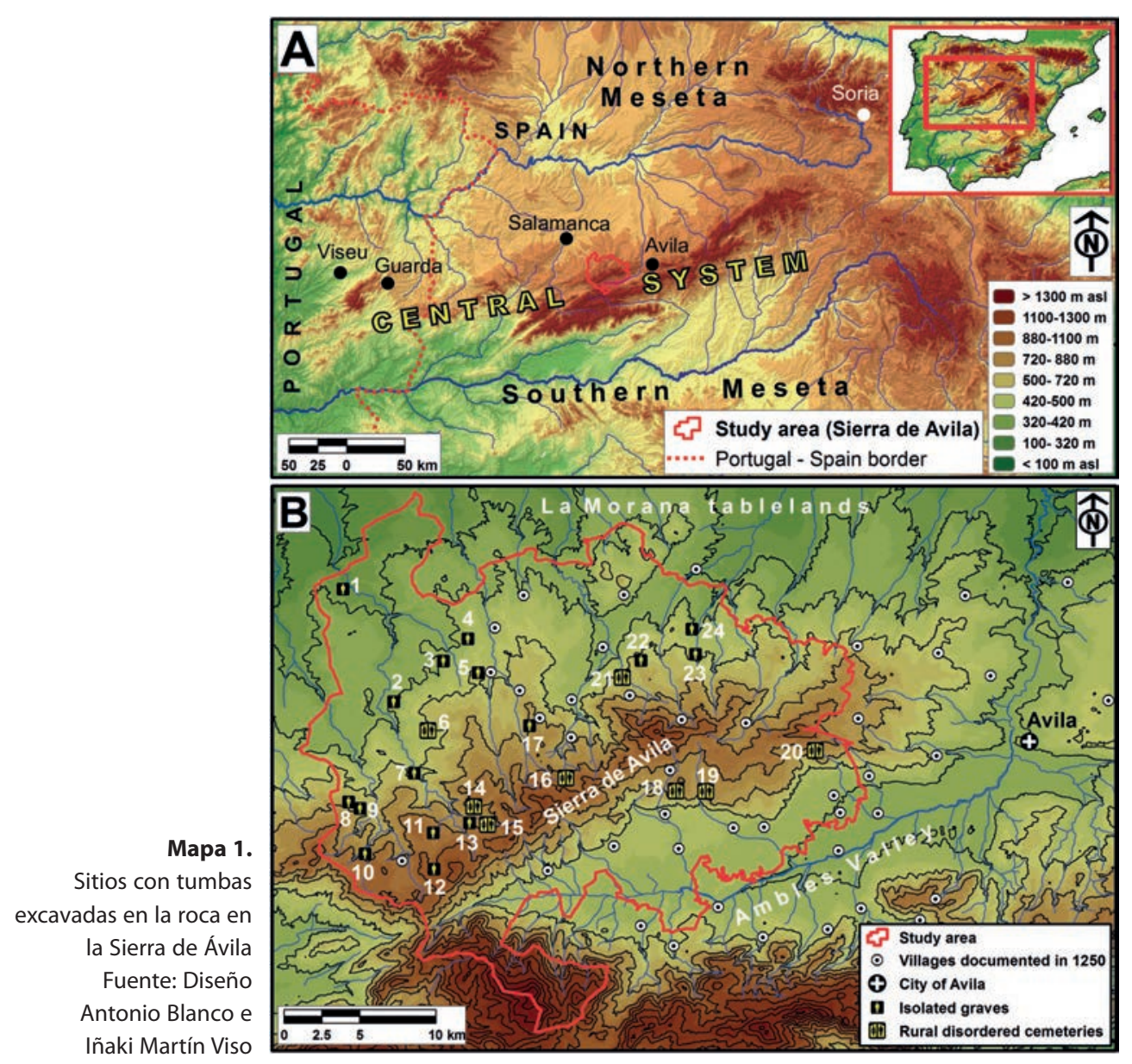

zonas de pasto estival posiblemente con rutas cortas de desplazamiento del ganado (transterminancia). Dada la ausencia de espacios de poder en la Sierra de Ávila, la hipótesis más factible es que estemos ante una iniciativa campesina.

La más interesante de esas necrópolis es La Coba (San Juan del Olmo). Este lugar se encuentra en un punto elevado de la Sierra de Ávila, a unos 1400 metros de altitud, cerca del nacimiento del río Almar, uno de los afluentes del Tormes. Se han podido identificar 81 tumbas distribuidas en cinco focos por un área de cercana a las 20 has, de las cuales nueve son de lajas y el resto excavadas en la roca (Mapa 2). También se han reconocido cinco estructuras cerca de uno de los focos, que podrían ser evidencias de un asentamiento. Hay algunos indicios sobre la datación, pues en una de las sepulturas de lajas - que podrían ser o no coetáneas de las excavadas en roca - se encontró un pequeño ajuar, compuesto por una jarrito-botella, un anillo y una cuenta de collar, que podría datarse en el siglo VII, por paralelos con el cercano 


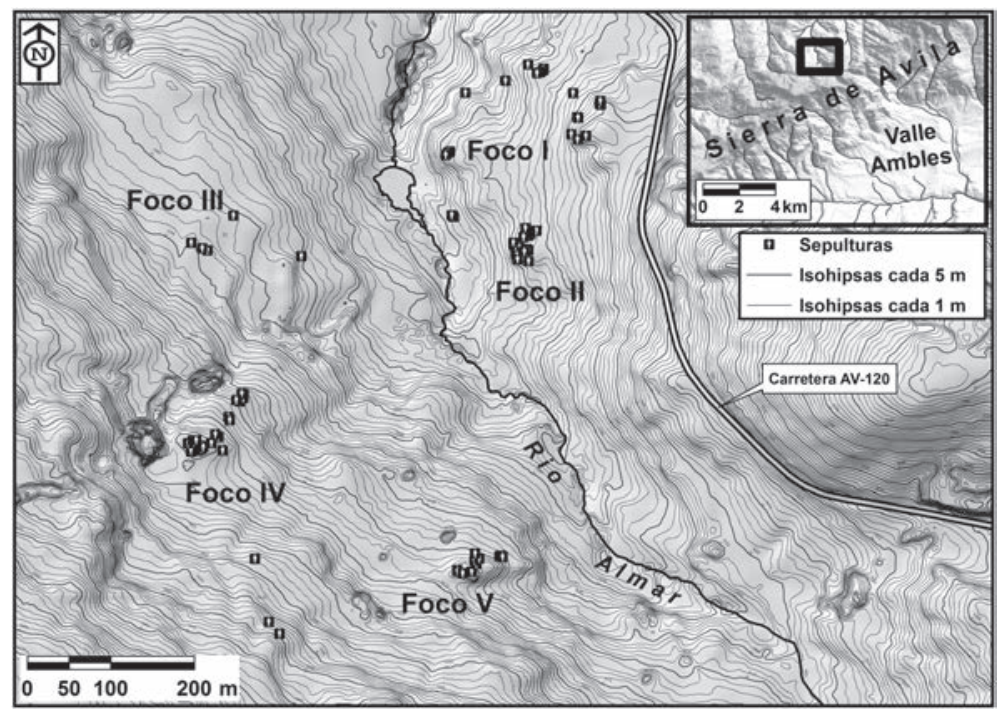

Mapa 2.

Topografía del sitio de La Coba (San Juan del Olmo, Ávila) Fuente: Planimetría María Sánchez y diseño de Antonio Blanco

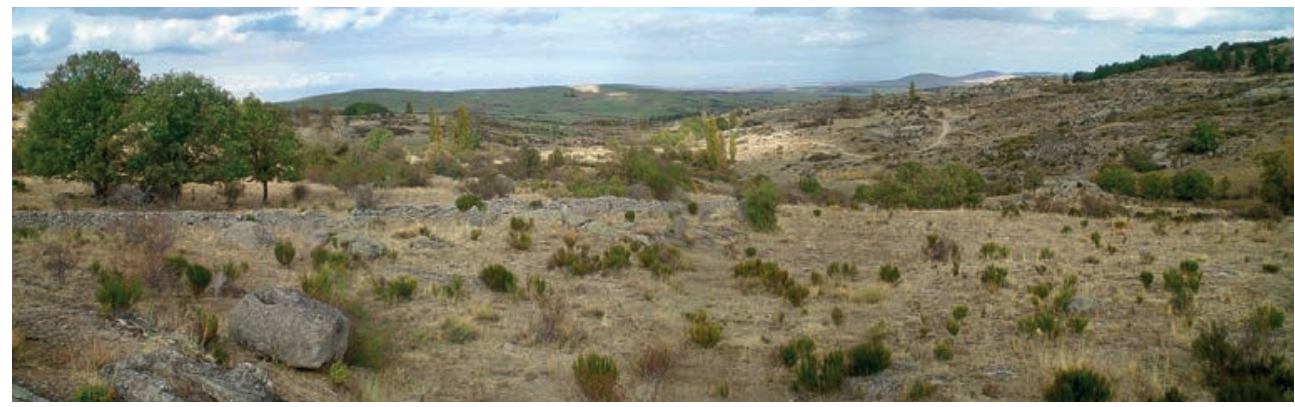

Fig. 9. El paisaje serrano en La Coba. Fuente: Fotografía Reyes Soto García

yacimiento de Cabeza de Navasangil ${ }^{58}$. Esto no significa que todas las tumbas tuvieran que ser coetáneas, pero nos ofrece al menos una aproximación cronológica. Por otro lado, el alto número de tumbas distribuidas por un extenso espacio no se ajusta a las posibles referencias a un pequeño poblado.

Alrededor de La Coba no se documentan sitios con tumbas excavadas en la roca, a pesar de que es una comarca que ha sido prospectada intensamente. Por consiguiente, es muy probable que varias comunidades cercanas concentrasen aquí las inhumaciones, configurando una comunidad de enterramiento. Una razón que explicaría esa elección es que estamos ante un lugar de pastos críticos, en un área elevada, por lo que podría haber sido objeto de rutas transterminantes (Fig. 9). De hecho, se halla junto a uno de los pasos tradicionales de la Sierra de Ávila: el paso de las Fuentes. Por otro lado, esta zona todavía a finales del siglo XV tenía una especial riqueza

${ }^{58}$ LARRÉN IZQUIERDO, 1989; CABALLERO ARRIBAS, PEÑAS PEDRERO, 2012. 
ganadera y se encontraba explotada de forma mancomunada por los habitantes de las aldeas pertenecientes al concejo de Ávila y los propietarios urbanos ${ }^{59}$. Posiblemente se trate de las reminiscencias, muy transformadas, de usos mancomunales de origen altomedieval. Debe añadirse que es el punto donde nace uno de los principales cursos fluviales de esta zona. Por tanto, un lugar de especial interés al que acudirían familias de distintos asentamientos que se enterraban aquí con el objeto de demostrar su pertenencia a una comunidad superior que se arrogaba el control sobre estos terrenos. Funcionaría como un foco de identidad comunitaria supralocal, que se plasmaba en un paisaje funerario compartido y reconocido. De nuevo no todos los miembros de la comunidad se enterrarían en este lugar, pero sí los más prestigiosos, e incluso puede que los distintos focos respondieran a distintas agrupaciones dentro de esa comunidad.

El caso de La Coba podría no ser tan excepcional en el marco local de la Sierra de Ávila. Sus dimensiones posiblemente sean semejantes a la de otros espacios funerarios que conocemos de manera más fragmentaria. Un ejemplo de ello serían los espacios funerarios que rodean a la actual población de Vadillo de la Sierra (a más de $1200 \mathrm{~ms}$ de altura). Los sitios de Carrilejos (cinco tumbas), Lancha del Trigo y La Lancha de la Lana (once enterramientos cada uno), todos ellos en la inmediata proximidad a Vadillo, podrían ser núcleos semejantes a los que se observan en La Coba. La formación de un asentamiento, documentado por primera vez en $1283^{60}$, habría transformado el paisaje, amortizando posibles núcleos funerarios. En cuanto a la localización, otros espacios funerarios repiten el patrón de zonas de altura cercanas a las cumbres y junto a rutas que atraviesan la sierra. Es el caso de Dehesa de Montefrío (Padiernos), San Simones (La Torre), Serranos de Avianos (Cabezas del Villar) y Canto de los Pilones (La Torre) y también del espacio funerario amortizado por la localidad de Vadillo de la Sierra. Por tanto, un paisaje funerario asociado a nuevas estrategias de reclamación de derechos, basadas a su vez en la memoria de los ancestros gestionada por las comunidades.

El ejemplo de la Sierra de Ávila nos abre una ventana hacia el estudio de la territorialidad y los espacios funerarios. En el Norte de Europa, se ha advertido el papel que desempeñaban determinados espacios funerarios, normalmente asociados a inhumaciones de ancestros. Un ejemplo de ello son los enterramientos paganos en Islandia, vinculados a los límites entre las granjas, una tipología que fue posteriormente sustituida por la eclosión de iglesias y capillas ${ }^{61}$. Pero también aparecen en ámbitos cristianizados, como en Escocia ${ }^{62}$ y en Irlanda, donde parecen relacionarse con los pequeños territorios relacionados con los múltiples reinos altomedievales ${ }^{63}$. El papel

\footnotetext{
${ }^{59}$ LUIS LÓPEZ, DEL SER QUIJANO, 1990: 155.

${ }^{60}$ BARRIOS GARCÍA, 2004: 120.

${ }^{61}$ FRIDIKSSON, VÉSTEINSSON, 2011.

${ }^{62}$ MALDONADO, 2013.

${ }^{63}$ FITZPATRICK, HENNESSY, 2017; GLEESON, en prensa.
} 
de marcadores territoriales de los espacios funerarios también aparece en el caso de los garamantes del sur de Libia, que emplazaron sus necrópolis en estrecha relación con los sistemas de irrigación subterráneos (foggaras) ${ }^{64}$. Todo ello se pone en relación con la construcción de territorios reclamados por comunidades que enterraban a sus muertos o que conmemoraban a sus ancestros en determinados lugares ${ }^{65}$. Una situación que exigía la reafirmación regular de esos derechos mediante la ritualización, que servía como mecanismo de legitimación por el control de recursos limitados ${ }^{66}$. En definitiva, los espacios funerarios pueden construir territorio, entendido como un dominio social sobre un espacio ${ }^{67}$. Es en este contexto donde se puede comprender mejor el modelo planteado en la Sierra de Ávila, con una territorialidad que se modificó profundamente a partir de la formación de las parroquias y del concejo de la villa de Ávila ${ }^{68}$. La hipótesis más factible es que fueran inicialmente áreas mancomunales cuyo dominio recaía en varias comunidades cercanas. Este modelo respondería a la afirmación y consolidación de grupos campesinos, con estratificaciones internas, relativamente autónomos con respecto a los centros de poder representados por los asentamientos rurales fortificados, en cuyas cercanías no se detecta este fenómeno funerario.

\section{TUMBAS EXCAVADAS EN ROCA Y COMUNIDAD POLÍTICA}

El estudio de la Sierra de Ávila muestra la diversidad de los usos de las tumbas excavadas en la roca. En tal sentido, un patrón diferente es el que puede observarse en las necrópolis alineadas de tumbas excavadas en roca, es decir la tercera de las tipologías que hemos establecido. Estas necrópolis son poco numerosas, pero su patrón es completamente distinto. Se emplazan normalmente en asentamientos actualmente ocupados, con tumbas que tienden a organizarse en líneas con una orientación E-W, se reconoce la presencia de tumbas infantiles - mucho menos frecuentes en las otras tipologías, lo que respondía al escaso valor como ancestros que pudieran tener los niños fallecidos - y muchas de ellas presentan vínculos con iglesias parroquiales construidas desde finales del siglo XI en adelante ${ }^{69}$.

Un rasgo relevante es que los emplazamientos responden a «lugares centrales» activos en los siglos IX y X. Se trata de los núcleos sobre los que se estableció el poder asturleonés en su proceso de expansión e integración. Eran los puntos desde los que se establecía el dominio regio, donde se implementaron mecanismos de organización política; funcionaban como «islas de autoridad»sobre esta región. A estos lugares pudieron llegar algunos representantes de la más alta aristocracia (magnates, obis-

\footnotetext{
${ }^{64}$ MATTINGLY, 2008.

65 SAXE, 1971.

${ }^{66}$ GOLDSTEIN, 1981.

67 SACK, 1986.

${ }^{68}$ BLANCO GONZÁLEZ, MARTÍN VISO, 2016.

${ }^{69}$ MARTÍN VISO, 2016.
} 
pos). Pero el control político tuvo que contar con las elites locales pertenecientes a estas comunidades. La fórmula para llevar a cabo esta vinculación fue la creación de un sistema de prestaciones militares que facilitó la militarización de esas elites loca$\operatorname{les}^{70}$. Es precisamente en estos puntos, conocidos sobre todo por el registro escrito, donde se reconoce el patrón de necrópolis alineadas. Desde Sepúlveda a Trancoso, pasando por Sacramenia, Cuéllar, Salamanca, Ledesma, Marialva; Moreira de Rei, Longroiva o Numão. Estos espacios funerarios se encuentran en lugares extramuros, pero generalmente cercanos a algunos puntos de acceso.

Por tanto, la revisión de los datos existentes en toda la región sur del valle del Duero constata cómo buena parte de los «lugares centrales» de época asturleonesa disponían de ese patrón de necrópolis. Un ejemplo de estos sitios es Salamanca. A lo largo del periodo posromano, fue sede episcopal y ceca en el siglo VII. Sin embargo, a partir del siglo VIII no tenemos noticias sobre Salamanca ni en las fuentes escritas ni en las arqueológicas. La Crónica de Sampiro, escrita en el primer tercio del siglo XI, nos informa de la integración del valle del Tormes en la red política de los reyes asturleoneses tras la victoria de Ramiro II frente al califa Abd-al-Rahman III en Simancas en 939. En ese pasaje, se menciona a Salamanca como el principal núcleo de la zona, calificándolo de sedes antiqua castrorum ${ }^{71}$. A partir de ese momento, tenemos constancia de la existencia de un conde en Salamanca, concretamente Bermudo Núñez, quien encabezó una fallida expedición contra el territorio fronterizo de al-Andalus ${ }^{72}$, o de su hijo Fernando que viajó a Córdoba en una embajada ante Al-Hakam II ${ }^{73}$. Por otro lado, las campañas de Almanzor, mayordomo (hayib) el califa Hisham II y auténtico poder en el último tercio del siglo $\mathrm{X}$ en el califato de Córdoba, se dirigieron en varias ocasiones contra Salamanca ${ }^{74}$. El resultado de estas acciones militares fue el colapso del poder asturleonés en este sector.

En Salamanca, se han podido identificar al menos dos zonas con necrópolis de tumbas excavadas en roca, todas ellas extramuros: San Pelayo-Patio de la Universidad Pontificia y San Cristóbal (Fig. 10). La de San Pelayo se encuentra cercana a la entrada Norte del antiguo recinto amurallado, la Cerca Vieja, de origen romano. San Cristóbal, en cambio, en una zona algo más alejada. Las evidencias conservadas en este caso son escasas, debido a la profunda alteración provocada por la construcción de la parroquia que da nombre al lugar. Apenas se aprecian algunas tumbas, sobre todo en torno al ábside, aunque con una orientación que no se corresponde a la del edificio de trazas románicas. En San Pelayo (Fig. 11), donde la excavación realizada

\footnotetext{
70 MARTÍN VISO, 2017.

${ }^{71}$ PÉREZ DE URBEL, 1952: § 23.

${ }^{72}$ IBN HAYYAN, 1981: § 326.

73 IBN HAYYAN, 1967: § 28.

${ }^{74}$ RUIZ ASENCIO, 1968; MOLINA, 1981.
} 


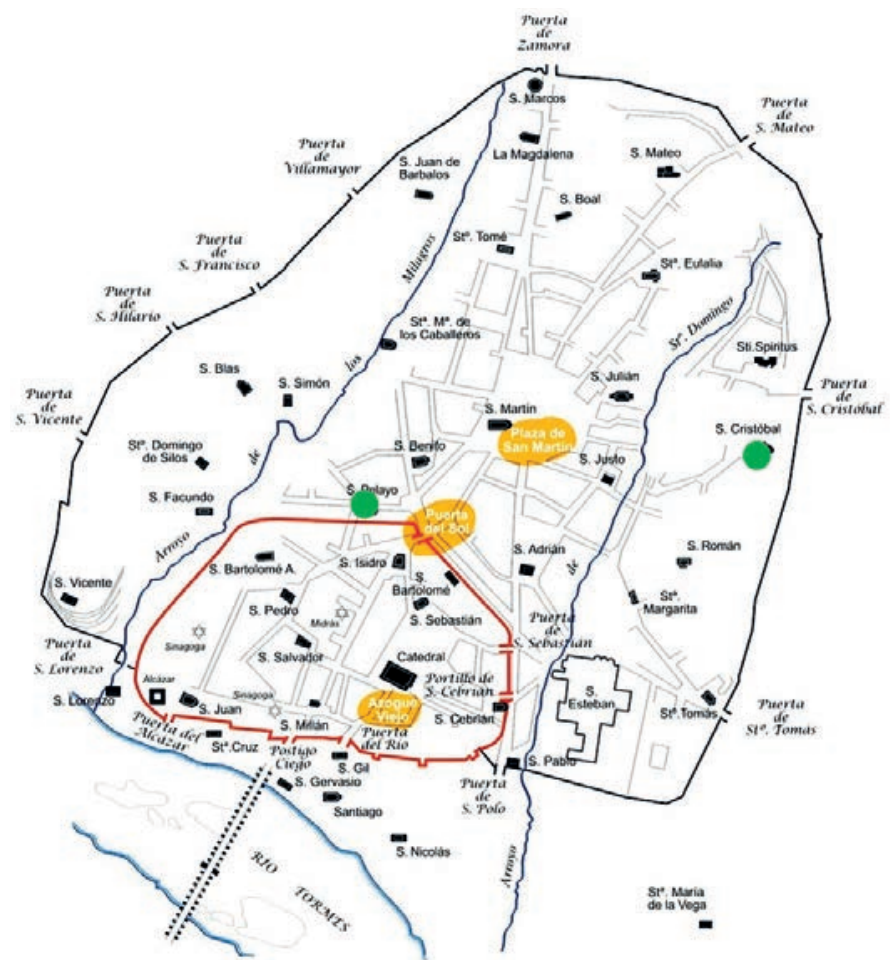

Fig. 10.

Localización de los sitios con tumbas excavadas en la roca en Salamanca

Fuente: De MONSALVO ANTÓN, 2010

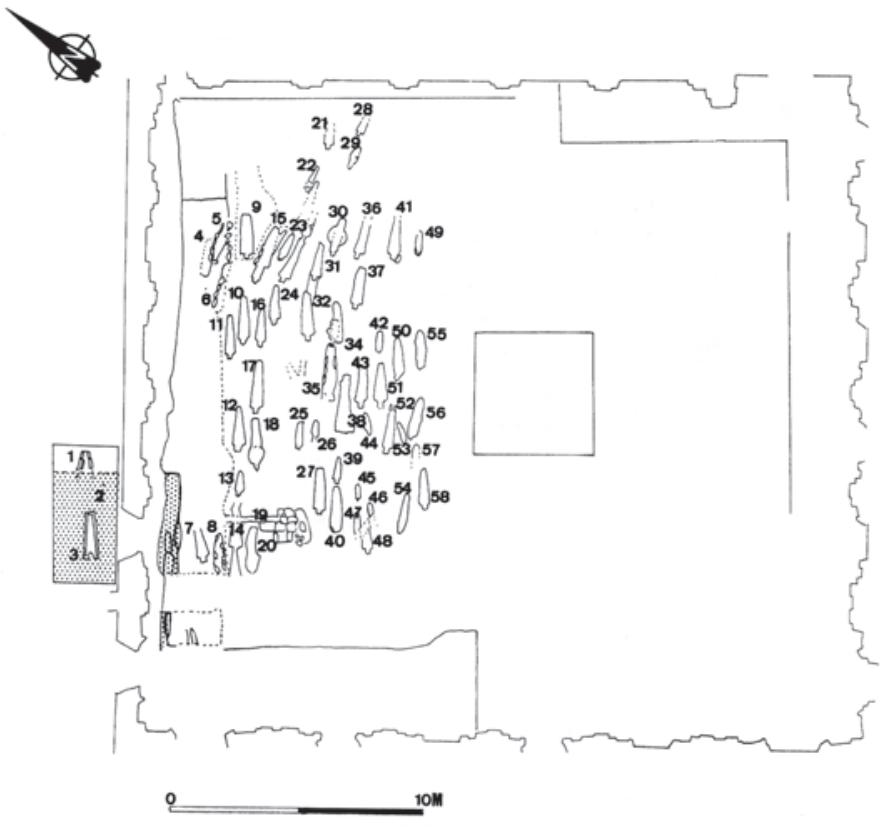

Fig. 11.

Plano de la excavación del patio de la Universidad Pontificia Fuente: De GONZÁLEZ ECHEGARAY, 2000: 56 
puso de manifiesto la existencia de una necrópolis con 64 tumbas, de las que 53 eran excavadas en la roca, con un diseño típico de las necrópolis alineadas ${ }^{75}$. Aunque se ha planteado su vinculación con la parroquia de San Pelayo, documentada en el siglo XIII, no hay evidencias sobre las que apoyar esa asociación. En realidad, se trata de una conclusión derivada de un par de consideraciones previas: que la ciudad estuvo despoblada hasta su definitiva repoblación a finales del siglo XI y que no pueden existir espacios funerarios sin centros eclesiásticos. Por el contrario, la lectura de los datos nos habla de un fragmento de una necrópolis más amplia, que no se relaciona con el templo posterior, sino que este se construye sobre las tumbas.

Salamanca sirve como ejemplo de las necrópolis alineadas. Son un rasgo específico - y, por ende, no muy numeroso en términos generales - de los puntos que surgieron con la integración política en el reino asturleonés en los siglos IX y X. Parece factible pensar que se trata de una consecuencia directa de ese proceso y de las transformaciones que trajo consigo en las comunidades allí residentes. Sería la plasmación de una memoria social vinculada a una comunidad política relevante, con unos espacios funerarios cercanos a las murallas, representación física de esa comunidad, y situados en áreas de paso. La presencia de tumbas excavadas en la roca - frente a lo que sucedía en los «lugares centrales» posromanos - podría ser la consecuencia de la expansión de prácticas funerarias presentes en ámbitos rurales y propias de elites campesinas hacia esos «lugares centrales», cuyos dirigentes adoptaron unas estrategias semejantes a partir del siglo VIII. La adopción de este modelo de tumba se unió con la tradición de espacios funerarios más densos en estos lugares $\mathrm{y}$, sobre todo, con una nueva situación sociopolítica a partir del siglo $\mathrm{X}$, que favoreció el papel político de algunas comunidades. De esta manera surgieron esas necrópolis, que posteriormente, con la implementación del sistema episcopal, fueron reutilizadas por la Iglesia para construir las parroquias en tales centros urbanos o semiurbanos, lo que explica su conexión topográfica con esas construcciones, que en realidad son posteriores. La presencia de zanjas de cimentación que rompen con las tumbas, como ocurre en Santa Marina de Moreira de Rei (Fig. 3) o Santa Elena de Ledesma, o la propia estratigrafía de las sepulturas con respecto a la construcción plenomedieval, como ocurre en San Salvador de Sepúlveda, ejemplificarían esa secuencia ${ }^{76}$. Se trataba de aprovechar el prestigio de unos lugares asociados a la memoria social de las comunidades, ahora interpretada desde parámetros eclesiásticos.

Un dato en negativo y, por tanto debe usarse con cautela, es la ausencia de este tipo de necrópolis en el área actualmente abulense o en los territorios situados alre-

\footnotetext{
75 GONZÁLEZ ECHEGARAY, 2000.

${ }^{76}$ MARTÍN VISO, 2016.
} 
dedor de la ciudad de Segovia. Este vacío puede interpretarse como el reflejo a su vez de la inexistencia de un control político por parte de las autoridades asturleonesas. Tales zonas no parecen haber estado dentro del espacio político del reino, sino que quedaron al margen, sin que se mencione ningún lugar como efectivamente operativo dentro de la nueva - y a la postre poco durable - estructura política asturleonesa. En cambio, la interacción entre el poder de los reyes asturleoneses o de los condes castellanos y algunas comunidades locales al sur del Duero - quizás las más fuertes o las más representativas, elegidas por ello por los asturianos como los puntos vertebradores de su dominio - propició la construcción de nuevas identidades plasmadas en este modelo de espacio funerario, donde la tumba excavada en la roca quizás perdió su carácter monumental.

\section{LA FORMACIÓN DE LOS CEMENTERIOS PARROQUIALES Y EL FINAL DE LOS ESPACIOS FUNERARIOS CON TUMBAS EXCAVADAS EN LA ROCA}

El caso de las necrópolis alineadas muestra de nuevo la diversidad inherente al fenómeno de las tumbas excavadas en roca, que parece oculta ante una imagen de uniformidad generada desde la investigación. En realidad, tenemos procesos muy distintos con cronologías igualmente dispares: las necrópolis alineadas parecen ser un fenómeno de los siglos IX a XI, mientras que las tumbas aisladas, por ejemplo, podrían ser del VI-VII, como hemos comprobado. Pero siempre estamos hablando de momentos anteriores a la definitiva integración de este espacio en el territorio de los reinos cristianos, que se verificó a finales del siglo XI y a lo largo del siglo XII.

La consolidación de este nuevo dominio tuvo como una de sus principales vías la implantación de un sistema parroquial articulado desde los obispados. Su configuración se produjo en los siglos XII y XIII, en un momento tardío en comparación con otras regiones europeas y peninsulares. Resulta interesante observar cómo en este sector el número de edificios eclesiásticos conocidos es muy bajo. Disponemos de un par de casos, como son el edificio hallado en Cuarto de Enmedio (Pelayos, Salamanca) ${ }^{77}$ y la supuesta iglesia de Prazo (Freixo de Numão) ${ }^{78}$; pero ambos casos tienen grandes problemas cronológicos. De hecho, la datación del edificio de Prazo se ha desplazado recientemente al siglo $\mathrm{X}^{79}$, aunque subsisten numerosos problemas de interpretación del sitio. En cambio, a partir del siglo X se advierte la construcción de alguna iglesia, como podría ser São Pedro de Lourosa, con una inscripción de comienzos del siglo X, que además se vincula a un conjunto de tumbas excavadas en

\footnotetext{
77 STORCH DE GRACIA, 1998: 151-154.

${ }^{78}$ COIXÃO, 1999: 54-124.

${ }^{79}$ REAL, 2013.
} 
Fig. 12.

Tumbas excavadas en la roca en

S. Pedro de Lourosa Fuente: Fotografía Iñaki Martín Viso

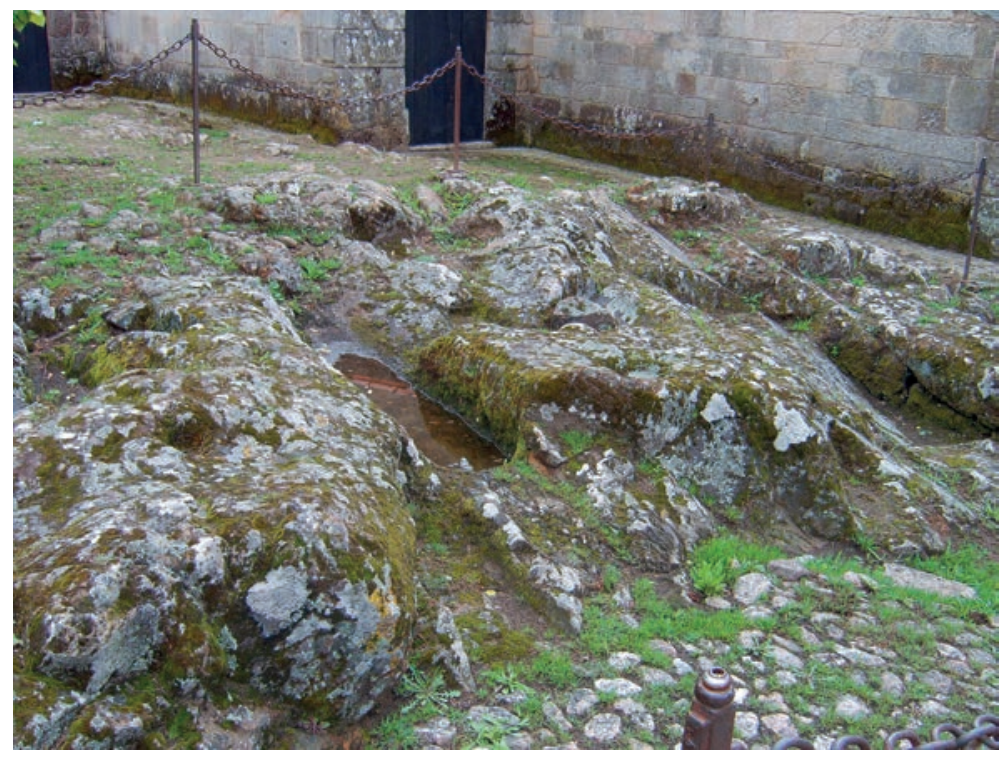

la $\operatorname{roca}^{80}$ (Fig. 12). Ahora bien, las sepulturas se concentran en una zona aislada a la entrada de la iglesia actual, sin respetar su orientación, por lo que podría tratarse de un espacio funerario previo sobre el que se erigió algún tipo de construcción ${ }^{81}$. Otro caso de iglesia construida en este mismo periodo procede de Senhora do Barrocal (Sátão), donde contamos únicamente con una evidencia epigráfica con una data de 971 y aparentemente relacionada con una iglesia ${ }^{82}$. Es llamativo que la eclosión de estas iglesias sea coetánea a la integración en el reino asturleonés. Un documento de 953 referido a Salamanca menciona a las iglesias erigidas por los pobladores procedentes de León que acudieron al lugar con Ramiro II, algunos de los cuales se han podido identificar con magnates ${ }^{83}$. Parece que una de las marcas de la nueva estructura de poder fue precisamente la edificación de iglesias monumentalizadas. Pero este proceso no fue generalizado ni masivo, por lo que no cabe interpretar el paisaje de los siglos X-XI en el centro-oeste peninsular en términos de una fuerte presencia de iglesias. No obstante, podría tratarse de una distorsión provocada por el hecho de que las iglesias locales no estuvieran monumentalizadas y se hubieran construido en materiales perecederos, como la madera, quedando amortizadas posteriormente con las edificaciones en piedra ${ }^{84}$. Sin descartar esa hipótesis, no se han reconocido hasta el momento ejemplos que la sustenten, toda vez que la monumentalidad en piedra

\footnotetext{
${ }^{80}$ BARROCA, 2000: II/1, 31-33; LOURENÇO, 2007: 152-153.

${ }^{81}$ MARTÍN VISO, 2005: 94.

82 TENTE et al., 2018c.

83 SÁEZ, SAÉZ, 1990: doc. 60; MÍNGUEZ, 1997: 32-33; MARTÍN VISO, 2017: 214.

${ }^{84}$ REAL, 2012.
} 
de las iglesias y monasterios parece haber sido una norma común en la Península Ibérica, aunque obviamente con grados de complejidad muy diferentes. Los análisis sobre la cercana Galicia parecen probarlo ${ }^{85}$.

Por tanto, la ausencia previa de monasterios o iglesias locales provocó que el proceso de formación de parroquias surgiese ex novo. La construcción de iglesias y la consiguiente formación de cementerios parroquiales debió ser un proceso lento y posterior a esa identificación. Estos cementerios marcaban una nueva articulación del espacio funerario: un área sacralizada y directamente controlada por la Iglesia ${ }^{86}$. Un dato recurrente es la inexistencia de una superposición de las iglesias y sus cementerios sobre antiguas áreas de enterramiento en ámbitos rurales, al menos en lo que respecta a las tumbas excavadas en la roca. Es verdad que hay algunas excepciones, entre las que destaca el caso de Marialva, donde la necrópolis preexistente se transformó en un cementerio parroquial, en uso todavía en el siglo $\mathrm{XV}^{87}$. Se trata de un caso muy particular de perduración, que debe relacionarse con la relevancia de las necrópolis alineadas, sobre muchas de las cuales se erigieron iglesias parroquiales que aprovecharon el prestigio de los espacios funerarios, con lo que la Iglesia se apropió del valor simbólico de dichos lugares en su beneficio. Pero las tumbas aisladas y las necrópolis segmentadas no dieron lugar a espacios funerarios de tipo parroquial.

La Sierra de Ávila nos proporciona de nuevo un marco sobre el que observar este proceso ${ }^{88}$. Aquí contamos con un interesante documento en el que se recoge un elenco de las parroquias de la diócesis de Ávila en 1250. El listado incluye toda la Sierra de Ávila, donde aparecen un total de veintisiete parroquias ${ }^{89}$. La comparación entre las parroquias citadas en el documento y los espacios funerarios altomedievales definidos por la presencia de tumbas excavadas en la roca revela que no hay conexión entre ellos (Mapa 3). Únicamente en tres casos existe una correlación entre ambos: Brieva, Cornejuelos y Serranos de Avianos. En el caso de Cornejuelos, se documenta una tumba aislada, emplazada cerca de restos de edificaciones. Se desconoce si este lugar dispuso de una iglesia, pero la tumba no está amortizada por ningún tipo de estructura posterior, por lo que no puede hablarse de superposición entre espacio funerario e iglesia. Brieva se identifica con una necrópolis dispuesta en varios núcleos y algunas de las tumbas se hallan dentro del área residencial, por lo que el poblado, abandonado en la Baja Edad Media, sería posterior a las fases de utilización de las sepulturas. No obstante, no se ha podido documentar arqueológicamente la existencia de una iglesia. Por último, Serranos de Avianos surge en los textos escritos de los siglos

\footnotetext{
${ }^{85}$ SÁNCHEZ PARDO et al., 2018.

${ }^{86}$ LAUWERS, 2005.

${ }^{87}$ AMARAL, 2001.

${ }^{88}$ BLANCO GONZÁLEZ, MARTÍN VISO, 2016.

${ }^{89}$ BARRIOS GARCÍA, 2004: 83.
} 


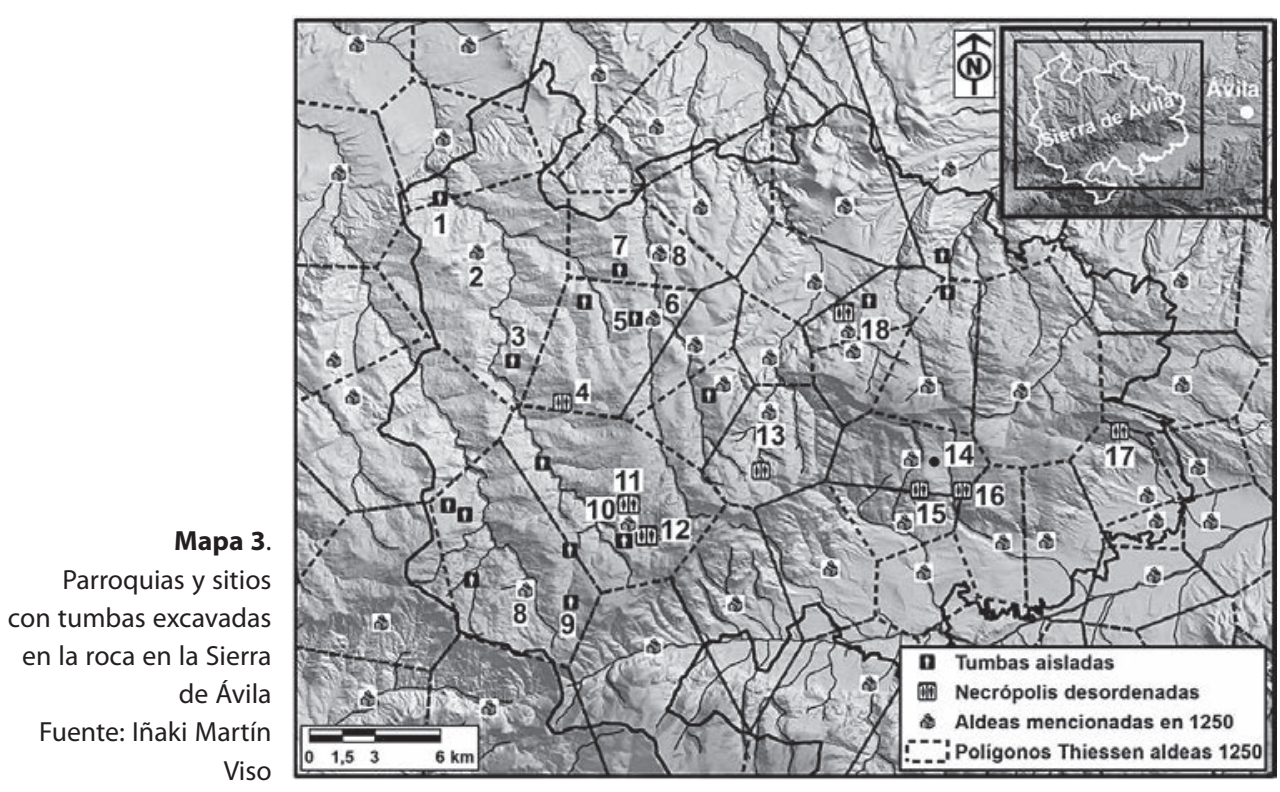

XIII a XV como un importante núcleo comarcal, uno de cuyos barrios o colaçiones pudo haber sido Cornejuelos ${ }^{90}$. Pero la localidad actualmente un despoblado - se encontraba al sur de la necrópolis, es decir en un punto diferente, y no se aprecia la construcción de ningún tipo de centro de culto. Por tanto, no parece que las parroquias y sus cementerios utilizasen los espacios funerarios previos.

En los cementerios parroquiales, los fallecidos mantenían su condición de ancestros, pero formando parte de una comunidad de muertos que esperaba el día del Juicio Final ayudados por las oraciones de los vivos y enterrados en un espacio común y sagrado. El cambio provocó el final de los significados asociados a determinados espacios funerarios previos. El éxito de este modelo fue incuestionable, aunque no debió ser ni inmediato ni automático. Existen algunos - pocos - ejemplos de iglesias, aparentemente parroquiales, que no tuvieron éxito. El lugar de San Martín, en Bercial de Zapardiel (Ávila), se excavó una iglesia junto con un cementerio con al menos una cuarentena de enterramientos y que se ha datado entre los siglos XII y XIII $^{91}$. Esta edificación situada a unos 500 metros de distancia del pueblo actual, se abandonó posiblemente en el siglo XIII y quizás se desplazó la parroquia a la iglesia actual dentro del asentamiento.

Al mismo tiempo, debe indicarse la presencia de huellas de una resiliencia de algunos espacios funerarios. Las evidencias, un tanto endebles, proceden de nuevo

\footnotetext{
${ }^{90}$ BARRIOS GARCÍA, 2004: 129.

${ }^{91}$ MARTÍIN CARBAJO et al., 1993-1994.
} 
de la Sierra de Ávila. Así sucede con San Simones (Sanchicorto, La Torre), una necrópolis rural desordenada, con al menos 18 tumbas, emplazada junto a una vía que atravesaba la Sierra de Ávila. En el lugar, se conserva un paredón, que algunos relacionan con un centro de culto, de factura bajomedieval ${ }^{92}$. Esta tardía datación no parece ajustarse al modelo de espacio funerario en torno a tumbas excavadas en la roca; ni siquiera podemos identificar este lugar con una de las parroquias de la diócesis abulense citadas en 1250 . Se trataría quizá de una edificación tardomedieval o moderna que se habría erigido en un lugar todavía recordado como de especial significación para los habitantes. Es posible que se hubiera perdido la memoria de la existencia de un área de enterramiento, pero se habría conservado algún tipo de historia sobre ese sitio. Algo semejante parece haberse producido en la ermita de Nuestra Señora de las Fuentes, una ermita situada a unos 500 metros de La Coba. Se trata de una edificación moderna, posiblemente del siglo XVIII, donde se lleva a cabo una romería anual a la que acuden los habitantes de los pueblos vecinos. Su existencia podría deberse a una adaptación del significado previo del espacio funerario en un nuevo contexto, sin que se desarrollase una parroquia.

\section{UN BREVE BALANCE}

Quisiera concluir con un pequeño balance sobre el proyecto. Creo que se han abierto perspectivas de estudio renovadoras que permiten integrar a las tumbas en el paisaje y en los procesos sociales. Pero debe abordarse su estudio a partir de un análisis integral de esos procesos, situando a las tumbas en el contexto y mirando más allá de las sepulturas. De esta manera, la evidencia se convierte en un dato relevante para la comprensión de las sociedades altomedievales. La ejecución de este proyecto permitió incorporar la evidencia funeraria al estudio de los paisajes, entendidos como construcciones sociales. El carácter netamente local y familiar de las decisiones relativas a los espacios de enterramiento en la Alta Edad Media implican una fuerte diversidad de situaciones. Por otro lado, las tumbas excavadas en la roca fueron una de las posibles fórmulas de inhumación que estaban al alcance de las distintas comunidades y familias durante un largo lapso de tiempo. La utilización de tumbas excavadas en la roca no debe entenderse como una fase cronológica ni como un conjunto unitario. Su uso respondía - dejando de lado las condiciones geológicas - a la formación de significados asociados con los difuntos y estos podían variar en el tiempo y en el espacio. Y tampoco era el único recurso al que se podía recurrir, lo que explica que puedan coexistir diversas modalidades de enterramiento. De hecho, la relación que parece haberse establecido entre este tipo de sepulturas y el papel de determinados ancestros conllevó que su utilización estuviera socialmente limitada a unos pocos individuos.

\footnotetext{
${ }^{92}$ LARRÉN IZQUIERDO, 1985.
} 
Además los estudios llevados a cabo han desechado la centralidad de la cronotipología y hacen hincapié en abandonar un discurso que nos lleva a un callejón sin salida.

Otros estudios recientes parecen corroborar algunas de las hipótesis que hemos manejado. Es el caso del trabajo de Rubén Rubio sobre el suroeste de Ciudad Rodrigo, en el que subraya el papel de monumentos campesinos de estas tumbas ${ }^{93}$. Recientemente, y dentro de un proyecto que analizó en profundidad la región de Viseu, Catarina Tente ha señalado cómo este modelo de enterramiento se sitúa en áreas alejadas de la ciudad y de los núcleos de poder, al tiempo que observa un marcado contraste entre las áreas con tumbas excavadas en la roca y aquellas que carecen de ese tipo de evidencias, pero, en cambio, poseen una información temprana sobre iglesias, como Lafões ${ }^{94}$. Y también he hecho ya referencia a la tesis doctoral de Sara Prata sobre la zona de San Mamede, al sur del Sistema Central, donde se han podido relacionar las tumbas excavadas en la roca con las áreas domésticas y con espacios de producción de aceite de los siglos VI-VII y quizás VIII ${ }^{95}$. Sin embargo, no se ha pretendido en absoluto establecer un modelo válido para todas las zonas, debido precisamente al carácter local y heterogéneo de unos usos que se dilataron a lo largo de un amplio segmento temporal. El estudio de otras regiones y con otras perspectivas seguramente posibilitará observar otras soluciones, como las que parecen abrirse para el caso del alto Arlanza según algunos interesantes trabajos recientes ${ }^{96}$. De todos modos, he de reconocer que la experiencia en la investigación del centro-oeste peninsular me ha hecho ser escéptico con respecto al papel de las iglesias en la articulación de los espacios funerarios con tumbas excavadas en la roca, aunque quizás pudieran estar funcionando en algunos casos regionales o incluso muy específicos ${ }^{97}$. Pero conviene ser cautos y profundizar más allá de su aparente conexión. En cualquier caso, no se han agotado los procesos en los que se insertaron las tumbas.

Pero algunos puntos creo que pueden ser útiles en todos los casos. Estamos ante patrones de control del espacio funerario que no estaban en manos de la Iglesia sino de las familias y comunidades. La clave es comprender que eran enterramientos de prestigio en el contexto social en el que se situaban: los muertos allí enterrados se convertían en ancestros y el uso de su memoria es fundamental para entender la función que desempeñaban las sepulturas. También debemos olvidarnos de conceptos rígidos de espacios funerarios, para abrirnos a un patrón de geografías funerarias muy laxo, en el que muertos, espacios agroganaderos y áreas residenciales configuraban un todo. En tal sentido, es imprescindible abordar el análisis de las áreas domésticas que

\footnotetext{
${ }_{93}^{93}$ RUBIO DÍEZ, 2015.

${ }^{94}$ TENTE, 2017.

${ }^{95}$ PRATA, 2018.

96 ÁLVARO RUEDA, TRAVÉ APELLUZ, LÓPEZ PÉREZ, 2018.

${ }^{97}$ LÓPEZ QUIROGA, 2017.
} 
permitan conocer cómo eran las comunidades que enterraban en las tumbas excavadas en la roca. Sin excavar los contextos domésticos y comprender las dinámicas del paisaje, las tumbas seguirán siendo un testimonio prácticamente mudo. Por tanto, esa debe ser la prioridad y no la continuidad de interpretaciones que se ciñan exclusivamente al estudio morfológico de las sepulturas, que representan un callejón sin salida.

\section{BIBLIOGRAFÍA}

ÁLVARO RUEDA, Karen; TRAVÉ APELLUZ, Esther; LÓPEZ PÉREZ, Maria Dolores (2018). Excavaciones arqueológicas en el yacimiento altomedieval de Revenga: nuevos datos para el conocimiento de los espacios de hábitat altomedieval en el Alto Arlanza (Burgos). «Territorio, Sociedad y Poder». 13, 5-28.

AMARAL, Maria Antónia (2001). A necrópole de São Pedro de Marialva. Estudo arqueológico. «Património e Estudos». 1, 129-138.

ANDRADE OLALLA, Antonia; RUIZ ZAPATA, Maria Blanca; DORADO, M. (1994). Estudio comparativo de la evolución de la vegetación a partir del tránsito Subboreal-Subtalántico en las sierras abulenses (Ávila, Sistema Central, España). In MATEU ANDRÉS, Isabel et al., ed. Trabajos de palinología básica y aplicada. Valencia: Universidad de Valencia, pp. 247-261.

ANDRIO GONZALO, Josefina (1987). Formas de enterramiento medievales en los valles del Ebro y Duero. In II Congreso de Arqueología Medieval Española. Madrid: Comunidad de Madrid, vol. III, pp. 273-286.

ANDRIO GONZALO, Josefina et al. (1992). El conjunto arqueológico del monasterio de San Juan de la Hoz de Cillaperlata, Burgos. Valladolid: Junta de Castilla y León.

BARRIOS GARCÎA, Ángel (2004). Documentos de la catedral de Ávila (siglos XII-XIII). Ávila: Institución Gran Duque de Alba.

BARROCA, Mário Jorge (1987). Necrópoles e sepulturas medievais de Entre-Douro-e-Minho (séculos V $a \mathrm{XV}$ ). Porto: Faculdade de Letras da Universidade do Porto. Dissertação para Provas Públicas de Aptidão Pedagógica e Capacidade Científica.

BARROCA, Mário Jorge (2000). Epigrafia medieval portuguesa (862-1422). Lisboa: Fundação Calouste Gulbenkian. 4 vols.

BARROCA, Mário Jorge (2010-2011). Sepulturas escavadas na rocha de Entre Douro e Minho. «Portvgalia». Nova Série. 31-32, 115-182.

BIELSA, Maria Asunción (1977). Tipología de las tumbas antropomorfas de la zona aragonesa al norte del Ebro. In XIV Congreso Nacional de Arqueología. Zaragoza: Secretaría General de los Congresos Nacionales de Arqueología, pp. 1235-1240.

BLANCO GONZÁLEZ, Antonio; MARTİN VISO, Iñaki (2016). Tumbas, parroquias y espacios ganaderos: configuración y evolución del paisaje medieval de la Sierra de Ávila. «Historia Agraria». 69, 11-41.

BOLÓS MASCLANS, Jordi; PAGÉS PARETAS, Montserrat (1982). Les sepultures excavades a la roca. In RIU, Manuel, dir. Necròpolis i sepultures medievals de Catalunya. Barcelona: Departament d'Història Medieval, pp. 59-103.

BROOKES, Stuart; TENTE, Catarina; PRATA, Sara (2017). Interpreting rock-cut cemeteries: the early medieval necropolis and enclosure of São Gens, Portugal. «Medieval Archaeology». 61: 2, 215-238.

CABALLERO ARRIBAS, Jesús; PEÑAS PEDRERO, David (2012). Un castrum de época visigoda en el Valle Amblés: La Cabeza de Navasangil (Solosancho, Ávila). In QUIRÓS CASTILLO, Juan Antonio; TEJADO SEBASTIÁN, José $\mathrm{M}^{\mathrm{a}}$, ed. Los castillos altomedievales en el Noroeste de la Península Ibérica. Bilbao: Universidad del País Vasco, pp. 213-238.

CASTILLO, Alberto del (1970). Cronología de las tumbas llamadas "olerdolanas". In XI Congreso Nacional de Arqueología. Zaragoza: Secretaría General de los Congresos Arqueológicos Nacionales, pp. 835-845. 
CASTILLO, Alberto del (1972). Excavaciones altomedievales en las provincias de Soria, Logroño y Burgos. Madrid: Comisaría General de Excavaciones Arqueológicas.

CHERRYSON, Annia; BUCKBERRY, Jo (2010). Introduction. In BUCKBERRY, Jo; CHERRYSON, Annia, ed. Burial in later Anglo-Saxon England, c. 650-1100 AD. Oxford: Oxbow, pp. IX-X.

COIXÃO, António do Nascimento Sá (1999). Rituais e cultos da norte na região de entre Douro e Côa. Almada: Associação Cultural, Desportiva e Recreativa de Freixo de Numão.

CORTLETT, Christian; POTTERTON, Michael, ed. (2010). Death and burial in early medieval Ireland in the light of recent archaeological excavations. Dublín: Wordwell.

DEVLIN, Zoe (2007). Remembering the dead in Anglo-Saxon England. Memory theory in archaeology and history. Oxford: Archaeopress.

DOMÉNECH, Carolina; GUTIÉRREZ LLORET, Sonia (2006). Viejas y nuevas monedas en la ciudad emiral de Madīnat Iyyuh (El Tolmo de Minateda, Hellín, Albacete). «Al-Qantara». 27: 2, 337-374.

FITZPATRICK, Elizabeth; HENNESSY, Ronan (2017). Finn's seat: topographies of power and royal marchlands of Gaelic polities in medieval Ireland. «Landscape History». 38: 2, $29-62$.

FRIDRIKSSON, Adolf; VÉSTEINSSON, Orri (2011). Landscapes of burial: contrasting the pagan and Christian paradigms of burial in Viking Age and Medieval Iceland. «Archaeologia Islandica». 9, 50-64.

GILCHRIST, Roberta (2012). Medieval life. Archaeology and the life course. Londres: Boydell Press.

GLEESON, Patrick (en prensa). Early medieval kingdoms and territories: negotiating sovereignty in the Irish sea region. In MARTÍN VISO, Iñaki, ed. La construcción de la territorialidad en la Alta Edad Media. Salamanca: Universidad de Salamanca.

GOLDSTEIN, Lynn (1981). One-dimensional archaeology and multi-dimensional people: spatial organization and mortuary analysis. In CHAPMAN, Robert; KINNEZ, Ian; RANDSBORG, Klaus, ed. The archaeology of death. Cambridge: Cambridge University Press, pp. 53-69.

GONZÁLEZ ECHEGARAY, Joaquín, coord. (2000). El Colegio de la Compañía de Jesús en Salamanca (Universidad Pontificia). Arqueología e Historia. Salamanca: Universidad Pontificia de Salamanca.

HERNÁNDEZ BELOQUI, Begoña; BURJACHS, Francesc; IRIARTE CHIPAUSSO, Maria José (2013). Antropización en el paisaje vegetal de época visigoda en el centro peninsular a través del registro paleopalinológico. In QUIRÓS CASTILLO, Juan Antonio, ed. El poblamiento rural de época visigoda en Hispania. Arqueología del campesinado en el interior peninsular. Bilbao: Universidad del País Vasco, pp. 345-361.

IBN HAYYAN (1967). El califato de Córdoba en el Muqtabis de Ibn Hayyan. Anales palatinos del califa de Córdoba al-Hakam II. Madrid: Sociedad de Estudios y Publicaciones.

IBN HAYYAN (1981). Crónica del califa 'Abdarrahman III an-Nasir entre los años 912 y 942 (al-Muqtabis V). Zaragoza: Anubar.

LALIENA COBRERA, Carlos; ORTEGA ORTEGA, Julián (2005). Arqueología y poblamiento. La cuenca del río Martín en los siglos V-VIII. Zaragoza: Universidad de Zaragoza.

LARRÉN IZQUIERDO, Hortensia (1985). Aportación al estudio de despoblados en la provincia de Ávila. «Cuadernos Abulenses». 4, 111-123.

LARRÉN IZQUIERDO, Hortensia (1989). Materiales cerámicos de la Cabeza de Navasangil (Ávila). «Boletín de Arqueología Medieval». 3, 53-74.

LAUWERS, Michel (2005). Naissance du cimetière. Lieux sacrés et terres des morts dans l'Occident medieval. París: Aubier.

LÓPEZ PÉREZ, María Dolores; ÁLVARO RUEDA, Karen; TRAVÉ APELLUZ, Esther (2016). Rock-cut cemeteries and settlement processes at the Upper Arlanza basin (Burgos, Spain): a late antique and early medieval landscape analysis. "Zephyrus». LXXVIII, 173-191.

LÓPEZ QUIROGA, Jorge (2004). El final de la Antigüedad en la Gallaecia. La transformación de las estructuras de poblamiento entre Miño y Duero (siglos V al X). La Coruña: Fundación Barrié de la Maza. 
LÓPEZ QUIROGA, Jorge (2010). Arqueología del mundo funerario en la Península Ibérica (siglos V-X). Madrid: La Ergástula.

LÓPEZ QUIROGA, Jorge (2017). Late Antique and early medieval rupestrian monasticism in the Iberian Peninsula. Landscapes and material contexts of the rupestrian settlements. «Hortus Artium Medievalium». 23: 1, 77-95.

LÓPEZ QUIROGA, Jorge; GARCÍA PÉREZ, LAURA (2014). Las tumbas excavadas en la roca en la Península Ibérica: tipología, cronología y problemas de interpretación. In LÓPEZ QUIROGA, Jorge; MARTÍNEZ TEJERA, Artemio M, ed. In concavis petrarum habitaverunt. El fenómeno rupestre en el Mediterráneo Medieval: de la investigación a la puesta en valor. Oxford: Archaeopress, pp. 36-83.

LÓPEZ QUIROGA, Jorge; RODRÍGUEZ LOVELLE, Mónica (1991). As sepulturas antropomorfas en rocha e a súa problemática histórica - unha proposta para o seu estudo. «Revista Larouco». 1, 61-77.

LÓPEZ QUIROGA, Jorge; RODRÍGUEZ LOVELLE, Mónica (1992). Propuesta de cronología e interpretación histórica de los enterramientos en piedra en Galicia durante la Alta Edad Media (ss. V-XI). «Boletín de Arqueología Medieval». 6, 139-155.

LÓPEZ QUIROGA, Jorge; RODRÍGUEZ LOVELLE, Mónica (1997). Un modelo de análisis del poblamiento rural en el valle del Duero (siglos VIII-X) a partir de un espacio macro-regional: las tierras galaicoportuguesas. «Anuario de Estudios Medievales». 27: 2, 687-784.

LOURENÇO, Sandra (2007). O povoamento alto-medieval entre os ríos Dão e Alva. Lisboa: Instituto Português de Arqueologia.

LOYOLA PEREA, Esther (1977). Nuevas aportaciones al estudio de la arqueología altomedieval en las provincia de Logroño y Burgos. In XIV Congreso Nacional de Arqueología. Zaragoza: Secretaría General de los Congresos Nacionales de Arqueología, pp. 1227-1230.

LOYOLA PEREA, Esther et al. (1990). El conjunto arqueológico de Santa María de la Piscina (San Vicente de la Sonsierra). Logroño: Instituto de Estudios Riojanos.

LUIS LÓPEZ, Carmel; DEL SER QUIJANO, Gregorio (1990). Documentación medieval del asocio de la extinguida universidad y tierra de Ávila. Ávila: Institución Gran Duque de Alba.

MALDONADO, Adrián (2013). Burial in early medieval Scotland: new questions. «Medieval Archaeology». 57, 1-34.

MARTÍN CARBAJO, Miguel Ángel et al. (1993-1994). La antigua iglesia de San Martín, en Bercial de Zapardiel (Ávila). Excavaciones arqueológicas. «Numantia». 6, 187-204.

MARTÍN VISO, Iñaki (2002). Espacio y poder en los territorios serranos en la región de Madrid (siglos $X$-XIII). «Arqueología y Territorio Medieval». 9, 53-84.

MARTÍN VISO, Iñaki (2007). Tumbas y sociedades locales en el centro de la Península Ibérica en la Alta Edad Media: el caso de la comarca de Riba Côa (Portugal). "Arqueología y Territorio Medieval». 14, 21-47.

MARTÍN VISO, Iñaki (2012a). Enterramientos, memoria social y paisaje en la Alta Edad Media: propuestas para un análisis de las tumbas excavadas en roca en el centro-oeste de la Península Ibérica. «Zephyrus». LXIX, 165-187.

MARTÍN VISO, Iñaki (2012b). Paisajes sagrados, paisajes eclesiásticos: de la necrópolis a la parroquia en el centro de la Península Ibérica. «Reti Medievali. Rivista». 13:2, 3-45.

MARTÍN VISO, Iñaki (2014a). ¿Datar tumbas o datar procesos? A vueltas con la cronología de las tumbas excavadas en la roca en la Península Ibérica. "Debates de Arqueología Medieval». 4, 29-65.

MARTÍN VISO, Iñaki (2014b). El espacio del más acá: las geografías funerarias entre la Alta y la Plena Edad Media. In LÓPEZ OJEDA, Esther, coord. De la tierra al cielo. Ubi sunt qui ante nos in hoc mundo fuere. Logroño: Instituto de Estudios Riojanos, pp. 75-140.

MARTÍN VISO, Iñaki (2014c). Castella y elites en el suroeste de la Meseta del Duero postromana. In CATALÁN, Raúl; FUENTES, Patricia; SASTRE, José Carlos, ed. Las fortificaciones en la 
tardoantigüedad: élites y articulación del territorio (siglos V-VIII d.C.). Madrid: La Ergástula, pp. 247-274.

MARTÍN VISO, Iñaki (2015). Espacios funerarios e iglesias en el centro peninsular: una relación compleja. In SABATÉ, Flocel; BRUFAL, Jesús, ed. Arqueologia medieval. Els espais sagrats. Lleida: Pagés, pp. 81-114.

MARTÍN VISO, Iñaki (2016). Comunidades locales, lugares centrales y espacios funerarios en la Extremadura del Duero alto medieval: las necrópolis de tumbas excavadas en roca alineadas. "Anuario de Estudios Medievales». 46: 2, 859-898.

MARTÍN VISO, Iñaki (2017). Integración política y regeneración: el sur del Duero en el reino asturleonés. «Edad Media. Revista de Historia». 18, 207-239.

MARTÍN VISO, Iñaki (2019). Ancestors and landscape: early medieval burial sites in the Central-Western regions of the Iberian Peninsula. In ESCALONA, Julio; VÉSTEINSSON, Orri; BROOKES, Stuart, ed. Polity and neighbourhood in early medieval Europe. Turnhout: Brepols, pp. 121-146.

MARTÍN VISO, Iñaki; BLANCO GONZÁLEZ, Antonio (2016). Ancestral memories and early medieval landscapes: the case of Sierra de Ávila (Spain). «Early Medieval Europe». 24: 4, 393-422

MARTÍN VISO, Iñaki et al. (2017). La formación de un nuevo paisaje en el centro de la Península Ibérica en el periodo posromano: el yacimiento de La Genestosa (Casillas de Flores, Salamanca). «Archivo Español de Arqueología». 90, 7-28.

MATTINGLY, David (2008). Technological or social landmarks? The foggaras of the garamants in Southern Lybia. In COMPANTANGELO-SOUSSIGNAN, Rita et al. Marqueurs des paysages et systems socio-économiques. Rennes: Presses Universitaires de Rennes, pp. 127-134.

MíNGUEZ, José María (1997). La repoblación de los territorios salmantinos. In MíNGUEZ, José María, coord. Historia de Salamanca, II. Edad Media. Salamanca: Centro de Estudios Salmantinos, pp. 13-74.

MOLINA, Luis (1981). Las campañas de Almanzor a la luz de un nuevo texto. "Al-Qantara». II, 209-264.

MOLIST CAPELLA, Núria; BOSCH CASADEVALL, Josep M. (2012). El cementiri medieval de Sant Miquel d'Olèrdola (Olèrdola, Alt Penedés). In MOLIST CAPELLA, Núria; RIPOLL, Gisela, ed. Arqueologia funeraria al nord-est peninsular (segles VI-XII). Barcelona: Museu d'Arqueologia de Barcelona, II, 469-494.

MONSALVO ANTÓN, José Ma (2010). Atlas histórico de la España medieval. Madrid: Síntesis.

NÓBREGA, Pedro Pina; NETO, Filipa; TENTE, Catarina (2012). A sepultura medieval de Alto da Quintinha (Mangualde). "Arqueologia Medieval». 12, 203-210.

PADILLA LAPUENTE, José Ignacio (2003). Yacimiento arqueológico de Cuyacabras. Despoblado, ermita y necrópolis de Cueva Andrés. Quintanar de la Sierra (Burgos). Barcelona: Universitat de Barcelona.

PADILLA LAPUENTE, José Ignacio; ÁLVARO RUEDA, Karen (2010). Necrópolis rupestres y el poblamiento altomedieval en el alto Arlanza (Burgos). «En la España Medieval». 32, 259-294.

PADILLA LAPUENTE, José Ignacio; ÁLVARO RUEDA, Karen (2013). Los asentamientos altomedievales del Alto Arlanza (Burgos). El despoblado medieval de Revenga. «Pyrenae». 44: 1, 11-41.

PALOMINO LÁZARO, Ángel L.; NEGREDO GARCÍA, María José (2012). Arqueología de la transición en la Castilla del Ebro. El yacimiento "Peña del Mazo" en Pajares, Valle de Tobalina (Burgos). In QUIRÓS CASTILLO, Juan Antonio, ed. Vasconia en la Alta Edad Media, 450-1000. Poderes y comunidades rurales en el Norte peninsular. Bilbao: Universidad del País Vasco, pp. 193-218.

PARKER PEARSON, Michael (1999). The archaeology of death and burial. Stroud: Sutton.

PÉREZ DE URBEL, Justo, ed. (1952). Sampiro: su crónica y la monarquía leonesa em el siglo X. Madrid: CSIC.

PRATA, Sara (2018). Arqueologia do povoamento rural alto-medieval no território de Castelo de Vide (séculos V-VIII). Salamanca: Departamento de Historia Medieval, Moderna y Contemporánea, Universidad de Salamanca. Tesis doctoral. 
QUIRÓS CASTILLO, Juan Antonio (2011). Early medieval landscapes in north-west Spain: local powers and communities, fifth-tenth centuries. "Early Medieval Europe». 19: 3, 285-311.

QUIRÓS CASTILLO, Juan Antonio (2013). Defensive sites of the Early Midle Ages in North-West Spain. In BAKER, John; BROOKES, Stuart; REYNOLDS, Andrew, ed. Landscapes of defence in early medieval Europe. Brepols: Turnhout, pp. 301-339.

REAL, Manuel Luis (2012). Materiais de construção utilizados na arquitectura cristã da Idade Média da Idade Média. In MELO, Arnaldo Sousa; RIBEIRO, Maria do Carmo, ed. História da construção. Os materiais. Braga: Centro de Investigação Transdisciplinar Cultura, Espaço e Memoria, pp. 89-125.

REAL, Manuel Luis (2013). O significado da basílica de Prazo (Vila Nova de Foz Côa) na Alta Idade Média duriense. In 1as conferéncias Museu de Lamego/CITCEM. História e Patrimonio no Douro: investigação e desenvolvimento. Lamego: Museu de Lamego, pp. 65-103.

RIU, Manuel (1982). Alguns costums de l'edat mitjana a Catalunya. In RIU, Manuel, dir. Necròpolis i sepultures medievals de Catalunya. Barcelona: Departament d'Història Medieval, pp. 29-51.

RUBIO DÍEZ, Rubén (2015). Arqueología, paisaje y territorio post-romano. Las tumbas excavadas en la roca en el Occidente del campo de Ciudad Rodrigo (Salamanca). Ciudad Rodrigo: Centro de Estudios Mirobrigenses.

RUBIO DÍEZ, Rubén; MARTÍN VISO, Iñaki; CENTENO CEA, Inés (en prensa). Un asentamiento campesino en los confines de la Meseta del Duero: El Pueblito (siglos VII-VIII). In Early Medieval Countryside Archaeological Meetings.

RUBIO DÍEZ, Rubén; PANIAGUA VARA, Enrique (2014). La piel de leopardo: espacios campesinos y espacios de poder en el Alto Valle del Águeda (Salamanca). In CATALÁN, Raúl; FUENTES, Patricia; SASTRE, José Carlos, ed. Las fortificaciones en la tardoantigüedad: élites y articulación del territorio (siglos V-VIII d.C.). Madrid: La Ergástula, pp. 383-392.

RUIZ ASENCIO, José Manuel (1968). Campañas de Almanzor contra el reino de León (981-986). «Archivos Leoneses». 5, 31-64.

SÁEZ, Carlos; SÁEZ, Emilio (1990). Colección documental del archivo de la catedral de León. II (953985). León: Centro de Estudios San Isidoro.

SACK, Robert David (1986). Human Territoriality. Its Theory and History. Cambridge: Cambridge University Press.

SÁNCHEZ PARDO, José Carlos et al. (2018). Cronotipología y datación absoluta de iglesias altomedievales en Galicia. Primeros resultados del proyecto EMCHAHE. «Hortus Artium Medievalium». 24, 90-104.

SAXE, Arthur (1971). Social dimensions of mortuary practices in a Mesolithic population from Wadi Halfa, Sudan. In BROWN, James A., ed. Approaches to the social dimensions of mortuary practices. Washington: Society for American Archaeology, pp. 39-57.

STORCH DE GRACIA, José Jacobo (1998). Avance de las primeras actividades arqueológicas en los hispano-visigodos de la Dehesa del Cañal (Pelayos, Salamanca). «Arqueología, Paleontología y Etnografía». 4, 141-160.

STRATO (2013). La Cárcava de la Peladera. In QUIRÓS CASTILLO, Juan Antonio, ed. El poblamiento rural de época visigoda en Hispania. Arqueología del campesinado en el interior peninsular. Bilbao: Universidad del País Vasco, pp. 101-116.

TEJERIZO GARCÍA, Carlos; CANOSA BETÉS, Jorge (2018). Power, control and social agency in postroman northern Iberia: an archaeological analysis of hill fort occupation. "Journal of Medieval Iberian Studies». 10: 3, 295-323.

TEJERIZO GARCÍA, Carlos; VIGIL-ESCALERA GUIRADO, Alfonso (2017). Castro Ventosa y La Cabeza de Navasangil: una revisión de sus secuencias de ocupación y el fenómeno de los asentamientos fortificados altomedievales. «Nailos. Estudios Interdisciplinares de Arqueología». 4, 126-161. 
TENTE, Catarina (2007). A ocupação alto-medieval da encosta noroeste da Serra da Estrela. Lisboa: Instituto Português de Arqueologia (Trabalhos de Arqueologia; 47).

TENTE, Catarina (2012). Settlement and territory in the Upper Mondego Basin (Centre of Portugal) between the $5^{\text {th }}$ century and the $11^{\text {th }}$ century. "Archeologia Medievale». XXXIX, 385-398.

TENTE, Catarina (2015). Tumbas rupestres en el Alto Mondego (Guarda, Portugal). Patrones de distribución, significados y construcción del paisaje rural altomedieval. «Munibe. AntropologiaArkeologia». 66, 271-290.

TENTE, Catarina (2017). Rock-cut graves and cemeteries in the medieval rural landscape of the Viseu region (Central Portugal). In BIS-WORCH, Christiane; THEUNE, Claudia, ed. Religion, cults and rituals in the medieval rural environment. Ruralia XI. Leiden: Sidestone Press, pp. 215-226.

TENTE, Catarina; LOURENÇO, Sandra (1998). Sepulturas medievais escavadas na rocha do concelho de Carregal do Sal e Gouveia: estudo comparativo. «Revista Portuguesa de Arqueologia». 1: 2, 191-218.

TENTE, Catarina et al. (2018a). Povoamento e modos de vida no limite oriental do territorio viseense durante o século X. O povoado de São Gens. In TENTE, Catarina, ed. Do império ao reino. Viseu e o territorio entre os séculos IV a XII. Viseu: Câmara Municipal de Viseu, pp. 197-228.

TENTE, Catarina et al. (2018b). O povoado do Penedo dos Mouros (Arcozelo, Gouveia) no contexto do século X no sector noroeste da Serra da Estrela. In TENTE, Catarina, ed. Do império ao reino. Viseu e o territorio entre os séculos IV a XII. Viseu: Câmara Municipal de Viseu, pp. 369-387.

TENTE, Catarina et al. (2018c). Senhora do Berrocal (Sátão) na viragem do milénio. Primeira abordagem. In TENTE, Catarina, ed. Do império ao reino. Viseu e o territorio entre os séculos IV a XII. Viseu: Câmara Municipal de Viseu, pp. 263-295.

THEUWS, Frans (1999). Changing settlement patterns, burial frounds and the symbolic construction of ancestors and communities in the late Merovingian Southern Netherlands. In FABECH, Charlotte; RINGTVED, Jytte, ed. Settlement and landscape. Aarhus: Jutland Archaeology Society, pp. 337-349.

THEUWS, Frans (2018). Rural cemeteries, cult places and community identities in the central Middle Ages in the Kempen region (Southern Netherlands). In VAN OOSTEN, Roos M. et al. The urban graveyard. Archaeological perspectives. Leiden: Sidestone Press, pp. 27-49.

TREFFORT, Cécile, ed. (2015). Le cimitiére au village dans l'Europe médiévale et moderne. Toulouse: Presses Universitaires du Midi.

VIEIRA, Marina (2004). Alto Paiva. Povoamento nas épocas romana e alto-medieval. Lisboa: Instituto Português de Arqueologia.

VIGIL-ESCALERA GUIRADO, Alfonso (2015). Los primeros paisajes altomedievales en el interior de Hispania. Registros campesinos del siglo quinto d.C. Bilbao: Universidad del País Vasco.

WILLIAMS, Howard (2003). Introduction. The archaeology of death, memory and material culture. In WILLIAMS, Howard, ed. Archaeologies of remembrance. Death and memory in past societies. Nueva York: Springer, pp. 1-23.

WILLIAMS, Howard (2006). Death and Memory in Early Medieval Britain. Cambridge: Cambridge University Press.

ZADORA-RIO, Elisabeth (2003). The making of churchyards and parish territories in the early medieval landscape of France and England in the 7th-12th centuries: a reconsideration. «Medieval Archaeology». 47, 1-19. 


\title{
OS ESTUDOS SOBRE SEPULTURAS ESCAVADAS NA ROCHA EM PORTUGAL, TRINTA ANOS DEPOIS
}

\author{
MÁRIO JORGE BARROCA*
}

\begin{abstract}
Resumo: A mudança de paradigma no estudo das sepulturas escavadas na rocha, ocorrida em Portugal há trinta anos, relançou o interesse por este tipo de estruturas arqueológicas. Desde então, têm-se multiplicado os contributos, com inventários e levantamentos realizados no âmbito de cartas arqueológicas, de investigações académicas ou de simples estudos regionais. A quantidade de dados acumulados nas últimas três décadas é significativa e vale a pena tentar fazer um ponto da situação dos conhecimentos adquiridos. É isso que tentaremos fazer neste texto, apresentando uma revisão bibliográfica sobre o tema, particularmente ao nível dos trabalhos académicos. Tentaremos, igualmente, apresentar os principais aspetos que estes monumentos funerários permitem abordar, desde as questões cronológicas, a sua filiação religiosa e as problemáticas relacionadas com a organização dos espaços de enterramento (cemiteriais ou não).
\end{abstract}

Palavras-chave: Sepulturas escavadas na rocha; Portugal; Investigações recentes.

\begin{abstract}
The change of paradigm in the study of rock-cut graves, which occurred in Portugal thirty years ago, has renewed the interest in these archaeological structures. Since then, contributions have multiplied, with inventories and surveys carried out in the context of archaeological maps, academic research or simple regional studies. The amount of data accumulated in the last three decades is significant and is worth trying to synthetize the acquired knowledge. In this paper we will present a bibliographic review on the topic, particularly concerning academic works. We will also present the main aspects related to these funerary monuments, from the chronological issues, their religious affiliation and the problems related to the organization of burial spaces (in cemeteries or not).
\end{abstract}

Keywords: Rock-cut graves; Portugal; Recent research.

Completaram-se, em 2017, trinta anos sobre a edição do nosso estudo Necrópoles e Sepulturas Medievais de Entre-Douro-e-Minho (Séculos V a XV), apresentado na Faculdade de Letras da Universidade do Porto no âmbito das Provas Públicas de Aptidão Pedagógica e Capacidade Científica, previstas na lei para progressão na carreira docente universitária nos casos das áreas científicas em que ainda não existiam cursos de mestrado ${ }^{1}$. A monografia que preparámos para essas provas debruçou-se sobre os testemunhos funerários do vasto espaço do Entre-Douro-e-Minho, abarcando os distritos de Viana do Castelo, Braga e Porto. Estruturado em três partes, o estudo consagrou a sua $2 .{ }^{a}$ Parte aos vestígios funerários do chamado período da Reconquista, que se desenvolve depois da Antiguidade Tardia e

* FLUP/DCTP; FLUP/CITCEM. Email: mbarroca@letras.up.pt.

${ }^{1}$ BARROCA, 1987. 
antes da plena Idade Média, grosso modo, entre os séculos IX e XI. Nesse estudo individualizámos uma série de sarcófagos sem solução antropomórfica e decorados com cruzes em relevo (cruzes apenas na cabeceira; ou cruzes duplas, na cabeceira e nos pés), bem como arcazes ornamentados com estruturas arquitetónicas (normalmente arcaturas), que associámos a essas recuadas centúrias. Analisámos e reenquadrámos, cronologicamente, as tampas em estola, galegas e portuguesas, que a maioria dos autores, na esteira de Manuel Chamoso Lamas, considerava serem «suévicas» e que, como então demonstrámos, pertencem a este período cronológico mais avançado, como eloquentemente nos provam diversos casos epigrafados, quer galegos, quer portugueses, dentro dos séculos X e XI. O exemplo mais recente, que se conserva no Mosteiro de Cête, foi criado em 1065 e reutilizado em 1117. E, por fim, chamámos a atenção para a riquíssima problemática que gravita em torno das sepulturas escavadas na rocha, maioritariamente enquadráveis dentro da cronologia acima referida, e que se configuram como um veículo privilegiado para o estudo das velhas matrizes de povoamento. Perdoe-se-me alguma imodéstia ao afirmar que, as mais de cem páginas que consagramos a estas sepulturas marcaram uma viragem na forma como os estudos arqueológicos portugueses passaram a olhar para estes testemunhos.

Passados trinta anos sobre a publicação desta obra, entendemos que seria interessante convocar uma reunião científica para discutir as problemáticas das sepulturas escavadas na rocha na fachada ocidental da Península Ibérica, realizando um pouco o contraponto ao congresso que Núria Molist e Gisela Ripoll organizaram no Museu de Olérdola, em 2009, em homenagem a Manuel Riu i Riu, intitulado Arqueologia funerária al nord-est peninsular entre els segles VI i XII ${ }^{2}$. Como essa reunião incidiu apenas sobre a área oriental da Península Ibérica - maioritariamente a zona da Catalunha - entendemos que se justificava uma nova reunião que dedicasse a sua atenção ao espaço atlântico da Península Ibérica, desde o mundo galego, asturiano e cantábrico até ao espaço algarvio e andaluz. E foi sob esse desígnio que surgiu a convocatória para o Congresso Internacional Sepulturas Escavadas na Rocha da Fachada Atlântica da Península Ibérica, que reuniu na FLUP, nos dias 19 e 20 de outubro de 2017. O nosso contributo estrutura-se em torno de quatro tópicos: uma revisão da bibliografia portuguesa mais recente sobre o tema; uma reflexão sobre os aspetos cronológicos (a origem e o abandono desta moda sepulcral); o contexto religioso a que corresponde este tipo de enterramentos; e os grandes modelos de organização espacial.

\footnotetext{
${ }^{2}$ MOLIST CAPELLA, RIPOLL, 2012.
} 


\section{PARA UMA REVISÃO BIBLIOGRÁFICA DO TEMA}

O estudo das sepulturas escavadas na rocha conheceu diferentes fases. Poderíamos dizer que existe uma fase inicial, que se estende desde as primeiras referências bibliográficas, do século XIX, até ao ano de 1968, em que a cronologia destes sepulcros foi objeto das mais díspares interpretações, que podiam ir desde os recuados tempos da Idade do Bronze até ao mundo romano ou posterior ${ }^{3}$. Essa fase, que podia ter sido ultrapassada em Portugal em 1934, fruto dos dados revelados em S. Pedro de Lourosa e na Sé Velha de Coimbra, prolongou-se até 1968, altura em que Alberto del Castillo apresentou, ao XI Congreso Nacional de Arqueologia, em Espanha, uma comunicação intitulada Cronologia de las tumbas llamadas Olerdola$n a s^{4}$, em que, pela primeira vez se demonstrou, de uma forma clara e inequívoca, a medievalidade de estes sepulcros. Os estudos de Castillo conheceram, ainda, uma segunda publicação determinante para o tema - o livro Excavaciones Altomedievales en las Provincias de Sória, Logroño y Burgos, integrado na coleção «Excavaciones Arqueológicas en España» e editado em 1972, onde aquele autor publicou os resultados das suas escavações nas extensas necrópoles de Duruelo de la Sierra, Revenga e Cuyacabras ${ }^{5}$. Baseando-se nestas três extensas necrópoles, Alberto del Castillo criou uma teoria evolucionista para as sepulturas escavadas na rocha, que partia de modelos arcaicos, não-antropomórficos (que atribuiu ao Século VII), para terminar em modelos complexos, antropomórficos (que datava dos Séculos IX-X e XI). Concorde-se ou não, a teoria de Alberto del Castillo marcou, definitivamente, os estudos de sepulturas escavadas na rocha. Os seus estudos haveriam de constituir a base para novas e diversificadas abordagens sobre as necrópoles rupestres peninsulares e, muito embora hoje estejam em muitos aspetos ultrapassados, o seu contributo foi inestimável.

Em Portugal, as principais linhas de força da tese de Castillo só começaram a ser difundidas e trabalhadas a partir dos anos oitenta. Surpreendentemente, os seus estudos demoraram mais de uma década a atrair a atenção dos investigadores portugueses... O primeiro estudo que se pode inscrever nesta nova fase foi realizado por nós, em colaboração com António Joaquim Cardoso Morais, sobre as sepulturas escavadas na rocha da zona da Terra de Aguiar da Pena, circunscrição territorial

\footnotetext{
${ }^{3}$ Como demonstrámos em 1987, Alberto Correia subscreveu a inverosímil cronologia dentro da «Idade do Bronze»; Emílio Hübner entendia que estes sepulcros eram «celtas» ou «iberos»; Augusto Filipe Simões e Aristides Amorim Girão consideravam serem «proto-históricos»; Simão Rodrigues Ferreira (a quem se deve o primeiro texto que publica sepulturas deste tipo em Portugal) e Santos Rocha defendiam que eram «romanos»; Francisco Martins Sarmento, José Leite de Vasconcelos, Rocha Peixoto, D. Domingos de Pinho Brandão e Fernando Lanhas declaravam-nos «pósromanos», "cristãos» ou "paleocristãos», sem precisarem muito melhor a datação; D. José Pessanha e Manuel de Aguiar Barreiros diziam-nos «bárbaros», talvez atribuindo ao período suevo-visigótico; e, por fim, Félix Alves Pereira e Vergílio Correia foram os únicos a proclamarem, de forma inequívoca, a sua medievalidade.

${ }^{4}$ CASTILLO, 1970.

${ }^{5}$ CASTILLO, 1972.
} 
medieval que correspondia grosso modo ao atual concelho de Vila Pouca de Aguiar e a parte do concelho de Ribeira de Pena ${ }^{6}$. Neste estudo inventariámos e estudámos as necrópoles do planalto do Alvão, tendo os dados sido revisitados e atualizados dois anos mais tarde, na publicação das escavações do castelo de Aguiar da Pena ${ }^{7}$. No ano seguinte, em 1987, apresentámos na Faculdade de Letras do Porto o estudo Necrópoles e Sepulturas Medievais de Entre-Douro-e-Minho ${ }^{8}$ onde, como referimos, o tema das sepulturas escavadas na rocha foi amplamente tratado, com uma abordagem teórica, de síntese, e com um inventário dos exemplares conhecidos para os três distritos em análise (Viana do Castelo, Braga e Porto). O interesse que esse capítulo suscitou, como se pode aferir pelas introduções e enquadramentos de vários trabalhos académicos publicados posteriormente, e a ausência de uma edição comercial da tese - que chegou a estar programada, mas que nunca se concretizou - levou-nos a publicar, mais tarde, uma versão revista desse capítulo, na "Portvgalia» ${ }^{9}$. De permeio estudámos diversos conjuntos sepulcrais, como os da zona de Baião ${ }^{10}$, os de Salvador do Monte (Amarante) ${ }^{11}$ e os dos concelhos raianos de Trás-os-Montes e de Riba Côa ${ }^{12}$. A convite da Biblioteca Municipal Rocha Peixoto, da Póvoa de Varzim, publicámos igualmente um trabalho sobre a posição defendida por Rocha Peixoto a propósito da cronologia das sepulturas escavadas na rocha, nas páginas da primeira série da revista "Portvgalia», que foi objeto de uma virulenta, e injusta, recensão crítica por parte de José Leite de Vasconcelos ${ }^{13}$.

Depois do nosso estudo de 1987, os trabalhos académicos que envolveram monograficamente o tema das sepulturas rupestres, ou nos quais estes sepulcros ocuparam uma parte significativa, foram-se alargando. Tentaremos arrolar, aqui, os principais estudos ao nível das dissertações de mestrado, cientes de que, saindo do restrito âmbito dos trabalhos académicos, a exaustividade seria impossível de alcançar.

Em 1996 Jorge Adolfo de Meneses Marques defendeu a sua dissertação de mestrado na Faculdade de Letras da Universidade do Porto, intitulada Sepulturas Escavadas na Rocha na região de Viseu, estudando uma ampla zona em torno da cidade de Viseu, abarcando os concelhos de S. Pedro do Sul, Castro Daire, Moimenta da Beira, Vila Nova de Paiva, Vouzela, Viseu, Sátão, Aguiar da Beira, Tondela, Carregal do Sal, Nelas, Mangualde, Penalva do Castelo, Fornos de Algodres e ainda a parte

\footnotetext{
${ }^{6}$ BARROCA, MORAIS 1983.

${ }^{7}$ BARROCA, MORAIS 1985-86.

${ }^{8}$ BARROCA, 1987. A parte relativa às sepulturas escavadas na rocha corresponde às páginas 103-175.

${ }^{9}$ BARROCA, 2010-2011.

${ }^{10}$ BARROCA, 1988.

${ }^{11}$ BARROCA, 1990.

12 BARROCA, 2008-2009.

${ }^{13}$ BARROCA, 2009.
} 
ocidental do concelho de Sernancelhe ${ }^{14}$. Ao todo foram inventariadas 543 sepulturas repartidas por 168 locais distintos. A maior parte das sepulturas correspondiam a exemplos isolados (53 locais com 1 sepultura) ou a núcleos muito reduzidos (45 locais com 2 ou 3 sepulturas). Apenas 30 estações arqueológicas tinham entre 4 e 10 sepulturas e, com mais de 10 sepulturas, só se identificaram 5 locais. Neste último grupo destacam-se, naturalmente, a necrópole das Forcadas (Matança, Fornos de Algodres), com 24 sepulcros, a necrópole da Tapada do Anjo (Fornos de Algodres), com 22 sepulturas, e a necrópole de Fornelos ou da Quinta da Raposeira (Sernancelhe), com 21 sepulcros. Para além destas necrópoles, destacam-se igualmente os cemitérios polarizados em torno de templos paroquiais, como é o caso da Igreja matriz de Mangualde, com os seus 44 sepulcros, e de outros templos onde não foi possível determinar a verdadeira extensão dos enterramentos, encontrados durante obras de restauro. Ao longo da sua dissertação, e do ponto de vista tipológico, Jorge Adolfo de Meneses Marques regista 178 sepulturas não-antropomórficas (32,8\%), 261 sepulturas antropomórficas (48,1\%), 92 sepulturas indeterminadas (16,9\%) e 12 sepulturas inacabadas $(2,2 \%)$. Posteriormente, o autor haveria de publicar diversos estudos consagrados ao tema ${ }^{15}$.

No mesmo ano de 1996, Ricardo Teixeira defendeu, também no Mestrado de Arqueologia da Faculdade de Letras da Universidade do Porto, uma dissertação intitulada De Aquae Flaviae a Chaves. Povoamento e organização do território entre a Antiguidade e a Idade Média, onde, entre muitos outros materiais, as sepulturas escavadas na rocha também foram objeto de atenção. Foram inventariadas 74 sepulturas escavadas na rocha na zona de Chaves, sendo 7 não-antropomórficas $(9,5 \%)$, 47 antropomórficas $(63,5 \%)$ e 20 de tipologia indeterminada $(27,0 \%)^{16}$.

No ano 2000, no Mestrado de Arqueologia da Faculdade de Letras da Universidade de Coimbra, Marina Afonso Vieira apresentou o estudo Alto Paiva. Povoamento nas épocas romana e alto-medieval, que viria a ser editado em $2004^{17}$. Ao longo desta obra foram inventariadas 87 sepulturas escavadas na rocha (mais 4 desaparecidas), onde se verifica uma larga predominância para as sepulturas que ignoram as soluções antropomórficas: 71 sepulturas são não-antropomórficas (49 ovaladas, 12 sub-retangulares, 6 retangulares e 4 trapezoidais), o que corresponde a 90,0\% dos exemplos estudados, e apenas 8 sepulcros optaram por soluções antropomórficas $(10,0 \%)^{18}$. Neste aspeto, a zona do Alto Paiva contrasta com a maior parte das regiões portuguesas já estudadas.

\footnotetext{
${ }^{14}$ A sua tese, com edição policopiada de 1996, foi editada em livro: MARQUES, 2000.

${ }^{15}$ Entre outros, MARQUES, 1991; MARQUES, 1997; MARQUES, GAMA 1995; MARQUES, 1999.

16 TEIXEIRA, 1996.

17 VIEIRA, 2004.

${ }^{18}$ VIEIRA, 2004: 131.
} 
Em 2002, Isabel Justo Lopes apresentou, no âmbito do Mestrado de Arqueologia da Faculdade de Letras da Universidade do Porto, uma dissertação intitulada Contextos Materiais da Morte durante a Idade Média: as necrópoles do Douro Superior ${ }^{19}$. Neste estudo, que se debruçou sobre concelhos das duas margens do curso superior do Douro português, foram inventariadas 455 sepulturas escavadas na rocha (71 a norte do Douro, correspondentes a 15,6\%; 396 a sul do rio, correspondentes a 84,4 \%). Para além de se verificar um peso muito distinto na distribuição do número total de sepulcros pelas duas margens do rio, verificou-se ainda uma diferença na opção (ou não) pelo antropomorfismo. Na realidade, a norte do Douro as sepulturas não-antropomórficas e antropomórficas encontravam-se em proporções relativamente equilibradas: 31 sepulcros são não-antropomórficos (43,7\%), 2 com antropomorfismo incipiente (2,8\%), 34 antropomórficos (47,9\%) e 4 indeterminados (5,6\%). Mas, a sul do Douro, a tendência para o antropomorfismo revela-se claramente predominante: 133 sepulcros são não-antropomórficos (34,6\%), 20 apresentam antropomorfismo incipiente $(5,2 \%)$ e 231 sepulturas são antropomórficas $(60,2 \%)^{20}$. Uma situação que contrasta com o panorama do vizinho Alto Paiva, definido pela tese de Mariana Afonso Vieira.

No ano de 2005 foram defendidas duas dissertações de Mestrado em Portugal onde o tema das sepulturas escavadas na rocha voltou a ser tratado de forma extensa.

No âmbito do Mestrado em Arqueologia da Faculdade de Ciências Sociais e Humanas da Universidade Nova de Lisboa, Catarina Tente apresentou um estudo sobre A ocupação alto-medieval da encosta noroeste da Serra da Estrela, onde, a par de outros testemunhos materiais, os sepulcros rupestres foram igualmente estudados $^{21}$. Foram inventariadas 158 sepulturas no espaço do Alto Mondego, na sua maioria integradas nos atuais concelhos de Celorico da Beira e de Gouveia. No que respeita à forma de organização, 14 sepulturas apresentam-se isoladas, 36 surgem em conjuntos de 2 ou 3 sepulturas (15 estações distintas) e 108 associadas em necrópoles com 5 a 22 sepulturas (12 estações arqueológicas). Nesta área salientam-se três necrópoles da freguesia de Mesquitela, Celorico da Beira - Tapada das Pedras, com 9 sepulturas; de Colícias, com 10 sepulturas; e de A-das-Pedras, com 14 sepulturas (esta com a particularidade de serem todas não-antropomórficas) e ainda a necrópole da Tapada do Anjo (Vila Ruiva, Fornos de Algodres), com 22

\footnotetext{
${ }^{19}$ LOPES, 2002.

${ }^{20}$ LOPES, 2002: I, 245 e 248.

21 TENTE, 2007a: 64-107.
} 
sepulturas $^{22}$. No conjunto das 158 sepulturas inventariadas, 60 são não-antropomórficas (38,0\%), 93 são antropomórficas $(58,8 \%)$ e 5 são indeterminadas $(3,2 \%)^{23}$.

No mesmo ano, mas em Coimbra, Sandra Lourenço apresentava a sua dissertação de mestrado sobre O povoamento alto-medieval entre os rios Dão e Alva, que conheceria edição impressa dois anos depois ${ }^{24}$. Neste estudo foram inventariadas e estudadas 255 sepulturas, correspondendo 105 ao espaço entre os rios Dão e Mondego (41,2\%) e 150 ao espaço compreendido entre o Mondego e o Alva (58,8\%). Do ponto de vista tipológico, as 105 sepulturas do primeiro interflúvio, repartidas por 46 sítios, correspondiam a 21 sepulturas não-antropomórficas $(20,0 \%)$ e a 84 antropomórficas (80,0\%). No segundo espaço, entre o Mondego e o Alva, os 150 sepulcros distribuem-se por 38 estações arqueológicas distintas e correspondem a 22 sepulturas não-antropomórficas (14,7\%), 11 com antropomorfismo incipiente (7,3\%), 71 sepulturas antropomórficas $(47,3 \%)$ e 46 de tipologia não determinada $(30,7 \%)$.

Em 2008 Luís Miguel Guerreiro Cabrita apresentou uma dissertação de Mestrado à Faculdade de Ciências Sociais e Humanas da Universidade Nova de Lisboa, intitulada Povoamento Alto Medieval de São Bartolomeu de Messines, onde abordou o povoamento tardo-antigo daquela freguesia do concelho de Silves ${ }^{25}$. A sua tese seria editada seis anos depois e constitui o estudo monográfico mais meridional que possuímos, em Portugal, sobre o tema das sepulturas escavadas na rocha ${ }^{26}$. A freguesia de S. Bartolomeu de Messines abarca uma área muito ampla - correspondendo a cerca de um terço do espaço do concelho de Silves - e no seu âmbito foram identificadas 43 sepulturas escavadas na rocha repartidas por dez estações arqueológicas. Cinco dessas estações são compostas por um único monumento, isolado, enquanto as restantes correspondem a necrópoles compostas por 3 a 18 sepulturas (sendo o valor mais elevado atingido na Necrópole da Amorosa). Todas as 43 sepulturas rupestres estudadas são não-antropomórficas e muitas apresentam um largo rebordo para colocação de tampa. Mais à frente, quando discutirmos o âmbito cronológico deste tipo de enterramentos voltaremos a este estudo, uma vez que ele encerra dados muito interessantes.

\footnotetext{
22 Para além do seu Mestrado, Catarina Tente tem muitos estudos em torno da temática das sepulturas escavadas na rocha, nomeadamente: TENTE, MARTINS, 1994; TENTE, LOURENÇO, 1998, 2002; TENTE, 2000, 2007a, 2007b, 2007c, 2011, 2012, 2015, 2017; TENTE, CARVALHO, 2015; BROOKES, TENTE, PRATA, 2017.

23 TENTE, 2007a: 88.

${ }^{24}$ LOURENÇO, 2007.

${ }^{25}$ CABRITA, 2008.

${ }^{26}$ CABRITA, 2014. O ponto 4 (pp. 77-166) é integralmente dedicado às sepulturas escavadas na rocha. O tema já fora tratado pelo mesmo autor em CABRITA, 2011.
} 
Em 2012 Sara Prata estudou os vestígios funerários dos concelhos de Marvão e de Castelo de Vide, no âmbito do seu mestrado na Faculdade de Ciências Sociais e Humanas da Universidade Nova de Lisboa ${ }^{27}$. A zona, que já tinha sido estudada, há muitos anos, por Maria da Conceição Rodrigues ${ }^{28}$ e depois por José Caeiro ${ }^{29}$, seria finalmente objeto de uma análise segundo as metodologias mais recentes, permitindo identificar dois grandes universos funerários - um, constituído por sepulturas de pedras avulsas, associado a materiais da Antiguidade Tardia, hispano-visigóticos, que é predominante na zona de vale; outro, comportando sepulturas escavadas na rocha, predominante nas zonas mais elevadas, da Serra de S. Mamede. Dentro deste último grupo foram inventariadas 166 sepulturas escavadas na rocha, sendo 59 não-antropomórficas (35,6\%), 96 antropomórficas (57,8\%) e 11 de tipologia indeterminada $(6,6 \%)$. As suas conclusões foram retomadas dois anos mais tarde, em estudo publicado em $2014^{30}$.

Por fim, registemos a mais recente dissertação de mestrado defendida sobre o tema das sepulturas escavadas na rocha em Portugal, que se ficou a dever a César Leandro Pereira Guedes e que foi submetida no âmbito do Mestrado em Arqueologia da Faculdade de Letras da Universidade do Porto ${ }^{31}$. César Guedes estudou as sepulturas rupestres entre os rios Távora e Cabrum, ou seja, ao longo dos concelhos de Tabuaço, Armamar, Tarouca, Lamego e Resende. Ao todo foram inventariadas 88 sepulturas: 45 no âmbito do concelho de Tabuaço; 12 no de Armamar; 6 no de Tarouca; outras 6 no de Lamego; e 19 no concelho de Resende. Tipologicamente 49 sepulturas são não-antropomórficas (55,7\%), 25 antropomórficas $(28,4 \%)$ e 14 indeterminadas $(15,9 \%)$.

Acrescente-se, a terminar, o relatório de Estágio apresentado por Ana Sofia Silva Pereira na Faculdade de Ciências Sociais e Humanas da Universidade Nova de Lisboa, que georreferenciou as sepulturas dos concelhos de Oliveira do Hospital, Penacova, Tábua, Aguiar da Beira, Celorico da Beira, Fornos de Algodres, Gouveia, Seia, Carregal do Sal, Mangualde, Nelas, Oliveira de Frades, Penalva do Castelo, Santa Comba Dão, S. Pedro do Sul, Satão, Tondela, Vila Nova de Paiva, Viseu e Vouzela ${ }^{32}$.

A situação resultante de todos estes estudos académicos pode ser sintetizada no seguinte quadro:

\footnotetext{
${ }^{27}$ PRATA, 2012.

${ }^{28}$ RODRIGUES, 1975, 1978.

${ }^{29}$ CAEIRO 1984a, 1984b.

${ }^{30}$ PRATA, 2014.

${ }^{31}$ GUEDES, 2015.

32 PEREIRA, 2015.
} 
Tabela 1. Dissertações de Mestrado com estudo de sepulturas escavadas na rocha em Portugal

\begin{tabular}{l|c}
\multicolumn{1}{c|}{ Autor } & N.o Sep. estudadas \\
\hline Jorge Adolfo de Meneses Marques (1996) & 543 \\
\hline Ricardo Teixeira (1996) & 74 \\
\hline Marina A. Vieira (2000) & 87 \\
\hline Isabel Justo Lopes (2002) & 455 \\
\hline Catarina Tente (2005) & 163 \\
\hline Sandra Lourenço (2005) & 255 \\
\hline Luís Miguel Cabrita (2008) & 43 \\
\hline Sara Prata (2012) & 166 \\
\hline César Guedes (2015) & 88 \\
\hline TOTAL & $\mathbf{1 8 7 4 ~ S e p . ~}$ \\
\hline
\end{tabular}

Fonte: Mário Jorge Barroca

Saindo do âmbito das dissertações académicas, registemos alguns concelhos com levantamentos publicados. É o caso de Fafe ${ }^{33}$, de Penafiel ${ }^{34}$, do Marco de Canaveses ${ }^{35}$, de Lousada ${ }^{36}$, de Vila Real ${ }^{37}$, de Vila Pouca de Aguiar ${ }^{38}$, de Sernancelhe ${ }^{39}$, de Fornos de Algodres $^{40}$, de Seia ${ }^{41}$, de Carregal do Sal e de Gouveia ${ }^{42}$ e de Mangualde ${ }^{43}$. Ou de algumas freguesias que, pela sua extensão e pelo número de sepulcros, merecem destaque, como é o caso da freguesia do Rosmaninhal (concelho de Idanha-a-Nova $)^{44}$. E não entraremos, aqui, no domínio das Cartas Arqueológicas, várias das quais apresentam dados sobre sepulturas rupestres.

Por fim, apontemos um ou outro caso de estudos monográficos, sem a preocupação de sermos exaustivos, mas atendendo apenas ao interesse que eles suscitam. É o caso da Necrópole do Senhor da Boa Morte, em Vila Franca de Xira, com as suas sepulturas antropomórficas com encaixes para estelas discoides ${ }^{45}$, situação que

${ }^{33}$ MACHADO, 2019. Publica as 5 sepulturas escavadas na rocha do concelho de Fafe (4 antropomórficas e 1 não-antropomórfica).

${ }^{34}$ SANTOS, 2005, inventaria 22 sepulturas escavadas na rocha no concelho de Penafiel.

${ }^{35}$ QUEIRÓS, 2011.

${ }^{36}$ NUNES, SOUSA, GONCALVES, 2006, 2008.

${ }^{37}$ ALMEIDA, 2009. A Autora inventaria 10 locais com um total de 27 sepulturas escavadas na rocha, mais 9 locais com referências a sepulturas entretanto desaparecidas.

${ }^{38}$ BARROCA, MORAIS, 1983, 1985-86.

${ }^{39}$ Embora com um enquadramento cronológico absolutamente surreal, vd. CORREIA, 1976.

${ }^{40}$ VALERA, 1990.

${ }^{41}$ RIBEIRO, SILVA, 1997. Os autores inventariam 23 sepulturas escavadas na rocha: 5 não-antropomórficas e 18 antropomórficas.

${ }^{42}$ TENTE, LOURENÇO, 1998. As autoras inventariam 63 sepulturas escavadas na rocha em Gouveia e 24 em Carregal do Sal, sendo 11 não antropomórficas $(12,6 \%)$ e 76 antropomórfica $(87,4 \%)$.

43 TAVARES, 1999, 2007.

${ }^{44}$ CHAMBINHO, HENRIQUES, CANINAS, 2015. Os autores publicam 47 sepulturas escavadas na rocha: 1 isolada, 7 sepulturas em conjuntos de 2 ou 3 sepulturas, e 39 sepulturas em 5 necrópoles.

${ }^{45}$ SANTOS, 1991-92. Esta necrópole e os encaixes para estelas discoides já tinham sido referidos por Vergílio Correia (CORREIA, 1946: 101). 
encontra paralelo nas sepulturas da Capela de S. Miguel, em Monsanto, em algumas sepulturas da necrópole da Malpartida (Almeida) ou em sepulturas de Jugueiros (Viseu) e de Alpendurada (Marco de Canaveses). Ou da Necrópole da Igreja de S. Pedro de Marialva, escavada por Maria Antónia Amaral, que foi, durante algum tempo, a mais extensa necrópole de sepulturas escavadas na rocha em Portugal ${ }^{46}$. A necrópole de $\mathrm{S}$. Pedro de Marialva destronou, nessa condição, a Igreja de St. ${ }^{a}$ Marinha de Moreira de Rei que, com mais de meia centena de sepulcros visíveis, foi durante muitos anos o mais extenso caso em território português. Mas o número total de sepulturas de $\mathrm{S}$. Pedro de Marialva foi largamente suplantado por esta mesma necrópole de Moreira de Rei que, em escavações recentes, ainda em curso, já ultrapassou as cinco centenas de sepulturas, tornando-se, assim, a mais extensa necrópole de sepulturas escavadas na rocha em Portugal e, até, julgamos nós, na Península Ibérica.

Por fim, não podemos deixar de registar os recentes contributos de Iñaki Martín Viso, que assinou algumas das mais estimulantes reflexões sobre as sepulturas escavadas na rocha no espaço da Beira portuguesa ${ }^{47}$.

\section{QUE ENQUADRAMENTO CRONOLÓGICO?}

Neste segundo tópico de reflexão abordaremos o enquadramento cronológico das sepulturas escavadas na rocha, procurando averiguar quando surgiram os primeiros exemplos e até quando perdurou esta moda de enterramento.

A questão das origens das sepulturas rupestres continua a ser objeto de debate entre os investigadores. Como se sabe, Alberto del Castillo defendia que as primeiras sepulturas escavadas na rocha, de tipologia não antropomórfica (ovaladas, trapezoidais ou retangulares), deviam ser atribuídas aos séculos VII/VIII e que as sepulturas antropomórficas seriam coevas da «Reconquista» e do «Repovoamento»:

Esta forma [antropomórfica] de tumbas parece privativa hispânica y hay que situarla en relación com la Reconquista y la Repoblación. Conocemos tumbas excavadas en la roca de la época tardorromana y visigótica. Pero son de forma rectangular o de bañera, no antropomorfas ${ }^{48}$.

O seu principal argumento para atribuir os sepulcros não-antropomórficos à fase final da monarquia visigótica era o caso de Sant Vicens de Obiols, onde Castillo tinha encontrado, em 1960, um triente de Égica (697-702) no interior de uma

\footnotetext{
${ }^{46}$ AMARAL, 2001; CUNHA, UMBELINO, TAVARES, 2001. Foram escavadas 86 sepulturas, correspondendo a 140 enterramentos, sendo 6 não-antropomórficas (7\%) e 80 antropomórficas (93\%). A escavação forneceu numismas de D. Afonso III a D. Sebastião e tem datação absoluta de C14 dentro do século XV: 1401-1497 cal AD (93,4\% prob.) (cf. TENTE, CARVALHO, 2015: 131).

${ }^{47}$ MARTÍN VISO, 2005-2006, 2007, 2011, 2012a, 2012b, 2016, 2017.

${ }^{48}$ CASTILLO 1970: 838.
} 
sepultura ovalada ${ }^{49}$. Mas o valor cronológico deste exemplo é muito discutível. Com efeito, Castillo não escavou o adro de Obiols. Procedeu a uma limpeza do interior da sepultura, para o seu registo, e foi então que, nas suas palavras, a moeda apareceu «en el rincón del fundo», ou seja, no fundo do sepulcro. Tal foi suficiente para associar as sepulturas ovaladas à «última época visigótica» e escrever: «El origen visigótico de las tumbas olerdolanas no parece ofrecer duda». No entanto, devemos assumir que o valor cronológico desta moeda é muito questionável. Com efeito, a sepultura não estava intacta, mas fora violada e esvaziada do seu conteúdo, e não é claro que os sedimentos que estavam no fundo da cavidade sepulcral fossem coevos do enterramento. Poderiam resultar de intrusões mais recentes, sedimentos que tivessem escorregado para o interior da cavidade quando esta já se encontrava a descoberto, o que será a situação mais provável. De resto, a colocação de uma moeda no fundo do sepulcro é uma situação pouco usual, porque normalmente o numisma, resquício da velha prática do óbolo a Caronte, era colocado sobre o corpo do morto (nas suas mãos, na sua face, sobre os olhos, no interior da boca), mas não por baixo do corpo, como seria neste caso (uma vez que a moeda apareceu colada ao fundo da sepultura). Por outro lado, o triente de Égica não assegura a contemporaneidade da sepultura com o reinado deste monarca visigodo. Quando muito, indicaria que o sepulcro era contemporâneo ou posterior a ele. De resto, seria interessante saber se o numisma apresentava (ou não) sinais de desgaste por circulação, o que poderia indiciar se a ocultação ocorreu pouco depois da sua cunhagem ou se foi realizada num período mais afastado, depois de a moeda ter circulado. Em suma, o argumento de Castillo parece-nos demasiado frágil.

No entanto, alguns autores avançaram com novos dados que recomendam cronologias em torno dos finais do século VII para os primeiros exemplos de sepulturas rupestres.

Jorge López Quiroga defendeu, em diversos estudos seus, uma origem tardo-antiga para as sepulturas escavadas na rocha não-antropomórficas, a que atribuiu uma cronologia «a lo largo del siglo VII» ${ }^{50}$. Entre os exemplos que invocou em abono da sua ideia salienta-se a Sepultura 7 da Necrópole de Gerena (Sevilha), uma sepultura que, no entanto, apresenta uma cabeceira quadrangular, sendo, portanto, antropomórfica. A Necrópole de Gerena tem sido datada dos séculos V-VII e forneceu inscrições datadas dos anos de 652 e 662. Outro exemplo convocado por Jorge López Quiroga foi o da basílica de El Tolmo de Minateda (Hellín, Albacete), erguida no século VII e escavada por Sónia Gutiérrez Lloret ${ }^{51}$. Em torno desta basílica, alinhadas na zona da cabeceira e na fachada ocidental do templo, foram criadas várias sepulturas escavadas

\footnotetext{
${ }^{49}$ CASTILLO, 1970: 838.

${ }^{50}$ LÓPEZ QUIROGA, 2004, 2010; LÓPEZ QUIROGA, GARCÍA PÉREZ, 2014 (de onde retiramos a frase citada, p. 37).

${ }^{51}$ GUTIÉRREZ LLORET, ABAD CASAL, GAMO PARRAS, 2004; GUTIÉRREZ LLORET, GAMO PARRAS, 2017.
} 
na rocha, de contorno retangular ou trapezoidal, sem sintomas de antropomorfismo e dotadas de largos rebordos para encaixe da tampa. Segundo Jorge López Quiroga, uma das sepulturas «ha sido objeto de una datación por C14 que proporciona una fecha calibrada de AD 602-674». E acrescenta: «Además, se han documentado cuatro tremisses de Witiza fechados a princípios del siglo VIII» ${ }^{52}$. Depois de analisar estes, e outros exemplos, Jorge López Quiroga concluiu:

En definitiva, el origen del tipo de inhumación que conformam las tumbas excavadas en la roca arranca del final de la tardo-antigüedad $y$, en funcion de las evidencias materiales y dataciones absolutas de C14 con las que contamos, concretamente en el siglo VII. En todos casos señalados estamos ante tumbas excavadas en la roca de forma rectangular, oval y/o de bañera, y trapezoidales, lo que corrobora, con datos arqueológicos contratados, la cronologia propuesta por Alberto del Castillo a partir exclusivamente de la tipologia de las inhumaciones ${ }^{53}$.

No Sul de Portugal também encontramos dados que corroboram uma cronologia dentro da Antiguidade Tardia para algumas sepulturas escavadas na rocha de configuração não-antropomórfica. A Necrópole do Poço dos Mouros (Alcantarilha, Silves), escavada e publicada por Mário Varela Gomes, é composta por 8 sepulturas escavadas na rocha de tipo não-antropomórfico (ovaladas ou sub-retangulares), com largos rebordos rebaixados, para encaixe de tampa, as quais forneceram espólio votivo tipicamente hispano-visigótico, nomeadamente as usuais vasilhas próprias para líquidos, o que não deixa dúvidas quanto à cronologia desta pequena necrópole ${ }^{54}$.

Estudando sepulturas rupestres de São Bartolomeu de Messines, no mesmo concelho, Luís Miguel Cabrita também defendeu que as sepulturas não-antropomórficas escavadas na rocha eram, no Algarve, «tardo-romanas ou visigóticas». O seu argumento de maior peso é a Sepultura 12 da Necrópole de Amorosa, que forneceu espólio osteológico que foi datado por C14, tendo fornecido uma datação de 1290 $\pm 40 \mathrm{BP}$, o que calibrado a $2 \sigma(95 \%$ probabilidade $)$ corresponde a $660-780 \mathrm{cal} \mathrm{AD}^{55}$ ou a 652-778 cal $\mathrm{AD}(91,8 \%)^{56}$.

Estes dados não colidem com o que outras estações arqueológicas têm vindo a revelar. Já em 1987 tínhamos tido oportunidade de sublinhar que, nas escavações do Convento de St. ${ }^{a}$ Marinha da Costa (Guimarães), havia um pequeno conjunto de sepulturas escavadas na rocha que tinham sido truncadas pela construção do templo

\footnotetext{
${ }^{52}$ LÓPEZ QUIROGA, GARCÍA PÉREZ, 2014: 41.

${ }^{53}$ LÓPEZ QUIROGA, 2010: 332; LÓPEZ QUIROGA, GARCÍA PÉREZ, 2014: 45.

${ }^{54}$ GOMES, 2002.

${ }^{55}$ CABRITA, 2014: 163. A Necrópole da Amorosa é tratada nesta obra, pp. 99-111 e a sepultura 12 na p. 107.

56 TENTE, CARVALHO, 2015: 132.
} 
II da Costa, a igreja asturiana erguida no último quartel do século IX. Essas cavidades sepulcrais tinham, por isso, de estar associada ao templo I da Costa, o templo que Manuel Real atribuiu ao período suevo-visigótico ${ }^{57}$.

Na zona do vale do Douro, as escavações que António Manuel P. Silva, J. A. Gonçalves Guimarães, Laura Sousa e Filipe Pinto têm vindo a realizar no Castelo de Crestuma (Crestuma, Vila Nova de Gaia), têm vindo a revelar uma importante estação arqueológica da Antiguidade Tardia, com abundantes materiais cerâmicos desta época (T.S. Clara D, Foceense, etc.) e cerâmicas posteriores (séculos X-XI). Entre as múltiplas estruturas rupestres criadas no substrato xistoso daquele morro regista-se uma sepultura escavada na rocha implantada na plataforma superior do monte. Trata-se de uma sepultura retangular, não-antropomórfica, com largo e profundo encaixe de tampa, a recordar alguns exemplos meridionais e de cronologias antigas.

Em suma, parece que podemos assumir que as sepulturas escavadas na rocha de tipo não-antropomórfico (ovaladas, retangulares, trapezoidais), particularmente aquelas que apresentam largos encaixes de tampa, muito rebaixados, podem ter uma origem que remonta ao século VII.

A partir de certa altura, as sepulturas não-antropomórficas passaram a conviver com sepulturas antropomórficas. Alberto del Castillo entendia que as diferenças tipológicas exteriorizavam cronologias diversas e, com base neste pressuposto, criou um quadro cronotipológico de matriz evolutiva, partindo de modelos mais simples e «arcaicos», para terminar em modelos mais complexos e «evoluídos». Esta era uma visão simplista do problema. Na realidade, estudos posteriores demonstraram ser seguro que a diferenciação tipológica não exterioriza necessariamente diferenças cronológicas. Parece claro que há tipologias que têm uma particular aceitação em algumas estações ou regiões, o que levou a que tenham sobrevivido durante mais tempo. E que, pelo contrário, há necrópoles que revelam uma pluralidade de soluções tipológicas, algumas seguramente convivendo no mesmo tempo. E se, como acabamos de ver, os casos mais antigos sugerem que as primeiras tipologias são não-antropomórficas, estamos longe de poder dizer que todas as sepulturas rupestres retangulares ou trapezoidais pertencem a uma época tão recuada. Ou, sequer, que o aparecimento e triunfo do antropomorfismo se traduziu no abandono das tipologias não-antropomórficas. A realidade é muito mais complexa...

Passemos, agora, para a segunda questão que gostaríamos de abordar: até quando perduraram as sepulturas escavadas na rocha (não-antropomórficas e antropomórficas)? Alberto del Castillo entendia que a partir do Século XI, quando as sepulturas escavadas na rocha tinham atingido as suas configurações mais elaboradas - com antropomorfismo axial perfeito, com o aparecimento de um desnível entre a cabeceira

${ }^{57}$ BARROCA, 1987: 137-139; 2010-2011: 143-145. Sobre a cronologia deste templo, veja-se REAL 1985: 9-11. 
e o corpo para apoio do occipital e com o desenvolvimento de rebordos alteados -, se teria passado para os sarcófagos. Terá sido assim? Não cremos. Há dados suficientes para podermos dizer que a criação e a utilização de sepulturas escavadas na rocha ultrapassaram em muito os finais do século XI. De resto, a teoria de Castillo partia do princípio que não existiam sarcófagos monolíticos entre os séculos VIII e $\mathrm{XI}$, ou seja, durante o período áureo das sepulturas escavadas na rocha, e que o seu regresso, a partir do século XII, teria resultado de uma evolução encetada a partir da fase final das sepulturas escavadas na rocha. Hoje sabemos que esta premissa é redondamente falsa. Temos abundantes testemunhos de sarcófagos anteriores ao século XI, que conviveram cronologicamente com o uso de sepulturas rupestres. Isto significa que, nesta altura, como em qualquer outra época da História, não existia uma só tipologia de enterramento, mas havia uma pluralidade de opções que tinham a ver com a presença (ou ausência) de afloramentos rochosos, com o poder económico do defunto ou da sua família, com a opção tomada para a localização da sepultura, com a vontade de exposição do sepulcro, ou com simples opções de foro privado e pessoal...

$\mathrm{Na}$ Galiza, as escavações conduzidas por Manuel Chamoso Lamas e José Guerra Campos na catedral de Santiago de Compostela, entre 1949 e 1956, forneceram alguns dados interessantes para esta questão ${ }^{58}$. Comecemos por sublinhar que não há nenhum elemento seguro que indique que, antes da construção do primeiro templo de Compostela, já existissem aqui enterramentos. Pelo contrário, todos os dados indicam que a grande necrópole revelada pelas escavações arqueológicas de 1949-56 diz respeito ao santuário de peregrinação, que foi rapidamente ganhando dimensão e prestígio. Com efeito, a imensa maioria das sepulturas - sejam sepulturas escavadas na rocha, sejam sepulturas com as caixas ferais definidas por lajes, sejam sarcófagos monolíticos - distribuem-se em torno do templo de Afonso III (Compostela II), sagrado em 899. Associada de forma clara e inequívoca ao templo de Afonso II (Compostela I), sagrado em 829 , só encontramos uma sepultura, e por sinal escavada na rocha, que ficou selada pelo narthex do templo de Afonso III. As sepulturas escavadas na rocha concentram-se no braço sul do transepto, que era a zona onde o afloramento rochoso era mais superficial. Na zona em frente do templo de Afonso III, onde os sedimentos tinham uma maior potência, a opção foi sobretudo para sepulturas de pedras avulsas já que, se se quisesse criar sepulcros rupestres, seria necessário escavar muito até se atingir o substrato rochoso. Na zona do braço sul do transepto, as sepulturas escavadas na rocha convivem com alinhamentos de muros de uma villa romana, que aqui existiu. Chamoso Lamas e José Guerra Campos entendiam que,

\footnotetext{
${ }^{58}$ Sobre as escavações de Santiago de Compostela veja-se CHAMOSO LAMAS, 1956a, 1956b, 1957; e a extensa monografia de GUERRA CAMPOS, 1982. Vd. também a nossa revisão crítica das escavações de Compostela em BARROCA, 1987: 225-230.
} 
porque se alinhavam com os muros romanos, as sepulturas escavadas na rocha eram «tardo-romanas» (sic), não compreendendo que, até pelo simples facto de conviverem no mesmo espaço, era impossível que a estrutura da villa e os enterramentos fossem contemporâneos. Como a interpretação de Manuel Chamoso Lamas e de José Guerra Campos obedecia a um esquema sequencial, para estes autores as tampas em estola, que surgiam a uma cota superior, seriam suévicas...

A revisão crítica das escavações de Santiago de Compostela revela que na fase inicial do culto ao Apóstolo, os templos I e II de Compostela começaram a cativar um número crescente de crentes, que elegeram este espaço para sua última morada. Nessa fase mais recuada, conviveram diferentes modas de enterramento: sepulturas escavadas na rocha, nas zonas onde os afloramentos rochosos eram mais superficiais; sepulturas de pedras avulsas onde os sedimentos tinham maior potência; e sarcófagos monolíticos, alguns cobertos com tampas em estola, que, ao contrário das anteriores modalidades sepulcrais, não se destinavam a ficar enterrados, encobertos pelos sedimentos, mas que eram peças aparentes, pousadas à superfície do terreno e visíveis. Só com o início da obra românica, quando foi necessário libertar o espaço envolvente do templo de Afonso III, é que se procedeu ao seu enterramento. Em vários casos esse processo levou ao corte do pavimento do templo de Afonso III ou do anexo norte, onde se localizava o batistério. As escavações de Santiago de Compostela forneceram um importante conjunto de tampas epigrafadas: Teodomiro $(\dagger 847)$, Aroaldo $(\dagger 885)$, Floro ( $\dagger$ na Era DCCCCX...), Vandila ( $\dagger 979)$, Anastásio ( $†$ 985), Ermegildo ( $†$ 1030), Martinho ( $† 1047)$, Vidramiro ( $\dagger 1058)$, Dagaredo $(\dagger$ 1062) e Mendo (†1072). As tampas mais antigas correspondem a cenotáfios — isto é, não são originais contemporâneos da data indicada, mas monumentos criados mais tarde, para dar sepultura condigna. A tampa de Teodomiro, oficialmente a pessoa que «descobriu» o túmulo do Apóstolo, foi criada no século X. A tampa de Aroaldo cobria um sarcófago antropomórfico. A tampa de Anastásio, na capela adossada a sul do templo, não estava associada a nenhum enterramento. Pousava apenas sobre o solo do mausoléu. O que esta notável sequência epigráfica compostelana nos revela é que, iniciada a obra românica, a partir de 1075, e definido o novo perímetro sagrado, o cemitério de Compostela mudou de local. Passou para o espaço exterior ao perímetro da obra românica.

Vejamos, então, o que as escavações de Compostela nos trazem para o nosso tema. As sepulturas escavadas na rocha concentram-se a sul e a oeste dos templos de Afonso II (sagrado em 829) e de Afonso III (sagrado em 899). Não invadem o espaço interior dos dois templos e apenas uma se encontra no átrio de Afonso III, sendo anterior a ele e, portanto, coeva do templo de Afonso II, podendo ser datada de [829-899]. O recinto funerário de Anastásio († 985) foi erguido sobre uma sepultura escavada na rocha, mas este espaço parece ser obra posterior à sepultura. A sepultura 
não está, de resto, no alinhamento da tampa de Anastásio, que se implanta muito acima dela, pousada na terra. Mas as tampas de Vandila ( $†$ 979), de Martinho ( $\dagger$ 1047) e de Dagaredo ( $\uparrow 1062)$ cobriam sepulturas escavadas na rocha, de tipologia antropomórfica, e tudo indica que seriam coevas do enterramento. Ou seja, em Santiago de Compostela as sepulturas escavadas na rocha foram utilizadas a partir de 814 (data da inventio do túmulo do Apóstolo) ou de 829 (data da sagração do templo I), em conexão com o templo de Afonso II, e continuavam a ser criadas em 1062, em torno do templo de Afonso III reconstruído por D. Pedro de Mezonzo na sequência da destruição causada pela investida de al-Mansur, em 997. Se continuaram a ser criadas depois de 1075 não o sabemos: o cemitério deslocou-se para fora do perímetro arquitetónico da Catedral e não foi abrangido pelas escavações de Manuel Chamoso Lamas e de José Guerra Campos.

Analisemos agora alguns casos portugueses onde a criação de sepulturas escavadas no substrato rochoso continuou a ser praticada muito depois dos finais do século XI. Comecemos pela Igreja de S. Pedro de Lourosa, que nos faculta alguns dados cronológicos para a origem e para a longa diacronia das sepulturas escavadas na rocha. A Igreja de Lourosa está datada por uma epígrafe que indica a Era de 950 (AD 912). É, portanto, um ano anterior a S. Miguel de Escalada (igreja iniciada em 913 e sagrada em 914). Durante o processo de restauro, conduzido pela DGEMN e largamente documentado pelo fotógrafo Marques Abreu, foi desmontado o campanário gótico, que se erguia à esquerda da fachada principal do templo, e que foi deslocado alguns metros para leste, para as traseiras da igreja ${ }^{59}$. Ao desmontar-se o campanário verificou-se que o mesmo selava um pequeno conjunto de sepulturas escavadas na rocha. O restauro implicou o levantamento de todo o pavimento da igreja. No interior do templo o afloramento rochoso revelou-se pejado de enterramentos rupestres, em número que, infelizmente, não foi devidamente registado. As fotografias do arquivo da DGEMN mostram a nave do templo cheia de enterramentos rupestres, e uma planta regista outras sepulturas mais à frente, na zona onde, outrora, se implantara a iconostasis. Esta foi demolida com a reforma românica da igreja de Lourosa, também datada epigraficamente, ocorrida em 1189. Isto significa que, em Lourosa da Serra, as sepulturas escavadas na rocha começaram a ser criadas por volta do ano de 912, mas que continuavam a ser modalidade de enterramento em 1189 e depois desta data, a ponto de se terem criado novos sepulcros na zona onde antes se apoiava a parede da iconostasis.

O segundo caso que revela a persistência do uso de sepulturas rupestres nos finais do século XII ou até em períodos mais avançados é a Sé Velha de Coimbra. A demolição do patim de acesso ao templo, substituído pela atual escadaria que serve

\footnotetext{
${ }^{59}$ Sobre o restauro de S. Pedro de Lourosa veja-se FERNANDES, 2002.
} 
a porta ocidental, permitiu colocar a descoberto uma série de sepulturas escavadas na rocha, de que António de Vasconcelos nos deixou uma planta ${ }^{60}$. Na sua planta é possível verificar que o alinhamento da fachada românica veio truncar sepulturas antropomórficas escavadas na rocha ${ }^{61}$. A construção da fachada românica pertence aos meados da segunda metade do século XII. Nela já se trabalhava no tempo do bispo D. Miguel Salomão, que foi o grande dinamizador da fábrica românica e que abdicou da cadeira episcopal em 1176. Nessa altura a obra já estava numa fase muito avançada ${ }^{62}$. As sepulturas truncadas pertenciam, portanto, ao cemitério que se polarizava em torno da igreja pré-românica de Coimbra. Mas, depois da fachada da Sé Velha ter sido construída, novas sepulturas foram criadas, agora alinhadas pela nova parede ocidental. A planta divulgada por António de Vasconcelos é bem clara e até revela que havia um ligeiro desvio axial entre os sepulcros da primeira e da segunda fase. Os enterramentos da primeira fase seguiam a orientação do curso solar; os da segunda fase foram alinhados pelos muros da nova construção. Portanto, em Coimbra, no último quartel do século XII, ou até numa fase um pouco mais avançada, ainda se criavam sepulturas escavadas na rocha.

Outro exemplo igualmente tardio é o do claustro do convento de Santa Marinha da Costa. Aqui, a última fase de sepulturas escavadas na rocha, que preenche a ala leste do claustro, está claramente alinhada com a estrutura claustral, que foi erguida nos inícios do século XIII. Isto significa que, na Costa, em pleno século XIII, se continuava a criar sepulturas rupestres, o que se explica pela escassa potencia estratigráfica que existia naquela zona do claustro, o que implicava que qualquer enterramento teria de ser rebaixado no substrato rochoso.

No adro da Sé do Porto, quando se fizeram escavações na década de 1940, apareceram diversas sepulturas escavadas na rocha contendo ceitis de D. Afonso V e encerradas com materiais tardo-medievos reaproveitados, o que parece documentar, se não a criação, pelo menos a utilização de sepulturas rupestres, em contexto urbano, ainda no século $\mathrm{XV}^{63}$.

Por fim, registemos que a necrópole de S. Pedro de Marialva, escavada por Maria Antónia Amaral, deu numismas entre D. Afonso III e D. Sebastião. Aparecidas em contexto funerário, isto é, no interior de sepulturas, registaram-se 14 moedas: uma romana, dois dinheiros de D. Afonso III (1248-1279), um dinheiro de D. Afonso XI de Castela (1312-1350), um dinheiro de D. Pedro I (1357-1367), três ceitis de D. Afonso V (1438-1481), dois ceitis de D. Manuel I (1495-1521), um ceitil de D. João

\footnotetext{
${ }^{60}$ VASCONCELOS, 1935: 2, 199; Suplemento ao vol. II:12. Esta planta foi reproduzida por nós em BARROCA, 1987: 125, Fig. 2 (= BARROCA, 2010-2011, Fig. 3), com tratamento gráfico para assinalar as duas fases da necrópole.

${ }^{61}$ BARROCA, 1987: 124-125; 2010-2011: 133-134.

62 REAL, 1974: 151-152.

${ }^{63}$ BARROCA, 1987: 164-165; 2010-2011: 166.
} 
III (1521-1557), dois ceitis e uma moeda de três reais de D. Sebastião (1557-1578) ${ }^{64}$. Se o primeiro numisma pode ter sido transportado para o interior do sepulcro com os sedimentos, já os restantes devem corresponder ao momento de utilização (e reutilização) da sepultura, percorrendo toda a baixa Idade Média e ainda os alvores da Época Moderna. Catarina Tente regista, ainda, uma datação de C14 para a necrópole de S. Pedro de Marialva, que forneceu uma data dentro do século XV - $460 \pm 40$ BP = 1401-1497 cal AD (93,4\% probabilidade) - o que confirma os dados fornecidos pela maioria dos numismas ${ }^{65}$. É claro que os numismas e a datação de C14 comprovam a utilização das sepulturas rupestres de Marialva ainda nos séculos XV e XVI. Mas não, necessariamente, a criação de sepulturas escavadas na rocha nessa época. Os casos de reutilização dos sepulcros foram muito abundantes.

Que conclusões podemos colher de todos estes exemplos? Que as sepulturas escavadas na rocha surgiram por volta do século VII, com soluções não-antropomórficas e com largos encaixes de tampa rebaixados. E que tiveram o seu auge entre os séculos IX e XI, com soluções antropomórficas (que conviveram, lado a lado, com soluções não-antropomórficas) e que foram, depois, paulatinamente substituídas por outras formas de enterramento. Mas que, até aos finais da Idade Média, e até em épocas posteriores, houve zonas onde continuaram a ser utilizadas e reutilizadas.

\section{QUE ENQUADRAMENTO RELIGIOSO?}

Apesar de não podermos afirmar que as sepulturas escavadas na rocha ou que as soluções antropomórficas em sepulcros medievais sejam opções exclusivas do espaço peninsular, é aqui que elas atingiram uma expressão mais significativa. Com efeito, conhecem-se vários exemplos de soluções antropomórficas em sepulcros medievais distribuídos um pouco por toda a Europa (França, Itália, Inglaterra), quer ao nível de sarcófagos, quer de sepulturas definidas por elementos avulsos ${ }^{66}$. E, mesmo para as sepulturas escavadas em afloramentos rochosos, também podemos apontar vários exemplos franceses e ingleses ${ }^{67}$. Mas não podemos deixar de sublinhar que, à vista dos milhares de exemplos conhecidos para a Península Ibérica, os casos de além-Pirenéus se afiguram como residuais.

Durante muito tempo aceitou-se - se não de forma explícita, pelo menos de uma forma implícita - que se estava perante uma manifestação funerária cristã.

\footnotetext{
${ }^{64}$ AMARAL 2001: 134.

65 TENTE, CARVALHO, 2015: 131.

${ }^{66}$ Vd., entre outros, CAMPECH, 2000; GALMICHE, BUCCIO, ROBIN, 2015; MASSON, RÉVEILLAS, MAURY, 2018; DURAND, 1978, 1988; BOISSAVIT-CAMUS et al., 1996.

${ }^{67}$ Veja-se, por exemplo, as sepulturas antropomórficas escavadas na rocha da Capela de St. Patrick, Heysham, Lancashire (Inglaterra); as sepulturas antropomórficas da abadia de Montmajour, Arles (França); ou o importante conjunto de sepulturas rupestre da Touraine, em torno de Chinon (França).
} 
Mas esta é uma ideia que também teremos de relativizar, porque sabemos que não o foram exclusivamente.

Com efeito, há necrópoles muçulmanas que utilizam sepulturas escavadas na rocha. Neste caso, e porque a deposição do corpo no mundo islâmico é em decúbito lateral, com a face voltada para Meca, os sepulcros não são, naturalmente, de configuração antropomórfica. São cavidades de configuração sub-retangular, muitas vezes dotados de largos encaixes para as tampas. Neste aspeto, elas não podem deixar de recordar o grupo mais recuado de enterramentos rupestres que atrás aflorámos, com os quais serão sensivelmente contemporâneas. Entre os exemplos conhecidos salientemos a maqbara de Marroquíes Bajos (Jaén), uma necrópole do período emiral (séculos VIII e IX) escavada por Juan Carlos Castillo Armenteros, Mercedes Navarro Pérez e José Luis Serrano Peña ${ }^{68}$, ou a maqbara de Tauste (Zaragoza), estudada por Francisco Javier Gutiérrez González, Carlos Laliena Corbera e Miriam Pina Pardos ${ }^{69}$. Mas há mais exemplos: San Nicolás (Ávila), Valdeherrera (Calatayud)... A opção pela criação de cavidade feral escavada em afloramentos rochosos também se estendeu, por isso, ao mundo islâmico.

Mas não só. Também se conhecem necrópoles judaicas que utilizam sepulturas escavadas na rocha, de configuração não-antropomórfica e antropomórfica. A extensa necrópole de Montjuïc (Barcelona), escavada em 1945-46, deu 171 sepulturas escavadas na rocha, antropomórficas ${ }^{70}$. A área da grande necrópole judaica de Barcelona seria de novo intervencionada por ocasião dos Jogos Olímpicos e, mais recentemente, entre 2001 e $2002^{71}$. Se, como vimos, quando optam por soluções rupestres, as sepulturas muçulmanas não adquirem perfil antropomórfico, já no caso das sepulturas judaicas podemos encontrar (ou não) o perfil antropomórfico.

Acrescentemos ainda o exemplo da necrópole judaica de La Cuesta de los Hoyos, o cemitério da comunidade sefardita de Segóvia, estudada por Sónia Fernández Estebán ${ }^{72}$, e que era composta por sepulcros rupestres antropomórficos, com caixa feral trapezoidal e cabeceira igualmente trapezoidal, dotados de um largo rebordo rebaixado, para receber tampa. Associado a um destes enterramentos apareceu um dinero, em bolhão, de Afonso VIII (1170-1212).

Em suma, também não podemos afirmar, de uma forma absoluta e generalizada, que as sepulturas escavadas na rocha são conotadas com as comunidades cristãs - elas existiram igualmente em comunidades muçulmanas e judaicas - nem tão pouco que o antropomorfismo é uma solução exclusivamente cristã. Será uma opção maioritariamente cristã, pela sua relação estreita com a crença na ressurreição no

\footnotetext{
${ }^{68}$ Cf. SERANO PEÑA, CASTILLO ARMENTEROS, 2000; CASTILLO ARMENTEROS, NAVARRO PÉREZ, SERRANO PEÑA, 2011; NAVARRO PÉREZ, 2018.

${ }^{69}$ GUTIÉRREZ GONZÁLEZ, LALIENA CORBERA, PINA PARDOS, 2016.

${ }^{70}$ DURAN Y SANPERE, MILLAS VALLICROSA, 1947.

${ }^{71}$ MAESE i FIDALGO, 2006.

${ }^{72}$ FERNÁNDEZ ESTEBAN, 1999, 2000.
} 
Dia do Juízo Final: a vontade de imobilizar a cabeça do morto olhando o céu, direcionando-a para Jerusalém. Mas não exclusivamente, uma vez que alguns sepulcros judaicos adotam, igualmente, a configuração antropomórfica.

De resto, a estarem relacionadas com a crença na ressurreição e com a vontade de imobilizar a cabeça do defunto, as soluções antropomórficas deveriam estar associadas à orientação cultual do sepulcro. Com efeito, a «norma» que se difundiu no mundo cristão acabou por recomendar que o sepulcro tivesse a cabeceira orientada para oeste e os pés para este. Ora conhecem-se muitas sepulturas escavadas na rocha que não estão cultualmente orientadas. Há, nomeadamente, um grupo relativamente numeroso de sepulcros que se alinham no sentido norte-sul, uma tendência que parece ter maior acolhimento junto de tipologias não-antropomórficas. Já em 1987 tínhamos constatado que no Alto Minho havia uma prevalência das sepulturas não-antropomórficas não orientadas. Acrescentemos que as sepulturas que Luís Miguel Cabrita estudou no Algarve, com cronologias recuadas, eram todas não-antropomórficas e a esmagadora maioria orientava-se no sentido norte-sul.

\section{OUTROS ENQUADRAMENTOS}

Analisemos, por fim, a forma como as necrópoles de sepulturas escavadas na rocha se organizam e se articulam com o povoamento e com a paisagem.

Como se sabe, as sepulturas escavadas na rocha podem ocorrer em quatro tipos de situações: podem surgir isoladas; podem aparecer em grupos restritos, de 2 a 5 sepulturas; podem surgir agrupadas em conjuntos mais numerosos, mas em locais sem vestígio da existência de estrutura de culto religioso; e podem, por fim, surgir em conjuntos numerosos e polarizados em trono de templos paroquiais. Esta tipologia de ocorrências já tinha sido enfatizada por Jordi Bolòs e Montserrat Pagès para a Catalunha ${ }^{73}$ e por nós para o Entre-Douro-e-Minho ${ }^{74}$. Um dos problemas que se coloca a quem estuda este tipo de enterramentos é a fronteira entre o que se deve considerar um «núcleo» de sepulturas e o que se pode classificar como uma «necrópole» ou um "cemitério». Todos os autores concordam que duas ou três sepulturas não fazem uma necrópole. Mas quando podemos classificar como necrópole uma estação arqueológica deste tipo? O limite de 5 sepulturas será legítimo? Isto é, podemos considerar uma estação com duas a cinco sepulturas como um «núcleo» e outra, sua vizinha, com seis sepulturas como uma necrópole? É sempre difícil de estabelecer este tipo de fronteiras, mas parece-nos que um conjunto de sepulcros próximo da dezena poderá configurar o local de enterramento de uma pequena comunidade. E que, se calhar, um número

\footnotetext{
${ }^{73}$ BOLÓS i MASCLANS, PAGÈS i PARETAS, 1982: 63-64.

${ }^{74}$ BARROCA, 1987: 128-129; 2010-2011: 136-137.
} 
inferior a cinco enterramentos poderá espelhar apenas um local de enterramento de uma família. Mas estas generalizações são sempre muito subjetivas.

No espaço de uma mesma paróquia podemos encontrar vários locais de enterramento. Às vezes, num mesmo aglomerado populacional encontramos sepulturas implantadas em vários sítios, nomeadamente na periferia do povoado, junto de velhos caminhos. Nos casos de Carrazeda do Alvão ou de Paredes do Alvão isso parece ser claro: os sepulcros localizam-se junto dos velhos caminhos vicinais que articulam as aldeias com a zona de exploração agrícola ou pastoril envolvente.

Iñaki Martín Viso, que em vários trabalhos (2012a; 2012b; 2016; 2017) deu um contributo decisivo para a compreensão deste processo, entende que as sepulturas escavadas na rocha tiveram o seu apogeu entre os séculos VIII e X e que «el momento de finalización del uso de estas necrópolis debe situarse en la consolidación del poblamiento aldeano y de la parroquia como centro de culto y eje de la articulación rural» ${ }^{75}$. Ou «En definitiva, podría aceptar-se que el final de la utilización de las tumbas excavadas en la roca debe situarse hacia el siglo XI, al menos en Riba Côa, como consecuencia de las transformaciones en la ordenación social del território» ${ }^{76}$.

Nos seus estudos propôs a classificação das sepulturas escavadas na rocha em quatro grandes grupos:

- Sepulturas isoladas ou agrupadas em conjuntos pequenos (de 2 ou 5 sepulturas) (que designou genericamente por «tumbas aisladas») - que refletiriam a autonomia das famílias no momento de eleição do local de sepultura;

- Sepulturas «aparentemente isoladas» ou agrupadas («tumbas aparentemente aisladas»), em conjuntos formados por 6 a 10 sepulturas, que espelhariam uma «memória familiar» e uma articulação com as áreas de produção;

- Necrópoles compostas por 10 ou mais sepulturas implantadas de forma aleatória ou desorganizada, formando pequenos grupos (a que chamou «necrópolis desordenadas») - que representariam a existência de iniciativas comunitárias na criação de espaços funerários, mas a ausência de uma instância de poder que os organizasse;

- E, por fim, necrópoles com 10 ou mais sepulturas, claramente polarizadas em torno de um espaço único concebido para enterramento (a que chamou «necrópoles alinhadas» ou «ordenadas» — «necrópolis de tumbas agrupadas y alineadas») - que refletiriam a existência de instâncias de poder controlando as comunidades campesinas ${ }^{77}$.

\footnotetext{
${ }^{75}$ MARTÍN VISO, 2005-2006: 86.

${ }^{76}$ MARTÍN VISO, 2005-2006: 87.

${ }^{77}$ MARTÍN VISO, 2005-2006, 2012a, 2012b, 2016, 2017.
} 
O último modelo, que espelha a existência de «comunidades controladas e geridas por uma instância de poder ${ }^{78}$, poderia ser plasmado nas necrópoles de sepulturas escavadas na rocha que se registam junto dos castelos de D. Flâmula, documentados no célebre diploma de 960 (PMH, DC 81): Numão, Longroiva, Moreira de Rei, Trancoso e Sernancelhe. Mas é também neste grupo que se devem incluir as necrópoles que surgem na sequência da afirmação e da territorialização da paróquia, à maneira da baixa Idade Média, fenómeno que conduziu à criação do espaço cemiterial único concentrado no adro do templo paroquial, e que corresponde à afirmação da Igreja enquanto «instância de poder».

Que significado podemos atribuir às sepulturas isoladas? Já em tempos defendemos que a opção por locais bem destacados na paisagem, muitas vezes junto de vias, parece indicar que essas sepulturas foram encaradas como uma forma de legitimar a posse de determinadas propriedades por uma família ${ }^{79}$. Se o sepulcro de um antepassado estava num terreno isso significava que essa propriedade estava, desde antanho, na posse daquela família. Preservar a memória dos antepassados era, assim, uma maneira de sancionar a posse das propriedades nas mãos dos seus descendentes. Mesmo que, paradoxalmente, as sepulturas escavadas na rocha sejam anónimas, despersonalizadas ${ }^{80}$. Neste sentido, as sepulturas isoladas poderão ser encaradas como vestígios fossilizados de velhos cadastros de propriedade. Ou como manifestações de poder, de afirmação perante a comunidade.

Se as sepulturas escavadas na rocha podem ser consideradas identificadores de propriedades, logo de espaços de habitat, a sua dispersão poderia indiciar um povoamento radicalmente disperso: «assi se ha planteado que las tumbas aisladas estarían relacionadas com un hábitat, disperso, mientras que las necrópolis serían producto de asentamientos concentrados» ${ }^{81}$. No entanto, como sublinhou Iñaki Martín Viso, a prevalência de sepulturas isoladas ou agrupadas em núcleos muito reduzidos, dispersas na paisagem, espelha a «la ausencia de un fuerte control de la elección de los lugares de enterramento», mas não necessariamente, nem automaticamente, um habitat disperso ${ }^{82}$. Mas este é um aspeto que carece de aprofundamentos monográficos, até porque um dos problemas que continua em aberto para muitas destas estações rupestres é o da localização do local de habitat... Sabemos alguma coisa sobre o local onde se enterravam, e como se enterravam, mas sabemos substancialmente menos sobre o local onde viviam estas comunidades.

\footnotetext{
${ }^{78}$ MARTÍN VISO, 2012b: 13-14.

${ }^{79}$ BARROCA, 1987: 134; MARTÍN VISO, 2012a: 10; 2012 b: 168.

${ }^{80}$ BARROCA, 2010: 437.

${ }^{81}$ MARTÍN VISO, 2012a: 10.

${ }^{82}$ MARTÍN VISO, 2012b: 10; 2012a: 168; 2016: 864.
} 
Mais interessantes se afiguram os agrupamentos de sepulturas. Como já sublinhámos em 1987, a presença de vários locais de enterramento - suficientemente próximos uns dos outros para sabermos que correspondem a uma mesma comunidade; mas suficientemente afastados entre si para impedir que formassem parte de um mesmo e único cemitério - espelha uma fase em que a Igreja ainda não tinha conseguido impor o modelo de gestão paroquial que resultou da reforma gregoriana. Esse modelo, que trouxe consigo a territorialização das paróquias e a definição rigorosa do seu âmbito geográfico, impôs que todo o espaço estivesse adstrito a uma paróquia; que essa paróquia tivesse um único responsável nomeado pela hierarquia da Igreja competente, o bispo; que o pároco fosse o único com autoridade para ministrar, dentro desse âmbito territorial, os sacramentos nos rituais de passagem (batizado, casamento e óbito); que existisse uma única igreja dotada de pia batismal, a paroquial; e que existisse um único espaço de enterramento, o cemitério, polarizado em torno do edifício paroquial, no adro. Esta era uma imposição que as velhas e extensas paróquias altimediévicas não podiam almejar. Quem olha para a dimensão territorial das paróquias suévicas compreende que, nessa altura, dentro do espaço de uma paróquia tivesse de coexistir diversos espaços de enterramento. Foi apenas quando o número de paróquias se multiplicou, e o seu âmbito territorial se reduziu, que essa pretensão passou a ser possível. Em suma, uma reforma que assentava na tríade um templo - um pároco - um cemitério. Este complexo processo desenrolou-se ao longo das últimas décadas do século XI e na centúria seguinte.

Ora, como se sabe, existem inúmeros casos de povoados onde encontramos vários pequenos núcleos de sepulturas disseminados pela sua periferia. Existem, ainda, cemitérios que apresentam 8,10 ou mais sepulturas, mas sem vestígios de ter existido templo na sua área ou imediações. Em S. Gens (Forno Telheiro), estação que Catarina Tente estudou, encontramos 56 sepulturas $^{83}$; na Malpartida (Almeida) temos 38 monumentos; em Vascoveiro registam-se 31 sepulcros; nas Forcadas (Fornos de Algodres) chegámos às 24 sepulturas; e a necrópole do Tribunal de Trancoso apresenta 18 sepulcros. Em todos estes exemplos regista-se a ausência de templo. Parece claro que já havia uma capacidade para impor o agrupamento dos enterramentos, mas não é claro que eles já se estruturassem em torno de edifícios de culto.

Por fim, temos os cemitérios que se polarizam em torno de templos paroquiais. Na maior parte dos casos, estes cemitérios já não optam pelas sepulturas escavadas na rocha, porque eles surgem numa fase em que esta moda de enterramento já estava a cair em desuso. Mas nos casos em que ainda optam por enterramentos rupestres facilmente se alcançam números de sepulcros muito elevados, fruto da prática continuada de enterramento de uma comunidade num espaço reduzido. Como vimos,

83 TENTE, 2010: 203 e ss.; BROOKES, TENTE, PRATA, 2017: 215-238. 
este é o modelo da plena Idade Média, o modelo imposto pela reforma gregoriana: uma paróquia estruturada em torno de um templo (o único dotado de pia batismal), com um único espaço de enterramento, entregue a um ministro da Igreja. Mas não é apenas a nomeação do pároco que depende da autoridade episcopal. A própria criação de um templo paroquial está sujeita a ela. Só o bispo pode presidir à cerimónia de sagração ou de dedicação de um novo templo. A reforma trouxe, portanto, um controle estreito de todos os procedimentos por parte da hierarquia eclesiástica.

Valeria a pena discutir, aqui, o que surgiu primeiro: se foi a existência de um cemitério que ditou a construção do edifício de culto, que veio sacralizar um espaço de enterramento ancestral; ou se, pelo contrário, foi a presença do edifício de culto que motivou a abertura das primeiras sepulturas. $\mathrm{O}$ facto de algumas sepulturas se apresentarem truncadas pelos muros das igrejas românicas (como vemos, por exemplo, em Sta . Marinha de Moreira de Rei) pode não significar que a necrópole antecedeu o espaço de culto. Podemos estar perante um templo pré-românico, de dimensões mais pequenas, que foi ampliado com a reforma românica.

Em todo o caso, cemitérios como os de S. Pedro de Marialva (com 86 sepulturas escavadas), de St. ${ }^{a}$ Marinha de Moreira de Rei (com 68 sepulturas visíveis antes do início das recentes escavações, que ampliaram o número total para perto das seis centenas de sepulcros), de S. Julião de Mangualde (com 44 sepulturas escavadas), S. Pedro de Lourosa (mais de 22 sepulturas), ou de St. ${ }^{a}$ Maria de Sendim (com 21 sepulturas visíveis), correspondem certamente a cemitérios paroquiais, quando a Igreja já tinha conseguido impor o seu modelo territorial.

A imposição do modelo paroquial, entre os finais do século XI e ao longo do século XII, levou a um reordenamento da matriz de povoamento, com a concentração ou nuclearização dos habitats. Um processo que talvez não tenha sido totalmente pacífico, já que são conhecidos problemas em torno da territorialização do espaço paroquial.

Os fracos índices de associação entre sepulturas escavadas na rocha e templos paroquiais, que encontramos um pouco por todo o país, refletem, afinal, a cronologia tardia da afirmação dos cemitérios paroquiais, que surgem numa fase em que as sepulturas rupestres já estavam a entrar em desuso.

Sintomaticamente, é nestas sepulturas escavadas na rocha mais tardias, polarizadas em torno de templos, que vamos encontrar os tímidos indícios da personalização dos enterramentos. Referimo-nos ao aparecimento de encaixes para estelas (provavelmente discoides) em S. Miguel de Monsanto (Idanha-a-Nova) e no Senhor da Boa Morte (Povos, Vila Franca de Xira), entre outros.

A aplicação do modelo de Iñaki Martín Viso à região de Viseu, ensaiada por Catarina Tente, revelou 197 locais com sepulturas isoladas (33,4\%); 288 locais com 2 a 10 sepulturas (55,2\%, num total de 987 túmulos); 18 locais com mais de 10 sepulturas em «cemitérios desordenados» (3,4\%, num total de 280 túmulos); 13 locais com 
«cemitérios ordenados» (2,5\%). Neste estudo, Catarina Tente faculta-nos ainda duas datações de C14: o Alto da Quintinha, estação com uma sepultura isolada, forneceu uma datação de 861-1032 cal AD (91,2\%); e o Cemitério de Algodres, uma necrópole de sepulturas «desordenadas», apresenta uma datação de $1224-1315$ cal AD $(77,7 \%)^{84}$. Estas cronologias parecem ir ao encontro do processo histórico que acabámos de traçar.

É tempo de terminar...

Alberto del Castillo construiu um modelo evolucionista que, baseando-se exclusivamente na tipologia das sepulturas, procurou alcançar datações. Como muitos autores constataram, sobretudo em estudos que viram a luz a partir da década de 1980, esse modelo faliu perante inúmeros casos que vieram demonstrar que a diversidade tipológica não pode ser entendida como um indicador cronológico, pelo menos de uma forma absoluta. Iñaki Martín Viso colocou de lado todos os indicadores tipológicos dos enterramentos para avançar com outros modelos interpretativos, baseados na articulação dos sepulcros entre si e com a paisagem. Se calhar é tempo de voltar atrás e de, partindo das análises sugeridas por Iñaki Martín Viso, regressar de novo às tipologias para verificar que tipos correspondem a cada um dos 4 ou 5 grandes modelos de organização destas sepulturas. Isto é, que tipologias correspondem às sepulturas isoladas, às sepulturas estruturadas em núcleos de 2 a 5 enterramentos, às «necrópoles desordenadas», às «necrópoles alinhadas ou ordenadas», nomeadamente em cemitérios paroquiais. Mas isso apenas se consegue com análises de grande amplitude geográfica. As duas grandes bases de dados para as sepulturas escavadas na rocha - a construída por Catarina Tente para a zona do centro de Portugal, e a que, sob nossa orientação, se está a construir para o norte de Portugal - irão, por certo, dar novos contributos na descodificação e no entendimento das sepulturas escavadas na rocha.

\section{BIBLIOGRAFIA}

ALMEIDA, Joana Filipa Tuna de (2009). Sepulturas Escavadas na Rocha no concelho de Vila Real. «Tellus». 50, 39/68.

AMARAL, Maria Antónia (2001). A Necrópole de São Pedro de Marialva. Estudo arqueológico. «Estudos/ Património». 1, 129-138.

BARROCA, Mário Jorge; MORAIS, António Joaquim Cardoso (1983). Sepulturas Medievais na Terra de Aguiar da Pena (Vila Pouca de Aguiar). «Arqueologia». n. ${ }^{\circ}$ 8, 92-102.

BARROCA, Mário Jorge; MORAIS, António Joaquim Cardoso (1985-86). A Terra e o Castelo - Uma Experiência Arqueológica em Aguiar da Pena. «Portvgalia». Nova Série, 6-7, 35-88.

BARROCA, Mário Jorge (1987). Necrópoles e sepulturas medievais de Entre Douro e Minho (século V a $X V$ ). Porto: Faculdade de Letras da Universidade do Porto. Dissertação para Provas Públicas de Aptidão Pedagógica e Capacidade Científica.

${ }^{84}$ TENTE, 2017: 215-226. 
BARROCA, Mário Jorge (1988). A Ocupação Medieval em Castelo de Matos - Primeira Abordagem. «Arqueologia». 17, 159-171.

BARROCA, Mário Jorge (1990). As Sepulturas rupestres de Salvador do Monte (Amarante). «Entremuros. Revista Cultural». 1, 31-36.

BARROCA, Mário Jorge (2008-2009). De Miranda do Douro ao Sabugal. Arquitectura Militar e Testemunhos Arqueológicos Medievais num espaço de fronteira. «Portvgalia». Nova Série. 29-30, 193-252.

BARROCA, Mário Jorge (2009). Rocha Peixoto e a cronologia das sepulturas escavadas na rocha. A propósito de uma polémica recensão à revista «Portvgalia». 43, 221-233.

BARROCA, Mário Jorge (2010-2011). Sepulturas Escavadas na Rocha de Entre Douro e Minho. «Portvgalia». Nova Série. 31-32, 115-182.

BOISSAVIT-CAMUS, Brigitte et al. (1996). Chrono-typologie des tombes en Anjou-Poitou-Touraine. In Archéologie du cimetière chrétien. Actes du 2e colloque ARCHEA (Orléans 1994), suplemento de Revue Archéologique du Centre de la France. Tours, pp. 257-269.

BOLÓS MASCLANS, Jordi; PAGÉS PARETAS, Montserrat (1982). Les sepultures excavades a la roca. In RIU, Manuel, dir. Necropolis i sepultures medievals de Catalunya. Barcelona: Departament d'Historia Medieval, pp. 59-103.

BROOKES, Stuart; TENTE, Catarina; PRATA, Sara (2017). Interpreting Rock-Cut Grave Cemeteries: the early medieval necropolis and enclosure of São Gens. «Medieval Archaeology». 61:2, 215-238.

CABRITA, Luís Miguel (2011). Contributo para o estudo do povoamento rural alto-medieval de Silves. In GOMES, Rosa Varela; GOMES, Mário Varela; TENTE, Catarina, ed. Cristãos e Muçulmanos na Idade Média Peninsular. Encontros e Desencontros. Lisboa: Instituto de Arqueologia e Paleociências, pp. 239-254.

CABRITA, Luís Miguel Guerreiro (2014). Cabrita, Povoamento Alto Medieval de São Bartolomeu de Messines. S. Bartolomeu de Messines: Junta de Freguesia de S. Bartolomeu de Messines. Lisboa: Faculdade de Ciências Sociais e Humanas da Universidade Nova de Lisboa. (Edição da Dissertação de Mestrado)

CAEIRO, José O. (1984a). A Necrópole I da Azinhaga da Boa Morte - Castelo de Vide. Portalegre: Junta Distrital de Portalegre.

CAEIRO, José O. (1984b). A Necrópole II da Azinhaga da Boa Morte - Castelo de Vide. Portalegre: Junta Distrital de Portalegre.

CAMPECH, Sylvie (2000). Le cimetière de Notre-Dame de Maubourguet (Hautes-Pyrénées): typochronologie des tombes. «Archéologie du Midi Médiéval». 18, 27-39.

CASTILLO ARMENTEROS, J. C.; NAVARRO PÉREZ, M.; SERRANO PEÑA, J. L. (2011). Las maqbaras de Marroquíes Bajos (Jáen) en torno al 711. In 711- Arqueologia e Historia entre dos mundos. Alcalá de Henares: Museo Arqueológico Regional, vol. 1, pp. 273-291.

CASTILLO, Alberto del (1970). Cronología de las tumbas llamadas "olerdolanas". In XI Congreso Nacional de Arqueología. Zaragoza: Secretaría General de los Congresos Arqueológicos Nacionales, pp. 835-845.

CASTILLO, Alberto del (1972). Excavaciones Altomedievales en las Provincias de Soria, Logrono y Burgos. «Excavaciones Arqueológicas en España». 74.

CHAMBINHO, Mário; HENRIQUES, Francisco:; CANINAS, João Carlos (2015). Sepulturas escavadas na rocha da freguesia do Rosmaninhal (Idanha-a-Nova). In Actas do Congresso Arqueologia de Transição: o mundo funerário. Évora: Universidade de Évora, pp. 272-288.

CHAMOSO LAMAS, Manuel (1956a). Notícia de las excavaciones arqueológicas que se realizaran en la Catedral de Santiago. «Compostellanum». I, 349-376.

CHAMOSO LAMAS, Manuel (1956b). Notícia de las excavaciones arqueológicas que se realizaran en la Catedral de Santiago - Segunda Fase. «Compostellanum». I :4, 803-856. 
CHAMOSO LAMAS, Manuel (1957). Excavaciones arqueológicas en la Catedral de Santiago - Tercera Fase. «Compostellanum». II: 4, 575-624.

CORREIA, Alberto (1976). Sepulturas cavadas na rocha no concelho de Sernancelhe. "Beira Alta». 35: 1, 93-136.

CORREIA, Vergílio (1946). O Cemitério da Sé Velha. In Obras. Coimbra: Imprensa da Universidade, vol. I, pp. 99-124.

CUNHA, Maria Eugénia; UMBELINO, Cláudia; TAVARES, Teresa (2001). A Necrópole de São Pedro de Marialva. Dados Antropológicos. «Estudos/Património». 1, 139-143.

DURAN Y SANPERE, A.; MILLAS VALLICROSA, J. M. (1947). Una necrópolis judaica en el Montjuich de Barcelona. «Sepharad». 7: 2, 231-259.

DURAND, Marc (1978). Les tombes construites médiévales à cuve céphalique du sud-est de l'Oise. «Revue archéologique de Picardie». 13, 41-44.

DURAND, Marc (1988). Archéologie du cimetière médiéval au sud-est de l'Oise. «Revue Archéologique de Picardie». 6: 6.

FERNANDES, Paulo Almeida (2002). A Igreja pré-românica de São Pedro de Lourosa. Lisboa: Faculdade de Letras da Universidade de Lisboa. Dissertação de Mestrado.

FERNÁNDEZ ESTEBAN, Sónia (1999). Análisis de las estruturas funerárias de la Cuesta de los Hoyos. Segovia. Un ejemplo de necrópolis medieval hebrea. In Actas del XXIV Congreso Nacional de Arqueología (Cartagena, 1997). Zaragoza: Instituto de Patrimonio Histórico, vol. V, pp. 225-232.

FERNÁNDEZ ESTEBAN, Sónia (2000). Las Necrópolis Medievales de la Comunidad Judaica. El caso de la Cuesta de los Hoyos (Segovia). In Actas do III Congresso de Arqueologia Peninsular. Porto: ADECAP, vol. VIII, pp. 191-205.

GALMICHE, Thierry; BUCCIO, Vincent; ROBIN, Nadège (2015). Le cimetière de la ferme de Pouy à Mortefontaine (Aisne) (VIIIe-XIe siècle). «Archéologie Médiévale». 45, 39-58.

GOMES, Mário Varela (2002). A Necrópole Visigótica do Poço dos Mouros (Silves). «Revista Portuguesa de Arqueologia». 5: 2, 339-391.

GUEDES, César Leandro Pereira (2015). A Sul do Douro: Percurso pelas sepulturas escavadas na rocha entre os rios Távora e Cabrum. Porto: Faculdade de Letras da Universidade do Porto. Dissertação de Mestrado.

GUERRA CAMPOS, José (1982). Exploraciones Arqueológicas en torno al Sepulcro del Apostolo Santiago. Santiago de Compostela.

GUTIÉRREZ GONZÁLEZ, Francisco Javier; LALIENA CORBERA, Carlos; PINA PARDOS, Miriam (2016). La Maqbara medieval de Tauste. Primeras investigaciones. In I Congreso Arqueologia y Patromónio Aragonés (CAPA). Zaragoza, pp. 433-442.

GUTIÉRREZ LLORET, Sónia; GAMO PARRAS, Blanca (2017). El Tomo de Minateda entre la Antigüedad Tardia y la Alta Edad Media: nuevos retos en nuevos tempos. In La Meseta Sur entre la Tardia Antigüedad y la Alta Edad Media. Madrid: Junta de Castilla-La Mancha, pp. 47-74.

GUTIÉRREZ LLORET, Sónia; ABAD CASAL, L.; GAMO PARRAS, Blanca (2004). La Iglesia visigoda de El Tolmo de Minateda (Hellín, Albacete). In BLÁZQUEZ, J. M.; GONZÁlEZ BLANCO, A., ed. Sacralidad y Arqueologia. Homeaje al Prof. Thilo Ulbert al cumplir 65 años. «Antigüedad y Cristianismo». 21, 139-170.

LOPES, Isabel Alexandra Resende Justo (2002). Contextos Materiais da Morte durante a Idade Média: as necrópoles do Douro Superior. Porto: Faculdade de Letras da Universidade do Porto. Dissertação de Mestrado. 2 vols.

LÓPEZ QUIROGA, Jorge (2004). El final de la Antiguedad en Gallaecia. La transformación de las estructuras de poblamiento entre Miño y Duero (Siglos V al X). A Coruña: Fundación Pedro Barrié de la Maza. 
LÓPEZ QUIROGA, Jorge (2010). Arqueologia del mundo funerário en la Península Ibérica (Siglos V-X). Madrid: La Ergástula.

LÓPEZ QUIROGA, Jorge; GARCÍA PÉREZ, LAURA (2014). Las tumbas excavadas en la roca en la Península Ibérica: tipología, cronología y problemas de interpretación. In LÓPEZ QUIROGA, Jorge; MARTÍNEZ TEJERA, Artemio M, ed. In concavis petrarum habitaverunt. El fenómeno rupestre en el Mediterráneo Medieval: de la investigación a la puesta en valor. Oxford: Archaeopress, pp. 36-83.

LOURENÇO, Sandra Clara Alves (2007). O Povoamento Alto-medieval entre os rios Dão e Alva. «Trabalhos de Arqueologia». 50.

MACHADO, João Nuno (2019). A Terra de Monte Longo na Idade Média. Das origens a 1438. Fafe: Câmara Municipal de Fafe.

MAESE i FIDALGO, Xavier (2006). Montjuïc: La Necrópolis Jueva de la Barcelona Medieval. Barcelona: Codex Arqueologia i Patrimoni.

MARQUES, Jorge Adolfo de Meneses (1991). Sepulturas rupestres da Côta, Viseu. «Beira Alta». 50: $1-2,169-178$.

MARQUES, Jorge Adolfo de Meneses (1997). Sepulturas escavadas na rocha no concelho de Penalva do Castelo. In Castelo e Terras de Pena Alba: Vestígios Histórico-Artísticos. Penalva do Castelo, pp. 33-45.

MARQUES, Jorge Adolfo de Meneses (1999). Carta Arqueológica do Concelho de Vouzela. Vouzela: Câmara Municipal de Vouzela.

MARQUES, Jorge Adolfo de Meneses (2000). Sepulturas escavadas na rocha na região de Viseu. Viseu: Ed. do Autor.

MARQUES, Jorge Adolfo de Meneses; GAMA, Teresa Maria Simões (1995). A Necrópole de sepulturas escavadas na rocha das Forcadas (Matança, Fornos de Algodres). Gouveia: ADRUSE.

MARTÍN VISO, Iñaki (2005-2006). Elementos para el análisis de las necrópolis de tumbas excavadas en la roca: el caso de Riba Côa. "CuPAUAM Cuadernos de Prehistoria y Arqueologia. Universidad Autonoma de Madrid». 31-32, 83-102.

MARTÍN VISO, Iñaki (2007). Tumbas y sociedades locales en el centro de la península en la alta edad media: el caso de la comarca de Riba Côa (Portugal). «Arqueología y Territorio Medieval». 14, 21-47.

MARTÍN VISO, Iñaki (2011). La organización social de los espacios funerarios altomedievales en los territórios al sur del Duero. In GOMES, Rosa Varela; GOMES, Mário Varela; TENTE, Catarina, coord. Cristãos e Muçulmanos na Idade Média Peninsular. Encontros e Desencontros. Lisboa: Instituto de Arqueologia e Paleociências, pp. 225-238.

MARTÍN VISO, Iñaki (2012a). Enterramientos, memoria social y paisaje en la Alta Edad Média: propuesta para un análisis de las tumbas excavadas en la roca en el centro oeste de la Península Ibérica. «Zephyrus». 69, 165-187.

MARTÍN VISO, Iñaki (2012b). Paisajes sagrados, paisajes eclesiásticos: de la necrópolis a la parroquia en el centro de la Península Ibérica. «Reti Medievali Rivista». 13: 2, 3-45.

MARTÍN VISO, Iñaki (2016). Comunidades locales, lugares centrales y espácios funerários en la Extremadura del Duero Altomedieval: Las necrópolis de tumbas excavadas en la roca alineadas. "Anuário de Estudios Medievales». 46: 2, 859-897.

MARTÍN VISO, Iñaki (2017). A place for the ancestors: early medieval burial sites in central area of the Iberian Peninsula. In BIS-WORCH, Christiane; THEUNE, Claudia ed. Ruralia XI. Leiden: Sidestone Press, pp. 227-240.

MASSON, Juliette; RÉVEILLAS, Hélène;; MAURY, Marie (2018). La fouille de la place de l'église Saint-Pierre à Bruges (Gironde): d’une occupation alto-médiévale à un cimetière paroissial. «Bulletin du Centre d'Études Médiévales d'Auxerre». 22. Disponível em <http://journals.openedition.org/cem/15922>.

MOLIST CAPELLA, Núria; RIPOLL, Gisela, coord. (2012). Arqueologia funerária al nord-est peninsular (segles VI-XII). Olèrdola, Museu d’Arqueologia de Catalunya. 2vols. 
NAVARRO PÉREZ, Mercedes (2018). La Maqbara del Camino de Bayyasa (Marroquíes Bajos, Jáen). «Lucentum». 37, 281-303.

NUNES, Manuel; SOUSA, Luís; GONÇALVES, Carlos (2006). Sepulturas medieviasi escavadas na rocha no concelho de Lousada: o cemitério rupestre do Irmeiro (Boim). «Oppidum». 1, 47-67.

NUNES, Manuel; SOUSA, Luís; GONÇALVES, Carlos (2008). Carta Arqueológica do Concelho de Lousada. Lousada: Câmara Municipal de Lousada.

PEREIRA, Ana Sofia Silva (2015). Inventário e Georreferenciação do mundo funerário rupestre medieval no centro de Portugal. Lisboa: Faculdade de Ciências Sociais e Humanas da Universidade Nova de Lisboa. Relatório de Estágio em Arqueologia.

PRATA, Sara (2012). As Necrópoles alto-medievais da Serra de São Mamede (concelhos de Castelo de Vide e Marvão). Lisboa: Faculdade de Ciências Sociais e Humanas da Universidade Nova de Lisboa. Dissertação de Mestrado.

PRATA, Sara (2014). Espacios funerários altomedievales del Norte de la Serra de São Mamede (Portalegre, Portugal): Una propuesta de organización espacial. «Revista Arkeogazte». 4, 261-279.

QUEIRÓS, Eugénio (2011). As sepulturas Medievais do Concelho de Marco de Canavezes. Porto. Disponível em <https://www.academia.edu/807507/Sepulturas_medievais_do_Marco_de_Canaveses $>$.

REAL, Manuel Luís (1974). A Arte Românica de Coimbra (Novos dados - Novas hipóteses). Porto: Faculdade de Letras da Universidade do Porto. Dissertação de Licenciatura.

REAL, Manuel Luís (1985). Notícia Histórica. In Pousada de Santa Marinha. Guimarães. «Boletim da Direcção-Geral dos Edifícios e Monumentos Nacionais». 130, 9-11.

RIBEIRO, Flávio Marques; SILVA, Maria Antónia (1997). Sepulturas escavadas na rocha do concelho de Seia. In Actas do II Colóquio Arqueológico de Viseu. Viseu, pp. 127-142.

RODRIGUES, Maria da Conceição Monteiro (1975). Carta Arqueológica do Concelho de Castelo de Vide. Lisboa: Junta Distrital de Portalegre.

RODRIGUES, Maria da Conceição Monteiro (1978). Sepulturas Medievais no Concelho de Castelo de Vide. Lisboa: Junta Distrital de Portalegre.

SANTOS, Ana Cristina Calais Freire dos (1991-1992). Contributo para o estudo das sepulturas rupestres do Monte do Senhor da Boa Morte. «Cira». 5, 11-48.

SANTOS, Maria José Ferreira dos (2005). A Terra de Penafiel na Idade Média. Estratégias de ocupação do território (875-1308). "Cadernos do Museu». 10.

SERRANO PEÑA, J. L.; CASTILLO ARMENTEROS, J. C. (2000). Las necrópolis medievales de Marroquíes Bajos, (Jaén). Avance de las investigaciones arqueológicas. «Arqueología y Territorio Medieval». 7, 93-120.

TAVARES, António Luís Marques (1999). Sepulturas escavadas na rocha no concelho de Mangualde. Mangualde: [s.n.].

TAVARES, António Luís Marques (2007). Sepulturas escavadas na rocha das freguesias de Cunha Baixa e Espinho (Mangualde). Contributo para a História da Alta Idade Média numa micro-região. Mangualde: [s.n.].

TEIXEIRA, Ricardo Jorge Coelho Marques Abrantes (1996). De Aquae Flaviae a Chaves: Povoamento e organização do território entre a Antiguidade e a Idade Média. Porto: Faculdade de Letras da Universidade do Porto. Dissertação de Mestrado.

TENTE, Catarina (2000). Estudo sobre as sepulturas rupestres do actual concelho de Gouveia (19931998). «Gaudela». 1, 44-72.

TENTE, Catarina (2007a). A ocupação alto-medieval da encosta noroeste da Serra da Estrela. Lisboa: Instituto Português de Arqueologia. (Trabalhos de Arqueologia; 47).

TENTE, Catarina (2007b). Paisagens humanas alto-medievais na Vertente Noroeste da Serra da Estrela (Portugal). «Territorio, Sociedad y Poder». 2, 87-108. 
TENTE, Catarina (2007c). Rock-cut graves and cemeteries in the medieval rural landscape of the Viseu region (central Portugal). In THEUNE, C.; BIS-WORCH, C., ed. Religion, cults \& rituals in the medieval rural environment. Ruralia XI. Leiden: Sidestone Press, pp. 215-226.

TENTE, Catarina (2010). Arqueologia Medieval Cristã no Alto Mondego, Ocupação e exploração do território nos séculos $V$ a XI. Lisboa: Faculdade de Ciências Sociais e Humanas da Universidade Nova de Lisboa. Tese de Doutoramento.

TENTE, Catarina (2011). Dos séculos IX ao XI no Alto Vale do Mondego (Guarda, Portugal): Dinâmicas de povoamento e estruturas sociais. «Debates de Arqueologia Medieval». 1, 23-43.

TENTE, Catarina (2012). Settlement and territory in the Upper Mondego Basin (Centre of Portugal) between the 5th century and the 11th century. "Archeologia Medievale». 39, 385-398.

TENTE, Catarina (2015). Tumbas rupestres en el Alto Mondego (Guarda, Portugal). Patrones de distribución, significados y construcción del paisaje rural altomedieval. «Munibe AntropologiaArkeologia». 66, 271-290.

TENTE, Catarina; CARVALHO, António Faustino (2015). Sepulturas e necrópoles alto medievais na investigação portuguesa. Metodologias, problemáticas e perspetiva. In QUIRÓS CASTILLO, J. A.; CASTELHANOS, S. ed. Identidad y etnicidad en Hispania. Propuestas teóricas y cultura material en los siglos V-VIII (DAM 8), Vitória: Gasteiz, pp. 125-144.

TENTE, Catarina; LOURENÇO, Sandra (1998). Sepulturas escavadas na rocha dos concelhos de Carregal do Sal e Gouveia: estudo comparativo. «Revista Portuguesa de Arqueologia». I: 2, 191-217.

TENTE, Catarina; LOURENÇO, Sandra (2002). Sepulturas escavadas na rocha do distrito de Évora. «Revista Portuguesa de Arqueologia». 5: 1, 239-258.

TENTE, Catarina; MARTINS, A. C. (1994). Levantamento arqueológico do concelho de Gouveia, $1^{a}$ fase: a necrópole medieval do Risado, o conjunto de Carreira Cova e a Sepultura do Penedo do Mouros. Notícia preliminar. «Trabalhos de Arqueologia da E.A.M.». 2, 283-291.

VALERA, António Carlos (1990). Sepulturas Escavadas na Rocha do Concelho de Fornos de Algodres. Fornos de Algodres: G.A.F.A.L.

VASCONCELOS, António de (1935). A Sé Velha de Coimbra. Coimbra: Imprensa da Universidade. 2 vols. VIEIRA, Marina Afonso (2004). Alto Paiva. Povoamento nas épocas romana e alto-medieval. «Trabalhos de Arqueologia». 36. 


\title{
O MUNDO DOS MORTOS NA QUINTA DE CRESTELOS: PARADIGMA DAS SEPULTURAS ESCAVADAS NA ROCHA DA NECRÓPOLE ESTE
}

\author{
ALEXANDRINA AMORIM* \\ ANA RORIZ* \\ SÉRGIO SIMÕES PEREIRA*** \\ ZÉLIA RODRIGUES
}

\begin{abstract}
Resumo: O presente trabalho pretende trazer, à luz do dia, os resultados arqueológicos de uma intervenção decorrente do projeto de Aproveitamento Hidroelétrico do Baixo Sabor (Torre de Moncorvo Bragança), que contemplou a construção de duas barragens. A Quinta de Crestelos, localizada em Meirinhos, Mogadouro, foi alvo de diversas intervenções arqueológicas, tendo apresentado uma ocupação diacrónica extensa, mais relevante entre a Pré-História recente e a Alta Idade Média. No decurso dos trabalhos foi identificada uma área sepulcral denominada Necrópole Este. Foram identificadas 33 sepulturas escavadas na rocha, 30 orientadas segundo os cânones da Igreja, três sepulturas com orientações distintas. Tipologicamente registam-se sepulturas trapezoidais, antropomórficas, retangulares e com caixa. Apenas 14 sepulturas apresentavam cobertura, variando entre lajes de xisto única ou várias lajes de pequenas e médias dimensões.
\end{abstract}

Palavras-chave: Sepulturas escavadas na rocha; Idade Média; Crestelos.

Abstract: The present work intends to bring to light the archaeological results of an intervention resulting from the Baixo Sabor Hydroelectric Project (Torre de Moncorvo - Bragança), which involved the construction of two dams. Quinta de Crestelos, located in Meirinhos, Mogadouro, suffered several archaeological interventions, and have exposed an extensive diachronic occupation, ranging from recent Prehistory to Middle Ages. In a small elevation was identified a sepulchral area, called the East Necropolis. The sepulchral area was well delimited, and were identified and excavated 33 rock-cut graves. The funerary structures denoted a normalization in the orientations, following Christians canons. Typologically, there were identified trapezoidal, anthropomorphic, rectangular and ovaloid rock-cut graves. Some of the graves had preserved an equally diverse type of lids, ranging from small and medium sized shale slabs to single slabs.

Keywords: Rock-cut graves; Middle Age; Crestelos.

* UAUM; CIAS. Email: alexandrina.amorim@gmail.com.

** Email: anaroriz@gmail.com.

*** Email: sergiomspereira71@gmail.com.

${ }_{* * * *}$ Email: zelimaria@hotmail.com. 
«Haverá paz no túmulo? Deus sabe o destino de cada homem. Para o que aí repousa sei eu que há na terra o esquecimento» ${ }^{1}$. Desde tempos imemoriais que o fenecimento fascinou o ser humano, preconizando uma evolução psicológica do género humano, que ao longo dos tempos, irá ocasionar distintas conceptualizações e atitudes perante a morte. Estas perceções originaram um manancial de mecanismos de processamento diferenciados e únicos, representativos de uma memória coletiva, refletindo costumes, crenças e civilizações ${ }^{2}$.

Na história do atual território europeu, o declínio do império romano, aliado a uma lenta e progressiva difusão e afirmação do Cristianismo, demarca um ponto fulcral de viragem na conceptualização do decesso, defendendo a existência de vida para além da morte. Estas mudanças ideológicas de foro religioso terão repercussões nos rituais funerários que acompanham o processo de mudança cultural, passando o corpo a ser encarado como um bem sagrado que não pode ser destruído, tornando-se fulcral a sua preservação para a Ressurreição do indivíduo no dia do Juízo Final ${ }^{3}$.

Surge assim uma nova preocupação na vida do Homem medieval: a salvação da sua alma individual para poder atingir a vita aeterna, sendo que para tal, o cumprimento de certas obrigações no decurso da sua vida física torna-se fundamental. Estas mudanças conceptuais ocasionam, inicialmente circunscrito aos meios urbanos, um fenómeno associado aos martyria e santos, que lhes veem serem conferidos "poderes», levando os cristãos a procurarem-nos para que estes intercedessem pela salvação das suas almas. Deste fenómeno nasce o tumulatio ad sanctos. Nos séculos seguintes, esta corrente evoluirá e culminará, quer no meio urbano, como rural, para uma tumulatio appud ecclesia, momento em que a Igreja procurava afastar os sepultamentos do interior dos templos, perpetuando, no entanto, o sepultamento em solo sagrado, nos adros e nas imediações das igrejas. Esta evolução dogmática e enquadramento sociocultural tem, como seria expectável, repercussões na caracterização das estruturas tumulares, cuja evolução segue o meio sociocultural ${ }^{4}$.

Desta forma, na Península Ibérica, nos últimos séculos da Alta Idade Média e numa época de Reconquista Cristã, num mundo em mudança, surge um fenómeno distinto, as necrópoles compostas por sepulturas talhadas em variados tipos de afloramentos rochosos. Apesar da sua difusão alargada e elevada representatividade, estas estruturas funerárias permanecem monumentos enigmáticos, não sendo consensual a sua classificação quer tipológica como cronológica ${ }^{5}$.

\footnotetext{
${ }^{1}$ HERCULANO, 1844.

${ }^{2}$ CUNHA, 1996; DUDAY et al., 1990; LARSEN, 1997, 2000, 2002.

${ }^{3}$ DUBY, 2007; ARIÉS, 1987, 1989.

${ }^{4}$ DUBY, 2007.

${ }^{5}$ BARROCA, 1987.
} 
Alguns investigadores defendem que estes túmulos terão originado no século VII, considerando as formas arcaicas os sepulcros de contornos regulares, trapezoidais e ovais, que irão, a partir do século VIII até ao IX, evoluir para formas mais complexas, com esboços de antropomorfismo, atendendo a pormenores de acabamento, nomeadamente ao nível da cabeceira e pés ${ }^{6}$.

Nas últimas décadas, foram resgatados vestígios osteológicos humanos destas estruturas tumulares, que tendo sido sujeitas a datações radiocarbónicas, comprovaram um uso diacrónico mais alargado destas realidades, apontando as datas obtidas para balizamentos cronológicos entre os séculos VII-XI' .

Assim sendo, com o presente trabalho, pretende-se aportar um pequeno contributo para a discussão acerca deste tipo de monumentos.

Os dados aqui apresentados são provenientes de uma intervenção sistemática realizada na Quinta de Crestelos (cerca de $11900 \mathrm{~m}^{2}$ ), que decorreu entre agosto de 2011 e janeiro de 2014, inserida no âmbito do Plano de Salvaguarda do Património do projeto, inserida no âmbito do Plano de Salvaguarda do Património do projeto de Aproveitamento Hidroelétrico do Baixo Sabor.

A Quinta de Crestelos ${ }^{8}$ localizada na margem esquerda do rio Sabor, a sul de Santo Antão da Barca, desenvolveu-se numa plataforma, a cerca de $185 \mathrm{~m}$ de altitude, com predomínio sobre a confluência da ribeira do Medal com o rio Sabor e protegida na extremidade norte por uma crista xistosa, com cerca de $160 \mathrm{~m}$ de extensão e $220 \mathrm{~m}$ de altitude. Topograficamente, a zona envolvente caracteriza-se por elevados contrastes, alternando entre áreas de vale, com pequenas plataformas e encostas com pendentes média e acentuada.

O perfeito enquadramento orográfico, que, concomitantemente fornece proteção natural e uma abundância quer de recursos hídricos, como florestais, formam componentes favoráveis para desenvolver uma ocupação humana prolongada. Esta ocupação foi comprovada arqueologicamente, tendo a intervenção revelado um sítio arqueológico único, com uma longa ocupação diacrónica desde a Pré-História recente até à atualidade, com eventuais fases de abandono. Com maior relevância destacam-se as ocupações do Calcolítico, Idade do Bronze, Idade do Ferro, Romana e Alta Idade Média.

As escavações expuseram um interessante conjunto arquitetónico, composto por estruturas habitacionais e funcionais resultantes de uma complexa evolução e

\footnotetext{
${ }^{6}$ BARROCA, 1987.

${ }^{7}$ MARTÍN VISO, 2012a.

${ }^{8}$ A Quinta de Crestelos encontra-se entre os lugares de Souto da Velha e S. Pedro, na margem oposta ao santuário de Santo Antão da Barca. As coordenadas do sítio segundo a projeção WGS84 são: M: 677067,18; P: 4569201,12. Administrativamente, pertence a freguesia de Meirinhos, concelho de Mogadouro e distrito de Bragança. No EIA do Baixo Sabor (1998), elaborado por Miguel Rodrigues e Ricardo Teixeira, foram ali identificados fragmentos de tegulae, imbrices e dolia, interpretando-se o local como um habitat romanizado.
} 


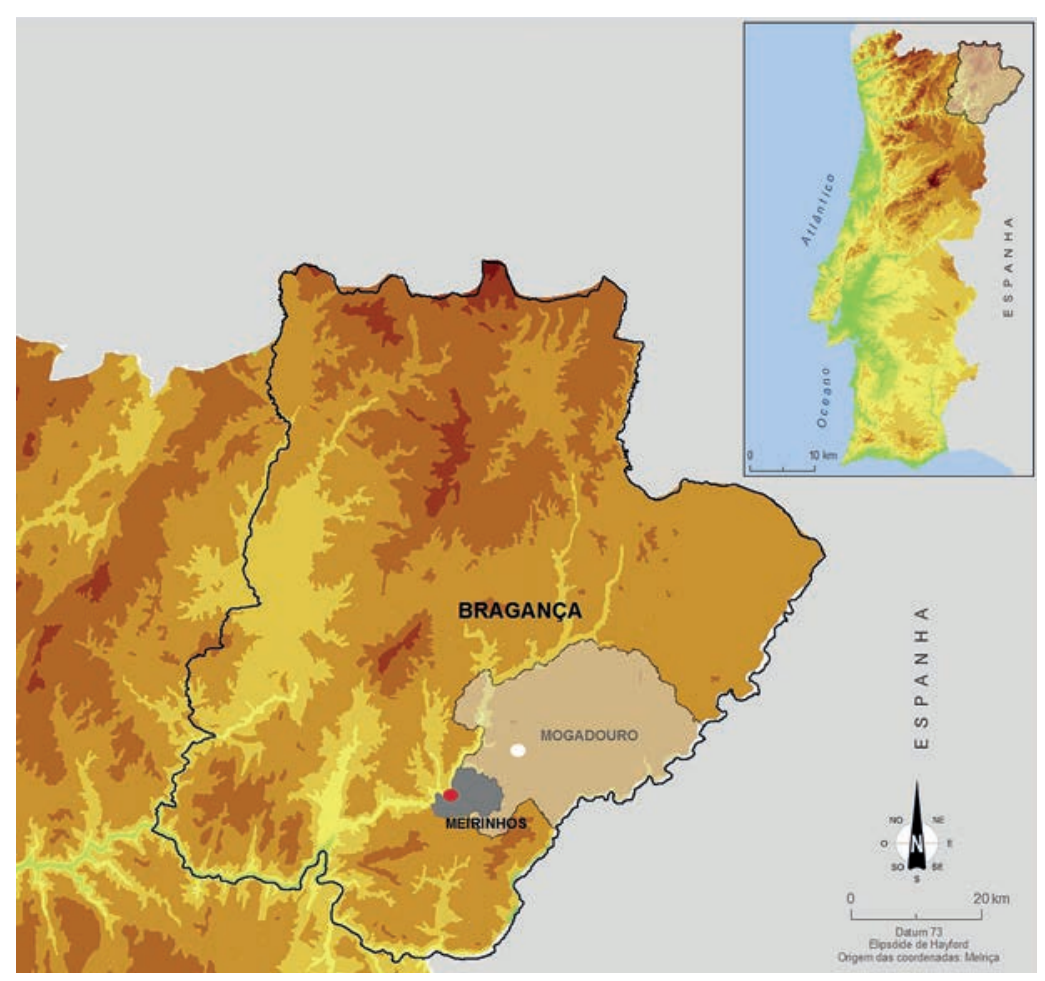

Mapa 1a.

Localização da Quinta de Crestelos no distrito de Bragança, concelho de Mogadouro e freguesia de Meirinhos Fonte: ArcGIS, 2104

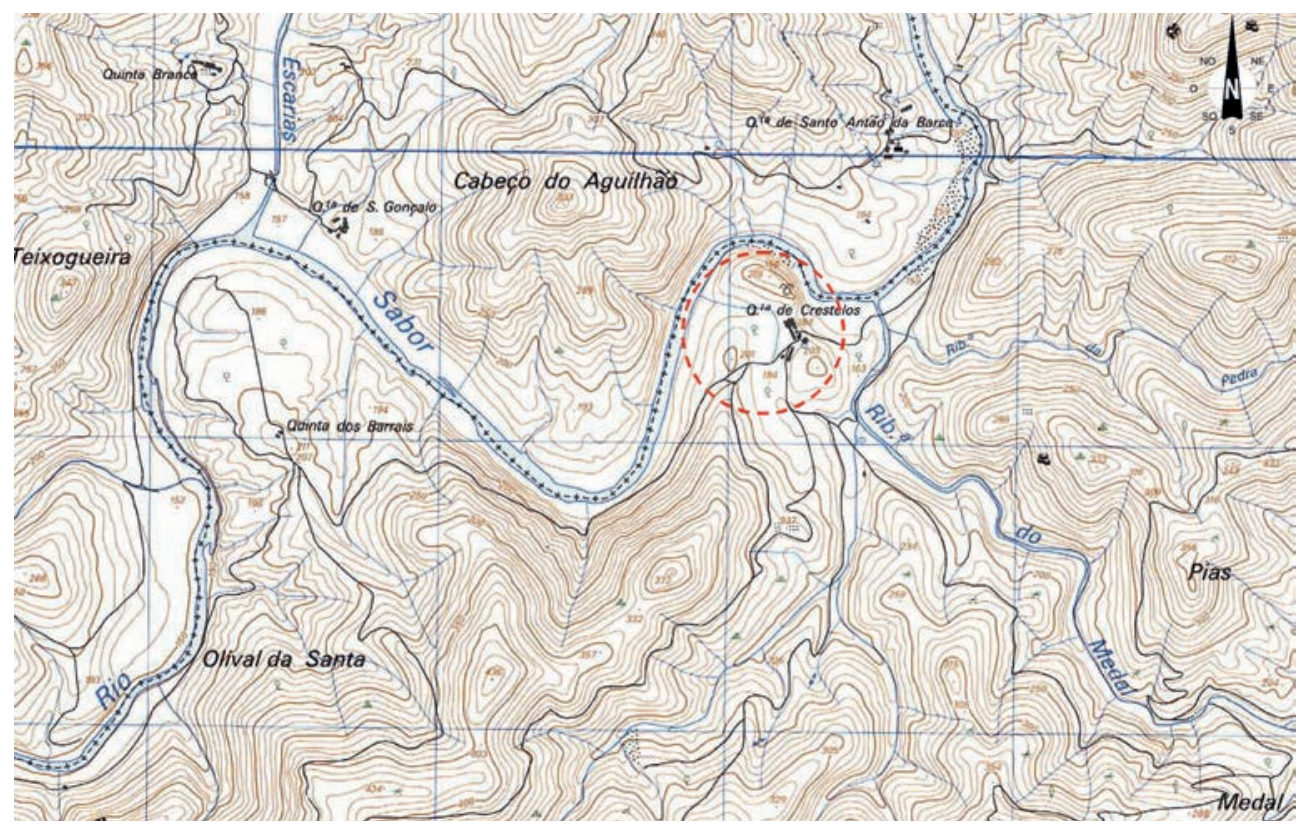

Mapa 1b. Localização administrativa da Quinta de Crestelos

Fonte: Carta Militar de Portugal, Folha 119 
adaptação do sítio ao longo das centúrias. De igual modo, o espólio recolhido, maioritariamente cerâmico e metálico, reflete uma intricada dinâmica das populações que aí habitaram. No entanto, após o primeiro ano de escavações arqueológicas intensivas em Crestelos e já com uma considerável área intervencionada, permanecia por desvendar a localização do espaço funcionalmente dedicado aos mortos.

Em 2012, numa pequena elevação a sul da contemporânea Quinta de Crestelos, orograficamente destacada ${ }^{9}$, sobranceira a paisagem envolvente e ligeiramente afastada, da área habitacional, a escavação em área de $606 \mathrm{~m}^{2}$ expôs um dos dois espaços funerários ${ }^{10}$ identificados, que passou a ser denominada como Necrópole Este.

A área intervencionada denotou um potencial estratigráfico diminuto, resultado da erosão natural dos sedimentos, dos sucessivos revolvimentos decorrentes da

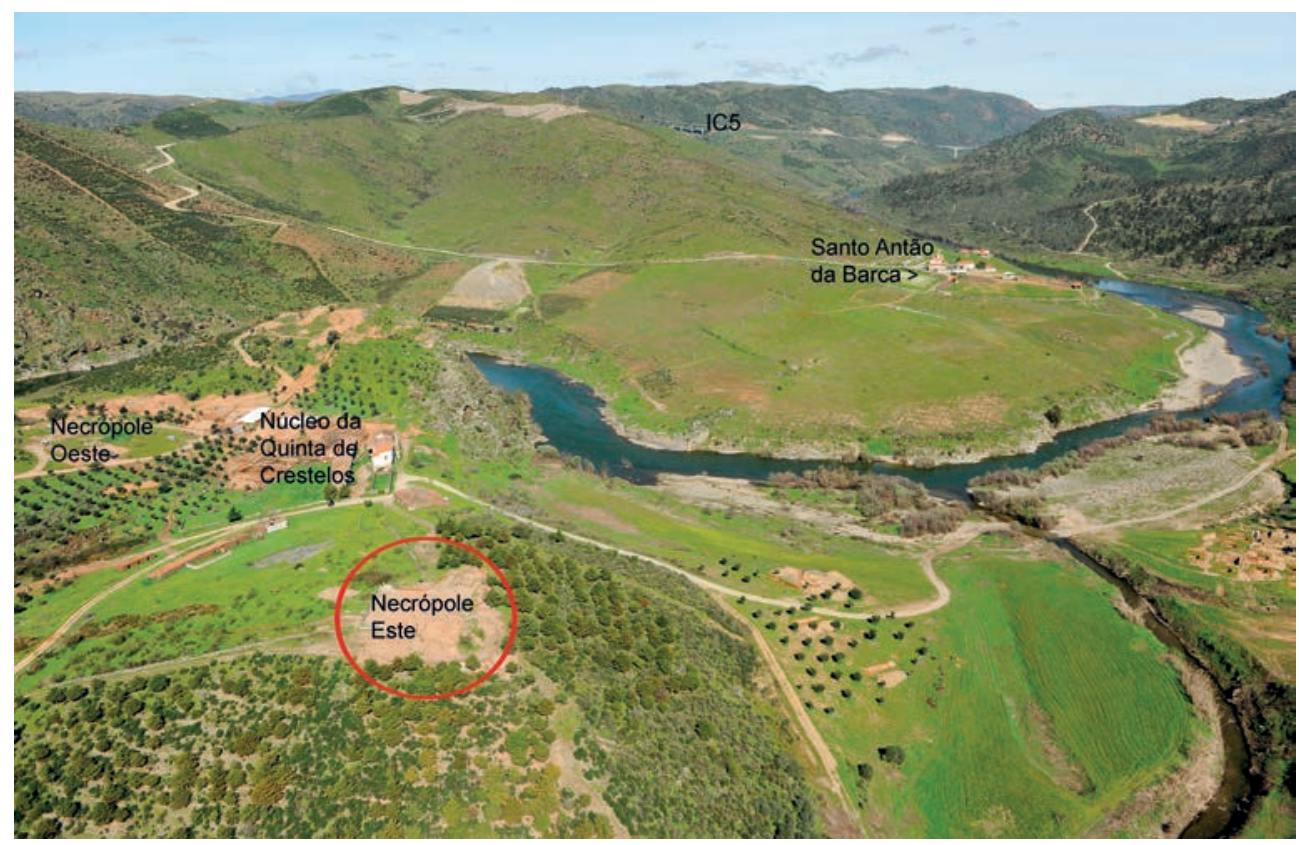

Fig. 1. Vista geral do sítio da Quinta de Crestelos Fonte: Arte Fotográfica Lda., Maio 2013

\footnotetext{
${ }^{9}$ Segundo informação oral de José Seixas (Felgar), na altura o caseiro, numa pequena elevação destacada e sobranceira à paisagem envolvente, a sudeste do núcleo de casas da Quinta de Crestelos e onde se construiu uma cerca de um viveiro de perdizes, teria existido uma capela em tempos mais recuados. No sentido de despistar a informação oral foram ali executadas duas sondagens de diagnóstico, no início de novembro de 2012, sob a responsabilidade científica de Susana Cosme. Nessa intervenção foram identificadas duas sepulturas, pelo que se decidiu alargar a área até cerca de $606 \mathrm{~m}^{2}$, com o objetivo de delimitar a possível necrópole.

${ }^{10}$ Durante o acompanhamento arqueológico, a posteriori, foi identificado um novo núcleo de sepulturas, cronológica e tipologicamente distintas, que confirmaram pertencer a uma segunda necrópole - a Necrópole Oeste, balizada entre os séculos V-VII (PEREIRA et al., 2015).
} 
atividade agrícola intensiva, da reformulação contemporânea da área em viveiro de perdizes e depois em canil, encontrando-se o substrato geológico de características xistosas em algumas zonas à superfície. Não obstante, neste pequeno outeiro comprovou-se uma dinâmica evolutiva e diacrónica do espaço.

Nesta área foram recolhidos vestígios compostos por vários fragmentos de cerâmica e um machado de pedra polida, cronologicamente balizados entre o Calcolítico/ Bronze inicial, infelizmente sem associação direta a estruturas. Não obstante, poderão indiciar uma ocupação antrópica deste outeiro, hipótese, no entanto, que terá que ser encarada com algumas reservas, face à carência de outras evidências arqueológicas. Para os períodos cronológicos posteriores destaca-se uma total ausência de evidências arqueológicas que parecem demonstrar um hiato ocupacional da área, podendo ter sido preterida ou abandonada ${ }^{11}$. A primeira ocupação efetivamente definida do espaço aponta já para uma funcionalidade dedicada aos mortos. O espaço do necrotério acabou eventualmente, por ficar votado ao esquecimento, denotando-se no outeiro um novo hiato ocupacional. A reutilização do local é retomada apenas no século XVII-XVIII, período em que a Quinta de Crestelos se revitalizou em termos de exploração agrícola. Processa-se uma transformação da paisagem envolvente e do respetivo espaço, tendo sido ali erguida uma habitação de apoio aos trabalhadores

Fig. 2.

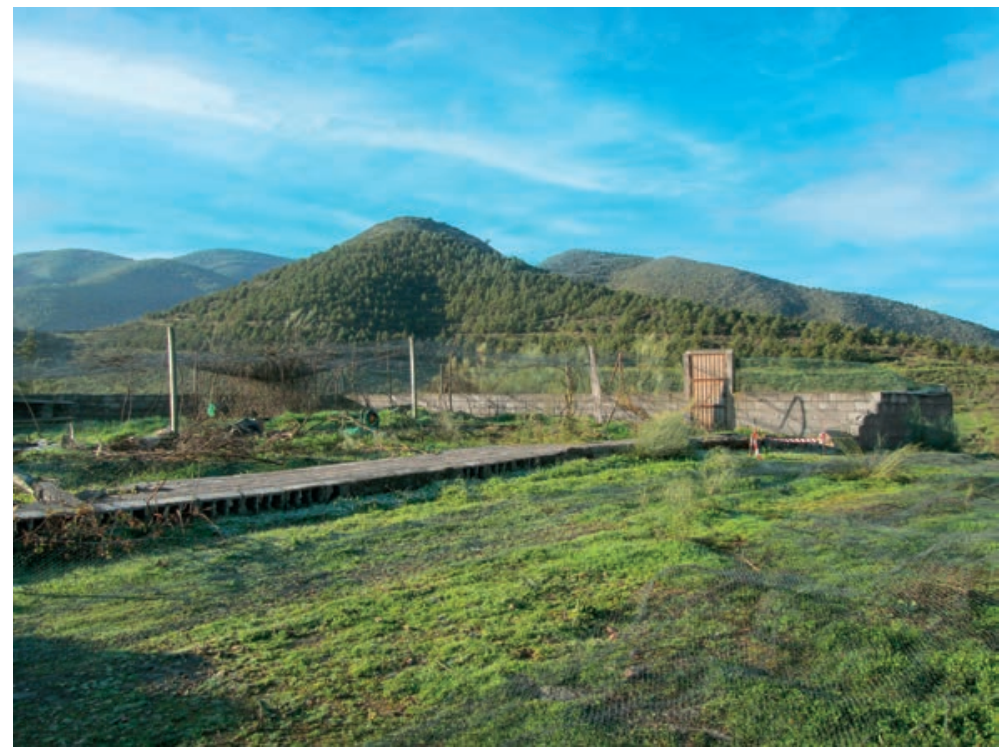

Vista geral do outeiro e do viveiro de perdizes, antes dos trabalhos Fonte: Ana Roriz, Archeo'Estudos; Arqueologia e Património, 2013

\footnotetext{
${ }^{11}$ Refira-se, apenas, o fortuito achado descontextualizado, à superfície de um anel de bronze, caracterizado por uma secção semicircular, com asas decoradas com incisões paralelas e mesa elíptica, possuindo uma cartela pontilhada a delimitar o campo epigráfico. Aí é visível uma inscrição: $\mathrm{V}+\mathrm{V}$, cuja interpretação poderá ser $\mathrm{V}(\mathrm{i}) \mathrm{V}($ as $)+(\mathrm{Cristo})$. Este tipo de anel encaixa na tipologia GUIRAUD 2G, cronologicamente balizada entre os séculos V-VII (GUIRAUD, 1989: 173-211).
} 
agrícolas sazonais no outeiro, que destruiu parte da necrópole. No final do século $\mathrm{XX}$, com vista à criação de perdizes, a área sofreu nova reformulação, tendo aí sido edificada uma cerca murada.

A pré-existência de uma capela no topo do outeiro, sugerida pelas fontes orais, não foi possível de confirmar arqueologicamente no decurso de toda a intervenção.

Já no que diz respeito ao necrotério, apesar das reformulações da área dos séculos XVIII e XX, este revelou um conjunto de 33 sepulturas escavadas na rocha, que ocupam uma área espacialmente circunscrita. No processo de escavação destas estruturas tumulares, ficaram expostas inumações primárias e secundárias. Os vestígios osteobiológicos humanos, apesar das limitações inerentes, revestem-se de suma importância, uma vez que, os ossos preservam memórias ontogénicas individuais, consequentemente permitindo reconstruir padrões socioculturais, o perfil paleodemográfico e paleopatológico de determinada comunidade.

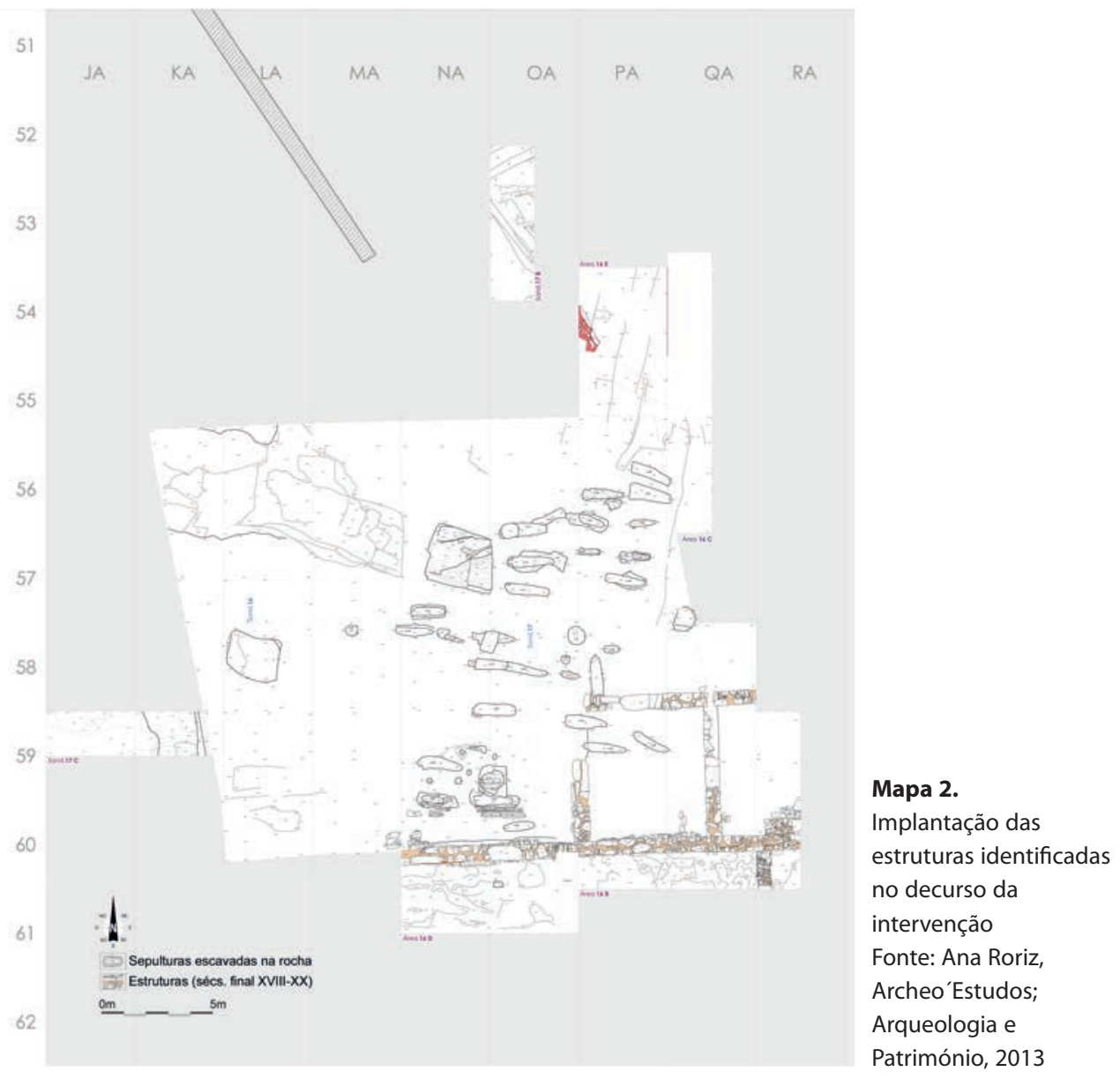


Tal, como já foi mencionado, as sepulturas foram abertas em solo xistoso, cujas características, em situações pontuais, inviabilizou uma análise adequada e consequente caracterização das estruturas. No entanto, estas apresentavam-se, de uma forma geral, relativamente bem preservadas ${ }^{12}$, tendo sido recuperados casos selados com tampa.

Considerando as soluções usadas na selagem dos sepulcros, o parco potencial estratigráfico não permitiu definir se a ausência de cobertura se revestia de intencionalidade ou se, por outro lado, poderia resultar de alterações pós-deposicionais. O sistema de colmatação das estruturas tumulares não ostentava uniformização, recorrendo por um lado, a várias lajes de pequenas e médias dimensões, de formas irregulares, dispostas transversalmente ao túmulo, e por outro lado, a laje única em xisto.

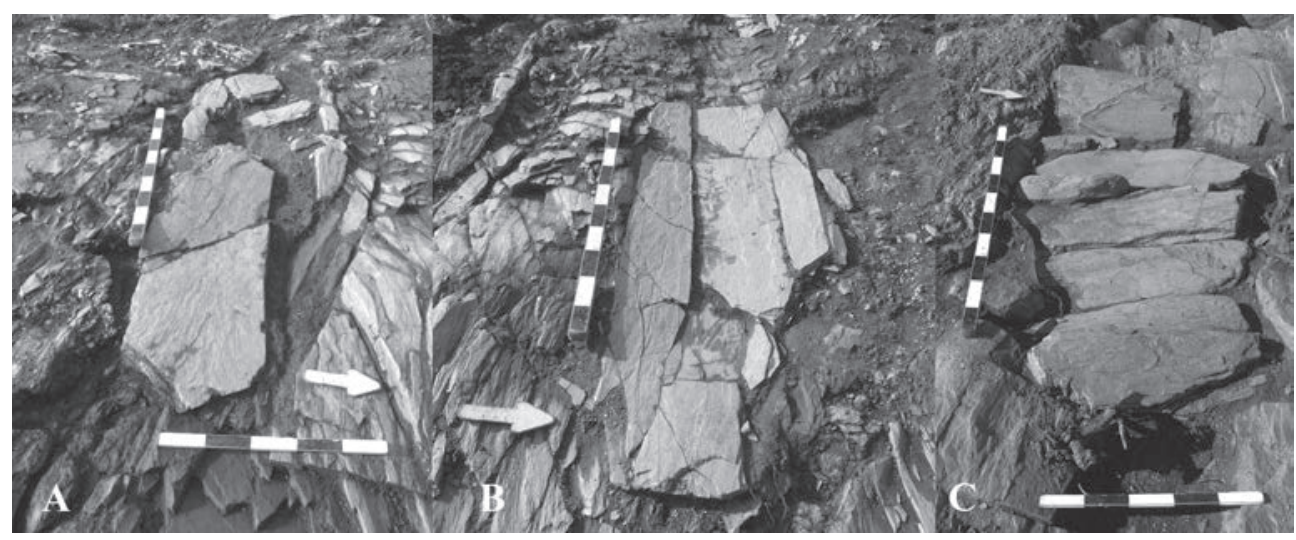

Fig. 3. Diferentes tipos de cobertura usadas na Necrópole Este de Crestelos (a) e b)- lajes de xisto únicas; c) várias lajes transversas ao túmulo)

Fonte: Ana Roriz, Archeo’Estudos; Arqueologia e Património, 2013

A grande maioria dos sepulcros ostentavam uma orientação canónica, oeste (cabeceira)/ este (pés), que parece estar intimamente correlacionada com à crença da ressurreição no dia Juízo Final, que determinou, desde o século VII, que a face dos indivíduos teria que estar virada para nascente, direção de Jerusalém. No entanto, surgiram ligeiras variações, nomeadamente nor-noroeste (cabeça)/ su-sudeste (pés) e su-sudoeste (cabeceira)/ nor-nordeste (pés), que, por sua vez, poderão refletir uma sazonalidade da construção das estruturas, sobretudo considerando a variação latitudinal do local do nascimento e pôr do sol em função da estação do ano.

\footnotetext{
${ }^{12}$ Do conjunto de 33 sepulturas, cinco $(5 / 33 ; 15,2 \%)$ estavam destruídas, 13 (13/33; 39,4\%) encontravam-se preservadas sem tampa e $15(15 / 33 ; 45,5 \%)$ estavam intactas e com tampa.
} 
Já os enterramentos denotaram uma normalização nos rituais de inumação, tendo os indivíduos sido depositados em decúbito dorsal, maioritariamente com orientação oeste (cabeça)/ este (pés), com os membros superiores fletidos sobre o tórax/abdómen, enquanto que os inferiores estavam estendidos e paralelos. Os enterramentos encontravam-se desprovidos de qualquer espólio funerário ou votivo, tendo

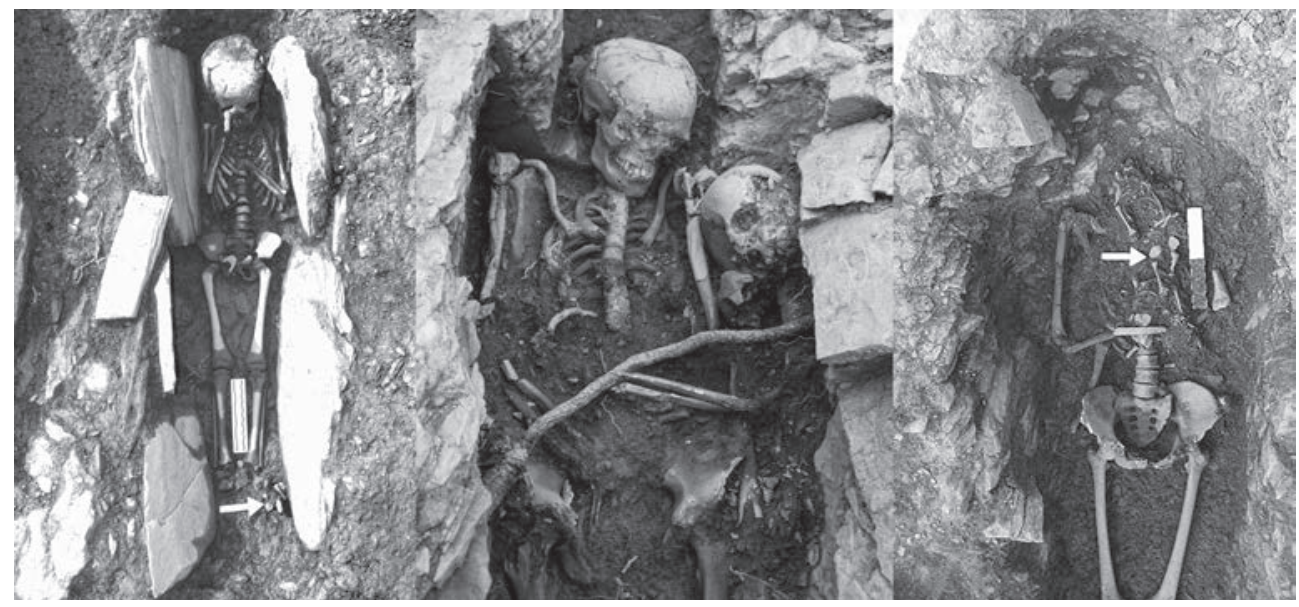

Fig. 4. Exemplo de inumações primárias e secundárias

Fonte: Ana Roriz, Archeo'Estudos; Arqueologia e Património, 2013

sido exclusivamente recolhida uma conta de vidro amarelada e opaca do interior de um sepulcro, sem qualquer conexão com o enterramento.

No conjunto da necrópole observou-se, heterogeneidade nas técnicas construtivas aplicadas na elaboração destas realidades funerárias ${ }^{13}$. De facto, apesar da totalidade das estruturas tumulares terem sido integralmente escavadas na rocha, alguns casos foram parcialmente complementados e delimitados por lajes, dispostas nas laterais e/ou cabeceira e pés, configurando, assim, em alguns casos, uma caixa.

Esta diversidade repercutiu-se, de igual modo, na tipologia das estruturas tumulares, assinalando-se a presença de uma maioria de sepulturas não-antropomórficas, a par de sepulturas antropomórficas.

Do conjunto de sepulturas não-antropomórficas, destacam-se as sepulturas de planta ovalada e sub-retangulares, seguindo-se com menor incidência as retangulares e trapezoidais.

No universo das sepulturas antropomórfica, observou-se, igualmente variações, caracterizando-se alguns túmulos por serem simétricos, e outros por denotarem apenas esboço do ombro esquerdo ou direito.

\footnotetext{
${ }^{13}$ Tipologia baseada em TENTE, LOURENÇO, 2002.
} 


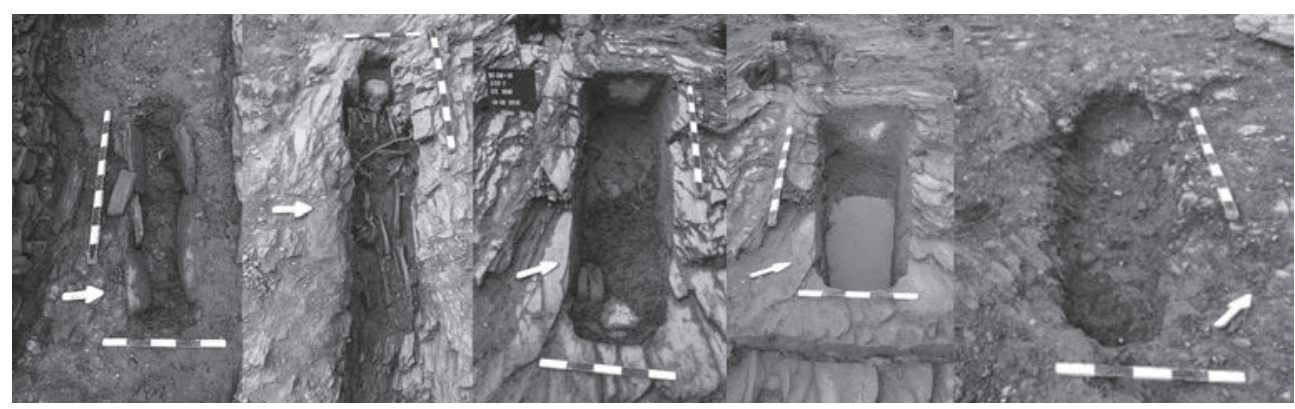

Fig. 5. Diversas tipologias de sepulturas identificadas

Fonte: Ana Roriz, Archeo’Estudos; Arqueologia e Património, 2013

A presença de diversas tipologias de sepulturas, em conjugação com a sobreposição de sepulturas ${ }^{14} \mathrm{e}$ a existência de deposições secundárias, indiciam uma ocupação diacrónica da necrópole, onde em determinadas situações ocorreu a reutilização das estruturas. Não obstante uma aparente ocupação alongada do espaço, esta não se refletiu na organização espacial das estruturas tumulares no seio da necrópole. A existência de vestígios osteológicos humanos associados a diferentes tipologias de sepulturas escavadas, permitiu uma seleção amostral para se proceder a datação através de C14.

Assim sendo, extraíram-se fragmentos de ossos provenientes quer de deposições primárias, bem como de deposições secundárias do interior de uma sepultura antropomórfica, uma sepultura ovalada e outra completada por lajes em cutelo. As datações para a sepultura antropomórfica balizam a sua utilização entre os séculos IX e XI ${ }^{15}$, enquanto a sepultura ovalada se enquadra entre os séculos IX e XIII ${ }^{16}$, por seu lado, a sepultura antropomórfica parcialmente revestida com caixa aponta para o século $\mathrm{XI}^{17}$, confirmando, assim, um uso diacrónico das estruturas tumulares.

No que concerne, especificamente, a reutilização de uma mesma sepultura, esta poderá correlacionar-se, por um lado, com a existência de laços familiares entre os indivíduos, ou por outro lado, com um organização e gestão do espaço sepulcral, uma vez que a elaboração deste tipo de estrutura exige determinados e elevados recursos.

\footnotetext{
${ }^{14}$ Durante a escavação foi possível verificar que a abertura de sepulturas mais recentes afetou parcialmente estruturas préexistentes, sugerindo que tenha decorrido tempo suficiente que permitisse olvidar a localização das sepulturas afetadas. ${ }^{15} \mathrm{Na}$ Sepultura 13, claramente antropomórfica, foram realizadas duas datações de C14, a primeira sobre o ossário [obtida sobre um fémur [UE 1710] - $1130 \pm 40$ BP (AD880-981 Dat. Calib. 1 Sigma] e a segunda sobre o enterramento [sobre um fémur direito [UE 1711] - $1055 \pm 35$ BP (AD 969-1027 Dat. Calib. 1 Sigma] - Laboratório Groningen/ Holanda (L. G.), sob a responsabilidade do Prof. J. van der Plicht.

${ }^{16} \mathrm{Na}$ Sepultura 20, ovalada, foram obtidas datações para o ossário (sobre um fémur direito do ossário [UE 1699] $-1030 \pm 35$ BP (AD 984-1026) Dat. Calib. 1 Sigma e para o enterramento (obtida sobre o fémur direito da inumação primária [UE 1709] foi $685 \pm 30$ BP (AD 1277-1300 Dat. Calib. 1 Sigma - L.G.).

${ }^{17}$ Sepultura 3, a datação C14 do ossário (sobre uma tíbia [UE 1640] - $975 \pm 40$ BP (AD 1018-1050 Dat. Calib. 1 Sigma) - realizadas no L.G.
} 


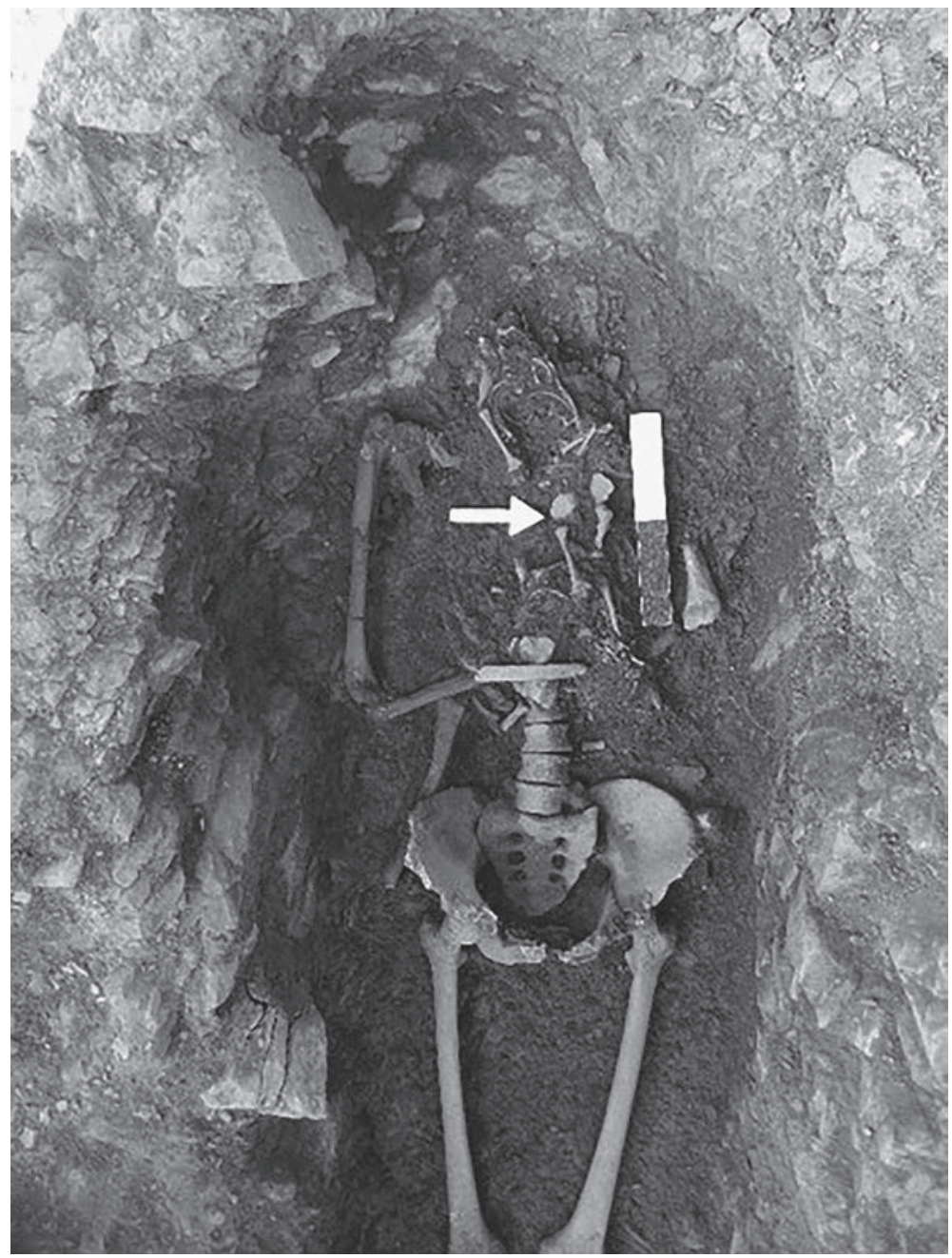

Fig. 6.

Caso de reutilização de sepultura Fonte: Ana Roriz, Archeo'Estudos; Arqueologia e Património, 2013

Um outro fator de destaque desta necrópole prende-se com as dimensões observadas nas sepulturas, nomeadamente o comprimento máximo, que ostenta uma oscilação, para as diferentes tipologias, alargada, variando entre um mínimo de $70 \mathrm{~cm}$ e um máximo de $211 \mathrm{~cm}$. Realce-se que as sepulturas com comprimentos máximos situados entre os $70 \mathrm{~cm}$ e $120 \mathrm{~cm}$ de comprimento máximo estarão, muito provavelmente, associados ao sepultamento de indivíduos não-adultos. A existência destes sepulcros associados a crianças leva-nos a questionar qual o papel e como seriam encaradas as crianças no seio destas comunidades rurais. A presença destes sepulcros remete para elementos de estatuto social relativamente elevado, atendendo, ao já preconizado anteriormente, sobre a exigência de recursos necessários para elabo- 
rar este tipo de monumentos funerários. A presença de sepultamentos de indivíduos imaturos nesta necrópole, foi, em última instância, comprovada pelas inumações identificadas associadas a estas sepulturas.

Do conjunto de sepulcros intervencionados, apenas 17, continham restos ósseos humanos, que denotavam uma parca preservação, provavelmente resultante do $\mathrm{pH}$ ácido dos solos envolventes. A acidez dos solos é uma característica química que contribui fortemente para a degradação do material osteológico, através da corrosão, solubilização e descalcificação do material ${ }^{18}$.

O estudo paleobiológico, fortemente limitado pelo estado de preservação, possibilitou estabelecer um diagnóstico sexual em apenas 11 indivíduos, que correspondem a um total de sete mulheres e quatro homens ${ }^{19}$. A elevada percentagem de indivíduos para os quais não foi possível determinar a diagnose sexual impede que sejam indagadas ilações. No entanto, refira-se que não se constatou diferenças na prática de gestos funerários que possam correlacionar-se com o sexo dos indivíduos.

Paralelamente à diagnose sexual, procurou-se obter uma estimativa da idade à morte, uma vez que poderá trazer dados relativamente a esperança média de vida, taxa de morbilidade, o que contribui para a compreensão das condições de vida das populações pretéritas. Infelizmente, esta análise, uma vez mais, foi substancialmente condicionada pelo estado de preservação dos restos osteológicos, tendo sido apenas possível aferir com alguma acuidade a idade à morte em oito indivíduos imaturos com idades compreendidas entre os 0 e 13 anos de idade, enquanto que nos adultos apenas se obteve um intervalo etário para dois indivíduos, que teriam uma idade compreendida entre os 21-30 anos ${ }^{20}$.

No âmbito do estudo morfológico, foi possível determinar a estatura em 3 indivíduos, de sexo feminino, com resultados compreendidos entre os 140,43 cm e os $157,88 \mathrm{~cm}$. Uma estatura reduzida pode ser interpretada como um indicador de condições de vida pouco favoráveis durante o crescimento, nomeadamente resultante de um maior stresse nutricional e exposições a agentes patogénicos ${ }^{21}$.

O exame paleopatológico, que teve por base uma observação macroscópica das peças ósseas, ficou igualmente condicionado. Ainda assim, foi possível observar algumas afeções da cavidade oral, entre as quais se destacam a perda de dentes ante mortem, uma baixa incidência de cáries e a presença de tártaro e desgaste dentário moderados, que parecem traduzir alguma precariedade nos cuidados de higiene

\footnotetext{
${ }^{18}$ NAWROCKI, 1995.

${ }^{19}$ BUIKSTRA, UBELAKER, 1989.

${ }^{20}$ FEREMBACH, SCHWIDETZKY, STLOUKAL, 1980; SCHEUER, BLACK, 2000.

${ }^{21}$ ROBERTS, MANCHESTER, 1995.
} 
oral e uma dieta alimentar, provavelmente constituída por algumas partículas duras e abrasivas, ricas em proteínas e pobres em hidratos de carbono ${ }^{22}$.

Registaram-se, ainda, escassas evidências de patologias de foro degenerativo, nomeadamente através da presença de artrose e lesões das enteses ligeiras. Uma vez que estas patologias poderão estar a ser subvalorizadas, atendendo ao estado fragmentário da amostra, será mais prudente não estabelecer ilações sobre possíveis atividades desempenhadas pelos indivíduos exumados.

Identificaram-se duas anomalias congénitas, nomeadamente, um caso de espinha bífida oculta no sacro e um outro caso de espinha bífida cística que poderá correlacionar-se com um caso de hidrocefalia, recuperado de uma deposição secundária.

Registou-se, de igual forma, a presença de alguns indicadores de stresse fisiológico, evidenciados através da presença de cribra orbitalia e hipoplasia do esmalte dentário, sugerindo que os indivíduos afetados terão sofrido episódios de stresse durante as suas vidas.

O caso da Necrópole Este assume um particular interesse pelo facto de a mesma se ter delimitado e escavado na íntegra e por se poder associar a uma área habitacional, igualmente escavada ${ }^{23}$. Desde logo salta à vista a localização das construções habitacionais, implantadas na área mais baixa da plataforma de Crestelos, abrigada e discreta, ao invés da necrópole encimada num outeiro e de considerável destaque na paisagem.

Importa agora integrar este espaço funerário numa escala mais alargada e regional, bem como no âmbito de outras intervenções próximas. O Plano de Salvaguarda do Património do Baixo Sabor contemplou a recolha de informação e a confirmação de dados bibliográficos sobre esta temática na região envolvente ao projeto, nomeadamente nos concelhos de Alfândega da Fé, Macedo de Cavaleiros, Mogadouro, Freixo de Espada à Cinta e Torre de Moncorvo ${ }^{24}$.

Em pleno vale do rio Sabor, a jusante de Crestelos, teve lugar outra intervenção de um espaço funerário, no sítio de Silhades/Laranjal (Felgar-Torre de Moncorvo). Foram ali exumadas cerca de 200 sepulturas de inumação, em caixa e em covacho, cronologicamente integráveis na Alta Idade Média. A discrição do local de implantação e a dimensão desta necrópole contrastam com o nosso caso, ainda que se possa justificar pela proporcionalidade do núcleo habitacional medieval de Silhades ou pela presença de um edifício religioso.

\footnotetext{
${ }^{22}$ HILLSON, 2001; LAMARQUE, 1991.

${ }^{23}$ O sítio da Quinta de Crestelos foi escavado parcialmente em diferentes fases, empresas e responsáveis, desde 2011. Relacionável com a Necrópole Oeste destacamos a intervenção dirigida por Susana Cosme e João Nisa (PEREIRA et al, 2014).

${ }^{24}$ Destaque-se o importante trabalho de recolha bibliográfica, prospeção ou reconhecimento de campo e sistematização de dados desenvolvido por Joan Garibo Bodí no âmbito do «Estudo sobre a Romanização do Vale do Sabor» — PSP do Baixo Sabor (PEREIRA et al, 2014).
} 
Outros espaços funerários intervencionados nesta região revelaram também uma clara homogeneidade cronológica: Necrópole de Vila dos Sinos (Mogadouro, n. ${ }^{\circ}$ 19) e a Necrópole de Mós (Torre de Moncorvo, n. ${ }^{\circ} 34$ ). No primeiro caso ${ }^{25}$, a intervenção ocorreu em 1981, os trabalhos desenvolvidos permitiram identificar 36 sepulturas e escavar 14 sepulturas, balizadas entre o século VIII e a Baixa Idade Média. No segundo caso, a intervenção remonta a 2007, tendo sido registadas várias sepulturas escavadas na rocha e exumados, pelo menos, nove esqueletos e dois ossários enquadráveis nos séculos IX-X.

Estes quatro exemplos, intervencionados na região, distinguem-se de muitos outros casos, em que os sepulcros rupestres foram identificados depois de esvaziados ou violados ou desprovidos de informação arqueológico-antropológica. Apesar de relativamente abundantes nos territórios transmontanos, a informação arqueológica ou científica é ainda escassa (Mapa 3).

À semelhança de outros núcleos estudados, também nesta região as sepulturas rupestres, em conjunto ou necrópole, encontram-se associadas a núcleos habitacionais (Silhades, Quinta de Crestelos, Cevadeiras ou Cabeço da Alfarela) ou edifícios religiosos (Silhades, Vila dos Sinos, Necrópole de Mós ou N. Sr. ${ }^{a}$ dos Anúncios).

Pontualmente, os espaços funerários parecem derivar ou dar continuidade a uma tradição funerária mais antiga, nomeadamente romana (Quinta de Crestelos, Silhades, N. Sr. ${ }^{a}$ dos Anúncios). Não podemos desconsiderar que nalguns casos o processo foi inverso e os espaços funerários de tradição tardo romana ou mesmo alto medieval foram sacralizados através da construção de uma capela ou pequeno templo.

Em qualquer dos casos, os necrotérios assumiam um elevado valor simbólico, eram encarados como locais sagrados e em que o destaque na paisagem podia ser secundarizado por outros fatores, como a proximidade com as vias de comunicação, cursos de água ou recursos naturais.

Para terminar, importa ainda destacar o papel das sepulturas isoladas, mais raras ou difíceis de identificar na região. A sua função, mais específica e baseada em outros casos de estudo, poderá relacionar-se com a necessidade de assinalar a propriedade rural. Parecem desempenhar um papel de marcadores de paisagem e de propriedade direta de terrenos férteis ou com outros recursos, não distantes de um habitat. Assim, estes sepulcros isolados são ainda mais discretos, parecem associados a uma estratégia de apropriação territorial através do recurso à inumação, como elemento legitimador de posse de uma determinada área produtiva, ao longo do tempo ${ }^{26}$.

\footnotetext{
${ }^{25}$ LEMOS, MARCOS, 1981.

${ }^{26}$ LAINELA CORBERA, ORTEGA ORTEGA, 2015; MARTÍN VISO, 2012a, 2012b; RUBIO DÍEZ, 2013.
} 


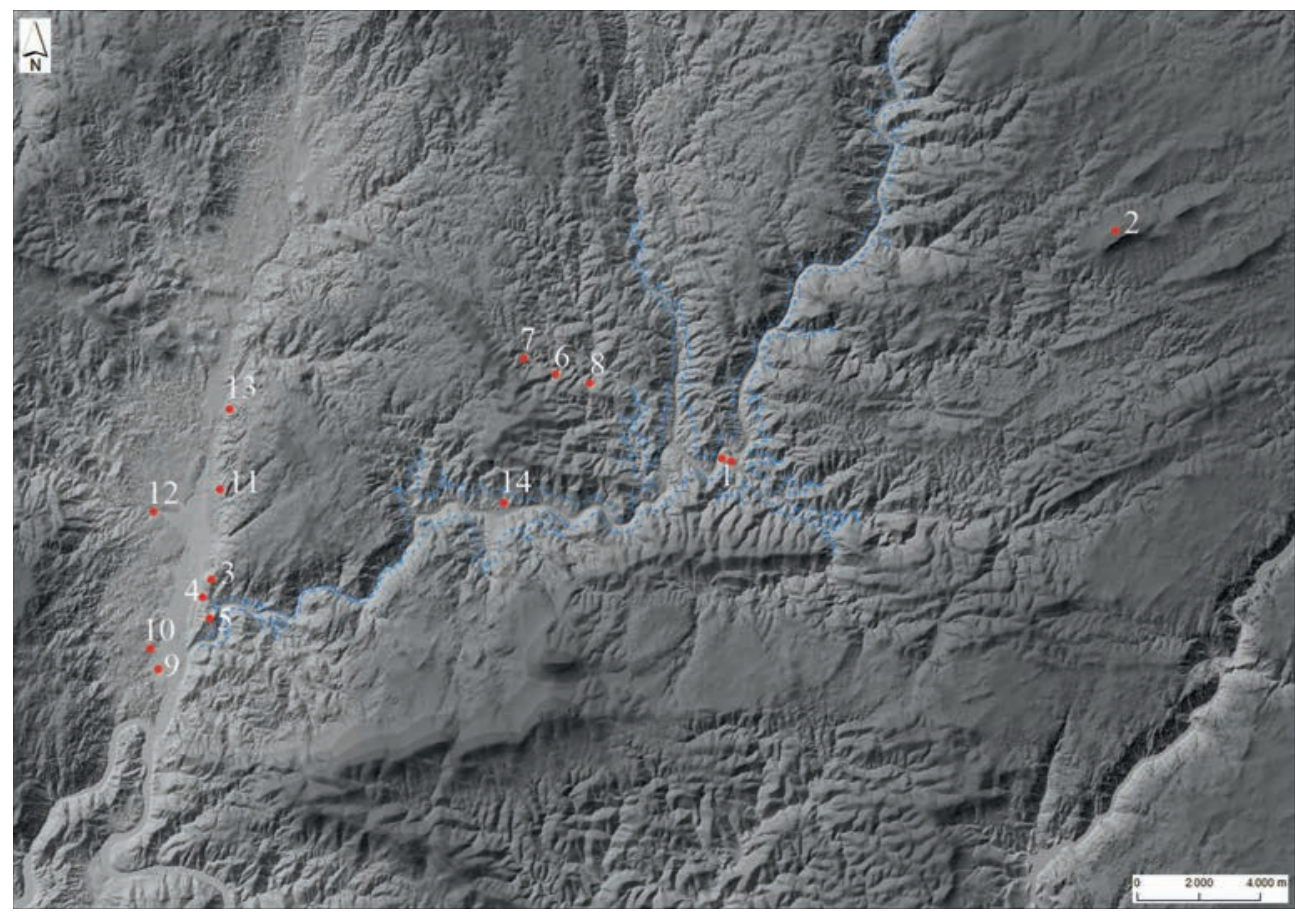

Mapa 3. Implantação dos sítios com vestígios de rituais funerários medievos na região envolvente ao Baixo Sabor e Vale da Vilariça: Alfândega da Fé: 1. Fonte Velha, 2. Igreja de Sendim da Serra, 3. Nossa Senhora de Jerusalém, 4. Santa Eufémia Sendim da Serra, 5. Senhora dos Anúncios; Freixo de Espada-à-Cinta, 6. Cabeço da Escória/Mulher de Pedra, 7. Igreja de Ligares, 8. Monte de São Paulo/ Castro de Alpajares; Macedo de Cavaleiros, 9. Bornes/Santa Marta, 10. Castelo de Balsamão, 11. Sobreda; Mogadouro, 12. Igreja de Santa Maria de Azinhoso, 13. Minas da Fonte Santa, 14. Quinta de Crestelos, 15. Núcleo do Castelo e Igreja Matriz de Mogadouro, 16. Quinta do Nogueira, 17. Ribeirinha, 18. Castelo e Vila de Penas Roias, 19. Adro da Igreja de Vila dos Sinos; Torre de Moncorvo, 20. Adeganha/ Igreja Santiago Maior, 21. Baldoeiro, 22. Cevadeiras, 23. Olival das Fragas, 24. Santa Cruz da Vilariça, 25. Vila Maior/Zambulheira/Olival da Rasa, 26. Caminho das Sepulturas/São Pedro, 27. Paredes, 28. São Cristóvão, 29. Silhades/Laranjal, 30. Eira de Santiago, 31. Lamelas II, 32. Santa Eufémia de Felgueiras, 33. Godeiros/Pala do Conde, 34. Necrópole de Mós, 35. Cabeço de Alfarela, 36. Igreja de Santiago, 37. Castelo de Nossa Senhora de Urros, 38. Lameirões/ Santo Apolinário de Urros.

Fonte: Google Earth, 2019

\section{BIBLIOGRAFIA}

ARIÉS, Philippe (1987). O Homem perante a Morte. Lisboa: Publicacoes Europa-America, vol. 1.

ARIÉS, Philippe (1989). Sobre a História da Morte no Ocidente desde a Idade Média. Lisboa: Editorial Teorema.

BARROCA, Mário Jorge (1987). Necrópoles e sepulturas medievais de Entre-Douro-e-Minho (séculos V a XV). Porto: Faculdade de Letras da Universidade do Porto. Dissertação para Provas Públicas de Aptidão Pedagógica e Capacidade Científica.

BARROCA, Mário Jorge (2008-2009). De Miranda do Douro ao Sabugal - Arquitectura militar e testemunhos arqueológicos medievais num espaço de fronteira. «Portvgalia». Nova Série. 29-30, 193-252. 
BUIKSTRA, J. E.; UBELAKER, D. H., ed. (1994). Standards for Data Collection from Human Skeletal Remains. Arkansas Archeological Survey Research Series.

CUNHA, Eugénia (1996). Viajar no tempo através dos ossos. A investigação paleobiológica. «al-Madan». II Série. 5, 131-141.

DUBY, Georges (2007). A Idade Média. Uma Idade do Homem. Lisboa: Editorial Teorema.

DUDAY, H. et al. (1990). L' Anthropologie "de terrain": reconnaissance et interpretation des geste funéraires. «Bulletins et Mémoires de la Sociétè d'Anthropologie de Paris». 2: 3-4, 29-49.

FEREMBACH, D.; SCHWIDETZKY, I.; STLOUKAL, M. (1980). Recommendations for Age and Sex Diagnoses of Skeletons. In CHIARELLI, A. B., ed. «Journal of Human Evolution». 9: 7, 517-550.

GUIRAUD, H., (1989). Bagues et anneaux á l’époque romaine en Gaule. "Gallia». 46, 173-211.

HERCULANO, A. (1844). Eurico o presbitero. Editora Ulisseia, p. 46.

HILlSON, S. (2001). Recording Dental Caries in Archeological Human Remains. «International Journal of Osteoarcheology». 11, 249-289.

LAINELA CORBERA, C.; ORTEGA ORTEGA, J. (2005). Arqueología y poblamiento. La cuenca del río Martín en los siglos V-VIII. Zaragoza.

LAMARQUE, C. (1991). Caries, usure et parodonte d'une population medieval provenant du Quartier Saint-Etienne a Toulouse. Bordéus: Universidade de Bordéus I.

LARSEN, C.S. (1997). Bioarchaeology. Interpreting behavior from the human skeleton. Cambridge: Cambridge University Press.

LARSEN, C. S. (2000). Skeleton in our closet: revealing our past though Bioarchaeology. Princeton: Princeton University Press.

LARSEN, C.S. (2002). Bioarchaeology: The lives and lifestyles of Pas People. «Journal of Archaeological Research». 10: 2, 119-166.

LEMOS, Francisco Sande (1993). Povoamento romano de Trás-os-Montes Oriental. Braga: Universidade do Minho. Tese de Doutoramento.

LEMOS, Francisco Sande.; MARCOS, Domingos (1981). A necrópole medieval de Vila dos Sinos. «Cadernos de Arqueologia». II Série. 1, 71-89.

MARTÍN VISO, Iñaki (2007). Tumbas y sociedades locales en el centro de la Península Ibérica en la Alta Edad Media: el caso de la comarca de Riba Côa (Portugal). «Arqueología y Territorio Medieval». 14. 21-47.

MARTÍN VISO, Iñaki (2012a). Enterramientos, memoria social y paisaje en la Alta Edad Media. Propuesta para un análisis de las tumbas excavadas en la roca en el centro-oeste de la Península Ibérica. «Zephyrus». 69, 165-187.

MARTÍN VISO, Iñaki (2012b). Paisajes sagrados, paisajes eclesiásticos. De la necrópolis a la parroquia en el centro de la Península Ibérica «Reti Medievali». 13: 2, 3-45.

NAWROCKI, S. (1995). Taphonomic processes in historic cemeteries. In GRAUER, A.L., coord. Body of evidence: Reconstructing history through skeletal analyses. New York: Wiley-Liss, pp. 49-66.

PEREIRA, Sérgio et al. (2015). Espaços funerarios no sitio da Quinta de Crestelos: do Baixo-império à Idade Média (Mogadouro, Portugal). In QUIRÓS CASTILLO, J-A.; CASTELLANOS, S., coord. Identidad y etnicidad en Hispania. Propuestas teóricas y cultura material en los siglos V-VIII. Vitória: Universidad del País Vasco.

PEREIRA, Sérgio et al. (2014). A Romanização do Vale do Sabor: de Meirinhos a Remondes (Mogadouro). In DINIS, António, coord. I Encontro de Arqueologia de Mogadouro. Mogadouro: Município de Mogadouro, pp. 95-143.

ROBERTS, C; MANCHESTER, K. (1995). The Archaeology of disease. New York: Cornell University Press. RUBIO DÍEZ, Rubén (2013). Geografía funeraria, comunidades campesinas y articulación territorial post-romana al suroeste de Salamanca. In COMPAÑY, G. et al. coord. Actas de las V Jornadas 
de Jóvenes en Investigación Arqueológica. Arqueología para el siglo XXI (Santiago de Compostela, mayo de 2012). Santiago de Compostela: Universidad de Santiago, pp. 119-125.

SCHEUER, L.; BLACK, S. (2000). Developmental juvenile osteology. London: Academic Press.

TEIXEIRA, Ricardo; RODRIGUES, Miguel (1998). Levantamento do património arqueológico no âmbito do Estudo Preliminar de Impacte Ambiental do Empreendimento Hidroelétrico do Baixo Sabor. [Relatorio Final]. Relatório Policopiado, IPA.

TENTE, Catarina; LOURENÇO, Sandra (2002). Sepulturas medievais do distrito de Évora. "Revista Portuguesa de Arqueologia». 5: 1, 239-258.

WICKHAM, C. (2009). Una nueva historia de la Alta Edad Media: Europa y el mundo Mediterráneo, 400-800 d. C.. Barcelona: Crítica.

WILLIAMS, H. (2006). Death and memory in Early Medieval Britain. Cambridge: Cambridge University Press. 



\title{
SEPULTURAS ESCAVADAS NA ROCHA NO CURSO INFERIOR DA BACIA DO RIO LIMA - O CONCELHO DE VIANA DO CASTELO EM PERSPETIVA
}

\author{
ANDREIA AREZES*
}

\begin{abstract}
Resumo: As sepulturas escavadas na rocha constituem formas particulares de expressão das comunidades medievais na sua resposta à morte. Dotadas de especificidades morfológicas cuja evolução e cronologia há muito se vem procurando delinear, marcam a paisagem e veiculam materialmente aspetos da sensibilidade religiosa e socioeconómica subjacente. Neste texto promovemos uma aproximação às sepulturas escavadas na rocha no setor jusante da bacia do Lima, território que, do ponto de vista administrativo, é em grande medida abarcado pelo atual concelho de Viana do Castelo, inserido na fachada ocidental do noroeste peninsular. Partindo de trabalhos e inventários previamente efetuados propomo-nos, por um lado, retornar a um conjunto de sítios já arrolados e descritos, no sentido de revisitar as existências documentadas e o presente estado de conservação das estruturas. Por outro, confrontar os diferentes dados publicados com renovadas observações, visando aferir e complementar o mapeamento deste tipo de manifestação sepulcral, transversal a diversas geografias europeias, muito embora com especial representatividade na Península lbérica.
\end{abstract}

Palavras-chave: Sepulturas escavadas na rocha; Setor jusante do Lima; Revisão; Mapeamento.

Abstract: Rock-cut graves are particular forms of expression of medieval communities in their response to death. Endowed with morphological specificities whose evolution and chronology have long been sought to outline, they mark the landscape and materialize aspects of the underlying religious and socioeconomic sensitivities. In this text I approach the rock-cut graves detected in the downstream sector of the Lima basin, a territory that, from an administrative point of view, is largely correspondent to the current municipality of Viana do Castelo, located in the western façade of the northwest of Iberian Peninsula. Using researches and inventories previously carried out as a starting point I propose, on the one hand, to return to a set of sites that have been already listed and described, in order to revisit the reported occurrences and the current state of conservation of the structures. On the other hand, to confront different published data with renewed observations, aiming to validate and to complement the mapping of this type of funerary manifestation, transversal to different European geographies, although with special representation in the Iberian Peninsula.

Keywords: Rock-cut graves; Downstream sector of Lima; Review; Mapping.

\section{INTRODUÇÃO}

O território abordado neste texto, inscrito no noroeste peninsular, foi ocupado por uma densa rede de castros na Idade do Ferro ${ }^{1}$. Já sob o domínio romano, encontramo-lo como parte integrante da província da Gallaecia, tendo começado

* FLUP/DCTP; FLUP/CITCEM. Email: aarezes@letras.up.pt.

${ }^{1}$ ALMEIDA, 1968: 12-13; SILVA, 2009: 103-168. 
a evidenciar a marca da organização eclesiástica, espelho inequívoco do avanço da cristianização, a partir do século IV. No quadro do reino suevo, por seu turno, a velha Gallaecia apresentava limites algo mal definidos, exceção feita, naturalmente, aos coincidentes com os limites impostos pelo Atlântico, a oeste ${ }^{2}$. E sendo certo que a repartição do seu território na segunda metade do século VI por treze dioceses (e paróquias dependentes), supostamente às ordens do rei Miro - conforme veiculado pelo Parochiale Suevum - representou um importante avanço organizacional do ponto de vista administrativo, tal não significa que o propósito de controlo e evangelização deste território ${ }^{3}$ tenha sido cumprido de modo integralmente homogéneo.

As referências à ocupação antiga da região, designadamente proto-histórica e romana, não são, como veremos, de somenos importância. Na verdade, os nexos de proximidade entre sepulturas rupestres e castros, vias (romanas ou medievais) ou simplesmente, velhos caminhos, têm sido atestados em vários estudos e para diversas geografias ${ }^{4}$. Em paralelo, também a correlação entre a implantação destas estruturas tumulares e a de edifícios religiosos merece ser sublinhada, sendo possível apontar múltiplos exemplos concretos que a corroboram ${ }^{5}$. No entanto, os templos atualmente observáveis em conexão são, em grande medida, mais tardios, ainda que possam configurar «roupagens» mais recentes de estruturas primitivas.

A situação apreciada para o curso inferior da bacia do Lima, atualmente correspondente, do ponto de vista administrativo, ao espaço abarcado pelo concelho de Viana do Castelo, denuncia pontos de contacto evidentes com a realidade genérica descrita. Pautado por uma matriz eminentemente granítica, é entrecortada por manchas de outros minerais. Com efeito, os granitos porfiroides constituem o substrato primordial observável na paisagem: na Serra de Santa Luzia, que se prolonga até Cuturo e Agrichouso, avultam os de grão fino ou médio; na Serra de Perre, que se ergue entre Outeiro e Nogueira, os de grão médio ou grosseiro. Já a sul do Lima, na mancha de Geraz e da Serra da Padela, sobranceira a Portela de Susã, ressaltam os granitos de grão médio ou fino. Há, contudo, alguns filões xistosos, por exemplo, em Santa Leocádia de Geraz do $\operatorname{Lima}^{6}$ ou, voltando a perspetivar a margem norte, entre a Arga e as Serras de Perre e Santa Luzia. Aliás, sobre a faixa xistenta foram-se erguendo povoações, caso de Montaria, Vilar de Murteda e Amonde ${ }^{7}$.

A referência a zonas de contacto entre granitos e xistos leva-nos a mencionar os recursos mineiros da região. Destacamos as explorações estaníferas, presentes espe-

\footnotetext{
${ }^{2}$ MARQUES, 2003: 153.

${ }^{3}$ MARQUES, 2003: 153, 155; ALARCÃO, 2015: 36-37.

${ }^{4}$ LOPES, 2002: 143, 150, 201; BARROCA, 2010-2011: 137, 140; GUEDES, 2015: 27, 101.

${ }^{5}$ REAL, 1985: 9-17; BARROCA, 2010-2011: 137, 142-143; MARTÍN VISO, 2016: 864.

6 TEIXEIRA, MEDEIROS, COELHO, 1972: 21-29.

7 TEIXEIRA, MEDEIROS, COELHO, 1972: 13.
} 
cialmente em áreas de aluvião e de filões pegmatíticos. É neste âmbito, precisamente, que podemos inserir a zona do Folgadoiro (em Amonde) ou a da Bouça das Freiras (em Nogueira), locais onde há sepulturas rupestres sinalizadas ${ }^{8}$.

O espaço em análise é, pois, cunhado por relevos acidentados, sobretudo na margem direita, mais montanhosa, onde a altitude máxima pode oscilar entre os 500 e os 700 metros. Na generalidade, porém, é no intervalo balizado entre os 100 e os $500^{9}$ que se integra a maior parte da área estudada. Não podemos, contudo, deixar de mencionar os terrenos da veiga limiana, aplanados, baixos e muito férteis ${ }^{10}$. Ladeiam o curso do Lima, onde confluem várias das linhas de água que aproveitam a pendente do terreno. Respondendo a diferentes motivações estratégicas, mais ou menos prementes consoante a cronologia e as circunstâncias, montes e áreas baixas foram palco de uma intensa ocupação humana, documentada para uma ampla diacronia.

É certo que a abordagem às manifestações funerárias que motivaram a construção deste texto implica, necessariamente, que nos concentremos no período altimedieval. Não obstante, parece inviável desarticulá-las, por um lado, da matriz antiga de povoamento e por outro, dos contornos que irão ditar a evolução posterior do território. E se, nalguns casos, a noção relativa à existência de sepulturas rupestres se perdeu, noutros é notória a persistência de memórias, ainda que sob a forma de estórias.

Note-se, em paralelo, que o estudo das sepulturas rupestres continua ainda a representar um desafio. Apesar dos desenvolvimentos da investigação na segunda metade do século XX, com a publicação de alguns estudos incontornáveis levados a cabo naquele que é hoje o território espanhol, sobretudo a partir dos anos $70^{11} \mathrm{e}$, em Portugal, inaugurados em $1987^{12}$, há ainda lacunas de conhecimento importantes a realçar.

No Noroeste, em que se inscreve o território que aqui tratamos, podemos apontar duas grandes dificuldades: a quase inexistência de escavações debruçadas sobre esta realidade arqueológica particular (de que decorre a escassez de dados contextualizados $)^{13}$ e, em paralelo, os problemas com que se confrontam as prospeções de terreno.

Fortemente ocupado e retalhado, tem sido sujeito a danos não negligenciáveis, pelo que algumas das referências patentes na bibliografia nos conduzem até zonas que, à época, eram rurais, e hoje estão recobertas de construções (habitações, polos des-

\footnotetext{
${ }^{8}$ TEIXEIRA, MEDEIROS, COELHO, 1972: 34; BARROCA, 2010-2011: 151-152.

${ }^{9}$ IGEO CAOP, GTF Viana do Castelo, 2012.

${ }^{10}$ PEREIRA, MARTINS, 2018: 1162, 1164.

${ }^{11}$ CASTILLO, 1970; CASTILLO, 1972.

12 BARROCA, 1987.

13 «A natureza deste tipo de cemitérios dificulta sobremaneira as investigações, pelo desaparecimento, na larga maioria dos casos, do seu contexto estratigráfico. No Entre Douro e Minho quase todos os exemplos de sepulturas rupestres que se conhecem são procedentes de prospecções de superfície, quedando os sepulcros violados e expostos» (BARROCA, 2010-2011: 117).
} 
portivos, estradas $)^{14}$. Noutros casos, porém, os sítios sinalizados mantêm-se à margem de uma presença continuada. Mas se, por um lado, surgem envoltos em vegetação, que inviabiliza a prospeção sistemática, por outro denotam as consequências decorrentes das profundas transformações do uso do solo ocorridas nas últimas décadas. Em lugares previamente ocupados por carvalhos, castanheiros e oliveiras, estendem-se agora manchas de eucaliptos: geradores de madeiras intensamente exploradas, em processos que envolvem maquinaria (por vezes pesada) e não raro culminam na destruição de velhas passagens e caminhos empedrados ${ }^{15}$. Da conjugação destas circunstâncias decorre, pois, a confrontação com espaços progressivamente alterados, onde os vestígios vão sendo expostos a perigo ou acabam mesmo por se perder.

Ora, se a prospeção (enquanto metodologia de abordagem aos testemunhos materiais) se debate com alguns dos problemas aqui evocados, a procura de indícios na documentação também não tem revelado resultados especialmente profícuos. Com efeito, as referências documentais potencialmente alusivas à existência de sepulturas rupestres não são especialmente abundantes. Não obstante, Mário Barroca assinalou algumas ocorrências sugestivas, como as que se encontram patentes no Liber Fidei e nas Inquirições de 1258, onde é feita menção a archas e piam pétreas. Um dos casos identificados nas Inquirições remete, precisamente, para o território do curso inferior do Lima, concretamente, para Santa Cristina da Meadela, à altura parte integrante do julgado de Ponte de Lima ${ }^{16}$.

É certo que, até ao momento, não foi possível detetar sepulturas rupestres em torno de Santa Cristina, onde terá existido uma igreja de invocação à mártir oriental, e que foi sede de antiga paróquia da Meadela. Contudo, escavações levadas a cabo em área entretanto adulterada pelas terraplanagens que precederam a construção dos acessos à nova ponte sobre o Lima ${ }^{17}$, colocaram a descoberto os alicerces do templo primitivo, a par de estruturas de enterramento, entre as quais um sarcófago de configuração antropomórfica. A interpretação avançada por Antunes Abreu e Cruz Lopes ${ }^{18}$ (responsáveis pela intervenção), e secundada por J. Matos, aponta no sentido de os vestígios em causa coincidirem com os do adro da velha igreja da Meadela $^{19}$, entretanto abandonada e desmantelada ${ }^{20}$,

\footnotetext{
${ }^{14}$ É este o caso, por exemplo, do entorno da Igreja da Senhora do Olival, em Perre.

${ }^{15}$ Situação perfeitamente ilustrada no Monte de Agrichouso, em Afife.

${ }^{16}$ BARROCA, 2010-2011: 146.

${ }^{17}$ Note-se ainda que, na sequência das referidas terraplanagens, foi identificado um bloco pétreo, que A. Abreu classificou como ara romana (MATOS, 1994: 19-20), facto que, a confirmar-se, atestaria a diacronia de ocupação daquele espaço. ${ }^{18}$ ABREU, LOPES, 1992.

${ }^{19}$ MATOS, 1994: 18.

${ }^{20}$ «Após o desativar do templo, as paredes foram demolidas e ficaram somente os alicerces, [...] cobertos por terra arável. Por esse motivo o sítio da igreja [...] virou campo de cultivo até ao momento em que se tornou necessária a intervenção arqueológica [...]. A intervenção arqueológica pôs a descoberto uma boa parte das estruturas da igreja, cuja cabeceira rematava em semicírculo. O aparelho, cuidado, com grandes silhares aparelhados, faz supor que externamente não teria argamassa, situação que [...] faz pensar numa estrutura românica, posteriormente reformulada [...] entre os túmulos descobertos alguns dos quais são sarcófagos — têm cronologias que os colocam entre o século XII e o XIV» (ALMEIDA, 2008: 282).
} 
e que Almeida Fernandes sugere derivar de um primitivo martyrium eremítico ${ }^{21}$, expressão equívoca e que exigiria apuramento. De qualquer modo, nas imediações da atual igreja da Meadela - construída em finais do século XVII e restaurada em $196^{22}$ - são observáveis dois sarcófagos, naturalmente descontextualizados, mas cuja presente implantação poderá não distar muita da original. Não havendo forma de afirmar categoricamente se a referência das Inquirições à petra da arca de Santa Cristina da Meadela ${ }^{23}$ se reportaria aos sarcófagos mencionados, ou antes a estruturas sepulcrais rupestres não identificadas, deixamos esta questão em aberto e avançamos para a abordagem aos dispositivos efetivamente detetados ou, pelo menos, sinalizados na bibliografia.

\section{AS ESTRUTURAS RUPESTRES DO CURSO INFERIOR DO LIMA}

A «história» das referências a sepulturas escavadas na rocha no território em análise cruza-se com a das primeiras «incursões» arqueológicas de um conjunto de figuras originárias do concelho, e que viriam a marcar as pesquisas dos meados do século XX, especialmente a nível local e regional. É este o caso de José Rosa de Araújo, que profundamente empenhado no desenvolvimento dos estudos regionais, foi cofundador do Arquivo do Alto $\mathrm{Minho}^{24}$, publicação que abarca alguns contributos valiosos para a construção da história da arqueologia de Viana.

Mas há outros nomes a merecer igualmente referência, e para um âmbito territorial mais amplo. Leandro Quintas Neves, Abel Viana e Afonso do Paço, em trabalhos de índole variada e mais ou menos exaustivos e providos de pormenores, forneceram indicações incontornáveis para a elaboração do inventário de sítios do concelho. Naturalmente marcados pelo contexto em que são produzidos, refletem a aplicação de metodologias que, nalguns casos, são cientificamente embrionárias; em contrapartida, porém, denotam um efetivo conhecimento do terreno.

De qualquer modo, seria preciso aguardar até 1987 para ser trazida a lume a primeira obra em que os vestígios de sepulturas escavadas na rocha de todo o Entre Douro e Minho viriam a ser não apenas sistematizados, mas também finalmente enquadrados e perspetivados à luz da história da investigação. Uma obra que, ao mesmo tempo, abria espaço para debater a correlação entre tipologias e cronologias, e trazer à colação toda uma série de problemáticas, das quais destacamos as linhas de tradução simbólica de um quadro mental muito particular, ou a possibilidade de discernir padrões de implantação ${ }^{25}$.

\footnotetext{
${ }^{21}$ FERNANDES, 1994: 19.

${ }^{22}$ MATOS, 1994: 15, 57.

${ }^{23}$ BARROCA, 2010-2011: 146.

${ }^{24}$ Foi também fundador da revista Alto Minho (ALMEIDA, 2008: 25).

${ }^{25}$ BARROCA, 1987. Registe-se, a propósito, que neste artigo iremos citar, preferencialmente, o texto revisto, publicado em 2010 no volume 31-32 da revista «Portvgalia» (BARROCA, 2010-2011: 115-182).
} 
Um ano mais tarde seria elaborado o primeiro esboço de uma Carta Arqueológica debruçada sobre o concelho de Viana. Entre as 133 fichas então preparadas por Carlos A. Brochado de Almeida e Alberto Antunes de Abreu ${ }^{26}$, encontramos referências a sepulcros rupestres: precisamente os mesmos que figuravam no trabalho de Mário Barroca, sem que qualquer ocorrência tenha sido acrescentada.

Vinte anos passados sobre a preparação dessas fichas, nunca publicadas, são editados dois volumes dedicados à arqueologia de Viana: o primeiro, novamente da autoria de Carlos A. Brochado de Almeida, abarca os vestígios datáveis da Pré-História ao período de ocupação romana ${ }^{27}$; o segundo, por seu turno assinado por Carlos A. Brochado de Almeida e Pedro Brochado de Almeida, aborda os testemunhos compreendidos entre a época medieval e a contemporânea. É neste, precisamente, que as sepulturas escavadas na rocha são novamente tratadas, assinalando-se onze ocorrências no total. E, neste quadro, encontramos quatro novos pontos a inserir na cartografia do concelho, três dos quais possuem um ponto em comum: a localização a sul do Lima ${ }^{28}$.

Há, em contrapartida, pelo menos dois sítios previamente arrolados e que já não aparecem mencionados na publicação de 2009. Um deles concerne, concretamente, ao núcleo do Folgadoiro, em Amonde ${ }^{29}$, a que adiante voltaremos; o segundo, a Santa Leocádia de Geraz do Lima. A indicação conhecida acerca deste último aponta no sentido da existência de estruturas rupestres na encosta poente do Alto do $\mathrm{Geraz}^{30}$. No entanto, as visitas ao terreno não nos permitiram localizá-las nem, consequentemente, reunir informação a seu respeito, pelo que o número de dispositivos ou a morfologia apresentada permanecem desconhecidos. Façamos então o ponto da situação para o território em estudo, começando por abordar as ocorrências da margem direita.

\subsection{A norte do Lima}

O primeiro dos sítios que se impõe aqui apresentar é a Capela das Almas, sede da paróquia de São Salvador do Átrio ${ }^{31}$. Referenciada já como Viana nas Inquirições de D. Afonso III, datadas de 1258, e na primeira versão da carta de foral, outorgada pelo mesmo monarca ${ }^{32}$, encontrava-se, à época, integrada no Julgado de Ponte de Lima.

\footnotetext{
${ }^{26}$ ALMEIDA, ABREU, 1988.

${ }^{27}$ ALMEIDA, 2008.

${ }^{28}$ ALMEIDA, ALMEIDA, 2009: 47-49.

${ }^{29}$ VIANA, 1955: 5-6; BARROCA, 1987: 147; 2010-2011: 142, 151.

${ }^{30}$ BARROCA, 1987: 148; 2010-2011: 152; BROCHADO, 2004: 93.

${ }^{31}$ MOREIRA, 1986: 20-21, nota 3.

${ }^{32}$ ALMEIDA, BARROCA, 2002: 139.
} 
Tudo indica, porém, que a ocupação daquele espaço remonta a tempos mais recuados. São conhecidas, ainda que não confirmadas, alusões ao aparecimento de cerâmicas «castrejas» e romanas na Capela das Almas e suas imediações ${ }^{33}$. E outras hipóteses foram entretanto aventadas, como a que aponta para a existência no local de uma villa (que supostamente teria evoluído para villa ecclesia) ${ }^{34}$, a par de um pequeno porto, a funcionar desde período romano ${ }^{35}$. De igual modo, foi também mencionada a possibilidade de o sítio se localizar nas proximidades da via romana que, depois de cruzado o Lima, ladeava o maciço de Santa Luzia e prosseguia para norte ${ }^{36}$.

É provável que o posicionamento estratégico da área justifique a continuidade da ocupação, traduzida também na construção de um dispositivo «suevo-visigótico», de que restou um alinhamento, reduzido ao nível do alicerce. Já no quadro da Reconquista, ali terá sido erguida uma estrutura pré-românica de planta quadrangular ${ }^{37}$, não sendo de excluir que as sepulturas rupestres identificadas sejam contemporâneas do mencionado dispositivo. Mais tardia é a igreja românica propriamente dita, da qual restam ainda alguns testemunhos arquitetónicos ${ }^{38}$, designadamente, o arcossólio observável na fachada sul. Em meados de Quatrocentos, a construção da Matriz no interior do perímetro muralhado relegou o espaço de culto das Almas (também chamado de Igreja Velha, e de que a Câmara possuía o padroado) para segundo plano. Estrutura de pequenas dimensões e desadequada para a função de igreja paroquial manteve, contudo, a sua utilização funerária: em seu redor, aliás, continuaria a funcionar o «principal cemitério da Vila» ${ }^{39}$.

Acerca das estruturas de enterramento rupestres das Almas é, contudo, muito pouco o que se sabe. Conforme percetível no registo fotográfico disponível ${ }^{40}$ (Fig. 1), apresentavam-se truncadas, tendo, além do mais, sido afetadas pelos meios mecânicos utilizados no quadro de intervenções recentes. É certo que, já em obra dada à estampa em 1882, e a propósito da construção do antigo mercado (desativado nos anos 70 do século XX) no entorno das Almas, mais concretamente, junto da antiga

\footnotetext{
${ }^{33}$ A exumação das cerâmicas terá ocorrido no quadro das escavações levadas a cabo por Sousa de Oliveira; no entanto, não houve possibilidade de aceder aos cadernos de campo em que tais recolhas estarão documentadas (LEAL, 2009: 24). Por seu turno, C. A. Brochado de Almeida refere, concretamente, o achado de um pequeno pote de origem e técnica castreja (ALMEIDA, 2008: 295). Contudo, em ponto mais avançado do mesmo texto, o autor refuta a possibilidade de as cerâmicas em causa serem originárias da Igreja das Almas (ALMEIDA, 2008: 295-296).

${ }^{34}$ LEAL, 2009: 26-27.

${ }^{35}$ LEAL, 2009. Ainda a respeito da presença de um porto na área das Almas, mas em cronologia mais avançada, atente-se nesta passagem de Pinho Leal: «Aquela ermida [de São Bento], ao pé da egreja das Almas, servia de desembarcadouro na passagem do rio Lima, e por isso vivia n’ella um ermitão, frei Hieronymo» (LEAL, 1882: 451).

${ }^{36}$ ALMEIDA, 2008: 295.

${ }^{37}$ LEAL, 2009: 26-27.

${ }^{38}$ LEAL, 2009: 27.

${ }^{39}$ MOREIRA, 1986: 222-223.

${ }^{40}$ Agradecemos a Miguel Costa, arqueólogo municipal de Viana do Castelo, o envio do ficheiro que incluímos nas estampas deste texto.
} 


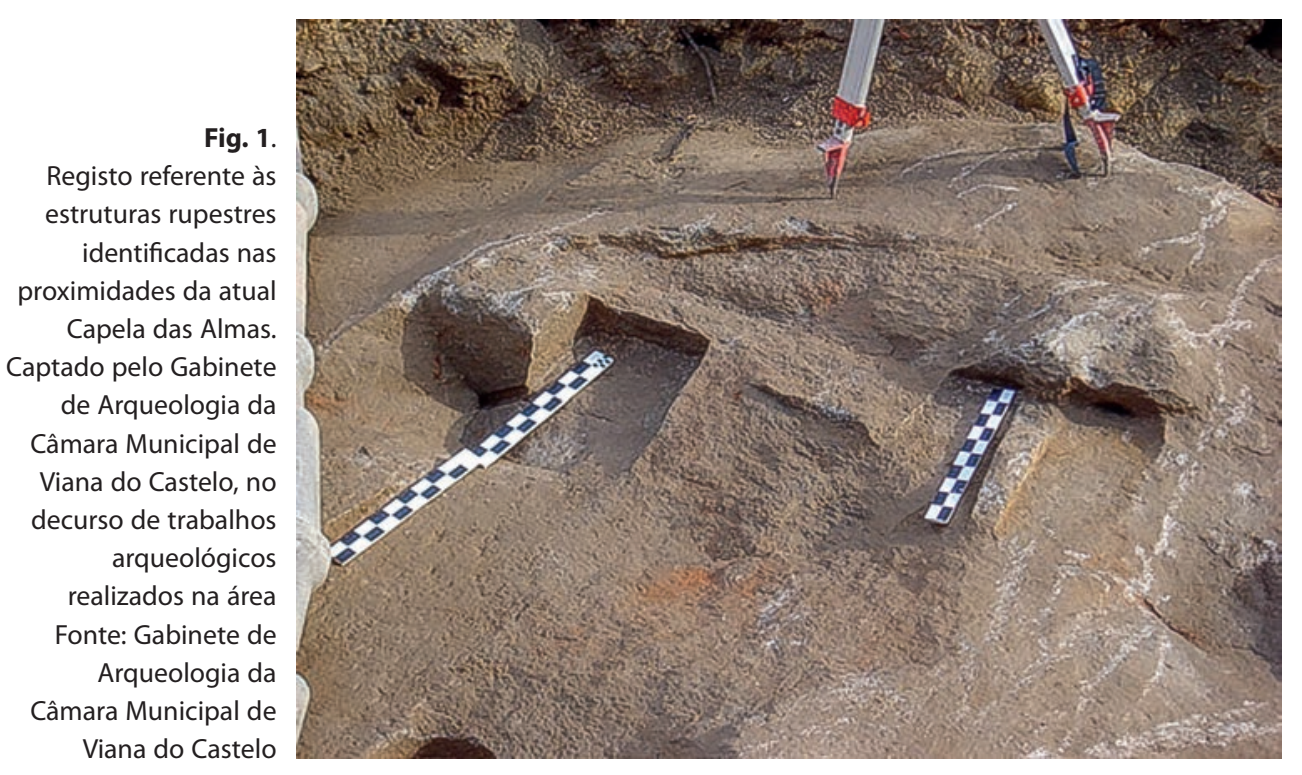

ermida de São Bento, Pinho Leal mencionava a existência de sepulturas escavadas na rocha, ocultas sob o Cruzeiro do Senhor da Boa Lembrança ${ }^{41}$. Desde as referências de Pinho Leal, decorreram mais de cem anos. E o espaço em causa foi sendo paulatinamente urbanizado. Dos três sepulcros que se conservam no afloramento granítico (dois dos quais em posição rigorosamente paralela entre si) não conseguimos apurar a orientação, as medidas ou a tipologia precisa. Não obstante, julgamos válido afirmar que integrariam um núcleo, mas não há como aferir a sua dimensão, ou se o número original de ocorrências justificaria falar em necrópole. É certo que entre o local preciso de identificação dos três sepulcros e a área de implantação da desaparecida ermida de São Bento, onde figurariam as sepulturas «contiguas, abertas em rocha ${ }^{42}$, há algumas dezenas de metros de permeio. Neste sentido, não será de excluir a hipótese de naquele intervalo ter, de facto, existido um espaço funerário de cariz cemiterial.

Ora, no quadro das velhas paróquias do território atualmente abarcado pelo concelho de Viana, há uma outra que aqui importa focar: Ovinia, que viria a originar o termo Vinha ${ }^{43}$. Mencionada no Parochiale Suevum ou Divisio Theodomiri, texto

\footnotetext{
${ }^{41}$ LEAL, 1882: 442; 451.

${ }^{42}$ LEAL, 1882: 451.

${ }^{43}$ MARQUES, 2004: 702.
} 
sobre o qual se debruçaram Pierre David ${ }^{44}$ e Avelino Jesus da Costa ${ }^{45}$, a sua origem poderá, pois, ser rastreada desde o período suevo-visigótico.

Em terreno da antiga paróquia, concretamente, na Pia dos Eidos foi identificada uma sepultura rupestre ${ }^{46}$. O único registo fotográfico conhecido deste dispositivo, de contorno trapezoidal, foi publicado por Abel Viana na década de $50^{47}$. No texto citado, o autor aludia às construções que por ali se vinham multiplicando desde os anos 20 e 30, e que começavam a dissimular as ocupações antigas, plasmadas em utensílios do Paleolítico e em restos de estruturas pétreas circulares da Idade do Ferro ${ }^{48}$. Aliás, e apesar de atualmente não ser possível apontar com precisão o local onde o sepulcro se encontraria implantado ${ }^{49}$ (sabe-se apenas que seria logo à saída da cidade, entre a linha férrea e a base do Monte de Santa $\operatorname{Luzia}^{50}$ ), não podíamos deixar de sublinhar a proximidade espacial entre essa zona e dois sítios com ocupação proto-histórica: o Castro do Pêgo e, sobranceiro a este, a Citânia de Santa Luzia ${ }^{51}$. Convém também registar a presença de vestígios da presença romana nos solos férteis de veiga da atual Areosa, plasmados em materiais de construção (tegulae e imbrex) ou em mós manuais ${ }^{52}$. Uma conjugação de indícios que, muito embora algo dispersos, insuficientemente estudados ou, nalguns casos, entretanto mesmo aniquilados, sugerem a vigência de uma ocupação longa naquela área.

Acrescente-se que, no próprio Monte de Santa Luzia poderá ter existido uma sepultura rupestre; contudo, a indicação conhecida carece de confirmação ${ }^{53}$. Situação idêntica será a de Carreço, na medida em que as informações disponíveis são igualmente omissas quanto ao local específico de implantação, ou à tipologia do vestígio $^{54}$. Neste sentido, os pontos sinalizados na cartografia apresentada em anexo para estes e para os demais casos de sepulturas mencionadas na bibliografia, mas já destruídas e sem restos associados, ou mesmo nunca localizadas, são meramente indicativos.

\footnotetext{
${ }^{44}$ DAVID, 1947.

${ }^{45}$ COSTA, 1997.

${ }^{46}$ VIANA, 1955: 4-5; BARROCA, 1987: 148; 2010-2011: 151;BROCHADO, 2004: 93; ALMEIDA, ALMEIDA, $2009: 47$.

${ }^{47}$ VIANA, 1955: 9, fig. 3.

48 VIANA, 1955: 4-5.

${ }^{49}$ A julgar pelas palavras de Abel Viana, não seria a única: «Por informações de uns pedreiros da Areosa, soubemos que sepulturas idênticas surgiram ali perto, ao edificar-se, em terreno de veiga, uma fábrica de capachos e artefatos similares. O dirigente da construção, porém, receando lhe embargassem a obra, mandou destruí-las sem detença» (VIANA, 1955: 4-5).

${ }^{50}$ VIANA, 1955: 4.

${ }^{51}$ PAÇO, QUESADO, 1956: 173.

${ }^{52}$ ALMEIDA, 2008: 266.

${ }^{53}$ BARROCA, 1987: 149; 2010-2011: 152; ALMEIDA, ALMEIDA, 2009: 48.

${ }^{54}$ BARROCA, 1987: 148; 2010-2011: 152.
} 
Já no que respeita ao Monte de Agrichouso (Afife) ${ }^{55}$, os dados são mais específicos, tendo além do mais havido possibilidade de os confirmarmos presencialmente no terreno. A primeira referência ao sepulcro rupestre de Agrichouso deve-se a Afonso do Paço e Aníbal Quesado do Paço. Integrado numa bouça privada, situa-se a meia encosta, a norte do caminho que se prolonga até à Casa do Velho ${ }^{56}$, cerne de uma lenda que continua viva entre os populares. Em pontos distintos da mesma elevação (concretamente, a nascente do sepulcro), erguem-se dois assentamentos proto-históricos: o Castro do Agrichouso e o do Monte do Crasto ${ }^{57}$. Há, contudo, vestígios medievais sinalizados nas imediações. Com efeito, a partir do século XI, na área rural do concelho de Viana começam a estabelecer-se mosteiros beneditinos. A leste, ergueram-se os de São Salvador da Torre e São Cláudio de Nogueira. No litoral, concretamente, em Afife, foi construído o de Cabanas ${ }^{58}$.

Ora, apesar de o texto de Afonso do Paço e Aníbal Q. do Paço não incluir descrição da morfologia desta sepultura isolada ${ }^{59}$, comprovámos a justeza das (escassas) indicações de implantação, assim como das medidas registadas. Trata-se de um exemplar sub-retangular ou trapezoidal, escavado num afloramento granítico, com rebordo elevado total (Figs. 2 e 3). Provido de cabeceira algo irregular (posicionada a $\mathrm{NO}$ ), denota ligeiro estreitamento na extremidade oposta. E há dois aspetos relativos ao estado de conservação do sepulcro que importa sublinhar. Por um lado, o facto de o crescimento de um eucalipto ter danificado completamente a zona dos pés; por outro, o de a laje da parede lateral sul ter quebrado, jazendo no interior da sepultura quando a localizámos no terreno.

Desloquemo-nos agora para Nogueira e Amonde, freguesias vizinhas, ambas com núcleos de sepulturas rupestres sinalizadas, respetivamente, a norte e nordeste da Serra de Perre e a nascente da de Santa Luzia. Nos dois casos, porém, as prospeções por nós levadas a cabo em fase prévia à da realização do Congresso de 2017 não se saldaram na relocalização das estruturas: uma situação idêntica à experienciada pela equipa de arqueologia do município de Viana do Castelo, que bateu o terreno

\footnotetext{
${ }^{55}$ PACO, QUESADO, 1956: 173; BARROCA, 1987: 147; 2010-2011: 150-151; ALMEIDA, ABREU, 1988, ficha n. ${ }^{\circ}$; ALMEIDA, ALMEIDA, 2009: 47.

56 PAÇO, QUESADO, 1956: 173.

${ }^{57}$ PAÇO, QUESADO, 1956: 83, 172-173.

${ }^{58}$ MOREIRA, 1986: 227.

${ }^{59}$ Note-se que, à luz da perspetiva enunciada por Katja Kliemann, as sepulturas isoladas ilustram a vigência de um povoamento disperso (KLIEMANN, 1986: 78-79). I., Martín Viso, todavia, questiona a validade desta correlação, no seu entender, demasiado simplista, atendendo sobretudo ao facto de algumas aldeias poderem não possuir espaços centralizados de sepultamento (MARTÍN VISO, 2016: 864). Já para Jordi Bolòs e Montserrat Pagès, as sepulturas isoladas poderiam eventualmente ter sido destinadas a eremitas (BOLÒS i MASCLANS, PAGÈS i PARETAS, 1982: 64; 70). Todavia, parece evidente a desproporção entre os diversos casos conhecidos de sepulcros isolados e a dimensão do fenómeno eremítico, circunstância que obriga a encarar esta hipótese com reservas (BARROCA, 2010-2011: 136).
} 

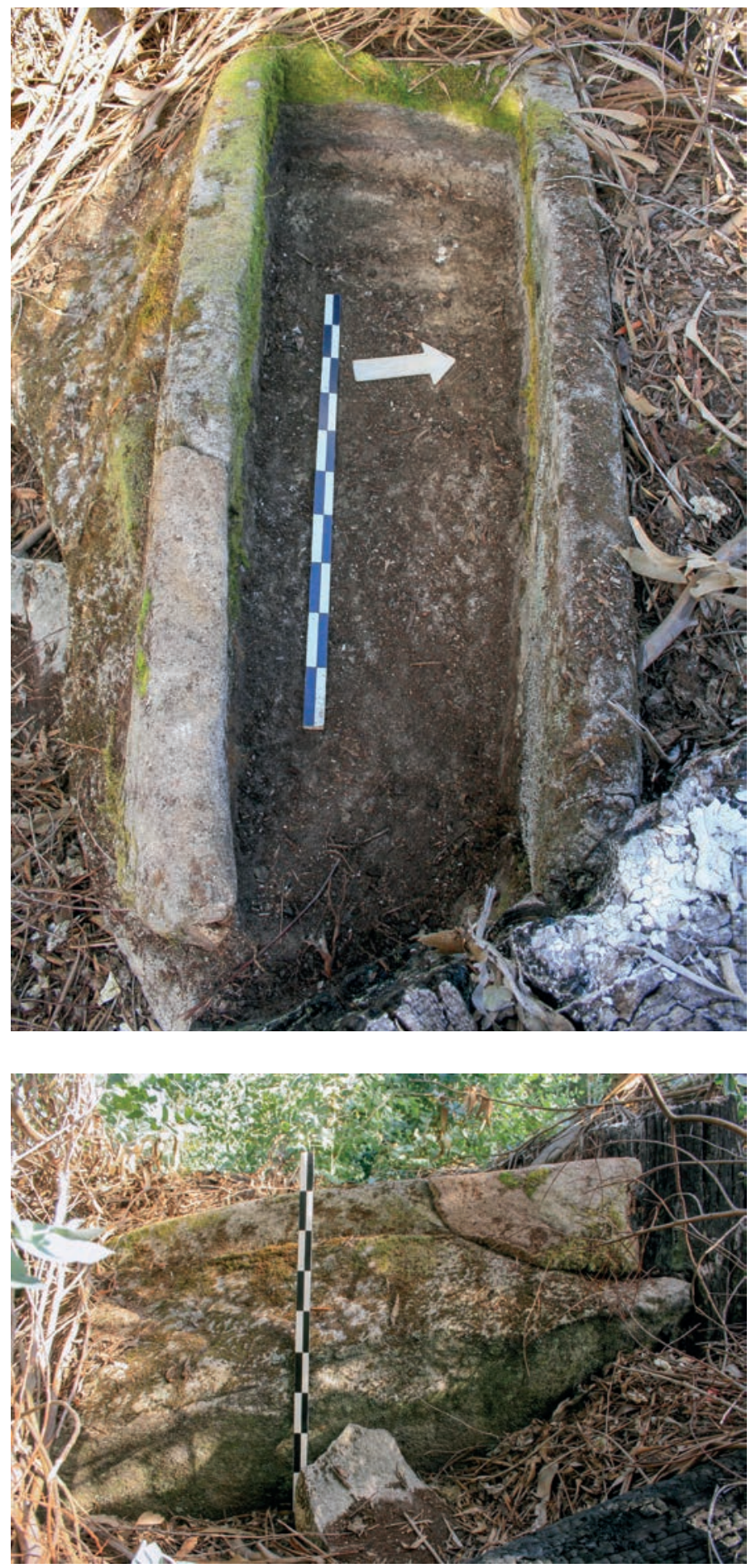

Fig. 2.

Sepultura sub-retangular de Agrichouso (Afife). Em primeiro plano é observável a zona dos pés, atualmente truncada, devido ao crescimento de um eucalipto

Fonte: Andreia Arezes

Fig. 3.

Perspetiva da parede lateral sul da mesma estrutura, parcialmente fragmentada. Conforme perceptível, a estrutura encontra-se completamente rodeada de vegetação

Fonte: Andreia Arezes 
no âmbito da revisão do $\mathrm{PDM}^{60}$. Não obstante, em fevereiro de 2020, fomos informados de que o núcleo de Nogueira, concretamente implantado na chamada Bouça das Freiras, fora entretanto relocalizado pela referida equipa, tendo as coordenadas apresentadas na cartografia em anexo sido corrigidas em conformidade ${ }^{61}$.

A maior dificuldade com que nos deparámos ao procurar identificar as sepulturas na Bouça das Freiras ${ }^{62}$ prendeu-se com a densidade da vegetação presente, que dissimulava os afloramentos graníticos e alguns restos de alinhamentos pétreos, fundamentalmente correspondentes a muros de divisão de propriedade. Para a área em questão começou por ser mencionada a existência de duas estruturas não antropomórficas: uma, de configuração sub-retangular, com ângulos arredondados; outra, tendencialmente quadrangular, marcada por pronunciado desvio para o lado direito ${ }^{63}$. Todavia, no arrolamento de sítios de 2009, é feita referência a três dispositivos ${ }^{64}$, mas sem apresentação de descrições tipológicas ou de imagens associadas a cada um deles. O único registo disponibilizado ${ }^{65}$ mostra um dispositivo truncado, mas que pelo contorno se presume poderia eventualmente ser ovalado.

É interessante sublinhar, contudo, a permanência de memórias acerca das estruturas da Bouça das Freiras entre os habitantes de Nogueira. Na base da elevação, um morador dizia recordar-se de uma sepultura onde chegou a deitar-se; atualmente, porém, era incapaz de lhe encontrar o rasto entre o mato denso. Não faltou, em paralelo, quem nos chamasse a atenção para o topónimo que, segundo a tradição ${ }^{66}$, remeteria para a existência de um antigo convento feminino na zona, com ligação subterrânea direta até ao Mosteiro Beneditino de São Cláudio de Nogueira, este sim, perfeitamente documentado, e do qual subsiste a igreja românica, com elementos resultantes da ampliação gótica ${ }^{67}$.

Já em relação ao conjunto do Folgadoiro, Amonde ${ }^{68}$, situado na área das minas de estanho, minério intensamente explorado no período de ocupação romana ${ }^{69}$,

\footnotetext{
${ }^{60}$ Também as prospeções realizadas por Cláudio Brochado tiveram desfecho similar, devido à forte presença de mato e eucaliptos (BROCHADO, 2004: 173).

${ }^{61}$ Deixamos aqui novo agradecimento ao Miguel Costa, pela atualização da informação e também pela indicação das coordenadas retificadas.

${ }^{62}$ BARROCA, 1987: 148; 2010-2011: 152; ALMEIDA, ABREU, 1988: ficha n. ${ }^{\circ}$ 66; BROCHADO, 2004: 172-173; ALMEIDA, ALMEIDA, 2009: 47.

${ }^{63}$ BARROCA, 1987: 148; 2010-2011: 152.

${ }^{64}$ Será este, de facto, o número efetivo de sepulturas conservadas no local, ainda que, segundo Miguel Costa, uma delas possa não ter sido devidamente acabada.

${ }^{65}$ ALMEIDA, ALMEIDA, 2009: 47.

${ }^{66}$ Sobre este ponto, ver também BROCHADO, 2004: 173.

${ }^{67}$ ALMEIDA, BARROCA, 2001: 92-93.

${ }^{68}$ VIANA, 1955: 5-6; BARROCA, 1987: 147; 2010-2011: 151; ALMEIDA, ABREU, 1988: ficha n. 20; BROCHADO, 2004: 173.

${ }^{69}$ ALMEIDA, 2008: 242.
} 
conhece-se igualmente uma única imagem, publicada por Abel Viana ${ }^{70}$. Desde então, porém, têm saído goradas as tentativas para localizar no terreno quer a sepultura fotografada (trapezoidal, com rebordo para apoio da tampa), quer as restantes que integrariam o núcleo, de que não se conhece número, dimensões ou tipologia. A propósito, aliás, convém mencionar que, segundo Abel Viana, a zona de exploração mineira de Amonde integrava não apenas diversas sepulturas rupestres, mas também restos de «alicerces de construções muito rudes», que se articulavam no espaço com os mencionados vestígios tumulares ${ }^{71}$. A descrição em causa levou Mário Barroca a sugerir a hipótese de as sepulturas de Amonde poderem estar associadas a uma estrutura pré-românica ${ }^{72}$, o que, a confirmar-se, seria de extraordinário interesse, especialmente se houvesse possibilidade de proceder a escavações no terreno e de confirmar, estratigraficamente, as relações vigentes entre os diversos dispositivos sinalizados. Contudo, os obstáculos colocados pela vegetação, conjugados com a presença de cortadas, decorrentes da exploração mineira, não facilitam o trabalho de prospeção. Assim, não nos é possível sequer assegurar que as estruturas se mantêm conservadas no terreno.

As dúvidas a respeito das sepulturas rupestres já elencadas são, de facto, consideráveis. Acresce notar que, para outras ocorrências identicamente assinaladas na margem direita do Lima, comprova-se que, de facto, já não restam vestígios materiais. É este o caso de São Gil, um lugar «encaixado» entre o Castro do Vieito (também chamado de Alto do Muro) $)^{73}$ e o Castro do Castelhão, onde Afonso do Paço e Aníbal do Paço Quesado afirmam ter existido dois sepulcros ${ }^{74}$.

O Castelhão, que dista do Vieito cerca de 500 metros $^{75}$, denota menor altitude e ergue-se a sudeste deste último povoado (entretanto escavado até à rocha de base), logo atrás do denso casario que hoje ocupa São Gil. As duas sepulturas, de contorno trapezoidal, e uma das quais provida de cantos arredondados, estariam localizadas nas imediações do Castelhão. De acordo com indicação dos autores, ambas foram mutiladas, num dos casos, devido à construção de um caminho ${ }^{76}$. De facto, e em visita ao local, percebemos o quanto o lugar vem sendo alterado. Persistem, contudo, indícios do forte cunho granítico daquele espaço: nas áreas ainda baldias, em afloramentos talhados aos quais entretanto se sobrepuseram

\footnotetext{
${ }^{70}$ VIANA, 1955: 13, fig. 8, n. ${ }^{\circ}$.

71 VIANA, 1955: 5-6.

${ }^{72}$ BARROCA, 2010-2011: 151.

${ }^{73}$ PAÇO, QUESADO, 1956: 84-85.

${ }^{74}$ PACO, QUESADO, 1956: 87; NEVES, 1965: 174-175; BARROCA, 1987: 148-149; 2010-2011: 152; ALMEIDA, ABREU, 1988, ficha n. ${ }^{\circ}$ 77; BROCHADO, 2004: 94, 183; ALMEIDA, ALMEIDA, 2009: 48.

${ }^{75}$ PAÇO, QUESADO, 1956: 84-85.

${ }^{76}$ PAÇO, QUESADO, 1956: 87.
} 


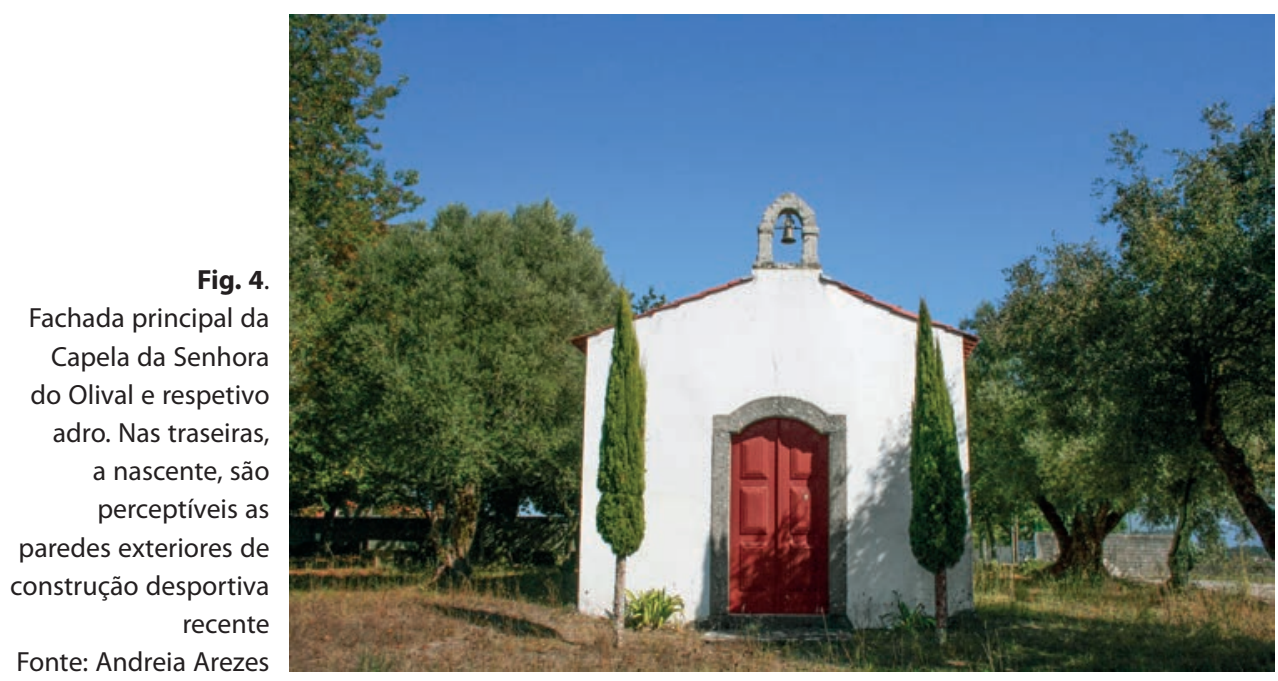

alinhamentos recentes, ou nos próprios caminhos, concretamente, nas lajes que pontuam entre os paralelos.

Não longe do Castro do Calvário (a cerca de 1,5 km do Vieito), os mesmos autores identificaram, junto da Capela de Nossa Senhora do Olival, à altura terreno privado (pertença da família Espregueira $\mathrm{Mendes}^{77}$ ), uma outra sepultura rupestre, já destruída ${ }^{78}$, da qual se desconhece a morfologia, a orientação e as dimensões. Subsiste a Capela (Fig. 4), lugar de antiga devoção popular, ladeada pelo que resta do adro e do antigo olival. No interior, do lado da Epístola, persiste igualmente o brasão com as Armas dos Bezerras e, sob ele, a inscrição funerária de Pedro Nunes Bezerra, falecido em $1600^{79}$. Em tempos espaço ermo onde, segundo informações orais, afluíam grupos de Perre e das freguesias vizinhas, pedindo proteção para as grávidas, é hoje ponto de afluência dominical por outras motivações, uma vez que, escassos metros a nascente, foi construído um polo desportivo ${ }^{80}$.

A mesma ausência de testemunhos é assinalada noutros casos. José Rosa de Araújo menciona um velho caminho que ladeava «sepulturas rupestres» no Lugar do Padrão, Cardielos ${ }^{81}$, área onde se terá firmado a única honra documentada no território atualmente abarcado pelo concelho de Viana em época medieval ${ }^{82}$. Dos

\footnotetext{
${ }^{77}$ ALMEIDA, ABREU, 1988.

${ }^{78}$ PACO, QUESADO, 1956: 82, 85; BARROCA, 1987: 148; 2010-2011: 152; ALMEIDA, ABREU, 1988, ficha n. ${ }^{\circ} 88$; BROCHADO, 2004: 182.

${ }^{79}$ GAIO, 1938: 30.

${ }^{80}$ A sul, por seu turno, sobressai um caminho recente em primeiro plano e, em segundo, o traçado da A27.

${ }^{81}$ ARAUJO, 1962: 64; BARROCA, 1987: 148; 2010-2011: 151; ALMEIDA, ABREU, 1988: ficha n. ${ }^{\circ}$ 36; BROCHADO, 2004: 93, 118; ALMEIDA, ALMEIDA, 2009: 48.

${ }^{82}$ MOREIRA, 1986: 40-41.
} 
referidos dispositivos, contudo, e mais uma vez, nada se sabe. Não obstante, no terreno envolvente da Igreja Paroquial de invocação a Santiago, sobre o qual se ergue a citânia de São Silvestre, conserva-se, em contrapartida, um sarcófago monolítico de configuração trapezoidal ${ }^{83}$.

\subsection{A sul do Lima}

Resta-nos abordar a margem esquerda do Lima, onde C. A. Brochado de Almeida e Pedro Brochado de Almeida cartografaram três novos sítios: um, na Gândara (São Romão do Neiva), outro em Figueiredo (Vila Franca do Lima) e o último em Outeiro (Portela de Susã). Como ponto de contacto entre as sepulturas de Figueiredo (Vila Franca do Lima) e Outeiro (Portela de Susã) ${ }^{84}$, destaque-se o facto de se encontrarem atualmente integradas em propriedades privadas.

Comecemos pelo sepulcro de Gândara ${ }^{85}$, São Romão do Neiva, situado a escassas dezenas de metros a norte do leito do Neiva, e não longe do traçado apontado para a velha Estrada Real que, segundo Brochado de Almeida, decalcaria o da antiga via secundária romana (Per Loca maritima), que estabelecia a ligação entre Porto e Caminha ${ }^{86}$. Anteriormente, já Carlos Alberto Ferreira de Almeida aludira à via que, desde Vila do Conde, cruzava a Póvoa de Varzim, Esposende, Marinhas e Neiva, daí prosseguindo até Viana: um eixo cuja importância é perfeitamente evidente em época moderna ${ }^{87}$. Também a propósito das Terras do Neiva, não poderíamos deixar de mencionar o facto de a fundação do Mosteiro Beneditino de São Romão recuar aos séculos X-XI. Contudo, da traça original não há vestígios: o século XVII marca a demolição da estrutura primitiva (que chegara a ser reedificada nos inícios da XII centúria) e a construção de um novo templo e área conventual, já ao gosto maneirista ${ }^{88}$.

Acerca da sepultura propriamente dita (Fig. 5), de contorno trapezoidal, importa sublinhar que atualmente se encontra envolta em densa vegetação, o que condiciona fortemente a perceção da sua presença no terreno, sensivelmente a meia encosta. Com 1,92 m de comprimento, orientada no sentido SO-NE, e dotada de rebordo bem evidente na zona da cabeceira, muito embora algo irregular, destaque-se o seu contorno sub-retangular, mas levemente arqueado. Acrescente-se ainda que a orla da zona dos pés (esta, alteada), a par de parte considerável da face sul da estrutura, se encontram danificadas, fruto da tentativa (frustrada) de a deslocar do seu contexto.

\footnotetext{
${ }^{83}$ BARROCA, 1987: 199.

${ }^{84}$ ALMEIDA, ALMEIDA, 2009: 48 -49.

${ }^{85}$ ALMEIDA, ALMEIDA, 2009: 49.

${ }^{86}$ ALMEIDA, 2008: 251, 275, 285.

${ }^{87}$ ALMEIDA, 1968: 180-181.

${ }^{88}$ GUERRA, 1923; ALMEIDA, 1987.
} 
Fig. 5. Imagem do sepulcro de Gândara (São Romão do Neiva). Devido à densa cobertura vegetal e às sombras patentes aquando da captação da fotografia, o registo apresenta algumas limitações de visibilidade Fonte: Andreia Arezes

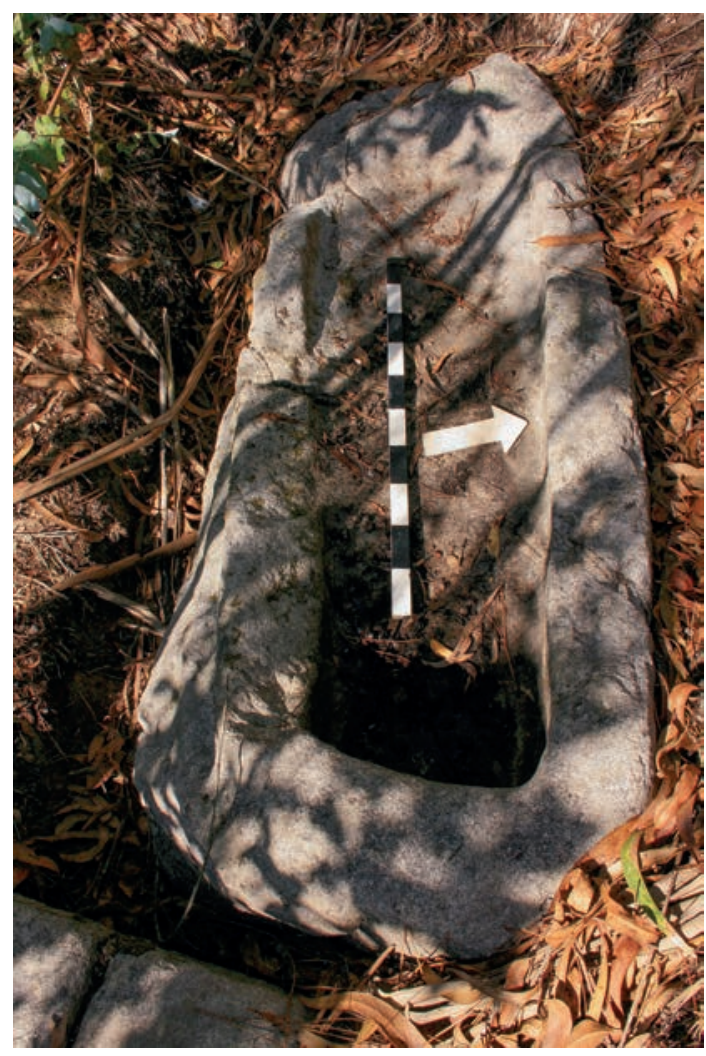

Seguindo agora para Vila Franca, reaproximamo-nos do curso do Lima. O núcleo de Figueiredo inscreve-se num planalto de terras férteis e com boa exposição solar ${ }^{89}$, localizado nas proximidades da Igreja Paroquial, e no sopé do Castro de Roques ou Santinho, que se ergue sensivelmente a noroeste.

De acordo com a obra que dá a conhecer o núcleo, o sepulcro apresentado em fotografia é o único conservado que um conjunto de três estruturas ${ }^{90}$. De configuração não antropomórfica, tendencialmente trapezoidal, mas com ângulos arredondados, esta sepultura alinhada segundo o eixo NE-SO, exibe rebordo pronunciado e atinge $1,80 \mathrm{~m}$ de comprimento. E apesar do amontoado de blocos graníticos que se acumulam sobre o afloramento onde foi talhada, concretamente, a norte, podemos afirmar que se encontra razoavelmente bem preservada (Fig. 6). De qualquer modo, e não obstante as indicações de aniquilação dos restantes dispositivos, optámos por

\footnotetext{
${ }^{89}$ ALMEIDA, 2008: 298.

${ }^{90}$ ALMEIDA, ALMEIDA, 2009: 49.
} 


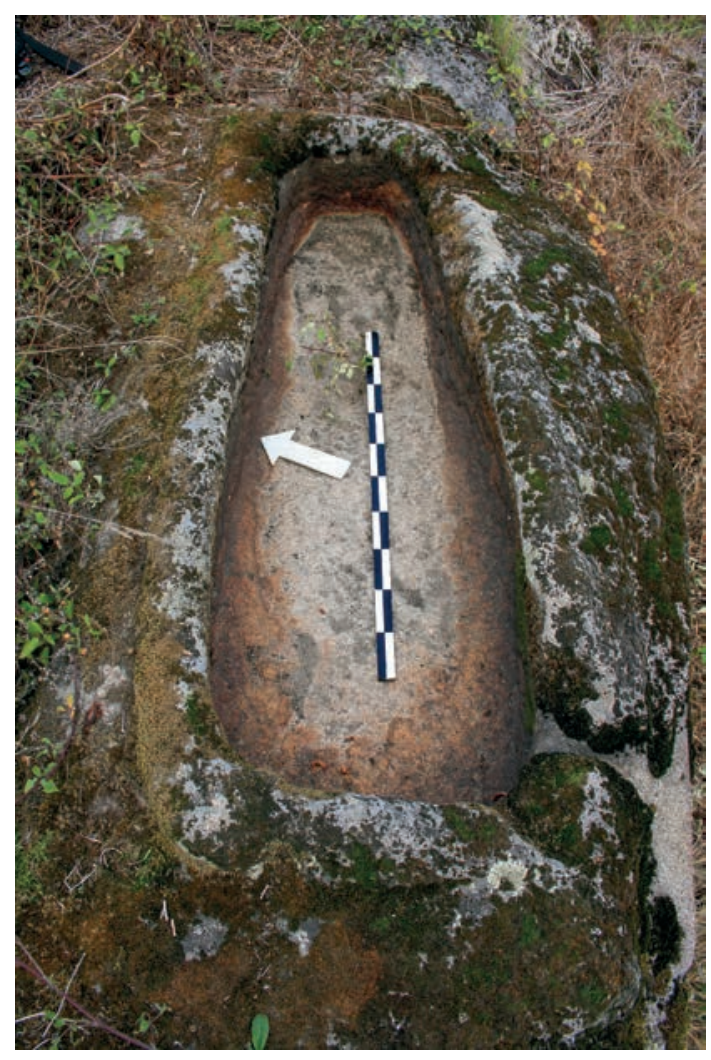

Fig. 6.

Perspetiva da primeira das sepulturas do núcleo de Figueiredo (Vila Franca do Lima). Apresenta configuração trapezoidal e em bom estado de conservação global

Fonte: Andreia Arezes

realizar prospeção na área envolvente, a qual se saldou na identificação de parte de uma outra sepultura.

Encontrámo-la truncada, conservada apenas na zona dos pés e arranque do corpo, o que inviabiliza a possibilidade de asseverar com segurança qual a tipologia que evidenciaria originalmente. Com efeito, o corte efetuado no terreno para a preparação da área de cultivo mutilou-a, deixando a descoberto apenas $86 \mathrm{~cm}$ da sua extensão original. Desconhecemos, em paralelo, se outras existiriam sob a habitação entretanto construída, cuja base é igualmente observável no registo apresentado em anexo (Fig. 7).

De notar também a identificação de um negativo numa área de penedia, a escassas dezenas de metros das duas estruturas funerárias. A configuração que apresenta, aliada à escassa profundidade e à orientação dissonante, contrariam a possibilidade de ser classificado como sepultura infantil, como à primeira vista se poderia supor. Contudo, não sabemos se a «terceira sepultura» mencionada na publicação de $2009^{91}$

${ }^{91}$ ALMEIDA, ALMEIDA, 2009: 49: 


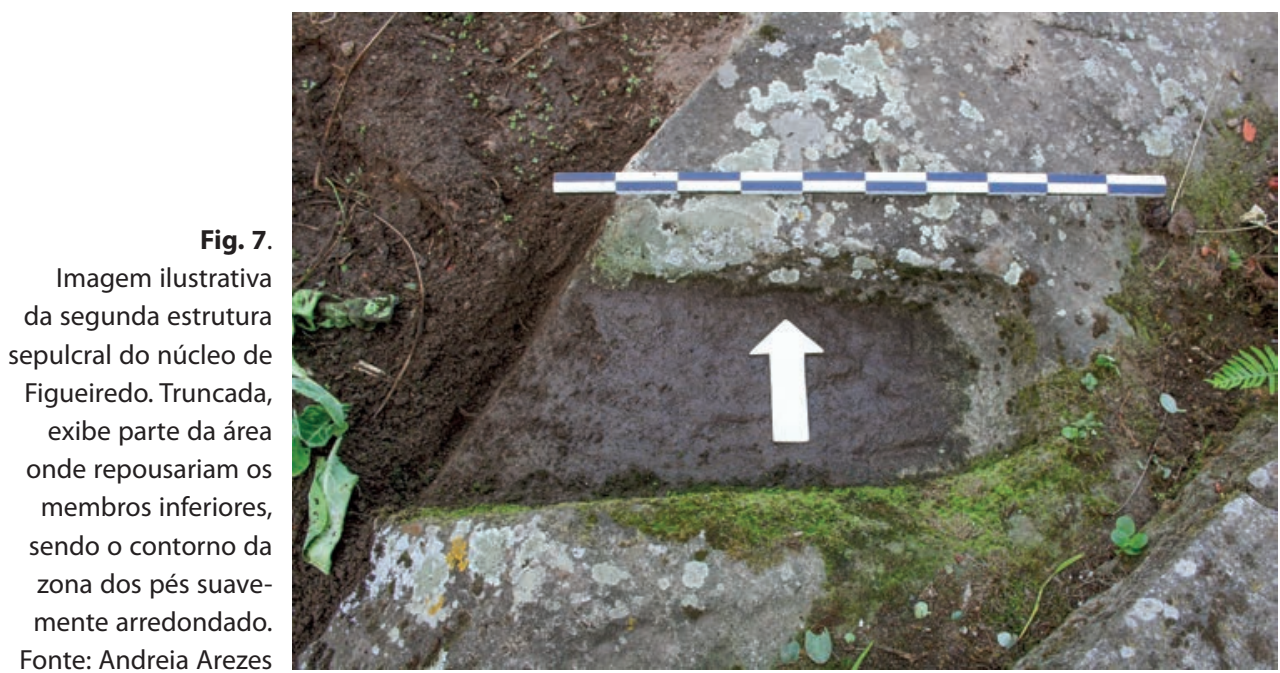

diria respeito a este negativo (à altura não localizado) ou, em alternativa, se existiria uma outra ocorrência efetivamente destruída aquando da construção de algum dos edifícios que agora se espraiam pelo local.

A última ocorrência leva-nos até ao lugar de Outeiro, freguesia de Portela de Susã ${ }^{92}$. Aí, mais propriamente, na Rua da Pia dos Mouros, um sugestivo topónimo identificado nas proximidades da Igreja Paroquial ${ }^{93}$, destaca-se numa pequena elevação de terreno, a poente da Serra da Padela, e a nascente do já mencionado Castro de Roques.

À semelhança das demais sepulturas apresentadas, a do Outeiro não possui contorno antropomórfico (Figs. 8 e 9). É, antes, trapezoidal, com ângulos arredondados. A orientação, por seu turno, diverge um pouco da evidenciada pelos outros exemplares aqui tratados, sendo que a cabeceira surge posicionada a nordeste e os pés a sudoeste. Há que notar, contudo, o facto de o alinhamento em causa coincidir exatamente com o da pendente do afloramento em que o sepulcro foi talhado ${ }^{94}$, denunciando uma perfeita adequação da construção ao bloco granítico. A realçar há ainda o facto de o sepulcro possuir um canal de escoamento, entretanto reforçado em diâmetro e robustez, com a colocação de uma pequena tubagem na abertura de

\footnotetext{
${ }^{92}$ ALMEIDA, ALMEIDA, 2009: 48.

${ }^{93}$ Segundo C. A. Brochado de Almeida «A igreja encontra-se na parte central da freguesia, voltada para Poente, para a depressão que a separa do Monte de Roques e que foi aproveitada para a passagem da via romana per loca marítima. Restos de ímbrices, de tegulae e de cerâmica [...] da parte final da ocupação romana, apareceram quando se alargou um velho caminho que fazia a ligação dos lugares do Outeiro ao Souto [Notícias de Viana de 27 de Junho de 1991]. O sítio onde aparecerem, dista cerca de duas centenas de metros da Igreja Paroquial» (ALMEIDA, 2008: 287).

${ }^{94}$ Este caso poderá ilustrar uma observação previamente registada por Mário Barroca: «os desvios podem estar relacionados com a própria morfologia do terreno onde o cemitério foi aberto» (BARROCA, 2010-2011: 132).
} 

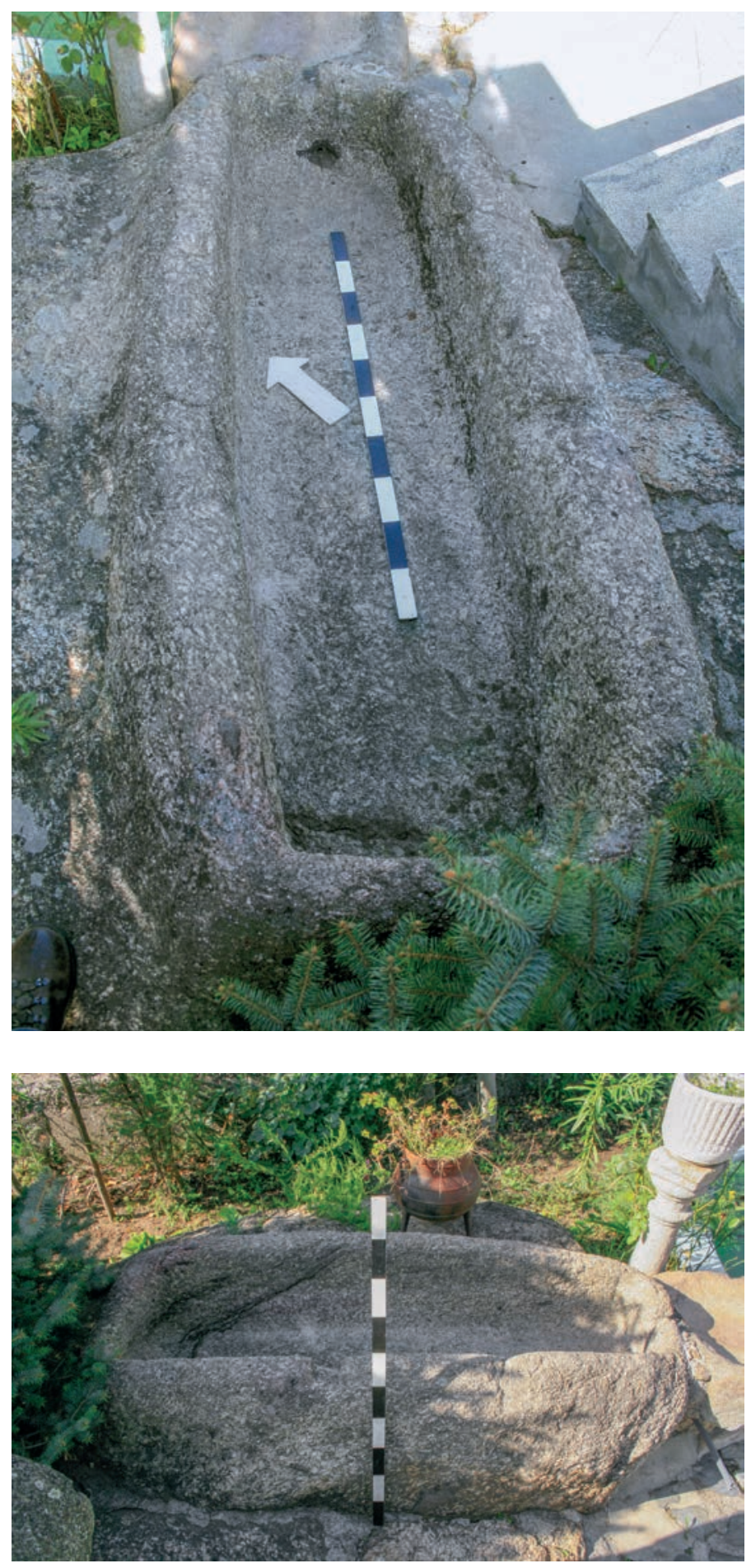

Figs. 8 e 9.

Registos relativos à sepultura trapezoidal de Outeiro (Portela de Susã). Ainda que preservada, denota alguns apontamentos intrusivos recentes

Fonte: Andreia Arezes 
secção circular. Este não é, contudo, o único testemunho da apropriação e reutilização da estrutura rupestre.

Com efeito, o terreno onde se localiza mostra-se muito alterado. O próprio penedo que a recebeu apresenta-se quase que dissimulado entre os elementos que o ladeiam, nomeadamente, entre as construções correlacionadas com a habitação e as peças decorativas. Contudo, e apesar do cenário envolvente, a sepultura persistiu e surge «insinuada» na toponímia.

\section{CONSIDERAÇÕES FINAIS}

Para um universo de quinze ocorrências arroladas no território em estudo (Mapas 1 a 4), começamos por assinalar o facto de em nenhuma das situações analisadas (diretamente, ou através de fontes secundárias), ter sido possível detetar as lajes de cobertura associadas, independentemente de constarem de exemplares monolíticos ou de uma sequência de blocos pétreos que se articulariam como tampa. Ou seja, todos os exemplares se apresentavam descobertos, circunstância que, eventualmente, poderá ficar a dever-se a episódios de espoliação. Por outro lado, e no que se refere ao domínio das tipologias, destacamos a prevalência absoluta das sepulturas sub-retangulares ou trapezoidais, e a ausência de estruturas dotadas de contornos antropomórficos. É certo que são conhecidas descrições de dispositivos compatíveis com a identificação do referido tipo de contorno (por exemplo, em Castelo de Neiva ${ }^{95}$ ), mas nenhuma delas foi, até ao momento, confirmada no terreno.

Relativamente à cronologia dos exemplares elencados, todos destinados a adultos, há algumas questões prementes a realçar. À luz da perspetiva «evolucionista» formulada por Alberto del Castillo, e atendendo, pois, à morfologia que apresentam, poderiam ser encarados como testemunhos arcaicos deste tipo de arquitetura, o que os remeteria para os primeiros tempos de afirmação desta manifestação funerária tão particular (séculos VII-VIII). Além do mais, o facto de, em grande medida, aparecerem isolados no terreno ou, quando muito, em pequenos núcleos corroboraria esta hipótese, na medida em que poderiam ser encarados como indício de uma malha de povoamento disperso, sintoma, por seu turno, da ausência de uma rede paroquial perfeitamente estabelecida. Todavia, e no que ao Entre Douro e Minho diz respeito, assumir sem reservas esta conexão levanta problemas, até porque a polarização assumida por um cemitério único junto do espaço de culto paroquial (premissa subjacente ao argumento evocado) só viria a generalizar-se substancialmente neste território na fase final da Alta Idade Média. Por outro lado, é sabido que a investigação continua

\footnotetext{
95 «Segundo informação de Eduardo Jorge Lopes da Silva, em Castelo de Neiva, num afloramento granítico implantado no alto de um monte, encontram-se duas sepulturas rupestres, abertas uma a par da outra. Trata-se de sepulturas subretangulares, com solução antropomórfica de arco ultrapassado e com desnível entre a cabeceira e a zona destinada ao corpo» (BARROCA, 2010-2011).
} 


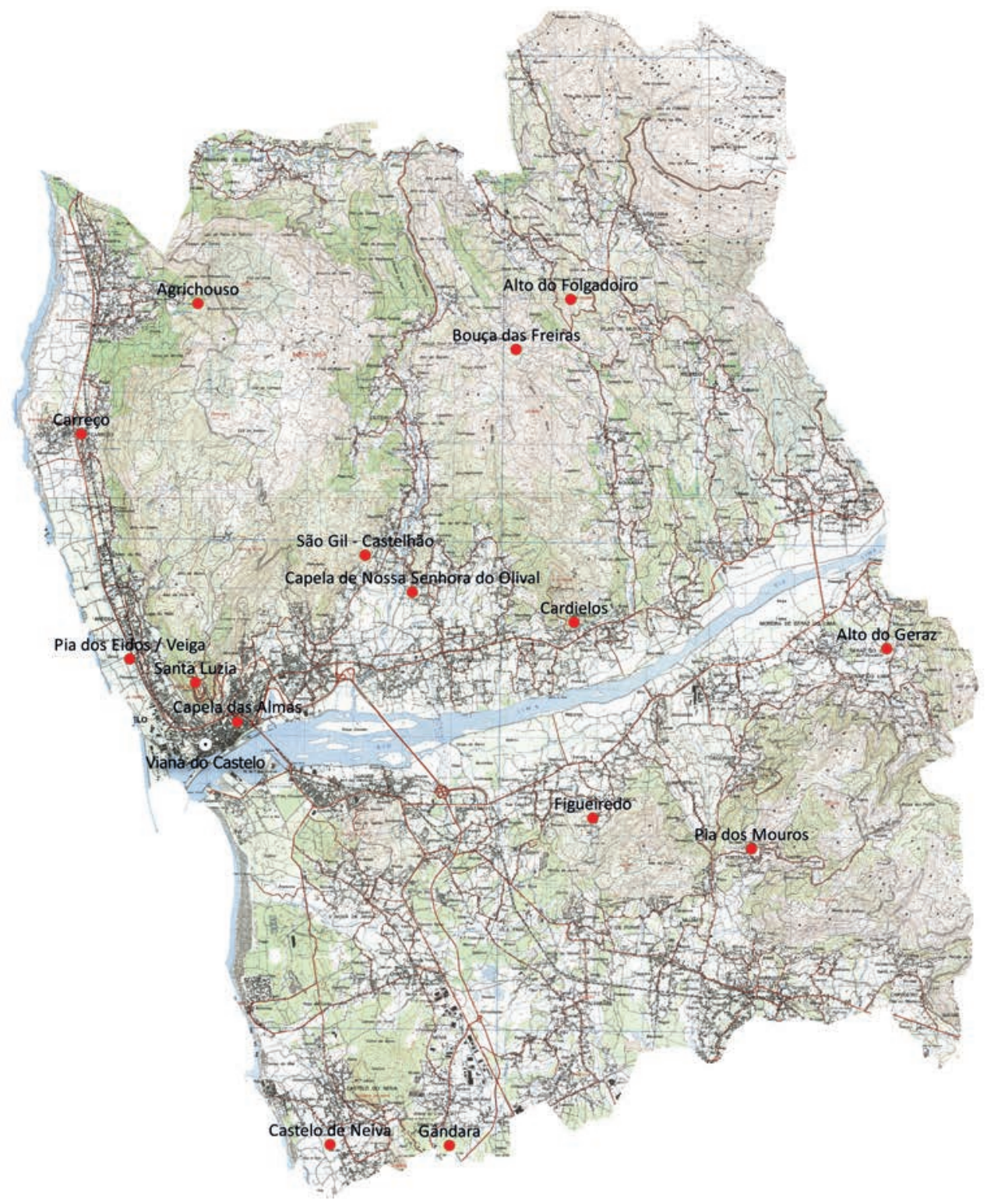

\section{Concelho de Viana do Castelo}

- Viana do Castelo - sede do Concelho

- Sepulturas isoladas ou núcleos de sepulturas

Carta Militar de Portugal - Série M888 -1/25 000, n.ㅇs 27, 28, 40, 41, 54 e 55

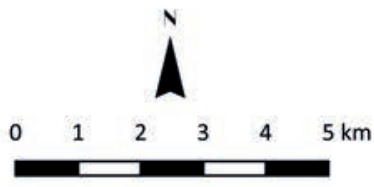

Mapa 1. Implantação das sepulturas escavadas na rocha do curso inferior do Lima sobre as Cartas Militares (escala 1/25 000) do concelho de Viana do Castelo

Fonte: composição de César Guedes 


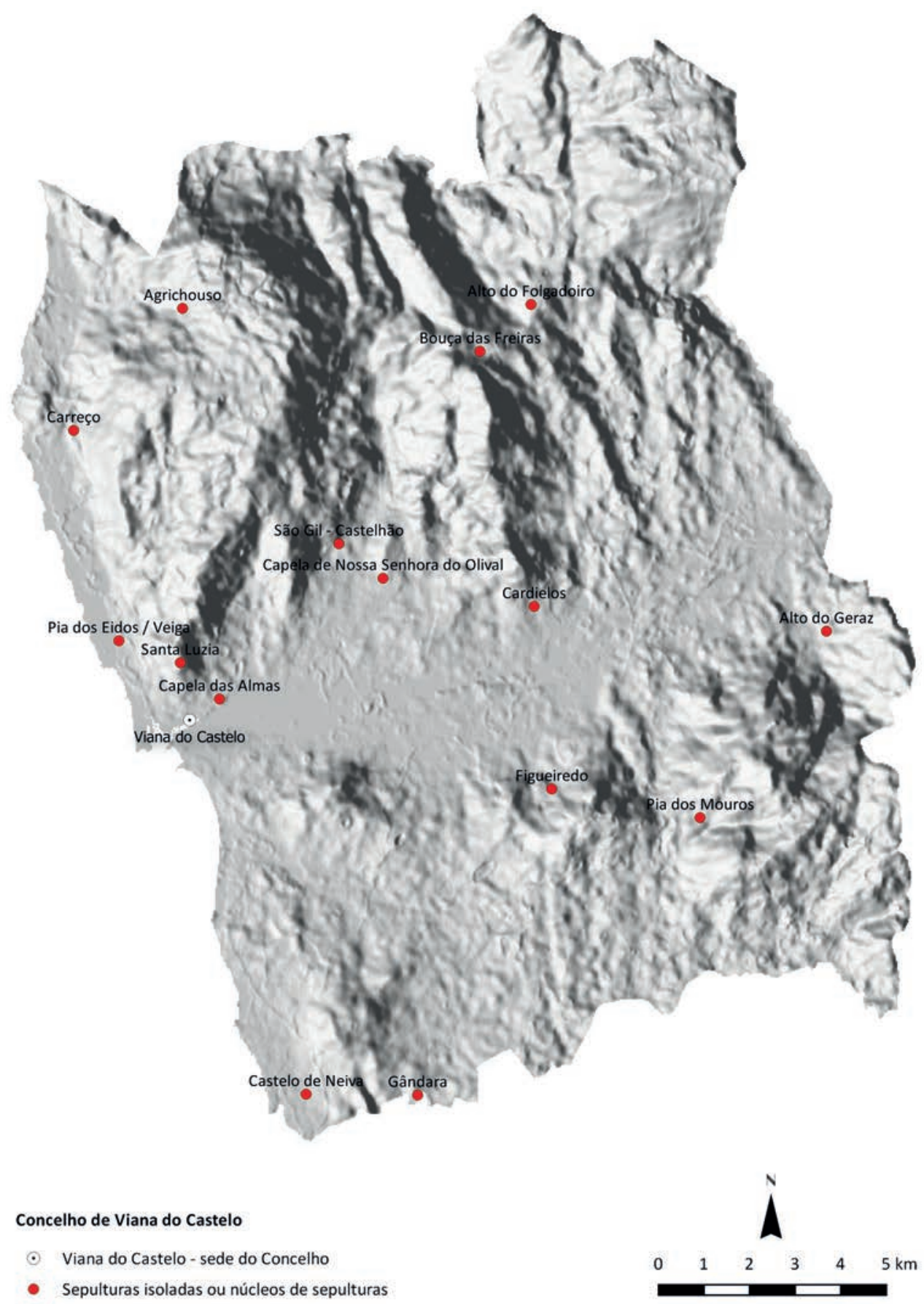

Mapa 2. Localização das estruturas rupestres sobre modelo digital com apresentação do relevo do concelho Fonte: composição de César Guedes 


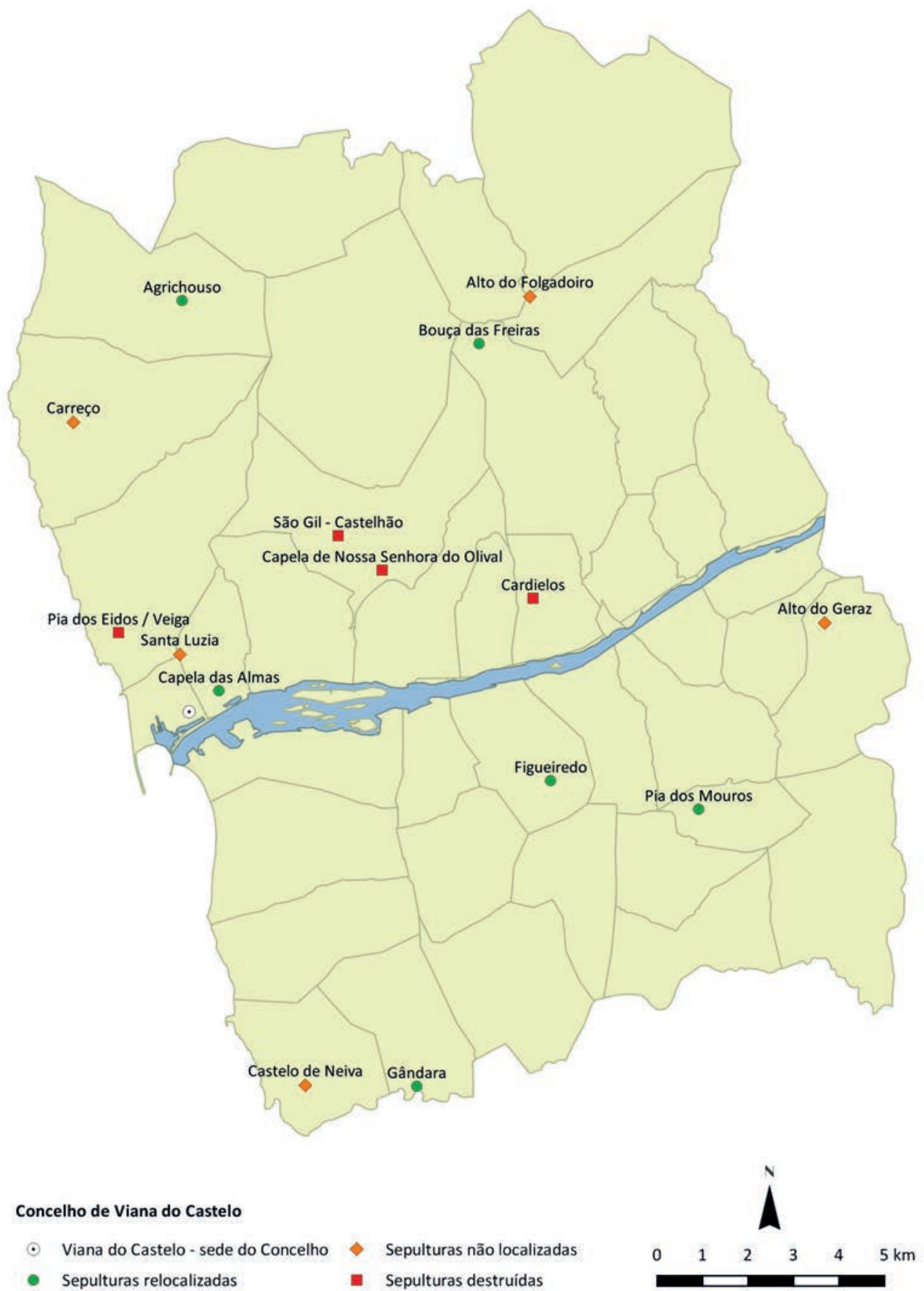

Mapa 3. Mapa das sepulturas, com indicação das ocorrências relocalizadas, não localizadas e destruídas Fonte: composição de César Guedes 


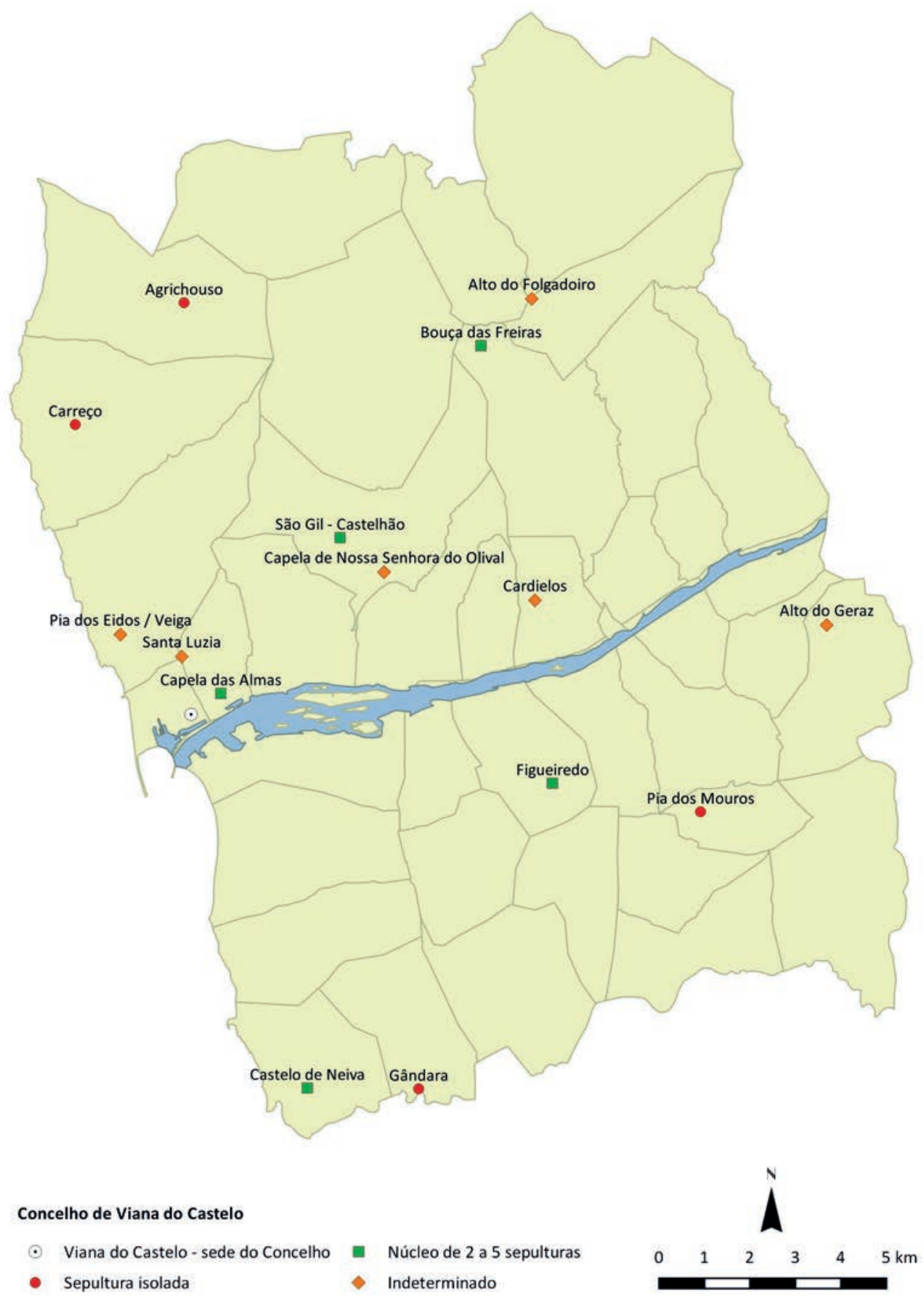

Mapa 4. Mapa das sepulturas, com referência às ocorrências isoladas, aos núcleos e às situações indeterminadas Fonte: composição de César Guedes 
a debater-se com dificuldades no que concerne ao estabelecimento de correlações entre tipologias e cronologias, e que a reiterada ausência de contextos estratigráficos selados no espaço em estudo não contribui para a afinação das propostas. Assim, consideramos complexo (por carência de dados) garantir que os sepulcros ovalados, assim como os sub-retangulares ou trapezoidais são, nesta região, necessariamente anteriores aos antropomórficos, de que não se conhecem testemunhos plenamente documentados. Mas, na esteira do que foi já assinalado por Mário Barroca, perfilamos a hipótese de as ocorrências sinalizadas poderem ser potencialmente enquadráveis entre o século VIII e o IX.

Menos problemática é a constatação de que, até ao momento, continua sem identificar no curso inferior do Lima um espaço passível de ser classificado, sem margem para dúvidas, como efetivo cemitério rupestre. É certo que alguns indícios correlativos ao núcleo das Almas seriam eventualmente sugestivos dessa possibilidade; contudo, não são suficientemente sólidos para sustentar afirmações categóricas. Por outro lado, e no que respeita à orientação apresentada pelos sepulcros inventariados, registou-se alguma regularidade, mas não a plena adoção do alinhamento canónico, na medida em que, quase invariavelmente, foram sinalizados desvios, mais ou menos acentuados. A esta evidência acrescenta-se uma outra: a da própria diversidade de opções no que respeita à localização das estruturas. Face, pois, à variedade de soluções documentadas no território em análise e para uma amostra que está longe de se afirmar como marcadamente expressiva, haverá margem para considerar a existência de um padrão? Os dados recolhidos não parecem corroborar a vigência de uma norma única, mas atendendo ao investimento que a construção de uma sepultura rupestre representa, também se afigura discutível evocar circunstâncias puramente aleatórias ou acidentais para explicar a implantação destes dispositivos. Julgamos, pelo contrário, que outras estratégias e condicionantes, eventualmente decorrentes da vontade individual e/ou familiar, ou talvez mesmo das especificidades da propriedade ou da paisagem, cuja posse se poderá ter pretendido vincar, teriam ditado a materialização de um conjunto de escolhas. Em declives pouco pronunciados do terreno, ou a meia encosta; junto de zonas de passagem (caminhos ou vias) ou de outros eixos de comunicação (como os próprios cursos fluviais); nas proximidades de lugares com ocupação anterior, designadamente, proto-histórica e romana. Porquê? Talvez porque esses sítios continuavam a revelar-se atrativos, nalguns casos em razão da visibilidade de que auferiam na paisagem. O que não deixa de merecer reflexão, na medida em que a memória e a identidade destes defuntos não eram, supostamente, conservadas. 


\section{AGRADECIMENTOS}

A realização deste trabalho contou com a ajuda de várias pessoas, a quem agradeço toda a disponibilidade manifestada, e os contributos com que apoiaram a sua construção.

Ao Sr. Presidente da Junta de Freguesia de São Romão do Neiva, Manuel Salgueiro, que percorreu comigo o terreno e me indicou o posicionamento preciso da sepultura da Gândara, à altura completamente dissimulada pela vegetação; ao Arquiteto Fernando Matos, que me acompanhou a Vila Franca, e me facultou o acesso à propriedade onde se localiza o núcleo de Figueiredo; à D. Isabel, ao Sr. João e ao Sr. Fernando Correia de Lima, proprietários do terreno onde se encontra implantada a sepultura de Outeiro, em Portela de Susã, que me receberam com toda a amabilidade; ao Joaquim Oliveira, que me abriu as portas do NAIAA (Núcleo Amador de Arqueologia de Afife) e prospetou comigo o Monte do Agrichouso, ajudando ainda na captação dos registos; à Fátima Rodrigues, à Dina e ao Mateus Vilar, que comigo percorreram toda a zona da Bouça das Freiras, Nogueira, apesar das dificuldades causadas pelo mato denso e pelo calor intenso.

Finalmente, ao Miguel Costa, arqueólogo do Gabinete de Arqueologia da Câmara Municipal de Viana do Castelo, pelas informações transmitidas e pela cedência de fotografias do núcleo da Capela das Almas, e ao César Guedes, por ter vertido os dados colhidos na bibliografia e no terreno para a cartografia que é apresentada em anexo.

\section{BIBLIOGRAFIA}

ABREU, A. Antunes et al. (1990). 1997-98 - Dois anos de pesquisa em arqueologia medieval e moderna em Viana do Castelo. "Cadernos Vianenses». 14, 121-182.

ABREU, A. Antunes; LOPES, J. da Cruz (1992). Descoberta do local da igreja medieval da Meadela. Festas da Meadela. Braga: Meadela.

ALARCÃO, Jorge de (2015). Os limites das dioceses suevas de Bracara e Portucale. «Portvgalia». Nova Série. 36, 35-48.

ALMEIDA, C. A. Ferreira de (1968). Vias medievais entre Douro e Minho. Porto: Faculdade de Letras da Universidade do Porto. Tese de Licenciatura.

ALMEIDA, C. A. Ferreira de (1987). Alto Minho. Lisboa: Editorial Presença.

ALMEIDA, C. A. Ferreira de; BARROCA, Mário Jorge (2001). História da Arte em Portugal: Gótico. Lisboa: Editorial Presença.

ALMEIDA, C. A. Ferreira de; BARROCA, Mário Jorge (2002). História da Arte em Portugal: o Românico. Lisboa: Editorial Presença.

ALMEIDA, C. A. Brochado de; ABREU, A. Antunes (1988). Carta Arqueológica de Viana do Castelo, 133 fichas soltas. Viana do Castelo: Câmara Municipal de Viana do Castelo.

ALMEIDA, C. A. Brochado de (2008). Sítios que fazem História. Arqueologia do Concelho de Viana do Castelo. I. Da Pré-História à Romanização. Viana do Castelo: Câmara Municipal de Viana do Castelo.

ALMEIDA, C. A. Brochado de; ALMEIDA, P. M. Brochado de (2009). Sítios que fazem História. Arqueologia do Concelho de Viana do Castelo. II. Da Idade Média à actualidade. Viana do Castelo: Câmara Municipal de Viana do Castelo. 
ARAÚJO, José Rosa (1962). Caminhos velhos e pontes de Viana e Ponte de Lima. Viana do Castelo.

BARROCA, Mário Jorge (1987). Necrópoles e sepulturas medievais de Entre Douro e Minho (século V a $X V$ ). Porto: Faculdade de Letras da Universidade do Porto. Dissertação para Provas Públicas de Aptidão Pedagógica e Capacidade Científica.

BARROCA, Mário Jorge (2010-2011). Sepulturas escavadas na rocha de Entre Douro e Minho. «Portvgalia». Nova Série. 31-32, 115-182.

BOLÓS MASCLANS, Jordi; PAGÉS PARETAS, Montserrat (1982). Les sepultures excavades a la roca. In RIU, Manuel, dir. Necropolis i sepultures medievals de Catalunya. Barcelona: Departament d'Historia Medieval, pp. 59-103.

BROCHADO, Cláudio (2004). Povoamento tardo-romano e alti-medieval na bacia terminal do Rio Lima (séculos VI-XI). Porto: Faculdade de Letras da Universidade do Porto. Dissertação de Mestrado.

CASTILLO, Alberto del (1970). Cronología de las tumbas llamadas "olerdolanas". In XI Congreso Nacional de Arqueología. Zaragoza: Secretaría General de los Congresos Arqueológicos Nacionales, pp. 835-845.

CASTILLO, Alberto del (1972). Excavaciones Altomedievales en las provincias de Sória, Logroño e Burgos. «Excavaciones Arqueológicas en España». 74.

COSTA, Avelino Jesus da (1997). O bispo D. Pedro e a organização da diocese de Braga. Coimbra: Instituto de Estudos Históricos Dr. António de Vasconcelos. 2 vols.

DAVID, Pierre (1947). Études historiques sur la Galice et le Portugal du VIe au XIIe siècle. Coimbra: Instituto de Estudos Históricos Dr. António de Vasconcelos.

FERNANDES, A. de Almeida (1994). Meadela Histórica. Viana do Castelo. Editor Paróquia de Santa Cristina da Meadela.

GAIO, Manuel J. da Costa Felgueiras (1938). Nobiliário de famílias de Portugal. Tomo VII. Barcelos: Santa Casa da Misericórdia de Barcelos.

GUEDES, César (2015). A sul do Douro: percurso pelas sepulturas escavadas na rocha entre os rios Távora e Cabrum. Porto: Faculdade de Letras da Universidade do Porto. Dissertação de Mestrado.

GUERRA, Luiz Figueiredo da (1923). Guia de Viana do Castelo. Viana do Castelo: [s.l.].

IGEO CAOP \& GTF Viana do Castelo (2012). Mapa Hipsométrico de Viana do Castelo. Viana do Castelo: Câmara Municipal de Viana do Castelo.

KLIEMANN, Katja (1986). Un aspecte de les necropolis medievals: les sepultures antropomorfes a Catalunya. Barcelona: Tese de Licenciatura.

LEAL, António (2009). Igreja das Almas: as almas da igreja velha. Viana do Castelo: Câmara Municipal de Viana do Castelo.

LEAL, Augusto Pinho (1882). Portugal Antigo e Moderno. Diccionario geográfico, estatistico, chorographico, heraldico, archeologico, histórico, biográfico e etymologico. Lisboa: Livraria Editora de Mattos Moreira \& Cardoso, vol. 10.

LOPES, Isabel Alexandra Resende Justo (2002). Contextos Materiais da Morte durante a Idade Média: as necrópoles do Douro Superior. Porto: Faculdade de Letras da Universidade do Porto. Dissertação de Mestrado. 2 vols.

LOPES, Isabel Alexandra Resende Justo (2002). Contextos Materiais da Morte durante a Idade Média: as necrópoles do Douro Superior. Porto: Faculdade de Letras da Universidade do Porto. Dissertação de Mestrado. 2 vols.

MARQUES, José (2003). Formas de organização do espaço na Idade Média. In JORGE, V., coord. Arquitectando espaços: da natureza à metapolis. Porto: FLUP; Coimbra: CEAUCP, pp. 151-171.

MARQUES, José (2004). A fronteira do Minho, espaço de convivência galaico-minhota, na Idade Média. In SILVA, F. R., coord. Estudos de Homenagem a Luís António de Oliveira Ramos. Porto: FLUP, pp. 697-712. 
MARTÍN VISO, Iñaki (2016). Comunidades locales, lugares centrales y espacios funerarios en la Extremadura del Duero Altomedieval: las necrópolis de tumbas excavadas en la roca alineadas. "Anuario de Estudios Medievales». 46: 2, 859-898.

MATOS, José M. (1994). A Igreja de Santa Cristina da Meadela. Viana do Castelo.

MOREIRA, António Fernandes Moreira (1986). O Município e os Forais de Viana do Castelo. Viana do Castelo: Câmara Municipal de Viana do Castelo.

NEVES, Leandro Quintas (1965). Os castros do Norte de Portugal. «Lucerna». 4, 172-180.

PAÇO, Afonso do; QUESADO, Aníbal do Paço (1956). Digressões Arqueológicas pelo Alto Minho. «Arquivo do Alto Minho». 1ª́rie. 6, 1-2.

PEREIRA, Andreia; MARTINS, Bruno (2018). Descodificadores da paisagem cultural no setor terminal da bacia do Lima: entre a geomorfologia e o património histórico-arqueológico. In VIEIRA, A. et al. Atas do II Encontro Luso-Afro-Americano de Geografia Física e Ambiental. Guimarães: CEGOTUniversidade do Minho, pp. 1159-1166.

REAL, Manuel (1985). Santa Marinha da Costa. Notícia histórica. «Boletim da D.G.E.M.N.». n. ${ }^{\circ} 130$.

SILVA, Armando Coelho Ferreira da (2007). A Cultura Castreja no Noroeste de Portugal. Paços de Ferreira: Câmara Municipal de Paços de Ferreira.

TEIXEIRA, Carlos; MEDEIROS, A. Cândido; COELHO, A. de Vasconcelos Pinto (1972). Carta Geológica de Portugal na escala 1/50 000. Notícia explicativa da Folha 5-A. Viana do Castelo. Lisboa: Serviços Geológicos de Portugal.

VIANA, Abel (1955). Alguns instrumentos de pedra pulida do Alto Minho. «Arquivo do Alto Minho». 5: 1. 


\title{
DIFERENTES MODELOS DE POVOAMENTO RURAL ALTO-MEDIEVAL DO ALGARVE OCIDENTAL
}

\author{
LUÍS MIGUEL CABRITA*
}

\begin{abstract}
Resumo: Os testemunhos arqueológicos da região de Silves, S. Bartolomeu de Messines, constituem, quanto a nós, fundamento para dar continuidade aos estudos que sobre ela foram publicados, ampliando a área de investigação ao Algarve Ocidental. Tencionamos contribuir um pouco mais para o conhecimento, da região e das sociedades rurais tardorromanas ou visigóticas que exploraram aquele território.
\end{abstract}

Palavras-chave: Sepulturas escavadas na rocha; Algarve; S. Bartolomeu de Messines.

Abstract: The archeological evidence from the S. Bartolomeu de Messines, Silves region provides, in our opinion, fundament for the continuation of studies already published regarding the area - therefore amplifying the area of investigation to the Western Algarve. We intend to contribute to the insight of the region and the late-roman or visigoth rural communities that then explored the territory.

Keywords: Rock cut graves; Algarve; S. Bartolomeu de Messines.

A Península Ibérica nos alvores do século VI apresentaria uma geografia política instável. A noroeste, nas zonas montanhosas da Galícia, os Suevos estariam acantonados, os Bascos formariam um outro grupo hostil ao centralismo visigodo que teria fundado a sua capital em Toledo, mantendo Mérida como a principal cidade da Lusitânia, herdeira da antiga província romana. Em meados da centúria de quinhentos as incursões Bizantinas perpetradas por Justiniano, que reclama ser o genuíno sucessor da Roma Imperial, assenhora-se de toda a costa sul da Península Ibérica, desde Lagos a Cartagena ${ }^{1}$.

No curto período que Bizâncio regrou a estreita faixa meridional do atual território português, teriam a sua capital em Faro (Ossonoba), assim como a sua sede episcopal regional. Estes conquistadores terão ainda conservado os templos de Loulé Velho e Senhora da Rocha como ordenadores espirituais na atual região algarvia. No entanto, as zonas interiores parecem não ter sido influenciadas por estes missionários mediterrânicos ${ }^{2}$.

A degradação da estrutura administrativa, decadência urbana dos oppida, de Cilpes, Lacobriga, Ipses que se localizavam não muito longe ${ }^{3}$, o desmantelamento das cúrias municipais, poderes fiscais, judiciais e organizações militares, herdeiras da

\footnotetext{
* Email: lmcabrita@gmail.com.

${ }^{1}$ SERRÃO, MARQUES, dir., 1993: 60-65.

${ }^{2}$ M. GOMES, 2002: 386.

${ }^{3}$ ALARCÃO, 1990: 360-361.
} 
romanização, provocada pela invasão dos povos germânicos, visigodos, no primeiro quartel do século VII, no atual território algarvio, culminando com o afastamento dos Bizantinos que submeteram este espaço em meados do século VI ${ }^{4}$. A dispersão das populações nos séculos VI e VII, pelos territórios mais ricos e protegidos terá provocado a falência da economia romanizada dos centros urbanos, que regulou a região a partir do século III a. C. nas explorações agrárias e mineiras ${ }^{5}$. A ausência de um edifício eclesiástico cristãos nesta região do Barlavento algarvio poderá ter sido um outro contributo para a dispersão das comunidades humanas, não tendo sido detetado nos atuais aglomerados populacionais qualquer vestígio da presença de um templo paleocristão, ou visigótico. Corroborando este facto é a dispersão dos cemitérios rupestres que foram construídos nas cercanias dos habitats comunitários.

\section{A POSIÇÃO GEOGRÁFICA E RELEVO}

O Algarve Ocidental ocupa o extremo ocidente sul da Península Ibérica dispondo uma posição geográfica entre os paralelos 37 1'30,91" e 37²6’15,99” norte e as latitudes $8^{\circ} 59^{\prime} 32,15^{\prime \prime}$ e $8^{\circ} 10^{\prime} 42,99^{\prime \prime}$ oeste. Ocupa sensivelmente uma área aproximada de $2029,5 \mathrm{~km}^{2}$, que tem as suas fronteiras orientais nos limites administrativos ocidentais no concelho de Loulé e nos limites administrativos leste do concelho de Albufeira. Os limites oeste e sul da região, confinam com o oceano Atlântico, a norte, é limitado pelas Serras de Espinhaço de Cão, Monchique e Caldeirão.

As serras que limitam o Algarve a norte só têm expressão na região, não mostram continuidade para além do curso do rio Guadiana ${ }^{6}$. A cota atinge o seu ponto mais alto na Serra de Monchique com $902 \mathrm{~m}^{7}$. As altitudes vão esbatendo-se até ao eixo

Limites administrativos do

Fig. 1. Algarve Ocidental (Barlavento) Fonte: CABRITA, 2007

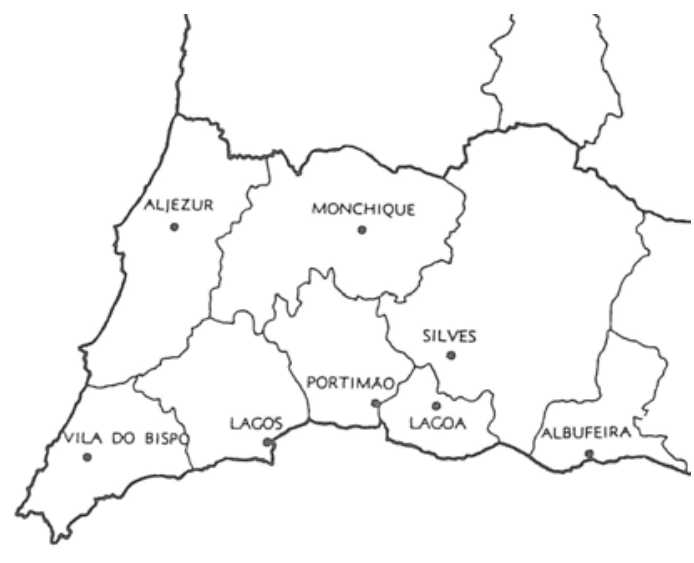

\footnotetext{
${ }^{4}$ M. GOMES, 2002: 386.

${ }^{5}$ MATTOSO, dir., 1993: 301-359.

${ }^{6}$ RIBEIRO, 1987: 13.

${ }^{7}$ RIBEIRO, 1987: 104-105.
} 
S. Bartolomeu de Messines - S. Marcos da Serra no concelho de Silves. A este daquele eixo iniciam-se as elevações da Serra do Caldeirão que atingem o seu ponto mais alto aos $589 \mathrm{~m}$. A oeste da Serra de Monchique, desenvolve-se a Serra do Espinhaço de Cão. A sul da anterior zona serrana desenvolve um relevo menos acentuado, as formações rochosas são constituídas maioritariamente por calcários dolomíticos e argilas vermelhas. A orla marítima desvenda acidentes suaves de baixa altitude, que se acentua no sentido de este para oeste, aquela é interrompida por zonas dunares recentes ${ }^{8}$.

\section{AS INVESTIGAÇÕES PRECEDENTES}

Nos finais da centúria de Oitocentos, Sebastião Philippes Martins Estácio da Veiga, colige informações e reúne artefactos na região em causa, anunciando uma diversidade cronológica da presença humana no território algarvio ${ }^{9}$. No final da primeira metade do século seguinte, Octávio da Veiga Ferreira e Albuquerque e Castro publicam o espólio da necrópole pré-histórica do sítio de Vale de Carro no concelho de Albufeira, entre os artefactos estudados são descritos o tipo de sepulturas e objetos que se mostram consentâneos com o período alto medieval ${ }^{10}$. Abel Viana, José Formosinho e Octávio da Veiga Ferreira publicam o espólio exumado das sepulturas visigóticas do sítio da Alcaria nas Caldas de Monchique ${ }^{11}$. Estes trabalhos de escavação terão tido o seu começo no ano de 1937, prolongaram-se até 1948 com a colaboração dos três investigadores ${ }^{12}$. O primeiro Congresso Nacional de Arqueologia que homenageou o digníssimo Doutor José Leite de Vasconcelos, realizado no derradeiro mês do ano de 1958, Maria Elisa Helena Henriques Gomes apresentou comunicação titulada Monumentos Arqueológicos Inéditos do Concelho de Silves. O referido trabalho documenta a existência de três núcleos de sepulturas apelidados de Fragão, Quinta da Unha e Pedreira ${ }^{13}$. O Doutor Fernando António de Almeida na sua obra Arte visigótica em Portugal, estuda alguns objetos e elementos arquitetónicos, capitel, provenientes da Vila de Alcantarilha ${ }^{14}$. Maria Luísa Estácio da Veiga Afonso Santos, regista testemunhos itálicos junto da atual Vila de S. Bartolomeu de Messines ${ }^{15}$. Achados isolados continuaram a suceder, chamando a atenção de arqueólogos como Caetano de Mello Beirão e Mário Varela Gomes, que nos privilegiaram com as suas campanhas arqueológicas na bacia hidrográfica do Alto-Arade, onde se documentou a existência de numerosos locais com vestígios da ação humana

\footnotetext{
${ }^{8}$ RIBEIRO, LAUTENSACH, 1987:158-159.

${ }^{9}$ VEIGA, 1887: 350-369.

${ }^{10}$ FERREIRA, CASTRO, 1948: 5-12.

${ }^{11}$ VIANA, FORMOSINHO, FERREIRA, 1949.

12 VIANA, FORMOSINHO, FERREIRA, 1950.

${ }^{13}$ GOMES, 1958: 75-94.

${ }^{14}$ ALMEIDA, 1962: 205-254.

${ }^{15}$ SANTOS, 1972: 117-118.
} 
e se iniciaram os estudos históricos e arqueológicos, segundo mitologias modernas, desta faixa interior do Algarve ${ }^{16}$.

O arqueólogo Mário Varela Gomes, estudou em 2002 a necrópole visigótica de Poço dos Mouros, nas imediações da povoação de Alcantarilha no concelho de Silves, composta por 8 sepulturas. Este arqueossítio foi precedentemente escavado pelo Padre José Manuel Semedo Azevedo, pároco de Albufeira, que resguardou numa singela coleção dois sepulcros e variado espólio provenientes daquela necrópole ${ }^{17}$.

Em 2007 apresentámos, na Faculdade de Ciências Sociais e Humanas da Universidade Nova de Lisboa, uma dissertação propondo um arquétipo de povoamento Alto Medieval para a região de S. Bartolomeu de Messines. A investigação foi firmada no estudo de cinco necrópoles e cinco sepulturas que totalizam quarenta e três fossas tumulares. Aquelas foram escavadas no extenso veio de arenito vermelho de Silves que emerge em todas as elevações, que limitam a norte o vale da aldeia da Amorosa e o sítio de Vale Fuzeiros ${ }^{18}$.

\section{O CASO DAS NECRÓPOLES RUPESTRES ALTO-MEDIEVAIS}

Os cemitérios alto-medievais de S. Bartolomeu de Messines privilegiaram as fragas rochosas de arenito vermelho, grés de Silves, que emergem nos pequenos cerros, que por vezes, exibem longos afloramentos e imponentes penedos, nas encostas voltadas a sul. Esporões rochosos sobressaem nos topos dos montes, atingindo cotas entre os 200 e 150 metros.

As oito necrópoles identificadas, Castelo, Amorosa, Forneca, Carrasqueira e Pedreirinha, Monte Branco, Falacho, Arge, exibem uma diversidade numérica de sepulcros, que nos permitiu sugerir a existência de diferentes tipos de comunidades que habitariam na região. A necrópole mais extensa é da Amorosa que conserva 18 sepulcros, numa daquelas fossas, foi ainda possível resgatar um individuo inumado que nos forneceu dados antropológicos, cronológicos e rituais, de grande relevância. A par daqueles cemitérios identificamos sete sepulturas isoladas que podem induzir à existência de comunidades mais singelas que não se alargariam além do núcleo familiar. O sítio dos Canhestros, Hortas de Baixo, Forneca e Pedreirinha, Barradas, Mata Ladrões, conservam fossas que foram abertas em penedos distantes dos principais núcleos sepulcrais.

O estudo destes conjuntos funerários, à luz das novas metodologias aplicadas à arqueologia da morte, permitiu coligir dados que podem sugerir novas perspetivas sobre as comunidades que ocuparam aquele espaço territorial.

\footnotetext{
${ }^{16}$ GOMES, 1994: 79-72.

${ }^{17}$ M. GOMES, 2002: 339-391.

${ }^{18}$ CABRITA, 2007: 137-142.
} 


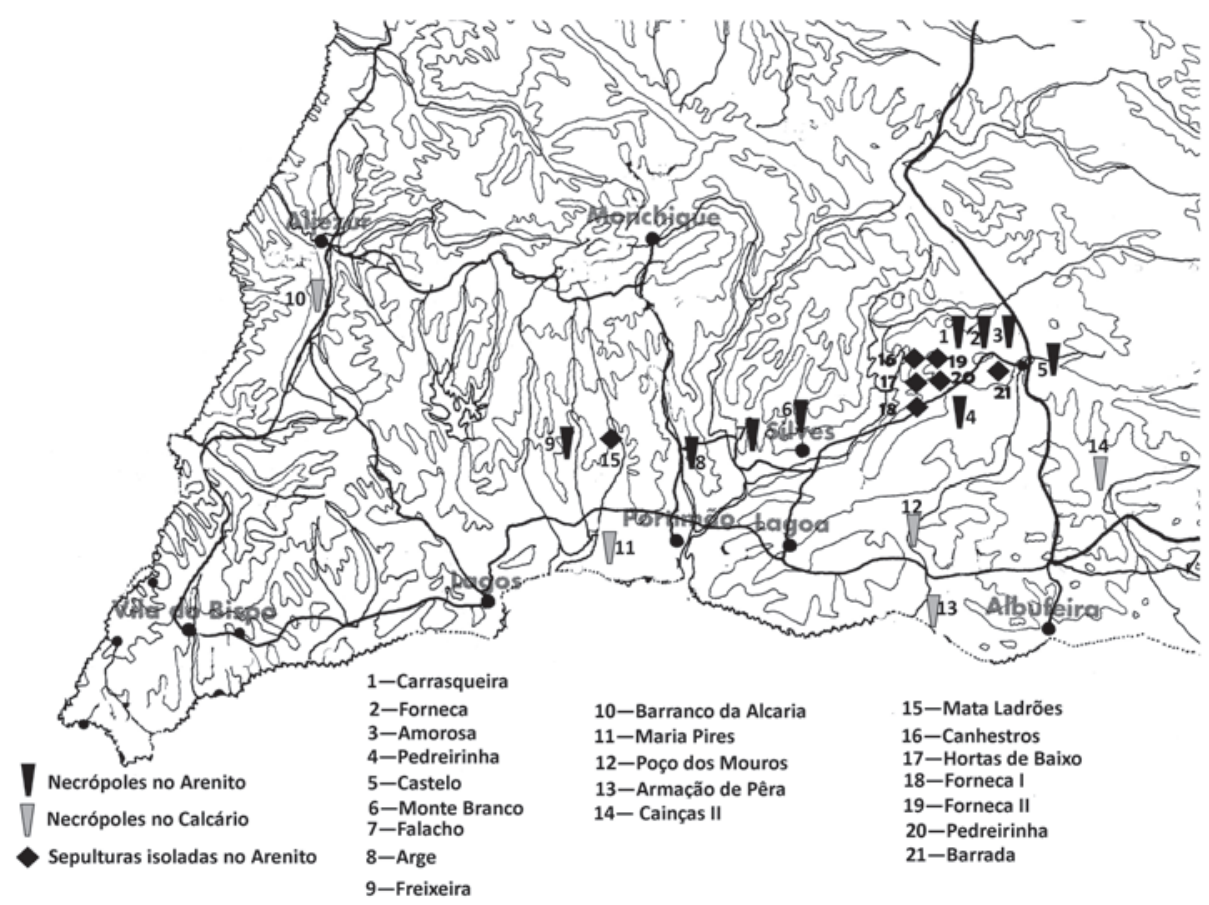

Fig. 2. Localização das necrópoles e sepulturas isoladas escavadas na rocha Fonte: CABRITA, 2007

Os recentes trabalhos dedicados às necrópoles fixadas nas margas de arenito vermelho de Silves, Arge, sepultura de Mata Ladrões, Freixeira no Concelho de Portimão; Monte Branco e Falacho e Sepultura das Barradas em Silves, até à data, não ofereceram a presença dos povoados que originaram aqueles campos funerários.

Semelhante horizonte reconhece-se nas necrópoles que ocuparam afloramentos rochosos calcários, Chaíças I e II no Concelho de Albufeira, Poço dos Mouros, Armação de Pera em Silves, Maria Pires em Portimão e Barranco da Alcaria em Aljezur.

Assim, reduzidos à investigação das fossas tumulares, sem a presença de outros testemunhos materiais que os possam complementar, ficamos limitados ao estudo das práticas funerárias.

\section{ARQUITETURA FUNERÁRIA}

A escolha de um afloramento rochoso para aí se construir um cemitério rupestre, não seria por certo de modo aleatório. A proximidade do habitat, um local que se deveria distinguir na paisagem próxima e a sua fácil identificação no horizonte, seriam, provavelmente, fatores a ter em conta pela comunidade. As necrópoles dos sítios ante mencionados, estão inseridas naqueles critérios. Os penedos onde foram 
construídos os aludidos cemitérios, destacam-se da paisagem, são facilmente identificáveis no horizonte e muito presumivelmente os habitats estariam próximos, apesar de não termos conseguido identificar a localização exata destes, muito verosimilmente pela atual ocupação habitacional do território ou, por se encontrarem sob as atuais povoações, e ainda, pela prática agrícola intensa que se comete.

A construção de habitações com materiais pouco perenes, a instalação destas em local que não interfira com a prática agrícola, a criação de gado, terá sido fatores, condicionantes, no tipo de povoamento implementado por estas comunidades. As condições precedentes terão inviabilizado a presença prolongada no tempo de testemunhos inerentes aos habitats, muros de habitações, buracos de postes ou fornos. A água está sempre presente no vale, presumivelmente, a curta distância do habitat. As serras a norte poderiam fornecer a madeira, para combustível ou para a construção e ainda, o alimento para o gado. $\mathrm{O}$ vale será reservado para o cultivo das leguminosas e dos cereais.

A indicação do local no penedo onde se iria proceder à abertura da sepultura, dependeria provavelmente de vários fatores. No caso de ser a fossa inaugural esta iria presumivelmente ocupar a parte central do afloramento rochoso. Na situação de já existirem outras câmaras funerárias construídas no penedo, esta seria fundada ao lado das existentes, formando assim um alinhamento paralelo. Ocorrem, também, situações de ocupação de penedos isolados em redor do núcleo funerário central, como sucede nas necrópoles da Forneca, Amorosa e na Carrasqueira. Escolhido o local onde se iria construir a morada definitiva do indivíduo, assinalava-se na superfície rochosa a planta da fossa tumular. Em seguida teria início, o desmonte, para a abertura da câmara funerária ${ }^{19}$. Esta operação seria efetuada com recurso a instrumentos metálicos, que podemos testemunhar e registar as suas marcas distintas, nas paredes internas das fossas sepulcrais. Escolhida a cobertura da sepultura esta seria aplanada interiormente e dimensionada para a encaixar no rebaixo anteriormente realizado na sua orla.

Justapondo a metodologia que o Professor Doutor Iñaki Martín Viso propõe, divisão em três grupos, com as devidas adaptações para a realidade atual do extremo ocidente do Algarve, repartição em três grupos, um primeiro grupo, sepulturas isoladas, um segundo conjunto, sepulturas agrupadas de 2 a 5 , e por último, necrópoles com mais de 5 fossas funerárias. Neste último grupo não os dividimos em necrópoles ordenadas e desordenadas porque todos aqueles conjuntos nos sugerem a existência de uma ordenação em grupos familiares ${ }^{20}$.

\footnotetext{
19 TENTE, LOURENÇO, 1998: 208.

${ }^{20}$ MARTÍN VISO, 2012: 170-172.
} 
Compilamos 7 sepulturas isoladas representando $12 \%$, com $26 \%$ e 15 sepulturas contabilizadas registamos conjuntos de 2 a 5 sepulturas, por último $62 \%$ dos sepulcros estão agrupados em necrópoles com 36 testemunhos, esta realidade foi aferida para as fossas abertas na rocha de arenito. Para os cemitérios fundados nos afloramentos rochosos de calcário as 35 sepulturas reconhecidas estão todas agrupadas em necrópole.

Junto das câmaras funerárias assinalámos a insculturação de pequenas covinhas circulares, que variam de diâmetro entre os $2 \mathrm{~cm}$, as mais pequenas e $15 \mathrm{~cm}$, as depressões maiores. A profundidade média que guardam varia entre os 2 e $3 \mathrm{~cm}$. Algumas destas covinhas estão inseridas em depressões maiores que os penedos oferecem, naturalmente, ou foram construídas por desmonte da superfície rochosa. Outras covinhas aparecem muito próximo das sepulturas, que sugerem a existência de uma prática ritual funerária associada a estes elementos A prática de tumular na rocha, que se verifica na região do barlavento algarvio descarta a presença de esquifes, de madeira, nos noventa e três túmulos deste universo, pois a profundidade e forma das fossas sepulcrais não comportaria tal funcionalidade.

A planta tumular mais comum das 58 sepulturas nos cemitérios escavados no arenito é ovalada, com 16 sepulcros e representando $27 \%$ das fossas. A planta sub-retangular, com 15 exemplos, revela $25 \%$ das sepulturas; 11 túmulos são trapezoidais, detendo $18 \%$ do universo; o traçado subtrapezoidal, com 4 sepulturas, detém $7 \%$ dos exemplos; as fossas retangulares representam $3 \%$ dos túmulos, com dois exemplares. Doze dos túmulos, que não conseguimos obter a planta com exatidão, representam $20 \%$ dos jazigos.

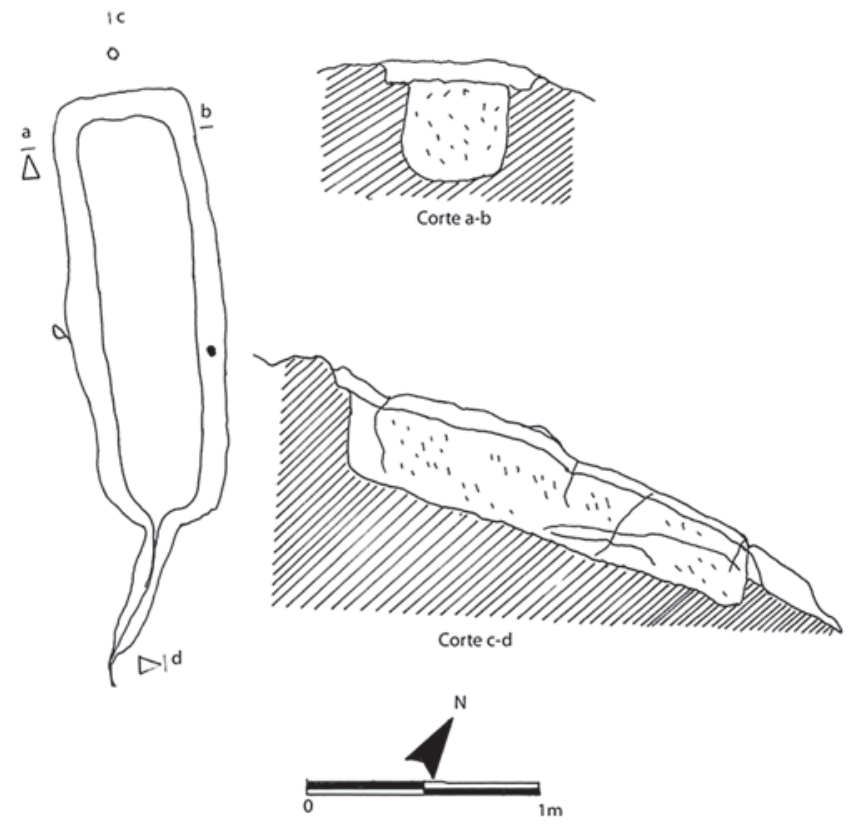

Fig. 3.

Sepultura isolada 1 da Forneca Fonte: CABRITA, 2007 
O universo dos sepulcros abertos no estrato rochoso calcário coligidos, são 35 fossas. A forma mais usual reconhecida é a subtrapzoidal com 7 sepulturas, representando 19\%. As depressões trapezoidais e ovais detém um exemplar cada, registando $3 \%$ cada uma. As plantas sepulcrais retangulares e sub-retangulares que reconhecemos têm 4 e 3 exemplos respetivamente, representando $11 \%$ e $8 \%$ deste universo. As formas aqui apresentadas são semelhantes às que encontramos nos cemitérios talhados no veio de arenito da região e verifica-se, igualmente, uma total ausência de sepulturas antropomórficas.

O comprimento médio das fossas tumulares das necrópoles abertas no arenito é de 1,75 m. Incluímos neste cálculo o fragmento de sepultura da Forneca que oferece pelo menos metade do túmulo, com 0,62 $\mathrm{m}$ de comprimento máximo, e o jazido de criança da Pedreirinha, com o comprimento de $0,58 \mathrm{~m}$. Os sepulcros abertos nos afloramentos calcários o comprimento médio atinge $1,42 \mathrm{~m}$, registamos ainda presença de túmulo de criança com 0,65 m, na necrópole do Barranco da Alcaria (Aljezur), e assinalamos a existência de 3 fossas com dimensões próximas de 1,00 m, na necrópole de Poço dos Mouros, (Silves), denunciando a presença de indivíduos jovens.

\section{RITUAL FUNERÁRIO}

O ritual funerário que ocorre nas necrópoles escavadas nos estratos rochosos de arenito de Silves, Cerro do Castelo em S. Bartolomeu de Messines, Amorosa, Forneca, Carrasqueira, Pedreirinha, Vale Fuzeiros, Monte Branco, Falacho, Mata Ladrões, Arge, Freixeira, e nas sepulturas isoladas da Forneca, Horta de Baixo, Canhestros e Pedreirinha, Barradas, é a prática da inumação em fossa, simples, aberta no arenito vermelho de Silves, coberta por laje monolítica ou composta por vários blocos.

Na necrópole do Poço dos Mouros, na freguesia de Alcantarilha, do concelho de Silves, cavadas no estrato calcário, também o arqueólogo Mário Varela Gomes sugere a opção ritual de inumação do cadáver, envolto em sudário na posição longitudinal, sem qualquer ataúde a proteger o corpo, pois a largura das fossas tumulares não comportaria mais que aquele ${ }^{21}$. Pratica semelhante deveria ocorrer nas necrópoles de Armação de Pera, (Silves), Maria Pires, (Portimão), Barranco da Alcaria, (Aljezur) e Chaiças I e II em Albufeira.

A profanação das sepulturas, de S. Bartolomeu de Messines e de Vale Fuzeiros, que ocorreu em épocas precedentes, não deixou testemunhos da existência de oferendas aos defuntos, prática que ocorre noutros cemitérios estudados neste concelho, como na necrópole anteriormente aludida de Poço dos Mouros.

Ali, Mário Varela Gomes recolheu, ainda, alguns fragmentos cerâmicos nas terras da necrópole, remexidas pelas intervenções, ocorridas em 1958 e 1970, dirigidas pelo

\footnotetext{
${ }^{21}$ M. GOMES, 2002: 374.
} 


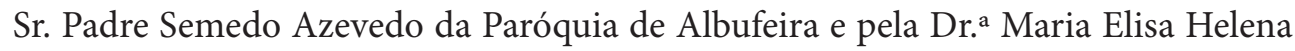
Henriques Gomes, respetivamente. O cemitério de Poço dos Mouros, ofereceu uma garrafa e um copo, exumados da Sepultura 1, fragmento cerâmico de jarro e fragmento cerâmico da parede de gargalo, provindos, provavelmente, da sepultura 2, tal como fragmentos cerâmicos correspondendo a um fundo de panela e de parede de vasilha recolhidos na sepultura $6^{22}$.

No universo de cinquenta e seis sepulcros estudados nas necrópoles de S. Bartolomeu de Messines, Vale Fuzeiros, Silves e Portimão a orientação mais comum é a noroeste-sudeste, correspondendo a primeira diretriz à deposição da cabeça e a segunda ao assentamento dos pés, com 26 exemplares, que representam a $47 \%$ dos testemunhos. Segue-se a orientação norte-sul, com 10 exemplares, que atingem $18 \%$ dos vestígios. Nove sepulcros estão orientados nordeste-sudoeste, representando $17 \%$ dos exemplares, o mesmo número foi coligido nos sepulcros que não conseguimos determinar a orientação. Foi registado um único sepulcro, que oferece orientação sudeste-noroeste e representa $2 \%$ deste universo, a sepultura isolada da Pedreirinha.

As sepulturas abertas na faixa calcária, localizada a sul da anterior formação rochosa, privilegiam a orientação norte-sul com 10 elementos, representado $32 \%$ do conjunto. A orientação sudoeste-nordeste agrupa 6 sepulcros, detendo 19\%, duas sepulturas estão orientadas oeste-este, que retratam 7\% dos casos, e em 13 exemplos deste universo não se conseguiu obter a informação da sua diretriz, denotando $42 \%$.

A exposição a sul, da maioria dos afloramentos rochosos de arenito vermelho de Silves, condicionou, muito provavelmente, a orientação e construção das fossas fúnebres, ostentando algumas necrópoles sepulturas que estão direcionadas para outras orientações, caso da necrópole da Amorosa, onde a extensão do afloramento rochoso permite construir a sepultura no rumo adequado. As sepulturas isoladas que foram construídas em penedos isolados, Horta de Baixo, Canhestros e Pedreirinha, Barradas, Arge, estão orientadas de acordo com a orientação que os penedos detêm.

Nas 35 necrópoles investigadas na região de Granada (Espanha) por Román Puzón, o autor do estudo mostra que a maioria das sepulturas $(79,30 \%)$ de época tardorromana, séculos VI a VIII d. C., estão orientadas de oeste para este. O primeiro ponto cardeal coincide com a deposição da cabeça. Direcionadas de este para oeste só registou $13,80 \%$ dos sepulcros. E somente 6,90\% dos sepulcros é que apresentam o sentido norte-sul.

Para a Antiguidade Tardia, anterior ao século V. d. C. o autor coligiu 65,72\% das sepulturas orientadas oeste-este, registando a existência de $22,14 \%$ no sentido este/ oeste e $12,08 \%$ orientadas norte-sul, concluindo que na Andaluzia Oriental, desde o

${ }^{22}$ M. GOMES, 2002: 339-391. 
estabelecimento decisivo do Cristianismo se praticava a orientação oeste-este ${ }^{23}$. No entanto, a maioria destas necrópoles foram abertas em solo vegetal e somente cinco necrópoles, daquele universo, foram construídas na rocha. Também só foi possível escrutinar a orientação da necrópole do bairro da Esperanza em Loja, com 24 sepulcros orientados oeste-este ${ }^{24}$.

Nos cemitérios de Albalate Las Nogueras, Cacera de las Ranas, Segobriga e Poço do Mouros, foram, também, registadas a existência de fossas mais alargadas, ou sepulturas onde estavam depositadas várias ossadas pertencentes a mais do que um individuo, ou a numerosos indivíduos. Estruturas similares parecem ocorrer em algumas necrópoles existentes no sítio de Vale Fuzeiros, necrópole da Forneca e necrópole da Amorosa.

No primeiro daqueles cemitérios, no topo do afloramento rochoso, apresenta-se fossa de forma circular e uma outra de forma quadrangular, a primeira depressão poderia ser utilizada para depositar os restos mortais e a depressão quadrangular pode sugerir a sua utilização na preparação do corpo, para ser entregue na derradeira morada.

Na pluralidade dos cemitérios anteriormente aludidos, a direção mais vulgar das fossas sepulcrais, é de oeste para este, coincidindo a primeira direção com a deposição da cabeça. Mesmo na necrópole onde esta não é a direção mais privilegiada, Albalate Las Nogueras, ela apresenta uma percentagem elevada de sepulturas posicionadas na direção mais comum. Nas necrópoles rupestres de Loja, perto Granada em Espanha, Tiermes, perto de Madrid, a orientação mais comum das fossas sepulcrais, é a oeste-este.

Fig. 4.

Sepultura isolada dos

Canhestros

Fonte: CABRITA, 2007
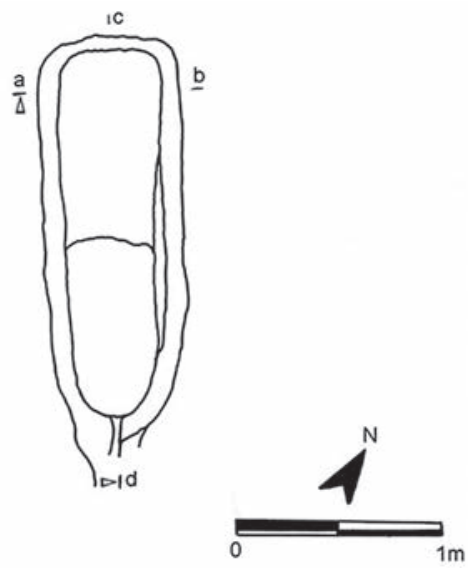
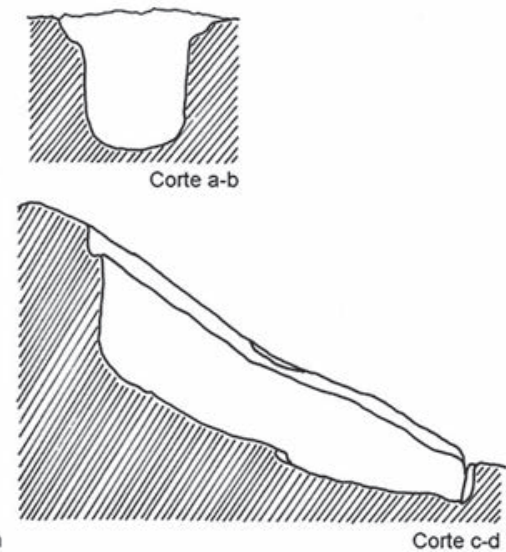

\footnotetext{
${ }^{23}$ ROMÁN PUNZÓN, 2004: 93 e 94.

${ }^{24}$ ROMÁN PUNZÓN, 2004: 52.
} 
Tabela 1. Singularidades das sepulturas escavadas na rocha de arenito

\begin{tabular}{|c|c|c|c|c|c|c|c|c|c|}
\hline \multirow{2}{*}{ Localização } & \multirow{2}{*}{$\begin{array}{c}n .^{\circ} \\
\text { de sep. }\end{array}$} & \multirow{2}{*}{ Forma } & \multirow{2}{*}{ Orientação } & \multicolumn{3}{|c|}{ Dimensões } & \multirow{2}{*}{ Inumações } & \multirow{2}{*}{ N.o } & \multirow{2}{*}{$\begin{array}{l}\text { Espólio } \\
\text { Material }\end{array}$} \\
\hline & & & & Comp. & Larg. & Prof. & & & \\
\hline $\begin{array}{c}\text { Portimão } \\
\text {-Mexilhoeira } \\
\text { Grande - Mata } \\
\text { Ladrões }\end{array}$ & 1 & Indeterminada & Indet. & & & & & & Não \\
\hline \multirow[t]{7}{*}{$\begin{array}{c}\text { Portimão - } \\
\text { Necrópole do Arge }\end{array}$} & S. 1 & Indeterminada & Indet. & & & & & & Não \\
\hline & S. 2 & Indeterminada & Indet. & & & & & & Não \\
\hline & S. 3 & Indeterminada & Indet. & & & & & & Não \\
\hline & S. 4 & Indeterminada & Indet. & & & & & & Não \\
\hline & S. 5 & Indeterminada & Indet. & & & & & & Não \\
\hline & S. 6 & Indeterminada & Indet. & & & & & & Não \\
\hline & S. 7 & Indeterminada & Indet. & & & & & & Não \\
\hline $\begin{array}{c}\text { Portimão - } \\
\text { Mexilhoeira Grande } \\
\text { - Freixeira }\end{array}$ & Indet. & Indeterminada & Indet. & & & & & & Não \\
\hline $\begin{array}{l}\text { Silves - Necrópole } \\
\text { do Monte Branco }\end{array}$ & Indet. & Trapezoidal & Indet. & & & & Sim & & Sim \\
\hline \multirow{3}{*}{$\begin{array}{c}\text { Silves - Necrópole } \\
\text { do Falacho }\end{array}$} & S. 1 & Trapezoidal & NO-SE & 1,88 & 0,40 & 0,46 & Não & & Não \\
\hline & S. 2 & Trapezoidal & NO-SE & 1,64 & 0,32 & 0,34 & Não & & Não \\
\hline & S. 3 & Trapezoidal & NO-SE & 1,97 & 0,45 & 0,50 & Não & & Não \\
\hline \multirow{18}{*}{$\begin{array}{c}\text { Silves - } \\
\text { Messines -Necrópole } \\
\text { da Amorosa }\end{array}$} & S. 1 & Ovalada & NO-SE & 2,01 & 0,57 & 0,51 & Não & & Não \\
\hline & S. 2 & Ovalada & NO-SE & 1,60 & 0,52 & 0,46 & Não & & Não \\
\hline & S. 3 & Trapezoidal & NO-SE & 1,87 & 0,48 & 0,37 & Não & & Não \\
\hline & S. 4 & Trapezoidal & NO-SE & 1,82 & 0,38 & 0,39 & Não & & Não \\
\hline & S. 5 & Ovalada & NO-SE & 1,75 & 0,37 & 0,39 & Não & & Não \\
\hline & S. 6 & Ovalada & NO-SE & 1,73 & 0,50 & 0,50 & Não & & Não \\
\hline & S. 7 & Ovalada & NO-SE & 1,78 & 0,40 & 0,41 & Não & & Não \\
\hline & S. 8 & Sub-retangular & NE-SO & 1,63 & 0,34 & 0,40 & Não & & Não \\
\hline & S. 9 & Ovalada & NO-SE & 1,87 & 0,40 & 0,29 & Não & & Não \\
\hline & S. 10 & Ovalada & NE-SO & 1,99 & 0,46 & 0,41 & Não & & Não \\
\hline & S. 11 & Ovalada & NO-SE & 2,12 & 0,46 & 0,47 & Não & & Não \\
\hline & S. 12 & Ovalada & $\mathrm{N}-\mathrm{S}$ & 1,82 & 0,45 & 0,42 & Sim & 1 & Não \\
\hline & S. 13 & Ovalada & $\mathrm{N}-\mathrm{S}$ & 2,00 & 0,46 & 0,35 & Não & & Não \\
\hline & S. 14 & Trapezoidal & $\mathrm{N}-\mathrm{S}$ & 1,70 & 0,54 & 0,34 & Não & & Não \\
\hline & S. 15 & Retangular & NO-SE & 1,84 & 0,46 & 0,41 & Não & & Não \\
\hline & S. 16 & Ovalada & NO-SE & 1,70 & 0,42 & 0,30 & Não & & Não \\
\hline & S. 17 & Ovalada & $\mathrm{N}-\mathrm{S}$ & 1,75 & 0,41 & 0,38 & Não & & Não \\
\hline & S. 18 & Ovalada & $\mathrm{N}-\mathrm{S}$ & 1,92 & 0,67 & 0,31 & Não & & Não \\
\hline
\end{tabular}




\begin{tabular}{|c|c|c|c|c|c|c|c|c|c|}
\hline \multirow{2}{*}{ Localização } & \multirow{2}{*}{$\begin{array}{c}\text { n. } \\
\text { de sep. }\end{array}$} & \multirow{2}{*}{ Forma } & \multirow{2}{*}{ Orientação } & \multicolumn{3}{|c|}{ Dimensões } & \multirow{2}{*}{ Inumações } & \multirow{2}{*}{ N.o } & \multirow{2}{*}{$\begin{array}{l}\text { Espólio } \\
\text { Material }\end{array}$} \\
\hline & & & & Comp. & Larg. & Prof. & & & \\
\hline \multirow{4}{*}{$\begin{array}{c}\text { Silves - } \\
\text { Messines -Necrópole } \\
\text { do Cerro do Castelo }\end{array}$} & S. 1 & Trapezoidal & N-S & 1,86 & 0,41 & 0,41 & Não & & Não \\
\hline & S. 2 & Ovalada & $\mathrm{N}-\mathrm{S}$ & 1,82 & 0,47 & 0,44 & Não & & Não \\
\hline & S. 3 & Trapezoidal & $\mathrm{N}-\mathrm{S}$ & 1,76 & 0,50 & 0,50 & Não & & Não \\
\hline & S. 4 & Trapezoidal & $\mathrm{N}-\mathrm{S}$ & 1,71 & 0,43 & 0,30 & Não & & Não \\
\hline \multirow{5}{*}{$\begin{array}{c}\text { Silves - } \\
\text { Messines - } \\
\text { Necrópole da } \\
\text { Carrasqueira }\end{array}$} & S. 1 & Sub-retangular & NO-SE & 1,86 & 0,64 & 0,59 & Não & & Não \\
\hline & S. 2 & Sub-retangular & NO-SE & 1,72 & 0,45 & 0,45 & Não & & Não \\
\hline & S. 3 & Sub-retangular & NO-SE & 1,86 & 0,45 & 0,50 & Não & & Não \\
\hline & S. 4 & Sub-retangular & NO-SE & 1,90 & 0,60 & 0,45 & Não & & Não \\
\hline & S. 5 & Sub-retangular & NO-SE & 1,84 & 0,46 & 0,44 & Não & & Não \\
\hline \multirow{3}{*}{$\begin{array}{l}\text { Silves-Messines } \\
\text {-Necrópole da } \\
\text { Pedreirinha }\end{array}$} & S. 1 & Sub-retangular & NE-SO & 1,97 & 0,53 & 0,40 & Não & & Não \\
\hline & S. 2 & Retangular & NE-SO & 0,58 & 0,25 & 0,26 & Não & & Não \\
\hline & S. 3 & Ovalada & NE-SO & 1,94 & 0.50 & 0,42 & Não & & Não \\
\hline \multirow{11}{*}{$\begin{array}{c}\text { Silves - } \\
\text { Messines - } \\
\text { Necrópole da } \\
\text { Forneca }\end{array}$} & S. 1 & Sub-retangular & NO-SE & 1,92 & 0,42 & 0,46 & Não & & Não \\
\hline & S. 2 & Sub-retangular & NO-SE & 1,82 & 0,46 & 0,54 & Não & & Não \\
\hline & S. 3 & Sub-retangular & NO-SE & 1,75 & 0,55 & 0,47 & Não & & Não \\
\hline & S. 4 & Sub-retangular & NO-SE & 1,68 & 0,62 & 0,72 & Não & & Não \\
\hline & S. 5 & Sub-retangular & NO-SE & 1,67 & 0,52 & 0,56 & Não & & Não \\
\hline & S. 6 & Sub-retangular & NE-SO & 1,65 & 0,50 & - & Não & & Não \\
\hline & S. 7 & Sub-retangular & - & $0,62+$ & 0,43 & 0,47 & Não & & Não \\
\hline & S. 8 & Sub-retangular & NE-SO & 1,60 & 0,43 & - & Não & & Não \\
\hline & S. 9 & Indeterminada & - & - & - & - & Não & & Não \\
\hline & S. 10 & Indeterminada & - & - & - & - & Não & & Não \\
\hline & S. 11 & Indeterminada & - & - & - & - & Não & & Não \\
\hline $\begin{array}{c}\text { Silves - Messines } \\
\text { Sepultura isolada } 1 \\
\text {-Forneca }\end{array}$ & 1 & Trapezoidal & NO-SE & 1,94 & 0,48 & 0,31 & Não & & Não \\
\hline $\begin{array}{c}\text { Silves - Messines } \\
\text { Sepultura isolada } 2 \\
\text {-Forneca }\end{array}$ & 1 & Ovalada & $\mathrm{N}-\mathrm{S}$ & 1,80 & 0,60 & 0,45 & Não & & Não \\
\hline $\begin{array}{c}\text { Silves - Messines } \\
\text {-Sepultura da } \\
\text { Pedreirinha }\end{array}$ & 1 & Subtrapezoidal & SE-NO & 1,62 & 0,38 & 0,33 & Não & & Não \\
\hline $\begin{array}{c}\text { Silves - Messines } \\
\text {-Sepultura da Horta } \\
\text { de Baixo }\end{array}$ & 1 & Subtrapezoidal & NE-SO & 1,40 & 0,36 & 0,26 & Não & & Não \\
\hline $\begin{array}{l}\text { Silves - Messines } \\
\text {-Sepultura dos } \\
\text { Canhestros }\end{array}$ & 1 & Subtrapezoidal & NO-SE & 1,92 & 0,49 & 0,38 & Não & & Não \\
\hline $\begin{array}{l}\text { Silves - Messines } \\
\text {-Sepultura das } \\
\text { Barradas }\end{array}$ & 1 & Subtrapezoidal & NE-SO & 1,71 & 0,40 & 0,20 & Não & & Não \\
\hline
\end{tabular}

Fonte: CABRITA, 2014 
Tabela 2. Singularidades das sepulturas escavadas na rocha de calcário

\begin{tabular}{|c|c|c|c|c|c|c|c|c|c|}
\hline \multirow{2}{*}{$\begin{array}{c}\text { Localização } \\
\text { Albufeira - Paderne } \\
\text { - Necropole das } \\
\text { Chaíças I }\end{array}$} & \multirow{2}{*}{$\begin{array}{c}\begin{array}{c}\text { n. } \\
\text { de sep. }\end{array} \\
\text { Indet. }\end{array}$} & \multirow{2}{*}{$\begin{array}{c}\text { Forma } \\
\text { Indeterminada }\end{array}$} & \multirow{2}{*}{$\begin{array}{c}\text { Orientação } \\
\text { Indet. }\end{array}$} & \multicolumn{3}{|c|}{ Dimensões } & \multirow[t]{2}{*}{ Inumações } & \multirow[t]{2}{*}{ N. ${ }^{\circ}$} & \multirow{2}{*}{\begin{tabular}{|c|}
$\begin{array}{c}\text { Espólio } \\
\text { Materia }\end{array}$ \\
Sim
\end{tabular}} \\
\hline & & & & & & & & & \\
\hline \multirow{10}{*}{$\begin{array}{c}\text { Albufeira - Paderne } \\
\text { - Necropole das } \\
\text { Chaíças II }\end{array}$} & S. 1 & Indeterminada & N-S & & & & Sim & 1 & \\
\hline & S. 2 & Indeterminada & N-S & & & & Sim & 1 & \\
\hline & S. 3 & Indeterminada & N-S & & & & Sim & 1 & \\
\hline & S. 4 & Indeterminada & N-S & & & & Sim & 1 & \\
\hline & S. 5 & Indeterminada & $\mathrm{N}-\mathrm{S}$ & & & & Sim & 1 & \\
\hline & S. 6 & Indeterminada & N-S & & & & Sim & 1 & \\
\hline & S. 7 & Indeterminada & $\mathrm{N}-\mathrm{S}$ & & & & Sim & 1 & \\
\hline & S. 8 & Indeterminada & N-S & & & & Sim & 1 & \\
\hline & S. 9 & Indeterminada & $\mathrm{N}-\mathrm{S}$ & & & & Sim & 1 & \\
\hline & S. 10 & Indeterminada & N-S & & & & Sim & 1 & \\
\hline \multirow{8}{*}{$\begin{array}{c}\text { Silves - Alcantarilha } \\
\text {-Necrópole Poço dos } \\
\text { Mouros }\end{array}$} & S. 1 & Sub-retangular & SO-NE & 1,05 & 0,30 & 0,40 & Sim & 2 & Sim \\
\hline & S. 2 & Retangular & SO-NE & 1,80 & 0,50 & 0,60 & Sim & 3 & Sim \\
\hline & S. 3 & Sub-retangular & O-E & 1,63 & 0,30 & 0,30 & Não & & Não \\
\hline & S. 4 & Ovalada & SO-NE & 0,98 & 0,29 & 0,33 & Sim & 1 & Não \\
\hline & S. 5 & Sub-retangular & SO-NE & 1,98 & 0,36 & 0,45 & Sim & 1 & Não \\
\hline & S. 6 & Sub-retangular & SO-NE & 1,04 & 0,23 & 0,31 & Não & & Sim \\
\hline & S. 7 & Sub-retangular & SO-NE & 1,90 & 0,42 & 0,30 & Sim & 1 & Não \\
\hline & S. 8 & Sub-retangular & O-E & 1,20 & 0,50 & 0,38 & Não & & Não \\
\hline \multirow{11}{*}{$\begin{array}{l}\text { Silves - Armação de } \\
\text { Pera - Necropole }\end{array}$} & S. 1 & Indeterminada & Indet. & & & & & & Sim \\
\hline & S. 2 & Indeterminada & Indet. & & & & & & Sim \\
\hline & S. 3 & Indeterminada & Indet. & & & & & & Sim \\
\hline & S. 4 & Indeterminada & Indet. & & & & & & Sim \\
\hline & S. 5 & Indeterminada & Indet. & & & & & & Sim \\
\hline & S. 6 & Indeterminada & Indet. & & & & & & Sim \\
\hline & S. 7 & Indeterminada & Indet. & & & & & & Sim \\
\hline & S. 8 & Indeterminada & Indet. & & & & & & Sim \\
\hline & S. 9 & Retangular & Indet. & 1,10 & 0,15 & & & & Sim \\
\hline & S. 10 & Trapezoidal & Indet. & 1,80 & 0,45 & & & & Sim \\
\hline & S. 11 & Indeterminada & Indet. & & & & & & Sim \\
\hline $\begin{array}{c}\text { Portimão -Necrópole } \\
\text { de Maria Pires }\end{array}$ & Indet. & Indeterminada & Indet. & & & & & & \\
\hline \multirow{6}{*}{$\begin{array}{c}\text { Aljezur - Necrópole } \\
\text { do Barranco da } \\
\text { Alcaria }\end{array}$} & S. 1 & subtrapezoidal & Indet. & 2,40 & 0,45 & 2,40 & Sim & 2 & Sim \\
\hline & S. 2 & Retangular & Indet. & 0,65 & 0,30 & 0,65 & Sim & 1 & Não \\
\hline & S. 3 & Retangular & Indet. & 1,60 & 0,45 & 1,60 & Sim & 1 & Não \\
\hline & S. 4 & Subtrapezoidal & Indet. & 0,85 & 0,30 & 0,85 & Não & & Sim \\
\hline & S. 5 & Subtrapezoidal & Indet. & 1,80 & 0,35 & 1,80 & Sim & 1 & Não \\
\hline & S. 6 & Subtrapezoidal & Indet. & 1,00 & 0,20 & 1,00 & Sim & 1 & Não \\
\hline
\end{tabular}

Fonte: CABRITA, 2014 


\section{CONCLUSÃO E PROPOSTA CRONOLÓGICA}

A quase ausência de vestígio de espólio material que logrem eventualmente ter pertencido a sepultura do universo funerário no estrato rochoso de arenito vermelho de Silves não contribui para o esclarecimento cronológico das necrópoles rupestres da região.

A orientação ritual daqueles sepulcros parece plausível, embora a maioria dos afloramentos rochosos, que guardam necrópoles, se encontre exposto nas vertentes voltadas a sul. Os espaços funerários manifestam dimensões que possibilitam as fossas sepulcrais obter outras orientações rituais. Supomos, assim, que o rumo traçado para as câmaras sepulcrais foi intencional e não terá sido limitado pela dimensão da fraga rochosa. As tumulizações praticadas no arenito beneficiam a orientação noroeste-sudeste com $47 \%$ dos seus testemunhos, as inumações na rocha calcária favorecem a orientação norte-sul com $32 \%$ das deposições. As restantes fossas tumulares exibidas no grés de Silves mostram orientações norte-sul e nordeste-sudoeste, 18\% e 17\% respetivamente, enquanto as sepulturas no calcário denunciam orientações sudoeste-nordeste com 19\% dos exemplos e 7\% dos testemunhos oeste-este.

No entanto, o período temporal proposto para este conjunto é balizado entre o século VII e os inícios do século X, de acordo com as caraterísticas atribuídas a outras necrópoles análogas ${ }^{25}$.

A escavação da sepultura 12 da necrópole da Amorosa revelou rara existência de espólio antropológico, pertencente a indivíduo ali depositado em decubitus dorsal, com os membros superiores ao longo do corpo e as mãos sobre o ventre, tendo a cabeça virada para sul, denunciando, claramente, inumação em posição canónica.

Sujeitámos porção de osso a análise de radiocarbono (C14), processada no Beta Analytic Radiocarbon Dating Laboratory, em Miami (Florida). O resultado foi de $1290 \pm 40 \mathrm{BP}$, que calibrado a $2 \sigma$, ou seja, com $95 \%$ de probabilidade, indicou intervalo de 660-780 cal AD.

A baliza temporal oferecida pela amostra encaixa perfeitamente no grande momento histórico em estudo, supondo-se que aquela foi uma das últimas inumações ali ocorridas dos tempos visigóticos, ou já moçárabes, em período de administração islâmica do atual território algarvio, problemática que cabe futuramente desenvolver.

O padrão de distribuição do universo das 58 sepulturas escavadas nas rochas de arenito revela, como aludimos anteriormente, a maioria dos sepulcros reunida em necrópole, $62 \%$. Os grupos dispersos pelo território que terão fundado panteões familiares em conjuntos de 2 a 5 sepulturas 15\% dos testemunhos. Mais deprimido, é o número de sepulturas isoladas que atinge $8 \%$ das manifestações funerárias. As sepulturas abertas no substrato rochoso calcário, estão todas agrupadas em necrópole, denunciando um diferente modelo de ocupação do território.

${ }^{25}$ DOMÉNECH ESTEBAN, 1994: 63-81. 
A arquitetura das necrópoles e sobretudo o ritual funerário que manifestam, integrando aspetos canónicos cristãos, tal como algum espólio e a primeira datação absoluta, permite-nos formular a hipótese de que os cemitérios em apreço terão tido dois grandes momentos distintos de construção. Um primeiro dever-se-ia à chegada das comunidades visigóticas, nos inícios do século VI e até à expulsão dos ocupantes bizantinos em 624 . O segundo relacionar-se-ia com a proliferação das comunidades humanas, ocorrido a partir de meados do século VII e até à implantação muçulmana no Garb al-Andalus na região, a partir de 713, podendo previver em tempos ulteriores. A ocupação do território é efetuado nas encostas expostas a sul ou em locais de média altura com boa visibilidade para os territórios que pretendem controlar, designadamente agrícolas e de pastoreio.

Tal ocupação seria efetuada em grupo, construindo-se pequenos aglomerados populacionais, assim conseguindo proteção coletiva e, eventualmente, distribuição das tarefas. Tal forma de implantação insere-se no tipo de assentamento humano que as populações visigóticas vinham usando ao longo da sua difusão no espaço ibérico. Ulteriormente, aquelas comunidades do interior poderão ter-se dispersado pela região, construindo pequenos habitats familiares provocando a proliferação das necrópoles que a Arqueologia constata e estuda. $\mathrm{O}$ anterior modelo de assentamento e a edificação dos panteões familiares, em grupo ou isolados, poderão ter como intento derradeiro a reclamação do direito de explorar os recursos naturais daqueles territórios ${ }^{26}$.

A região algarvia detém atualmente parcos testemunhos da presença visigótica. A ermida de Nossa Senhora da Rocha, concelho de Lagoa, ostenta na sua arcaria de entrada duas colunas, sendo uma destas encimada por capitel atribuído ao Período Visigótico ${ }^{27}$. O Museu Municipal de Arqueologia de Silves, guarda capitel, ábaco e importante coleção de fragmentos de vasilhas de cerâmica daquele período. Ainda no concelho de Silves, na atual vila de Alcantarilha, foram reconhecidos por Fernando de Almeida, em meados do século XX, dois capitéis que Sebastião Ramalho Ortigão guardava em sua casa. Este possuía ainda garrafa com uma asa, talvez proveniente de cemitério das imediações de Alcantarilha ${ }^{28}$.

Outros locais do Algarve têm proporcionado, de igual modo, materiais cerâmicos, metálicos e funerários atribuídos do Período Visigótico. Deste último conjunto importa referir importante necrópole, Bensafrim, cemitério intervencionado em meados do século XX por Santos Rocha, Raposeira (Vila do Bispo) onde, no sítio do Padrão, várias sepulturas foram alvo de escavação arqueológica por Mário Varela Gomes ${ }^{29}$.

$\mathrm{Na}$ área de S. Bartolomeu de Messines, perto de Vale Fuzeiros, vale dos Abrutiais, sítios da Bica Alta e das Passadeiras, integrámos a equipa de Mário Varela Gomes, que intervencionou três sepulturas tardorromanas, anteriormente violadas e de onde

\footnotetext{
26 TENTE, 2015: 286-287.

${ }^{27}$ M. GOMES, 2002: 109.

${ }^{28}$ M. GOMES, 2002: 386-388.

${ }^{29}$ M. GOMES, 2002: 386-388.
} 
foi exumado jarro bitroncocónico, passador litúrgico de bronze, resto de fíbula, fragmentos cerâmicos de paredes de vasilha e contas de pasta vítrea ${ }^{30}$.

As necrópoles e sepulturas anteriormente citadas não entram no universo que temos vindo a descrever, aquelas são sepulturas abertas em solo vegetal, estruturadas por lajes, revelando outra dimensão do contexto do povoamento visigótico rural do Barlavento algarvio, que abordaremos futuramente.
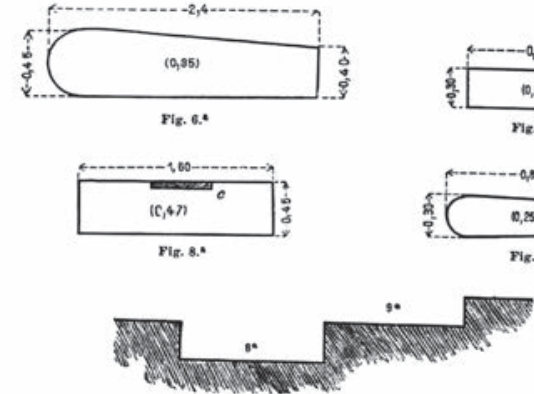

Fig. 10.*
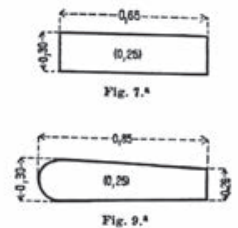

Fig. 5. Planta das sepulturas da necrópole do Barranco da Alcaria, Aljezur Des. Bernardo de Sá; Fonte: SÁ, 1904
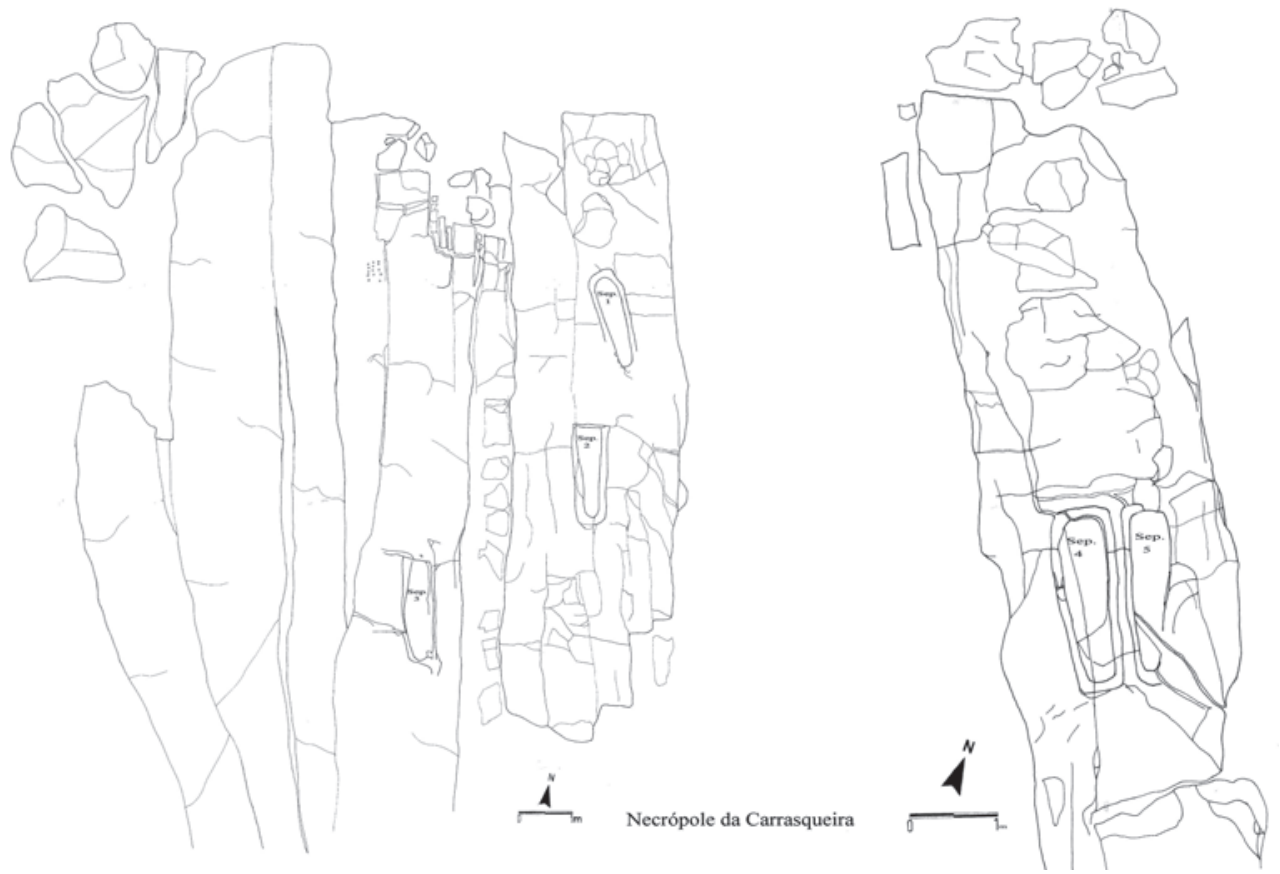

Fig. 6. Planta da Necrópole da Carrasqueira, S. B. Messines Fonte: CABRITA, 2007

${ }^{30}$ M. GOMES, 2002: 385. 


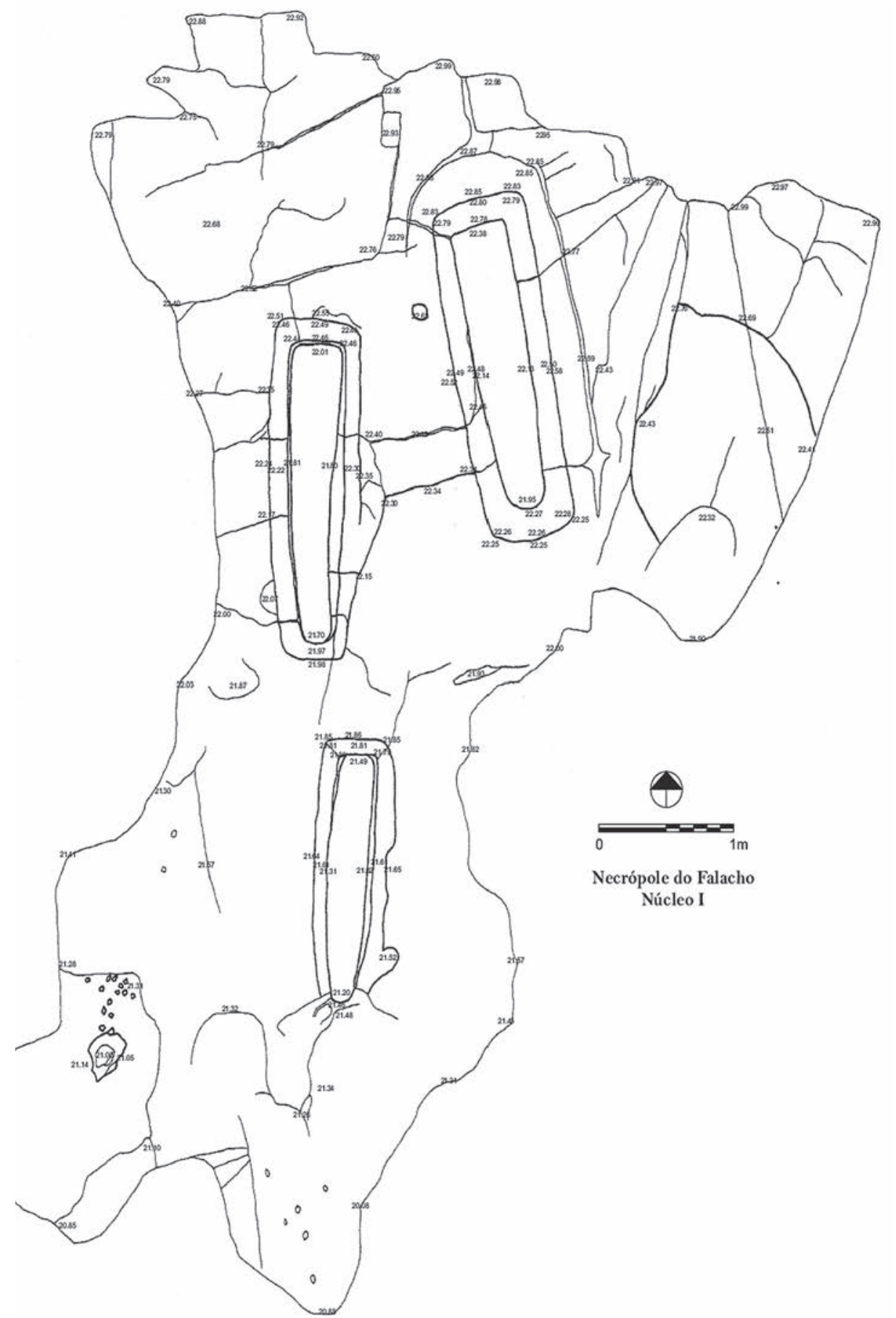

Fig. 7. Planta da necrópole do Falacho, Silves

Fonte: CABRITA, 2011a 


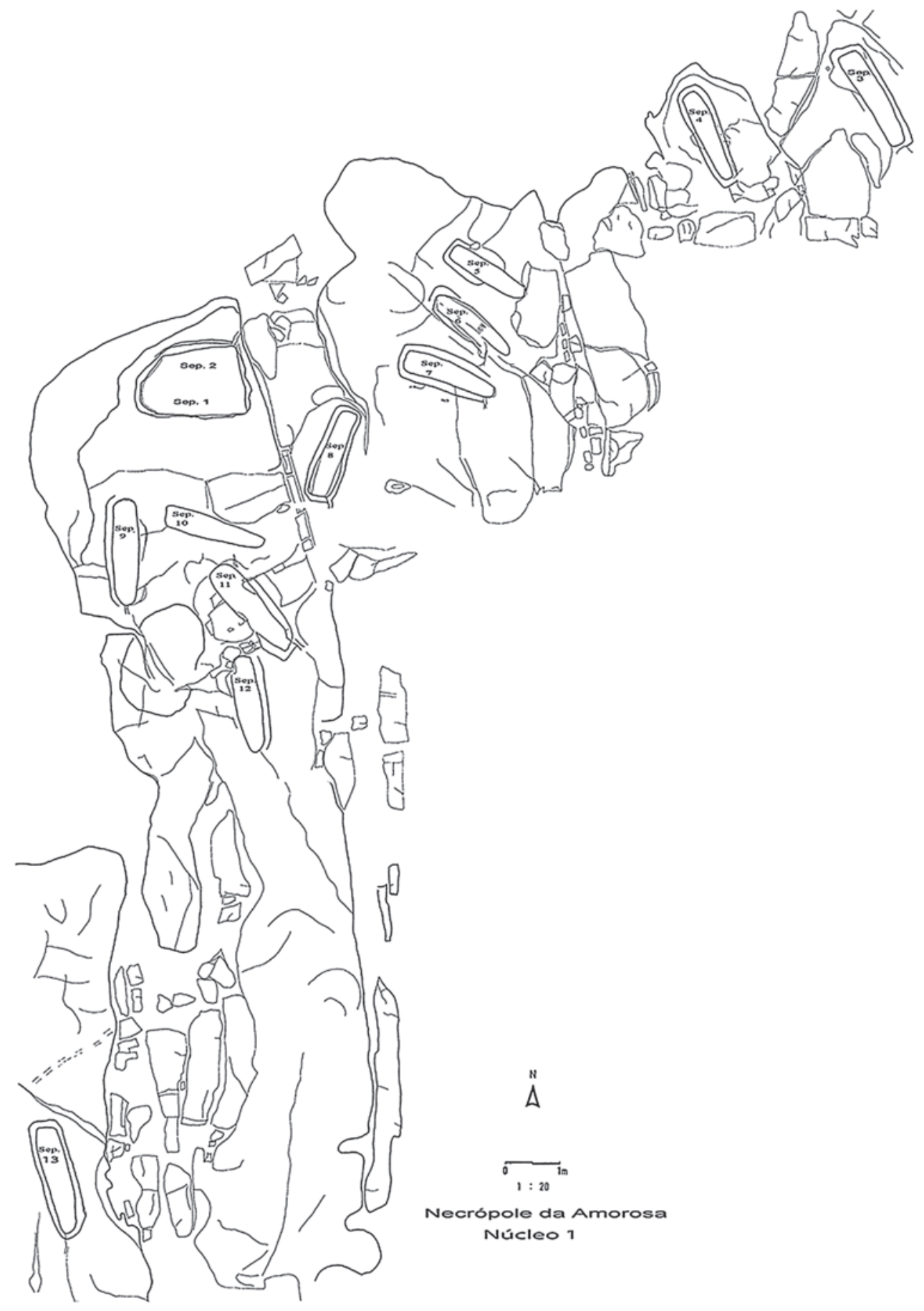

Fig. 8. Planta da necrópole da Amorosa - núcleo 1

Fonte: CABRITA, 2007 


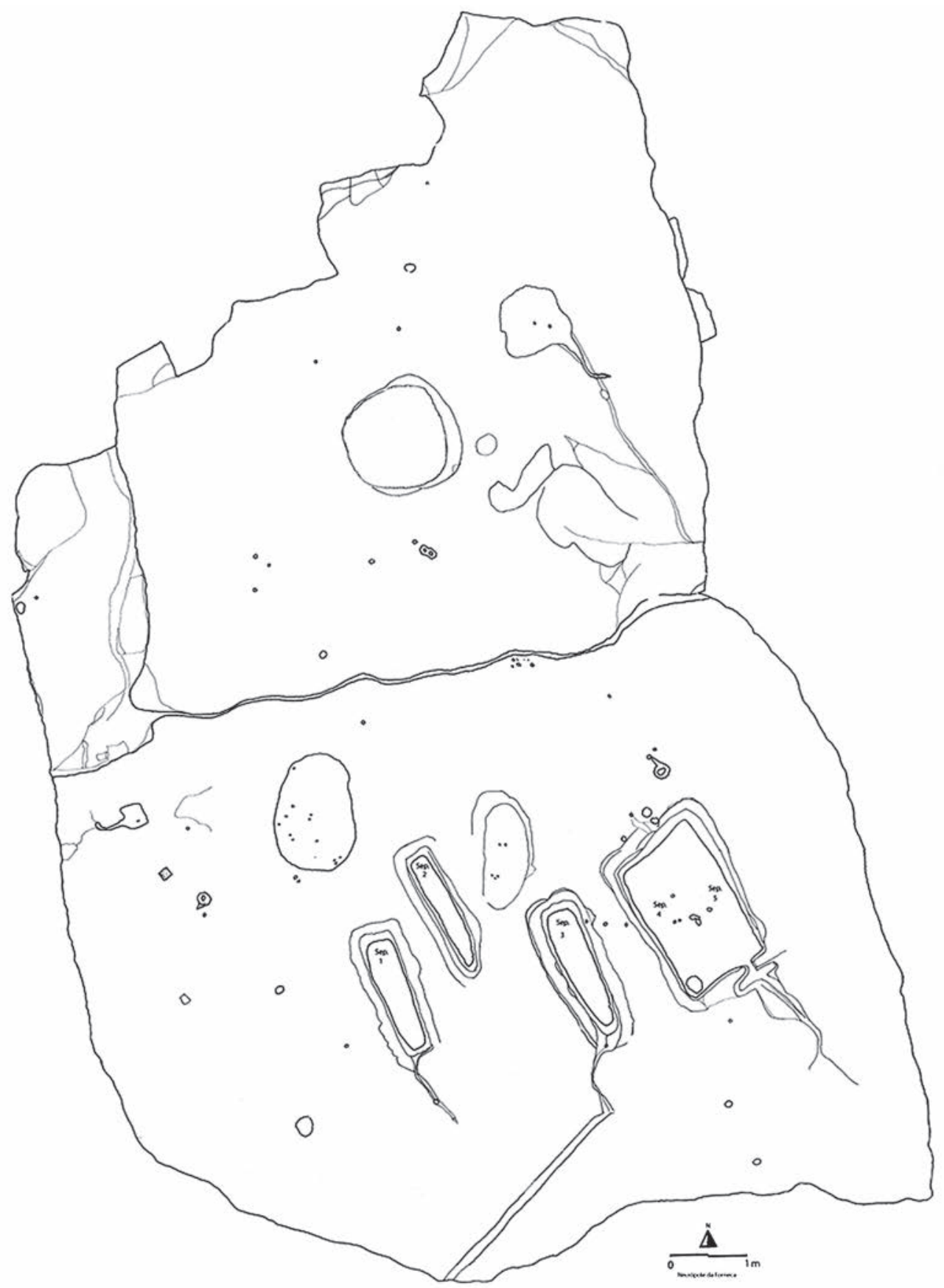

Fig. 9. Planta da necrópole da Forneca, S. B. Messines Fonte: CABRITA, 2007 


\section{BIBLIOGRAFIA}

ALARCÃO, Jorge de (1990).O domínio romano. In SERRÃO, Joel; MARQUES, A. H. de Oliveira , dir. Nova História de Portugal. Lisboa: Editorial Presença, vol. 1, pp. 345-381. Vol. 1: Portugal das Origens à Romanização.

ALMEIDA, Fernando de (1962). Arte visigótica em Portugal. «O Arqueólogo Português». Nova série. 4.

CABRITA, Luís Miguel (2007). Povoamento Alto Medieval de S. Bartolomeu de Messines. Dissertação de Mestrado.

CABRITA, Luís Miguel (2011a). Contributo para o estudo do povoamento rural Alto-Medieval de Silves. In GOMES, Rosa Varela; GOMES, Mário Varela; TENTE, Catarina, coord. Cristãos e Muçulmanos na Idade Média Peninsular, Encontros e Desencontros. Lisboa: Instituto de Arqueologia e Paleociências, pp. 239-254.

CABRITA, Luís Miguel (2011b). O Povoamento Alto Medieval do Algarve Ocidental. Trabalho final do Curso de Doutoramento em História e Arqueologia Medievais da Universidade Nova de Lisboa. Lisboa.

CABRITA, Luís Miguel (2014). Povoamento Alto Medieval de S. Bartolomeu de Messines. Silves: [Edição do autor].

DOMÉNECH ESTEBAN, M. (1984). Escavaciones arqueológicas en la necrópolis rupestre de Tiermes. Campañas de 1981 y 1982. In Tiermes III, Escavaciones realizadas en la Ciudad Romana y en las necrópolis medievales. Madrid: Casa de Velázquez.

FERREIRA, Octávio da Veiga; CASTRO, Luís de Albuquerque e (1948). A Estação Pré-Histórica de Vale de Carro (Albufeira). Separata de «Estudos». 4.

GOMES, Maria Elisa H. H. (1958). Monumentos arqueológicos inéditos do concelho de Silves. In Actas e Memórias do I Congresso Nacional de Arqueologia. Lisboa: Instituto de Alta Cultura, vol. II, pp. 75-94.

GOMES, Mário Varela (1994). A Necrópole da Alfarrobeira (S. Bartolomeu de Messines) e a Idade do Bronze no Concelho de Silves. «XELB». 2.

GOMES, Mário Varela (2002). A necrópole Visigótica do Poço dos Mouros (Silves). «Revista Portuguesa de Arqueologia». 5: 2, 339-391.

GOMES, Rosa Varela (2002). Xelb uma cidade do Garb al-Andalus: arqueologia e história. Lisboa: Instituto Português de Arqueologia.

MARTÍN VISO, Iñaki (2012). Enterramientos, memoria social y paisage en Alta edad Media: propuestas para un análises de las tumbas excavadas en roca en el centro-oeste de la Península Ibérica. «Zephyrus». 69, 165-187.

MATTOSO, José, dir. (1993). História de Portugal. Lisboa: Editorial Estampa. Vol. 1: Antes de Portugal.

ROMAN PUNZÓN, Júlio M. (2004). El Mundo Funerário Rural en la Província de Granada durante la Antiguedad Tardia. Granada: Universidade de Granada.

RIBEIRO, Orlando; LAUTENSACH, Hermann (1987). Geografia de Portugal. Organização, comentários e actualização de Suzanne Daveau. Lisboa: Edições João Sá da Costa, vol. 1.

SÁ, Bernardo de, (1904). Explorações archeológicas no Algarve em Março de 1904. «O Arqueólogo Portugues». IX, 173-179.

SANTOS, Maria Luísa Estácio da Veiga Affonso dos (1971). Arqueologia romana do Algarve. Lisboa: Associação dos Arqueólogos Portugueses, vol. I.

SANTOS, Maria Luísa Estácio da Veiga Affonso dos (1972). Arqueologia Romana do Algarve. Lisboa: Associação dos Arqueólogos Portugueses, vol. II.

SERRÃO, Joel; MARQUES, A. H. de Oliveira, dir. (1993). Nova História de Portugal. Lisboa: Editorial Presença. Vol. 2: Portugal das Invasões Germânicas à "Reconquista".

TENTE, Catarina; LOURENÇO, Sandra (1998). Sepulturas Medievais escavadas na rocha dos concelhos de Carregal do Sal e Gouveia: Estudo Comparativo. «Revista Portuguesa de Arqueologia». 1: 2, 191-218. 
TENTE, Catarina (2015). Tumbas rupestres en el Alto Mondego (Guarda, Portugal). Patrones de distribuicion, significados e construccion del paisaje rural altomedieval. «Munibe AntropologiaArkeologia». 66, 271-290.

VEIGA, Sebastião Philippes Martins Estácio da (1887). Antiguidades Monumentais do Algarve, Tempos Préhistóricos. Lisboa: Imprensa Nacional, vol. II, pp. 350-368.

VIANA, Abel; FORMOSINHO, José; FERREIRA, Octávio da Veiga (1949). O conjunto visigótico de Alcaria (Caldas de Monchique). Lisboa: [s.n.].

VIANA, Abel; FORMOSINHO, José; FERREIRA, Octávio da Veiga (1950). Necropolis de las Caldas de Monchique. Madrid: [s.n]. 



\title{
SE HACE CAMINO AL ANDAR. SEPULTURAS RUPESTRES Y POBLAMIENTO ALTOMEDIEVAL EN EL VALE DE GALEGOS (CASTELO DE VIDE, PORTUGAL)
}

\author{
FABIÁN CUESTA-GÓMEZ* \\ SARA PRATA**
}

\begin{abstract}
Resumen: El Vale de Galegos (Castelo de Vide) conserva un paisaje de penillanura con numerosos afloramientos graníticos donde se documentan sepulturas excavadas en la roca, normalmente individualizadas, en ocasiones formando conjuntos de dos o tres ejemplares. Estos sepulcros son la evidencia más representativa del periodo altomedieval en el territorio, aunque también son frecuentes los vestigios en superficie que revelan la presencia de espacios productivos y habitacionales, como pesos de lagar, alineamientos pétreos y dispersión de material cerámico. La existencia de una vía con un claro protagonismo en la articulación del poblamiento de la zona hace de este un territorio idóneo para el estudio de las comunidades campesinas de la Alta Edad Media. Proponemos aquí una reconstrucción de la ocupación rural altomedieval en el Vale de Galegos a partir de los resultados obtenidos en las campañas de prospección y excavación durante el proyecto PramCV. Defendemos la idea de que en este territorio se observa un modelo de poblamiento disperso, pero no aislado, en el que los sepulcros rupestres muestran un claro vínculo con los espacios de los vivos.
\end{abstract}

Palabras clave: Arqueología altomedieval; Castelo de Vide; Comunidades campesinas; Paisajes rurales.

Abstract: The area of Vale de Galegos (Castelo de Vide) presents a peneplain landscape with a number of granite outcrops, some of which preserve rock-cut graves, usually isolated, or in groups of 2 to 3 . These graves are the most illustrative remain of the early medieval period, however, evidence of productive and domestic structures, in the form of press weights, remains of stone walls and concentrations of ceramic sherds, are also frequent. The existence of a previous trackway with clear significance for settlement layout makes this an excellent area for analysing early medieval peasant communities. In this text we offer a reconstruction of the early medieval peasant occupation in Vale de Galegos, drawing from the results obtained in excavations and surface field-surveys carried out during the PramCV project. We will defend the notion that in this territory there is evidence of row settlements and that rock-cut graves are built in close relation to the areas of the living.

Keywords: Early Medieval Archaeology; Castelo de Vide; Peasant communities; Rural landscapes.

\section{INTRODUCCIÓN}

En el conocido poema XXIX de sus «Proverbios y Cantares» (Campos de Castilla, 1912), Antonio Machado reflexionaba acerca de la necesidad de abrir nuevos caminos ante la incertidumbre de los paisajes que el ser humano afronta en la vida.

\footnotetext{
* USAL; IEM/FCSH-UNL. Email: jfabian.cuestag@gmail.com.

** IEM/FCSH-UNL. Email: sara.m.prata@gmail.com.
} 
Jugando con esos versos, y utilizando la arqueología como herramienta, queremos con este texto recorrer el Vale de Galegos, una parte del concelho de Castelo de Vide (Portalegre, Portugal) donde hemos llevado a cabo excavaciones en área, sondeos y prospecciones orientadas dentro del proyecto de investigación: Povoamento rural alto-medieval no território de Castelo de Vide (PramCV) ${ }^{1}$. Este proyecto, desarrollado entre 2014 y 2018, fue planteado con el objetivo de reconstruir la ocupación rural de este territorio en los siglos posteriores a la desarticulación del Imperio romano, partiendo desde una base arqueológica en la que se combinaran las excavaciones y los sondeos, los estudios de material, el análisis mediante SIG, la revisión de trabajos previos y la formación de estudiantes en Arqueología ${ }^{2}$.

A lo largo de las próximas páginas vamos a utilizar el camino que recorre el Vale de Galegos como articulador del discurso, de la misma manera que él articuló el poblamiento altomedieval en la zona. Una de las cuestiones que llama la atención al recorrer esta vía es la presencia sistemática de sepulturas excavadas en la roca en su entorno. Pero no solo; también son abundantes las evidencias constructivas situadas en las inmediaciones de dichas sepulturas. ¿Qué relación tienen entre sí? ¿Encontraremos respuestas al espacio de los muertos en el territorio de los vivos? Caminemos para hacer camino.

\section{EL ESPACIO FÍSICO DEL VALE DE GALEGOS}

El Vale de Galegos aparece como topónimo en la zona occidental del municipio de Castelo de Vide, abarcando un espacio cuyo límite oeste es nítido: la rivera de Figueiró, que es también el límite administrativo municipal. La demarcación oriental es algo más difusa al superponerse a un topónimo de nivel inferior, Taberna Seca, por lo que decidimos establecer un límite geográfico en la rivera de Cogulo (Mapa 1 y 2). La distancia lineal entre ambos términos (este-oeste) es ligeramente inferior a 4,1 km, con cerca de 2,7 km en el eje norte-sur, con una superficie total definida como Vale de Galegos que abarcaría, aproximadamente, $9,3 \mathrm{~km}^{2}$.

El paisaje a lo largo de este valle es semejante al de buena parte del territorio castelovidense, especialmente en sus áreas central y sudoccidental: penillanura con suaves ondulaciones, frecuentes afloramientos graníticos (tanto pequeños berrocales como lanchas y bloques aislados), cortos cursos de agua (la mayoría de carácter estacional), relativa abundancia de charcas y una sucesión de parcelas (tapadas) destinadas fundamentalmente a la ganadería bovina, con diferentes especies arbóreas entre las que predominan los robles melojos, además de alcornoques, encinas y olivos, así como matorral variado donde señorean retamas, brezos y zarzas (Fig. 1).

\footnotetext{
${ }^{1}$ PRATA, CUESTA-GÓMEZ, 2017.

${ }^{2}$ Agradecemos desde aquí el trabajo realizado por alumnos y voluntarios a lo largo del proyecto PramCV.
} 


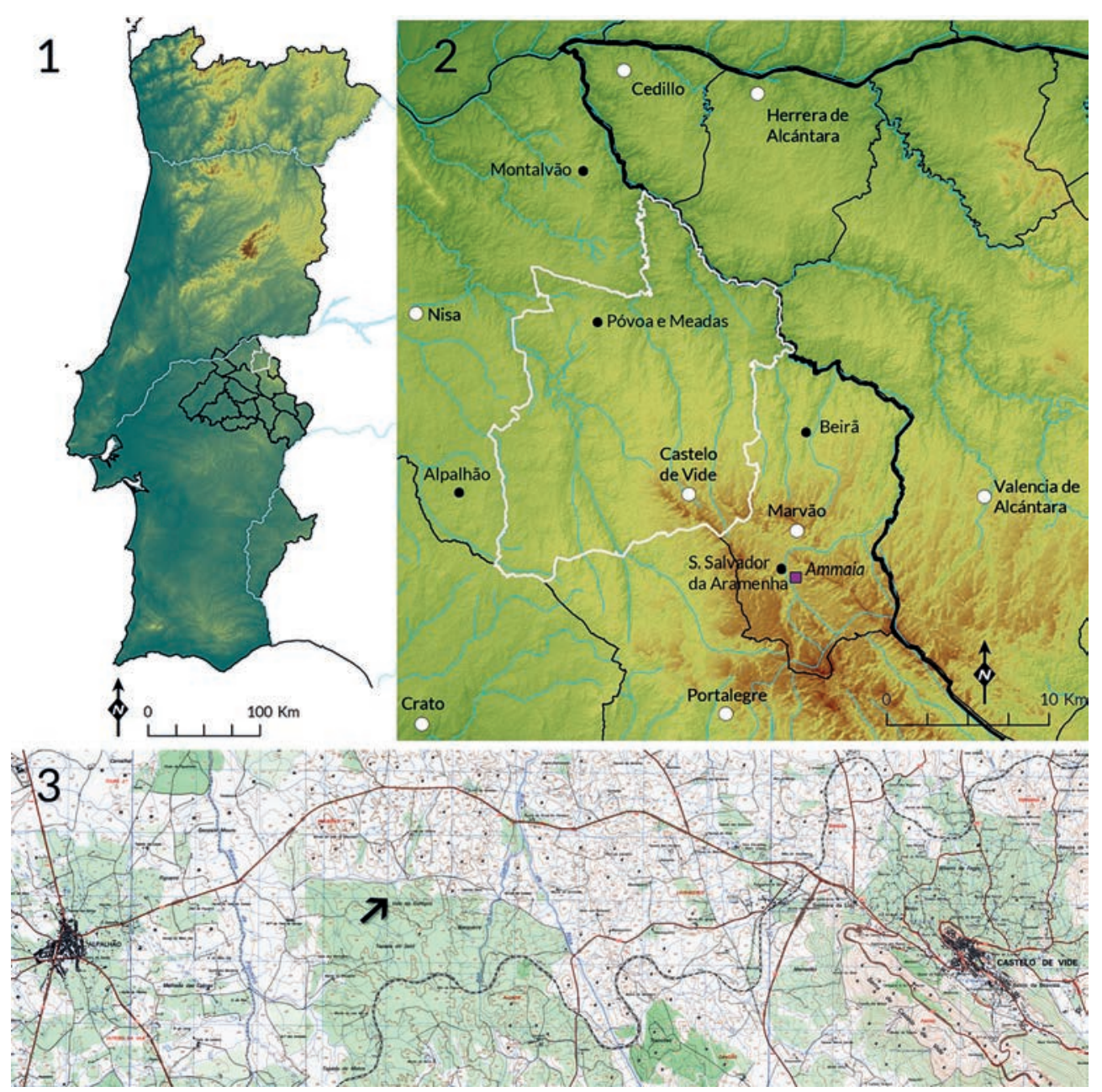

Mapa 1. 1) Localización del municipio de Castelo de Vide (en blanco) respecto a Portugal y el distrito de Portalegre; 2) Municipio de Castelo de Vide y referencia a algunos de los lugares vecinos; 3) Vale de Galegos (indicado con una flecha), referencia en la Carta Militar de Portugal, hojas 334 (Alpalhão) y 335 (Castelo de Vide). Fonte: Fabián Cuesta-Gómez

\section{TRAZANDO EL CAMINO: BREVE HISTORIOGRAFÍA DE LA ARQUEOLOGÍA ALTOMEDIEVAL EN EL TERRITORIO DE CASTELO DE VIDE}

La elección del municipio de Castelo de Vide como espacio geográfico de análisis fue debida a una serie de razones interrelacionadas: además de la trayectoria investigadora de uno de los autores, que ya había incluido el territorio de Castelo 
de Vide en su Tese de Mestrado ${ }^{3}$, y del interés y apoyo de la Câmara Municipal a los estudios arqueológicos y patrimoniales, cabe destacar la profusión, variedad y, en general, buena conservación de los yacimientos altomedievales del territorio. Aunque no existía un estudio sistemático previo ${ }^{4}$, sí eran numerosas las evidencias inventariadas - principalmente de carácter funerario y los materiales asociados - que podrían encuadrarse en este periodo, circunstancias que motivaron la construcción de un proyecto de investigación de largo recorrido desde la arqueología.

Los trabajos desarrollados por diferentes investigadores durante el último medio siglo permitieron generar un conjunto de datos que han servido como base para los análisis posteriores. Cabe señalar como hito inicial la Carta Arqueológica do concelho de Castelo de Vide, elaborada por M. ${ }^{a}$ C. Rodrigues como Trabajo Final de Licenciatura (curso de 1971/1972) y publicada en 1975; además de un opúsculo de 1978: Sepulturas medievais no concelho de Castelo de Vide, suplemento de la Carta Arqueológica, que añadía nuevas sepulturas de lajas y proponía la clasificación matricial de 11 de los recipientes cerámicos recuperados en estas sepulturas.

La Carta Arqueológica constituyó la primera recopilación de las evidencias arqueológicas del territorio con una baliza cronológica amplia, desde la Prehistoria hasta la Edad Media, además de incluir elementos etnográficos como los característicos chafurdões (chozos de piedra seca). No fue, en la práctica, un trabajo exhaustivo, quedando buena parte del concelho sin recorrer. Se documentaron esencialmente aquellos espacios en los que la autora tenía conocimiento - casi siempre por terceros - de la existencia de dólmenes, sepulturas, materiales en superficie, pesos de lagar, etc. En ocasiones se realizaron pequeñas excavaciones con el objeto de salvaguarda (caso de algunas sepulturas), definición cronológica o la sencilla curiosidad. La limitada precisión de la implantación de los yacimientos inventariados (iconos en un mapa general del municipio escala 1:50.000), se compensa por su descripción narrativa, el abundante apartado gráfico (tanto dibujos como fotografías) y la toma de las dimensiones, por ejemplo, de todas las sepulturas excavadas en la roca, lo que permitió su identificación posterior.

Centrándonos en las evidencias altomedievales, Rodrigues distinguió, por una parte, vestígios de habitação $0^{5}$ y necrópoles visigóticas ${ }^{6} \mathrm{y}$, por otra, las sepulturas excavadas en la roca que, para ella, eran de época medieval (sensu lato), pero indudablemente posteriores al dominio visigodo por no ajustarse a los patrones de enterramiento romanos ni visigodos ${ }^{7}$. Las «sepulturas visigóticas» serían, por tanto, apenas las sepulturas de lajas, documentadas en el territorio de forma individual o formando

\footnotetext{
${ }^{3}$ PRATA, 2012, 2014.

${ }^{4}$ PRATA, 2018a: 31 y ss.

${ }^{5}$ Dentro de los vestígios de habitação solo recoge el yacimiento de Mascarro (RODRIGUES, 1975: 187-189), debido al hallazgo previo de dos tremises, uno de ellos identificado como una emisión toledana de Égica.

${ }^{6}$ RODRIGUES, 1975: 187-179 y 176-186.

${ }^{7}$ RODRIGUES, 1975: 196.
} 

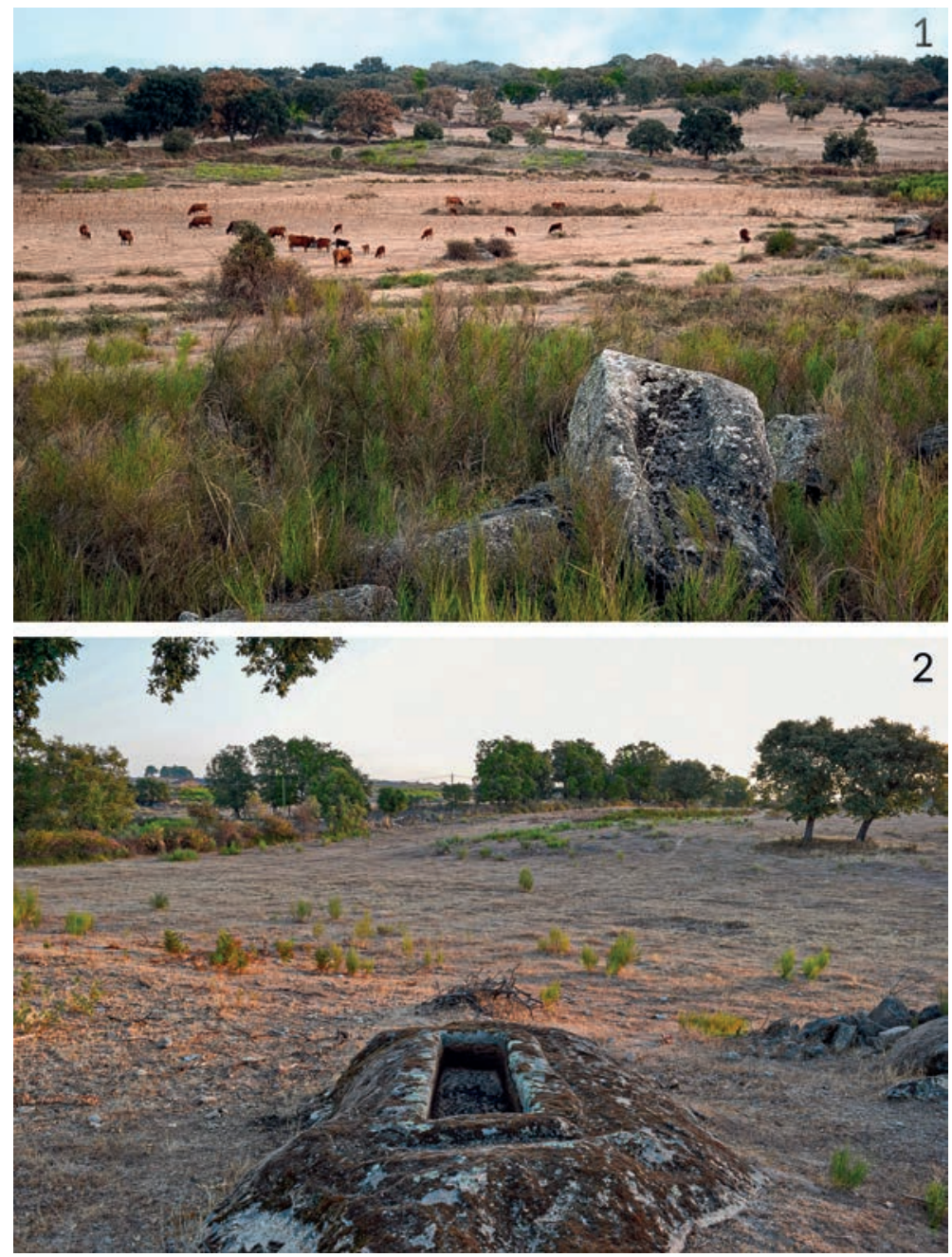

Fig. 1.

1) Fotografía desde el Vale da Manceba, en primer término una de las sepulturas inacabadas localizadas en el área de estudio; 2) Sepultura situada junto al sector I de la Tapada das Guaritas; al fondo, la línea de árboles marca el camino que atraviesa el Vale de Galegos.

Fonte: Fabián Cuesta-Gómez

necrópolis como Boa Morte I y Sto. Amarinho, además de referencias indirectas a los conjuntos de Cerejeiro, Chão Salgado y Barbuda. Rodrigues descarta explícitamente que las sepulturas excavadas en la roca ${ }^{8}$, «um dos mais enigmáticos problemas da arqueología nacional» y de las que recogió un total de 52 ejemplares en su trabajo, pudieran encuadrarse cronológicamente en la etapa visigoda, circunstancia que ya había sido ponderada por Leite de Vasconcelos, por ejemplo, para el caso de los sepulcros del couto da Fajã (Montalvão, Nisa) ${ }^{9}$.

\footnotetext{
${ }^{8}$ RODRIGUES, 1975: 196.

${ }^{9}$ LEITE DE VASCONCELOS, 1933: 185. Y, anteriormente, en la correspondencia entre Martins Sarmiento y Leite de Vasconcelos en los años 80 del s. XIX, en las que el primero señala la existencia «às centenas» de este tipo de
} 
Lo verdaderamente significativo de la identificación del poblamiento altomedieval por parte de Rodrigues en la Carta Arqueológica — precisiones cronológicas al margen -, fue destacar la habitual conjunción de materiales de construcción («fragmentos de ímbrices, com espessura média de $2 \mathrm{~cm}$ [...] [e] decoradas com sulcos digitais»), fragmentos de grandes recipientes (tipo dolia) y de estructuras («alicerces de construcções circulares com enormes blocos graníticos e pesos de lagar de médias proporções») en las inmediaciones de las sepulturas excavadas en la roca ${ }^{10}$.

En el año 1984 verán la luz dos trabajos sobre las excavaciones dirigidas por J. O. Caeiro en la zona norte del embalse de Póvoa e Meadas, situado en el centrooeste del municipio ${ }^{11}$. Se trata de dos conjuntos de sepulturas de lajas: Boa Morte I (ya intervenido previamente por Rodrigues), con 8 ejemplares, y Boa Morte II, con 2 , además de los zócalos de dos estructuras, que no fueron excavadas, construidas con bloques irregulares de granito y alzados de doble paramento. Caeiro equipara su cronología - ss. VI-VII - a la de las sepulturas de lajas de los conjuntos mencionados tras comparar las vasijas que formaban parte del ajuar funerario y los fragmentos de cerámica recuperados en superficie asociados a las estructuras habitacionales. Si Rodrigues ya había destacado la habitual proximidad entre este tipo de estructuras y las sepulturas excavadas en la roca, Caeiro establecía también esos vínculos, apenas una década más tarde, con las sepulturas de lajas ${ }^{12}$.

El siguiente paso en la investigación vendrá de la mano de los técnicos de la Secção de Arqueologia de la Câmara Municipal ${ }^{13}$, fundamentalmente durante los años 80 y 90 . Nos referimos tanto a las excavaciones realizadas bajo la dirección de arqueólogos, como a los trabajos de inventario, prospección y registro elaborados por iniciativa propia y que tenían, originalmente, la intención de actualizar la Carta Arqueológica. El creciente inventario recogerá, de manera heterogénea, la información

\footnotetext{
sepulturas en las regiones de Minho y Beira, atribuyéndolas al periodo post-romano, probablemente ya vinculadas a la cristianización del ritual de enterramiento.

${ }^{10}$ RODRIGUES, 1975: 194-195. Es importante señalar que esta circunstancia ya había sido expuesta por A. do Paço para el territorio del vecino concelho de Marvão más de 30 años antes, a raíz de algunos trabajos de prospección y de la excavación de una estructura habitacional en el yacimiento de Monte Velho (probablemente una granja similar a las documentadas en las tapadas das Guaritas y das Freiras, vid. infra). En este trabajo, recogido en la bibliografía de la Carta Arqueológica de Rodrigues (1975) pero aparentemente no utilizado, Paço (1949: 42) afirma que el poblamiento de época visigoda en el territorio se caracterizaría por «a existência de casas cobertas de telha, cultivos de cereais e vinha, denunciada esta pela abundancia de pesos de lagar, industria muito rudimentar de ferro, repouso dos mortos em sepulturas abertas nos rochedos que existiam nas imediações dos locais de habitação».

11 Ver PRATA, 2018b.

12 CAEIRO, 1984b: 4.

${ }^{13}$ La base de este grupo de técnicos arranca a principios de los 80 desde el Grupo de Arqueologia de Castelo de Vide, un conjunto de jóvenes que participaron en las diversas excavaciones llevadas a cabo en el concelho y en la villa bajo la dirección de arqueólogos como O. Caeiro, D. Trindade o J. de Oliveira. En 1991 seis de los participantes pasaron a integrar, ya como funcionarios municipales, la Seç̧ão de Arqueologia. A día de hoy [enero, 2019] la Secção está representada por cuatro técnicos.
} 


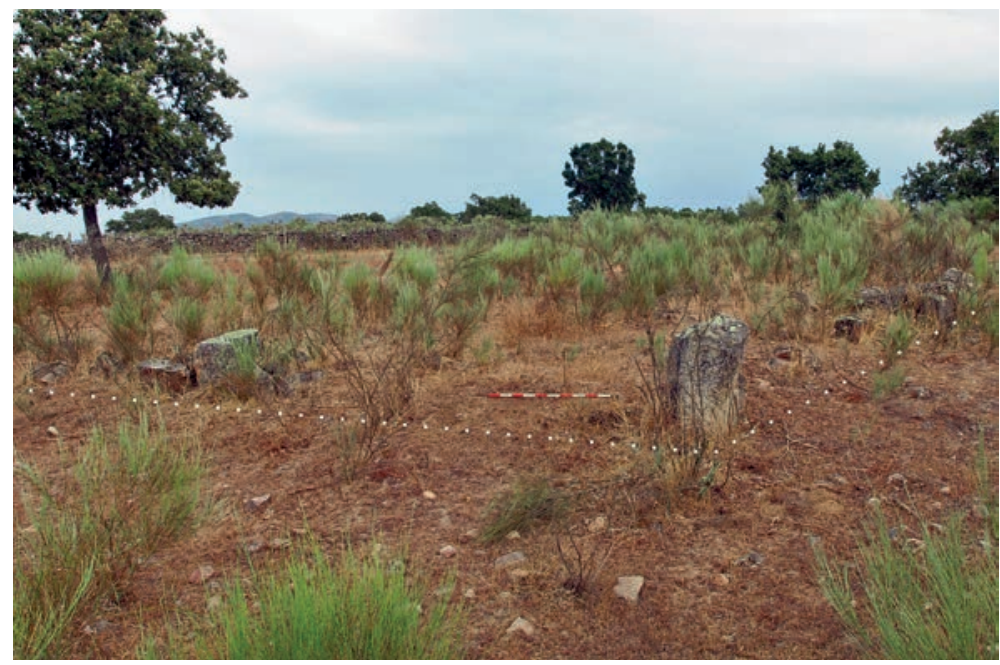

Fig. 2.

La línea de puntos marca el perímetro de una de las estructuras identificadas a lo largo del Proyecto PramCV; en superficie suelen advertirse alineamientos de piedras parcialmente trabajadas que forman un doble paramento, bloques pertenecientes al nivel de derrumbe $y$ algunos fragmentos de teja y otros materiales cerámicos.

Fonte: Fabián Cuesta-Gómez

recuperada en las campañas de prospección extensiva ${ }^{14}$ en diferentes áreas del municipio, especialmente en la freguesía de S. João Baptista y en la envolvente del embalse de Póvoa. En él destacan las entradas relativas a las sepulturas, tanto rupestres como de lajas, y las referencias a la dispersión de materiales (sobre todo cerámica de cobertura), a la presencia de derrumbes y los alineamientos de bloques de granito que se documentaron a medida que se desarrollaban los trabajos. La sistemática asociación entre sepulcros y evidencias constructivas conllevó su natural vinculación cronológica en las fichas del inventario, intuyéndose un amplio poblamiento disperso de probables granjas altomedievales.

Aunque la distribución de estas evidencias ocupa buena parte del territorio prospectado, existen dos zonas llamativamente densas: las márgenes del tramo medio de la rivera de Nisa y los arroyos contiguos (espacio hoy en día parcialmente sumergido por la construcción del embalse de Póvoa en los años 20 del siglo pasado, así como el Vale de Galegos y el área suroeste del concelho. Hay también algunos llamativos vacíos (significativamente en las áreas central y meridional del territorio) que pueden deberse a una conjunción de factores: menor incidencia de los trabajos de campo, peor conservación de las evidencias en superficie por la mayor actividad agrícola, peor visibilidad de las mismas y/o circunstancias históricas que condicionaron el patrón de poblamiento en esas zonas.

Para finalizar esta revisión historiográfica cabe señalar que parte de estos datos referentes a la Tardoantigüedad / Alta Edad Media del territorio castelovidense,

\footnotetext{
${ }^{14}$ Estos trabajos de prospección y registro se realizaron sobre todo en 1990-1991 y 1994-1995, revisando, sobre el papel, aproximadamente la mitad de la superficie del municipio.
} 
fueron integrados en una serie de tesis doctorales defendidas a partir de 2010 cuyas perspectivas de análisis presentaban temáticas, cronologías o territorios mucho más amplios $^{15}$. Por último, el reciente trabajo de Prata recoge el análisis y sistematización de la información sobre poblamiento romano y, sobre todo, altomedieval disponible - específicamente - para Castelo de Vide, conjugando los trabajos previos con los resultados del proyecto PramCV, sirviendo además de base para el establecimiento de nuevas líneas de investigación arqueológica en el territorio del norte alentejano ${ }^{16}$.

\section{ARQUEOLOGÍA ALTOMEDIEVAL EN EL VALE DE GALEGOS}

Para el Vale de Galegos habían sido reseñados cuatro focos de evidencias en la Carta Arqueológica: Vale da Manceba y Vale da Bexiga (vid. infra), encuadrados en el capítulo del Periodo Lusitano-Romano e interpretadas laxamente como "villas rústicas» debido a la abundancia de material cerámico y arquitectónico detectado en superficie ${ }^{17}$; así como las sepulturas excavadas en la roca de Vale de Galegos (3 ejemplares) y Vale da Silvana (1 sepulcro $)^{18}$, a los que habría que añadir dos pesos de lagar marcados en el mapa general de la Carta, situados en el entorno del Vale da Silvana. En su trabajo de 1978, Rodrigues añadirá una sepultura de lajas en la Tapada da Couticeira, situada al norte del camino que atraviesa el Vale de Galegos ${ }^{19}$.

Los trabajos de prospección de la Secção de Arqueologia sobre esta área del municipio ampliaron enormemente el número de evidencias registradas ${ }^{20}$, especialmente con la inclusión de 30 nuevas sepulturas excavadas en la roca y la definición de, al menos, una decena de estructuras y manchas de dispersión de material cerámico y escorias que podrían atribuirse al periodo altomedieval ${ }^{21}$. Destaca también la excavación parcial en 1982 del Sítio arqueológico $n .^{\circ} 6$ del Vale da Bexiga ${ }^{22}$, donde se localizaron cinco sepulturas de lajas asociadas a un edificio probablemente de culto, así como la presencia de dos pequeñas columnas y un parteluz, además de materiales cerámicos (tanto de construcción como de cocina y servicio) y algunos

\footnotetext{
${ }^{15}$ CARNEIRO, 2014 [2011], WOLFRAM, 2011 y AREZES 2017 [2014] abordaron, respectivamente: el poblamiento rural romano (imperial y tardoantiguo) en el Alto Alentejo; la cristianización del mundo rural en el sur de la Lusitania; y la ocupación germánica en Portugal a partir de los ajuares funerarios de las necrópolis de los ss. V a VIII.

${ }^{16}$ PRATA, 2018a.

${ }^{17}$ RODRIGUES, 1975: 146-148 y 155-156.

${ }^{18}$ RODRIGUES, 1975: 208-209. Estas sepulturas se refieren a 3 de las 6 conocidas en la Tapada das Guaritas y a una de las dos inventariadas en el Monte do Vale Silvano.

${ }^{19}$ RODRIGUES, 1978: 19.

${ }^{20}$ PITA, MAGUSTO, 1994; MAGUSTO, FÉLIX, 1995.

${ }^{21}$ Además de una posible necrópolis de sepulturas de lajas en el Vale da Manceba, lugar en el que el hijo del arrendatario de la propiedad hizo referencia a la existencia (y posterior destrucción) de «caixas de pedra» donde se recuperaron «fragmentos de cerâmica do tipo das cantarinas» (PITA, MAGUSTO, 1994: [49]).

${ }^{22}$ Inventario de la Seç̧ão de Arqueologia, ficha n. ${ }^{\circ} 64$.
} 
objetos metálicos vinculados a los enterramientos, que permiten plantear una datación general del espacio en torno al siglo VI d. C. ${ }^{23}$

A lo largo de los trabajos llevados a cabo por el PramCV (2014-2018) en el Vale de Galegos, se identificaron 7 sepulturas excavadas en la roca inéditas, además de 1 sarcófago y 7 nuevas estructuras con características y evidencias materiales análogas a las observadas en las edificaciones excavadas durante el proyecto (vid. infra) (Fig. 2).

A modo de resumen, los sucesivos trabajos de prospección y excavación llevados a cabo en esta área del municipio desde la Carta Arqueológica de 1975, permiten señalar un conjunto de evidencias que revelan la diversidad del poblamiento altomedieval en el Vale de Galegos. Hasta el momento, se han documentado en este área de estudio un total de: 41 sepulturas excavadas en la roca, 1 sepultura de lajas, 1 sarcófago, un mínimo de 15 estructuras y 2 lagares rupestres, además de varios elementos (7 pesos de lagar documentados en superficie y 1 pileta rupestre) que ofrecen una perspectiva compleja sobre las comunidades campesinas asentadas a ambos lados del camino ${ }^{24}$ (Mapa 2). En este punto, resultaba evidente que la información relativa al espacio de los vivos tendría que venir necesariamente de la mano de las excavaciones en las estructuras localizadas.

Fueron varios los factores que incidieron en la selección de este área para el desarrollo de buena parte de los trabajos arqueológicos realizados durante el proyecto: la documentación previa de numerosos yacimientos de posible cronología tardoantigua y/o altomedieval, lo que permitía la selección de los espacios de intervención y su comparación; y la homogeneidad paisajística y la presencia de una probable vía de comunicación, que resultaban sugerentes de cara al análisis del territorio y la distribución del poblamiento. Además, la amable disponibilidad de los propietarios de los terrenos para realizar excavaciones y la buena accesibilidad con vehículos fueron condicionantes favorables para la selección de este espacio desde la vertiente logística.

Las excavaciones arqueológicas llevadas a cabo se centraron en las estructuras de cuatro yacimientos, todas con clara relación directa con sepulturas rupestres: Tapada das Guaritas, sector I y Tapada das Guaritas, sector II; Tapada das Freiras y Curral do Caras. Las dos primeras fueron excavaciones en área, correspondiendo, respectivamente, a una granja con dos espacios de corral/patio asociados ${ }^{25}$; y en el

\footnotetext{
${ }^{23}$ Aunque este yacimiento queda ligeramente al sur del área definida por nosotros para el Vale de Galegos, resulta sumamente interesante por sus características y por los materiales recogidos, pudiendo interpretarse como un espacio que, por sus implicaciones socio-ideológicas, tuvo importancia entre las ocupaciones rurales de la zona en la transición hacia la Alta Edad Media (PRATA, 2018a: 185-197). Ha de añadirse que existen 15 sepulturas excavadas en la roca en el entorno, así como varias zonas con dispersión de material cerámico en superficie, reflejando una intensa ocupación. Lamentablemente, la excavación no pudo ser completada y el yacimiento fue arrasado por trabajos agrícolas en 1986. ${ }^{24}$ Cabe indicar que, para el total del municipio, se conocen 203 sepulturas excavadas en la roca, 56 sepulturas de lajas, 4 sarcófagos, 56 estructuras - muy probablemente altomedievales — y 4 lagares rupestres asociados a evidencias constructivas o funerarias altomedievales (PRATA, 2018a).

${ }^{25}$ PRATA, 2017.
} 


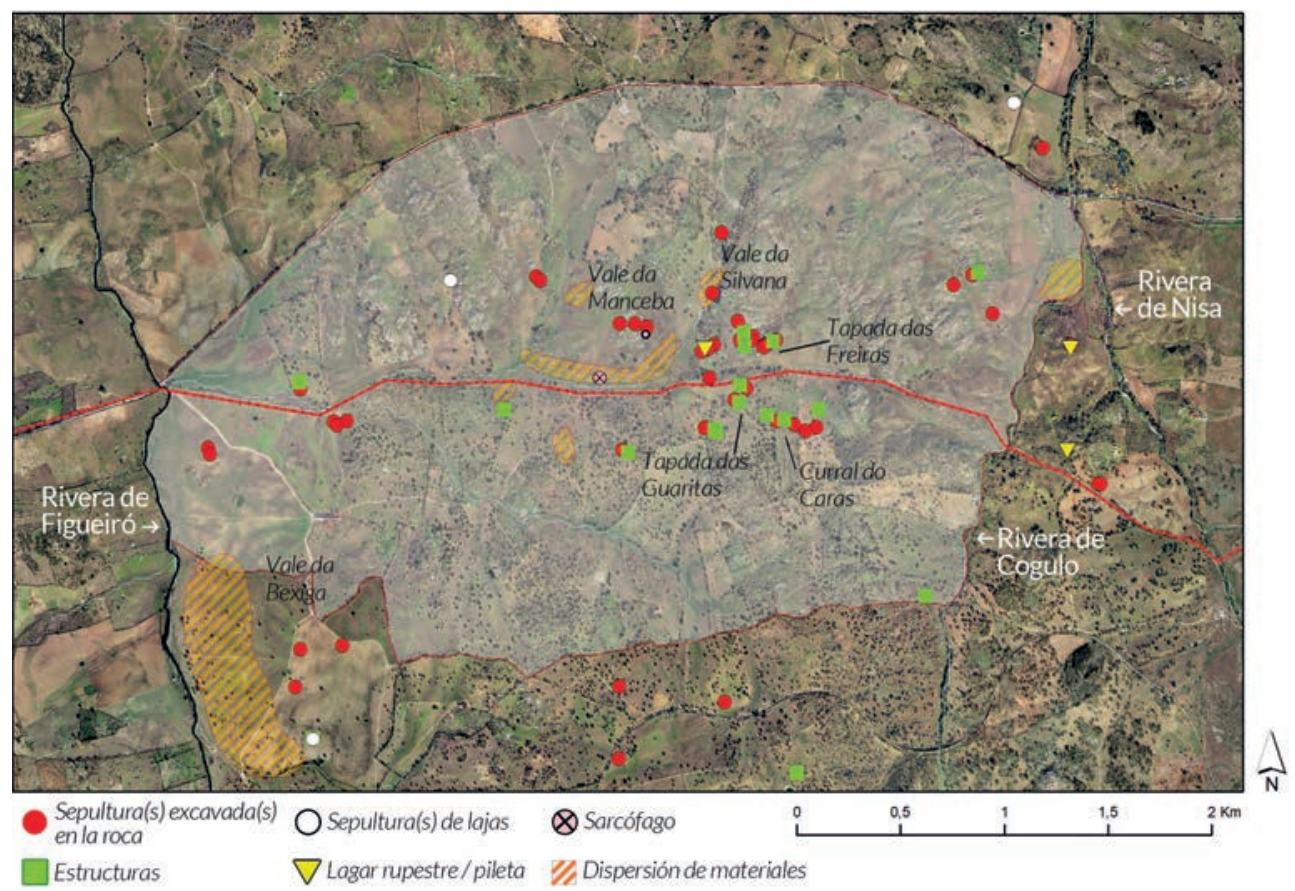

Mapa 2. Distribución de las evidencias arqueológicas altomedievales en el Vale de Galegos (zona sombreada) y en sus inmediaciones, además de marcar el probable camino que se mantuvo en uso desde el periodo romano. Fonte: Fabián Cuesta-Gómez

sector II, a un probable espacio de almacén, además de un sondeo realizado en el edificio que acogería la estructura de prensa de un lagar. Del mencionado almacén proceden sendas dataciones $\mathrm{C} 14$ que indican que, a finales del s. VII o durante la primera mitad del VIII, el edificio ya habría sido abandonado ${ }^{26}$. El sondeo en la Tapada das Freiras reveló una estructura de habitación que, tras el análisis de la cultura material, permite asimilarla a la granja de Tapada das Guaritas I. La intervención en el Curral de Caras ofreció resultados algo más vagos debido a la escasa potencia del yacimiento, pero se advierte al menos una estructura cuadrangular y un muro semicircular, lo que nos lleva a pensar que también se trate de una granja con un corral circundante.

No es objeto de este trabajo desarrollar los resultados de las excavaciones, pero sí nos interesa resaltar una serie de aspectos documentados en ellas que, extrapolados, resultan significativos para la comprensión de los espacios altomedievales en el territorio castelovidense. Las estructuras altomedievales intervenidas consisten en pequeñas granjas de carácter unifamiliar o edificios vinculados a la producción agrícola ${ }^{27}$. Todas

\footnotetext{
${ }^{26}$ Se trata de dos muestras carbonizadas — una escama de piña (Pinus sp.) y una rama de madroño (Arbutus unedo) - recogidas en un nivel de incendio que se produjo en un momento ya posterior al abandono de la estructura.

27 VIGIL-ESCALERA GUIRADO, 2006: 90.
} 
ellas fueron construidas ex novo: su emplazamiento no se superpone a edificaciones previas. Por otra parte, las secuencias estratigráficas documentadas, la ausencia de reformas de los espacios y la inexistencia de niveles de uso sucesivos reflejan una corta ocupación, posiblemente entre una y tres generaciones. Su implantación busca un cierto control visual sobre el espacio circundante: no son construidos en las zonas más elevadas del entorno pero sí se eligen para su instalación las cimas de las pequeñas lomas habituales en el paisaje. Al pie de las estructuras es fácil observar hoy el curso de arroyos estacionales y también zonas de acumulación de agua durante la época más lluviosa, que se trasforman en áreas con mayor pervivencia de pasto durante el resto del año. Todos los espacios intervenidos eran claramente visibles desde el camino que atraviesa el valle $y$, asumiendo su contemporaneidad, eran también intervisibles entre sí; o, al menos, existiría un sentimiento de proximidad. Se observa, incluso en superficie, una significativa homogeneidad en las técnicas constructivas: muros de doble paramento; alzados en aparejo irregular constituido por bloques de granito poco regularizados y de tamaño variable $(c a .20-75 \mathrm{~cm})$; en algunos casos se observa también el reaprovechamiento de sillares bien escuadrados utilizados para dar consistencia a los vanos; y destaca la presencia constante de cerámica de cobertura (teja curva, Fig. 3.2), tanto lisa como con decoraciones digitadas o incisas ${ }^{28}$.

La cultura material recuperada es fundamentalmente de tipo cerámico, muy similar en cuanto a su forma y técnicas de producción entre todos los yacimientos intervenidos. También se ha documentado la presencia de molinos manuales en granito, afiladores en piedras de grano fino, algunos objetos en hierro (cuchillos, argollas, clavos), así como escorias, y fusayolas (tanto en cerámica como en hueso). La cerámica puede dividirse entre grandes recipientes de almacenamiento (tinajas/ talhas) y cerámica común, tanto de cocina (ollas y cazuelas/potes-panelas) como de servicio (cuencos/taças, jarros, cántaros/bilhas) y de usos variados (barreños/ alguidares). Las tinajas presentan una fuerte diversidad formal en sus bordes, pero las pastas (con variedades rojizas y castañas) y la técnica de fabricación (mediante labores o rollos) parecen responder a una o dos fuentes de producción centralizada. La cerámica común, por el contrario, ofrece un catálogo formal limitado (Fig. 3.1), pero de enorme variabilidad individual, realizada con pastas de matriz granítica, en general poco depuradas, cocciones poco controladas, sin acabados (salvo algún engobe u ocasionales alisados y espatulados) y prácticamente sin recurrir a la decoración ${ }^{29}$. Estas circunstancias nos llevan a pensar en una fabricación reservada al ámbito doméstico, según fuera necesaria la incorporación de nuevas piezas a la vajilla familiar, aunque sin descartar que existieran círculos de comercio a nivel local o regional que

\footnotetext{
${ }^{28}$ CUESTA-GÓMEZ, PRATA, RAMOS, 2018.

${ }^{29}$ PRATA, 2017.
} 

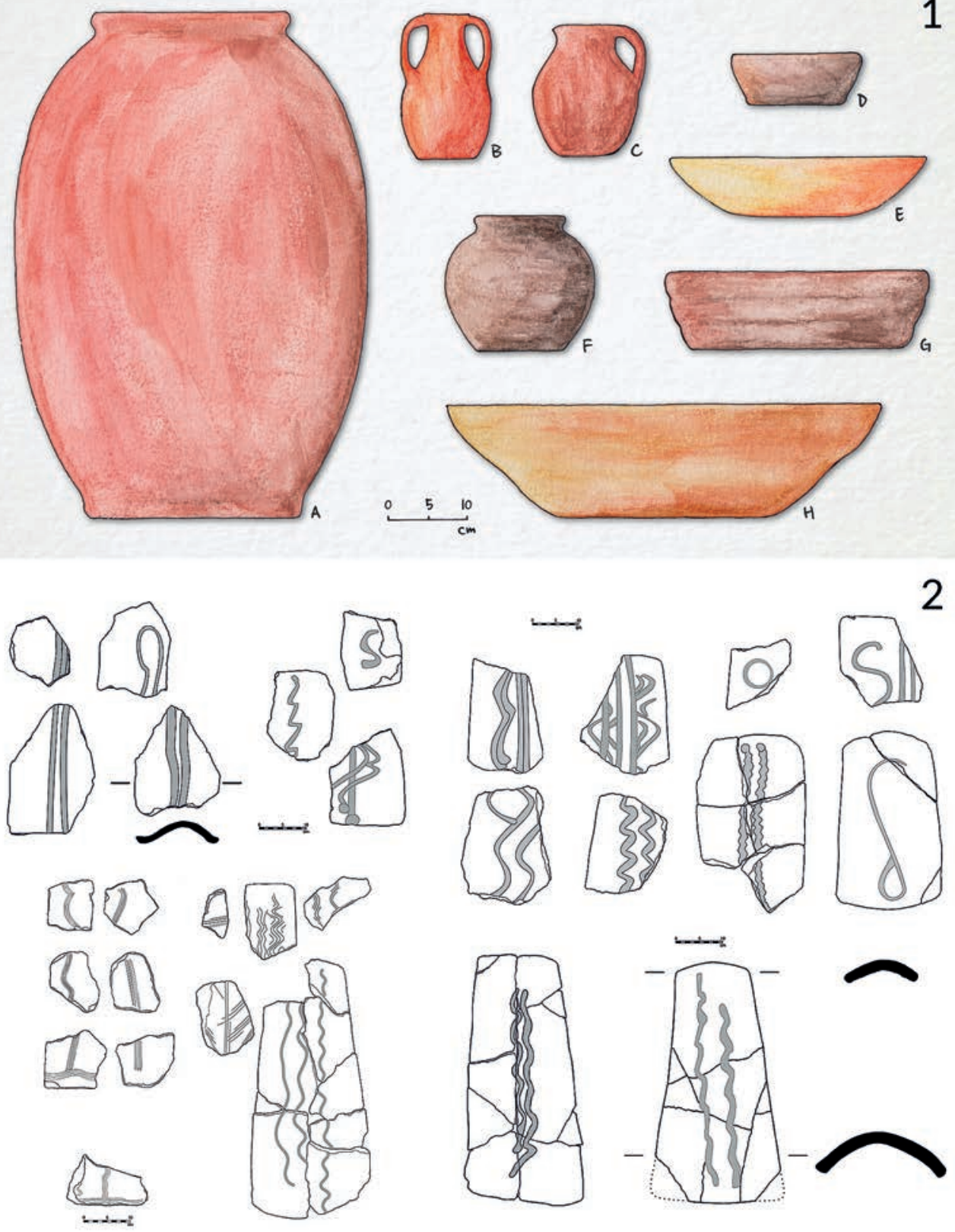

Fig. 3. 1) Esquema con las formas cerámicas documentadas en los contextos altomedievales excavados en (astelo de Vide: $a$ ) tinaja; $b$ ) botella; c) jarro; d) cuenco; e) plato de servicio; $f$ ) orza/olla; $g$ ) plato de cocina; $h$ ) barreño; 2) Representación de algunas de las decoraciones - digitadas e incisas - presentes en las tejas de los yacimientos estudiados (las escalas indican $10 \mathrm{~cm}$ ).

Fonte: Fabián Cuesta-Gómez 
permitieran el intercambio de estas piezas, así como la introducción de elementos de factura más regular y cuidada y de pastas más depuradas que, aunque en menor medida, también se han documentado. Es posible que los escasos objetos de vidrio y de bronce recuperados, respectivamente, en las excavaciones de contextos domésticos y funerarios también se incorporaran a través de estos circuitos supralocales.

Por último, es importante resaltar la presencia de sepulturas excavadas en la roca en las inmediaciones de todas las estructuras intervenidas, bien en forma de sepulturas aisladas, bien formando grupos de dos o tres ejemplares. En el Vale de Galegos, 13 de las 15 estructuras identificadas hasta el momento tienen al menos una sepultura excavada en la roca a 100 metros o menos $(\overline{\mathrm{x}}=36,13 \pm 18,7 \mathrm{~m})$. Todas ellas ocupan afloramientos graníticos del entorno, con multiplicidad de localizaciones, tanto a nivel de suelo como en bloques a más de un metro de altura. A pesar de existir lanchas más amplias o formaciones más destacadas visualmente en el territorio, parece existir una preferencia por seleccionar los barruecos más próximos a las estructuras para su construcción. Resulta llamativo que de los 41 casos estudiados, 3 de ellos se correspondan a sepulcros inacabados (todos destinados a adultos, uno apenas esbozado el contorno) y 10 se identifiquen como de enterramientos infantiles individualizados ${ }^{30}$ (Fig. 4), elevado porcentaje de inhumaciones de niños que supone una circunstancia poco habitual en este tipo de contextos. El trabajo de talla de las sepulturas resulta claramente heterogéneo, ofreciendo una enorme variedad en cuanto a la morfología y los detalles habitualmente considerados en el estudio de estos sepulcros: presencia / ausencia de reborde exterior; antropomorfismo; indicación de detalles anatómicos en la cabecera o en los pies; orientación; ratios longitud/anchura/profundidad, etc.

Parece claro que no existe una estandarización formal en su elaboración, con características particulares en cada ejemplo documentado, circunstancia que permite considerar que su talla responde a preferencias de carácter doméstico. La familiarización de estas comunidades con el trabajo de cantería de granito para la construcción de estructuras; el fuerte peso de las producciones domésticas (tanto de cerámica como para parte del aceite y/o del vino ${ }^{31}$ ) y la existencia de espacios cerrados (corrales) que permiten inferir una gestión autónoma o particular de, al menos, algunos componentes de la actividad agropecuaria (ganadería, silvicultura, leña, almacenamiento de cereal), nos llevan a plantear una probable generación y

\footnotetext{
${ }^{30}$ Además de un caso que presenta apenas $139 \mathrm{~cm}$; consideramos infantiles todas aquellas sepulturas que presentan una longitud inferior a $130 \mathrm{~cm}$ (BROOKES, TENTE, PRATA, 2017: 224).

${ }^{31}$ El elevado número de pesos de lagar y la presencia de estructuras rupestres (lagares, lagaretas y piletas), vinculadas al prensado y/o pisado de la aceituna o de la uva, en relación espacial directa con estructuras habitacionales, permite considerar factible la gestión a nivel familiar de parte de la producción de vino y aceite. La aparente ausencia de edificios comunales y de necrópolis nos lleva a pensar que, por elección o por imposición, el peso principal de las actividades recaía en los pequeños grupos familiares, sin que hasta el momento hayamos detectado manifestaciones materiales del sentimiento de comunidad.
} 
Gráfico con la representación de las 39 sepulturas con dimensiones conocidas en el Vale de Galegos (sobre un total de 41); las líneas punteadas marcan los valores de la mediana de la longitud y la anchura.

Fonte: Fabián Cuesta-Gómez

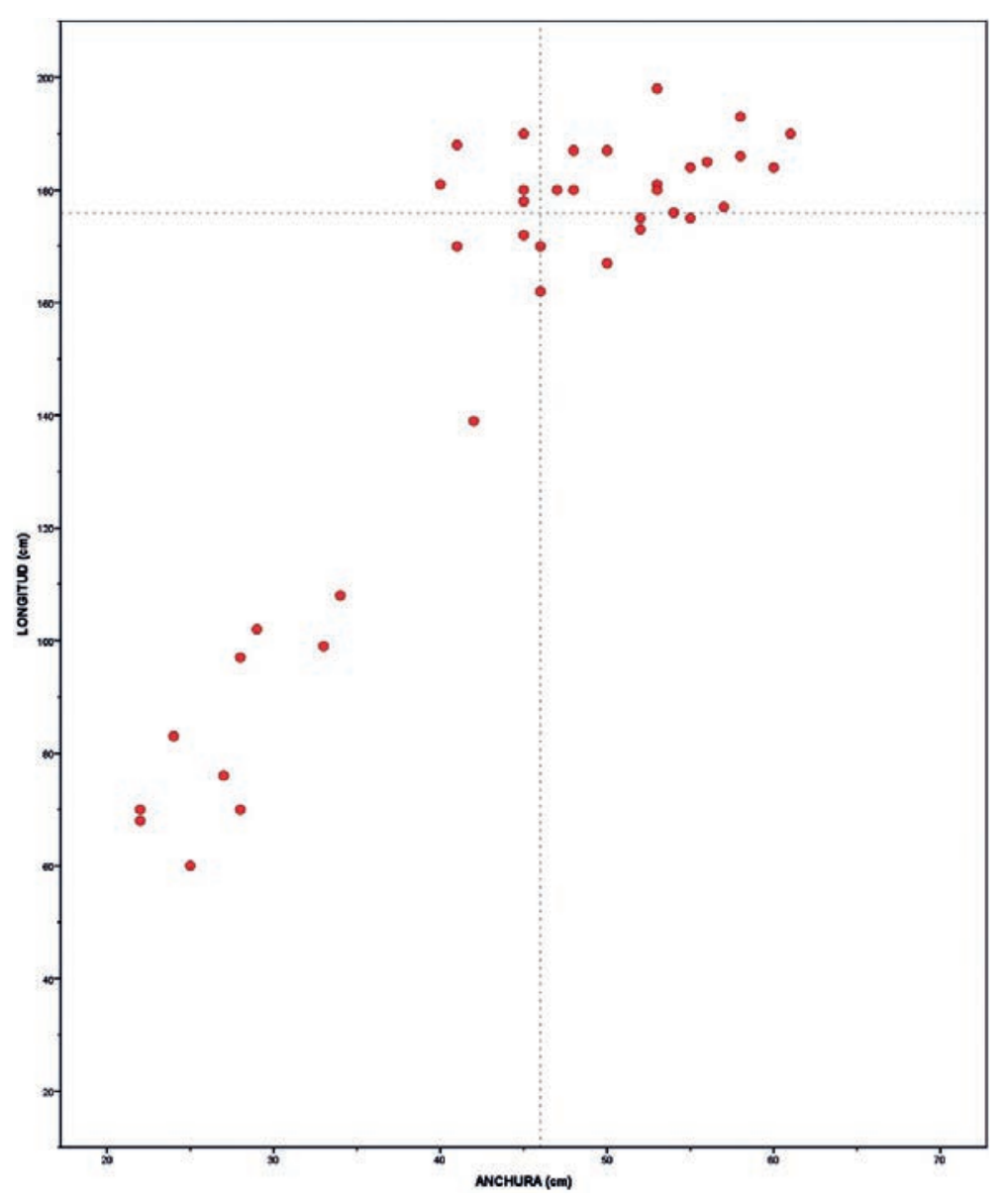

gestión de los espacios funerarios también desde el ámbito doméstico: sería cada grupo familiar el que eligiera el espacio y el que tallara la sepultura. Resulta evidente que se trata de comunidades con la suficiente capacidad técnica, agencia y autonomía en la gestión de su entorno como para definir formalmente cómo y dónde enterrar a sus miembros. Esta situación explicaría la amplia variabilidad observada en las sepulturas y descarta, o al menos hace innecesaria, la presencia de un artesano especialista que acuda al llamamiento de la muerte para ejercer su trabajo a nivel local o regional.

\section{EL CAMINO DEL VALE DO GALEGOS: EJE ARTICULADOR DEL POBLAMIENTO}

Se ha señalado anteriormente la importancia que parece ejercer el camino que aún hoy atraviesa el Vale de Galegos para comprender la articulación del poblamiento altomedieval. Aceptando siempre la cautela en la reconstrucción de ejes viarios de la 


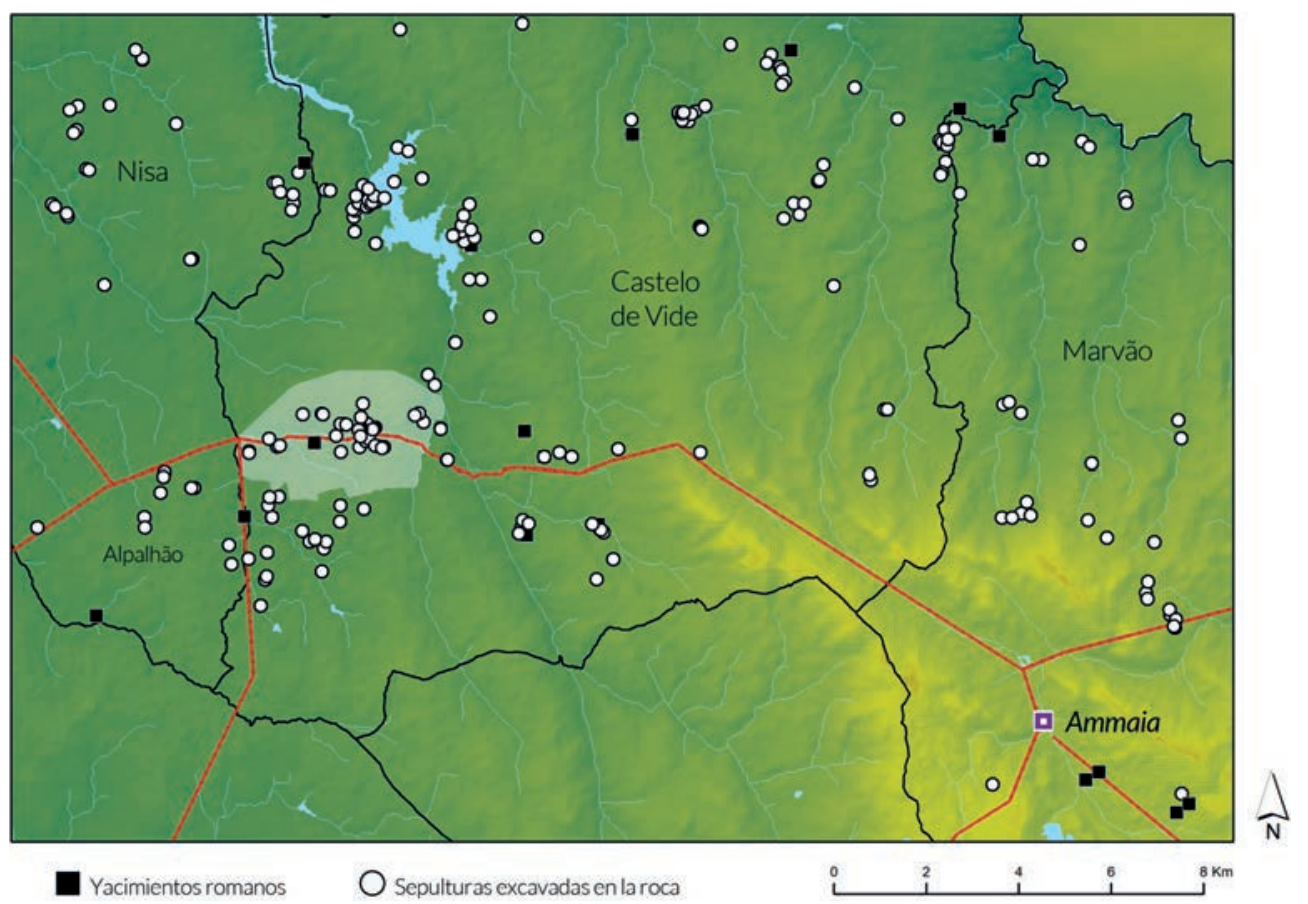

Mapa 3. Mapa de la zona sur del concelho de Castelo de Vide, y de los vecinos Marvão y Nisa, con la indicación de los emplazamientos de yacimientos de época romana (cuadrados negros) y de las sepulturas excavadas en la roca (círculos blancos), que podrían evidenciar el mantenimiento en uso de estos caminos a medida que el poblamiento altomedieval se articulaba a lo largo de los mismos. Las líneas rojas representan las probables vías que recorrían este espacio en relación a la ciudad de Ammaia.

Fonte: Fabián Cuesta-Gómez

Antigüedad y sin olvidar que la trama viaria es un elemento mutable en el tiempo ( $v$. $g r$ reformas, nuevos trazados y abandono de rutas), hay una serie de factores que hacen especialmente interesante el análisis de esta vía como trazado fósil probablemente desde época romana ${ }^{32}$.

Nuestro punto de referencia ha de ser la ciudad de Ammaia (Marvão), enclave que funcionaría como principal nudo de comunicaciones de la región en época imperial, a pesar de que ninguna de las vías de su entorno aparece referenciada en las fuentes clásicas ${ }^{33}$. Su relativa distancia respecto a otros centros urbanos contemporáneos, su limitado desarrollo socio-económico y político durante el Imperio, y la irregular

\footnotetext{
${ }^{32}$ A este camino ya había hecho referencia Mário Saa (1967: 138-139, nota 2; vid. también CARNEIRO, 2008: 27 y ss. como crítica necesaria al trabajo de Saa), mencionando que: «Cerca de $600 \mathrm{~m}$ ao sul das casas da Lameira Velha passa o arqueológico caminho romano de Alpalhão a Castelo de Vide que, no alto das Guaritas, antes de transpor a ribeira de Nisa, corta uma necrópole de sepulturas antropomórficas. O velho caminho apresenta lanços de calcetaria». ${ }^{33}$ Pueden consultarse los trabajos de CARNEIRO, 2008 y MANTAS, 2012 como panorama general de los estudios viarios romanos en la provincia lusitana.
} 
orografía de esta parte del norte alentejano, probablemente motivaron la ausencia de grandes trazados viarios reconocibles.

Se ha propuesto que de Ammaia partirían, al menos, cuatro vías principales, de las que apenas quedan como testimonio unos pocos metros documentados en las inmediaciones del solar de la ciudad y la interpretación de la ordenación de las parcelas agrícolas y su posible pervivencia en el trazado de los caminos actuales ${ }^{34}$. La que resulta de mayor interés para el presente trabajo es la que, desde Ammaia, toma dirección noroeste. Su trazado discurriría inmediatamente al sur de las actuales poblaciones de Escusa y Castelo de Vide, en un corredor natural entre las sierras de Marvão y Castelo de Vide, bordeando esta última hasta llegar a la zona de Nossa Senhora da Luz, desde donde viraría ligeramente hacia el suroeste, coincidiendo su trazado con la actual M1023, hasta las inmediaciones del cruce con la ribeira de Nisa, para continuar en dirección noroeste hacia Alpalhão ${ }^{35}$, atravesando el Vale de Galegos.

Todo indica que esa posible vía romana se habría mantenido en uso también en época altomedieval, articulando el poblamiento de la zona a lo largo de su recorrido. Testimonio de ello serían los numerosos yacimientos documentados a ambos lados del camino desde su «inicio» en las estribaciones de la sierra, con las sepulturas excavadas en la roca (y algunas estructuras) conocidas en: Nossa Senhora da Luz, Celeiro, Lameira, Lavradores, Pedreira y Barqueira antes de afrontar el Vale de Galegos, tras el cruce de la rivera de Cogulo. Desde este punto, como hemos visto en el presente texto, se suceden aún más nítidamente las estructuras productivas, habitacionales y sepulturas excavadas en la roca, no sólo hasta el final del camino, sino también más allá de la rivera de Figueiró, en dirección a Alpalhão. La amplia mayoría de estos yacimientos se sitúan en pequeñas elevaciones del terreno junto a vallejos (como pone de manifiesto la toponimia) y siempre con el camino a la vista. El análisis de la implantación de estos yacimientos demuestra que, lejos del aislamiento o la ocultación en el paisaje ${ }^{36}$, los espacios habitacionales y productivos creados a lo largo de los siglos VI y VII buscan activamente la relación con caminos como este, manteniendo su uso. Es muy probable que la otra gran concentración de yacimientos altomedievales en el concelho, detectada en la zona del embalse de Póvoa, también responda a la pervivencia / reaprovechamiento de los espacios articulados a lo largo de un camino

\footnotetext{
${ }^{34}$ CORSI, VERMEULEN, 2006: 26-29.

35 Todo indica que el entorno de Alpalhão funcionó como un importante nudo de caminos ya desde época romana (¿quizá existiera una mansio en la Horta de Fraguil? vid. CARNEIRO, 2014: 377-378), pues en ella confluirían la vía noroeste desde Ammaia (que podría unirse a la vía XV a la altura de la mansio de Fraxinum (¿Monte da Pedra?, Crato) y una vía transversal en sentido sur-norte (posiblemente un deverticulum de la vía XV), que desde Abelterium (Alter do Chão) se dirigiera hacia el cruce del Tajo en las inmediaciones de las actuales poblaciones de Amieira do Tejo / Barca de Amieira (CARNEIRO, 2008).

${ }^{36}$ Cf. CARNEIRO, 2016.
} 
que corriera paralelo a la rivera de $\mathrm{Nisa}^{37}$, reflejando un patrón de asentamientos en hilera caracterizado como row settlements para contextos anglosajones ${ }^{38}$.

La explicación de por qué se produce esta situación puede remitir a varios factores relacionados entre sí: por un lado porque se trata de vías que permitían el control geográfico del territorio y una mayor (y más fácil) movilidad por él; por otro, porque aunque se tratara de caminos secundarios (viae rusticae, vicinales o privatae), probablemente articulaban los establecimientos rurales romanos ligados a Ammaia y, por tanto, también sus espacios agropecuarios, lo que permite el reaprovechamiento de estructuras y materiales, pero también de manantiales, árboles, tierras de labor y pastos; por último, porque las propias relaciones entre los ocupantes del territorio durante el periodo altomedieval debían ser intensas, bien entre sí, bien de cara a contactos con el exterior, siempre a escala regional, y hacían uso de esas vías de comunicación y transporte.

\section{REFLEXIONES FINALES}

Pie a tierra, es hora de volver la vista atrás. Resulta interesante destacar cómo entre principios de los años 70 y mediados de los 90, los trabajos arqueológicos desarrollados en el territorio de Castelo de Vide sirvieron para apuntar una serie de características materiales y de relaciones espaciales y cronológicas entre los ámbitos de los muertos y de los vivos para el periodo altomedieval. Las huellas en el camino comenzaban a apuntar en una misma dirección: sepulcros de lajas, sepulturas excavadas en la roca, estructuras de doble paramento, tejas decoradas, grandes recipientes de almacenamiento, cerámicas de cocina de pastas graníticas, contrapesos de lagar, etc. Las asociaciones espaciales entre las sepulturas y las estructuras formaban un patrón recurrente que obligaba a plantear nuevas preguntas relativas a su cronología, a las evidentes diferencias en cuanto al ritual funerario y a su interrelación con las estructuras (habitacionales y productivas) detectadas en las inmediaciones.

Una circunstancia que resulta innegable, tanto para el caso del Vale de Galegos como para el resto del territorio de Castelo de Vide, es la importancia de las sepulturas excavadas en la roca como operadores del diálogo entre el espacio y sus habitantes ${ }^{39}$ $\mathrm{y}$, de la misma manera que las sepulturas tuvieron un claro papel en el paisaje físico e ideológico de estas comunidades, hoy en día también funcionan como referencia arqueológica a la hora de definir la existencia de nuevas evidencias. No resulta exagerado señalar que la localización de una nueva sepultura conlleva el hallazgo de un grupo de estructuras en el entorno; y lo mismo sucede a la inversa. Estas evidencias funerarias - más fácilmente visibles y mejor conservadas - sirven como faro en

\footnotetext{
${ }^{37}$ PRATA, 2018b.

${ }^{38}$ HAMEROW, 2002: 54.

${ }^{39}$ MARTÍN VISO, 2012.
} 
el paisaje para localizar el poblamiento altomedieval. Las recientes revisiones de los inventarios de los vecinos concelhos de Nisa ${ }^{40}$ y Marvão ${ }^{41}$, parecen confirmar esta tendencia, al menos para el norte del norte alentejano.

Los problemas interpretativos que planteaba el fenómeno de las sepulturas excavadas en la roca diseminadas por los paisajes rurales, tan en boga en las décadas finiseculares, no está resuelto. En nuestra opinión, lo que debería centrar la atención como investigadores es definir si las características formales de estas sepulturas suponen un factor discriminante, a qué preguntas están respondiendo los porcentajes tipológicos y, en definitiva, si estas evidencias del fenómeno funerario altomedieval deben ser objeto de estudio per se. El vacío interior que revelan la práctica totalidad de estas sepulturas permite ser llenado de cuantas interpretaciones queramos, pero eso no conlleva un mejor conocimiento de las comunidades que eligieron esos lechos de piedra para el descanso de sus individuos. Resulta evidente que su fenomenología debe incorporarse al análisis arqueológico de las comunidades campesinas y sus paisajes, pero siempre reflexionando desde los contextos donde esos grupos humanos desarrollaron sus vidas y acerca de las pautas que condujeron hacia esas manifestaciones funerarias extraordinarias.

Los trabajos arqueológicos llevados a cabo dentro del proyecto PramCV en Castelo de Vide nos han permitido poner sobre la mesa una serie de cuestiones que han supuesto un avance importante en la caracterización del poblamiento rural altomedieval de este territorio: su relación espacial con el poblamiento imperial, las características arquitectónicas de las estructuras de hábitat y productivas, las técnicas empleadas en la fabricación de la cultura material y sus implicaciones socioeconómicas, la pervivencia y transformación de actividades agropecuarias y la gestión de vías y espacios en un paisaje en mudanza constante.

El análisis de áreas como el Vale de Galegos, donde resulta evidente la relación entre vías, estructuras productivas / de hábitat y las manifestaciones funerarias, reflejan la construcción de un poblamiento disperso, en el sentido de no agrupado, pero, por encima de todo, articulado, en habitual relación con otros espacios habitados, con los paisajes aprovechados económicamente y con los referentes ideológicos que suponen las sepulturas.

Para finalizar, conviene reseñar que hasta el momento no tenemos ningún indicio que refleje la pervivencia de este modelo de poblamiento en esta región más allá del siglo VIII, situación similar a la documentada en otros territorios peninsulares ${ }^{42}$. De la misma manera, cabe subrayar que las tumbas excavadas en la roca - en el ámbito rural y no asociadas a centros de culto parroquiales - también se reconocen en

\footnotetext{
${ }^{40}$ ARCHEOSTUDOS, 2009.

${ }^{41}$ OLIVEIRA, PEREIRA, PARREIRA, 2007.

42 MARTÍN VISO et al., 2017; GÓMEZ OSUNA et al., 2018.
} 
etapas más tardías ${ }^{43}$. Estas variables cronológicas y geográficas nos llevan a resaltar la importancia de la realización de excavaciones arqueológicas sin las cuales es imposible la construcción de marcos temporales para el fenómeno funerario rupestre y el conocimiento del poblamiento asociado.

Pero todo ello no es sino un largo camino en el que, inevitablemente, se plantean nuevos interrogantes a cada paso. Hemos de seguir caminando.

\section{BIBLIOGRAFIA}

ARCHEOESTUDOS (2009). Carta arqueológica de Nisa - Fase II. Relatório Final. Policopiado.

AREZES, Andreia (2017). O Mundo Funerário na Antiguidade Tardia em Portugal: As Necrópoles dos Séculos V a VIII. Porto: CITCEM.

BROOKES, Stuart; TENTE, Catarina; PRATA, Sara (2017). Interpreting Rock-Cut Grave Cemeteries: The Early Medieval Necropolis and Enclosure of São Gens, Portugal. «Medieval Archaeology». 61: 2, 36-40.

CAEIRO, José Olívio (1984a). A Necrópole I da Azinhaga da Boa Morte - Castelo de Vide. Évora: Assembleia Distrital de Portalegre.

CAEIRO, José Olívio (1984b). A Necrópole II da Azinhaga da Boa Morte - Castelo de Vide. Évora: Assembleia Distrital de Portalegre.

CARNEIRO, André (2008). Itinerários romanos do Alentejo. Lisboa: Edições Colibrí.

CARNEIRO, André (2014). Lugares, tempos e pessoas: povoamento rural romano no Alto Alentejo. Coimbra: Universidade de Coimbra: Annablume Editora. 2 vols.

CARNEIRO, André (2016). Mudança e continuidade no povoamento rural no Alto Alentejo durante a Antiguidade Tardia. In ENCARNAÇÃO, José d'; LOPES, M. Conceição; CARVALHO, Pedro C., coord. A Lusitânia entre Romanos e Bárbaros. Coimbra: Universidade de Coimbra, pp. 281-307.

CORSI, Cristina; VERMEULEN, Frank (2006). Elementi per la ricostruzione del paesaggio urbano e suburbano della città romana di Ammaia in Lusitania. "Archeologia Aerea». 3, 13-30.

CUESTA-GÓMEZ, Fabián; PRATA, Sara; RAMOS, Tiago (2018). Empezar la casa por el tejado: las cerámicas de cobertura en los contextos altomedievales del territorio de Castelo de Vide (Portugal). In MARTÍN VISO, Iñaki et al. Cerámicas Altomedievales en Hispania y su entorno (siglos V-VIII d.C.). Valladolid: Glyphos, pp. 137-158.

GÓMEZ OSUNA, Rosario et al. (2018). Las cerámicas altomedievales de la Cuenca Alta del Manzanares, Sierra de Guadarrama, Madrid. In MARTÍN VISO, Iñaki et al. Cerámicas Altomedievales en Hispania y su entorno (siglos V-VIII d.C.). Valladolid: Glyphos.

HAMEROW, Helena (2002). Early medieval settlements: The Archaeology of Rural Communities in NorthWest Europe 400-900. Oxford: Oxford University Press.

LEITE DE VASCONCELOS, José (1933). Antiguidades alentejanas. «O Archeólogo Português».

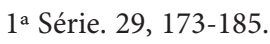

MAGUSTO, João; FÉLIX, Nuno (1995). Prospecção de superfície na Zona C, Parcela 6. Castelo de Vide: relatório policopiado.

MANTAS, Vasco (2012). As vias romanas da Lusitânia. «Studia Lusitania». 7.

MARTÍN VISO, Iñaki (2012). Enterramientos, memoria social y paisaje en la Alta Edad Media: Propuestas para un análisis de las tumbas excavadas en roca en el centro-oeste de la Península Ibérica. «Zephyrus». 69, 165-187.

\footnotetext{
${ }^{43}$ TENTE, 2015.
} 
MARTÍN VISO, Iñaki et al. (2017). La formación de un nuevo paisaje en el centro de la Península Ibérica en el periodo posromano: el yacimiento de La Genestosa (Casillas de Flores, Salamanca). "Archivo Español de Arqueología». 90, 7-28.

OLIVEIRA, Jorge de; PEREIRA, Sérgio; PARREIRA, João (2007). Nova Carta Arqueológica do Concelho de Marvão. «Ibn Maruan». 14.

PAÇO, Afonso do (1949). Inscrição Cristã do Monte-Velho (Beirã - Marvão). «Brotéria». 49: 1, 40-54.

PITA, António; MAGUSTO, João (1994). Relatório de Levantamento histórico-arqueológico Zona C, Parcela 5. Castelo de Vide: relatório policopiado.

PRATA, Sara (2012). As necrópoles alto-medievais da Serra de São Mamede (Concelhos de Castelo de Vide e Marvão). Lisboa: FCSH/UNL. Dissertação de Mestrado.

PRATA, Sara (2014). Espacios funerarios altomedievales del norte de la Serra de São Mamede (Portalegre, Portugal): una propuesta de organización espacial. «ArkeoGazte». 4, 261-279.

PRATA, Sara (2017). Objectos arqueológicos alto-medievais em contexto doméstico: o caso da Tapada das Guaritas (Castelo de Vide, Portugal). «Medieval Sophia». 19, 413-429.

PRATA, Sara (2018a). Arqueologia do povoamento rural alto-medieval no território de Castelo de Vide (séculos V-VIII). Salamanca: Facultad de Geografía e Historia, USAL. Tese de Doutoramento.

PRATA, Sara (2018b). Articulação da paisagem rural pós-romana no territorio de Castelo de Vide (Portugal). In Fortificaciones, poblados y pizarras. La Raya en los inicios del Medievo. Ciudad Rodrigo: Ayto. de Ciudad Rodrigo, pp. 216-234. [Catálogo de la Exposición]

PRATA, Sara; CUESTA-GÓMEZ, Fabián (2017). Antes da vide e do castelo: arqueologia da Alta Idade Média no território de Castelo de Vide. In COSTA, Adelaide; ANDRADE, Amelia; TENTE, Catarina, coord. O papel das pequenas cidades na construção da Europa Medieval. Atas das I Jornadas Internacionais de Idade Média. Colecção Estudos. Lisboa: IEM; Castelo de Vide: CM Castelo de Vide, vol. 17, pp. 144-159.

RODRIGUES, Maria da Conceição (1975). Carta Arqueológica do concelho de Castelo de Vide. Lisboa: Junta Distrital de Portalegre.

RODRIGUES, Maria da Conceição (1978). Sepulturas medievais do concelho de Castelo de Vide. Lisboa: Junta Distrital de Portalegre.

SAA, Mário (1967). As grandes vias da Lusitania. Tomo VI. Livros XVI e XVII. Lisboa: [s.n.].

TENTE, Catarina (2015). Tumbas rupestres en el Alto Mondego (Guarda, Portugal). Patrones de distribución, significados y construcción del paisaje rural altomedieval. «Munibe». 66, 271-290.

VIGIL-ESCALERA GUIRADO, Alfonso (2006). Aspectos sobre la cultura material en Hispania. El modelo de poblamiento rural en la Meseta y algunas cuestiones de visibilidad arqueológica. In LÓPEZ QUIROGA, Jorge; MARTÍNEZ TEJERA, Artemio Manuel; MORÍN de PABLOS, Jorge, ed. Gallia e Hispania en el contexto de la presencia Germánica (ss. V-VII). Balance y perspectivas. BAR International Series. Oxford: Archaeopress, vol. 1534, pp. 89-108.

WOLFRAM, Mélanie (2011). Uma síntese sobre a cristianização do mundo rural no sul da Lusitania. Lisboa: Faculdade de Letras da Universidade de Lisboa. Tese de Doutoramento. 


\title{
SEPULTURAS RUPESTRES NA \\ IGREJA PAROQUIAL DE TRAVANCA \\ (SANTA MARIA DA FEIRA)
}

\author{
CARLOS FERREIRA* \\ LINDA MELO** \\ ARTUR FONTINHA***
}

\begin{abstract}
Resumo: A intervenção arqueológica na igreja paroquial de Travanca (Santa Maria da Feira) decorreu entre 2016 e 2017. Foram identificadas e escavadas um total de 410 sepulturas com uma longa diacronia, desde época altimedieval até ao início da época contemporânea. Apresentam-se os dados arqueográficos obtidos sobre a ocupação mais antiga identificada no sítio arqueológico. Trata-se de sepulturas escavadas na rocha de época altimedieval. A sua orientação era divergente em relação ao templo atual e apresentavam essencialmente quatro formas distintas. A apresentação destas sepulturas possibilita participar no ainda aceso debate sobre as sepulturas escavadas na rocha por constituírem uma realidade problemática no seio da Arqueologia.
\end{abstract}

Palavras-chave: Sepulturas escavadas na rocha; Necrópole; Alta Idade Média; Arqueologia funerária.

Abstract: The archaeological intervention in the parish church of Travanca (Santa Maria da Feira) took place between 2016 and 2017. A total of 410 graves were identified and excavated with a long diachrony from high medieval times until the beginning of the contemporary era. The archaeological data obtained on the oldest occupation identified in the archaeological site are presented. These are graves dug in the rock of a high medieval time. Their orientation was divergent from the present temple and they essentially presented four distinct forms. The presentation of these graves makes it possible to participate in the still heated debate about the graves excavated in the rock because they constitute a problematic reality within Archaeology.

Keywords: Rock-cut graves; Necropolis; High Middle Ages; Funerary Archaeology.

\section{INTRODUÇÃO: AS RAZÕES DA INTERVENÇÃO}

A igreja paroquial de Travanca foi alvo de uma ampla intervenção arqueológica entre 2016 e 2017 no âmbito do Projeto de Recuperação e Ampliação da Igreja Paroquial de Travanca em Santa Maria da Feira. Esta intervenção foi realizada pela empresa AFA, tendo como responsáveis científicos os arqueólogos Carlos Ferreira e Artur Fontinha e a antropóloga Linda Melo. A intervenção arqueológica teve a duração de um ano e foram escavados manualmente $480 \mathrm{~m}^{2}$. A considerável área de

\footnotetext{
* Arqueologia e Formação Aplicada (AFA). Email: del.charles@gmail.com.

** Bolseira de Doutoramento FCT- SFRH/BD/130165/2017 (Laboratório de Préhistória, CIAS - Departamento

Ciências da Vida, Universidade de Coimbra).

*** Arqueologia e Formação Aplicada (AFA).
} 
escavação bem como o avultado número de sepulturas e indivíduos tornou morosos os trabalhos tendo em conta a sensibilidade do contexto arqueológico ${ }^{1}$.

Escavaram-se 410 sepulturas e exumaram-se 266 indivíduos, 47 ossários, 3 reduções e mais de 1000 ossos soltos foram identificados. Os dados obtidos constituem uma grande valia na medida em que esta é a primeira grande intervenção arqueológica realizada em Travanca e, nesse sentido, permite caracterizar as práticas funerárias ali exercidas. Observaram-se várias reformulações arquitetónicas dos espaços cultuais associados a uma ocupação sepulcral sucessiva do recinto. A longa diacronia do uso do espaço desde pelo menos a Alta Idade Média até aos alvores do período Contemporâneo permitiu registar distintos momentos, distintos tipos e determinadas particularidades funerárias. Porém, neste trabalho, aborda-se apenas as sepulturas escavadas na rocha identificadas e localizadas na nave e no adro sul da igreja e que constituem o testemunho mais antigo da utilização deste sítio como espaço sepulcral.

\subsection{Enquadramento}

A igreja paroquial de Travanca insere-se administrativamente na União das freguesias de Santa Maria da Feira, Travanca, Sanfins e Espargo, no concelho de Santa Maria da Feira e distrito de Aveiro.

O entorno deste edifício é caracterizado pelo largo da igreja, ladeado por várias casas, e pelos vários campos agrícolas. O local apresenta ligeira pendente em direção ao rio Cáster que se localiza nas proximidades, a oeste. Em termos geológicos predominam os xistos, embora existam algumas manchas graníticas.

Existem desde o século XI algumas referências a Travanca, nomeadamente, na relação de bens de Gonçalo Viegas e Dona Châmoa onde se lê «Item in trabanca at radize de sancta maria quanta fuit de auio nostro dom creconio $»^{2}$ o que permite atestar a antiguidade da ocupação humana do território desde época medieval, pelo menos.

A igreja paroquial de Travanca ${ }^{3}$ apresenta várias reformulações arquitetónicas até ter obtido o aspeto atual. As mais recentes são facilmente identificadas pois ou estão gravadas em lápides ou epigrafadas na própria argamassa de revestimento e datam da década de 50 do século XX. Consistiram na ampliação do coro alto e do altar-mor, na edificação de escadaria exterior de acesso ao coro alto, na reformulação do adro sul, entre outras.

\footnotetext{
${ }^{1}$ FONTINHA, FERREIRA, MELO, 2017.

${ }^{2}$ GONÇALVES, 1981.

${ }^{3}$ Inventário do Património Arquitetónico n. ${ }^{\circ} 00030959$.
} 


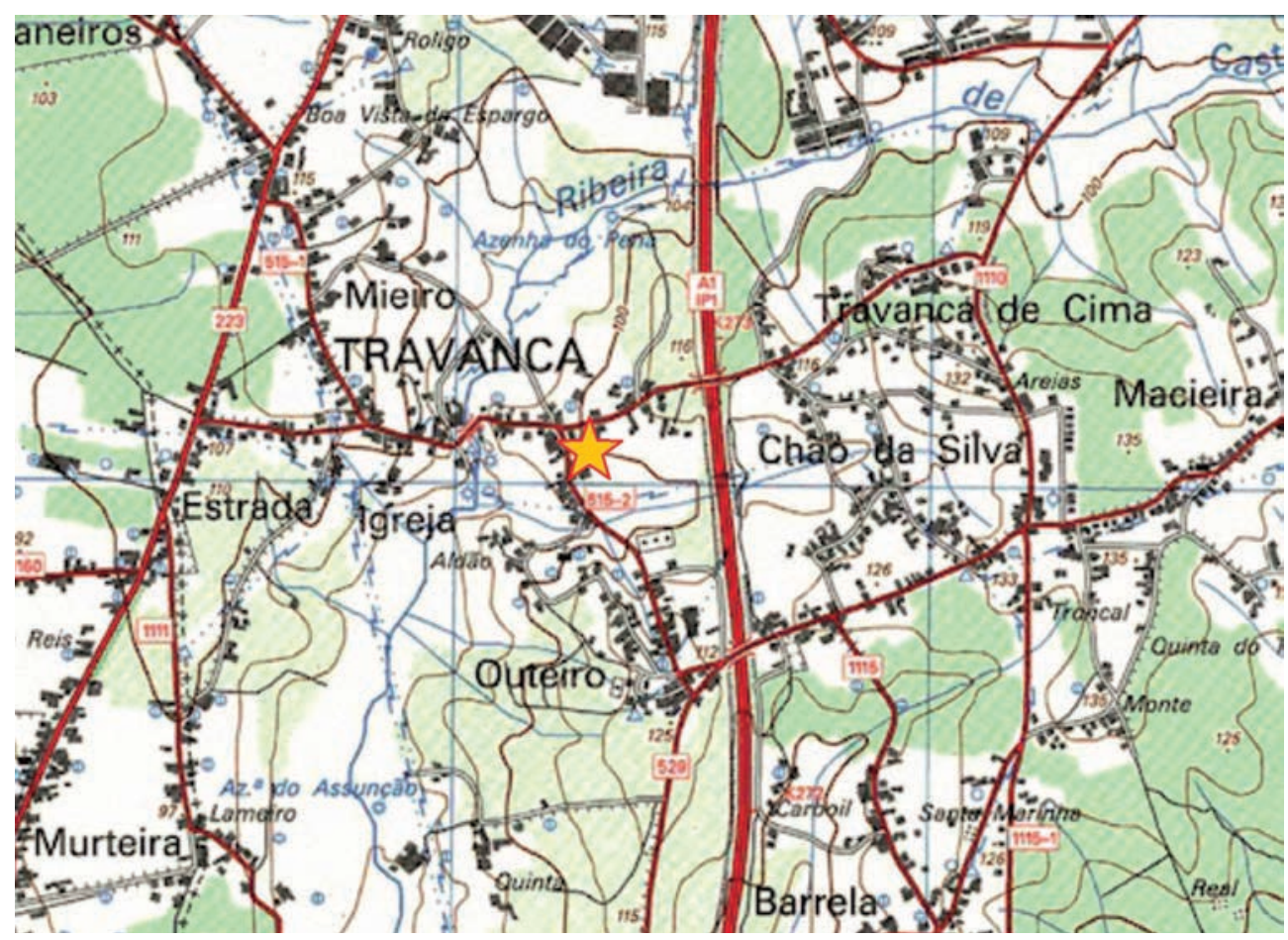

Fig. 1. Localização da Igreja de Travanca. Excerto da C.M.P, 1/25000, folha n. ${ }^{\circ} 153$, com a indicação da igreja de Travanca Fonte: Excerto da Carta Militar de Portugal, Escala: 1:25000, folha 153

No Sistema de Informação para o Património Arquitetónico ${ }^{4}$ descreve-se no enquadramento histórico-cultural uma fundação medieval do templo sendo posteriormente reconstruído no século XIX e alterado pelas transformações acima descritas.

Na obra «Inventário Artístico de Portugal: Distrito de Aveiro Zona do Norte», Nogueira Gonçalves ${ }^{5}$ refere que «o edifício atual, inteiramente reconstruído em dois períodos principais, mostra o comum aspeto geral das obras dos construtores regionais; capela-mor, executada nos fins do último século, o corpo já no decénio de 50 do corrente. Colocaram a torre a meio da fachada, metida dentro da obra. O retábulo principal e os dois dos flancos são correntes, sob a sugestão dos tradicionais. Revestiram de talhas douradas todo o pano de parede em que se abre o arco-cruzeiro. Utilizaram os colaterais antigos - do fim do século XVII, de dois pares de colunas torcidas e com pâmpanos, a ladearem o pano médio, e de dois outros mas de pilastras-misuladas no corpo de cima - e completaram-nos lateralmente, enchendo todo o pano do alto, de talhas novas». Esta longa citação sintetiza as várias fases do edifício, sendo importante a referência cronológica do século XVII.

\footnotetext{
${ }^{4}$ Disponível em <http://www.monumentos.gov.pt>. [Consult. 14 abr. 2016].

${ }^{5}$ GONÇALVES, 1981.
} 
A mesma obra faz referência à escultura do padroeiro São Mamede realizada em pedra de Ançã e que será do final do século XV, obra esta que estaria presente na igreja sendo que atualmente estará guardada, estando exposta no nicho da torre sineira uma cópia. Na tradição oral é referida a existência de uma pequena capela anterior à igreja.

Em termos arqueológicos não há indicação no portal Endovélico ${ }^{6}$ de nenhum elemento arqueológico na antiga freguesia. Existem três arqueossítios assinalados na união de freguesias atual, porém, distantes do local em questão.

\subsection{As sepulturas escavadas na rocha: breve Estado da Arte}

O estudo de sepulturas escavadas na rocha em Portugal iniciou-se na década de 30 na sequência de estudos desenvolvidos por diversos e ilustres autores da época tais como: Leite de Vasconcelos, Santos Rocha, Martins Sarmento, Félix Alves Pereira e Vergílio Correia ${ }^{7}$.

Após alguns avanços e recuos é na década de 70, pelas mãos de António Cruz, que há uma clara associação destas sepulturas ao que Catarina Tente e Sandra Lourenço ${ }^{8}$ designaram como periodização medieval.

Porém, abordar esta temática é abordar um assunto complexo e que em determinados pontos divide a opinião dos investigadores. Talvez no que respeita à incerteza da cronologia, da tipologia ${ }^{9}$ e a frequente ausência do contexto estratigráfico ${ }^{10}$ torne esta forma de sepultar na Idade Média umas das mais enigmáticas ${ }^{11}$. São escassas as sepulturas/necrópoles rupestres que não tenham sido violadas ou reutilizadas ${ }^{12}$.

No entanto, este tema fica marcado na década de 80 com os estudos sistemáticos de Mário Barroca, resultado de algumas escavações arqueológicas e nomeadamente, fruto do trabalho apresentado à FLUP intitulado Necrópoles e sepulturas medievais de Entre-Douro-e-Minho (Séc. V a XV) ${ }^{13}$.

A partir daí assistiu-se ao aumento de publicações, quer sejam de Norte a Sul de Portugal. Enumerando alguns casos na região nortenha temos os exemplos de trabalhos que abordam diretamente as sepulturas escavadas na rocha ou as incluem no estudo mais alargado do povoamento, como, por exemplo: sobre as necrópoles

\footnotetext{
${ }^{6}$ Disponível em <http://arqueologia.patrimoniocultural.pt>. [Consult. 14 abr. 2016].

7 TENTE, LOURENÇO, 1998: 191.

${ }^{8}$ TENTE, LOURENÇO, 1998: 192.

${ }^{9}$ GUEDES, 2007: 276.

${ }^{10}$ BARROCA, 2010-2011: 117.

${ }^{11}$ GUEDES, 2007:276.

12 BARROCA, 2010-2011: 117.

${ }^{13}$ BARROCA, 1987.
} 
de Fão e Chafé ${ }^{14}$; sobre Chaves e os territórios em redor ${ }^{15}$; na região do Alto Paiva ${ }^{16}$; em redor do Douro ${ }^{17}$; no concelho de Lousada ${ }^{18}$; sobre Penafiel ${ }^{19}$; entre outros.

Em relação à zona centro do país, nomeadamente sobre a zona beirã (interior) temos os casos do estudo sobre a região de Viseu ${ }^{20}$; sobre a encosta noroeste da Serra da Estrela ${ }^{21}$; a zona que medeia os rios Dão e Alva ${ }^{22}$; sobre a serra de Montemuro ${ }^{23}$; concelho de Mangualde ${ }^{24}$; Tondela ${ }^{25}$; Fornos de Algodres ${ }^{26}$; sobre Miranda do Corvo ${ }^{27}$; Fundão ${ }^{28}$, entre outros.

Sobre o sul do país os trabalhos que versam as sepulturas escavadas na rocha são menores, destacando-se a tese de mestrado sobre a ocupação da serra de São Mamede $^{29}$; sobre o distrito de Évora ${ }^{30}$; e já para a zona algarvia destaca-se uma tese sobre São Bartolomeu de Messines ${ }^{31}$.

\section{A INTERVENÇÃO ARQUEOLÓGICA NA IGREJA PAROQUIAL DE TRAVANCA}

Ao longo de um ano de intervenção arqueológica foram escavados manualmente $480 \mathrm{~m}^{2}$. A considerável área de escavação obrigou à divisão do espaço em cinco áreas como estratégia metodológica, designadas de «A» $\mathrm{a}$ «E».

A área A corresponde à nave da igreja, onde foram identificadas sepulturas desde época altimedieval até ao início de época Contemporânea. As sepulturas medievais identificadas e escavadas apresentavam várias formas: valas de planta subretangular, onde ainda se preservava o revestimento da base em placas de xisto, localizadas a sudeste da nave; identificaram-se também algumas sepulturas escavadas na rocha de planta subtrapezoidal, sendo que nalgumas era possível observar alguns traços de antropomorfismo. Apenas numa destas sepulturas foi identificado um indivíduo parcialmente preservado. Observou-se ainda outro tipo de sepultura, apresentando

\footnotetext{
${ }^{14}$ ARAÚJO et al., 1993.

15 TEIXEIRA, 1996.

16 VIEIRA, 2004.

${ }^{17}$ GUEDES, 2015; 2017: 275-287; LOPES, 2002.

${ }^{18}$ NUNES et al., 2006.

${ }^{19}$ SANTOS, 2005.

${ }^{20}$ MARQUES, 2000.

21 TENTE, 2007, 2010.

${ }^{22}$ LOURENÇO, 2007.

${ }^{23}$ RAMOS, 2012.

${ }^{24}$ NÓBREGA, 2004; TAVARES, 1999, 2007.

${ }^{25}$ ARRAIS, 2012.

${ }^{26}$ VALERA, 1990, 1993.

${ }^{27}$ SANTOS, 2013.

28 ÂNGELO, 2018: 71-87.

${ }^{29}$ PRATA, 2012.

30 TENTE, LOURENÇO, 2002: 239-258.

${ }^{31}$ CABRITA, 2008.
} 
diferença em relação às demais: vala inferior de planta antropomórfica e vala superior de formato subretangular onde ainda restavam pedras a delimitar. Um aspeto arqueologicamente relevante foi a identificação de uma vala de fundação, posteriormente saqueada, de orientação E-W que cortou parte destas sepulturas, possivelmente de cronologia Moderna. Apesar de apenas terem sido observados alguns vestígios estruturais, visto estas fundações terem sido posteriormente saqueadas na ampliação do templo, é visível que em dado momento existiria aqui uma igreja mais pequena com a fachada recuada em relação à atual. Os dois alinhamentos referidos, de orientação N-S, poderiam aparentemente configurar a zona do primitivo nártex. Observaram-se no limite NW do que seria este templo mais pequeno, provavelmente de Época Moderna, ainda vestígios do cunhal das fachadas oeste e norte. Identificaram-se ainda alguns embasamentos pétreos associados a este edifício que se prolongavam quer para norte quer para sul, e que se encontram hoje integrados sob as fundações do edifício atual, reaproveitados. Identificaram-se também sepulturas pós-medievais cortadas quer pela fachada do templo de época Moderna quer pela construção da torre sineira. Os últimos enterramentos terão sido realizados já no século XIX antes da proibição da utilização das naves das igrejas como espaços sepulcrais. Algumas destas sepulturas acabaram por ser cortadas aquando da instalação da plataforma que vai desde o nártex até cerca de $2 / 3$ da nave e pela escavação para a instalação de um degrau nesta área.

$\mathrm{Na}$ área $\mathbf{B}$ também foram identificadas algumas sepulturas embora apenas na zona correspondente ao altar-mor antigo, identificado pelos embasamentos pétreos postos

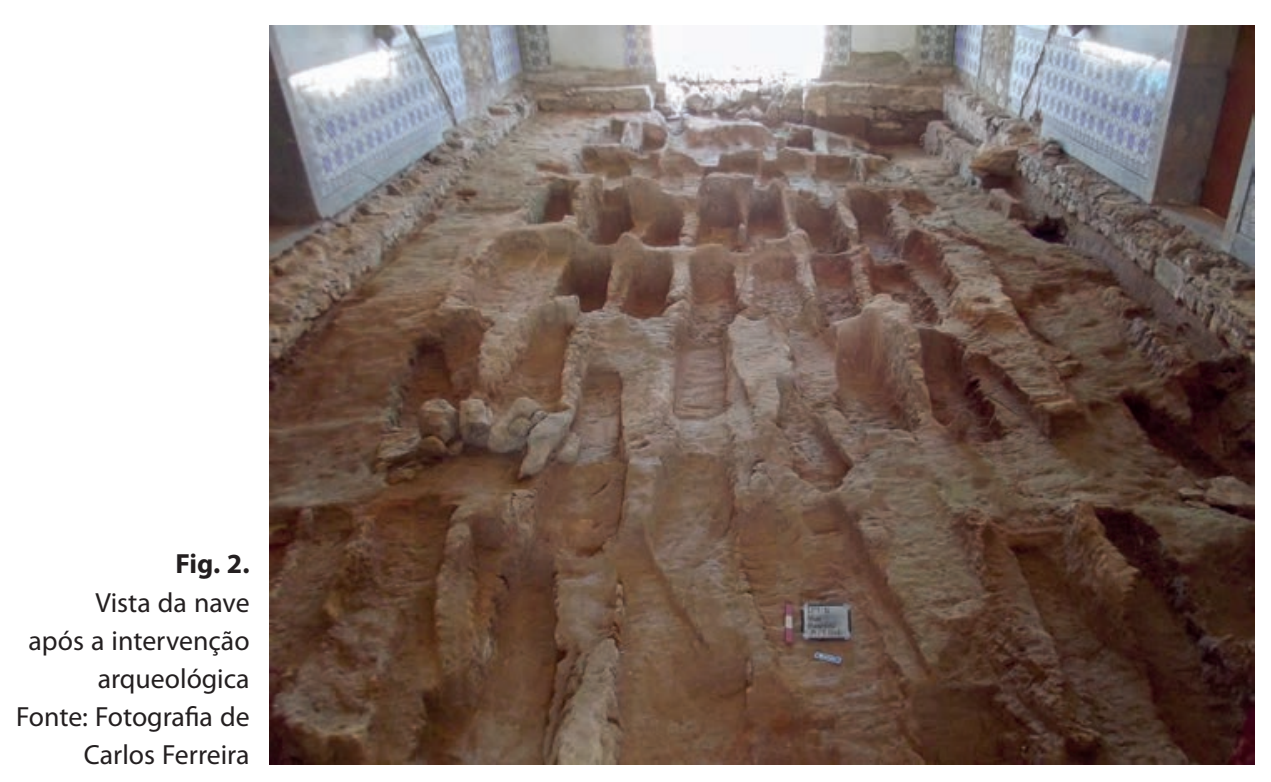


a descoberto. Algumas destas sepulturas aparentam corresponder a enterramentos de sacerdotes visto estarem sepultados com uma orientação divergente dos fiéis, ou seja, com a cabeça voltada para nascente. Observaram-se alinhamentos pétreos de diversas épocas, desde época Contemporânea formados por pedras argamassadas com cimento industrial - no local a SE da área B. Porém, nos flancos leste e sul desta área identificaram-me outras estruturas cronologicamente anteriores. No flanco leste os embasamentos pétreos eram formados por blocos de granito e xisto ligados entre si com uma argamassa à base de cal e areia. Não foi possível identificar a sua relação com o restante conjunto arquitetónico, devido à limitação da área intervencionada. No lado sul identificaram-se dois alinhamentos pétreos claramente relacionados entre si, numa zona onde o substrato geológico exibia um pendente assinalável. $\mathrm{Na}$ verdade, cada alinhamento pétreo aparenta corresponder a dois momentos distintos embora não seja possível identificar, com os dados obtidos, se as primeiras estruturas identificadas corresponderiam ao embasamento das estruturas posteriores ou se seriam momentos temporais distintos, com reaproveitamento posterior. De realçar a identificação no alinhamento pétreo de orientação E-W de vestígios de revestimento com reboco de cal e areia. Esta estrutura acabou por ser reaproveitada em época Contemporânea como alicerce da área de alargamento do altar-mor. Sob esta estrutura pétrea foi parcialmente identificada uma sepultura rupestre, não tendo sido escavada uma vez que não iria ser afetada pelas obras de engenharia previstas. A sul desta estrutura foram identificadas outras estruturas aparentemente anteriores às acima citadas. Destaca-se um alinhamento pétreo, de planta linear, de orientação WWS-EEN (posteriormente identificado também na área $\mathbf{C}$ ), assente parcialmente no substrato geológico, que constituirá a estrutura arqueológica mais antiga identificada, embora sem elementos que a possam balizar cronologicamente. Sobre este alinhamento foi posteriormente assente outro, embora já com a planta ligeiramente curva, provavelmente correspondendo ou a uma abside ou a um muro definidor de um adro antigo. Estará relacionado com uma estrutura orientada N-S cortada posteriormente pela estrutura acima descrita.

A área $\mathbf{C}$ caracteriza-se por ser um intenso espaço sepulcral, revelando a maior diacronia da intervenção realizada, visto aqui terem sido identificadas sepulturas desde época altimedieval até aos alvores do século XX. As sepulturas mais antigas observadas encontram-se escavadas no substrato geológico, perfeitamente orientadas no sentido E-W. Quase todas apresentam um patamar mais largo, onde nalgumas delas foram identificados blocos de granito e/ou xistos, possivelmente definidores da sepultura. Identificaram-se sepulturas de adultos e não-adultos enquadrados nesta tipologia. As sepulturas posteriores acabaram por cortar parte destas e encontram-se orientadas no sentido WWS-EEN. Acima já se fez referência a um alinhamento pétreo identificado com esta orientação, também identificado nesta área. Poderia corresponder a 
um templo antigo, a cerca de 5/6 metros a sul do atual, sendo que estas sepulturas poderiam estar relacionadas com esse espaço cultual, pois encontram-se praticamente alinhadas. Os enterramentos realizados nestes interfaces já apresentam os indivíduos depositados em caixão. Sucedem-se enterramentos já alinhados com a igreja atual e a anterior (Área A) que acabam por cortar parte das sepulturas acima referidas. O último momento sepulcral parece confinar o lado leste da área $\mathbf{C}$ (a partir da porta lateral) ao enterramento de não-adultos, tendo esta prática terminado nos inícios do século XX. Importa referir três aspetos: a) nalgumas destas sepulturas foram identificados fragmentos de telha industrial de época Contemporânea; b) a sul da Igreja, a cerca de 500 metros, passou a partir de 1912 a funcionar um novo cemitério; c) nos registos paroquiais o último óbito descrito data de $1911^{32}$. Identificaram-se várias ações antrópicas em época recente que afetaram algumas das sepulturas, para lá da intensa reutilização do local como espaço de enterramento.

$\mathrm{Na}$ área $\mathbf{D}$ observaram-se igualmente várias sepulturas alinhadas com a igreja. Os dados da escavação arqueológica permitem concluir que poderia existir uma plataforma no adro frontal da igreja que acabou por ser alterada com a instalação da escadaria na zona frontal. Este ato construtivo acabou por levar à destruição de várias sepulturas. Nesta área, à semelhança do observado no interior da igreja e no adro sul observou-se uma sucessiva reutilização do espaço, embora não tenham sido identificadas sepulturas rupestres antropomórficas.

Entre as distintas realidades identificadas destaca-se o momento de ocupação mais antigo neste sítio arqueológico, pela presença de dezassete sepulturas escavadas na rocha. Os resultados apresentados em seguida são ainda preliminares visto encontrar-se ainda em fase de estudo.

\subsection{Sepulturas escavadas na rocha}

Em virtude da sucessiva reutilização funerária do lugar eclesiástico apenas se observaram claramente cerca de dezassete sepulturas escavadas no substrato rochoso de época altimedieval. A contínua escavação de novas valas terá decerto destruído algumas de um conjunto que apresenta algumas variantes.

No essencial pode-se observar quatro tipos distintos de sepulturas escavadas na rocha.

No primeiro grupo, onde apenas foi identificado um exemplar, caracteriza-se pela identificação de uma sepultura rupestre de formato antropomórfico, no interior da nave. Nesta sepultura foi identificado o único indivíduo preservado, embora, aparente corresponder a uma possível reutilização. A altura do indivíduo sepultado é

${ }^{32}$ Disponível em <http://digitarq.adavr.arquivos.pt>. [Consult. 22 abr. 2016]. 


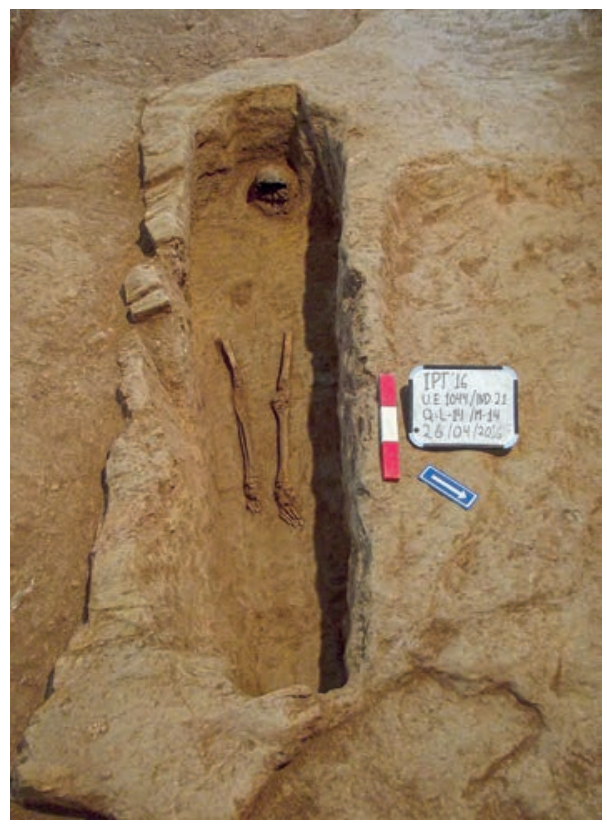

Fig. 3. Sepultura n. ${ }^{\circ} 21$

Fonte: Fotografia de Carlos Ferreira

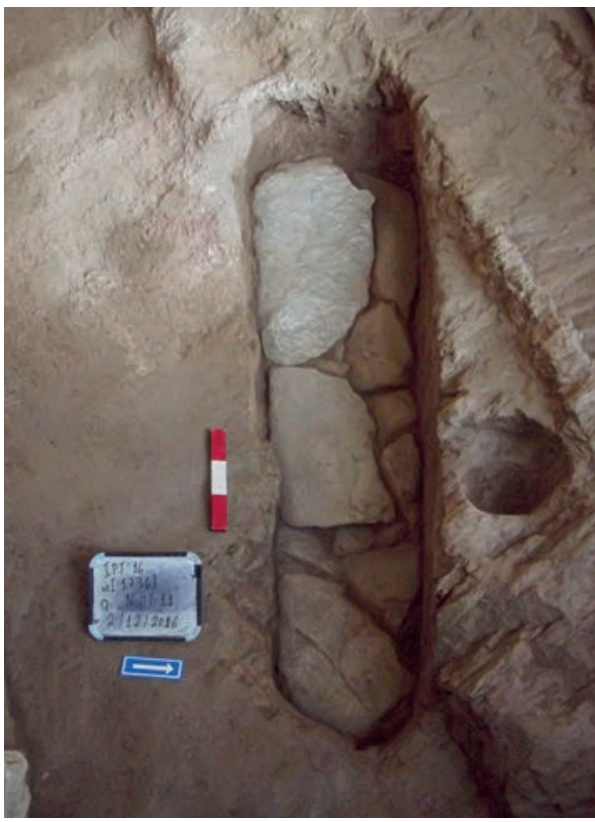

Fig. 4. Sepultura n. ${ }^{\circ} 49$

Fonte: Fotografia de Carlos Ferreira

claramente menor do que o comprimento da sepultura. A vala da sepultura encontra-se orientada com a igreja atual.

Num segundo grupo, foram observados dois exemplares, e constitui como relevante a utilização de lajes de xisto a preencherem o fundo da sepultura de forma

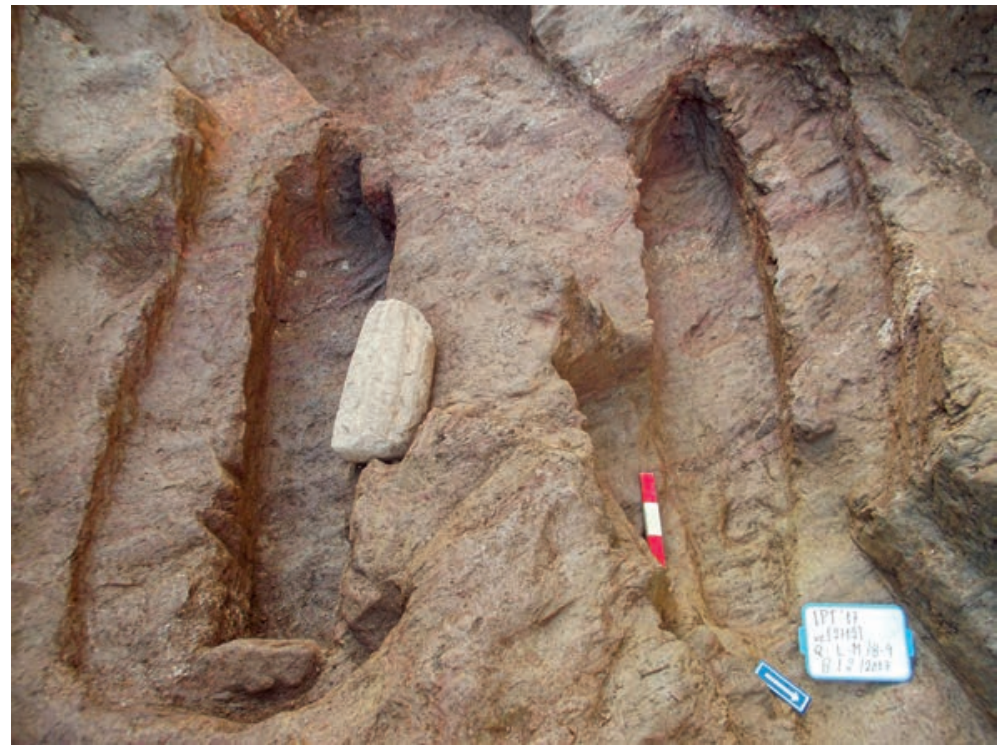

Fig. 5.

Sepultura n. 361 e

Sepultura n. 362

Fonte: Fotografia de

Carlos Ferreira 
Fig. 6.

Sepultura n. ${ }^{\circ} 299$

Fonte: Fotografia de Carlos Ferreira

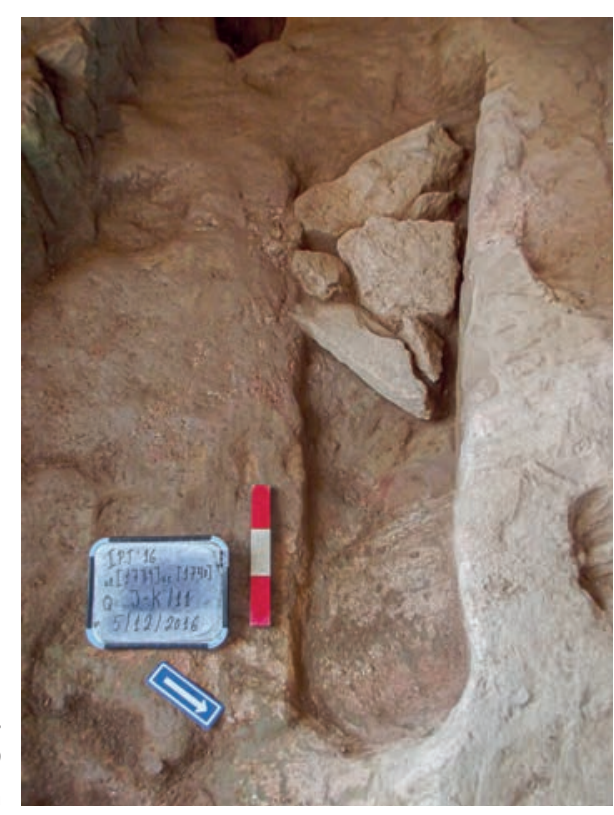

subtrapezoidal. O fundo de uma das sepulturas encontra-se bem preservado enquanto que noutra sepultura apenas já se observam algumas lajes de xisto. Apesar de apenas numa das valas se ter preservado relativamente bem o contorno, neste grupo de duas sepulturas a forma seria subtrapezoidal.

No terceiro grupo, mais numeroso com cerca de dez exemplares identificados, alguns bem preservados, outros menos, apresenta-se de tipo biforme, com um patamar inferior de sepultura com planta antropomórfica e um patamar superior, de planta subretangular, onde nalguns casos ainda se preservam alguns blocos pétreos.

A orientação das sepulturas do segundo e terceiro grupo são similares, rondando os $270^{\circ}$, divergentes com a planta do templo atual.

Num quarto grupo, englobam-se quatro sepulturas que pelo seu grau de destruição posterior não é possível o seu enquadramento no grupo I, II ou III (indeterminadas).

\section{CONSIDERAÇÕES FINAIS}

Os dados arqueológicos aqui apresentados, de forma ainda preliminar, pretendem contribuir para a caracterização do povoamento medieval de Travanca. Território este que se encontrava inserido nas Terras da Feira, importante polo no Entre-Douro-e- Vouga ${ }^{33}$, e que durante a Alta Idade Média se encontrava em permanente alteração.

${ }^{33}$ MATTOSO, KRUS, ANDRADE, 1989. 
Se é verdade que muitas vezes conhecemos melhor o mundo dos mortos, precisamente por esta forma tão característica peninsular de os enterrar, do que a paisagem que habitavam e cultivavam os vivos ${ }^{34}$, com os dados desta intervenção arqueológica permanecemos (ainda) com a falta de dados para conhecer o mundo dos vivos do período da Alta Idade Média em Travanca.

Porém, tal número de sepulturas observadas parece indicar que já se estaria perante uma forma de povoamento organizada, visto não se estar em presença de enterramentos isolados ou restritos a pequenos núcleos. O que dará pistas para compreender a paisagem altimedieval de Travanca, precisamente inserida nos importantes domínios das Terras da Feira, importante núcleo que liga o eixo Porto- Coimbra e o interior ao litoral.

Daí que poderá concluir-se que as formas de enterramento mais antigas identificadas já estariam inseridas numa organização social mais complexa, mais aglutinadora. Utilizando a tipologia que Inaki Martín Viso ${ }^{35}$ definiu, no caso do grupo «III» de Travanca estar-se-ia perante uma necrópole de sepulturas agrupadas alinhadas, com cerca de dez sepulturas, que seguem todas uma orientação comum (neste caso, cerca de $270^{\circ}$ ). Apesar de uma visão arqueológica certamente parcelar, devido à já referida sucessiva ocupação do espaço, não se identificam grupos isolados de sepulturas. Uma das questões que os dados da intervenção arqueológica não conseguiram ainda apurar é se esta necrópole altimedieval estaria associada a um templo, pois esta associação não pode ser direta. As observações da intervenção arqueológica, nomeadamente das várias estruturas / alinhamentos identificados no adro sul, não permitam definir, com certeza, a existência de um templo. No território português se há casos em que isso sucede, por exemplo na Beira Interior, como São Pedro de Lourosa, Moreira de Rei, Trancoso, Numão, noutros tal não se verifica, como é o caso de São Gens (Celorico da Beira).

Outra das questões que fica por resolver é a sua cronologia. Efetivamente, não há dados arqueológicos que permitam balizar a ocupação mais antiga na igreja paroquial, plasmada, numa dezena de sepulturas escavadas na rocha conservadas.

Ainda assim, a relevância dos contextos arqueológicos observados sugere que Travanca, ainda antes de ser paróquia, pudesse já ocupar um lugar de relevo nas Terras da Feira, ao observar-se uma ocupação altimedieval, plasmada nas diversas sepulturas escavadas na rocha.

\footnotetext{
${ }^{34}$ MARTÍN VISO, 2012a: 3

${ }^{35}$ MARTÍN VISO, 2012a: 3-45; 2012b: 165-187.
} 


\section{BIBLIOGRAFIA}

ÂNGELO, Maria João (2018). Sepulturas escavadas na rocha na envolvente da Torre dos Namorados em Quintas da Torre, Fundão. «EBVROBRIGA, História, Arqueologia, Património, Museologia».9, 71-87.

ARAÚJO, Teresa et al. (1993). Antropologia de duas necrópoles medievais do Norte de Portugal: Fão e Chafé, um exemplo de duas escavações "antagónicas». "Trabalhos de Antropologia e Etnologia». 33: 1-2, 431-447.

ARRAIS, A. J. do N. (2012). Arqueologia das terras de Besteiros: contributos para a carta do património arqueológico do concelho de Tondela. Coimbra: Faculdade de Letras da Universidade de Coimbra. Dissertação de mestrado.

BARROCA, Mário (1987). Necrópoles e sepulturas medievais de Entre-Douro-e-Minho (Séc. V a XV). Porto: Faculdade de Letras da Universidade do Porto. Dissertação para Provas Públicas de Aptidão pedagógica e Capacidade Científica.

BARROCA, Mário (2010-2011). Sepulturas escavadas na rocha de Entre Douro e Minho. «Portvgalia». Nova série. 31-32, 115-182.

CABRITA, Luís Miguel Guerreiro (2008). Povoamento Alto Medieval de São Bartolomeu de Messines. Lisboa. Faculdade de Ciências Sociais e Humanas da Universidade Nova de Lisboa. Dissertação de Mestrado.

FONTINHA, Artur; FERREIRA, Carlos; MELO, Linda (2017). Recuperação e Ampliação da Igreja de Travanca em Santa Maria da Feira. Matosinhos. [Relatório preliminar].

GONÇALVES, António Nogueira (1981). Inventário Artístico de Portugal: Distrito de Aveiro Zona do Norte. Lisboa: Academia Nacional de Belas-Artes.

GUEDES, César (2015). A sul do Douro: percurso pelas sepulturas escavadas na rocha entre os rios Távora e Cabrum. Porto: Faculdade de Letras da Universidade do Porto. Dissertação de Mestrado.

GUEDES, César (2017). As sepulturas escavadas na rocha e as leituras possíveis de um território a sul do Douro. In ROSAS, Lúcia; SOUSA, Ana; BARREIRA, Hugo, coord. Genius Loci, Lugares e Significados / Places and Meanings. Porto: CITCEM, vol. 2, pp. 275-287.

INVENTARIO do Património Arquitetónico n. ${ }^{\circ} 00030959$. [Consult. 14 abr. 2016]. Disponível em <http:// www.monumentos.gov.pt/site/app_pagesuser/SIPA.aspx?id=30959>.

LOPES, Isabel Alexandra Resende Justo (2002). Contextos Materiais da Morte durante a Idade Média: as Necrópoles do Douro Superior. Porto: Faculdade de Letras da Universidade do Porto. Dissertação de Mestrado.

LOURENÇO, Sandra (2007). O povoamento alto-medieval entre os rios Dão e Alva. "Trabalhos de Arqueologia». 50.

MARQUES, Jorge Adolfo de Meneses (2000). Sepulturas escavadas na rocha na região de Viseu, Viseu: Ed. do Autor.

MARTÍN VISO, Iñaki, (2012a). Paisajes sagrados, paisajes eclesiásticos. De la necrópolis a la parroquia en el centro de la Península Ibérica. «Reti Medievali. Rivista». 12: 2, 3-45.

MARTÍN VISO, Iñaki (2012b). Enterramientos, memoria social y paisaje en la alta edad media: propuestas para un análisis de las tumbas excavadas en roca en el centro oeste de la Península Ibérica. «Zephyrus». 69, 165-187.

MATTOSO, José; KRUS, Luís; ANDRADE, Amélia Aguiar (1989). O Castelo e a Feira: séculos XI a XIII. Lisboa: Editorial Estampa.

NÓBREGA, Pedro Pina (2004). Sepulturas escavadas na rocha da freguesia de Quintela da Azurara. Lisboa: Faculdade de Letras da Universidade de Lisboa.

NUNES, M. et al. (2006). Sepulturas medievais escavadas na rocha no concelho de Lousada: o cemitério rupestre do Irmeiro (Boim). «OPPIDUM. Revista de Arqueologia, História e Património». 1. 
PRATA, Sara (2012). As Necrópoles alto-medievais da Serra de São Mamede (Concelhos de Castelo de Vide e Marvão). Lisboa: Faculdade de Ciências Sociais e Humanas da Universidade Nova de Lisboa. Dissertação de Mestrado.

RAMOS, Mafalda (2012). Para o estudo de Montemuro na Idade Média (Sécs. V-XII): Entre a serra e o curso médio do Bestança. Coimbra: Faculdade de Letras da Universidade de Coimbra. Dissertação de Mestrado.

SANTOS, Maria José Ferreira dos (2005). A Terra de Penafiel na Idade Média. Estratégias de Ocupação do Território (875-1308). «Cadernos do Museu». 10, 5-100 [CD Rom].

SANTOS, Vera (2013). Intervenção arqueológica no Alto do Calvário, Miranda do Corvo: a necrópole rupestre. «Medievalista [Online]». 14. Disponível em <http://journals.openedition.org/medievalista/383> [Consult. 19 abr. 2017].

TAVARES, António (1999). Sepulturas escavadas na rocha no Concelho de Mangualde. Mangualde: [Edição do autor].

TAVARES, António (2007). Sepulturas escavadas na rocha das freguesias de Cunha Baixa e Espinho (Mangualde). Contributos para a História da Alta Idade Média numa micro-região. Mangualde: Grupo Cultural e Recreativo de Santo Amaro de Azurara.

TEIXEIRA, Ricardo (1996). De Aquae Flaviae a Chaves. Povoamento e organização do território entre a Antiguidade e a Idade Média. Porto: Faculdade de Letras da Universidade do Porto. Dissertação de Mestrado

TENTE, Catarina, (2007). A ocupação alto-medieval da encosta noroeste da Serra da Estrela. Lisboa: Instituto Português de Arqueologia. (Trabalhos de Arqueologia; 47).

TENTE, Catarina (2010). Arqueologia Medieval Cristã no Alto Mondego. Ocupação e exploração do território nos séculos $V$ a XI. Lisboa: Faculdade de Ciências Sociais e Humanas da Universidade Nova de Lisboa. Tese de Doutoramento.

TENTE, Catarina; LOURENÇO, Sandra (1998). Sepulturas medievais escavadas na rocha dos concelhos de Carregal do Sal e Gouveia: estudo comparativo. «Revista Portuguesa de Arqueologia». 1: 2, 191-218.

TENTE, Catarina; LOURENÇO, Sandra (2002). Sepulturas medievais do distrito de Évora. "Revista Portuguesa de Arqueologia». 5: 1, 239-258.

VALERA, António (1990). Sepulturas escavadas na rocha do concelho de Fornos de Algodres. Fornos de Algodres: G.A.F.A.L.

VALERA, António Carlos (1993). Património arqueológico do Concelho de Fornos de Algodres, $1^{a}$ fase da carta e roteiro. Lisboa: Associação de Promoção Social Cultural e Desportiva de Fornos de Algodres.

VIEIRA, Marina Afonso (2004). Alto Paiva. Povoamento nas épocas romana e alto-medieval. «Trabalhos de Arqueologia». 36. 



\title{
AS SEPULTURAS ESCAVADAS NA ROCHA ENTRE OS RIOS TÁVORA E CABRUM. TIPOLOGIAS, IMPLANTAÇÃO E AS LEITURAS POSSIIVEIS DO TERRITÓRIO
}

\author{
CÉSAR GUEDES*
}

Resumo: Partindo da análise das sepulturas escavadas na rocha existentes entre os rios Távora e Cabrum, procura-se enquadrar estes monumentos num contexto de dinâmica de ocupação do território durante a Alta Idade Média. Pretende-se relacionar a implantação destes sepulcros e as suas diferentes tipologias com os elementos estruturadores da paisagem: vestígios de habitats, vias, templos e estruturas militares. Procura-se assim observar de que forma elas se articulam ou refletem o período conturbado vivido entre os séculos VIII e XI, quando, durante o processo da Reconquista Cristã, se assistiram a profundas alterações tanto na reorganização territorial como no quadro mental das populações e que culminará numa nova forma de organizar a sociedade: as Terras.

Palavras-chave: Sepulturas escavadas na rocha; Necrópoles; Povoamento; Alta Idade Média.

Abstract: In this paper we study the existing rock-cut graves in the south area of the Douro river. These early medieval graves are framed in a context of dynamic occupation and exploitation of the territory. Their landscape positioning is related and compared to the known archaeological sites of habitat, the religious buildings and the military structures. We seek to observe how these funerary monuments reflect or articulate with the profound changes that have taken place in both the territorial reorganization as in the people's mindset. These modifications to the population's modus vivendi are particularly intensive between the 8th and 11th centuries, during the Reconquista, and culminate in a new way of organizing society: the Terras.

Keywords: Rock-cut graves; Necropolis; Settlement; Early Middle Ages.

\section{APRESENTAÇÃO ${ }^{1}$}

Entre as diferentes manifestações funerárias da Alta Idade Média, as sepulturas escavadas na rocha constituem um dos vestígios arqueológicos mais abundantes e visíveis. Estes monumentos de configuração antropomórfica ou geométrica encontram-se presentes um pouco por toda a Europa, mas concentram-se sobretudo no sul do continente, em países como Portugal, Espanha, França e Itália, existindo também exemplares em Inglaterra, Grécia e até na setentrional Suécia² ${ }^{2}$.

\footnotetext{
* CITCEM. Email: cesarlguedes@gmail.com.

${ }^{1}$ Os dados e as leituras apresentadas resultam da dissertação de mestrado A sul do Douro: percurso pelas sepulturas escavadas na rocha entre os rios Távora e Cabrum, apresentada pelo autor à Faculdade de Letras da Universidade do Porto, em 2015. GUEDES, 2015.

2 BOLÒS i MASCLANS, PAGÈS i PARETAS, 1982: 62.
} 
O estudo das sepulturas escavadas na rocha e a análise das questões relacionadas com a sua localização, organização e a tipologia de espaço funerário onde se inserem, revestem-se de particular interesse. A sua análise certamente contribuirá para uma melhor compreensão dos ritmos de desenvolvimento ocorridos entre o mundo romano e tardo-antigo e a implementação do modelo de organização paroquial e da formação das aldeias, com a polarização de espaços cemiteriais em torno dos templos.

A análise da articulação entre as diferentes tipologias de espaços funerários e os locais de habitat, os espaços de culto e as estruturas de cariz militar ou defensivo, constitui uma ferramenta útil para o melhor entendimento da evolução da organização política, administrativa e religiosa do território.

Tendo como base estas premissas, procurou-se identificar e inventariar as sepulturas escavadas na rocha existentes na área geográfica situada entre os rios Távora e Cabrum, tentando sempre que possível enquadrar estes monumentos funerários num contexto de dinâmica de ocupação e exploração do território em época alto-medieval. Nesse sentido, a apresentação e descrição dos sepulcros procurou ter em consideração as questões relacionadas com a sua organização na paisagem, as diferentes tipologias e os seus particularismos, bem como a sua orientação. Sempre que possível procurou-se integrar os monumentos num contexto paisagístico, de análise do território, relacionando-os com os sítios arqueológicos de habitat conhecidos e/ ou vias de comunicação hipoteticamente coevas.

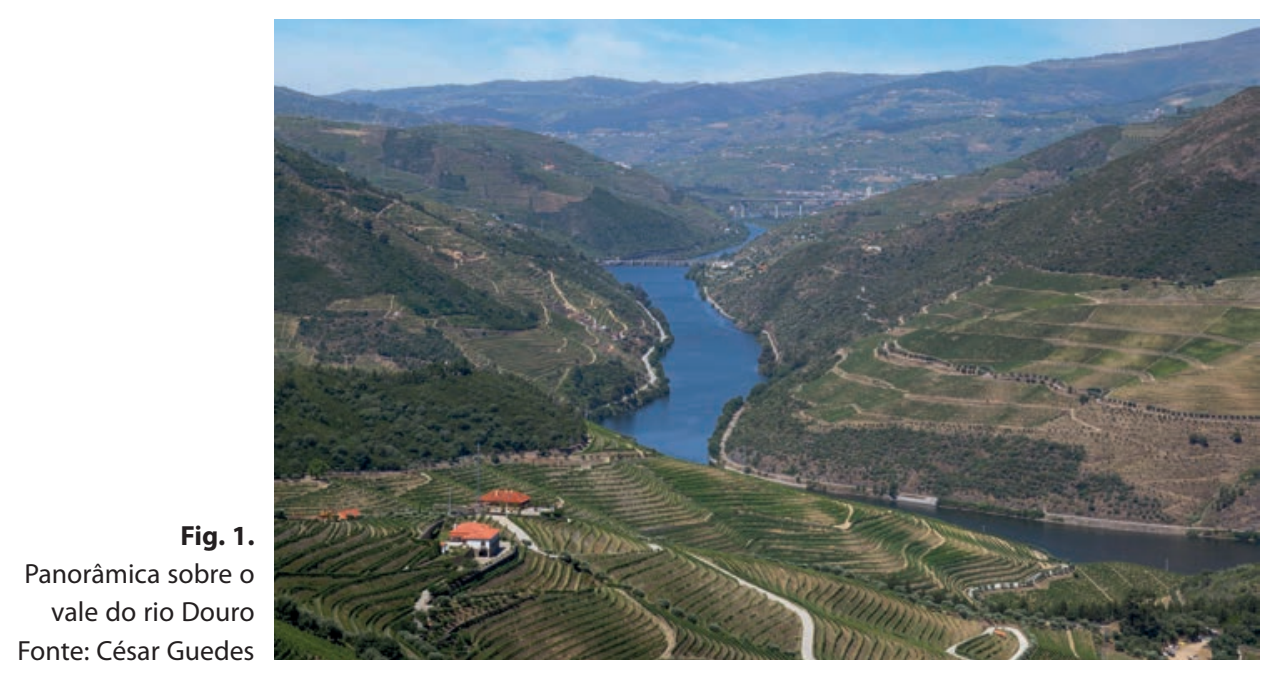

O estudo das sepulturas abertas na rocha apresenta algumas dificuldades que condicionam os trabalhos de investigação e que podem constituir, à partida, um entrave sobre o esclarecimento destes monumentos e das populações que os construíram e utilizaram. 
A ausência quase total de estratigrafia que permita associar estes monumentos a contextos arqueológicos precisos, bem como a ausência de espólio arqueológico e vestígios osteológicos preservados, fruto de destruições/violações e exposição às condições meteorológicas, constituem as principais dificuldades ao estudo das sepulturas rupestres. Estes dois fatores são, grosso modo, os principais responsáveis por não se conseguir balizar, com precisão, o âmbito cronológico da construção da sepultura e do seu período de utilização. Uma das formas utilizadas para superar estas dificuldades consiste na procura de paralelos em sítios arqueológicos de outras áreas peninsulares onde, fruto de condicionalismos muito particulares, foram encontradas sepulturas escavadas na rocha intactas e com o seu conteúdo preservado, permitindo a obtenção de datações através de análises radiocarbónicas.

Reconhecendo a importância que os fatores regionais e as especificidades locais imprimem no desenvolvimento ou adoção de novos usos ou costumes, estamos em crer que os resultados das datações radiocarbónicas que ao longo dos anos têm vindo a ser realizadas não se afastarão demasiadamente da realidade vivida na região duriense em estudo.

O estudo e levantamento das sepulturas abertas na rocha por si só não permitem responder à totalidade das questões dos investigadores sobre a Alta Idade Média e as transformações vividas naquela época. Porém, constituem uma ferramenta excecional para a compreensão da evolução do povoamento e da exploração do território, entreabrindo uma janela para o quadro mental vigente entre as populações.

\section{A SUL DO DOURO: AS ESTAÇÕES ARQUEOLÓGICAS}

A complexa zona de montanha que se estende na margem sul do rio Douro e engloba os concelhos de Tabuaço, Armamar, Tarouca, Lamego e Resende apresenta um conjunto de 26 estações arqueológicas com 88 sepulturas escavadas na rocha (Mapa 1).

As estações arqueológicas com sepulturas escavadas na rocha identificadas constituem apenas uma amostra do que seria a realidade funerária nesta região durante a Alta Idade Média. As transformações da paisagem promovidas pelos intensos trabalhos agrícolas e pela extração de pedra terão seguramente destruído ou soterrado muitos monumentos. Os numerosos trabalhos de prospeção arqueológica que têm vindo a ser realizados no âmbito de estudos de impacto ambiental e de acompanhamentos arqueológicos da construção de grandes obras, tais como aerogeradores ou linhas de alta e muito alta tensão, permitirão seguramente identificar não só outras sepulturas escavadas na rocha, mas também novos sítios arqueológicos e outros locais de habitat.

Os núcleos funerários identificados distribuem-se geograficamente da seguinte forma: no limite leste, correspondendo grosso modo ao concelho de Tabuaço, identificaram-se 9 estações com 45 sepulturas. De salientar que a região em torno de 
Sendim apresenta uma concentração elevada de necrópoles e sepulturas (6 estações com 40 monumentos), e que as restantes estações deste concelho não se localizam muito afastadas desta zona.

O concelho de Armamar tem apenas dois sítios com sepulturas escavadas na rocha: a necrópole da Tapada do Abade em Goujoim, com 9 sepulturas e a Quinta da Silveira, em Travanca, com 3 monumentos (Mapa 1, Est. n. ${ }^{\text {os }} 10$ e 11).

Em Tarouca os espaços cemiteriais distribuem-se por 4 locais com um total de 6 monumentos (Mapa 1, Est. n. ${ }^{\text {os }} 12$; 13; 14 e 15).

Em Lamego registou-se uma concentração de sepulturas na área envolvente à povoação de Lazarim, com quatro sepulcros, um de cabeceira dupla (Mapa 1, Est. n. ${ }^{\text {os }} 16,17$ e 18). As intervenções arqueológicas que têm decorrido na cidade de Lamego revelaram a existência de mais duas sepulturas escavadas na rocha no bairro do Castelo (Mapa 1, Est. n. ${ }^{\circ}$ 19).

A região a oeste da serra das Meadas, inserida no atual concelho de Resende, apresenta uma distribuição de sepulturas escavadas na rocha por 7 locais distintos, perfazendo um total de 19 monumentos. A necrópole da Mogueira, em S. Martinho de Mouros (Mapa 1, Est. n. ${ }^{\circ}$ 21), é a mais numerosa, com 9 sepulcros.

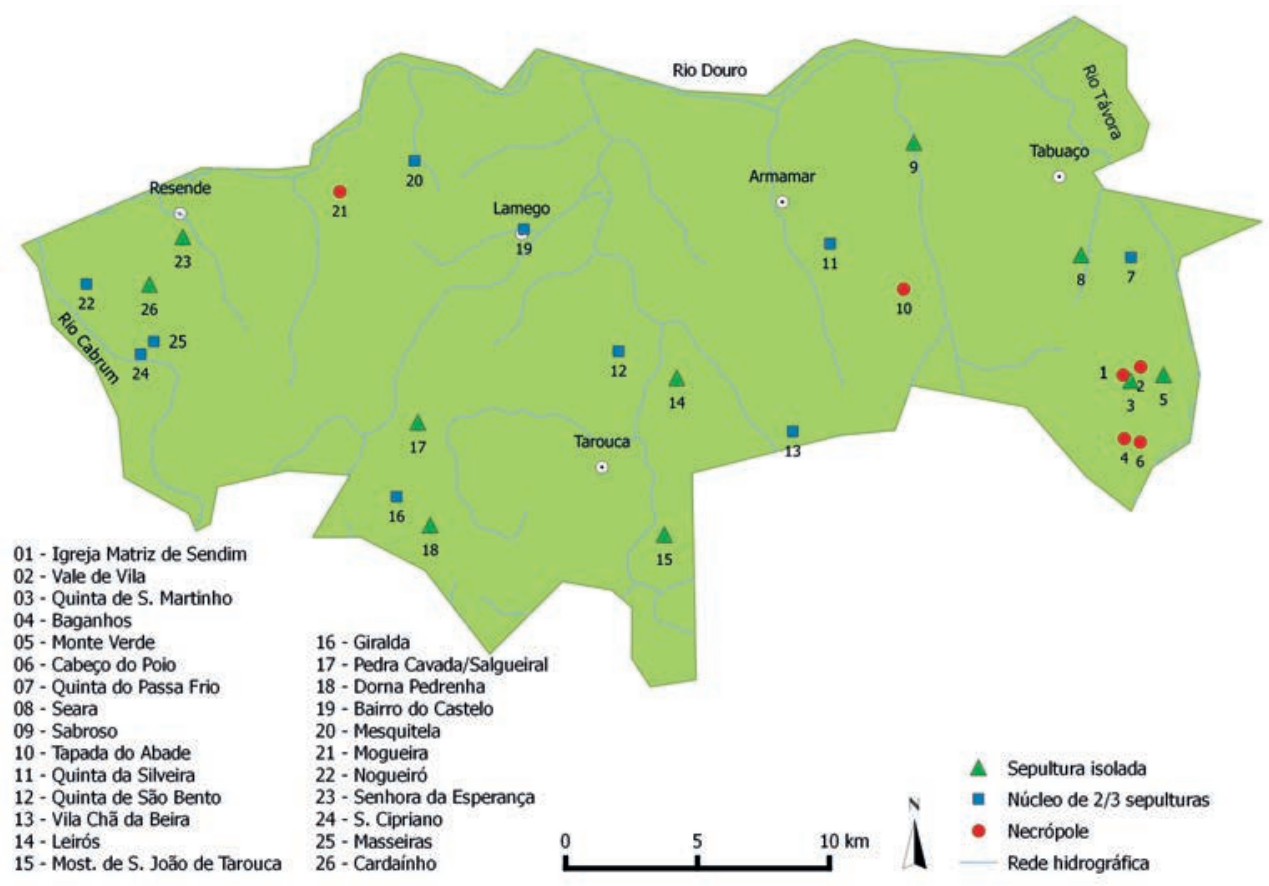

Mapa 1. Mapa com a localização dos núcleos funerários identificados Fonte: César Guedes 
Os núcleos funerários distribuem-se pela área de estudo com algumas lacunas, sobretudo nas áreas mais montanhosas como a serra das Meadas, a serra de Santa Helena, os cumes altos de S. Martinho das Chãs ou o maciço planáltico granítico de Chavães, em Tabuaço. $\mathrm{O}$ relevo destas áreas, muito montanhoso e com difíceis condições de habitabilidade, por vezes com altitudes acima dos 1000 metros, terá condicionado a fixação de populações e consequentemente a utilização de sepulcros escavados na rocha. De facto, observa-se que a grande maioria das estações se implanta a cotas que variam entre os 400 e os $800 \mathrm{~m}$, havendo, no entanto, algumas sepulturas na área de Lazarim (Lamego) que se implantam a altitudes de 940 e 1000 m (Mapa 1).

A zona geologicamente correspondente ao complexo Xisto-Grauváquico, que em grande parte é coincidente com a região demarcada do vinho do Porto, apresenta apenas uma sepultura escavada na rocha (Mapa 1, Est. n. ${ }^{\circ}$ 9). Esta quase total ausência de sepulcros poderá relacionar-se com os arroteamentos e a construção dos socalcos para o plantio da vinha, que terão seguramente destruído ou ocultado os monumentos. De igual modo se verifica que a transformação da paisagem para plantio de pomares, sobretudo de maçã, nas zonas de Tarouca e Armamar, poderá também ser uma das causas para o reduzido número de estações identificadas nestas áreas.

A localização das estações arqueológicas relaciona-se sobretudo com as bacias hidrográficas dos rios Távora, Tedo, Varosa, Balsemão e Cabrum, implantando-se nas proximidades de linhas de água tributárias dos principais rios.

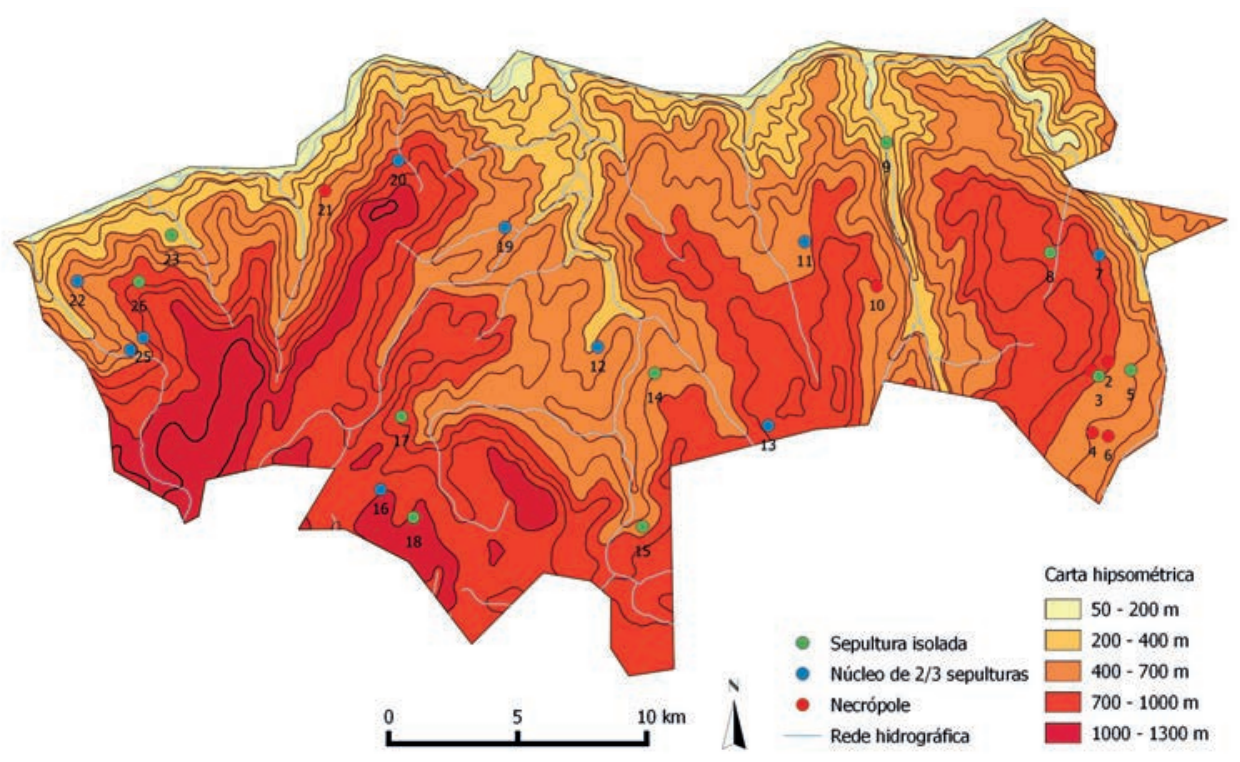

Mapa 2. Mapa com a carta hipsométrica e a localização dos núcleos funerários identificados Fonte: César Guedes 


\section{AS SEPULTURAS ESCAVADAS NA ROCHA}

O conjunto sepulcral identificado é constituído por 88 monumentos. A maioria tem planta não antropomórfica, com 49 exemplares desta tipologia, correspondendo a $56 \%$ do total de sepulturas. Os túmulos antropomórficos são menos numerosos e constituem $28 \%$ do conjunto contando apenas com 25 exemplares. As sepulturas indeterminadas são14 e correspondem aos restantes $16 \%$.

A maioria dos túmulos foi criada para acolher indivíduos adultos variando as suas dimensões entre o 1,70 e $2 \mathrm{~m}$ de comprimento e entre 0,40 e 0,70 m de largura. As sepulturas de indivíduos subadultos são apenas 5 e as suas dimensões variam entre os 0,60 e os $1,14 \mathrm{~m}$ de comprimento e 0,26 e os $0,34 \mathrm{~m}$ de largura.

\subsection{Sepulturas não antropomórficas}

As sepulturas não antropomórficas são 49 e dividem-se em três subtipologias: as sepulturas de planta retangular, que contam com 23 exemplares e estão presentes em 7 estações (Est. n. ${ }^{\circ}$ 2, 4, 7, 8, 10, 13 e 21); os de planta trapezoidal, com 8 sepulcros dispersos por 6 espaços funerários (Est. n. ${ }^{o s} 10,14,16,18,21$ e 24), e as sepulturas de configuração ovalada, cujos 13 exemplares se encontram presentes em 9 sítios (Est.

Fig. 2.

Sepultura não antropomórfica de configuração trapezoidal (S. Cipriano, Est. n. 24)

Fonte: César Guedes

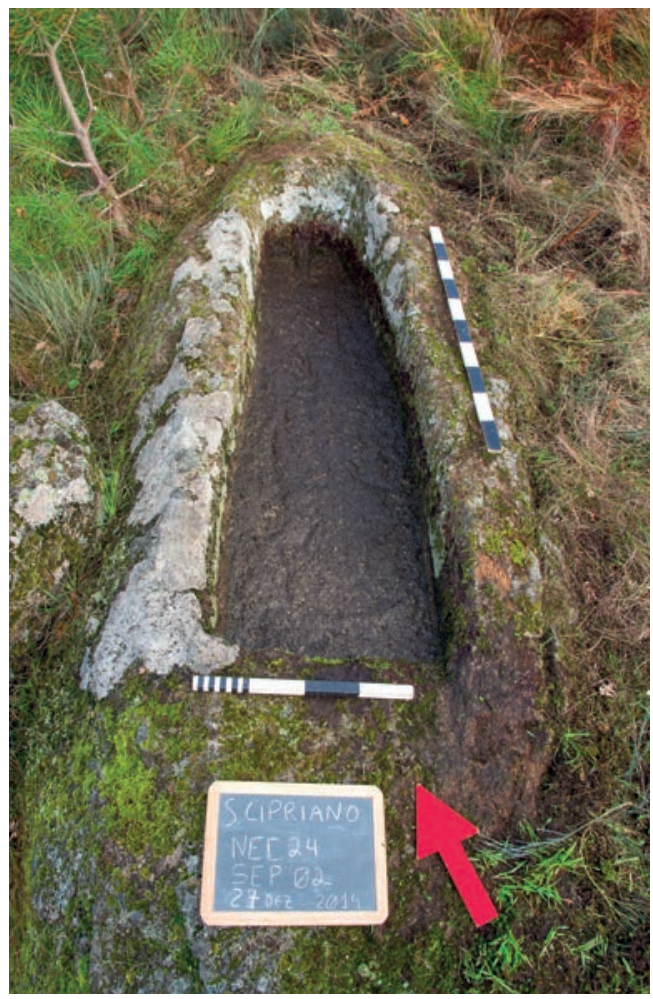


n. ${ }^{\text {s }} 4,7,10,11,13,21,22,23$ e 25$)$. As 5 sepulturas indeterminadas correspondem aos exemplares que não foram localizados em campo e não permitem aferir a sua planta, ou que se encontravam severamente destruídos. O sepulcro da Quinta de S. Martinho (Est. n. ${ }^{\circ} 3$ ) e os dois monumentos de Mesquitela (Est. n. ${ }^{\circ} 20$ ) correspondem aos que não se puderam observar. As sepulturas n. ${ }^{\text {os }} 6$ e 7 da Mogueira (Est. n. ${ }^{\circ}$ 21) são as que se encontram quase totalmente destruídas.

As sepulturas de configuração não antropomórfica estão presentes em diferentes tipologias de espaço funerário. Entre as sepulturas isoladas, contam-se 5 destes monumentos. A sepultura inacabada de Seara, de planta retangular (Est. n. ${ }^{\circ}$ ), as sepulturas trapezoidais de Leirós e de Dorna Pedrenha (Est. n. ${ }^{\text {os }} 14$ e 18, respetivamente) e a sepultura de Nossa Senhora da Esperança, de planta ovalada (Est. n. ${ }^{\circ} 23$ ). A sepultura da Quinta de S. Martinho (Est. n. ${ }^{\circ}$ 3), de planta indeterminada integra também esta tipologia de espaço funerário.

Os conjuntos de 2 ou 3 sepulturas são também maioritariamente constituídos por sepulturas de configuração geométrica. Entre os 8 núcleos sepulcrais desta tipologia (Est. n. ${ }^{\text {os }} 7,11,13,16,20,22,24$ e 25), verifica-se a existência de 14 sepulturas não antropomórficas. As sepulturas presentes nas estações da Quinta de Passa Frio e em Vila Chã da Beira (Est. n. ${ }^{\text {os }} 7$ e 13) são duas e têm planta retangular; os 4 monumentos que se encontram nas estações de Giralda e S. Cipriano (Est. n. ${ }^{\text {os }} 16$ e 24) são de configuração trapezoidal e as sepulturas de planta ovalada que integram os núcleos de 2 ou 3 monumentos são 6 e situam-se na Quinta de Passa Frio (2 exemplares), na Quinta da Silveira, em Vila Chã da Beira, Nogueiró e em

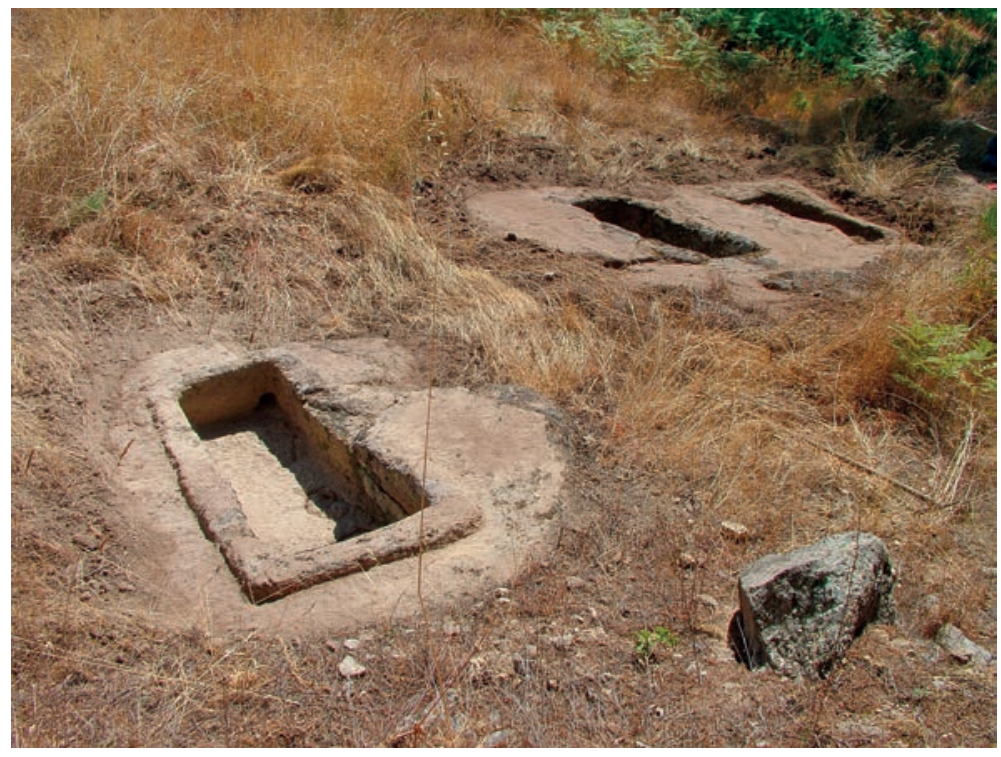

Fig. 3.

Sepulturas de planta retangular da necrópole de Baganhos (Est. n. ${ }^{4)}$ Fonte: César Guedes 


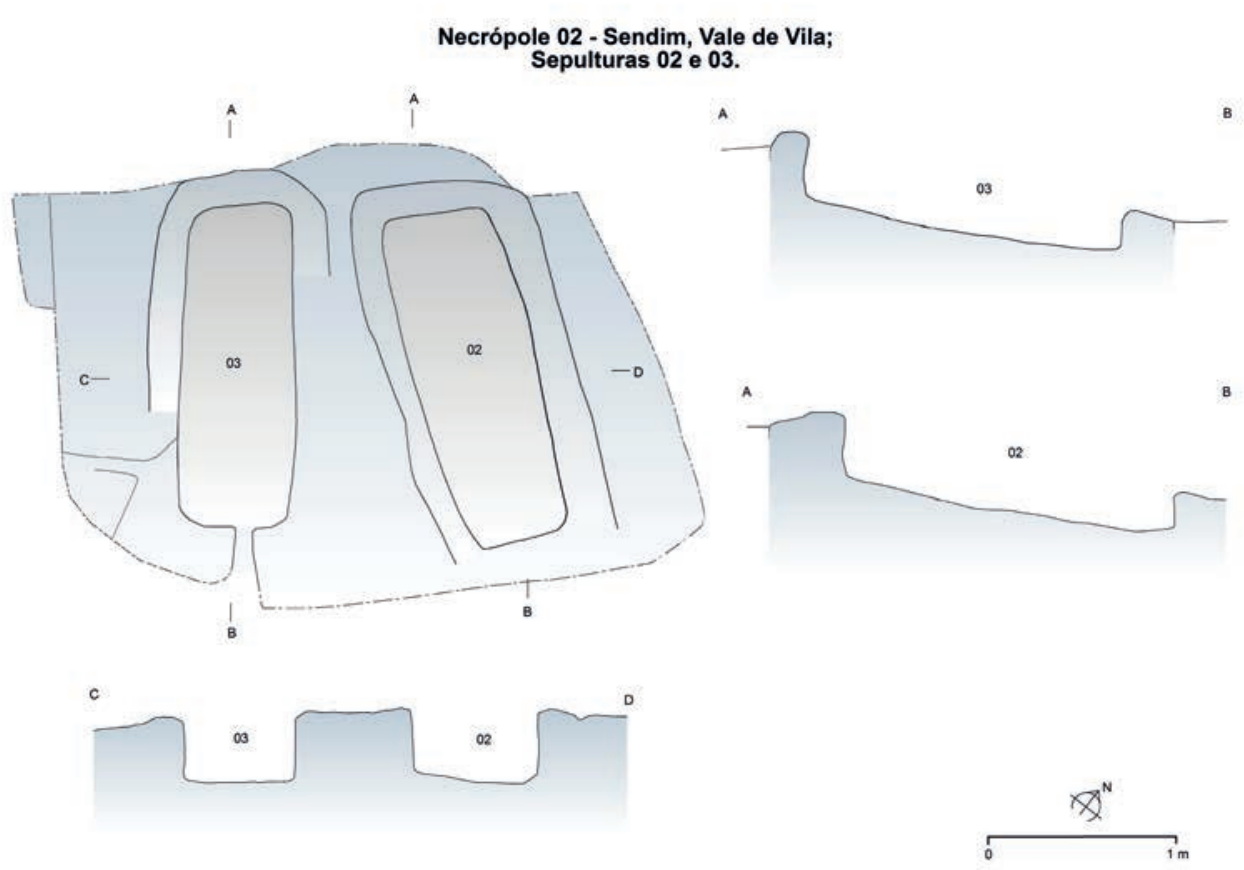

Fig. 4. Planta das sepulturas 2 e 3 da necrópole de Vale de Vila (Est. n. ${ }^{\circ} 02$ ) Fonte: Ana Maria Oliveira e César Guedes

Masseiras (Est. n. ${ }^{\text {os }}$ 7, 11, 13, 22 e 25). As sepulturas de Mesquitela (Est. n. ${ }^{\circ}$ 20) integram também esta tipologia de espaço funerário, apesar de não terem sido identificadas em campo e a tipologia da sua planta não ser conhecida, apenas se sabe que são de configuração "pouco definida, cantos arredondados, fundo plano ${ }^{3}$ (Sep. 1 e 2 da Est. N. ${ }^{\circ} 20$ ).

As necrópoles são a tipologia de espaço funerário com maior número de sepulturas não antropomórficas, integrando 30 monumentos em 4 espaços funerários. A necrópole de Vale de Vila (Est. n. ${ }^{\circ}$ 2) é composta por 8 sepulturas, todas de planta retangular. A estação de Baganhos (Est. n. ${ }^{\circ}$ 4) é constituída por 3 sepulturas de planta retangular e uma ovalada. Em Goujoim, na necrópole da Tapada do Abade (Est. n. ${ }^{\circ} 10$ ), entre as 8 sepulturas não antropomórficas, 6 têm planta retangular, 1 é ovalada e outra é trapezoidal. A necrópole da Mogueira (Est. n. $\left.{ }^{\circ} 21\right)$ é constituída por 9 sepulcros, 4 são de planta ovalada, 2 são retangulares, 1 é trapezoidal e 2, devido ao seu grau de destruição, são de configuração indeterminada. 


\subsection{Sepulturas antropomórficas}

Os túmulos antropomórficos são representados por 25 exemplares distribuídos por 11 estações. Apresentam maioritariamente planta trapezoidal e as principais diferenças entre estes sepulcros concentram-se sobretudo na zona da cabeceira, onde a solução mais frequente é a que utiliza o arco ultrapassado, logo seguida das cabeceiras retangulares e trapezoidais.

Entre as 25 sepulturas de configuração antropomórfica registadas, constata-se que a maioria apresenta planta trapezoidal, com 8 sepulturas concentradas junto da igreja matriz de Sendim (Est. n. ${ }^{\circ}$ ) e 5 exemplares distribuídos pelas estações n. ${ }^{\circ s} 10$; $11 ; 12 ; 15$ e 25. Os 3 monumentos de planta retangular localizam-se exclusivamente junto da igreja de Sendim (Est. n. ${ }^{\circ}$ ) e as sepulturas de planta ovalada distribuem-se por duas localizações com um exemplar cada: a sepultura de Pedra Cavada/Salgueiral (Est. n. ${ }^{\circ}$ 17) e o sepulcro de Nogueiró (Est. n. ${ }^{\circ} 22$ ). As restantes sepulturas de tipologia antropomórfica são de planta indeterminada e correspondem a 6 exemplares distribuídos pelas estações n. ${ }^{\text {os }} 6,19$ e 26, que não se observaram no terreno, e pela sepultura n. ${ }^{\circ} 13$ da igreja matriz de Sendim que se encontrava destruída (Est. n. ${ }^{\circ} 1$ ).

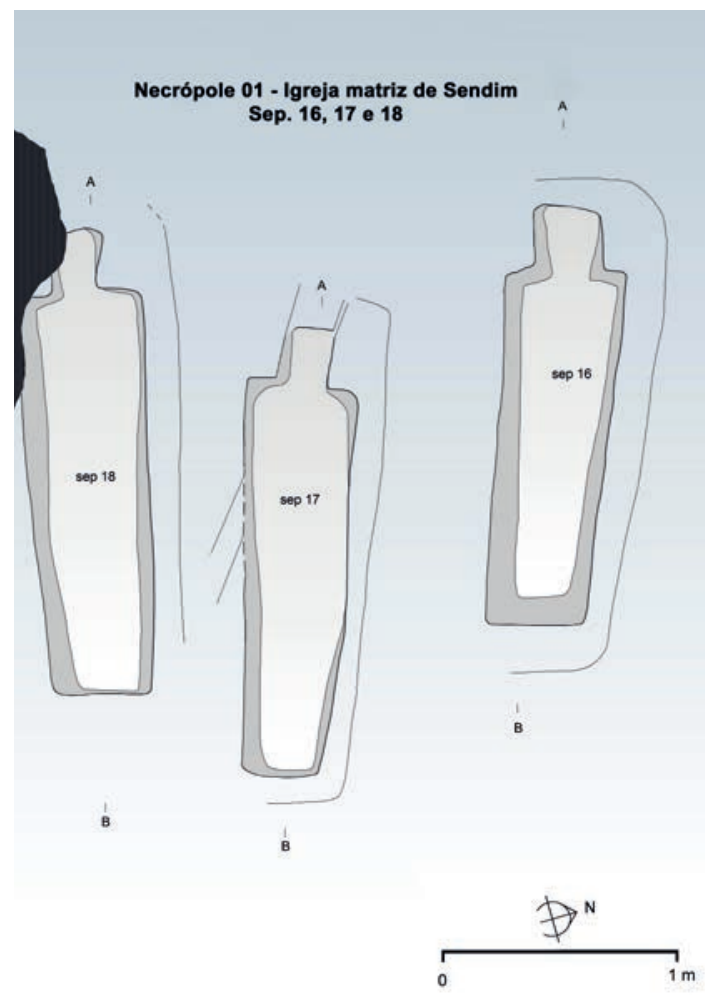

Fig. 5.

Sepulturas antropomórficas de configuração trapezoidal da Igreja Matriz de Sendim (Est. n. ${ }^{\circ}$ 1) Fonte: Ana Maria Oliveira e César Guedes 
A estação n. ${ }^{\circ}$ 6, Cabeço do Poio, de acordo com as referências bibliográficas seria composta por 4 sepulturas, mas não foi possível confirmar esta informação 4 .

As sepulturas escavadas na rocha de configuração antropomórfica encontram-se presentes nas diferentes tipologias de espaços funerários.

Entre as sepulturas isoladas, três estações são compostas por esta tipologia de sepulcro, o monumento do Mosteiro de S. João de Tarouca (Est. n. ${ }^{\circ}$ 15), a sepultura de Pedra Cavada/Salgueiral (Est. n. ${ }^{\circ}$ 17) e a sepultura de Cardaínho (Est. n. ${ }^{\circ}$ 26), que não foi identificada em campo.

Nos núcleos compostos por 2 ou 3 sepulturas, os monumentos antropomórficos estão presentes em 5 locais, cada um com uma sepultura desta tipologia. Assim encontram-se exemplares na Quinta da Silveira (Est. n. ${ }^{\circ} 11$ ), na Quinta de S. Bento (Est. n. ${ }^{\circ}$ 12), no Bairro do Castelo (Est. n. $\left.{ }^{\circ} 19\right)$, em Nogueiró (Est. n. ${ }^{\circ} 22$ ) e em Masseiras (Est. n. ${ }^{\circ}$ 25).

A maior concentração de sepulturas desta tipologia encontra-se na necrópole existente junto da igreja matriz de Sendim, com 13 exemplares (Est. n. ${ }^{\circ}$ 1). As 4 sepulturas da necrópole do Cabeço do Poio (Est. n. ${ }^{\circ}$ 6), apesar de não terem sido localizadas, constituem a segunda maior concentração destes sepulcros. Na necrópole da Tapada do Abade, constituída, sobretudo, por sepulturas geométricas, observa-se a existência de uma sepultura de configuração antropomórfica (Fig. 11, sep. 8 da Est. n. $\left.{ }^{\circ} 10\right)$ e vestígios de lá terem existido outros exemplares de planta similar ${ }^{5}$.

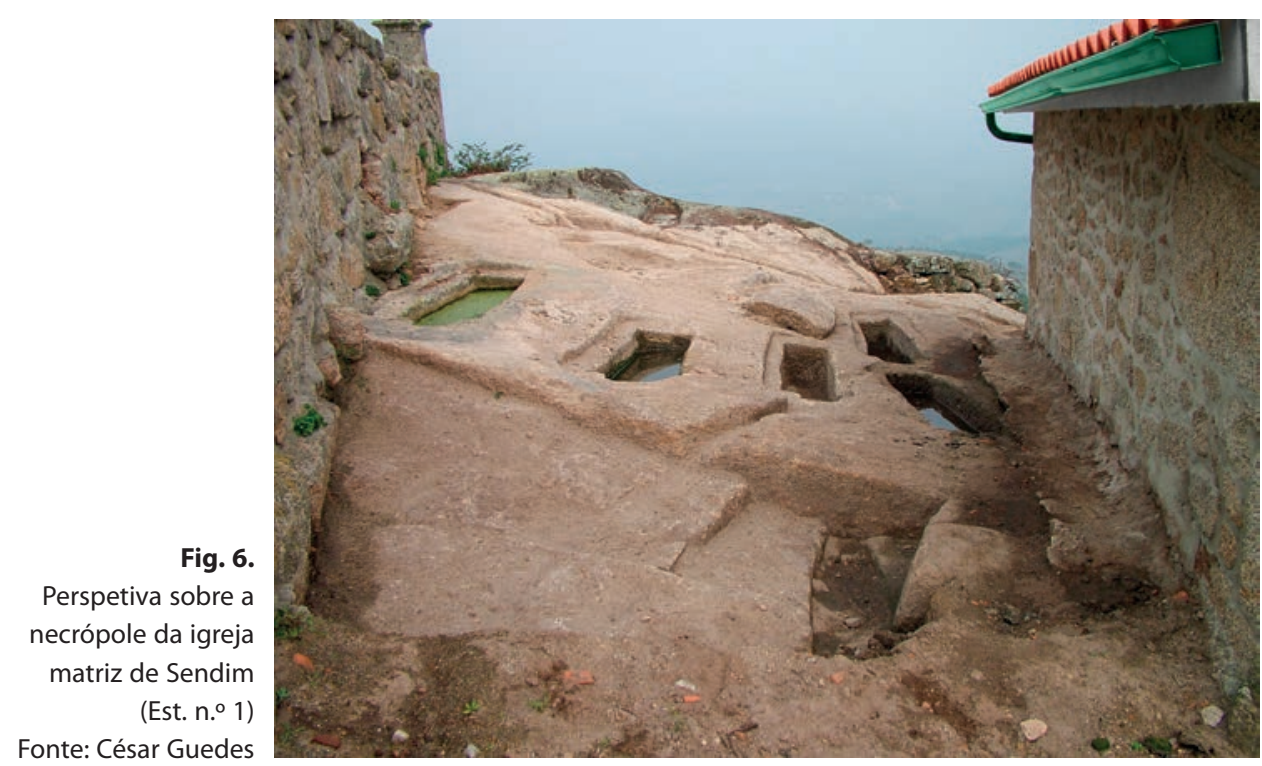




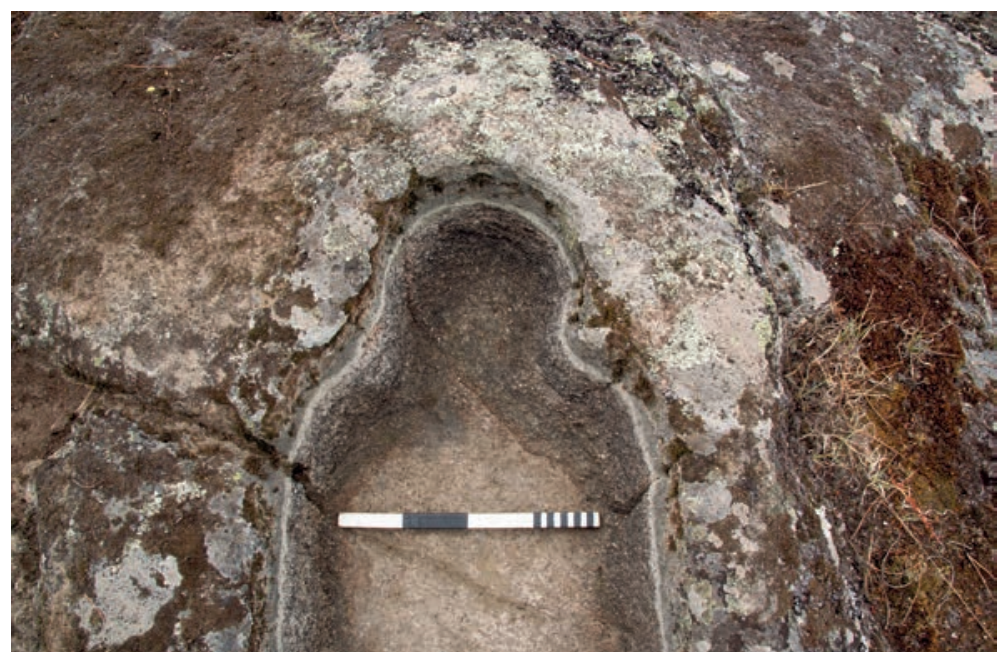

Fig. 7.

Cabeceira em arco ultrapassado da sepultura 2 da Quinta da Silveira (Est. n. ${ }^{\circ} 11$ ) Fonte: César Guedes

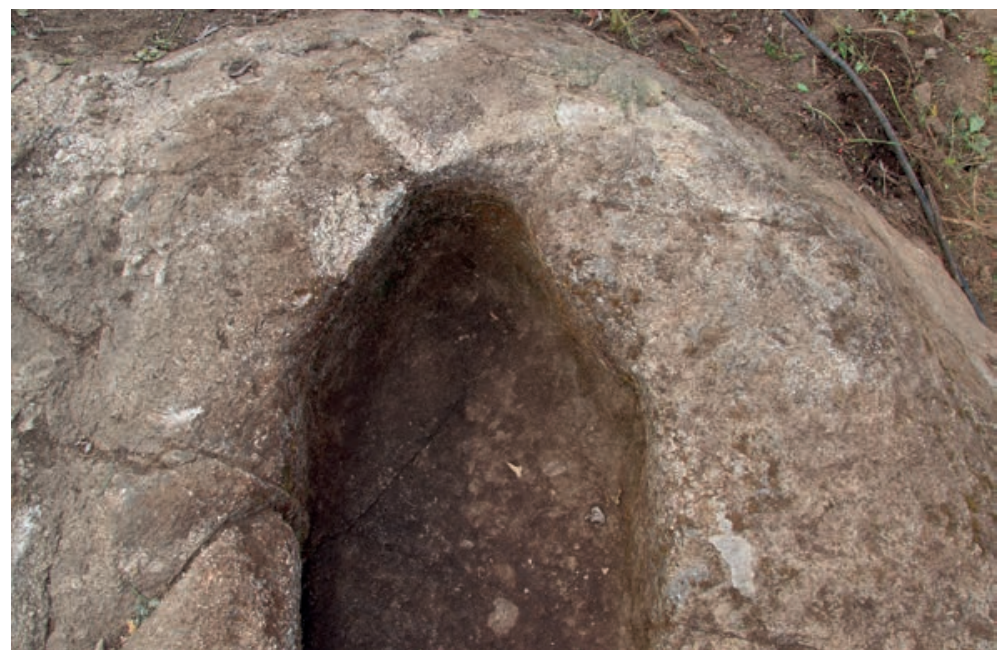

Fig. 8.

Cabeceira assimétrica da sepultura da Quinta de S. Bento (Est. n. ${ }^{\circ} 12$ ) Fonte: César Guedes

Esta tipologia de sepultura também aparece associada a sepulturas não antropomórficas como acontece no caso das sepulturas das estações de Tapada do Abade, Quinta da Silveira, em Nogueiró e em Masseiras (Est. n. ${ }^{\text {os }} 10,11,22$, e 25, respetivamente).

As soluções apresentadas na zona da cabeceira das sepulturas antropomórficas são variadas. A maioria dos sepulcros apresenta a zona da cabeceira em arco ultrapassado, observando-se esta característica em 7 exemplares (Figura n. ${ }^{\circ}$ 7). Os sepulcros cuja zona craniana se apresenta em arco de volta perfeita são em número de 3. Observam-se 4 sepulturas cuja cabeceira é de planta retangular e em outros 4 monumentos a planta é trapezoidal ou angulosa. A sepultura observada na Quinta de São Bento (Est. n. ${ }^{\circ}$ 12) tem cabeceira de planta assimétrica (Figura n. ${ }^{\circ} 8$ ). 
As sepulturas de planta trapezoidal são as mais numerosas e são também as que apresentam maior diversidade de soluções na zona da cabeceira. Dentro desta tipologia observam-se 5 soluções distintas para a zona da cabeceira: 5 monumentos apresentam cabeceira em arco ultrapassado (sep. 2, 3 e 10 da Est. n. ${ }^{\circ}$ 1; sep. 8 da Est. n. ${ }^{\circ} 10$ e sep. 2 da Est. n. ${ }^{\circ} 11$ ), 2 têm planta retangular (sep. 4 da Est. n. ${ }^{\circ} 1$ e sep. 2 da Est. n. ${ }^{\circ}$ 25), 4 são de configuração trapezoidal ou angulosa (sep. 16, 17, 18 e 19 da Est. $\mathrm{N},{ }^{\circ} 1$ ), 1 é assimétrica e outra é em arco de volta perfeita (Est. n. ${ }^{\text {os }} 12$ e 15, respetivamente).

Dentro das sepulturas de planta retangular 2 têm cabeceira retangular e 1 é em arco ultrapassado (sepulturas n. ${ }^{\text {os }} 1,21$ e 22 da Est. n. ${ }^{\circ} 1$ ).

As sepulturas de planta ovalada apresentam cabeceira em arco de volta perfeita. São constituídas pela sepultura n. ${ }^{\circ} 1$ de Nogueiró (Est. n. ${ }^{\circ} 22$ ) e pela sepultura de Pedra Cavada/Salgueiral, cuja cabeceira tem a particularidade de ser dupla (Est. n. ${ }^{\circ} 17$ ).

Entre as 7 sepulturas indeterminadas, uma poderá apresentar cabeceira em arco ultrapassado. Trata-se da sepultura n. ${ }^{\circ} 13$ da igreja matriz de Sendim (Est. n. ${ }^{\circ} 1$ ) que se encontra quase integralmente destruída, subsistindo apenas a cabeceira.

Tabela 1. Planta das sepulturas antropomórficas e tipologias da zona da cabeceira

\begin{tabular}{|c|c|c|c|c|}
\hline Planta & Cabeceira & N. ${ }^{\circ}$ de sepulturas & N. ${ }^{\circ}$ & Total \\
\hline \multirow{2}{*}{ Retangular } & Arco ultrapassado & 1 & \multirow{2}{*}{3} & \multirow{10}{*}{25} \\
\hline & Retangular & 2 & & \\
\hline \multirow{5}{*}{ Trapezoidal } & Arco ultrapassado & 5 & \multirow{5}{*}{13} & \\
\hline & Retangular & 2 & & \\
\hline & $\begin{array}{c}\text { Trapezoidal ou } \\
\text { Angulosa }\end{array}$ & 4 & & \\
\hline & Assimétrica & 1 & & \\
\hline & Arco volta perfeita & 1 & & \\
\hline Ovalada & Arco de volta perfeita & 2 & 2 & \\
\hline Indeterminada & Arco ultrapassado & 1 & \multirow{2}{*}{7} & \\
\hline Indeterminada & Indeterminada & 6 & & \\
\hline
\end{tabular}

Fonte: César Guedes

\subsection{Sepulturas de indivíduos subadultos}

Entre o conjunto sepulcral observamos a existência de alguns monumentos que, pelo seu reduzido tamanho, terão sido criados para inumar indivíduos subadultos. Inventariaram-se 5 sepulturas desta tipologia distribuídas por apenas duas estações arqueológicas. Na necrópole da Mogueira, em S. Martinho de Mouros (Est. n. ${ }^{\circ} 21$; Figura n. ${ }^{\circ}$ ), identificaram-se 4 sepulcros e em Masseiras (Est. n. ${ }^{\circ} 25$ ) registou-se 1 sepultura desta tipologia. 
As sepulturas têm configuração não antropomórfica, de planta ovalada, constituindo a única exceção o monumento n. ${ }^{\circ} 8$ da necrópole da Mogueira (Est. n. ${ }^{\circ}$ 21) que, a confirmar que se trata de uma sepultura, tem planta trapezoidal.

A dimensão das sepulturas varia entre os 95 e os $114 \mathrm{~cm}$ de comprimento e a largura entre os 26 e $34 \mathrm{~cm}$. A sepultura n. 8 da Mogueira é a mais pequena, medindo apenas $60 \mathrm{~cm}$ de comprimento e $33 \mathrm{~cm}$ de largura. Se for uma sepultura, terá certamente acolhido um individuo recém-nascido.

A associação entre sepulcros de criança e sepulturas de adulto encontra-se patente em ambas as estações e, embora não possamos afirmar que se tratam claramente de núcleos familiares, esta ideia não pode, no estado atual de conhecimentos, ser posta de parte.

No caso da necrópole de Mogueira observa-se que 3 das 4 inumações se localizam no mesmo afloramento e respeitam a mesma orientação da sepultura de adulto. Para além disso, constata-se que elas se articulam entre si, encontrando-se as sepulturas n. ${ }^{\text {os }} 3$ e 5 , claramente no mesmo alinhamento, e a sepultura n. ${ }^{\circ} 4$, dispondo-se à direita da sepultura n. 5 e respeitando a mesma orientação (Fig. 9). A sepultura n. ${ }^{\circ} 8$ desta necrópole não se parece articular diretamente com as restantes, uma vez que, para além de se implantar num afloramento autónomo e apresentar dimensões mais reduzidas, tem planta diferente e não respeita a mesma orientação.

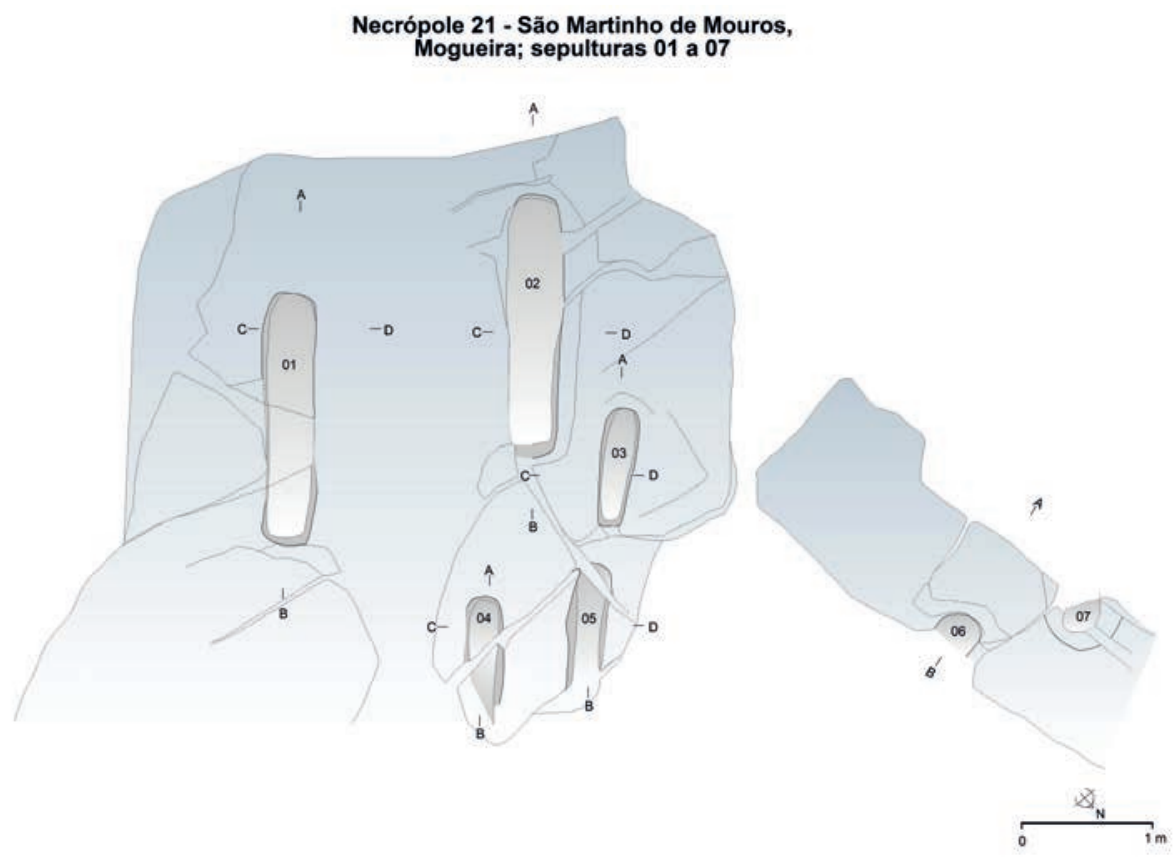

Fig. 9. Núcleo sepulcral da Mogueira representando as sepulturas de dois adultos e de três subadultos (Est. n. $\left.{ }^{\circ} 21\right)$ Fonte: Ana Maria Oliveira e César Guedes 


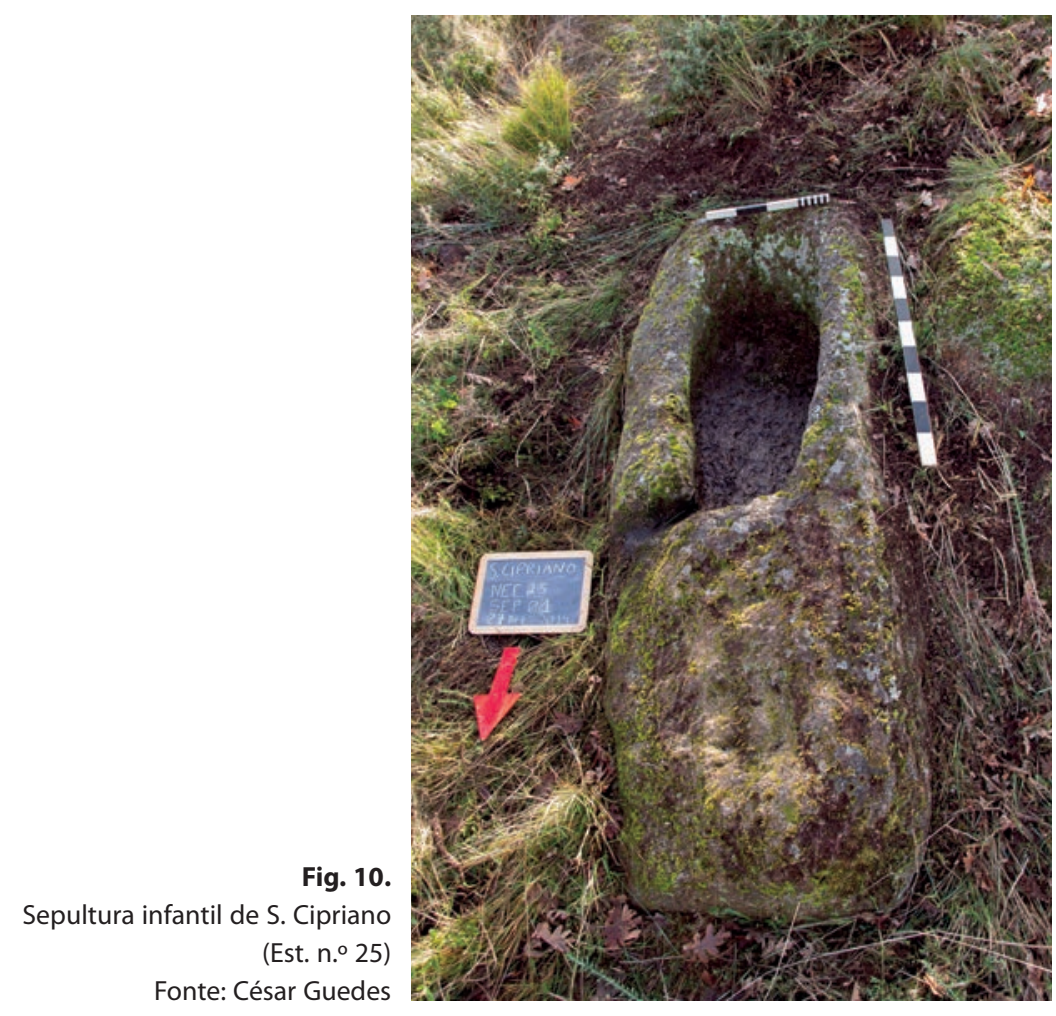

A sepultura infantil de Masseiras integra um núcleo de duas sepulturas que se implanta em penedos autónomos, mas a escassos metros de distância. A sepultura foi escavada num pequeno afloramento granítico, quase ao nível do solo, não se destacando na paisagem (Figura n. ${ }^{\circ} 10$ ). Por seu turno, a sepultura de adulto, de planta antropomórfica, implanta-se num bloco mais proeminente, localizado numa zona de maior impacto visual, tendo inclusive sido desbastado na lateral voltada ao caminho e aos campos agrícolas, para criar uma parede vertical e reforçar a sua presença.

A associação de uma sepultura de adulto, de planta antropomórfica, com uma sepultura infantil de planta ovalada, é interessante e poderá permitir levantar a hipótese de estarmos perante um pequeno núcleo familiar.

\subsection{A orientação das sepulturas}

No que concerne à orientação dos monumentos observa-se que a maioria apresenta uma orientação canónica, ou seja, alinhada de oeste para leste, com 40 exemplares; 29 monumentos apresentam outras orientações e em 19 sepulcros não foi possível determinar o seu alinhamento. 


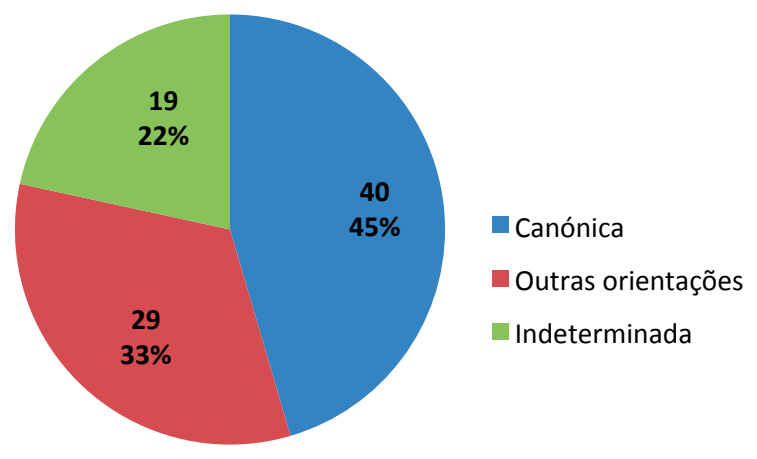

\section{Gráfico 1.}

A diferente orientação das sepulturas e a sua distribuição percentual Fonte: César Guedes

A orientação canónica dos sepulcros prende-se com a tendência de alinhar o sepulcro sobre um o eixo direcionado de ocidente para oriente, de modo que a cabeça do defunto se enquadre com o nascer do sol, olhando-o de frente, pois será dessa direção que «se ha de producir la segunda venida de Cristo (Parusía), y el establecimiento de su reino» ${ }^{6}$.

Esta forma de alinhamento, sensivelmente orientada entre os pontos cardeais leste e oeste, poderá permitir inferir algumas observações quanto à época do ano em que foram abertos, podendo denunciar as estações em que a taxa de mortalidade seria mais elevada.

Assim, os monumentos cuja orientação se encontra desviada entre os $60^{\circ} \mathrm{e}$ os $120^{\circ}$ do norte magnético integram este conjunto de sepulcros totalizando 40 monumentos. A abertura dos sepulcros terá sido realizada ao longo do ano solar integrando-se a grande parte nas variações entre os $80^{\circ}$ e os $100^{\circ}$. Valores que

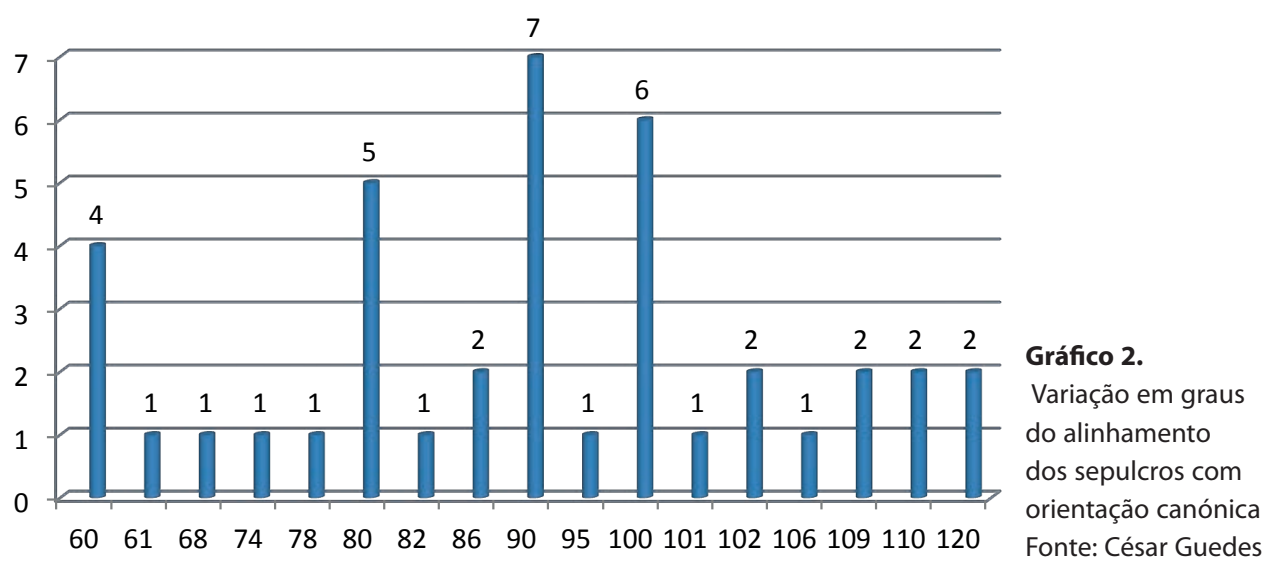

${ }^{6}$ VIZCAÍNO SÁNCHEZ, 2007: 547-548. 
correspondem a mais de metade dos sepulcros e coincidem, grosso modo, com a passagem do inverno para a primavera (fevereiro, março e abril) e do verão para o outono (agosto, setembro e outubro), alturas do ano possivelmente propensas a uma mais alta taxa de mortalidade.

De igual modo constata-se que a orientação canónica é comum tanto a monumentos de configuração não antropomórfica, patente em 19 exemplares, como às sepulturas de configuração antropomórfica, com 21 monumentos, quase todos localizados na necrópole da igreja matriz de Sendim (Est. n. ${ }^{\circ} 1$ ). As sepulturas desta estação encontram-se alinhadas e agrupadas, com tendência para uma orientação comum. Estas características, segundo Iñaki Martín Viso poderão permitir enquadrar este núcleo sepulcral numa paisagem hierarquizada em que há uma memória comunitária gerida por uma instância de poder que restringiu ou eliminou a capacidade de gestão da memória familiar ${ }^{7}$.

Tabela 2. Distribuição hipotética da abertura dos sepulcros ao longo do ano solar

\begin{tabular}{c|c|c|c}
\cline { 2 - 4 } & $\begin{array}{c}\text { Inverno } \\
\text { (dezembro- março) }\end{array}$ & $\begin{array}{c}\text { Equinócio da primavera } \\
\text { (março) }\end{array}$ & $\begin{array}{c}\text { Primavera } \\
\text { (março - julho) }\end{array}$ \\
\hline Graus & $120^{\circ}-90^{\circ}$ & $90^{\circ}$ & $90^{\circ}-60^{\circ}$ \\
\hline N.o de sepulturas & 17 & 7 & 16 \\
\hline Graus & $120^{\circ}-90^{\circ}$ & & $90^{\circ}-60^{\circ}$ \\
\hline & Outono & $90^{\circ}$ & Verão \\
& (setembro- dezembro) & $\begin{array}{c}\text { Equinócio do outono } \\
\text { (setembro) }\end{array}$ & (julho - setembro) \\
\hline
\end{tabular}

Fonte: César Guedes

As sepulturas que não seguem as orientações canónicas constituem 29 exemplares do total de sepulcros. Entre estes, observa-se que a grande maioria se encontra orientada de sudoeste para nordeste, com 12 exemplares cuja variação em graus se enquadra entre os $24,5^{\circ}$ e os $60^{\circ}$. O segundo grupo mais numeroso é das sepulturas cujo alinhamento está entre o $337,5^{\circ}$ e os $24,5^{\circ}$ e as coloca de face voltada para o norte. Os sepulcros voltados a sul são apenas 4 e os que se encontram orientados de noroeste para sudeste são em igual número. Observam-se 2 sepulturas alinhadas de sudeste para noroeste e apenas 1 de nordeste para sudoeste.

\footnotetext{
${ }^{7}$ MARTÍN VISO, 2012: 172.
} 


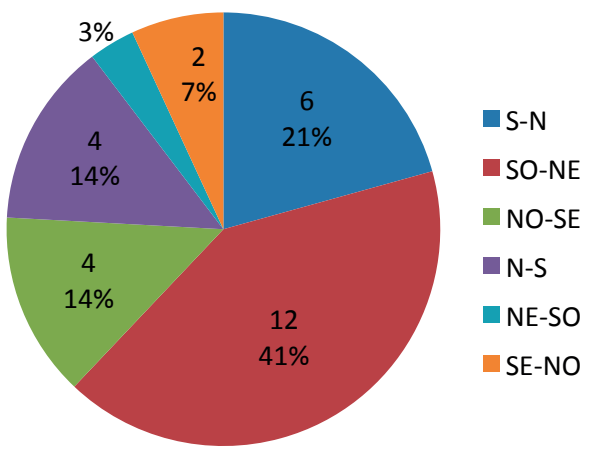

\section{Gráfico 3.}

Orientação das sepulturas

Fonte: César Guedes

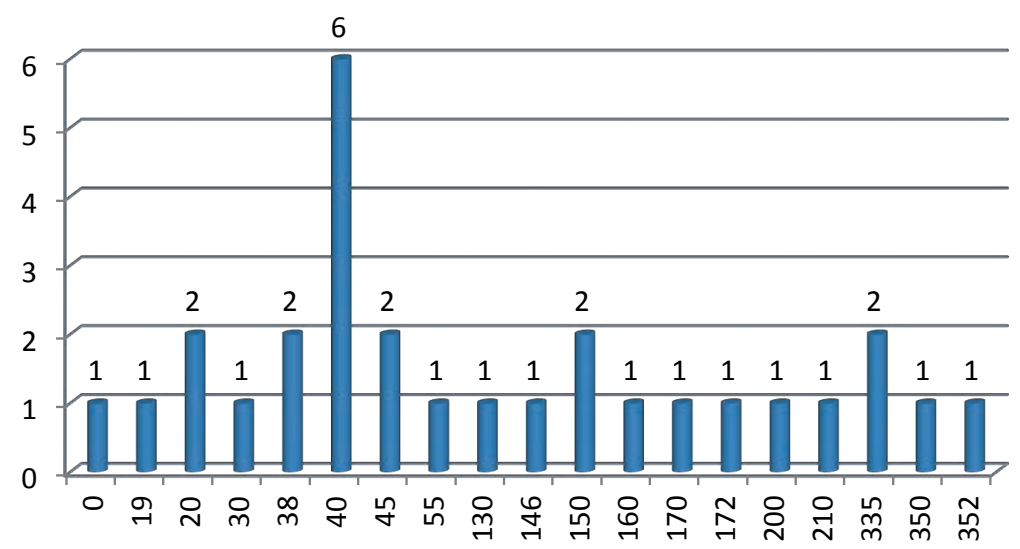

\section{OS ESPAÇOS FUNERÁRIOS}

Entre as diferentes propostas metodológicas para interpretar a organização do espaço funerário optou-se por agrupar as estações em três tipologias distintas: as que eram compostas exclusivamente por sepulturas isoladas, as de pequenos núcleos de 2 ou 3 sepulcros e os grupos constituídos por mais de três monumentos (Mapa 1).

Os dados recolhidos revelaram que as sepulturas se organizam em 6 necrópoles, 10 grupos de 2 ou 3 sepulturas e que 10 das sepulturas identificadas se encontram isoladas.

As sepulturas escavadas na rocha que se implantam isoladamente distribuem-se por 10 locais. São compostas por 5 monumentos de configuração não antropomórfica, 3 sepulturas antropomórficas e 2 sepulturas indeterminadas.

Os núcleos de 2 ou 3 sepulturas integram 10 estações arqueológicas compostas por 22 monumentos. Os grupos de 2 sepulturas são em maior número e distribuem-se por 8 locais. Apenas se observam associações de 3 sepulcros em duas estações: na Quinta de Passa Frio (Est. n. ${ }^{\circ}$ ) e na Quinta da Silveira (Est. n. ${ }^{\circ}$ 11). A maioria dos sepulcros apresenta configuração não antropomórfica distribuindo-se por 8 estações 
arqueológicas e contando com 14 exemplares. Os sepulcros de planta antropomórfica são 5 e distribuem-se por 5 estações. As sepulturas indeterminadas localizam-se na Quinta da Silveira (Est. n. ${ }^{\circ} 11$ ), na Quinta de S. Bento (Est. n. ${ }^{\circ}$ 12) e no Bairro do Castelo, em Lamego (Est. n. $\left.{ }^{\circ} 19\right)$.

A coexistência de sepulturas de configuração antropomórfica com monumentos de planta geométrica só se observa em 3 locais: na Quinta da Silveira (Est. n. ${ }^{\circ} 11$ ), núcleo com três sepulturas; em Nogueiró (Est. n. ${ }^{\circ} 22$ ), núcleo de 2 sepulcros, e em Masseiras (Est. n. $\left.{ }^{\circ} 25\right)$, núcleo também de duas sepulturas.

As necrópoles são 6, um total de $23 \%$ das estações identificadas e são constituídas por 56 sepulturas, perfazendo $64 \%$ do total de monumentos.

A necrópole existente junto da igreja matriz de Sendim é a mais numerosa com 21 sepulcros de configuração antropomórfica (Est. n. ${ }^{\circ} 1$ ), seguindo-se as necrópoles da Tapada do Abade (Est. n. $\left.{ }^{\circ} 10\right)$, composta por 8 sepulturas de planta geométrica e 1 antropomórfica (Figura n. ${ }^{\circ} 11$ ), e a da Mogueira (Est. n. ${ }^{\circ}$ 21), constituída por 9 sepulturas de planta não antropomórfica. A necrópole de Vale de Vila é composta por 8 sepulcros não antropomórficos (Est. n. ${ }^{\circ}$ 2) e a de Baganhos é composta por cinco monumentos sem evidências de antropomorfismo (Est. n. $\left.{ }^{\circ} 4\right)$. A necrópole de Cabeço do Poio (Est. n. ${ }^{\circ}{ }^{6}$ ) seria constituída por 4 sepulturas de configuração antropomórfica ${ }^{8}$.

A distribuição das diferentes tipologias de espaço funerário pelo território não é homogénea, sobretudo no que concerne às necrópoles, que se concentram no limite

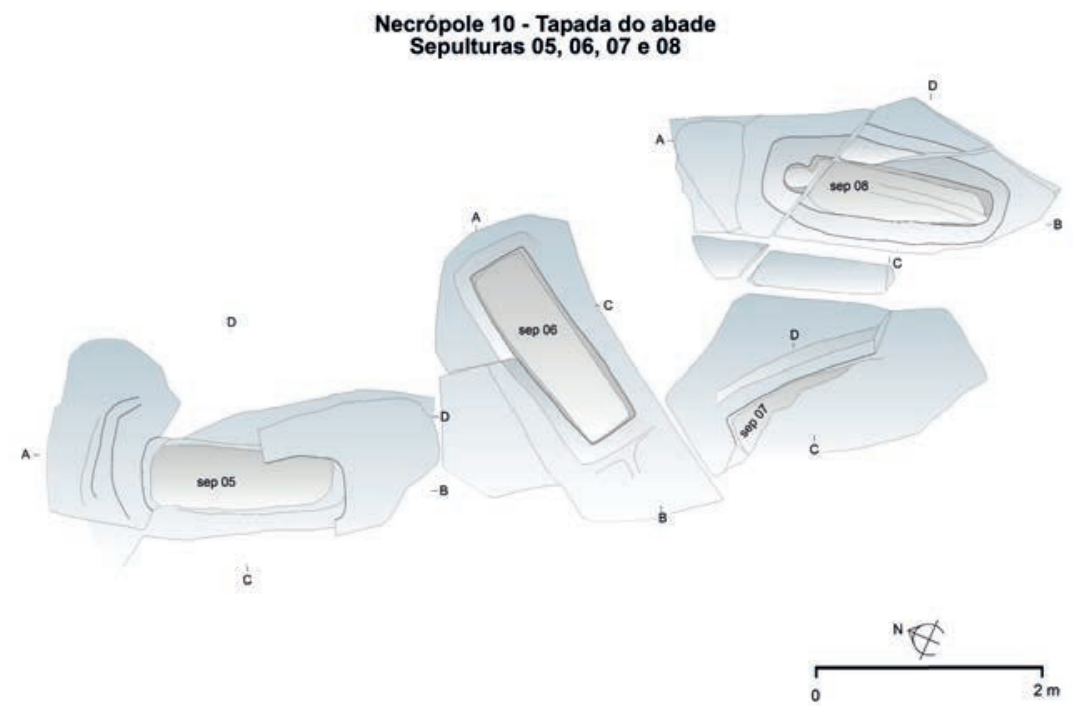

Fig. 11. Necrópole da Tapada do Abade (Est. n. ${ }^{\circ}$ 10). Coexistência entre sepulturas geométricas e antropomórficas Fonte: Ana Maria Oliveira e César Guedes

${ }^{8}$ CORREIA, 2007: 61. 
sudeste da área de estudo, no vale do rio Távora, junto de Sendim. Os núcleos de 2 ou 3 sepulturas existem por toda a região, com exceção para as encostas voltadas ao Douro, na zona nordeste, onde não existe nenhum exemplar. As sepulturas isoladas distribuem-se pelas franjas da área de estudo, ocupando zonas de relevo muito acidentado no limite oeste do território, coincidente com a serra das Meadas e a de Santa Helena, e em áreas mais planas nas zonas de Tarouca e Tabuaço e em torno de Sendim.

A análise da organização do espaço funerário nesta região permitiu aferir que as estações constituídas pelos núcleos de monumentos isolados e de $2 / 3$ sepulturas são as mais numerosas e correspondem a $77 \%$ do total de estações, seguindo em linha com que se pode observar para as outras regiões de Portugal ${ }^{9}$. Este fenómeno é transversal a toda a Europa Ocidental, podendo até afirmar-se que constitui o tipo de espaço funerário predominante a partir dos séculos VII-VIII ${ }^{10}$.

\section{OS MONUMENTOS E A SUA RELAÇÃO COM A PAISAGEM}

As manifestações funerárias constituem uma importante fonte de informações que podem permitir antever, não só os pressupostos mentais subjacentes às populações que as produziram, mas também inferir evidências da sua organização social e administrativa. Neste sentido procurou-se articular os núcleos de sepulturas com os elementos estruturadores e polarizadores do povoamento: as áreas residenciais, os locais de culto e os centros de poder, civitates ou outros locais centrais fortificados.

A identificação das áreas de residência das populações que criaram e utilizaram as sepulturas levanta algumas dificuldades. Apesar de frequentemente se observarem vestígios arqueológicos de superfície nas imediações destes espaços sepulcrais, as dificuldades sentidas na atribuição de uma funcionalidade habitacional, ou na definição de um âmbito cronológico mais restrito para estes elementos, são inúmeras. De facto, as leituras provenientes da análise de materiais cerâmicos de superfície, sobretudo da existência de fragmentos de tegulae, devem ser encaradas com muita cautela pois, como refere Mário Barroca, a produção de telha plana terá sobrevivido no Entre Douro e Minho até ao século XI ${ }^{11}$. Para além disso, a existência de materiais de cronologia inequivocamente romana nas proximidades de sepulcros rupestres não invalida a existência de uma ocupação alto-medieval naquele local. Muito pelo contrário, apenas a reforça, uma vez que se anteriormente o sítio era favorável ao assentamento de comunidades e à exploração agropecuária, também o seria em

\footnotetext{
${ }^{9}$ GUEDES, 2015: 40.

${ }^{10}$ MARTÍN VISO, 2014: 104.

${ }^{11}$ BARROCA, 1987: 59.
} 
época alto-medieval, não se devendo excluir a possibilidade de se observarem reaproveitamentos de materiais cerâmicos ou líticos ${ }^{12}$.

A relação entre sepulturas escavadas na rocha e vestígios de elementos de habitat encontra-se presente em 17 locais, sendo de destacar o caso de Sendim onde se concentram 4 das 6 necrópoles identificadas (Mapa 3). Este conjunto de 40 monumentos corresponde a cerca de $45 \%$ do total de sepulturas identificadas. Na envolvente a estes espaços funerários as prospeções arqueológicas permitiram elencar dois prováveis casais, duas villae, um importante e extenso vicus (Fontelo) e vários lagares escavados na rocha ${ }^{13}$. O caso da Necrópole da Mogueira (Est. n. ${ }^{\circ}$ 21) é também paradigmático apresentando importantes vestígios de um habitat constituído por inúmeras estruturas em negativo escavadas no afloramento granítico. A importância dos vestígios militares e de habitat desta estação arqueológica já haviam sido destacados por Mário Barroca e foram recentemente confirmados pela intervenção arqueológica realizada por Maria João Santos que atribui aos vestígios de habitat uma cronologia «entre los siglos IX y $\mathrm{X}{ }^{14}$.

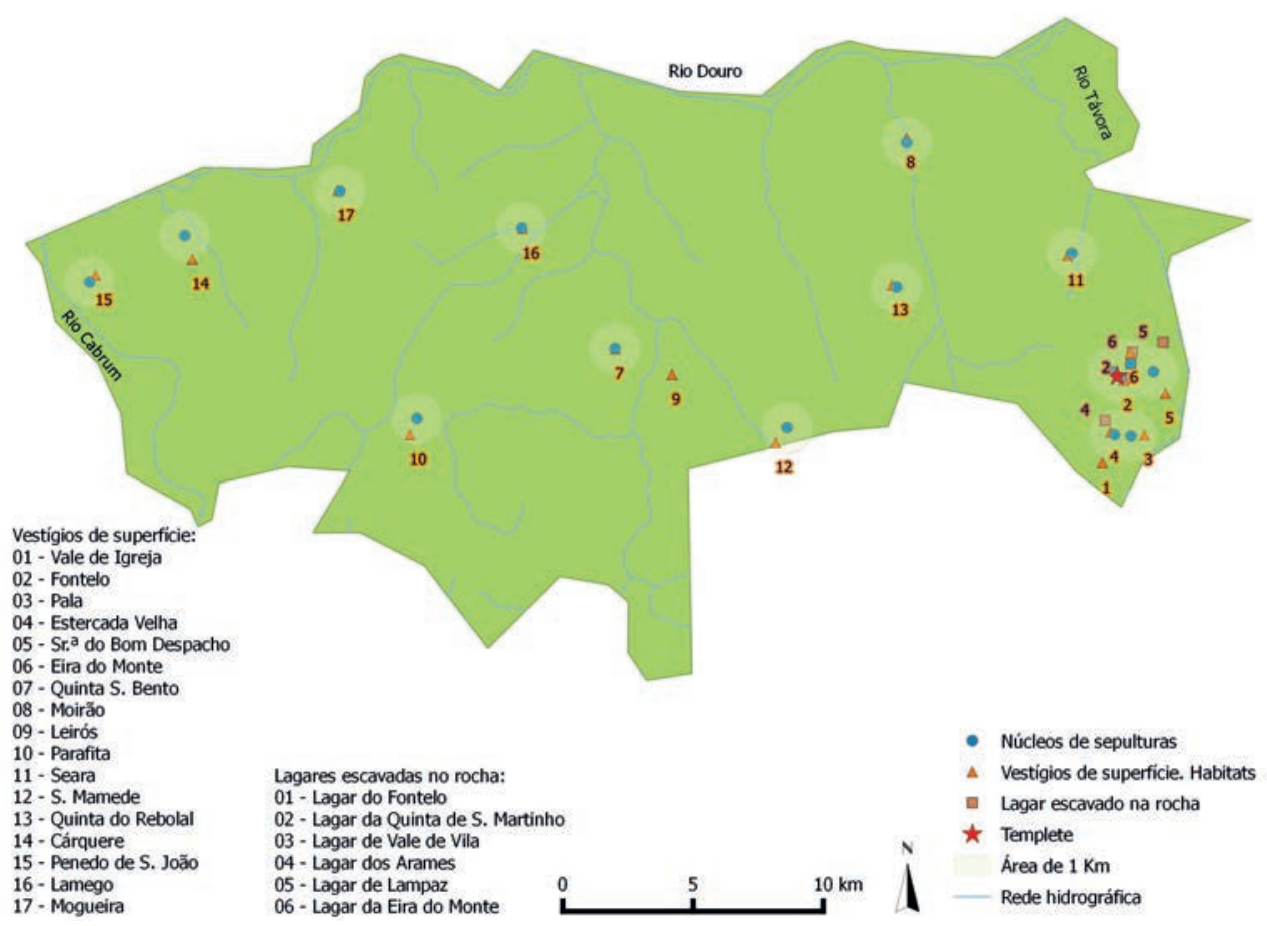

Mapa 3. Mapa com a articulação entre os sepulcros rupestres e os vestígios de habitat Fonte: César Guedes

\footnotetext{
12 ALARCÃO, 1990: 378.

${ }^{13}$ PERPÉTUO et al., 1999: 175-245.

${ }^{14}$ BARROCA, 1990-1991: 103, 110-111; SANTOS, 2012: 490.
} 
A articulação das sepulturas com as vias e os caminhos também apresenta algumas dificuldades que se prendem sobretudo com a cronologia das vias. Verifica-se a existência de 8 estações nas proximidades de caminhos ou vias, porém em nenhum dos casos onde esta situação ocorre se pode afirmar com segurança tratarem-se de vestígios cronologicamente coevos, ou até de utilização contemporânea.

A associação entre sepulturas e locais de culto verifica-se em 8 locais (Mapa 4). Em variadas situações é possível observar que as sepulturas são anteriores aos templos e, nestes casos, poder-se-á estar perante uma amortização da sacralidade do espaço materializada na construção de um local de culto. Poderá ser este o caso das sepulturas de Nossa Senhora da Esperança (Est. n. ${ }^{\circ}$ 23), localizadas junto de uma capela cuja inscrição no portal the atribui a data de 1609 , e das sepulturas de Vila Chã da Beira (Est. n. ${ }^{\circ} 13$ ) próximas da capela de S. Pedro. O túmulo da Quinta de S. Bento (Est. n. ${ }^{\circ} 12$ ) poderá também corresponder a um destes casos, no entanto a destruição e transladação da capela de Santa Luzia para a casa da quinta não permite aferir esta condição.

As situações onde é possível observar que as sepulturas escavadas na rocha são contemporâneas ou posteriores aos templos, constituindo casos de tumulação apud ecclesia não se verificam inequivocamente nesta área. Apenas a necrópole de Sendim (Est. n. ${ }^{\circ} 1$ ) e as sepulturas do Bairro do Castelo (Est. n. ${ }^{\circ} 19$ ) poderiam eventualmente integrar esta tipologia. No primeiro caso a igreja sofreu profundas obras não sendo possível confirmar esta situação, porém é certo que o templo já existiria na segunda metade do século XII, sendo referido no Censual do Cabido de Lamego ${ }^{15}$. No caso das sepulturas do Bairro do Castelo, os resultados da intervenção arqueológica poderão confirmar se as sepulturas identificadas se enquadram com a desaparecida igreja de S. Salvador, constituindo assim, de facto, sepulturas tumulatio apud ecclesia ${ }^{16}$.

Os sepulcros da Quinta de Passa Frio (Est. n. ${ }^{\circ}$ 7) e da Mogueira (Est. n. ${ }^{\circ}$ 21) parecem corresponder a situações em que os espaços funerários se articulam com os espaços cultuais, mas que não constituem verdadeiramente sepulturas tumulatio apud ecclesia, sendo anteriores à constituição da rede paroquial. No primeiro caso, a igreja localizar-se-ia junto de um povoado fortificado, hoje conhecido por Senhora do Calfão, e teria sido fundada no século XI ${ }^{17}$. Em S. Martinho de Mouros, a existência de um templo não está confirmada, mas Ricardo Teixeira observou a existência de alguns alinhamentos do que supõe "poder tratar-se dos vestígios do templo que serviria o povoado e ao qual as sepulturas estariam associadas» ${ }^{18}$. A existência de um templo neste local remontaria certamente a época pré-românica, tendo posteriormente

\footnotetext{
${ }^{15}$ Grande Enciclopédia Portuguesa e Brasileira, s.v. Sendim, vol. XXVIII: 268.

${ }^{16}$ ARQUEOLOGIA, PATRIMÓNIO, [s.d.].

${ }^{17}$ COSTA, 1979: 192.

18 TEIXEIRA, 2001: 471.
} 


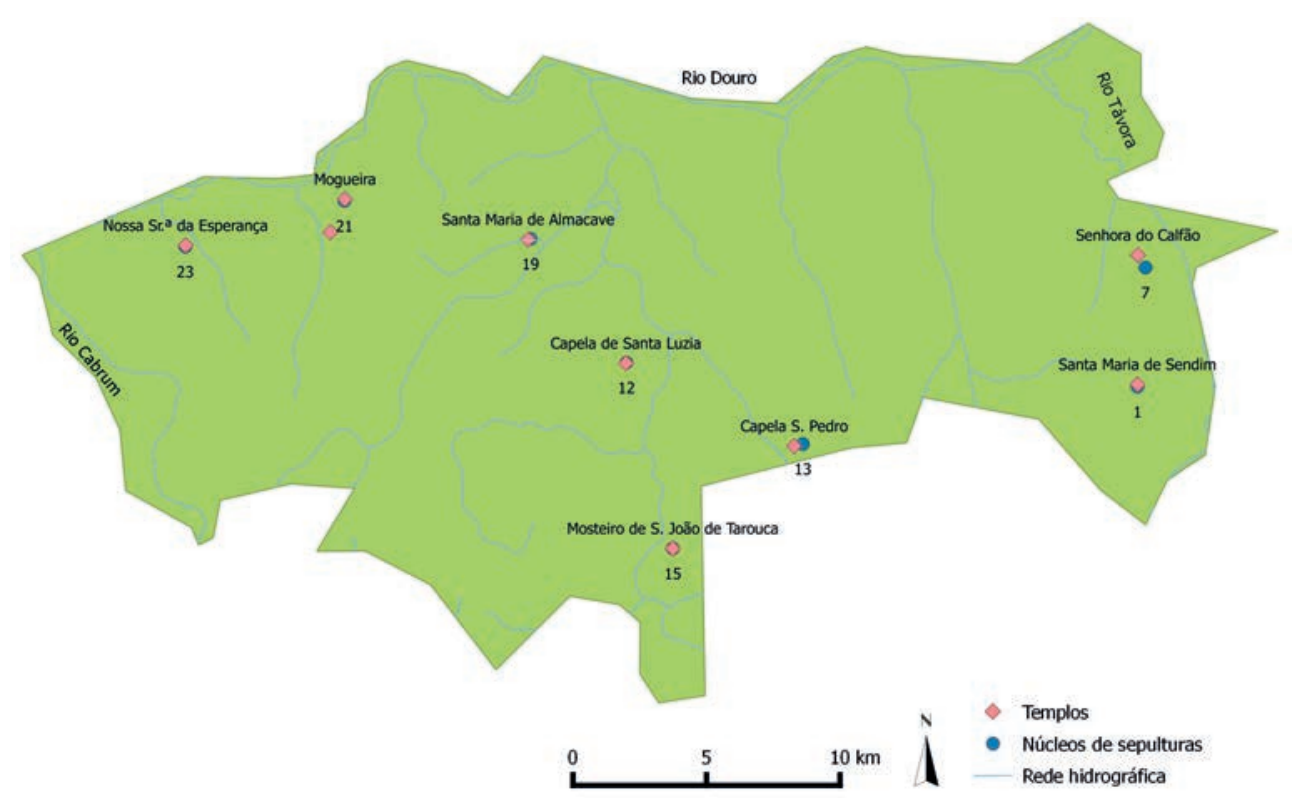

Mapa 4. Mapa representando a articulação entre as sepulturas e os templos Fonte: César Guedes

sido substituído pela igreja de traça românica atualmente existente em S. Martinho de Mouros e que terá sido construída demoradamente entre os séculos XII e XIII ${ }^{19}$. A ligação entre os sepulcros e centros de poder, sejam civitates ou outros locais centrais fortificados, como os castros ou os castelos, constitui uma importante pista para a compreensão da evolução da organização administrativa do território (Mapa 5).

Esta região integrar-se-ia dentro da influência da civitas de Lamego, cujos limites se desconhecem, mas que muito provavelmente confrontariam a ocidente e a sudoeste com a civitas de Anegia e de Santa Maria e a sul com a civitas de Viseu.

A totalidade de estruturas fortificadas que se encontravam sob o domínio desta civitates é ainda desconhecida. Poderiam corresponder a simples reconversões ou reocupações de antigos locais fortificados que remontavam à Idade do Ferro e ao período Romano, ou poderiam tratar-se de «novas» construções, muitas delas da iniciativa das populações locais ${ }^{20}$. Este fenómeno, designado de incastelamento, não está ainda devidamente esclarecido para esta área geográfica e apenas prospeções orientadas para a identificação destes primeiros castelos roqueiros poderão trazer alguma luz sobre a organização militar desta região entre os séculos VIII e XII.

\footnotetext{
${ }^{19}$ ALMEIDA, 2001: 128.

${ }^{20}$ BARROCA, 2004: 183; 1990-1991: 91.
} 


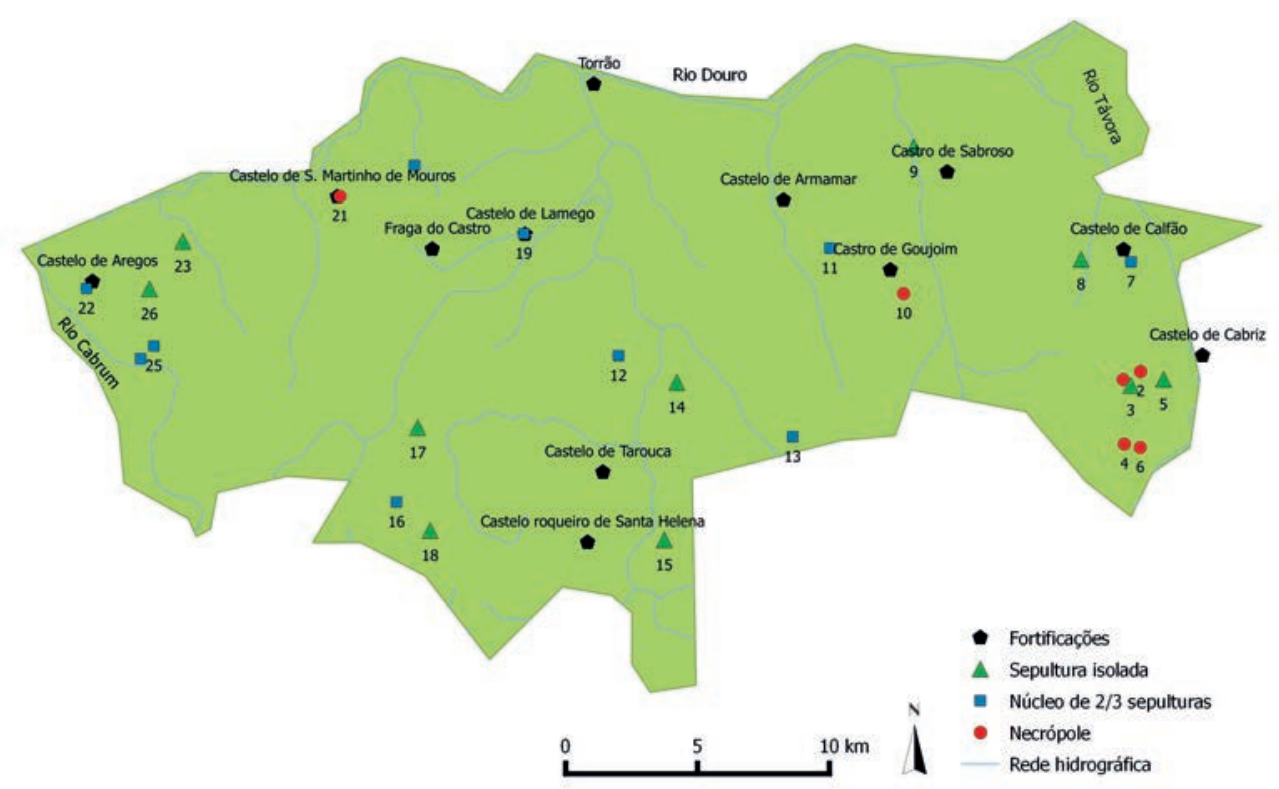

Mapa 5. Representação da articulação entre os sepulcros rupestres e as fortificações Fonte: César Guedes

Entre as fortificações mais rudimentares, que aproveitaram estruturas pré-existentes, existem referências a vestígios de época medieval no Castro de Sabroso ${ }^{21}$, no Povoado da Senhora do Calfão ${ }^{22}$ e, apesar de não haver notícias, é provável que o Castro de Goujoim (Est. n. $\left.{ }^{\circ} 10\right)$ e o núcleo sepulcral de Giralda (Est. n. $\left.{ }^{\circ} 16\right)$ possam também constituir um destes exemplos.

Entre os castelos roqueiros temos notícias da existência de 6 destas estruturas. O Castelo de Cabriz em Tabuaço ${ }^{23}$; o castelo roqueiro de Santa Helena, em Tarouca ${ }^{24}$; a Fraga do Castro, em Lamego ${ }^{25}$, e sobranceiro à foz do rio Varosa implantar-se-ia o povoado fortificado de Torrão ${ }^{26}$. O Castro da Mogueira (Est. n. ${ }^{\circ} 21$ ) também conhecido por castelo de S. Martinho de Mouros localiza-se na vertente oeste da serra das Meadas e a sua importância no decorrer do processo da Reconquista Cristã é inegável. Este castelo após a desagregação das civitates, deixará de ser um castelo roqueiro para passar a encabeçar a terra de S. Martinho de Mouros. O local conhecido por Penedo de S. João, localizado na freguesia de Freigil (Resende) e com amplo domínio

\footnotetext{
${ }^{21}$ PERPÉTUO et al., 1999: 78-79.

22 PERPÉTUO et al., 1999: 266.

${ }^{23}$ PERPÉTUO et al., 1999: 211-213.

${ }^{24}$ Portal do Arqueólogo, CNS 22206.

${ }^{25}$ Portal do Arqueólogo, CNS 31846.

${ }^{26}$ Portal do Arqueólogo, CNS 13962.
} 
visual sobre o rio Douro, constitui, segundo António Lima, a provável localização do Castelo de Aregos ${ }^{27}$.

Após a desagregação da civitas de Lamego e integrados numa organização administrativa de terras, os castelos de Armamar, Lamego, Tarouca, S. Martinho de Mouros e o Castelo de Aregos são as estruturas militares conhecidas para esta região.

A relação espacial entre os sepulcros escavados na rocha e estas estruturas fortificadas de características defensivas apenas se observa em 4 locais distintos. $\mathrm{Na}$ necrópole de Passa Frio (Est. n. ${ }^{\circ}$ 7), localizada nas proximidades do castelo de Calfão; nas sepulturas do Bairro do Castelo (Est. n. $\left.{ }^{\circ} 19\right)$; no castro da Mogueira, em S. Martinho de Mouros (Est. n. ${ }^{\circ}$ 21) e nas sepulturas de Nogueiró, nas proximidades do Penedo de S. João ou Castelo de Aregos. Estes espaços sepulcrais localizam-se a uma distância inferior a $1 \mathrm{~km}$ das fortificações e, nos casos do Bairro do Castelo e das sepulturas de Mogueira, encontram-se espacialmente associadas às fortificações implantando-se junto de templos e áreas residenciais.

\section{AS LEITURAS POSSÍVEIS DE UM TERRITÓRIO A SUL DO DOURO}

As leituras que se podem fazer deste espaço montanhoso encaixado entre os rios Távora, Douro e Cabrum são ainda muito incipientes. Seriam necessários trabalhos intensivos de prospeção arqueológica, seguidos de um programa de escavações arqueológicas abrangentes que permitissem analisar com outro grau de pormenor a relação entre os sepulcros rupestres e a paisagem humanizada, procurando definir matrizes de assentamento e observar as suas linhas evolutivas.

A paisagem funerária desta região é composta sobretudo por monumentos isolados ou núcleos de 2 ou 3 sepulcros, tal como acontece em outras áreas do país, sendo um fenómeno transversal a toda a Europa Ocidental a partir dos séculos VII-VIII.

A dispersão destes pequenos núcleos de sepulturas poderá significar um povoamento disperso, assente em pequenos casais agrícolas implantados em zonas de solos de fraca produtividade e promovendo uma agricultura de subsistência, mais assente na pastorícia do que na produção hortícola.

Este facto parece sobressair quando se constata que das 26 sepulturas inventariadas, 11 se localizam perto de vestígios de habitats, 8 se implantam nas proximidades de caminhos, 6 se articulam com espaços de culto ou templos e que 4 se localizam perto de povoados fortificados ou estruturas defensivas.

Os espaços sepulcrais compostos por mais de 3 sepulturas concentram-se quase exclusivamente no limite sudoeste do território, na zona fértil do vale do rio Távora,

${ }^{27}$ LIMA, 1993: 249. 
ou junto de habitats medievais como acontece no caso de S. Martinho de Mouros e eventualmente na Tapada do Abade, em Goujoim.

Nas zonas mais férteis junto dos vales, onde os terrenos são de maior dimensão e permitiriam uma agricultura mais intensiva, com exceção da região de Sendim, observam-se poucos exemplares de sepulcros escavados na rocha. Quererá isto significar que as elites que dominavam os espaços agrícolas mais amplos e produtivos terão optado por receber outro tipo de sepultura? Ou estariam estes amplos espaços, que em época romana e tardo-antiga foram intensamente explorados, em estado de semiabandono?

Uma das respostas a esta questão poderá relacionar-se com o ambiente de insegurança vivido no século VIII, provocado pelo avanço das tropas muçulmanas e o recuo das linhas de fronteira para o norte da península. Esta situação terá obrigado à retirada dos principais quadros civis e religiosos deixando as regiões desgovernadas civil e eclesiasticamente. A fixação do bispo de Lamego em Iria Flavia (Padrón), durante o reinado de Afonso I das Astúrias parece corroborar esta retirada ${ }^{28}$.

Face a esta realidade as populações terão novamente procurado refúgio nas terras altas e inóspitas, reocupando e recuperando muitas das antigas fortificações, tal como havia já acontecido no decorrer do século $\mathrm{V}$ e $\mathrm{VI}^{29}$.

A instabilidade e insegurança sentida nesta região prolongar-se-á durante o reinado de Afonso III das Astúrias (866-909) e ter-se-á intensificado quando, após a criação das civitates de Anégia e Santa Maria, que, nas palavras de Mário Barroca, garantia à coroa asturiana «a defesa da margem Norte e Sul do curso terminal do Douro, desde a zona de Baião até à Foz», a transformou num espaço de fronteira ${ }^{30}$. Esta situação manter-se-á até meados do século XI, quando as campanhas de Fernando o Magno, na região da Beira, permitiram tomar, entre outros, os castelos de Lamego e S. Martinho de Mouros, em 1057 e 1058, respetivamente, e preparar o caminho para a conquista definitiva de Coimbra, o que viria a ocorrer em 1064.

A conquista definitiva do território e a reorganização administrativa e possivelmente eclesiástica que seguramente lhe sucedeu terá trazido a estabilidade necessária a esta região para que uma centúria depois se assista à fundação de dois grandes mosteiros cistercienses, S. João de Tarouca e Santa Maria de Salzedas, no fértil vale do Varosa.

\footnotetext{
${ }^{28}$ BARROCA, 2003: 22.

${ }^{29}$ BARROCA, 1990-1991: 91.

${ }^{30}$ BARROCA, 1990-1991: 92.
} 


\section{CONSIDERAÇÕES FINAIS}

O estudo e análise das sepulturas escavadas na rocha reveste-se de grande importância para a compreensão da transição entre o mundo funerário tardo-antigo e a organização da sociedade em paróquias, característica do mundo medieval e feudal.

Este período de tempo encontra-se repleto de acontecimentos que alteraram a organização social e religiosa então vigentes e contribuíram para profundas mudanças culturais e mentais. Estas alterações refletiram-se nas formas de ocupar e explorar o território e, necessariamente, nos espaços funerários.

Algumas das questões que se colocam quando se aborda o estudo das sepulturas rupestres incidem sobre a cronologia dos monumentos, sua tipologia e de que forma é que é possível, a partir da sua localização, inferir modelos de ocupação e exploração do território. Todas estas questões estão interligadas e são indissociáveis.

A tipologia das sepulturas e a sua cronologia, nomeadamente a discussão sobre a anterioridade dos túmulos de configuração não antropomórfica em relação aos antropomórficos, continua ainda a gerar opiniões divergentes entre os investigadores. As leituras que se apresentam podem contribuir para esta discussão com algumas perspetivas que passamos a destacar.

Desde logo se observa que a maioria das sepulturas apresenta configuração não antropomórfica e que se dispersa pelo território em pequenos núcleos funerários deixando antever um povoamento disperso. Por outro lado, as sepulturas antropomórficas, se não se considerar as necrópoles da igreja matriz de Sendim, do Cabeço do Poio e as sepulturas do Bairro do Castelo, constituem um número residual de sepulcros que também se dispersam pelo território, coexistindo em 4 estações com sepulturas de planta geométrica. Este facto, per se, apesar de não significar uma relação de contemporaneidade entre os monumentos poderia reforçar esta perspetiva. Porém, ao incluir-se na análise as sepulturas das 3 necrópoles supracitadas, sobretudo a da igreja matriz de Sendim, em que os túmulos se encontram alinhados e agrupados com tendência para a orientação comum, e que alguns autores integram numa paisagem hierarquizada, em que há uma memória comunitária gerida por uma instância de poder, permitirá a associar estes sepulcros a uma fase posterior. Significando que estes locais, e consequentemente os sepulcros que os compõem, teriam sido construídos e utilizados numa altura em que o território já se encontrava devidamente estruturado e nuclearizado em torno de um espaço de poder, que neste caso concreto, poderia muito bem ser a paróquia de Santa Maria de Sendim referida na documentação desde o século XII.

Para além disso, a análise do conjunto sepulcral existente em torno de Sendim revela que as necrópoles de sepulcros exclusivamente não antropomórficos se implantam nas zonas baixas, próximas das áreas agrícolas mais férteis e onde são abundantes 
os vestígios ocupacionais de casais e villae. Quererá isto significar que nos finais do século VII e inícios do século VIII, as populações exploravam o território a partir de um modelo próximo ao romano e tardo-antigo, habitando em casais e villae, ainda que de forma dispersa, junto do ager? Será que as movimentações militares relacionadas com a chegada das forças muçulmanas e o clima de instabilidade obrigou as populações a procurar refúgio nas zonas mais altas, dispersando-se e reocupando os povoados fortificados de épocas anteriores?

Esta última leitura parece sair reforçada ao constar-se que nesta região se observam relações de proximidade entre vários núcleos de sepulturas e povoados fortificados que remontam a épocas proto-históricas ou romanas e com estruturas defensivas roqueiras. Entre estas situações destaca-se o caso de S. Martinho de Mouros e da necrópole da Mogueira, estação que constitui um importante exemplo de povoado alto-medieval, em que a fortificação militar, o espaço habitacional, possivelmente a área de culto e o espaço funerário, coexistem no mesmo espaço, constituindo um raro exemplo no panorama das estações alto-mediévicas portuguesas.

A análise desta estação permite algumas leituras que podem reforçar as ideias constatadas e a enunciadas nos parágrafos anteriores.

A necrópole é inteiramente constituída por sepulcros não antropomórficos que se implantam no sopé de um castelo roqueiro. As referências documentais sobre a relação do Castelo de S. Martinho de Mouros com as movimentações do período da Reconquista Cristã remetem para o século XI e para épocas anteriores. Há notícia da conquista desta estrutura defensiva em 1058, e sabe-se que sofreu obras de melhoramentos no último quartel do século XI, logo após a conquista definitiva de Coimbra em 1064, que afastou definitivamente a fronteira para o vale do rio Mondego. Terá sido a partir de então que o castelo passou a ter uma posição estratégica periférica tendo as populações progressivamente abandonado este habitat e procurado estabelecer-se junto das áreas mais férteis. Não será de estranhar, portanto, que na centúria seguinte haja notícias da construção da atual igreja românica, provavelmente iniciada por volta de 1217, numa encosta menos acidentada, aberta para o vale e dominando os campos agrícolas.

Estas perspetivas sobre a cronologia dos monumentos e sobre as modificações verificadas na organização do povoamento referem-se exclusivamente a esta área. Certamente que outras regiões, fruto dos seus condicionalismos específicos, poderão permitir leituras distintas. Apenas quando existir um conjunto mais amplo de levantamentos dos sepulcros rupestres e da sua integração num contexto paisagístico é que se poderá ambicionar obter uma leitura mais fidedigna da Alta Idade Média e do período da Reconquista. 


\section{BIBLIOGRAFIA}

ALARCÃO, Jorge de (1990). O domínio romano. In SERRÃO, Joel; MARQUES, A. H. de Oliveira, dir. Nova História de Portugal. Lisboa: Editorial Presença, vol. I, pp. 343-489. Vol. I: Portugal das origens à romanização.

ALMEIDA, Carlos Alberto Ferreira de (2001). História da Arte em Portugal - O Românico. Lisboa: Editorial Presença.

ARQUEOLOGIA \& PATRIMÓNIO [s.d.]. Trabalhos Arqueológicos, Bairro do Castelo, Programa Viver Lamego, Valorização e Integração Urbana do Centro Histórico, Lamego, Câmara Municipal de Lamego. Brochura disponível em <http://www.viverlamego.com $>$.

BARROCA, Mário Jorge (1987). Necrópoles e Sepulturas Medievais de Entre-Douro-e-Minho (Séculos V $a X V$ ). Porto: Faculdade de Letras da Universidade do Porto. Dissertação para Provas Públicas de Aptidão Pedagógica e Capacidade Científica.

BARROCA, Mário Jorge (1990-1991). Do castelo da reconquista ao castelo românico (Séc. IX a XII). «Portvgalia». Nova Série. 11-12, 89-136.

BARROCA, Mário Jorge (2003). Da reconquista a D. Dinis. In MATTOSO, José, coord. Nova História Militar de Portugal. Lisboa: Círculo de Leitores, vol. 1, pp. 22-161.

BARROCA, Mário Jorge (2004). Fortificações e Povoamento no Norte de Portugal (Séc. IX a XI). «Portvgalia». Nova Série. 25, 181-203.

BOLÓS MASCLANS, Jordi; PAGÉS PARETAS, Montserrat (1982). Les sepultures excavades a la roca. In RIU, Manuel, dir. Necropolis i sepultures medievals de Catalunya. Barcelona: Departament d'Historia Medieval, pp. 59-103.

CORREIA, Alberto (2007). Tabuaço. Roteiro turístico. Viseu: Câmara Municipal de Tabuaço.

COSTA, M. Gonçalves da (1979). História do bispado e cidade de Lamego. Idade Média: Paróquias e Conventos. Lamego: Oficinas Gráficas de Barbosa \& Xavier, vol. II.

GRANDE ENCICLOPÉDIA PORTUGUESA E BRASILEIRA - s.v. Sendim, Vol. XXVIII. Lisboa; Rio de Janeiro: Editorial Enciclopédia, Lda, pp. 267-269.

GUEDES, César (2015). A sul do Douro: percurso pelas sepulturas escavadas na rocha entre os rios Távora e Cabrum. Porto: Faculdade de Letras da Universidade do Porto. Dissertação de Mestrado.

LIMA, António (1993). Castelos Medievais do Curso Terminal do Douro (Séc. IX -XII). Porto: Faculdade de Letras da Universidade do Porto. Dissertação de Mestrado.

LÓPEZ QUIROGA, Jorge (2005-2006). Después del "final" de las Villae entre el miño y el Duero (ss. VII-X): Comunidades "fructuosianas", hábitat rupestre y "aldeas". "Cuadernos de Prehistoria y Arqueologia». 31-32, 219-245.

MARTÍN VISO, Iñaki (2012). Enterramientos, memoria social y paisaje en la alta edad media: propuestas para un análisis de las tumbas excavadas en roca en el centro oeste de la Península Ibérica. «Zephyrus». 69, 165-187.

MARTÍN VISO, Iñaki (2014). El espacio del más acá: las geografías funerarias entre la Alta y la Plena Edad Media. In LÓPEZ OJEDA, Esther, coord. De la tierra al cielo. Ubi sunt qui ante nos in hoc mundo fuere? Logroño: Instituto de Estudios Riojanos, pp. 75-140.

PERPÉTUO, João et al. (1999). Tabuaço. Um passado presente. Tabuaço: Câmara Municipal de Tabuaço.

PORTAL DO ARQUEÓLOGO. Disponível em <http://arqueologia.patrimoniocultural.pt/>

SANTOS, Carla (2011). Corte e remoção da vegetação arbustiva na necrópole da Tapada do Abade (Armamar-Viseu) - Acompanhamento Arqueológico, Viseu: Arqueohoje Lda.

SANTOS, Maria João Correia dos (2012). La arqueologia, lo imaginário y lo real. El santuário rupestre de Mogueira (São Martinho de Mouros). «Madrider Mitteilungen». 53, 455-496.

SILVA, Eduardo; MEDEIROS, Maria; CORREIA, Alexandre (1997). Carta Arqueológica do Concelho de Resende. Resende: Câmara Municipal de Resende. 
TEIXEIRA, Ricardo (2001). Castelos e Organização dos territórios nas duas margens do Douro (Séculos IX-XIV). In FERNANDES, Isabel, coord. Mil Anos de Fortificações na Península Ibérica e no Magreb (500-1500): Actas do Simpósio Internacional sobre Castelos. Lisboa: Edições Colibri, pp. 463-476. VIZCAÍNO SÁNCHEZ, Jaime (2007). Introducción. El estudio del mundo funerário tardoantiguo en el área Hispana: ¿Bizantinos, Visigodos o Hispanorromanos?. La presencia bizantina en Hispania (siglos VI-VII). La documentación arqueológica. "Antigüedad y Cristianismo: Monografías Históricas sobre la Antigüedad Tardía». XXIV, 535-596. 



\title{
LAS NECRÓPOLIS DE TUMBAS \\ EXCAVADAS EN LA ROCA EN \\ CANTABRIA (ESPAÑA)
}

\author{
ENRIQUE GUTIÉRREZ CUENCA*
}

Resumo: Este artigo reúne uma visão geral das necrópoles de sepulturas na rocha na região de Cantábria (Espanha). Uma síntese é feita em que diferentes questões são abordadas, como a sua distribuição geográfica, os aspetos formais de necrópoles e sepulturas ou uma breve discussão sobre sua cronologia.

Palavras-chave: Necrópoles; Sepulturas na rocha; Cantábria; Idade Média.

Abstract: This paper gathers an overview of the cemeteries of rock-cut tombs of Cantabria (Spain). A synthesis is made in which different issues are addressed such as their geographical distribution, the formal aspects of cemeteries and graves or a brief discussion about its chronology.

Keywords: Cemeteries; Rock-cut graves; Cantabria; Middle Ages.

\section{INTRODUCCIÓN}

Han pasado más de 30 años desde que se realizó el último estudio de conjunto de las necrópolis de tumbas excavadas en la roca de Cantabria ${ }^{1}$. Desde entonces, la realización de nuevos trabajos de prospección, excavación y documentación de este tipo de enclaves han permitido ampliar y corregir el corpus de yacimientos, así como avanzar en su caracterización formal y cronológica de los mismos. La síntesis que aquí se recoge parte de la elaboración de un catálogo actualizado de las necrópolis existentes en toda la región y del estudio detallado de un número significativo de tumbas en la zona meridional ${ }^{2}$. Las tumbas excavadas en la roca representan una cifra que se puede considerar marginal en el conjunto regional de manifestaciones funerarios desde la época visigoda hasta la Baja Edad Media - con un número de necrópolis inferior al $10 \%$ del total - pero tienen un gran protagonismo en los territorios más meridionales, sobre todo en Valderredible. En total, contamos con 26 localizaciones que han podido ser documentadas sobre el terreno y algunas más de las que hay noticias no confirmadas (Mapa 1).

\footnotetext{
*Email: egcuenca@gmail.com.

${ }^{1}$ BOHIGAS ROLDÁN, 1982.

${ }^{2}$ GUTIÉRREZ CUENCA, 2015, 2016. Este trabajo recoge una parte de la tesis doctoral Génesis y evolución del cementerio medieval en Cantabria, defendida el 28/9/2015 en la Universidad de Cantabria y dirigida por la profesora Carmen Díez Herrera (UC) [DOI: hdl.handle.net/10803/311798].
} 


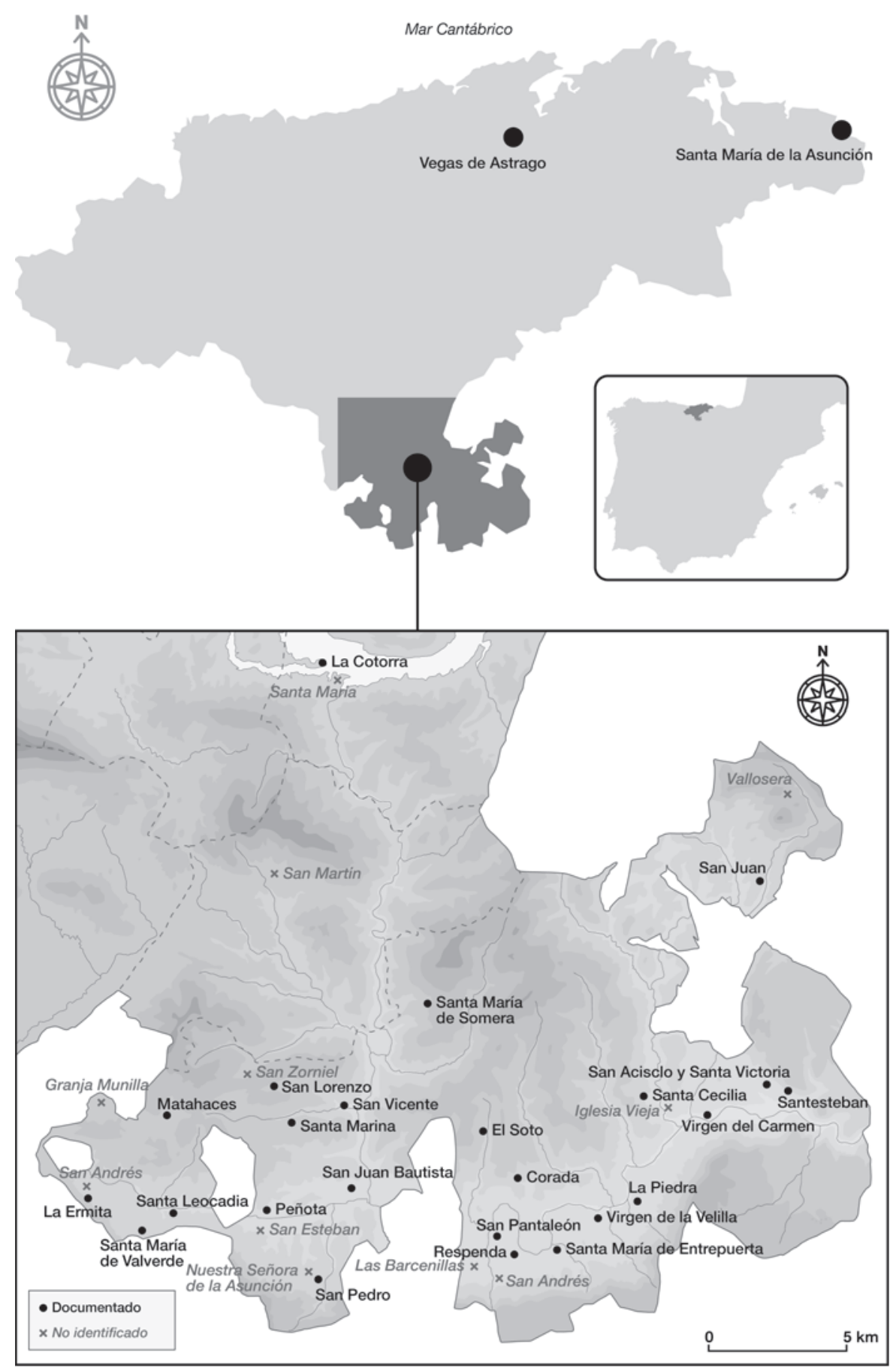

Mapa 1. Localización de las necrópolis excavadas en la roca de Cantabria Fuente: Enrique Gutiérrez Cuenca 
El conocimiento que tenemos sobre este tipo de tumbas en Cantabria está muy condicionado tanto por el limitado alcance de las actuaciones arqueológicas que se han llevado a cabo en los cementerios donde están presentes, como por la conservación del registro arqueológico. Solo se han realizado excavaciones en cuatro necrópolis: en Santa María de Valverde ${ }^{3}$, Santa María de la Asunción de Castro Urdiales ${ }^{4}$, San Pantaleón de la Puente del Valle ${ }^{5}$ y una muy reciente en San Pedro de Villamoñico, aún inédita (Fig. 1). En el resto de los casos, las actuaciones se han limitado a la documentación de las estructuras visibles. Por otro lado, la conservación del registro arqueológico en las necrópolis también dificulta su estudio, tanto de las estructuras como de su contenido. Son excepcionales los casos, por ejemplo, en los que se ha localizado la cubierta de la tumba en su posición original, o en los que han aparecido restos óseos conservados en el interior. Los más habitual es que las tumbas estén vacías o tengan depósitos sedimentarios estériles. Esto condiciona que se puedan realizar descripciones más o menos precisas sobre los vanos de las tumbas y sus características formales, pero que tengamos serios problemas para abordar otras cuestiones como la gestión de las sepulturas o incluso su cronología. Es una problemática bastante habitual en toda la Península Ibérica, donde una buena parte de los estudios sobre tumbas excavadas en la roca se ha realizado a partir de la descripción de los conjuntos «visibles», con tumbas vacías que se han ido clasificando a partir de su morfología, pero cada vez es más evidente que sólo las excavaciones de contextos bien conservados permitirán aportar avances significativos en la investigación.

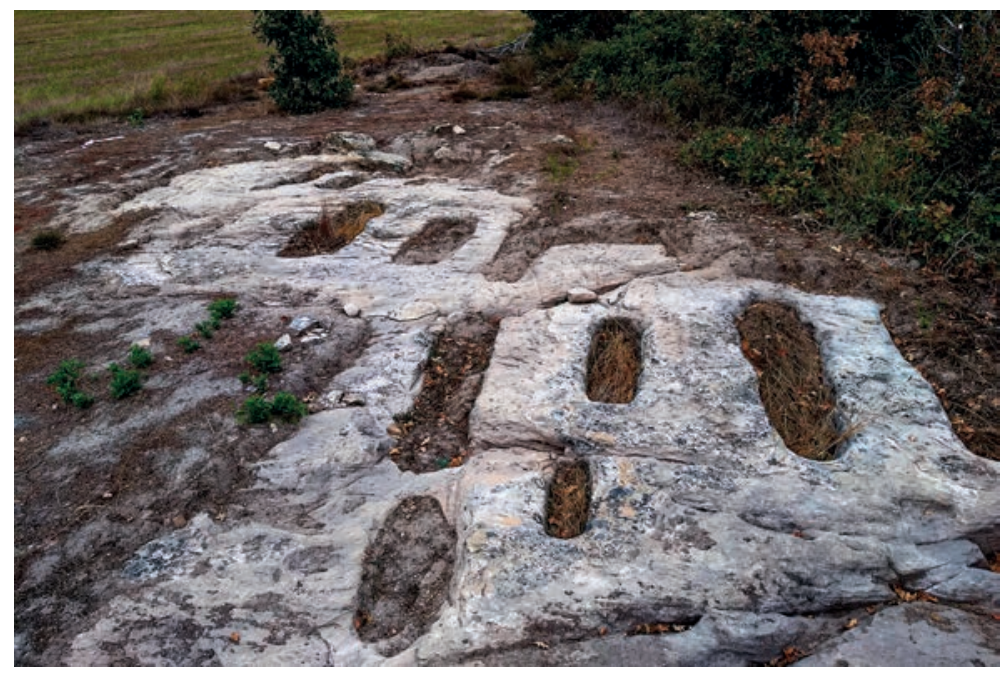

Fig. 1.

Necrópolis de San Pedro de Villamoñico Fuente: Enrique Gutiérrez Cuenca

\footnotetext{
${ }^{3}$ MARCOS MARTÍNEZ, 2010.

${ }^{4}$ MARCOS MARTÍNEZ, 2013.

${ }^{5}$ LAMALFA DÍAZ, 2000; FERNÁNDEZ et al., 2003; LAMALFA DÍAZ et al., 2008.
} 


\section{DISTRIBUCIÓN GEOGRÁFICA}

La distribución geográfica de las necrópolis con tumbas excavadas en la roca de Cantabria está caracterizada por una mayor concentración al sur de la cordillera Cantábrica y una presencia testimonial, aunque suficientemente significativa, en la zona costera (vid. Mapa 1). De hecho, hasta la identificación en 2012 de una veintena de tumbas excavadas en la roca en la cabecera de Santa María de la Asunción de Castro Urdiales ${ }^{6}$, la única referencia conocida de la zona costera era una fotografía y una breve descripción de una tumba que documentó J. Carballo en la década de 1940 en el paraje conocido como Vegas de Astrago de Parbayón ${ }^{7}$. Los demás casos recogidos en la bibliografía se reparten por Las Rozas de Valdearroyo, Valdeprado del Río y, sobre todo, por Valderredible, donde se concentran más del $80 \%$ de las necrópolis con este tipo de tumbas. La concentración en la zona del valle del Ebro ha sido interpretada por algunos investigadores como el resultado de un condicionamiento ambiental ${ }^{8}$, puesto que consideran que es la disponibilidad de sustratos litológicos adecuados para la excavación de este tipo de tumbas como el principal motivo de su presencia. Es cierto que la mayoría de las necrópolis aparecen en afloramientos de areniscas de grano grueso del Cretácico Inferior fáciles de trabajar, pero el hallazgo de tumbas excavadas en las calizas albienses de Castro Urdiales pone de manifiesto que la facilidad para la labra no es el único criterio a la hora de decantarse por un tipo de tumba u otro. De hecho, hay zonas con importante presencia de tumbas excavadas en la roca en otras zonas de la Península Ibérica en cuyo sustrato geológico predomina el granito y otras rocas duras, como la comarca portuguesa de Riba Côa9 .

Aunque no se ha abordado aún la relación entre el poblamiento medieval y la presencia de este tipo de necrópolis a la escala en la que se ha hecho en otros espacios como el Alto Arlanza ${ }^{10}$, disponemos de algunos datos referidos a Valderredible que nos permiten apuntar algunas ideas sobre su significado en la articulación del espacio, sobre todo por el contraste que ofrece frente a las propuestas planteadas para otras zonas de la Península Ibérica.

\footnotetext{
${ }^{6}$ MARCOS MARTÍNEZ, 2013.

${ }^{7}$ FERNÁNDEZ ACEBO, 2003. No se incluyen en esta categoría los ejemplares de Santa María de Bareyo y de la Abadía de los Cuerpos Santos de Santander que han sido catalogados como tumbas excavadas en la roca porque consideramos que no se pueden definir como tales, ya que no se ha horadado la roca de forma intencionada para conformar el contenedor, sino que la transformación de la matriz rocosa se ha producido al excavar el vano para otro tipo de tumbas, de lajas en el primer caso y de fosa simple en el segundo (vid. GUTIÉRREZ CUENCA, 2015).

${ }^{8}$ VANDEN EYNDE CERUTI, 1985; BOHIGAS ROLDÁN, 1999.

${ }^{9}$ MARTÍN VISO, 2007.

${ }^{10}$ PADILLA LAPUENTE, ÁLVARO RUEDA, 2010.
} 
En líneas generales, la distribución de las tumbas excavadas en la roca en Valderredible ofrece un reflejo del modelo de articulación del territorio en la Alta Edad Media, un momento en el que el número de núcleos habitado era que el actual e incluso que el de la Baja Edad Media. Estas necrópolis son uno de los principales indicadores de una eclosión poblacional muy visible para la Alta Edad Media frente etapas precedentes - especialmente si lo comparamos para los datos disponibles para época romana, anecdóticos - que posiblemente se inicie en época visigoda. Su abandono, por otro lado, refleja el desarrollo de procesos propios de la Plena Edad Media, detectados en otras zonas de la región, entre los que destacada la consolidación de la organización territorial de las diócesis.

De los 26 enclaves con tumbas excavadas en la roca atribuidos a la Alta Edad Media cuya existencia ha podido ser verificada sobre el terreno, hay indicios arqueológicos o toponímicos que indican su relación con edificios de culto en la mayor parte de los casos, lo que indicaría que funcionaron como cementerio de la comunidad que frecuentaba estas pequeñas iglesias rurales, anticipando el modelo del cementerio parroquial. Sin embargo, llegado el siglo XII, cuando se inicia la transformación de la red parroquial, varios de esos lugares no se convertirán en parroquia y se abandonan en algún momento de la Edad Media, mientras que los que siguen en funcionamiento o se transforman en ermitas sin autorización para administrar determinados sacramentos o recibir sepulturas son los menos. Un número importante de los enclaves abandonados son necrópolis de tumbas excavadas en la roca, un tipo de espacio funerario sobre cuyas dificultades para la integración en la red parroquial en otros ámbitos geográficos se hacen eco trabajos recientes ${ }^{11}$. Según este investigador, en el centro de la Península Ibérica la implantación de las parroquias supone una ruptura con los patrones anteriores, abandonándose los conjuntos de tumbas excavadas en la roca aisladas o compuestas por un número reducido de unidades, que correspondían a grupos familiares o pequeñas comunidades de campesinos libres, e incorporándose a las nuevas iglesias parroquiales sólo las necrópolis de mayor extensión. Sin embargo, este modelo, en el que el control eclesiástico sólo se interesa por integrar los lugares con mayor "capital simbólico acumulado» ${ }^{12}$, refleja una situación que difiere de la observada en Valderredible. En el valle cántabro se abandonan por igual cementerios de gran extensión, como San Pantaléon de La Puente del Valle o San Pedro de Villamoñico; de mediano tamaño, como San Juan de Rucandio; y aquellos que se podrían considerar «conjuntos aislados» por el escaso número de sepulturas visibles como

\footnotetext{
${ }^{11}$ MARTÍN VISO, 2012, 2014.

12 MARTÍN VISO, 2012: 30.
} 
Respenda de Quintanilla de An, El Soto de Quinanasolmo o Matahaces de San Cristóbal del Monte.

Para explicar esta transformación hay que atender a la confluencia, al menos en el caso de Valderredible, de dos factores: la contracción del poblamiento que se observa en el tránsito hacia la Baja Edad Media, vinculados con episodios de crisis demográficas o con cambios en el modelo de explotación del terrazgo ${ }^{13}$; y el propio proceso de organización parroquial desarrollado a partir del siglo XII que afecta a su definición territorial, que implicaría la pérdida de funciones sacramentales en algunos de los edificios religiosos existentes. Esto se traduciría en el abandono de numerosos cementerios, muchos de ellos de tumbas excavadas en la roca. Se trataría, por lo tanto, de una mutación compleja y en algunos casos ajena a la propia naturaleza de los cementerios o a las dinámicas internas de las comunidades que los utilizan, ya que el abandono estaría motivado por una reordenación territorial impuesta por las autoridades eclesiásticas que tendrá consecuencias en otros muchos aspectos de las comunidades rurales. Otro factor a tener en cuenta es que el proceso no afecta sólo a los cementerios de tumbas excavadas en la roca, tal y como parece que sucede en el centro de la Península Ibérica, donde la transformación del espacio funerario implicaría cambios en el tipo de contenedor utilizado ${ }^{14}$. En el caso de Valderredible comprobamos que también se abandonan cementerios de tumbas de lajas, como sucede en Ermita Blanca o San Esteban de Susilla, por señalar algunos ejemplos.

De todos modos, es un tema sobre el que hasta ahora solo se ha realizado un acercamiento superficial y habrá que corroborar estas primeras impresiones con un análisis más detallado del conjunto del territorio y de su desarrollo durante la Edad Media.

\section{ASPECTOS FORMALES}

En la mayor parte de los casos las necrópolis excavadas en la roca de Cantabria son conjuntos conformados por muy pocas tumbas, el $70 \%$ de los ejemplos conocidos tienen cinco o menos. Los grandes conjuntos, con 20 o más tumbas a la vista, se concentran en la zona occidental de Valderredible (Mapa 2), la cuenca del río Mardancho, con la única excepción de San Pantaleón de La Puente del Valle (Fig. 2), necrópolis ubicada en el sector central de la comarca, ya en el valle del Ebro.

\footnotetext{
${ }^{13}$ No estamos en condiciones de evaluar la incidencia real que tuvo la reducción en el número de núcleos de población que se aprecia en Valderredible a lo largo de la Edad Media. Es un fenómeno escasamente estudiado, más allá de algunos trabajos concretos (MARTÍNEZ RUIZ, 1997; BERKOSA GUERRERO, 2013) y en el que la escasez de documentación escrita supone un obstáculo importante. Sin embargo, todo indica que la organización de la red de poblamiento sufrió una profunda transformación que se salda con la desaparición de cerca de un $50 \%$ de las aldeas al final de la Edad Media.

${ }^{14}$ MARTÍN VISO, 2012.
} 


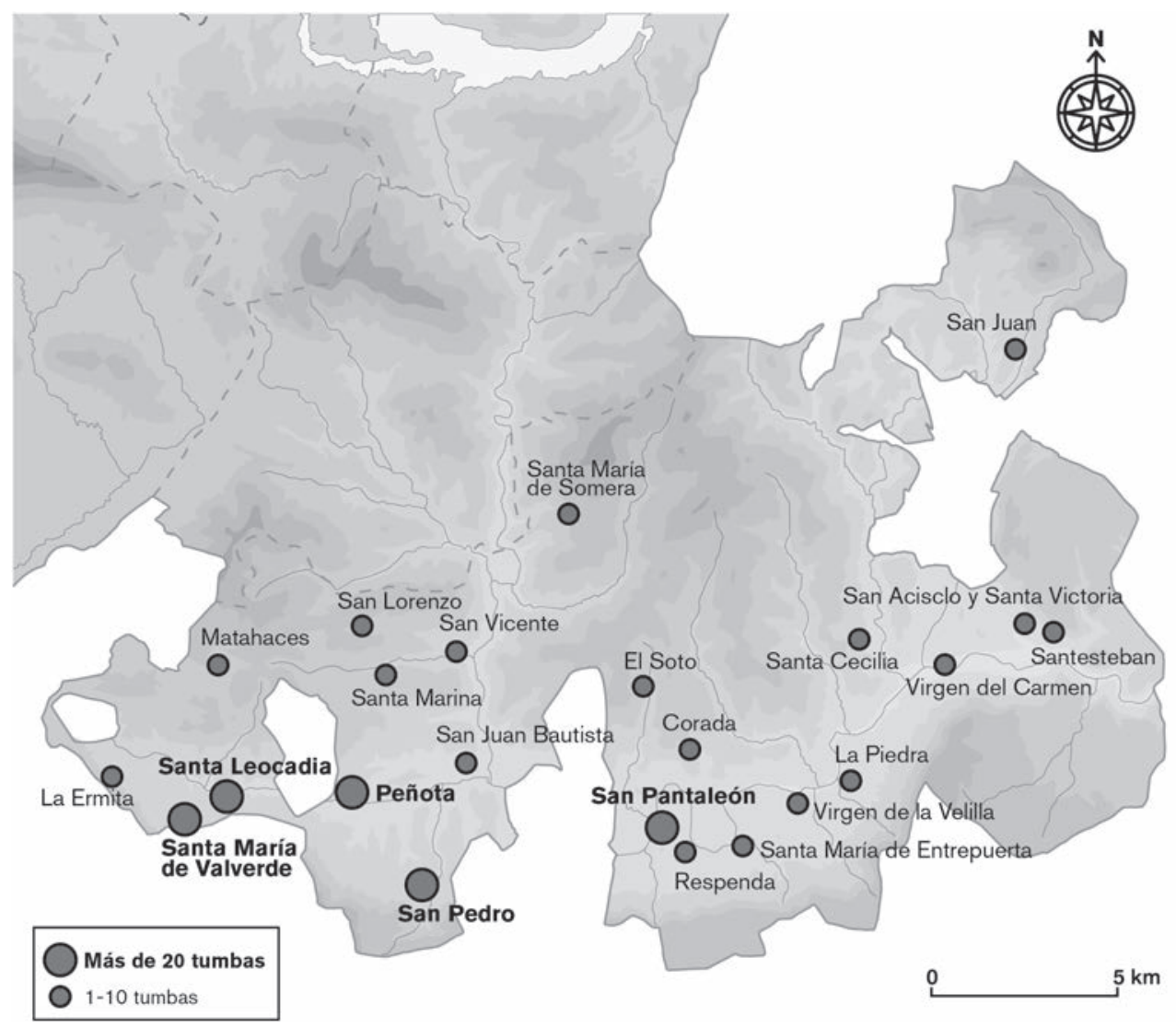

Mapa 2. Localización de las necrópolis excavadas en la roca de Valderredible, con indicación del número de tumbas Fuente: Enrique Gutiérrez Cuenca

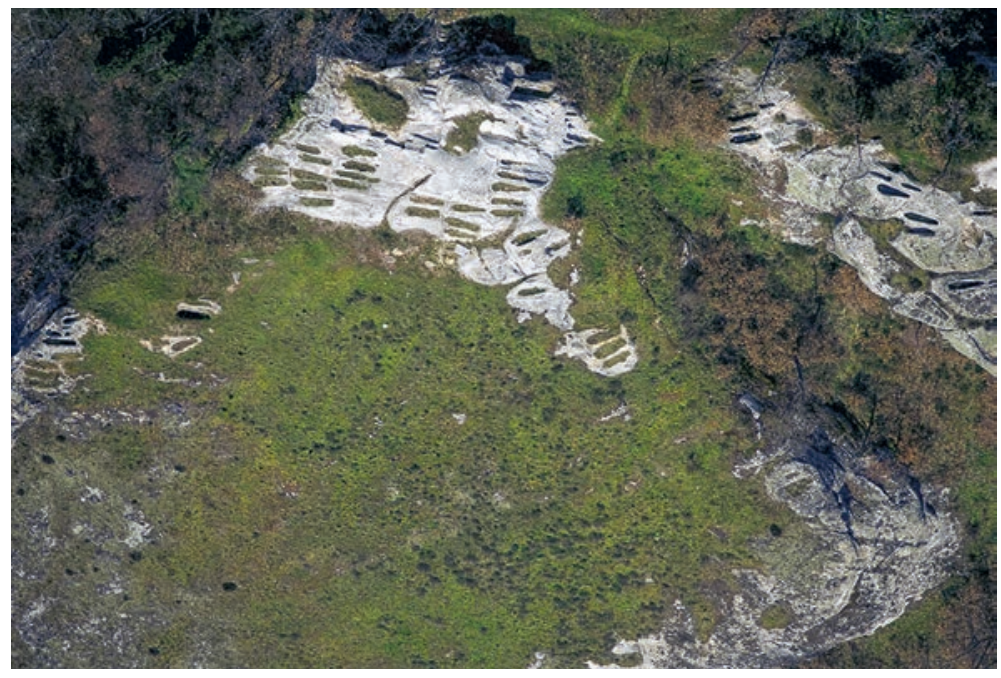

Fig. 2.

Vista aérea de la necrópolis de San Pantaléon de La Puente del Valle Fuente: Museo de Prehistoria y Arqueología de Cantabria (MUPAC) 
También en el grupo de necrópolis de mayor tamaño se incluiría la de Santa María de Castro Urdiales.

La frecuencia de esos pequeños grupos de tumbas sin aparente conexión con otro tipo de estructuras podría encajar en el modelo de «conjuntos aislados» ${ }^{15}$. Los ejemplos vallucos que mejor se adaptan a esa descripción, todos ellos compuestos por tumbas excavadas en la roca de planta antropomorfa, son: Respenda de Quintanilla de An, con cinco tumbas, dos de ellas de adulto y tres infantiles (Fig. 3); El Soto de Quintanasolmo, con dos tumbas de adulto; y Matahaces de San Cristóbal del Monte, también con dos tumbas de adulto. En ninguno de los tres casos existe una conexión directa con un edificio religioso, aunque El Soto está a unos $60 \mathrm{~m}$ en línea recta de la iglesia de La Concepción, de fábrica barroca, y Matahaces a unos $150 \mathrm{~m}$ de la iglesia de San Cristóbal, en la que se conservan algunos restos de sarcófagos medievales y cuya fábrica se remonta, al menos, al siglo XIII. En el caso de Respenda, existen indicios de un despoblado próximo denominado Santa Coloma. Resulta también significativo que la denominación no es hagonímica, a diferencia de lo que sucede con otros conjuntos de tumbas excavadas en la roca, asociados o no con edificios religiosos ${ }^{16}$.

Que se trate de auténticos conjuntos aislados o lo sean sólo en apariencia podría tener importancia desde el punto de vista cronológico, ya que, algunos investigadores consideran que se trata de un modelo característico de momentos anteriores al siglo VIII ${ }^{17}$. También desde el punto de vista de su interpretación en clave social, al ser considerados como enterramientos de carácter familiar, realizados al margen de una estructura de poder que organice la gestión de las necrópolis, a diferencia de las necrópolis de mayor tamaño, espacios centralizados y controlados por la jerarquía eclesiástica $^{18}$.

Sin embargo, a falta de una prospección intensiva del entorno que confirme la ausencia de otro tipo de evidencias contemporáneas, conviene observar cierta prudencia a la hora de catalogar estos enclaves como conjuntos aislados y, sobre todo, de extrapolar esos modelos de interpretación que tanto éxito parecen estar cosechando en la historiografía reciente ${ }^{19}$. Existen necrópolis en las que las tumbas se disponen por parejas en afloramientos de reducidas dimensiones que podrían señalarse a priori como conjuntos aislados, pero que parecen formar parte de conjuntos más amplios,

\footnotetext{
15 BLAIZOT, 2006.

${ }^{16}$ Cerca del $80 \%$ de las necrópolis de tumbas excavadas en la roca de Cantabria tienen una denominación hagiotoponímica, en algunos casos derivada de edificios religiosos posteriores asentados sobre ellas o en las proximidades, una asociación que no parece casual. La proporción difiere bastante de lo que se observa en otras regiones, especialmente al sur del Duero (MARTÍN VISO, 2016).

17 VIGIL-ESCALERA GUIRADO, 2013.

18 MARTÍN VISO, 2012.

${ }^{19}$ RUBIO DÍEZ, 2013; TENTE, 2015.
} 

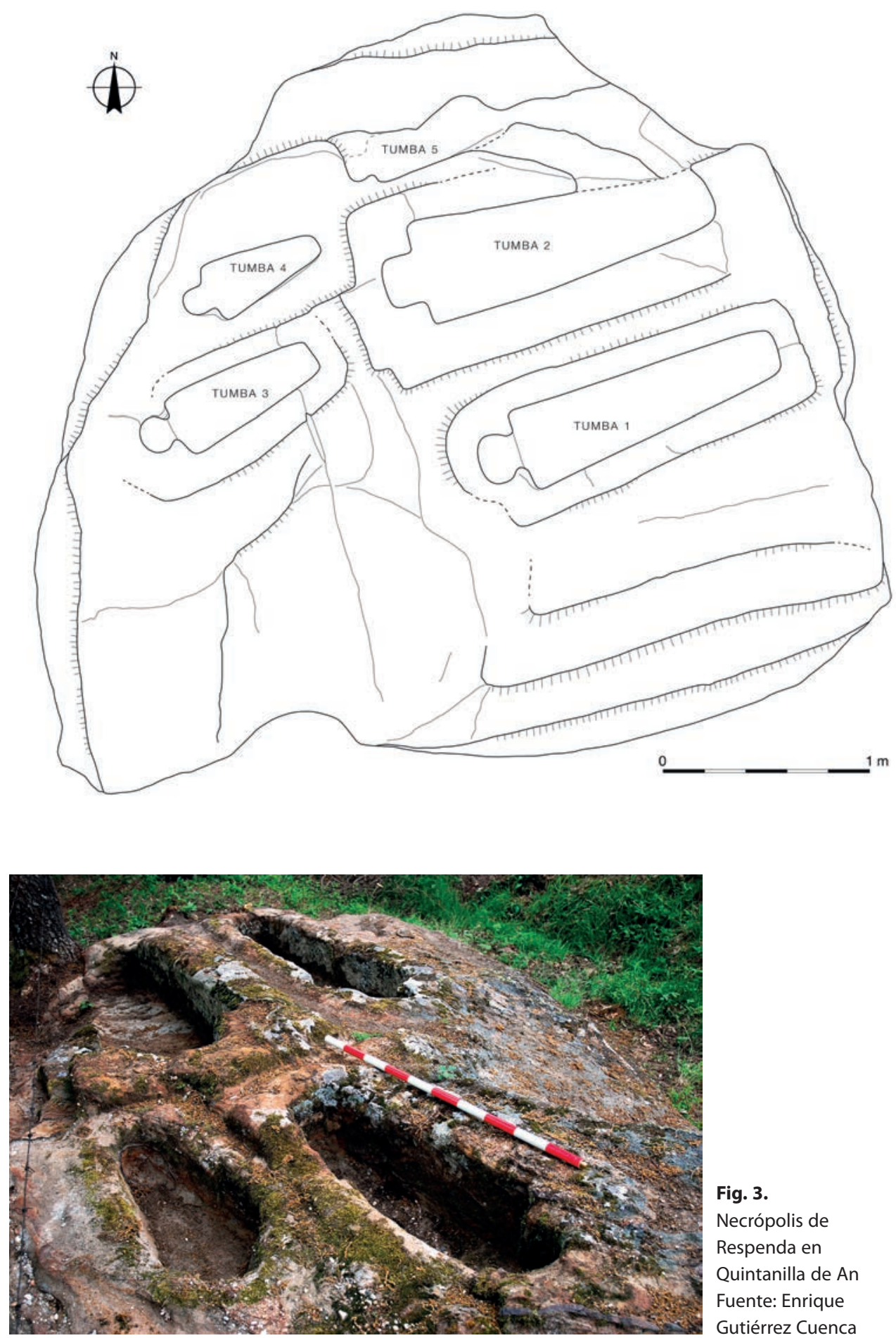

Fig. 3.

Necrópolis de

Respenda en

Quintanilla de An

Fuente: Enrique

Gutiérrez Cuenca 


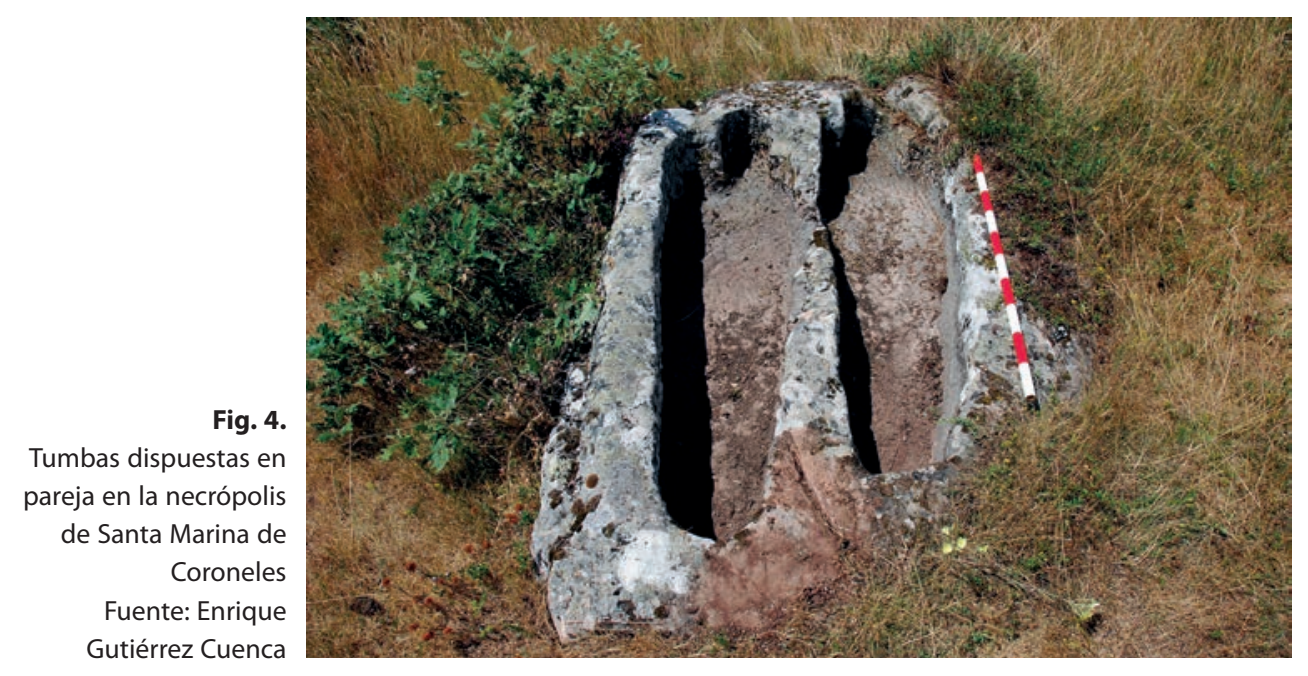

como sucede en Santa María de Somera, San Juan Bautista de Villanueva de la Nía y, con total seguridad, en Santa Marina de Coroneles (Fig. 4). Hay cierta tendencia, incluso en las necrópolis más extensas, a que aparezcan estas agrupaciones separadas del resto de las tumbas, como se aprecia en San Pantaleón de La Puente del Valle. Quizá tenga que ver con la propia configuración del terreno en la que se instala el cementerio, con afloramientos rocosos dispersos, o a una voluntad intencionada de aislar determinados conjuntos de tumbas, dando lugar a una organización dispersa del espacio cementerial.

La segmentación del espacio cementerial también podría responder a la delimitación de zonas reservadas a grupos concretos. En este sentido, ya A. del Castillo ${ }^{20}$ llamó la atención sobre la concentración de tumbas infantiles en la zona más próxima al ábside de la iglesia y de «panteones familiares» en la necrópolis de Revenga (Burgos), definiendo los dos tipos básicos de agrupaciones que se han rastreado desde entonces en las necrópolis excavadas en la roca. En Cantabria solo se puede identificar una concentración de tumbas de individuos infantiles en la cabecera de la iglesia semirrupestre de San Pantaleón de La Puente del Valle, ya que en el resto de los casos las tumbas infantiles y las de adulto están repartidas sin distinción por toda la necrópolis. Y por lo que respecta a las agrupaciones familiares, podrían encajar en ese modelo conjuntos bien delimitados como el de Respenda en Quintanilla de An, con dos tumbas de adulto y tres infantiles en mismo afloramiento, o la recurrencia con la que aparecen tumbas por pares aisladas del resto, como sucede en Santa Marina de Coroneles o en Santa Cecilia en Población de Abajo (Fig. 5). En cualquier caso, al ser tumbas en las que los restos óseos han desaparecido, es imposible comprobar

${ }^{20}$ CASTILLO, 1970: 9-16. 
si existen vínculos familiares o no entre sus ocupantes. Es evidente que los vínculos familiares jugaron un papel destacado en la ordenación interna del cementerio, al menos desde época tardoantigua y no debemos descartar la posibilidad de que la organización a partir de una yuxtaposición de conjuntos menores bien delimitados que parece observarse en alguna necrópolis pueda tener que ver con un crecimiento
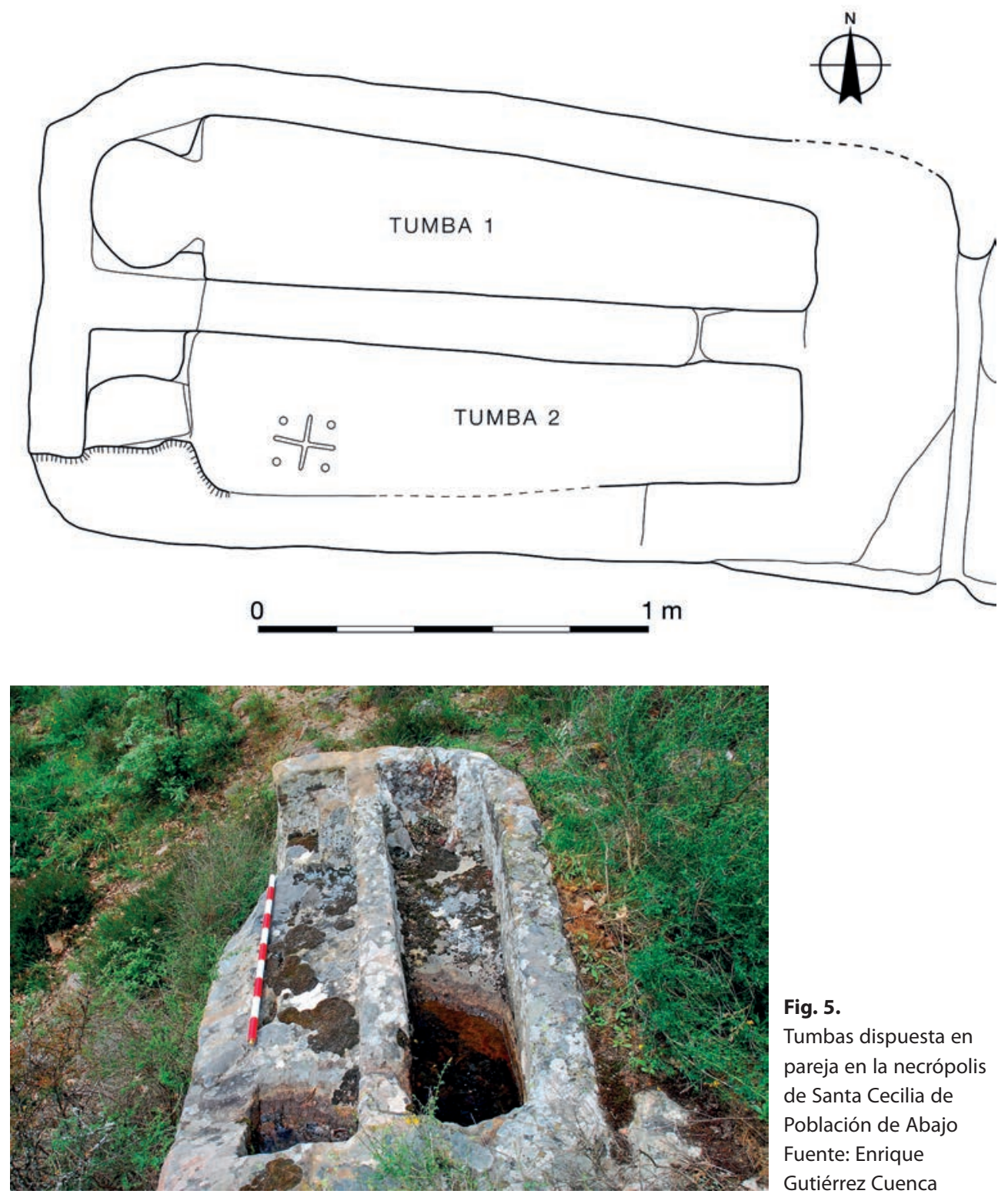

Fig. 5.

Tumbas dispuesta en pareja en la necrópolis de Santa Cecilia de Población de Abajo Fuente: Enrique Gutiérrez Cuenca 
acumulativo del cementerio, a partir de agrupaciones de tipo familiar, que daría como resultado un espacio funerario discontinuo y polinuclear ${ }^{21}$.

Para trazar una visión de conjunto sobre los aspectos formales de las tumbas, disponemos de una muestra estudiada de 112 sepulturas de 22 necrópolis ubicadas en Valderredible y Las Rozas de Valdearroyo ${ }^{22}$. A esto hay que añadir los datos de San Pantaléon de La Puente del Valle - no evaluados cuantitativamente, pero relevantes en términos cualitativos - y los de la excavación realizada en Santa María de la Asunción en Castro Urdiales ${ }^{23}$, fuera ya de la zona meridional.

Por lo que respecta a la orientación de las tumbas, los casos analizados en Valderredible indican que la mayor parte de ellas se orientan hacia el este, aunque el arco en el que se distribuyen es amplio. Los extremos del arco están definidos por tumbas que se orientan hacia los $60^{\circ}$ (NE por el E) y los $128^{\circ}$ (SE por el E), aunque el promedio obtenido de los 112 casos registrados se sitúa en $91^{\circ}$ (E). Más de un $80 \%$ del total tienen una orientación comprendida entre el ENE y el ESE, en un arco de unos $40^{\circ}$, con un cierto predominio del sector ENE-E sobre el sector E-ESE (Fig. 6) La variabilidad en la orientación está ligada en muchos casos a condicionantes naturales, especialmente a la alineación de los afloramientos rocosos en los que se excavan las tumbas. De hecho, en la mayor parte de los conjuntos de tumbas todos los ejemplares tienen una orientación similar, mientras que las diferencias entre conjuntos son mucho mayores, incluso dentro de una misma necrópolis. Así, los valores de mayor inclinación hacia el sureste, por ejemplo, se aprecian en Santesteban de Arroyuelos y afectan a todas las tumbas, porque el afloramiento rocoso en el que se asientan tiene esa misma orientación. En otros casos como Santa María de Somera el tamaño reducido de los afloramientos afecta a la orientación individual de cada tumba, fenómeno que se aprecia a mayor escala en San Pantaleón de La Puente del Valle. Las orientaciones en las tumbas de Cantabria son, a grandes rasgos, similares a las que se registran en las necrópolis de tumbas excavadas en la roca del Alto Arlanza, en los que la mayor parte de los casos están orientadas hacia el este con variaciones un arco de unos $40^{\circ}$, y para los que se consideran determinantes en la orientación de las tumbas factores relacionados con la ordenación del espacio funerario ${ }^{24}$.

Tomando como criterio las dimensiones, parece que las tumbas excavadas en la roca se emplean tanto para individuos adultos como para individuos infantiles.

\footnotetext{
${ }^{21}$ Este modelo polinuclear, que también se vislumbra en el caso de Cantabria en las necrópolis altomedievales de tumbas de lajas, supone una alternativa a la idea de que los cementerios crecen en anillos concéntricos alrededor de las iglesias, propuesta para algunas necrópolis excavadas en la roca como la de Cuyacabras (Burgos) (PADILLA LAPUENTE, ÁLVARO RUEDA, 2008), y permitiría explicar mejor la evolución de las necrópolis más extensas de Valderredible.

22 GUTIÉRREZ CUENCA, 2016.

${ }^{23}$ MARCOS MARTÍNEZ, 2013.

${ }^{24}$ ÁLVARO RUEDA, 2012: 189-198.
} 


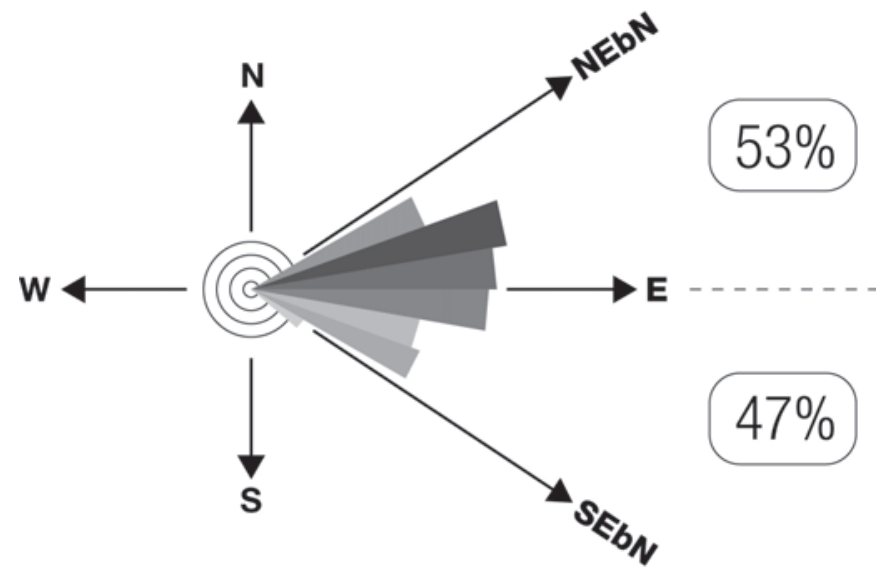

Fig. 6.

Orientación de las tumbas excavadas en la roca de Valderredible Fuente: Enrique Gutiérrez Cuenca

Las longitudes de las tumbas de la muestra del sur de Cantabria oscilan entre los 204 $\mathrm{cm}$ y los $140 \mathrm{~cm}$ para los adultos, y los $60 \mathrm{~cm}$ y los $138 \mathrm{~cm}$ para los infantiles ${ }^{25}$. La proporción entre adultos e infantiles se sitúa en torno a $70 \%$ para los primeros y $30 \%$ para los segundos, lo que se ajusta a grandes rasgos a las proporciones determinadas en los cementerios medievales en los que se conservan restos óseos ${ }^{26}$.

La forma de las tumbas presenta poca variabilidad, con dos modelos predominantes: tumbas de planta antropomorfa y tumbas de planta trapezoidal. Entre los ejemplares de del sur de la región cuya forma se puede determinar, las antropomorfas constituyen el 74\%, mientras que las trapezoidales suponen el 23\%, con una presencia testimonial de tumbas de planta rectangular y de planta oval o de bañera. La variabilidad formal de las tumbas infantiles presenta la misma distribución que las de los individuos adultos, con predominio de contenedores antropomorfos. Por lo que respecta a la cabecera, en las tumbas antropomorfas puede presentar formas diversas, desde una simple insinuación, hasta cabeceras ultrasemicirculares con el cuello muy marcado, casi siempre empleando líneas curvas (Fig. 7). No llega a la media docena el número de ejemplares con cabecera cuadrangular, entre más de 70 tumbas antropomorfas, repartidas por diferentes necrópolis, sin alcanzar en ningún conjunto una presencia destacada. Por lo general, y atendiendo a los lugares en los que se documentan un número importante de tumbas como Santa Leocadia de Castrillo de Valdelomar, Santa María de Peñota o Santa María de Valverde, las tumbas de distintas formas y

\footnotetext{
${ }^{25} \mathrm{Si}$ tenemos en cuenta los datos referidos a la única población medieval estudiada en Valderredible de la que tenemos referencias morfométricas, la de Santa María de Hito, la estatura mínima estimada para los individuos de sexo femenino es de153 cm y de 163,7 cm para los de sexo masculino (GALERA, 1989: anexo V). No obstante, hemos preferido utilizar valores más bajos para marcar el límite, aun a riesgo de que los individuos subadultos estén sobrerrepresentados en nuestra estimación.

${ }^{26}$ vid. GUTIÉRREZ CUENCA, 2015: apéndice 3.
} 

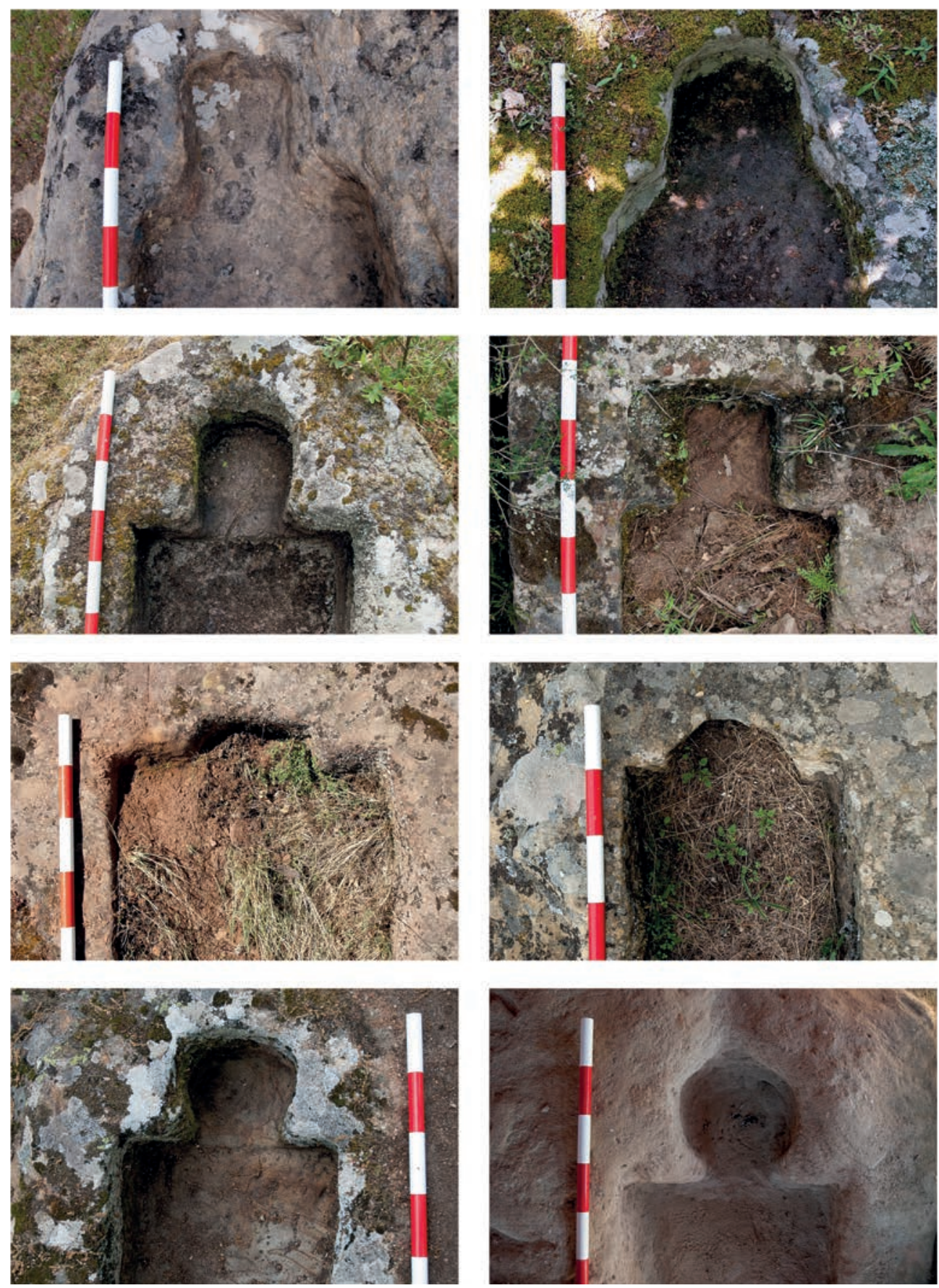

Fig. 7. Diversidad formal de las cabeceras en las tumbas excavadas en la roca de Valderredible Fuente: Enrique Gutiérrez Cuenca 
con diferentes tipos de cabecera aparecen mezcladas, sin que se pueda suponer que el cambio en el contorno de su planta pueda relacionarse de forma clara con una variación cronológica - y mucho menos regional - como la que se planteaba en las primeras etapas de la investigación sobre este tipo de tumbas ${ }^{27}$.

Además de la forma en planta del hueco de la cabeza, en las cabeceras de las tumbas antropomorfas se aprecian otras variantes. Hay algunos casos de cabecera antropomorfa en los que se ha procedido a rebajar la zona de los hombros, como en Corada o en Santa Cecilia de Población de Abajo, y otros en los que el hueco destinado a la cabeza está ligeramente elevado sobre el fondo del hueco en el que descansaba el cuerpo, tal y como sucede en Santa María de Somera y en Matahaces. En algunas ocasiones la cabecera antropomorfa presenta un rebaje en la pared de la cabecera que conforma la denominada «oquedad occipital» (Fig. 8), que posiblemente servía para encajar la cabeza del difunto. Hay varios ejemplos en Santa María de Peñota y Santa Leocadia de Castrillo de Valdelomar, coincidiendo habitualmente con tumbas de cabecera poco marcada en planta. Mucho más rara es la presencia de una oquedad similar en la zona de los pies, quizá necesaria para colocar en la tumba un difunto de mayor talla del que se tenía intención inicialmente.

$\mathrm{Al}$ menos en el primer uso que reciben estas tumbas ${ }^{28}$, es probable que se hagan a medida del ocupante, a juzgar por la diversidad de dimensiones que se registran. Quizá sólo se labren sin atender a la talla real del difunto aquellas que se disponen

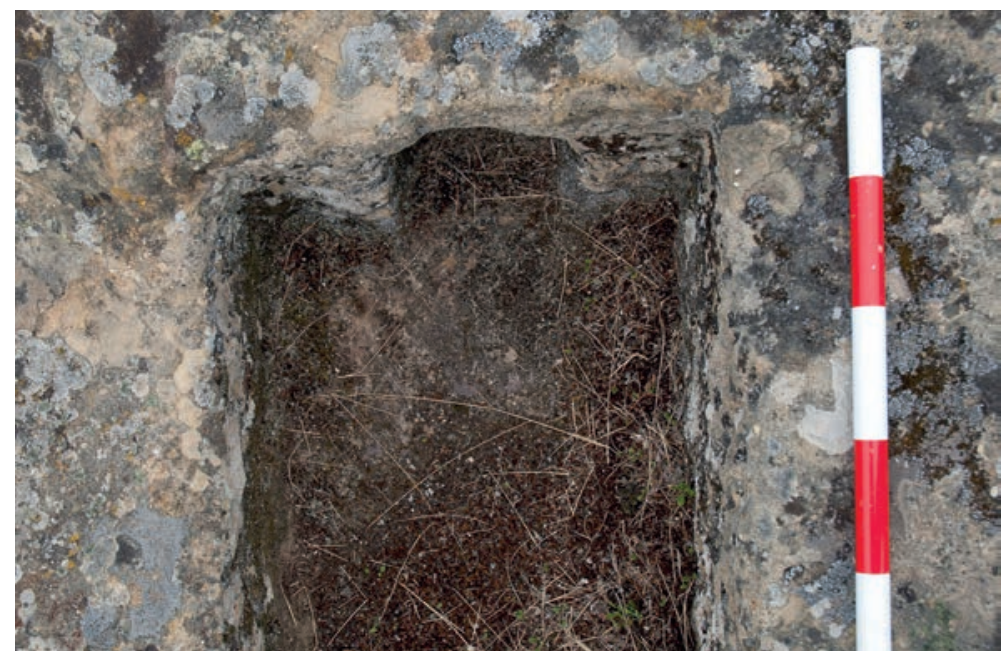

Fig. 8.

Cabecera con oquedad occipital de Santa Leocadia de Castrillo de Valdelomar Fuente: Enrique Gutiérrez Cuenca

\footnotetext{
${ }^{27}$ CASTILLO, 1970; ANDRIO GONZALO, 1987.
}

${ }^{28}$ A pesar de que la presencia de restos óseos conservados en las tumbas es una circunstancia excepcional, existe constancia de su reutilización, que en algunos casos alcanza una significativa intensidad como sucede en Santa María de Valverde (MARCOS MARTÍNEZ, 2010). Los ejemplos de otras zonas de la Península Ibérica y la gestión que se realiza en Cantabria en otros tipos de cementerios altomedievales invitan a pensar que este tipo de reutilizaciones eran habituales. 


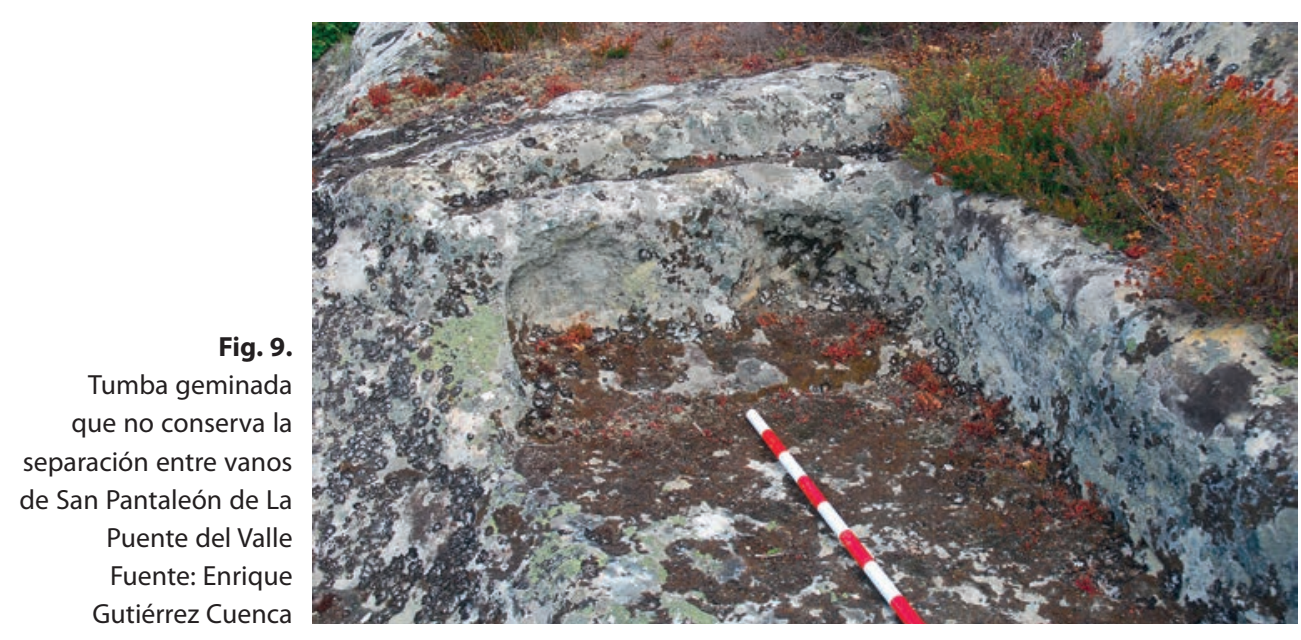

Fig. 10.

Conjunto oriental de la necrópolis de Santa María de Valverde con una posible tumba doble en primer plano Fuente: Enrique Gutiérrez Cuenca

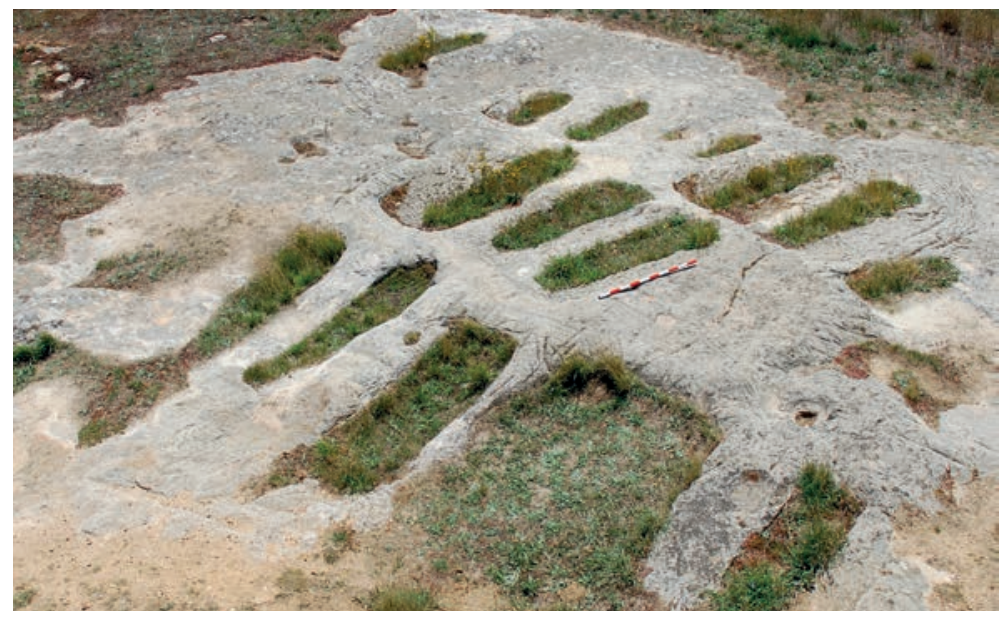

por pares y separadas del resto del cementerio, que en ocasiones se han descrito como «tumbas geminadas», como algunos ejemplos documentados en Santa Cecilia de Población de Abajo (vid. Fig. 5) o en Santa Marina de Coroneles (vid. Fig. 4). En ocasiones estas tumbas dobles o geminadas pudieron estar separadas por material perecedero o por losas que no se han conservado en su posición original, tal y como se deduce de la presencia en San Pantaleón de La Puente del Valle de acanaladuras verticales en vanos del doble de ancho de las tumbas individuales (Fig. 9). En Santa María de Valverde hay una estructura que tiene aproximadamente el doble de anchura de una tumba, sin indicios de división interna (Fig. 10), que se asemeja a las de la necrópolis de Bañuelos (Burgos), identificadas como sepulturas dobles ${ }^{29}$.

${ }^{29}$ PADILLA LAPUENTE, ÁLVARO RUEDA, 2010. 


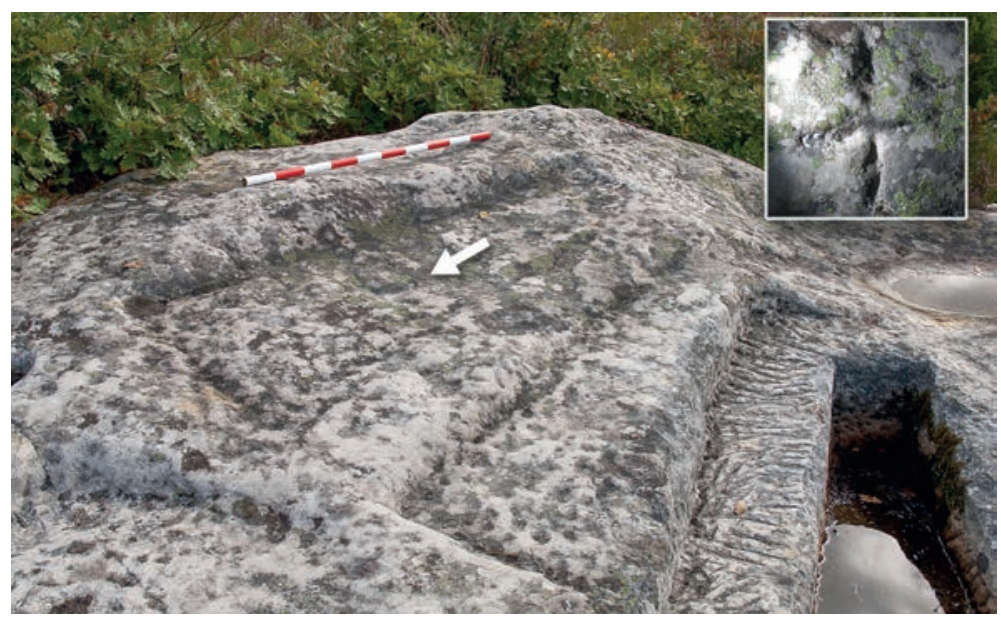

Fig. 11.

Tumbas delimitadas en superficie y sin labrar en la necrópolis de San Pantaléon de La Puente del Valle Fuente: Enrique Gutiérrez Cuenca

Gracias a algún testimonio poco frecuente, podemos reconstruir cuáles son los primeros pasos del proceso de trabajo en el vaciado de las tumbas. En San Pantaleón de La Puente del Valle hay una zona en la que se ha definido la planta de dos tumbas que finalmente no se han excavado conforme al diseño inicial. Otra tumba ha ocupado parte del espacio seleccionado para una de ellas y eso ha permitido que se haya conservado esta singular evidencia de las operaciones previas al vaciado del vano de la tumba. El espacio destinado para cada tumba se delimita en superficie y se marca con una cruz (Fig. 11). En una siguiente etapa, la labra de las tumbas se realiza con herramientas metálicas, que dejan marcas del trabajo sobre todo en el interior, con frecuencia muy evidentes. En ocasiones se revoca con mortero de cal el interior de las tumbas, bien las paredes, como en Santa María de Valverde y en Santa Leocadia de Castrillo de Valdelomar, bien el fondo, como sucede en una tumba infantil de Santa María de Peñota.

Disponemos de mucha menos información sobre la forma en la que se cubrían las tumbas, ya que la cubierta no se conserva más que en algún caso aislado y con evidencias de haber sido abierta y cerrada en más de una ocasión, como en Santa María de la Asunción en Castro Urdiales. Las cubiertas estarían formadas por una o varias losas, dependiendo del tamaño y de la disponibilidad de materia prima, y para facilitar su colocación el vano se podía conformar de diversas formas. Lo más habitual era realizar un rebaje en el contorno, presente en Valderredible en una treintena de casos - tanto en tumbas trapezoidales como antropomorfas - pero también se procedía a regularizar el contorno y delimitarlo mediante un resalte, una opción presente en una veintena de tumbas siempre antropomorfas (Fig. 12). En aquellos lugares donde las tumbas se disponen de forma escalonada, aprovechando la pendiente del afloramiento rocoso, se combinan rebaje y resalte para facilitar la 


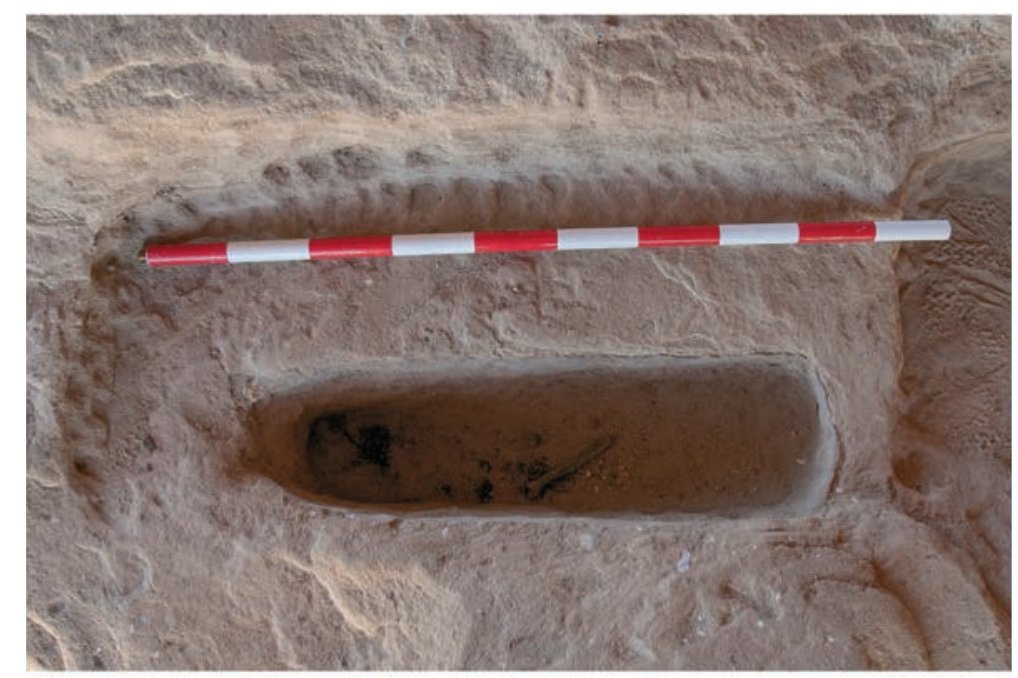

Fig. 12.

Acondicionamientos para colocar la cubierta: rebaje perimetral en una tumba de la necrópolis de Santa María de Valverde y borde resaltado en Santa Cecilia de Población de Abajo Fuente: Enrique Gutiérrez Cuenca

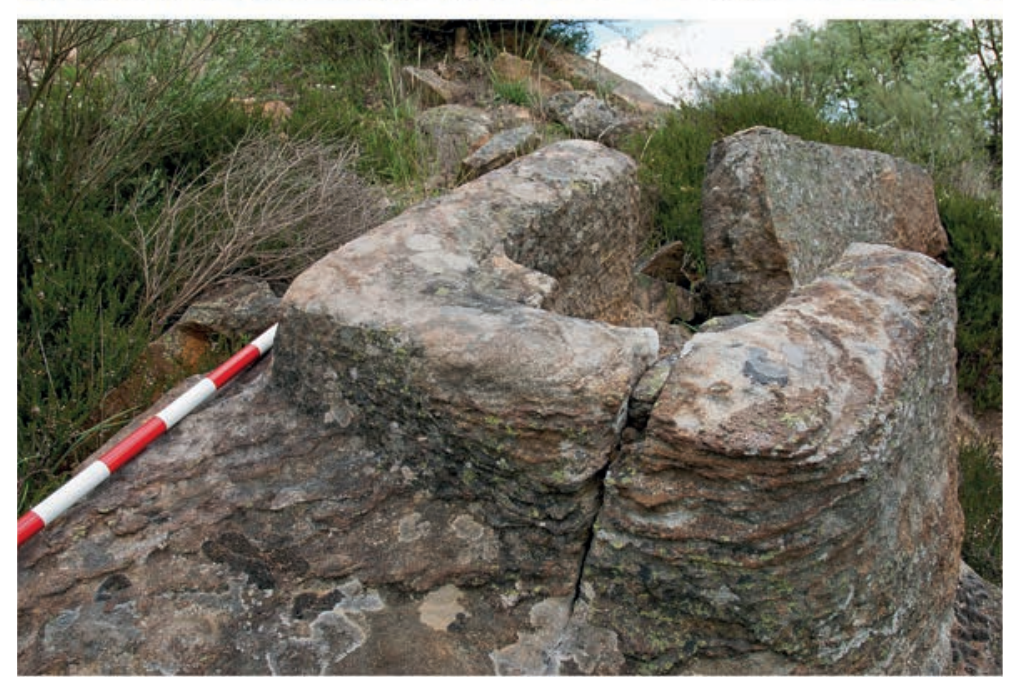

colocación de la cubierta como sucede en Santa María de Peñota (Fig. 13). En Santa María de la Asunción de Castro Urdiales se ha identificado un sistema de cubierta complejo, con unos rebajes que han sido interpretados como mechinales para colocar una cubierta de madera ${ }^{30}$. El empleo de estructuras de madera en las tumbas excavadas en la roca se conoce en algunos casos de Cataluña como Sant Julià d'Altura y Sant Iscle de la Salut ${ }^{31}$.

\footnotetext{
${ }^{30}$ MARCOS MARTÍNEZ, 2013.

${ }^{31}$ ROIG BUXÓ, COLL RIERA, 2012.
} 


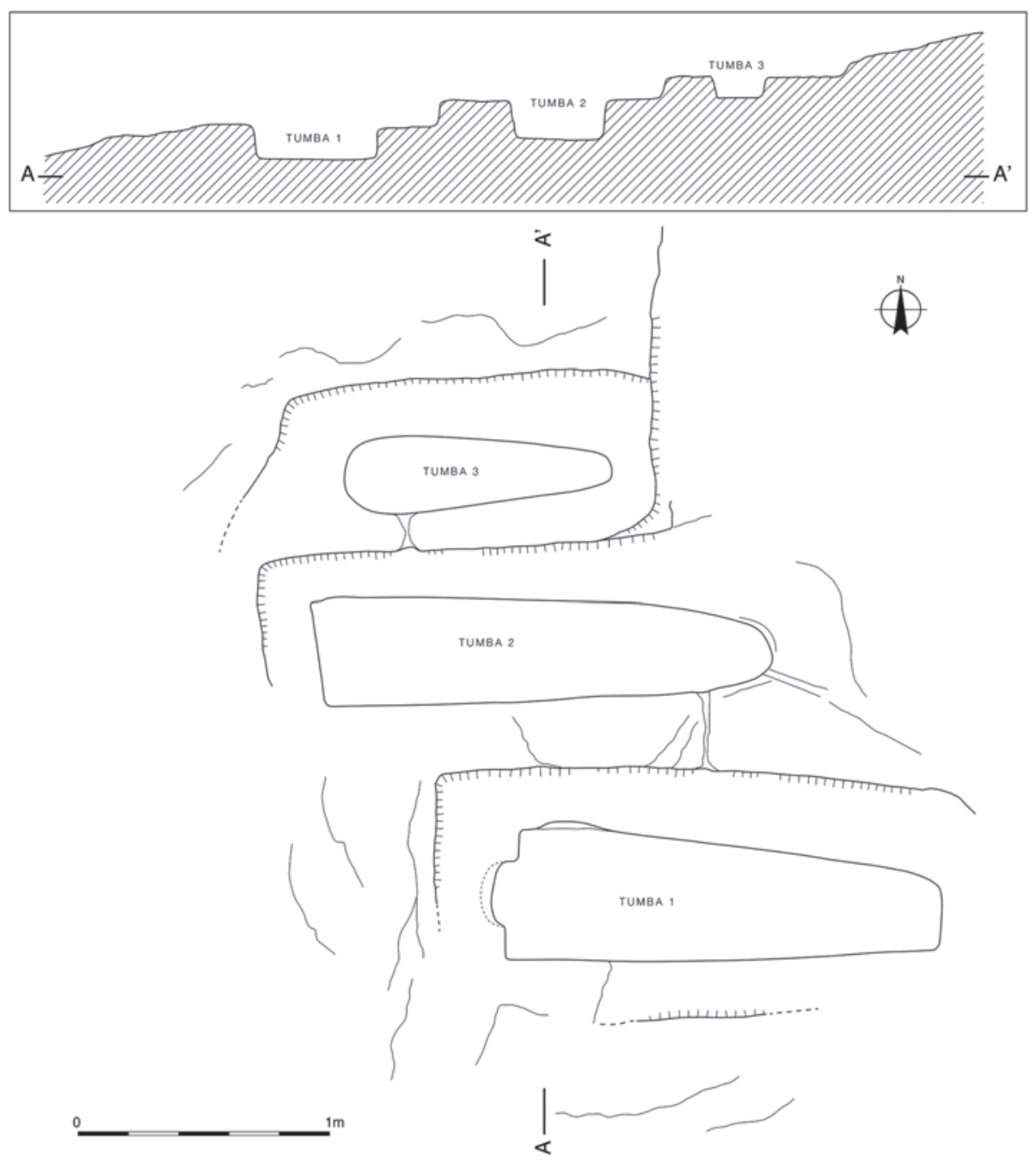

Fig. 13. Conjunto de tumbas dispuestas de forma escalonada de la necrópolis de Peñota en Susilla Fuente: Enrique Gutiérrez Cuenca

En algunas necrópolis están presentes otro tipo de estructuras funerarias excavadas en la roca menos habituales. En Santa Pantaleón de La Puente del Valle se conservan tres pequeñas cuevas artificiales de planta cuadrangular que se abren en diferentes puntos del farallón rocoso (Fig. 14). La denominada Cueva 1 ha perdido una parte importante de la bóveda de cubierta, pero conserva intacta la zona inferior. Se han excavado dos huecos de forma rectangular: uno con las proporciones y las dimensiones de una tumba de un individuo adulto y otro el doble de ancho, con una ancha ranura en la zona que correspondería con la cabecera y otra en la zona de los pies, que sirven como encaje para colocar un separador dividiendo en dos el hueco, a modo de tumba 
bísoma o geminada. La Cueva 2 y la Cueva 4 se conservan completas, con una boca de acceso rematada en arco de medio punto. También en su interior se ha realizado un rebaje, en ambos casos para conformar un hueco de planta rectangular, con una ranura vertical en la zona que correspondería con la cabecera y otra en la zona de los pies, que sirven como encaje para colocar un separador dividiendo en dos el hueco, a modo de tumba bísoma o geminada. El eje más largo de las estructuras, que correspondería con el eje longitudinal de las tumbas, está orientado hacia el este, como es habitual en las sepulturas medievales. Ya Bohigas ${ }^{32}$ había identificado estas estructuras como funerarias, relacionándolas con las tumbas excavadas en la roca, pero algunos trabajos posteriores han puesto en duda esa interpretación y consideran que son estructuras funerarias del
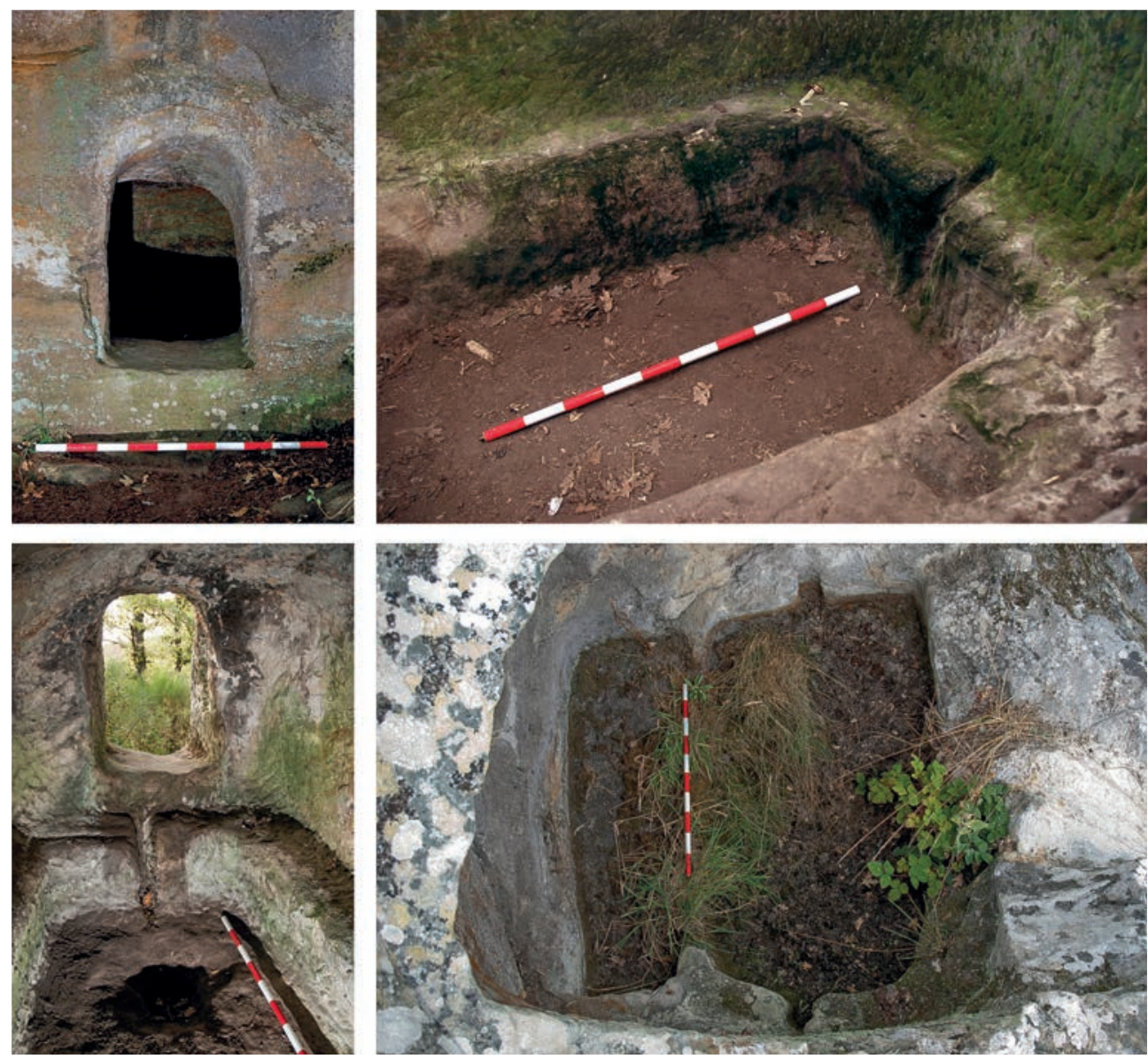

Fig. 14. Cuevas artificiales con sepulturas de San Pantaléon de La Puente del Valle Fuente: Enrique Gutiérrez Cuenca

32 BOHIGAS ROLDÁN, 1986: 192. 


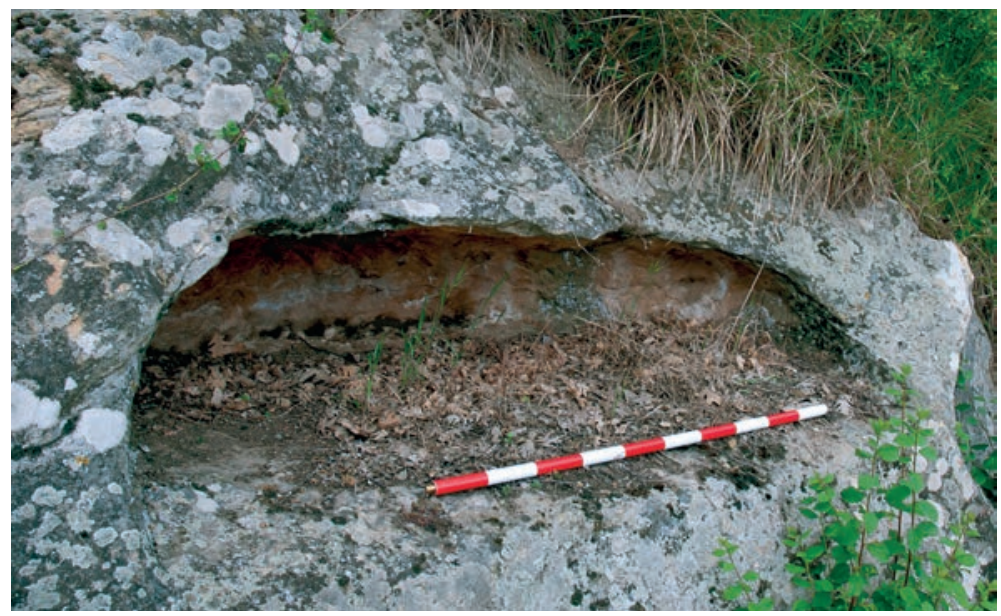

Fig. 15.

Posible nicho junto a la iglesia rupestre de Virgen del Carmen de Cadalso

Fuente: Enrique Gutiérrez Cuenca

Calcolítico o la Edad del Bronce ${ }^{33}$ o que sirvieron primero como piscinas bautismales y fueron posteriormente reutilizadas como depósitos de agua para alimentar una ferrería ${ }^{34}$. Sin embargo, consideramos que existen suficientes argumentos como para retomar la interpretación inicial y considerar estas cuevas como lugares de sepultura relacionados con el cementerio medieval. La propia morfología de las cuevas y de los rebajes que se practican en el interior de las mismas es un factor a tener en cuenta, ya que la longitud, anchura y profundidad de los huecos es semejante a la de las tumbas, y están orientados hacia el este. El separador vertical y la cubierta de los huecos pudo ser de losas de piedra o de planchas de madera. En San Pantaleón este sistema de separador vertical encajado en una ranura no es exclusivo de las estructuras excavadas dentro de cuevas artificiales, hay al menos un caso en la zona occidental del conjunto ( $\mathrm{vid}$. supra). También hay que tener en cuenta el contexto espacial, ya que en San Pantaleón lo que aparece fundamentalmente son estructuras relacionadas con la iglesia construida en la plataforma superior y en su mayoría tienen carácter funerario. De hecho, por su disposición, la Cueva 4, situada en el extremo occidental de la peña, puede interpretarse como una auténtica cripta que queda bajo los pies de la iglesia, con la que comparte su eje de orientación. Además, se conocen estructuras similares en otros conjuntos rupestres del valle del Ebro como Las Gobas 2 y Santorcaria 6 (Álava), con tumbas alojadas es cuevas artificiales abovedadas de planta más o menos cuadrangular ${ }^{35}$.

Junto a la iglesia rupestre de la Virgen del Carmen de Cadalso se ha identificado una oquedad excavada en un afloramiento rocoso situado al este del templo que ha sido descrita como un nicho (Fig. 15), por su similitud con los «nichos laterales» que

\footnotetext{
${ }^{33}$ LAMALFA DÍAZ, 2004.

34 VEGA ALMAZÁN, 2011.

${ }^{35}$ AZKARATE GARAI-OLAUN, 1988: 175 y 191-193.
} 
aparecen en el conjunto rupestre de Cuyacabras (Burgos) ${ }^{36}$. En el caso burgalés no hay duda de que este tipo de nichos, excavados en una pared vertical y de formas más regulares que el de Virgen del Carmen de Cadalso, fueron usados como sepultura, pero el ejemplo cántabro presenta algunas dudas, por encontrarse aislado, y por la propia excepcionalidad de este tipo de solución.

\section{CRONOLOGÍA}

Las dificultades para establecer una cronología precisa de las tumbas excavadas en la roca a partir de criterios objetivos, debido a la problemática que presenta el propio registro arqueológico - desaparición de los restos óseos, ausencia de ajuares, etc. - son una constante en la investigación y trabajos recientes reflexionan acerca de la complejidad del fenómeno y de las dificultades para ubicar y ordenar en el tiempo muchos de los conjuntos ${ }^{37}$. Esa peculiaridad del registro arqueológico y la tendencia a estudiar las necrópolis excavadas en la roca como un fenómeno particular han sido algunas de las razones para que durante mucho tiempo el criterio formal haya sido el principal elemento para determinar la cronología de este tipo de tumba, predominando un enfoque tipocronológico deudor, en muchos casos, de paradigmas historiográficos que condicionaban la definición del marco temporal al que se asignaban las necrópolis.

En la actualidad, la opinión más generalizada es que las tumbas excavadas en la roca se utilizan en la Península Ibérica ya en época visigoda y que se generalizan a partir del siglo VII ${ }^{38}$ y se admite, en términos generales, que las tumbas rectangulares, trapezoidales y ovales o de bañera son anteriores a las antropomorfas ${ }^{39}$. Sigue existiendo, no obstante, cierta discrepancia sobre el momento en el que comienzan a aparecer las tumbas excavadas en la roca de planta antropomorfa en diferentes territorios de la mitad norte de la Península Ibérica: mientras que para el ámbito castellano se admite un origen temprano, de época visigoda ${ }^{40}$, para Cataluña se sigue sosteniendo un origen carolingio y una cronología en torno a los siglos IX- $\mathrm{X}^{41}$, apoyado en dataciones absolutas.

Los datos que aportan las necrópolis de Cantabria no contribuyen en exceso a clarificar este debate, ya que formas no antropomorfas y antropomorfas suelen aparecer mezcladas, sobre todo en los conjuntos más extensos, y no hay posibilidad de establecer una datación precisa. Sí se pueden apuntar, sin embargo, algunos datos que podrían interpretarse en el marco de evolución formal generalmente aceptado. Tanto en Santa Leocadia de Castrillo de Valdelomar (Fig. 16) como en Santa María

\footnotetext{
${ }^{36}$ PADILLA LAPUENTE, ÁLVARO RUEDA, 2008.

${ }^{37}$ PADILLA LAPUENTE, ÁLVARO RUEDA, 2010; MARTÍN VISO, 2012

${ }^{38}$ LÓPEZ QUIROGA, 2010: 301 y ss.

${ }^{39}$ LÓPEZ QUIROGA, GARCÍA PÉREZ, 2014.

40 PADILLA LAPUENTE, ÁLVARO RUEDA, 2012.

${ }^{41}$ ROIG BUXÓ, COLL RIERA, 2012.
} 

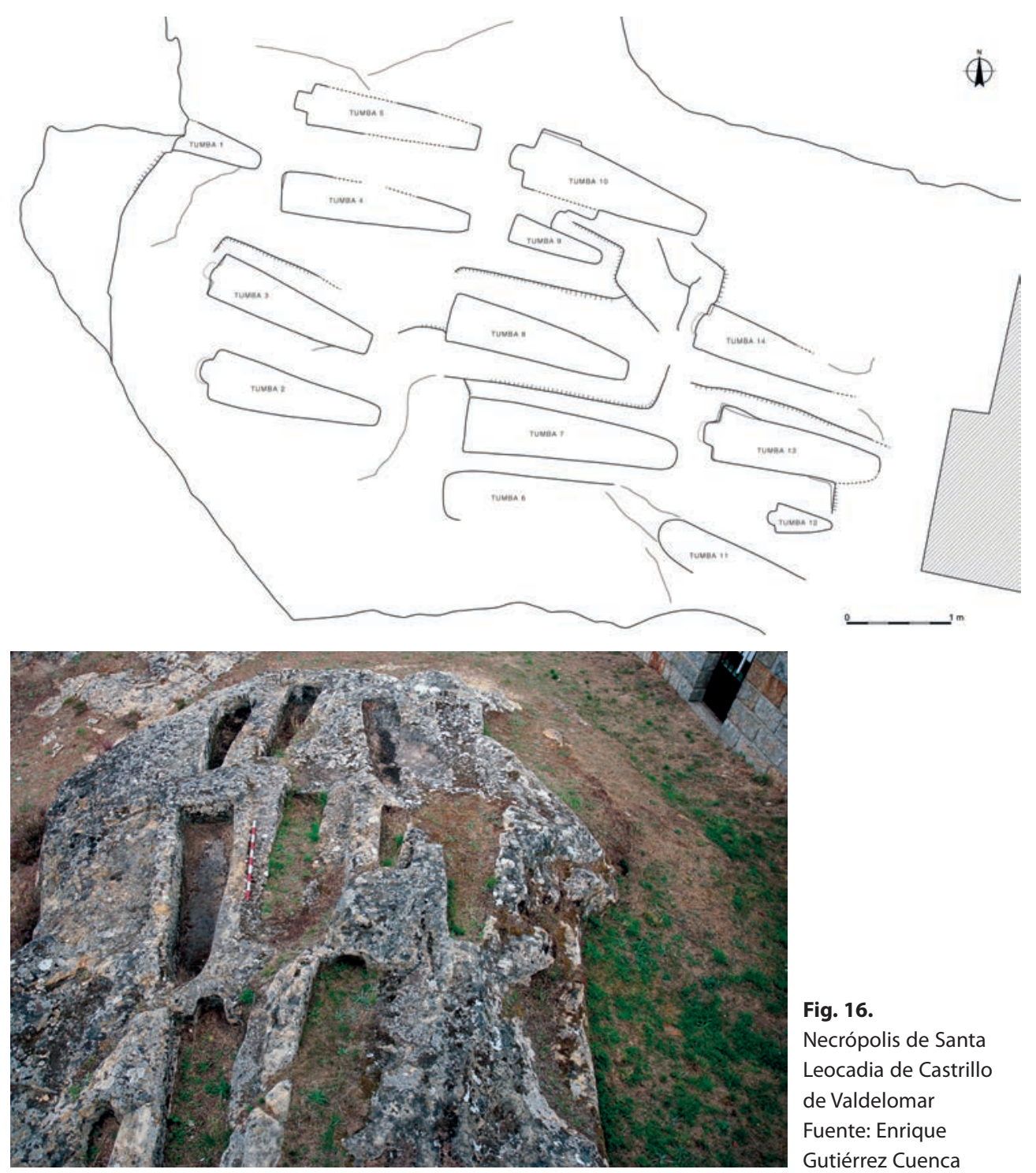

Fig. 16.

Necrópolis de Santa Leocadia de Castrillo de Valdelomar Fuente: Enrique Gutiérrez Cuenca

de Peñota las tumbas son de planta cuadrangular, trapezoidal o antropomorfa con cabeceras poco desarrolladas y de tendencia rectilínea, y son muy escasas o están ausentes las tumbas antropomorfas de cabecera semicircular o ultrasemicircular bien diferenciada. Este repertorio formal podría estar indicando un origen algo más antiguo para estos conjuntos que para otros de la comarca, aunque de momento no se pueda plantear más que como una conjetura sin un respaldo sólido. En otros casos, como el de Santa María de Valverde, donde se puede considerar que el sector noroeste de 
la necrópolis es más antiguo que el sector sureste - partiendo del supuesto de que la iglesia excavada en la roca evolucionó desde un habitáculo de una sola nave con la cabecera orientada hacia el este, ubicada donde ahora está el baptisterio, hasta su configuración actual tras una expansión hacia el $\mathrm{S}-$, no se aprecias diferencias y las tumbas de planta trapezoidal se mezclan en uno y otro sector con tumbas antropomorfas de cabeceras bien definidas, sin que esta diferencia de formas permita establecer una cronología relativa.

Más allá de las limitaciones que ofrece la caracterización crono-tipológica, disponemos de algunos datos que aportan información más fiable sobre el marco temporal en el que están en uso algunas necrópolis de tumbas excavadas en la roca de Cantabria, como son las dataciones absolutas, las relaciones estratigráficas o la presencia de objetos dentro de las tumbas.

Únicamente disponemos de dos dataciones de C14 para Santa María de Valverde ${ }^{42}$, ambas de la misma tumba, en la que se conservaban restos de al menos siete individuos. Los resultados determinan que el último individuo fue depositado en torno a comienzos del siglo XIII (Poz-5128: 830 30 BP, 1161-1264 cal AD 95,4\%), mientras que los restos de un ocupante previo ofrecen una datación prácticamente coincidente, también hacia comienzos del siglo XIII (Poz-5462: 835 30 BP, 1157-1264 cal AD 95,4\%). Estas dataciones ponen de manifiesto que la intensa reutilización de las tumbas excavadas en la roca se prolonga hasta épocas bastante posteriores a las que se supone para su labra, pero no ofrecen una fecha que pueda relacionarse con este primer momento. Algunas necrópolis del centro de la Península Ibérica como la de La Mezquita (Madrid) muestran que este tipo de tumbas siguen en uso en torno a los siglos XII-XIII ${ }^{43}$, pero debemos suponer también que se labraron en un momento bastante anterior.

Las relaciones estratigráficas de las tumbas excavadas en la roca con construcciones de época medieval u otros elementos que puedan proporcionar una fecha ante quem relevante no son demasiados frecuentes. De hecho, sólo en la espadaña de Santa Leocadia de Castrillo de Valdelomar, levantada en torno al siglo XIII, se aprecia una superposición de este tipo, donde una tumba ha sido amortizada y posiblemente rellenada de forma intencional para facilitar la cimentación (Fig. 17).

Otro indicio indirecto que remite a una cronología ante quem similar es la presencia de tres excepcionales vasijas incensario (Fig. 18) en la Tumba 9 de Santa María de la Asunción en Castro Urdiales cuya tipología podría corresponderse con modelos del siglo XII ${ }^{44}$. Además, muchas de las tumbas de esa necrópolis están bajo las estructuras de la iglesia gótica que se comenzó a construir a comienzos del siglo XIII.

\footnotetext{
42 MARCOS MARTÍNEZ, 2010.

43 BENITO LÓPEZ et al., 1999.

${ }^{44}$ MARCOS MARTÍNEZ, 2013; GUTIÉRREZ CUENCA, 2017.
} 

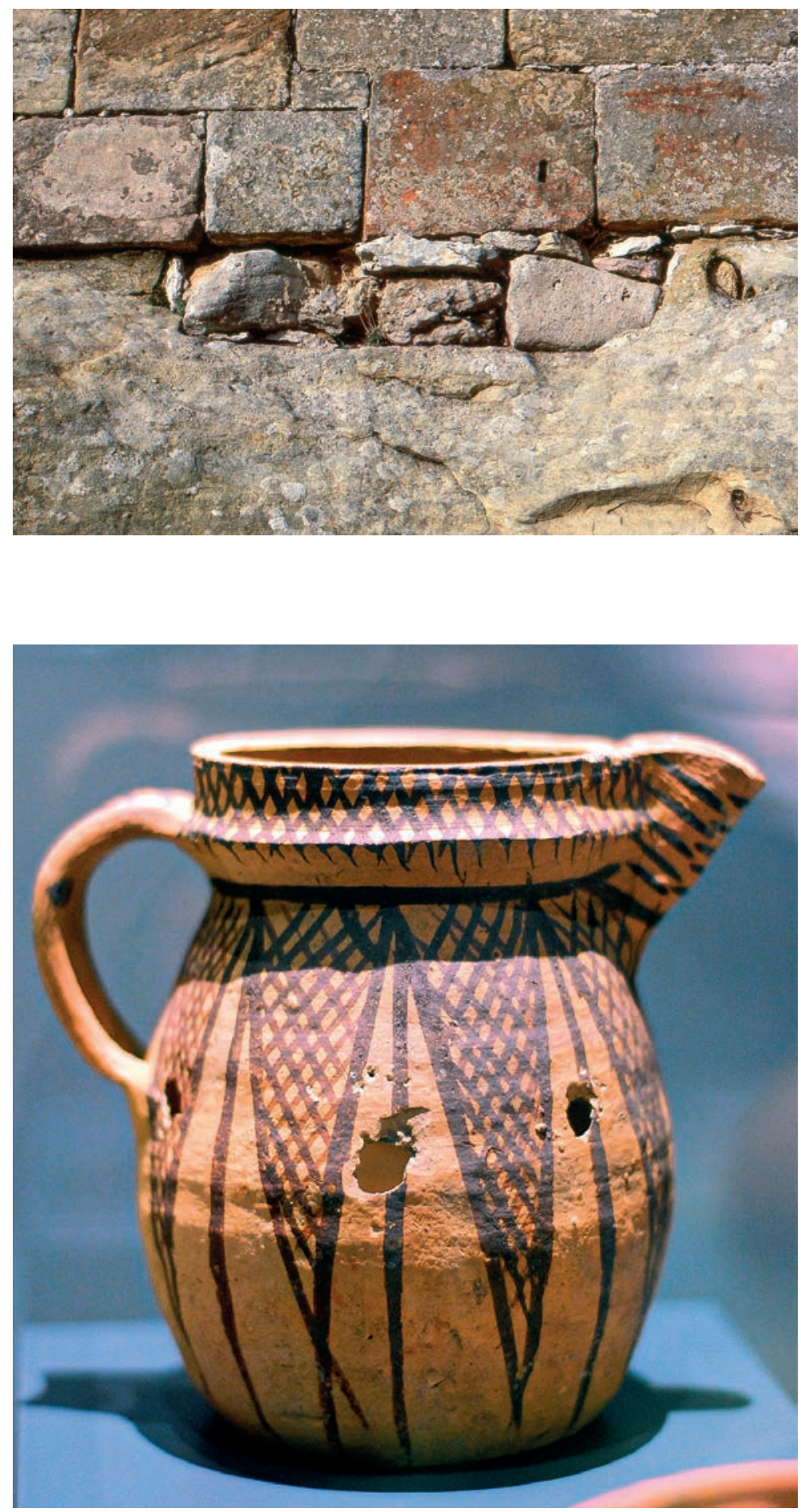

Fig. 17.

Tumba rellenada para sentar los cimientos de la espadaña de la iglesia románica de Santa Leocadia de Castrillo de Valdelomar Fuente: Rosa Gimeno García-Lomas
Fig. 18.

Jarrito incensario de la necrópolis de Santa María de la Asunción de Castro Urdiales Fuente: Enrique Gutiérrez Cuenca 
En el otro extremo del arco temporal, podemos asociar las tumbas excavadas en la roca con algunas manifestaciones tempranas, fechadas en torno a los siglos VI-VIII, como sucede en San Pantaleón de La Puente del Valle. La datación de los restos hallados en un sarcófago que apareció al pie del afloramiento rocoso sobre el que se asientan la iglesia semirrupestre y la mayor parte de las tumbas excavadas en la roca que componen este extenso cementerio en torno a mediados del siglo VIII (UBAR-737: 1275 \pm 45 BP, 659-869 cal AD 95,4\%), indica que el lugar ya está siendo utilizado con fines funerarios en un momento temprano. A ello habría que añadir la datación de TL ofrecida por un fragmento de cerámica recuperado en los niveles de amortización de un silo, que se sitúa en torno a fines del siglo VI (ARQA-3828: 1413 \pm 129 BP, 845-329 AD 95,4\% ${ }^{45}$, un indicio de que la ocupación del lugar como espacio de hábitat desde época visigoda. No se debe descartar, por tanto, que las primeras tumbas se labrasen en la roca ya en ese periodo.

Aunque los datos disponibles actualmente no permiten trazar un esquema cronológico detallado, parece que las necrópolis de tumbas excavadas en la roca de Cantabria responden a un marco temporal amplio. Las primeras tumbas de este tipo aparecen, muy probablemente, en época visigoda, a partir de mediados o finales del siglo VI, y su uso persiste hasta el siglo XIII, sin que se pueda asegurar que en momentos tardíos sigan labrándose nuevas tumbas. Lo que sí parece claro, atendiendo a lo que se observa en Valderredible, es que no hay ningún periodo para el que se pueda hablar de un uso exclusivo de este tipo de contenedor. Las tumbas excavadas en la roca se utilizan al mismo tiempo que otros tipos de tumbas - tumbas de lajas, sarcófagos, quizá tumbas de fosa simple... - en el mismo ámbito geográfico, como se puede apreciar en necrópolis con secuencias completas entre los siglos VII y XV como Santa María de Hito ${ }^{46}$ y de hecho conviven algunos en lugares como San Pantaleón de La Puente del Valle ${ }^{47}$ o Santa María de Somera. No definen una etapa concreta en la evolución de los espacios funerarios, sino que son una variante más dentro de la diversidad de formatos funerarios de la Alta Edad Media.

\section{CONCLUSIONES}

El estado de conocimiento actual sobre las necrópolis de tumbas excavadas en la roca de Cantabria se ha beneficiado de una mejor documentación gracias al trabajo de campo realizado para la revisión de los enclaves recogidos en la bibliografía y en los catálogos de gestión del patrimonio, y a la incorporación de los datos procedentes de nuevas excavaciones. Uno de los hitos más significativos es la confirmación de una distribución geográfica más amplia, no sólo confinada al sur de Cantabria.

\footnotetext{
${ }^{45}$ FERNÁNDEZ VEGA et al., 2003.

${ }^{46}$ vid. GUTIÉRREZ CUENCA, 2015: 335-372.

${ }^{47}$ FERNÁNDEZ VEGA et al., 2003.
} 
Disponemos ahora, además, de un repertorio con datos actualizados que permite hacer un análisis más fiable de diversos aspectos formales de las tumbas excavadas en la roca. Sin embargo, somos conscientes de que la clasificación tipológica, más allá de ser una herramienta descriptiva, no permite aportar avances significativos en la investigación.

La tipocronología, más allá de ofrecer un esquema general no exento de discusión, no aporta soluciones concluyentes a la perpetua incertidumbre cronológica que acompaña a los estudios sobre este tipo de manifestaciones funerarias. En el caso de Cantabria, únicamente disponemos de datos objetivos para cuestiones concretas como la constatación del uso de tumbas excavadas en la roca hasta, al menos, el siglo XIII, pero siguen sin resolverse con solvencia otros aspectos relativos a sus orígenes aparentemente tempranos - o a su desarrollo diacrónico. Por otra parte, el estudio de estas necrópolis dentro un marco más amplio, como parte de una investigación a escala regional sobre los espacios cementeriales abordado desde la perspectiva de la larga duración, deja claro que las tumbas excavadas en la roca no responden a una facies cultural o a un momento cronológico exclusivo. Conviven con tumbas de lajas y con sarcófagos en los mismos momentos, en los mismos territorios e incluso en los mismos cementerios, tal y como pone de manifiesto el estudio de comarcas concretas como Valderredible.

La evaluación de los datos disponibles para Cantabria y las conclusiones que hemos extraído de los mismos nos hacen reflexionar sobre la validez de los estudios que centran el análisis territorial en una investigación que sólo atiende a las tumbas excavadas en la roca, por ser elementos visibles y cuya identificación y catalogación no exige de actuaciones arqueológicas costosas - en términos de recursos materiales o tiempo- obviando que son sólo una parte de un registro arqueológico más compleja. No tiene mucho sentido realizar estudios sobre el poblamiento o la geografía funeraria de un territorio únicamente basados en las tumbas excavadas en la roca, si sabemos que existen también otro tipo de manifestaciones materiales coetáneas que pueden resultar tan interesantes o más para conocer la evolución del cementerio y de otros procesos asociados. Algunas pautas que observamos en el sur Cantabria, como la presencia de conjuntos con un número importante de tumbas que están en uso, muy probablemente, desde momentos tempranos o de aparentes «conjuntos aislados» que son, en realidad, porciones de necrópolis de mayor tamaño que solo un trabajo de prospección minucioso o una excavación permiten delimitar en toda su extensión, contradice en cierto modo los modelos teóricos que están teniendo mayor éxito en la investigación actual. Consideramos que es más factible que se trate de una cuestión de criterio en el manejo de los datos y no de una particularidad regional.

Las necrópolis de tumbas excavadas en la roca de Cantabria, que deben ser entendidas como sepulturas cristianas - algunas de las interpretaciones vigentes 
hoy en día, postprocesualistas en su definición teórica y prehistoricistas en su implementación, parecen olvidarlo - tienen un papel destacado en el desarrollo del cementerio medieval tal y como termina por configurarse con el paso de los siglos: un espacio consagrado, delimitado, asociado a un edificio de culto, lugar de enterramiento para una comunidad concreta, etc. El éxito o el fracaso de este proceso en cada caso concreto, en el que la estructuración de la red parroquial parece interferir de forma evidente, determinará la continuidad o el abandono de algunas necrópolis que quedan en la actualidad como testigo de eventos históricos escasamente reflejados en otras fuentes.

\section{BIBLIOGRAFÍA}

ÁLVARO RUEDA, Karen (2012). El poblamiento altomedieval y sus manifestaciones funerarias en la cuenca del Alto Arlanza (s. IX y XI). Barcelona: Universidad de Barcelona. Tese de doutoramento. Disponível em <http://hdl.handle.net/10803/80651> [Consult. 17 dez. 2018].

ANDRIO GONZALO, Josefina (1987). Formas de enterramiento medievales en los valles del Ebro y Duero. In II Congreso de Arqueología Medieval Española, Tomo III. Madrid: AEAM, pp. 274-286.

AZKARATE GARAI-OLAUN, Agustín (1988). Arqueología Cristiana de la Antigüedad Tardía en Álava, Guipúzcoa y Vizcaya. Vitoria: Diputación Foral de Álava.

BENITO LÓPEZ, José Enrique et al. (1999). Aportación al estudio de las necrópolis medievales en la meseta: «La Mezquita» (Cadalso de Vidrios, Madrid). In II Congreso de Arqueología Peninsular. Tomo IV. Arqueología romana y medieval. Zamora: Universidad de Alcalá-Fundación Rei Afonso Henriques, pp. 561-566.

BERKOSA GUERRERO, Julián (2013). Despoblados de Valderredible (Cantabria). Madrid: Cultivalibros. BLAIZOT, Frédérique (2006). Ensembles funéraires isolés dans la moyenne vallée du Rhône. In MAUFRAS, Odile, ed. Habitats, nécropoles et paysages dans la moyenne et la basse vallée du Rhône (VIIe-XVe siècles). París: Maison des Sciences de l'Homme, pp. 282-362.

BOHIGAS ROLDÁN, Ramón (1982). Los restos arqueológicos altomedievales en Cantabria. Resumen de la Tesis Doctoral «Los yacimientos arqueológicos altomedievales del sector central de los montes cantábricos». Valladolid: Universidad de Valladolid.

BOHIGAS ROLDÁN, Ramón (1986). Yacimientos arqueológicos medievales del sector central de la montaña cantábrica. Santander: ACDPS.

BOHIGAS ROLDÁN, Ramón (1999). La organización del espacio través de la Arqueología Medieval: veinte años de investigaciones. In I Encuentro de Historia de Cantabria. Santander: Universidad de Cantabria-Gobierno de Cantabria, pp. 401-441.

CASTILLO, Alberto del (1970). Excavaciones altomedievales en las provincias de Soria, Logroño y Burgos. «Excavaciones Arqueológicas en España». 74.

FERNÁNDEZ ACEBO, Virgilio (2003). Una crónica de la arqueología de posguerra en Cantabria a través de las actas del Centro de Estudios Montañeses (1939-1951). «Altamira». LXII, 7-70.

FERNÁNDEZ VEGA, Pedro Ángel et al. (2003). Avance a la 4. ${ }^{a}$ campaña de excavaciones en el conjunto arqueológico de la Peña de San Pantaléon (La Puente del Valle, Cantabria). «Sautuola». IX, 321-340.

GALERA, Virginia (1989). La población medieval cántabra de Santa María de Hito. Aspectos Paleobiodemográficos, Morfológicos, Paleopatológicos, Paleoepidemiológicos y de Etnogénesis. Alcalá de Henares: Universidad de Alcalá de Henares. Tese de doutoramento. 
GUTIÉRREZ CUENCA, Enrique (2015). Génesis y evolución del cementerio medieval en Cantabria. Santander: Universidad de Cantabria. Tese de doutoramento. Disponível em $<$ http://hdl.handle. net/10803/311798> [Consult. 17 dez. 2018].

GUTIÉRREZ CUENCA, Enrique (2016). Documentación de necrópolis excavadas en la roca de Valderredible $y$ Las Rozas de Valdearroyo. In SANZ PALOMERA, Gustavo, ed. Actuaciones arqueológicas en Cantabria (2004-2011). Santander: Gobierno de Cantabria, pp. 208-211.

GUTIÉRREZ CUENCA, Enrique (2017). Reivindicación de estatus y costumbres foráneas en el registro funerario medieval castellano. A propósito de dos casos de Cantabria. «Studia Historica. Historia Medieval». 35: 1, 73-103.

LAMALFA DÍAZ, Carlos (2000). Excavación del complejo rupestre de San Pantaléon, Puente del Valle (Valderredible). In ONTAÑON PEREDO, Roberto, ed. Actuaciones arqueológicas en Cantabria 1984-1999. Santander: Gobierno de Cantabria, pp. 379-380.

LAMALFA DÍAZ, Carlos (2004). Notas en torno a la arquitectura rupestre del área geográfica de Valderredible (Cantabria). «Sautuola». X, 307-315.

LAMALFA DÍAZ, Carlos et al. (2008). Excavaciones en Valderredible. IIIa (2000) y IVa (2001/02) campañas en el conjunto arqueológico de la Peña de San Pantaléon (La Puente del Valle, Polientes). In ONTAÑON PEREDO, Roberto, ed. Actuaciones arqueológicas en Cantabria 2000-2003. Santander: Gobierno de Cantabria, pp. 207-212.

LÓPEZ QUIROGA, Jorge (2010). Arqueología del mundo funerario en la Península Ibérica (siglos V-X). Madrid: La Ergástula.

LÓPEZ QUIROGA, Jorge; GARCÍA PÉREZ, Laura (2014). Las tumbas excavadas en la roca en la Península Ibérica: tipología, cronología y problemas de interpretación. In LÓPEZ QUIROGA, Jorge; MARTÍNEZ TEJERA, Artemio M, ed. In concavis petrarum habitaverunt. El fenómeno rupestre en el Mediterráneo Medieval: de la investigación a la puesta en valor. Oxford: Archaeopress, pp. 36-83.

MARCOS MARTÍNEZ, Javier (2010). Seguimiento de la obra de restauración de la iglesia rupestre de Santa María de Valverde (Valderredible). In ONTAÑON PEREDO, Roberto; SANZ PALOMERA, Gustavo, ed. Actuaciones Arqueológicas en Cantabria. Arqueología de Gestión 2000-2003. Santander: Gobierno de Cantabria, pp. 289-292.

MARCOS MARTÍNEZ, Javier (2013). Trabajos de arqueología en la restauración de la girola de Santa María de Castro Urdiales. «Clavis». 6.

MARTÍN VISO, Iñaki (2007). Tumbas y sociedades locales en el centro de la península en la alta edad media: el caso de la comarca de Riba Côa (Portugal). «Arqueología y Territorio Medieval». 14, 21-47.

MARTÍN VISO, Iñaki (2012). Paisajes sagrados, paisajes eclesiásticos: de la necrópolis a la parroquia en el centro de la Península Ibérica. «Reti Medievali». 13,2. Disponível em <http://dx.doi.org/10.6092/15932214/362> [Consult. 17 dez. 2018].

MARTÍN VISO, Iñaki (2014). El espacio del más acá: las geografías funerarias entre la Alta y la Plena Edad Media. In LÓPEZ OJEDA, Esther, ed. De la Tierra al Cielo. Ubi sunt qui ante nos in hoc mundo fuere? Logroño: Instituto de Estudios Riojanos, pp. 75-140.

MARTÍN VISO, Iñaki (2016). Comunidades locales, lugares centrales y espacios funerarios en la Extremadura del Duero altomedieval: las necrópolis de tumbas excavadas en la roca alineadas. "Anuario de Estudios Medievales». 46: 2, 859-898.

MARTÍNEZ RUIZ, Encarnación Niceas (1997). Despoblados. Pueblos desaparecidos de Campoo. «Cuadernos de Campoo». 8, 25-30.

PADILLA LAPUENTE, José Ignacio; ÁLVARO RUEDA, Karen (2008). El despoblado altomedieval de Cuyacabras (Burgos): realidad, principios y argumentos. «Acta Historica et Archaeologica Mediaevalia». 29, 575-604. 
PADILLA LAPUENTE, José Ignacio; ÁLVARO RUEDA, Karen (2010). Necrópolis rupestres y el poblamiento altomedieval en el Alto Arlanza (Burgos). «En la España Medieval». 33, 259-294.

PADILLA LAPUENTE, José Ignacio; ÁLVARO RUEDA, Karen (2012). Alberto del Castillo y la cronología de las tumbas llamadas «olerdolanas». In MOLIST CAPELLA, Núria; RIPOLL LÓPEZ, Gisela, ed. Arqueologia funerària al nord-est peninsular (segles VI-XII). Barcelona: Museu d’Arqueologia de Catalunya, vol. I, pp. 33-40.

ROIG BUXÓ, Jordi; COLL RIERA, Joan Manuel (2012). El món funerari dels territoria de Barcino i Egara entre l'Antiguitat Tardana i lèpoca altmedieval (segles V al XII): caracterizació de les necròpolis $i$ cronotipologia de les sepultures. In MOLIST CAPELLA, Núria; RIPOLL LÓPEZ, Gisela, ed. Arqueologia funerària al nord-est peninsular (segles VI-XII). Barcelona: Museu d'Arqueologia de Catalunya, vol. 2, pp. 374-401.

RUBIO DÍEZ, Rubén (2013). Geografía funeraria, comunidades campesinas y articulación territorial post-romana al suroeste de Salamanca. In Arqueología para el siglo XXI actas de las V Jornadas de Jóvenes en Investigación Arqueológica, Santiago de Compostela, mayo de 2012. Madrid: JAS Arqueología, pp. 119-125.

TENTE, Catarina (2015). Tumbas rupestres en el Alto Mondego (Guarda, Portugal). Patrones de distribución, significados y construcción del paisaje rural altomedieval. «Munibe (AntropologiaArkeologia)». 66, 271-290.

VANDEN EYNDE CERUTI, Eduardo (1985). La época de repoblación. In GARCÍA GUINEA, Miguel Angel, ed. Historia de Cantabria. Prehistoria. Edades Antigua y Media. Santander: Ed. Estvdio, pp. 287-343.

VEGA ALMAZÁN, Diana. (2011). Arquitectura rupestre en la cabecera del Ebro y el alto valle del Pisuerga. «Cuadernos de Campoo». 9: II, 5-32.

VIGIL-ESCALERA GUIRADO, Alfonso (2013). Comunidad política aldeana y exclusión. Una revisión de las formas de inhumación altomedievales (ss. V-VIII d.C.). «Reti Medievali». 14: 1. 


\title{
SEPULTURAS ESCAVADAS NA ROCHA DO MÉDIO TEJO: OS CASOS DE TOMAR E DE FERREIRA DO ZÊEZER
}

\author{
SANDRA LOURENÇO* \\ PAULO ARSÉNIO**
}

\begin{abstract}
Resumo: Os concelhos de Tomar e de Ferreira do Zêzere, fazendo este último, fronteira a norte com o primeiro, localizam-se administrativamente no distrito de Santarém, estando inseridos na região do Médio Tejo. Nesta região trata-se dos dois únicos concelhos onde estão inventariadas sepulturas escavadas na rocha, as quais, apesar de estarem inventariadas há muitos anos nas respetivas Cartas Arqueológicas, não foram ainda alvo de um estudo mais aprofundado no âmbito desta temática, o que se pretende agora efetuar, nomeadamente procedendo-se a algumas análises comparativas. É frequente a associação destes núcleos de sepulturas a antigos caminhos, bem como a pequenos casais.
\end{abstract}

Palavras-chave: Médio Tejo; Sepulturas; Tipologias; Povoamento.

Abstract: The municipalities of Tomar and Ferreira do Zêzere, the latter having its north frontier border with the former, are located administratively in the district of Santarém, being inserted in the region of Middle Tejo. In this region there are the only two counties where we have rock-cut, although they have been inventoried for many years in the respective Archeological Charts, but have not yet been the subject of a more in-depth study in this area, hence it is now proposed to carry out some comparative analyses. The association of these rock-cut graves with ancient paths is frequent, as well as with small settlements.

Keywords: Middle Tagus Region; Graves; Typologies; Settlement.

\section{ENQUADRAMENTO GEOGRÁFICO}

Os concelhos de Tomar e de Ferreira do Zêzere, fazendo este último, fronteira a norte com o primeiro, localizam-se no distrito de Santarém, estando inseridos na região do Médio Tejo no centro de Portugal.

No concelho de Tomar, hidrologicamente, destaca-se a presença do rio Zêzere a oriente, do rio Nabão que percorre o território de norte para sul, bem como a ribeira da Beselga, da Fervença ou da Milheira. Ao nível geológico assiste-se a uma grande variedade, estando presente o xisto e o calcário, entre os quais existe uma faixa de contacto composta por grés e argilas vermelhas, localizando-se a sul do concelho a bacia terciária, com as suas cascalheiras. Do ponto de vista orográfico é na zona do

* DGPC. Email: slourenco@dgpc.pt.

** AESJT. Email: paulo.arsenio@gmail.com. 


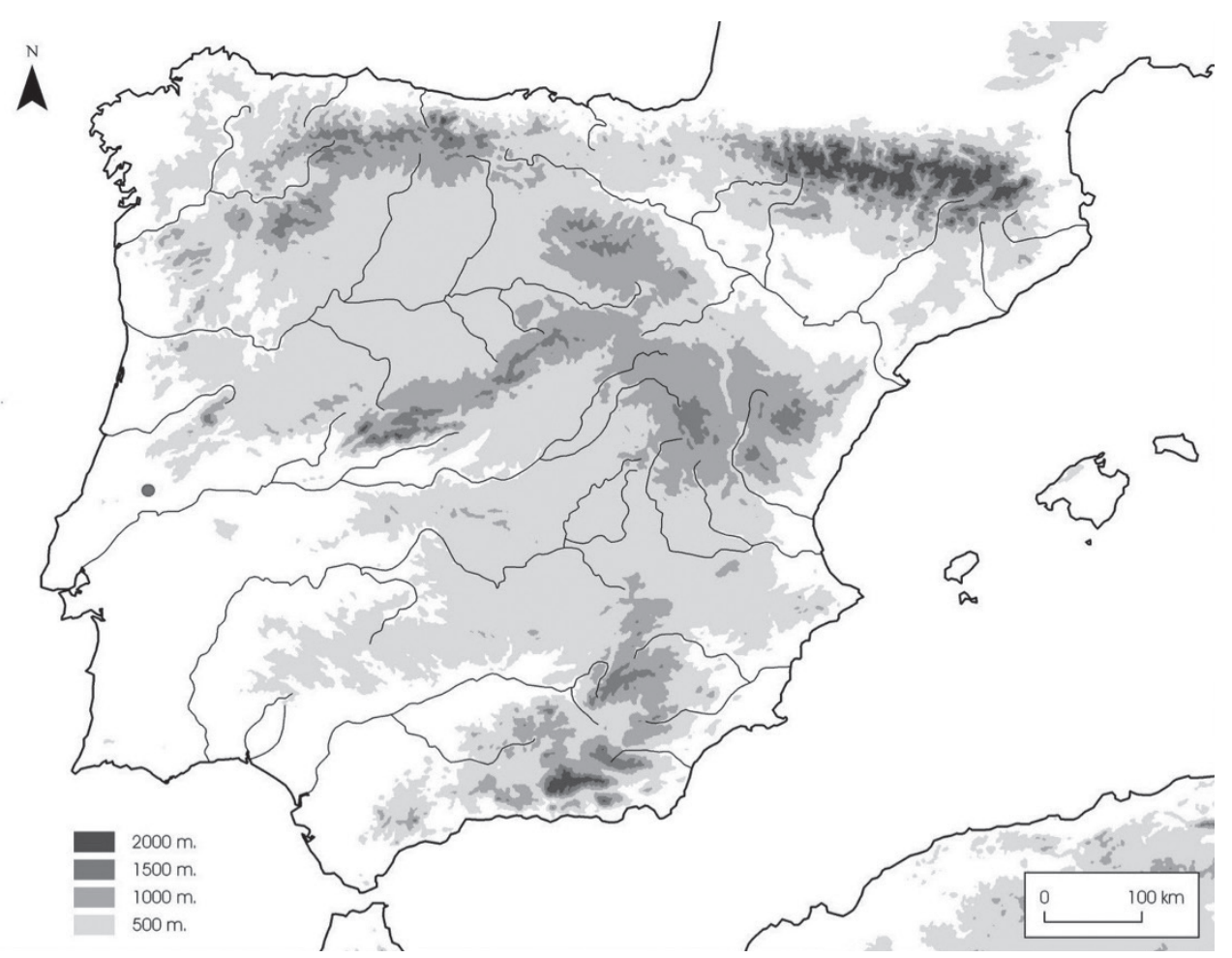

Mapa 1. Localização dos concelhos de Tomar e Ferreira do Zêzere na Península Ibérica'

xisto e do calcário que o relevo é mais acentuado, atingindo uma altitude média de $250 \mathrm{~m}$, existindo alguns cabeços com $350 \mathrm{~m}^{1}$.

No concelho de Ferreira do Zêzere, destaca-se igualmente o rio Zêzere, bem como as ribeiras de Ceras e do Rego da Murta. Assiste-se também a uma variedade do ponto de vista geológico, estando presente o xisto e o calcário, entre os quais existe uma faixa de contacto composta por grés e argilas vermelhas. Do ponto de vista orográfico este concelho tem maiores relevos, com algumas serras e cabeços que atingem os $451 \mathrm{~m}$.

\section{ENQUADRAMENTO HISTÓRICO}

Em época romana a atual cidade de Tomar era a capital da civitas Sellium, de acordo com Jorge de Alarcão a civitas seiliense, teria o Zêzere como fronteira oriental, confrontaria a sul com Scallabis pelo paralelo de Torres Novas e a norte com Conímbriga pelos paralelos de Alvaiázere e de Ansião, a ocidente as serras de Aire e de Sicó2 ${ }^{2}$

\footnotetext{
${ }^{1}$ Consulta disponível em <https://blocs.xtec.cat/socialsnet/tag/mapa-mut/>.

${ }^{2}$ ALARCÃO, 1998: 48.
} 
Para além da cidade romana, o povoamento rural romano, quer das villae, quer dos casais, está patente um pouco por todo o concelho com uma ampla cronologia que abrange a duração do império romano (século I - V d. C.), conforme o demonstram as estações arqueológicas romanas inventariadas na Carta Arqueológica do Concelho de Tomar ${ }^{3}$. De acordo com o exposto por este arqueólogo estão igualmente documentadas «uma grande quantidade de pequenas propriedades tardias (normalmente interpretadas como o desmembramento destas grandes villae), pois a maior parte situa-se na sua periferias, cujos materiais, poucos característicos e pobres, talvez se possam inserir em finais do Baixo Império (século. IV-V d. C.)» ${ }^{4}$.

Testemunhando a continuidade da ocupação humana de Sellium, e, à luz do Parochiale Suevum, temos a paróquia de Selio, a mais meridional, que ter-se-á mantido em época visigótica, sendo referida a paróquia de Naba.

Em 711 o exército muçulmano, composto maioritariamente por berberes, entra na Península Ibérica num momento em que a desagregação do reino visigótico, destacando-se as disputas entre a nobreza visigoda e a debilidade económico-social, teria trazido a ruralização das comunidades ${ }^{5}$.

A maioria das cidades submete-se por capitulação, continuando os habitantes em posse das suas terras, sendo exemplo as facilidades concedidas aos distritos de Santarém e de Coimbra, tomadas por capitulação. De um modo geral, a população cristã que vivia nos campos «continuava a ter liberdade religiosa e a posse dos seus bens, mediante o pagamento de tributos sobre as colheitas e o imposto de capitação» ${ }^{6}$.

Devem destacar-se para esta área geográfica outros dados históricos, nomeadamente, que D. Afonso Henriques, em 1159, doou o Termo de Ceras à Ordem do Templo, sendo neste documento feita referência ao Mosteiro da Murta; que em 1160 inicia-se em Tomar a construção do Castelo templário e no ano 1169 D. Afonso Henriques confirma a posse do Castelo de Tomar. Refira-se ainda em 1162 a primeira carta de foral aos povoadores de Tomar e em 1178 a Carta de foral aos povoadores do Carvalhal de Ceras.

\section{METODOLOGIA}

Do ponto de vista metodológico este trabalho assentou na consulta das Cartas Arqueológicas dos concelhos de Tomar ${ }^{7}$ e de Ferreira do Zêzere ${ }^{8}$, na pesquisa do Sistema de Informação Endovélico e do Portal do Arqueólogo, na consulta de bibliografia específica e de relatórios de trabalhos arqueológicos desta área geográfica, bem como

\footnotetext{
${ }^{3}$ BATATA, 1997: 169-215.

${ }^{4}$ BATATA, 1997: 91.

${ }^{5}$ MATTOSO, dir., 1993: 445.

${ }^{6}$ CATARINO, 2004: 275.

${ }^{7}$ BATATA, 1997.

${ }^{8}$ BATATA, ARSÉNIO, 2006.
} 
na relocalização de algumas das estações arqueológicas com sepulturas escavadas na rocha, respetivamente, de 7 sítios no concelho de Tomar e de 4 sítios no concelho de Ferreira do Zêzere.

Da pesquisa efetuada foi possível constatar que, na região do Médio Tejo, trata-se dos dois únicos concelhos onde, até ao momento, estão inventariadas sepulturas escavadas na rocha.

\section{DESCRIÇÃO DAS SEPULTURAS ESCAVADAS NA ROCHA}

De forma a sistematizarmos os dados recolhidos, num total de 17 estações arqueológicas inventariadas com 29 sepulturas escavadas na rocha, seguimos o modelo descritivo anteriormente apresentado ${ }^{9}$, associando-se à descrição do sítio a tabela de sepultura cujos itens e respetivas soluções enumeramos no Anexo I, onde são igualmente apresentados os desenhos das sepulturas.

\subsection{Concelho de Tomar}

\subsubsection{Sepulturas isoladas}

- Pia dos Moribundos/ Fonte da Romã (CNS 25080) - Freguesia: Além da Ribeira e Pedreira; Lugar: Cadaval; Latitude: 39 39' 12”, Longitude: 8 24' 49” (WGS84); fl. 310 da CMP escala 1:25000; Altitude: 130 m. Descrição: Sepultura antropomórfica escavada no afloramento calcário orientada a sul, implantada numa encosta sobranceira ao vale do rio Nabão e próximo de um caminho de cronologia indeterminada. Esta sepultura destaca-se pelo facto de o antropomorfismo não estar delineado no contorno da sepultura, mas, sim, na escavação da cabeceira em arco de volta perfeita ao nível do leito. A zona da cabeceira apresenta uma «almofada» rebaixada. Encontra-se fraturada no contorno do lado esquerdo e com destacamento da rocha, provavelmente devido a algum incêndio que terá assolado esta zona. De acordo com a Carta Arqueológica do Concelho de Tomar no topo do cabeço «encontram-se telhas grossas curvas de um possível casal» ${ }^{10}$.

Tabela 1. Síntese das caraterísticas da sepultura da Pia dos Moribundos/ Fonte da Romã conforme o Anexo I

\begin{tabular}{c|c|c|c|c|c|c|c|c|c|c|c|c|c|c|c|c|c|c|c|c|c|c|c|c|c|c}
\hline $\mathbf{N}$ & $\mathbf{S}$ & $\mathbf{S 1}$ & $\mathbf{0}$ & $\mathbf{G}$ & $\mathbf{C S}$ & $\mathbf{T G}$ & $\mathbf{T G A}$ & $\mathbf{T G B}$ & $\mathbf{C 1}$ & $\mathbf{C 2}$ & $\mathbf{P 1}$ & $\mathbf{P 2}$ & $\mathbf{L}$ & $\mathbf{L M}$ & $\mathbf{C}$ & $\mathbf{C C}$ & LC & $\mathbf{P M}$ & $\mathbf{R 1}$ & $\mathbf{R 2}$ & $\mathbf{C L}$ & $\mathbf{C L}$ & $\mathbf{M}$ & $\mathbf{A}$ & IG & IC \\
\hline 1 & 0 & - & 1 & $358^{\circ}$ & 2 & 0 & - & 0 & 1 & 2 & 0 & 1 & 50 & 48 & 176 & 22 & 22 & 34 & 0 & - & 3 & 2 & 0 & 0 & 1 & - \\
\hline
\end{tabular}

Fonte: BATATA, 1997: 219; Sistema de Informação Endovélico e Portal do Arqueólogo

- Carvalhal (CNS 35818) - Freguesia: Além da Ribeira e Pedreira; Lugar: Carvalhal da Póvoa; Latitude: 39 40’ 36", Longitude: 8 23’ 41”(WGS84); fl.299 da CMP 
escala 1:25000; Altitude: 170 m. Descrição: Sepultura não antropomórfica de planta sub-retangular, inédita, localiza-se num cabeço. De acordo com o Sr.Ivo Guia, proprietário do terreno, a sepultura encontrava-se num afloramento calcário coincidente com a área de implantação da sua casa, pelo que cortou a rocha e deslocou-a do seu local original para uma zona do terreno onde a sepultura não seria destruída pela obra. Segundo informação do proprietário não existiam mais sepulturas no seu terreno. Todavia, devemos salientar que a mesma localiza-se a cerca de $300 \mathrm{~m}$ das sepulturas da Poça da Moira, podendo ter integrado um espaço único de necrópole.

Tabela 2. Síntese das caraterísticas da sepultura do Carvalhal conforme o Anexo I

\begin{tabular}{c|c|c|c|c|c|c|c|c|c|c|c|c|c|c|c|c|c|c|c|c|c|c|c|c|c|c}
\hline $\mathbf{N}$ & S & S1 & O & G & CS & TG & TGA & TGB & C1 & C2 & P1 & P2 & L & LM & C & CC & LC & PM & R1 & R2 & CL & CL' & M & A & IG & IC \\
\hline 1 & 0 & - & - & - & 1 & 1 & 2 & - & - & 0 & 0 & 0 & 64 & 60 & 175 & - & - & 40 & 0 & - & 2 & 0 & 0 & 0 & 2 & - \\
\hline
\end{tabular}

Fonte: Sistema de Informação Endovélico e Portal do Arqueólogo

- Choiralves I (CNS 35819) - Freguesia: Casais e Alviobeira; Lugar: Choiralves; Latitude: 39 39' 49", Longitude: 8 23' 32" (WGS84); fl. 310 da CMP escala 1:25000; Altitude: $165 \mathrm{~m}$. Descrição: Não nos foi possível relocalizar esta sepultura não antropomórfica e de planta retangular. Encontra-se implantada em parte de uma crista calcária, tem orientação oeste-este e apresenta $191 \mathrm{~cm}$ de comprimento, $63 \mathrm{~cm}$ de largura e $36 \mathrm{~cm}$ de profundidade. De acordo com a Carta Arqueológica de Tomar «O lado exterior à cabeceira parece ter sido ligeiramente aprofundado para a colocação de uma estela (?)», mencionando-se ainda a «Existência de cerâmica grosseira onde se incluem imbrices com cozedura oxidante/redutora» ${ }^{11}$. Observando-se a fotografia da sepultura que consta da mencionada publicação verifica-se que apresenta um rebordo horizontal no seu contorno esquerdo.

- Choiralves II (CNS 35820) - Freguesia: Casais e Alviobeira; Lugar: Choiralves; Latitude: 39³9' 54", Longitude: 8 23' 45”' (WGS84); fl. 310 da CMP escala 1:25000; Altitude:160 m. Descrição: Não nos foi possível efetuar a sua relocalização. De acordo com a descrição da Carta Arqueológica de Tomar trata-se de uma sepultura não antropomórfica escavada no afloramento calcário, de planta retangular e com orientação oeste-este. É salientado que esta sepultura se encontra cortada na zona dos pés pela abertura de um caminho, indicando-se as dimensões de $106 \times 45 \times 27 \mathrm{~cm}$, e, mencionando-se que «Perto encontra-se uma laje monolítica em calcário, com as dimensões de $170 \times 75 \times 16$ que pode ser a sua tampa ${ }^{12}$. Refere-se igualmente a presença de cerâmica grosseira e imbrices.

\footnotetext{
${ }^{11}$ ARSÉNIO, 1997: 328.

12 ARSÉNIO, 1997: 329.
} 
- Seixeira I (CNS 25079) - Freguesia: Casais e Alviobeira; Lugar: Soianda; Latitude: 39’ 39' 15”, Longitude: 8 23' 42" (WGS84); fl. 310 da CMP escala 1:25000; Altitude: 155 m. Descrição: Não foi possível relocalizar o sítio. Trata-se de uma sepultura não antropomórfica escavada no afloramento calcário, de planta retangular e com orientação oeste-este, indicando-se as seguintes dimensões $187 \times 70 \times 62^{13}$. Observando-se a fotografia da sepultura que consta da Carta Arqueológica de Tomar verifica-se que apresenta um rebordo horizontal em todo o seu contorno. Esta sepultura estará associada a um casal, localizado a cerca de $150 \mathrm{~m}$, mencionando-se que «Na encosta aparecem imbrices grossos e cerâmica comum, associados a grossos muros de divisão de propriedade» ${ }^{14}$.

\subsubsection{Conjunto de duas sepulturas}

- Póvoa (CNS 1819) - Freguesia: Além da Ribeira e Pedreira; Lugar: Póvoa; Latitude: 39' 39' 20", Longitude: 8 24' 73" (WGS84); fl.310 da CMP escala 1:25000; Altitude: $100 \mathrm{~m}$. Descrição: Conjunto de duas sepulturas alinhadas no mesmo afloramento calcário, orientadas a Este. Localizam-se num cabeço que domina o vale da Ribeira das Milheiras, nas imediações da aldeia da Póvoa. A sepultura 1 apresenta o delineamento do ombro esquerdo, pelo que foi considerada como antropomórfica incipiente. A sepultura 2, não antropomórfica, encontra-se fraturada no contorno esquerdo, verificando-se que na zona dos pés o calcário está a desfazer-se ${ }^{15}$.

Tabela 3. Síntese das caraterísticas das sepulturas da Póvoa conforme o Anexo I

\begin{tabular}{c|c|c|c|c|c|c|c|c|c|c|c|c|c|c|c|c|c|c|c|c|c|c|c|c|c|c}
\hline $\mathbf{N}$ & $\mathbf{S}$ & $\mathbf{S 1}$ & $\mathbf{0}$ & $\mathbf{G}$ & $\mathbf{C S}$ & $\mathbf{T G}$ & $\mathbf{T G A}$ & $\mathbf{T G B}$ & $\mathbf{C 1}$ & $\mathbf{C 2}$ & $\mathbf{P 1}$ & $\mathbf{P 2}$ & $\mathbf{L}$ & $\mathbf{L M}$ & $\mathbf{C}$ & $\mathbf{C C}$ & $\mathbf{L C}$ & $\mathbf{P M}$ & $\mathbf{R 1}$ & $\mathbf{R 2}$ & $\mathbf{C L}$ & $\mathbf{C L}$ & $\mathbf{M}$ & $\mathbf{A}$ & IG & IC \\
\hline 1 & 1 & - & 2 & $250^{\circ}$ & 1 & 2 & - & 4 & 3 & 0 & 0 & 1 & 56 & 54 & 192 & 35 & 48 & 42 & 0 & - & 2 & 1 & 0 & 0 & 2 & - \\
\hline 2 & 1 & - & 2 & $250^{\circ}$ & 2 & 1 & 2 & - & - & 0 & 0 & 1 & 56 & 46 & 172 & - & - & 51 & 0 & - & 2 & 1 & 0 & 0 & 2 & - \\
\hline
\end{tabular}

Fonte: BATATA, 1997: 218; ARSÉNIO, BATATA, 1992: 56; Sistema de Informaação Endovélico e Portal do Arqueólogo

- Carvalhal 1 (CNS 25077) - Freguesia: Além da Ribeira e Pedreira; Lugar: Carvalhal da Póvoa; Latitude: 39 40’29”, Longitude: 8 23' 39" (WGS84); fl. 299 da CMP escala 1:25000; Altitude: $159 \mathrm{~m}$. Descrição: Conjunto de duas sepulturas escavadas lado a lado no mesmo afloramento calcário, destacando-se pelo facto de a sepultura 1 ter duplo antropomorfismo, enquanto a sepultura 2 encontra-se inacabada. $\mathrm{Na}$ sepultura 1 a cabeceira trapezoidal, com cantos paralelepipédicos, está orientada a oeste $\left(78^{\circ}\right)$, enquanto a cabeceira em arco de volta perfeita com cantos arqueados está orientada a este $\left(260^{\circ}\right)$. Refira-se que imediatamente ao lado da sepultura 2 foi escavada uma pequena pia com cerca de $15 \mathrm{~cm}$ de diâmetro e apenas $5 \mathrm{~cm}$ de profundidade. Coloca-se a hipótese da sepultura 2 ter sido reutilizada como lagareta,

\footnotetext{
${ }^{13}$ ARSÉNIO: 1997: 327.

${ }^{14}$ BATATA, 1997: 218.

${ }^{15}$ BATATA, 1997: 218; ARSÉNIO, BATATA, 1992: 56.
} 
dado que apresenta um canal escavado na zona da cabeceira com cerca de $20 \mathrm{~cm}$ de profundidade. Encontram-se implantadas num pequeno cabeço, junto a um caminho de cronologia indeterminada, a cerca de $600 \mathrm{~m}$ da necrópole da Poça da Moira. De acordo com a Carta Arqueológica de Tomar «No topo do outeiro encontram-se espalhados muitos imbrices rudes, associados a duas sepulturas escavadas na rocha» ${ }^{16}$.

Tabela 4. Síntese das caraterísticas das sepulturas do Carvalhal 1 conforme o Anexo I

\begin{tabular}{l|l|l|l|l|l|l|l|l|l|l|l|l|l|l|l|l|l|l|l|l|l|l|l|l|l|l}
\hline $\mathbf{N}$ & $\mathbf{S}$ & $\mathbf{S 1}$ & $\mathbf{O}$ & $\mathbf{G}$ & $\mathbf{C S}$ & $\mathbf{T G}$ & $\mathbf{T G A}$ & $\mathbf{T G B}$ & $\mathbf{C 1}$ & $\mathbf{C 2}$ & $\mathbf{P 1}$ & $\mathbf{P 2}$ & $\mathbf{L}$ & $\mathbf{L M}$ & $\mathbf{C}$ & $\mathbf{C C}$ & $\mathbf{L C}$ & $\mathbf{P M}$ & $\mathbf{R 1}$ & $\mathbf{R 2}$ & $\mathbf{C L}$ & $\mathbf{C L}$ & $\mathbf{M}$ & $\mathbf{A}$ & $\mathbf{I G}$ & $\mathbf{I C}$ \\
\hline 1 & 2 & - & $\begin{array}{l}3 \\
2\end{array}$ & $\begin{array}{l}78^{\circ} \\
260^{\circ}\end{array}$ & 2 & 4 & - & 4 & $\begin{array}{r}6-9 \\
1-8\end{array}$ & 0 & 0 & 0 & 56 & 54 & 190 & $\begin{array}{l}14 \\
18\end{array}$ & $\begin{array}{l}34 \\
30\end{array}$ & 30 & 0 & - & 2 & 3 & 0 & 0 & $\begin{array}{l}2 \\
7.3\end{array}$ & - \\
\hline 2 & 2 & - & $\begin{array}{l}3 \\
2\end{array}$ & $\begin{array}{l}78^{\circ} \\
260^{\circ}\end{array}$ & 3 & 1 & 0 & - & - & 0 & 0 & 1 & 60 & 56 & 192 & - & - & 16 & 0 & - & 2 & 3 & 0 & 0 & $\begin{array}{l}2 \\
7.3\end{array}$ & - \\
\hline
\end{tabular}

Fonte: BATATA, 1997: 217; Sistema de Informação Endovélico e Portal do Arqueólogo

- Choiralves III (CNS 35821) - Freguesia: Casais e Alviobeira; Lugar: Casal de Baixo; Latitude: 39 40’ 10", Longitude: 8 23' 33" (WGS84); fl. 299 da CMP escala 1:25000; Altitude:170 m. Descrição: Conjunto de duas sepulturas não antropomórficas de planta sub-retangular e alinhadas no mesmo afloramento calcário, encontrando-se ambas parcialmente fraturadas nos seus contornos. Estas sepulturas têm dimensões muito semelhantes na sua largura e comprimento, ambas apresentam no seu contorno direito um rebordo horizontal com cerca de $27 \mathrm{~cm}$ de largura. Localizam-se num cabeço, nas proximidades de um caminho de cronologia indeterminada. A cerca de 300 para oeste encontrámos alguns fragmentos de imbrices grosseiros e fragmentos de cerâmica comum. Na Carta Arqueológica de Tomar, refere-se o seguinte: «Curiosamente, as sepulturas estão assinaladas por um marco (?), que ostenta a cruz de Cristo, com as dimensões de $37 \mathrm{~cm}$ de largura, por $71 \mathrm{~cm}$ (altura visível) e $17 \mathrm{~cm}$. Encontra-se fraturado devido à ação do fogo e no nosso entender não parece ser uma estela. A cruz tem as dimensões de $36 \times 28 \mathrm{~cm} »^{17}$, sendo que na relocalização já não observámos esse marco.

Tabela 5. Síntese das caraterísticas das sepulturas de Choiralves III conforme o Anexo I

\begin{tabular}{c|c|c|c|c|c|c|c|c|c|c|c|c|c|c|c|c|c|c|c|c|c|c|c|c|c|c}
\hline $\mathbf{N}$ & $\mathbf{S}$ & $\mathbf{S 1}$ & $\mathbf{O}$ & $\mathbf{G}$ & $\mathbf{C S}$ & $\mathbf{T G}$ & $\mathbf{T G A}$ & $\mathbf{T G B}$ & $\mathbf{C 1}$ & $\mathbf{C 2}$ & $\mathbf{P 1}$ & $\mathbf{P 2}$ & $\mathbf{L}$ & $\mathbf{L M}$ & $\mathbf{C}$ & $\mathbf{C C}$ & $\mathbf{L C}$ & $\mathbf{P M}$ & $\mathbf{R 1}$ & $\mathbf{R 2}$ & $\mathbf{C L}$ & $\mathbf{C L}$ & $\mathbf{M}$ & $\mathbf{A}$ & $\mathbf{I G}$ & $\mathbf{I C}$ \\
\hline 1 & 1 & - & 0 & $170^{\circ}$ & 2 & 1 & 2 & - & - & 0 & 0 & 1 & 54 & 50 & 190 & - & - & 22 & 2 & 0 & 2 & 0 & 0 & 2 & 2 & - \\
\hline 2 & 1 & - & 0 & $170^{\circ}$ & 2 & 1 & 2 & - & - & 0 & 0 & 1 & 53 & 50 & 192 & - & - & 29 & 2 & 0 & 2 & 0 & 0 & 2 & 2 & - \\
\hline
\end{tabular}

Fonte: ARSÉNIO, 1997: 330; Sistema de Informação Endovélico e Portal do Arqueólogo

- Vales (CNS 14186) - Freguesia: Serra e Junceira; Lugar: Junceira; Latitude: 39 36’ 12", Longitude: 8 20' 52" (WGS84); fl. 310 da CMP escala 1:25000; Altitude: 158 m.

\footnotetext{
${ }^{16}$ BATATA, 1997: 217.

${ }^{17}$ ARSÉNIO, 1997: 330.
} 
Descrição: Duas sepulturas não antropomórficas escavadas no afloramento, encontram-se lado a lado, a maior tem $200 \times 85 \times 20 \mathrm{~cm}$ e a mais pequena $60 \times 60 \times 20^{18}$, as quais não nos foi possível relocalizar.

- Paixinha I (CNS 25082) - Freguesia: Serra e Junceira; Lugar: Paixinha; Latitude: 39 36' 35", Longitude: 80 21' 49" (WGS84); fl. 310 da CMP escala 1:25000; Altitude: 160 m. Descrição: Este sítio não foi relocalizado. De acordo com a Carta Arqueológica de Tomar as duas (?) sepulturas escavadas na rocha localizam-se numa encosta, porém, foram cobertas com terras devido a trabalhos agrícolas ${ }^{19}$.

\subsubsection{Necrópole}

- Poça da Moira (CNS 35822) - Freguesia: Além da Ribeira e Pedreira; Lugar: Carvalhal da Póvoa; Latitude: 39 40' 35", Longitude: 8 23’ 38" (WGS84); fl. 299 da CMP escala 1:25000; Altitude: $156 \mathrm{~m}$. Descrição: Atualmente apenas existem duas sepulturas não antropomórficas localizadas no quintal de uma casa, porém, de acordo com a informação oral recolhida e também com o descrito na Carta Arqueológica de Tomar existiriam pelo menos mais 4 sepulturas escavadas na rocha calcária ${ }^{20}$ que terão sido destruídas aquando da construção da vivenda na década de 80 do século XX. A sepultura 1 , fraturada na zona da cabeceira, continha apenas algumas folhas no fundo, enquanto a sepultura 2, fraturada na zona dos pés, estava preenchida com terra, não apresentando laje de cobertura ou pedras a tapar, observando-se o seu contorno. Aquando da limpeza manual destes sedimentos, identificámos praticamente à superfície fragmentos de ossos humanos, tendo-se procedido à escavação arqueológica da sepultura, a qual revelou um contexto de deposição secundária identificando-se três indivíduos adultos do género masculino e um contexto de deposição primária de um individuo adulto do género feminino. Ambas as sepulturas apresentam rebordos horizontais com $27 \mathrm{~cm}$ de largura, sendo que junto à sepultura 1 , na zona dos pés, encontra-se escavada no afloramento uma pequena pia com cerca de $20 \mathrm{~cm}$ de diâmetro e $8 \mathrm{~cm}$ de profundidade.

Tabela 6. Síntese das caraterísticas das sepulturas da Poça da Moira conforme o Anexo I

\begin{tabular}{c|c|c|c|c|c|c|c|c|c|c|c|c|c|c|c|c|c|c|c|c|c|c|c|c|c|c}
\hline $\mathbf{N}$ & $\mathbf{S}$ & $\mathbf{S 1}$ & $\mathbf{O}$ & $\mathbf{G}$ & $\mathbf{C S}$ & $\mathbf{T G}$ & $\mathbf{T G A}$ & $\mathbf{T G B}$ & $\mathbf{C} 1$ & $\mathbf{C} 2$ & $\mathbf{P 1}$ & $\mathbf{P 2}$ & $\mathbf{L}$ & $\mathbf{L M}$ & $\mathbf{C}$ & $\mathbf{C C}$ & $\mathbf{L C}$ & $\mathbf{P M}$ & $\mathbf{R 1}$ & $\mathbf{R 2}$ & $\mathbf{C L}$ & $\mathbf{C L}$ & $\mathbf{M}$ & $\mathbf{A}$ & $\mathbf{I G}$ & $\mathbf{I C}$ \\
\hline 1 & 4 & 1 & 1 & $350^{\circ}$ & 2 & 1 & 3 & - & - & 0 & 0 & 1 & 55 & 55 & 193 & - & - & 40 & 2 & 0 & 2 & 0 & 0 & 2 & 1 & - \\
\hline 2 & 4 & 1 & 5 & $320^{\circ}$ & 2 & 1 & 6 & - & - & 0 & 0 & 0 & 56 & 54 & 188 & - & - & 38 & 2 & 0 & 2 & 0 & 0 & 2 & 1 & - \\
\hline
\end{tabular}

Fonte: ARSÉNIO, 1997: 328; Sistema de Informação Endovélico e Portal do Arqueólogo

\footnotetext{
${ }^{18}$ BATATA, 1997: 220 e 221.

${ }^{19}$ BATATA, 1997: 221.

${ }^{20}$ ARSÉNIO, 1997: 328.
} 


\subsection{Concelho de Ferreira do Zêzere}

\subsubsection{Sepulturas isoladas}

- Pinheiros I (CNS12792) - Freguesia: Chãos; Lugar: Pinheiros; Latitude: 39 41' 7", Longitude: 8²3’ 40" (WGS84); fl. 299 da CMP escala 1:25000; Altitude: 198 m. Descrição: Sepultura não antropomórfica de planta retangular, orientada a sul, localiza-se numa eira a cerca de $20 \mathrm{~m}$ da linha de muralha do povoado calcolítico de Pinheiros. Foi alvo de escavação arqueológica em 1998 por Luiz Oosterbeek e Ana Rosa Cruz no âmbito do PNTA «TEMPOAR», tendo sido recolhidos 947 ossos humanos, correspondentes de 3 a 5 indivíduos ${ }^{21}$. Todavia, estes arqueólogos salientam que a mesma já teria sido revolvida, dado na terra depositada sobre o afloramento da eira terem identificado «abundantes fragmentos ósseos» ${ }^{22}$. Esta sepultura tem a particularidade de ter à sua volta o rebordo rebaixado para encaixe da tampa, com cerca de $15 \mathrm{~cm}$ de largura, ainda que em algumas zonas esteja atualmente fraturado. Encontra-se igualmente inventariada na Carta Arqueológica de Ferreira do Zêzere ${ }^{23}$.

Tabela 7. Síntese das caraterísticas da sepultura de Pinheiros I conforme o Anexo I

\begin{tabular}{c|c|c|c|c|c|c|c|c|c|c|c|c|c|c|c|c|c|c|c|c|c|c|c|c|c|c}
\hline $\mathbf{N}$ & $\mathbf{S}$ & $\mathbf{S 1}$ & $\mathbf{O}$ & $\mathbf{G}$ & $\mathbf{C S}$ & $\mathbf{T G}$ & TGA & TGB & $\mathbf{C 1}$ & $\mathbf{C 2}$ & $\mathbf{P 1}$ & $\mathbf{P 2}$ & $\mathbf{L}$ & $\mathbf{L M}$ & $\mathbf{C}$ & $\mathbf{C C}$ & LC & PM & R1 & R2 & CL & CL' & M & A & IG & IC \\
\hline 1 & 0 & - & 1 & $0^{\circ}$ & 1 & 1 & 0 & - & - & 0 & 0 & 1 & 64 & 64 & 190 & - & - & 43 & 2 & 2 & 2 & 2 & 0 & 0 & 4 & - \\
\hline
\end{tabular}

Fonte: BATATA, ARSÉNIO, 2006: 119; Sistema de Informação Endovélico e Portal do Arqueólogo

- Pinheiros II (CNS 12791) - Freguesia: Chãos; Lugar: Pinheiros; Latitude: 39 41' 16"; Longitude: 80 23' 39" (WGS84); fl. 299 da CMP escala 1:25000; Altitude: 204 $\mathrm{m}$. Descrição: Sepultura não antropomórfica escavada no afloramento calcário que não nos foi possível relocalizar. De acordo com a Carta Arqueológica de Ferreira do Zêzere tem planta retangular, orientação E-O, um comprimento máximo de $184 \mathrm{~cm}$ e uma largura de $70 \mathrm{~cm}$. Tem $26,5 \mathrm{~cm}$ de profundidade na zona da cabeceira e 37,5 $\mathrm{cm}$ na zona dos pés ${ }^{24}$. Nas suas imediações foi identificado numa pequena elevação uma grande quantidade de imbrices toscos, de várias espessuras, bem como «bastante e cerâmica de perfil em $S$ e cerâmica manual $»^{25}$, interpretado como casal.

- Loba II (CNS 24831) - Freguesia: Areias e Pias; Lugar: Outeiro dos Pereiros; Latitude: 39० 42' 35", Longitude: 8 20’ 47" (WGS84); fl. 299 da CMP escala 1:25000; Altitude: $192 \mathrm{~m}$. Descrição: Sepultura antropomórfica escavada no afloramento calcário

\footnotetext{
${ }^{21}$ OOSTERBEEK, CRUZ, 2000: 111 e 112.

22 OOSTERBEEK, CRUZ, 2000: 111.

${ }^{23}$ BATATA, ARSÉNIO, 2006: 119.

${ }^{24}$ BATATA, ARSÉNIO, 2006: 112 e 113.

${ }^{25}$ BATATA, ARSÉNIO, 2006: 89 e 90
} 
que não nos foi possível relocalizar. De acordo com a Carta Arqueológica de Ferreira do Zêzere localiza-se numa encosta, tem planta trapezoidal, orientação O-E $\left(285^{\circ}\right)$, um comprimento máximo de $190 \mathrm{~cm}$, uma largura máxima de $43 \mathrm{~cm}$ e $34 \mathrm{~cm}$ de profundidade ${ }^{26}$. Observando a fotografia publicada parece ter cabeceira de arco de volta perfeita. Nas suas imediações foram identificados «muitos fragmentos de imbrices nas montureiras provenientes da limpeza dos campos para fins agrícolas» ${ }^{27}$, interpretado como casal, designado como Loba IV (CNS 24794).

- Loba III (CNS 24792) - Freguesia: Areias e Pias; Lugar: Outeiro dos Pereiros; Latitude: 39॰ 42' 19”, Longitude: 8 20’ 44” (WGS84); fl. 299 da CMP escala 1:25000; Altitude: 194 m. Descrição: Sepultura não antropomórfica, orientada a sul, de planta ovalada escavada num penedo calcário isolado a cerca de $1 \mathrm{~m}$ de altura do solo, a única com esta característica do conjunto estudado. Encontra-se nas proximidades de um caminho de cronologia indeterminada e está ligeiramente fraturada no contorno dos pés e na metade superior do leito. De acordo com a Carta Arqueológica de Ferreira do Zêzere estará relacionada com o casal Loba (CNS 24789), onde foram identificados muitos fragmentos de imbrices, o qual se localiza a cerca de $100 \mathrm{~m}$ a sul da sepultura ${ }^{28}$.

Tabela 8. Síntese das caraterísticas da sepultura de Loba III conforme o Anexo I

\begin{tabular}{c|c|c|c|c|c|c|c|c|c|c|c|c|c|c|c|c|c|c|c|c|c|c|c|c|c|c}
\hline $\mathbf{N}$ & $\mathbf{S}$ & $\mathbf{S 1}$ & $\mathbf{0}$ & $\mathbf{G}$ & $\mathbf{C S}$ & $\mathbf{T G}$ & $\mathbf{T G A}$ & $\mathbf{T G B}$ & $\mathbf{C 1}$ & $\mathbf{C 2}$ & $\mathbf{P 1}$ & $\mathbf{P 2}$ & $\mathbf{L}$ & $\mathbf{L M}$ & $\mathbf{C}$ & $\mathbf{C C}$ & $\mathbf{L C}$ & $\mathbf{P M}$ & $\mathbf{R 1}$ & $\mathbf{R 2}$ & $\mathbf{C L}$ & $\mathbf{C L}$ & $\mathbf{M}$ & $\mathbf{A}$ & IG & IC \\
\hline 1 & 0 & - & 1 & $350^{\circ}$ & 1 & 1 & 6 & - & - & 0 & 0 & 0 & 52 & 50 & 168 & - & - & 30 & - & - & 2 & 0 & 0 & 2 & 1 & - \\
\hline
\end{tabular}

Fonte: BATATA, ARSÉNIO, 2006: 86 e 110; Sistema de Informação Endovélico e Portal do Arqueólogo

\subsubsection{Conjunto de duas sepulturas}

- Fonte Seca (CNS 24813) - Freguesia: Beco; Lugar: Fonte Seca; Latitude: 39 47’ 76", Longitude: 8 18' 00" (WGS84); fl. 288 da CMP escala 1:25000; Altitude: 274 m. Descrição: Conjunto de duas sepulturas antropomórficas orientadas a este e escavadas lado a lado no afloramento xistoso, localizadas numa encosta da Serra de S. Paulo e nas imediações de um caminho de cronologia indeterminada. Saliente-se que estas sepulturas foram afetadas pelo grande incêndio de agosto de 2017 que percorreu o concelho de Ferreira de Zêzere, verificando-se que as altas temperaturas provocaram destacamentos na rocha, fragilizando o seu estado de conservação. Ambas as sepulturas apresentam-se fraturadas no seu contorno, provavelmente, consequência da surriba do terreno para o plantio de eucaliptos. Saliente-se que a sepultura 1 apresenta a cabeceira alteada tipo «almofada» e a zona dos pés rebaixada de forma a servir de

\footnotetext{
${ }^{26}$ BATATA, ARSÉNIO, 2006: 109 e 110.

${ }^{27}$ BATATA, ARSÉNIO, 2006: 86 e 87.

${ }^{28}$ BATATA, ARSÉNIO, 2006: 86 e 110.
} 
encaixe para os mesmos. Ambas as sepulturas apresentam no seu contorno exterior o rebordo rebaixado com cerca de $20 \mathrm{~cm}$.

De acordo com a Carta Arqueológica de Ferreira do Zêzere nas proximidades destas sepulturas, no topo de um cabeço, existem muitos imbrices e pedras dispersas por uma área de $50 \mathrm{~m}^{2}$, vestígios que poderão corresponder a um sítio de habitat destruído pela plantação de eucaliptos. Refere-se igualmente que no caminho de acesso encontram-se materiais de construção (telhas finas) da desaparecida ermida de S. Francisco ${ }^{29}$.

Tabela 9. Síntese das caraterísticas das sepulturas da Fonte Seca conforme o Anexo I

\begin{tabular}{c|c|c|c|c|c|c|c|c|c|c|c|c|c|c|c|c|c|c|c|c|c|c|c|c|c|c}
\hline $\mathbf{N}$ & $\mathbf{S}$ & $\mathbf{S 1}$ & $\mathbf{O}$ & $\mathbf{G}$ & $\mathbf{C S}$ & $\mathbf{T G}$ & $\mathbf{T G A}$ & $\mathbf{T G B}$ & $\mathbf{C 1}$ & $\mathbf{C 2}$ & $\mathbf{P 1}$ & $\mathbf{P 2}$ & $\mathbf{L}$ & $\mathbf{L M}$ & $\mathbf{C}$ & $\mathbf{C C}$ & $\mathbf{L C}$ & $\mathbf{P M}$ & $\mathbf{R 1}$ & $\mathbf{R 2}$ & $\mathbf{C L}$ & $\mathbf{C L}$ & $\mathbf{M}$ & $\mathbf{A}$ & IG & IC \\
\hline 1 & 1 & - & 2 & $250^{\circ}$ & 2 & 0 & - & 2 & 0 & 2 & 1 & 2 & 60 & 50 & 180 & 26 & 38 & 32 & 2 & 2 & 3 & 2 & 1 & 0 & 1 & - \\
\hline 2 & 1 & - & 2 & $250^{\circ}$ & 2 & 0 & - & 4 & 3 & 0 & 0 & 1 & 50 & 48 & 180 & 16 & 30 & 38 & 2 & 2 & 3 & 2 & 1 & 0 & 1 & - \\
\hline
\end{tabular}

Fonte: BATATA, ARSÉNIO, 2006: 90 e 115; Sistema de Informação Endovélico e Portal do Arqueólogo

- Madroeira (CNS 24814) - Freguesia: Beco; Lugar: Madroeira ; Latitude: 39॰ 47’ 11”, Longitude: 8 18' 13" (WGS84); fl. 288 da CMP escala 1:25000; Altitude: 320 m. Descrição: Estão inventariadas duas sepulturas escavadas no afloramento xistoso, porém, na relocalização apenas identificámos a sepultura 1 , não antropomórfica de planta retangular e orientada a este, que se destaca pelo seu rebordo elevado com cerca de $18 \mathrm{~cm}$ de largura. $\mathrm{Na}$ fotografia desta sepultura publicada na Carta Arqueológica de Ferreira do Zêzere observa-se, ainda, o rebordo completo que é descrito como «de gola alta» ${ }^{30}$, atualmente, o rebordo está parcialmente destruído e nalguns pontos com vestígios de cimento.

A sepultura 2 em 2006 já se encontrava destruída na zona da cabeceira, impossibilitando aferir a sua tipologia geral. Apresentava planta trapezoidal e um comprimento visível de $154 \mathrm{~cm}$, estaria também orientada a este $\left(290^{\circ}\right)$. Na zona dos pés apresentava $18 \mathrm{~cm}$ de largura e uma profundidade de $20 \mathrm{~cm}$. Tendo em conta que o terreno estava limpo de vegetação e na prospeção realizada não a detetamos, deduzimos que já tenha sido destruída.

$\mathrm{Na}$ Carta Arqueológica de Ferreira do Zêzere refere-se que em volta das sepulturas encontrava-se «alguma cerâmica de aspeto muito arcaico»" ${ }^{31}$.

Tabela 10. Síntese das caraterísticas das sepulturas da Madroeira conforme o Anexo

\begin{tabular}{c|c|c|c|c|c|c|c|c|c|c|c|c|c|c|c|c|c|c|c|c|c|c|c|c|c|c}
\hline $\mathbf{N}$ & $\mathbf{S}$ & $\mathbf{S 1}$ & $\mathbf{O}$ & $\mathbf{G}$ & $\mathbf{C S}$ & $\mathbf{T G}$ & $\mathbf{T G A}$ & $\mathbf{T G B}$ & $\mathbf{C 1}$ & $\mathbf{C 2}$ & $\mathbf{P 1}$ & $\mathbf{P 2}$ & $\mathbf{L}$ & $\mathbf{L M}$ & $\mathbf{C}$ & $\mathbf{C C}$ & $\mathbf{L C}$ & $\mathbf{P M}$ & $\mathbf{R 1}$ & $\mathbf{R 2}$ & $\mathbf{C L}$ & $\mathbf{C L}$ & $\mathbf{M}$ & $\mathbf{A}$ & IG & IC \\
\hline 1 & 1 & - & 2 & $280^{\circ}$ & 1 & 1 & 2 & - & - & 0 & 0 & 0 & 80 & 74 & 172 & - & - & 40 & 1 & 1 & 2 & 2 & 1 & 0 & 4 & - \\
\hline 2 & 1 & - & 2 & $290^{\circ}$ & - & - & - & - & - & - & - & - & - & - & - & - & - & - & - & - & - & - & 1 & 0 & 4 & - \\
\hline
\end{tabular}

Fonte: BATATA, ARSÉNIO, 2006: 91; Sistema de Informação Endovélico e Portal do Arqueólogo

\footnotetext{
${ }^{29}$ BATATA, ARSÉNIO, 2006: 90 e 115.

${ }^{30}$ BATATA, ARSÉNIO, 2006: 113.

${ }^{31}$ BATATA, ARSÉNIO, 2006: 91.
} 


\section{ANÁLISE COMPARATIVA ENTRE AS SEPULTURAS DOS CONCELHOS DE TOMAR E DE FERREIRA DO ZÊZERE}

Verificamos que no concelho de Tomar temos 11 sítios com sepulturas escavadas na rocha correspondendo a 17 sepulturas inventariadas, às quais se somam as 4 sepulturas que existiriam na Poça da Moira, o que assim equivaleria a um total de 21 sepulturas.

Neste concelho estão ainda inventariados dois sítios arqueológicos sobre os quais se coloca a hipótese de existirem sepulturas escavadas na rocha, respetivamente, na Demesenda (CNS 11591, freguesia da Serra e Junceira) onde também foram identificados imbrices grosseiros e alguma cerâmica ${ }^{32}$, bem como no Carvalhal II /Igreja do Carvalhal (CNS12615, freguesia de Além da Ribeira e Pedreira), tendo-se detetado imbrices grosseiros, e, onde de acordo com a tradição local terá também existido uma antiga igreja dedicada a São Silvestre, observando-se derrubes de pedras e algumas pedras aparelhadas ${ }^{33}$.

Gráfico 1. Número de estações arqueológicas com sepulturas escavadas na rocha nos concelhos de Tomar e de Ferreira do Zêzere

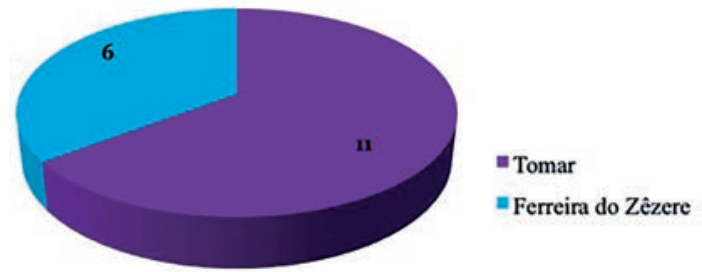

Fonte: BATATA, 1997; BATATA, ARSÉNIO, 2006; Sistema de Informação Endovélico e Portal do Arqueólogo

Relativamente ao concelho de Ferreira do Zêzere estão inventariados 6 sítios com sepulturas escavadas na rocha equivalente a 8 sepulturas identificadas.

Contabilizamos assim um total de 17 sítios inventariados com 29 sepulturas escavadas na rocha, sendo que estas encontram-se sobretudo isoladas e em conjunto de duas. De acordo, com a informação recolhida apenas o sítio da Poça da Moira, no concelho de Tomar, seria uma necrópole constituída, pelo menos, por 6 sepulturas.

Tabela 11. Situação das sepulturas nos concelhos de Tomar e de Ferreira do Zêzere

\begin{tabular}{c|c|c|c}
\hline Situação da Sepultura & Tomar & Ferreira do Zêzere & Total \\
\hline Isolada & 5 & 4 & 9 \\
\hline Conjunto de 2 sepulturas & 5 & 2 & 7 \\
\hline Necrópole & 1 & 0 & 1 \\
\hline
\end{tabular}

Fonte: BATATA, 1997; BATATA, ARSÉNIO, 2006; Sistema de Informação Endovélico e Portal do Arqueólogo 
Quanto ao comprimento todas as sepulturas inventariadas são de adulto, com exceção da sepultura 2 de Vales, com $60 \mathrm{~cm}$ de comprimento, a qual se localiza ao lado de uma sepultura de adulto com $200 \mathrm{~cm}$.

Tabela 12. Comprimento total das sepulturas

\begin{tabular}{c|c}
\hline Comprimento & Sepulturas \\
\hline $60-70$ & 1 \\
\hline $160-170$ & 1 \\
\hline $170-180$ & 4 \\
\hline $180-190$ & 5 \\
\hline $190-200$ & 9 \\
\hline $200-210$ & 1 \\
\hline Indeterminadas & 8 \\
\hline
\end{tabular}

Fonte: BATATA, 1997; BATATA, ARSÉNIO, 2006; Sistema de Informação Endovélico e Portal do Arqueólogo

\subsection{Tipologia geral}

Verificamos que a maioria das sepulturas inventariadas é de tipologia geral não antropomórfica, contabilizando-se nos dois concelhos apenas 5 sepulturas antropomórficas.

Tabela 13. Tipologia geral das sepulturas nos concelhos de Tomar e de Ferreira do Zêzere

\begin{tabular}{c|c|c|c}
\hline Tipologia Geral & Tomar & Ferreira do Zêzere & Total \\
\hline Não Antropomórfica & 12 & 4 & 16 \\
\hline Antropomórfica & 2 & 3 & 5 \\
\hline Antropomorfismo Incipiente & 1 & 0 & 1 \\
\hline Indeterminada & 6 & 1 & 7 \\
\hline
\end{tabular}

Fonte: BATATA, 1997; BATATA, ARSÉNIO, 2006; Sistema de Informação Endovélico e Portal do Arqueólogo

\subsubsection{Sepulturas antropomórficas}

Para além da escassez desta tipologia, também não existe grande variedade tipológica. Em Ferreira do Zêzere temos a sepultura isolada da Loba II, com cabeceira em arco de volta perfeita, e, o conjunto de duas sepulturas da Fonte Seca, a sepultura 1 com cabeceira em arco volta perfeita, e, a sepultura 2 com cabeceira retangular.

Tabela 14. Tipologia das sepulturas antropomórficas nos concelhos de Tomar e de Ferreira do Zêzere

\begin{tabular}{c|c|c|c}
\hline Tipologia & Tomar & Ferreira do Zêzere & Total \\
\hline Ovalada & 1 & 0 & 1 \\
\hline Sub-retangular & 1 & 1 & 2 \\
\hline Trapezoidal & 0 & 1 & 1 \\
\hline Subtrapezoidal & 0 & 1 & 1 \\
\hline
\end{tabular}

Fonte: BATATA, 1997; BATATA, ARSÉNIO, 2006; Sistema de Informação Endovélico e Portal do Arqueólogo 
No concelho de Tomar devemos destacar a sepultura da Pia dos Moribundos/ Fonte da Romã, onde o antropomorfismo não está patente no contorno da sepultura, mas, sim, na escavação ao nível do leito da cabeceira em arco de volta perfeita.

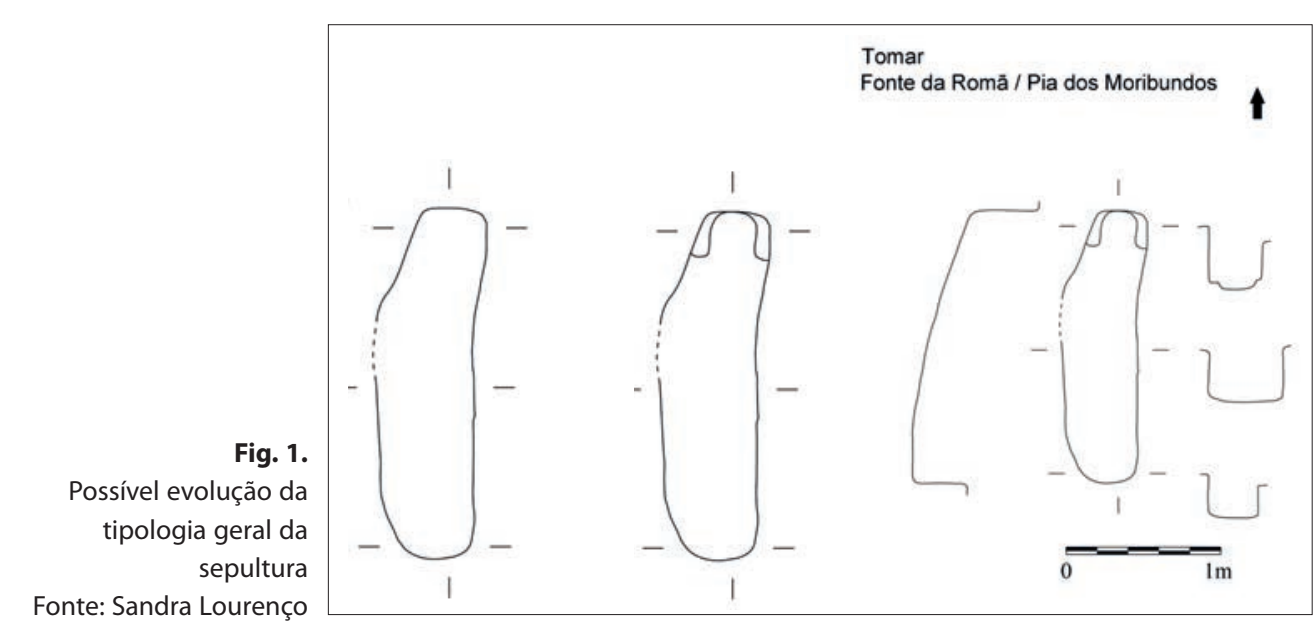

Colocamos a hipótese desta sepultura poder ter tido mais do que um momento de utilização, ou seja, numa primeira fase, seria não antropomórfica, e, num segundo momento o antropomorfismo teria sido conseguido com a escavação da cabeceira no leito da sepultura.

Ainda no concelho de Tomar temos a sepultura 1 do Carvalhal I com a singularidade de ter duas cabeceiras, uma trapezoidal com cantos paralelepipédicos, e, outra em arco de volta perfeita com os cantos arqueados.

Fig. 2.

Carvalhal I: destaque para a sepultura $1 \mathrm{com}$ duas cabeceiras Fonte: Sandra Lourenço

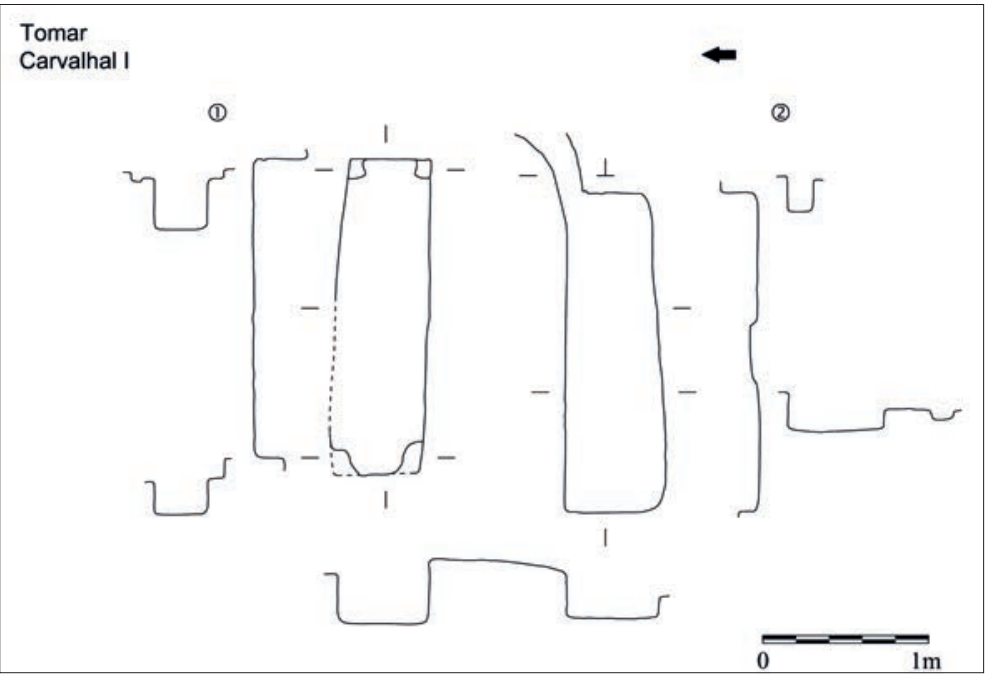


Corresponderá esta duplicidade de cabeceiras a dois momentos de inumação (?), ou, terá existido um engano na execução da sepultura (?). Saliente-se, ainda, que a sepultura 2 localizada ao seu lado, ainda que de contorno não antropomórfico, está inacabada.

\subsubsection{Sepulturas com antropomorfismo incipiente e sepulturas não antropomórficas}

Neste conjunto de sepulturas somente no concelho de Tomar identificámos um único caso de antropomorfismo incipiente, trata-se da sepultura 1 da Póvoa, a qual apresenta apenas o delineamento do ombro esquerdo.

Conforme supra referimos a maioria das sepulturas inventariadas são de tipologia não antropomórfica, num total de 16 sepulturas, com predomínio da tipologia retangular, como é o caso da sepultura 2 do Carvalhal, de Choiralves I, de Choiralves II, da Seixeira I, de Pinheiros I, de Pinheiros II e da sepultura 1 da Madroeira.

Segue-se a tipologia sub-retangular identificada apenas no concelho de Tomar, respetivamente, no Carvalhal, na sepultura 2 da Póvoa, e, nas duas sepulturas de Choiralves III. De tipologia ovalada temos a sepultura 2 da Poça da Moira e a sepultura isolada da Loba III. Somente a sepultura 1 da Poça da Moira apresenta tipologia sub-retangular com os lados arqueados. Em relação às duas sepulturas de Vales não dispomos de informação sobre a sua tipologia.

Tabela 15. Tipologia das sepulturas não antropomórficas nos concelhos de Tomar e de Ferreira do Zêzere

\begin{tabular}{c|c|c|c}
\hline Tipologia & Tomar & Ferreira do Zêzere & Total \\
\hline Retangular & 4 & 3 & 7 \\
\hline Sub-retangular & 4 & 0 & 4 \\
\hline Ovalada & 1 & 1 & 1 \\
\hline Sub-retangular com lados arqueados & 1 & 0 & 2 \\
\hline Indeterminada & 2 & 0 & 2 \\
\hline
\end{tabular}

Fonte: BATATA, 1997; BATATA, ARSÉNIO, 2006; Sistema de Informação Endovélico e Portal do Arqueólogo

Dentro desta tipologia devemos salientar a sepultura da Loba III, a única que se localiza num penedo isolado, elevado a cerca de $1 \mathrm{~m}$ acima da superfície do solo, conferindo-lhe algum destaque na paisagem, característica que não se verifica nas restantes sepulturas. 
Fig. 3.

Penedo isolado

onde foi escavada a

sepultura da Loba III

Fonte: Sandra Lourenço

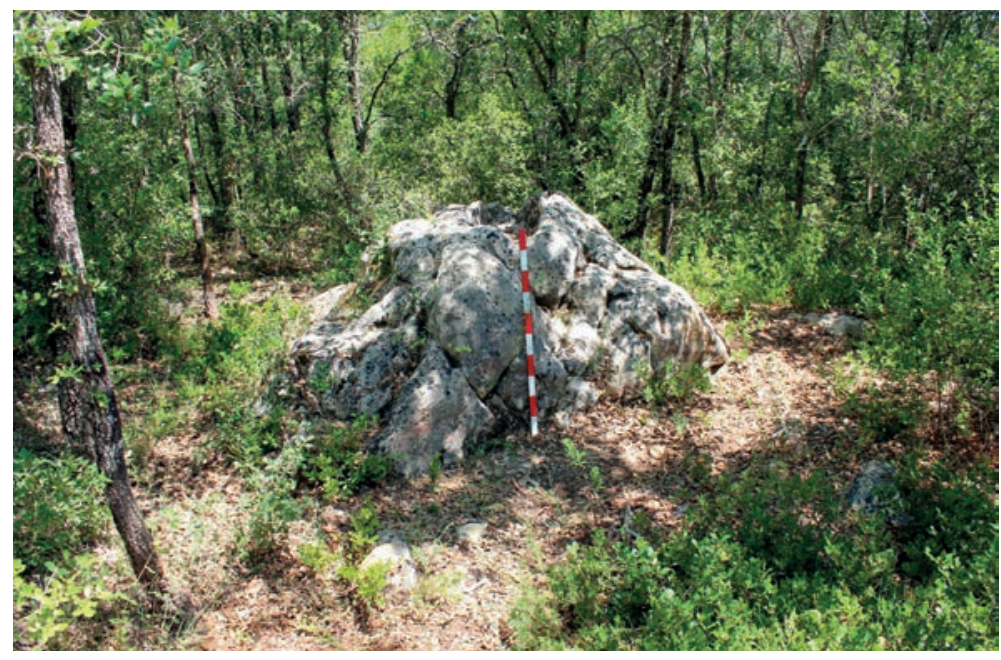

\subsection{Orientação das sepulturas}

No concelho de Tomar ainda que tenhamos 5 sepulturas com orientação O-E, verifica-se que há diversidade nas orientações, não havendo correspondência entre uma tipologia e uma orientação concreta. Temos sepulturas não antropomórficas com orientação O-E, N-S, ou S-N.

Destaca-se, novamente, o caso específico da sepultura 1 do Carvalhal I, com as duas cabeceiras e como tal com orientações opostas, e, a da Pia dos Moribundos/ Fonte da Romã com orientação N-S.

Para algumas das sepulturas do concelho de Tomar que não nos foi possível relocalizar, não dispomos de informação sobre os graus, conforme se constata na tabela infra.

Tabela 16. Orientação das sepulturas do concelho de Tomar

\begin{tabular}{|c|c|c|}
\hline Sepultura/Sítio & Tipologia & Orientação \\
\hline Sepultura n.o 1 da Póvoa & Antropomorfismo Incipiente & $250^{\circ}$ \\
\hline Sepultura n. ${ }^{\circ} 2$ da Póvoa & Não antropomórfica & $250^{\circ}$ \\
\hline Pia dos Moribundos/Fonte da Romã & Antropomórfica & $358^{\circ}$ \\
\hline Carvalhal & Não antropomórfica & Indeterminada \\
\hline Sepultura n. ${ }^{\circ} 1$ do Carvalhal 1 & Antropomórfica & $78 \% / 260^{\circ}$ \\
\hline Sepultura n. ${ }^{\circ} 2$ do Carvalhal 1 & Não antropomórfica/Inacabada & $78 \% / 260^{\circ}$ \\
\hline Sepultura n. 1 da Poça da Moira & Não antropomórfica & $350^{\circ}$ \\
\hline Sepultura n. 2 da Poça da Moira & Não antropomórfica & $320^{\circ}$ \\
\hline Choiralves I & Não antropomórfica & O-E \\
\hline
\end{tabular}




\begin{tabular}{c|c|c}
\hline Choiralves II & Não antropomórfica & O-E \\
\hline Sepultura n. ${ }^{\circ}$ da Choiralves III & Não antropomórfica & $170^{\circ}$ \\
\hline Sepultura . $^{\circ} 2$ da Choiralves III & Não antropomórfica & O-E \\
\hline Seixeira I & Não antropomórfica & Indeterminada \\
\hline Vales (2 sepulturas) & Não antropomórfica & Indeterminada \\
\hline Paixinha I & Indeterminada \\
\hline
\end{tabular}

Fonte: BATATA, 1997; Sistema de Informação Endovélico e Portal do Arqueólogo

Para o concelho de Ferreira do Zêzere das 8 sepulturas, 5 têm orientação O-E. Neste caso e ainda que as antropomórficas tenham orientação canónica, constata-se que esta também está presente na sepultura não antropomórfica da Madroeira.

Tabela 17. Orientação das sepulturas do concelho de Ferreira do Zêzere

\begin{tabular}{|c|c|c|}
\hline Sítio & Tipologia & Graus \\
\hline Pinheiros I & Não antropomórfica & $0^{\circ}$ \\
\hline Pinheiros II & Não antropomórfica & $80^{\circ}$ \\
\hline Loba II & Antropomórfica & $285^{\circ}$ \\
\hline Loba III & Não antropomórfica & $350^{\circ}$ \\
\hline Sepultura n. ${ }^{\circ} 1$ da Fonte Seca & Antropomórfica & $250^{\circ}$ \\
\hline Sepultura $\mathrm{n} \cdot{ }^{\circ} 2$ da Fonte Seca & Antropomórfica & $250^{\circ}$ \\
\hline Sepultura n. ${ }^{\circ} 1$ da Madroeira & Não antropomórfica & $280^{\circ}$ \\
\hline Sepultura n. ${ }^{\circ} 2$ da Madroeira & Indeterminada & $290^{\circ}$ \\
\hline
\end{tabular}

Fonte: BATATA, ARSÉNIO, 2006; Sistema de Informação Endovélico e Portal do Arqueólogo

\subsection{Outros dados: pias, sepulturas inacabadas e tampas/rebordos}

Apenas temos dois casos, ambos no concelho de Tomar, onde observamos a associação das sepulturas a pequenas pias escavadas no afloramento calcário, respetivamente, na sepultura 1 da Poça da Moira com cerca de $20 \mathrm{~cm}$ de diâmetro e $8 \mathrm{~cm}$ de profundidade, e, na sepultura 2 do Carvalhal 1, aproximadamente com $15 \mathrm{~cm}$ de diâmetro e $7 \mathrm{~cm}$ de profundidade. Nesta última sepultura inacabada, observa-se igualmente um canal de escorrência, colocando-se a hipótese de poder ter sido, eventualmente, utilizada como lagareta.

De acordo com a descrição apresentada na Carta Arqueológica de Tomar junto à sepultura não antropomórfica de Choiralves II observou-se a presença de uma laje monolítica em calcário com a dimensão de $170 \times 75 \times 16 \mathrm{~cm}$. Nas fotografias integradas nesta publicação observa-se ainda a presença de rebordos horizontais nas sepulturas não antropomórficas de Seixeira I e Choiralves I ${ }^{34}$.

\footnotetext{
${ }^{34}$ ARSÉNIO, 1996: 326 e 328.
} 
Nas relocalizações efetuadas identificámos no concelho de Tomar a presença de rebordos horizontais nas duas sepulturas da Poça da Moira e nas duas sepulturas de Choiralves III, e, no concelho de Ferreira do Zêzere rebordos rebaixados na sepultura isolada de Pinheiros I e nas duas sepulturas da Fonte Seca, bem como o rebordo elevado na sepultura 1 da Madroeira.

\subsection{Implantação geográfica}

Da análise efetuada a este conjunto de sítios, constata-se que estes implantam-se quer em pequenos cabeços, sem defensabilidade natural, quer em encostas suaves.

Gráfico 2. Implantação geográfica das estações arqueológicas com sepulturas escavadas na rocha nos concelhos de Tomar e de Ferreira do Zêzere

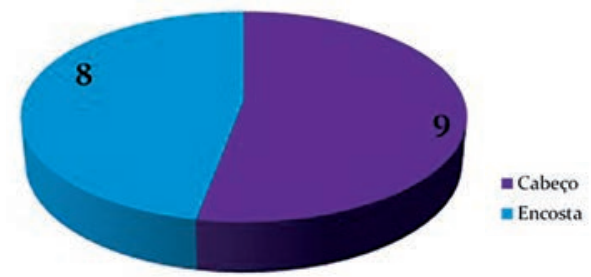

Fonte: BATATA, 1997; BATATA, ARSÉNIO, 2006; Sistema de Informação Endovélico e Portal do Arqueólogo

Localizam-se em áreas sobranceiras a vales férteis e ricos em água (vale do rio Nabão, da ribeira da Milheira, da ribeira da Fervença, da ribeira da Soianda Velha, da ribeira de Ceras, da ribeira de Ribelas) e propícios à prática agrícola.

De um modo geral, estas sepulturas localizam-se nas imediações de caminhos de cronologia indeterminada. Destacando-se pela sua implantação mesmo ao lado de caminhos as sepulturas isoladas da Pia dos Moribundos/Fonte da Romã e da Loba III, bem como o conjunto das duas sepulturas do Carvalhal I.

Analisando o mapa supra, nomeadamente, a localização das sepulturas, verifica-se que existe uma elevada concentração de sepulturas entre os atuais limites administrativos dos concelhos Tomar (Carvalhal I, Carvalhal, Poça da Moira, Choiralves I, Choiralves II, e, Chorialves III) e de Ferreira do Zêzere (Pinheiros I e Pinheiros II).

Esta concentração verifica-se, sobretudo, em torno da atual aldeia do Carvalhal da Póvoa, indiciando uma forte ocupação desta área no período alto-medieval.

Colocando-se a hipótese da necrópole da Poça da Moira, corresponder à necrópole de uma comunidade rural mais expressiva (pequena aldeia?), onde poderiam coexistir vários núcleos familiares.

Saliente-se que dada a proximidade entre a sepultura não antropomórfica do Carvalhal e as sepulturas não antropomórficas da Poça da Moira é possível que a primeira tenha integrado o espaço de necrópole da segunda, pelo que o que hoje vemos no terreno como separado poderá no passado ter sido um espaço único de enterramentos. 


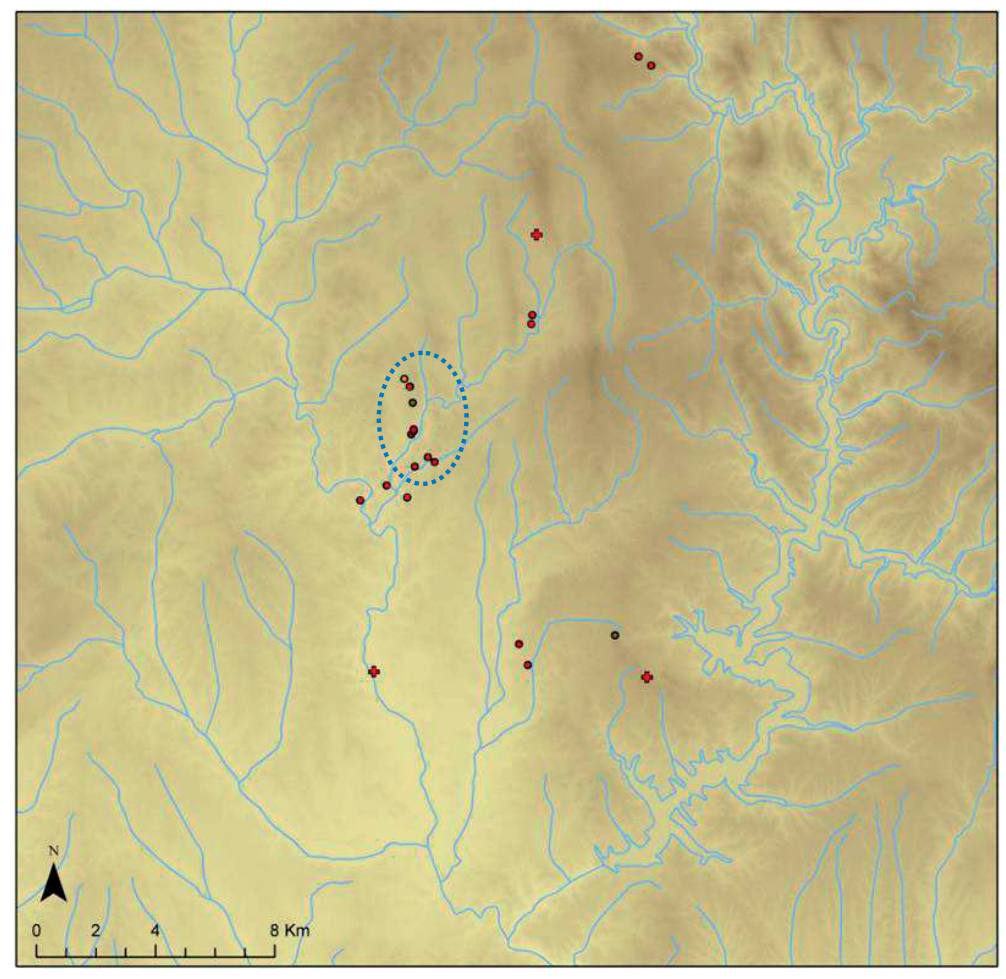

Casal Rústico/Sepultura

- Sepulturas

* Necrópoles/lgreja

- Sepultura com Laje

\section{Mapa 2.}

Implantação das sepulturas nos concelhos de Tomar e de Ferreira do Zêzere, com destaque para a concentração de sepulturas sinalizadas com o círculo azul Fonte: Sistema de Informação Endovélico e Portal do Arqueólogo. Mapa da autoria de Filipa Bragança

Acrescente-se ainda que nos Anais do Município de Tomar é feita referência a Carvalhal de Ceras, que recebe foral em $1178^{35}$, cujos limites parecem coincidir com a zona do Carvalhal da Póvoa, área que revela forte concentração de vestígios arqueológicos pelo menos desde a Alta Idade Média e que se prolongará pela Baixa Idade Média.

\section{IDENTIFICAÇÃO DE ESPÓLIO OSTEOLÓGICO}

Apesar da raridade na identificação de ossos humanos nas sepulturas escavadas na rocha, temos nesta área geográfica dois sítios arqueológicos onde foram detetados vestígios osteológicos, nomeadamente, na sepultura isolada e não antropomórfica de Pinheiros I e na sepultura 2 não antropomórfica da necrópole da Poça da Moira, estas distam entre si, aproximadamente, $1 \mathrm{~km}$, localizando-se a primeira no concelho de Ferreira do Zêzere e a segunda no concelho de Tomar.

A sepultura de Pinheiros I que se localiza na área do povoado calcolítico de Pinheiros (CNS11709) foi escavada em julho de 1998 por Luiz Oosterbeek e Ana Rosa Cruz, no âmbito do PNTA/98 - Territórios, Mobilidade e Povoamento na

\footnotetext{
${ }^{35}$ ROSA, 1972: 46.
} 
Pré-História Recente do Alto Ribatejo. De acordo com a publicação dos resultados deste trabalho, foram recolhidos 947 ossos humanos, mencionando-se que a sepultura «integrava entre 3 a 5 indivíduos» ${ }^{36}$, e, que a mesma já teria sido violada, pois na pequena película de terra que se depositava sobre o afloramento da eira, onde se encontra a sepultura, foram identificados «abundantes fragmentos ósseos» ${ }^{37}$. Face aos dados publicados colocamos a hipótese desta sepultura poder ter sido reutilizada para várias inumações, possivelmente, de indivíduos com ligações familiares entre si. Atualmente, estamos a tentar localizar este conjunto de espólio osteológico, de forma a se efetuar o seu estudo em conjunto com o espólio da sepultura 2 da Poça da Moira.

A necrópole da Poça da Moira (CNS 35822), localiza-se atualmente no quintal de uma casa construída na década de 80 do século XX, estando os seus proprietários emigrados em França. A sepultura 1 estava limpa de terras, apenas com algumas folhas no fundo. A sepultura 2 encontrava-se preenchida com terras, sem qualquer laje de cobertura ou pedras a tapar, observando-se o seu contorno.

Tendo em conta a sua localização num quintal limpo e com árvores de fruto, bem como que neste tipo de situação, normalmente, no interior destas sepulturas são colocadas as terras e pedras resultantes das limpezas das áreas agrícolas, iniciou-se a remoção manual das terras de forma a procedermos aos respetivos registos da sepultura.

Todavia, praticamente no topo da terra que preenchia a sepultura 2 identificaram-se alguns ossos humanos, muito fragmentados, dispersos pelo leito, sem qualquer conexão anatómica e alguns dispostos na vertical.

Face a esta evidência foi efetuada a escavação arqueológica da sepultura sob a responsabilidade da autora e com a colaboração da especialista em antropologia biológica Filipa $\mathrm{Neto}^{38}$. Apresentam-se alguns dados preliminares, uma vez que o conjunto osteológico será alvo do respetivo estudo bioantropológico, procurando-se igualmente financiamento para análises de isótopos estáveis e datações por radiocarbono, fundamentais, para o estudo deste contexto funerário excecional identificado no Alto Ribatejo. Saliente-se que não temos espólio arqueológico associado, com exceção de escassos e pequenos fragmentos de bojo de cerâmica manual e a torno que se recolheram no sedimento da sepultura, os quais não nos permitem avançar com uma datação deste contexto funerário.

\footnotetext{
${ }^{36}$ OOSTERBEEK, CRUZ, 2000: 111 e 112.

${ }^{37}$ OOSTERBEEK, CRUZ, 2000: 111.

${ }^{38}$ DGPC. Email: fneto@dgpc.pt.
} 


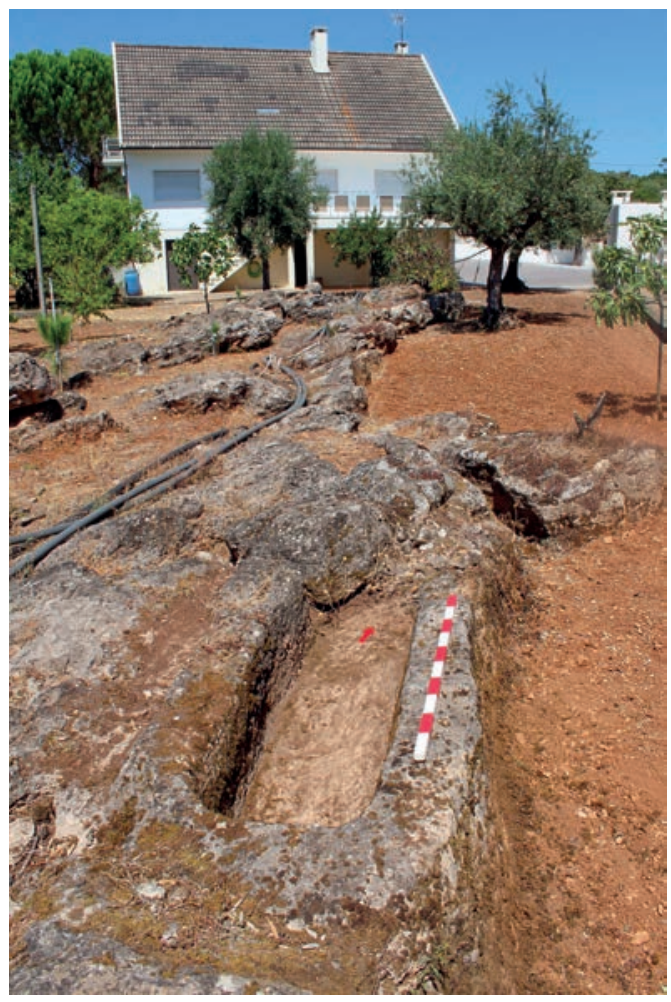

Fig. 4.

Em primeiro plano a sepultura 1 da Poça da Moira completamente limpa de terras

Fonte: Sandra Lourenço

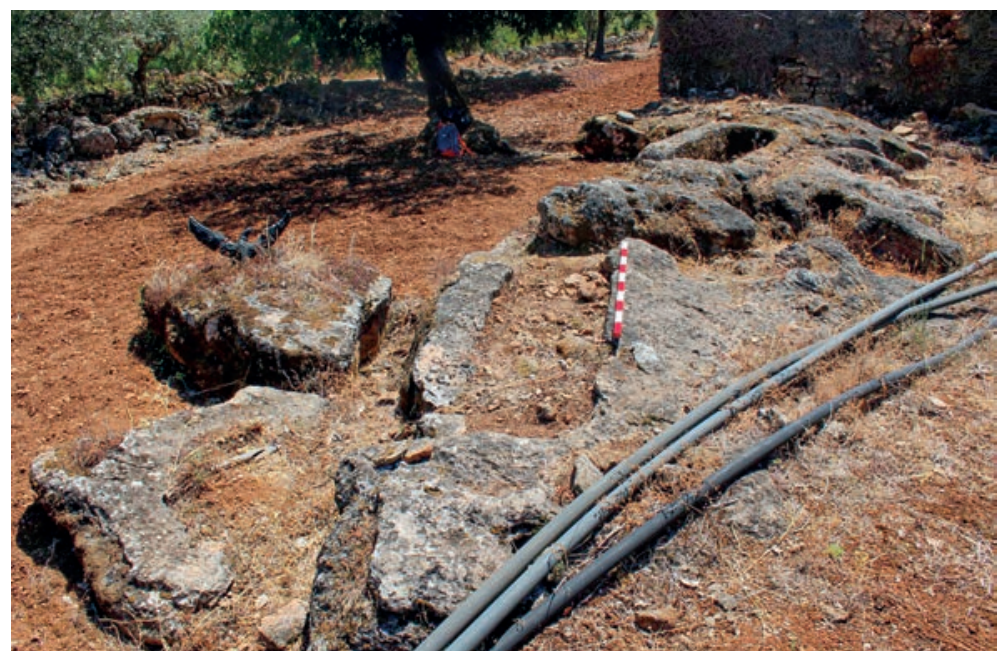

Fig. 5.

Em primeiro plano a sepultura 2 da Poça da Moira preenchida com terras, observando-se em segundo plano a sepultura 1 Fonte: Sandra Lourenço 
Verificámos que nos primeiros $25 \mathrm{~cm}$ de sedimento a fragmentação e dispersão dos ossos era elevada, observando-se depois uma efetiva concentração de ossos humanos na zona dos pés da sepultura, estando presentes e melhor conservados os ossos longos dos membros superiores e inferiores. Alguns ossos de crânios de mais do que um indivíduo, embora presentes, encontravam-se muito fragmentados. As vértebras e costelas, apareciam em menor número e também muito mal conservadas e fragmentadas, enquanto os ossos dos pés e mão estavam praticamente ausentes.

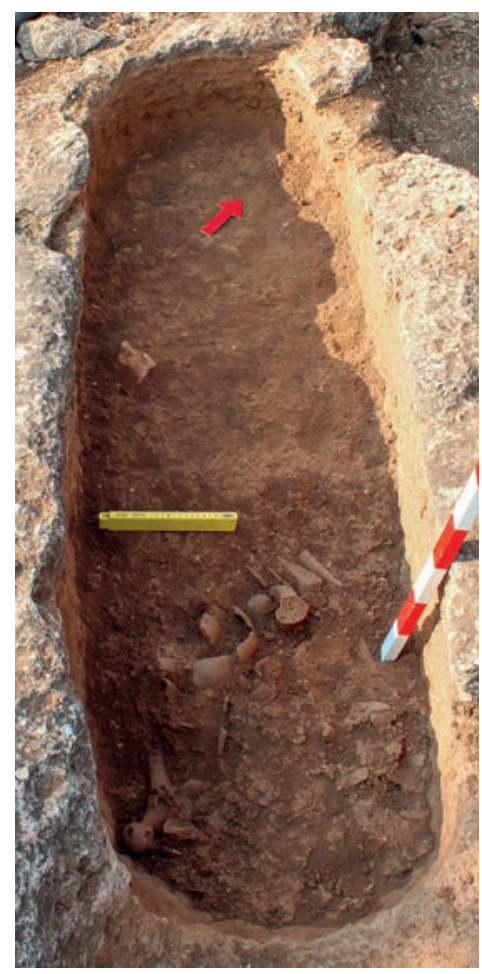

Fig. 6.

Ossos depositados de forma aparentemente organizada na base da sepultura Fonte: Sandra Lourenço

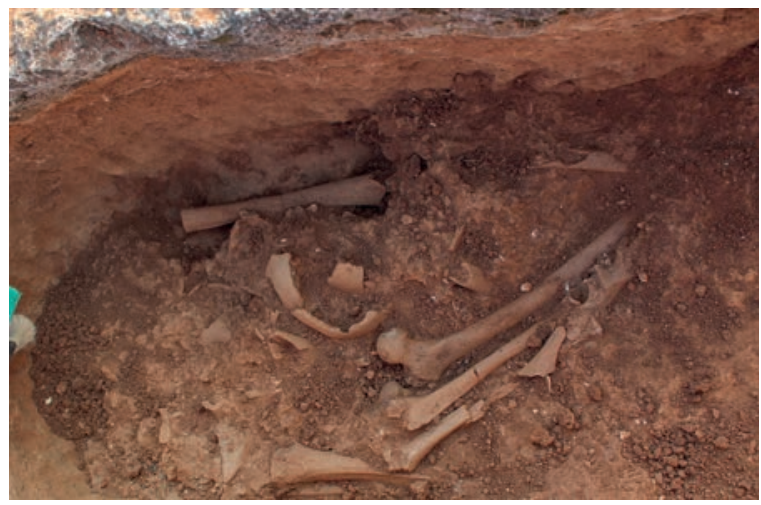

Fig. 7. Pormenor da deposição de ossos pertencentes a mais do que um indivíduo

Fonte: Sandra Lourenço

O estado de conservação e preservação destes ossos, e a sua aparente arrumação por tipos de ossos parece indicar um contexto de deposição secundária aparentemente organizada. Até ao momento foi possível identificar três indivíduos adultos e do género masculino. A deposição dos ossos longos (tanto dos membros superiores, quanto dos membros inferiores) numa mesma orientação e sobrepostos, indiciam a possível seleção de ossos de um outro contexto funerário e a sua deposição neste, ou, então, a limpeza da sepultura e nova rearrumação dos esqueletos, com seleção de ossos e da área de deposição. 


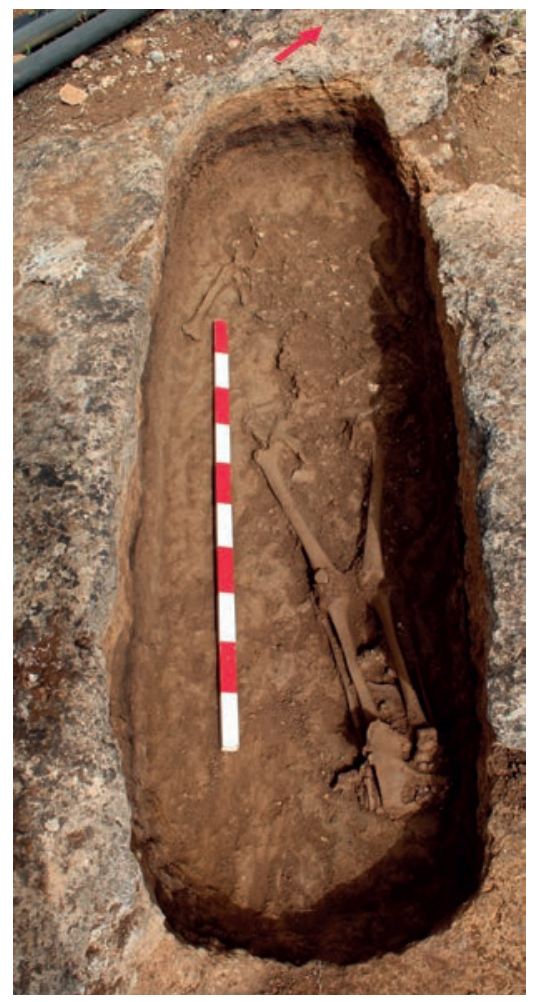

Fig. 8.

Inumação do indivíduo feminino identificada em contexto primário Fonte: Sandra Lourenço

Ora, efetivamente, após o levantamento deste contexto em deposição secundária, identificou-se um outro nível correspondente a uma inumação em contexto primário de um individuo adulto do género feminino depositado sobre o leito da sepultura, a qual tem cerca de $38 \mathrm{~cm}$ de profundidade.

O esqueleto encontrava-se em conexão anatómica depositado em decúbito dorsal, numa orientação NNO - SSE, com os membros superiores fletidos, as mãos colocadas sobre o baixo ventre e os membros inferiores estendidos e paralelos entre si, com os pés juntos. $\mathrm{O}$ crânio encontrava-se totalmente fragmentado, todavia foi possível verificar que o maxilar inferior e parte do maxilar superior estavam ainda bem conservados. As características dos sedimentos e a humidade do solo não permitiram, no entanto, o levantamento integral dos mesmos, e com a sua remoção os vestígios acabaram por fragmentar-se. Partindo da observação do maxilar inferior pode aperceber-se que o crânio ou estaria voltado para a direita, ou teria tombado para esse lado no decurso do processo de decomposição.

Pela forma como os ossos estavam dispostos e as respetivas articulações, nomeadamente os pés sobrepostos, coloca-se a hipótese deste indivíduo ter sido colocado envolto numa mortalha ou sudário e depois coberto por terra. 
Nestes indivíduos não se registaram lesões patológicas observáveis durante o trabalho de campo, dados que deverão ser confirmados ainda pelo trabalho de gabinete a realizar futuramente.

Assim, tal como na sepultura de Pinheiros I, também na sepultura 2 da Poça da Moira temos mais do que um individuo, dados que nos remetem definitivamente para a reutilização das sepulturas escavadas na rocha para várias inumações, conforme, aliás já o foi confirmado na sepultura do Alto da Quintinha, na Beira Alta ${ }^{39}$.

Estes novos dados abrem-nos, definitivamente, uma nova perspetiva de análise quer para estes contextos funerários alto medievais, sendo que uma sepultura pode ter tido várias inumações, provavelmente, de indivíduos com ligações familiares entre si, quer para as próprias comunidades rurais que nelas se fariam sepultar, as quais com a sua reutilização otimizariam o investimento efetuado na abertura da sepultura.

\section{OUTROS TIPOS DE INUMAÇÃO}

Para além das sepulturas escavadas na rocha, estão inventariadas na Carta Arqueológica de Ferreira do Zêzere, outros tipos de inumação, como é o caso do conjunto das duas sepulturas em lajes calcárias de Pinheiros III (CNS 24812), não antropomórficas, retangulares, dispostas lado a lado (com $185 \mathrm{~cm}$ e $169 \mathrm{~cm}$ de comprimento) e com orientação $\mathrm{O}-\mathrm{E}^{40}$, localizadas nas imediações das sepulturas escavadas na rocha não antropomórficas de Pinheiros I e Pinheiros II.

Na mesma publicação refere-se a existência no lugar de Carril (Dornes) de um possível sarcófago retangular, antropomórfico (?) com o apoio para a cabeça e 220 cm de comprimento ${ }^{41}$.

\section{ASSOCIAÇÃO ENTRE O ESPAÇO FUNERÁRIO E RELIGIOSO}

Conforme supra referimos, ainda que tenhamos a referência oral da existência de sepulturas escavadas na rocha próximo de um local onde terá existido uma antiga igreja dedicada a São Silvestre (Carvalhal II/Igreja do Carvalhal - CNS 12615), constatamos que as sepulturas analisadas não estão associadas a espaços religiosos.

Todavia, atendendo a que este tipo de inumação se prolonga no tempo, sendo frequente a sua associação a igrejas paroquiais, devemos referir o aparecimento de sepulturas escavadas na rocha, de tipologia antropomórfica ${ }^{42}$ no adro da Igreja Matriz da Serra (CNS 11692), na freguesia da Serra, concelho de Tomar.

De igual forma, devemos destacar a necrópole da Igreja de Santa Maria do Olival (CNS 3615), na cidade de Tomar, intervencionada entre 2007 e 2009 no âmbito

\footnotetext{
${ }^{39}$ NÓBREGA, NETO, TENTE, 2012: 203-210.

${ }^{40}$ BATATA, ARSÉNIO, 2006: 111e 112.

${ }^{41}$ BATATA, ARSÉNIO, 2006: 120.

${ }^{42}$ BATATA, 2016: 292.
} 
do Tomar Polis onde também foram identificadas sepulturas antropomórficas escavadas no substrato geológico, bem como sepulturas estruturadas variando entre a simples delimitação de blocos pétreos irregulares até ao aparelho em alvenaria bem construído e cobertas com tampas calcárias ${ }^{43}$.

\section{ESPAÇO DOS MORTOS E ESPAÇO DOS VIVOS: SEPULTURAS E CASAIS}

Também no concelho de Tomar e nas imediações da maioria das sepulturas escavadas na rocha (c.d.100 m) é feita menção na Carta Arqueológica à presença de vestígios arqueológicos que corresponderão a pequenos casais rurais, os quais, provavelmente, pertenceriam a núcleos familiares.

Tabela 18. Associação entre as sepulturas e os sítios de povoamento no concelho de Tomar

\begin{tabular}{c|c}
\hline Sepulturas ( $\mathbf{n}^{\circ}$ ) & Casais \\
\hline Póvoa (2) & imbrices grosseiros \\
\hline Pia dos Moribundos/Fonte da Romã (1) & imbrices grosseiros \\
\hline Carvalhal 1 (2) & - \\
\hline Carvalhal (1) & - \\
\hline Poça da Moira (6) & imbrices grosseiros e cerâmica comum \\
\hline Choiralves I (1) & imbrices grosseiros e cerâmica comum \\
\hline Choiralves II (1) & imbrices grosseiros e cerâmica comum \\
\hline Choiralves III (2) & imbrices grosseiros e cerâmica comum \\
\hline Seixeira I & imbrices grosseiros \\
\hline Vales & Paixinha I \\
\hline
\end{tabular}

Fonte: BATATA, 1997. Sistema de Informação Endovélico e Portal do Arqueólogo

A exceção a esta regra poderá estar representada na necrópole da Poça da Moira, a qual pode indiciar um espaço de povoamento mais consistente, como uma pequena aldeia, onde poderiam coexistir vários núcleos familiares, conforme supra mencionámos.

O anteriormente referido replica-se para as sepulturas do concelho de Ferreira do Zêzere, sendo que de um modo geral os vestígios materiais têm pouca expressão à superfície do terreno, descrevendo-se áreas de dispersão que vão dos $50 \mathrm{~m}^{2}$ aos $200 \mathrm{~m}^{2}$.

\footnotetext{
${ }^{43}$ SANTOS, CARRONDO, RIBEIRO, 2009. PEREIRA, PEREIRA, 2010.
} 
Tabela 19. Associação entre as sepulturas e sítios de povoamento no concelho de Ferreira do Zêzere

\begin{tabular}{c|c}
\hline Sepulturas $\left(\mathbf{n}^{\circ}\right)$ & Casais \\
\hline Pinheiros I (1) & $\begin{array}{c}\text { imbrices grosseiros e cerâmica comum; «estruturas de casas dentro da mata de carvalhos e } \\
\text { azinheiras.» (BATATA, ARSENIO, 2006: 88) }\end{array}$ \\
\hline Pinheiros II (1) & imbrices grosseiros e cerâmica comum manual \\
\hline Loba II (1) & imbrices grosseiros \\
\hline Loba III (1) & imbrices grosseiros e cerâmica comum; muro pedra solta \\
\hline Fonte Seca (2) & imbrices grosseiros e pedras de estruturas \\
\hline Madroeira (2) & "cerâmica de aspeto muito arcaico» (BATATA, ARSENIO, 2006: 91) \\
\hline
\end{tabular}

Fonte: BATATA, ARSÉNIO, 2006; Sistema de Informação Endovélico e Portal do Arqueólogo

No concelho de Tomar, para além das associações de sepulturas/casais acima referidas, estão ainda identificados um total de 36 casais, e, no concelho de Ferreira do Zêzere mais 6 casais, integráveis na Alta Idade Média, que obviamente terão também tido o seu espaço funerário.

Localizam-se, predominantemente, em pequenos cabeços, sem defesa natural, e encostas suaves sobranceiras a vales férteis para a prática agrícola.

Recorrentemente, o material arqueológico observado em prospeção são os imbrices grosseiros, alguma cerâmica manual ou a torno lento de pastas castanhas e micáceas, e, a cerâmica a torno de cozedura oxidante.

A estes dados diretamente associados às sepulturas escavadas na rocha, devemos ainda acrescentar o aparecimento no concelho de Tomar de pequenos casais rurais enquadrados, pelos arqueólogos responsáveis das escavações arqueológicas preventivas e de emergência, no período tardo romano/visigótico, como são o exemplo do Casal do Acipreste (CNS 29660), do Casal das Gazelas (CNS 29863) e da Quinta da Ponte de Peniche (CNS30070), os dois primeiros escavados por Elisabete Barradas (2006) e o último por Nélson Borges (2007). Estes sítios, provavelmente, não terão características muito diferentes ao nível da implantação, das estruturas e do espólio dos pequenos casais associados ao contexto funerário das sepulturas rupestres, mas, tal, apenas poderá ser efetivamente comprovado com trabalhos de escavação arqueológica.

O sítio do Casal do Acipreste, já estudado por Elisabete Barradas e Carlos Batata, encontra-se implantado num pequeno cabeço sobranceiro à Ribeira do Tripeiro e ao Rio Nabão, tendo sido identificado no acompanhamento dos trabalhos de desmatação, quando se observou uma mancha de dispersão de telhas e grandes amontoados de blocos de pedra calcária. 


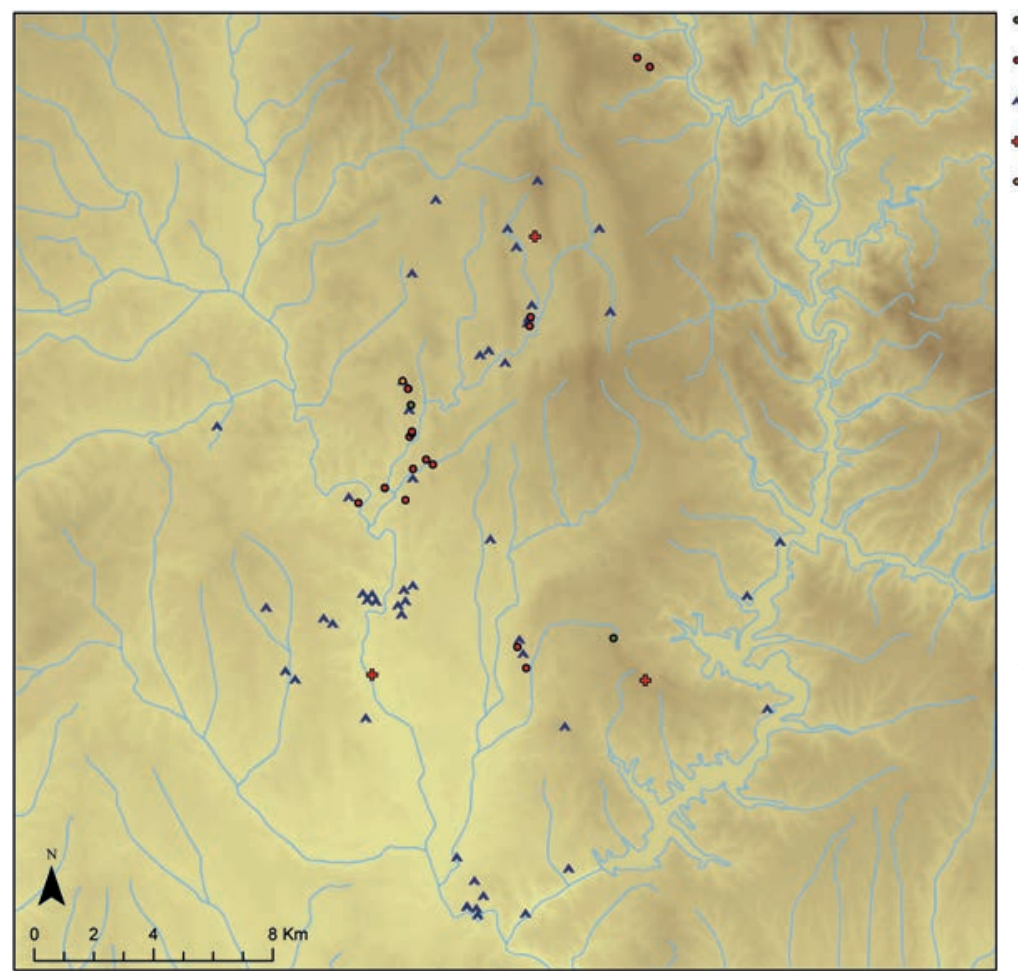

- Casal Rústico/Sepultura

- Sepulturas

^ Casal Rústico

- Necrópoles/lgreja

- Sepultura com Laje

Mapa 3.

Implantação das estações arqueológicas Alto-Medievais nos concelhos de Tomar e Ferreira do Zêzere Fonte: Sistema de Informação Endovélico e Portal do Arqueólogo. Mapa da autoria de Filipa Bragança

$\mathrm{Na}$ escavação arqueológica foram identificados vestígios de uma estrutura habitacional de planta quadrangular, que terá tido um segundo momento de remodelação, referindo-se que «No canto interior sul da casa surgiu uma fossa escavada na rocha, com contornos vagamente antropomórficos mas sem vestígios osteológicos. Na área exterior da habitação derrubes de telha indiciam a existência de telheiros na zona Este» ${ }^{44}$. Do espólio destacam-se os imbrices grosseiros com decorações digitadas com motivos variados, a cerâmica comum de fabrico local com pastas mal depuradas e grande quantidade de desengordurantes micáceos; alguns fragmentos de cerâmica comum de pastas alaranjadas, bem depuradas, de tradição romanas. As formas mais frequentes são as panelas e os potes, fazendo também parte do conjunto artefactual alguns jarros, cântaros, dolia e alguidares ${ }^{45}$.

\footnotetext{
${ }^{44}$ BARRADAS, BATATA: no prelo.

${ }^{45}$ BARRADAS, BATATA: no prelo.
} 


\section{SÍNTESE}

Esta análise assentou na sistematização e análise de sítios que já se encontravam inventariados nas Cartas Arqueológicas do concelho de Tomar e de Ferreira do Zêzere, e, no Sistema de Informação Endovélico, sendo que no âmbito das relocalizações foi inventariada a nova sepultura do Carvalhal, e, identificado espólio osteológico na sepultura 2 da Poça da Moira que conduziu à sua escavação e consequentemente à recolha de novos dados sobre a reutilização das sepulturas escavadas na rocha para várias inumações no seio de uma comunidade rural.

Apesar do número de sepulturas aqui apresentado ser bem mais reduzido do que aquele que estudámos no âmbito do projeto de investigação sobre o Povoamento alto-medieval entre os rios Dão e Alva (2007) e de observarmos, também, grandes diferenças em termos tipológicos, nomeadamente, com o predomínio do não antropomorfismo, há um ponto de união nestas regiões, estaremos, também aqui perante, um povoamento assente em pequenos casais, com um sustento muito provavelmente relacionado com a prática agrícola (entre outras?), mas que, certamente, formariam uma rede entre si.

Os inúmeros casais que acima fizemos referência e que se integrarão neste mundo alto-medieval, terão também o seu espaço funerário, provavelmente, também, com outras soluções de inumação.

Muito estará por descobrir e estudar nesta área do Alto Ribatejo, porém, estamos certos que um trabalho de investigação sobre esta temática trará outros dados quer sobre as sepulturas rupestres, ou, outro tipo de inumação, quer sobre os locais de povoamento das comunidades rurais que ao longo da Alta Idade Média habitaram neste território.

\section{BIBLIOGRAFIA}

ALARCÃO, Jorge de (1988a). Roman Portugal. Warminster: Aris and Phillips Lt., fasc. 1, vol. 2.

ALARCÃO, Jorge de (1988b). O domínio romano em Portugal. Lisboa: Publicações Europa-América.

ALARCÃO, Jorge de (1998). A Paisagem Rural Romana e Alto Medieval em Portugal. «Conimbriga». 37, 89-119.

ALARCÃO, Jorge de (2000). As paróquias suévicas do território actualmente português. «Religión, lengua y cultura prerromanas de Hispania». Separata. Salamanca: Universidad de Salamanca, pp. 29-59.

ARSÉNIO, Paulo; BATATA, Carlos (1992). Sepulturas escavadas na rocha da região de Tomar. In Boletim Cultural da Câmara Municipal de Tomar. Tomar: Camara Municipal de Tomar, vol. 16, pp. 92-102. ARSÉNIO, Paulo (1997). Sepulturas escavadas na rocha (Anexo C). In As Origens de Tomar. Carta Arqueológica do Concelho. Tomar: CEPPRT, pp. 325-330.

BARRADAS, Elisabete (2007a). Relatório final das sondagens arqueológicas no Casal das Gazelas (p.k.5+150). IC9 - Nó de Carregueiros/Tomar (IC3). Ed. policopiada.

BARRADAS, Elisabete (2007b). Relatório final dos trabalhos de escavação arqueológica no Casal do Acipreste ao p.k. 4+900. IC9 - Sublanço Nó de Carregueiros/Tomar (IC3). Ed. policopiada.

BARRADAS, Elisabete; BATATA, Carlos (no prelo). O Casal do Acipreste (Tomar) - um habitat tardoromano/visigótico. Évora: Universidade de Évora. Poster apresentado no I Congresso Internacional sobre Arqueologia de Transição. 
BARROCA, Mário Jorge (1987). Necrópoles e sepulturas medievais de Entre-Douro-e-Minho (Séc. V a $X V$ ). Porto: Faculdade de Letras da Universidade do Porto. Dissertação para Provas Públicas de Aptidão Pedagógica e Capacidade Científica.

BATATA, Carlos (1997). As Origens de Tomar. Carta Arqueológica do Concelho. Tomar: CEPPRT.

BATATA, Carlos; ARSÉNIO, Paulo (2006). Carta Arqueológica de Ferreira do Zêzere. Tomar: Câmara Municipal de Ferreira do Zêzere e OZECARUS, Serviços Arqueológicos, Lda.

BATATA, Carlos (2016). Relatório do Património Arqueológico. Revisão do Plano Diretor Municipal de Tomar. Fase II. Ed. policopiada.

BORGES, Nélson; SILVA, Ricardo (2007). Relatório final das escavações arqueológicas na Quinta da Ponte de Peniche (p.k.4+500). IC9 - Nó de Carregueiros/Tomar (IC3). Ed. policopiada.

CATARINO, Helena (2004). A Ocupação Islâmica. In MEDINA, João, coord. História de Portugal. Portugal Medieval (I). Amadora: Edição Ediclube, vol. III, pp. 269-349.

CONDE, Manuel Sílvio Alves (2000). Uma paisagem humanizada. O Médio Tejo nos finais da Idade Média. Cascais: Patrimonia. 2 vols.

FERREIRA, Carlos Jorge Alves (1992). A necrópole tardo-romana e visigótica de Pedreira. Rio de Moinhos - Abrantes. «Arqueologia Medieval». 1, 91-110.

LOURENÇO, Sandra (2006). O povoamento alto-medieval entre os rios Dão e Alva. "Trabalhos de Arqueologia». 50.

MATTOSO, José, dir. (1993). História de Portugal. Lisboa: Editorial Estampa, vol. 1, pp. 441-526. Vol. 1: Antes de Portugal.

NÓBREGA, Pedro Pina; NETO, Filipa; TENTE, Catarina (2012). A sepultura medieval do Alto da Quintinha (Mangualde). "Arqueologia Medieval». 12, 203-210.

OLIVEIRA, Jorge de (2017). Necrópole Alto-Medieval da Coudelaria de Alter. In TEIXEIRA, Cláudia; CARNEIRO, André, coord. Arqueologia da transição: entre o mundo romano e a Idade Média. Coimbra: Imprensa da Universidade de Coimbra, pp. 433-451.

OOSTERBEEK, Luiz; CRUZ, Ana Rosa (2000). Povoado de Pinheiros. Campanha arqueológica. 1998. «Techne». 6, 107-120.

PEREIRA, Elisabete; PEREIRA, Sérgio (2010). Relatório final da empreitada de construção dos Arranjos Exteriores e Arruamentos no Flecheiro e Mercado (TomarPolis). Ed. policopiada.

PONTE, Salete da (1992). Tomar e o Seu Território. «O espaço Rural na Lusitânia, Tomar e o Seu Território. Atas do Seminário. (1989)». Tomar, pp. 25-29.

PONTE, Salete da (1995). Presença paleo-cristã em Tomar. In IV Reunião de Arqueologia Cristã Hispânica. Barcelona: Institut d'Estudis Catalans, pp. 515-520.

PONTE, Salete da (2012). Interfaces Culturais em Tomar Cidade. Tomar: TCEL.

PRATA, Sara (2017). Sobre o estudo das necrópoles alto-medievais da Serra de São Mamede (Castelo de Vide e Marvão, Portugal): Uma perspectiva metodológica. In TEIXEIRA, Cláudia; CARNEIRO, André, coords. Arqueologia da transição: entre o mundo romano e a Idade Média. Coimbra: Imprensa da Universidade de Coimbra, pp. 415-432.

ROSA, Amorim (1972). Anais do Município de Tomar. Tomar, vol. VIII, pp. 1137-1453.

SANTOS, Helena; CARRONDO, Joana; RIBEIRO, Ricardo (2009). Relatório final da empreitada de construção da Ponte entre o Flecheiro e o mercado e Remodelação do Açude do Mercado (TomarPolis). Ed. policopiada.

TENTE, Catarina; LOURENÇO, Sandra (1998). Sepulturas medievais escavadas na rocha dos concelhos de Carregal do Sal e Gouveia: estudo comparativo. «Revista Portuguesa de Arqueologia». 1: 2, 191-217.

TENTE, Catarina; LOURENÇO, Sandra (2002). Sepulturas medievais do distrito de Évora. "Revista Portuguesa de Arqueologia». 5: 1, 239-258.

TENTE, Catarina (2017). Entre o fim do Império e o início da Idade Média: As mudanças na estrutura do povoamento na região noroeste da Serra da Estrela (Centro de Portugal). In TEIXEIRA, Cláudia; CARNEIRO, André coord. Arqueologia da transição: entre o mundo romano e a Idade Média. Coimbra: Imprensa da Universidade de Coimbra, pp. 19-38. 


\section{ANEXOS}

Anexo I. Tabela Geral das Sepulturas e Desenhos

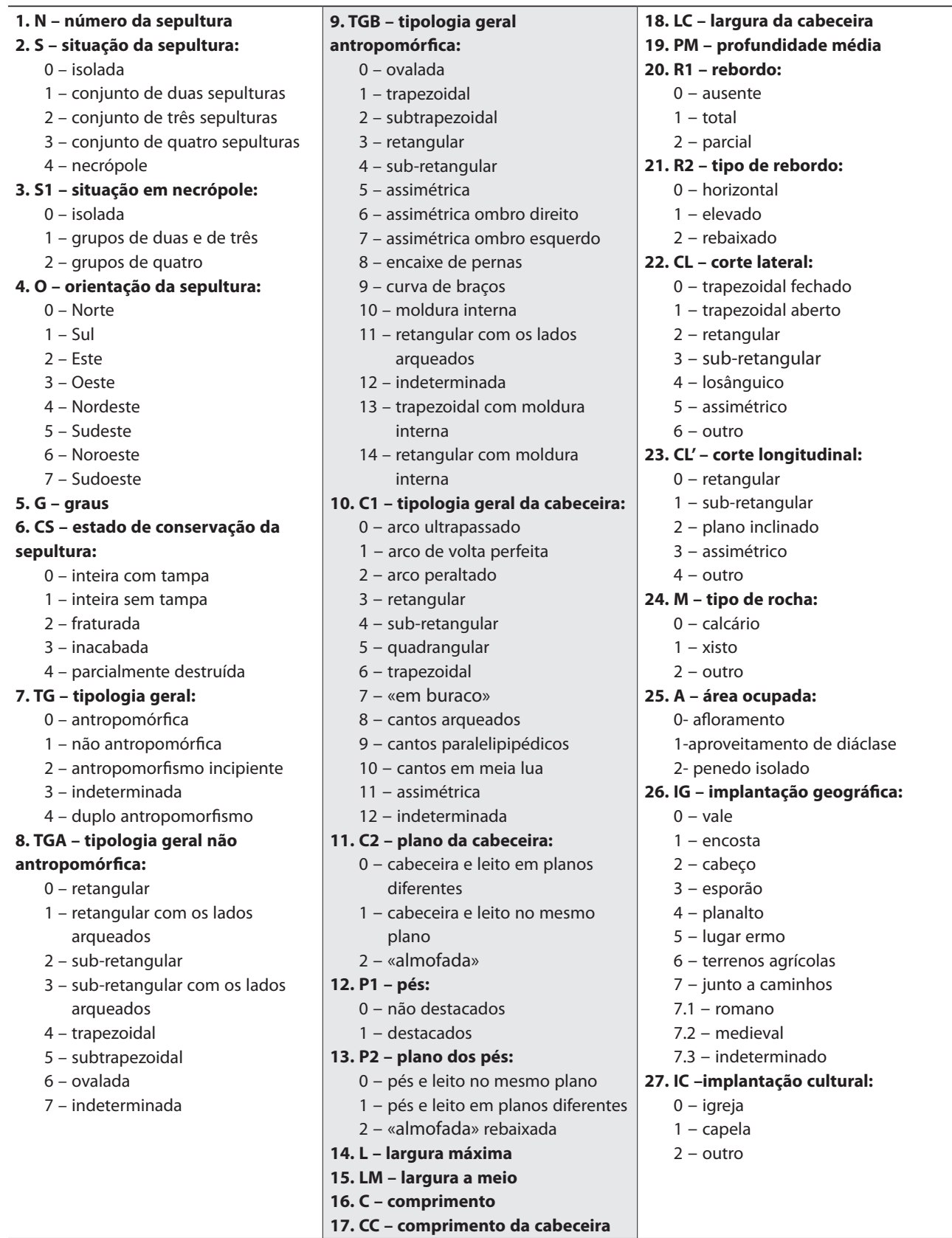


Anexo II. Desenhos das sepulturas escavadas na rocha

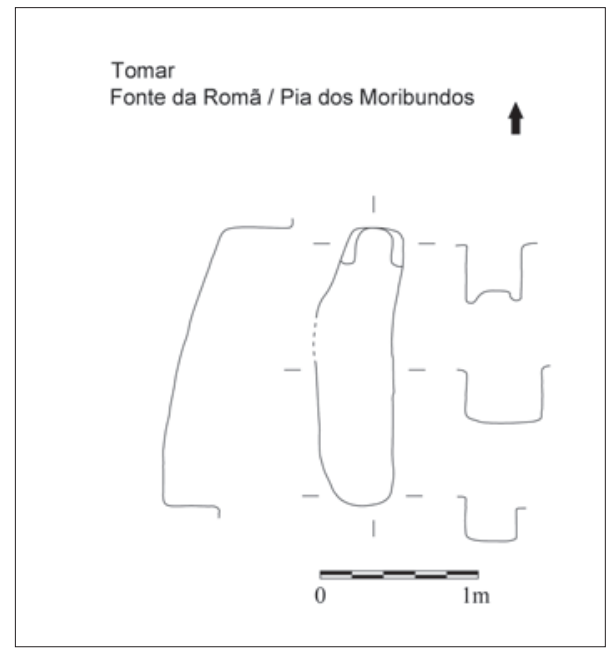

a)

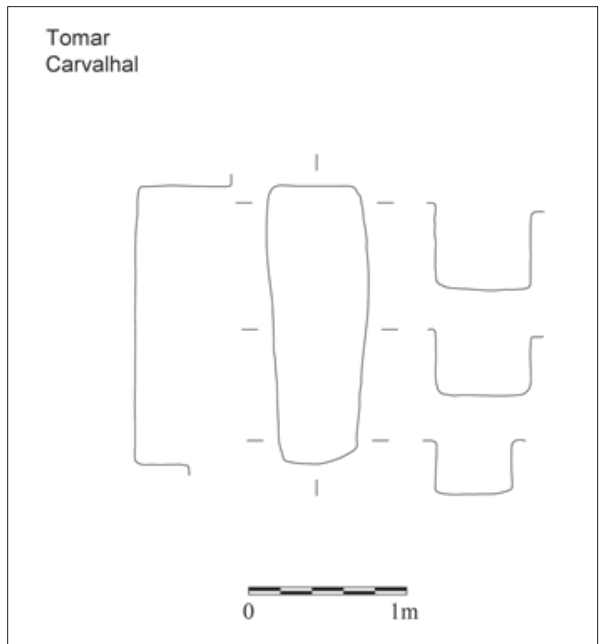

b)

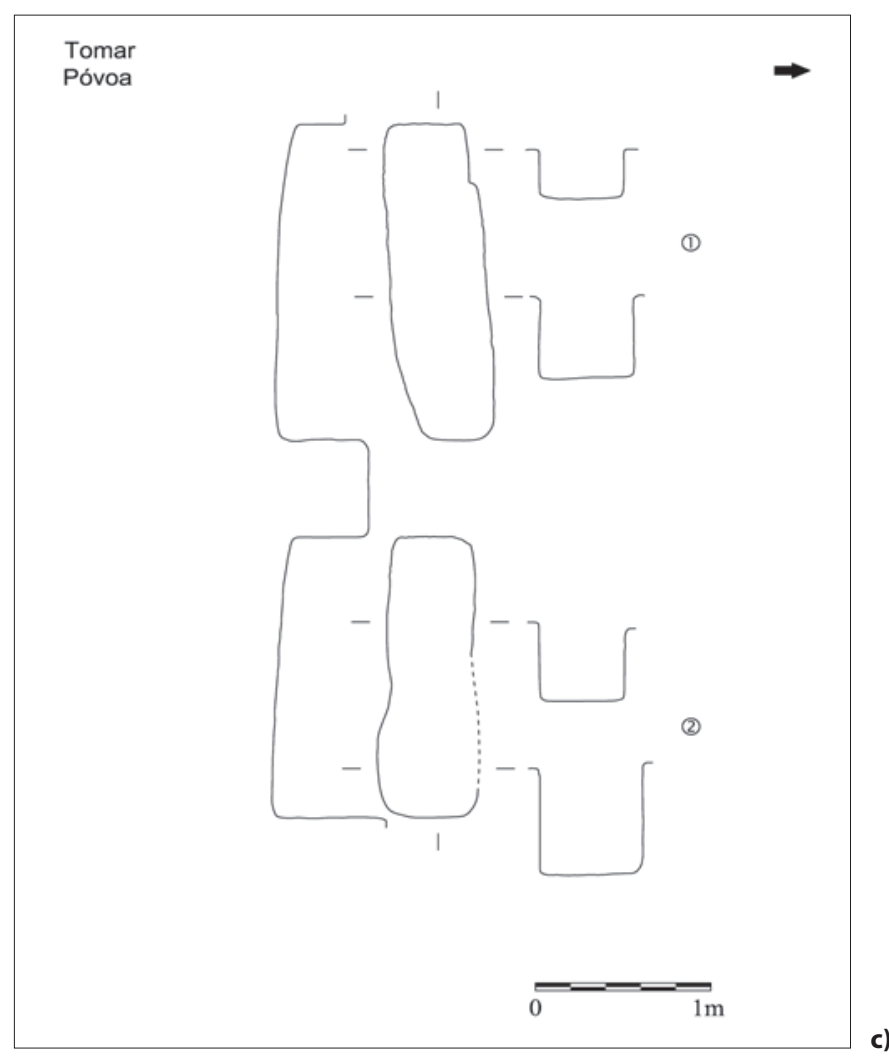

Fonte: autoria de Sandra Lourenço 


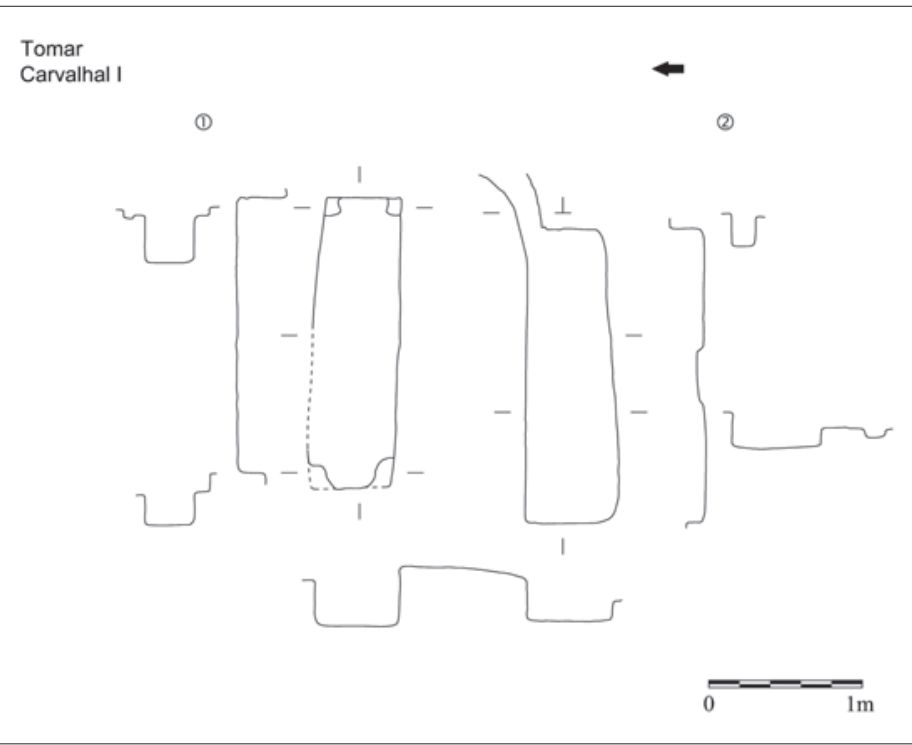

d)

Tomar

Choiralves III
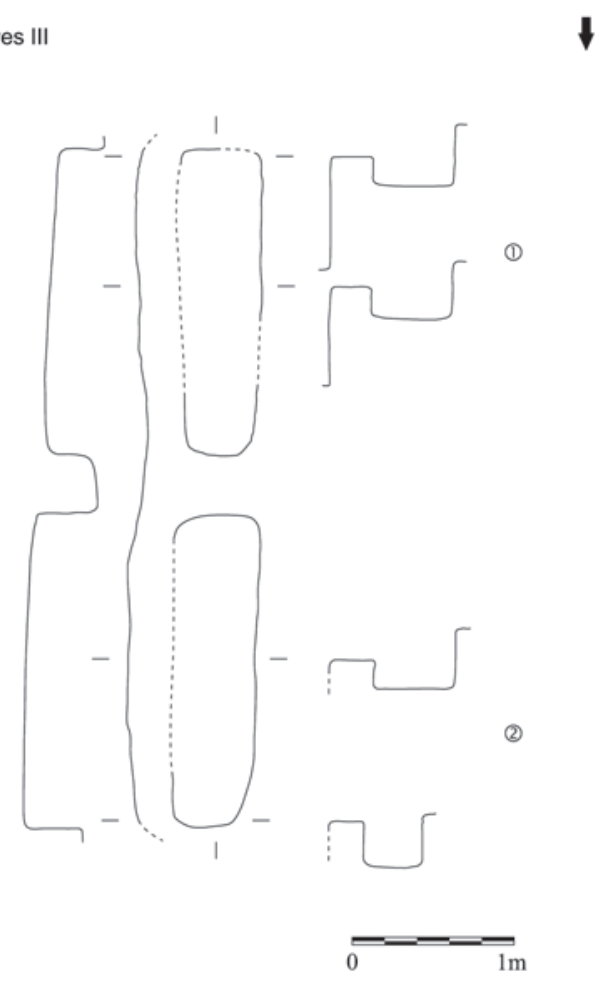

e) 

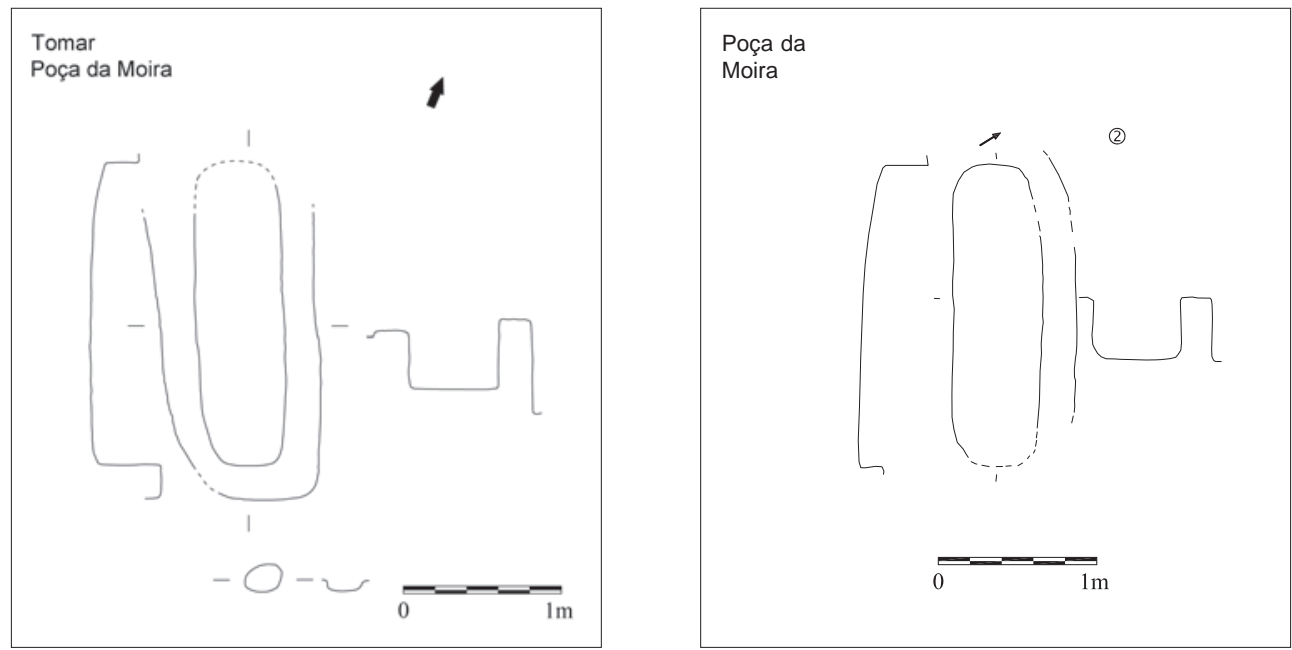

f)

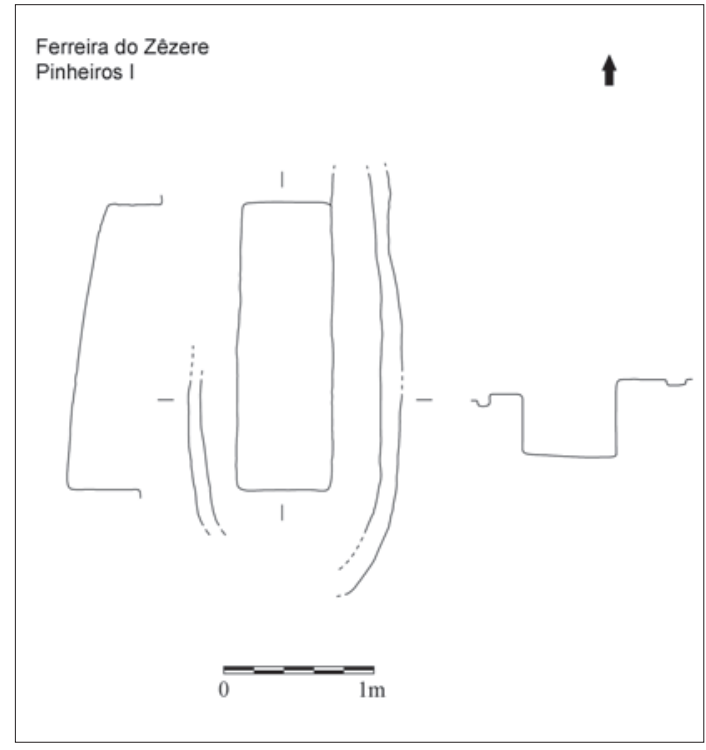

g)

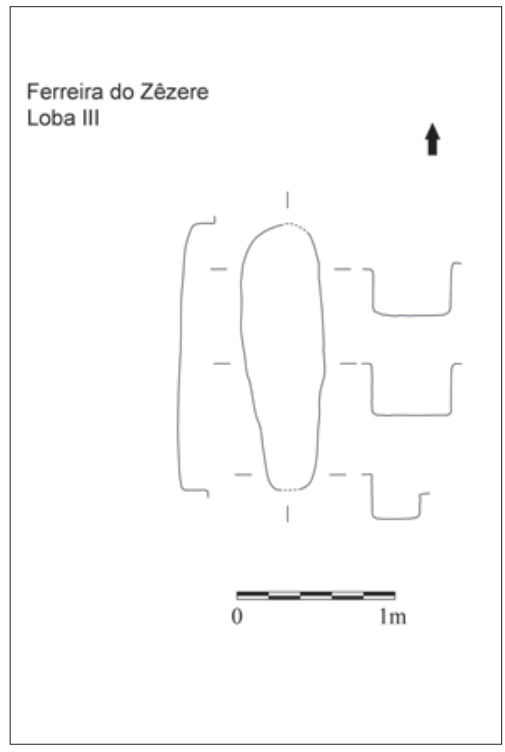

h) 

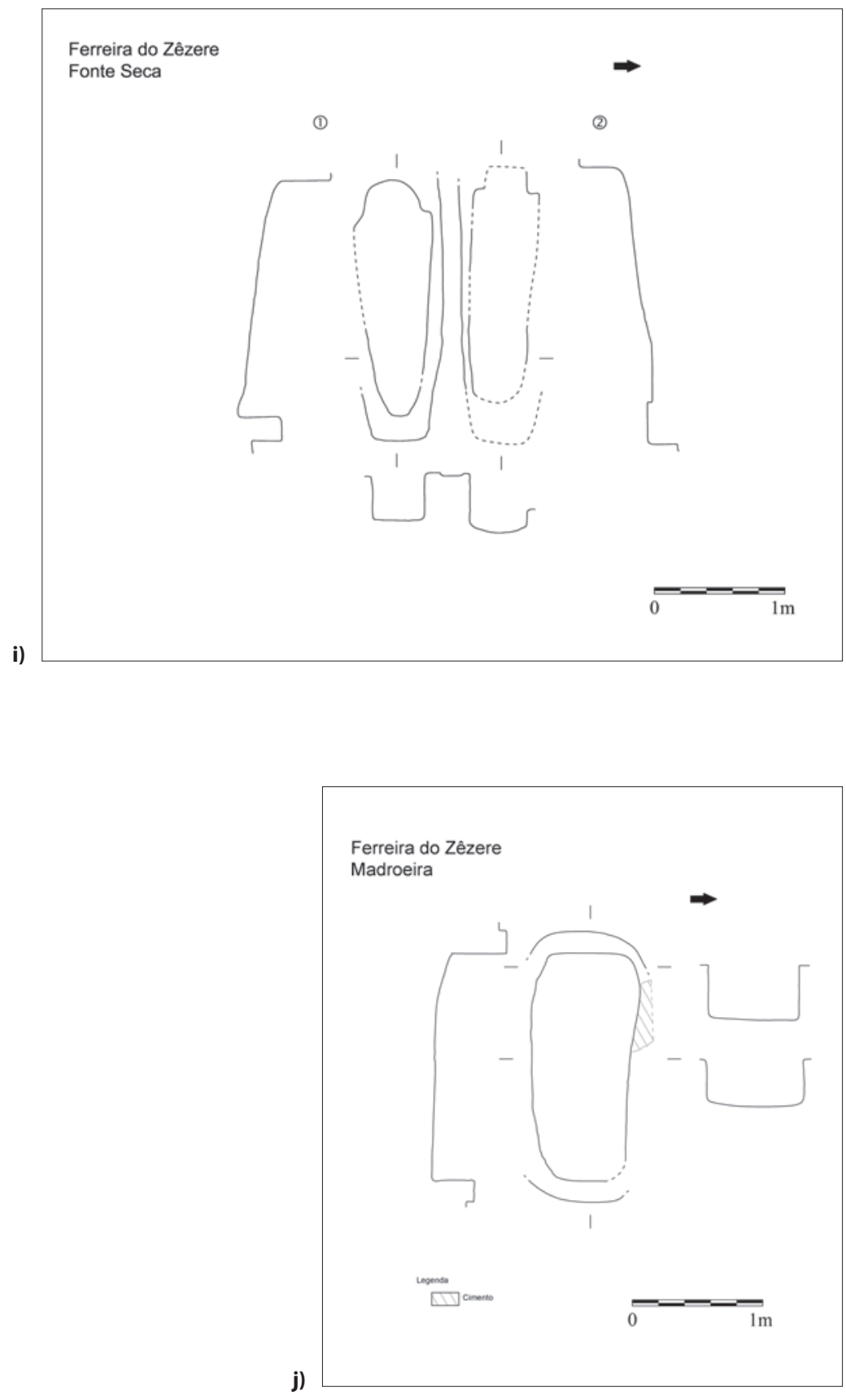


\title{
SEPULTURAS, TOPÓNIMOS E HABITATS: ELEMENTOS PARA A COMPREENSÃO DO POVOAMENTO ALTO-MEDIEVAL NO MUNICÍPIO DE SANTA COMBA DÃO (VISEU)
}

\author{
PEDRO MATOS* \\ HELENA CATARINO**
}

\begin{abstract}
Resumo: $O$ estudo agora apresentado resulta de trabalhos de prospeções arqueológicas no território do concelho de Santa Comba Dão (Viseu), centrando-se na relação das sepulturas rupestres com os vestígios do povoamento antigo, possivelmente coevo ou com os quais possa ter relações de continuidade. A análise conjunta dos dados arqueológicos e da documentação histórica servirá de base para a tentativa de reconstituição da ocupação antiga na zona em estudo, inserida entre a Antiguidade tardia e a Alta Idade Média.
\end{abstract}

Palavras-chave: Santa Comba Dão; Sepulturas rupestres; Ocupação alto-medieval.

Abstract: The present study results from archaeological surveys in the territory of Santa Comba Dão (Viseu), centered on the relation between cave graves and vestiges of ancient settlements, possibly contemporary or with which it may have continuity relations. The joint analysis of archaeological data and historical documents, will then support the attempt to reconstruct the settlements patterns of the area under study, between late Antiquity and the Early Middle Ages.

Keywords: Santa Comba Dão; Rock-cut graves; Early medieval settlements.

\section{CONSIDERAÇÕES INICIAIS}

Na Península Ibérica, para o estudo das sociedades da Alta Idade Média, guiado por campanhas de prospeções arqueológicas e análises espaciais, as sepulturas rupestres são, sem dúvida, os vestígios arqueológicos mais expressivos e, muitas vezes, um dos poucos remanescentes deste período. O seu valor, todavia, é tanto maior quanto maior for a sua vinculação a possíveis núcleos habitacionais e espaços religiosos. A análise morfológica pormenorizada destes monumentos, embora incontornável, por si só, não contribui minimamente para a compreensão da dinâmica e evolução do povoamento medieval, podendo refletir, ocasionalmente, mais uma tendência de

\footnotetext{
* Bolseiro FCT - Universidade de Coimbra (CEAACP). Email: pjmatos27@hotmail.com.

** FLUC/DHEEAA; FLUC/CEAACP. Email: hcatarino@fl.uc.pt.
} 
entalhe local - e talvez resida aqui um dos seus principais valores científicos - do que propriamente um indício de evolução cronológica.

Nas palavras de Mário Barroca, para o estudo das necrópoles rupestres, «torna-se extremamente difícil, enquanto não se realizarem escavações arqueológicas [...] propor qualquer intento de ordenação quer tipológico quer cronológico» ${ }^{1}$, ou seja, principalmente na falta de vestígios ósseos nas sepulturas, a análise estratigráfica acaba por ser o processo mais seguro para a sua periodização e para a construção do seu quadro morfológico evolutivo, conforme bem demonstrado por este autor através das intervenções no convento de Santa Marinha da Costa. A aproximação à evolução morfológica condicionada aos dados de superfície resulta extremamente complexa e, frequentemente, quase impossível.

Ao registar uma sepultura rupestre, tentar identificar manchas de ocupação que, possivelmente, remetam a habitats associados aos monumentos, ou que mantenham com estes uma aparente relação de continuidade, deve ser um exercício imediato do investigador, bem como condição sine qua non à sua metodologia de estudo. Nesta linha, os trabalhos de Marina Afonso Vieira (2004), na zona do Alto Paiva, e de Catarina Tente (2007) e Sandra Lourenço (2007), na Beira Alta, representaram marcos importantes para o estudo do mundo rural na Alta Idade Média. Nos últimos anos, trabalhos como os de Iñaki Martín Viso (2012) e Rubio Díez (2013), no centro oeste peninsular, têm vindo a demonstrar como a observação de um conjunto de quesitos pode conduzir à elaboração de modelos de povoamento antigo a partir das sepulturas rupestres.

Posto isto, tentaremos uma aproximação ao povoamento antigo do território de Santa Comba Dão ${ }^{2}$, no período inserido entre a Antiguidade tardia e a crise do reino de Leão na segunda metade do século $\mathrm{X}$, fundamentalmente, com base na análise espacial conjunta da distribuição de algumas das sepulturas rupestres inventariadas, dos habitats antigos, e das vilas (villas) registadas em documentos do século X. Desta forma, pelo número de amostras utilizadas e pelas dimensões do nosso território, não temos a pretensão de extrapolar as nossas ilações para além da zona do Baixo Dão ${ }^{3}$, e sabemos, também, que essa aproximação consiste num processo abarrotado de questionamentos, mas que, todavia, acabariam por minar qualquer tentativa de enquadramento social e cronológico fossem amiúde analisados ao longo da linha de raciocínio que se segue. Assim, tentaremos ser o mais sucintos possível, com a plena consciência da fragilidade destas ilações, provocada tão-somente por camadas de terra, entre especulações embasadas em vestígios de superfície e a realidade subjacente.

\footnotetext{
${ }^{1}$ BARROCA, 2010-2011: 142-144.

2 Processo n. ${ }^{\circ}$ DRC/ 2017/18 -14/112 / PATA / 8337 (C. S: 158063), submetido pelos signatários, aprovado e em fase de publicação.

${ }^{3}$ Por «Baixo Dão», designa-se, genericamente, o vale do rio Dão a partir da zona de Póvoa do Dão (Viseu), onde passa a correr abaixo dos $200 \mathrm{~m}$ de altitude.
} 


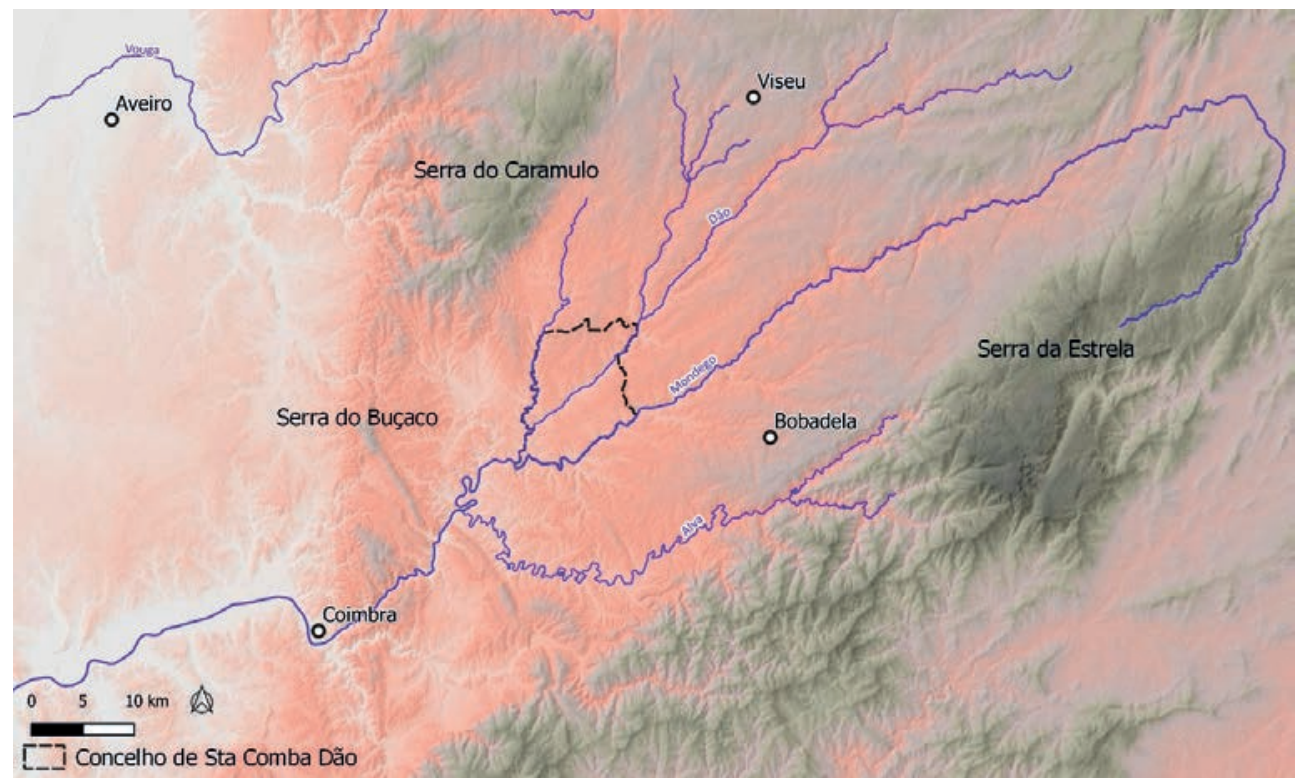

Mapa 1. Localização do concelho de Santa Comba Dão

Fonte: Pedro Matos e Helena Catarino

\section{ENQUADRAMENTO GEOGRÁFICO}

O concelho de Santa Comba Dão, com cerca de $112 \mathrm{~km}^{2}$, está localizado numa zona de planalto (Mapa 1), com uma altimetria que oscila entre $119-314 \mathrm{~m}$, encaixado entre as serras do Caramulo e Buçaco a oeste, e da Estrela e Lousã, a leste e sudeste. É banhado por três linhas hidrográficas principais, designadamente os rios Criz, Dão e Mondego. Este último, em termos de limites administrativos, marca a fronteira sul do concelho e do distrito de Viseu, pertencendo a sua margem esquerda ao distrito de Coimbra. O Criz, vindo da serra do Caramulo, delimita a extrema poente, e o Dão, vindo de Aguiar da Beira (Guarda), depois de percorrer cerca de $90 \mathrm{~km}$, trespassa o concelho de Santa Comba Dão até desaguar no Mondego, ainda em território concelhio.

No tocante à geomorfologia, Santa Comba Dão encontra-se sobre o Maciço Antigo $^{4}$, na zona de contacto da grande plataforma granítica que domina quase integralmente o quadro geológico da Beira Alta, com as formações xistosas encaixadas entre o granito e as bacias sedimentares terciário-quaternárias da orla ocidental ${ }^{5}$.

\footnotetext{
${ }^{4}$ Formação de Rochas eruptivas e metamórficas que cobre cerca de sete décimos de Portugal continental (BRITO, 1997: 29).

5 BRITO, 1997: 30.
} 


\section{BREVE ENQUADRAMENTO HISTÓRICO}

Em época romana, o território de Santa Comba Dão faria parte da civitas de Bobadela (Oliveira do Hospital), certamente localizado numa zona periférica em relação à capital, bem como a Vissaium (Viseu), a norte, e Aeminium (Coimbra), a sul. Durante o domínio visigodo, sendo Viseo sede episcopal, a zona em estudo teria sido integrada na sua comarca ${ }^{6}$. Com a invasão muçulmana, aqui, chefiada por Muça b. Nuçair, esta zona passou a estar na região da Marca Inferior, onde Mérida era a cidade mais importante e, posteriormente, Badajoz ${ }^{7}$.

O domínio muçulmano sobre as antigas comunidades romano-visigodas da Beira Alta deve ter ocorrido em contornos relativamente pacíficos. Não dispunha o invasor de contingentes suficientes nem para efetivar a conquista de vastos territórios, nem para administrar as terras que lhes eram vinculadas ${ }^{8}$, pelo que, frequentemente, recorriam a pactos de capitulação para submeter pacificamente as comunidades autóctones. Desta forma, teriam capitulado, entre outros, os centros episcopais de Coimbra ${ }^{9} \mathrm{eViseu}^{10}$, e nas palavras de Helena Catarino, «se as cidades pactuaram com o invasor, mais facilmente a população autóctone dos meios rurais aí permaneceu, numa certa autonomia, arabizando-se culturalmente, mas mantendo-se cristã» ${ }^{11}$.

A reorganização administrativa de Afonso III das Astúrias colocou a zona do Baixo Dão na circunscrição do condado de Coimbra. Este território foi então palco de pouca - ou talvez nenhuma - algazarra militar face à alvoroçada trama política que grassou principalmente durante a crise da segunda metade do século $\mathrm{X}^{12}$, que corresponde a uma das balizas cronológicas do presente estudo.

Em $878^{13}$ começa, com Hermenegildo Guterres, a linhagem dos condes de Coimbra, representantes da autoridade régia a sul do Douro. Na primeira metade do século $\mathrm{X}$, esta zona assume, brevemente, um protagonismo no reino de Leão consoante a transferência da sua capital para Viseu, durante parte dos reinados de Ordonho II (914-924) e Ramiro II (931-951), o que, de acordo com Maria Teresa Veloso, teria «impulsionado um fomento agrário no vale do Dão» ${ }^{14}$, embora o verdadeiro impacto deste processo seja hoje bastante questionável. Coincidiu, todavia, com um período de clima quente e seco que grassou na Europa entre o século VIII e a segunda metade do século XII, proporcionando um crescimento económico essencialmente agrícola ${ }^{15}$,

\footnotetext{
${ }^{6}$ TENTE, DE MAN, 2016: 385.

${ }^{7}$ CATARINO, 2005: 195.

${ }^{8}$ FERNANDES, 2016: 49.

${ }^{9}$ REAL, 2014: 23.

${ }^{10}$ CATARINO, 2005: 200.

${ }^{11}$ CATARINO, 2005: 196.

${ }^{12}$ Para a crise da monarquia de Leão, consultar, entre outros: MATTOSO, 1997: 474-477.

${ }^{13}$ AZEVEDO, 1933: 20; MATTOSO, 1987: 117.

${ }^{14}$ VELOSO, 2008-2009: 156.

${ }^{15}$ DUBY, 1993: 20-23.
} 
ou seja, conforme referiu Pérez Marinas, coincidiu com o início do Período Quente Medieval, que esteve relacionado com a prosperidade das comunidades aldeãs entre o Douro e o Sistema Central ${ }^{16}$.

José Mattoso, por sua vez, referiu o "duplo movimento colonizador» ${ }^{17}$ caracterizado pela confluência de colonos vindos do norte e do sul para o atual Centro e Norte de Portugal, a partir das conquistas de Afonso III. A zona do Baixo Dão, em meados do século $X$, portanto, não poderia ter deixado de sentir os efeitos deste incremento agrário e populacional da região Beirã, ou seja, teria assistido então ao início do delineamento de uma organização política local que não seria alheia a uma hierarquia paroquial incipiente, momento em que o culto a Santa Columba poderia ter penetrado nestas paragens.

\section{ELEMENTOS PARA A ANÁLISE DO POVOAMENTO ANTIGO}

Conforme afirmado mais acima, na tentativa de vislumbrar os contornos do povoamento antigo da nossa zona, procurámos estabelecer a relação entre o registo arqueológico e a documentação histórica. O primeiro, corresponde às sepulturas rupestres e manchas de ocupação que indiciam a presença de assentamentos enquadrados entre o período romano e a época medieval. Já do segundo, extraímos a informação toponímica por meio da qual tentámos perceber, até que ponto, as villas e lugares registados na segunda metade do século $\mathrm{X}$ podem estar direta ou indiretamente relacionados com o registo arqueológico de superfície.

\subsection{As fontes históricas e a toponímia alto-medieval}

A documentação histórica mais antiga do território de Santa Comba Dão, corresponde a três cartas de doação, por meio das quais foram entregues ao mosteiro de Lorvão, no intervalo de onze anos, por iniciativa da família condal de Coimbra, villas e povoações hoje integradas nos limites administrativos do nosso estudo. Nestes diplomas encontram-se já registadas oito povoações atuais - uma delas, a própria villa de Sancta Columba (atual Couto do Mosteiro) - que correspondem à quase totalidade dos topónimos elencados nos documentos.

É do ano de 974 o registo ${ }^{18}$ mais antigo de Santa Comba Dão, realizado por ocasião da doação do conde Oveco Garcia de parte da sua villa de Sancta Columba ao mosteiro de Lorvão. Sete anos depois foi a vez do seu sogro, o conde Gonçalo Moniz, de beneficiar o cenóbio lorvanense com a doação da villa e mosteiro de Traxede (Treixedo) entre outras propriedades ${ }^{19}$. Foi este um dos magnatas mais poderosos do

\footnotetext{
16 PÉREZ MARINAS, 2016: 161.

${ }^{17}$ MATTOSO, 1997: 406.

${ }^{18}$ LP, Doc. n. ${ }^{\circ} 2$ (924, julho, 22).

${ }^{19} \mathrm{PMH}, \mathrm{DC}$, Doc. CXXX (981).
} 


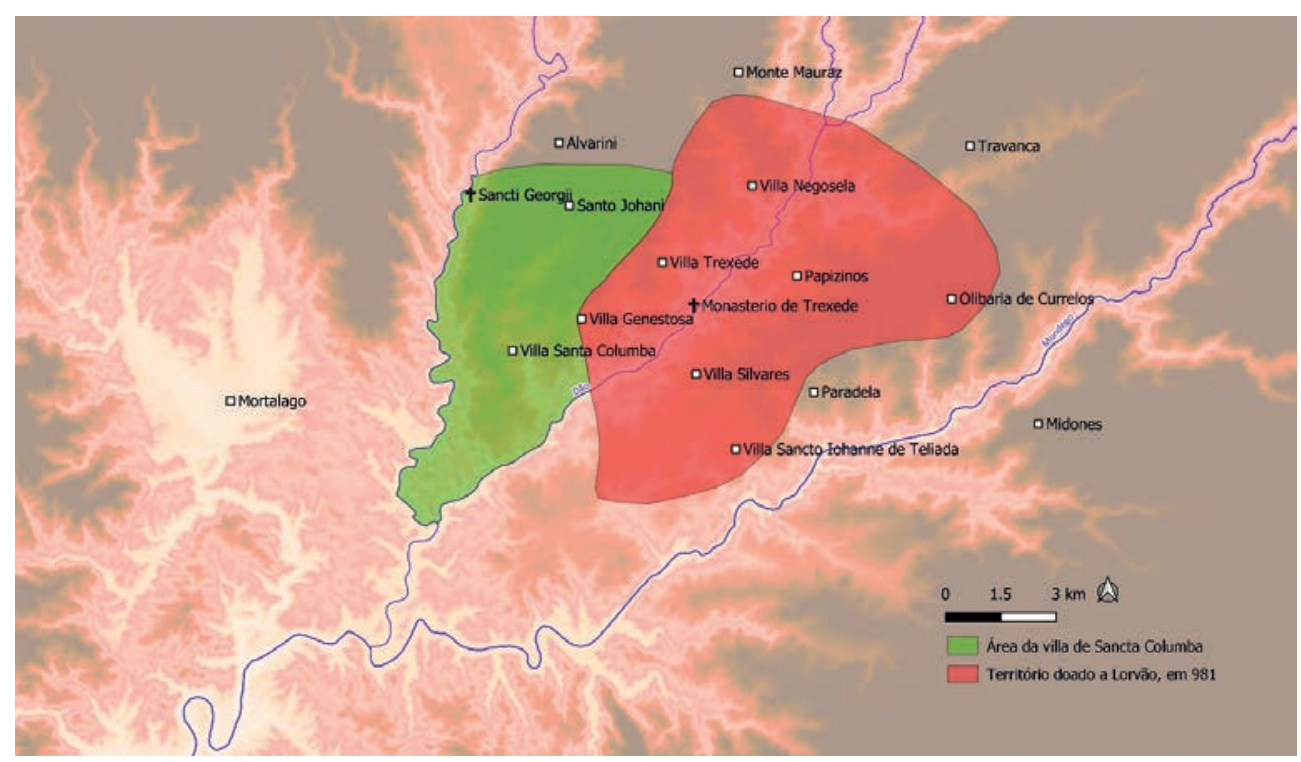

Mapa 2. Povoamento do Baixo Dão na segunda metade do século $X$

Fonte: Pedro Matos e Helena Catarino

reino de Leão, engajou-se na crise do século $\mathrm{X}$ tomando parte ativa contra o rei ${ }^{20}$, sendo mesmo responsável pelo assassinato de Sancho I o Gordo, em $965^{21}$. Por último, em $985^{22}$, Mónio Gonçalves - filho de Gonçalo Moniz — entregou àquela abadia a sua metade da villa de Sancta Columba, já que a outra fora doada onze anos antes.

A invulgar sobrevivência da toponímia alto-medieval de Santa Comba Dão reflete a antiguidade dos seus lugares, e representa, para o nosso estudo, não apenas um trunfo para a compreensão da paisagem humana do Baixo Dão no século X, como também, para a aproximação aos contornos das antigas villas, dada a detalhada descrição dos seus limites, o que inclusive nos permitiu, tanto quanto possível, a reconstrução do quadro administrativo local (Mapa 2).

Para maximizar o potencial informativo dos diplomas acima referidos, ao longo do nosso estudo, optámos por abordá-los em duas escalas de análise; uma supraterritorial, ou seja, fora dos limites espaciais do território estudado, com o objetivo de compreender o ambiente sociopolítico que ocupava em período asturo-leonês, e outra, local, portanto, dentro dos limites atuais do concelho de Santa Comba Dão, centrada fundamentalmente na toponímia e na sua distribuição espacial, para: delimitação de extremas de propriedade (limite das villas); provável localização de igrejas

\footnotetext{
${ }^{20}$ MATTOSO, 1997: 446.

${ }^{21}$ MATTOSO, 1987: 124.

${ }^{22}$ LP, Doc. n. ${ }^{\circ} 1$ (985, julho, 22).
} 
e mosteiros; traçar possíveis caminhos antigos. Para o presente estudo, interessa-nos, portanto, a segunda escala de análise.

\subsection{Sepulturas rupestres e habitats}

Estão atualmente identificadas 34 sepulturas rupestres no concelho de Santa Comba Dão, das quais 18 encontram-se distribuídas por 3 necrópoles, 7 por grupos de $2 / 3$ e 9 são monumentos isolados.

A distribuição das sepulturas pelo território concelhio resulta bastante desigual, com apenas 4 monumentos a norte do Dão face aos 30 registados no interflúvio Dão-Mondego, aqui, especialmente na zona leste, implantados na freguesia de São João de Areias. Esta realidade pode dever-se mais ao facto de ter sido a margem sul do Dão a mais estudada ao longo dos últimos 20 anos, do que necessariamente à verdadeira escassez destes monumentos a norte do rio. Todavia, pelo que pudemos perceber ao bater os terrenos desta zona, dificilmente haverá aqui uma quantidade de sepulturas tão expressiva quanto no lado oposto, pelo menos no que se refere aos monumentos isolados ou inseridos em pequenos grupos. Quanto à possível existência de uma necrópole, julgamos que, provavelmente, futuras intervenções arqueológicas

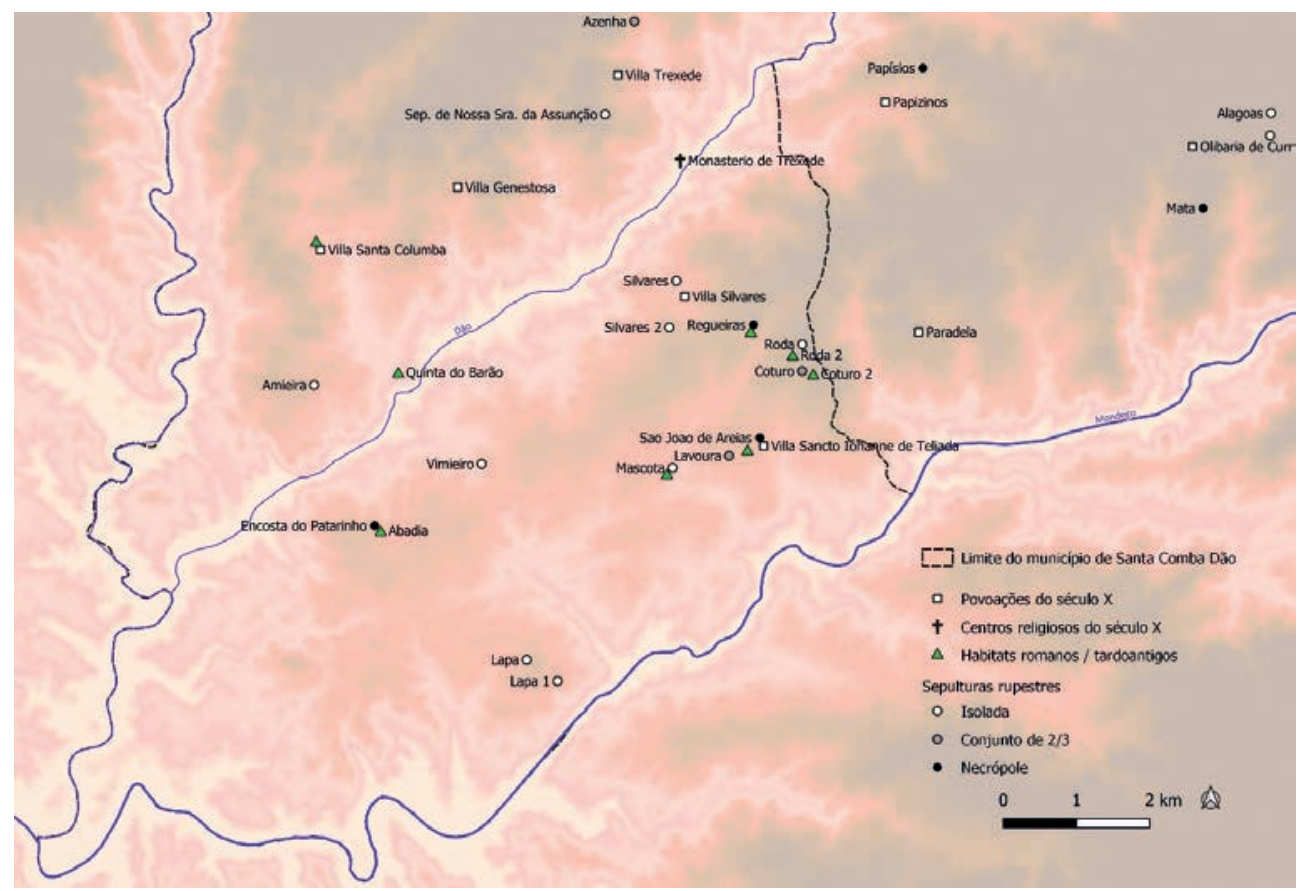

Mapa 3. Topónimos e vestígios arqueológicos

Fonte: Pedro Matos e Helena Catarino 
na igreja de Santa Columba (Igreja Matriz do Couto do Mosteiro) deverão por a descoberto um representativo número de sepulturas associadas ao templo e núcleo aldeão que esteve na origem da villa de Sancta Columba registada no século X. Esta temática, contudo, deverá ser abordada noutro momento.

Centraremos agora a nossa atenção em dois locais do concelho, ambos situados entre o Dão e o Mondego, onde resulta mais evidente as relações entre a toponímia medieval, os habitats antigos e as sepulturas rupestres (Mapa 3). A poente, a zona da villa romana da Abadia; a nascente, a zona de São João de Areias, onde um conjunto de sítios estão implantados nas proximidades dos ribeiros de Silvares, Vila Dianteira e São João de Areias.

\subsubsection{A villa da Abadia e a encosta do Patarinho}

Em terrenos localizados entre as povoações de Óvoa e Cagido, encontra-se um habitat caracterizado por uma mancha de ocupação com materiais de construção de tradição romana e fragmentos de cerâmica comum, dispersos por uma área com cerca de 5 ha (Mapa 4). No seu lado poente, na designada Encosta do Patarinho, está implantado um conjunto de cinco sepulturas rupestres, distribuídas por três núcleos funerários.

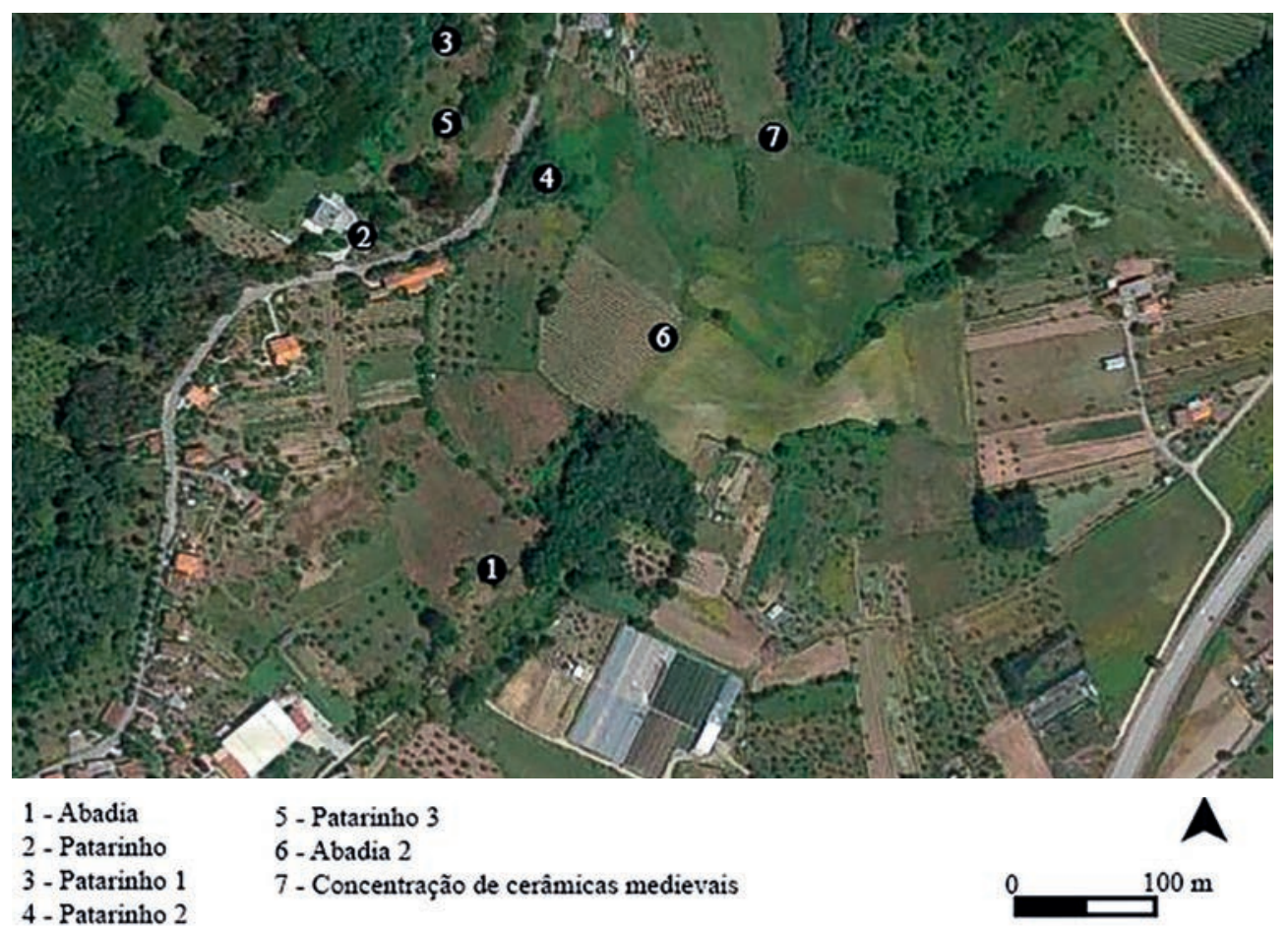

Mapa 4. Villa da Abadia (fotografia aérea obtida no Google Earth)

Fonte: Pedro Matos e Helena Catarino 


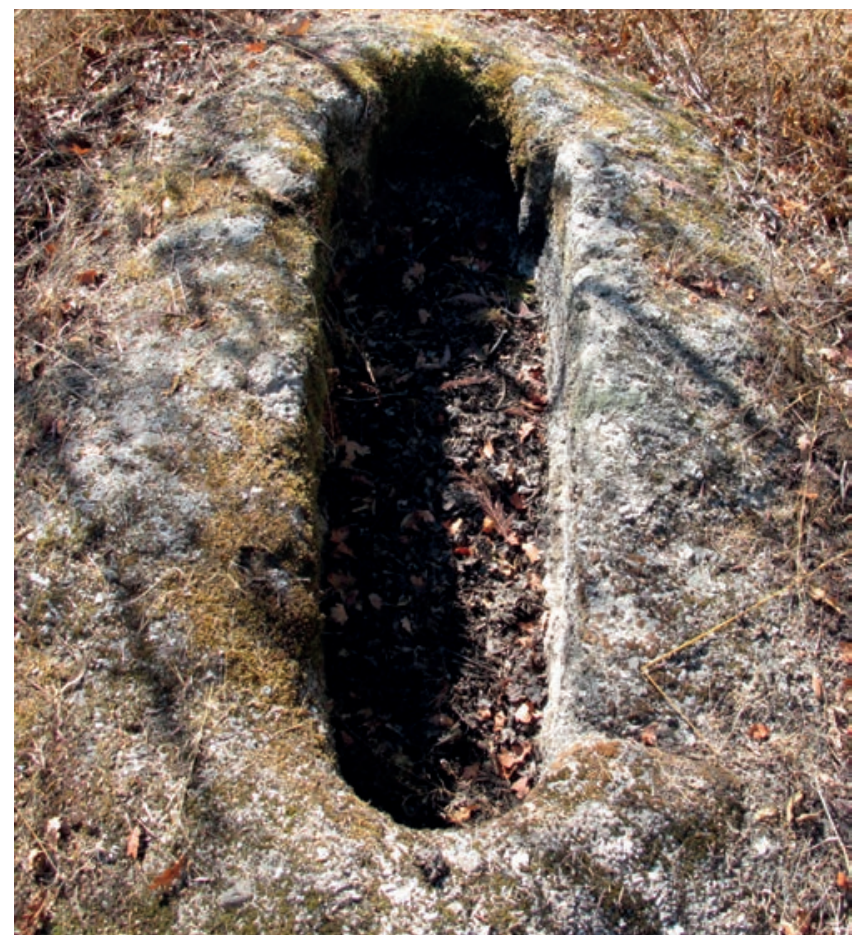

Fig. 1.

Patarinho 1

Fonte: Pedro Matos

Antigas escavações realizadas nos extremos oeste e sul deste habitat indiciam a existência de uma villa romana, encabeçada por uma domus que deveria estar no sítio de Abadia, onde foram registados fragmentos de canalização em chumbo associados a cerâmicas de época imperial, a pouco mais de $300 \mathrm{~m}$ para sul da encosta do Patarinho. Aqui, em escavações no sítio do Patarinho 3, a cerca de $110 \mathrm{~m}$ para norte do grupo das 3 sepulturas do Patarinho, e $50 \mathrm{~m}$ a sul da sepultura do Patarinho 1 (Fig. 1), foi identificado parte de um compartimento de planta retangular, e exumado um espólio que atesta uma ocupação inserida, possivelmente, entre o período pré-romano e a Alta Idade Média, intercalada, ou não, por momentos de abandono.

O momento entre a ocupação pós-romana e a conversão da encosta do Patarinho em espaço sepulcral, em inícios da Alta Idade Média, possivelmente, está representado por um conjunto de cerâmicas alaranjadas com decoração incisa (Fig. 2), um fragmento de sigillata hispânica tardia (Fig. 3), um bordo de cerâmica calcítica (Fig. 4) originária da zona de Conimbriga, e, talvez, alguns fragmentos de cerâmicas alaranjadas finas (Fig. 5). Esperamos que, num futuro próximo, este espólio venha a ser apresentado em toda a sua extensão, pois através da análise que iniciámos foi 


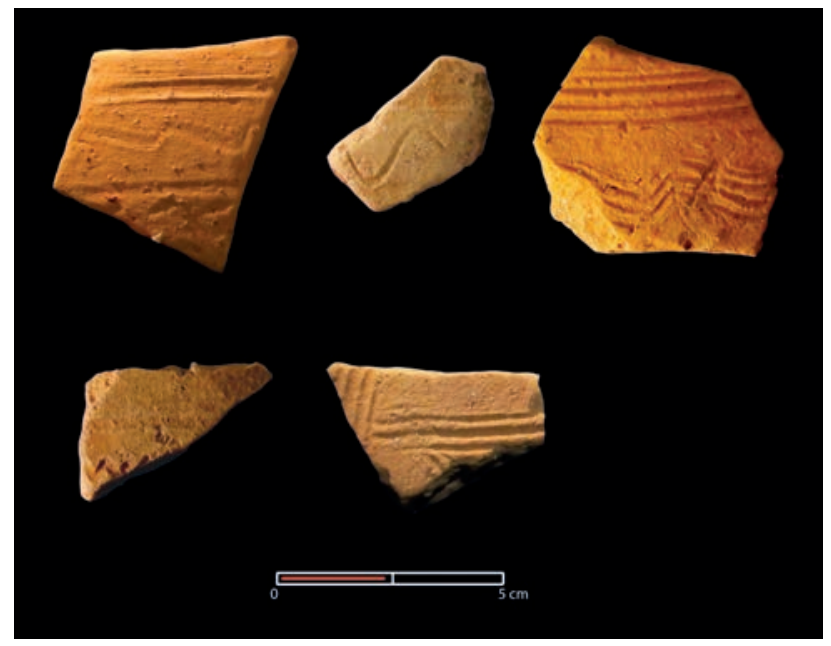

Fig. 2. Cerâmicas com decoração incisa (Patarinho 3) Fonte: Pedro Matos

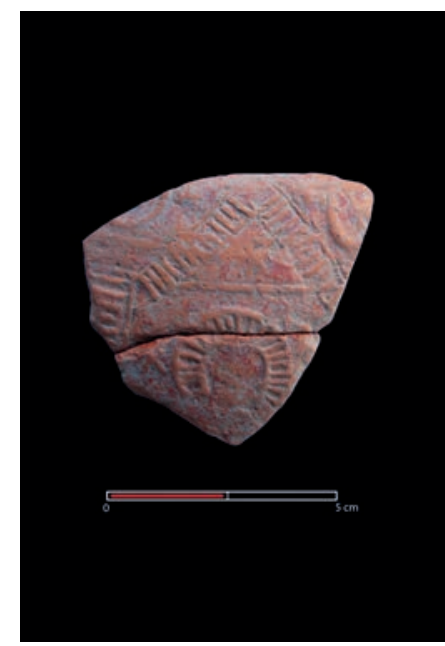

Fig. 3. fragmento de TSHT decorado (Patarinho 3)

Fonte: Pedro Matos

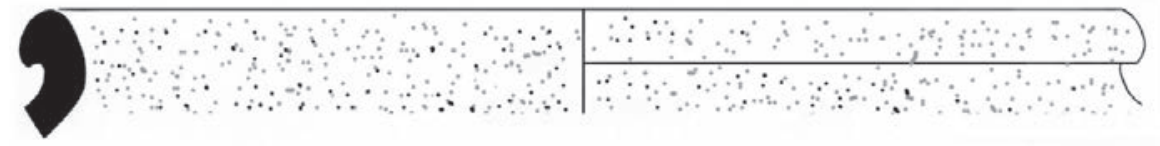

Fig. 4. Cerâmica calcítica (Patarinho 3) Fonte: Pedro Matos
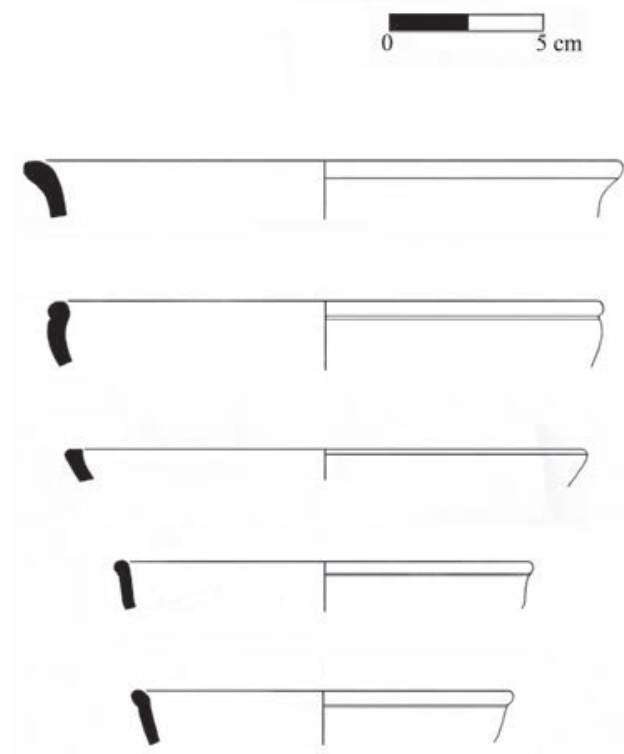

Fig. 5.

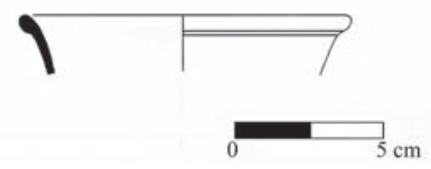

cerâmicas alaranjadas finas (Patarinho 3)

Fonte: Pedro Matos 
possível descortinar a evolução da ocupação de, pelo menos, uma pequena parcela dessa grande villa romana ${ }^{23}$.

Ainda distantes de compreender, por completo, os detalhes da ocupação deste assentamento, com base na informação atual, julgamos seguro propor que a encosta do Patarinho permaneceu como espaço de habitação em época pós-romana, pelo menos até à sua conversão em cemitério medieval, onde estariam no mínimo 7 monumentos, dos quais até há pouco tempo restavam $5^{24}$, mas que somam hoje apenas quatro. Respeitante aos núcleos habitacionais associados às sepulturas rupestres, admitimos que deveriam estar localizados nos terrenos registados como Abadia 2, onde a dispersão de cerâmicas de construção de tradição romana dever-se-á, talvez, ao reaproveitamento destes materiais a partir de inícios da Alta Idade Média.

\subsubsection{São João de Areias}

Seguindo para nordeste, na zona dos ribeiros de Silvares, Vila Dianteira e São João de Areias estão localizados dois conjuntos de habitats e núcleos funerários.

O primeiro, a norte, encontra-se entre as povoações de Castelejo e Vila Dianteira, e integra: duas sepulturas isoladas em Silvares (Silvares e Silvares 2); a necrópole das Regueiras (Fig. 6), com 6 sepulturas na zona de Casas Novas; e em Vila Dianteira,

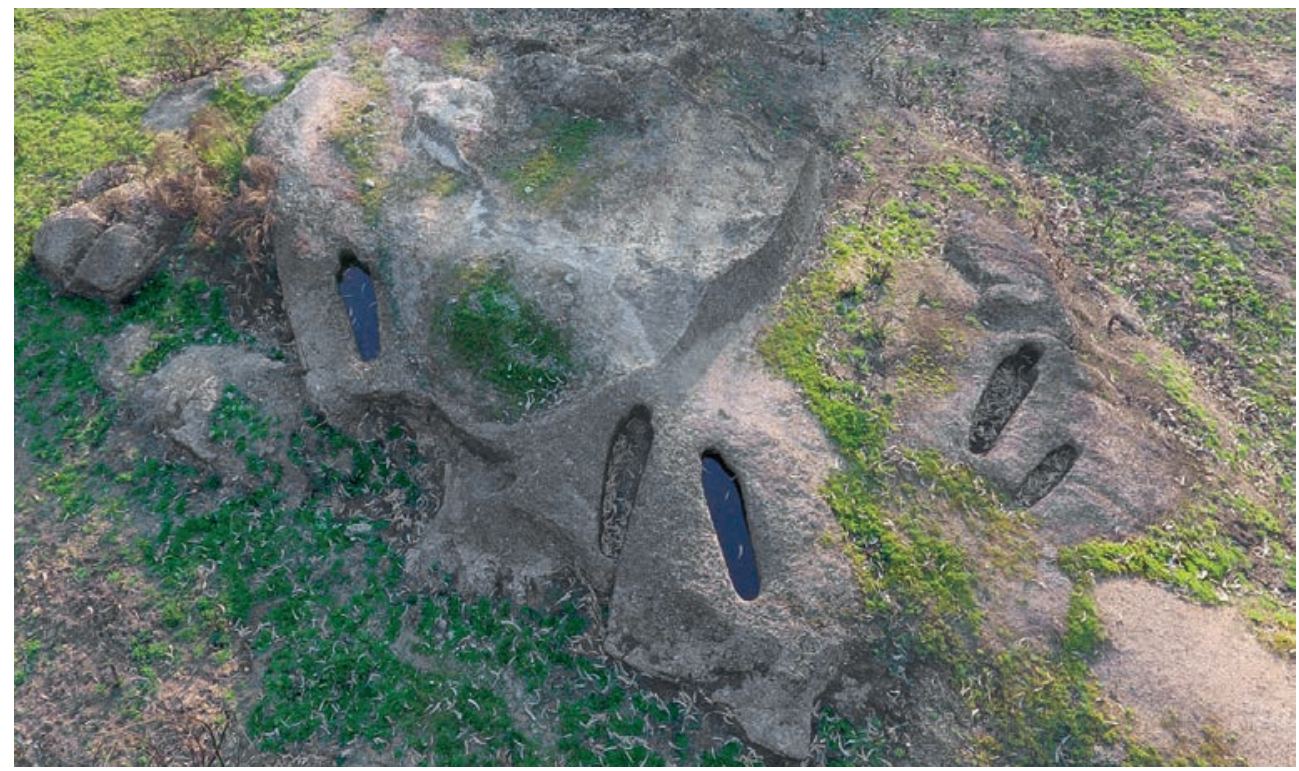

Fig. 6. Necrópole das Regueiras

Fonte: Pedro Matos

${ }^{23} \mathrm{O}$ estudo deste espólio foi realizado no âmbito da dissertação de mestrado do primeiro signatário, atualmente, em fase de publicação.

${ }^{24}$ LOURENÇO, 2007: 35. 


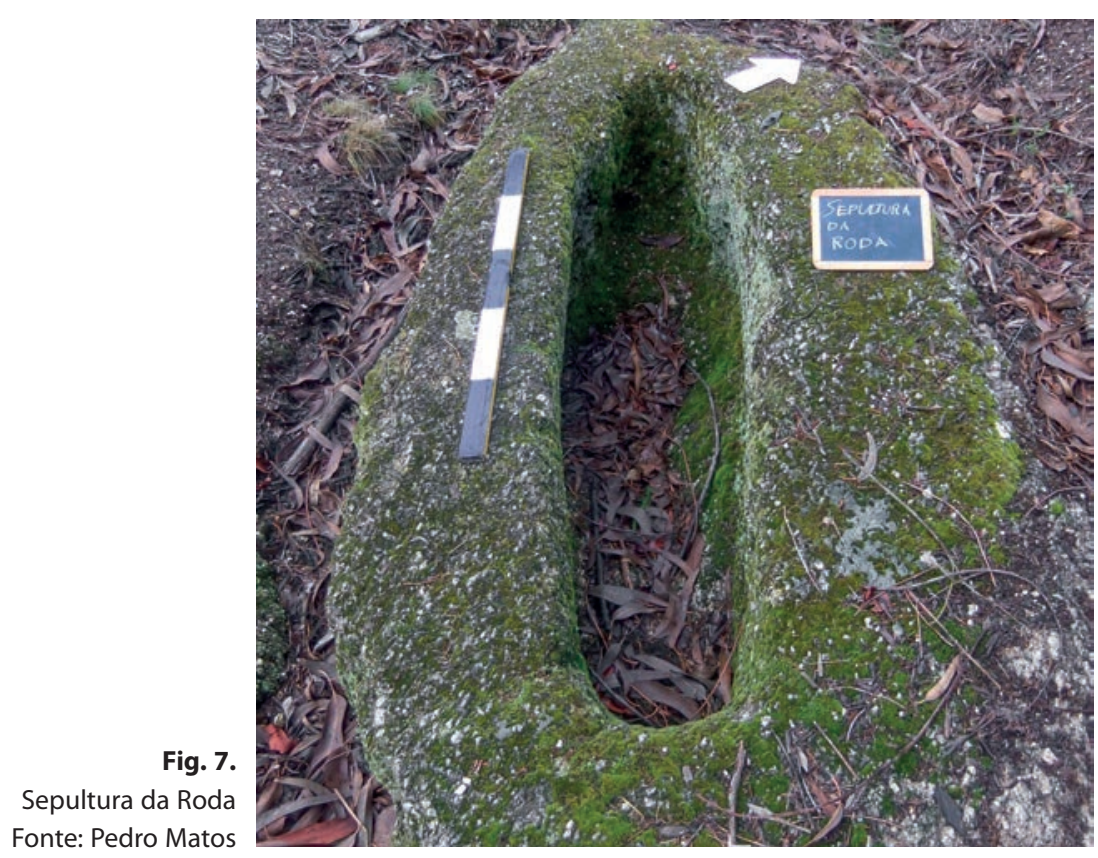

a sepultura da Roda (Fig. 7) e o conjunto das 2 sepulturas do Coturo. Os habitats foram registados: ao redor da necrópole das Regueiras ${ }^{25}$, numa área com cerca de $10000 \mathrm{~m}^{2}$; na mancha de ocupação da Roda 2, a cerca de $350 \mathrm{~m}$ da sepultura de Roda, com uma área entre 100 e $150 \mathrm{~m}^{2}$; e na zona das sepulturas do Coturo, na mancha registada como Coturo 2, que abrange duas áreas com dispersão de materiais ${ }^{26}$ separadas por menos de $200 \mathrm{~m}$, uma com $5000 \mathrm{~m}^{2}$, e a outra com $2000 \mathrm{~m}^{2}$. Até ao momento, não foram identificados materiais arqueológicos na zona das sepulturas de Silvares.

Nas Regueiras, a presença de cerâmica tardo-antiga foi já detetada por Sandra Lourenço, com destaque para um exemplar estampilhado com uma palmeta, motivo que a autora remeteu a imitação da sigillata paleocristã ${ }^{27}$.

Na Roda 2, António Neves recolheu o bojo de um recipiente de armazenamento (Fig. 8), de cozedura oxidante, com um cordão plástico largo e decoração incisa de pouca profundidade, que combina pequenas incisões horizontais, motivos ondulados e meandros em ziguezague, realizados a pente, portanto, enquadrados no tipo B de decoração incisa de Gutiérrez Lloret ${ }^{28}$. Mas, assim como nos materiais do Patarinho

\footnotetext{
25 NEVES, 2014: 18.

${ }^{26}$ NEVES, 2014: 10-12.

${ }^{27}$ LOURENÇO, 2007: 57.

${ }^{28}$ GUTIÉRREZ LLORET, 1996: 156.
} 


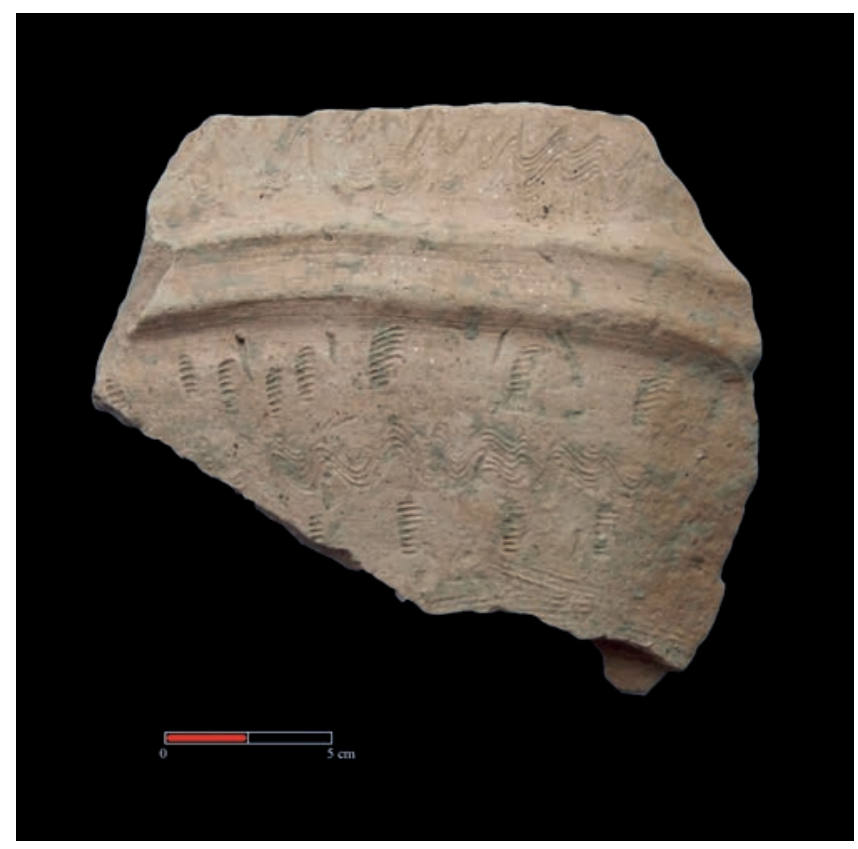

Fig. 8.

Bojo de cerâmica alaranjada com decoração incisa (Roda 2)

Fonte: Pedro Matos

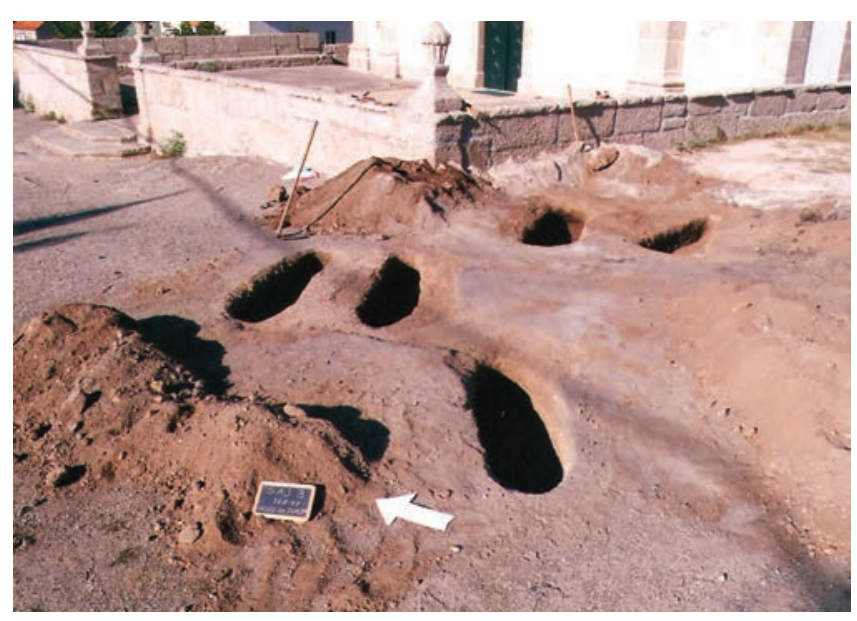

Fig. 9.

Necrópole de São João de Areias

Fonte: Arquivo fotográfico de António Nunes da Costa Neves

3, também na Roda 2 não se pode afirmar com segurança se os exemplares decorados por incisão estariam enquadrados em contextos de ocupação pós-romana ou já associados às sepulturas rupestres, pelo que julgamos correto admitir tratar-se de artefactos balizados entre a Antiguidade tardia e os inícios da Alta Idade Média.

No Coturo 2, os rebordos de tegullae, ímbrices, fragmentos de dolia e de cerâmicas utilitárias, algumas de cozedura oxidante destinadas a serviços de mesa finos, indiciam uma ocupação possivelmente enquadrada entre a época romana e tardo-an- 
tiga. Destacamos aqui o bordo de um dolium de cozedura redutora, que se assemelha aos dolia tardo-antigos registados na zona do Baixo Sabor ${ }^{29}$.

O segundo grupo de estações arqueológicas, mais a sul, na zona de São João de Areias, é formado pela necrópole homónima (Fig. 9), com no mínimo 7 monumentos junto ao adro da igreja matriz; pelo conjunto das três sepulturas da Lavoura; pela sepultura da Quinta do Mascote. Nessa zona, uma das manchas de ocupação localiza-se num terreno entre a necrópole de S. João de Areias e as sepulturas da Lavoura, onde foram identificadas cerâmicas de construção e silhares aparelhados reaproveitados em muros, por uma área com cerca de 1,5 ha; a outra, encontra-se ao redor da sepultura do Mascote, onde voltaram a aparecer fragmento de cerâmica utilitária com decoração incisa ${ }^{30}$, por uma área não superior a $3000 \mathrm{~m}^{2}$.

\section{DINÂMICAS DE POVOAMENTO}

Apresentados os dados arqueológicos e, sumariamente, a documentação histórica, resta agora analisá-los em conjunto na tentativa de decifrar as prováveis relações.

$\mathrm{Na}$ zona dos sítios à nascente havia, na segunda metade do século $\mathrm{X}$, duas villas: Silvares (Silvares) e Sancto Iohanne de Teliada (São João de Areias). A primeira é, na zona em estudo, o único caso em que o topónimo sobreviveu ao povoado, portanto, um exemplo daquilo que Michael Aston definiu como uma «vila desertificada» 31 . A villa de Silvares, contudo, não deveria estar afastada do vale de um pequeno ribeiro que separa as duas sepulturas de Silvares e Silvares 2. Nesta zona não foram ainda identificados quaisquer vestígios materiais e é provável que, em momento incerto, os habitantes de Silvares se tenham deslocado para a aldeia de Castelejo, no cimo de um morro a norte do vale, com melhores condições de defesa e onde deveria existir alguma estrutura amuralhada.

Na zona da villa de Sancto Iohanne de Teliada, por outro lado, os vestígios identificados remetem a uma ocupação diacrónica, provavelmente desde a época romana, o que nos coloca outro problema, concretamente, como explicar a sua evolução face ao abandono dos assentamentos associados às sepulturas de Casas Novas (Necrópole das Regueiras) e Vila Dianteira? Porque foi construída uma igreja sobre a necrópole de São João de Areias e não sobre a das Regueiras? E ainda, como justificar que esta zona e a de Vila Dianteira, onde estão ao todo nove sepulturas rupestres, para além dos habitats já referidos, tenha ficado marginalizada em relação às villas de Silvares e Sancto Iohanne de Teliada, sendo que na primeira, os vestígios mais antigos resumem-se a duas sepulturas isoladas?

\footnotetext{
${ }^{29}$ BAÉZ et al., 2014: 905.

30 NEVES, 2014: 17.

${ }^{31}$ ASTON, 1985: 53-61 (livre tradução dos autores).
} 
Conforme observou Sánchez Pardo, teria ocorrido, a partir do século IX, uma paulatina mudança no caráter fundacional das igrejas rurais, que passaram a ser, «cada vez mas, un fenomeno controlado por las jerarquias eclesiasticas y dirigido al encuadramiento de las comunidades en la organizacion de la Iglesia» ${ }^{32}$, fenómeno este que culminou na progressiva definição do território de cada igreja ${ }^{33}$. De volta à nossa zona, a hipótese a considerar seria de que, entre a conquista asturo-leonesa, em finais do século IX, e a crise do reino de Leão, na segunda metade do século X, uma reformulação e incremento no povoamento teria acompanhado a organização do quadro paroquial, que, por sua vez, agora em caráter generalista, teria sido «contemporâneo do estabelecimento da aldeia como marco social e modelo de fixação dos homens» ${ }^{34}$, processo que teria culminado no surgimento das villas e, de acordo com Martín Viso ${ }^{35}$, acabaria por marcar também o final do período de utilização das sepulturas rupestres.

A implantação do templo — «centro paroquial» — sobre a necrópole de São João de Areias teria levado, portanto, à consolidação do núcleo aldeão associado às sepulturas desta zona e, possivelmente, provocado o deslocamento dos grupos familiares a norte de Vila Dianteira para a villa de Sancto Johanne de Teliada ou, em menor escala, para junto dos assentamentos associados às sepulturas de Silvares e Silvares 2 , onde viria a surgir a villa homónima, hoje desaparecida. Por explicar permanece, por enquanto, a preferência por São João de Areias; talvez houvesse aqui uma maior coesão social, ou já então, conforme em outros locais, «um oratório isolado na orla do avanço arroteador» ${ }^{36}$, ou uma capela junto à necrópole rupestre ${ }^{37}$, sobre a qual fora erigido o templo paroquial, ou talvez, ainda, o povoado estivesse em local privilegiado, junto a uma antiga via romana bem como nas proximidades de um ponto de travessia do Mondego.

Assim como no sítio das Regueiras, a ocupação associada às sepulturas da encosta do Patarinho não evoluiu para villa no século X, pelo contrário, encontra-se completamente apartada dos lugares mencionados nas cartas de doação, não sendo possível, aqui, o estabelecimento de qualquer ligação com o registo histórico alto-medieval. Com efeito, o quadrante sudoeste do concelho começa a figurar na documentação medieval apenas a partir do século XII ${ }^{38}$.

\footnotetext{
32 SÁNCHEZ PARDO, 2010: 158.

33 SÁNCHEZ PARDO, 2010: 160.

${ }^{34}$ JORGE, 2000: 141.

35 MARTÍN VISO, 2005-2006: 86

${ }^{36}$ GARCÍA DE CORTAZAR, RUIZ DE AGUIRRE, 1983: 134.

${ }^{37}$ Conforme afirmou Ana Jorge, muitas paróquias teriam surgido «a partir de igrejas monásticas, e mesmo de igrejas fundadas por agrupamentos de camponeses» (JORGE, 2000: 140).

${ }^{38}$ MORAIS, 2013: 22-24.
} 


\section{CONCLUSÃO}

Diminuindo agora a escala de análise, de forma a lançar um olhar mais amplo sobre o território santacombadense, percebemos que, aqui, a relação espacial entre os núcleos de sepulturas rupestres e a toponímia alto-medieval não remete a uma ligação direta entre os habitats possivelmente associados àqueles monumentos, e os lugares registados no século X, exceto nas zonas das sepulturas de Silvares e São João de Areias, e com marcadas reservas, em Treixedo, onde conjuntos de núcleos habitacionais, ou mais precisamente, aldeias tardo-antigas ou alto-medievais (séculos V-IX/X) teriam evoluído para villas em período asturo-leonês. Dos sete núcleos funerários implantados em zonas com assentamentos antigos, apenas na encosta do Patarinho foi possível perceber os contornos dessa evolução. Aqui, houve claramente, em inícios da Alta Idade Média, uma conversão em espaço funerário de uma zona que, até a Antiguidade tardia, servira de vivenda.

Ficou mais evidente a relação de continuidade entre grupos humanos associados às sepulturas rupestres e a anterior ocupação pós-romana. Arriscando-nos agora numa aproximação cronológica, a ser futuramente confirmada ou infirmada, sugere-se, em Santa Comba Dão, a possível associação destes monumentos funerários com o período de colapso do reino visigodo cujas características foram bem definidas por Martín Viso (2016), portanto, um momento de grande isolamento administrativo e religioso dessas comunidades rurais em relação às sedes de bispado, bem como da progressiva autossuficiência dos núcleos de povoamento, no seio dos quais a pastorícia teria ganho preponderância face à agricultura, e onde as sepulturas rupestres poderiam estar vinculadas «a la reclamación de derechos de pasto por parte de ciertas comunidades» ${ }^{39}$.

A reorganização administrativa que teria ocorrido a partir dos meados do século $\mathrm{X}$, conforme já afirmado, provavelmente provocou o reagrupamento - norteado pelo estabelecimento do quadro paroquial - dos casais e aldeias de época visigoda e emiral, de forma a desenhar as bases da organização do povoamento que, em linhas gerais, se mantêm até hoje.

\section{FONTES}

PMH, DC: Portugaliae Monumenta Historica: a saecvlo octavo post Christvm vsque adqvintvmdecimvm. Diplomata et chartae. Lisboa: Academia das Ciências de Lisboa, vol. 1, pp. 1867-1873.

\section{BIBLIOGRAFIA}

ASTON, Michael (1985). Interpreting the Landscape: Landscape Archaeology in Local Studies. Londres: B.T. Batsford.

\footnotetext{
${ }^{39}$ MARTÍN VISO, 2016: 21.
} 
AZEVEDO, Ruy de. (1933). O Mosteiro de Lorvão na reconquista cristã. Sep. «Arquivo Histórico de Portugal». Lisboa.

BÁEZ, Beatriz et al. (2014). Recipientes de armazenamento no vale do Baixo Sabor (Portugal), da época romana à antiguidade tardia. Ensaio cronotipológico. In JÁRREGA, R; BERNI, P., coord. Amphorae ex Hispania: paisajes de producción y consumo. Monografías «Ex Officina Hispania». III, 898-917.

BARROCA, Mário (2010-2011). Sepulturas escavadas na rocha de Entre-Douro-e-Minho. «Portvgalia». Nova Série. 31-32, 115-182.

BRANQUINHO, José Morais (1984). Quatro freguesias do concelho de Santa Comba Dão - Subsídios para o seu levantamento arqueológico (Santa Comba Dão, Couto do Mosteiro, S. Joaninho e Treixedo). Coimbra: Faculdade de Letras da Universidade de Coimbra. Trabalho curricular n. ${ }^{\circ} 69$.

BRITO, Raquel (1997). Introdução Geográfica. In MATTOSO, José, dir. História de Portugal. Lisboa: Editorial Estampa, vol. 1, pp. 29-78. Vol. 1: Antes de Portugal.

BUGALHÃO, Jacinta; FOLGADO, Deolinda (2001). O arrabalde ocidental da Lisboa islâmica: urbanismo e produção oleira. «Arqueologia Medieval». 7, 111-146.

CAMPOS, Maria do Céu (1984). Levantamento arqueológico do concelho de Santa Comba Dão. Coimbra: Faculdade de Letras da Universidade de Coimbra. Trabalho curricular n. ${ }^{\circ} 70$.

CATARINO, Helena (2005). Notas sobre o período islâmico na Marca Inferior (Tagr al-Gharbí) e as escavações na Universidade de Coimbra. In BARROCA, Mário Jorge; FERNANDES, Isabel Cristina F., coord. Muçulmanos e Cristãos entre o Tejo e o Douro (Sécs VIII a XIII). Palmela/Porto: Câmara Municipal de Palmela/ Faculdade de Letras da Universidade do Porto, pp. 195-214.

DUBY, Georges (1993). Guerreiros e Camponeses. Os Primórdios do Crescimento Económico Europeu, séc VII - XII. Lisboa: Editorial Estampa.

FERNANDES, Paulo Almeida (2016). Matéria das Astúrias. Ritmos e realizações da expansão asturianoleonesa no actual centro de Portugal, séculos VIII-X. Coimbra: Faculdade de Letras da Universidade de Coimbra. Tese de Doutoramento.

GARCÍA DE CORTAZAR, J. A.; RUIZ DE AGUIRRE, Y. (1983). História Rural Medieval. Lisboa: Editora Estampa

GUTIÉRREZ LLORET, Sónia (1996). La cora de Tudmir: de la antigüedad tardía al mundo islámico: poblamiento y cultura material. Madrid: Casa de Velázquez.

JORGE, Ana (2000). As instituições e o elemento humano. In.: História Religiosa de Portugal, Vol I. Formação e Limites da Cristandade. Lisboa: Círculo de Leitores, pp. 203-260.

LOURENÇO, Sandra. (2007). O Povoamento Alto Medieval entre os rios Dão e Alva. "Trabalhos de Arqueologia». 50.

LP: Livro Preto: cartulário da Sé de Coimbra. Ed. Manuel Augusto Rodrigues. Coimbra: Arquivo da Universidade, 1999.

MARTÍN VISO, Iñaki (2005-2006). Elementos para el análisis de las necrópolis de tumbas excavadas en la roca: el caso de Riba Côa. «CuPAUAM». 31-32, 83-102.

MARTÍN VISO, Iñaki (2012). Enterramientos, memoria social y paisaje en la Alta Edad Media: propuestas para un análisis de las tumbas excavadas en roca en el Centro-Oeste de la Península Ibérica. «Zephyrus». 69, 165-187.

MARTÍN VISO, Iñaki (2016). Colapso político y sociedades locales: el Noroeste de la Península Ibérica (siglos VIII - IX). «Reti Medievali». 17: 2, 1-29. Disponível em <http://www.rmojs.unina.it/index. php/rm/article/view/5009/5585> [Consult. 12 jul. 2018]. (antes de disponivel)

MATTOSO, José (1987). A nobreza medieval portuguesa. A família e o poder. Lisboa: Editorial Estampa.

MATTOSO, José (1997). Portugal no Reino Asturiano-Leonês. In MATTOSO, José, dir. História de Portugal. Lisboa: Editorial Estampa, vol. 1, pp. 393-496. Vol. 1: Antes de Portugal. 
MENDES, Henrique; PIMENTA, João; VALONGO, António (2002). Cerâmicas medievais provenientes da escavação da Travessa da Lameira n. ${ }^{\circ}$ 21. Centro Histórico de Santarém. «Revista Portuguesa de Arqueologia». 5: 1, 259-276.

MORAIS, Carlos (2013). Santa Comba Dão na Idade Média: uma Multiplicidade de Espaços e Poderes. Coimbra: Faculdade de Letras da Universidade de Coimbra. Dissertação de Mestrado.

NEVES, António (2014). Vestígios Arqueológicos e o povoamento da freguesia de S. João de Areias (concelho de Santa Comba Dão). Disponível em <https://escolasecundriadetbua.academia.edu/ Ant\%C3\%B3nioNeves> [Consult. 10 set. 2018] ( antes de disponível)

PÉREZ MARINAS, D. I. (2016). Tierra de nadie. Sociedad y poblamiento entre el Duero y el Sistema Central (Siglos VIII-XI). Madrid: Universidad Nova de Madrid. Departamento de Historia Antigua, Historia Medieval, Paleografía y Diplomática. Tese de Doutoramento.

RAMALHO, Maria et al. (2001). Vestígios da Santarém Islâmica. Um silo no convento de S. Francisco. «Arqueologia Medieval». 7, 147-184.

REAL, Manuel L. (2014). A dinâmica cultural em Portucale e Colimbrie nos séculos VIII-XI. In DE MAN, A.; TENTE, C. coord. Estudos de cerâmica medieval. O Norte e Centro e Portugal - séculos XI a XII. Lisboa: Instituto de Estudos Medievais, pp. 13-56.

RUBIO DÍEZ, Rúben (2013). Tumbas excavadas en roca y poblamiento rural post-romano al suroeste del Duero. In Arqueología en el valle del Duero. Del Neolítico a la Antiguedad Tardía: nuevas perspectivas. Salamanca: Universidade de Salamanca, pp. 269-280.

SÁNCHEZ PARDO, José Carlos (2010). Las iglesias rurales y su papel en La articulación territorial de la Galicia medieval (ss. VI-XIII). Un caso de estúdio. «Mélanges de la Casa de Velázquez». 40: 1, 149-170.

TENTE, Catarina (2007). A ocupação alto-medieval da encosta noroeste da Serra da Estrela. Lisboa: Instituto Português de Arqueologia. (Trabalhos de Arqueologia; 47).

TENTE, Catarina; DE MAN, Adrian (2016). O fim da Lusitânia: fragmentação e emergência de poderes no território de Viseu. In A Lusitânia Entre Romanos e Bárbaros. Coimbra: Mangualde, pp. 375-396.

VELOSO, Maria Teresa (2008-2009). O culto de Santa Comba e o (re)povoamento do vale do Dão (sécs. $X-X I)$. «Revista Portuguesa de História». 40, 251-271.

VIEIRA, Marina Afonso (2004). Alto Paiva: povoamento nas épocas romana e alto-medieval. «Trabalhos de Arqueologia». 36. 


\title{
A NECRÓPOLE RUPESTRE DE SAN VITOR DE BARXACOVA (PARADA DE SIL, OURENSE) - O DESCUBRIMENTO DUNHA NOVA REALIDADE ARQUEOLÓXICA NA RIBEIRA SACRA (GALIZA)
}

\author{
EDUARDO-BREOGÁN NIETO MUÑIZ*
}

Resumo: Apresentam-se neste artigo os resultados das intervenções arqueológicas que decorreram em San Vítor de Barxacova entre os anos 2010 e 2018, nas quais se pôs ao descoberto uma das maiores necrópoles rupestres do noroeste peninsular. A diversidade de dados arqueológicos, conjuntamente com os estudos transversais realizados na sequência das escavações, revelou uma nova realidade histórica no marco da Idade Média galega.

Palavras-chave: Necrópole; Arqueologia; Tumbas antropomórficas.

Abstract: This article presents the results of the archaeological excavations carried out in San Vitor de Barxacova between 2010 and 2018, which have brought to light one of the greatest rock necropolis of the northwestern Iberian Peninsula. The diversity of archaeological data, together with the crosssectional studies carried out at the same time, have revealed a new historical reality within the framework of medieval Galicia.

Keywords: Necropolis; Archaeology; Anthropomorphic tombs.

A necrópole rupestre de San Vitor de Barxacova sitúase na parroquia de San Lourenzo de Barxacova, no concello de Parada de Sil (Ourense, Galiza). Emprázase nun saínte rochoso no medio dunha empinada ladeira na ribeira oeste do río Mao, dende onde se domina o curso final do río ata a súa desembocadura no Sil.

$\mathrm{O}$ acceso actual ao sitio realízase a través dun sendeiro que comunica os núcleos e parroquias de San Lourenzo e Forcas, sendo a antiga e única vía de comunicación entre as zonas de ribeira e montaña, hoxe transformada en ruta de sendeirismo (PR-G-155).

Transcorridos uns $700 \mathrm{~m}$ dende San Lourenzo a ladeira anchea nunha pequena rechán de $15 \mathrm{~m}$ de largura por outro tanto de cumprimento, coroada no seu extremo leste por nunha grande peneda de máis de $5 \mathrm{~m}$ de altura ${ }^{1}$.

\footnotetext{
* Grupo de Estudos de Arqueoloxía, Antigüidade e Territorio (GEAAT-H2Ou), Universidade de Vigo. Email: info@ breoganarqueoloxia.com.

${ }^{1}$ Coordenadas UTM ETRS89 F29: 623405, 4692573; 590 msnm.
} 

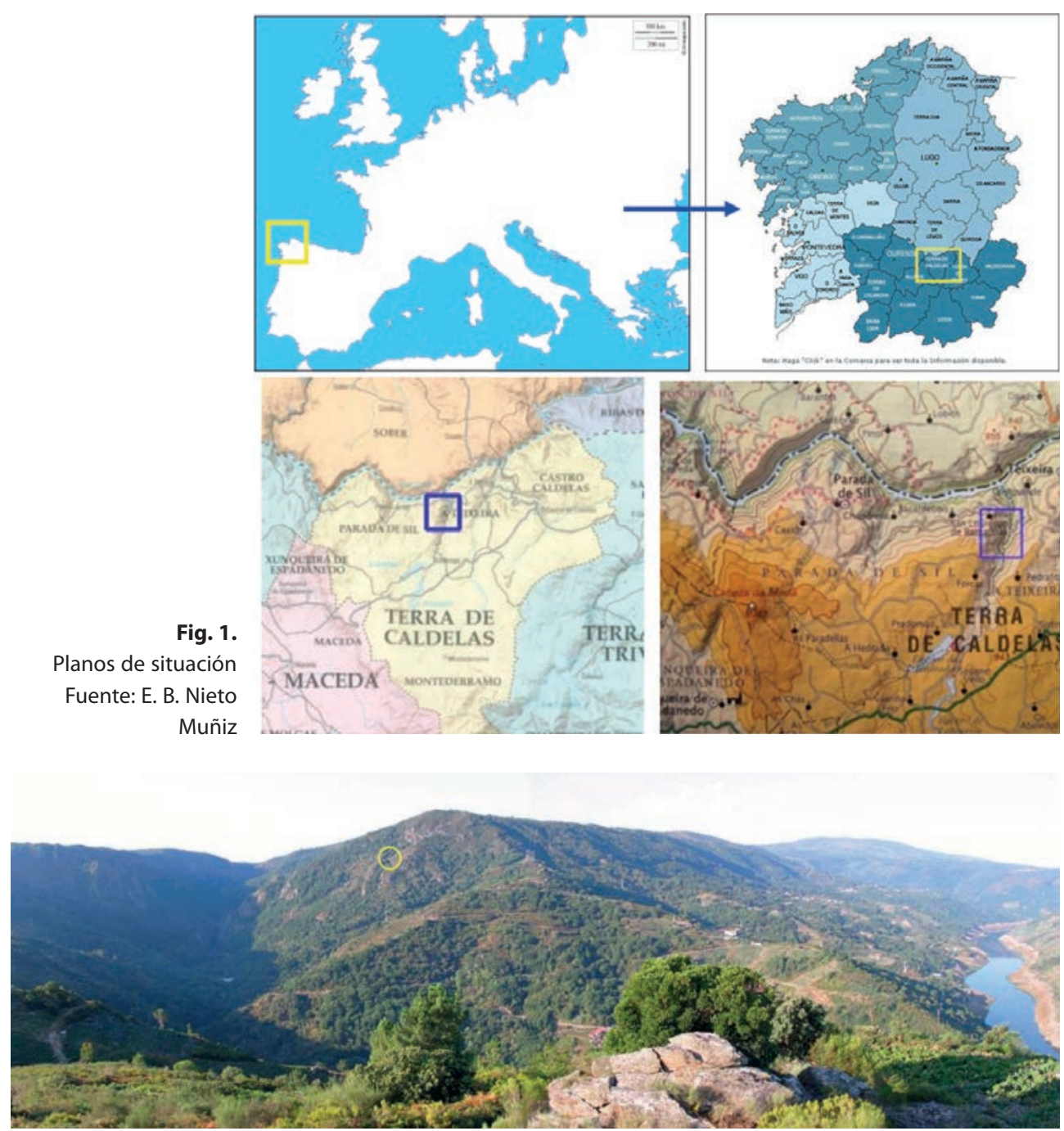

Fig. 2. Panorámica do val do Mao e do Sil Fuente: E. B. Nieto Muñiz

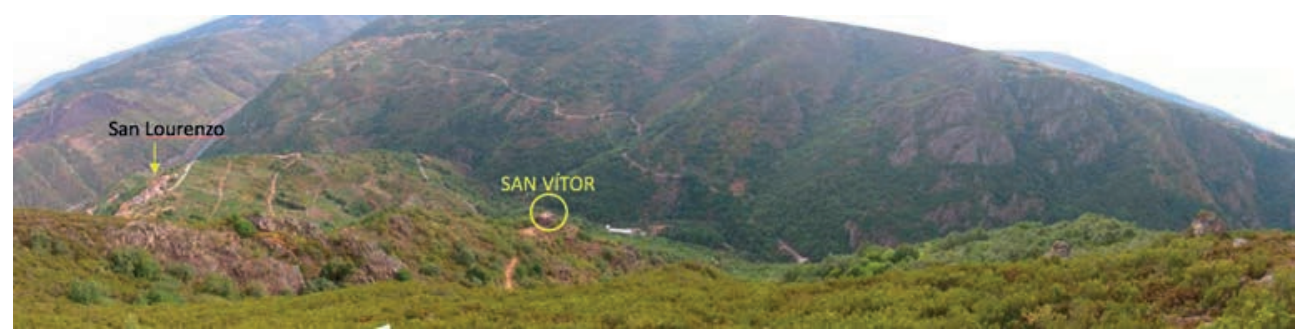

Fig. 3. Panorámica do val do Mao sobre o San Vitor Fuente: E. B. Nieto Muñiz 


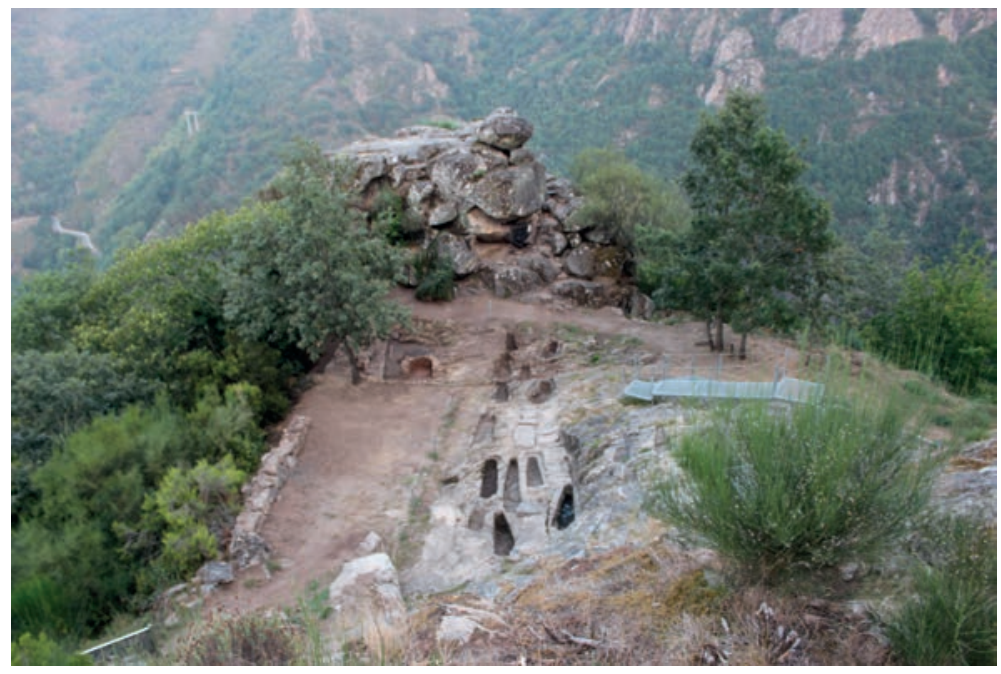

Fig. 4.

Vista xeral do xacemento Fuente: E. B. Nieto Muñiz

O xacemento foi dado a coñecer por vez primeira na bibliografía no relato que fai J. Arias Sanjurjo no seu artigo "Una aproximación a la Ribera Sagrada», no que describe diversos restos e sepulturas alí presentes, das que di ter recoñecido unha decena, considera o lugar coma o mosteiro máis importante da hoxe chamada Ribeira $\mathrm{Sacra}^{2}$, e de onde conta o seguinte:

Nos refirió un anciano que en su juventud lo había destruído en unión a otros mozos, arrojando las piedras de los muros por el precipicio sobre que se hallaba la capilla. Según el eran éstos de la altura de una persona. Quedan todavía en la roca vestigios que descubren el lugar donde estuvo la puerta de entrada ${ }^{3}$.

Nas visitas previas ás intervencións arqueolóxicas, efectivamente víanse tallados na peneda chanzos que facilitan o ascenso ao cumio da mesma, onde se erixía a capela, ademais dalgunhas sepulturas. Na parte chaira inferior, informa o propio Arias Sanjurjo que:

algunas [sepulturas] fueron destruídas al abrir el camino de la fábrica de Barjacova, que cruza esa plazoleta ${ }^{4}$.

\footnotetext{
2 Termo hoxe en día turístico e enolóxico que abrangue a ribeira do curso baixo do río Sil e do curso medio do Miño, inda que naquel entón referíndose só ao curso do Sil.

${ }^{3}$ ARIAS, 1914: 49.

${ }^{4}$ ARIAS, 1914: 50.
} 
Finaliza o relato cunha aproximación histórica:

os anacoretas o monjes que habitaron esa comarca, debieron de tener su centro o residencia principal un kilómetro más abajo del santuario, en el lugar que ocupa el Priorato de San Adrián, que es la parte de la ribera más próxima susceptible de cultivo. [...] Conservó su personalidad e independencia hata el siglo XII, en que el Emperador Alonso VII, siguiendo las corrientes de la época, se lo entregó a la Orden el Císter 5 .

O sitio de San Vitor tamén ven recollido por J. Freire Camaniel na súa obra «El Monacato Gallego en la Edad Media» ${ }^{6}$, que segue no esencial a Arias Sanjurjo. En 1991 é incluído no inventario de xacementos arqueolóxicos da Xunta de Galicia ${ }^{7}$, describíndose tres sepulturas visibles na zona chaira, ademais das da parte superior da peneda, onde se indica tamén a presenza de negativos de estruturas, e a localización de cerámica medieval en superficie. Seguindo a clasificación tipolóxica e cronoló-

Fig. 5.

Foto oblícua a vista de dron do xacemento, con San Lourenzo e o Sil ao fondo

Fuente: E. B. Nieto

Muñiz

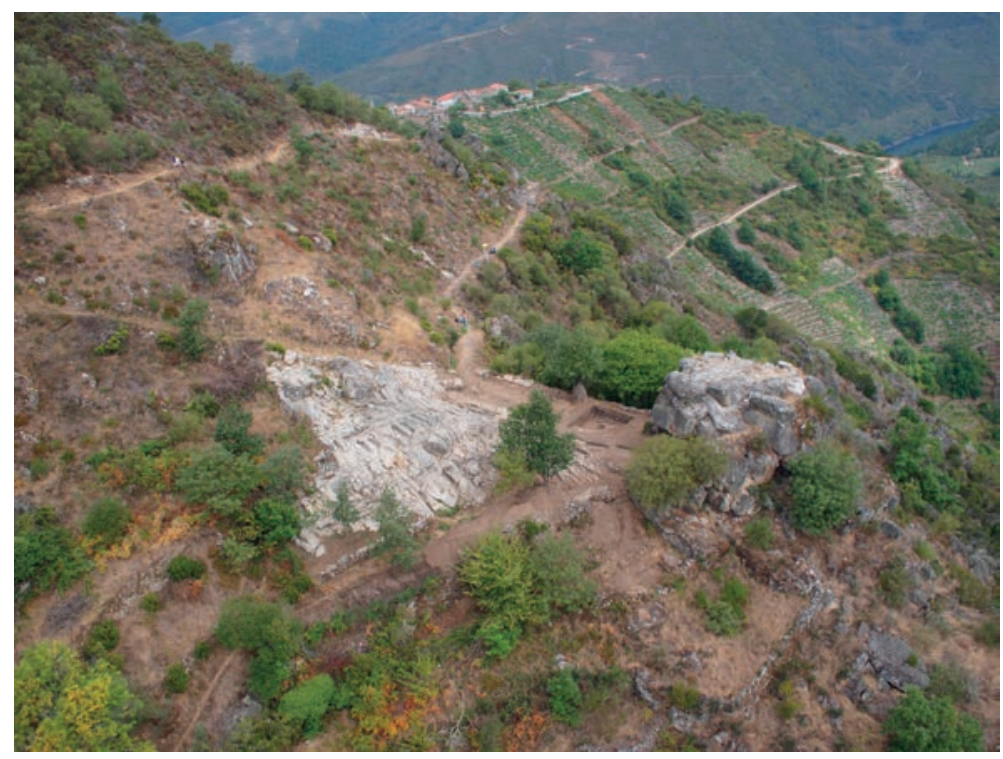

\footnotetext{
${ }^{5}$ ARIAS, 1914: 51. De acordo a documentación, San Adrián foi logo incorporado ao mosteiro de Montederramo. Do pequeno priorado, rexido pola orde bieita, queda algún resto hoxe incorporado a unha casa particular.

Un estudo documental do sitio foi realizado, dentro dos proxectos de actuación sobre San Vitor de Barxacova, por Víctor Rodríguez Muñiz, quen expón de forma ampla e minuciosa as súas conclusións noutro artigo destas mesmas actas. ${ }^{6}$ FREIRE, 1998: 220-223.

${ }^{7}$ Ficha de catálogo redactada por J.F. Romalde Purriños e M. González Méndez.
} 
xica proposta por López Quiroga e Lovelle ${ }^{8}$, de acordo a tipoloxía de sartegos fixos rupestres e de marcado antropomorfismo, encadraríanse entre os séculos IX e X.

Desde o ano 2010 ao 2018 o xacemento de San Vitor foi obxecto de sucesivas campañas de escavación e estudo arqueolóxico, ademais de someterse a labores de restauración, consolidación, limpeza e mantemento periódicas para facer o sitio visitable e asegurar a súa conservación 9 .

O xacemento componse de dúas partes ben diferenciadas: por un lado, a alta peneda que coroa o sitio, ao leste e colgada na extrema pendente, facendo o xacemento doadamente recoñecible na contorna; por outro, ao oeste e contra a ladeira, o afloramento granítico no que se sitúa a necrópole. Entre ambas esténdese unha rechán pola que atravesa o camiño de acceso, que continúa cara o $\mathrm{S}$.

As escavacións levadas a cabo no alto da pena puxeron ao descuberto toda unha serie de marcas, negativos e entalles tallados na rocha que axudan a proxectar a planta e algunhas características da antiga capela que no alto se erixía ${ }^{10}$. O acceso á mesma realizábase polo sur, onde se abre un corredor entre rochas e, xa no alto, se

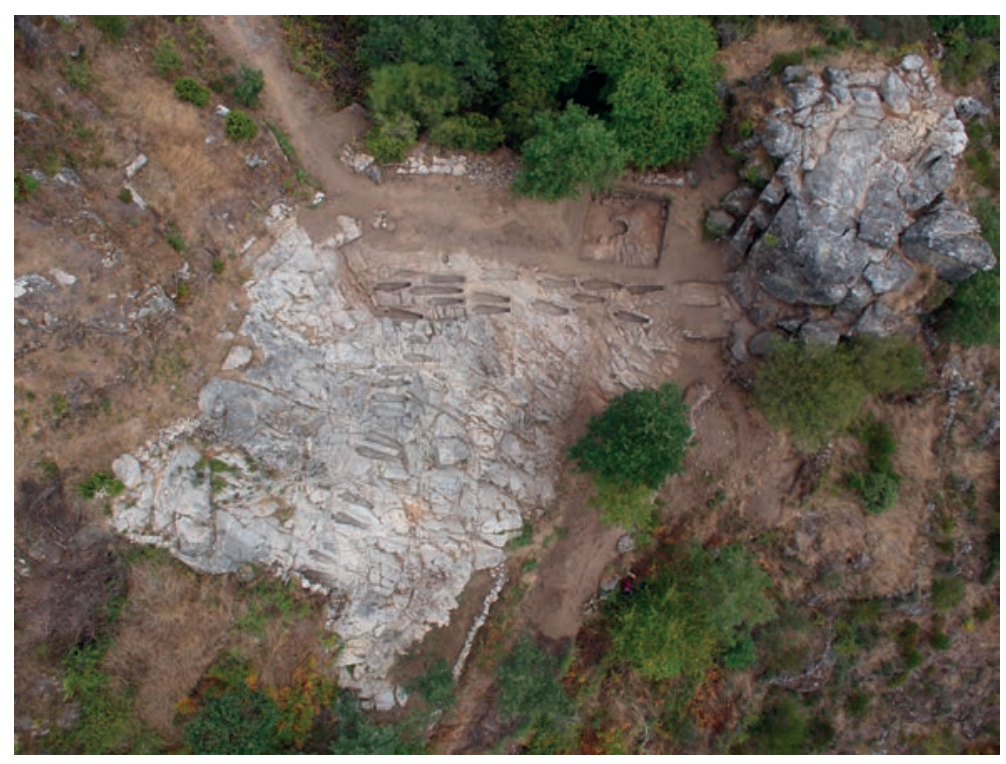

Fig. 6.

Foto cenital da necrópole e rocha da capela

Fuente: E. B. Nieto Muñiz

\footnotetext{
${ }^{8}$ LÓPEZ QUIROGA, RODRÍGUEZ LOVELLE, 1991.

${ }^{9}$ As intervencións arqueolóxicas e de restauración foron promocionadas e financiadas polo Concello de Parada de Sil, con fondos propios, achegas a través de subvencións do Plan Leader, ou con colaboracións doutras institucións como a Dirección Xeral de Patrimonio da Xunta de Galicia, Universidade de Vigo ou Deputación Provincial de Ourense. Os labores de mantemento na actualidade están sometidos a un procedemento protocolario de periodicidade anual a cargo do Concello de Parada de Sil.

${ }^{10} \mathrm{O}$ alto da rocha estaba ocupado por un poste dunha liña eléctrica en desuso, que foi retirado na primeira intervención en 2010, e cuxa cimentación tiña afectado seriamente a planta da capela, véndose hoxe un gran furado no medio e medio desta.
} 
definen unha serie de chanzos e couzóns que marcan a entrada ${ }^{11}$. Na superficie chaira superior distínguense os alicerces, definindo unha planta cuadrangular de non máis de $12 \mathrm{~m}^{2}$. Dende estes, cara o oeste e mirando cara a necrópole, ábrese un balcón, definido por lousas horizontais colocadas entre o rochedo e mostrando marcas dunha eventual estrutura de madeira. No alto da rocha localizáronse catro sepulturas, unha escavada a carón da entrada da capela e outras dúas apenas insinuadas e inacabadas, destacando entre elas entre a chamada «tumba privilexiada» (identificada como T.I) que escapa ao esquema de sartego tallado na rocha do resto da necrópole ${ }^{12}$. Trátase dunha tumba construída nun espazo reenchido intencionadamente entre dúas penas coa clara intención de gañar espazo para a súa construción, quedando incorporada ao interior da capela, polo norte. Foi construída con perpiaños graníticos reaproveitados dalgunha construción anterior, como testemuñan as marcas decorativas e entalles dalgunhas delas, tallándose na da testeira a forma da cabeza. Sobre as laxas do fondo, revoltos, apareceron restos óseos que se puideron datar a finais do século $\mathrm{X}^{13}$; data

Fig. 7.

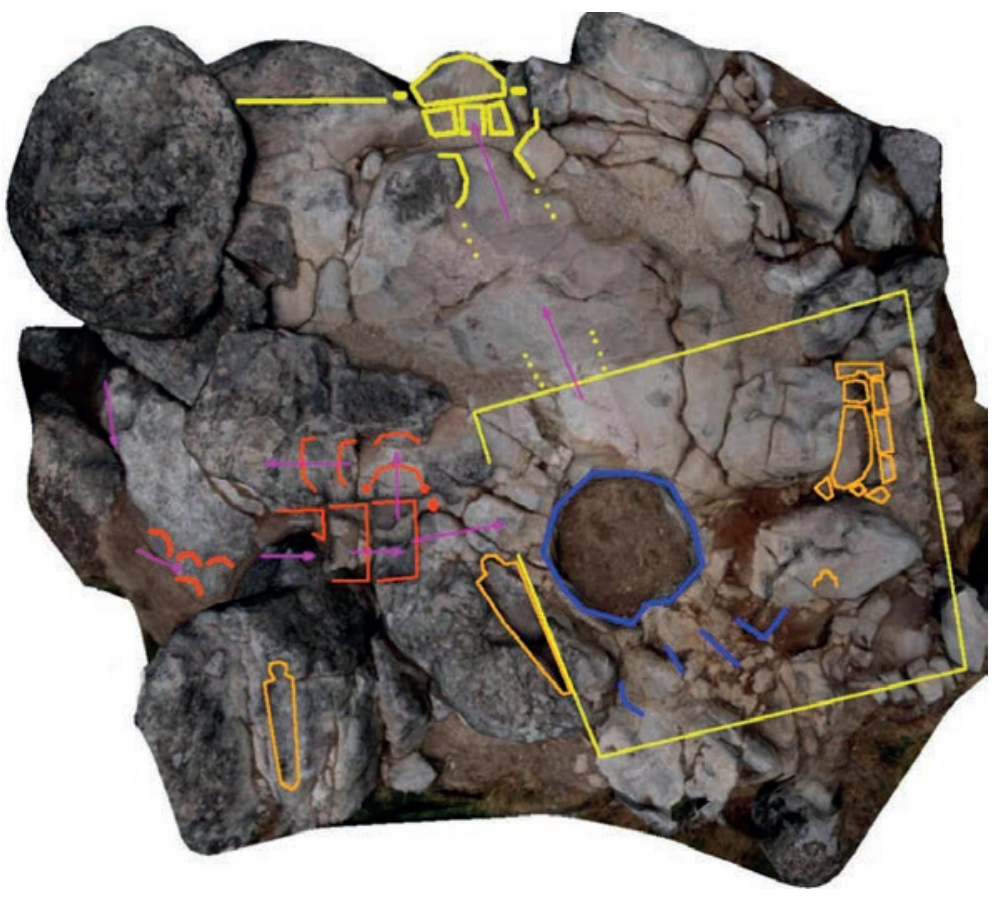

Esquema da planta da capela sobre a rocha Fuente: E. B. Nieto Muñiz

\footnotetext{
${ }^{11}$ Unha serie de chanzos laterais, acompañados dos seus respectivos couzóns, parece estar marcando estruturas anexas ao corpo principal da capela no sector sur ou de entrada.

${ }^{12}$ Dos sartegos localizados no alto da rocha, e polo tanto relacionados directamente co espazo da capela, só un deles, ademais da «tumba privilexiada», está rematado (T.II) e podería estar indicando os limites da capela polo sur; os outros dous están apenas insinuados e carecen de fondo, identificándoos como sartegos inacabados, un deles no exterior (T.III) e outro no interior do espazo identificado como capela (T.IV).

${ }^{13}$ Datación obtida por C14 dos propios ósos: 995+-30BP (cal. 2 sig.).
} 


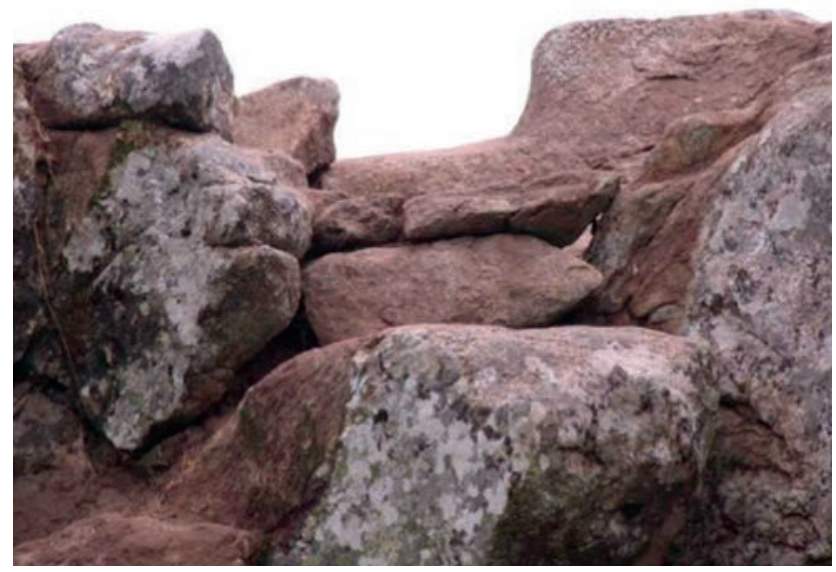

Fig. 8. Balcón na capela aberto cara a necrópole Fuente: E. B. Nieto Muñiz

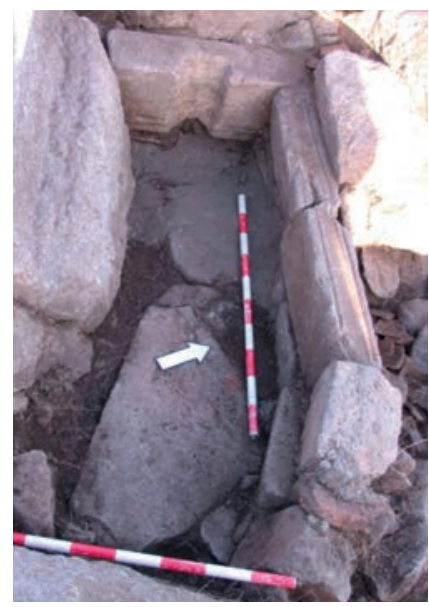

Fig. 9. Tumba privelexiada

Fuente: E. B. Nieto Muñiz

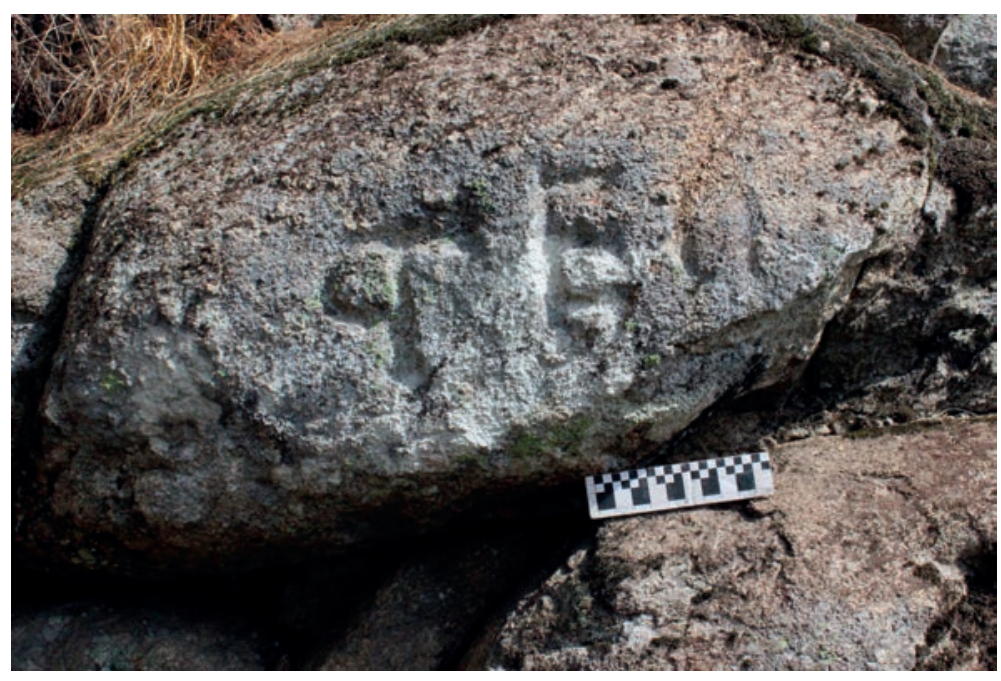

Fig. 10.

Inscrición na parte baixa da rocha da capela Fuente: E. B. Nieto Muñiz

que marcaría o momento de uso central da capela e polo tanto da necrópole, e unha data ante quem para a presenza dunha construción máis antiga de cuxas ruínas terían reutilizado as pezas arquitectónicas.

$\mathrm{Na}$ base da rocha que sustenta a capela, polo sur, localizouse unha inscrición rupestre composta por catro letras capitais, duns $10 \mathrm{~cm}$ de alto e trazo de $1 \mathrm{~cm}$ de grosor, de sección fonda e redondeada, na que se le: «TECI». Destes caracteres só se len claramente os dous primeiros, adornados con prolongacións traseiras e inferiores propias da escritura epigráfica visigótica, que podemos enmarcar entre os século X e XI. 
Fig. 11. Foxo de fundición de campás

Fuente: E. B. Nieto Muñiz

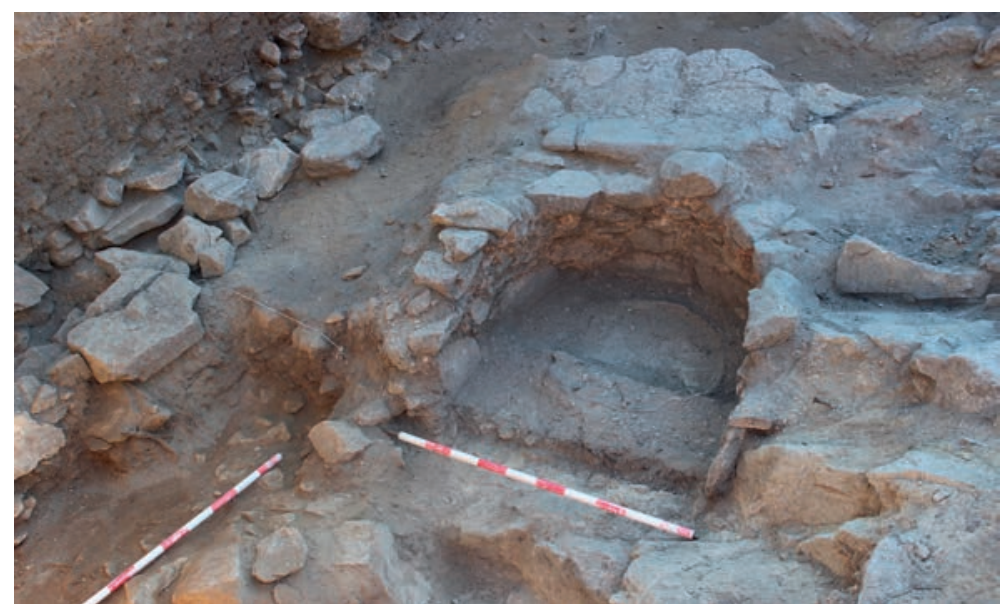

Fig. 12.

Restos dos moldes das campás recuperados do interior do foxo Fuente: E. B. Nieto Muñiz

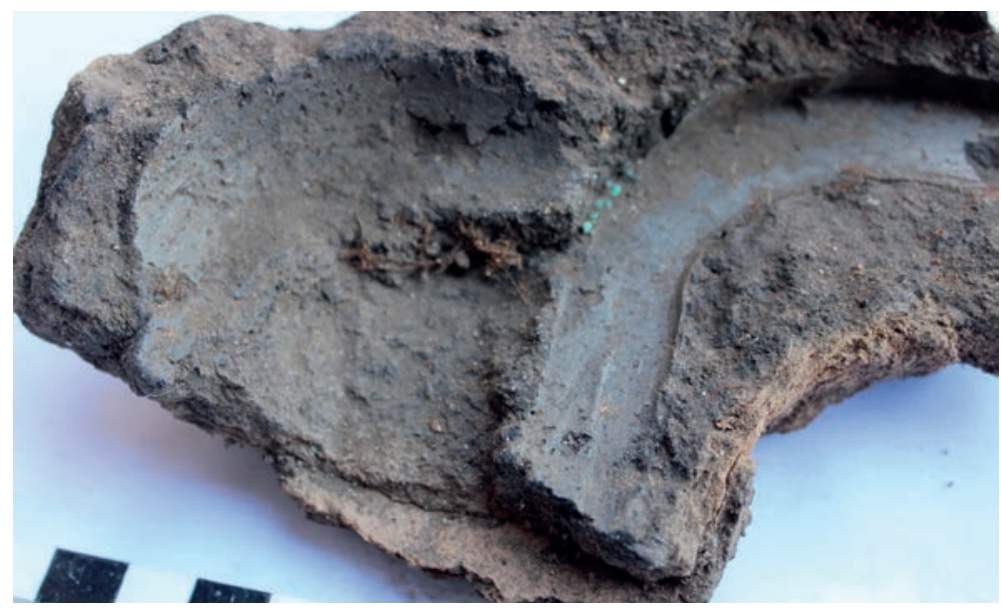

Fig. 13.

Proceso de produción dos moldes da campá

Fuente: M. A. Nieto
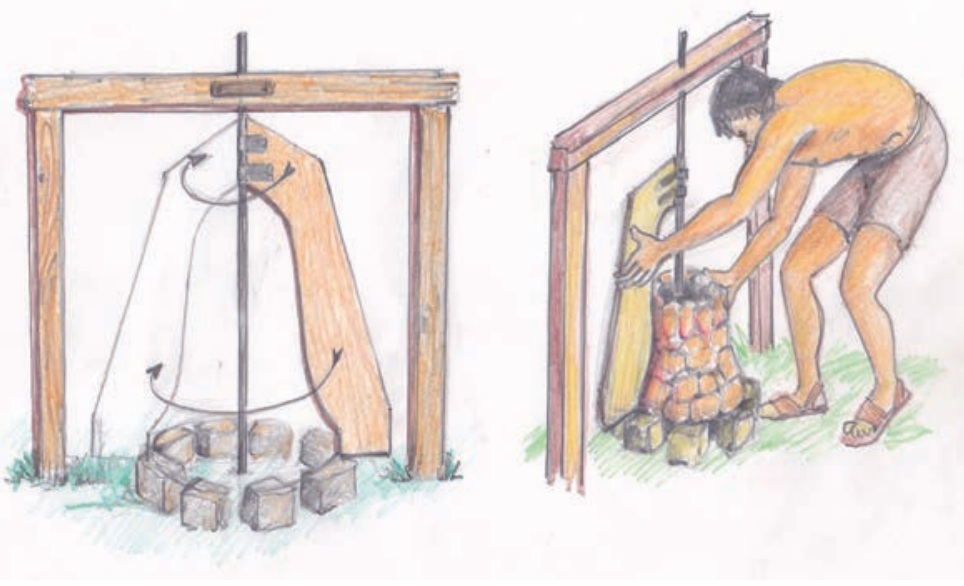

Dorado 
No afloramento que alberga a necrópole distínguense, asemade, dous sectores ben diferenciados - o sector S e o sector N. O meridional caracterízase pola disposición en abano de tres bandas de sepulturas, todas antropomórficas, salvo aquelas de conservación deficiente, cunha sinxela preparación previa da superficie onde se escavaron, alcanzando a adiviñar certas agrupacións. O setentrional pódese subdividir tamén en dúas partes, a NW e a NE. Na primeira amoréanse as tumbas en coidada aliñación, contando tamén con casos de superposicións e ampliacións forzadas, organizadas todas elas dentro dunha superficie horizontal cortada no sector $\mathrm{N}$ do afloramento (aparentemente correspondente a unha construción anterior á propia necrópole). Na segunda as tumbas vanse dispondo de xeito máis desorganizado, deixando incluso espazos baleiros entre elas, estendéndose cara o E e cara o descenso ás parcelas ao $S$ da peneda.

No sector N, xa fóra da área ocupada polo afloramento, atopouse o foxo de función de campás, cunha datación de entre finais do século IX e comezo do século X d. C. ${ }^{14}$. O forno está formado por un semicírculo de cachotes graníticos e fragmentos de ladrillo e tella, recebado con barro, construído nunha foxa escavada no limite rochoso. Na súa base disponse unha coidada preparación de barro moi fino no que se conserva a impronta do aro de barro que formaba o sistema de triplo molde ${ }^{15}$. O forno foi amortizado despois da fundición da campá, atoándoo cos propios restos dos moldes, polo que a súa datación márcanos o momento de culminación da capela, ou cando menos do seu campanario, coincidindo coa datación aportada polos restos óseos da «tumba privilexiada».

$\mathrm{Na}$ área da necrópole, ademais dos sartegos, localizáronse unha serie de rebaixes e cortes que crean unha sucesión de superficies horizontais, co chan repicado, que arrodean o sector sur polo súa parte inferior oeste e enmarcan o sector norte dentro dunha superficie regularizada no afloramento. Estes rebaixes puideran ter servido para a cimentación e construción de estruturas no sector baixo do afloramento, como

\footnotetext{
${ }^{14}$ Datación obtida por termoluminiscencia dos barros refractarios do forno: 1121+-69 BP / 893+-69 DC.

${ }^{15} \mathrm{O}$ sistema de fabricación da campá era o seguinte: dentro da foxa preparábase un primeiro molde de barro, que se remataba cunha plantilla de madeira para darlle a forma do interior da campá; recubríase logo con sebo e sobre este unha segunda capa de barro, co grosor e forma que se lle quixera dar a campá, aplicando un segundo molde e dispondo os eventuais motivos decorativos. Cubríase de novo cunha segunda capa de sebo que, do mesmo xeito, se recubría de barro. Finalizado este proceso prendíase lume no interior ata endurecer os moldes e derreter o sebo. A seguir retirábanse os dous moldes exteriores, rexeitando o do medio e volvendo colocar o máis exterior, creando un espazo oco entre este e o molde interior, co espesor e forma desexados para a campá. Cubríase despois todo con area, deixando visibles os respiros e os tubos de alimentación para o bronce, que se fundiría nas inmediacións (de feito apareceron restos de queimado ao redor dunha gran lousa achegada ao forno). Vertíase o bronce dentro dos moldes, ocupando así o oco deixado entre estes. Unha vez arrefriado todo abríase a foxa, rompendo os moldes e a propia estrutura que o albergaba, para extracción da campá. Finalizado o proceso, os moldes e os restos todos amortizábanse na propia foxa. O oficio de campaneiro era itinerante, levando consigo os artesáns a técnica e as plantillas. A materia prima tanto para a foxa como para a campá sería facilitada polas comunidades que requirían os seus servizos.

Este sistema de fabricación é o mesmo empregado dende o século XVI e aínda hoxe pola familia Ocampo en Arcos da Condesa (Pontevedra, Galiza), quen amablemente nos recibiron no seu taller.
} 
testemuña, no extremo sur, o único resto construtivo atopado no sector da necrópole. Trátase dun muro de mediocre construción, pero coidando mediante pequenas canles a drenaxe e a escorrentía da auga na súa parte traseira, contra o afloramento, evitando así posibles enchoupamentos e conseguintes derrubes.

A relación estratigráfica deste rebaixes coa necrópole presenta certas controversias. No sector sur do afloramento estas marcas ocupan espazos libres de enterramentos, só coa excepción da T.XLVII, atopado entre fendas no suposto espazo interior dunha desas áreas construídas. No sector norte, en cambio, esta relación é máis clara, aparecendo cortados os rebaixes polas cabeceiras dos sartegos T.XXIX e T.XXXIII, nunha clara superposición que demostra a maior antigüidade dos rebaixes en relación aos enterramentos ${ }^{16}$.

Entre as sepulturas distínguense tamén varias cavidades elípticas, de función indeterminada, ademais de entalles e canles, que poderían ter que ver cos enterramentos ou coas estruturas anteriores descritas.

O número total de sartegos rexistrados na necrópole é de 56, divididos en varios sectores: 4 na capela, 24 no sector sur e 26 no sector norte, que se pode subdividir en subsector noroeste, con 12 enterramentos, e nordeste, con 14. A estes sectores hai que sumar outros dous de carácter illado: o xa citado ao sueste (T.XLVII) no sector dos rebaixes, e outro a noroeste (T.XXXVI), coincidindo co camiño aberto canda a construción da liña eléctrica citado no artigo de $1914^{17}$.

A orientación xeral de todas elas é en sentido nor-noroeste, con pequenas variacións que se escapan deses canons no sector sur e no alto da capela, debido a unha evidente adaptación dos sartegos á disposición do soporte. Esta adaptación ao terreo é moi patente tanto no sector sur, no que se van dispondo en abano en función do rochedo, coma no sector norte, no que se organizan en función do espazo regularizado preexistente, ao tempo que se van desorganizando cara o sector nordeste, xa fóra desa superficie.

Os sartegos presentan tipoloxías variadas, sendo as máis abondosas as de pareces rectas de proxección converxente cara os pés, con ombreiras e cabeza ben marcadas. Entre estas hai tamén algunha de laterais en arco de paréntese ou paralelas, e moitas outras de forma irregular combinando ambas características. Tamén se contan dúas sen cabeza marcada, ou de bañeira (T.VII no sector sur e T.LV no nordeste) e incluso unha de bañeira con cabeza marcada no fondo (T.XVII no sector noroeste). A estas hai que sumar a de laxas da tumba privilexiada (T.I) e outra de tipo mixto: escavada na rocha na cabeceira de laxas na metade inferior (T.XLVIII, no sector nordeste). A posición destas tipoloxías diverxentes entre o resto do conxunto semella casual,

\footnotetext{
${ }^{16}$ No caso do sector norte, como xa se indicou, os enterramentos dispóñense aproveitando ao máximo ese espazo de aparente regularización previa.

${ }^{17}$ ARIAS, 1914: 49, facendo referencia á aparición dunhas dez, que foron destruídas canda a apertura do camiño.
} 


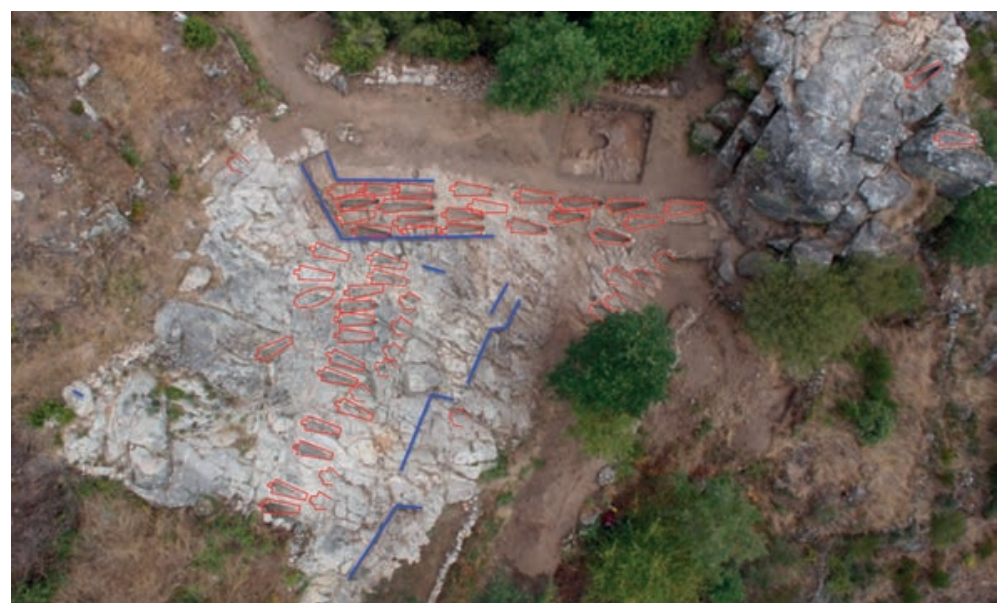

Fig. 14.

Disposición xeral do xacemento, con indicación dos rebaixes para construcións Fuente: E. B. Nieto Muñiz

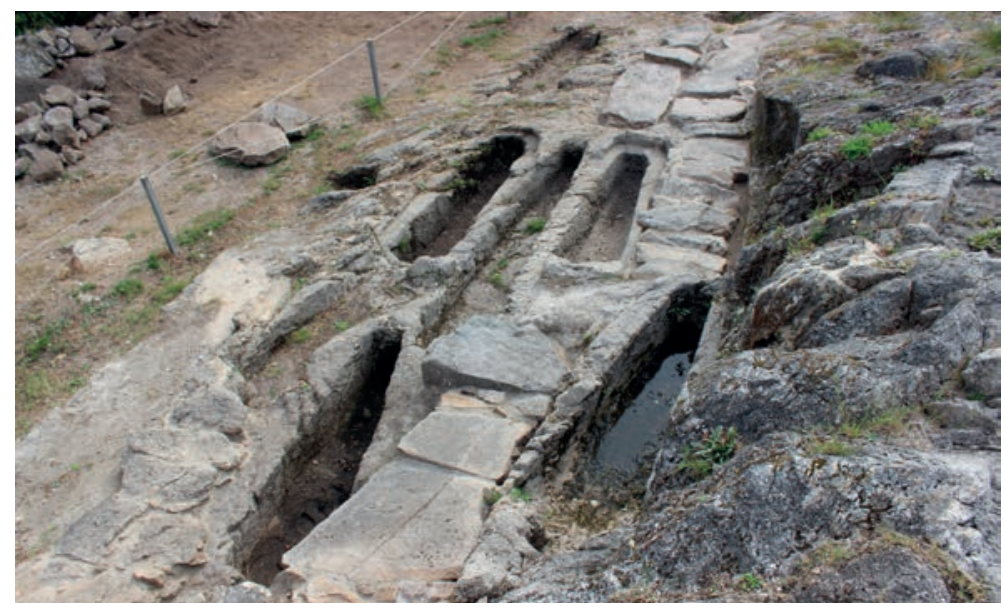

Fig. 15.

Sector norte da necrópole

Fuente: E. B. Nieto Muñiz
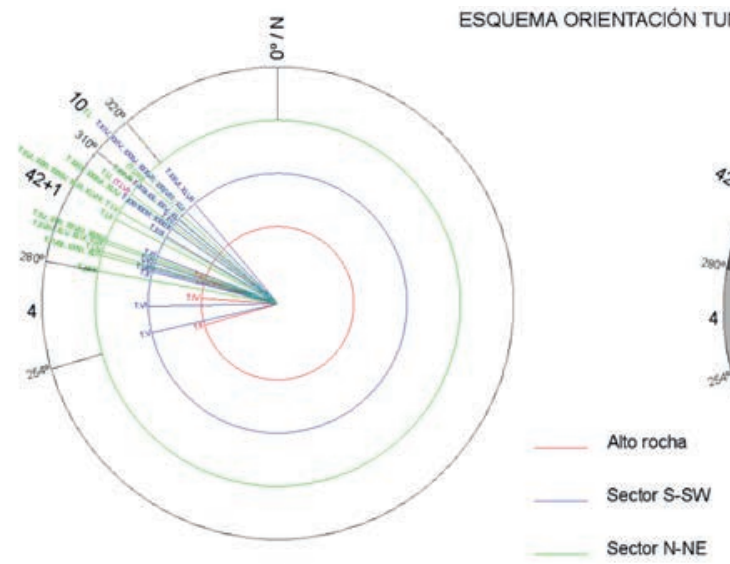

Fig. 16. Esquema de orientación das tumbas Fuente: E. B. Nieto Muñiz 
Fig. 17. Sartego XLII, con apéndices laterais Fuente: E. B. Nieto Muñiz

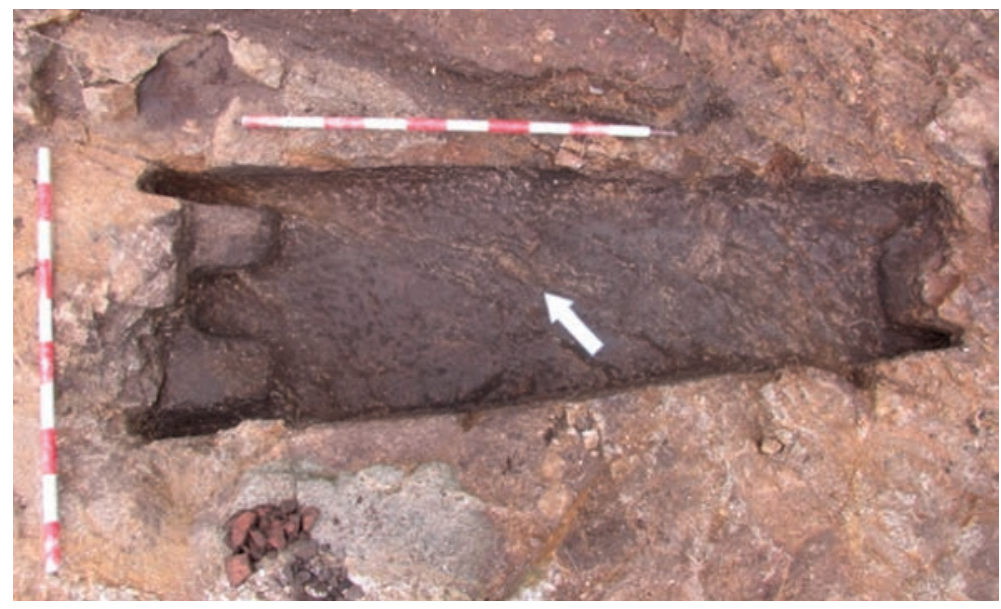

Fig. 18.

Sartego incabado na necrópole de Pombeiro Fuente: E. B. Nieto Muñiz

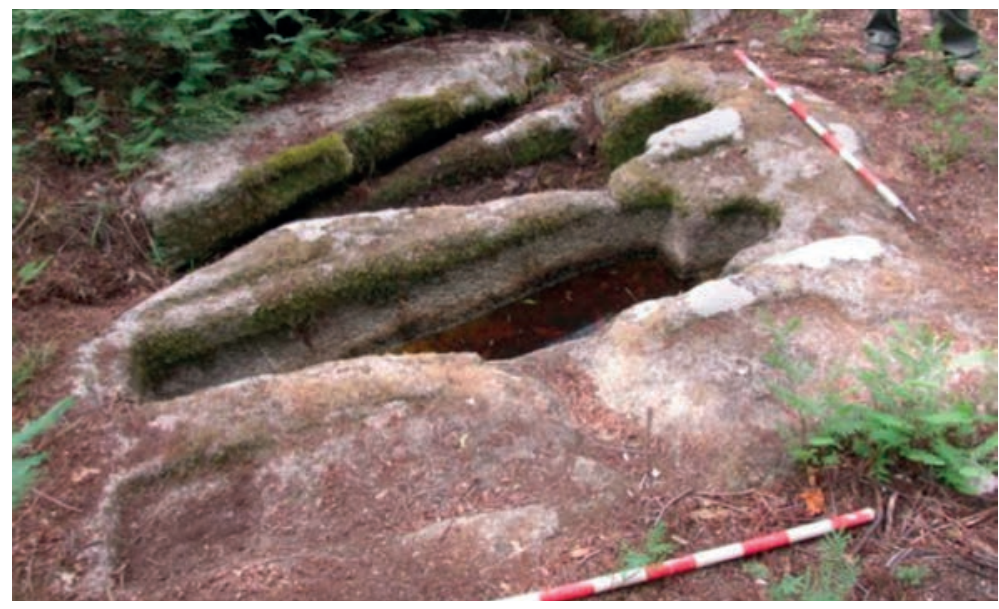

Fig. 19. Sartego XLVIII, de tipo mixto Fuente: E. B. Nieto Muñiz

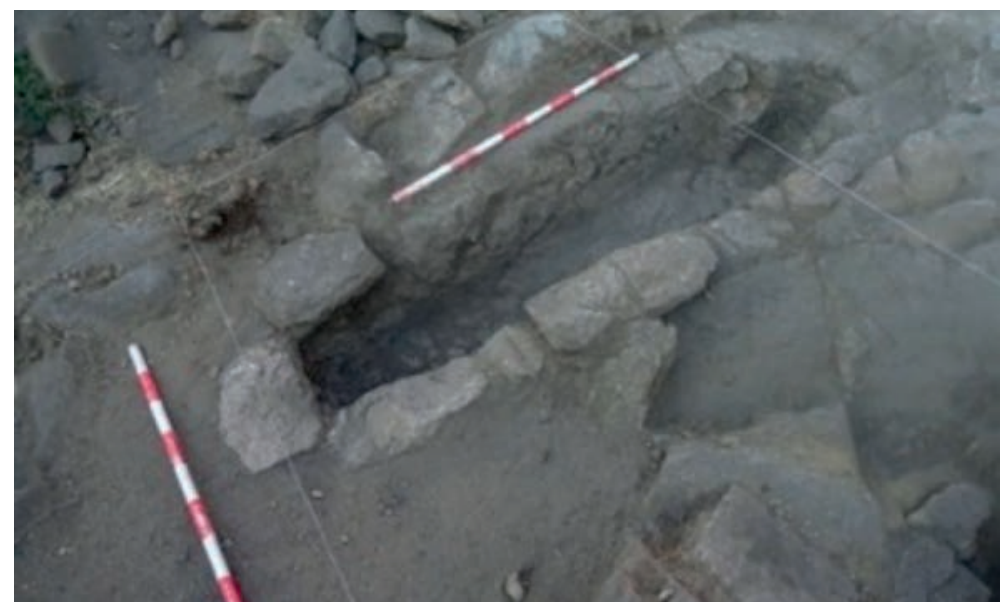


e non parece marcar evolución tipolóxica de ningunha clase, se non máis ben que se teña debido a maior ou menor pericia do canteiro e á propia dureza e consistencia da rocha.

No conxunto da necrópole chama a atención tamén o sartego T.XLII, xa que presenta uns apéndices laterais tanto a carón da cabeceira coma aos pés. A explicación a estes apéndices acadouse coa aparición da inacabada T.LIV, que aparece delimitada por dúas liñas laterais que se prolongan, coma na T.XLII, a ambos laterais da cabeza. A inacabada T.LIV estanos a mostrar o proceso de escavación dos sartegos, para o que se marcarían inicialmente dúas liñas laterais que delimitarían o espazo a tallar. A excesiva prolongación desas liñas laterais tería creado os apéndices indicados para a T.XLII, que ocuparía na escavación interior posterior menor espazo do inicialmente marcado. Esta escavación interior realizábase coa talla sucesiva de camadas ata acadar a fondura desexada ${ }^{18}$.

Son varios os sartegos inacabados, o que nos fala dunha planificación previa dese espazo da morte, finalmente rexeitado por motivos descoñecidos. No alto da capela xa citamos os sartegos T.III e T.IV, ademais do T.LIV na explanada do xacemento. A estes hai que engadir a T.VI, da que só se tallou unha forma oval.

Non podemos contar coma tumbas inacabadas aquelas das que só se conserva a parte da cabeceira na terceira aliñación do sector sur. Toda esta liña de enterramentos aparecen cortados coa pendente do propio afloramento, no que hai testemuñas claras de actividades canteiras tradicionais ${ }^{19}$; feito que explicaría a ausencia de toda a parte inferior dos sartegos. De tódolos xeitos, a presenza das marcas e entalles que marcan a presenza de estruturas construtivas mesmo baixo estas, suxire que a extracción de pedra non tería sido tan intensa. Xunto a isto, a localización da T.XLVIII, de tipo mixto, móstranos a posibilidade de que toda esa liña puidera encaixar neste modelo de sartegos rupestres na cabeceira, en función da pendente, e completados con laxas xa en superficies térreas ou habilitadas de pé feito para albergar o enterramento. Algo semellante ocorrería cos sartegos do extremo sur do sector noroeste.

A maioría dos enterramentos apareceron abertos. Só cinco, todos eles no sector noroeste, apareceron coas tampas orixinais, e entre estes só tres con elas completas ${ }^{20}$. O sistema das tampas é nestas a base de laxas de tamaño pequeno ou mediano, achegadas unhas a outras ata cubrir a superficie completa do sartego, e en ningún caso monolíticas. No camiño de acceso, en cambio, si se rexistrou unha tampa aproveitada no lastrado, de lonxitude suficiente para cubrir un sartego completo.

\footnotetext{
${ }^{18}$ Este proceso quedou perfectamente testemuñado nun dos sartegos inacabados da necrópole do Preguntoiro (San Vicenzo de Pombeiro, Ferreira de Pantón, Lugo), situada no curso final do río Sil.

${ }^{19}$ A pesar de que os veciños da zona aseguran que non se extraía pedra pola súa mala calidade, foi atopada una cuña de ferro de canteiro no sector inferior do afloramento.

${ }^{20}$ Coas laxas orixinais completas apareceron os sartegos XXVIII, XXIX e XXXII, mentres que o XXXIII e XXXIV apareceron con elas rotas ou incompletas, e polo tanto co enterramento alterado.
} 
Fig. 20. Sartego XXIX, coas tampas orixinais Fuente: E. B. Nieto Muñiz

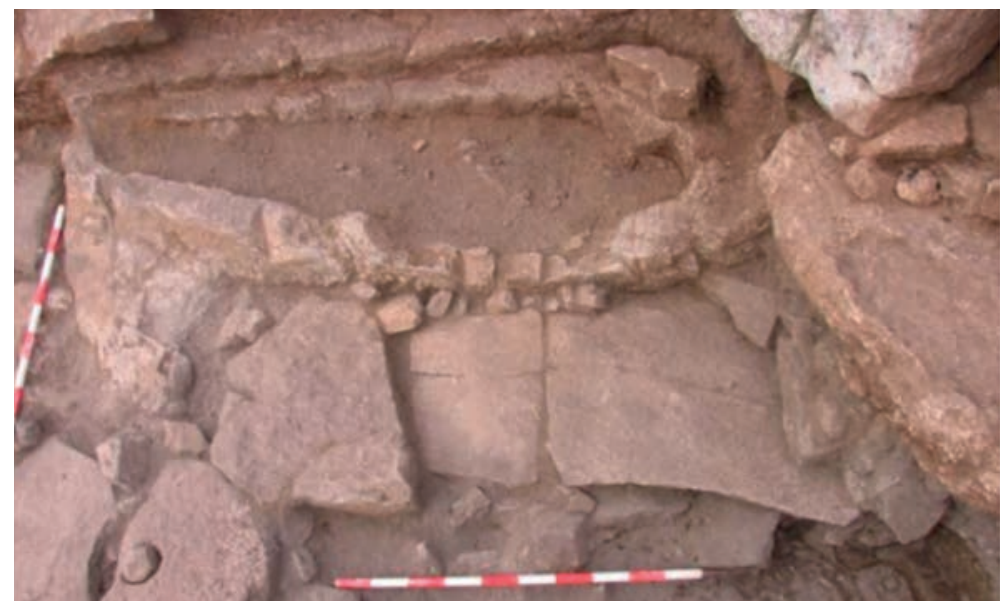

Fig. 21. Sartego XXVIII, coas tampas orixinais Fuente: E. B. Nieto Muñiz

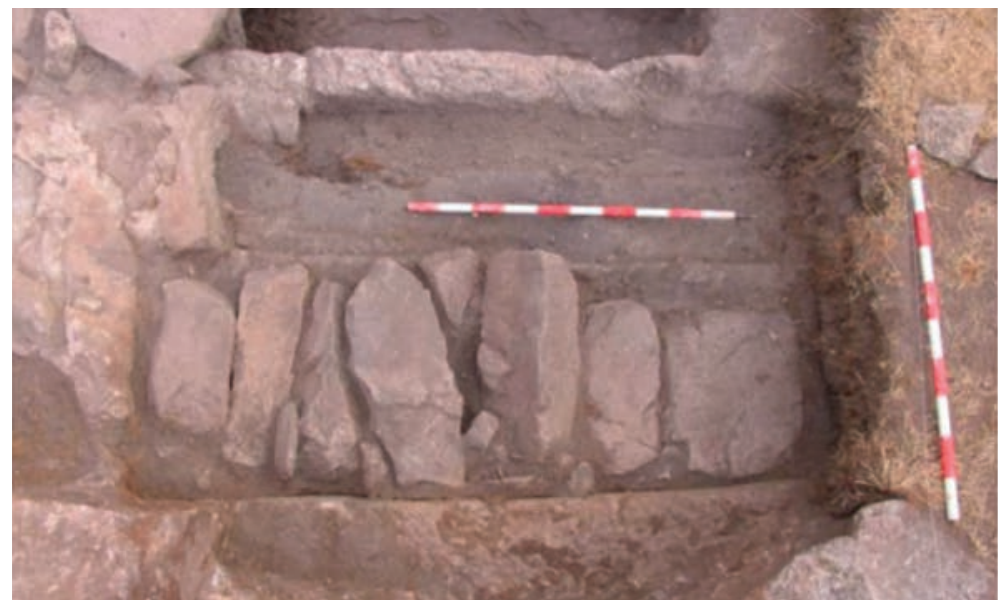

Fig. 22.

Entalles laterais no sartego XII Fuente: E. B. Nieto Muñiz

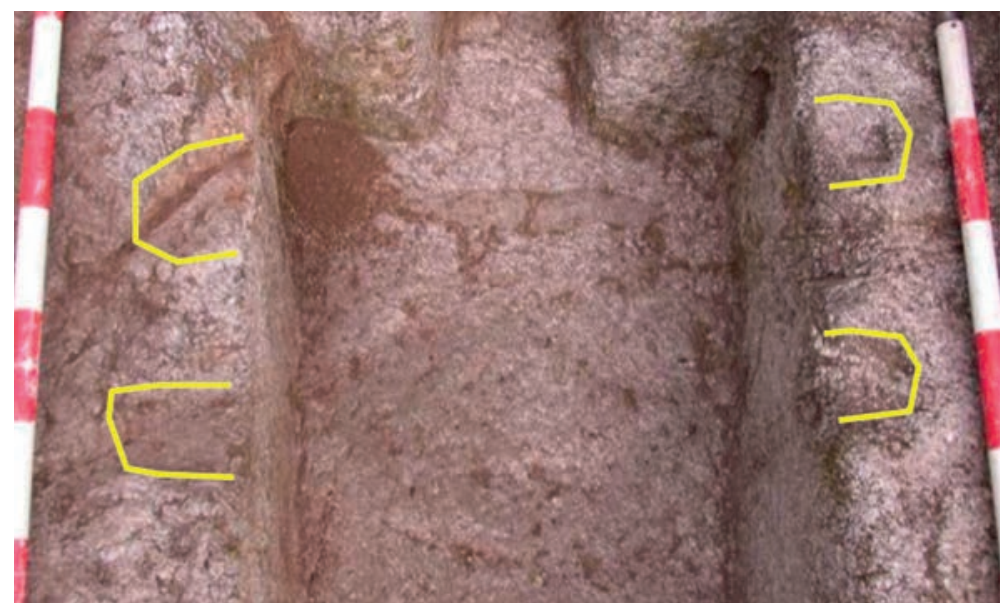


As laxas localizadas in situ sobre os sartegos tamén non se adaptan aos limites desta, se non que se ven colocadas de xeito irregular na súa maioría, o que parece falar de posibles recolocacións das mesmas, nun proceso de sucesivas aperturas para o enterramento de varios individuos ao longo de tempo, é dicir, unha reutilización do espazo sepulcral ${ }^{21}$.

Inda en ausencia das tampas, nalgúns sartegos, caso da T. X, T.XI e T.XII, consérvanse unhas marcas ou entalles laterais enfrontados que parecen testemuñar a presenza de travesaños, posiblemente de material perecedoiro, como a madeira. Estas marcas suxiren un sistema de reforzo para as tampas, ou incluso un tipo de cubrición alternativo aos das laxas pétreas, abríndose a hipótese dun sistema diferente de tampas, tal vez de madeira, que poderían ser logo cubertas de terra.

A reutilización do espazo sepulcral, xa indicada, faise evidente na aparición dun fragmento de mandíbula e molar do enterramento XXXII ${ }^{22}$, depositado entre aos pés dun segundo individuo. Este feito débese á práctica de amoreamento dos restos óseos do esquelete anterior aos pés do sartego no momento de enterrar ao seguinte. Este costume vese testemuñado noutros sartegos a través dun elemento físico: os osarios; que en San Vitor se detectaron de varios tipos. O máis claro deles é o da T.XVIII, onde presenta un apéndice inferior en forma de caixa rectangular; estrutura que se insinúa tamén na T.XIII, inda estando incompleta. Outros non están tan claros, pero identificáronse como tales unhas prolongacións certamente forzadas aos pés da T.XLIV e T.XLVI, que terían sido talladas con esa función.

A reutilización dos sartegos indica un dilatado uso da necrópole; como tamén o testemuña a superposición de varios deles sobre outros. É o caso da T.XXXI sobre a T.XXXII, onde a cabeceira da primeira corta a laxa dos pés da segunda, ou da T.XVI, obxecto dunha prolongación no sector da cabeceira, rompendo a aliñación coas veciñas e dándolle unha lonxitude fóra do normal que se explicaría por esa ampliación.

Ademais das datacións obtidas para o forno das campás e a «tumba privilexiada», que xunto coa inscrición na base de pena da capela sitúan o momento central do xacemento ao longo de todo o século $\mathrm{X}$, puidéronse analizar tamén as terras de varios enterramentos. O problema das datacións do interior dos sartegos é que foron tiradas dos carbóns que contiñan esas terras, sen poder ter determinado con exactitude o desfase correspondente á vida das madeiras das cales estas proceden ${ }^{23}$. Así, as idades calibradas en anos DC ofrecen un abano excesivamente elevado, de entre o século $\mathrm{V}$

\footnotetext{
${ }^{21}$ A testemuñada apertura das tampas para a reutilización do sartego podería tamén explicar a ausencia de enterramentos infantís en toda a necrópole.

${ }^{22}$ A T.XXXII foi o único enterramento que proporcionou restos óseos ademais da T.I. Con todo, ao contrario que nesta, os fragmentos recuperados estaban moi descompostos e carecían de coláxeno que permitise o seu estudo e análise. No caso da T.XXXII só permitiu adiviñar a disposición do corpo a través dos negativos das pernas e recuperar o molar indicado como testemuña do reaproveitamento do espazo de enterramento.

${ }^{23}$ Entre as que contamos dende urces ata carballos, de acordo ao estudo taxonómico levado a cabo.
} 
Fig. 23. Marcas con restos óseos na T.XXXII

Fuente: E. B. Nieto Muñiz

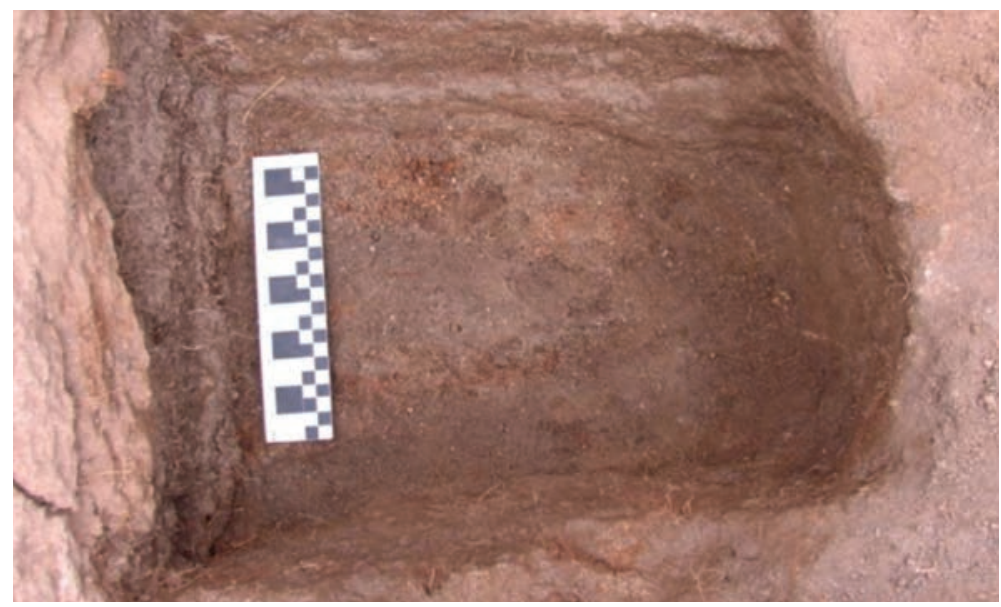

Fig. 24.

Sartego XVIII, con osario aos pés

Fuente: E. B. Nieto Muñiz

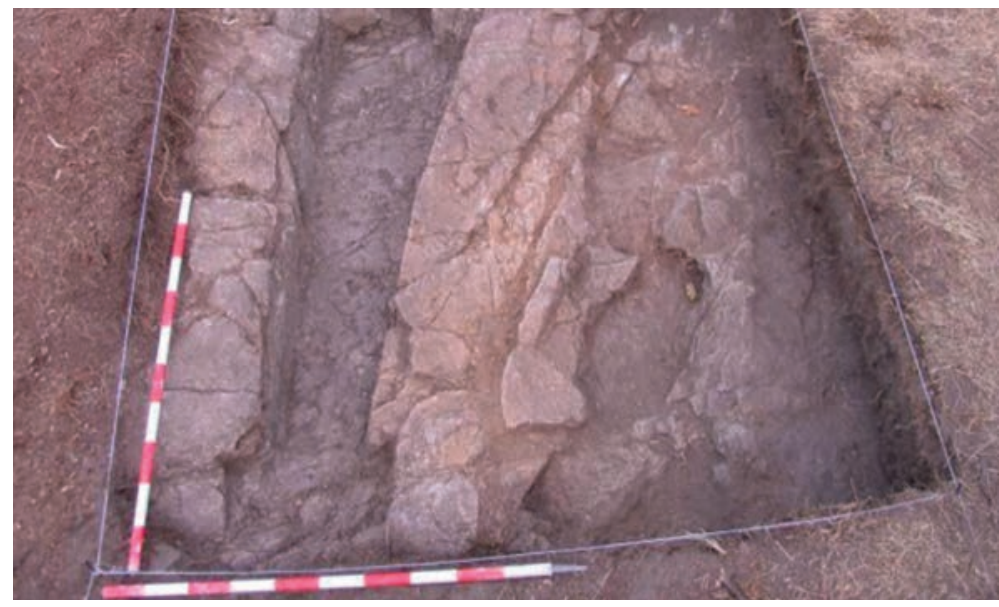

Fig. 25. Sartego XXXII cos pés cortados pola cabeceira de do XXXI

Fuente: E. B. Nieto Muñiz

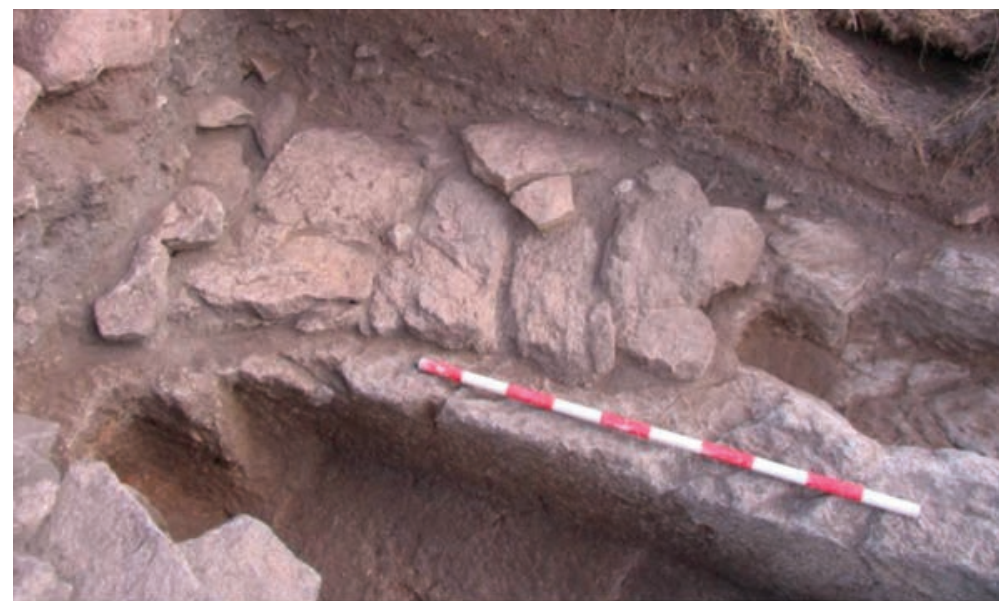


ata o mediados do XII, que en ningún caso se deben interpretar como data absoluta dos enterramentos, inda que si como data de referencia para o final destes. No alto da capela, en revolto e fóra de calquera dos sartegos, localizáronse tamén restos óseos humanos que se dataron no século XIV, o que de novo ofrece unha data de referencia para o final dun prolongado uso da necrópole, ou cando menos dos enterramentos dentro da capela.

Esta datación tardía vai parella ás proporcionadas polas moedas localizadas nos traballos de escavación, entre as que contamos un Cornado de Sancho IV de Castela (1284-1295), un Dinheiro de Fernando I de Portugal (1367-1383), un Real de Vellón de Henrique II de Castela (1369-1379) e un Ceitil de Afonso V de Portugal (1438-1481).

A estratigrafía de todo o xacemento é ben escasa, por non dicir nula. Deixando aparte os sartegos selados, os recheos ao redor do sartego mixto T.XLVIII e a área do forno das campás, no resto redúcese a un só nivel de terra disposto sobre o afloramento rochoso e cubrindo coa mesma o interior dos sartegos. Só na base da capela se identificaron dous niveis, ambos de derrube, no que se concentra a maioría do material exhumado. No alto da capela recuperouse tamén gran cantidade de restos nas fendas da rocha e na terra que cubría a súa superficie.

O material atopado é maioritariamente cerámico, sempre moi fragmentado, xunto coas moedas citadas, algún lítico, tacholas de bronce e ferros correspondentes a cravos, unha fibela de cinto e incluso unha punta de seta de tipoloxía plenomedieval. No interior dos sartegos, tanto os aparecidos abertos coma os selados, o material foi sempre moi escaso e a base de pequenos fragmentos cerámicos. No caso das tumbas seladas estes fragmentos terían chegado alí xunto coas terras empregadas para os enterramentos, e polo tanto procedentes da contorna inmediata.

Entre as cerámicas destacan, tanto no interior dos sartegos coma nos niveis superficiais, non poucos fragmentos de cerámica común de pasta marrón con engobe ou augada exterior, tanto laranxa, coma marrón clara ou avermellada, algúns deles con liñas de pintura branca. Un tipo cerámico con paralelos noutros xacementos medievais da contorna en contextos do século X a XII ${ }^{24}$. Ademais destes tipos, nos recheos exteriores da T.XLVIII recuperáronse varios fragmentos dunha xerra con decoración de liñas curvas incisas, de cronoloxía igualmente medieval, inda que tal vez algo máis tardía, pudendo chegar ata os século XIII ou XIV, e que nos marcaría o momento de construción do propio sartego.

No alto da capela, e nos derrubes ao pé da pena que a albergaba, recolléronse numerosos fragmentos de tégula, que nos leva de novo a tempos altomedievais ou incluso anteriores, inda que a ausencia de cerámica de adscrición clara a tempos previos ao medievo é absoluta.

\footnotetext{
${ }^{24}$ Nomeadamente en varios soares da cidade de Ourense escavados por nós mesmos.
} 


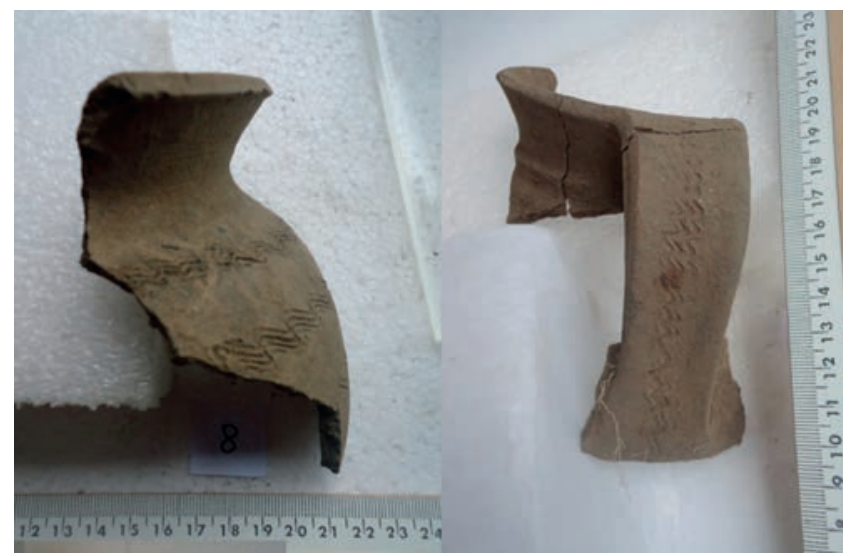

Fig. 26. Cerámica medieval atopada nos recheos exteriores da T.XLVIII Fuente: E. B. Nieto Muñiz

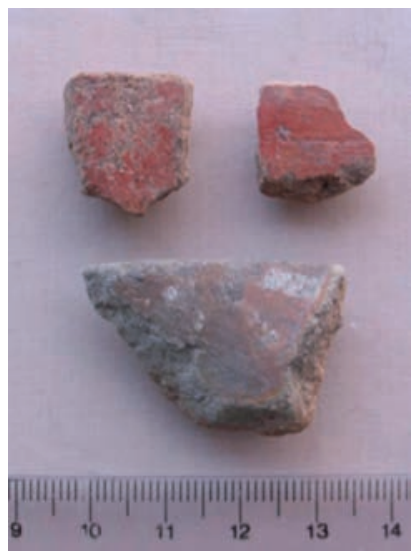

Fig. 27. Cerámicas engobadas atopadas no interior da T.VI. Fuente: E. B. Nieto Muñiz

Os datos arqueolóxicos recollidos permiten situar a orixe da necrópole e da capela, coma elementos indisociables, nos albores do século X. Os estudos documentais e históricos que acompañaron á investigación arqueolóxica non permiten dilatar o uso da necrópole máis alá do século XII, inda que a presenza de material de ata o século XV están a indicar a perduración do culto na capela ata este momento.

Os traballos de prospección desta paisaxe levados a cabo en paralelo ás intervencións arqueolóxicas no xacemento mostraron unha importante concentración de sitios medievais. Mesmo a carón do San Vitor, chegando de San Lourenzo, están Os Padróns, onde conflúen o camiño de Forcas e o que leva á necrópole, e onde a tradición oral fala da presenza de sartegos antropomórficos. A propia aldea de San Lourenzo está documentada coma unha das parroquias primitivas da contorna, conservando algún vestixio construtivo entre as súas casas. Ladeira abaixo, cara o norte, está a granxa do San Adrián, inda con restos arquitectónicos visibles, e cara o leste o San Miguel, onde se di había tumbas «como as do San Vitor». Augas arriba está San Salvador, con documentación doutra antiga capela e abondosos restos cerámicos medievais atopados en escavación arqueolóxica a carón de vellas construcións inda visibles. Na ladeira contraria documentouse A Penalba, nas aforas da aldea de Cristosende (A Teixeira), onde se di estaba «a antiga aldea e un cemiterio», e augas arriba a esta O Castelo, outro xacemento medieval caracterizado por unha alta peneda enfrontada coa do San Vitor. É moi suxestivo pensar nun control combinado do acceso a ribeira entre ambos. Unindo ambas ribeiras augas arriba está tamén a ponte medieval de Conceliñas, que leva ata o antigo priorado de Seoane Vello, primitiva fundación de Montederramo. 


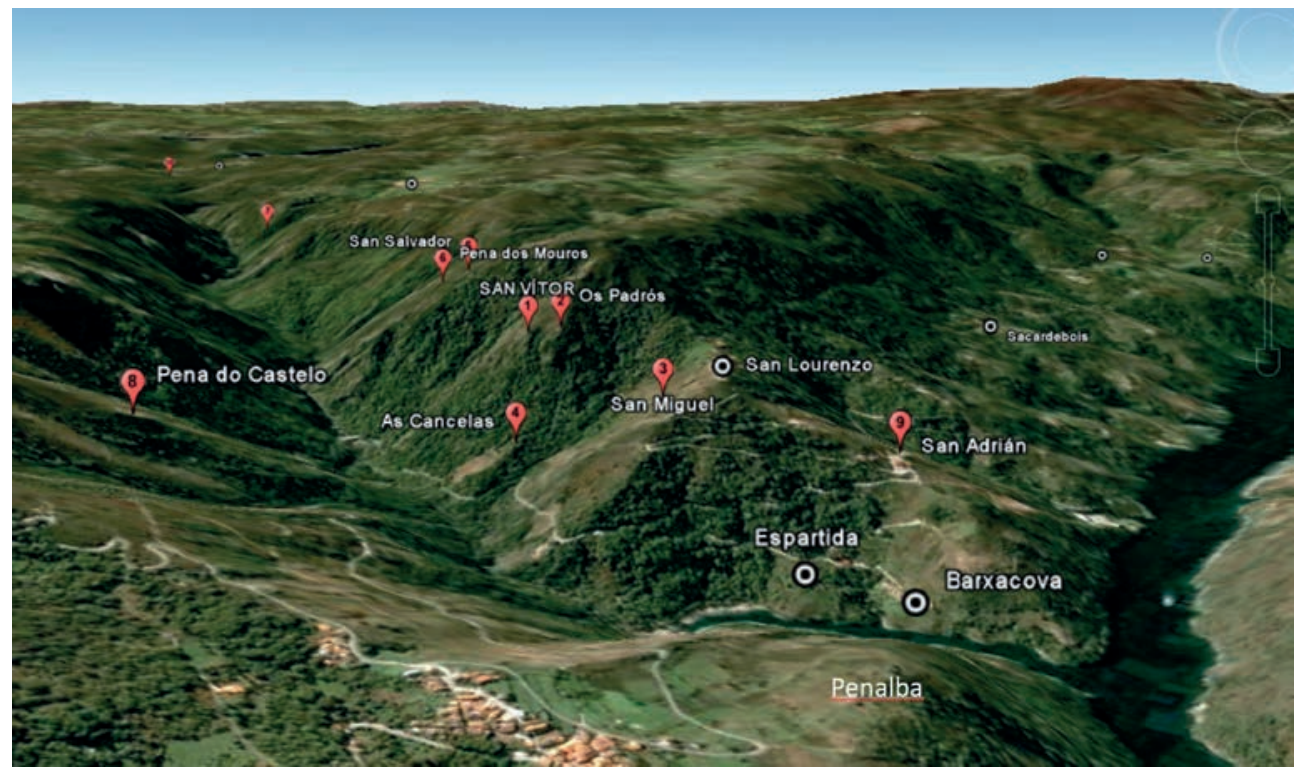

Fig. 28. Situación doutros sitios medievais vinculados co San Vitor na contorna do río Mao Fuente: E. B. Nieto Muñiz a partir de google maps

A posición estratéxica de San Vitor en relación á vía principal de comunicación coa rica zona ribeira non parece ser casual, contando cun dominio visual absoluto dos canóns do río Mao, hoxe ateigados de viñedos ${ }^{25}$. Coñecido é o costume de empregar coma lugares de enterramento lugares de referencia na comunidade, e este tería sido o caso do San Vitor, que podería ter xogado un papel destacado, xunto co Castelo mesmo enfronte, como atalaia para e control dese territorio en tempos incluso anteriores ao medievo ${ }^{26}$. Na escolla dese vello enclave como lugar sacralizado non tería sido allea tampouco a espectacularidade paisaxística do lugar.

Os estudos arqueolóxicos foron completados, ao longo dos anos que duraron as intervencións, coa recollida da tradición oral, na que destacamos o vínculo da Casa de Ivil coa necrópole, ademais da ampla análise documental dos fondos dos mosteiros de Santa Cristina de Ribas de Sil - en cuxo couto se atopaba teoricamente incluída a capela e necrópole de San Víctor - , Santo Estevo de Ribas de Sil, San Pedro de Rocas e San Vicenzo de Pombeiro.

\footnotetext{
${ }^{25}$ A importancia desta vía de acceso cara o Sil está testemuñada incluso en tempos prehistóricos, coa aparición da xa célebre espada de Forcas, datada no Bronce Medio, localizada nun penedío a comezos do século XX canda a construción da mesma canle hidráulica que levou ao descubrimento do San Vitor.

${ }^{26}$ Cómpre recordar que a ruta do Mao une o val do Sil, de coñecida riqueza aurífera, coa vía XVIII que transcorre polas zonas máis chairas das zonas altas.
} 
Fig. 29.

Vista xeral do xacemento Fuente: E. B. Nieto Muñiz
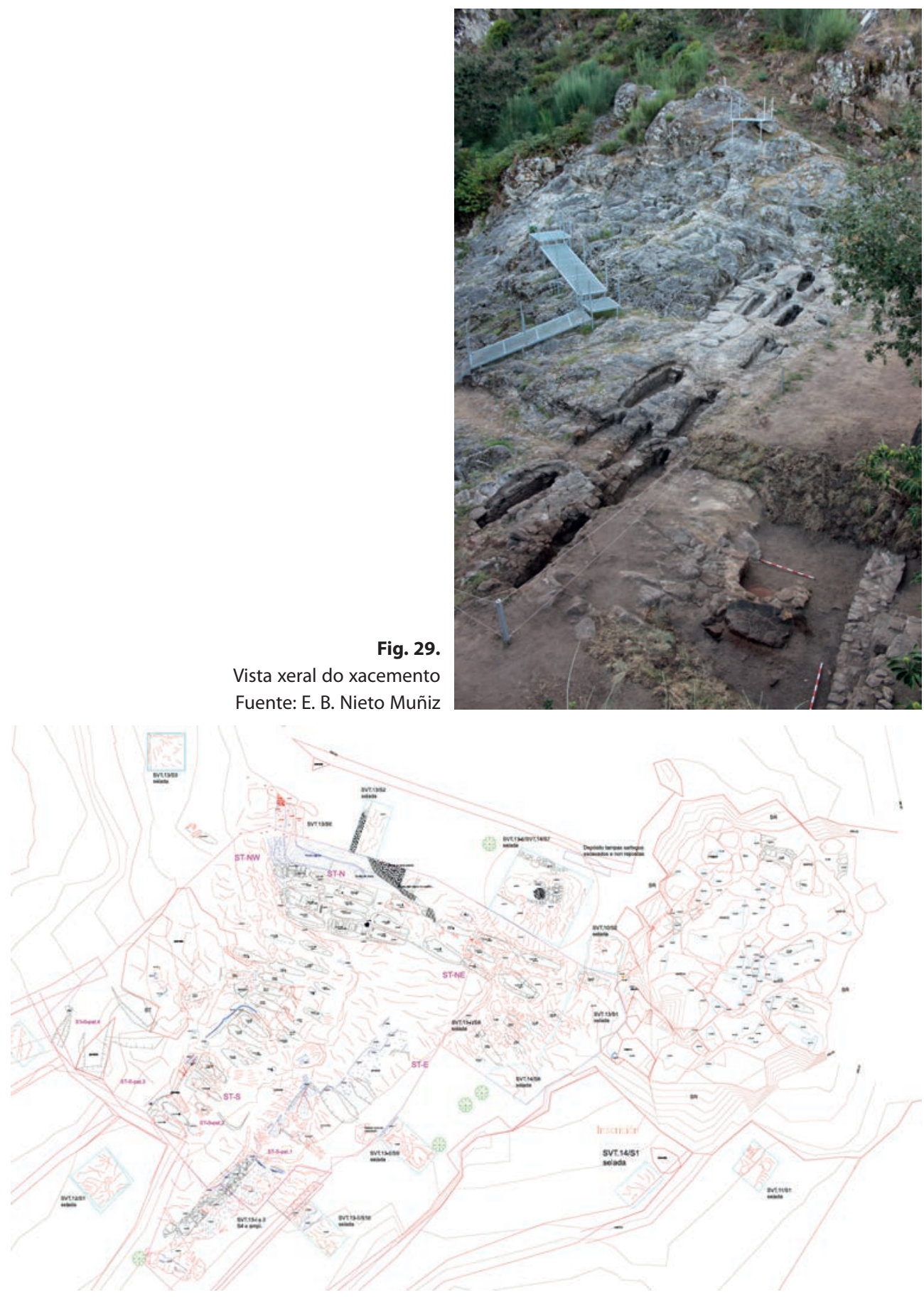

Fig. 30. Planimetría xeral do xacemento Fuente: E. B. Nieto Muñiz 
Como complemento aos traballos arqueolóxicos ao redor do San Vitor, relatados neste artigo, faise indispensable a detida lectura do artigo presentado nestas mesmas actas por Víctor Rodríguez Muñiz, relativos e asa análise documental.

\section{BIBLIOGRAFÍA}

ARIAS SANJURJO, Joaquin (1914). Una excursión a la Ribera Sagrada. «Boletín de la Comisión Provincial de Monumentos históricos y artísticos de Orense», Tomo V, n. ${ }^{\circ} 98$. Orense, pp. 49-52. BOLÓS MASCLANS, Jordi; PAGÉS PARETAS, Montserrat (1982). Les sepultures excavades a la roca. In RIU, Manuel, dir. Necropolis i sepultures medievals de Catalunya. Barcelona: Departament d'Historia Medieval, pp. 59-103.

CARBALLO CARBALLO, F. (1995). A Igrexa galega. In Historia de Galicia, Tomo 7. Vigo: A Nosa Terra. CASTRO PÉREZ, L. et al. (1996). Historia de Ourense. Oleiros: Vía Láctea.

DURO PEÑA, Emilio (1972). El monasterio de San Pedro de Rocas y su colección documental. Ourense: Instituto de Estudios Orensanos Padre Feijoo.

DURO PEÑA, Emilio (1977). Monasterio de S. Esteban de Ribas de Sil. Ourense: Instituto de Estudios Orensanos Padre Feijoo.

FARIÑA BUSTO, F.; SUÁREZ OTERO J. (1988). Arqueoloxía medieval en Galicia. Unha aproximación. «Traballos de Antropología e Etnología». 28: 3-4, 49-77.

FERREIRA PRIEGUE, Elisa (1988). Los caminos medievales de Galicia. Ourense : Museo Arqueolóxico Provincial de Ourense. Anexo 9.

FREIRE CAMANIEL, José (1998). El Monacato Gallego en la Edad Media. A Coruña: Fundación Barrié de la Maza, I, pp. 220-223.

GALLEGO DOMÍNGUEZ, Olga (1988). La organización administrativa territorial de la antigua provincia de Ourense a mediados del siglo XVIII. Anexo 10, Boletín Avriense. Ourense.

GARCÍA TATO, Isidro (2004). Las encomiendas gallegas de la Orden militar de San Juan de Jerusalén. Estudio y edición documental. Tomo I, Época medieval. Santiago de Compostela: Instituto de Estudios Gallegos 'Padre Sarmiento'- C.S.I.C. - Xunta de Galicia.

LÓPEZ QUIROGA, Jorge; RODRÍGUEZ LOVELLE, Mónica (1991). As sepulturas antropomorfas en rocha e a súa problemática histórica - unha proposta para o seu estudo. «Revista Larouco». 1, 61-77.

LOPEZ QUIROGA, Jorge (2004). El final de la antigüedad en la Gallaecia - la transformación de las estruturas de poblamiento entre Miño y Duero (siglos V al X). A Coruña: Fundación Pedro Barrié de la Maza.

LOPEZ QUIROGA, Jorge (2009). Arqueología del hábitat rural en la Península Ibérica (siglos V-X). Madrid: La Ergástula.

LOPEZ QUIROGA, Jorge (2010). Arqueología del mundo funerario en la Península Ibérica (siglos V-X). Madrid: La Ergástula.

MARTÍN VISO, Iñaki (2007). Tumbas y sociedades locales en el centro de la península en la alta edad media - el caso de la comarca de Riba Côa (Portugal). «Arqueología y Territorio Medieval». 14, 21-47.

NIETO MUÑIZ, Eduardo-Breogán (2010). Estudo, limpeza e mantemento do despoboado de San Vítor (San Lourenzo de Barxacova, Parada de Sil, Ourense). Informe valorativo de intervención arqueolóxica.

NIETO MUÑIZ, Eduardo-Breogán (2011). Estudo, limpeza e mantemento do despoboado de San Vitor (San Lourenzo de Barxacova, Parada de Sil, Ourense). Informe valorativo de intervención arqueolóxica.

NIETO MUÑIZ, Eduardo-Breogán (2012). Limpeza, mantemento, estudo, ampliacion da área escavada e sondaxes en novos sectores na necrópole rupestre de San Vitor e no enclave de San Salvador (San Lourenzo de Barxacova, Parada de Sil, Ourense). Informe valorativo de intervención arqueolóxica. 
NIETO MUÑIZ, Eduardo-Breogán (2013a). Limpeza, mantemento e sondaxe valorativas no contorno da necrópole rupestre de San Vitor (San Lourenzo de Barxacova, Parada de Sil, Ourense). Informe valorativo de intervención arqueolóxica.

NIETO MUÑIZ, Eduardo-Breogán (2013b). Romanos en San Vitor. In Actas de las V Jornadas de Jóvenes en Investigación Arqueológica, Arqueología para el Siglo XXI, Santiago de Compostela (maio 2012). Madrid, pp. 126-130.

NIETO MUÑIZ, Eduardo-Breogán (2014a). Ampliación de sondaxes da $4^{a}$ campaña de escavacións na necrópole rupestre de San Vitor (Parada de Sil, Ourense). Informe valorativo de intervención arqueolóxica.

NIETO MUÑIZ, Eduardo-Breogán (2014b). Limpeza, consolidación, acondicionamento xeral e escavación para ampliación da área visitable, rexistro completo e toma de mostras na necrópole rupestre de San Vitor (San Lourenzo de Barxacova, Parada de Sil, Ourense). Informe valorativo de intervención arqueolóxica.

NIETO MUÑIZ, Eduardo-Breogán (2014c). A necrópole rupestre de San Vitor (San Lourenzo de Barxacova, Parada de Sil, Ourense) - algo máis cunha necrópole rupestre. In LÓPEZ QUIROGA, Jorge; MARTÍNEZ TEJERA, A.M., ed. In concavis petrarunt habitaverunt. El fenómeno rupestre en el Mediterráneo medieval - De la investigación a la puesta en valor. Oxford: British Archeology Resorts (BAR, International Series 2591), pp. 84-116.

NIETO MUÑIZ, Eduardo-Breogán (2014d). Achádegos cerámicos na necrópole rupestre de San Vitor de Barxacova (Parada de Sil, Ourense). In DE MAN, A.; TENTE, C. ed. Estudos de Cerâmica Medieval, o Norte e Centro de Portugal (ss. IX-XII). Lisboa: IEM, pp. 235-240.

NIETO MUÑIZ, Eduardo-Breogán (2016). Control e seguimento arqueolóxico da actuación de protección e mellora na necrópole rupestre de San Vitor de Barxacova (Parada de Sil, Ourense). Informe valorativo de intervención arqueolóxica.

NIETO MUÑIZ, Eduardo-Breogán; BUCETA BRUNETI, G. (2015). Consolidación, mantemento e control biolóxico na necrópole de San Vitor de Barxacova (Parada de Sil, Ourense). Informe valorativo de intervención arqueolóxica.

NIETO MUÑIZ, Eduardo-Breogán; BUCETA BRUNETI, G. (2016). Proposta de consolidación, mantemento e control biolóxico na necrópole de San Vitor de Barxacova (Parada de Sil, Ourense). Informe valorativo de intervención arqueolóxica.

RIVAS FERNÁNDEZ, Xosé Carlos (1981). Vestigios perrománicos de algunos olvidados monasterios y eremitorios orensanos. «Boletín Avriense». 11, 49-199.

RIVAS FERNÁNDEZ, Xosé Carlos (2003). Antigüedad del episcopando auriense. Ourense: Duen de Bux.

RODRÍGUEZ MUÑIZ, Víctor (2010). O mosteiro de Santa Cristina de Ribas de Sil na Idade Media. «Boletín Avriense». Anexo 32.

RODRÍGUEZ RESINO, A. (2005). Do Imperio Romano á Alta Idade Media, arqueoloxía da tardoantigüidade en Galicia (séculos V-VIII). Noia: Toxosoutos. 


\title{
SEPULTURAS ESCAVADAS NA ROCHA DA REGIÃO DE BRAGANÇA: CONTRIBUTO PARA O ESTUDO DO POVOAMENTO MEDIEVAL
}

\author{
ANA MARIA DA COSTA OLIVEIRA*
}

\begin{abstract}
Resumo: Pretende-se proceder ao inventário, sistematização e estudo das sepulturas escavadas na rocha e analisar a sua relação com os elementos estruturadores do território, expressa em povoados, estruturas fortificadas e templos. Esta análise poderá proporcionar informação fundamental para o conhecimento e compreensão do povoamento medieval na região do nordeste transmontano. Esta leitura integrada possibilitará esboçar uma proposta de evolução da ocupação humana desta região fronteiriça, identificando zonas preferenciais ou estratégicas de fixação e possíveis matrizes de povoamento que caracterize momentos-chave da sua história.
\end{abstract}

Palavras-Chave: Sepulturas; Trás-os-Montes; Território; Povoamento.

Abstract: In this paper we present the inventory, systematization and study of the rock-cut graves of the northeast area of Trás-os-Montes (Vinhais, Bragança, Vimioso and Miranda do Douro) and seek to analyze its relation with settlements, military structures, and religious buildings. We expect that this integrated view will help to understand and develop a proposal of the human occupation of this border region, identifying preferential or strategic areas of settlement and possible settlement matrices that could characterize the key moments of its history.

Keywords: Rock-cut graves; Trás-os-Montes; Territory; Settlement.

\section{INTRODUÇÃO}

O levantamento e análise das sepulturas escavadas na rocha, localizadas na região leste transmontana (concelhos de Vinhais, Bragança; Vimioso e Miranda do Douro), foi realizado no contexto do nosso estudo sobre o povoamento medieval neste território que, a dado momento, foi determinado pelo desenho de uma fronteira e a consequente necessidade da sua defesa através de castelos. Este processo, longo e complexo, sustenta a nossa investigação no âmbito do doutoramento em Estudos do Património - Arqueologia, na FLUP, com o título Os castelos e a fronteira entre Vinhais e Miranda do Douro (Séc. XI-XVI): estratégias e diálogos na raia transmontana, iniciado em 2016 e que conta com o apoio da FCT e do CITCEM.

A evolução do povoamento transmontano, impulsionado pelos monarcas, pelos nobres e pela Igreja, materializou-se em diferentes realidades deixando ao longo dos tempos marcas e testemunhos na paisagem que nos ajudam a compreender o pas-

\footnotetext{
* Bolseira da FCT. Doutoranda em Estudos do Património (Arqueologia). CITCEM. Email: anamcoliveira@gmail.com.
} 
sado. Entre estes testemunhos contam-se as sepulturas escavadas na rocha; os templos e outros espaços sagrados; os habitats de diferentes tipologias; as vias e, claro, as estruturas defensivas que garantiam a defesa das populações e dos seus bens e a manutenção do território: os castelos.

Ancorados nestas extraordinárias estruturas que são os castelos, e na sua importância enquanto marcos territoriais, pretendemos identificar fases estruturantes da ocupação do espaço transmontano ao longo de um período temporal extenso, balizado entre o «nascimento» do reino de Portugal e os alvores da modernidade.

Dada a escassez e limitação da documentação escrita para períodos que marcam os inícios da Idade Média, torna-se incontornável a análise arqueológica dos «vestígios» deixados pelas populações, nomeadamente, os locais de enterramento e a sua associação a habitats, templos, fortificações, etc. Ora dentro da realidade funerária, as sepulturas escavadas na rocha tornaram-se elementos incontornáveis para a análise da ocupação e entendimento do território, não só pela sua originalidade como pela sua prevalência enquanto "vestígio».

A falta de estudos sistemáticos sobre estas formas de enterramento para a região leste transmontana, obrigou-nos a recolher, sistematizar e analisar o que se encontrava disperso pela bibliografia, pelas bases de dados online, nas cartas arqueológicas e em relatórios de trabalhos arqueológicos entretanto realizados. Deste trabalho resultou não só a compilação de dados sobre sepulturas escavadas na rocha, mas também sobre outras formas de enterramento, que interessam para o nosso estudo, mas não para o contexto deste artigo. Os elementos recolhidos foram sistematizados e depois verificados em visitas aos locais, possibilitando assim uma abordagem e conhecimento real da região.

\section{O TERRITÓRIO}

Tendo a fronteira nordeste transmontana, entre Vinhais e Miranda do Douro, como foco de estudo, definimos os atuais concelhos administrativos de Vinhais, Bragança, Vimioso e Miranda do Douro como área de análise. Os limites atuais destes municípios não correspondem às diferentes divisões administrativas que, ao longo da Idade Média, desenharam esta região. Dada a complexidade e a dificuldade em definir com precisão estas antigas divisões, e tendo em conta que o eixo do nosso estudo é a fronteira, pensamos ser mais conveniente tomar os limites administrativos atuais como termos para balizar a nossa análise, enquadrando os territórios e os seus elementos nos termos medievais correspondentes a cada época.

Em termos geográficos e geológicos, esta região fronteiriça apresenta uma complexa e diversificada caracterização que resulta na coexistência de diferentes realidades num espaço que fisicamente se encontra mais ou menos delimitado.

Assim, e no extremo oeste da região, a área de estudo está definida pelos rios Mente e Rabaçal; a sul, as serras da Padrela, Nogueira e Mogadouro, que servem de barreira 


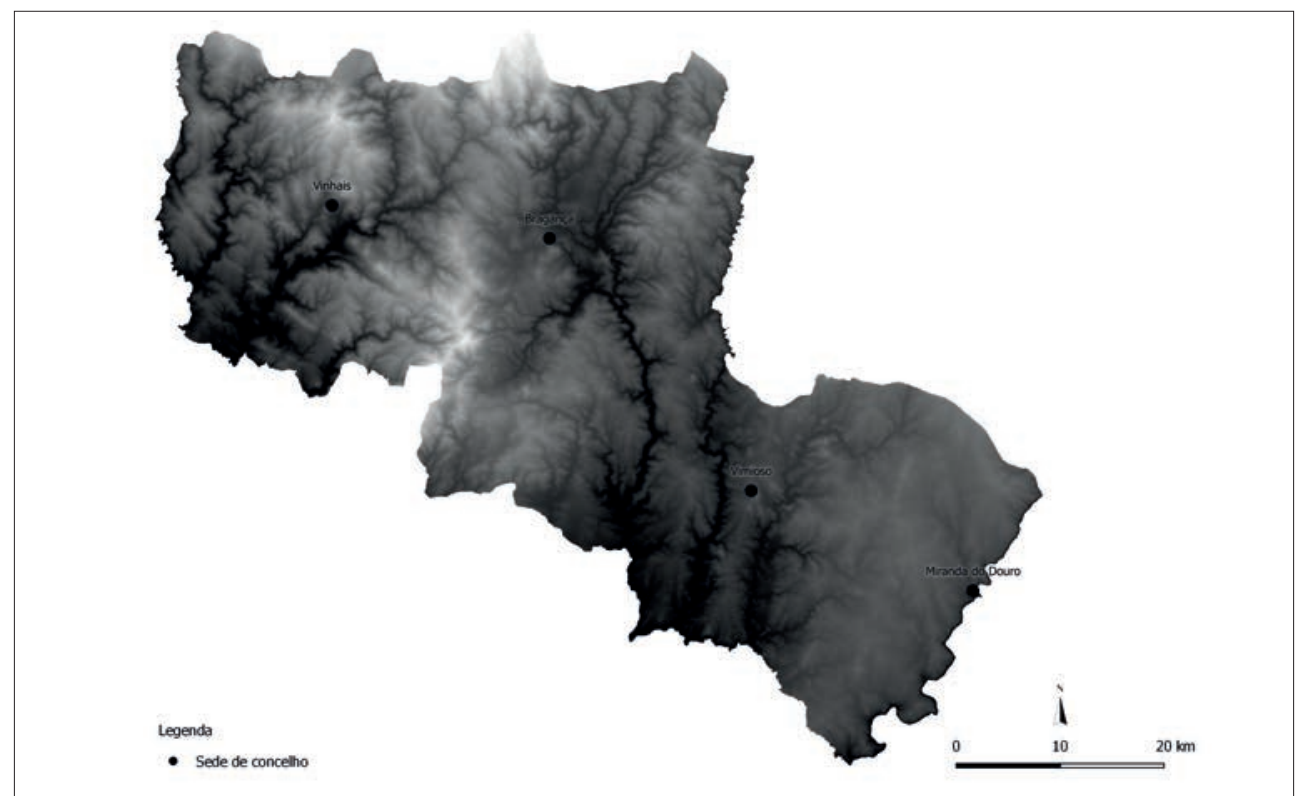

Mapa 1. Área de estudo

Fonte: César Guedes

ao vale do Douro, marcam também os nossos limites. A norte, a linha desenhada passa pelas serras da Coroa e de Montesinho; e a leste a fronteira é o rio Maçãs e o rio Douro.

Relativamente à rede hidrográfica, e para além dos já referidos rios Maças e Douro, interessa sublinhar a importância dos rios Tuela e, sobretudo, do Sabor, que cortam, juntamento com outros rios menores, o território de norte para sul e de oeste para leste, ou vice-versa, sendo todos tributários do rio Douro o «grande coletor ibérico» ${ }^{1}$.

Em termos geológicos, «estamos perante um quadro geológico de grande complexidade», cuja explicação não interessa para este artigo. Interessa apenas sublinhar que na "parte ocidental [...], predominam rochas como os xistos, os quartzitos, e os anfibolitos, entre outras», e na parte mais oriental da região de estudo, "predominam rochas magmáticas intrusivas e filonianas, como os granitos e algumas rochas metamórficas, como os metagrauvaques e os gnaisses» ${ }^{2}$.

Simplificando, podemos concluir que temos granitos em Vimioso, em Miranda do Douro e em toda a faixa da fronteira da região de Bragança e Vinhais, sendo a zona central de Vinhais, Bragança e um pouco de Vimioso, predominantemente xistosa.

Uma parte substancial deste território tem altitudes superiores aos $700 \mathrm{~m}$, como é o caso da serra da Nogueira, de Montesinho e da Coroa. Contudo, o que aqui ganha destaque são os planaltos que se estendem entre Bragança e Vimioso, bem como o de

\footnotetext{
${ }^{1}$ MEIRINHOS, 2014: 25.

2 MEIRINHOS, 2014: 22.
} 
Miranda do Douro, que têm altitudes que rondam os 600-800 m. Estas planuras são interrompidas por elevações, «cujos topos se elevam entre 200 e 300 metros acima da Superfície Fundamental» ${ }^{3}$, ou por canais de água, por vezes vincados por ligeira cumeada ${ }^{4}$. Destes canais destacam-se os rios Sabor e Douro, cujas vertentes abruptas quebram a sequência dos planaltos.

\section{AS FONTES DE ESTUDO}

Neste vasto território, de contrastes acentuados, a fixação de populações foi sempre um desafio. Os registos, gradualmente acrescentados, vão indicando uma contínua fixação de gente, cuja expressão está longe de ser esclarecedora por falta de elementos e de estudos aprofundados.

A bibliografia analisada, da qual destacamos os trabalhos de Francisco Manuel Alves (Abade de Baçal) e de Francisco Sande Lemos, por serem abrangentes e abarcarem todo o território em estudo, apresentam, muitas vezes, informações ambíguas, baseadas em referências mais antigas que, por sua vez, se fundamentaram em depoimentos orais, cuja memória atual já não recorda e não conhece.

A identificação de sepulturas escavadas na rocha com base na bibliografia levanta muitas dúvidas e imprecisões. As informações deixadas pelos autores são quase sempre escassas e imprecisas quanto a localizações, tipos de sepulcros, número de túmulos e o seu estado de conservação.

Até à data, não existe nenhum trabalho de sistematização, com indicações precisas sobre este tipo de estruturas. O que mais se aproxima a uma compilação de dados, com opções de pesquisa e informações adicionais, como a localização ou bibliografia é a base de dados Endovélico, disponível no Portal do Arqueólogo ${ }^{5}$.

Os inventários arqueológicos, realizados no âmbito das revisões dos Planos Diretores Municipais e, principalmente, os trabalhos de escavação arqueológica ${ }^{6}$, contribuíram significativamente para o estudo dos locais de enterramento da Idade Média na região leste transmontana. Embora estes trabalhos sejam ainda diminutos e parcelares - dado que quase sempre correspondem a escavações de natureza preventiva ou de emergência, ou a planos de trabalhos de curta duração, onde nem sempre as necrópoles são totalmente registadas e as sepulturas não são escavadas na sua totalidade - eles têm revelado até agora uma diversidade de localizações e, sobretudo, uma certa continuidade dos espaços de enterramento, aspeto que trataremos mais à frente.

\footnotetext{
${ }^{3}$ RODRIGUES, DIAS, ALVES, 2009: 249.

${ }^{4}$ MEIRINHOS, 2014: 21.

${ }^{5}$ Disponível em <http://arqueologia.patrimoniocultural.pt>.

${ }^{6} \mathrm{O}$ levantamento dos relatórios dos trabalhos arqueológicos realizados na região, até à data de setembro de 2016, teve como base o Portal do Arqueólogo, contatos com os municípios e publicações monográficas. Foi feita uma seleção dos trabalhos cujo objeto de intervenção ou resultados integrassem no período cronológico em estudo (séculos XI-XVI). Num total de 31 processos de trabalhos arqueológicos, foram consultados 46 relatórios.
} 
Esta lacuna no estudo dos modos de enterramento na Idade Média transmontana, e particularmente das sepulturas escavadas na rocha, constituía um obstáculo para a compreensão da ocupação territorial desta região.

Tornava-se, pois, urgente proceder a uma sistematização de dados, com referências a pormenores imprescindíveis para a compreensão da sua ocorrência. Este trabalho tem que ser feito de forma rigorosa sob pena de se perder muita informação. Neste momento, e considerando o universo de sepulcros inventariados, deparámo-nos com um número significativo de estruturas (cerca de 18\%) que não têm outro tipo de informação senão a da sua existência. Outras indicam unicamente a sua tipologia/ planta. Esta escassez de informação, associada ao desaparecimento das estruturas, causou a perda irremediável de um conjunto importante de referentes que poderiam caracterizar melhor as necrópoles desta região. A urgência da sua sistematização e estudo continuam prementes, pois os investimentos agrícolas que se têm intensificado desde os anos 80 da centúria passada, nomeadamente o plantio de soutos e de olival, bem como a abertura de caminhos agrícolas e estradas municipais, têm ignorado estes vestígios e contribuído para a sua destruição silenciosa.

\section{SEPULTURAS ESCAVADAS NA ROCHA DO NORDESTE TRANSMONTANO}

Comparativamente com outras regiões, nomeadamente o vale do Douro, a região leste transmontana apresenta uma grande escassez de registos de sepulturas escavadas

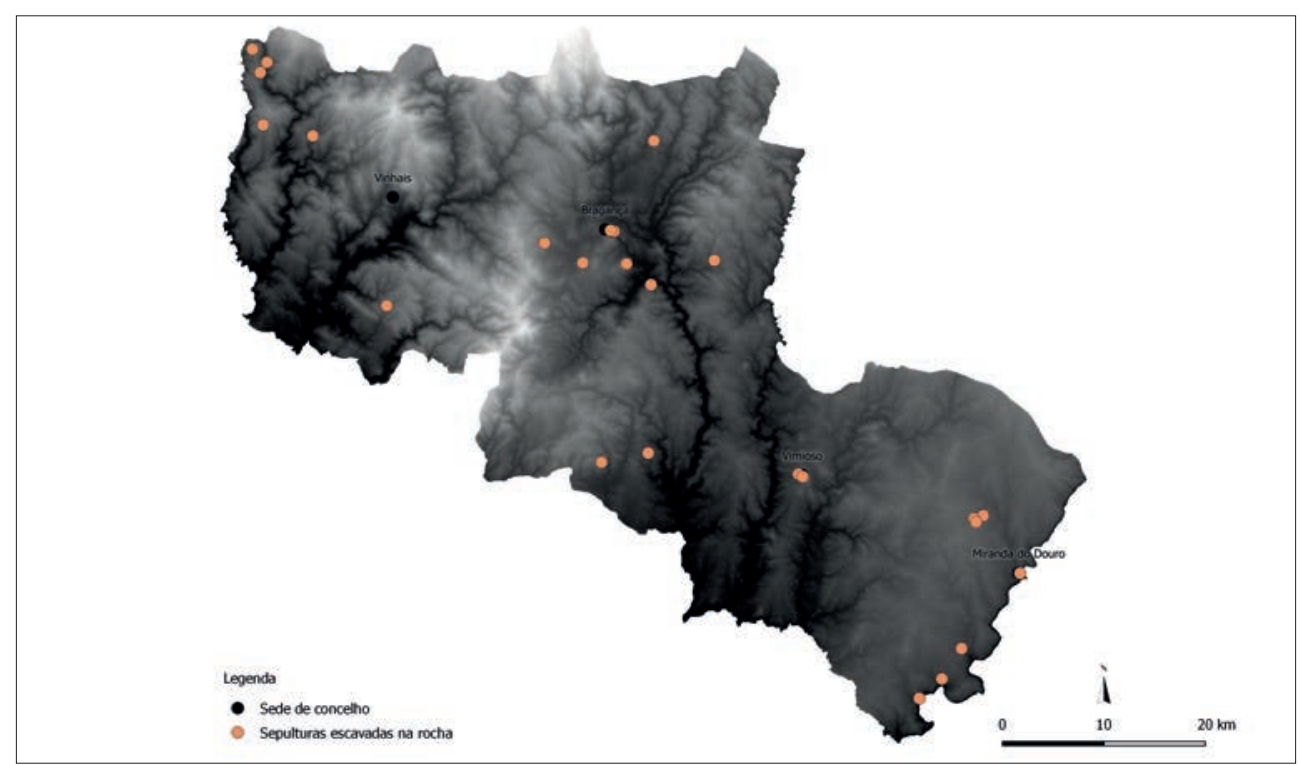

Mapa 2. Sítios inventariados com sepulturas escavadas na rocha no nordeste transmontano Fonte: César Guedes 
na rocha. No total, foram inventariados 26 locais, 8 dos quais sem informação quanto ao número de sepulcros. Nos restantes 18 locais, foram contabilizadas 68 sepulturas para uma área com cerca de $7000 \mathrm{~km}^{2}$. Do número total de sepulcros, apenas observamos e registamos no terreno 4 monumentos; 40 das sepulturas foram escavadas em trabalhos arqueológicos e as restantes apenas foram identificadas ou surgem referidas na bibliografia.

Tabela 1. Quadro dos locais com sepulturas escavadas na rocha

\begin{tabular}{|c|c|c|c|c|c|c|}
\hline \multicolumn{7}{|c|}{ Vinhais } \\
\hline Cód. & Sítio & $\begin{array}{l}\text { Lugar/ } \\
\text { Freguesia }\end{array}$ & CNS & $\begin{array}{l}\text { No } \\
\text { SER }\end{array}$ & Fontes & OBS \\
\hline SERF2 & Souane & Quirás & - & $?$ & ALVES, 2000, X: 253. & Não identificada \\
\hline SERPF4 & Lagoa de Cisterna & Quirás & 18165 & $?$ & $\begin{array}{l}\text { Portal do Arqueólogo. } \\
\text { Plano Diretor Municipal de } \\
\text { Vinhais, } 2009 . \\
\text { ALVES, 2000, IX: } 692 . \\
\text { LEMOS, 1993, II: } 454 .\end{array}$ & Destruídas \\
\hline SERT1 & Poula dos Mouros & $\begin{array}{l}\text { Vilar Seco } \\
\text { de Lomba }\end{array}$ & 5089 & 22 & $\begin{array}{l}\text { Portal Arqueólogo. } \\
\text { Plano Diretor Municipal de } \\
\text { Vinhais, } 2009 . \\
\text { ALVES, 2000, IX: } 693 . \\
\text { ALVES, 2000, X: } 228 . \\
\text { LEMOS, 1993, II: } 468 .\end{array}$ & Não visíveis \\
\hline SERT5 & Santa Locaia & Santalha & 19078 & 1 & Portal do Arqueólogo. & Destruída \\
\hline SERTH6 & $\begin{array}{l}\text { Igreja de Penhas } \\
\text { Juntas }\end{array}$ & $\begin{array}{l}\text { Penhas } \\
\text { Juntas }\end{array}$ & 18022 & $?$ & Portal do Arqueólogo. & - \\
\hline SERTPF3 & Santa Rufina & \begin{tabular}{|l|} 
Pinheiro \\
Novo
\end{tabular} & 18993 & 2 & $\begin{array}{l}\text { Portal do Arqueólogo. } \\
\text { LEMOS, 1993, II: 453-454. }\end{array}$ & Identificadas \\
\hline \multicolumn{7}{|c|}{ Bragança } \\
\hline Cód. & Sítio & $\begin{array}{c}\text { Lugar/ } \\
\text { Freguesia }\end{array}$ & CNS & $\begin{array}{r}\text { No } \\
\text { SER }\end{array}$ & Fontes & OBS \\
\hline SER22 & Martim Cansado & Samil & - & $?$ & $\begin{array}{l}\text { ALVES, 2000, IX: } 693 . \\
\text { LEMOS, 1993, II: 131-132. } \\
\text { LOPO, 1987: } 59 .\end{array}$ & Não visíveis \\
\hline SERT18 & São Cláudio & Gostei & 2834 & 2 & Portal do Arqueólogo. & Destruídas \\
\hline SERT23 & Alto do Outeiro & Alfaião & 17315 & 6 & Portal do Arqueólogo. & Não identificadas \\
\hline SERT24 & Senhora do Aviso & Serapicos & 17617 & 1 & $\begin{array}{l}\text { Portal do Arqueólogo. } \\
\text { LEMOS, 1993, II: } 135 .\end{array}$ & Não visível \\
\hline SERTH19 & $\begin{array}{l}\text { Quinta São } \\
\text { Lourenço }\end{array}$ & Samil & 17576 & $?$ & $\begin{array}{l}\text { Portal do Arqueólogo. } \\
\text { ALVES, 2000, X: 62-64. } \\
\text { LEMOS, 1993, II: 130-131. }\end{array}$ & Destruídas \\
\hline SERTH20 & Vale de Igrejas & Aveleda & 17332 & 1 & Portal do Arqueólogo. & Destruída \\
\hline SERTH21 & $\begin{array}{l}\text { Igreja de São } \\
\text { Lourenço }\end{array}$ & Milhão & 17470 & 1 & $\begin{array}{l}\text { Portal do Arqueólogo. } \\
\text { LEMOS, 1993, II:109. } \\
\text { LOPO, 1987: } 60 .\end{array}$ & Destruída \\
\hline SERTH25 & São Justo & Calvelhe & 17299 & $?$ & Portal do Arqueólogo. & Não visíveis \\
\hline SERTH26 & $\begin{array}{l}\text { Igreja de São } \\
\text { Francisco }\end{array}$ & $\begin{array}{l}\text { Santa Maria/ } \\
\text { Cidade }\end{array}$ & 4696 & 18 & $\begin{array}{l}\text { Portal do Arqueólogo. } \\
\text { Relatórios Trabalhos. }\end{array}$ & Não visíveis \\
\hline SERTH37 & Igreja São João & $\begin{array}{l}\text { Santa Maria/ } \\
\text { Cidade }\end{array}$ & - & 1 & $\begin{array}{l}\text { BRAGANÇA, 2008: 67-151. } \\
\text { BRAGANÇA, 2004: 47-97. }\end{array}$ & Não visível \\
\hline SERTH40 & $\begin{array}{l}\text { Capela São } \\
\text { Sebastião }\end{array}$ & $\begin{array}{l}\text { Santa Maria/ } \\
\text { Cidade }\end{array}$ & - & 2 & BRAGANÇA, 2004: 47-97. & Não visível \\
\hline
\end{tabular}




\begin{tabular}{|c|c|c|c|c|c|c|}
\hline \multicolumn{7}{|c|}{ Vimioso } \\
\hline Cód. & Sítio & $\begin{array}{c}\text { Lugar/ } \\
\text { Freguesia }\end{array}$ & CNS & $\begin{array}{r}N^{\circ} \\
\text { SER }\end{array}$ & Fontes & OBS \\
\hline SERTH52 & Cruzes & Vimioso & 4549 & 3 & $\begin{array}{l}\text { Portal do Arqueólogo. } \\
\text { Plano Diretor Municipal de } \\
\text { Vinhais (2015). } \\
\text { ALVES, 2000, VI: } 575 . \\
\text { LEMOS, 1993, II: } 431 .\end{array}$ & Não visíveis \\
\hline SERTH53 & Igreja Matriz & Vimioso & - & 1 & $\begin{array}{l}\text { Plano Diretor Municipal de } \\
\text { Vinhais (2015). } \\
\text { ALVES, } 2007 .\end{array}$ & Não visível \\
\hline \multicolumn{7}{|c|}{ Miranda do Douro } \\
\hline Cód. & Sítio & $\begin{array}{c}\text { Lugar/ } \\
\text { Freguesia }\end{array}$ & CNS & $\begin{array}{r}N^{\circ} \\
\text { SER }\end{array}$ & Fontes & OBS \\
\hline SER76 & Fraga da Penhalta & Malhadas & - & $?$ & $\begin{array}{l}\text { SALGADO, 2013: 53-54. } \\
\text { ALVES, 2000, IX: 637. }\end{array}$ & Não identificado \\
\hline SERH75 & Cortinha do Poço & Malhadas & - & 1 & ALVES, 2000, IX: 636-637. & Não identificada \\
\hline SERTH65 & Capela São Paulo & Sendim & 2228 & 1 & $\begin{array}{l}\text { Portal do Arqueólogo. } \\
\text { SALGADO, 2013: } 197 . \\
\text { LEMOS, 1993, II: 246-247. }\end{array}$ & Identificada \\
\hline SERTH66 & $\begin{array}{l}\text { Igreja Matriz de } \\
\text { Picote }\end{array}$ & Picote & - & $?$ & $\begin{array}{l}\text { ALVES, 2000, X: 815-818. } \\
\text { LEMOS, 1993, II: 244-245. } \\
\text { LOPO, 1987: 105-106. }\end{array}$ & Não visíveis \\
\hline SERTH68 & $\begin{array}{l}\text { Igreja Matriz Vila } \\
\text { Chã Braciosa }\end{array}$ & Malhadas & - & 1 & SALGADO, 2013: 532 & Identificada \\
\hline SERTH74 & $\begin{array}{l}\text { Igreja Nossa Sra } \\
\text { Expectação }\end{array}$ & Malhadas & 31827 & 3 & $\begin{array}{l}\text { Portal do Arqueólogo. } \\
\text { SALGADO, 2013: 53-54. } \\
\text { LARRAZABAL GALARZA, } 2009 . \\
\text { ALVES, 2000, IX: 636-637. }\end{array}$ & Não visíveis \\
\hline SERTPF63 & $\begin{array}{l}\text { Adro da Sé de } \\
\text { Miranda do } \\
\text { Douro }\end{array}$ & $\begin{array}{l}\text { Miranda do } \\
\text { Douro }\end{array}$ & 31496 & 1 & $\begin{array}{l}\text { Portal do Arqueólogo. } \\
\text { Plano Diretor Municipal de } \\
\text { Vinhais (2015). } \\
\text { SALGADO, 2009. }\end{array}$ & Não visível \\
\hline
\end{tabular}

Fonte: Ana Oliveira

Considerando a sua distribuição por concelho, e nunca esquecendo a natureza dos registos e o estado atual dos estudos, temos 25 sepulturas escavadas na rocha em Vinhais, 32 em Bragança, 4 em Vimioso e 7 em Miranda do Douro.

Dos 25 sepulcros em Vinhais, 16 foram escavados na necrópole da Poula dos Mouros (Vilar Seco da Lomba) e 6 apenas identificadas. A bibliografia refere 1 sepultura em Santalha, entretanto destruída, e nós registamos 2 em Santa Rufina (Pinheiro Novo).

Em Bragança, e segundo os relatórios de trabalhos arqueológicos, foram escavadas 18 sepulturas na igreja de São Francisco, 1 no local onde existia a igreja de São João e 2 na capela de São Sebastião, templos que fazem parte da atual estrutura urbana da cidade. Registadas na bibliografia existiam 2 sepulturas em São Cláudio (Gostei), 6 no Alto do Outeiro (Alfaião), 1 na Senhora do Aviso (Serapicos), 1 em Vale de Igrejas (Aveleda) e 1 na igreja de São Lourenço (Milhão), estas duas últimas dadas como destruídas. 
Das 4 sepulturas escavadas na rocha registadas em Vimioso, 3 são referidas na bibliografia, num lugar à entrada da cidade chamado Cruzes e 1 foi escavada junto à igreja matriz, portanto, todas nas imediações da cidade.

Finalmente, Miranda do Douro, onde registamos as outras 2 sepulturas, das quatro observadas. 1 sepultura foi registada no lugar designado por Capela de São Paulo (Sendim) e 1 na igreja de Vila Chã da Braciosa. A bibliografia dá conta de 1 sepultura na Cortinha do Poço (Malhadas) e as escavações arqueológicas registaram 3 sepulturas na igreja de Nossa Senhora da Expectação (Malhadas) e 1 no adro da Sé de Miranda do Douro.

Gráfico 1. Sepulturas escavadas na rocha por tipologia

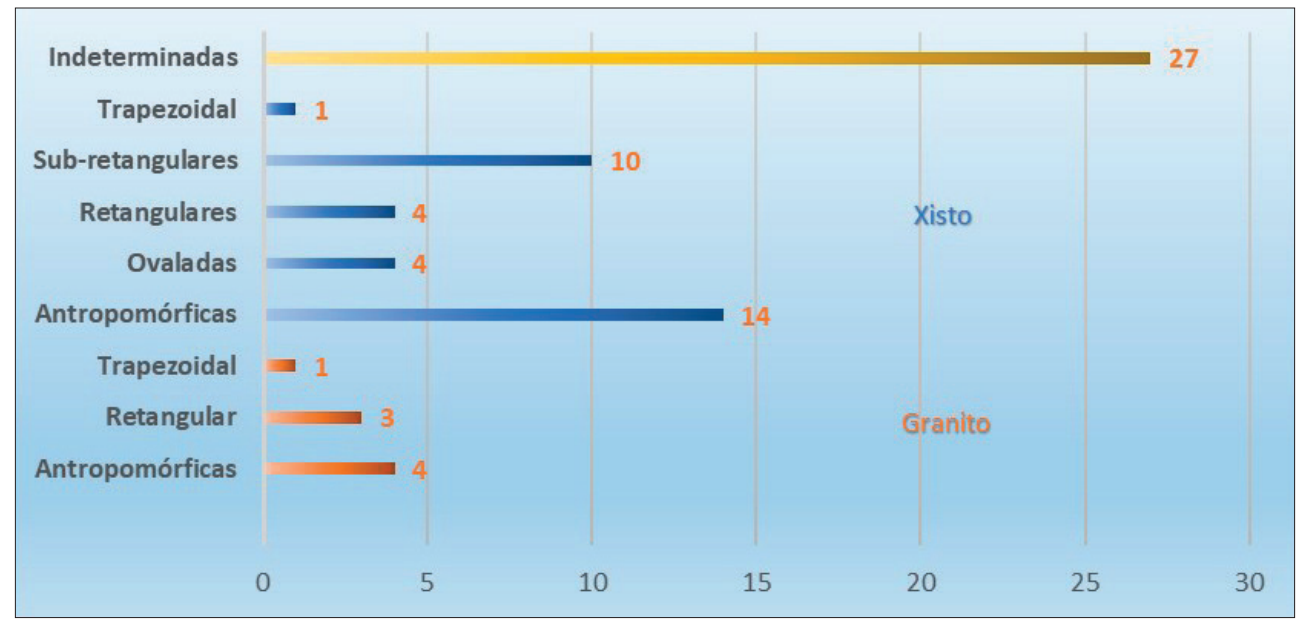

Fonte: Ana Oliveira

Relativamente à tipologia dos sepulcros, o conjunto das indeterminadas (27 sepulturas) é o mais numeroso, reflexo da natureza dos registos, cuja referência bibliográfica é pouco esclarecedora. Segue-se o grupo das sepulturas antropomórficas com 18 estruturas, sendo 4 escavadas em granitos e 14 nos xistos. Este é o segundo grupo mais numeroso, representando mais de $26 \%$ do total das sepulturas referidas e registadas. Segue-se o grupo das sepulturas sub-retangulares, com 10 estruturas, todas elas escavadas nos xistos. Depois registam-se as retangulares, com 7 sepulturas, sendo 3 escavadas no granito e 4 nos xistos. As ovaladas, com 4 sepulturas, todas escavadas no xisto e, finalmente, as trapezoidais, apenas com 2 sepulturas, sendo uma escavada no xisto e outra no granito.

Ainda relativamente aos dados sistematizados, e considerando agora os 26 locais referenciados com sepulturas escavadas na rocha, o levantamento efetuado possibilitou associar as necrópoles ou as sepulturas com os elementos estruturadores do território. Lembramos que esta associação tem por base a atual paisagem e os vestígios conheci- 


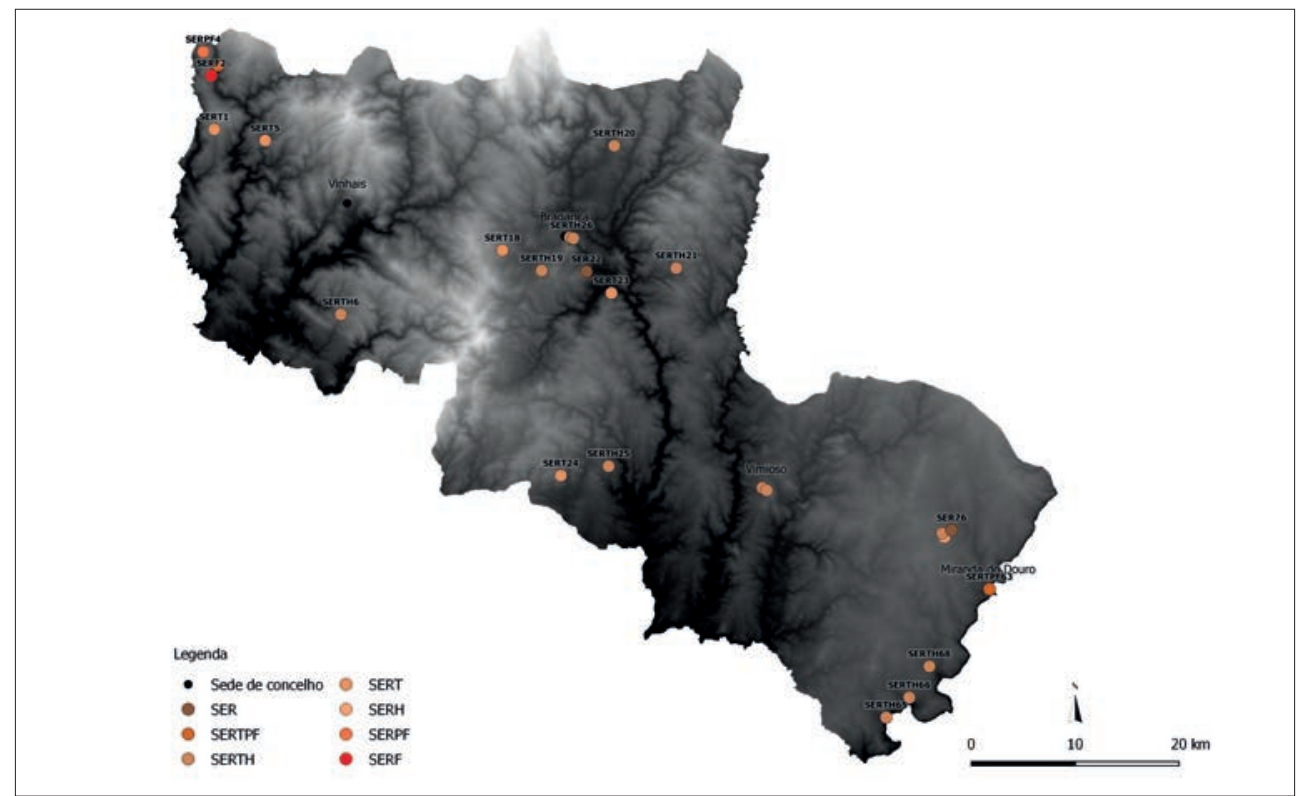

Mapa 3. Relação das sepulturas escavadas na rocha com as estruturas de povoamento Fonte: César Guedes

dos, cenário que poderá ser alterado com futuros trabalhos de prospeção arqueológica ou escavação. Temos então sepulturas associadas a fortificações (SERF) - 1 local; a povoados fortificados (SERPF) - 1 local; a templos e povoados fortificados (SERTPF) -2 locais; a povoado/habitat abertos (SERH) - 1 local; a templos (SERT) - 5 locais; a templos e povoado/habitat abertos (SERTH) - 14 locais; e por fim, necrópoles e/ ou sepulturas aparentemente isoladas ou sem outras referências (SER) - 2 locais.

Olhando para a distribuição destes locais na paisagem concluímos que a grande maioria das necrópoles/sepulturas foram referenciadas associadas a um templo e a um povoado ou habitat aberto. Dos 14 locais registados, 7 localizam-se em Bragança, sendo 4 no perímetro da atual cidade, fora das muralhas. Destes quatro, 3 estavam associados às igrejas de São Francisco, São João e São Sebastião, todas localizadas ao longo da rua de São Francisco, na encosta norte do castelo, a uma distância não superior a $200 \mathrm{~m}$ umas das outras. O outro local fica no presente limite sudoeste da cidade, num sítio designado como Quinta de São Lourenço (Samil). Quanto aos restantes locais, 2 ficam em freguesias em redor da cidade, em zonas de vale, nomeadamente em Aveleda e em Milhão. Em Aveleda a necrópole estaria associada a um templo que já não existe e em Milhão estaria associada à igreja matriz de São Lourenço. A sétima necrópole desta tipologia localiza-se mais a sul do concelho de Bragança, em Calvelhe, e está associada à igreja matriz de São Justo. Todas estas necrópoles estão em altitudes que rondam os $700 \mathrm{~m}$. 
Este grupo de sepulturas de Bragança associadas a um templo e habitat, totaliza 25 sepulturas. Será importante referir que à exceção das sepulturas identificadas nas igrejas de São Francisco, São João e São Sebastião, que foram registadas em escavações arqueológicas, as restantes estruturas apenas são referidas na bibliografia e são dadas como destruídas. As mais numerosas (7 sepulturas) são de tipologia sub-retangular, todas identificadas na igreja de São Francisco. O segundo grupo mais numeroso é o das sepulturas designadas como antropomórficas (6 sepulturas), com destaque para a que foi registada na igreja de São João de cabeceira de arco ultrapassado. Para além desta também foram identificadas 2 sepulturas antropomórficas na capela de São Sebastião. Todas as outras são referenciadas na bibliografia e no Portal do Arqueólogo e dadas como destruídas. Por fim, foram registadas 3 sepulturas retangulares e uma ovalada na igreja de São Francisco, sendo todas as restantes indeterminadas.

Em Miranda do Douro existem 4 sítios com sepulturas escavadas na rocha associadas a templos e povoado/habitats. Um fica situado em Sendim e é conhecido por Capela de São Paulo. Está referido na bibliografia, no Portal do Arqueólogo e na Carta Arqueológica, mas sem qualquer outra informação para além da sua referência. Este sítio foi identificado por nós, onde registamos uma sepultura escavada na rocha, retangular e com orientação O-E. Fica a pouco mais de $550 \mathrm{~m}$ de altitude, numa encosta voltada ao Douro, junto a um estradão que dá acesso à capela de São Paulo, situada no limite da atual linha de água (a $300 \mathrm{~m}$ em linha reta da sepultura). Acima da necrópole fica o ermitério dos Santos (a cerca de $200 \mathrm{~m}$ ). O terreno é acidentado e rochoso, com alguns socalcos, outrora agricultados, definidos por muros em pedra seca. Junto à necrópole é visível à superfície grande quantidade de pedra solta e telha de meia cana. Sande Lemos refere a existência de cerâmica romana ${ }^{7}$

Registamos uma outra sepultura, referenciada na Carta Arqueológica ${ }^{8}$, junto à igreja matriz de Vila Chã da Braciosa, cujo orago é São Cristóvão. Foi aberta num afloramento a norte da igreja, a cerca de $40 \mathrm{~m}$ desta e a $690 \mathrm{~m}$ de altitude. Trata-se de uma sepultura trapezoidal, muito irregular, com orientação NE-SO.

Há ainda registos de necrópoles junto à igreja matriz de Picote, referida na bibliografia e hoje sem vestígios visíveis, e outra localiza-se no adro da igreja matriz de Malhadas, onde foram escavadas 3 sepulturas antropomórficas.

Em Vimioso, referenciamos 2 locais com sepulturas escavadas na rocha associadas a templos e a povoado/habitats. Um ficou registado na bibliografia e no Portal do Arqueólogo e tem o sugestivo nome de Cruzes. Este local fica na periferia da cidade

\footnotetext{
${ }^{7}$ LEMOS, 1993, II: 246.

${ }^{8}$ SALGADO, 2013: 532.
} 


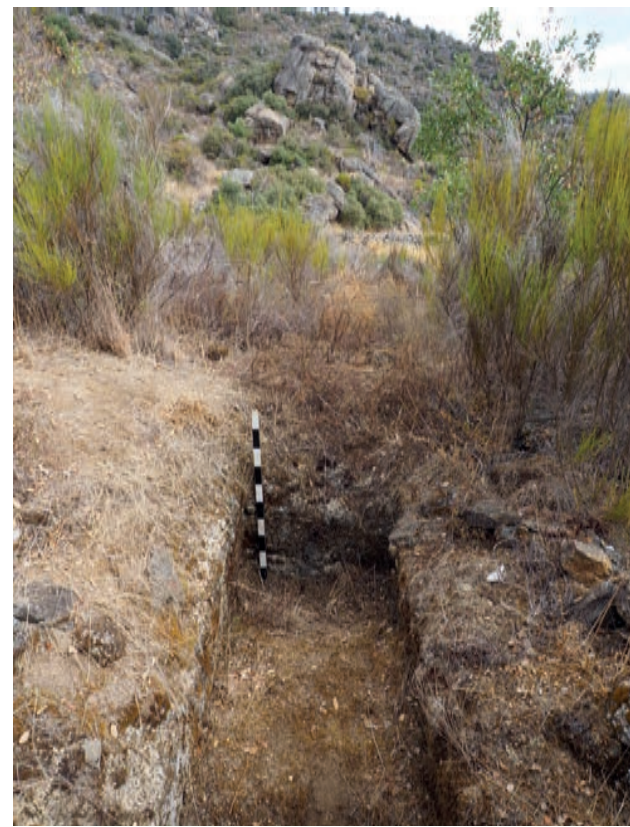

Fig. 1. Sepultura escavada da Capela de São Paulo (Sendim, Miranda do Douro)

Fonte: Ana Oliveira

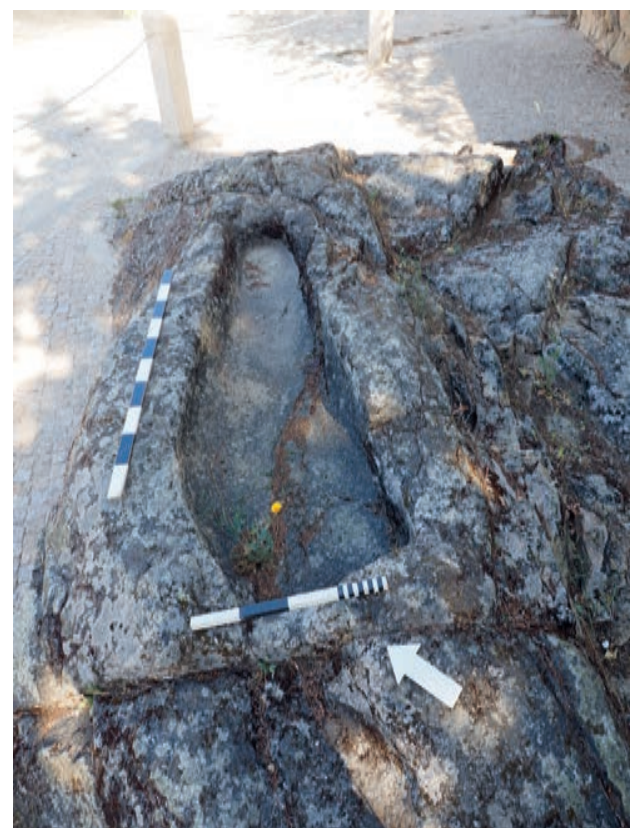

Fig. 2. Sepultura escavada na rocha da igreja de Vila Chã da Braciosa

Fonte: Ana Oliveira

e seria constituído por três sepulturas de tipologia indeterminada. No desenho de Duarte de Armas, que representa o castelo e a povoação de Vimioso, é visível uma igreja ou capela no local onde terá existido esta necrópole. Hoje não existem quaisquer vestígios dela. $\mathrm{O}$ outro sítio onde foi registada uma sepultura escavada na rocha, de tipologia indeterminada, localiza-se no exterior da igreja Matriz de Vimioso, junta da parede sudeste.

A norte da região, em Vinhais, apenas foi registado o local de Penhas Juntas, que segundo o Portal do Arqueólogo, teria, no interior da igreja matriz, sepulturas escavadas na rocha antropomórficas, identificadas nas obras de renovação do soalho. Embora não tenham ficado visíveis, supõe-se que tenham sido preservadas.

As necrópoles de sepulturas escavadas na rocha associadas a templos (SERT), são a segunda categoria mais representada no nosso levantamento, contando com 5 sítios, registados apenas em Vinhais e em Bragança.

Em Vinhais, destaca-se a necrópole de Poula dos Mouros (Vilar Seco da Lomba) referida na bibliografia desde o início do século passado e objeto de intervenção arqueológica nos anos 80 da mesma centúria, na sequência da realização de trabalhos agrícolas que destruíram e puseram à vista alguns sepulcros. Esta necrópole de sepulturas escavadas na rocha, a mais significativa identificada até aos dias de hoje na região em estudo, contava com 22 sepulturas, tendo sido escavadas apenas 16 . 
No relatório dos trabalhos arqueológicos são referidas 3 sepulturas sub-retangulares, 3 ovaladas, 1 trapezoidal, 7 antropomórficas e 2 indeterminadas. Alguns sepulcros estavam cobertos com lajes de xisto, sobrepostas e colocadas transversalmente, e continham restos osteológicos. Os túmulos tinham orientação E-O e estavam organizados em grupos. Segundo informações orais, terá existido no local uma igreja com invocação a São Martinho. Foi ainda identificado um possível habitat, mas de cronologia anterior à necrópole.

Ainda em Vinhais fica o sítio de Santa Locaia (Santalha), referido no Portal do Arqueólogo. Aqui existiria uma igreja dedicada a Santa Leocádia, onde se terá encontrado uma sepultura escavada na rocha antropomórfica, com orientação E-O, coberta com lajes de xisto e, entretanto, destruída. Atualmente, existe no local uma plantação de castanheiros e não são visíveis quaisquer sepulturas. Contudo, observa-se muita pedra solta pelos terrenos e vêem-se alguns alinhamentos de pedra que podem sugerir a existência de estruturas.

Em Bragança, existem referências a sepulturas associadas a templos em São Cláudio (Gostei), onde as informações indicam terem aparecido duas sepulturas antropomórficas junto à igreja de São Cláudio, precisamente, e que foram destruídas pela abertura de um caminho. O outro local registado é o Alto do Outeiro (Alfaião), com seis sepulturas antropomórficas que, segundo o Portal do Arqueólogo, ficaria no alto da aldeia da Pena, junto da capela de Santo Inácio. No local indicado não identificamos quaisquer vestígios de sepulturas e as populações desconhecem a sua existência.

As necrópoles associadas a templos e povoados fortificados, cuja ocupação poderá ter sido diacrónica, surgem em dois locais. Um em Vinhais e outro em Miranda do Douro. No caso de Vinhais, o sítio designa-se por Santa Rufina (Pinheiro Novo) e surge referenciado na bibliografia e no Portal do Arqueólogo. Segundo estas fontes, trata-se de um povoado fortificado, a $670 \mathrm{~m}$ de altitude, com um templo de invocação a santa Rufina. O sítio fica junto a um antigo caminho medieval que atravessa o rio Rabaçal através da ponte de Santa Rufina. Na nossa visita ao local identificamos as ruínas de uma estrutura que parece ser um templo e a sepultura retangular referida, para além de uma outra, da mesma tipologia, que está bastante destruída. As sepulturas têm uma orientação NE-SO. Para além destas estruturas são visíveis alinhamentos de muros em pedra seca, placas de xisto, mós, um possível capitel em granito, buracos de postes e fossetes.

Por fim, em Miranda do Douro, no lado leste da igreja da Sé de Miranda, no local onde se implantaria a antiga igreja de Santa Maria, os trabalhos arqueológicos de 2008/2009 puseram a descoberto uma necrópole onde se registou uma sepultura escavada na rocha de configuração antropomórfica. 


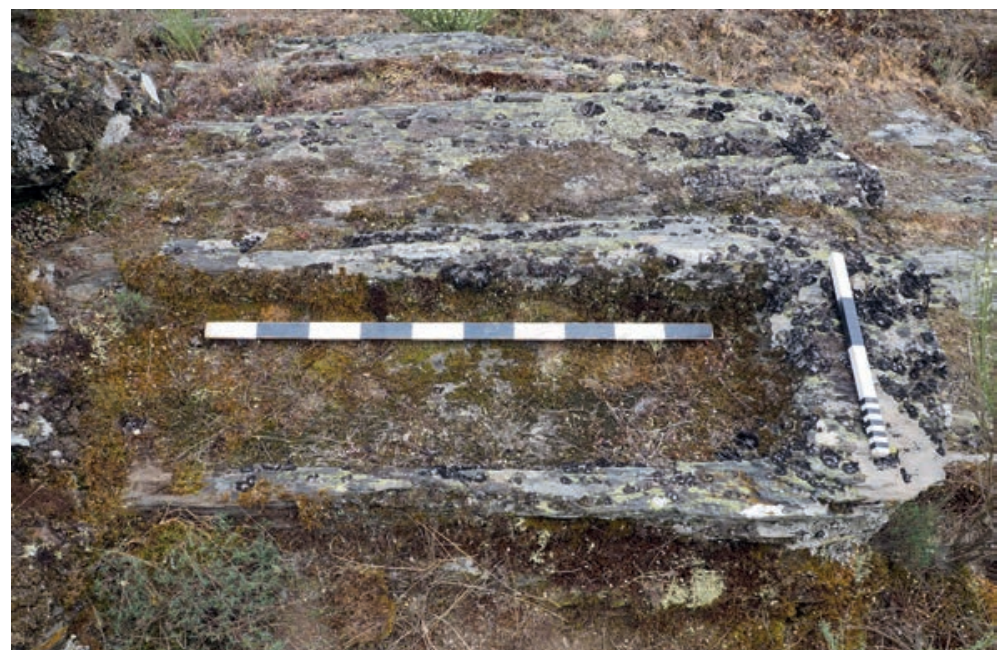

Fig. 3.

Sepultura escavada na rocha de Santa Rufina (Pinheiro Novo, Vinhais) Fonte: Ana Oliveira

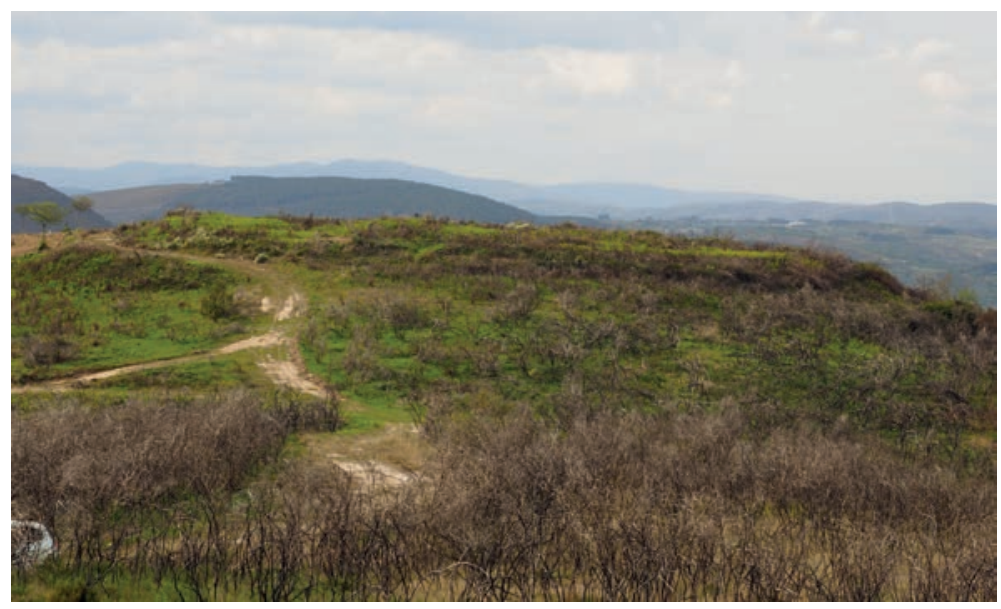

Fig. 4.

Possível fortificação junto a Souane (Quirás, Vinhais) onde há notícia de uma sepultura escavada na rocha Fonte: Ana Oliveira

As necrópoles ou sepulturas aparentemente isoladas (SER), contam com 2 locais: um em Bragança, em Martim Cansado (Samil); e outro em Miranda do Douro, na Fraga da Penhalta (Malhadas). Ambas sem qualquer outra informação para além da referência a sepulturas escavadas na rocha.

As restantes sepulturas escavadas na rocha ou necrópoles, associadas a fortificações (SERF), a povoados fortificados (SERPF), ou a povoado/habitat abertos (SERH), contam apenas com uma ocorrência por cada categoria. A sepultura que se associa a uma fortificação fica em Souane (Quirás, Vinhais); a associada a um povoado fortificado fica também em Vinhais, em Lagoa de Cisterna (Quirás), ambas sem informações relevantes. A sepultura que está associada ao povoado/habitat aberto situar-se-ia em Miranda do Douro, na Cortinha do Poço (Malhadas). 


\section{AS SEPULTURAS ESCAVADAS NA ROCHA E O TERRITÓRIO}

Tendo em conta o atual inventário, verificamos que a implantação das necrópoles e sepulturas escavadas na rocha se situam preferencialmente na zona norte da região de estudo, com maior incidência na zona de Bragança, e são maioritariamente escavadas no substrato rochoso xistoso, rocha predominante na região.

Distribuem-se por locais cujas altitudes variam entre os $550 \mathrm{~m}$ (em Sendim, Miranda do Douro) e os $860 \mathrm{~m}$ de altitude (Gostei, Bragança). A maioria não ultrapassa os $700 \mathrm{~m}$. Parece haver uma preferência por sítios de média altitude, afastados dos planaltos e dos rios Sabor e Tuela. Esta distribuição mostra um vazio nas regiões de Vinhais e Vimioso e manchas preferenciais em torno de Bragança, nas margens do Douro, em Miranda do Douro, e no extremo de Vinhais, em terrenos acidentados, entre os rios Mente e Rabaçal. A sudoeste da região de estudo, apenas se contabilizam três sítios: um em Vinhais e dois em Bragança.

Uma parte considerável dos sítios localiza-se junto aos cursos de água, mas não necessariamente dos principais. Por exemplo, enquanto em Vinhais os sítios se polarizam preferencialmente nas imediações do rio Mente e Rabaçal, em Bragança distribuem-se, maioritariamente, no vale da cidade em torno do rio Fervença. Em Miranda do Douro temos núcleos próximos do rio Douro, mas também junto ao rio Fresno.

Curiosamente, temos apenas duas ocorrências em Vimioso, que ficam entre os rios Angueira e Maçãs, e uma única ocorrência entre este rio e o rio Sabor. Esta faixa de planaltos, cortados por linhas de água e onde se iria riscar a fronteira, caracteriza-se por um aparente vazio que parece perdurar ao longo dos séculos. Esta observação parece corroborada quando associamos ao mapa das sepulturas escavadas na rocha as necrópoles de outros tipos de enterramentos ${ }^{9}$. Esta ausência de «vestígios» requer ponderação e análise, pois poderá não corresponder a uma real «desertificação», mas antes a uma falha nas prospeções e análises.

$\mathrm{Na}$ verdade, a falta de trabalhos arqueológicos e de inventários nesta região, bem como os recentes trabalhos agrícolas e de abertura de infraestruturas municipais, podem explicar parte desta escassa distribuição de sepulturas escavadas na rocha, e mesmo de outras estruturas reveladoras da ocupação territorial. Contudo, lembramos que alguns autores, nomeadamente nos inícios do século passado, dedicaram grande parte do seu tempo a registar os vestígios da passagem do homem nestas paragens e, nem por isso, a informação se tornou mais profícua, pois os seus resultados constam do atual inventário ${ }^{10}$.

\footnotetext{
${ }^{9}$ O Mapa 4 não incluiu o registo dos sarcófagos, tampas ou estelas que também foram inventariadas.

${ }^{10}$ Referimo-nos, sobretudo, à obra de Francisco Manuel Alves (Abade de Baçal), mas também de Albino dos Santos Pereira Lopo.
} 


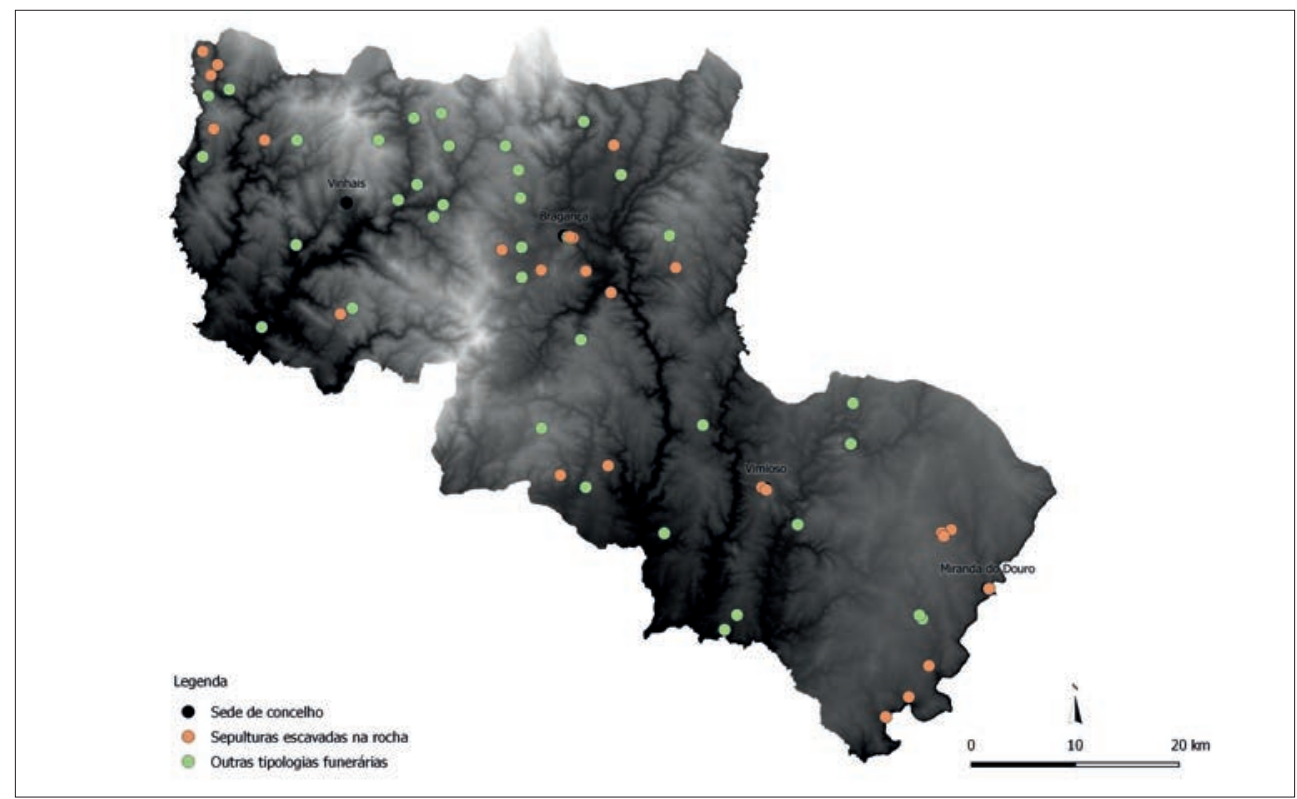

Mapa 4. Mapa com os sítios das sepulturas escavadas na rocha e com os sítios com outro tipo de enterramentos Fonte: César Guedes

Dada a natureza das estruturas que aqui tratamos, e tendo em conta que estas podem não estar visíveis, pensamos ser urgente a sensibilização das populações e das entidades públicas e religiosas para colaborarem no processo do seu registo e preservação. Por outro lado, os trabalhos arqueológicos, como escavações arqueológicas e prospeções, têm acrescentado dados importantes para o estudo das necrópoles transmontanas e serão sempre um recurso imprescindível para o incremento do seu conhecimento. Destes trabalhos interessa destacar alguns exemplos que nos parecem bastante interessantes.

O primeiro exemplo, e talvez o mais eloquente, trata-se da Necrópole Medieval de Poula dos Mouros, situada a $250 \mathrm{~m}$ a norte da aldeia de Passos, freguesia de Vilar Seco da Lomba (Vinhais). A sua escavação resultou de uma intervenção de emergência, em resposta ao aparecimento de sepulturas em trabalhos agrícolas. As escavações arqueológicas decorreram em duas campanhas realizadas em 1986 e 1987 e foram da responsabilidade de Ricardo Teixeira, Paulo Amaral e Américo Gonçalves. Nesta necrópole, exclusivamente de sepulturas escavadas na rocha, foram identificadas 22 sepulturas e escavadas 16 . Os sepulcros foram abertos no substrato rochoso alterado, com uma grande variedade de formas, destacando-se o número de túmulos de tipologia antropomórfica (7). Nenhum enterramento tinha espólio associado, mas alguns conservavam restos osteológicos, que segundo os autores não proporcionaram uma 
Fig. 5. Convento e igreja de São Francisco,

Bragança. Atual Arquivo Municipal Fonte: Ana Oliveira

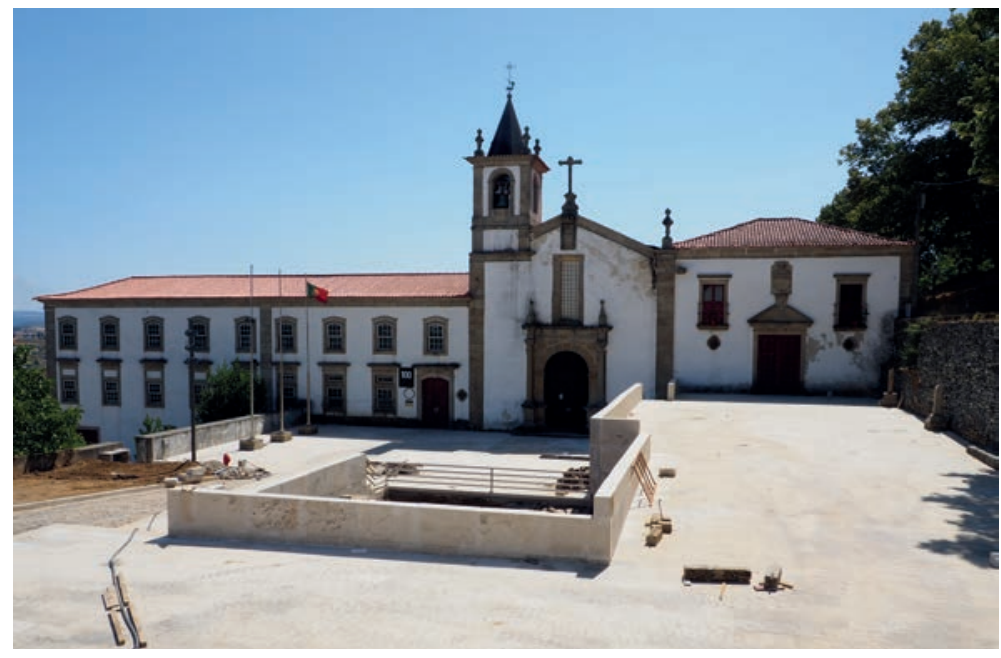

análise antropológica conveniente ${ }^{11}$. Do total das 16 sepulturas, 7 eram de subadultos. Os indivíduos foram depositados em decúbito supino, com as mãos cruzadas sobre o ventre. Algumas sepulturas apresentavam cobertura com lajes de xisto, colocadas de forma transversal e sobrepostas.

Segundo os autores «a pobreza e escassez de materiais, a orientação e a tipologia das sepulturas evocam um ritual de tumulação cristã, cujos paralelos conhecidos apontam cronologias medievais entre os séculos IX-XI» ${ }^{12}$. Acrescentam ainda que a tradição oral refere uma capela, cujo hagiotopónimo seria São Martinho, e que ficaria a SE da necrópole ${ }^{13}$.

Não podemos deixar de referir que os arqueólogos responsáveis pelos trabalhos registaram, a cerca de $20 \mathrm{~m}$ a NNE da necrópole, fragmentos de tégula, cerâmica comum, terra sigillata e uma foice de ferro, «de lâmina curta que encontra paralelos próximos nas foicinhas representadas nos silhares siglados do nosso românico», bem como uma estrutura de combustão, talvez relacionada «com o trabalho do ferro, como a abundante quantidade de escória deixa supor» ${ }^{14}$. Ainda segundo os investigadores estes vestígios poderão indicar uma possível área de habitat de cronologias anteriores à necrópole.

$\mathrm{Na}$ região de Bragança identificaram-se sepulturas escavadas na rocha em 3 sítios: na igreja de São João, na capela de São Sebastião e na igreja de São Francisco. Todos os templos, situados na atual urbe, são próximos uns dos outros.

\footnotetext{
11 TEIXEIRA, AMARAL, GONÇALVES, [s.d.]: 3.

12 TEIXEIRA, AMARAL, GONÇALVES, [s.d.]: 3.

13 TEIXEIRA, AMARAL, [s.d.]: 12.

14 TEIXEIRA, AMARAL, GONÇALVES, [s.d.]: 3-4.
} 
Deste grupo destacaremos as escavações realizadas na igreja de São Francisco, que decorreram em diferentes campanhas, entre 1996 e 1997, e cuja responsável do projeto foi Maria Mulize Neves Ferreira, contando com a colaboração de outros técnicos.

Foram escavados 62 enterramentos, sendo 18 de sepulturas escavadas na rocha. Segundo os autores, foram identificadas diferentes fases de enterramento, sendo grande parte dos sepulcros enquadrados em cronologias do século XVIII e da 1. a metade do século XIX. Sublinham ainda que, o término dos enterramentos datará de 1848, data a partir da qual se deixa de enterrar dentro das igrejas. Acrescentam que as sepulturas escavadas, mesmo as que pertencem a um período mais recuado, não serão anteriores aos finais do século XVIII, isto porque sobreviveram restos de tecido e outros materiais que não se deterioraram num período curto de tempo ${ }^{15}$.

No entanto, e apesar da baliza cronológica apontada, foram observadas algumas situações estratigráficas que levantaram dúvidas, pois umas sepulturas escavadas na rocha foram destruídas pelos enterramentos superiores, outras não têm relação estratigráfica com o edifício e outras são cortadas pelas valas das paredes do templo, sucessivamente alterado. Uma sepultura escavada na rocha conservava ainda restos osteológicos, um rosário e cabedal dos sapatos, encontrando-se destruída por enterramentos de fases posteriores. Neste caso as autoras não atribuíram à sepultura uma cronologia anterior ao século XVIII ${ }^{16}$.

Contudo, no relatório das escavações realizadas no nártex da igreja de São Francisco, as mesmas autoras referem uma primeira fase de enterramentos com duas sepulturas escavadas na rocha sem quaisquer vestígios osteológicos ou espólio. Acrescentam que «foram destruídas por acontecimentos exteriores, delas só restando os buracos de sepultura não possuem elementos intrínsecos de datação. Só é possível datá-las como anteriores a todas as outras estruturas e depósitos» ${ }^{17}$.

Ora, no mesmo relatório, são ainda identificadas outras duas fases que interessam para a nossa análise. A fase 2 que tem sepulturas escavadas na rocha, sem enterramentos e espólio e que cortam as sepulturas da fase 1, e a fase 3 que diz respeito à construção do muro "que forma a parede Oeste na nave da igreja de São Francisco», cujo alicerce encosta à rocha base e corta uma sepultura escavada na rocha da fase 2. Todos os sedimentos escavados encostariam a esta parede e cobriam os níveis anteriores $^{18}$. Os enterramentos com vestígios osteológicos e espólio registam-se em relação com estes sedimentos.

\footnotetext{
15 FERREIRA, PINTO, 1996a: 67.

${ }^{16}$ FERREIRA, PINTO, 1996a: 10.

${ }^{17}$ FERREIRA, PINTO, 1996b: 5.

${ }^{18}$ FERREIRA, PINTO, 1996b: 8-9.
} 
Fig. 6.

Vale do Douro (Sendim,

Miranda do Douro)

Fonte: Ana Oliveira

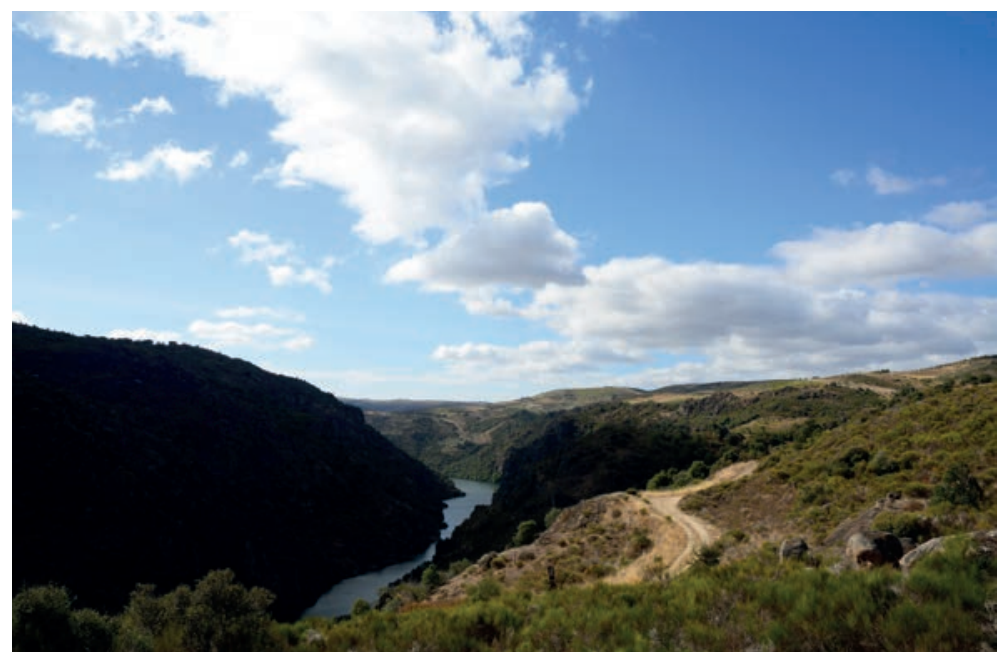

Ora, lendo os relatórios podemos aceitar que, pelo menos na zona do nártex, os enterramentos posteriores à fase 2 poderão ter ocorrido em cronologias a partir do século XVIII. Contudo, os da fase 2 e, principalmente, os da fase 1, são claramente anteriores, assumindo as autoras desconhecerem a sua cronologia. Esta conclusão, associado à certeza, apresentada pelas mesmas autoras, da reutilização de sepulturas e ao facto da igreja ter sofrido grandes alterações, sobretudo nos séculos XVII e XVIII, poderá sugerir uma cronologia muito mais recuada para algumas das sepulturas escavadas na rocha, nomeadamente para as que foram identificadas nas primeiras fases.

De facto, a questão cronológica das sepulturas escavadas na rocha ainda não encontrou um consenso razoável. Dada a sua natureza rupestre, em que a estrutura é escavada diretamente na rocha, as datações são sugeridas, em caso de serem alvo de escavações, pelas relações estratigráficas de elementos externos aos sepulcros (como muros, valas, outros enterramentos, etc.), ou nos sedimentos e espólio que os enche, cujo grau de fiabilidade é pouco seguro, pois, não raras vezes, sofreram violações, alterações, ou reaproveitamentos, como terá sido o caso dos enterramentos da igreja de São Francisco (Bragança). Por outro lado, a falta de espólio, como no caso da necrópole da Poula dos Mouros (Vilar Seco da Lomba, Vinhais), não deixa outra solução senão a sugestão cronológica baseada em paralelos tipológicos, sugeridos em trabalhos anteriores.

Não sendo nossa intenção problematizar as conclusões dos trabalhos arqueológicos realizados e muito menos os estudos que têm caracterizado esta original forma de enterramento, cuja investigação conta com largos e importantes contributos, convenientemente fundamentados, parece-nos que será mais interessante, neste 


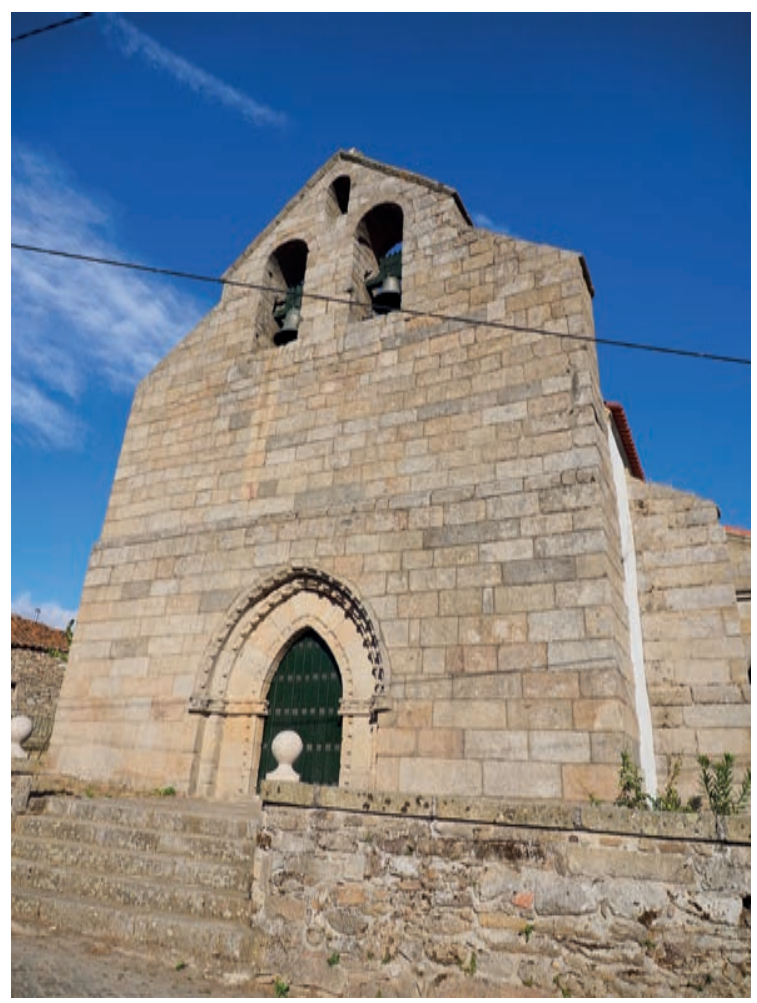

Fig. 7.

Igreja matriz de Malhadas

(Miranda do Douro)

Fonte: Ana Oliveira

caso, relacionar este tipo de sepulcros rupestres com outros tipos de sepulcros que, na região em análise, sobreviveram num mesmo espaço cemiterial tentando estabelecer padrões ou modos de uma ocupação contínua ou descontínua do território.

Assim, e para além do exemplo já referido da igreja de São Francisco de Bragança, onde há uma sobreposição de enterramentos, ao que tudo indica de diferentes tipologias e cronologias, existiria ainda esta "convivência» na capela de São Sebastião e na igreja de São João, também em Bragança. Esta continuidade de enterramentos em espaços cemiteriais da cidade não sugere uma novidade, tendo em conta que esta urbe terá sido um dos principais polos de fixação de populações ao longo de séculos, como bem atestam os vestígios encontrados nas intervenções arqueológicas que, entretanto, aí se realizaram e que apontam para cronologias de época romana ${ }^{19}$.

A questão da continuidade, coloca-se então com mais pertinência para o resto do território braganção. Dos 26 locais identificados com sepulturas escavadas na

\footnotetext{
${ }^{19}$ Para o caso, referimo-nos sobretudo aos trabalhos arqueológicos desenvolvidos no âmbito da Polis de Bragança, em que parte dos resultados constam nas monografias Bragança um olhar sobre a História e Bragança um olhar sobre a História II (BRAGANÇA, 2004, 2008).
} 
rocha, 7 têm referências a sepulturas escavadas na rocha e a sepulturas delimitadas por lajes. Destes sete locais, quatro são em meio urbano: três ficam em Bragança, como já referimos, e o outro fica em Miranda do Douro, junto da Sé. Em todos estes locais, a maioria dos enterramentos pertencem a outra tipologia funerária, nomeadamente a sepulturas delimitadas por lajes.

Os outros três locais são em Sendim (Miranda do Douro), no sítio da Capela de São Paulo, onde nos parece existirem sepulturas delimitadas por lajes; outro fica em Gostei (Bragança), no sítio da Capela de São Cláudio, onde haveriam sepulturas também delimitadas por lajes, todas destruídas, bem como, epígrafes romanas e um miliário de Maximiano; por fim, na igreja de Nossa Senhora da Expectação, em Malhadas (Miranda do Douro).

Porque não temos oportunidade de, neste espaço, analisar convenientemente todos estes casos, escolhemos o exemplo da necrópole da igreja matriz de Malhadas com invocação de Nossa Senhora da Expectação, intervencionada em 2001, com a escavação de várias sondagens no exterior e à volta do templo e cujos trabalhos foram da responsabilidade de Javier Larrazabal Galarza. Parece-nos um exemplo claro de continuidade dentro dos espaços sepulcrais.

Os trabalhos arqueológicos realizados na igreja de Malhadas permitiram identificar 24 inumações, tendo sido escavadas apenas 11. Os trabalhos de escavação foram realizados em fase prévia à obra que pretendia instalar infraestruturas relacionadas com a drenagem de águas pluviais. As sepulturas escavadas na rocha foram identificadas, segundo o autor, nas sondagens 4, 7 e 8, localizando-se uma junto ao portal e duas na zona da cabeceira. Duas das sepulturas foram cortadas pela construção da igreja, sugerindo assim a sua anterioridade em relação ao edifício. Nos sedimentos que cobriam estes sepulcros escavados na rocha foram identificadas outras sepulturas, delimitadas por pedras e cobertas por lajes sobrepostas, constituindo claramente enterramentos de época posterior.

Devemos referir que no mesmo espaço, zona norte da igreja, foi escavada uma estrutura de combustão, que o autor diz poder tratar-se de um forno de cerâmica alto-imperial, que, de acordo com o que é dado a entender, não se relacionaria com a necrópole. Foram ainda recolhidas cerâmicas de cronologias romanas, nomeadamente sigillata, e uma epígrafe reaproveitada na construção da igreja, somando-se às que já se conheciam usadas com o mesmo fim.

Quanto a cronologias o autor diz que a fase das sepulturas escavadas na rocha poderá ser integrada num momento prévio

à instauração da paroquia de Malhadas nos começos do século XIII, vinculadas seguramente a uma comunidade rural reduzida e dispersa que teria o seu cemitério na superfície de um penedo granítico delimitado por um pequeno muro. 
Posteriormente, após a criação da paroquia, a zona seria aterrada inaugurando-se a prática de um novo tipo de inumação individual, em cistas de lajes construídas sobre um pequeno rebaixe efetuado na terra. Esta fase desenvolver-se-á até a construção do novo templo nos finais do século XV - começos do XVI e a ela deverão associar-se algumas estelas discoides decoradas com cruzes que se encontram atualmente no interior da igreja ${ }^{20}$.

Esta hipótese cronológica sugere uma continuidade no uso desta área como espaço cemiterial e a possível associação desta necrópole a um templo. Como refere o autor, as inquirições de 1258 fazem referência à paróquia de Santa Maria de Malhadas. O autor levanta ainda a hipótese de ter existido um templo primitivo, talvez com uma necrópole de sepulturas escavadas na rocha, que, entretanto, foi substituída por um outro templo, mantendo-se o espaço cemiterial, agora com formas de enterramento. Note-se, que o autor não encontrou vestígios de um templo anterior ao atual.

\section{NOTAS FINAIS}

Numa análise, ainda que superficial, aos elementos que fomos recolhendo podemos sugerir, para o período cronológico que diz respeito ao nosso trabalho, uma continuidade de ocupação em algumas regiões deste território transmontano. Tomando como ponto as sepulturas escavadas na rocha e comparando a sua distribuição com as informações obtidas nas inquirições de 1258 e 1288, altura em que grande parte das paróquias já estão estabelecidas, bem como as suas igrejas, encontramos correspondências entre 5 sítios com sepulturas escavadas na rocha e paróquias do século XIII. O primeiro é o sítio da Igreja Penhas Juntas (Penhas Juntas, Vinhais) que corresponde à paróquia e freguesia de Penhas Juntas das Inquirições de 1288-1290²1. Em 1258 esta paróquia não é referida; o segundo é a igreja de São João (cidade de Bragança), igreja hoje desaparecida, referida como paróquia de São João em 1258 22 ; o terceiro é o sítio de São Justo (Calvelhe, Bragança), junto à igreja matriz e que corresponde à paróquia de São Justo de Calvelhe em 1258 ${ }^{23}$; o quarto exemplo, é referente ao sítio da Igreja Matriz de Vimioso e corresponde à paróquia de São Vicente de Vimioso de $1258^{24}$; e por fim, a Igreja de Nossa Senhora da Expec-

\footnotetext{
${ }^{20}$ LARRAZABAL GALARZA, 2009.

${ }^{21}$ PMH, Inq. 1288-1290, 4(2), IV, 1958: 260-262. Pertencente ao Julgado de Bragança.

${ }^{22} \mathrm{PMH}$, Inq. 1258, I, 1961: 1289-1290. Pertencente ao Julgado de Bragança.

${ }^{23}$ PMH, Inq. 1258, I, 1961: 1308. Pertencente ao Julgado de Lamas de Orelhão.

${ }^{24} \mathrm{PMH}$, Inq. 1258, I, 1961: 1284-1285. Pertencente ao Julgado de Algoso, terra de Miranda.
} 
tação em Malhadas (Miranda do Douro) que corresponde à paróquia de Santa Maria de Malhadas, referida em $1258^{25}$.

Além destes locais, registamos ainda 2 sítios com sepulturas cuja localização e hagiotopónimo correspondem a paróquias do século XIII, mas que, na atualidade, as sedes de freguesia e igrejas matrizes estão deslocadas em relação às necrópoles. Trata-se do sítio de Santa Locaia, que fica a pouco mais de $1 \mathrm{~km}$ da atual paróquia e freguesia de Santalha (Vinhais), que mantém o orago de Santa Eulália. Esta localidade é referida nas inquirições de $1258^{26}$ e nas de $1288-1290^{27}$. Outro sítio é o de São Cláudio com referência a sepulturas junto à capela que fica entre a localidade de Formil (Gostei, Bragança) (a 500 m) e a localidade de Gostei (Bragança) (a cerca de $800 \mathrm{~m}$ ). A paróquia de Gostei não é referida nas inquirições, mas a localidade de Formil aparece como paróquia nas inquirições de $1258^{28}$ e como paróquia e freguesia nas inquirições de 1288-129029. Hoje, Formil é uma aldeia pertencente a Gostei, sendo esta localidade sede de freguesia e cuja igreja matriz tem como orago de São Cláudio.

Não esquecendo os condicionalismos que determinaram este levantamento de sepulturas escavadas na rocha, e tendo em conta que nem todas as paróquias terão sido interrogadas em 1258 ou em 1288, temos, de momento, uma continuidade na ocupação dos espaços religiosos e de habitat em 19\% dos sítios registados, entre o período que medeia a abertura dos sepulcros rupestres e os finais do século XIII.

Esta análise poderá ser muito mais aprofundada se considerarmos outras variáveis, contudo a complexidade de associações e hipóteses não cabem neste artigo, sendo motivo de estudo na investigação em curso no âmbito do doutoramento.

O tratamento dos dados recolhidos é um trabalho ainda em progresso. Requer uma análise atenta e aprofundada, que permita cruzar as informações obtidas através dos trabalhos arqueológicos com os dados enunciados na documentação medieval, entretanto recolhida e em processamento, e que não se resume apenas às inquirições do século XIII.

Cremos que a sistematização e análise das sepulturas escavadas na rocha, conjugada com a análise dos elementos estruturadores do povoamento, como os locais de habitat, os templos, as fortificações e as vias, conjugada com outras análises, nomeadamente toponímicas permitirá esboçar uma proposta de evolução territorial ao longo da Idade Média e entender como este território complexo acabou integrado no reino de Portugal.

\footnotetext{
${ }^{25}$ PMH, Inq. 1258, I, 1961: 1283. Pertencente ao Julgado de Algoso, terra de Miranda.

${ }^{26} \mathrm{PMH}$, Inq. 1258, I, 1961: 1341-1342. Pertencente ao Julgado de Vinhais.

${ }^{27} \mathrm{PMH}$, Inq. 1288-1290, IV, 1958: 225. Pertencente ao Julgado de Vinhais.

${ }^{28}$ PMH, Inq. 1258, I, 1961: 1321. Pertencente ao Julgado de Lamas de Orelhão.

${ }^{29}$ PMH, Inq. 1288-1290, IV, 1958: 250. Pertencente ao Julgado de Bragança.
} 


\section{FONTES}

ARMAS, Duarte de (2006). Livro das Fortalezas. Introdução de Manuel da Silva Castelo Branco. 3. ${ }^{a}$ Edição. Lisboa: Arquivo Nacional da Torre do Tombo; Edições Inapa. Fac-simile do Ms. 159 da Casa Forte do Arquivo Nacional da Torre do Tombo.

PMH, Inq: Portugaliae Monumenta Historica: Inquisitiones. Inquirições Gerais de D. Afonso III (1258). Lisboa: Academia das Ciências de Lisboa, 1961, vol. I, pars II, fasciculo VIII.

PMH, Inq: Portugaliae Monumenta Historica: Inquisitiones. Inquirições Gerais de D. Diniz de 1288, Setenças de 1290 e Execuções de 1290. Lisboa: Academia das Ciências de Lisboa, 2015, Nova Serie, vol. 4, pars II.

\section{BIBLIOGRAFIA}

ALVES, Francisco Manuel (Abade de Baçal) (2000). Memórias Arqueológico-Históricas do Distrito de Bragança. Bragança: Câmara Municipal de Bragança; Instituto Português de Museus - Museu do Abade de Baçal. Tomo I-XII.

ALVES, Paulo Carlos (2007). Praça Eduardo Coelho e zona envolvente (Vimioso). Sondagens Arqueológicas. Gabinete Técnico Municipal. Câmara Municipal de Vimioso.

BRAGANÇA (2004). Bragança um olhar sobre a História. Bragança: Câmara Municipal de Bragança. BRAGANÇA (2008). Bragança um olhar sobre a História II. Bragança: Câmara Municipal de Bragança. FERREIRA, Maria Mulize Neves; PINTO, Maria Jacinta Ordaz Paiva (1996a). Escavações Arqueológicas na Igreja de S. Francisco, Bragança. Relatório Preliminar - Sondagem na área B. (Processo: S - 04696).

FERREIRA, Maria Mulize Neves; PINTO, Maria Jacinta Ordaz Paiva (1996b). Escavações arqueológicas na igreja de S. Francisco, Bragança. Relatório Preliminar - Sondagem na área D. (Processo: S - 04696).

LARRAZABAL GALARZA, Javier (2009). Trabalhos de acompanhamento arqueológico na Igreja Paroquial de Malhadas. Relatório Final. (Processo: S - 31827).

LEMOS, Francisco de Sande (1993). Povoamento Romano de Trás-os-Montes Oriental. Braga: Universidade do Minho. Tese de Doutoramento.

LOPO, Albino dos Santos Pereira (1987). Apontamentos Arqueológicos. Braga: Instituto Português do Património Cultural.

MEIRINHOS, Luís Miguel Pires (2014). A evolução da Terra de Miranda: Um estudo com base nos Sistemas de Informação Geográfica. Porto: Faculdade de Letras da Universidade do Porto. Dissertação de Mestrado.

RODRIGUES, Joana; DIAS, Graciete; ALVES, M. Isabel Caetano (2009). Caracterização do Património Geomorfológico do Parque Natural do Douro Internacional (NE de Portugal) com vista à sua valorização. Braga: Associação Portuguesa de Geomorfólogos, vol. VI, pp. 249-254.

SALGADO, Mónica (2009). Relatório preliminar das sondagens arqueológicas realizadas do lado nascente da igreja e Largo da Igreja, antiga Sé de Miranda do Douro. Miranda do Douro.

SALGADO, Mónica (2013). Revisão do PDM do concelho de Miranda do Douro. Câmara Municipal de Miranda do Douro.

TEIXEIRA, Ricardo; AMARAL, Paulo; GONÇALVES, Américo [s.d.]. Relatório preliminar da 2. ${ }^{a}$ intervenção arqueológica de emergência na necrópole da Poula dos Mouros - Vinhais. Processo: S - 5089 .

TEIXEIRA, Ricardo; AMARAL, Paulo [s.d.]. Relatório preliminar da Intervenção Arqueológica de emergência na Necrópole da Poula dos Mouros - Vinhais. (Processo: S - 02496). 


\section{Endereços eletrónicos}

Portal do Arqueólogo. Disponível em <http://arqueologia.patrimoniocultural.pt.>.

Carta Arqueológica de Miranda do Douro. Disponível em <https://www.cm-mdouro.pt/uploads/ document/file/692/Carta-Arqueologica-e-Patrimonio-Cultural.pdf.>.

Plano Diretor Municipal de Vinhais. Disponível em <https://www.cm-vinhais.pt.>.

Plano Diretor Municipal de Miranda do Douro. Revisão 2015. Disponível em <https://www.cm-mdouro.pt.>. 


\title{
A NECRÓPOLE MEDIEVAL DO MOSTEIRO DE S. MIGUEL DE REFOJOS, CABECEIRAS DE BASTO
}

\author{
FRANCISCO M. V. REIMÃO QUEIROGA* \\ CLÁUDIA MARIA MARTINHO LEMOS**
}

Resumo: Sondagens de avaliação arqueológica realizadas no jardim do claustro do Mosteiro de S. Miguel de Refojos, em Cabeceiras de Basto, por ocasião de obras de remodelação do espaço, trouxeram à luz um conjunto de sepulturas. Trata-se de parte de uma necrópole que se localizaria no exterior de uma fase construtiva do mosteiro, a qual foi obliterada pelo edifício que o constitui atualmente. A necrópole enquadra-se entre os séculos XII-XIII e os meados do século XVII. O conjunto é formado por vestígios de 35 enterramentos, entre masculinos e femininos, sendo que um deles pertence a um canídeo, deposto em circunstâncias e época que não foi possivel determinar.

Palavras-chave: Mosteiro de S. Miguel de Refojos; Sepultura; Rituais funerários; Necrópole medieval.

\begin{abstract}
As a measure of previous evaluation for the project of remodelling of the cloister garden of the Monastery of S. Miguel de Refojos, in Cabeceiras de Basto, an archaeological excavation was required, in the course of which a number of human graves was uncovered. This is a portion of a cemetery presumably located outside of a church from an earlier phase of the monastery, which was superposed by the later phase cloister that is still standing. The cemetery is dated between the XII-XIII to the XVIIth centuries. The excavation of the cemetery has yielded remains of 35 burials, amongst male and female individuals, in addition to one pit where a canine burial was performed in a time and circumstances as yet undetermined.
\end{abstract}

Keywords: Monastery of S. Miguel de Refojos; Grave; Funerary rituals; Medieval cemetery.

\section{INTRODUÇÃO}

O projeto de remodelação do espaço ajardinado interior do claustro do Mosteiro de S. Miguel de Refojos, promovido pela autarquia local em 2013, motivou a realização de medidas de avaliação arqueológica prévia que se materializaram em sondagens de diagnóstico, trabalho que se revestiu de alguma urgência em função do prazo previsto para a obra ${ }^{1}$.

Tendo como objetivo auscultar toda a área interior do quadrângulo do claustro num curto espaço de tempo, optou-se pela implantação de uma malha de valas de

\footnotetext{
* FLUP; UFP; CLEPUL.. Email: fqueiroga@letras.up.pt.

${ }^{* *}$ Lic. em Arqueologia, Pós-Graduada em Museologia FLUP.

${ }^{1} \mathrm{~A}$ escavação foi dirigida pelos autores, tendo a equipe integrado a antropóloga Linda Melo, o técnico Manuel António Vitorino, com a colaboração de Pedro Gonçalves e de voluntários locais e trabalhadores indiferenciados cedidos pela autarquia.
} 
sondagem para detetar quaisquer vestígios existentes, e assim avaliar a sua dispersão neste espaço. Esta abordagem cumpriu com os objetivos, e assim constatou-se que apenas cerca de um quarto do espaço continha vestígios de ocupação antigos, os quais se circunscreviam ao limite sul do claustro.

Com este conhecimento preliminar foi possível estabelecer um programa de escavação em área, por forma a abarcar todo o espaço disponível, o qual estava naturalmente delimitado no lado sul, pelo pavimento e colunada do claustro.

Respeitando a temática deste colóquio, apenas aqui trazemos a informação que concerne aos sepultamentos, deixando para outro momento o tratamento das estruturas que lhes estão adjacentes, algumas das quais são visíveis nas ilustrações anexas.

\section{ENQUADRAMENTO HISTÓRICO}

O Mosteiro de São Miguel de Refojos de Basto, é composto por um conjunto arquitetónico de grande monumentalidade, estando a igreja e a sacristia, assim como o teto de uma das salas, classificadas como Imóvel de Interesse Público desde 1933. Este importante cenóbio afirma-se não só pela imponência da sua construção, mas igualmente pela centralidade e papel dinamizador de toda uma região envolvente, a qual marcou de forma indelével ao longo da sua existência.

As origens deste mosteiro são ainda ambíguas à luz da documentação disponível. Passando ao lado da referência de Frei Leão de S. Tomás (1644), na Benedictina Lusitana, ainda envolta em controvérsia, temos como primeiro documento conhecido, que refere a Ordem de São Bento, uma carta de couto passada por D. Afonso Henriques em 1131, o que testemunha a sua existência em princípios do século XII. Reza o documento:

Foi este couto dado e feito ao mosteiro de Relligiosos do Patriarcha S. Bento (cito no dito concelho, entitulado de S. Miguel de Refoios) por o Infante D. Affonço Henriques» "El Rei D. Affonso 2. ${ }^{\circ}$ e a Rainha D. Urraca, sua mulher e seos filhos, os Infantes D. Sancho, D. Affonço, D. Fernando, e D. Leonor confirmarão esta doação (a do couto) em esta villa de Guimarães, no primeiro de Março da era de 1227 que são annos de Christo de $1189^{2}$.

Desta forma, fundamenta-se a presunção de ter existido no local um mosteiro, certamente de pequena dimensão, anteriormente à fundação da nacionalidade, cuja dinâmica monástica terá propiciado o desenvolvimento populacional e económico de Refojos. Sabemos que desde o século XII os seus padroeiros eram os descendentes do rico-homem D. Gomes Mendes «Guedeão». O mais antigo dos seus possessores que viveu na segunda metade do século XI era um «domno» Mendo a quem sucedeu o filho, D. Gueda «o

${ }^{2}$ CRAESBEECK, 1992: 257. 
velho». Grande protetor do mosteiro, D. Gueda Mendes doou-lhe em 1152 um magnífico cálice de prata dourada, que ainda hoje é uma referência da ourivesaria medieval ${ }^{3}$.

$\mathrm{O}$ período seguinte foi de crescimento, tendo o mosteiro adquirido um vasto conjunto de terras, sendo um dos mais ricos do Minho, pois pelo século XIII adiante possuía domínios em Fafe, Celorico de Basto, e Cabeceiras de Basto. Estas rendas, quase todas de terras situadas em Trás-os-Montes, tornaram o convento um dos mais ricos da Ordem Beneditina. No século XIII a maior parte do padroado do mosteiro passou de Gomes Mendes a seu filho D. Egas Gomes Barroso e à sua descendência, os quais possuíam vastas propriedades em torno do convento nos séculos XII e XIII. Até ao reinado de D. Duarte, o mosteiro foi governado por abades perpétuos passando posteriormente a sê-lo por abades comendatários que fruíam benefício de comenda. De 1428 a 1537 o governo do mosteiro ficou a cargo dos Abades Comendatários mais propriamente nas mãos da família Borges, a qual delapidou muitos dos bens e das rendas do mosteiro. Com a administração ruinosa dos abades comendatários o mosteiro enfrentou uma época de decadência, que apenas foi superada com a integração de Refojos na Congregação Beneditina Portuguesa a partir de 1570.

Foi com este regime que o mosteiro iniciou a sua recuperação económica e também arquitetónica, segundo relata Frei Leão de S. Tomás ${ }^{4}$.

Em 1590 o Capítulo Geral estabeleceu como prioridades as obras dos mosteiros da ordem, pelo que as de Refojos foram iniciadas na primeira metade do século XVII, incluindo a igreja nova, que em 1644 ainda estava a ser construída passando a ter duas torres. O templo foi demolido, e reconstruído segundo os ditames de Tibães, seguindo as inspirações barrocas.

Hoje apenas sobrevive o claustro ${ }^{5}$, reminiscência do período de obras iniciado na primeira metade do século XVII, e à conclusão das quais se crê que alude a data «1690», inscrita na portaria.

O claustro atual, construído ao longo do século XVII, além de servir de acesso à igreja, foi local de oração e de reunião. Também serviu de local de sepultura de

\footnotetext{
${ }^{3}$ GONÇALVES, 1980: 79.

${ }_{4}$ «Neste tempo presente tudo quanto vemos no Mosteyro de Refoyos (tirando os Dormitorios, Claustra, \& outras oficinas, que são de tempo mais antigo) tudo he renovado, ou feito de novo por industria dos Abbades triennaes. Vemos hu(m)a Igreja nova fermosa, \& clara, capaz de recolher em si a grande freguesia que tem. Vemos seus altares muy ornados com retabolos dourados, com image(n)s, \& pinturas muy excelentes; A Sancristia nova com muitas peças de prata, \& ornamentos ricos pera perfeição do culto divino. A cerca, q(ue) dantes era muy abreviada, vemola agora muy estendida, plantada toda de arvores fructiferas, \& $\operatorname{co}(\mathrm{m})$ suas fontes de agua perenne dentro. Defronte da porta da Igreja vemos a mais fermosa entrada, \& Lameda que ha» ( SÃO TOMÁS, 1644: 501).

${ }^{5}$ «Depois que se desfez o antiguo mosteiro (de que ainda se vem vestigios), se fez no mesmo citio outro de novo, com muita grandeza, que hoje existe, não de todo acabado pello interior delle, com 30 cellas, e hum claustro de 200 palmos en quadra, medidos pello interior das paredes, com 9 arcos de cada banda, muito levantados, e columnas inteiriças; por cada banda, 4 janellas rasgadas; e nas oficinas inteirores, bem repartido tudo, e na porta que está na face, que cae para o terreiro, está somente na simalha, o seguinte =1690; e, por sima, huma pedra dourada, com as armas da religião do patriarca São Bento» (CRAESBEECK, 1992: 263).
} 
outros monges, como são exemplo algumas das pedras com números gravados nas grandes lajes do pavimento das galerias, as quais possuem forfex para sepultamento. Trata-se de um corpo singular de espaço fechado, de forma quadrangular, com um andar superior fechado. É assente em nove arcos suportados por colunas monolíticas dóricas, determinando quatro galerias de trinta metros cada.

A campanha de construção barroca, iniciada no século XVII, prolongou-se pelo século seguinte centrando-se na segunda metade de setecentos a sua época de maior fulgor. As obras realizadas entre 1755 e 1766 configuraram a igreja tal como hoje a conhecemos, e a partir de então é muito justamente considerada como a mais monumental da Ordem Beneditina no país, e a única com zimbório.

Deste breve percurso sobre as fases construtivas do mosteiro, salientamos que a construção do claustro e a última fase de intervenção sobre a igreja, já no século XVIII, obliteraram todos os vestígios de épocas anteriores, que desconhecemos. Por esta razão, a sondagem foi encarada com bastante expetativa, por se constituir num momento único, e há muito esperado, de auscultar indícios arqueológicos sobre as fases de ocupação anteriores ao claustro.

\section{A ESCAVAÇÃO}

A escavação incidiu sobre todo o espaço do claustro destinado a ajardinamento, pois importava verificar a existência de quaisquer vestígios uma vez que a implantação de drenagens e de outras estruturas afetaria a totalidade da área. Salvaguardando a economia de recursos, foram implantadas valas de sondagem por todo o espaço de intervenção, tendo como objetivo delimitar os vestígios de ocupação, sobre os quais incidiria a escavação posterior. Este método deu frutos, uma vez que se circunscreveu a área de dispersão de estruturas ao extremo sul do claustro, conforme ilustra a Figura 1. Em virtude do aparecimento de sepulturas e de alicerces de muros na vala de sondagem situada junto ao lado sul do claustro, esta foi alargada em cerca de sete metros para norte, ressalvando-se apenas um pequeno ressalto para preservar uma árvore existente no jardim do claustro. Desta forma, a área intervencionada pela escavação (Fig. 2) abarcou todos os vestígios existentes na área útil do quadrângulo.

O decurso do trabalho revelou o caráter superficial do substrato rochoso, de xistos, bem assim como o facto de este começar a aprofundar gradualmente a cerca de uma dezena de metros aquém do limite sul do claustro. Por todo o espaço se constatou existirem níveis de perturbação, nomeadamente os referentes à instalação de caixas de drenagem de águas pluviais e respetivas tubagens de escoamento, que constituíam uma malha orientada para o lado nascente (Fig. 1), denunciando a preocupação no enxugamento do espaço interior do claustro. Esta preocupação revelou-se legítima, uma vez que no decurso da escavação se verificou que o nível freático é muito superficial, tendo o espaço escavado ficado gradualmente inundado de água. 


\section{A NECRÓPOLE}

O espaço intervencionado revelou um conjunto de sepultamentos e de estruturas que se revestem de grande interesse, por documentarem fases de ocupação do mosteiro das quais apenas havia referência documental, mas nenhuma evidência arqueológica. Foi escavado o que presumimos ser o extremo norte de um cemitério anexo ao antigo mosteiro, o qual será anterior à construção do claustro.

$\mathrm{Na}$ totalidade do espaço intervencionado foram identificadas 35 sepulturas, das quais foram escavadas 28 na íntegra, uma vez que as restantes ou se prolongavam fora dos limites da sondagem, ou se encontravam parcialmente sob alguma estrutura. Do total de sepulturas foram exumados 14 enterramentos ${ }^{6}$ em conexão anatómica, e 2 ossários. As sepulturas exumadas apresentam estruturas tumulares que evidenciam três soluções tipológicas.

Sepulturas estruturadas com lajes laterais (Foto 9), maioritariamente de granito, formando uma caixa que assenta diretamente no solo ou no substrato rochoso. $\mathrm{Na}$ sua construção foram utilizadas pedras aparelhadas em pelo menos duas faces, a superior e a lateral interior, as quais poderão ter sido reaproveitadas de construções anteriores, variando a composição das paredes laterais entre as duas e quatro pedras. Não foi encontrado nenhum vestígio de tampa nos escassos exemplares deste tipo de sepultura. A forma dominante é a de tendência retangular, excetuando a sepultura 11 (Foto 8), que tem formato subtrapezoidal.

Sepulturas escavadas no substrato rochoso, no qual formam uma caixa tanto quanto possível estanque, emulando um espaço do tipo sarcófago. Nos casos em que a irregularidade da rocha não o permite, entalha-se uma base para apoio de pedras que irão complementar a irregularidade do espaço, nivelando-o. A sepultura 21 mostra-nos um exemplo desta solução no qual ainda sobrevivem algumas pedras laterais (Foto 7). Esta regularidade destina-se ao assentamento da tampa, como ilustra a sepultura 17 (Foto 5), com a qual se formaria um espaço estanque, destinado à deposição do corpo. A forma ovalada é dominante, registando-se duas sepulturas de formato subtrapezoidal (sepulturas 9 e 17) e duas sub-retangulares (sepulturas 20 e 35).

Dentre as sepulturas escavadas na rocha, temos variantes nas quais se constata que não existe um contorno bem definido, nem alinhamento de guias laterais ou afeiçoamento da pedra para apoio de tampa. De resto, as respetivas plantas apresentam contornos mais arredondados (sepulturas 12 a 16) dentro da forma subtrapezoidal, e uma organização mais caótica, no alinhamento e nas sobreposições (Fotos 2 e 3). Algumas destas são manifestamente mais tardias dentro da necrópole, conforme o sugere a sua organização e a estratigrafia relativa.

\footnotetext{
${ }^{6} \mathrm{O}$ enterramento 2 corresponde a um canídeo (QUEIROGA et al., no prelo).
} 
Por último, temos as sepulturas simples, em covacho (Foto 6), que correspondem a simples valas abertas no solo sem qualquer outra definição da cavidade de inumação (sepulturas 27, 3132 e 33). As sepulturas deste tipo existem apenas no extremo poente da área intervencionada, onde o nível da terra humosa é mais profundo. Cremos que, a ser mais superficial o substrato rochoso, elas se integrariam no modelo definido anteriormente, razão pela qual se deveriam considerar como uma variante deste. Estes dois últimos modelos tiveram uma larga perduração ${ }^{7}$, estando vulgarizado o seu uso na Baixa Idade Média.

Apresentam-se, em seguida, alguns quadros sinópticos do conjunto das sepulturas, das suas dimensões e caraterísticas, dispensando assim a descrição e o comentário individual de cada um dos exemplos registados.

Tabela 1. Análise geral das sepulturas em «caixa»

\begin{tabular}{|c|c|c|c|c|c|c|c|}
\hline & Orientação & Tipologia & Comprimento & $\begin{array}{l}\text { Largura } \\
\text { Máxima }\end{array}$ & $\begin{array}{c}\text { N. de } \\
\text { Lajes de } \\
\text { Cobertura }\end{array}$ & $\begin{array}{l}\text { N. de } \\
\text { Lajes } \\
\text { Direita }\end{array}$ & $\begin{array}{c}\text { N.º de } \\
\text { Lajes } \\
\text { Esquerda }\end{array}$ \\
\hline $\begin{array}{c}\text { Sepultura } \\
1\end{array}$ & NO-SE & Retangular & $1,43 \mathrm{~m}$ & $0,29 \mathrm{~m}$ & 0 & 1 & 4 \\
\hline $\begin{array}{c}\text { Sepultura } \\
2\end{array}$ & NO-SE & Retangular & $1,86 \mathrm{~m}$ & $0,36 \mathrm{~m}$ & 1 & 2 & 2 \\
\hline $\begin{array}{c}\text { Sepultura } \\
3\end{array}$ & NO-SE & Retangular & $1,83 \mathrm{~m}$ & $0,39 \mathrm{~m}$ & 0 & 2 & 2 \\
\hline $\begin{array}{c}\text { Sepultura } \\
11\end{array}$ & NO-SE & Subtrapezoidal & $1,02 \mathrm{~m}$ & $0,33 \mathrm{~m}$ & 2 & 2 & 2 \\
\hline $\begin{array}{c}\text { Sepultura } \\
26\end{array}$ & NO-SE & Indeterminada & $1,52 \mathrm{~m}$ & $0,36 \mathrm{~m}$ & 0 & 1 & 3 \\
\hline $\begin{array}{c}\text { Sepultura } \\
30\end{array}$ & Indet. & Indeterminada & $1,12 \mathrm{~m}$ & $?$ & 0 & 2 & 0 \\
\hline
\end{tabular}

Fonte: elaboração própria

Tabela 2. Análise geral das sepulturas escavadas na rocha

\begin{tabular}{c|c|c|c|c}
\hline & Orientação & Tipologia & Comprimento & $\begin{array}{l}\text { Largura } \\
\text { máxima }\end{array}$ \\
\hline Sepultura 4 & NO-SE & Ovalada & $1,23 \mathrm{~m}$ & $0,36 \mathrm{~m}$ \\
\hline Sepultura 5 & NO-SE & Ovalada & $1,84 \mathrm{~m}$ & $0,36 \mathrm{~m}$ \\
\hline Sepultura 6 & NO-SE & Ovalada & $2,43 \mathrm{~m}$ & $0,53 \mathrm{~m}$ \\
\hline Sepultura 7 & NO-SE & Ovalada & $1,78 \mathrm{~m}$ & $0,50 \mathrm{~m}$ \\
\hline
\end{tabular}

${ }^{7}$ BARROCA, 1987: 300 . 


\begin{tabular}{|c|c|c|c|c|}
\hline Sepultura 8 & NO-SE & Ovalada & $1,82 \mathrm{~m}$ & $0,38 \mathrm{~m}$ \\
\hline Sepultura 9 & NO-SE & Subtrapezoidal & $1,07 \mathrm{~m}$ & $0,35 \mathrm{~m}$ \\
\hline Sepultura 10 & NO-SE & Ovalada & $?$ & $0,52 \mathrm{~m}$ \\
\hline Sepultura 12 & NO-SE & Ovalada & $1,59 \mathrm{~m}$ & $0,44 \mathrm{~m}$ \\
\hline Sepultura 13 & SO-NE & Sub-retangular & $1,92 \mathrm{~m}$ & $0,68 \mathrm{~m}$ \\
\hline Sepultura 14 & SO-NE & Sub-retangular & $1,94 \mathrm{~m}$ & $0,64 \mathrm{~m}$ \\
\hline Sepultura 15 & SO-NE & Sub-retangular & $1,15 \mathrm{~m}$ & $0,65 \mathrm{~m}$ \\
\hline Sepultura 16 & NO-SE & Sub-retangular & $2,17 \mathrm{~m}$ & $0,56 \mathrm{~m}$ \\
\hline Sepultura 17 & NO-SE & Subtrapezoidal & $1,05 \mathrm{~m}$ & $0,31 \mathrm{~m}$ \\
\hline Sepultura 18 & SO-NE & Ovalada & $1,89 \mathrm{~m}$ & $0,52 \mathrm{~m}$ \\
\hline Sepultura 19 & SO-NE & Ovalada & $1,84 \mathrm{~m}$ & $0,43 \mathrm{~m}$ \\
\hline Sepultura 20 & NO-SE & Sub-retangular & $0,90 \mathrm{~m}$ & $0,40 \mathrm{~m}$ \\
\hline Sepultura 21 & NO-SE & Ovalada & $1,86 \mathrm{~m}$ & $0,40 \mathrm{~m}$ \\
\hline Sepultura 22 & NO-SE & Ovalada & $2,05 \mathrm{~m}$ & $0,36 \mathrm{~m}$ \\
\hline Sepultura 23 & NO-SE & Ovalada & $1,83 \mathrm{~m}$ & $0,40 \mathrm{~m}$ \\
\hline Sepultura 24 & NO-SE & Ovalada & $1,55 \mathrm{~m}$ & $?$ \\
\hline Sepultura 25 & NO-SE & Ovalada & $1,36 \mathrm{~m}$ & $0,32 \mathrm{~m}$ \\
\hline Sepultura 28 & NO-SE & Indeterminada & $?$ & $0,45 \mathrm{~m}$ \\
\hline Sepultura 29 & NO-SE & Ovalada & $0,45 \mathrm{~m}$ & $0,39 \mathrm{~m}$ \\
\hline Sepultura 34 & NO-SE & Ovalada & $1,87 \mathrm{~m}$ & $0,28 \mathrm{~m}$ \\
\hline Sepultura 35 & NO-SE & Sub-retangular & $1,91 \mathrm{~m}$ & $0,29 \mathrm{~m}$ \\
\hline
\end{tabular}

Fonte: elaboração própria

Tabela 3. Análise geral dos covachos

\begin{tabular}{c|c|c|c}
\hline & Orientação & Comprimento & $\begin{array}{c}\text { Largura } \\
\text { máxima }\end{array}$ \\
\hline Sepultura 27 & O-E & $1,35 \mathrm{~m}$ & $0,53 \mathrm{~m}$ \\
\hline Sepultura 31 & O-E & $1,50 \mathrm{~m}$ & $0,26 \mathrm{~m}$ \\
\hline Sepultura 32 & O-E & $?$ & $?$ \\
\hline Sepultura 33 & $?$ & $0,55 \mathrm{~m}$ & $0,35 \mathrm{~m}$ \\
\hline
\end{tabular}

Fonte: elaboração própria 
Tabela 4. Análise geral dos enterramentos

\begin{tabular}{|c|c|c|c|c|c|c|}
\hline Designação & Orientação & Posição & $\begin{array}{c}\text { Membros } \\
\text { superiores }\end{array}$ & $\begin{array}{l}\text { Membros } \\
\text { inferiores }\end{array}$ & $\begin{array}{l}\text { Grupo } \\
\text { etário }\end{array}$ & Sexo \\
\hline Enterramento 1 & NO-SE & Dec. dorsal & Úmeros paralelos & Paralelos & Adulto & Indet. \\
\hline Enterramento 2 & NO-SE & $\begin{array}{l}\text { Dec. lateral } \\
\text { direito }\end{array}$ & Fletidos & Fletidos & & \\
\hline Enterramento 3 & SO-NE & Dec. dorsal & $\begin{array}{c}\text { Úmeros paralelos e } \\
\text { antebraços sobre o } \\
\text { tórax }\end{array}$ & Paralelos & Adulto & Masculino \\
\hline Ossário 1 & SO-NE & & & & Adulto & Feminino \\
\hline Enterramento 4 & SO-NE & Dec. dorsal & $\begin{array}{c}\text { Úmeros paralelos e } \\
\text { antebraços sobre o } \\
\text { tórax }\end{array}$ & Paralelos & Adulto & Masculino \\
\hline Ossário 2 & SO-NE & & & & Adulto & Masculino \\
\hline Enterramento 5 & SO-NE & Dec. dorsal & $\begin{array}{c}\text { Úmeros paralelos e } \\
\text { antebraços sobre os } \\
\text { ilíacos, com a mão } \\
\text { esquerda sobre a mão } \\
\text { direita }\end{array}$ & Paralelos & Adulto & Masculino \\
\hline Enterramento 6 & NO-SE & Dec. dorsal & $\begin{array}{l}\text { Úmeros paralelos e } \\
\text { antebraço direito sobre } \\
\text { o tórax e o esquerdo } \\
\text { sobre os ilíacos }\end{array}$ & Paralelos & Adulto & Masculino \\
\hline Enterramento 7 & SO-NE & Dec. dorsal & $\begin{array}{c}\text { Antebraços paralelos } \\
\text { sobre os ilíacos }\end{array}$ & Paralelos & Adulto & Indet. \\
\hline Enterramento 8 & SO-NE & Dec. dorsal & $?$ & $?$ & Criança & Indet. \\
\hline Enterramento 9 & NO-SE & Dec. dorsal & $?$ & $?$ & Adulto & Indet. \\
\hline Enterramento 10 & O-E & Dec. dorsal & $\begin{array}{c}\text { Úmeros paralelos e } \\
\text { antebraços sobre o } \\
\text { tórax }\end{array}$ & Paralelos & Adulto & Indet. \\
\hline Enterramento 11 & NO-SE & Dec. dorsal & $?$ & Paralelos & Adulto & Indet. \\
\hline Enterramento 12 & O-E & Dec. dorsal & $?$ & Paralelos & Adulto & Indet. \\
\hline Enterramento 13 & O-E & $?$ & $?$ & $?$ & Criança & Indet. \\
\hline Enterramento 14 & $?$ & Dec. dorsal & $?$ & $?$ & Adulto & Indet. \\
\hline
\end{tabular}

Fonte: elaboração própria

As caraterísticas das sepulturas dão-nos algumas indicações sobre os rituais de enterramento. A orientação predominante observada nas sepulturas de época medieval é noroeste-sudeste sendo menos expressivos os casos nos quais a orientação é oeste-este, por se resumirem a três inumações em covacho (sepulturas 27, 
31 e 32). Apesar de a inumação com orientação da cabeceira a poente ser um ritual tipicamente associado ao enterramento cristão, as variações a este padrão ocorrem com alguma frequência. Poderia argumentar-se que esta ligeira variação se deveria a inumações em diferentes períodos do ano, portanto com diferentes declinações solares, ou mesmo com os constrangimentos colocados pelo alinhamento do veio rochoso, como se constata nas sepulturas 5, 6, 7 e 8, as quais estão orientadas segundo as clivagens do xisto. Contudo, nenhum destes argumentos pode ofuscar o facto de a necrópole em qualquer uma das suas fases se encontrar em espaço claramente definido pela ortogonalidade de edifícios, aos quais se juntariam, eventualmente, referências superficiais dos enterramentos, como lápides ou crucifixos, constituindo todos eles uma orientação axial permanente.

A prática de inumação em todos os casos identificados é a deposição em decúbito dorsal, e nos casos em que foi possível pormenorizar o crânio estava inclinado sobre a face direita (enterramentos 1 e 12). Apenas dois esqueletos revelam a posição dos membros superiores, pois em todos os restantes os ossos degradaram-se. No enterramento 1, os antebraços não se preservaram, sendo visíveis apenas os úmeros, que se encontravam paralelos. No enterramento 10, os úmeros também se encontravam paralelos e os antebraços localizavam-se sobre o tórax. Nos casos em que a preservação dos ossos permitiu apurar (Foto 3), os membros inferiores encontravam-se paralelos.

Ainda sobre o processo de enterramento, e complementado o que acima foi dito sobre a tipologia das sepulturas, temos indício de uma prática, a mais generalizada, na qual se constata que o indivíduo inumado seria recoberto com terra. No entanto, algumas sepulturas apresentam-se bem definido por pedras (sepulturas 1, $2,3,11,26$ ), ou escavado na rocha com ressalto para apoio de tampa (sepulturas 21 e 35), e tapadas com lajes de cobertura bem calafetadas (sepulturas 2, 11 e 17) para impedir a entrada de terra. Formavam assim um espaço que emulava um esquife, ou sarcófago, no qual o cadáver não era recoberto por terra ${ }^{8}$, modelo que encontramos mais vulgarizado nos enterramentos da Alta Idade Média99.

Um outro pormenor digno de nota é o apoio de cabeça em ressalto ou em rampa, dos quais encontramos documentado em entalhe nas sepulturas 5 (Foto 4), 8, 16, 21 (Foto 7) e 25. Cremos que a pequena pedra na cabeceira da 22 terá a mesma função, o que poderia sugerir uma datação algo mais antiga para esta inumação ${ }^{10}$, dentro do século XII. Esta solução, que está bem documentada nos

\footnotetext{
${ }^{8}$ Esta solução tipológica está bem representada na necrópole de S. Miguel, em Vizela (QUEIROGA, 2013: Figs. 8, 10, e 14), em cujas sepulturas se nota uma calafetagem tão eficaz que apenas se depositaram escassos centímetros de sedimento na sua base.

${ }^{9}$ BARROCA, 1987.

${ }^{10}$ BARROCA, 1987: 303.
} 
desníveis em rampa encontrados nas cabeceiras dos sarcófagos a partir do século $\mathrm{XIII}^{11}$, corrobora as impressões acima expressas acerca da tipologia de inumação. A propósito, referimos a cabeceira de um grande sarcófago, em granito de grão fino, que aflora no alicerce da parte média do lado sul do claustro, descortinando-se a cabeceira de uma peça monolítica, de formato semicircular ultrapassado (Foto 10), com contorno perfeito e parede exterior vertical. O interior da cabeceira revelou um espaço bem entalhado, de configuração simétrica ao perfil exterior, tendo o plano de apoio da cabeça em rampa longitudinal. Pelas suas caraterísticas, mormente a configuração formal e a qualidade do talhe, de pico fino, cremos tratar-se de uma peça de grande prestígio e portanto ligada a um dos notáveis inumados no mosteiro. Considerando o tempo necessário para a erosão da memória de alguém inumado numa peça de tal qualidade, e a sua degradação à função de entulho nesta obra do século XVII, cremos que a sua utilização como sepultura não deverá ser posterior aos inícios-meados do século XV.

Voltando à necrópole, e às sepulturas com tampa, constatamos que o processo de enterramento era concluído com a cobertura da sepultura por meio de uma, ou mais frequentemente, de várias lajes. A maioria das sepulturas foi encontrada sem tampa, podendo esta ausência dever-se a perturbações e reutilizações, uma vez que algumas apresentam afeiçoamento lateral destinado ao apoio das lajes de cobertura.

Apenas as sepulturas 2, 11 e 17 foram encontradas com a cobertura intacta. $\mathrm{Na}$ sepultura 2 foi identificada apenas uma das lajes, com formato sub-retangular, na 11 a cobertura era formada por 2 lajes, bastante irregulares e de afeiçoamento grosseiro (Foto 8), enquanto as duas lajes de cobertura da 17 (Foto 5) tinham uma forma retangular, mais regular. Nenhuma das peças continha qualquer inscrição ou elemento decorativo, e tampouco apresentavam afeiçoamento consentâneo com a função. Este facto, aliado à cota a que se encontram os exemplares deste tipo, sugere que estariam recobertas com terra, não se destinando a ser vistas, o que levanta a questão se existiria algum elemento de demarcação de cada uma das sepulturas à superfície do cemitério.

Uma breve referência ao pouco que os restos osteológicos nos permitem inferir sobre a população inumada, evidência que se concentra naturalmente nas sepulturas mais tardias (Foto 3), nas quais se observa melhor conservação dos esqueletos ${ }^{12}$. Foi possível determinar que, no contexto da população inumada, três indivíduos são do sexo masculino, dois do feminino, e nos restantes nove não foi possível determinar o sexo. Quanto ao perfil etário, temos dez adultos identificados, e dois não-adultos, sendo um com $\pm 2-3$ anos.

\footnotetext{
${ }^{11}$ BARROCA, 1987: 319-320.

${ }^{12}$ Informação baseada no estudo produzido por Linda Melo, Mosteiro de São Miguel dos Refojos - Cabeceiras de Basto, Relatório de Antropologia, 2013, relatório apresentado à DRCN.
} 


\section{CRONOLOGIA DOS SEPULTAMENTOS}

Nenhum dos sepultamentos escavados possuía qualquer mobiliário funerário, facto que parece indicar a observância da norma cristã de inumação em total desapego de bens materiais, na qual o corpo seria envolto em sudário, sendo enterrado sem esquife, uma vez que não foram encontrados pregos em nenhuma das sepulturas. São escassos, e de pouca fiabilidade contextual, os materiais exumados neste trecho da necrópole, uma vez que não estão diretamente associados a qualquer uma das sepulturas.

No decurso da escavação foram detetados materiais diversos, desde os de uso doméstico aos utilizados na construção, como fragmentos de azulejo e tijolo. Contudo, estes apenas surgiram nas camadas superficiais e nos contextos de perturbação, mormente os provocados pelas inúmeras drenagens que entrecortam o espaço, razão pela qual os desconsideramos neste âmbito, referindo apenas os que foram encontrados em contexto com as estruturas.

O escasso espólio cerâmico que foi encontrado associado às sepulturas é atribuível à época medieval, variando as suas cronologias entre os séculos XII e XIV. Trata-se, contudo, de material cujo revolvimento estratigráfico não permite uma articulação com as inumações que seja suscetível de contribuir para a datação destas. Por outro lado, alguns fragmentos cerâmicos integrados nas argamassas dos muros são datáveis de época moderna, em torno do século XVI, articulando-se, portanto, em anterioridade, com a época da obra do claustro. Sugerimos que poderão estar associados ao conjunto de obras efetuadas, entre 1555 e 1560 durante a administração de D. Diogo de Murça, nomeadamente nas oficinas, dormitórios e no claustro, ou aos acrescentos que se fomentaram posteriormente com a passagem dos abades comendatários a abades trienais, tendo-se inclusive construído uma nova igreja no local da anterior ${ }^{13}$.

A dificuldade em estabelecer a cronologia deste conjunto de sepulturas por meio de datação cultural, junto com o facto de dispormos de alguns restos ósseos, forçou a alternativa de realizar datações por radiocarbono de algumas das sepulturas $^{14}$, bem assim como o estudo osteológico dos seus conteúdos. A configuração tipológica das sepulturas desde logo fundamentou a suspeita de na sua maioria pertencerem a uma fase tardia dentro da Idade Média, mas o seu contributo para as cronologias de ocupação do mosteiro não poderia ser negligenciado. Desta forma, e tendo como base o estudo osteológico efetuado por Linda Melo, estabeleceu-se uma amostragem o mais adequada possível tanto aos objetivos de datação como à

\footnotetext{
${ }^{13}$ SÃO TOMÁS, 1644: 497.

${ }^{14}$ Não podemos deixar de registar o empenho da Câmara Municipal de Cabeceiras de Basto no incitamento e apoio à realização destes estudos e análises, os quais custeou integralmente, promovendo ainda o estudo osteológico desta necrópole (QUEIROGA et al., no prelo).
} 
exequibilidade das amostras, uma vez que os restos ósseos se encontravam muito degradados. Com efeito, a maioria das sepulturas encontram-se imersas no nível freático na maior parte do ano, conforme se constatou durante a escavação, realizada durante o verão, mas cremos que tal não terá ocorrido no período de funcionamento da necrópole, podendo dever-se ao edificado da última fase do mosteiro a alteração do fluxo das águas superficiais. Em todo o caso, este contexto deposicional húmido contribuiu de alguma forma para retardar a degradação dos vestígios osteológicos, mas também ocasionou a lixiviação da matéria orgânica mais perene, mormente o colagénio, que é fundamental para a datação pelo radiocarbono. Por esta razão, apenas parte das amostras reuniam condições para ser datadas, nomeadamente as provenientes das sepulturas 14, 15, 16 e 18. Junto com as datações foi ainda possível determinar os valores de isótopos de $\partial 13 \mathrm{C}$ e $\partial 15 \mathrm{~N}$ para estudo de paleodietas. Estando limitados às amostras passíveis de análise, provenientes dos esqueletos melhor conservados, fomos inevitavelmente conduzidos aos exemplares do conjunto que apresentam cronologia mais tardia dentro da necrópole.

Os resultados obtidos são apresentados na tabela seguinte:

Tabela 5. Datações por Carbono 14

\begin{tabular}{|c|c|c|c|c|c|c|}
\hline ref. amostra & idade BP-DC & cal 1 sigma & cal 2 sigma & $\begin{array}{l}\text { IRMS } \\
\delta 13 C \\
\end{array}$ & $\begin{array}{l}\text { IRMS } \\
\delta 15 N \\
\end{array}$ & $\begin{array}{l}\text { Carb./ } \\
\text { Nitrog. }\end{array}$ \\
\hline $\begin{array}{c}\text { Beta }-513765 \\
\text { Sepultura } 14\end{array}$ & $\begin{array}{c}350 \pm 30 \mathrm{BP} \\
1600 \pm 30 \mathrm{DC}\end{array}$ & $\begin{array}{c}(68 \%)-1470-1525 \mathrm{cal} D C \\
-1555-1630 \mathrm{cal} D C\end{array}$ & $(95 \%)-1450-1640 \mathrm{cal}$ DC & $\begin{array}{l}\circ \\
\stackrel{0}{0} \\
0 \\
0 \\
0 \\
1\end{array}$ & $\begin{array}{l}\stackrel{\circ}{\circ} \\
\stackrel{\circ}{1} \\
\stackrel{+}{+}\end{array}$ & 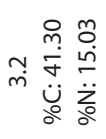 \\
\hline $\begin{array}{l}\text { Beta }-520906 \\
\text { Sepultura } 15\end{array}$ & $\begin{array}{c}430 \pm 30 \mathrm{BP} \\
1520 \pm 30 \mathrm{AC}\end{array}$ & (68\%)- $1440-1455$ cal DC & $(95 \%)-1430-1485$ cal DC & 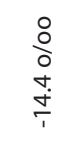 & $\frac{\circ}{\frac{\circ}{0}} \frac{\bar{m}}{\frac{m}{+}}$ & 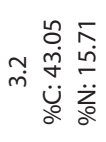 \\
\hline $\begin{array}{c}\text { Beta }-513767 \\
\text { Sepultura } 16\end{array}$ & $\begin{array}{c}350 \pm 30 \mathrm{BP} \\
1600 \pm 30 \mathrm{DC}\end{array}$ & $\begin{array}{c}(68 \%)-1470-1525 \mathrm{cal} D C \\
-1555-1630 \mathrm{cal} D C\end{array}$ & $(95 \%)-1450-1640 \mathrm{cal}$ DC & $\begin{array}{l}\circ \\
\circ \\
\infty \\
\stackrel{\infty}{0} \\
\frac{1}{1}\end{array}$ & $\begin{array}{l}\stackrel{\circ}{\circ} \\
\stackrel{+}{+} \\
\stackrel{+}{+}\end{array}$ & 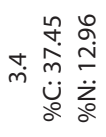 \\
\hline $\begin{array}{c}\text { Beta }-510960 \\
\text { Sepultura } 18\end{array}$ & $\begin{array}{c}400 \pm 30 \mathrm{BP} \\
1550 \pm 30 \mathrm{AC}\end{array}$ & $(68 \%)-1445-1485$ cal DC & $\begin{array}{c}(95 \%)-1440-1520 \mathrm{cal} D C \\
-1595-1620 \mathrm{cal} \mathrm{DC}\end{array}$ & $\begin{array}{l}8 \\
\frac{0}{0} \\
\circ \\
\frac{0}{1}\end{array}$ & $\begin{array}{l}\stackrel{\circ}{o} \\
\stackrel{a}{m} \\
\frac{m}{+}\end{array}$ & 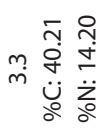 \\
\hline
\end{tabular}

Fonte: Beta Analytics

Dos valores expressos nesta tabela constata-se que, apesar de o desvio padrão das datas ser comparativamente pequeno, de apenas 30 anos em todas elas, a calibração alarga substancialmente o espaço temporal no qual a data se encontra. 
Deve-se ao facto de a curva de calibração do C14 possuir um perfil mais aplanado na época em questão, facto que alarga consideravelmente a amplitude das interseções de anos C14 com o calendário, e mormente as das datas referentes às sepulturas 14 e 16 .

Fazendo agora um comentário às cronologias obtidas, temos a análise da Sepultura 14 (Beta - 513765: MSMR2013-SEP14), que forneceu uma cronologia idêntica à da Sepultura 16 (Beta - 513767: MSMR2013-SEP16), razão pela qual as trataremos em conjunto, dispensando a duplicação de gráficos e de argumentação.

Gráfico 1. Curva de calibração da amostra Beta - 513765

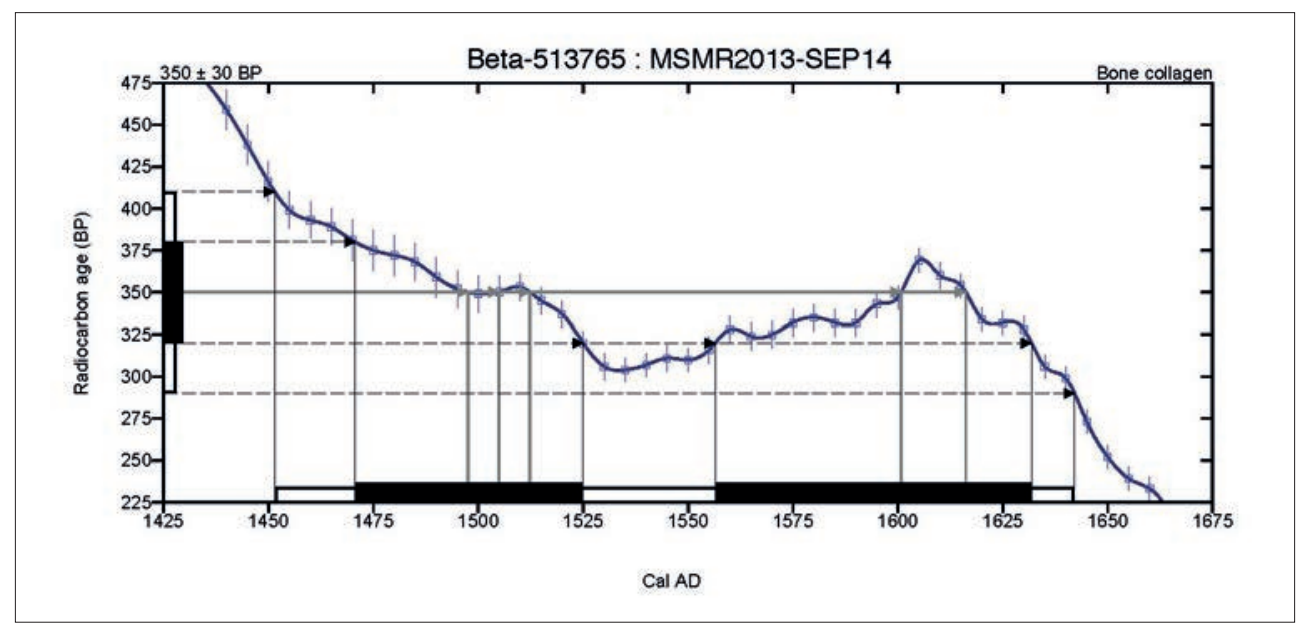

Fonte: Beta Analytics

Como se constata pelo gráfico de calibração desta datação, a curva apresenta uma configuração muito aplanada e entrecortada na época na qual a amostra se enquadra, apesar do valor comparativamente reduzido do desvio padrão. Desta forma, as interseções dos anos C14 sobre a curva de calendário alargam substancialmente a sua amplitude cronológica, como se constata pelas projeções sobre a linha de anos de calendário dos valores de 1 sigma e 2 sigma. Estamos perante a circunstância infeliz de os valores de 2 sigma - que é o espaço no qual existe $95 \%$ de probabilidade de nele se encontrar a data real- se dividirem em duas datas apartadas, e com probabilidades relativamente aproximadas: $54,1 \%$ para uma data entre 1538 e 1635 , e 41,3\% para uma data entre 1458 e 1530 . Em todo o caso, o cálculo de probabilidades apresentado pelo laboratório para as interseções, tanto de 1 como de 2 sigma, aponta para os valores cronológicos mais tardios, e neste último cômputo para a segunda metade do século XVI e as primeiras décadas do século XVII, o que é consentâneo com a datação cultural acima avançada. 
Gráfico 2. Curva de calibração da amostra Beta - 52090

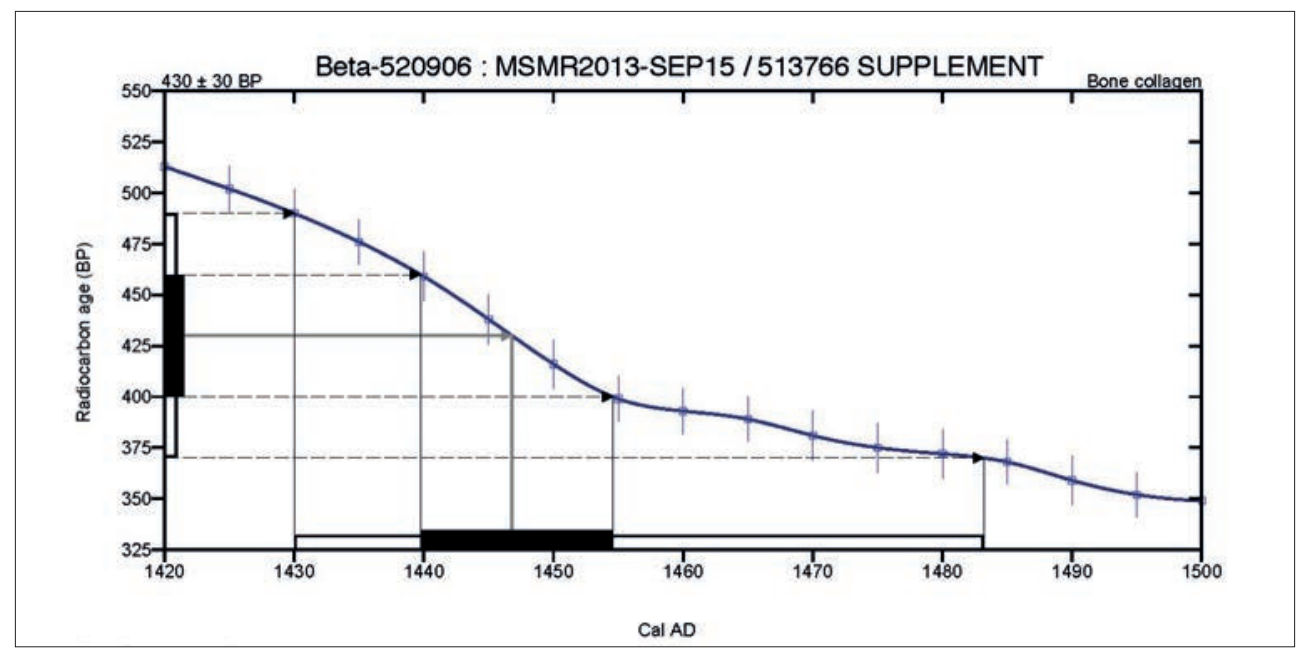

Fonte: Beta Analytics

Gráfico 3. Curva de calibração da amostra Beta - 510960

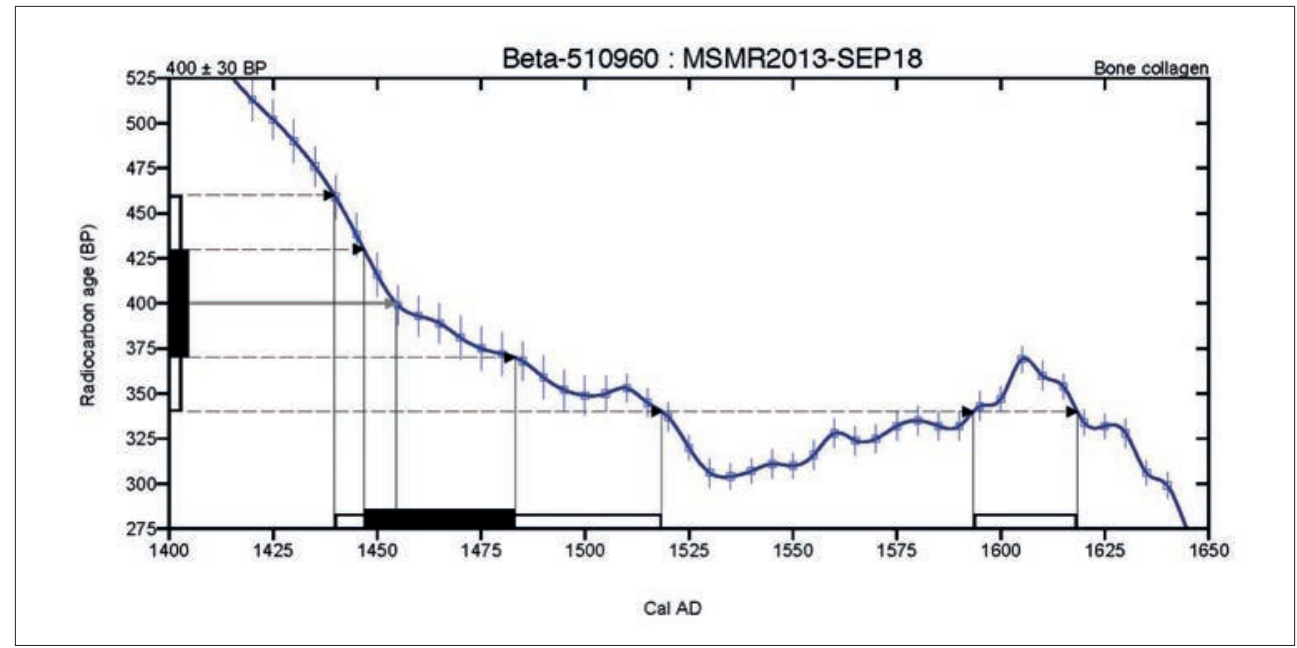

Fonte: Beta Analytics

As datas obtidas para as sepulturas 15 e 18 posicionam-se num período no qual a curva de calibração é mais uniforme, facto que se salda em menores desvios. Esta última data interseta ainda um pequeno pico da curva, como se verifica no gráfico acima, no qual se obtém uma projeção em torno de 1600, a qual, contudo, não fere a coerência da data. Desta forma, temos uma diacronia coerente de 1440-1520 neste grau máximo de probabilidade, pese o facto de a curva de calibração iniciar uma subida irregular por volta de 1530, o que provoca interseções num pico da curva 
entre 1595 e 1620, como pode constatar-se no gráfico correspondente. Em face destes resultados, cremos que a data real desta sepultura se situará na segunda metade do século XV, o que é consentâneo com a data obtida para a sepultura 15, mas poderá colocar em causa a sua articulação com o espaço de inumação entre muros de cronologia posterior.

No que concerne à data obtida para a sepultura 15 , temos que a sua conversão em anos de calendário interseta uma curva com um pendor uniforme, facto que se salda em uma amplitude cronológica coerente, dentro dos 90,5\% de probabilidades, entre os anos 1421 e 1498. Este espaço dilata-se ao longo da segunda metade do século $\mathrm{XV}$, em virtude de a curva de calibração reduzir subitamente o seu pendor a partir de 1455, como se verifica no gráfico acima. Em todo o caso, os valores são coerentes podendo considerar-se que a data não deve ultrapassar os meados do século XV. Assim, conclui-se que este enterramento pertence a uma fase anterior à construção dos muros que lhe são anexos, no século XVI, tendo em mente que é sobreposto pela sepultura 16, a qual apresenta cronologia mais tardia.

Aquando da construção do atual claustro, nos meados do século XVII, foram previstos espaços de inumação, debaixo das grandes lajes retangulares ao longo do seu perímetro, algumas das quais possuem forfex de levantamento, e, portanto, indícios evidentes de utilização. Desta forma, não parece sustentável que a partir de então persistisse a prática de enterramento no claustro, e sobretudo a uma cota tão elevada como a verificada nas sepulturas mais tardias. Com base na evidência tipológica e na articulação interna entre as sepulturas, e o apoio complementar das datações por radiocarbono, estamos convictos de que a construção do claustro terá encerrado a utilização desta necrópole, tendo como possível exceção o enterramento de canídeo da sepultura 4, em época posterior.

\section{BIBLIOGRAFIA}

ALMEIDA, Carlos Alberto Ferreira de (2001). História da Arte em Portugal. O Românico. Lisboa: Editorial Presença.

ARIÉS, Philippe (1987). Sobre a História da Morte no Ocidente desde a Idade Média. 2a edição. Lisboa: Teorema.

ARIÉS, Philippe (1991). O Homem perante a morte. Mem-Martins: Publicações Europa América, vol. 1. ARSÉNIO, Paulo; BATATA, Carlos (1992). Sepulturas escavadas na rocha da região de Tomar. In Boletim Cultural da Câmara Municipal de Tomar. Tomar: Camara Municipal de Tomar, vol. 16, pp. 92-102. AZEVEDO, R. de (1958-1962). Documentos Medievais Portugueses. Documentos Régios. Lisboa: Academia Portuguesa da História, vol. 1.

BARROCA, Mário Jorge; MORAIS, António Cardoso (1984). Sepulturas medievais na terra de Aguiar da Pena (Vila Pouca de Aguiar). «Arqueologia». 8, 92-101.

BARROCA, Mário Jorge; MORAIS, António Cardoso (1986). A Terra e o Castelo - Uma experiência arqueológica em Aguiar da Pena. «Portvgalia». Nova Série. 6-7, 35-87. 
BARROCA, Mário Jorge (1987). Necrópoles e sepulturas medievais de Entre-Douro-e-Minho (Séculos V $a \mathrm{XV}$ ). Porto: Faculdade de Letras da Universidade do Porto. Dissertação para Provas Públicas de Aptidão Pedagógica e Capacidade Científica.

BARROCA, Mário Jorge (2010). Memórias. In MATTOSO, José, dir. SOUSA, Bernardo Vasconcelos e, coord. História da Vida Privada em Portugal. Lisboa: Círculo de Leitores, vol. I, pp. 418-456.

CRAESBEECK, Francisco Xavier da Serra (1992). Memórias Ressuscitadas da Província de Entre Douro e Minho no ano de 1726. Ponte de Lima: Edições Carvalhos de Basto, vol. II.

CUNHA, Vítor (1958). Monografia de Cabeceiras de Basto. Cabeceiras de Basto.

FAURE, Francisco G. C. L. M. (2012). Casa de Deus e de Homens. Uma leitura arqueológica do Convento de S. Salvador de Vilar de Frades. Porto: Universidade Fernando Pessoa. Dissertação de Mestrado.

GONÇALVES, António Nogueira (1980). Estudos de História da Arte Medieval. Coimbra.

MATTOSO, José (1997). Pressupostos mentais do culto dos mortos. «Arqueologia Medieval». 5, 5-11.

PINA, Isabel Castro (1996). Ritos e imaginário da morte em testamentos dos séculos XIV e XV. In MATTOSO, José, ed. O Reino dos Mortos na Idade Média Peninsular. Lisboa: Edições Sá da Costa.

QUEIROGA, Francisco M.V.R. (2013). Algumas notas sobre a arqueologia da área urbana de Vizela. «Revista da Faculdade de Letras: Ciências e Técnicas do Património». 12, 181-201.

QUEIROGA, Francisco M.V.R.; MELO et al. (no prelo). Monges, corpos e claustros: A necrópole e o Mosteiro de S. Miguel de Refojos. Os restos osteológicos humanos e não humanos provenientes do Claustro do Mosteiro de São Miguel de Refojos. Cabeceiras de Basto: Câmara Municipal de Cabeceiras de Basto.

ROSA, Maria de Lurdes (2010). A morte e o Além. In MATTOSO, José, dir. SOUSA, Bernardo Vasconcelos e. coord. História da Vida Privada em Portugal. Lisboa: Círculo de Leitores, vol. I, pp. 402-417.

SÃO TOMÁS, Frei Leão de (1644). Benedictina Lusitana. Lisboa, vol. I, pp. 493-502.

SEQUEIRA, Maria O. P. G. de Paz (2006). A igreja do Mosteiro de São Miguel de Refojos de Cabeceiras de Basto. In Estudos em homenagem ao Professor Doutor José Amadeu Coelho Dias. Porto: FLUP.

SILVA, João Belmiro Pinto da (1990). Marco de Canaveses - Sepulturas Medievais Concelhias: Sepulturas cavadas na rocha. Marco de Canaveses: Ed. do Autor.

TAVARES, António L.M. (1999). Sepulturas escavadas na rocha no concelho de Mangualde. Mangualde: Associação Cultural Azurara da Beira.

TENTE, Catarina; LOURENÇO, Sandra (1998). Sepulturas medievais escavadas na rocha dos concelhos de Carregal do Sal e Gouveia: estudo comparativo. «Revista Portuguesa de Arqueologia». 1: 2, 191-218.

TENTE, Catarina; LOURENÇO, Sandra (2002). Sepulturas Medievais do Distrito de Évora. «Revista Portuguesa de Arqueologia». 5: 1, 239-258. 

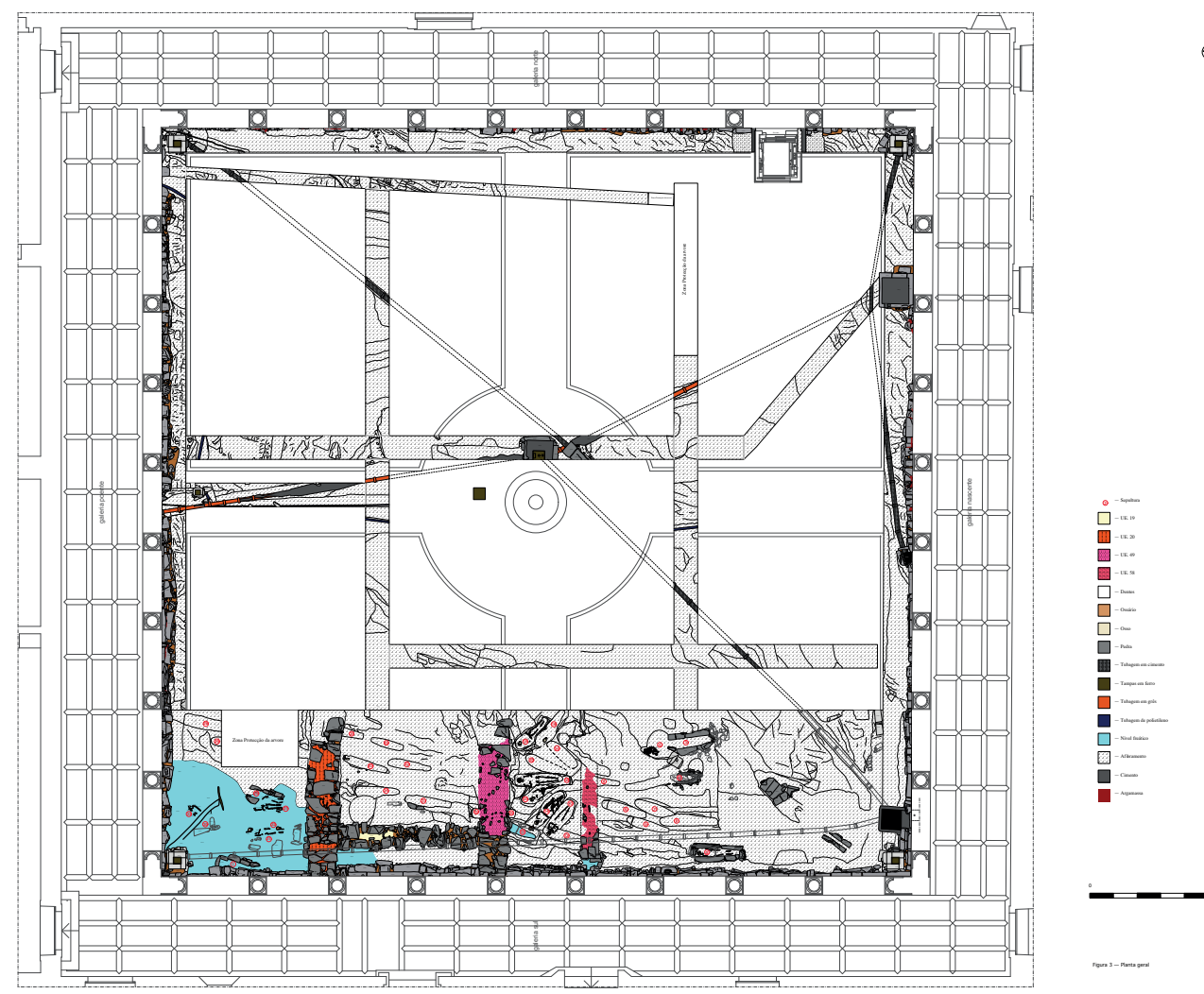

Fig. 1. Planta do claustro, com a localização das sepulturas Fonte: Desenho de Manuel Vitorino

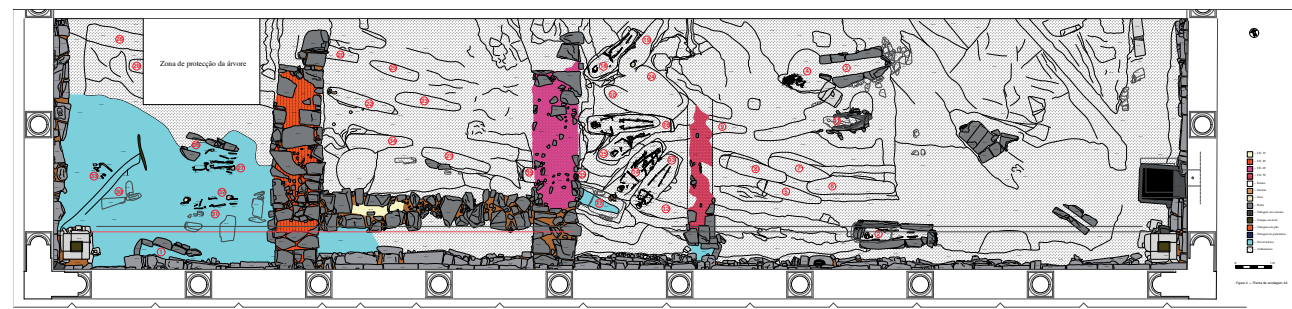

Fig. 2. Planta da necrópole

Fonte: Desenho de Manuel Vitorino 

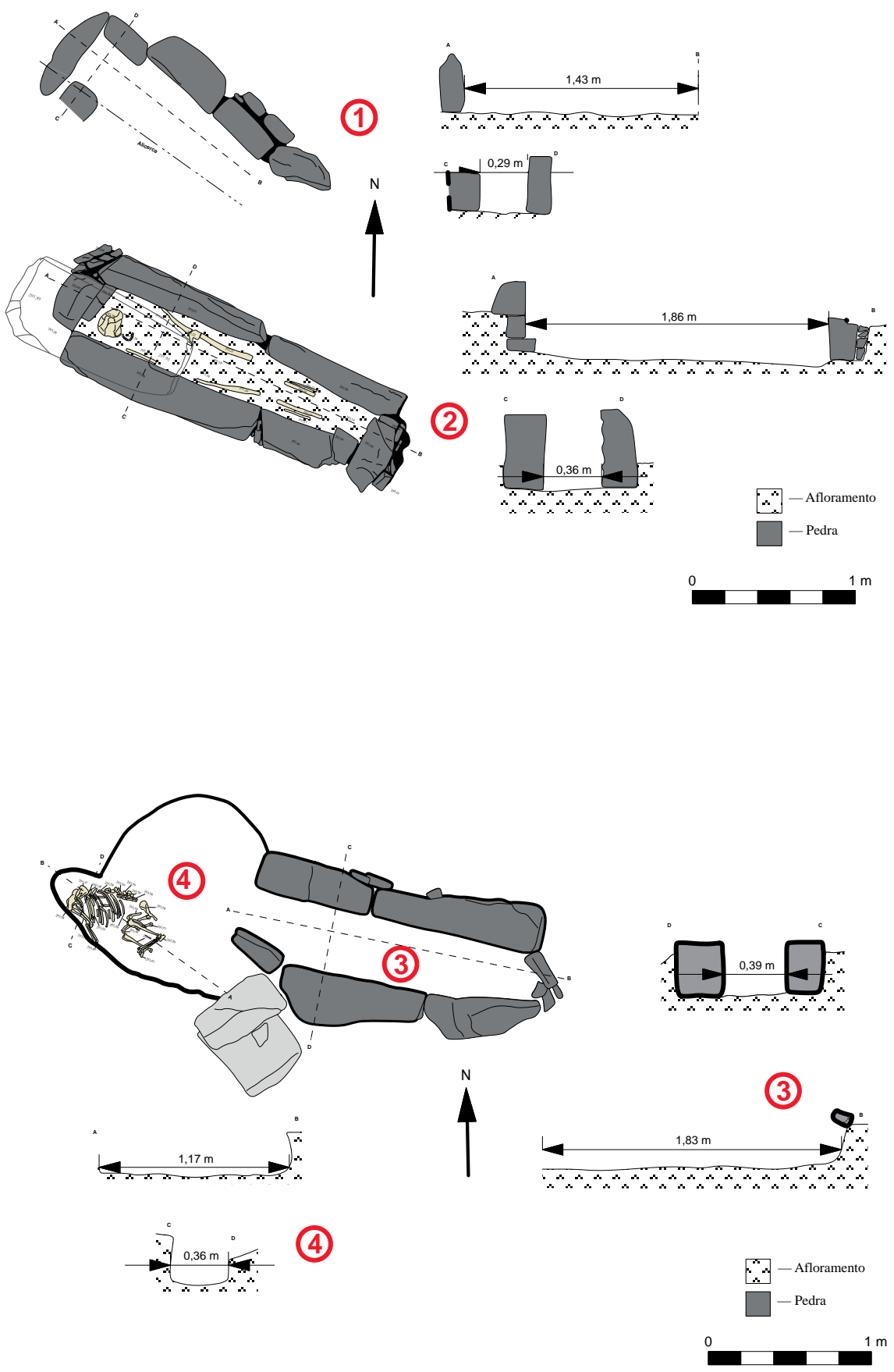

Fig. 3. Plantas e cortes das sepulturas 1, 2, 3, 4

Fonte: Desenho de Manuel Vitorino 


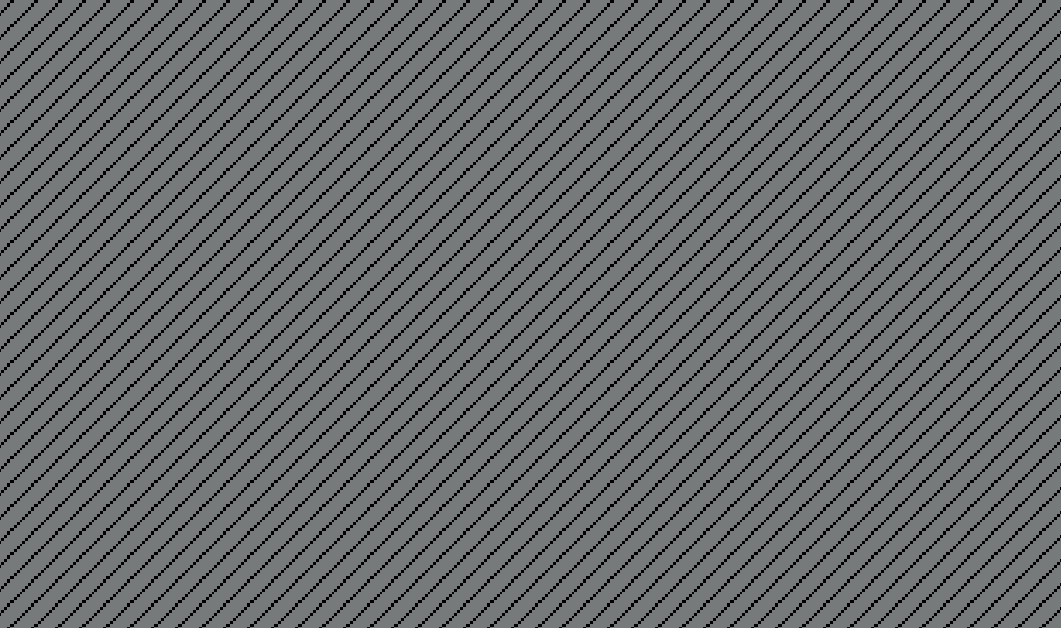

(5)

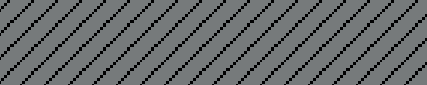

(7)
(8)

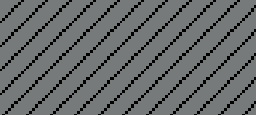

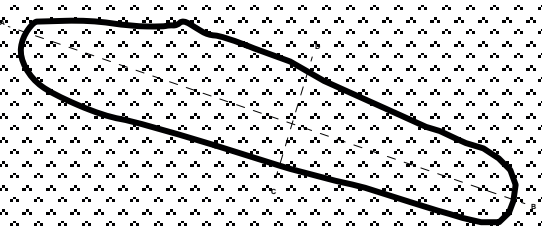

(6)

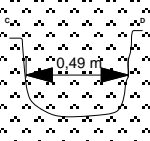

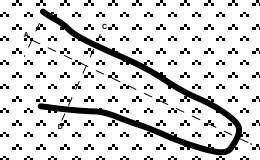

(9)
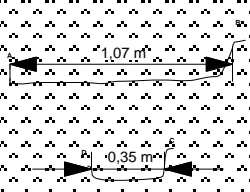

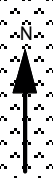

2
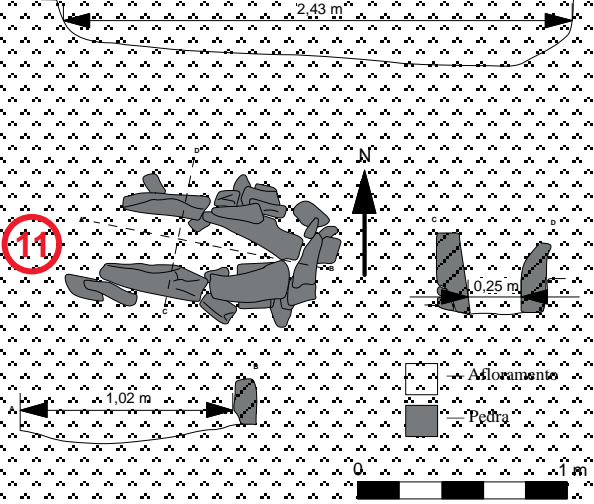

Fig. 4. Plantas e cortes das sepulturas 5 a 9 e 11

Fonte: Desenho de Manuel Vitorino 


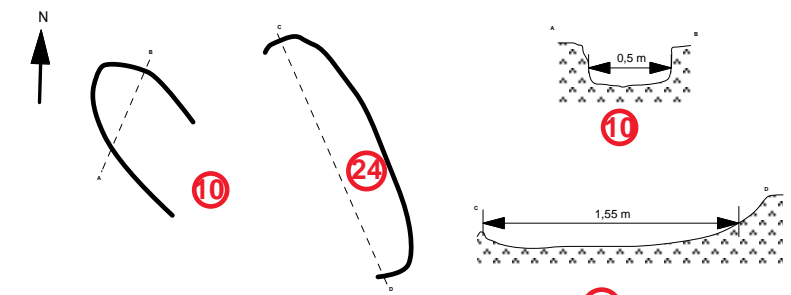

(24)
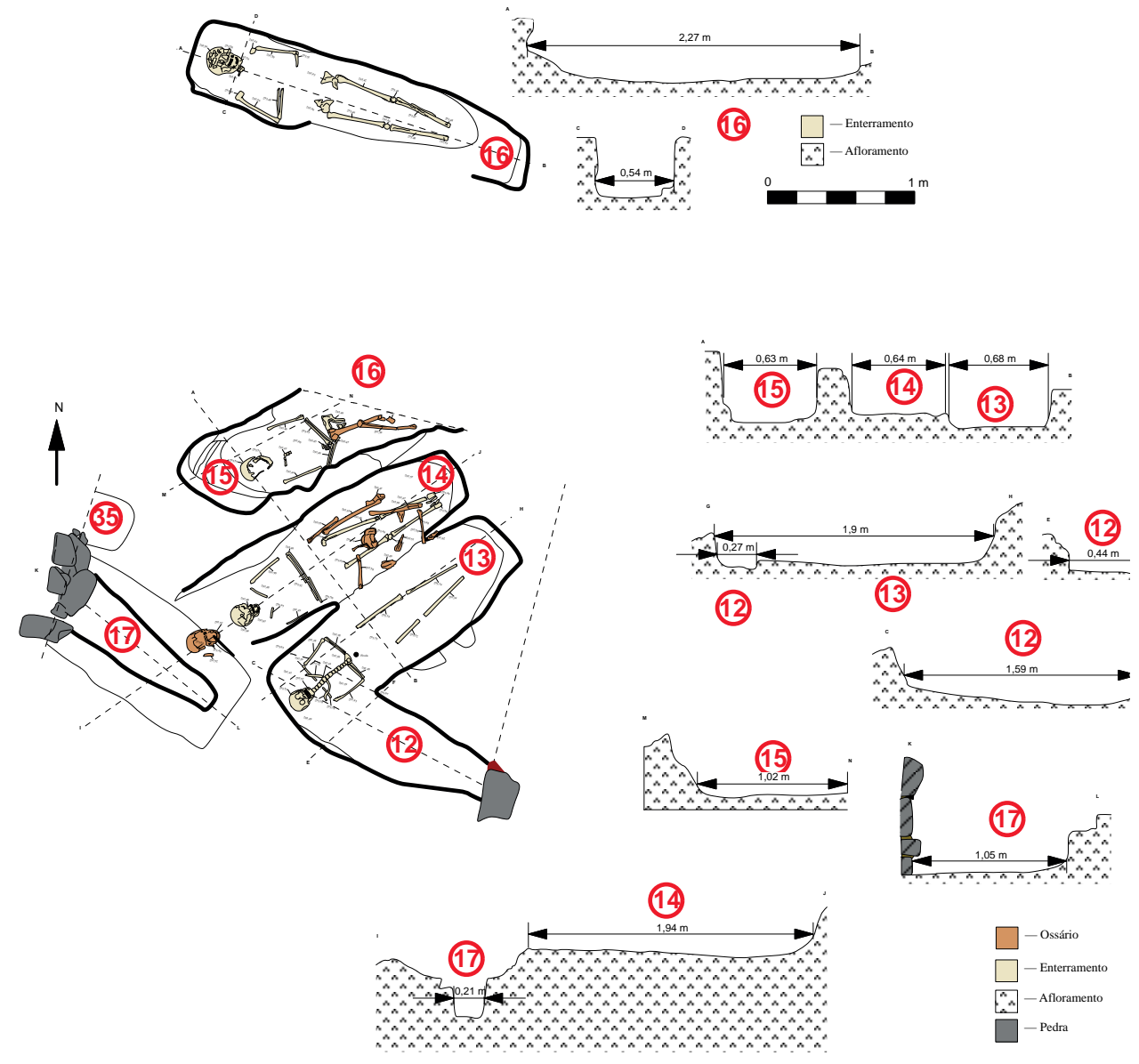

Fig. 5. Plantas e cortes das sepulturas no espaço central da necrópole Fonte: Desenho de Manuel Vitorino 

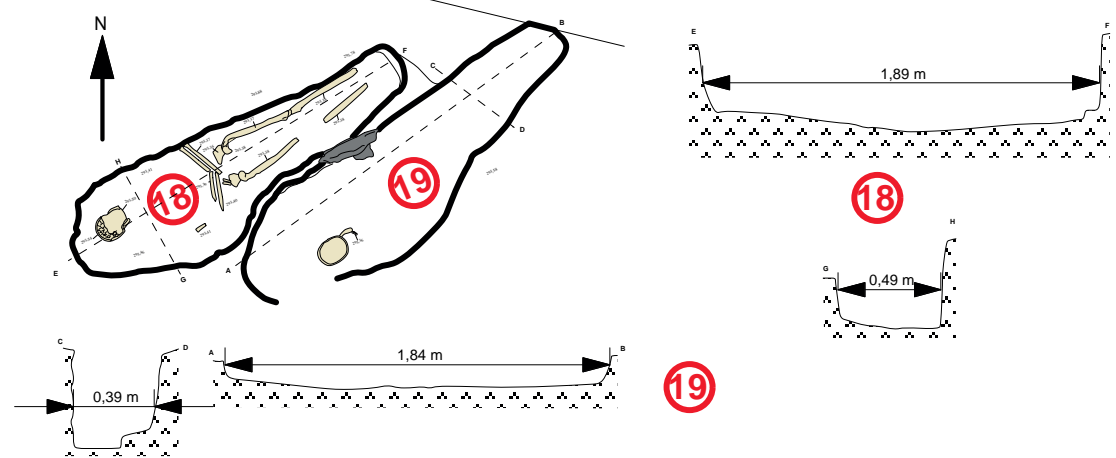

(19)
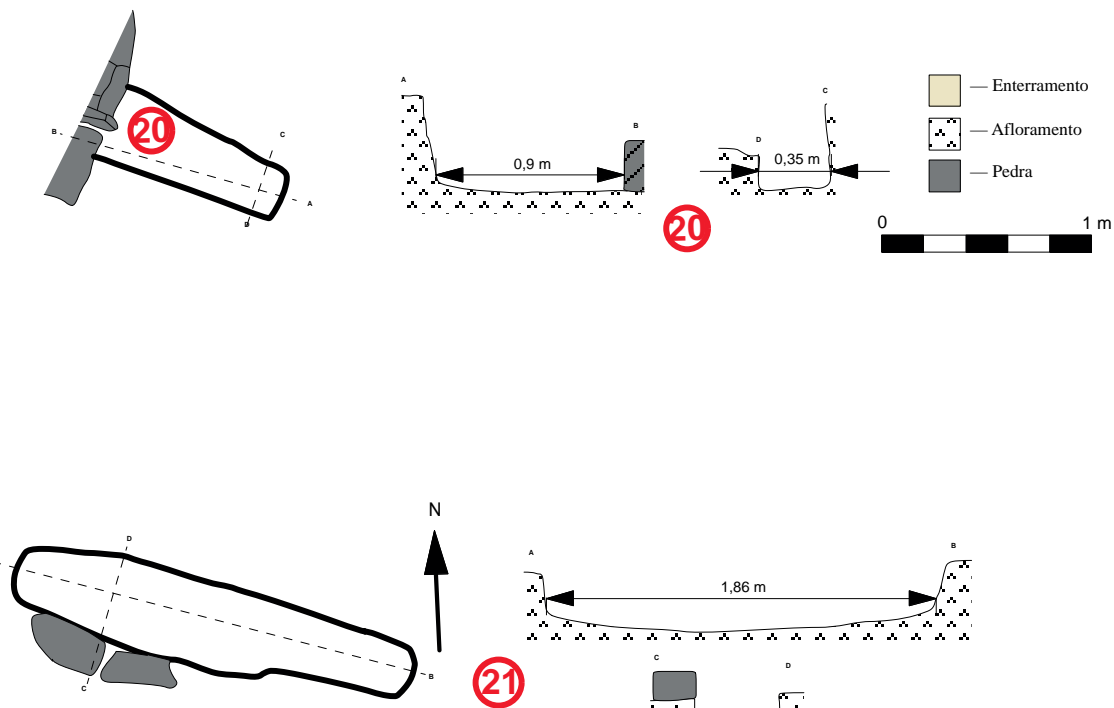

(21)
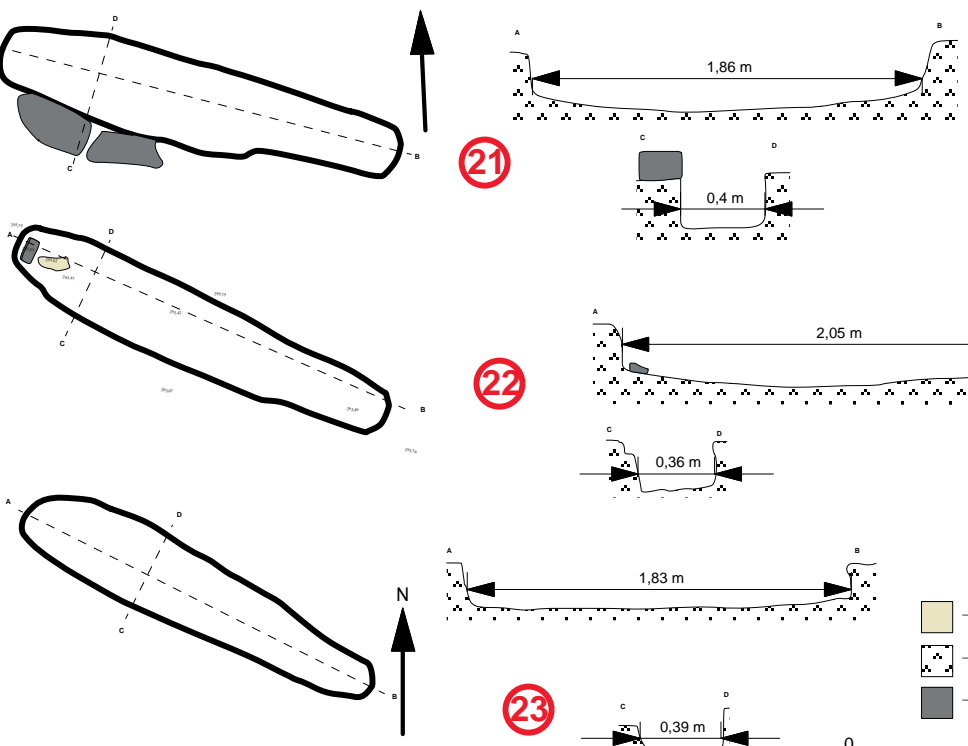

22
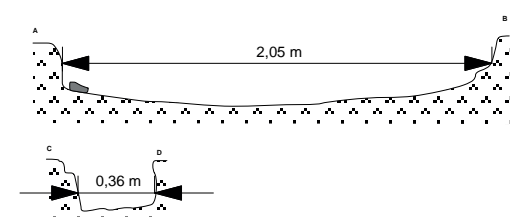

Fig. 6. Plantas e cortes das sepulturas 18 a 23

Fonte: Desenho de Manuel Vitorino 

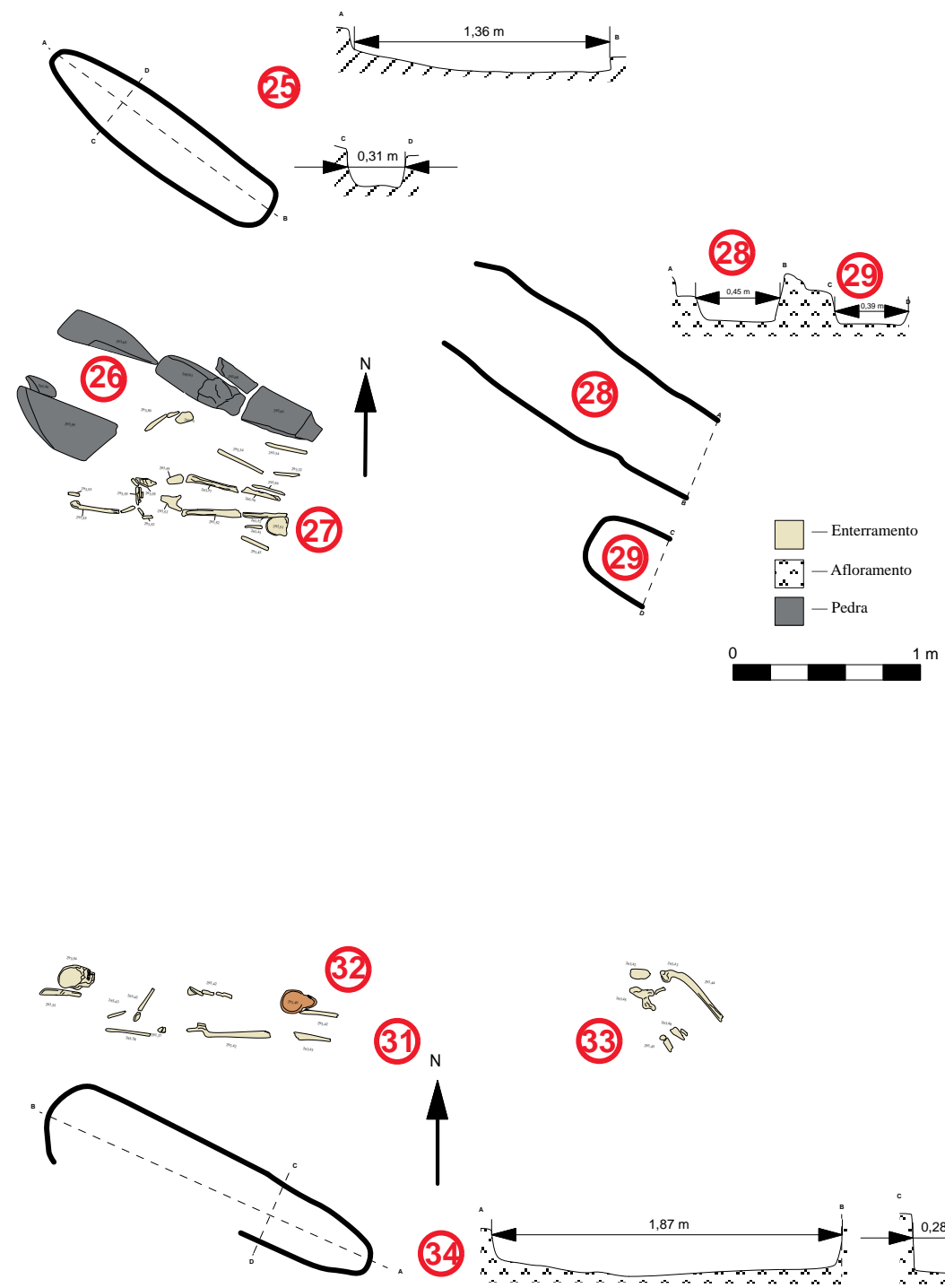

(31)

(33)
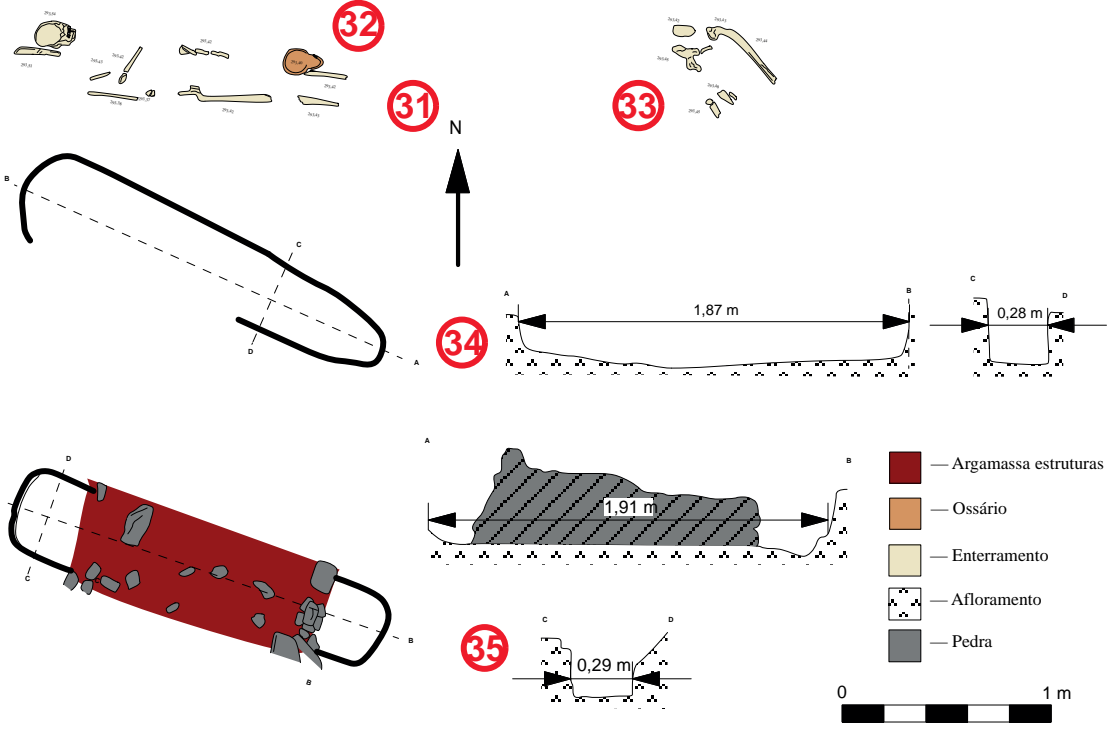

Fig. 7. Plantas e cortes das sepulturas 25 a 35 Fonte: Desenho de Manuel Vitorino 


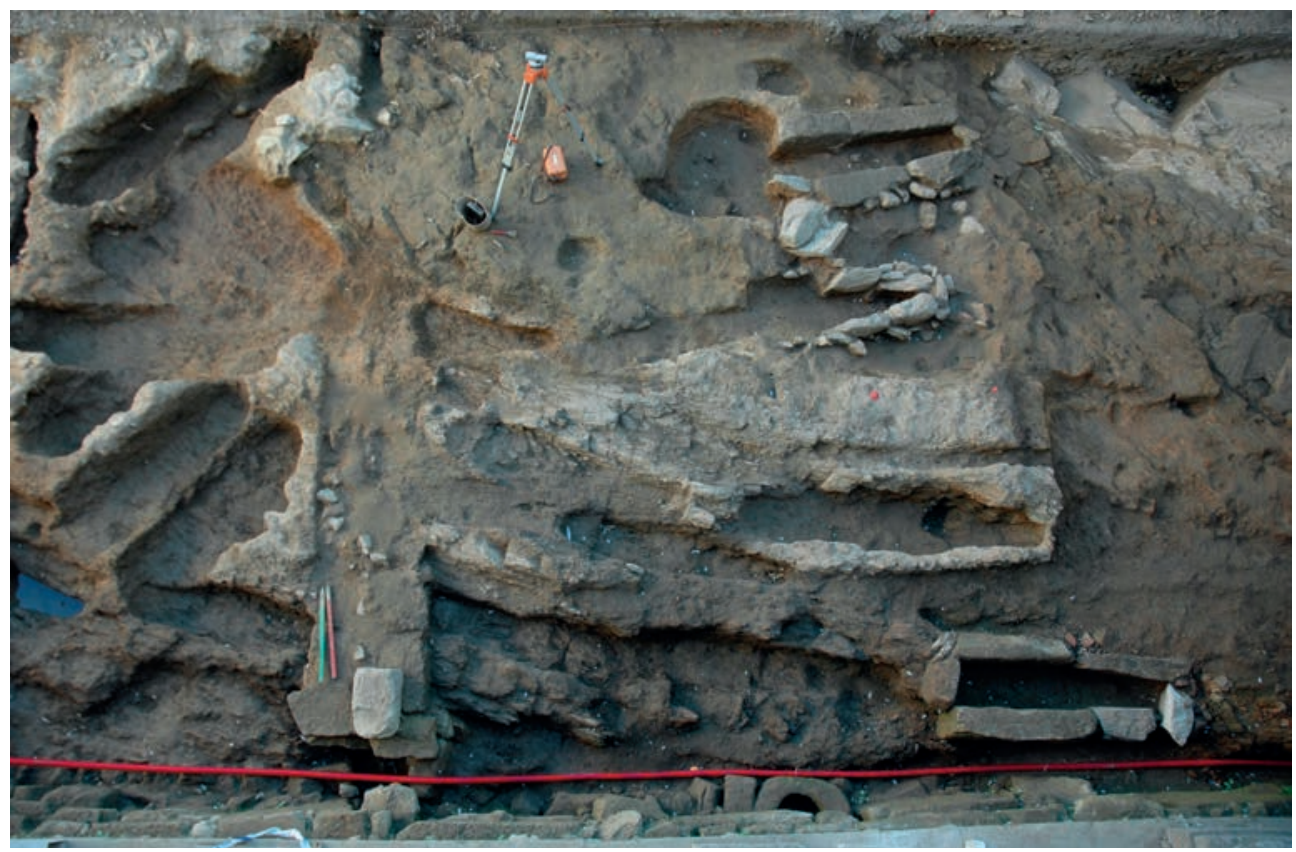

Foto 1. Vista das sepulturas no lado nascente da necrópole Fonte: Francisco M. V. R. Queiroga e Claudia M. Martinho Lemos

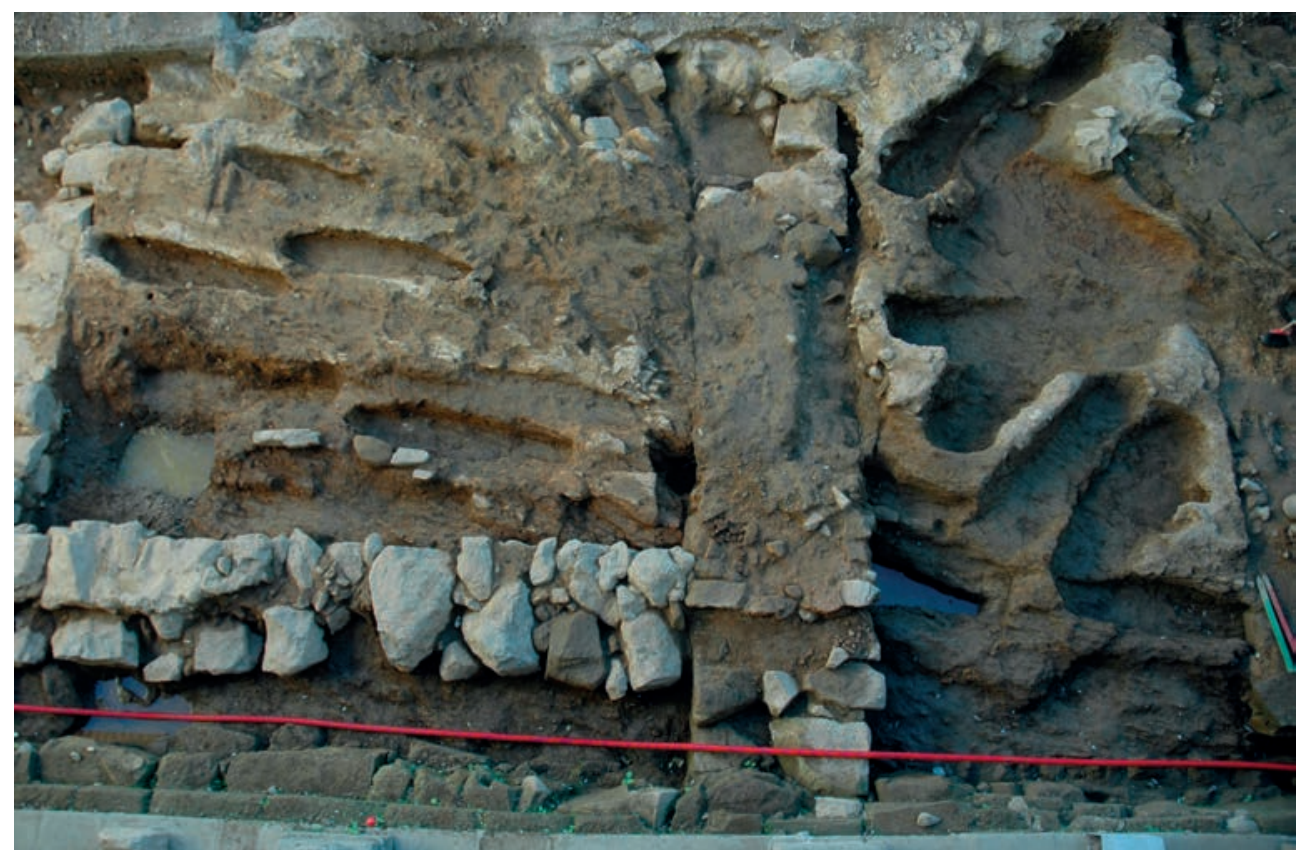

Foto 2. Vista das sepulturas no lado poente da necrópole Fonte: Francisco M. V. R. Queiroga e Claudia M. Martinho Lemos 


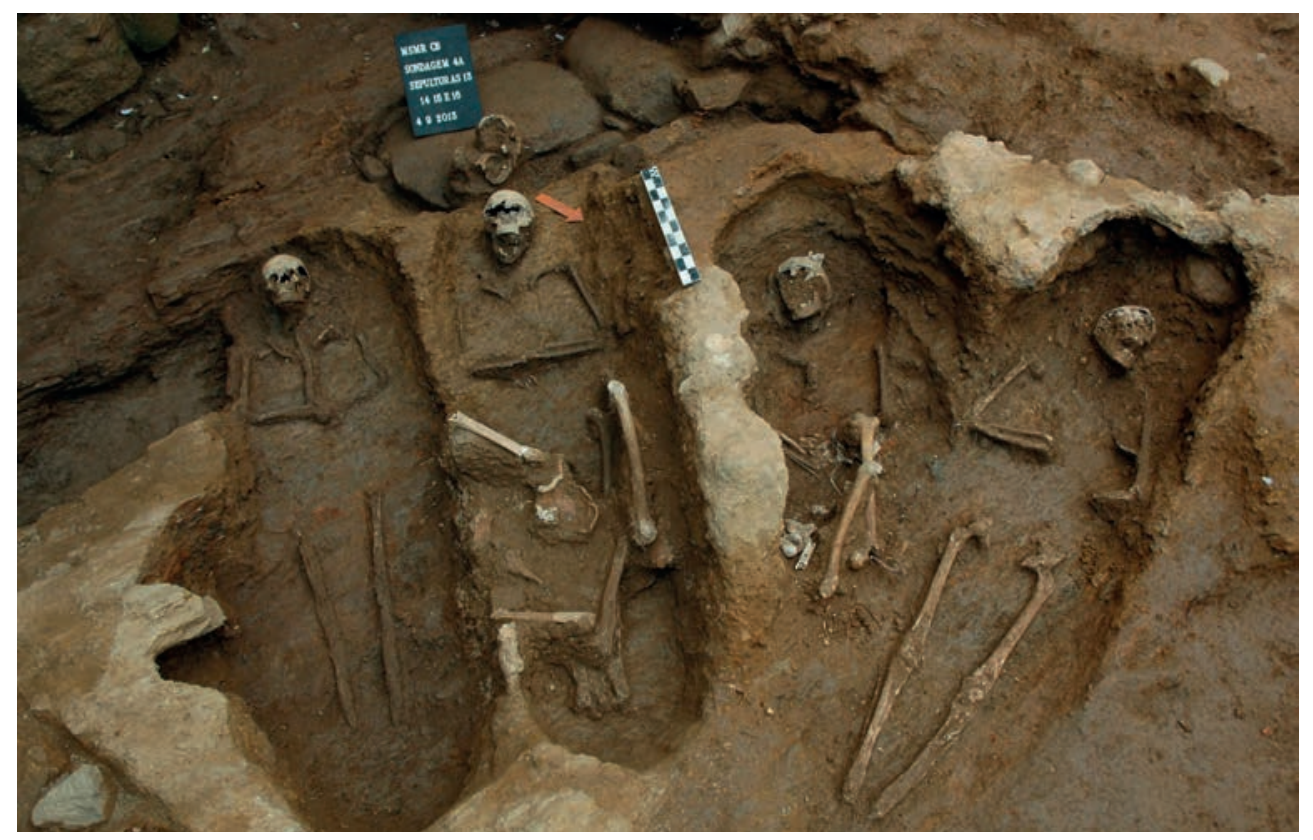

Foto 3. Conjunto se sepulturas escavadas na rocha, com intersecções entre si Fonte: Francisco M. V. R. Queiroga e Claudia M. Martinho Lemos

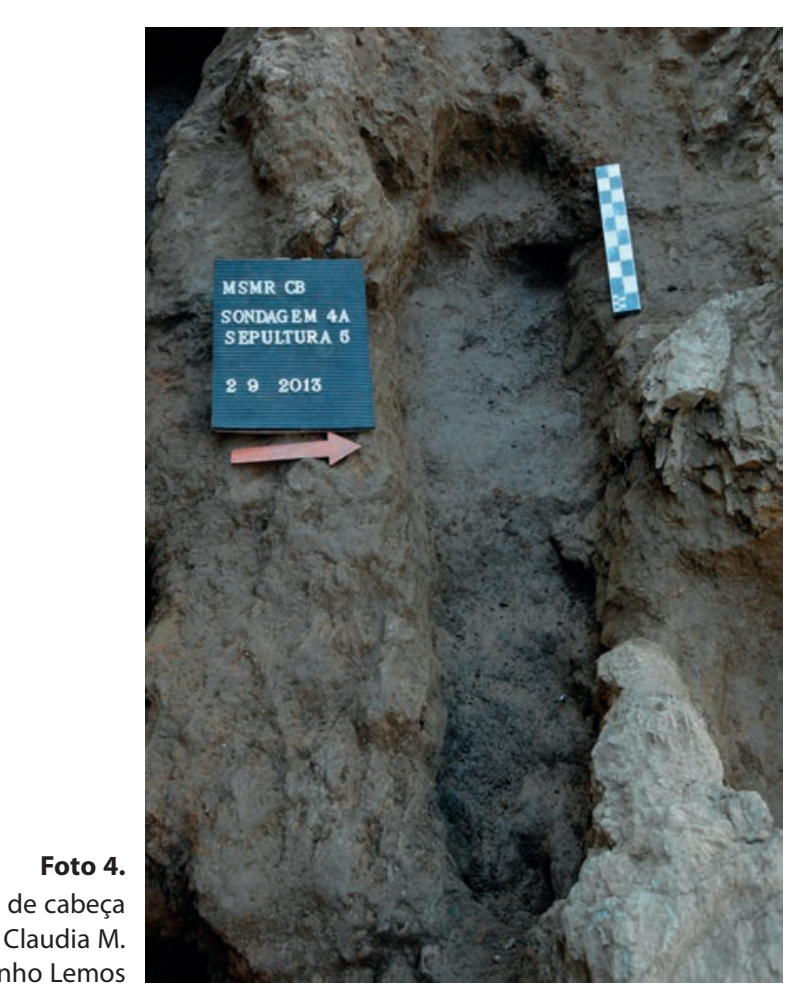




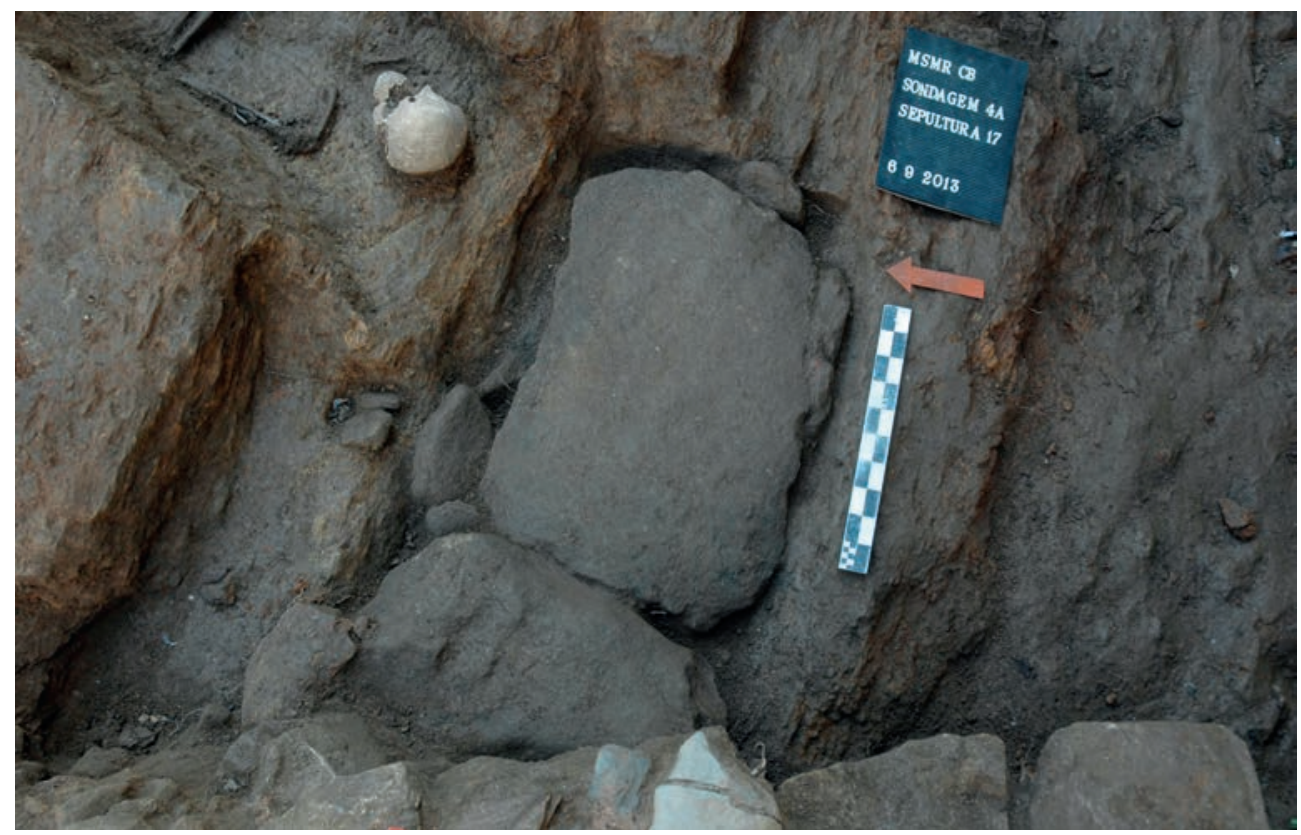

Foto 5. Sepultura escavada na rocha, ainda intacta, e sobreposta por muro Fonte: Francisco M. V. R. Queiroga e Claudia M. Martinho Lemos

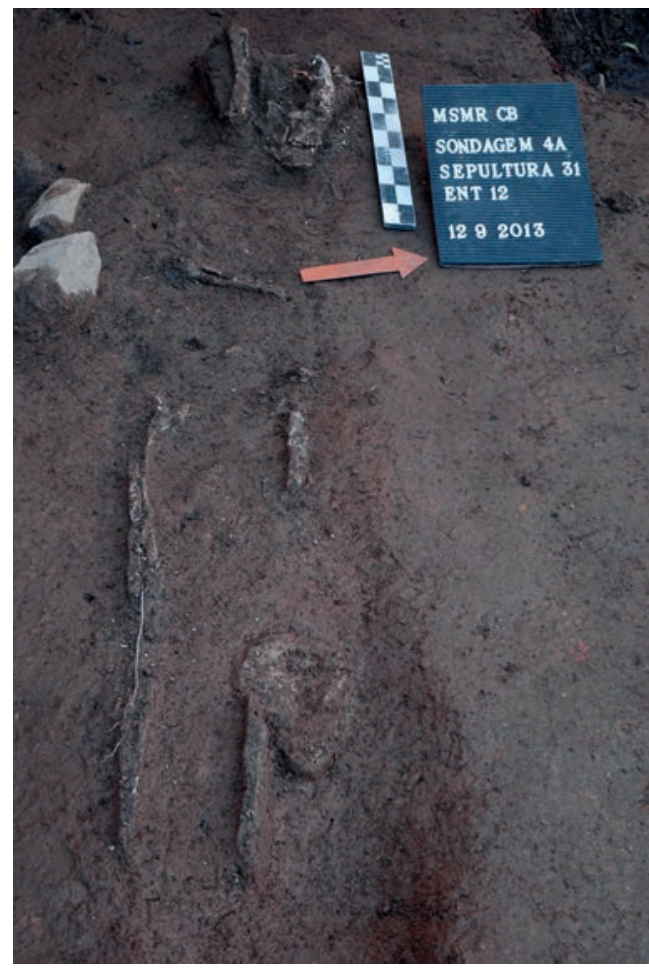

Foto 6.

Sepultura assente em terra, ainda com vestígios de alguns ossos da inumação

Fonte: Francisco M. V. R. Queiroga e Claudia M. Martinho Lemos 
Foto 7.

Sepultura assente em terra, ainda com vestígios de alguns ossos da inumação Fonte: Francisco M. V. R. Queiroga e Claudia M. Martinho Lemos
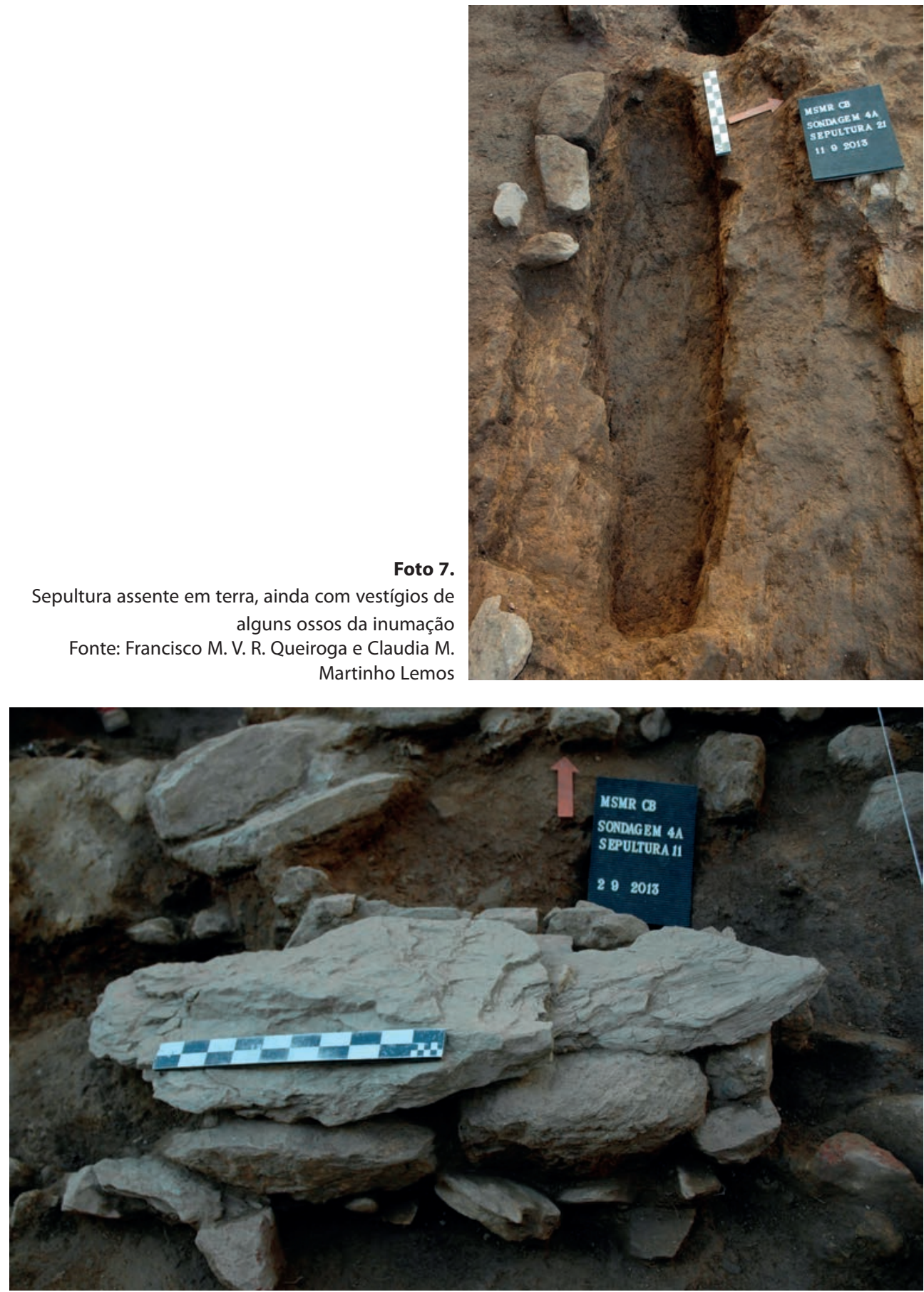

Foto 8. Sepultura estruturada com um conjunto muito fruste de pedras, com tampa Fonte: Francisco M. V. R. Queiroga e Claudia M. Martinho Lemos 


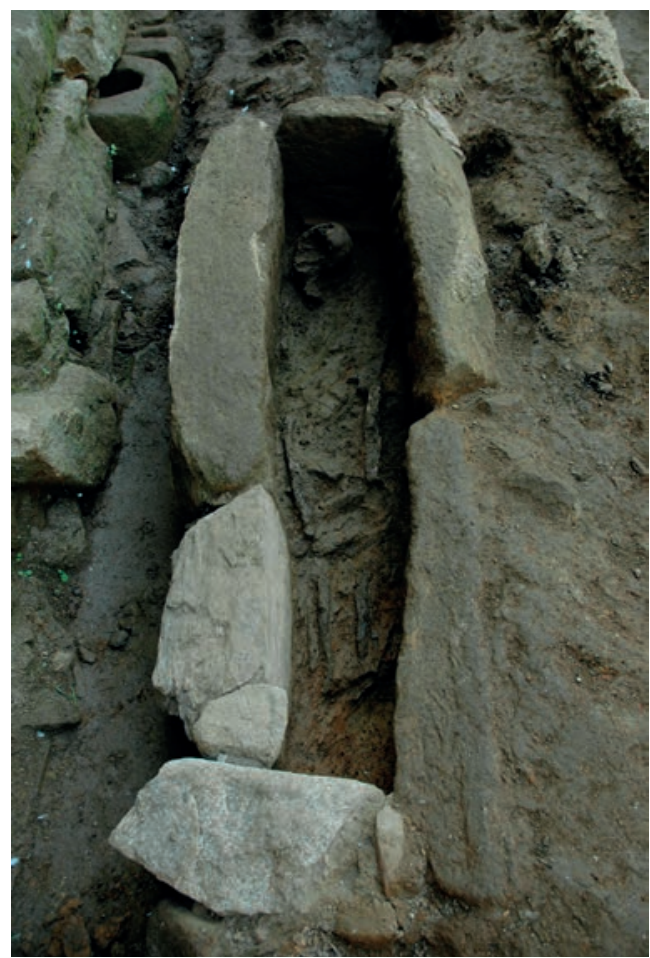

Foto 9.

Sepultura «em caixão», composta por grandes lajes aparelhadas

Fonte: Francisco M. V. R. Queiroga e Claudia M.

Martinho Lemos

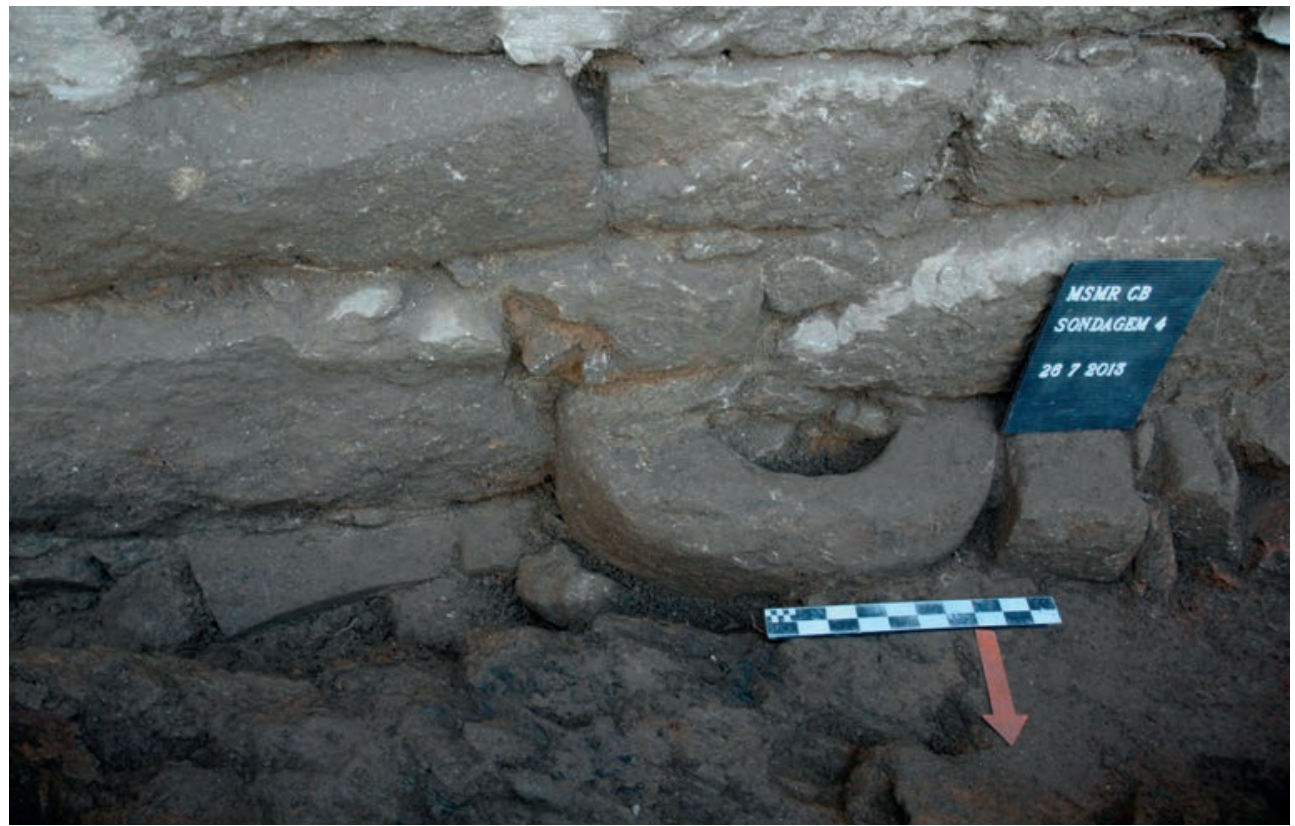

Foto 10. Cabeceira de sarcófago em granito, reutilizado como alicerce na colunada do claustro Fonte: Francisco M. V. R. Queiroga e Claudia M. Martinho Lemos 



\title{
SEPULTURAS ESCAVADAS NA ROCHA E REPOVOAMENTO MEDIEVAL. O CASO DO CONCELHO DE MONTALEGRE
}

\author{
MANUEL RAMOS*
}

\begin{abstract}
Resumo: O concelho de Montalegre conta com, pelo menos, onze necrópoles com sepulturas escavadas na rocha as quais são apenas uma das várias formas de inumação dos povos locais ao longo dos tempos. É nossa convicção de que todas elas se ligam ao repovoamento da região no período pós-Reconquista. Com este artigo propomo-nos, em primeiro lugar, fazer o levantamento de todos os cemitérios rupestres com sepulturas escavadas na rocha; depois, apresentar os dados metrológicos e tipológicos das suas sepulturas; depois ainda o seu contexto arqueológico e integrá-las na situação de repovoamento pós-Reconquista.
\end{abstract}

Palavras-chave: Sepulturas escavadas na rocha; Cemitérios rupestres; Repovoamento medieval; Montalegre.

Abstract: The municipality of Montalegre has at least eleven necropolis with fixed graves on the rock; this is only one form among several possible forms of burial throughout time. We are sure that all of them are connected to the resettlement of this region during the post-Muslim Reconquest period. In this article it is our main purpose to report all the cemeteries with fixed graves on the rock; secondly, to present their metrological and typological data; thirdly, to present their archaeological context and integrate them into the post-Reconquest repopulation background.

Keywords: Rock-cut graves; Rock cemeteries; Medieval settlement; Montalegre.

Com a área de $805 \mathrm{~km}^{2}$, o atual concelho de Montalegre localiza-se no extremo norte de Portugal, distrito de Vila Real e sub-região do Alto-Tâmega (NUTS-III), tendo como cidade mais próxima Chaves, a oriente. Juntamente com o vizinho concelho de Boticas, forma a sub-região de Barroso, designação que provém de ambos terem integrado, completos e a partir do século XI, a antiga circunscrição Terra de Barroso. Desde 1971, 26\% da superfície ocidental do concelho agrega-se no Parque Nacional da Peneda-Gerês $\left(211,7 \mathrm{~km}^{2}\right)$, formando uma parte significativa da sua parte oriental. Partilha com os concelhos vizinhos cinco sistemas montanhosos: a $\mathrm{N}$ o Larouco, a $\mathrm{O}$ e NO o Gerês, a E a serra do Leiranco e a $\mathrm{S}$ e $\mathrm{SO}$ as serras das Alturas e da Cabreira. Zona de montanha, a altitude varia entre os $300 \mathrm{~m}$ (Cabril) e os $1535 \mathrm{~m}$ (Larouco); a sua parte central é formada por uma zona de planalto, à média de cerca de $900 \mathrm{~m}$ de altitude, e é nela que se situam a maioria dos núcleos de sepulturas rupestres. Sendo das zonas mais húmidas de Portugal, tem no Cávado e Regavão (ou Rabagão),

* FLUP/IF; FLUP/CITCEM. Email: manuel.ramos2@gmail.com. 
afluente do anterior, os rios maiores. Seu povoamento é antigo, mas por ser zona de montanha, agreste e de clima rigoroso, foi sempre escasso, como muito escassas foram as casas senhoriais. No entanto, mantém ainda hoje um rico e bem conservado acervo arqueológico, sobretudo castrejo, em razão do seu isolamento secular.

O concelho de Montalegre conta com, pelo menos, onze necrópoles com sepulturas escavadas na rocha, num total de 45 moimentos, as quais nunca foram devidamente estudadas. Numa primeira tentativa de classificação geral e abrangente, de acordo com o local de implantação, as onze necrópoles rurais de Montalegre podem ser agrupadas em dois núcleos: um formado pelas necrópoles implantadas em vales (Cávado e Regavão); outro formado pelas necrópoles implantadas em veigas, ambos lugares que, pela sua fertilidade, permitiam a sobrevivência digna de uma comunidade. Por aqui se vê o apreço que temos em associar cemitérios rupestres e povoamento.

(A) Núcleo da margem direita do vale do Cávado:

(1) Necrópole medieval de Santo Adrião, Montalegre;

(2) Sepultura isolada medieval de Quadrela, lugar de Donões,

(3) Necrópole medieval de Santo Amaro, lugar de Donões.

(B) Núcleo do vale do rio Regavão, afluente do Cávado:

(4) Necrópole medieval de Leiras dos Padrões, lugar de Penedones,

(5) Necrópole medieval de Monte das Cotas, lugar de Travassos da Chã,

(6) Necrópole medieval de Portela do Antigo, lugar de Penedones.

(C) Núcleo de necrópoles implantadas em veigas:

(7) Necrópole medieval de Vilar de Perdizes,

(8) Necrópole medieval da Sr. a de Galegos (ou Sr. a da Natividade), lugares de Cortiço-Zebral,

(9) Necrópole medieval de Antigo de Sarraquinhos,

(10) Necrópole medieval de Lamego / Pipa, lugar de Pedrário.

(11) Necrópole medieval de Cristelo / Outeiral, lugar de Seara, Salto.

(D) Necrópole medieval descrita por Fernando Braga Barreiros:

(12) Necrópole medieval de Agrovelho, Montalegre.

Todos os 45 monumentos rupestres são túmulos que chegaram até nós violados. Há distinção entre moimentos completos e incompletos, íntegros e mutilados, mais perfeitos e menos, de adulto e de criança (ainda que mais raros), individuais e de

\footnotetext{
${ }^{1}$ Carla Cascais refere a existência de mais uma necrópole em Cabril, no microtopónimo Sepultura do Frade/Campa do Frade, tratando-se de uma sepultura aberta na rocha e estando o processo de classificação em reapreciação. Localização: EN 308 e 308 - 1 (Amares - Portela do Homem), caminho florestal à saída das Caldas do Gerês, que conduz à Pedra Bela. Vd. CASCAIS, 2007-2008: 3580.
} 


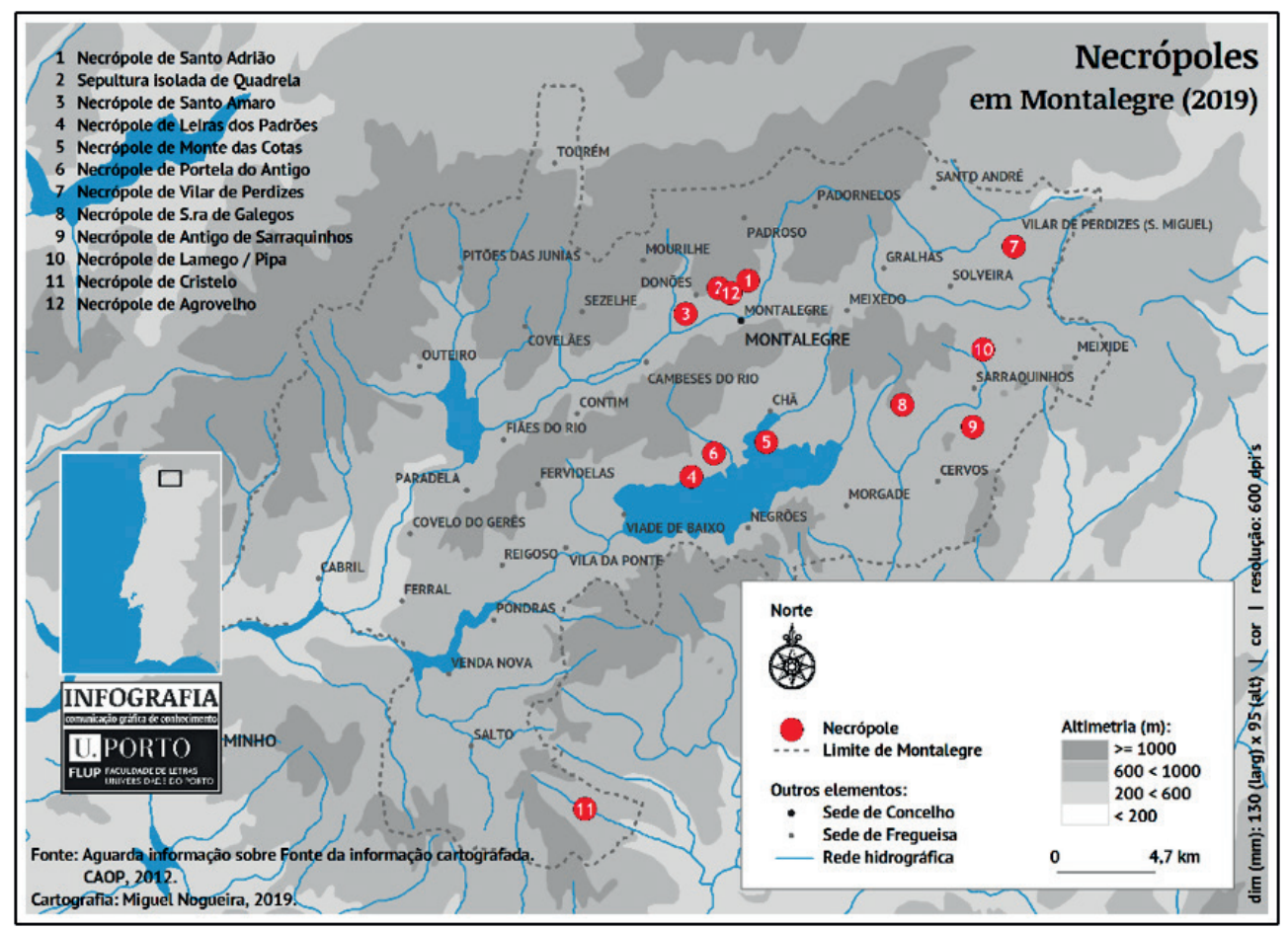

Mapa 1. Mapa que dá uma visão de conjunto dos cemitérios rupestres do concelho de Montalegre

Fonte: Manuel Ramos e Miguel Nogueira Infografia, FLUP

casal, isolados e juntos (apontando estes para uma relação de família), mas não há distinção entre túmulos de homem e de mulher. De igual forma, quase não há distinção entre sepulturas isoladas e necrópoles, pois o único caso em que é certo que se trata de uma sepultura isolada, em Quadrela, poderá não ter sido no passado. Dado o número reduzido de sepulturas, achamos que esta forma de tumulação conviveria com outras formas e que destinar-se-ia, em razão do seu preço, a pessoas mais abastadas.

Associamos cemitérios rupestres a (re)povoamento medieval e à existência aí de uma comunidade por três razões. Em primeiro lugar, por todos os núcleos assentarem em lugares soalheiros: vales e veigas com aptidão agropecuária; e quanto mais fértil é a zona, mais as necrópoles salpicam a paisagem. Em segundo lugar, porque todos os assentamentos, maiores ou menores, são necrópoles de habitat ou de lugar: localizam-se em aldeias vivas ou em lugares que já foram morada de gente, mas que atualmente se encontram extintos. Em terceiro lugar, porque todos os assentamentos se situam na proximidade das principais vias antigas que outrora atravessavam a região.

Seria esta a estrutura da paisagem rural humanizada em que as necrópoles, maiores ou menores e nunca muradas, estavam implantadas: pequenas pobras, ou 
então agregados familiares que habitavam villae ou casais agrícolas, aí se achando as três áreas indispensáveis à sobrevivência humana e das quais há plenos vestígios: a área residencial, a económica e a área funerária / religiosa. Quanto à área económica, haveria diferentes estruturas fundiárias que não se sabe com exatidão como seriam, mas tratar-se-ia com certeza de vastas extensões compostas por terra agrícola, lameiros (nas zonas mais húmidas), touças, soutos e extenso monte baldio. Os núcleos rupestres seriam parte da necrópole afeta aos povoados, local de inumação dos falecidos.

Observando as onze necrópoles rurais no seu conjunto, é possível estabelecer entre elas mais relações de semelhanças do que de diferença. Grande semelhança é todas elas andarem associadas a habitat ou lugar de que já falámos, estando, por isso, intimamente ligadas à rede de povoamento medieval; e por todas se situarem nas imediações das grandes vias que atravessavam a região. Em quase todos os moimentos se privilegiou a orientação a oriente, de acordo com os cânones da Igreja, havendo naturalmente desvios axiais de algumas dezenas de graus nessa normalização de orientação. A grandíssima maioria deles está virada a este (entre os $80^{\circ}$ e os $102^{\circ}$ ), seguida de SE (entre os $123^{\circ}$ e os $153^{\circ}$ ). Fora destes ângulos, os casos são raros.

Quanto à morfologia das sepulturas, há diferentes tipologias, que em parte devem corresponder a diferentes cronologias: antropomórficas (que são dominantes) e não antropomórficas: retangulares, ovaladas e com vestígios de antropomorfismo. No entanto, o mais comum é, dentro da mesma estação necrológica, haver a mesma tipologia, o que sugere o mesmo artífice, um tempo cronológico próximo ou a mesma tradição escultória. Quanto à tipologia das cabeceiras das antropomórficas, quase sempre com cabeceira mais elevada relativamente ao plano do leito, há diferentes tipologias: arco de volta perfeita, arco peraltado, arco ultrapassado, de cantos arqueados e as indeterminadas. A única tampa de sepultura sobrevivente acha-se no cemitério rupestre de Santo Amaro: está mutilada, mas é evidente que é monolítica, abulada, bem trabalhada e anónima.

Não é fácil indagar acerca da cronologia deste tipo de monumento, que em abstrato é costume situar entre os séculos VI e XIII, e mais concretamente associar ao movimento da Reconquista (VIII-XI), parecendo ser essa a situação do concelho de Montalegre: os mais antigos túmulos poderão remontar à reorganização do povoamento no territorium Civitas Flavias durante a presúria de Odoário, na segunda metade do século IX (ano de 872) e estender-se-iam até ao século XIII, altura em que este tipo de monumento entrou em desuso.

\section{NECRÓPOLE MEDIEVAL DE SANTO ADRIÃO}

É um cemitério rupestre de lugar extinto, que se situa a norte do centro de Montalegre (c. de $2 \mathrm{~km}$ ), no microtopónimo Santo Adrião, a $1006 \mathrm{~m}$ de altitude e com a georreferenciação $41.841644^{\circ} \mathrm{N}-7.788205^{\circ} \mathrm{W}$. Situa-se na margem direita 
do Cávado, em lugar soalheiro, algo distante do rio (bastante menos do que a meia encosta), protegido dos ventos do norte e próximo de uma veiga com aptidão agrícola. Por conseguinte, seria rural a comunidade que ali foi sepultada. Não há dúvida de que foi uma póvoa em tempos antigos, situando-se o povo a $\mathrm{N}$ e $\mathrm{NO}$ da capela. No entanto há muita confusão quanto ao seu antigo nome, que com probabilidade se chamaria Pedra ${ }^{2}$. Era «muito populoza» ${ }^{3}$ e bastante anterior à vila de Montalegre, para onde as pessoas posteriormente se mudaram, antes e depois da construção do castelo (c. 1281). Diz a lenda que foi devido a uma peste que a mudança das gentes se efetuou para a colina de «Monta Alegre», mas é mais provável que se devesse ao desenvolvimento, crescimento e segurança deste burgo, na margem esquerda do rio, à volta do seu altaneiro castelo que D. Afonso III aí mandou construir.

Há nas redondezas vestígios de ocupação diacrónica extensa: pré-histórica, castreja, romana e medieval. Na verdade, perto deste cemitério rupestre, existe o povoado de Agrovelho (800 m a O da capela), o Monte do Crasto (a sul) e Muradelhas (400 m a NE); a fonte de água que abasteceria o pequeno povoado situava-se a um «tiro de pedra» a N da capela ${ }^{4}$. Em 1258, como registam as Inquirições de D. Afonso III, Santo Adrião ainda sobrevivia como pequena póvoa, reguenga do rei e de importância menor do que Donões (à colação da qual pertencia), que pagava ao rei um doze avos do que colhia: «Item, dixit quod de Covelio et de Sancto Adriano et de Sancto Vereximo et de Raigoso et de Magrou dant Domino Regi de XII. quinionibus unum» ${ }^{5}$. Neste tempo Montalegre («Raigoso») era insignificante, quando comparado com os lugares vizinhos da margem direita do Cávado, mas a sua importância estava rapidamente a crescer.

Poderá ter no passado organização paroquial. Na verdade, possui capela do século XVII-XVIII, igualmente orientada a oriente (E 97º), dedicada a um santo de culto antigo: Santo Adrião (Adriano de Nicomédia, †306), que deve ter sido o orago do lugarejo, mas não parece ser a capela antiga que por certo ali existiu, a crer nas Memórias Paroquiais de 1758: «Santo Adrião, que se diz fora abbadia e com effeito perto della se divizam ruinas de cazas e se mostram signais donde existiram vários lugares que no anno da peste se despovoaram e todas estavam dentro do espacço de hum quarto de legoa» ${ }^{6}$. De facto, acham-se no adro da capela três sarcófagos antropomórficos em granito, bem conservados e eventualmente do século XIII, que serviram de inumação possivelmente no adro. Tal como a capela, também os sarcó-

\footnotetext{
${ }^{2}$ Para a tradição popular seria Agrovelho, o que não é verdade, pois este lugar situa-se a cerca de $800 \mathrm{~m}$ a oeste; Barreiros (1920: 59) identifica-a com Muradelhas (o que não parece certo, pois situa-se a cerca de $400 \mathrm{~m}$ a NE); as Memórias Paroquiais, porém (e parece mais verdadeiro), identificam-na com Pedra.

${ }^{3}$ BORRALHEIRO, 2005: 281.

${ }^{4}$ Cf. BARREIROS, 1920: 59-60.

${ }^{5}$ BAPTISTA, 2011: 65.

${ }^{6}$ BORRALHEIRO, 2005: 281; cf. CARVALHO, 1981: 85.
} 
fagos constam nas Memórias Paroquiais de $1758^{7}$, mas não sobrevivem as três tampas que ainda naquele tempo existiam; além de outros sarcófagos com tampas que se descobriram na vizinhança «com huma cruz como a que uzavam os Templários» 8 .

Além dos três sarcófagos antropomórficos em granito, a necrópole é constituída hoje por duas sepulturas antropomórficas a afunilar para os pés e integralmente escavadas no afloramento xistoso: uma íntegra e em bom estado de conservação (n. $\left.{ }^{\circ} 1\right)$ e a segunda muito destruída pela extração de pedra para paredes e nunca catalogada. A primeira sobrevive junto à capela, bem conservada e íntegra, de orientação canónica a oriente $\left(\mathrm{NE} 59^{\circ}\right)$, possuindo o seu antropomorfismo simetria axial imperfeita por ter sido aberta em rocha xistosa. É moimento violado, não se encontra selado, nem há vestígios de tampa, que poderá ter sido formada por um bloco, pelo facto de possuir rebordo parcial e de tipo alteado, à volta do qual a tampa deveria encaixar. De forma alguma estaria coberta com terra. A cabeceira alteada possui arco de volta perfeita, jazendo esta um pouco mais elevada do que o plano do leito; os ombros encontram-se individualizados e com a curva bem destacada; os pés não se acham destacados e encontram-se no mesmo plano que o leito. Seguindo a morfologia dos rochedos, jaz em plano horizontal. Como particularidade sua, verifica-se que, em parte dela, o fundo é mais largo do que o rebordo superior, sinal de que as paredes do moimento alargam à medida que descem.

Mas há uma segunda sepultura muito destruída (n.o 2). Como se privilegiou a orientação a oriente mais do que a concentração, teve de ser aberta bastante longe (35 m a este), e foi por isso que passou sempre despercebida e nunca foi registada. O seu grau de destruição é grande, mas é possível indagar a partir da sua base uniforme que seria antropomórfica como a primeira e com orientação igualmente a oriente $\left(\mathrm{NE} 47^{\circ}\right)$. Seguindo a morfologia do rochedo, jaz em plano horizontal.

Eis alguns dados metrológicos e tipológicos seus:

Tabela 1. Dados metrológicos e tipológicos da necrópole de Santo Adrião, Montalegre

\begin{tabular}{c|c|c|c|c|c|c|c|c}
\hline $\mathbf{N .}$ & Tipologia & $\begin{array}{c}\text { Tipologia } \\
\text { cabeceira }\end{array}$ & $\begin{array}{c}\text { Comp. } \\
\text { total }\end{array}$ & $\begin{array}{c}\text { Largura } \\
\text { ombros }\end{array}$ & $\begin{array}{c}\text { Largura a } \\
\text { meio do } \\
\text { corpo }\end{array}$ & $\begin{array}{c}\text { Cabeceira } \\
\text { (larg. } \mathbf{x} \\
\text { comp.) }\end{array}$ & $\begin{array}{c}\text { Profun- } \\
\text { didade } \\
\text { média }\end{array}$ & $\begin{array}{c}\text { Orien- } \\
\text { tação }\end{array}$ \\
\hline $\begin{array}{c}\text { bom } \\
2\end{array}$ & Antrop. & $\begin{array}{c}\text { Volta } \\
\text { perfeita }\end{array}$ & $1,72 \mathrm{~m}$ & $0,34 \mathrm{~m}$ & $0,39 \mathrm{~m}$ & $\begin{array}{c}0,20 \times 0,16 \\
\mathrm{~m}\end{array}$ & $0,43 \mathrm{~m}$ & $\mathrm{NE} 59^{\circ}$ \\
\hline \begin{tabular}{c} 
destruída \\
\hline
\end{tabular} & Antrop. & - & $\begin{array}{c}\text { adulto } \\
1,90 \mathrm{~m}\end{array}$ & - & - & - & - & $\mathrm{NE} 47^{\circ}$ \\
\hline
\end{tabular}

Fonte: Elaboração própria

\footnotetext{
${ }^{7}$ BORRALHEIRO, 2005: 204 e 282.

${ }^{8}$ BORRALHEIRO, 2005: 282.

${ }^{9}$ Neste cemitério rupestre, há uma oscilação de $12^{\circ}$ entre os moimentos (NE 59 $-\mathrm{NE} 47^{\circ}$ ).
} 

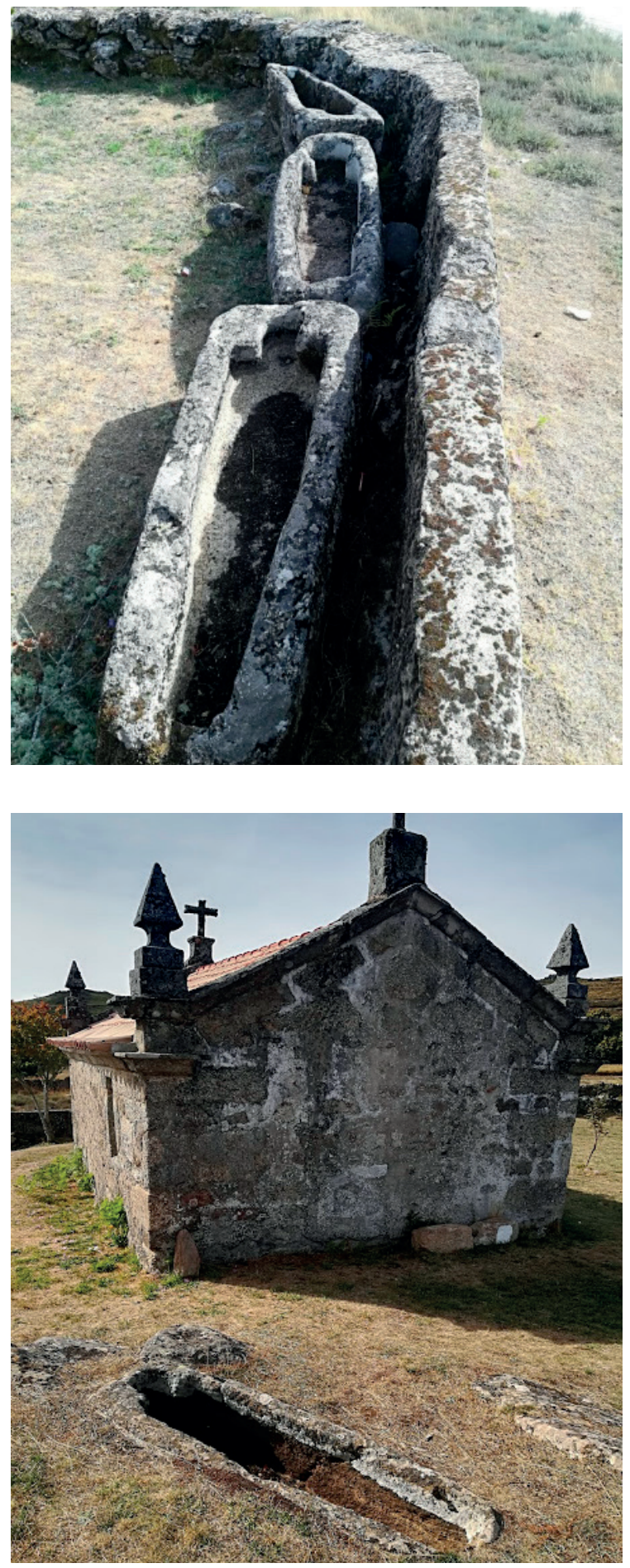

Fig. 1.

Três sepulturas líticas móveis no adro da capela de Santo Adrião, Montalegre. O escoamento para líquido junto aos pés indica que jazeriam no adro à superfície Fonte: Arquivo pessoal do autor

\section{Fig. 2.}

Capela de Santo Adrião, Montalegre, e sepultura antropomórfica aberta na rocha em pleno adro. Uma segunda sepultura, agora destruída, acha-se a $60 \mathrm{~m}$ do recinto do adro

Fonte: Arquivo pessoal do autor 


\section{SEPULTURA ISOLADA MEDIEVAL DE QUADRELA}

É uma necrópole de habitat, que se situa a este de Donões (c. $1060 \mathrm{~m}$ ), no microtopónimo Quadrela, a $1001 \mathrm{~m}$ de altitude e com a georreferenciação: $41.838496^{\circ} \mathrm{N}$ - 7.805418 $\mathrm{W}$. Situa-se na margem direita do Cávado, em lugar um pouco elevado, soalheiro, algo distante do rio (bastante menos do que a meia encosta), bem protegido dos ventos do $\mathrm{NO}$ e $\mathrm{N}$ e nas imediações de uma veiga fértil. Não possui capela, talvez por no passado ter estado ligada a um habitat de tipo villa ou casal rural. Alguma da toponímia menor das redondezas é: Relvado, Fonte da Barriga e Enforcados.

Como o microtopónimo Quadrela sugere, houve neste lugar, em tempos antigos, algum tipo de construção, pois quadrela significa lanço de muro ou de parede de edifício, podendo ser um complexo habitacional de tipo villa ou casal. Observando a superfície, é possível descobrir restos de construção a norte. Pelo facto de restar uma só sepultura, tanto pode significar que as demais foram destruídas pela extração de pedra para os muros das propriedades (como aparenta a extração de granito nas imediações), como que a comunidade aí existente era muito pequena. O lugar parece ter tido ocupação diacrónica extensa, desde a Pré-História, passando pela época castreja, até à Idade Média.

A necrópole é formada por uma só sepultura (verdadeiramente a única sepultura isolada do concelho), integralmente escavada no afloramento granítico com cerca de $2 \mathrm{~m}$ de altura (é, aliás, a mais elevada de todas as necrópoles), não havendo conhecimento de ter existido mais alguma. É antropomórfica, a afunilar para os pés e possui orientação canónica a oriente; também se encontra em excelente estado de conservação; é moimento violado: não se encontra selado, nem há vestígios de

Fig. 3.

Sepultura isolada em

Quadrela

Fonte: Arquivo pessoal do autor

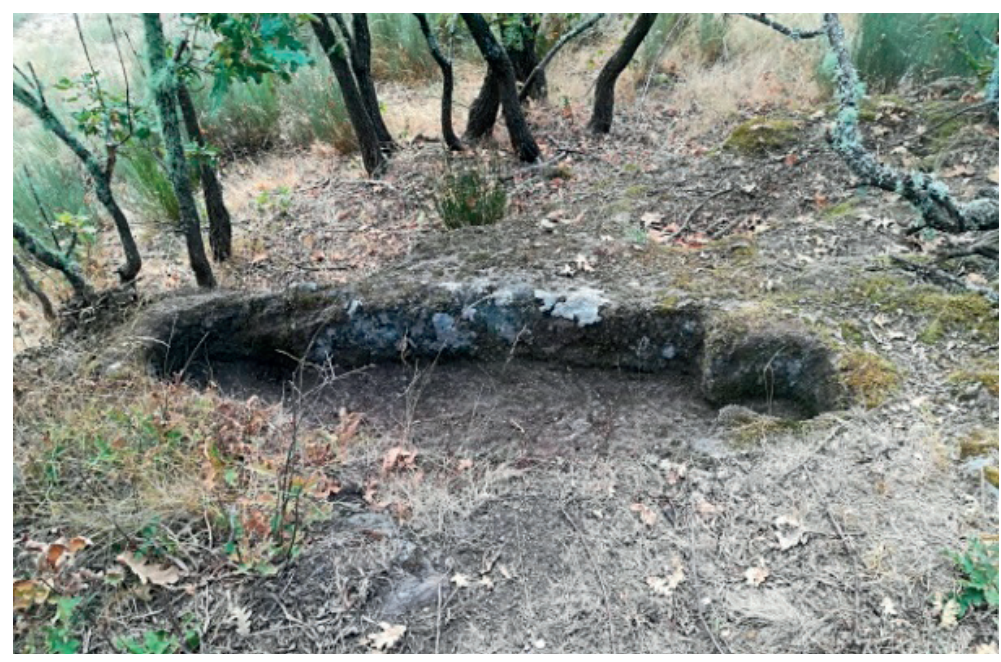


tampa, que deverá ter sido formada por uma ou mais lajes lisas sobrepostas; de forma alguma estaria coberto com terra.

Em termos de cabeceira, possui arco de volta perfeita, jazendo um pouco mais elevada do que o plano do leito. Seus ombros encontram-se individualizados e com a curva bem destacada; os pés não se acham destacados e encontram-se no mesmo plano que o leito. Acha-se em plano horizontal, tal como o rochedo em que foi aberta. Possui rebordo de tipo horizontal, não são visíveis nele encaixes para a tampa e quase atinge a axialidade perfeita. Possui orifício lateral proeminente e circular junto aos pés para escoamento de líquidos, razão por que deve no passado ter sido selada com lajes lisas.

Eis alguns dados metrológicos e tipológicos:

Tabela 2. Dados metrológicos e tipológicos da sepultura isolada de Quadrela, Donões

\begin{tabular}{c|c|c|c|c|c|c|c|c}
\hline N.॰ & Tipologia & $\begin{array}{c}\text { Tipologia } \\
\text { cabeceira }\end{array}$ & $\begin{array}{c}\text { Comp. } \\
\text { total }\end{array}$ & $\begin{array}{c}\text { Largura } \\
\text { ombros }\end{array}$ & $\begin{array}{c}\text { Largura a } \\
\text { meio do } \\
\text { corpo }\end{array}$ & $\begin{array}{c}\text { Cabeceira } \\
\text { (larg. } \mathbf{x} \\
\text { comp.) }\end{array}$ & $\begin{array}{c}\text { Profun- } \\
\text { didade } \\
\text { média }\end{array}$ & $\begin{array}{c}\text { Orien- } \\
\text { tação }\end{array}$ \\
\hline M.to bom & Antrop. & $\begin{array}{c}\text { Volta } \\
\text { perfeita }\end{array}$ & $1,80 \mathrm{~m}$ & $0,40 \mathrm{~m}$ & $0,39 \mathrm{~m}$ & $\begin{array}{c}0,25 \times 0,24 \\
\mathrm{~m}\end{array}$ & $0,24 \mathrm{~m}$ & $\mathrm{E} 102^{\circ}$ \\
\hline
\end{tabular}

Fonte: Elaboração própria

\section{NECRÓPOLE MEDIEVAL DE SANTO AMARO}

É um cemitério rupestre de lugar extinto, que se situa na aldeia de Donões (c. $2000 \mathrm{~m}$ a sul), no microtopónimo atual Santo Adrião (microtopónimo antigo: Igreja), a $968 \mathrm{~m}$ de altitude e com a georreferenciação: $41.827279^{\circ} \mathrm{N}-7.824536^{\circ} \mathrm{W}$. Situa-se na margem direita do Cávado, em lugar soalheiro e protegido dos ventos $\mathrm{N}$ e NO, numa planura um pouco elevada e algo distante do rio, para evitar as geadas, e nas imediações de uma veiga apropriada para a agricultura e a criação de gado. Por conseguinte, seria rural a comunidade que ali foi sepultada.

Há nas redondezas vestígios de ocupação diacrónica extensa: castreja, romana e medieval. No espaço circundante à capela e nos campos agrícolas mais a SE, a arqueóloga Carla Cascais identificou evidências de povoamento romano e restos de estruturas de habitações que apontam para um povoado antigo ${ }^{10}$. Por conseguinte, não há dúvida de que foi uma póvoa em tempos antigos, como o atestam os «vestígios de uma povoação antiga, extinta, como sejam restos de paredes, telha e tijolos» ${ }^{11}$, além da mina de água, mas é desconhecido o seu nome. Alguma da toponímia menor das redondezas é impressionante: Igrejas e Fonte do Sino (alusão à instituição paroquial), Pedregalho, Crasto e Cremadouro.

\footnotetext{
${ }^{10}$ CASCAIS, 2007-2008: 32542.

${ }^{11}$ COSTA, 1961: 18.
} 
Perto $(2,6 \mathrm{~km}$ a sul) existe um castro de forma quase circular (com o diâmetro de c. 66 metros), conhecido por Castro de Donões ou Covancas do Crasto, e era cercado por muralha de pedra solta e por três fossos circulares, ainda visíveis, um dos quais é profundo ${ }^{12}$. Como é habitual, «a ele andam ligadas diversas tradições lendárias, relacionadas com lutas contra os mouros e com mouras encantadas» ${ }^{13}$. É muito provável que tenha havido sucessão, mais ou menos contínua, entre o crasto, o povoado desta necrópole e a atual aldeia de Donões (a N), que consta das Inquirições de D. Afonso III de $1258^{14}$ e no rol de igrejas de D. Dinis, em que pagava 60 libras ${ }^{15}$. Bastante a norte da aldeia, também sobrevive um rochedo proeminente que tem o nome de Castelo de Tamilos.

Possui capela com galilé orientada a oriente $\left(\mathrm{E} 77^{\circ}\right)$ e dedicada a um santo de culto antigo: Santo Amaro (século VI), com festa a 15 de janeiro de cada ano, que deve ter sido o orago do lugarejo, mas não é a capela antiga que naquele mesmo sítio deverá ter existido, atendendo à toponímia menor. Efetivamente, uma inscrição pintada na padieira da porta informa que foi construída pelo benemérito António Chaffes em 1746: ESTA CAPELA MANDOU A FAZER ANTÓNIO CHAFFES. 1746, presumimos que não para sacralizar o lugar, mas pela convicção de que aquele solo era santo, quer pela existência de um cemitério, quer possivelmente pela existência de vestígios da antiga capela/igreja. De facto, tudo aponta, dado o microtopónimo antigo do local ser Igreja, para que tenha havido aí no passado igreja e quiçá organização paroquial, como presume a tradição popular e que Monsenhor Costa regista: «Diz uma tradição antiga, transmitida por via oral, que a capela de Santo Amaro foi outrora igreja paroquial da referida povoação desaparecida há séculos» ${ }^{16}$.

A capela com o seu adro foi implantada no meio do cemitério (e possivelmente no lugar da antiga) - e é provável que a sua construção e a do seu adro tenha implicado o soterramento de algumas sepulturas. Sobrevivem seis moimentos escavados no afloramento granítico, antropomórficos, a afunilar para os pés e de orientação canónica; são moimentos violados: não se encontram selados, mas conserva-se parte de uma tampa, pelo que estiveram no passado cobertos, quer por tampas monolíticas, quer sobretudo por uma ou mais lajes sobrepostas; de forma alguma estariam cobertos com terra.

As sepulturas mais afastadas distam entre si em $40 \mathrm{~m}$ e estão dispostas em dois grupos. A norte da capela acham-se duas sepulturas em mau estado de conservação (n. ${ }^{\text {s }} 5$ e 6) e em afloramento rente ao chão; as lajes onde foram escavadas são delgadas,

\footnotetext{
${ }^{12}$ Cf. BARREIROS, 1920: 86; cf. COSTA, 1961: 18-19.

${ }^{13}$ COSTA, 1961: 19.

${ }^{14}$ Cf. BAPTISTA, 2011: 65-66.

15 «Item ecclesiam Sancti Petri de Donoes ad sexaginta libras» (BOISSELLIER, 2012: 159).

${ }^{16}$ COSTA, 1961: 18; cf. BORRALHEIRO, 2005: 211 e 252.
} 


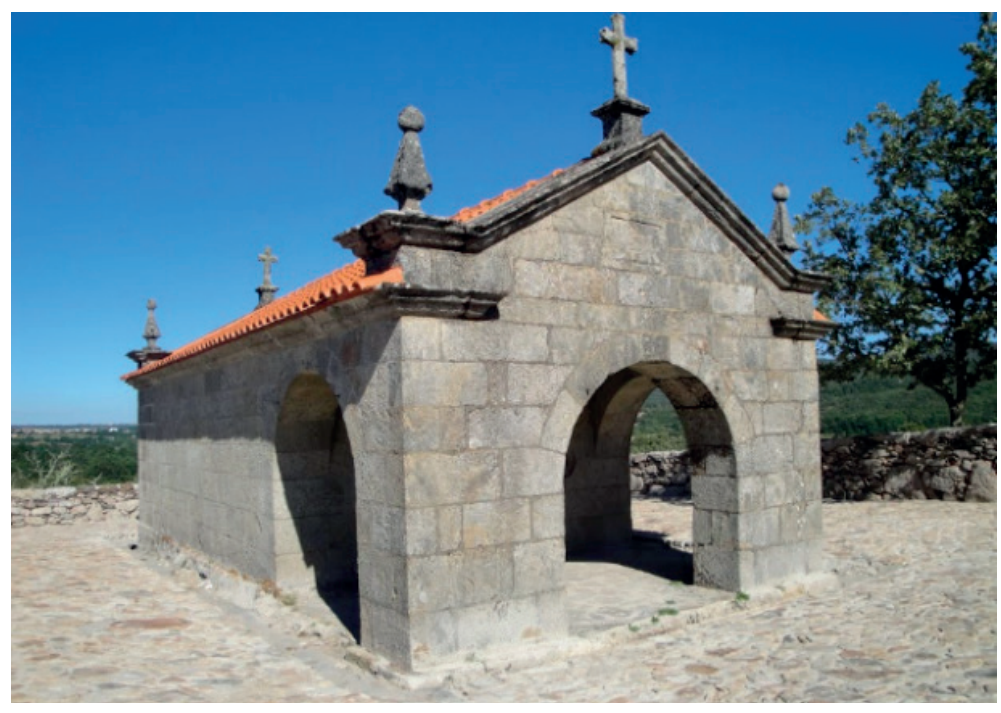

Fig. 4.

Capela com galilé da necrópole de Santo Amaro, Donões. Possui a data de 1743 Fonte: Arquivo pessoal do autor

o que não contribuiu para a sua perfeição e preservação. A sul da capela acham-se mais quatro sepulturas, todas elas cuidadosamente talhadas no proeminente afloramento granítico raso. Só parte do imponente rochedo foi aproveitado para a abertura de moimentos, talvez porque aquela comunidade possuísse formas alternativas e mais baratas de enterramento, como a inumação em cova. Este segundo grupo está bastante bem preservado e está igualmente orientado a oriente. Uma delas, a mais periférica (n. ${ }^{\circ}$ ), é claramente uma sepultura incompleta, dada a sua escassa profundidade.

Em termos globais, são monumentos antropomórficos, a afunilar para os pés, achando-se uma (n. ${ }^{\circ}$ ) em muito bom estado de conservação, uma inacabada (n. $\left.{ }^{\circ} 3\right)$, outra mutilada aos pés $\left(n .^{\circ} 1\right)$, duas muito mutiladas na parte inferior $\left(n .^{o s} 4\right.$ e 5) e a última (.$^{\circ} 6$ ), de criança (a avaliar pela pequenez da caixa craniana), muito destruída, pelo que não é possível tirar ilações seguras, para lá de ser certo que é antropomórfica, que está orientada para oriente (E $\left.81^{\circ}\right)$ e que é de criança. Nenhuma se encontra selada, mas conserva-se parte de uma tampa monolítica, talvez pertencente à n. ${ }^{\circ}$ 2. Quanto às cabeceiras, são de arco de volta perfeita, arco ultrapassado e arco peraltado, jazendo a cabeceira um pouco mais elevada do que o plano do leito. Os ombros encontram-se geralmente individualizados e com a curva bem destacada; os pés não se acham destacados e encontram-se no mesmo plano que o leito; nas íntegras, não há vestígios de orifício sangrador. Possuem geralmente rebordo de tipo horizontal e, seguindo a morfologia dos rochedos, quase todas jazem um pouco inclinadas $\left(c .4^{\circ}\right)$ para os pés. Só a n. ${ }^{\circ} 2$ atinge a axialidade perfeita.

Em duas das sepulturas (n. ${ }^{\text {os }} 1$ e 2 ), com rebordo total de tipo alteado, é perfeitamente visível o alisamento a toda a volta onde a tampa assentava, mais rego 
exterior, que serviria para que a água das chuvas não entrasse, pois estes moimentos não possuem orifício de escoamento. A n. ${ }^{\circ} 2$ é a sepultura mais perfeita de todos os cemitérios rupestres e em que o antropomorfismo jaz com simetria axial perfeita; e é possível que, dada a sua perfeição e a perfeição da sua tampa monolítica, que se conserva em parte, pertencesse a alguém mais abastado; além de o facto apontar para uma fase mais tardia de construção, quiçá do século XIII.

Eis alguns dados metrológicos e tipológicos:

Tabela 3. Dados metrológicos e tipológicos da necrópole de Santo Amaro, Donões

\begin{tabular}{|c|c|c|c|c|c|c|c|c|}
\hline N. ${ }^{\circ}$ & Tipologia & $\begin{array}{l}\text { Tipologia } \\
\text { cabeceira }\end{array}$ & $\begin{array}{l}\text { Comp. } \\
\text { total }\end{array}$ & $\begin{array}{l}\text { Largura } \\
\text { ombros }\end{array}$ & $\begin{array}{c}\text { Largura a } \\
\text { meio do } \\
\text { corpo }\end{array}$ & $\begin{array}{l}\text { Cabeceira } \\
\text { (larg. } x \\
\text { comp.) }\end{array}$ & $\begin{array}{l}\text { Profun- } \\
\text { didade } \\
\text { média }\end{array}$ & $\begin{array}{l}\text { Orien- } \\
\text { tação }^{17}\end{array}$ \\
\hline $\begin{array}{c}1 \\
\text { mutil.da pés }\end{array}$ & Antrop. & Peraltada & $1,80 \mathrm{~m}$ & $0,36 \mathrm{~m}$ & $0,40 \mathrm{~m}$ & $0,20 \times 0,22 \mathrm{~m}$ & $0,27 \mathrm{~m}$ & E $101^{\circ}$ \\
\hline $\begin{array}{c}2 \\
\text { perfeita }\end{array}$ & Antrop. & Ultrapassada & $1,80 \mathrm{~m}$ & $0,46 \mathrm{~m}$ & $0,37 \mathrm{~m}$ & $0,20 \times 0,20 \mathrm{~m}$ & $0,28 \mathrm{~m}$ & E $89^{\circ}$ \\
\hline $\begin{array}{c}3 \\
\text { inacab.da }\end{array}$ & Antrop. & $\begin{array}{c}\text { Volta } \\
\text { perfeita }\end{array}$ & $1,86 \mathrm{~m}$ & $0,46 \mathrm{~m}$ & $0,42 \mathrm{~m}$ & $0,22 \times 0,18 \mathrm{~m}$ & $0,11 \mathrm{~m}$ & $\mathrm{E} 84^{\circ}$ \\
\hline $\begin{array}{c}4 \\
\text { fratur. }^{\text {da }} \\
\text { fundo }\end{array}$ & Antrop. & Peraltada & $1,80 \mathrm{~m}$ & $0,45 \mathrm{~m}$ & $0,39 \mathrm{~m}$ & $0,17 \times 0,21 \mathrm{~m}$ & $0,28 \mathrm{~m}$ & E $90^{\circ}$ \\
\hline $\begin{array}{c}5 \\
\text { mutil. }{ }^{d a} \\
\text { fundo }\end{array}$ & Antrop. & Peraltada & adulto & $0,34 \mathrm{~m}$ & $0,38 \mathrm{~m}$ & $0,20 \times 0,20 \mathrm{~m}$ & $0,30 \mathrm{~m}$ & E $89^{\circ}$ \\
\hline $\begin{array}{c}6 \\
\text { muito dest. }{ }^{\text {da }}\end{array}$ & Antrop. & Ultrapassada & $\begin{array}{c}- \\
\text { criança }\end{array}$ & $0,14 \mathrm{~m}$ & - & $0,06 \times 0,06 \mathrm{~m}$ & $\begin{array}{c}0,06 \mathrm{~m} \\
\text { (ombros) }\end{array}$ & $\mathrm{E} 81^{\circ}$ \\
\hline
\end{tabular}

Fonte: Elaboração própria

É nesta necrópole que se acha o único vestígio de tampa de uma sepultura. Conserva-se mutilada, mas é possível observar que é monolítica, abaulada, bem trabalhada e anónima; seguindo o formato da sepultura, também afunila para a base. Pertencia seguramente ao moimento $n .^{\circ} 2$, que tem encaixe para tampa, e, dada a sua perfeição e solução cara e não acessível a todos, aumentaria muito o valor estético e arquitetónico do túmulo; de forma alguma haveria terra a cobrir esta bela tampa (e as restantes), que foi feita para cobrir um moimento caro e para ser vista. Daí que a conclusão de que algumas sepulturas «não se destinavam a ficar à vista» ${ }^{18}$ não pareça ser válida aqui e nos restantes cemitérios de Montalegre.

\footnotetext{
${ }^{17}$ Neste cemitério rupestre, há uma oscilação de $20^{\circ}$ entre os moimentos (entre E $81^{\circ}-\mathrm{E} 101^{\circ}$ ).

${ }^{18}$ BARROCA, 2010-2011: 130.
} 


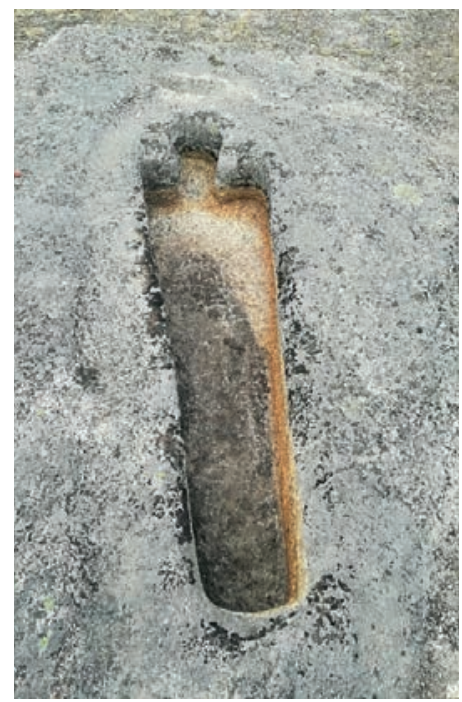

Fig. 5. Sepultura antropomórfica com axialidade perfeita da necrópole de Santo Amaro. É visível onde a tampa monolítica assentava e a protegia da infiltração de humidade.

Fonte: Arquivo pessoal do autor

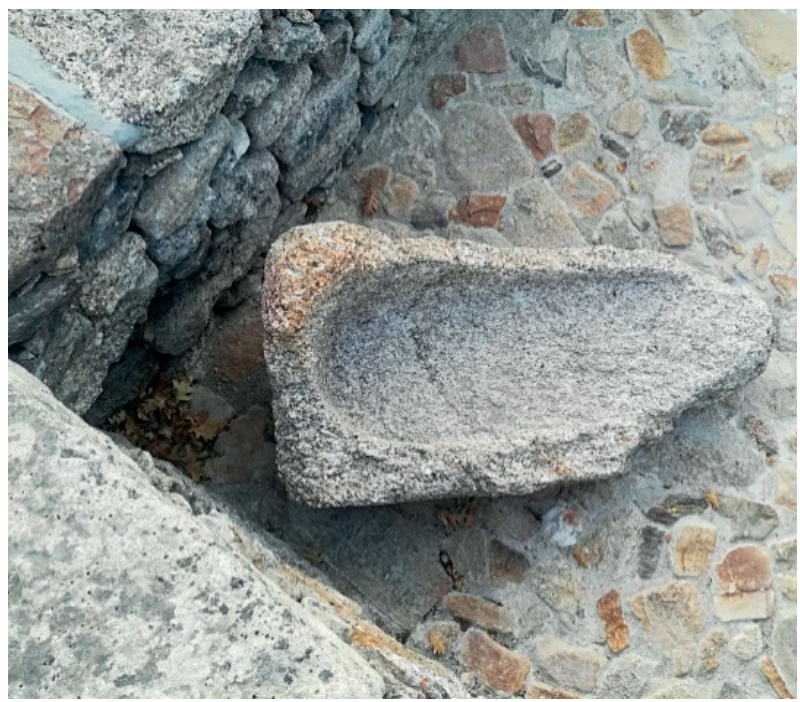

Fig. 6. Resto de tampa monolítica abobadada a afunilar para a base de uma sepultura de Santo Amaro; é a única que resta em todo o concelho de Montalegre. A solução mais comum e barata recorria a lousas que assentavam sobre o moimento; o recurso à tampa monolítica implicava gastos acrescidos e não seria acessível a todos. Fonte: Arquivo pessoal do autor

Eis alguns dados metrológicos do que resta de uma tampa monolítica, caso menos comum no panorama dos cemitérios rupestres. Acha-se mutilada na parte inferior e parece pertencer à sepultura $n .^{\circ} 2$ :

Tabela 4. Dados metrológicos de tampa monolítica da necrópole de Santo Amaro, Donões

\begin{tabular}{c|c|c|c|c|c|c}
\hline Tipologia & Estado & Comp. max. & $\begin{array}{c}\text { Largura } \\
\text { cabeceira }\end{array}$ & $\begin{array}{c}\text { Largura } \\
\text { ombros }\end{array}$ & $\begin{array}{c}\text { Altura } \\
\text { cabeceira }\end{array}$ & $\begin{array}{c}\text { Larg. max. cav. } \\
\text { de int.or }\end{array}$ \\
\hline $\begin{array}{c}\text { Tampa monol.ca q. } \\
\text { afunila para a base }\end{array}$ & ${\text { incomp. }{ }^{\text {ta }}}^{\text {cinte }}$ & $\begin{array}{c}1,40 \mathrm{~m} \text { (parte } \\
\text { conservada) }\end{array}$ & $0,60 \mathrm{~m}$ & $0,60 \mathrm{~m}$ & $0,55 \mathrm{~m}$ & $\begin{array}{c}0,42 \mathrm{~m} \\
(0,40 \mathrm{a} \text { meio) }\end{array}$ \\
\hline
\end{tabular}

Fonte: Elaboração própria

\section{NECRÓPOLE MEDIEVAL DE LEIRAS DOS PADRÕES}

É um cemitério rupestre de habitat, que se situa a cerca de $2,6 \mathrm{~km}$ a SO na aldeia de Penedones, no microtopónimo Leiras dos Padrões, a $870 \mathrm{~m}$ de altitude e com a georreferenciação: $41.751560^{\circ} \mathrm{N}-7.820412^{\circ} \mathrm{W}$. Situa-se na margem direita do rio Regavão, afluente do Cávado, em lugar soalheiro, algo distante do rio e protegido dos ventos do N e NO. Implantada no alto de um promontório, tem hoje vistas para a barragem dos Pisões, mas no passado tinha de um lado uma veiga com aptidão 
agrícola e do outro estava fronteira a verdes lameiros com aptidão pecuária, agora submersos; mais a norte o mons a perder de vista. Por conseguinte, seria rural a comunidade que ali foi sepultada. Mesmo ao lado deste núcleo, cujo nome antigo é desconhecido, passava o Itinerário XVII, que ligava Bracara Augusta a Asturica por Aquae Flaviae, pelo que dispunha de bons acessos ${ }^{19}$. A avaliar pelo cemitério rupestre, o maior de todos (pois conservam-se em mau estado pelo menos 15 moimentos) seria um grande povoado.

Não possui capela nas imediações, mas algo distante (c. $1030 \mathrm{~m}$ a este), que no passado (de acordo com a tradição popular) já foi igreja, a qual deve ter sido importante em toda a zona, mas nos últimos séculos foi demolida, pela antiguidade, e erigida no seu lugar a presente capela. É provável que seja do século XVII, está orientada a oriente, como de costume, e já consta das Memórias Paroquiais de $1758^{20}$.

Alguma da toponímia menor das redondezas é: Santo Aleixo (alusão à antiga igreja depois capela), Anta, Porto Carro (alusão à Via XVII), Vale do Martins e Castelo do Romão. De facto, do outro lado do rio Regavão e quase defronte, situava-se o castelo roqueiro medieval de São Romão (2,9 km), «advogado contra a peste», que consta do Julgado de Barroso nas Inquirições de 1258, e deve ter tido um papel importante durante a Reconquista e depois dela. Em 1258, a povoação do castelo era reguenga do rei e estava povoada: «Item dixit quod Sanctus Romanus est totum regalengum Domni Regis, et quicunque ibi laborauerit cum iugo bovum, dabit ij. quartarios, et qui laborauerit cum uno bove dabit j. quartarium per mensuram de Barroso, excepto... $\rangle^{21}$; em 1306, continuava habitada, com a povoação adstrita ${ }^{22}$. A capela do povoado ainda sobrevivia em 1758, como atestam as Memórias Paroquiais ${ }^{23}$. Todavia, depois desta data até aos dias de hoje, todas as estruturas erigidas (castelo e povoação adstrita) foram desmanteladas e saqueadas pelas aldeias vizinhas, não restando praticamente nada ${ }^{24}$.

Há nas redondezas vestígios de ocupação diacrónica extensa: castreja, romana e medieval, sendo a Via XVII e o referido castelo roqueiro os mais importantes. De facto, não seria uma necrópole isolada, dada a abundância, à superfície, nas proximidades, de vestígios arqueológicos salientados por vários autores: o povo identifica o local com uma «cidade» ou «cidade moura». A arqueóloga Carla Cascais descreve que «na zona envolvente às sepulturas encontram-se numerosos fragmentos de cerâmica de construção romana... o local tem vários topónimos sugestivos de ocupação

\footnotetext{
${ }^{19}$ Lugar de paragem; cf. "parada» e "paradela».

${ }^{20}$ BORRALHEIRO, 2005: 203.

${ }^{21}$ BAPTISTA, 2011: 43.

${ }^{22}$ BAPTISTA, 2011: 43 e 265.

${ }^{23}$ BORRALHEIRO, 2005: 205 e 212.

${ }^{24}$ ALVES, 2006: 123-126.
} 
antiga e na zona imediatamente a norte e este existiu um povoado romano» ${ }^{25}$. Fernando Braga Barreiros, numa visita ao local, descreveu desta forma os seus achados:

Têm ali aparecido pedras de esquadria, restos de encanamentos, fragmentos de objetos de barro e de tijolos, e de mós de mão... vimos uma grande pia aberta em pedra, e um grande bloco de granito em forma de paralelepípedo, a que chamam Padrão, tendo em três das suas faces vestígios muito apagados de relevos de figuras humanas ${ }^{26}$.

A necrópole é conhecida por dois nomes: Leiras dos Padrões e, menos, Santo Aleixo, dada alguma proximidade à capela deste santo. Se o segundo microtopónimo recorda um santo romano de culto antigo $(\uparrow 412)$ e venerado na Europa depois do século XI, cuja capela se encontra não muito longe, o primeiro (Leira dos Padrões) parece recordar marcos divisórios das propriedades agrícolas cultiváveis (leiras) ${ }^{27}$. J. D. Baptista, em mais do que uma obra sua, liga a este cemitério rupestre a existência da antiga Villa $\mathrm{Mel}$, que se situaria nas imediações.

Esta necrópole, que é a mais numerosa das doze do concelho de Montalegre, encontra-se em mau estado de conservação, muito devido à erosão provocada pelas águas da barragem que, à cota alta, a fustigam com a ondulação; no lado contrário, a oeste, foi a proximidade de uma terra agricultada que contribuiu para a sua destruição.

Possui 15 sepulturas de tipo antropomórfico escavadas num afloramento xistoso-granítico, com orientação oeste/este e rente ao chão, distando as mais remotas entre si em $80 \mathrm{~m}$. São antropomórficas e algumas a afunilar muito pouco para os pés, achando-se apenas duas em bom estado de conservação ( $n .^{\text {os }} 1$ e 15). São moimentos violados: não se encontram selados, nem há vestígios de tampa, que deverá ter sido formada por uma ou mais lousas sobrepostas ou por monólitos. Quanto às cabeceiras, algumas das quais são de longo diâmetro e em que predomina o arco de volta perfeita, jazem um pouco mais elevadas do que o plano do leito. Nelas os ombros encontram-se geralmente pouco individualizados e com a curva arredondada e pouco destacada; os pés não se acham destacados e encontram-se no mesmo plano que o leito; é difícil de indagar se havia vestígios de orifício para escoamento de líquidos (pelo menos nas $n .^{\text {os }} 1$ e 15, bem conservadas, não há). O rebordo é indefinido e de tipo horizontal. Acham-se em plano um pouco a descair para os pés, tal como os rochedos em que foram abertas. As duas bem conservadas atingem uma axialidade bastante perfeita.

De entre os 15 moimentos, 14 encontram-se bastante concentrados, a norte, e um deles ( . $^{\circ}$ 15) bastante a sul, num afloramento algo elevado e perto da água

\footnotetext{
${ }^{25}$ CASCAIS, 2007-2008: 32161.

${ }^{26}$ BARREIROS, 1920: 80.

${ }^{27}$ Em alternativa, o termo padrões identificaria marcos da Via XVII.
} 
da albufeira. A norte do afloramento granítico, ao lado das sepulturas, há cortes na rocha, contemporâneos dos túmulos, que denunciam o lugar de assentamento de algum tipo de estrutura. O que seria não é fácil de indagar, mas estaria ligada ao cemitério rupestre e poderiam ser muretes.

Eis alguns dados metrológicos e tipológicos:

Tabela 5. Dados metrológicos e tipológicos da necrópole de Leiras dos Padrões, Penedones

\begin{tabular}{|c|c|c|c|c|c|c|c|c|}
\hline N. ${ }^{\circ}$ & Tipologia & $\begin{array}{l}\text { Tipologia } \\
\text { cabeceira }\end{array}$ & $\begin{array}{l}\text { Comp. } \\
\text { total }\end{array}$ & $\begin{array}{l}\text { Largura } \\
\text { ombros }\end{array}$ & \begin{tabular}{|c|} 
Largura a \\
meio do corpo \\
\end{tabular} & $\begin{array}{c}\text { Cabeceira } \\
\text { (larg. } x \text { comp.) }\end{array}$ & $\begin{array}{c}\text { Profundidade } \\
\text { média }\end{array}$ & $\begin{array}{l}\text { Orien- } \\
\text { tação }\end{array}$ \\
\hline $\begin{array}{c}1 \\
\text { Bom }\end{array}$ & Antrop. & $\begin{array}{c}\text { Volta } \\
\text { perfeita }\end{array}$ & $1,90 \mathrm{~m}$ & $0,57 \mathrm{~m}$ & $0,54 \mathrm{~m}$ & $0,40 \times 0,30 \mathrm{~m}$ & $0,33 \mathrm{~m}$ & E 94응 \\
\hline $\begin{array}{c}2 \\
\text { mutil.da } \\
\text { metade inferior }\end{array}$ & Antrop. & $\begin{array}{c}\text { Volta } \\
\text { perfeita }\end{array}$ & adulto & $0,34 \mathrm{~m}$ & $0,42 \mathrm{~m}$ & $0,25 \times 0,23 \mathrm{~m}$ & $0,25 \mathrm{~m}$ & $\mathrm{E} 81^{\circ}$ \\
\hline $\begin{array}{c}3 \\
\text { bastante destr. }{ }^{\text {da }}\end{array}$ & Antrop. & $\begin{array}{c}\text { Volta } \\
\text { perfeita }\end{array}$ & adulto & $0,37 \mathrm{~m}$ & $0,44 \mathrm{~m}$ & $0,25 \times 0,25 \mathrm{~m}$ & $0,36 \mathrm{~m}$ & $\mathrm{E} 85^{\circ}$ \\
\hline $\begin{array}{c}4 \\
\text { muito destr. }{ }^{\text {da }}\end{array}$ & Antrop. & $\begin{array}{c}\text { Volta } \\
\text { perfeita }\end{array}$ & adulto & $0,50 \mathrm{~m}$ & ---- & $0,35 \times 0,32 \mathrm{~m}$ & $0,34 \mathrm{~m}$ & SE $139^{\circ}$ \\
\hline $\begin{array}{c}5 \\
\text { muito destr. }{ }^{d a}\end{array}$ & Antrop. & $\begin{array}{l}\text { Retang. } \\
\text { arred.da }\end{array}$ & adulto & --- & --- & $0,29 \mathrm{~m} \times$ ? & --- & E $93^{\circ}$ \\
\hline $\begin{array}{c}6 \\
\text { muito destr. }{ }^{\text {da }}\end{array}$ & Antrop. & --- & adulto & --- & --- & $0,27 \mathrm{~m} \times$ ? & --- & E $88^{\circ}$ \\
\hline $\begin{array}{c}7 \\
\text { destr. }^{\text {da }} \\
\end{array}$ & Antrop. & --- & --- & --- & --- & --- & --- & --- \\
\hline $\begin{array}{c}8 \\
\text { muito destr. }^{\text {da }}\end{array}$ & Antrop. & $\begin{array}{l}\text { Retang. } \\
\text { arred.da }\end{array}$ & adulto & --- & --- & $0,28 \mathrm{~m} \times ?$ & --- & $\mathrm{E} 90^{\circ}$ \\
\hline $\begin{array}{c}9 \\
\text { muito destr. }{ }^{\text {da }}\end{array}$ & --- & --- & adulto & --- & $0,40 \mathrm{~m}$ & --- & $0,32 \mathrm{~m}$ & E $110^{\circ}$ \\
\hline $\begin{array}{c}10 \\
\text { muito destr. da }\end{array}$ & Antrop. & --- & adulto & --- & --- & --- & --- & E 95० \\
\hline $\begin{array}{c}11 \\
\text { muito destr. da }\end{array}$ & Antrop. & --- & adulto & --- & --- & --- & --- & E $106^{\circ}$ \\
\hline $\begin{array}{c}12 \\
\text { muito destr.da }\end{array}$ & Antrop. & Peraltada & adulto & --- & --- & --- & --- & SE $146^{\circ}$ \\
\hline $\begin{array}{c}13 \\
\text { muito destr. da }\end{array}$ & --- & --- & adulto & --- & --- & --- & --- & SE $148^{\circ}$ \\
\hline $\begin{array}{c}14 \\
\text { muito destr. } \\
\text { da }\end{array}$ & --- & --- & --- & --- & --- & --- & --- & SE $118^{\circ}$ \\
\hline $\begin{array}{c}15 \\
\text { Bom }\end{array}$ & Antrop. & Peraltada & $1,85 \mathrm{~m}$ & $0,47 \mathrm{~m}$ & $0,48 \mathrm{~m}$ & $0,15 \times 0,22 \mathrm{~m}$ & $0,33 \mathrm{~m}$ & E $101^{\circ}$ \\
\hline
\end{tabular}

Fonte: Elaboração própria

\footnotetext{
${ }^{28}$ Neste cemitério rupestre, há uma oscilação de $67^{\circ}$ entre os moimentos (entre E81 ${ }^{\circ}-\mathrm{SE} 148^{\circ}$ ).
} 


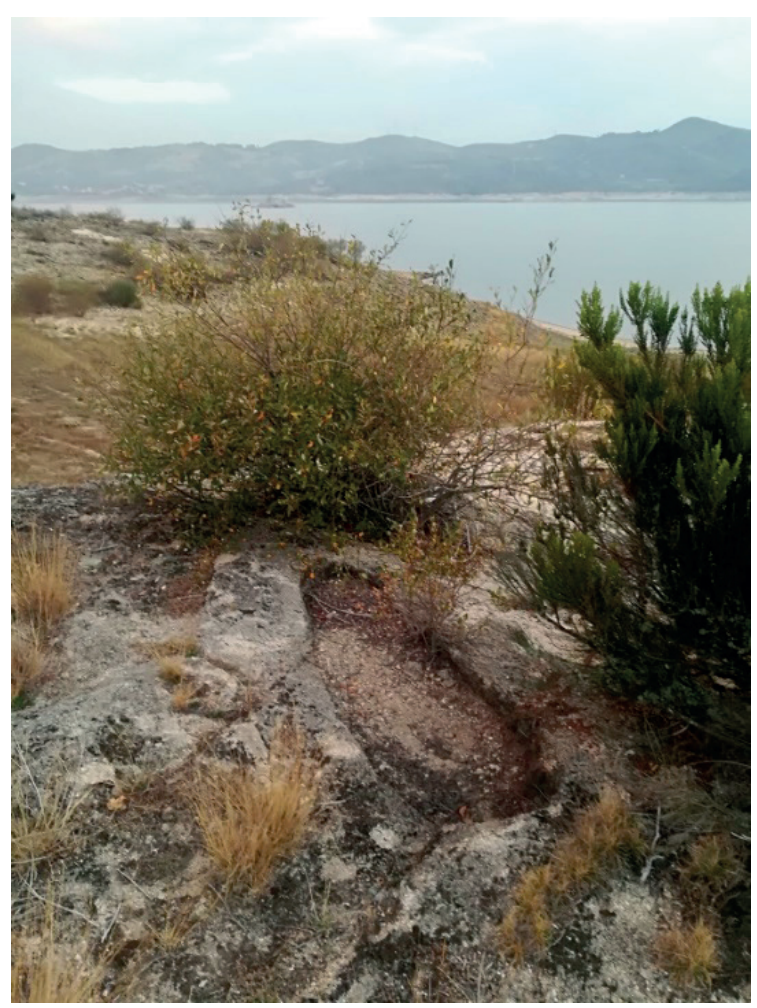

Fig. 7.

Uma das poucas sepulturas bem preservadas de Leira dos Padrões.

A necrópole tem hoje vista para a barragem dos Pisões, mas outrora era para verdes prados agora submersos

Fonte: Arquivo pessoal do autor

\section{NECRÓPOLE MEDIEVAL DE MONTE DAS COTAS}

É um cemitério rupestre de habitat, que se situa na margem esquerda do Regavão, afluente do Cávado, no microtopónimo Monte das Cotas, a $890 \mathrm{~m}$ de altitude e com a georreferenciação: $41.771332^{\circ} \mathrm{N}-7.778130^{\circ} \mathrm{W}$. Situado um pouco distante do leito do rio e implantado num lugar um pouco elevado e plano, fica fronteiro de uma veiga com aptidão agrícola e de verdes lameiros com aptidão pecuária, agora submersos pela barragem dos Pisões; mais longe, o mons a perder de vista. Por conseguinte, seria rural a comunidade que ali foi sepultada. Defronte e bastante perto (430 m a NO) fica o Castro de São Vicente. Como nas imediações passava o Itinerário XVII, o local dispunha de bons acessos. Não possui capela próxima.

O microtopónimo é conhecido por Monte das Cotas. As aldeias mais próximas são Travassos da Chã (c. 1370 m a O) e São Vicente (c. 1500 m a N), as quais já constam do Julgado de Barroso das Inquirições de D. Afonso III de $1258^{29}$.

\footnotetext{
${ }^{29}$ Cf. BAPTISTA, 2011: 59-61.
} 
A necrópole é formada atualmente por uma sepultura isolada integralmente escavada no afloramento xistoso, de orientação canónica (E 90), ovalada e achando-se em razoável estado de conservação. É um moimento violado: não se encontra selado, nem há vestígios de tampa, que deveria ter sido formada por uma ou mais lajes lisas; dada a altura, de forma alguma estaria coberto com terra. A área da cabeceira, do leito e dos pés encontra-se no mesmo plano, mas o túmulo decai para os pés em $7^{\circ}$, tal como o afloramento em que se encontra. Aos pés há orifício arredondado e pouco proeminente para escoamento de líquidos, o que obrigou ao rasgo da rocha exterior. O rebordo é indefinido e de tipo horizontal.

Há nas redondezas vestígios de ocupação diacrónica extensa: castreja, romana e medieval, entre os quais o famoso castro de São Vicente (430 m a NO), que se localiza defronte e que foi escavado por Santos Júnior e Osvaldo Freire ${ }^{30}$ na década de 60 e brevemente descrito e acompanhado de desenho topográfico por F. Barreiros; também ficava muito próximo da Via XVII, pelo que dispunha de bons acessos.

F. Barreiros ${ }^{31}$ fez em 1914 o levantamento arqueológico do local com desenho topográfico e assinalou a existência de mais duas sepulturas rupestres, todas de adulto (que distavam entre si em $80 \mathrm{~m}$ ), além de "três mamoas» a oriente (o que denota uma ocupação diacrónica extensa), «fragmentos de mós, e pedras com vestígios de terem sido utilizadas em construções». Todavia, dos moimentos referidos, apenas subsiste a sua sepultura n. ${ }^{\circ}$, jazendo a n. ${ }^{\circ} 1$ sob a barragem e tendo a n. ${ }^{\circ} 2$ (muito perto da $\mathrm{n}^{\circ} 3$ ) sido destruída posteriormente por máquinas que aplanaram o local. Refere ainda Barreiros ${ }^{32}$ que às sepulturas chama o povo «masseirões dos mouros» ${ }^{33}$.

Como já dissemos, a única sepultura sobrevivente, naquele lugar bastante remexido por máquinas, é a n. ${ }^{\circ} 3$ identificada no levantamento topográfico de Barreiros. Está totalmente escavada na rocha xistosa, num afloramento com cerca de $2,50 \mathrm{~m}$ de altura e possui orientação canónica a oriente (E 90). É ovalada, jazendo a cabeceira, corpo e pés no mesmo plano, todavia encontra-se com uma inclinação para os pés de $7^{\circ}$, tal como o rochedo em que se acha. Que «tem em volta vestígios dum rebaixo» (lado esquerdo), já Barreiros ${ }^{34}$ notou em 1914 e seria com certeza para evitar a entrada de água. Junto aos pés, é também bem visível um pequeno orifício circular que servia de escoamento de líquidos, razão por que no passado devia ter estado selada por tampa composta de uma ou mais lajes sobrepostas.

Eis alguns dados metrológicos e tipológicos:

\footnotetext{
30 SANTOS JÚNIOR, 1963; SANTOS JÚNIOR, ISIDORO, 1963; SANTOS JÚNIOR, FREIRE, 1964.

${ }^{31}$ BARREIROS, 1920: 76-78.

${ }^{32}$ BARREIROS, 1920: 77.

${ }^{33}$ CASCAIS, 2007-2008: 32312.

${ }^{34}$ BARREIROS, 1920: 78.
} 
Tabela 6. Dados metrológicos e tipológicos da única sepultura que resta da necrópole de Monte das Cotas, Travassos da Chã

\begin{tabular}{c|c|c|c|c|c|c|c|c}
\hline N.॰ & Tipologia & $\begin{array}{c}\text { Tipologia } \\
\text { cabeceira }\end{array}$ & $\begin{array}{c}\text { Comp. } \\
\text { total }\end{array}$ & $\begin{array}{c}\text { Largura } \\
\text { ombros }\end{array}$ & $\begin{array}{c}\text { Largura a meio } \\
\text { do corpo }\end{array}$ & $\begin{array}{c}\text { Cabeceira } \\
\text { (larg. } \mathbf{x} \text { comp.) }\end{array}$ & $\begin{array}{c}\text { Profundidade } \\
\text { média }\end{array}$ & $\begin{array}{c}\text { Orien- } \\
\text { tação }\end{array}$ \\
\hline $\begin{array}{c}1 \\
\text { bom }\end{array}$ & $\begin{array}{c}\text { Não } \\
\text { Antrop. }\end{array}$ & - & $1,78 \mathrm{~m}$ & $0,33 \mathrm{~m}$ & $0,43 \mathrm{~m}$ & $0,29 \mathrm{~m}$ & $0,30 \mathrm{~m}$ & $\mathrm{E} \mathrm{90^{ \circ }}$ \\
\hline
\end{tabular}

Fonte: Elaboração própria

F. Barreiros, que visitou o local em 1914 e descreveu o castro, apresenta das três sepulturas aí existentes os dados metrológicos a seguir registados, devendo atender-se no seguinte: que a sepultura sobrevivente é a sua n. ${ }^{\circ}$; que a sua $n .{ }^{\circ} 1$ se encontra agora submersa pela barragem e já se achava muito destruída em 1914, aquando da sua visita, e, por isso, não apresenta dados metrológicos na maioria dos parâmetros; e que a sua n. 2 (bastante perto da n. ${ }^{\circ}$ ) já não se conserva, tendo sido destruída por máquinas que aplanaram o local:

Tabela 7. Dados metrológicos da necrópole de Monte das Cotas, Travassos da Chã, em 1914

\begin{tabular}{c|c|c|c|c|c|c}
\hline N.` sepult. & Comp. total & $\begin{array}{c}\text { Larg. } \\
\text { ombros }\end{array}$ & $\begin{array}{c}\text { Comp. linha } \\
\text { ombros-pés }\end{array}$ & Larg. nos pés & $\begin{array}{c}\text { Fundos lados } \\
\text { cabeça-pés }\end{array}$ & $\begin{array}{c}\text { Diâm. máx. da } \\
\text { cabeça }\end{array}$ \\
\hline 1 & $1,85 \mathrm{~m}$ & - & - & - & - & - \\
\hline 2 & $1,77 \mathrm{~m}$ & $0,25 \mathrm{~m}$ & $1,44 \mathrm{~m}$ & $0,20 \mathrm{~m}$ & 0,32 e $0,23 \mathrm{~m}$ & $0,24 \mathrm{~m}$ \\
\hline 3 & $1,78 \mathrm{~m}$ & $0,39 \mathrm{~m}$ & $1,56 \mathrm{~m}$ & $0,16 \mathrm{~m}$ & 0,22 e $0,20 \mathrm{~m}$ & $0,20 \mathrm{~m}$ \\
\hline
\end{tabular}

Fonte: Barreiros, 1920: 78

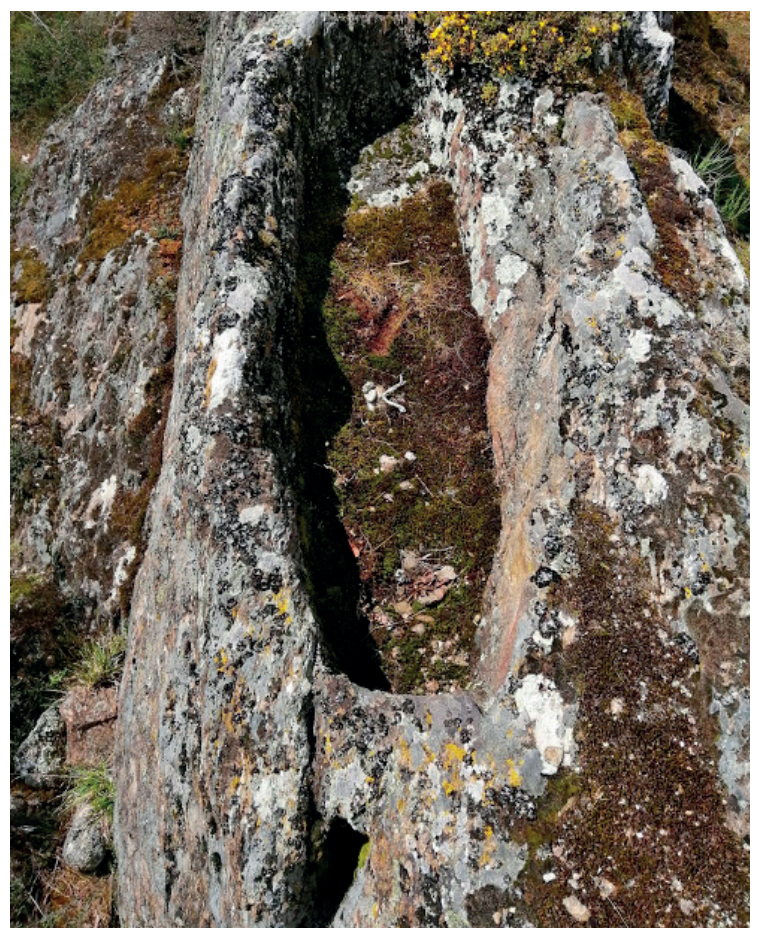

Fig. 8.

Sepultura ovalada de Monte das Cotas. É a única que resta do cemitério rupestre, que em 1914 era formado por três tumuli Fonte: Arquivo pessoal do autor 


\section{NECRÓPOLE MEDIEVAL DE PORTELA DO ANTIGO}

É um cemitério rupestre de habitat, que se situa na aldeia de Penedones (c. $700 \mathrm{~m}$ a N, a qual já consta do Julgado de Barroso das Inquirições de D. Afonso $I I I^{35}$, no microtopónimo Portela do Antigo, a $960 \mathrm{~m}$ de altitude, em lugar com aptidão agrícola e com a georreferenciação: $41.766655^{\circ} \mathrm{N}-7.808586^{\circ} \mathrm{W}$. Situa-se na margem direita do rio Regavão, afluente do Cávado, a meia encosta, mas, ao contrário das duas últimas necrópoles, acha-se bem distante do rio $(2,5 \mathrm{~km})$ e implantada num lugar elevado, mas nas imediações de uma veiga com aptidão agrícola; a norte situa-se o mons a perder de vista. Por conseguinte, seria rural a comunidade que ali foi sepultada. Deste local, por ser elevado e sobranceiro ao vale do Regavão, identificam-se perfeitamente os dois cemitérios rupestres vizinhos: Leiras dos Padrões e Monte das Cotas, e ainda o castelo de São Romão. O lugar não possui capela.

Há nas redondezas vestígios de ocupação diacrónica extensa: romana e medieval. Como no sopé da montanha $(1330 \mathrm{~m})$ passava o Itinerário XVII, o local dispunha de bons acessos. A distância relativamente à atual aldeia de Penedones é de apenas $407 \mathrm{~m}$, a sul, pelo que poderá haver continuidade de povoamento, mais ou menos ininterrupto, entre este local e a aldeia.

O microtopónimo é conhecido por Portela do Antigo. Por portela (portinha) entende-se o lugar elevado e sobranceiro, em que passa um caminho, e a partir do qual já se vê a aldeia (Penedones) do outro lado da montanha; antigo (que também encontramos em Antigo de Sarraquinhos e parece ser sinónimo do velho de Agrovelho) é o nome que os novos povoadores de Penedones chamaram àquele lugar anteriormente habitado e depois abandonado, mas no qual sobrevivem restos de construções e túmulos ${ }^{36}$. Não tendo explicação para aqueles vestígios, os habitantes locais, como é costume, associaram o local a várias lendas de mouros e mouras encantadas. Possivelmente a pobra antiga situar-se-ia a sul do cemitério, em lugar pouco acima da atual aldeia. $\mathrm{O}$ abastecimento de água proviria de minas, as quais ainda sobrevivem.

A necrópole é constituída atualmente por seis sepulturas antropomórficas escavadas no afloramento granítico rente ao chão, encontrando-se em mau estado de conservação, para o qual tanto contribuiu a incúria de um poste metálico de média tensão, como a extração de pedra para as paredes dos terrenos contíguos, levada a cabo ao longo dos séculos. Cinco são de adulto e acham-se bem visíveis e próximas. Distante do conjunto, a dezenas de metros para oeste (colhemos a informação junto

\footnotetext{
${ }^{35}$ Cf. BAPTISTA, 2011: 62 e 103.

${ }^{36}$ Para opinião diferente, vd. Ferreira Priegue apud TEIXEIRA, 1996: 135, n. ${ }^{\circ} 32$. Teria antes uma conotação viária: «la "antigua" o "antigoa", en los deslindes y apeos, designa a un camino cualquiera, viejo o nuevo» e seria uma simplificação de «antiqua vereta».
} 
do povo da aldeia), há uma sepultura de criança em bom estado de conservação e em pequeno rochedo raso de granito, mas que não conseguimos localizar por causa da densa vegetação.

São antropomórficas e a afunilarem para os pés, distando em $40 \mathrm{~m}$ as mais afastadas entre si, e todas possuem orientação canónica a oriente (E). São moimentos violados: não se encontram selados, nem há vestígios de tampa, que deverá ter sido formada por uma ou mais lajes lisas sobrepostas e com encaixe (pelo menos nas n. ${ }^{\text {s }} 1,2$ e 3 ). As cabeceiras são indefinidas numas, em arco de volta perfeita noutra e retangular arredondada noutra, encontrando-se a cabeceira num plano superior relativamente ao plano do leito e dos pés; os ombros encontram-se mal individualizados e os pés não se acham destacados; nenhum monumento decai para os pés, como habitualmente, jazendo todos em plano horizontal. O rebordo é tanto de tipo alteado como horizontal. O grau de destruição não permite indagar se aos pés há ou não vestígios de orifício para escoamento de líquidos. O rebordo tanto é indefinido nuns casos, como alteado noutros, como ainda de tipo horizontal.

Três delas (n. ${ }^{\text {os }} 1,2$ e 3 ) aparentam constituir um «jazigo familiar» pelo facto de se encontrarem contíguas $(0,2 \mathrm{~m})$ e de possuírem igual alinhamento (E 89) e comprimento $(1,80 \mathrm{~m})$. Isso pode indicar que foram abertas na rocha ao mesmo tempo. Nestas três existem proeminentes vestígios de encaixe da tampa, sobretudo na zona da cabeceira, que aparenta ter sido monolítica. Estão, porém, bastante destruídas, sobretudo na sua parte interior, por ter sido extraída do afloramento pedra para a construção de uma base de poste de média tensão.

É certo que havia mais sepulturas além destas seis, por informação de Barreiros colhida no local. Aquando da sua visita em 1914 ainda viu restos de outras, mas não diz quantas e notou a existência de orifício junto aos pés para escoamento de água, sinal de que, no passado, estavam seladas com lousas de granito:

há seis sepulturas abertas em rocha, e vestígios doutras danificadas pelos pedreiros. Nota-se nestes moimentos um orifício circular pequeno visivelmente artificial. Algumas delas são contíguas entre si, e uma era de criança. O povo supõe que eram estas cavidades para os mouros se deitarem ${ }^{37}$.

\footnotetext{
${ }^{37}$ BARREIROS, 1920: 80.
} 
Eis alguns dados metrológicos e tipológicos:

Tabela 8. Dados metrológicos e tipológicos da necrópole de Portela do Antigo, Penedones

\begin{tabular}{|c|c|c|c|c|c|c|c|c|}
\hline N. ${ }^{\circ}$ & Tipologia & $\begin{array}{l}\text { Tipologia } \\
\text { cabeceira }\end{array}$ & $\begin{array}{l}\text { Comp. } \\
\text { total }\end{array}$ & \begin{tabular}{|l|} 
Largura \\
ombros \\
\end{tabular} & $\begin{array}{l}\text { Largura a meio } \\
\text { do corpo }\end{array}$ & $\begin{array}{c}\text { Cabeceira } \\
\text { (larg. x comp.) }\end{array}$ & \begin{tabular}{|c|}
$\begin{array}{c}\text { Profundidade } \\
\text { média }\end{array}$ \\
\end{tabular} & $\begin{array}{l}\text { Orien- } \\
\text { tação }^{38}\end{array}$ \\
\hline $\begin{array}{c}1 \\
\text { muito destr. }{ }^{\text {da }}\end{array}$ & Antrop. & $\begin{array}{c}\text { Volta } \\
\text { perfeita }\end{array}$ & $1,80 \mathrm{~m}$ & - & - & $0,30 \times 0,30 \mathrm{~m}$ & - & E $89^{\circ}$ \\
\hline $\begin{array}{c}2 \\
\text { muito destr. }^{\text {da }}\end{array}$ & Antrop. & $\begin{array}{c}\text { Retang. } \\
\text { arredondada }\end{array}$ & $1,80 \mathrm{~m}$ & - & - & $0,28 \times 0,18 \mathrm{~m}$ & - & E $89^{\circ}$ \\
\hline $\begin{array}{c}3 \\
\text { muito destr. }{ }^{\text {da }}\end{array}$ & Antrop. & Indef. & $1,80 \mathrm{~m}$ & - & - & - & - & E $89^{\circ}$ \\
\hline $\begin{array}{c}4 \\
\text { muito destr. }^{\text {da }}\end{array}$ & - & - & $\begin{array}{c}- \\
\text { Adulto } \\
\end{array}$ & - & - & - & - & $\mathrm{E} 80^{\circ}$ \\
\hline $\begin{array}{c}5 \\
\text { muito destr. }{ }^{\text {da }}\end{array}$ & Subovalada & Indef. & $1,80 \mathrm{~m}$ & - & - & $\begin{array}{c}0,25 \mathrm{~m} \\
\mathrm{x}-\end{array}$ & - & E $98^{\circ}$ \\
\hline $\begin{array}{c}6 \\
-39\end{array}$ & - & - & $\begin{array}{c}- \\
\text { criança }\end{array}$ & - & - & - & - & - \\
\hline
\end{tabular}

Fonte: Elaboração própria

\section{NECRÓPOLE MEDIEVAL DE VILAR DE PERDIZES}

É um cemitério rupestre de lugar, que se situa no lugar de Vilar de Perdizes, no microtopónimo Igreja, a $882 \mathrm{~m}$ de altitude e com a georreferenciação: $41.855859^{\circ} \mathrm{N}$ $7.633827^{\circ} \mathrm{W}$. Em termos de implantação geográfica, o cemitério rupestre está situado dentro da aldeia: numa quelha, pelo lado este, de acesso à igreja matriz de S. Miguel, em lugar um pouco elevado, com vista para uma próspera veiga orientada a este e abrigada dos ventos norte e oeste. Por conseguinte, seria rural a comunidade que ali foi sepultada.

A zona é de longa ocupação diacrónica: castreja, romana e medieval, e não há, entre as 12 necrópoles do concelho, nenhuma em que os vestígios arqueológicos sejam tão numerosos ${ }^{40}$. Pelo facto de se situar em lugar tão central, é possível conjeturar que tenha havido continuidade de povoamento, mais ou menos constante, entre a comunidade que ali foi sepultada, porventura pelos séculos IX-X, e a atual aldeia.

São Miguel de Vilar de Perdizes surge no Julgado de Barroso das Inquirições de D. Afonso III de 1258 como colação, sendo o rei de Portugal patrono de metade da igreja e de metade da aldeia e as outras metades apanágio do rei de Leão. Aí é apresentada a colação com os seus lugares, casais e impostos que pagavam a D. Afonso III ${ }^{41}$.

A necrópole é hoje composta por uma única sepultura de antropomorfismo incipiente virada a oriente (E) e escavada no afloramento granítico, mas é certo que havia mais nas imediações. Encontra-se em mau estado de conservação, muito

\footnotetext{
${ }^{38}$ Neste cemitério rupestre, há uma oscilação de apenas $18^{\circ}$ entre os moimentos (entre E 80 - E 98º).

${ }^{39}$ Sepultura de criança localizada, a oeste, algo distante das restantes, mas de difícil localização, apesar de a termos procurado por duas vezes.

${ }^{40}$ Cf. BARREIROS, 1920: 61-65; FONTES, 1978: 15-24.

${ }^{41}$ BAPTISTA, 2011: 96-98, 104.
} 
devido ao facto de estar no meio de uma vereda por onde muita gente passou ao longo dos tempos. É absolutamente certo (por informações que nós recolhemos no local) que havia mais sepulturas à sua esquerda e direita, mas acham-se soterradas: umas, a norte, pela terra de uma horta, outras, a sul, por uma casa de habitação recentemente construída. O número total delas é desconhecido, nem Barreiros, que durante o ano de 1914 visitou o local, se refere a este cemitério rupestre, que parece formar uma necrópole bastante concentrada.

O moimento agora isolado encontra-se em mau estado de conservação; não se encontra selado, nem há vestígios de tampa, que deverá ter sido formada por uma ou mais lajes lisas sobrepostas e com encaixe. A cabeceira é indefinida, jazendo cabeceira e leito no mesmo plano. Os ombros encontram-se mal individualizados; os pés não se acham destacados e encontram-se no mesmo plano que o leito; aos pés há vestígios de orifício para escoamento de líquidos, o que obrigou ao desbravamento da rocha exterior; o rebordo é indefinido e de tipo horizontal e ainda possui na cabeceira vestígios do encaixe da tampa, como conjetura Carla Cascais: «Na cabeceira nota-se um pequeno rasgo, na horizontal, que poderá ter servido para encaixe de tampa». Jaz a decair levemente para os pés, tal como o rochedo em que se encontra.

Eis alguns dados metrológicos e tipológicos seus:

Tabela 9. Dados metrológicos e tipológicos da única sepultura sobrevivente da necrópole de Vilar de Perdizes

\begin{tabular}{c|c|c|c|c|c|c|c|c}
\hline N. & Tipologia & $\begin{array}{c}\text { Tipologia } \\
\text { cabeceira }\end{array}$ & $\begin{array}{c}\text { Comp. } \\
\text { total }\end{array}$ & $\begin{array}{c}\text { Largura } \\
\text { ombros }\end{array}$ & $\begin{array}{c}\text { Largura a } \\
\text { meio do } \\
\text { corpo }\end{array}$ & $\begin{array}{c}\text { Cabeceira } \\
\text { (larg. } \mathbf{x} \\
\text { comp.) }\end{array}$ & $\begin{array}{c}\text { Profun- } \\
\text { didade } \\
\text { média }\end{array}$ & $\begin{array}{c}\text { Orien- } \\
\text { tação }\end{array}$ \\
\hline $\begin{array}{c}1 \\
\text { muito mau }\end{array}$ & Indef. & Indef. & $1,82 \mathrm{~m}$ & $0,40 \mathrm{~m}$ & $0,48 \mathrm{~m}$ & Indef. & $0,29 \mathrm{~m}$ & $\mathrm{E} 73^{\circ}$ \\
\hline
\end{tabular}

Fonte: Elaboração própria

\section{NECRÓPOLE MEDIEVAL DE SR. ${ }^{a}$ DE GALEGOS / SR. ${ }^{a}$ DA NATIVIDADE}

É um cemitério rupestre de lugar extinto, formado atualmente por cinco sepulturas de adulto integralmente escavadas no afloramento granítico-xistoso, que se situa ente as aldeias de Cortiço e Zebral, no microtopónimo Senhora de Galegos, a $980 \mathrm{~m}$ de altitude e com a georreferenciação: $41.787326^{\circ} \mathrm{N}-7.699049^{\circ} \mathrm{W}$. Situa-se num lugar um pouco elevado, tendo de um lado a vasta montanha, que o protege dos ventos frios de $\mathrm{N}$ e $\mathrm{NO}$ e fornece pasto para o gado, e do outro uma veiga fértil bem apropriada para a agricultura e com orientação a SE. Por conseguinte, seria rural a comunidade que ali foi sepultada.

Alguma da toponímia menor das redondezas é: Galegos, Carqueijal, Fonte da Madre, Raposeiras, Ameixeira e Pedregal. Nas redondezas há vestígios de ocupação com extensa diacronia, a avaliar pelos vestígios arqueológicos de superfície: sobretudo 
romana ${ }^{42}$ e mais ainda medieval, o que mostra uma ocupação antiga mais ou menos contínua à sombra daquela veiga fértil, abundante em água e bem orientada a SE; também ficava próximo da Via XVII, pelo que dispunha de bons acessos. Ainda é bem visível a mina de água e os restos de habitações soterradas a este; além de que a capela, ampliada nos últimos séculos, possui traçado de construção antiga.

F. Barreiros ${ }^{43}$, que em 1914 visitou o lugar, descreveu a SO da capela, no microtopónimo Pedregal, fragmentos de tijolos de barro vermelho; e pelo P. ${ }^{\mathrm{e}}$ João Álvares de Moura, de Fírvidas, foi informado do achamento de uma ponta de lança de cobre junto à capela. Nos terrenos que circundam a capela, asseveram as gentes que lavram os terrenos ser frequente encontrar fragmentos de cerâmica comum, identificando ainda restos de construções com abundante pedra afeiçoada dispersa.

Por isso não admira que já tenha sido uma póvoa. De facto, sabemos pelas Inquirições de D. Afonso III de 1258, Julgado de Barroso, que a pobra tinha o nome de «Villa de Galletos» e não era pequena: possuía cerca de 12 casais e integrava a colação de Santa Cristina de Cervos: «Item de villa de Galletos est tercia pars Domini Regis et sunt ibi quattuor casalia, de quibus dant annuatim sex sex quartarios de pane et singulos carnarios et ij.ij panes. Item de alia tercia pars ipsius ville dant Domino Regi annuatim oetavam partem tocius fructus et alia tertia est herdatorum» ${ }^{44}$.

Como já referimos (e é a convicção de A. Lourenço Fontes), é provável que o nome «Villa de Galletos» tenha a ver com a organização do repovoamento da zona por gentes da Galiza no período pós-Reconquista e durante a presúria de Odoário, no século IX: «uma colónia de Galegos a povoar, após a Reconquista desta zona, como outras por esse Portugal fora... o galego, devido à sua grande e fácil proliferação, foi um grande elemento no repovoamento do Norte de Portugal» ${ }^{45}$.

Todavia, pouco depois dos meados do século XIII, o povoado entrou em decadência e acabou por se extinguir décadas depois. Porque as pessoas se deslocaram para os povoados vizinhos (Cortiço e Zebral), extinguindo-se o local que até aí tinha sido próspero (mas continuando a trabalhar as férteis terras circundantes), é difícil de indagar. A tradição popular, como em outros lugares extintos (p. ex., Santo Adrião, Agrovelho e Santo Amaro) fala em pestes, mas não terá sido sempre assim. Diz a tradição popular que os dois últimos habitantes a sair foram duas velhinhas, uma das quais se mudou para a aldeia do Cortiço e a outra preferiu ir para Zebral. Pode ser uma estória, mas num aspeto tem sentido: quando associa este povoado às duas aldeias vizinhas, uma de cada lado, que se acham ambas herdeiras e continuadoras daquele povoado antigo e que, por isso, preservaram em comunhão de esforços o templo aí erigido.

\footnotetext{
${ }^{42}$ CASCAIS, 2007-2008: 32156.

${ }^{43}$ BARREIROS, 1920: 71.

${ }^{44}$ BAPTISTA, 2011: 88; cf. FONTES, 1978: 31.

${ }^{45}$ FONTES, 1978: 31.
} 
Na verdade, localiza-se no local uma próspera capela com galilé, com nave, arco, altar-mor e dois altares laterais, mais dois edifícios contemporâneos que lhe servem de apoio, cuja prosperidade só se explica pela manutenção conjunta das duas aldeias e não de uma só. Consta das Memórias Paroquiais de 1758, com festa celebrada uma vez no ano, a oito de setembro, cuja senhora da Natividade «se venera por milagrosa» ${ }^{46}$. Se hoje (e já assim era em 1758) é apenas uma capela de romaria, bastante próspera para a zona, no passado estamos convictos de que terá sido igreja de aldeia (ou então uma simples capela), e que o templo sobrevivente é o continuador do antigo e é o resultado de sucessivas ampliações ao longo dos tempos, especialmente no século XVIII ou XIX.

O cemitério rupestre é hoje composto por cinco sepulturas de adulto integralmente escavadas no afloramento granítico-xistoso de cor rosada (mas no século XIX havia bastantes mais), distando as mais remotas entre si em $90 \mathrm{~m}$, pelo que é a necrópole mais dispersa de todas. São moimentos violados: não se encontram selados, nem há vestígios de tampa, que deverá ter sido formada por uma ou mais lajes lisas sobrepostas, sem encaixe, e numa (n. ${ }^{\circ}$ 5) seguramente por monólito. As cabeceiras são geralmente em arco peraltado, jazendo a cabeceira e o leito no mesmo plano; os ombros encontram-se individualizados, com a curva dos ombros bem destacada, mas não acontece isso com a n. ${ }^{\circ} 1$, que é bastante ovalada; os pés não se acham destacados e encontram-se no mesmo plano que o leito; aos pés não há em nenhum vestígio de orifício para escoamento de líquidos. Três delas (n. ${ }^{\text {os }} 3,4$ e 5) atingem uma axialidade bastante perfeita; as mesmas três acham-se em plano horizontal, tal como os rochedos rasos em que foram abertas.

Acham-se agrupadas em dois núcleos. Um primeiro conjunto, mais perto da capela (cerca de $25 \mathrm{~m}$ a O), é formado por duas sepulturas antropomórficas em afloramento granítico de 1,50 $\mathrm{m}$ de altura e de orientação canónica, a primeira das quais, com os contornos dos ombros ligeiramente torneados, se acha íntegra e a segunda bastante destruída, por causa da extração de pedra e assentamento de um alpendre. Possuem rebordo de tipo horizontal; como o afloramento onde se localizam é inclinado, também os dois moimentos se encontram com um grau de inclinação de $8^{\circ}$ no sentido cabeceira-pés. A n. ${ }^{\circ} 1$ é bastante profunda, é justamente a sepultura mais profunda de todas as necrópoles de Montalegre.

Há, todavia, um segundo núcleo de três moimentos, mais distante $(110 \mathrm{~m}$ a NO da capela), composto por três sepulturas antropomórficas (n. ${ }^{\circ s} 3,4$, e 5) em afloramento raso xistoso de cor rosada. Encontram-se bem preservadas e não thes falta elegância. Numa delas, individual, a mais distante de todas e a mais elaborada (n. ${ }^{\circ}$ ), possui rebordo uniforme e alteado; fora do rebordo, a rocha foi desbravada a alisada para que a tampa monolítica assentasse bem e a envolvesse completamente;

\footnotetext{
${ }^{46}$ BORRALHEIRO, 2005: 203, 211, 233.
} 
aparenta ter sido feito para não ser coberta de terra. Como habitual, neste tipo de monumento com tampa monolítica não há orifício para escoamento de líquidos; é o segundo caso em que isso acontece, depois do caso da sepultura n. ${ }^{\circ} 2$ da necrópole de Santo Amaro, Donões. As outras duas (n. 3 e 4) aparentam ser de casal e surgem perto, num outro belo afloramento raso. Podendo ser talhadas paralelas e com a mesma orientação a oriente (como, p. ex., no aparente «jazigo familiar» de Portela do Antigo, Penedones), não o foram propositadamente. Na verdade, o artífice quis tirar belo e cordial efeito de as cabeças estarem entre si bem mais próximas do que os pés $(0,40 \mathrm{~m}$ à cabeceira e $1,30 \mathrm{~m}$ aos pés). Dessa forma, o que se ganhou em desalinhamento a oriente ganhou-se em afeição - é essa a nossa convicção — razão por que também achamos que são de um casal.

Eis alguns dados metrológicos e tipológicos das cinco sepulturas:

Tabela 10. Dados metrológicos e tipológicos da necrópole de Sr. a de Galegos, Cortiço-Zebral

\begin{tabular}{|c|c|c|c|c|c|c|c|c|}
\hline N. ${ }^{\circ}$ & Tipologia & $\begin{array}{l}\text { Tipologia } \\
\text { cabeceira }\end{array}$ & $\begin{array}{l}\text { Comp. } \\
\text { total }\end{array}$ & $\begin{array}{l}\text { Largura } \\
\text { ombros }\end{array}$ & $\begin{array}{c}\text { Largura a } \\
\text { meio do } \\
\text { corpo }\end{array}$ & $\begin{array}{c}\text { Cabeceira } \\
\text { (larg. } x \\
\text { comp.) }\end{array}$ & $\begin{array}{l}\text { Profun- } \\
\text { didade } \\
\text { média }\end{array}$ & $\begin{array}{l}\text { Orien- } \\
\text { tação }^{47}\end{array}$ \\
\hline $\begin{array}{c}1 \\
\text { bom }\end{array}$ & Antrop. & Peraltada & $1,83 \mathrm{~m}$ & $0,40 \mathrm{~m}$ & $0,40 \mathrm{~m}$ & $0,25 \times 0,30 \mathrm{~m}$ & $0,42 \mathrm{~m}$ & SE $133^{\circ}$ \\
\hline $\begin{array}{c}2 \\
\text { Muito dest. ída }\end{array}$ & Antrop. & $\begin{array}{c}\text { Volta } \\
\text { perfeita }\end{array}$ & --- & $0,39 \mathrm{~m}$ & $0,36 \mathrm{~m}$ & $0,27 \times 0,25 \mathrm{~m}$ & $0,30 \mathrm{~m}$ & SE $123^{\circ}$ \\
\hline $\begin{array}{c}3 \\
\text { Bom }\end{array}$ & Antrop. & Peraltada & $1,60 \mathrm{~m}$ & $0,35 \mathrm{~m}$ & $0,33 \mathrm{~m}$ & $0,24 \times 0,33 \mathrm{~m}$ & $0,30 \mathrm{~m}$ & SE $119^{\circ}$ \\
\hline $\begin{array}{c}4 \\
\text { Bom }\end{array}$ & Antrop. & Peraltada & $1,60 \mathrm{~m}$ & $0,38 \mathrm{~m}$ & $0,36 \mathrm{~m}$ & $0,28 \times 0,35 \mathrm{~m}$ & $0,30 \mathrm{~m}$ & $\mathrm{E} 82^{\circ}$ \\
\hline $\begin{array}{c}5 \\
\text { Perfeita }\end{array}$ & Antrop. & Peraltada & $1,70 \mathrm{~m}$ & $0,38 \mathrm{~m}$ & $0,34 \mathrm{~m}$ & $0,22 \times 0,26 \mathrm{~m}$ & $0,28 \mathrm{~m}$ & SE $153^{\circ}$ \\
\hline
\end{tabular}

Fonte: Elaboração própria

No entanto, em 1914, quando Fernando Barreiros ${ }^{48}$ visitou o local, a n. ${ }^{\circ} 2$ ainda se achava íntegra e é desta forma que a apresenta nos seus dados metrológicos:

Tabela 11. Dados metrológicos antigos da sepultura n. 2 da necrópole de Sr. a de Galegos

\begin{tabular}{c|c|c|c|c|c|c}
\hline N.॰ & Comp. total & $\begin{array}{c}\text { Comp. } \\
\text { ombros-pés }\end{array}$ & $\begin{array}{c}\text { Larg. dos } \\
\text { ombros }\end{array}$ & $\begin{array}{c}\text { Diâm. da } \\
\text { cabeça }\end{array}$ & Prof. média & Larg. dos pés \\
\hline 2 & $1,80 \mathrm{~m}$ & $1,64 \mathrm{~m}$ & $0,38 \mathrm{~m}$ & $0,27 \mathrm{~m}$ & $0,21 \mathrm{~m}$ & $0,18 \mathrm{~m}$ \\
\hline
\end{tabular}

Fonte: Barreiros, 1920: 71

Depois assevera aquilo de que já suspeitávamos, nesta e noutros cemitérios rupestres: a destruição de muitas das sepulturas, habitualmente pela extração de pedra ou

\footnotetext{
${ }^{47}$ Neste cemitério rupestre, há uma oscilação de $71^{\circ}$ entre os moimentos (entre E $82^{\circ}-\mathrm{SE} 153^{\circ}$ ).

${ }^{48}$ BARREIROS, 1920: 71.
} 


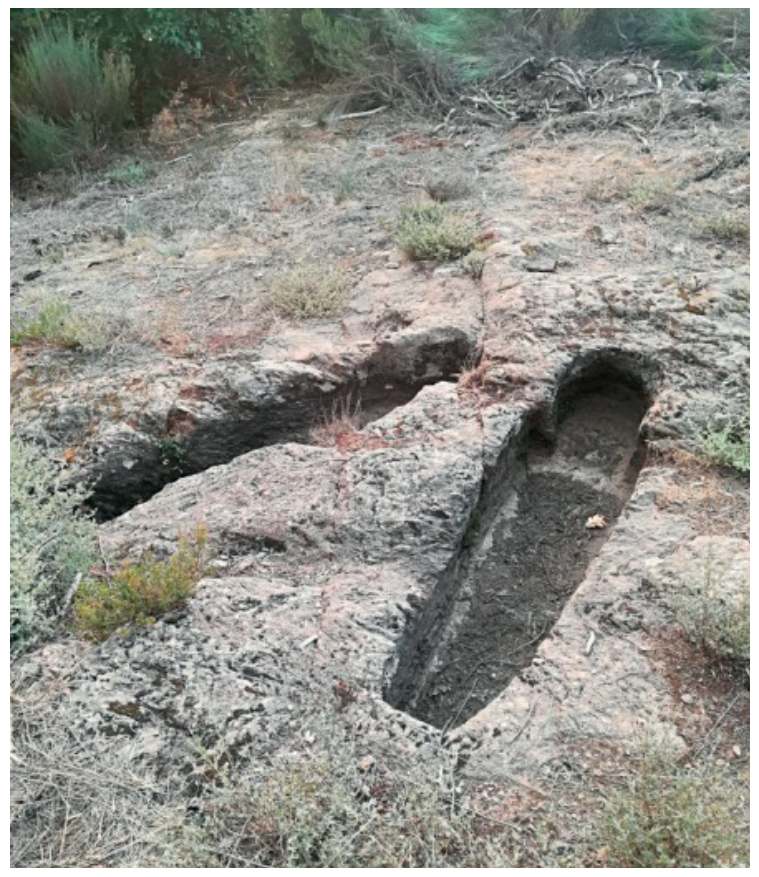

Fig. 9.

Sepulturas que aparentam ser de casal. O artífice quis tirar belo e cordial efeito de as cabeças estarem entre si bem mais próximas do que os pés. Dessa forma, o que se perdeu em desalinhamento a oriente ganhou-se em afeição Fonte: Arquivo pessoal do autor

para assentamento de construções: «informaram-nos que houve ali mais sepulturas, mas que tinham sido destruídas pelos pedreiros» ${ }^{49}$. Barreiros está a referir-se aos pedreiros que, poucos anos antes da sua visita, construíram as duas habitações que servem de apoio à capela, especialmente a casa-alpendre para acolher os peregrinos, o que implicou a destruição de todo o afloramento rochoso a sul da atual necrópole e a consequente destruição dos moimentos aí existentes.

Por fim, Barreiros ${ }^{50}$ localiza a cerca de 100 metros a sul da capela uma outra sepultura, retangular e de criança, que, por se situar mais longe, tinha escapado à voracidade dos construtores do século XIX. No entanto, não escapou à cegueira das gentes do século XX, que aplanaram aquele lugar e aí construíram um cruzeiro. Não se conserva atualmente e possuía a singularidade de ter duas goteiras do lado dos pés. Apresenta dela os seguintes dados metrológicos:

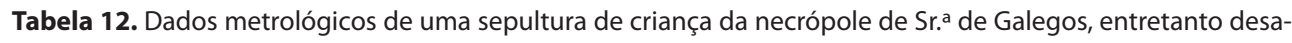
parecida

\begin{tabular}{c|c|c|c|c}
\hline Comp. total & Comp. ombros- pés & Larg. dos pés & Prof. média & Larg. dos ombros \\
\hline $0,52 \mathrm{~m}$ & $0,38 \mathrm{~m}$ & $0,15 \mathrm{~m}$ & $0,18 \mathrm{~m}^{51}$ & $0,24 \mathrm{~m}$ \\
\hline
\end{tabular}

Fonte: Barreiros 1920: 71

\footnotetext{
${ }^{49}$ BARREIROS, 1920: 71.

${ }^{50}$ BARREIROS, 1920: 71.

${ }^{51}$ Fundo do lado da cabeça, 0,21; fundo do lado dos pés, 0,15.
} 


\section{NECRÓPOLE MEDIEVAL DE ANTIGO DE SARRAQUINHOS}

É um cemitério rupestre de lugar, que se situa no centro da aldeia de Antigo de Sarraquinhos (não confundir com a aldeia homónima de Sarraquinhos), a $923 \mathrm{~m}$ de altitude, em lugar com a georreferenciação: $41.777649^{\circ} \mathrm{N}-7.658376^{\circ} \mathrm{W}$. A igreja da aldeia, de orientação canónica a oriente, fica muito perto $(75 \mathrm{~m})$. Em termos de implantação geográfica, a necrópole situa-se no meio da aldeia e próximo de uma veiga com aptidão agropecuária; nas redondezas há monte a perder de vista. Por conseguinte, seria rural a comunidade que ali foi sepultada.

O antropónimo Sarraquinhos (tanto válido para o topónimo Sarraquinhos como Antigo de Sarraquinhos), que parece provir etimologicamente de Sarracinus, está bem documentado nos diplomas dos séculos IX-XI, sob a forma Sarracino, Sarrazino; e no feminino Sarracina, Sarrazina, além de inúmeras variantes, como $^{52}$ : Saracino, Sar $(r)$ azino, Sarrazim, Sarrazinho e Sarracenus (variante culta)... Informa J. P. Machado ${ }^{53}$ que "cronologicamente o seu uso estende-se entre 875-1059, depois torna-se raro». Como em muitos outros nomes de aldeias, é possível que este antropónimo seja o (re)povoador do lugar, pós-Reconquista, no século IX ou X, convicção que coincide com a cronologia onomástica apresentada por J. P. Machado. $\mathrm{O}$ adjetivo antigo (que já encontramos em Portela do Antigo) é uma alusão ao espaço arqueológico composto de antigas habitações e necrópole antes de o lugar ser reocupado num tempo posterior.

Há nas redondezas vestígios de ocupação diacrónica extensa: sobretudo castreja e medieval. De facto, há nas imediações o castro de Antigo de Sarraquinhos ou castro de Fernão Mouro, o qual é fronteiro ao castro de Pedrário (vd. Necrópole de Lamego / Pipa $)^{54}$.

Uma variante secundária do Itinerário XVII, na sua ligação a Aquae Flaviae, passava perto do povoado, pelo que aquela comunidade dispunha de bons acessos; conserva-se na periferia da aldeia um marco miliário anepígrafo.

O lugar surge no Julgado de Barroso das Inquirições de D. Afonso III de 1258, integrava a colação de Santa Cristina de Cervos, possuía quatro casais e o rei tinha aí o seu reguengo: «Item, dixit de Cerraquinos quod est tercia pars Domini Regis et sunt ibi iiij.or casalia, de quibus dant annuatim singulos modios et singulos cabritos vel singulos solidos leoneses, et de alia tercia dant Domino Regi annuatim octavam partem tocius fructus et alia tercia est herdatorum $»^{55}$.

O cemitério rupestre é formado hoje por uma só sepultura mutilada, integralmente escavada no afloramento granítico rente ao chão, quase na borda do caminho

\footnotetext{
52 MACHADO, 2003: s.v. «Sarracino».

${ }^{53}$ MACHADO, 2003: s.v. «Sarracino».

54 «Diz a lenda que o governador do primeiro, chamado Fernão, e o do segundo chamado Crasto, só tinham uma marra, e quando algum deles precisava dela pedia ao outro para lha atirar» (BARREIROS, 1920: 69). A lenda pretende indicar tanto quão perto os dois castros se encontravam, como quanto o ferro era raro.

${ }^{55}$ BAPTISTA, 2011: 89.
} 
central da aldeia (Rua Direita, circa n. ${ }^{\circ}$ 30) e sob a parede de uma casa de Setecentos ou de Oitocentos. É um moimento violado: não se encontra selado, nem há vestígios de tampa, que deverá ter sido formada por uma ou mais lajes lisas sobrepostas ou por monólito, e encontra-se em bom estado de conservação na parte superior, já que de meio para baixo se acha entulhada. Sabe-se que não é moimento isolado por nas imediações e no mesmo afloramento haver um número indeterminado deles soterrados sob a mesma habitação, que é de difícil acesso por o seu dono me ter recusado uma visita meramente para efeitos de catalogação. A cabeceira é em arco ultrapassado, jazendo cabeceira e leito no mesmo plano. Os ombros encontram-se individualizados e bem delineados na sua curva; os pés encontravam-se possivelmente no mesmo plano que o leito; talvez não houvesse vestígios de orifício para escoamento de líquidos. Não atinge a axialidade perfeita e, em parte da sepultura, a base é mais larga do que a superfície, lembrando a íntegra de Santo Adrião. Tal como o rochedo raso em que se encontra, decai para os pés em $4^{\circ}$. O rebordo é de tipo horizontal. Curiosamente (e não deixa de ser uma singularidade) está virada a norte $\left(18^{\circ}\right)$, sendo a única sepultura de todos os cemitérios que não segue as normas canónicas de orientação.

Eis alguns dados metrológicos e tipológicos desta sepultura agora isolada:

Tabela 13. Dados metrológicos e tipológicos da sepultura isolada da necrópole de Antigo de Sarraquinhos

\begin{tabular}{c|c|c|c|c|c|c|c|c}
\hline N.o & Tipologia & $\begin{array}{c}\text { Tipologia } \\
\text { cabeceira }\end{array}$ & $\begin{array}{c}\text { Comp. } \\
\text { total }\end{array}$ & $\begin{array}{c}\text { Largura } \\
\text { ombros }\end{array}$ & $\begin{array}{c}\text { Largura a } \\
\text { meio do } \\
\text { corpo }\end{array}$ & $\begin{array}{c}\text { Cabeceira } \\
\text { (larg. } \mathbf{x} \\
\text { comp.) }\end{array}$ & $\begin{array}{c}\text { Profun- } \\
\text { didade } \\
\text { média }\end{array}$ & $\begin{array}{c}\text { Orien- } \\
\text { tação }\end{array}$ \\
\hline 1 & Antrop. & Ultrapassada & $\begin{array}{c}- \\
\text { adulto }\end{array}$ & $0,43 \mathrm{~m}$ & $0,47 \mathrm{~m}$ & $0,28 \times 0,22 \mathrm{~m}$ & $0,30 \mathrm{~m}$ & $\begin{array}{c}\mathrm{N} 18^{\circ} \\
\text { (orient.ção } \\
\text { insólita) }\end{array}$ \\
\hline
\end{tabular}

Fonte: Elaboração própria

\section{NECRÓPOLE MEDIEVAL DE LAMEGO / PIPA}

No aro da aldeia de Pedrário, a oeste, fica o microtopónimo Lamego, em zona de férteis lameiros com aptidão para a agropecuária. Na sua parte norte, não muito longe do crasto $($ c. $600 \mathrm{~m})$ e da atual aldeia $(c .900 \mathrm{~m})$, precisamente onde termina a zona fértil e começa a zona pedregosa da serra, situa-se o microtopónimo Pipa. Pois é aí, entre uma mata de carvalhos e a $960 \mathrm{~m}$ de altitude, que se localiza o cemitério rupestre de Lamego ou Pipa, com a georreferenciação: $41.811110^{\circ} \mathrm{N}-7.652214^{\circ} \mathrm{W}$. Como em todos os cemitérios rupestres de Montalegre, seria rural a comunidade que ali foi sepultada.

Se o topónimo da aldeia, Pedrário, é relativo à abundância de pedra, já o nome Lamego (do lat. lamaecu-) refere-se a um tipo de solo, geralmente em lugar plano, abundante em húmus e água; os nomes lameiro(a) e lamas são da mesma família. O nome Pipa, porém, de origem latina (pippa, ae significa «pequena flauta»), onde se localiza o cemitério rupestre, pode muito bem ser uma referência às concavidades 
no afloramento raso em granito em forma de tonel retangular. Há nas redondezas vestígios de ocupação diacrónica extensa: sobretudo castreja e medieval. Fernando Barreiros $^{56}$, que em 1914 visitou o local, refere como vestígios arqueológicos antigos, para lá do castro de Pedrário (600 m a norte), mós $^{57}$, telhas e tijolos de barro vermelho.

Como microtopónimos circundantes, contam-se (além de Lamego e de Pipa): Gralheira, Baixa João Dias e Crasto. Vale a pena atender neste último. Trata-se do famoso castro de Pedrário, possivelmente de abandono tardio, dada a sua imponência e boa conservação, que em 1990 foi classificado como Imóvel de Interesse Público. É difícil, porém, de estabelecer a ligação que a necrópole poderá ter tido com este castro e com a atual aldeia de Pedrário.

Este cemitério rupestre formava com o de Sr. ${ }^{a}$ de Galegos e o de Antigo de Sarraquinhos um alinhamento de três necrópoles, que correspondiam a outras tantas pobras antigas servidas pela mesma via que ia dar a Chaves, o Itinerário XVII, pelo que dispunha de bons acessos. De facto, não há dúvida de que se trata de uma necrópole de lugar extinto, devendo o povoado localizar-se nas imediações: entre a veiga e a serra, abrigado dos ventos norte e noroeste e em lugar virado a sul e com boa aptidão agropecuária. Sabe-se, efetivamente, que o local era povoado em 1258 por cerca de oito casais, integrando a colação de Santa Cristina de Cervos, como informa o Julgado de Barroso das Inquirições de D. Afonso III:

Item de Lamego est mediales Domini Regis et sunt ibi iiij. ${ }^{\text {or }}$ casalia, de quibus dant Domino Regi annuatim singulos modios et singulos cabritos vel singulos solidos et alia medietas est herdatorum, exceptis duabus leiris que jacent in portu de Antas, de quibus dant octavam partem Domino Regi ${ }^{58}$.

O cemitério rupestre atual é composto apenas por três moimentos antropomórficos de adulto, abertos no afloramento raso de granito, mas é possível que no passado, por ser necrópole de um lugar extinto, existissem mais. Duas encontram-se bastante próximas $(2,5 \mathrm{~m})$ e uma terceira afastada 15 metros para oeste. Uma encontra-se em bom estado de conservação ( $n .^{\circ} 2$ ) e duas em razoável estado; em razoável pelo facto de as raízes dos carvalhos contíguos terem destruído a cabeceira da $n .^{\circ} 1$ (que já estava danificada em 1914, aquando da visita de F. Barreiros) ${ }^{59}$ e por o centro da n. 3 medrar uma árvore de pequeno porte. Possuem orientação canónica a oriente, mas a n. 3 acha-se orientada demasiado a sul.

\footnotetext{
${ }^{56}$ BARREIROS, 1920: 67-68.

${ }^{57}$ Mola manuária, granitica, vazada pelo orificio central e cilindrico; achatada, de media espessura, o monticulo que circunda o orificio é descaido para dentro, e tem pequeno relevo (BARREIROS, 1920: 68).

${ }^{58}$ BAPTISTA, 2011: 89.

${ }^{59}$ BARREIROS, 1920: 67.
} 
São sepulturas antropomórficas de adulto e parecem ter sido abertas com cuidado e perfeição no afloramento raso de granito. Como os túmulos de todas as necrópoles, são moimentos violados: não se encontram selados, nem há vestígios de tampa, que deverá ter sido formada por uma ou mais lousas sobrepostas com encaixe ou por tampas monolíticas. A cabeceira é geralmente sub-retangular e jaz no mesmo plano que o leito e os pés. Os ombros encontram-se individualizados e bem delineados, com a curva bem destacada (exceto na n. ${ }^{\circ} 1$ por ter sido danificada por raízes de carvalho); só na n. ${ }^{\circ} 1$, a mais imperfeita, se acha orifício (aliás pequeno) para escoamento de líquidos, no seu lado direito e aos pés, talvez por ter como tampa lousas lisas sobrepostas com encaixe. Acham-se em plano horizontal, tal como o rochedo em que foram abertas, mas as n. ${ }^{\text {s }} 1$ e 2 decaem ligeiramente para os pés. O rebordo é de tipo horizontal e atinge uma perfeição bastante grande nas n. ${ }^{\circ} 2$ e 3 , talvez por serem cobertas com tampa monolítica.

Apesar de ter sido cemitério de lugar, ainda próspero em 1258, não há capela, nem vestígios dela nas redondezas.

Eis alguns dados metrológicos e tipológicos:

Tabela 14. Dados metrológicos e tipológicos da necrópole de Lamego / Pipa, lugar de Pedrário

\begin{tabular}{|c|c|c|c|c|c|c|c|c|}
\hline N.o & Tipologia & $\begin{array}{l}\text { Tipologia } \\
\text { cabeceira }\end{array}$ & $\begin{array}{l}\text { Comp. } \\
\text { total }\end{array}$ & $\begin{array}{l}\text { Largura } \\
\text { ombros }\end{array}$ & $\begin{array}{c}\text { Largura a } \\
\text { meio do } \\
\text { corpo }\end{array}$ & $\begin{array}{c}\text { Cabeceira } \\
\text { (larg. } x \\
\text { comp.) }\end{array}$ & $\begin{array}{l}\text { Profun- } \\
\text { didade } \\
\text { média }\end{array}$ & $\begin{array}{l}\text { Orien- } \\
\text { tação }^{60}\end{array}$ \\
\hline $\begin{array}{c}1 \\
\text { razoável }\end{array}$ & Antrop. & Indef. & $1,77 \mathrm{~m}$ & $0,42 \mathrm{~m}$ & $0,41 \mathrm{~m}$ & Indef. & $0,34 \mathrm{~m}$ & SE $126^{\circ}$ \\
\hline $\begin{array}{c}2 \\
\text { bom }\end{array}$ & Antrop. & Sub-retang. ${ }^{\text {ar }}$ & $1,66 \mathrm{~m}$ & $0,50 \mathrm{~m}$ & $0,44 \mathrm{~m}$ & $\begin{array}{c}0,24 \times 0,22 \\
\mathrm{~m}\end{array}$ & $0,30 \mathrm{~m}$ & SE $128^{\circ}$ \\
\hline $\begin{array}{c}3 \\
\text { razoável }\end{array}$ & Antrop. & Sub-retang. ${ }^{\text {ar }}$ & $1,84 \mathrm{~m}$ & $0,47 \mathrm{~m}$ & $0,43 \mathrm{~m}$ & $\begin{array}{c}0,29 \times 0,23 \\
\mathrm{~m}\end{array}$ & $0,40 \mathrm{~m}$ & S $175^{\circ}$ \\
\hline
\end{tabular}

Fonte: Elaboração própria

Por último, vale a pena referir um dado que, segundo Barreiros, parece constituir uma singularidade entre todas as necrópoles: o revestimento a tijolo da $n .^{\circ} 3$, assim crê este autor: "Na terra que lhe foi extraída, a fim de poder ser medida, apareceu um fragmento de tijolo vermelho, chato, e que naturalmente denota ter sido esta sepultura revestida de tejolo». ${ }^{61}$ No entanto, o aparecimento de um só tijolo não prova que esta sepultura fosse revestida a tijolos; parece mais provável que o referido objeto se destinasse, como registam outros investigadores, a manter a verticalidade da cabeça olhando o céu, coisa que noutros túmulos é desempenhado por «pequenas lajes laterais na parte interna da cabeça para imobilizar o crânio» ${ }^{62}$.

\footnotetext{
${ }^{60}$ Neste cemitério rupestre, há uma oscilação de $49^{\circ}$ entre os moimentos (entre SE $126^{\circ}-\mathrm{S} 175^{\circ}$ ).

${ }^{61}$ BARREIROS, 1920: 68.

${ }^{62}$ BARROCA, 2010-2011: 138.
} 


\section{NECRÓPOLE MEDIEVAL DE CRISTELO (OU OUTEIRAL)}

É um cemitério rupestre de lugar extinto em 1975, que se situa a NO da aldeia de Seara, freguesia de Salto, no microtopónimo Cristelo (ou Outeiral), a $873 \mathrm{~m}$ de altitude e com a georreferenciação: $41.612125^{\circ} \mathrm{N}-7.883770^{\circ} \mathrm{W}$. Em termos de implantação geográfica, a necrópole situa-se a $890 \mathrm{~m}$, em plena serra, mas junto a uma pequena veiga algo fértil pelas terras e lameiros, que ainda hoje são cultivados e pastoreados, razão por que o cemitério deve estar ligado a uma situação de (re) povoamento e de exploração agropecuária do local. Por conseguinte, seria rural a comunidade que ali foi sepultada. Nas redondezas há monte a perder de vista; e de acordo com as Memórias Paroquiais, passava por aí uma «estrada» antiga ${ }^{63}$.

Atendendo ao nome, o lugar poderá ter sido no passado um pequeno castro. De facto, conjetura J. P. Machado ${ }^{64}$ que o topónimo Cristelo tira o seu nome do diminutivo de crasto, significando "pequena fortaleza», e é o mesmo que crastelo, crestelo ou cristelos. Não é de excluir, em termos filológicos, que a palavra crastelo ou crestelo tenha sido contaminada pela palavra «crista», que tão bem representa a orografia do terreno onde foi implantada a pequena necrópole, a norte do povoado. $\mathrm{O}$ topónimo também é conhecido pelo nome de Oiteiral ou Outeiral. Dado o muito bom estado de conservação do povoado e da necrópole rupestre, é possível indagar que as zonas de inumação e de habitação distavam entre si em 115 metros. Esta situação seria comum aos restantes habitats ou lugares: as duas zonas distariam entre si entre 80 a 200 m e o cemitério rupestre não seria murado.

O pequeno povoado foi morada desde tempos antigos de algumas poucas famílias, que se dedicavam à exploração agropecuária do local. Surge, por isso, no Julgado de Barroso das Inquirições de D. Afonso III de 1258, colação de Salto, com o nome de «Villa de Crastelo» e é propriedade de dois moradores: «et villa de Crastelo que est Fernandi Gomecii et Egas Ramiriz» ${ }^{65}$; nas Memórias Paroquiais de 1758, «o sitio Oiteiral (Cristelo) hé destrito do lugar da Seara desta freguezia e serve de seus curraes de gados» ${ }^{66}$. Foi definitivamente abandonado em 1975 com a saída dos caseiros das propriedades. É por essa razão que ainda hoje se conservam erguidas as paredes de seis casas (duas habitações, mais quatro cortes de gado), mais a rua principal e uma transversal. Durante o período da II Guerra Mundial, o lugar viu a sua parca população crescer muito por ter sido abrigo temporário de exploradores de volfrâmio.

Como microtopónimos relevantes, destacam-se: Cividade, Campo Grande, Outeiro da Santa e Archeira. Pelo primeiro, a SO, é possível conjeturar que no passado havia nas cercanias outro povoado, entretanto extinto, que também explorava a

\footnotetext{
${ }^{63}$ BORRALHEIRO, 2005: 345.

${ }^{64}$ MACHADO, 2003: s.v. «Cristelo».

${ }^{65}$ BAPTISTA, 2011: 28.

${ }^{66}$ BORRALHEIRO, 2005: 345.
} 
pouca fertilidade do local, mais a grande montanha para os rebanhos; Campo Grande tira o seu nome das terras de cultivo; Archeira poderá tirar o seu nome de «arco» e indicar o lugar onde, pela abundância de material lenhoso, se extraíam bons arcos; a este $(347 \mathrm{~m})$, num monte denominado Outeiro da Santa, onde atualmente se localiza a casa florestal, existiu no passado (mas já não surge nas Memórias Paroquiais de $1758^{67}$ ) uma capela cuja padroeira foi Santa Sofia. Por conseguinte, o lugar não tem nem nunca teve capela, dada a pobreza e pequenez, mas terá havido perto uma antiga capela de romaria, comum a outras pobras das redondezas.

Uma pequena e recente placa metálica, cravada numa rocha do afloramento, por Augusto Fernandes, e que não passa despercebida a quem visita a necrópole, contém a seguinte informação:

\section{CRISTELO ANO 932 TERRA DO DEGRADADO (sic) GIL P. ALCASSUS DAQUI NASCEU SALTO AGOSTO 1989 POR AUGUSTO FERNANDES}

Esta pequena informação contém dois erros históricos. Primeiro, porque a vila de Salto é mais antiga, pois ela (ou um pagus muito próximo, em razão de o nome Saltus surgir com preposição: Ad Saltum) já aparece no famoso Parochiale Suevum (século VI). Em segundo lugar, porque nos meados do século X os nomes de homem não englobam tria nomina, como é o caso de GIL PEREIRA ALCASSUS, com praenomen, nomen e cognomen, mas sim com praenomen e patronímico em genitivo.

É um cemitério rupestre composto por quatro sepulturas integralmente escavadas no afloramento em xisto pouco elevado. A beleza, antiguidade e erosão destas sepulturas têm grande paralelo com o próprio espaço em que se encontram - também ele inóspito, agreste e batido pelos elementos, que deixaram as suas marcas na frágil rocha das sepulturas. É provável que a necrópole fosse composta por mais moimentos, mas que foram destruídos por o local ter servido para a extração de pedra para paredes e muros, e disso há claros vestígios. Distam as mais remotas entre si em $50 \mathrm{~m}$.

Três acham-se íntegras (n. ${ }^{\text {os }} 1,2$ e 3 ) e uma mutilada (n. ${ }^{\circ}$ ), não sendo possível indagar acerca do seu comprimento, mas seria de adulto. De entre as íntegras, duas são de adulto (n. ${ }^{\text {os }} 1$ e 3 ) e a terceira é de criança (n. ${ }^{\circ}$ ). De acordo com as normas canónicas, estão todas orientadas a este; a n. ${ }^{\circ} 1$ é ovalada e as restantes retangulares; nenhuma possui cavidade encefálica, mas nesta última há vestígios. A de adulto (n. ${ }^{\circ} 1$ ) acha-se em plano horizontal, tal como o rochedo em que foi aberta, mas as restantes (n. ${ }^{\text {os }} 2$, 3 e 4 ) jazem em plano bastante inclinado (sentido cabeceira-pés), circa $7^{\circ}$, por imposição da morfologia da rocha. Possuem geralmente rebordo total

\footnotetext{
${ }^{67}$ BORRALHEIRO, 2005: 205.
} 
ou parcial e de tipo horizontal ou alteado; em todas o lugar da cabeça, corpo e pés acha-se no mesmo plano. Como todos os túmulos de todas as necrópoles, são moimentos violados: não se encontram selados, nem há vestígios de tampa, que deverá ter sido formada por uma ou mais lousas sobrepostas sem encaixe, que de forma alguma estariam cobertas por terra.

O moimento n. ${ }^{\circ} 1$ é o único que possui orifício circular, junto aos pés, para escoamento de líquidos. No entanto, acerca do orifício sangrador, há duas curiosidades a reter que constituem duas singularidades: na de criança ( . $\left.^{\circ} 2\right)$ foi tentada a sua abertura, mas não foi completada, talvez por o artífice reconhecer que, dado o grau de inclinação (cabeceira-pés), a água escoar-se-ia facilmente pelo rebordo inferior; na n. ${ }^{\circ}$, de adulto, o orifício não foi tentado, achamos que pela mesma razão: o acentuado grau de inclinação, mas, ainda assim, o artífice dentou a superfície junto aos pés, para facilitar o escoamento da água.

Eis alguns dados metrológicos e tipológicos:

Tabela 15. Dados metrológicos e tipológicos da necrópole de Cristelo / Outeiral, lugar de Seara, Salto

\begin{tabular}{c|c|c|c|c|c|c|c|c}
\hline $\mathbf{N .}$ & Tipologia & $\begin{array}{c}\text { Tipologia } \\
\text { cabeceira }\end{array}$ & $\begin{array}{c}\text { Comp. } \\
\text { total }\end{array}$ & $\begin{array}{c}\text { Largura } \\
\text { ombros }\end{array}$ & $\begin{array}{c}\text { Largura a } \\
\text { meio do } \\
\text { corpo }\end{array}$ & $\begin{array}{c}\text { Cabeceira } \\
\text { (larg. } \mathbf{x} \\
\text { comp.) }\end{array}$ & $\begin{array}{c}\text { Profun- } \\
\text { didade } \\
\text { média }\end{array}$ & $\begin{array}{c}\text { Orien- } \\
\text { tação }\end{array}$ \\
\hline $\begin{array}{c}1 \\
\text { razoável }\end{array}$ & Ovalada & $\begin{array}{c}\text { Vestígios } \\
\text { antrop. }\end{array}$ & $1,90 \mathrm{~m}$ & - & $0,55 \mathrm{~m}$ & $\begin{array}{c}0,25 \mathrm{~m} \\
\text { larg. } .^{\text {ra }}\end{array}$ & $0,32 \mathrm{~m}$ & Este \\
\hline $\begin{array}{c}2 \\
\text { muito bom }\end{array}$ & Retang. & - & $1,00 \mathrm{~m}$ & $0,33 \mathrm{~m}$ & $0,32 \mathrm{~m}$ & - & $0,17 \mathrm{~m}^{68}$ & Este \\
\hline $\begin{array}{c}3 \\
\text { bom }\end{array}$ & Retang. & - & $1,70 \mathrm{~m}$ & $0,33 \mathrm{~m}$ & $0,43 \mathrm{~m}$ & - & $0,30 \mathrm{~m}$ & Este \\
\hline $\begin{array}{c}4 \\
\text { mutil.da } \\
\text { a meio }\end{array}$ & Retang. & - & - & $0,40 \mathrm{~m}$ & $0,45 \mathrm{~m}$ & - & $0,30 \mathrm{~m}$ & Este \\
\hline
\end{tabular}

Fonte: Elaboração própria

Carla Cascais conjetura que estas sepulturas poderão estar relacionadas com o «caminho real», que passava próximo, ou com a referida capela de Santa Sofia, a qual, como já dissemos, já não consta das Memórias Paroquiais de $1758^{69}$. Nós, porém, achamos que, sendo verdade o que fica dito, o que até aos dias de hoje motivou a fixação de exploradores no local terá sido a pequena veiga contígua, com terras e lameiros, que permitia alimentar uma pequenina comunidade; e que a capela, possivelmente de romaria (perto, a oeste, situa-se o microtopónimo Civitas e há restos de habitações), terá sido construída, em comunhão de esforços, pelos povoados circundantes, entre os quais se destacava a «Villa de Crastelo».

\footnotetext{
${ }^{68}$ Profundidade de $0,28 \mathrm{~m}$ na zona da cabeceira e vai baixando gradualmente; média de $0,18 \mathrm{~m}$ de profundidade.

${ }^{69}$ CASCAIS, 2007-2008: 32717.
} 


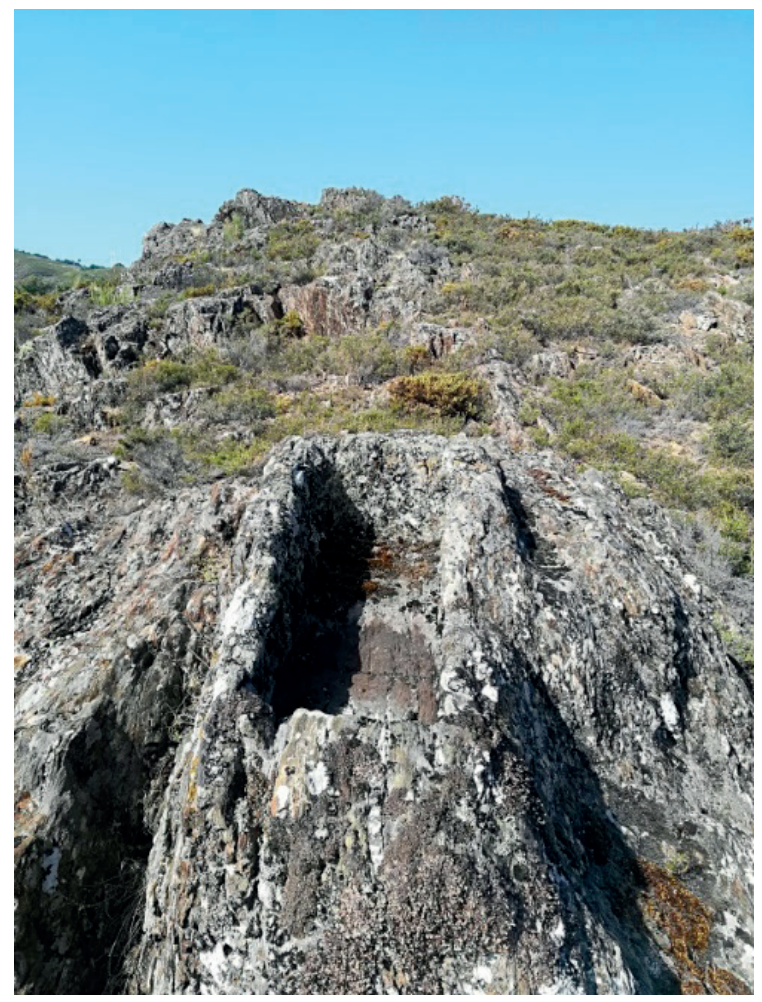

Fig. 10.

Sepultura de criança em afloramento xistoso e pouco elevado. Devido à inclinação da sepultura e do afloramento, o artífice preferiu que o escoamento de líquidos fosse feito à superfície, com ranhura junto aos pés, do que com o típico furo circular na base Fonte: Arquivo pessoal do autor

Como já referimos, se se admitir que, de entre as sepulturas fixas, as ovais, retangulares ou trapezoidais devem pertencer aos séculos VI-VII e que, a partir do século VIII ter-se-á iniciado um movimento no sentido da antropomorfização, então os moimentos desta necrópole, que na sua maioria são retangulares, serão os mais antigos de $\operatorname{todos}^{70}$. No entanto, esta conviç̧ão poderá não ser verdade, uma vez que, em qualquer período histórico, o(s) artífice(s) poderão ter optado pela tipologia retangular simplesmente por este formato ser o mais fácil de trabalhar num afloramento xistoso, que, quando talhado, se esboroa com facilidade.

\section{NECRÓPOLE MEDIEVAL DE AGROVELHO}

O cemitério rupestre de Agrovelho (um povoado localizado a $800 \mathrm{~m}$ a oeste de Santo Adrião e a $1800 \mathrm{~m}$ a norte de Montalegre), com uma sepultura em mau estado de conservação, foi atestado por Fernando Braga Barreiros, em 1914. Mas nada mais acrescentou acerca dela: nem dimensões, nem tipologia, nem a orientação, nem a localização precisa, talvez por estar «um pouco destruída».

\footnotetext{
${ }^{70}$ Não consideramos minimamente possível que este pobre povoado seja mais antigo do que Salto.
} 
Diz a tradição que aí se localizou em tempos remotos, muito antes da fundação de Montalegre, uma "próspera cidade» (civitas) que, dada a proximidade, está na posterior origem da pobra de Montalegre, depois que este burgo cresceu em população e em importância regional à sombra do seu castelo. Que o lugar teve uma ocupação diacrónica extensa - desde a Pré-História até à Idade Média -, atestam-no a descoberta aí de cinco machados planos de bronze, datados da Idade do Bronze ${ }^{71}$.

Etimologicamente o microtopónimo apresenta a composição de agro- (campo de cultivo) + velho (que é sinónimo do já referido antigo em razão da antiguidade de construções por comparação com um povoado mais recente). Barreiros confirma a existência aí de restos arqueológicos:

A uns 1800 metros ao Norte de Montalegre fica um sitio chamado Agrovelho, onde o povo diz ter havido uma grande cidade com aquele nome, e cuja população afligida por uma epidemia se viu obrigada a mudar para o lugar onde atualmente é a vila. Parece verem-se ainda ali restos duma muralha de terra, no alto da qual se nos deparou uma sepultura aberta em rocha, e já um pouco destruída. Nos campos próximos encontram-se fragmentos de telhas ou tijolos ${ }^{72}$.

Apesar de mal localizado, nós visitamos o local referido (circa 41.836253 7.798393), mas não encontrámos a referida sepultura, que em 1914 já se achava em mau estado de conservação.

\section{CONCLUSÃO}

Sobrevivem atualmente no concelho de Montalegre 11 cemitérios medievais com sepulturas escavadas na rocha, num total de 45 moimentos, três dos quais de criança e um incompleto, que são apenas uma das várias formas de inumação utilizadas pelos povos locais. Como muitos moimentos foram destruídos, não cremos que, no passado, tenha havido cemitérios rupestres de uma só sepultura.

Há mais elementos a unir os cemitérios rupestres entre si do que a separá-los. Vistos no seu conjunto, estamos convictos de que, sendo necrópoles de habitat e de lugar, estão ligados à (re)organização do povoamento na região do Alto-Tâmega e Barroso, no período pós-Reconquista, séculos IX-XI, por se localizarem nas zonas mais férteis e aprazíveis do concelho, precisamente as que melhor podiam assegurar a sobrevivência de uma comunidade, quer pela prática da agricultura, quer da criação de gado ou pastorícia.

\footnotetext{
${ }^{71}$ COSTA, 1987: 37; TEIXEIRA, FERNANDES, 1963-1964: 169-173.

${ }^{72}$ BARREIROS, 1920: 60-61.
} 
Todas as necrópoles rurais não surgem isoladas no espaço, mas num contexto de restos arqueológicos antigos e de ocupação diacrónica extensa. Atendendo aos vestígios arqueológicos de superfície - pois são áreas muito pouco intervencionadas -, verificamos que houve uma longa continuidade de povoamento nesses locais, que remonta à Pré-História e que teve continuação, mais ou menos ininterrupta, no período romano, na Reconquista e Baixa Idade Média. Nos meados do século XIII (sabemos isso pelo Julgado de Barroso das Inquirições de D. Afonso III de 1258), já a configuração do concelho de Montalegre era, mutatis mutandis, igual à que hoje mantém.

Quanto à natureza dessas comunidades, seriam povoados maiores ou menores, que podiam ir de uma pobra ou aldeola, com a sua propriedade individual e comunitária (baldio), até casais onde habitavam poucas famílias. Por conseguinte, as necrópoles escavadas na rocha seriam o lugar de inumação dos falecidos e corresponderiam aos usos locais do tempo (século IX-XIII).

Além disso, quase todos os cemitérios rupestres se localizam ao lado das grandes vias que atravessavam a região, nomeadamente o Itinerário XVII, que ligava Bracara Augusta a Asturica (Astorga) por Aquae Flaviae e que, atravessando a planáltica zona de Barroso a meio, bifurcava-se em duas. Por esta razão, essas comunidades não se achavam isoladas, como no tempo da anterior civilização castreja ou em tempos posteriores à Reconquista, mas seriam comunidades rurais dinâmicas e com capacidade de vender os seus produtos dentro ou fora da região.

Quanto à tipologia, há-as de todos os tipos: antropomórficas, em maior número, de antropomorfismo incipiente e não antropomórficas (retangulares, sub-retangulares, ovais e indefinidas). O mais comum é haver dentro de uma estação necrológica a mesma tipologia, o que sugere um artífice comum, uma cronologia próxima ou uma mesma tradição.

Quanto à orientação, estão direcionadas, de acordo com as normas canónicas, para oriente, mas há variações regionais nessa orientação, quer para este (vale do Cávado), quer para E-SE-S (parte oriental do concelho). Nota-se que houve o privilégio da correta orientação, mais do que da concentração, mesmo que isso implicasse a dispersão, no caso de não haver perto rocha apropriada.

Quanto à selagem das sepulturas, seria feita com três tipos de tampa: as mais simples (que também seriam as mais numerosas) possuiriam mais do que uma laje reta que encaixaria ou não sobre a sepultura; outra forma é haver uma tampa monolítica que encaixaria ou não sobre a sepultura; as mais complexas seriam cobertas por um grande monolítico, de forma côncava e trabalhado, que taparia completamente a sepultura de rebordo alteado e impediria a água de entrar. Estas nunca possuem orifício para escoamento de líquidos por não precisarem, o qual parece que seria mais típico dos moimentos com várias lousas sobrepostas. 
Só parte de uma tampa se conserva: côncava, trabalhada, abaulada e anónima, a qual, dada a sua beleza, parece ter sido feita para ser vista e não coberta. É por isso que presumimos que, de forma alguma haveria terra a cobrir os moimentos: quer os cobertos com uma ou mais lajes retas, quer com monólitos, quer os assentes em rochedos rasos, quer em rochedos elevados ou muito elevados.

Nota-se que não houve preocupação de que os túmulos ficassem destacados na paisagem e com propósitos de servirem de balizas ou limites territoriais ou de propriedade. De igual forma, não encontrámos junto aos moimentos nichos destinados à colocação de água benta; tal como não há vestígios de que algum tenha servido em tempos posteriores de lagareta, por a região não ser produtora de vinho nem de azeite. No entanto, sobrevivem no afloramento granítico de Leira dos Padrões cortes na rocha, talvez contemporâneos dos túmulos, que denunciam o lugar de assentamento de algum tipo de estrutura, quiçá muretes.

Entre os 11 cemitérios rupestres visitados há elementos que constituem singularidades por se afastarem da regularidade de todas elas: nalgumas sepulturas ainda é bem visível o encaixe a toda a volta para a tampa côncava e um rego exterior para escoamento da água; noutras, conservam-se junto à cabeceira cortes que denunciam bem o lugar onde a tampa encaixava, quer fosse formada por uma ou mais lousas retas; numa crê-se que estava revestida de tijolos, mas que nós achamos que seria apenas na zona do crânio do defunto, a fim de manter a verticalidade da cabeça olhando o céu; noutra, de criança, é certo que possuía duas goteiras; noutra ainda, de criança, foi tentada a abertura de orifício sangrador, mas não foi completada, talvez por o artífice reconhecer que, dado o grau de inclinação (cabeceira-pés), a água escoar-se-ia facilmente pelo rebordo; noutra, de adulto, o orifício não foi tentado, achamos que pela mesma razão: o acentuado grau de inclinação, mas, ainda assim, o artífice dentou a superfície junto aos pés, para facilitar o escoamento da água. A orientação da sepultura isolada de Antigo de Sarraquinhos, a norte, é insólita e constitui uma singularidade.

\section{BIBLIOGRAFIA}

ALVES, P. Manuel (2006). Parafita. Foral concedido pelo rei de Portugal D. Afonso III (31 de maio 1268) à aldeia de Parafita. Análise histórica. Vila Real: Minerva Transmontana.

BAPTISTA, José Dias (1993). Caminhos medievais de Barroso. «Aquae Flaviae». 9, 106-139.

BAPTISTA, José Dias (2011). Inquirições de D. Afonso III (1258). Relativas aos julgados medievais de Chaves, Barroso, Monforte de Rio Livre, Montenegro e Aguiar da Pena. «Aquae Flaviae». 43, 16-104.

BARREIROS, Fernando B. (1915). Ensaio de inventário dos castros do concelho de Montalegre.

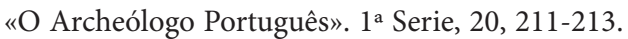

BARREIROS, Fernando B. (1920). Materiais para a arqueologia do concelho de Montalegre. «O Archeólogo Português». $1^{\text {a }}$ Serie, 24, 58-87.

BARROCA, Mário Jorge; MORAIS, António J. Cardoso (1983). Sepulturas medievais na Terra de Aguiar da Pena (Vila Pouca de Aguiar). «Arqueologia». 8, 92-102. 
BARROCA, Mário Jorge (1987). Necrópoles e sepulturas medievais de Entre-Douro-e-Minho (Séculos V $a \mathrm{XV}$ ). Porto: Faculdade de Letras da Universidade do Porto. Dissertação para Provas Públicas de Aptidão Pedagógica e Capacidade Científica.

BARROCA, Mário Jorge (2010-2011). Sepulturas escavadas na rocha de Entre-Douro-e-Minho. «Portvgalia». Nova Série, 31-32, 115-182.

BOISSELLIER, Stéphane, ed. (2012). La construction administrative d'un royaume. Registres de bénéfices ecclésiastiques Portugais. Portugais (XIII-XIV.e siècles). Lisboa: UCP-CEHR.

BORRALHEIRO, Rogério (2005). Montalegre: memória e história. Montalegre: Barrosana, E.M.

CARVALHO, Manuel Homem de Mello (1981). Concelho de Montalegre. Achegas para a sua história. In I Jogos Florais de Montalegre. Montalegre: Câmara Municipal de Montalegre, pp. 83-93.

CASCAIS, Carla Alexandra Afonso de Carvalho (2007-2008). Portal do Arqueólogo. CNS: 32553 (Santo Adrião); 32543 (Quadrela); 32542 (Santo Amaro); 32161 (Leira dos Padrões); 32312 (Monte das Cotas); 32518 (Portela do Antigo); 32980 (Vilar de Perdizes); 32156 (Senhora de Galegos); 32738 (Antigo de Sarraquinhos); 32717 (Cristelo / Outeiral); 3580 (Sepultura do Frade / Campo do Frade). Disponível em <http://arqueologia.patrimoniocultural.pt/>.

COSTA, P. .e João Gonçalves da (1961). A senhora da Peneda de Donões. Origem histórica da Capela e apontamentos para a história religiosa da freguesia. Vila Real: Minerva Transmontana.

COSTA, P. ${ }^{\mathrm{e}}$ João Gonçalves da (1987). Montalegre e Terras de Barroso. Montalegre: Câmara Municipal de Montalegre.

FONTES, António Lourenço (1978). Aras romanas e terras de Barroso desaparecidas. In Milenário de S. Rosendo - 977-1977. Montalegre: Câmara Municipal de Montalegre, pp. 15-24.

LOURENÇO, Sandra (2006). O povoamento alto-medieval entre os rios Dão e Alva. "Trabalhos de Arqueologia». 50.

MACHADO, José Pedro (2003). Dicionário onomástico e etimológico da língua Portuguesa. Lisboa: Livros Horizonte.

SANTOS JÚNIOR, Joaquim Rodrigo dos (1963). O castro de S. Vicente da Chã (Barroso). «Trabalhos de Antropologia e Etnologia». 19: 1, 79-80.

SANTOS JÚNIOR, Joaquim Rodrigo dos; ISIDORO, Agostinho (1963). Escavações no castro de S. Vicente da Chã (Barroso). «Trabalhos de Antropologia e Etnologia». 19: 2, 178-186.

SANTOS JÚNIOR, Joaquim Rodrigo dos; FREIRE, Osvaldo (1964). O castro de S. Vicente da Chã (Barroso). Campanha de escavações de 1964. "Trabalhos de Antropologia e Etnologia». 19: 3-4, 366-371.

TEIXEIRA, Carlos; FERNANDES, Maria S. C. (1963-1964). Machados Planos de Montalegre. «Trabalhos de Antropologia e Etnologia». 19: 2, 169-173.

TEIXEIRA, Ricardo Jorge C. M. Abrantes (1996). De Aquae Flaviae a Chaves. Povoamento e organização do território entre a Antiguidade e a Idade Média. Porto: Faculdade de Letras da Universidade do Porto. Dissertação de Mestrado.

TENTE, Catarina; LOURENÇO, Sandra (1998). Sepulturas medievais escavadas na rocha dos concelhos de Carregal do Sal e Gouveia: estudo comparativo. «Revista Portuguesa de Arqueologia». 1: 2, 191-218. 



\title{
DO SAN CIBRAO AO SAN VÍTOR. A NECRÓPOLE DE BARXACOVA NAS FONTES ORAIS E ESCRITAS
}

\author{
VÍCTOR RODRÍGUEZ MUÑIZ*
}

\begin{abstract}
Resumo: San Vítor de Barxacova (Parada de Sil, Ourense) revelou ser, à vista dos resultados das escavações arqueológicas da última década, uma das maiores necrópoles rupestres do noroeste peninsular. O propósito deste artigo é analisar as informações que os textos e a tradição oral possibilitam para a compreensão da sua história, permitindo-nos saber do conjunto de mosteiros a quais a necrópole se vinculou, a continuidade medieval da igreja, o abandono e nova advocação modernos e, ainda, como evoluiu neste processo histórico a construção do território. Arqueologia, documentação e tradição oral constituem, portanto, três fontes de informação complementares para o conhecimento da necrópole e da sua relevância para as comunidades locais desde a Idade Média até aos nossos dias.
\end{abstract}

Palavras-chave: Necrópole; Território; Documentação; Tradição oral.

Abstract: San Vitor de Barxacova (Parada de Sil, Ourense) appears to be one of the largest cut-stone graveyards all over the NW of the Iberian Peninsula as it is shown by the archaeological researches developed for the last decade. The aim of this paper is to analize the data that written sources and oral traditions provide, in order to understand its history and its relation with the local settlements. It will allow to learn about the set of monasteries the necropolis was related to, the church that went on, its final change of dedication and how its relation with the surroundings evolved. Archaeology, written sources and oral traditions are three complementary ways to get a proper knowledge about the graveyard and its meaning for the local communities from the Middle Ages up to nowadays.

Keywords: Graveyard; Territory; Document; Oral tradition.

Coa publicación en 1914 do artigo Una excursión a la Ribera Sagrada Joaquín Arias Sanjurjo converteuse no primeiro estudoso en volver os seus ollos á necrópole do San Vítor de Barxacova ${ }^{1}$. Mesmo coas imprecisións en que incorre no seu relato - pois identifica o lugar cun mosteiro de orixe visigoda desde o que terá irradiado o fenómeno monástico ás terras que se deron en chamar «Ribeira Sacra» ${ }^{2}-$ o autor dá minuciosa conta do privilexiado emprazamento sobre o río Mao na desembocadura no Sil e describe o conxunto, co promontorio da capela e a serie de tumbas - en número de doce, sumando as adxacentes ao templo e as dez da parte inferior - que tiñan quedado á vista logo da apertura do camiño para a instalación do tendido

\footnotetext{
* Universidade de Vigo (Área de Historia Medieval). Email: victor_muniz@hotmail.es.

${ }^{1}$ ARIAS SANJURJO, 1914: 49-51.

${ }^{2}$ Convén lembrar como este nome, por máis feliz que poida resultar o equívoco á hora de denominar esta comarca caracterizada pola concentración monástica, procede dunha lectura indubidablemente errónea dun documento de 1124

- de por si considerado falso - no que dona Teresa de Portugal incluía a «Rovoyra sacrata» - carballeira sagrada, pois - na doazón ao mosteiro de San Xoán de Montederramo. Deféndeo así, entre outros, RIVAS FERNÁNDEZ, $2004: 61$.
} 
conducente á «Fábrica da Luz», central hidroeléctrica que nese momento entraba en funcionamento.

Trátase do primeiro texto en que se detalla este conxunto relixioso, o cal non obsta para que fose un lugar ben coñecido para a veciñanza dos arredores e, nomeadamente, para os moradores de San Lourenzo, a localidade máis inmediata ao enclave. Proba isto o lugar central que o San Vítor ocupa na tradición oral local, na que se conserva un repertorio moi vivo de lendas que explican a súa historia e relación coa contorna, dando con estas narracións resposta a quen e por que razón se enterraba na necrópole ou o motivo do seu esquecemento como lugar de culto e descanso eterno.

Se na historiografía tradicional sobre a Ribeira Sacra o eremitismo tivo moito peso á hora de interpretar as orixes dos diferentes mosteiros e igrexas que bordean os vales de Miño e Sil, nunca nas lendas e narracións orais dos veciños de San Lourenzo a necrópole aparece vinculada a ermitáns que se puidesen ter afastado do mundo neste lugar. Antes ben, todos os entrevistados a este respecto coinciden en indicar con rotundidade como o San Vítor era o lugar en que se enterraban «os da casa de Vil».

Ivil - na toponimia oficial - garda, en efecto, un estreito vínculo histórico con San Lourenzo. Mostra desta relación é a obriga, da que aínda se conserva memoria, que tiñan os veciños deste último lugar de acudir ás obras da ponte de Conceliñas medieval e sita no límite do que outrora foi o termo de Ivil - sempre que houbese mester de ser reparada ${ }^{3}$. A comunicación entre esta aldea e a necrópole vese dificultada non tanto polo perfil do camiño, aberto a media ladeira sobre o canón do Mao suave pendente que motivou que, coa construción da central hidroeléctrica, boa parte do seu trazado se acondicionase como canle para a antiga traída de augas senón pola distancia que os separaba, superior aos $4 \mathrm{~km}$ e co inconveniente de ter que atravesar diferentes parroquias, nomeadamente as de Pradomao e Forcas, coa conseguinte obriga de satisfacer dereitos de paso polas mesmas. Ante a esixencia dos fregueses de Forcas, a negativa a entregar este pagamento por parte da comitiva fúnebre procedente de Ivil tería motivado outro episodio recollido nas narracións locais: unha discusión dirimida no chamado "rego das Porfías» - de nome máis que elocuente - e que, sen noticias de cal terá sido o destino do defunto, se saldou con que o escano ou padiola en que era transportado o cadáver ficou requisado en Forcas, en cuxa igrexa parroquial, pendurado a un lado do pórtico setentrional, os veciños de maior idade do lugar afirman telo visto tempo atrás.

\footnotetext{
${ }^{3}$ Información referida por Finamor Vázquez Matías. Sirvan estas liñas como sinal de gratitude a el e a todos os veciños de San Lourenzo e, en xeral, de Parada de Sil, polas atencións prodigadas nestes últimos anos a todo o equipo de arqueólogos.
} 
A «lenda do bispo», pola súa parte, narra o porqué do seu declive e definitivo abandono ${ }^{4}$. Segundo esta, o bispo, visiblemente irritado pola devoción que suscitaba o santo e a masiva afluencia de fieis aos oficios celebrados no templo rupestre, tería ordenado aos veciños que, no sucesivo, unicamente acudisen a misa e fosen enterrados na igrexa parroquial de San Lourenzo. Lonxe de ser unha tradición «inocente», casual, esta narración parece agachar — por máis que nunha visión popular dos feitos - as significativas transformacións no tecido eclesiástico que debeu traer consigo a reforma gregoriana que, entre outras cuestións estruturais, marcou o fin ou, cando menos, a lateralización destes templos rupestres en favor das súas respectivas parroquias, ás que se adscribían os fregueses en vida - quer no espiritual, coa administración dos sacramentos, quer no temporal, co pago de tributos como o décimo - e na morte, cando habían de repousar no cemiterio da súa correspondente freguesía.

Á luz destes relatos, o San Vítor teríase constituído nun antigo lugar de culto de grande devoción, co seu cemiterio asociado, vinculado en preferencia - se non de xeito privativo - aos moradores de Ivil, e que, coas grandes reformas relixiosas no tránsito dos séculos XI a XII, tería decaído en favor da igrexa parroquial de San Lourenzo, ficando reducido a unha humilde capela. Un relato sen dúbida atractivo, coherente e verosímil, pero que - adianto - non encontra correspondencia nas fontes escritas, que describen unha configuración territorial máis complexa e un recorrido histórico tortuoso no que a este enclave se refire.

Cómpre advertir a concorrencia de varias dificultades á hora de afondar no coñecemento deste lugar desde unha perspectiva documental: por unha parte, a ausencia de calquera mención expresa á existencia da necrópole e, por outra - tal vez causante da anterior - o feito de tratarse, agás contadas excepcións, de textos dunha cronoloxía claramente máis tardía, pleno e baixomedievais cando non modernos.

As fontes escritas de maior significación para a necrópole e o seu contexto proceden das coleccións documentais dos dous principais mosteiros da súa contorna: Santa Cristina de Ribas de Sil e Santa María de Montederramo.

Se ben non se conservan na fábrica monástica de Santa Cristina elementos anteriores ao século XII - a igrexa, datada en 1199, enmárcase nun estilo tardorrománico, ao igual que o arco de acceso ao claustro, reconstruído este no século XVI cunha evidente influencia renacentista - a súa existencia está testemuñada no X e diversos documentos - de cuestionable autenticidade paleográfica, por máis que o seu contido si teña verosimilitude - permiten retrotraer a súa fundación á centuria anterior ${ }^{5}$. Deste

\footnotetext{
${ }^{4}$ Información recollida por Mercedes Martínez, a quen agradezo a transmisión da lenda.

${ }^{5}$ É o caso dun memorial sen data pero de factura moderna no que se refiren diversas doazóns de igrexas entre os anos 862 e 916. Dubidoso formalmente, o seu contido, porén, está acreditado pois trátase das igrexas sobre as que desde antigo Santa Cristina exerce os seus dereitos, e as referentes ao territorio auriense son aquelas que conformarán o seu couto: Parada, Paradela, Edrada e a propia do mosteiro (RODRÍGUEZ MUÑIZ, 2010: doc. n. ${ }^{\circ}$ 129).
} 
xeito, Santa Cristina e a necrópole de San Vítor terían solapado as súas cronoloxías, cunhas orixes moi próximas no tempo.

Máis significativa é a delimitación do couto dentro do cal o mosteiro de Santa Cristina exerceu os seus dereitos como señor desas terras que era. Privilexio de concesión real, a primeira noticia sobre un espazo acoutado propio do mosteiro data do século XIII - por tanto, posterior ao abandono da necrópole: Afonso X confirma en 1265 o outorgado polo seu pai Fernando III en 1249, cuxo orixinal non se conserva ${ }^{6}$. O interesante desta concesión de couto son os termos en que se realiza: a demarcación do territorio efectuouse "por averiguación de homes bos», e segundo os termos antigos que se fan remontar ao emperador don Afonso, isto é, a Afonso VII.

O espazo que a concesión de couto demarca correspóndese mimeticamente co actual concello de Parada de Sil. Establece como límite oriental «ubi intrat riuulo Mayore in Sile» - a desembocadura do río Mao no Sil - , para remontar despois o primeiro, o que implicitamente supón que a necrópole se encontraba dentro do dominio do mosteiro de Santa Cristina. En teoría, cando menos, pois a práctica indica unha realidade ben diferente. A relación e precisión dos varios puntos que se utilizan como límite do couto é moi distinta entre a parte occidental do mesmo onde están ben definidos - e a oriental, máis espazados e vagos, e a sospeita sobre a autenticidade do contido no diploma - por máis que as sucesivas confirmacións reais naturalizasen a súa validade - ratifícase coa visión dos diferentes coutos na Idade Moderna e, en concreto, no Catastro do Marqués de Ensenada, a máis fiable averiguación fiscal da Coroa de Castela para tal período: a metade oriental do suposto couto subtráese do dominio de Santa Cristina e corresponde na súa práctica totalidade ao señorío do mosteiro de Santa María de Montederramo.

Tras varias décadas como bieito baixo a advocación a San Xoán, Montederramo aparece como casa cisterciense probablemente desde $1153^{7}$, e con toda certeza desde 1163, cando se di que nel se segue a regra bieita et institutionem Cisterciensium fratrum ${ }^{8}$. O paso ao hábito branco, a máis de conlevar a habitual advocación mariana grata aos monxes cistercienses, acompaña máis ou menos polas mesmas datas o reasentamento da comunidade augas arriba do río Mao desde o seu primitivo lugar de Seoane Vello. O novo mosteiro constrúese nunha zona de penechaira a unha considerable altura, na cota dos $900 \mathrm{~m}$, o que converte as terras circundantes en especialmente aptas para pastos e cultivo de cereal, pero motivará que os monxes procuren o abastecemento doutros produtos - castaña e, sobre todo, viño - en terras que sexan para isto máis propicias: ao sur, no val do Támega, e ao norte, nas ribeiras do Sil. Este último

\footnotetext{
${ }^{6}$ RODRÍGUEZ MUÑIZ, 2010: docs.n. ${ }^{\circ} 15$ e 10, respectivamente.

${ }^{7}$ SUÁREZ GONZÁLEZ, 2012: 98.

${ }^{8}$ Bula de Alexandre III na que confirma bens e dereitos ao mosteiro de Montederramo e o acolle baixo a protección da Santa Sé (ACO. Pergameos monacais, Santa María de Montederramo, doc. n. ${ }^{\circ}$ ).
} 


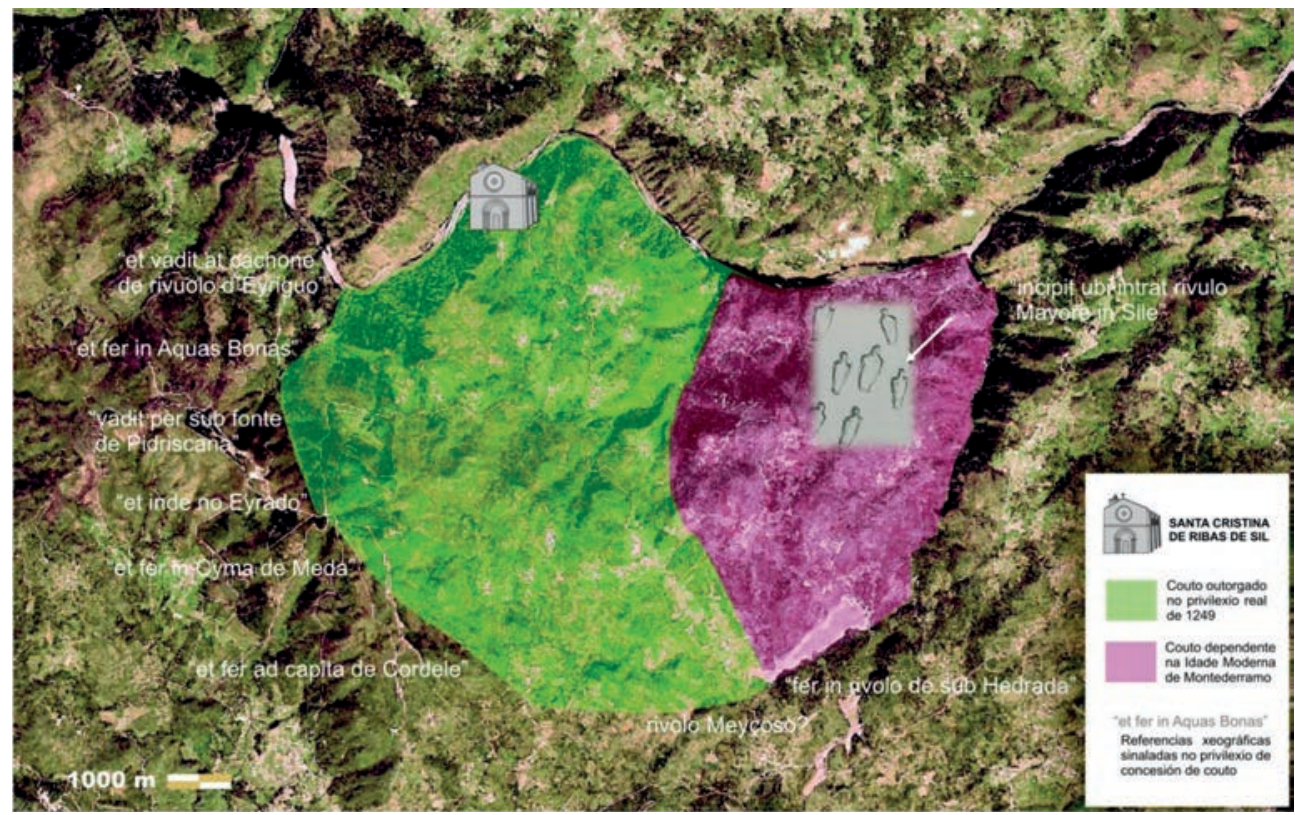

Fig. 1. Couto do mosteiro de Santa Cristina

Fuente: elaboración propia

dominio articularase no denominado "couto de Chandrexa", termo que recolle precisamente aquelas zonas só nominalmente baixo dominio do mosteiro de Santa Cristina: as parroquias de Pradomao e Forcas na meseta e as de Sacardebois e parte de Chandrexa na ribeira. A máis de por unha decidida política de adquisicións nesta serie de freguesías ao longo do século XIII, o seu dominio sobre estas terras abertas ao Sil farase efectivo coa absorción de varios pequenos mosteiros, entretanto extintos, que pasarán á súa dependencia: os de Santo Adrao, San Miguel e San Cibrao.

Os catro monasteriolos de Ribas de Sil - os tres arriba enumerados máis o de San Lourenzo, que tomará un camiño diferente - supoñen, con toda probabilidade, o máis acabado exemplo de congregación de mosteiros no noroeste peninsular ${ }^{9}$. Moi mal documentados durante o seu período altomedieval - naquel en que tiveron entidade propia - deben ter chegado aos albores do século XII depauperados e cunhas comunidades reducidas á súa mínima expresión, co que ningún deles sobreviviu como casa independente á reforma beneditina. Non axuda ao seu coñecemento nin a escaseza de diplomas que falen destas comunidades nin a tipoloxía dos textos, pois xunto aos reais ou papais que sobre eles dispoñen unha vez extintos, as que chegaron ao presente

\footnotetext{
${ }^{9}$ Un caso semellante coñécese no Bierzo, onde o mosteiro de San Pedro de Montes está acompañado por tres igrexas, dedicadas á santa Cruz, san Martiño e san Cebrián (DURANY CASTRILLO, 2006: 43-44).
} 


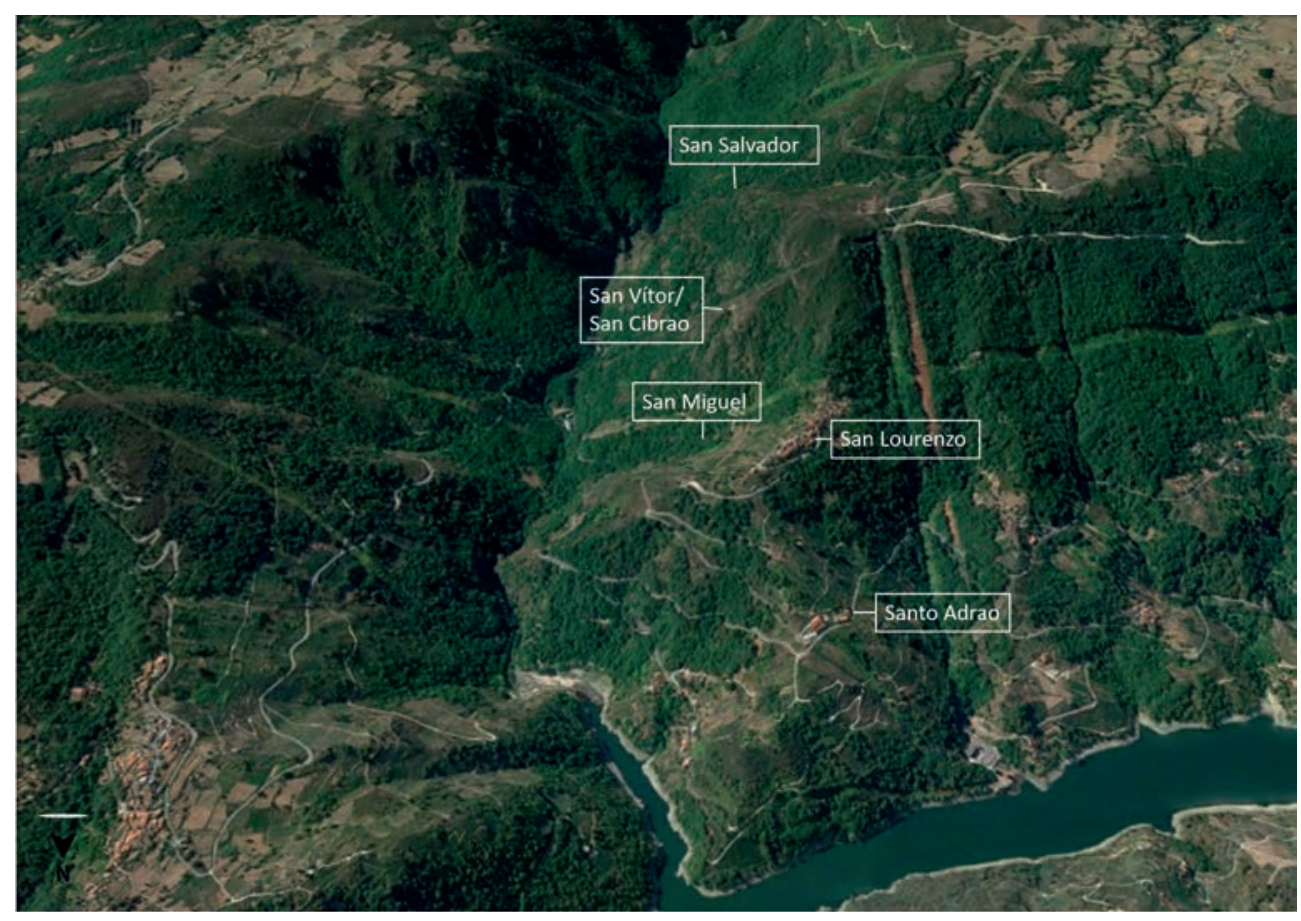

Fig. 2. Localización dos monasteriolos de Ribas de Sil

Fuente: elaboración propia

son referencias illadas a integrantes das súas congregacións, e resulta excepcional a existencia dun único documento emanado desde estes mosteiros que - como se verá - achega valiosa información sobre dous deles, os de Santo Adrao e San Miguel.

Estas limitacións non impiden apreciar unha estreita relación entre as catro casas, inclusive desde unha perspectiva xeográfica pois compartían un moi reducido espazo na confluencia do río Mao no Sil como varios documentos o poñen graficamente de manifesto ${ }^{10}$. Así, cando en 1152 Montederramo recibe o mosteiro de San Miguel, exprésase como o seu termo «exterminat cum illo monasterio Sancti Cipriani et Sancti Laurencii et Sancti Adriani», o que se ratifica tres anos despois, cando o rei Fernando II sanciona o destino de San Lourenzo, xa que este se describe como situado «inter duos monasteria, scilicet Sancti Cypriani et Sancti Adriani».

Nada se pode afirmar con garantías sobre o momento e circunstancias da fundación destas casas - verbigratia, se se produciu en conxunto ou secuenciada — nin sobre a relación que se terá establecido entre elas, pero o feito de que, cando

\footnotetext{
${ }^{10}$ Cómpre subliñalo pois diversos estudos dan localizacións diferentes, do que é paradigmático o caso do San Lourenzo, que Freire Camaniel sitúa no lugar do Mosteiro, concello da Pobra de Trives (FREIRE CAMANIEL, 1998: 901) e Ferro Couselo en Siabal, Paderne de Allariz (FERRO COUSELO, 1967: 209).
} 
menos, Santo Adrao e San Cibrao se sitúen baixo cadanseu abade permite pensar en que han de considerarse en pé de igualdade, sen unha xerarquía evidente. Fica a dúbida de cal terá sido a condición do San Lourenzo, o único completamente indocumentado con anterioridade á doazón real no século XII.

Finalmente, o documento propio referido liñas arriba permite aseverar que o último dos mosteiros, o dedicado a san Miguel, foi lugar de retiro dunha comunidade feminina. O texto, datado en 955 e conservado por copia no Tombo de Celanova11, recolle a entrada en relixión de Aseredo Armentáriz como profeso en Santo Adrao - rexido na altura polo abade Tandino - , a onde doa a metade das súas herdades, pois a outra porción correspondía á casa de San Miguel, «ubi filia ipsius cum aliis mulieribus sanctimonialibus habitabat». O abandono dos hábitos por parte do dito Aseredo - quen fuxira do mosteiro «sagita diaboli vulneratus... et ad desideria seculi devolutus» - resólvese co reparto de varios dos bens deste, sitos a ambos lados do Sil, en tres partes iguais: unha para cada un dos mosteiros e unha terceira en beneficio do propio san Rosendo.

Esta sorte de pléiade de mosteiros comparte tamén o destino de, unha vez extintos por desaparición da súa comunidade ou suprimidos na secuencia da reforma beneditina, teren pasado á dependencia doutras institucións.

Os testemuños inícianse co diploma polo que, en 1152, o mosteiro de San Miguel é doado a un Montederramo a piques de se converter en casa cisterciense. En calquera caso, cómpre pensar que o proceso de entrega destes monasteriolos a outras mans se tivese comezado non con esta casa senón coa de San Lourenzo. Ao respecto desta o escrito máis antigo data de 1155, cando Fernando II o pon na posesión do seu crego Roi Méndez e os seus herdeiros, mais esta cesión non supón un acto ex novo senón a confirmación da doazón - da que non se coñece o texto orixinal nin, en consecuencia, a data - que Afonso VII tiña feito a Mendo Méndez, pai do agora beneficiario $^{12}$. O recorrido da cesión sanciónase en 1187, cando os fillos deste Mendo Méndez - entre eles, o Roi Méndez que recibira a confirmación rexia - deciden conxuntamente a súa entrega á orde de San Xoán de Xerusalén na figura do seu comendador Pedro Fernández ${ }^{13}$.

San Lourenzo quedará así vinculado á orde hospitalaria, inicialmente con entidade de seu ${ }^{14}$ e integrándose na Encomenda de Quiroga cando menos desde o século XVI, a través da bailía sita na veciña localidade de Cristosende (A Teixeira) ${ }^{15}$. En San Lourenzo, a orde de San Xoán exercerá tanto a xurisdición espiritual como a temporal,

\footnotetext{
${ }^{11}$ ANDRADE CERNADAS, 1995: doc. n. ${ }^{\circ} 511$.

${ }^{12}$ GARCÍA TATO, 2004: doc. n. ${ }^{\circ} 11$.

${ }^{13}$ GARCÍA TATO, 2004: doc. n. ${ }^{\circ} 43$.

${ }^{14}$ Aparece referido como bailía en 1318 (ACO. Pergameos monacais, Santa María de Montederramo, doc. n. ${ }^{\circ}$ 1984) e como comenda en 1365 (AHN. Clero secular- regular, carp.1496, doc. n. ${ }^{\circ}$ 12).

${ }^{15}$ GARCÍA TATO, ÁlVAREZ ÁLVAREZ, 2010: 18, (nota 1) e 178-179.
} 
do que é testemuña a chamada «casa da Cadea Vella», unha construción con elementos arquitectónicos reaproveitados - entre eles, un escudo que cómpre identificar como unha variante da representación heráldica de Quiroga - que posiblemente refire o lugar en que se exercían os dereitos señoriais por parte da Orde. A máis do propio San Lourenzo - e, en concreto, do barrio da Torre dentro del, pois o circuíto deste señorío abarcaba unicamente a igrexa e as casas a norte da mesma e deixaba fóra o lugar do Horto ${ }^{16}$ - a Encomenda tiña diversos bens materiais na aldea de Barxacova e dereitos plenos sobre un anexo de San Lourenzo: Santa Lucía de Ivil. A vinculación estreita entre San Lourenzo e Ivil - recórdese o dito no apartado correspondente á tradición oral - debe ter a súa orixe no mundo altomedieval, probablemente nunha posesión que o entón mosteiro de San Lourenzo tivese de seu e que se consolidou coa doazón de que foi obxecto no XII, levándoa consigo. Independentemente da súa orixe, a relación entre ambos está testemuñada ao longo de todo o período, como se aprecia no preito, en 1563, entre a Encomenda e Montederramo pola posesión de Ivil — entón referido como granxa ${ }^{17}$ —, favorable a Quiroga por canto esta continuará a aforar o lugar ao longo do período moderno. Máis expresivo da identidade entre San Lourenzo e Ivil é o nome co que a documentación medieval refire esta administración da orde hospitalaria: San Lourenço de Viin - de Ivil, pois - [vid. nota 14], retrasando o seu epíteto «de Barxacova» ás reformas territoriais contemporáneas.

A diferenza de San Lourenzo - tal vez motivada esta excepcionalidade por ter sido o primeiro dos mosteiros en ser doado, escapando así ao destino común aos outros tres - os restantes monasteriolos foron anexionados ao longo do terceiro cuarto do século XII a Montederramo. A primeira en ser absorbida foi a antiga casa feminina de San Miguel, entregada por carta de Afonso VII datada en marzo de $1152^{18}$. A doazón incluía non só o edificio monástico senón tamén os seus dereitos sobre as terras circundantes, pois especifícanse no texto os límites do seu termo, que ha de corresponderse co "couto de Barxacova» que aínda no XVIII se diferenciaba do seu limítrofe de Chandrexa por máis que ambos estivesen na posesión e señorío do mosteiro de Montederramo. Outra especificidade deste couto de Barxacova, que abranguía a localidade epónima - agás o barrio de Espartida - e as de Valdaión e Rabotesón - desaparecidas trala construción do encoro no Sil - é que nel o dominio de Montederramo érao só no referente á xurisdición civil, pero non na relixiosa, na que dependía de San Lourenzo e, por iso, da Encomenda de Quiroga ${ }^{19}$.

\footnotetext{
${ }^{16}$ A mínima dimensión do enclave sobre o que, no núcleo de San Lourenzo, tiña couto a Orde confírmase no Catastro do Marqués de Ensenada. Neste afírmase como o perímetro do acoutado non tiña unha lonxitude maior a 120 pasos, cuns eixos N-S e W-E de unicamente 40. (AGS. Catastro del Marqués de Ensenada, libro 229, fol.260v)

${ }^{17}$ GARCÍA TATO, 2004: 578.

${ }^{18}$ AHN. Clero secular-regular, carp.1481, doc. n. ${ }^{\circ}$ 10. (RECUERO ASTRAY et al, 1998: doc. n. ${ }^{\circ}$ 145; PARADELA (1933-5): 203-205).

${ }^{19}$ AGS. Catastro del Marqués de Ensenada, libro 229, fols. 272r e 278r, respectivamente.
} 
Na bula de 1163 na que o papa Alexandre III acollía o mosteiro de Montederramo baixo a protección da Santa Sé San Miguel aparece caracterizado como grangia, se ben este termo parece pouco definitorio na redacción: coa excepción de Pradomao, referido como vila, todos os bens terrenais que se recoñecen ao cenobio fano baixo este termo de granxa, incluídos aí os antigos mosteiros de San Cibrao e Santo Adrao ${ }^{20}$. De ter sido efectiva a conversión do San Miguel en granxa esta non prosperou, pois ao longo da Idade Media o topónimo identifica unicamente unha aldea cos seus terreos de cultivo - viñedo, de xeito principal - sitos na aba do monte que desde o San Lourenzo descende ao Mao, onde aínda na actualidade se poden apreciar ruínas das antigas construcións e, entre elas, unha de sólidos muros que a tradición local identifica como os restos da capela coa que outrora contou o lugar.

O que si se consolidará como granxa é o antigo mosteiro de Santo Adrao. Un memorial moderno de Montederramo ${ }^{21}$ afirma a súa fundación no ano $925^{22}$ por un abade de nome Froila, ao que houbo de suceder o Randino de que deixou constancia o documento de 955 en que se fala da condición feminina de San Miguel. Non se coñece máis dato ningún para Santo Adrao desde este momento e ata a súa anexión a Montederramo, que houbo de se ter producido con anterioridade a xullo de 1168 por canto se inclúe expresamente este antigo monasteriolo entre a relación de propiedades que o monarca Fernando II tiña doado a Montederramo e neste intre lle confirma e acouta ${ }^{23}$.

Ao longo da Baixa Idade Media e no período moderno xerarase unha importante colección diplomática arredor desta granxa, que se estableceu como o lugar desde o que o mosteiro de Montederramo xestionaba a súa serie de propiedades nas ribeiras do Sil, sendo asemade un importante centro de recepción de rendas. A primeira referencia conservada a este respecto dátase en 1252, cando entre as condicións dun foro se estipula que os receptores han de satisfacer seis xornadas de traballo - searas - a Santo Adrao ${ }^{24}$. Noutro aforamento, xa en 1303, confírmase a presenza de monxes á fronte desta granxa coa mención, entre os asinantes do contrato de arrendo, dun «frei Joham de Santo Adrao» ${ }^{25}$. Posiblemente a presenza dunha pequena comunidade

\footnotetext{
${ }^{20}$ A bula, no caso de se ter efectivamente levado a termo o nela disposto, viría anteceder en varios anos as doazóns rexias sobre estes dous enclaves.

${ }^{21}$ AHPOu. Clero, libro 409 - Tombo Novo-, fol. 230-r.

22 Pódese considerar o stauratum do texto como un «restauratum» (FERRO COUSELO, 1967: 207) que non falaría dunha fundación ex novo e si dunha restauración. En favor desta teoría xoga a existencia dun documento, supostamente datado no 922, no que o bispo san Rosendo recibe, entre diversos bens, a metade do vilar de Molas que linda co río Mao «ad cellario fratres Sancti Adriani» (ANDRADE CERNADAS, 1997: doc. n. ${ }^{\circ}$ 173, p.241-2). Freire Camaniel indica a plausible posibilidade de que o copista autor do tombo tivese obviado o L aspado no X, convertendo a data no ano da era do 960 no 990 e, polo tanto, no 952 do calendario actual (FREIRE CAMANIEL, 1998: 865, nota 1013). ${ }^{23}$ DURO PEÑA, 1972: doc. n. ${ }^{\circ} 267$.

${ }^{24}$ ACO. Pergameos monacais, Santa María de Montederramo, doc. n. 890.

${ }^{25}$ Non debe considerarse ese cualificativo de Santo Adrao como un lugar de nacemento do confirmante senón de profesión, pois inmediatamente a continuación entre as testemuñas aparece referido frey Martino de Santa Christina (ACO. Pergameos monacais, Santa María de Montederramo, doc. n. ${ }^{\circ}$ 1763).
} 
monástica encargada de realizar estas tarefas administrativas e de xestión de bens teña conducido a que, popularmente, este Santo Adrao sexa coñecido como «O Priorado ${ }^{26}$, sen que conste tal promoción á condición prioral en momento ningún do período medieval.

A nómina destes catro monasteriolos péchase co de San Cibrao, para o que, ao igual que acontecía en Santo Adrao, se sabe da súa condición como abadía ao longo da Alta Idade Media. O primeiro abade que deste mosteiro se coñece pode ser o «Adaulfus abbas in loco de Sancto Cipriano» que aparece como confirmante en xaneiro do 977 ao outorgamento do testamento de san Rosendo ${ }^{27}$, mentres o último documentado - e posiblemente o derradeiro da casa - ha de ser o «Gundisalvus abbas de Sancto Cipriano» que asiste a unha entrega ao mosteiro de San Salvador de Celanova de bens sitos nesta mesma terra de Caldelas, en febreiro de $1095^{28}$. Entregado por doazón rexia a Montederramo en 1170, o tortuoso da súa existencia baixomedieval e a relación que garda coa necrópole aconsellan volver sobre esta casa de San Cibrao, con maior detalle, en próximos parágrafos.

Aos monasteriolos ata aquí referidos cómpre, en puridade, acrecentar un quinto e último lugar de actividade espiritual nesta mesma contorna do canón do río Mao: o San Salvador. Considero que se pode identificar este lugar con aquel en que se terían acollido os «anacorites Dei Sancti Salvatoris Ripe Silis» mencionados nun preito entre o frade Vimara e o conde Mendo González pola posesión da igrexa e herdades de San Pedro de Laroá (Xinzo de Limia), supostamente datado en 1054 e copiado no tombo de Celanova ${ }^{29}$.

Analizado en detalle o texto por Freire Camaniel ${ }^{30}$, concordo co autor á hora de cualificar como falso - ou, cando menos, falseado - este documento, que se tería redactado con posterioridade a aquela data para xustificar as pretensións do mosteiro de san Rosendo sobre a igrexa de Laroá ${ }^{31}$. Independentemente dos dereitos que tivese - ou pretendese ter - Celanova sobre a igrexa, discrepo da interpretación

\footnotetext{
${ }^{26}$ Existe no lugar un conxunto de voluminosos edificios cuxa construción se data a mediados do século XVII (RIVAS FERNÁNDEZ, 2004: 63) e nos que se asentou a granxa ata os procesos desamortizadores do século XIX. Nunha das dependencias - actualmente rehabilitada como vivenda particular - consérvase unha xanela xeminada e trilobulada, así coma tres modillóns do edificio tardomedieval.

${ }^{27}$ FREIRE CAMANIEL, 1998: 804, seguindo a Yepes e Díaz y Díaz.

${ }^{28}$ ANDRADE CERNADAS,1995: doc. n. ${ }^{\circ} 227$.

${ }^{29}$ ANDRADE CERNADAS, 1995: doc. n. ${ }^{\circ} 267$.

${ }^{30}$ FREIRE CAMANIEL, 1998: 202-6.

${ }^{31}$ Así o refire tamén Andrade Cernadas na súa edición do texto (ANDRADE CERNADAS, 1995: 388 e nota 108) seguindo a interpretación a este respecto de Isla Frez, ao que cómpre engadir a dubidosa cronoloxía para algún dos personaxes referidos. A súa elaboración - aínda que faga referencia a feitos máis antigos e talvez datados por volta dese ano de 1054 - debe ter tido lugar no século XII, cando o mosteiro estaba inmerso nun conflito coa diocese auriense no que Celanova pretendía manter os dereitos espirituais sobre as terras do seu dominio inmediato, que finalmente e tras longas décadas se saldará coa concesión ao mosteiro da condición de arcediago. É nesta liña que deben ser consideradas as referencias á Ovetanense sedis, pois era en Oviedo que Celanova tiña un dos seus máis relevantes apoios (PÉREZ RODRÍGUEZ, 2002: 401).
} 
que Freire Camaniel realiza sobre o sentido do texto. Segundo este autor, a resolución será favorable ao frade Vimara e contraria ao defendido polo conde, quen fala en nome dos monxes dun San Salvador que identifica co de Celanova. Isto deriva da súa negativa a aceptar a existencia da casa homónima Ripe Silis, xustificando a confusión textual nunha mala lectura de documentos do século X que os escribas terían tomado como modelo para elaborar este falso, e obviando para iso a referencia ao eremitismo explícita no diploma.

Considero que a narración - sexa esta falsa ou non no seu contido - non necesita desta reviravolta e pode ser interpretada cunha lectura máis lineal: na contenda acerca dos dereitos de Laroá o conde Mendo González é «dicente in voce anacorites Dei Sancti Salvatoris Ripe Silis», aos que supostamente tiña concedido a igrexa en testamento o rei Vermudo e desfrutaran da súa posesión ata a intromisión do frade Vimara. Este, pola súa parte, afirma a fundación da igrexa polos seus antepasados, narrando as circunstancias da súa creación e consagración. A sentencia foi favorable a este frade - probablemente, vinculado a Celanova, co que o mosteiro poderá fundamentar os seus dereitos sobre Laroá - e contraria á parte defendida polo conde, que se compromete a que nin el nin «qui ipsas cellas tenuerint» — os ermitáns de Ribas de Sil, pois - han de perturbar esta resolución. Esta interpretación salva aínda o paradoxo que, na lectura de Freire Camaniel, supuña que Celanova, para a defensa dos seus intereses na dita igrexa, tivese elaborado ou manipulado un documento no que aparecía como parte perdedora. Considero así, con independencia da motivación para o seu concurso no proceso, que tal comunidade anacorética nas ribeiras do Sil houbo de existir.

Coa necesaria prudencia derivada de se tratar dunha única mención, fala en favor desta posibilidade a pervivencia do topónimo - ao igual que acontece con todos os outros mosteiros que comparten este epíteto Ripa Silis que no texto se foron analizando, agás San Cibrao - dando nome a un souto a pouco máis dun quilómetro de San Lourenzo, augas arriba do Mao, sobre o que os veciños coinciden en sinalar un pasado vinculado á vida relixiosa no lugar. Inciden neste feito as fontes escritas, que aínda en 1570 refiren a condición como ermida deste San Salvador ${ }^{32}$.

Cómpre subliñar a definición que dos seus moradores se ofrece. Se San Cibrao e San Lourenzo aparecen baixo a dirección e disciplina dos seus respectivos abades, e San Miguel se erixe como comunidade de sanctimoniales - recórdese que San Lourenzo non está documentado neste período pregregoriano - o termo con que San Salvador é caracterizado non ofrece dúbida ningunha, pois non son «monxes» senón «anacoretas» os que nese lugar se acollen. Pode considerarse que teña sido unha casa

\footnotetext{
${ }^{32}$ Neste souto consérvase a ruína dunha única edificación, que pola súa configuración non cabe asimilar a un templo. Coa eiva de non ter podido intervir no seu interior, unha cata arqueolóxica nas súas inmediacións deu como resultado a exhumación dun conxunto moi numeroso de fragmentos cerámicos de indiscutible adscrición medieval.
} 
- posiblemente vinculada aos monasteriolos - destinada a un retiro espiritual máis estrito, temporal ou permanente, para quen así o desexase na súa vivencia relixiosa, e talvez garde cos restantes catro mosteiros de Ribas de Sil a mesma relación que o berciano de Santa Cruz coas outras casas vinculadas a San Pedro de Montes ${ }^{33}$ ou a que, xa no século XV, o «hermitaño de Santa Catarina» tería co priorado de Rocas ${ }^{34}$.

Non terá pasado desapercibido ao lector que neste recorrido histórico e documental o termo «San Vitor» non teña aínda saído a relucir. Ningunha referencia hai na Idade Media a esta advocación, e haberá que agardar ao século XVIII para encontrar testemuños documentais que remitan a este topónimo.

Dáse o paradoxo de existir un enclave relixioso e espiritual de primeira magnitude, innominado na Idade Media - o San Vítor - e un nome, o de San Cibrao, que téndose perdido o topónimo, carece dunha realidade física asociada. Defendo, con isto, que se pode establecer e xustificar unha identidade plena entre o San Cibrao medieval e o San Vítor unicamente referido nas fontes modernas e contemporáneas.

Un repaso á morfoloxía e localización do San Cibrao conduce a considerar que o territorio da antiga casa garda notorias semellanzas coa situación e configuración do San Vítor como hoxe en día se identifica. Cuestión significativa pode ser o epíteto da Pena que permanentemente acompaña o nome do San Cibrao na documentación pleno e baixomedieval e que ben pode tratarse do esporón rochoso en que se asentou a capela e ante o cal se dispón a necrópole. Xunto ao indicio desta concordancia semántica entre a denominación do antigo lugar e a realidade física do «novo» San Vítor, as referencias escritas ao marco xeográfico apuntan nesta mesma liña. Así, na doazón rexia sobre San Lourenzo, este aparecía circundado por Santo Adrao - na aba que cae ao Sil - e San Cibrao - que, por isto, ha de estar augas arriba do Mao. Non menos elocuente é o preito de 1365 entre o crego de San Cibrao da Pena e o "comendador e teedores da comenda de San Lourenço de Viin», na que o primeiro protestaba como estes últimos lle tiñan tornado a auga á que tiña dereito e que, como aínda hoxe acontece, só pode proceder dos mananciais situados ladeira arriba, no Montecide á cuxa sombra, a media encosta e nunha pendente íngreme no canón do Mao, se sitúa San Vítor, en correspondencia co monte Penso - tamén topónimo perdido - que na doazón de 1170 se describía para San Cibrao.

Convén retomar o recorrido histórico de San Cibrao, interrompido trala mención ao que pode ter sido o seu último abade como casa independente, o Gundisalvus referenciado en 1095, cando a reforma bieita estaba a se afirmar en territorio galaico ${ }^{35}$.

\footnotetext{
${ }^{33}$ RIVAS FERNÁNDEZ, 1981: 59.

${ }^{34}$ RODRÍGUEZ MUÑIZ, 2010: doc. n. ${ }^{\circ} 117$.

${ }^{35}$ Segundo Mattoso pode darse por concluída a implantación da reforma na década de 1120 no caso concreto de Portugal, se ben as datas han de ser extrapolables aos restantes reinos occidentais peninsulares (MATTOSO, 1992: 260-261). Cómpre destacar, ao respecto da adopción da reforma no caso específico da Galiza, a obra de Andrade Cernadas (1997).
} 
É de supoñer que o mosteiro ficou baleiro ou foi suprimido pouco despois, nos primeiros anos do século XII, e desde logo con anterioridade ao 1170. Neste ano Fernando II doa a Montederramo San $\mathrm{Cibrao}^{36}$, descrito como igrexa e non como mosteiro, o que apuntala a idea de que carecese de comunidade - da mesma maneira que se sospeita para as outras tres casas, por máis que na doazón daqueles se faga constar unha condición monástica sen dúbida xa perdida.

A cesión rexia parece ter incomodado ao bispo de Ourense - ao que non debe ser alleo que Montederramo, co seu recente paso ao hábito branco, ficara á marxe da autoridade episcopal á que si estaban suxeitos os monxes bieitos - , quen protestou ante instancias vaticanas. A resposta de Urbano III chegou cunha bula datada en abril de 1186, que se refire en duros termos ao acontecido cos dous mosteiros que Fernando II tiña doado a Montederramo: San Cibrao e Santo Adrao ${ }^{37}$. No texto pontificio recóllense os motivos da protesta do diocesano: Montederramo tíñase despreocupado dos bens destes monasteriolos, entregando parte do seu haber a leigos, e non manifestara interese en manter vida monástica en ningún dos dous, obviando o parecer do bispo auriense. Ante a gravidade das queixas, o papa ordenaba aos abades de Sobrado, Melón e Santo Estevo que velasen pola restitución de comunidade monástica nestas dúas casas de Ribas de Sil.

A resolución, con todo, non parece ter chegado a cumprirse. Santo Adrao constituíuse como granxa - co que a presenza de monxes no lugar non obedecía á instauración dunha comunidade individualizada e autónoma - e na continuidade do San Cibrao tampouco houbo lugar para unha nova congregación monástica.

En efecto, o antigo mosteiro continuará a súa existencia medieval unicamente como parroquia, como se testemuña cando menos desde $1257^{38}$, momento no que o «prelatus ecclesie Sancti Cipriani de Penna» afora o monte do Verengo ${ }^{39}$. Isto implica que o relixioso non só proporcionaba atención sacramental aos seus fregueses, senón que se erixía como "crego reitor» - e así aparece reiteradamente designado -, administrador dos bens que á igrexa eran propios e que, con certeza, han de ser herdeiros directos do haber que ao antigo mosteiro correspondía ${ }^{40}$.

A relación de lugares que aparecen baixo a xestión directa do reitor do San Cibrao e que, por tanto, deben ter configurado o dominio do antigo monasteriolo

\footnotetext{
${ }^{36}$ AHN. Clero regular- secular, carp. 1481, doc. n. ${ }^{\circ} 15$ (RECUERO ASTRAY et al, 2000: doc. n. ${ }^{\circ} 110$ ).

${ }^{37}$ ACO. Pergameos monacais, Santa María de Montederramo, doc. n. 57 (DURO PEÑA, 1977: doc. n. ${ }^{\circ}$ 6).

${ }^{38}$ ACO. Pergameos monacais, Santa María de Montederramo, doc. n. 757.

${ }^{39}$ A redacción do contrato incide na cuestión dos termos efectivos do couto de Santa Cristina. O lugar aforado delimítase polos termos das parroquias de Forcas e Pradomao pero tamén «cum caucto Sancte Christine». A diferenza da demarcación teórica do falseado documento rexio de 1249, esta referencia si fai alusión ao límite real do couto do mosteiro, entre as freguesías de Santiago de Edrada - de Santa Cristina - e as de Forcas e Pradomao - de Montederramo. ${ }^{40}$ En 1259, Sancho Pérez aparece como «rector ecclesie Sancti Cipriani de Penna», e «reutor da igleia de San Cibrao» é Pedro Eanes cando menos entre 1314 e 1342, ao que substituirá Pedro Escribán, documentado entre 1347 e 1351 e, finalmente, Roi González, á fronte do San Cibrao da Pena en 1355.
} 


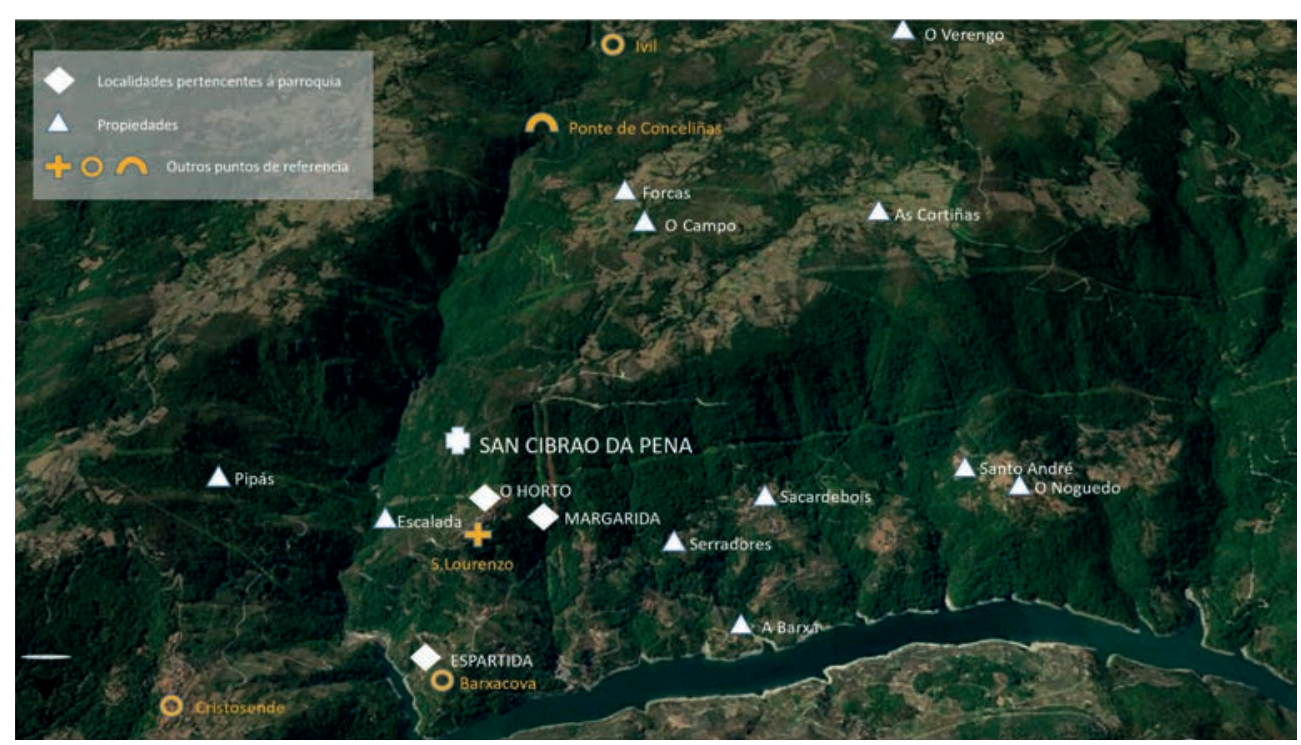

Fig. 3. Propiedades e localidades dependentes da igrexa de San Cibrao da Pena Fuente: elaboración propia

sitúase de maneira maioritaria na súa contorna máis inmediata, pois afora bens nas freguesías de Sacardebois e Forcas - as que foron limítrofes coa igrexa da Pena - e só puntualmente en Pradomao - en Verengo - ou Chandrexa do Sil, onde dispón dos casais do Noguedo e de Santo André. Na outra beira do Mao San Cibrao ten propiedades no lugar de Pipás, na parroquia de Cristosende. Adicionalmente, a colección diplomática que a San Cibrao da Pena se refire permite facer un reconto, sequera aproximado, das localidades que se adscribían á parroquia - que estaban «so o seu syno», segundo o termo con que na época se expresaba -, e que da mesma maneira que as diferentes herdades se situaban a unha curta distancia da súa igrexa: cóntanse entre elas as aldeas de Margarida, Espartida - barrio de Barxacova - e aínda O Horto - inmediato ao San Lourenzo - , o que fala ás claras do compartimentado deste territorio ao longo da Idade Media, sen dúbida derivado da estreita relación - en ocasións, con bens compartidos - que entre si gardaban os monasteriolos altomedievais.

Non obstante a doazón pola que Fernando II facía depender o antigo mosteiro de San Cibrao de Santa María de Montederramo, o encabezamento dos documentos expedidos polo reitor da igrexa da Pena indica unha realidade diferente ao que sería de agardar. $\mathrm{O}$ acto xurídico que este crego desenrole - normalmente, a concesión dun foro - non se fai de maneira autónoma, pois non era casa independente, pero non 
é co consentimento do abade do mosteiro de Montederramo que se realiza ${ }^{41}$, como podería presupoñerse, senón dun dos cóengos do cabido catedralicio auriense e, máis en concreto, ante aquel que á sazón fose «tenente de Caldelas» ou «do préstamo de Caldelas». O reitor da igrexa da Pena conta, porén, con capacidade para se opoñer ás decisións daquel, como se certifica en 1324 cando o crego se nega ante o tenente a aforar o casal de Pipás a Lopo Méndez, pois «seeria en perigoo da mia alma e en dano da dita miña igleia» ${ }^{42}$.

Considero que a aparente contradición entre a doazón a Montederramo e a tutela efectiva polo cabido pode ser explicada poñéndoa en relación coa sentenza pola que o papa Urbano III ditaminaba a restitución a San Cibrao da súa comunidade monástica. É posible que o incumprimento desta resolución por parte de Montederramo tivese levado a unha intervención da diocese auriense - que non en van fora a promotora da queixa ante o pontífice - tomando para si certos dereitos sobre a parroquia da Pena.

Tal situación dará un importante xiro en 1355, coincidindo co ascenso a crego de San Cibrao de Roi González. Este renuncia á súa condición de reitor en beneficio do cabido de Ourense, o cal non reserva para si esa titularidade sobre a igrexa senón que a cede ao mosteiro de Montederramo, se ben coa obriga expresa de que este haxa de manter e dotar esta parroquia da Pena de canto for mester, así como de pagar os tributos que sobre ela fosen requiridos. Finalmente, Montederramo resolve crear a figura dun vigairo para a administración da igrexa - transitoria, pois será só durante o tempo da vida do elixido - , dignidade que recae no mesmo Roi González quen tiña renunciado ao cargo de reitor ${ }^{43}$. Trátase dun proceso alambicado que agacha no seu desenrolo un acordo entre o cabido auriense e o propio mosteiro de Montederramo, quen pasa a dispor de dereitos íntegros sobre a igrexa da Pena. $\mathrm{O}$ enunciado do acordo ao que o mosteiro chega co antes reitor e agora vigairo deixa entrever a existencia dunha relación que nunca antes tiña sido expresada: unha vez asuma o seu novo cargo, Roi González levará os froitos e rendas derivados dos bens de San Cibrao, pero ha de satisfacer un pago anual a Montederramo de nove mollos de centeo - e aquí o máis relevante - en vez dos seis que viñan dando os reitores que ata o momento foran. A referencia a unha renda a entregar ao mosteiro por parte dunha igrexa tutelada polo cabido auriense está a indicar a existencia dunha sorte de avinza ou acordo entre as tres institucións involucradas mentres San Cibrao da Pena estivo baixo dependencia capitular.

\footnotetext{
${ }^{41}$ Só nun caso Montederramo e o seu abade xestionan un ben de San Cibrao: o casal de Santo André en Chandrexa en 1274. Na redacción incídese en que dito casal non está directamente baixo autoridade do abade senón que o ten — en termos que non se reproducen, co que pode ter sido cedido ou doado - de San Cibrao (ACO. Pergameos monacais, Santa María de Montederramo, doc. n. $\left.{ }^{\circ} 1111\right)$.

${ }^{42}$ ACO. Pergameos monacais, Santa María de Montederramo, doc. n. 2076.

${ }^{43}$ ACO. Pergameos monacais, Santa María de Montederramo, doc. n. 2667.
} 
Desde este intre os foros de bens pertencentes á igrexa aparecen realizados baixo a conformidade e autorización do abade de Montederramo e, logo da morte de Roi González como reitor e vigairo perpetuo que foi, directamente outorgados por aquel, como se constata xa en 1371, cando o abade Xoán de Montederramo afora o casal do Horto, «casar que nos auemos ena frigisia de San Çibrao da Pena» ${ }^{44}$.

Como manifesta esta última referencia, a perda de autonomía do San Cibrao non significou a súa desaparición como parroquia, condición que manterá cando menos ata mediados do século XV. A última vez que esta igrexa aparece citada como parroquial é en 1449, nun foro do lugar da Escalada, «que esta su o sino do San Çibrao da Pena» ${ }^{45}$. Sen que, por mor dun importante baleiro documental, se poida dicir máis sobre o como, o cando e o porqué da súa extinción, a desaparición do San Cibrao como freguesía queda clara á altura de 1542, cando o lugar de Espartida que en 1444 era «su o syno de San Çibraao» - apareza identificado como sito «so el signo de San Martinno de Sacardebueys» ${ }^{46}$, parroquia esta de Sacardebois en cuxo beneficio se saldou a desaparición da de San Cibrao da Pena.

A perda da condición parroquial e o deterioro das dependencias do San Cibrao certifícase en 1570, en dous foros emitidos na granxa de Santo Adrao ${ }^{47}$. Nestes arrendábase en senllas porcións unha ampla extensión, a fraga de San Salbador e San Çibrao. Ao elocuente do nome con que se designa cómpre engadir os termos polos que se demarca, que supoñen unha parte moi substantiva do que debeu ser dominio directo do monasteriolo e da igrexa que del derivou: o rego de Cazafón - límite coa parroquia de Forcas - , a herdade do Barlamé - limítrofe con Sacardebois —, o lugar do Horto - barrio da aldea de San Lourenzo - e a herdade da Escalada — na ladeira cara ao Mao, lindeira con San Miguel.

Máis significativa é aínda a introdución dunha cláusula que indica o estado en que á sazón se encontraban os outrora mosteiro e eremitorio de San Cibrao e San Salvador, sitos dentro das demarcacións do foro e nel incluídos como calquera outro ben. Reducidos á condición de senllas ermidas, estas han de ser reparadas «de manera qu'esten linpias y honestas y bien tratadas, de manera que en ellas no entren los ganados»; disposición esta que habería de resultar innecesaria no caso de que mantivesen un culto regular, co que cómpre pensar que ambas se encontrarían nun avanzado proceso de desacralización.

Mosteiro, igrexa e finalmente ermida, San Cibrao ten neste foro de 1570 a súa derradeira referencia documental coñecida. Ábrese desde este momento un paréntese

\footnotetext{
${ }^{44}$ ACO. Pergameos monacais, Santa María de Montederramo, doc. n. 2894.

${ }^{45}$ ACO. Pergameos monacais, Santa María de Montederramo, doc. n. 4275.

${ }^{46}$ Respectivamente: ACO. Pergameos monacais, Santa María de Montederramo, doc. n. ${ }^{\circ}$ 4201, e AHPOu. Clero, libro 404, fol. 476-v.

${ }^{47}$ AHPOu. Clero, libro 416, fols. 36-v a 39-r.
} 
de dous séculos ata que, xa ben avanzado o século XVIII, unha nova fonte achegue información sobre este mesmo entorno, se ben baixo unha nova advocación.

Dentro dos censos adicionais ao interrogatorio xeral do Catastro do Marqués de Ensenada, e en concreto no libro Real de Leigos correspondente á parroquia de San Martiño de Sacardebois - lémbrese que é nesta que se integran os bens da extinta igrexa da Pena - un dos capítulos corresponde coa relación de bens referida aos lugares de Bouzas e Margarida. Na declaración de haberes de Francisco Álvarez, este afirma traballar diversas propiedades aforadas ao mosteiro de Montederramo, e nese mesmo lugar posuía "un monte en San Víctor», de catro maquías e calidade única que, entre outros lindeiros, delimitaba ao mediodía coa "capilla de San Victorio» ${ }^{48}$.

O proceso polo que a antiga ermida do San Cibrao foi reocupada coa nova advocación do San Vítor - ou, con maior propiedade, o "San Vitór», pois é desta maneira en que os veciños se refiren - non deixou pegada documental ou arqueolóxica que permita a súa reconstrución. En calquera caso, a refundada capela non tivo unha longa continuidade temporal, como o testemuña - pechando o círculo deste artigo - a publicación de Arias Sanjurjo en 1914, na que inicia a súa presentación do San Vítor referindo como un ancián do lugar «en su juventud lo había destruído en unión con otros mozos, arrojando las piedras de los muros por el precipio sobre que se hallaba la capilla; según él, eran éstos de la altura de una persona». Por máis que sexa evidente a diferente esperanza de vida entre 1914 e os tempos actuais, o ancián relata a demolición, conveñamos por volta de 1860-70, do que xa non era máis que a ruína do antigo templo no que tiña recibido honras san Vítor, de tal xeito que, para motivar este deterioro, o seu abandono debeu ter acaecido na primeira metade do século XIX.

Esquecido o culto na capela e derruído o seu edificio, a devoción a san Vítor non desapareceu na comarca. Padroeiro inhabitual nas advocacións de parroquias galegas, san Vítor recibe culto na actualidade nunha freguesía próxima e que xa foi referida nestas liñas: San Xoán de Seoane Vello. O antigo emprazamento do mosteiro de Montederramo antes da súa refundación e reasentamento como casa cisterciense na honra de Santa María continuou a súa existencia como granxa da nova comunidade e, finalmente, como simple parroquia. Como está a indicar con toda claridade a redundancia do nome - San Xoán de Sant'Iohane, co cualificativo Vello facendo alusión á antiga casa monástica - o seu padroeiro non é o san Vítor, se ben é este o santo venerado na parroquia, e do cal se custodian nesta dúas tallas en madeira. A celebración non pode vir de antigo por canto a advocación da freguesía continúa a ser a tradicional, o que abre a porta a que a devoción que na derruída capela se tivese suscitado arredor do santo se tivese trasladado a este novo emprazamento augas arriba do Mao. Reforza esta

${ }^{48}$ AHPOu. Catastro del Marqués de Ensenada, libro 461, fol. $23 \mathrm{v}$. 


\begin{tabular}{|c|c|c|}
\hline Evidencias arqueolóxicas & San Cibrao (documentos) & San Vítor \\
\hline $\begin{array}{l}\text { c. } 900: \text { foxo de fundición de campás } \\
\text { c.960: enterramento en tumba privilexiada }\end{array}$ & 977: primeiro abade documentado & \\
\hline \multirow{2}{*}{ c.1100: abandono da necrópole } & 1095: última referencia a abade & \\
\hline & 1170: baleiro. Doazón a Montederramo & \\
\hline Materiais baixomedievais & 1257-1371: igrexa baixo crego reitor & \\
\hline \multirow[t]{3}{*}{ s.XV: últimos restos datados (moedas) } & Parroquia testemuñada ata 1449 & \\
\hline & 1570: ermida. Edificio en pé, xa sen culto & \\
\hline & & $\begin{array}{l}\text { c.1760: Catastro de Ensenada. } \\
\text { Capela do San Vítor }\end{array}$ \\
\hline \multirow[t]{2}{*}{ c.1860: destrución das ruínas da capela } & & \\
\hline & & $\begin{array}{l}\text { Momento indeterminado: Culto a San Vítor } \\
\text { en Seoane de Montederramo }\end{array}$ \\
\hline
\end{tabular}

Cadro 1. Cadro cronolóxico comparativo: San Cibrao- San Vítor

Fuente: elaboración propia

teoría, desde unha perspectiva etnográfica, a ofrenda que os veciños do lugar acostuman facer ao santo no día da súa festa grande, o 29 de agosto: o primeiro cacho de uvas maduras das súas colleitas. Nada tería de extraordinario de non ser porque no entorno de Montederramo, na cota dos $900 \mathrm{~m}$, o viñedo é un cultivo simplemente inexistente, e estas uvas proceden das propiedades que, aínda hoxe, os veciños da contorna cultivan na Ribeira, maioritariamente nas inmediacións de San Miguel ${ }^{49}$.

Considero xustificada a premisa coa que iniciaba este apartado: a identidade entre San Cibrao e San Vítor, dúas denominacións distintas que, en momentos diferentes, fan referencia a unha mesma realidade. Mais graficamente a secuencia de acontecementos entre un e outro pode verse no Cadro 1.

Cómpre pechar este recorrido pola historia deste enclave relixioso volvendo atrás, ás lendas de transmisión oral que versan sobre o San Vítor, a súa historia e as xentes que a el se vinculaban. Se sobre o seu devir histórico arqueoloxía e documentación se combinan para en boa medida encher os baleiros de información e ofrecer un relato con poucos cabos soltos, a dúbida está permitida no referente aos destinatarios dos enterramentos da necrópole rupestre. A dimensión desta podería facer pensar que constituíse un lugar central espiritual e funerario para a contorna, co que terían recibido

\footnotetext{
${ }^{49}$ É frecuente na documentación correspondente a San Miguel encontrar foros nos que o beneficiario era morador nas localidades da parte alta da comarca. Tal fenómeno debe terse perpetuado historicamente e chegou ata a actualidade: varios propietarios de viñas nesta ladeira de San Miguel son veciños de Montederramo, herdeiros daqueles que as terían traballado deste antigo e que as adquirirán nos procesos desamortizadores no século XIX.
} 
sepultura nela os fieis ou vasalos dos distintos monasteriolos que neste artigo se referiron. Esta hipótese, porén, ha de quedar descartada ou cando menos moi matizada en virtude ás informacións que refiren os veciños sobre San Miguel, lugar no que décadas atrás, ao pór de viña diferentes socalcos, saíron á luz «tumbas como as do San Vítor», en palabras daqueles que as viran. Nada se sabe de necrópole ningunha vinculada ao Santo Adrao, pero é razoable pensar que o San Lourenzo tivese contado con camposanto de seu desde antigo, do que o cemiterio actual fose o directo sucesor adaptado aos usos e costumes que substituíron aos enterramentos en rocha e ata a actualidade.

A necrópole sobre a que versa este artigo parece, polo tanto, ter sido o lugar de enterramento daqueles vinculados ao antigo mosteiro de San Cibrao, dependentes da institución monástica ou moradores no seu dominio. A diferenza do que a tradición oral sostén, o culto no lugar non quedou marxinado en favor de San Lourenzo senón que, como se viu, unha vez suprimida a vida cenobítica en San Cibrao este perdurou como a igrexa parroquial da Pena, de cuxo cemiterio baixomedieval nin as fontes escritas nin as diversas campañas de escavación arqueolóxica deixaron noticia.

Estas diverxencias entre a tradición oral e as informacións que textos escritos e realidade arqueolóxica forneceron ao longo das investigacións non obstan para concluír que, desde a Alta Idade Media e ao longo dos séculos, as diferentes institucións relixiosas da contorna - aínda que só o San Lourenzo chegase a tempos presentes - deixaron unha indubidable pegada tanto na configuración espacial destas terras como na construción simbólica e ideolóxica dun territorio, no que a necrópole aquí presentada xogou un papel, sen dúbida, primordial.

\section{FUENTES}

\section{Arquivo da Catedral de Ourense}

ACO. Pergameos monacais, Santa María de Montederramo. Doc. n. ${ }^{\circ}$ 7, 1111, 1984, 2076, 2667, 2894, 4201 y 4275.

Archivo General de Simancas

AGS. Catastro del Marqués de Ensenada. Libro 229.

Arquivo Histórico Provincial de Ourense

AHPOu. Clero. Libro 404, 416 y 461.

Archivo Histórico Nacional

AHN. Clero secular-regular, carp.1496. Doc. n. ${ }^{\circ} 12$.

\section{BIBLIOGRAFÍA}

ANDRADE CERNADAS, José Miguel (1995). O Tombo de Celanova. Santiago de Compostela: Consello da Cultura Galega. 2 vols.

ANDRADE CERNADAS, José Miguel (1997). El monacato benedictino y la sociedad de la Galicia medieval (siglos X al XIII). Sada: Seminario de Estudios Galegos- Ediciós do Castro. 
ARIAS SANJURJO, Joaquín (1914). Una excursión a la Ribera Sagrada. In Boletín de la Comisión Provincial de Monumentos Históricos y Artísticos de Orense, Tomo 5. Orense, pp. 49-57.

DURANY CASTRILlO, Mercedes (2006). San Pedro de Montes en la Edad Media. In Actas. San Pedro de Montes. Luz en la memoria. Ponferrada: Instituto de Estudios Bercianos, pp. 29-77.

DURO PEÑA, Emilio (1972). Catálogo de documentos reales del Archivo de la Catedral de Orense (8441520). «Miscelánea de Textos Medievales». 1, 9-146.

DURO PEÑA, Emilio (1977). El monasterio de San Esteban de Ribas de Sil. Ourense: Deputación Provincial.

FERRO COUSELO, Jesús (1967). Monjes y eremitas en las riberas del Miño y del Sil. «Bracara Augusta». 21, 199-214.

FREIRE CAMANIEL, José (1998). El monacato gallego en la Alta Edad Media. A Coruña: Fundación Pedro Barrié de la Maza. 2 vols.

GALLEGO DOMÍNGUEZ, Olga (1988). La organización administrativa territorial de la antigua provincia de Ourense a mediados del siglo XVIII. «Boletín Avriense». Anexo n. ${ }^{\circ} 10$.

GARCÍA TATO, Isidro (2004). Las encomiendas gallegas de la Orden militar de San Juan de Jerusalén. Estudio y edición documental. Tomo I. Época medieval. Santiago de Compostela: Instituto de Estudios Gallegos 'Padre Sarmiento'; C.S.I.C.; Xunta de Galicia.

GARCÍA TATO, Isidro; ÁLVAREZ ÁLVAREZ, Eleutino (2010). Las encomiendas gallegas de la Orden militar de San Juan de Jerusalén. Estudio y edición documental. Tomo II-a. La encomienda de Quiroga. Santiago de Compostela: Instituto de Estudios Gallegos 'Padre Sarmiento' - C.S.I.C. Xunta de Galicia.

LEIRÓS FERNÁNDEZ, Eladio (1951). Catálogo de los pergaminos monacales del Archivo de la S.I. Catedral de Orense. Santiago de Compostela: El Eco Franciscano.

MATTOSO, José (1992). Portugal medieval: novas interpretações. Lisboa: Imprensa Nacional-Casa da Moeda. NIETO MUÑIZ, Eduardo-Breogán; RODRÍGUEZ MUÑIZ, Víctor (2014). A necrópole de San Vítor (San Lourenzo de Barxacova, Parada de Sil, Ourense). Algo máis ca unha necrópole rupestre. In LÓPEZ QUIROGA, Jorge; MARTÍNEZ TEJERA, Artemio, ed. In concavis petrarum habitaverunt. El fenómeno rupestre en el Mediterráneo Medieval: de la investigación a la puesta en valor. Oxford: British Archaeological Reports, pp. 84-116.

PARADELA, Benito (1933-1935). Documentos del Monasterio de Montederramo. «Boletín de la Comisión Provincial de Monumentos Históricos y Artísticos de Orense». 10, 203-220.

PÉREZ RODRÍGUEZ, Francisco Javier (2002). La diócesis de Orense: de la reforma gregoriana al Concilio de Trento (siglos XII-XVI). In GARCÍA ORO, José, dir. Historia de las diócesis españolas. 15. Iglesias de Lugo, Mondoñedo-Ferrol y Orense. Madrid: Biblioteca de Autores Cristianos, pp. 395-469.

PÉREZ RODRÍGUEZ, Francisco Javier (2008). Mosteiros de Galicia na Idade Media (Séculos XII-XV). Guía histórica. Ourense: Deputación Provincial-Fundación Caixa Galicia.

RECUERO ASTRAY, Manuel et al. (1998). Documentos Medievales del Reino de Galicia: Alfonso VII (1116-1157). Xunta de Galicia.

RECUERO ASTRAY, Manuel et al. (2000). Documentos Medievales del Reino de Galicia: Fernando II (1155-1188). Xunta de Galicia.

RIVAS FERNÁNDEZ, Xosé Carlos (2004). Mosteiros prerrománicos ourensáns. In Ribeira Sacra. Esencia de espiritualidade de Galicia. Xunta de Galicia, pp. 57-78.

RIVAS FERNÁNDEZ, Xosé Carlos (1981). Vestigios prerrománicos de algunos olvidados monasterios y eremitorios orensanos. «Boletín Avriense». 11, 49-100.

RODRÍGUEZ MUÑIZ, Víctor (2010). O mosteiro de Santa Cristina de Ribas de Sil na Idade Media. «Boletín Avriense». Anexo 32.

SUÁREZ GONZÁLEZ, Ana (2012). Notas «de viaje» sobre un libro viajero (Arouca, Museu de Arte Sacra, Livro L-Ms.19). «Rudesindus». 8, 87-114. 


\title{
AS SEPULTURAS ESCAVADAS NA ROCHA DO CASTELO DE CRESTUMA (VILA NOVA DE GAIA, NORTE DE PORTUGAL): CONTEXTOS E PROBLEMÁTICA
}

\author{
ANTÓNIO MANUEL S. P. SILVA* \\ LAURA C. P. SOUSA** \\ PAULO A. P. LEMOS $* * * *$ \\ FILIPE M. S. PINTO*****
}

\begin{abstract}
Resumo: O complexo arqueológico do Castelo de Crestuma, situado na margem esquerda do rio Douro, a cerca de $16 \mathrm{~km}$ da sua foz, constitui um sítio arqueológico de longa diacronia, balizado entre a Proto-História e a Idade Média, mas com maior pujança de vestígios no período tardo-antigo. Entre os resultados de um recente projeto de investigação, conta-se a descoberta de duas sepulturas escavadas na rocha, em locais distintos, uma com planta «em banheira» e outra constituída por uma estrutura em dupla fossa, tipologia rara entre as sepulturas rupestres do território português. O estudo apresenta estas sepulturas e analisa o seu enquadramento cultural e cronológico, com alguns paralelos peninsulares para a de tipo mais singular.
\end{abstract}

Palavras-chave: Sepulturas escavadas na rocha; Sepulturas de dupla fossa; Arqueologia funerária medieval; Crestuma.

Abstract: The archaeological complex of Castelo de Crestuma is located on the left bank of the Douro River, about $16 \mathrm{~km}$ from its mouth. It is an archeological site with a long-term diachrony, marked out between Protohistory and the Middle Ages, but with a greater force of vestiges in the Late-Antique period. Among the results of a recent research project, there is the discovery of two rock-cut graves, in different places, one with a «bathtub» plant and the other consisting of a double-pit structure, a rare typology among the rocky graves of the Portuguese territory. The study presents these graves and analyzes their cultural and chronological framework, with some peninsular parallels for the more unique type.

Keywords: Rock-cut graves; «Double-pit» graves; Medieval funerary archaeology; Crestuma.

\section{O CASTELO DE CRESTUMA, O SÍTIO E A SUA HISTORIOGRAFIA}

O complexo arqueológico tem como ponto central uma colina à cota de 57 metros de altitude, situada na margem esquerda do rio Douro, a cerca de 16 quilómetros da sua foz, em Vila Nova de Gaia ${ }^{1}$. Trata-se de um esporão rochoso, assente

* GHAP/ASCR - Confraria Queirosiana; CITCEM. Email: amspsilva@hotmail.com.

** GHAP/ASCR - Confraria Queirosiana; CITCEM. Email: laura_sousa@hotmail.com.

*** GHAP/ASCR - Confraria Queirosiana. Email: paplemos@gmail.com.

${ }^{* * * *}$ GHAP/ASCR - Confraria Queirosiana; CITCEM. Email: filipemspinto@gmail.com.

${ }^{1}$ Coordenadas geográficas centrais: 4104’06.97”N e 8³0’12.53”O (WGS84). 
num substrato litológico metassedimentar de xistos, metaconglomerados, metagrauvaques e outras rochas, ladeado por dois pequenos areais onde desaguam linhas de água tributárias do Douro (Figs. 1 e 2).

A ocupação antiga deixou tradição no microtopónimo Castelo como em registos historiográficos que remontam ao século XVIII, mas só a partir de meados do século $\mathrm{XX}$, os vestígios arqueológicos, revelados fortuitamente, atraíram a atenção de estudiosos como Arlindo de Sousa ${ }^{2}$ e Carlos A. Ferreira de Almeida ${ }^{3}$. A caracterização do sítio variou entre «estação lusitano-romana ${ }^{4}$ e fortificação medieva com antecedentes proto-históricos, ou pelo menos tardorromanos ou tardo-antigos ${ }^{5}$. Outros autores referiram-se ainda ao sítio antes do início das escavações arqueológicas, pouco acrescentando à sua natureza, mas fundamentando uma alargada cronologia de ocupação, nomeadamente em resultado de destruições ocorridas na sequência de obras públicas na transição do século XX para o atual ${ }^{6}$.

Como resultado dos trabalhos arqueológicos feitos entre 2010 e $2015^{7}$, foi proposto um faseamento geral da ocupação ${ }^{8}$, em parte apoiado por datações absolutas, balizado entre a Proto-História e as épocas moderna e contemporânea. O período mais antigo é reconhecível apenas por artefactos em depósito secundário, sem associação a qualquer estrutura ou depósito homogéneo ${ }^{9}$, e no que respeita à ocupação romana, salvo alguns achados epigráficos ${ }^{10}$, as séries cerâmica e numismática parecem iniciar-se apenas no século IV. A fase de ocupação mais intensa no Castelo de Crestuma ter-se-á situado entre os séculos V e VI, abalizada por significativos conjuntos cerâmicos tardo-antigos ${ }^{11}$, uma excecional tegula epigrafada ${ }^{12}$ e diversas estruturas, nomeadamente um impressionante conjunto de buracos de poste distribuídos por toda a colina, a indiciar uma intensa utilização do espaço e evidentes vestígios de estruturas portuárias ${ }^{13}$. Por fim, é patente também o uso do local na Alta Idade Média, nomeadamente através de materiais cerâmicos atribuídos aos séculos IX-XI ${ }^{14}$, provavelmente relacionados com uma parte dos numerosos entalhes, afeiçoamentos e buracos de poste que caracteri-

\footnotetext{
2 SOUSA, 1945, 1957.

${ }^{3}$ ALMEIDA, 1978, 1989, 1992.

${ }^{4}$ SOUSA, 1945: 405, n. ${ }^{\circ}$.

${ }^{5}$ ALMEIDA, 1978: 11, 36, 51; 1989: 43; 1992: 374.

${ }^{6}$ GUIMARÃES, 1993a; 1993b: 20; SILVA, 2007; GUIMARÃES, GUIMARÃES, 2001.

${ }^{7}$ SILVA et al., 2017.

${ }^{8}$ SILVA, GUIMARÃES, 2011; SILVA, SOUSA, 2014.

${ }^{9}$ SILVA, SOUSA, PINTO, 2018.

${ }^{10}$ Nomeadamente, a lápide funerária encontrada em meados do século XX, datável de época flaviana ou da primeira metade do século II (GUIMARÃES, GUIMARÃES, 2001: 43-6, com remissão para bibliografia anterior) e, mais recentemente, uma ara, ainda inédita.

${ }^{11}$ SILVA, GUIMARÃES, 2013a; SILVA, CARVALHO, 2014; SILVA, 2015; SILVA, PEREIRA, CARVALHO, $2015 \mathrm{a}, 2015 \mathrm{~b}$.

12 VELÁZQUEZ SORIANO, 2017.

${ }^{13}$ SILVA, GUIMARÂES, 2013a, 2013b; SILVA, 2014.

14 SILVA, SOUSA, 2014.
} 
zam o sítio, não tendo ainda sido possível, pela falta de depósitos estratigráficos conservados, distinguir as arquiteturas em madeira medievas indiciadas pelas estruturas negativas daquelas de cronologia tardo-antiga, ou a eventual relação de continuidade entre ambas.

Constitui igualmente resultado do projeto de investigação arqueológica, aliás na linha das informações de A. Sousa ${ }^{15}$, a perceção de que a ocupação antiga do local não se cinge à colina do «Castelo», mas se encontrava distribuída espacialmente, não só por toda a frente de rio, a montante e a jusante daquela colina, numa extensão de pelo menos uns $350 \mathrm{~m}$, como também na elevação do Outeiro, localizada imediatamente a sudoeste, assim se justificando a designação de «complexo arqueológico» de Crestuma ${ }^{16}$.

\section{OS CONTEXTOS FUNERÁRIOS DE CRESTUMA}

As primeiras notícias sobre achados funerários antigos, como sepulturas escavadas na rocha, devem-se também a Arlindo de Sousa, que visitou o local nas décadas de 1940-1950. Sobre as primeiras descobertas registou:

Visitei, no verão de 1943, a freguesia de Crestuma, e descobri uma estação lusitano-romana [...]. Encontrei várias sepulturas cavadas na rocha; muitas covas redondas e rectangulares, igualmente cavadas na pedra firme, fragmentos de tégulas, de tijolo e de louças; um fragmento de lousa preta, adornada; um fragmento de mó manuária; muitos restos de muralhas; e de um grande fôsso artificial; um fragmento de lápide funerária [...] e outros objectos importantes ${ }^{17}$.

Este apontamento identifica diferentes contextos funerários, indiciando a existência de, pelo menos, uma necrópole romana, referenciada pelo «fragmento de lápide funerária» com inscrição transcrita e lida pelo autor, e outra (ou outras) de cronologia tardo-antiga ou altimedieval, indicada pelas «várias sepulturas» rupestres. É omisso, todavia, quanto à localização dos achados, quantidade e morfologia das sepulturas observadas. Em 1957, após revisitar o sítio com um guia local, o mesmo autor retoma o tema com novos dados e a notícia de outras descobertas, referindo-se a «sepulturas cavadas na fraga» designadamente "na base do Outeiro», "nas proximidades do lugar da Vessada», ficando até a sugestão da existência de mais do que um núcleo de enterramentos e inclusivamente «em outros montes de Crestuma»:

\footnotetext{
${ }^{15}$ SOUSA, 1945, 1957.

16 SILVA, 2007.

${ }^{17}$ SOUSA, 1945: 405-406, n. ${ }^{\circ}$ 5, sublinhados nossos.
} 
$\mathrm{Na}$ base do Outeiro apareceram, segundo o testemunho de vários crestumenses, sepulturas cavadas na fraga. [...]. É, também, de Crestuma, possivelmente do Castelo, o fragmento de uma lápide funerária [...]. De 1943 até agora, soubemos que no monte do Outeiro, nas proximidades do lugar da Vessada, quando se procedia à tiragem de pedra para um muro da estrada Crestuma-Porto, apareceram diversas sepulturas, cavadas nas fragas, de vários tamanhos, isoladas ou em grupos, principalmente, de duas, havendo, dentro delas, fragmentos de cal, de tijolos e de telhas, estando algumas, cobertas com terra, e outras, com pedaços de lousa. Disseram-nos que em outros montes de Crestuma, também, apareciam sepulturas, feitas nas fragas, assim como covas ou pias iguais às do Castelo ${ }^{18}$.

Estes achados serviram como referência a vários investigadores, levando à inclusão do sítio em estudos e inventários temáticos ${ }^{19}$, sendo de interesse anotar que estas sepulturas ou necrópoles rupestres são as únicas conhecidas em todo o concelho de Vila Nova de Gaia ${ }^{20}$.

\section{A SEPULTURA 1 DO CASTELO}

A colina do Castelo é superiormente pontuada por um pequeno edifício em alvenaria, constituída por dois compartimentos de diferente cronologia, certamente ligados à utilização agrícola daquele espaço em época contemporânea. A esta construção está associada uma «eira», de plano trapezoidal, com cerca de $100 \mathrm{~m}^{2}$, limitada a NNO e, em parte, a SSO por um corte vertical no afloramento rochoso; a sudeste e do que resta do lado SSO por uma fiada baixa de blocos de pedra, servindo-lhe por fim o referido anexo agrícola de enquadramento a nordeste. $\mathrm{O}$ solo corresponde na sua quase totalidade ao aplanamento do substrato xistoso original, completado na parte mais a sul e sudeste, por necessidade de nivelamento, por grandes lajes do mesmo material (Figs. 4 e 5). Não obstante o espaço ter sido reutilizado para a função agrícola em tempos modernos (construção do anexo e delimitação da área com o murete de pedra), a sua abertura é claramente muito mais antiga, como se evidencia pelas circunstâncias de existirem entalhes e negativos sobre a rocha no interior da construção referida ${ }^{21}$, da sepultura que nela foi identificada e até de uma tradição

\footnotetext{
${ }^{18}$ SOUSA, 1957: 16-18, sublinhados nossos.

${ }^{19}$ BARROCA, 1987: 165, n. ${ }^{\circ}$ 91; GUIMARÃES, 1993a, 1993b; SILVA, 2007: ficha 24.

${ }^{20}$ BARROCA, 2010-2011: 167, n. ${ }^{\circ} 105$.

${ }^{21}$ Nos muros desta construção reconhecem-se elementos pétreos, nomeadamente em granito, reaproveitados de anteriores estruturas e na base da sua parede nascente (a que se adossou um anexo menor) foi recolhida uma base de coluna.
} 
local que alude à suposta existência de uma cisterna ou qualquer outra estrutura subterrânea sob as lajes que prolongam o nivelamento da rocha ${ }^{22}$.

$\mathrm{Na}$ campanha de trabalhos arqueológicos de 2013 pretendeu-se, entre outros aspetos, avaliar o rebordo da plataforma rochosa superior e a ligação ao caminho, aparentemente moderno, que lhe dá acesso por NNO, tendo para isso sido intervencionada uma área de cerca de $12 \mathrm{~m}^{2}$. Os resultados da escavação revelaram que o rebordo rochoso terá sido aparentemente cortado, ou pelo menos afeiçoado, na vertical, por razões desconhecidas, vindo a encontrar-se o sepulcro aqui noticiado precisamente no extremo nor-noroeste da plataforma superior e da eira que já descre$\operatorname{vemos}^{23}$. A escavação da sepultura revelou, após o levantamento do nível de circulação atual e de uma pequena estrutura com pedras de xisto que correspondia à base de assentamento do muro delimitador da eira apenas duas unidades estratigráficas, uma preenchendo a fossa superior e a seguinte a cavidade feral, correspondendo a níveis de aterro muito similares, compostos essencialmente por sedimento com abundantes pedras de xisto de pequenas dimensões, muito desagregadas, resultantes de trabalhos de desmonte do substrato geológico ${ }^{24}$.

Não foram identificados quaisquer vestígios orgânicos de deposição funerária ou qualquer espólio arqueológico relevante, o que significa naturalmente que a tumba, se chegou a ser utilizada, terá sido, em época desconhecida, esvaziada e aterrada. Assim, tudo indica que os depósitos que preenchiam as duas cavidades foram efetuados num momento único, com o objetivo de colmatar o espaço interno do sepulcro, provavelmente para nivelamento da área e delimitação da «eira» em época moderna ou contemporânea. $\mathrm{O}$ único conteúdo artefactual registou-se no depósito que preenchia a fossa superior e era constituído por 15 pequenos fragmentos de telha de meia cana ou imbrex e tijolo, impossíveis de classificar cronologicamente.

A sepultura, que designámos convencionalmente como n. ${ }^{\circ} 1$ do Castelo (não obstante não haver evidência de quaisquer outras nas imediações), apresenta uma orientação NNO-SSE $\left(330^{\circ}\right)$, relativamente canónica na tradição cristã. É composta por dois planos desnivelados (Figs. 6, 7a e 7b), correspondendo ao tipo de sepultura «de secção em T», ou com fossa (sepulcral) e pré-fossa ou sobrecâmara, como adiante explanaremos.

A pré-fossa, de plano sub-retangular, abaulada nos lados maiores, tem comprimento máximo de 1,94 metros e largura entre 0,90 metros (na cabeceira e pés do sepulcro) e 1,24 metros na parte central. A uma profundidade entre 0,30 e 0,62 metros foi aberta, no eixo da cavidade a fossa ou cavidade feral, de configuração tra-

\footnotetext{
${ }^{22} \mathrm{Na}$ campanha arqueológica de 2013 foi levantada uma dessas lajes e escavada a superfície inferior, sem que se vislumbrasse qualquer indício de obras anteriores (GUIMARÃES et al., 2014).

${ }^{23} 41^{\circ} 4^{\prime} 7.46^{\prime \prime} \mathrm{N} ; 8^{\circ} 30^{\prime} 15.18^{\prime \prime} \mathrm{O}$ (WGS84).

${ }^{24}$ GUIMARÃES et al., 2014.
} 
pezoidal, com comprimento de 1,72 metros e largura entre $0,52 \mathrm{~m}$ (cabeceira), e 0,31 metros, sendo de $0,45 \mathrm{~m}$ a profundidade máxima. A base da cabeceira foi levemente rebaixada para apoio da cabeça do defunto, resultando numa pequena depressão arredondada com 0,38 $\mathrm{m}$ de diâmetro e $0,03 \mathrm{~m}$ de profundidade (Figs. 6, 7a e 7b). $\mathrm{O}$ degrau ou patamar que serve de base à pré-fossa, com um desnível entre 0,30 e $0,62 \mathrm{~m}$ para a superfície, constitui um rebordo aplanado ao redor da fossa sepulcral com uma largura entre 0,10 e 0,28 metros.

A segunda realidade observada nesta área é constituída pela presença nas imediações da sepultura de dezassete entalhes escavados na rocha (Figs. 5, 6, 7a e $7 b$ ), produzidos na sua totalidade em superfícies horizontais, patenteando as interfaces uma orientação vertical. Tipologicamente são entalhes de plano subcircular, sub-retangular, regos ou canais escavados na rocha e aplanamentos delimitados ${ }^{25}$, desconhecendo-se a sua funcionalidade ou eventual relação com o sepulcro, dadas as dificuldades de sequenciação estratigráfica dos entalhes no xisto e a escassa possança ou caráter contemporâneo dos respetivos enchimentos; todavia, é claro que aquele espaço foi sucessivamente alterado ou reformulado, dadas as sobreposições de alguns daqueles interfaces ${ }^{26}$.

\section{A SEPULTURA 1 DO OUTEIRO}

A existência de sepulturas no monte do Outeiro, a escassos 150 metros a SSO. do Castelo, havia sido apontada por Arlindo de Sousa, no trecho atrás citado, e consta igualmente da memória de alguns naturais. Na companhia de um deles ${ }^{27}$, que se recordava de, quando novo, ter observado uma dessas cavidades, de contorno antropomórfico, prospetámos a área entre o monte do Castelo e o lugar da Vessada (Fig. 2), acabando por identificar não o suposto sepulcro antropomórfico mas a sepultura escavada na rocha que agora se descreve.

Situa-se a o sepulcro, que numerámos como n. ${ }^{\circ} 1$ do Outeiro, na parte superior daquele monte, à cota aproximada de 65 metros e a menos de uma centena de metros da estrada municipal n. ${ }^{\circ} 109-2$, do lado poente de um velho caminho carral, marcado por profundas rodeiras na rocha viva, que conduzia do cimeiro lugar da Vessada à ribeirinha colina do Castelo $^{28}$ (Figs. 2 e 3). A sepultura, aberta no substrato geológico de xisto, localiza-se no rebordo de um afloramento cortado por trabalhos de extração de pedra imediatamente a norte e encontrava-se preenchida apenas por detritos vegetais e manta morta, não possuindo já quaisquer depósitos de preenchi-

\footnotetext{
${ }^{25}$ Cfr. SILVA, GUIMARÃES, 2013b para a definição destas tipologias e o relatório técnico da campanha (GUIMARÂES et al., 2014) para outros detalhes estratigráficos e a respetiva matriz estratigráfica.

${ }^{26}$ SILVA, 2013; GUIMARÃES et al., 2014.

${ }^{27} \mathrm{O}$ senhor Eng. ${ }^{\circ}$ Álvaro Meireles, a quem nos cumpre agradecer a disponibilidade e as informações facultadas.

${ }^{28} 41^{\circ} 4^{\prime} 3.50$ ”'N; 8³0'17.16”O (WGS84).
} 
mento antigos. Após a sua limpeza e registo, verificou-se que se trata de uma sepultura escavada na rocha não antropomórfica, apresentando contorno entre o ovalado e o sub-retangular, com cantos arredondados, tipo «banheira», na designação que se tornou comum. Na cabeceira regista-se um pequeno entalhe circular, com aproximadamente $5 \mathrm{~cm}$ de diâmetro, que nos parece resultar de ação moderna associada à exploração de pedra vizinha. A base do sepulcro apresenta uma pequena inclinação, com a cabeceira um pouco mais elevada. De orientação NNE-SSO $\left(218^{\circ}\right)$, mede 1,85 $\mathrm{m}$ por 0,50 $\mathrm{m}$ de largura média, com cerca de $0,40 \mathrm{~m}$ de profundidade (Figs. 8 e 9).

Embora a cobertura vegetal não permita a observação da rocha natural, o enquadramento e a morfologia do maciço fazem supor a eventual existência de outras sepulturas nas proximidades, e uma pequena prospeção na envolvência imediata permitiu detetar algumas lajes em xisto, de configuração esteliforme, que poderão ser aproximadas às lousas referidas por Arlindo de Sousa utilizadas quer para cobertura das sepulturas, quer como estelas ou suporte de epitáfios, como se pode ler nas passagens que transcrevemos. Num terreno a cerca de uma centena de metros a SSO. desta sepultura, onde a tradição local situa também o achado das sepulturas referidas por aquele Autor, foram recentemente feitas sondagens arqueológicas de pré-avaliação de impactes de um projeto imobiliário, resultando desses trabalhos a identificação de depósitos culturalmente homogéneos, com materiais cerâmicos e vidros tardo-romanos, relacionados com estruturas aparentemente de caráter não funerário ${ }^{29}$.

\section{DISCUSSÃO E PARALELOS FORMAIS}

Como interpretar ou relacionar, se for o caso, estas duas ocorrências de sepulturas escavadas na rocha (Fig. 3)? A sepultura 1 do Outeiro, que julgamos provável que esteja inserida numa necrópole de maior dimensão - considerando o contexto microtopográfico e os informes de Arlindo de Sousa ${ }^{30}$ - pode dever a sua localização à simples proximidade de um caminho antigo, circunstância que justifica a situação de muitas pequenas necrópoles de sepulturas escavadas na rocha sem ligação evidente a qualquer templo. Todavia não pode deixar de evocar-se (para este sepulcro como para o do Castelo) uma eventual relação com o mosteiro eremítico de Crestuma, que poderá remontar aos começos do século $\mathrm{X}^{31}$ e sobreviveu pelo menos até ao ano de $1118^{32}$. A admitir-se a relação desta possível necrópole com o sítio do Castelo (e este

\footnotetext{
${ }^{29}$ COUTO, 2018.

${ }^{30}$ SOUSA, 1945, 1957.

${ }^{31}$ A referência mais antiga a este cenóbio data de 922 e encontra-se num documento controverso (o n. ${ }^{\circ} 25$ dos Diplomata et Chartae), considerado falso por muitos autores, mas que outros entendem legítimo, ainda que admitindo interpolações na cópia do século XII; tal é o caso de J. ALARCÃO (2019: 19, 37-38) e M. CARRIEDO, que sugere mesmo que o mosteiro de Crestuma possa ser anterior a 915 (1998-1999: 320-1, 379, n 123). Cfr., sobre este assunto, SILVA, REAL, no prelo.

${ }^{32}$ MATTOSO, 2002: 93.
} 
como um "povoado», o que ainda não é totalmente claro), a sua implantação seria verdadeiramente privilegiada no quadro de um modelo locacional no qual as áreas sepulcrais surgem em relevos destacados sobre o casario e os campos de cultivo ${ }^{33}$, embora a relação entre os cemitérios e os povoados seja usualmente problemática no quadro da organização territorial anterior à rede paroquial ${ }^{34}$.

Quanto à sua cronologia, muitos investigadores atribuem uma cronologia na generalidade mais antiga às sepulturas escavadas na rocha de contorno ovalado, ou do «tipo banheira», em relação às antropomórficas ${ }^{35}$, na senda da teoria evolutiva de Alberto del Castillo ${ }^{36}$, que propôs uma datação inicial pelo menos do século VII para este morfotipo, bem como para os sepulcros de contorno retangular e trapezoidal, que teriam começado a evoluir para formas antropomórficas, de execução mais complexa, em meados do século IX, sendo estas - muitas vezes designadas como olérdolanas, do sítio epónimo de Santa Maria e São Miguel de Olèrdola, Alt Penêdes, Catalunha ${ }^{37}$ - as tipologias mais comuns nos séculos X e XI. Não obstante, aquele Autor admitiu também, com base no estudo das necrópoles da Revenga e de Cuyacabras (Burgos), a perduração do tipo ovalado até ao período da Reconquista ${ }^{38}$. Castillo defendia também que as cabeceiras antropomórficas se distribuíam em duas grandes regiões geográficas: as de contorno angular seriam especificamente catalãs, enquanto as de plano curvilíneo ou em arco de ferradura seriam típicas das regiões mais ocidentais ${ }^{39}$. Não obstante o mérito das suas observações, as teses de Castillo rapidamente foram postas em causa, primeiro pelos fundamentos históricos de algumas das suas propostas ${ }^{40}$ (ainda que os discípulos e outros autores mantivessem o ênfase nas tipologias e, no geral, a sequência cronológica de Castillo) ${ }^{41}$; e depois, com maior trabalho de campo e a renovação epistemológica nos estudos de arqueologia medieval, também no que toca à distribuição geográfica das tipologias, ao rigor da sequência evolutiva e à excessiva valorização dos aspetos formais das tumbas ${ }^{42}$.

\footnotetext{
${ }^{33}$ LALIENA COBRERA, 2009: 155. Por necessidade de economia de espaço, utilizámos nas referências bibliográficas do texto apenas o primeiro apelido nos antropónimos hispânicos (salvo os compostos ou mais consagrados pelo uso). ${ }^{34}$ ARIÑO, 2013: 97; MARTÍN VISO, 2007: 23.

${ }^{35}$ LÓPEZ QUIROGA, GARCÍA PÉREZ, 2014; MARTÍN VISO, 2014.

${ }^{36}$ CASTILLO 1970; 1972.

${ }^{37}$ Ver, a este propósito, BARROCA, 2010-2011: n. ${ }^{\circ} 6$.

${ }^{38} \mathrm{O}$ que a investigação moderna tem claramente comprovado (LÓPEZ QUIROGA, GARCÍA PÉREZ, 2014; MARTÍN VISO, 2014).

${ }^{39}$ CASTILLO, 1970: 837-9.

${ }^{40}$ Castillo atribuía estas sepulturas, que julgava exclusivamente hispânicas, ao «repovoamento» moçárabe após a Reconquista (CASTILLO, 1970: 838), tese que a investigação histórica invalidou.

${ }^{41}$ Cfr., por exemplo, RIU, 1977: 454-6 e BOLÒS i MASCLANS, PAGES i PARETAS, 1982.

42 BIELSA, 1975; KLIEMANN, 1986 (trabalho académico não publicado, citado por BARROCA, 1987: 115 e ss.; 2010-2011: 126-128)
} 
Não interessando a este estudo a crítica ou revisão das teses de Alberto del Castillo $^{43}$, devemos sublinhar, todavia, a profunda mudança de perspetiva verificada no estudo das sepulturas e necrópoles medievais observada nas últimas décadas, secundarizando os meros ensaios tipológico-evolutivos em função de análises de caráter mais holístico, na ótica, designadamente da arqueologia da paisagem e da compreensão mais alargada dos contextos sociais, económicos, culturais e políticos nos quais devem inserir-se os ritos funerários e hábitos tumulares das comunidades pós-romanas e alti-medievais. Esta inflexão de abordagem é patente em numerosos estudos, inaugurados no nosso país com o já referido ensaio fundamental de Mário Barroca $^{44}$ e continuados por levantamentos e estudos de povoamento de âmbito regional ${ }^{45}$ e estudos de caso $^{46}$, merecendo destaque nos últimos anos os trabalhos orientados para a Beira Interior e a região de Riba Côa ${ }^{47}$.

Nesta linha, a investigação mais proveitosa orienta-se na atualidade para a compreensão dos espaços funerários «dentro de un paisaje, y sobre todo dentro de la construcción simbólica de ese paisaje como un escenario en el que se mueve la identidad individual y colectiva ${ }^{48}$, entendendo-se a paisagem como uma

arena privilegiada para la construcción de la memoria y de la identidad, una construcción en la que ni es un mero espejo de procesos externos, ya que resulta ser parte activa, ni es un resultado fi jo y estable, sino que los mismos paisajes son vividos y conceptualizados de formas diferentes por los individuos, los grupos sociales y las instituciones ${ }^{49}$.

Deste modo, a eleição dos cemitérios rupestres, como das sepulturas isoladas - considerados ambos como espaços seletivos e de particular investimento material e simbólico - poderá ter correspondido a uma estratégia de manipulação da paisagem por parte das comunidades camponesas ${ }^{50}$, assim se gerando uma matizada «geografía funerária» na qual os espaços sepulcrais não são meros elementos passivos ou monofuncionais mas, pelo contrário, constituem dispositivos mnemónicos,

\footnotetext{
${ }^{43}$ Cfr. entre outros, LÓPEZ QUIROGA, 2010: 297 ss.; BARROCA, 2010-2011: 122-9; MARTÍN VISO, 2012a: 166-7; 2012b: 5-6; 2014: 31-5; LÓPEZ QUIROGA, GARCÍA PÉREZ, 2014:

${ }^{44}$ BARROCA, 2010-2011 [1987].

${ }^{45}$ Cf. TEIXEIRA, 1996; LOPES, 2002; VIEIRA, 2004; SANTOS, 2005; LOURENÇO, 2007; TENTE, $2007,2010$. (entre muitos outros, recentemente sintetizados numa abordagem de tipo similar - GUEDES, 2015: I, 27-48; II, 148, mapa 2). Para uma perspetiva histórica mais abrangente desta temática em Portugal, vejam-se BARROCA, 2010-2011: 117-122 e TENTE, CARVALHO, 2015.

46 TENTE, LOURENÇO, 1998, 2002; CABRITA, 2011; TENTE, 2015.

${ }^{47}$ MARTÍN VISO, 2007, 2008, 2011, 2012b, 2014a: 107-17; TENTE, 2017; BROOKES, TENTE, PRATA, 2017.

${ }^{48}$ MARTÍN VISO, 2016: 865.

${ }^{49}$ MARTÍN VISO, 2016: 865.

${ }^{50}$ RUBIO DÍEZ, 2018: 287; LALIENA COBRERA, ORTEGA ORTEGA, 2005: 182.
} 
tecnologias de memória geradoras de identidades, numa palavra, arquiteturas para os vivos e não mero local de deposição funerária ${ }^{51}$.

Nesta perspetiva, a análise crítica dos singelos testemunhos de arqueologia tumular de Crestuma pouco alcançará num plano de mera analogia tipológica ainda assim útil para contextualizar um pouco o modelo incomum da sepultura do Castelo - e pouco acrescentará talvez ao quadro cronológico, uma vez que a questão fundamental, como sintetizou Martín Viso ${ }^{52}$, não é tanto a de datar as tumbas, mas sim a de questionar e tentar interpretar no tempo e na paisagem os processos sociais que enquadraram a sua construção.

A sepultura do Castelo destaca-se por três aspetos: a sua tipologia incomum, singularidade e localização. No que respeita à sua forma, o acentuado rebaixamento do plano onde se insere a fossa sepulcral (entre 0,30 e 0,62 m) quase não encontra paralelo em sepulturas congéneres do nosso país. Na verdade, ocorrem por vezes sepulcros com pequenos rebordos ou molduras para encaixe da laje ou lajes da cobertura, mas de muito menor desnível, como pode ver-se em vários casos do Entre Douro e Minho $^{53}$, ou por exemplo em sepulturas da necrópole que rodeia a igreja de Sendim, Tabuaço, com 21 sepulcros antropomórficos ${ }^{54}$. De acordo com o estudo mais recente deste conjunto sepulcral, 19 dos túmulos apresentam um pequeno rebordo rebaixado a emoldurar parcialmente o contorno das sepulturas, conservando-se mesmo num deles (sepultura 20) a tampa monolítica, que mede 1,66 por 0,71 metros, com uma espessura de $0,22 \mathrm{~m}^{55}$.

$\mathrm{Na}$ verdade, as sepulturas que vêm sendo designadas como de «secção em $T{ }^{56}$, de fossa escalonada, fossa e pré-fossa ou de fossa e sobrecâmara ${ }^{57}$, raras em Portugal, são mais comuns noutras áreas da Península Ibérica e em países vizinhos, com a particularidade de ocorrerem tanto em ritos funerários cristãos, como muçulmanos ou judaicos, num arco cronológico muito extenso. Não podendo detalhar aqui o volume já relativamente numeroso de ocorrências, tanto peninsulares como de outros países ${ }^{58}$ recordamos só alguns dos casos mais paradigmáticos.

No período pós-romano, esta arquitetura funerária evidencia-se especialmente em contextos funerários visigóticos da região de Madrid, Toledo e do sul de Espanha, podendo destacar-se como exemplos as necrópoles de Gózquez (Madrid) e Marro-

\footnotetext{
${ }^{51}$ WILLIAMS, 2006: 191; SEMPLE, WILLIAMS, 2015; MARTÍN VISO 2014a: 75-78.

${ }^{52}$ MARTÍN VISO, 2014b.

${ }^{53}$ BARROCA, 2010-2011, fig. 6.

${ }^{54}$ PERPÉTUO et al., 1999: 223-32; GUEDES, 2015.

${ }^{55}$ GUEDES, 2015: I: 71-3; II: 7, 9, 182, 240.

${ }^{56}$ CONTRERAS MARTÍNEZ, FERNÁNDEZ UGALDE, 2006: 547; NAVARRO, 2017: 284.

57 VIGIL-ESCALERA GUIRADO, 2015: 257.

${ }^{58}$ Por necessária economia de espaço, os elementos descritivos e comentários aqui apresentados sobre estes e outros casos de sepulturas de dupla fossa serão muito resumidos e limitados à Península Ibérica, reservando-se para outro estudo (SILVA, no prelo) uma análise mais aprofundada.
} 
quíes Bajos (Jaén). No primeiro caso, uma necrópole com centenas de enterramentos datados de entre o segundo terço do século VI e meados do século VIII ${ }^{59}$, as sepulturas de secção em $\mathrm{T}$ constituem um dos géneros melhor representados, tendo sido definido particularmente o subtipo II2, caracterizado por uma pré-fossa de significativa profundidade em relação à cavidade feral, sendo o espaço compreendido entre as lajes ou a cobertura em madeira que a fechavam e a superfície do terreno colmatado normalmente com terra ${ }^{60}$.

No grande complexo de necrópoles de Marroquíes Bajos, em Jaén, com nove áreas de inumação cristã e muçulmanas, identificam-se também numerosas sepulturas de fossa escalonada em contextos tardo-antigos, de época visigoda e moçárabe, ou seja, globalmente entre os séculos VI-VII e o século VIII, coexistindo já com a ocupação muçulmana ${ }^{61}$. A configuração da cavidade tumular é variável, entre o ovalado, o trapezoidal ou o contorno antropomórfico, e a profundidade da pré-fossa é também distinta, bem como os sistemas de cobertura da fossa inferior (madeira, lajes de pedra ou mesmo tegulae nos casos mais antigos), admitindo-se que a maior parte das sepulturas tivessem sinalização externa, nomeadamente por um pequeno tumulus de terra que sobressaía sobre a cota de circulação ${ }^{62}$.

Por uma confluência de tradições de arquitetura funerária ainda não totalmente esclarecida ${ }^{63}$ as inumações de rito islâmico em Marroquíes Bajos utilizam também de forma muito significativa as sepulturas de dupla fossa, nomeadamente a grande maqbara "do caminho de Bayyāsa», que conta com cerca de 700 enterramentos, onde esta tipologia se observa em $27 \%$ das sepulturas, com uma cronologia entre a segunda metade do século VIII e o século XIII ${ }^{64}$. Há paralelos para o uso de sepulturas de fossa escalonada, com maior ou menor profundidade, correspondendo ao tipo designado como shaqq na tradição islâmica maliquita (a dominante na Península após o século $\mathrm{X}$ ), em diversos maqabir, nomeadamente nas regiões de Múrcia, Alicante, Huelva ou Almeria, frequentemente datados a partir da época emiral e podendo ainda subsistir, de forma cada vez mais pontual, no período almóada ${ }^{65}$.

Passando aos contextos funerários medievais cristãos, parece observar-se este tipo de sepulturas essencialmente em áreas de enterramento que poderíamos designar como moçárabes, como sucedeu em Mérida, onde uma intervenção urbana permitiu a escavação de 216 inumações em decúbito supino, integrando os dispositivos sepulcrais

\footnotetext{
${ }^{59}$ VIGIL-ESCALERA GUIRADO, 2013: 7.

${ }^{60}$ CONTRERAS MARTÍNEZ, 2006; CONTRERAS MARTÍNEZ, FERNÁNDEZ UGALDE, 2006.

${ }^{61}$ NAVARRO, 2017: 404 e ss.

${ }^{62}$ NAVARRO, 2017; CASTILLO ARMENTEROS, NAVARRO PÉREZ, SERRANO PEÑA, 2011. SERRANO PEÑA, CASTILLO ARMENTEROS, 2000.

${ }^{63}$ SILVA, no prelo.

${ }^{64}$ SERRANO PEÑA, CASTILLO ARMENTEROS, 2000; CASTILLO ARMENTEROS, NAVARRO PÉREZ, SERRANO PEÑA, 2011. NAVARRO, 2017, 2018.

${ }^{65}$ SILVA, no prelo.
} 
$7 \%$ de sepulturas em «doble fossa», tendo sido a necrópole datada entre os séculos VIII e IX ${ }^{66}$. Todavia, os casos que talvez melhor possamos aproximar da sepultura do Castelo de Crestuma encontram-se em Granada, nomeadamente na necrópole de Tózar (Moclín), onde tem vindo a ser estudada uma necrópole rupestre, com mais de 70 tumbas já identificadas, na sua grande maioria de contorno antropomórfico, das quais cerca de metade apresentam «escalón para cubierta», sendo possível, com base em datações de radiocarbono, propor uma utilização daquele espaço cemiterial entre o século X e o século XII, ou quando muito $1 .^{a}$ metade do XIII ${ }^{67}$.

Curiosamente, também alguns dos cemitérios judaicos peninsulares adotam o mesmo tipo de sepultura, sendo melhor conhecidos os casos de Montjuïc, em Barcelona, e Lucena, Córdoba. No primeiro foram identificadas fossas de plano antropomórfico, ovalado e trapezoidal, estas últimos muitas vezes dotadas de ataúde, variando também a altura da pré-fossa, parecendo que, no caso das mais profundas, o espaço entre a cobertura (normalmente com lajes) da fossa inferior e a superfície seria objeto de aterro, sinalizando-se externamente o sepulcro com lápides; a cronologia proposta para o fossar medeia entre os séculos IX e XIV ${ }^{68}$. Em Lucena as sepulturas em fossa escalonada constituem o tipo mais comum, sendo a pré-fossa na maior parte dos casos de planta retangular e a fossa sepulcral essencialmente retangular ou ovalada. Foram realizadas datações por Carbono 14 de duas das sepulturas em fossa escalo-

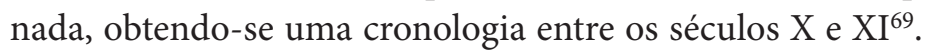

Regressando a Portugal, o recenseamento da utilização de sepulturas de dupla fossa em enterramentos dos ritos religiosos aqui tratados mostra por enquanto evidência muito rara. Entre as necrópoles muçulmanas, recentemente objeto de trabalho de síntese ${ }^{70}$, apenas em três sítios poderá observar-se esta arquitetura, e nem sempre de forma clara: em Beja (Escola Secundária Diogo de Gouveia), na Horta do Pinheiro (Alcácer do Sal) e sobretudo no sítio da Xancra $2(\mathrm{Cuba})^{71}$, onde, entre três dezenas de enterramentos, alguns poderiam corresponder a fossas tipo shaqq, embora o desnível nas paredes laterais seja explicado sobretudo como forma de apoio das coberturas ${ }^{72}$.

Entre as necrópoles de sepulturas escavadas na rocha distribuídas um pouco por todo o nosso país, não eram conhecidas sepulturas desta tipologia, mas duas escavações arqueológicas recentes matizaram um pouco este panorama. Na verdade, algumas sepulturas de fossa escalonada, se bem que com características muito particulares, foram recentemente identificadas na necrópole da igreja de Paço de Sousa,

\footnotetext{
${ }^{66}$ DELGADO MOLINA, 2006.

${ }^{67}$ JIMÉNEZ PUERTAS, MATTEI, RUIZ JIMÉNEZ, 2011; MATTEI, 2014: 186-192; 2018: 518.

${ }^{68}$ MAESE i FIDALGO, 2003, 2006; MAESE i FIDALGO, CASANOVAS i MIRÓ, 2002-2003.

${ }^{69}$ BOTELLA ORTEGA, CASANOVAS i MIRÓ, 2009.

${ }^{70}$ GONZAGA, 2018.

${ }^{71}$ Cfr. GONZAGA, 2018 e SILVA, no prelo, com bibliografia.

${ }^{72}$ BRAZUNA, GODINHO, 2014: 221.
} 
Penafiel ${ }^{73}$. Junto à cabeceira do templo, a nascente, foram escavadas duas inumações singulares, definidas "por uma vala de grandes dimensões com forma sub-retangular, paredes com pouca inclinação e fundo aplanado. $\mathrm{Na}$ área central encontra-se a cavidade sepulcral, coberta por lajes de granito e/ou xisto ${ }^{74}$. A profundidade da pré-fossa (numa das sepulturas com mais de um metro de profundidade) identifica esta arquitetura com as sepulturas de dupla câmara que vimos tratando, mas os sepulcros de Paço de Sousa apresentavam ainda um elemento particularmente estranho, pois aparentemente a pré-fossa era recoberta por um nível de saibro compactado onde se abria um orifício subcircular de apreciáveis dimensões - suficiente para a passagem de uma pessoa ${ }^{75}$ - permitindo supor que originalmente o espaço da pré-fossa não fosse colmatado e constituísse uma espécie de câmara hipogeia.

Por fim, merece nota de destaque uma intervenção na Mouraria, em Lisboa, que terá exumado, porventura, o primeiro cemitério judaico português. Sob uma necrópole muçulmana, tardia, e níveis de aterro com interessantes restos das olarias locais da época moderna, encontraram-se mais de duas centenas de inumações com os corpos em decúbito supino, as quais, pelo conteúdo artefactual das sepulturas e outros dados históricos, os Autores da escavação não têm dúvida em classificar como de rito judaico, ligando mesmo o final da utilização da necrópole ao decreto de expulsão dos judeus em $1497^{76}$. O que aqui nos interessa em particular é que $5 \%$ das sepulturas escavadas na rocha correspondem aparentemente ao modelo de dupla fossa ${ }^{77}$, e sendo a datação de finais do século XV apresentada pelos autores um terminus ante quem, a cronologia destas sepulturas poderá certamente ser bem mais antiga.

A análise de todos estes paralelos, diversos na geografia, na cronologia e no ritual religioso permitir-nos-á agora, num segundo andamento, equacionar melhor as sepulturas escavadas na rocha de Crestuma, não só na singularidade tipológica que a do Castelo patenteia, como também na análise da espacialidade e contextualização arqueológica que ambas requerem, tanto mais que estão situadas num sítio profundamente complexo e que ainda não foi possível enquadrar cabalmente em termos de funcionalidade, significado e posicionamento histórico.

\footnotetext{
73 TEIXEIRA, FONSECA, 2017.

74 TEIXEIRA, FONSECA, 2017: 34.

75 TEIXEIRA, FONSECA, 2017: 34-39.

${ }^{76}$ PONCE et al., 2017a; 2017b: 1709.

${ }^{77}$ PONCE et al., 2017a: 157-9; 2017b: 1707.
} 


\section{AGRADECIMENTOS}

Queremos deixar expresso o nosso reconhecimento a vários investigadores e entidades por informações prestadas para este trabalho, designadamente a Luca Mattei (Univ. Granada), Mercedes Navarro Perez (Univ. Jaén), Miguel Lago e Sandra Brazuna (Era Arqueologia) e Ricardo Teixeira (Arqueologia e Património).

\section{BIBLIOGRAFIA ${ }^{78}$}

ALARCÃO, Jorge (2019). O nome e os lugares de Portucale. «Revista de Portugal». 16, 8-15.

ALMEIDA, Carlos A. Ferreira de (1978). Castelologia Medieval de Entre-Douro-e-Minho, desde as origens até 1220. Porto: Faculdade de Letras da Universidade do Porto. Dissertação complementar de Doutoramento.

ALMEIDA, Carlos A. Ferreira de (1989). Castelos e cercas medievais, séculos X a XIII. In MOREIRA, Rafael, dir. História das Fortificações Portuguesas no Mundo. Lisboa: Alfa, pp. 38-54.

ALMEIDA, Carlos A. Ferreira de (1992). Castelos medievais do Noroeste de Portugal. In Finis Terrae. Estudios en Lembranza do Prof. Dr. Alberto Balil. Santiago de Compostela: Universidade de Santiago de Compostela, pp. 371-385.

ARIÑO, Enrique (2013). El hábitat rural en la Península Ibérica entre finales del siglo IV y princípios del VIII: un ensayo interpretativo. "Antiquité Tardive». 21, 93-123.

BARROCA, Mário Jorge (1987). Necrópoles e Sepulturas Medievais de Entre-Douro-e-Minho (Séculos V $a X V)$. Porto: Faculdade de Letras da Universidade do Porto. Dissertação para Provas Públicas de Aptidão Pedagógica e Capacidade Científica.

BARROCA, Mário Jorge (2010-2011). Sepulturas escavadas na rocha de Entre Douro e Minho. «Portvgalia». Nova Serie, 31-32, 115-182.

BIELSA, Maria Asunción (1975). Necrópolis altomedievales en Aragón. In Crónica del XIII Congreso Arqueológico Nacional. Zaragoza: Universidad de Zaragoza, pp. 995-1002.

BOLÓS MASCLANS, Jordi; PAGÉS PARETAS, Montserrat (1982). Les sepultures excavades a la roca. In RIU, Manuel, dir. Necropolis i sepultures medievals de Catalunya. Barcelona: Departament d'Historia Medieval, pp. 59-103.

BOTELLA ORTEGA, Daniel; CASANOVAS i MIRÓ, Jordi (2009). El cementerio judío de Lucena (Cordoba). «MEAH. Sec. Hebreo». 58, 3-25.

BRAZUNA, Sandra; GODINHO, R. (2014). Xancra II (Cuba, Beja): resultados preliminares da necrópole islâmica. In $4^{\circ}$ Colóquio de Arqueologia do Alqueva - O Plano de Rega (2002-2010) [Memórias d’Odiana, 2a Série]. Évora: EDIA, pp. 219-224.

BROOKES, Stuart; TENTE, Catarina; PRATA, Sara (2017). Interpreting Rock-Cut Grave Cemeteries: The Early Medieval Necropolis and Enclosure of São Gens, Portugal. «Medieval Archaeology». 61: 2, 215-238.

CABRITA, Luís (2011). Contributo para o estudo do povoamento rural alto-medieval de Silves. In GOMES, M. V.; GOMES, R. V.; TENTE, C. coord. Cristãos e Muçulmanos na Idade Média Peninsular. Encontros e Desencontros. Lisboa: Instituto de Arqueologia e Paleociências, pp. 239-254.

CARRIEDO TEJEDO, Manuel (1998-1999). Los episcopológios portugueses en los siglos IX y X a través de dos obispos de Oporto, Froarengo (890-918) y Hermogio (923-927) y su situación a comienzos del siglo XI. «Bracara Augusta». 48, 101-102, 114-115, 311-401.

\footnotetext{
${ }^{78}$ Para não alongar demasiado a listagem, reduzimos as ligações para os conteúdos em linha aos casos onde são indispensáveis.
} 
CASTILLO ARMENTEROS, J. C.; NAVARRO PÉREZ, M.; SERRANO PEÑA, J. L. (2011). Las maqbaras de Marroquíes Bajos (Jáen) en torno al 711. In 711- Arqueologia e Historia entre dos mundos. Alcalá de Henares: Museo Arqueológico Regional, vol. 1, pp. 273-291.

CASTILLO, Alberto del (1970). Cronología de las tumbas llamadas "olerdolanas". In XI Congreso Nacional de Arqueología. Zaragoza: Secretaría General de los Congresos Arqueológicos Nacionales, pp. 835-845.

CASTILLO, Alberto del (1972). Excavaciones altomedievales en las provincias de Soria, Logroño y Burgos. Madrid: Ministério de Educación y Ciencia.

CONTRERAS MARTÍNEZ, Miguel (2006). Evolución del ritual funerario entre los ss. VI y VIII d.C. en el asentamiento de Gózquez de Arriba (San Martín de la Vega, Madrid). In LOPEZ QUIROGA, Jorge; MARTÍNEZ TEJERA, A.; MORÍN DE PABLOS, J., ed. Galia e Hispania en el contexto de la presencia germánica (ss. V-VII). Balance y perspectivas. Oxford: Archeopress, pp. 273-288.

CONTRERAS MARTÍNEZ, Miguel; FERNÁNDEZ UGALDE, A. (2006). El espacio funerario en el poblado de época visigoda de Gózquez de Arriba (San Martín de la Vega, Madrid). In La investigación arqueológica de la época visigoda en la Comunidad de Madrid. 2 - La Ciudad y el Campo [Zona Arqueológica, 8]. Alcalá de Henares: Museo Arqueológico Regional, pp. 539-557.

COUTO, Marcos (2018). Relatório Preliminar. Obras de Construção de um Edifício sito na Estrada da Vessada, Lugar de Vessada. Vila Nova de Gaia. Porto: Império Arqueologia.

DELGADO MOLINA, Pedro (2006). Excavación de un área funeraria cristiana en época andalusí. Intervención arqueológica llevada a cabo en la calle B. Arias Montano c.v. a Avda. Reina Sofía (Mérida). In Mérida. Excavaciones Arqueológicas 2003. Mérida: Consorcio Ciudad Monumental, pp. 285-312.

GONZAGA, Ana (2018). Arqueologia da Morte no Gharb "português"Almocavares e outros registos funerários. Coimbra: Faculdade de Letras da Universidade de Coimbra. Dissertação de Mestrado.

GUEDES, César (2015). A sul do Douro: percurso pelas sepulturas escavadas na rocha entre os rios Távora e Cabrum. Porto: Faculdade de Letras da Universidade do Porto. Dissertação de Mestrado.

GUIMARÃES, J. Gonçalves (1993a). Alguns materiais arqueológicos de estações da margem sul do Rio Douro: as tegulae. «Lvcerna». 2. a Serie, 3, 217-235. (Actas do VI Coloquio Portuense de Arqueologia, 1987).

GUIMARÃES, J. Gonçalves (1993b). Roteiro Arqueológico de Vila Nova de Gaia. Vila Nova de Gaia: Câmara Municipal; Solar Condes de Resende.

GUIMARÃES, J. Gonçalves; GUIMARÃES, S. (2001). O Castelo de Crestuma, uma estação arqueológica

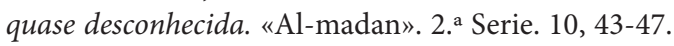

GUIMARAES, J. Goncalves et al. (2014). Programa de investigação arqueológica e valorização cultural do Complexo Arqueológico do Castelo de Crestuma - Vila Nova de Gaia. Projeto CASTR'UÍMA. $4^{a}$ Campanha de Trabalhos Arqueológicos (2013). Relatório Final. Vila Nova de Gaia: Gab. História, Arqueologia e Património (ASCR/CQ).

JIMÉNEZ PUERTAS Miguel; MATTEI, L.; RUIZ JIMÉNEZ, A. (2011). Rituales y espacios funerarios en la Alta Edad Media: las necrópolis excavadas en la roca de Martilla y Tózar (Granada). In JIMÉNEZ PUERTAS, M.; GARCÍA-CONTRERAS RUIZ, G., ed. Paisajes históricos y arqueología medieval. Salobreña (Granada): Alhulia, pp. 139-175.

KLIEMANN, Katja (1986). Un aspecte de les necropolis medievals: les sepultures antropomorfes a Catalunya. Barcelona: Universidad de Barcelona. Tese de Licenciatura.

LALIENA COBRERA, Carlos (2009). Acerca de la articulación social de los espácios rurales en el Ebro medio (siglos V-IX). «Mainake». 31, 149-163.

LALIENA COBRERA, Carlos; ORTEGA ORTEGA, J. (2005). Arqueología y poblamiento. La cuenca del río Martín en los siglos V-VIII. Zaragoza. 
LOPES, Isabel Alexandra Resende Justo (2002). Contextos Materiais da Morte durante a Idade Média: as necrópoles do Douro Superior. Porto: Faculdade de Letras da Universidade do Porto. Dissertação de Mestrado. 2 vols.

LÓPEZ QUIROGA, Jorge (2010). Arqueología del Mundo Funerário en la Península Ibérica (siglos V-X). Madrid: La Ergástula.

LÓPEZ QUIROGA, Jorge; GARCÍA PÉREZ, Laura (2014). Las tumbas excavadas en la roca en la Península Ibérica: tipología, cronología y problemas de interpretación. In LÓPEZ QUIROGA, Jorge; MARTÍNEZ TEJERA, Artemio M, ed. In concavis petrarum habitaverunt. El fenómeno rupestre en el Mediterráneo Medieval: de la investigación a la puesta en valor. Oxford: Archaeopress, pp. 36-83.

LOURENÇO, Sandra (2007). O povoamento alto-medieval entre os rios Dão e Alva. "Trabalhos de Arqueologia». 50.

MAESE i FIDALGO, Xavier (2003). Montjü̈, el cementiri jueu de la Barcelona medieval. «Seqüència». $14,4-7$.

MAESE i FIDALGO, Xavier (2006). Montjü̈: La necròpolis jueva de la Barcelona medieval. Barcelona: CODEX. Arqueologia i Patrimoni. Dispinível em <http://cartaarqueologica.bcn.cat/ Docs/3061/2013_09_26_13_32_23_Memòria\%20129-01.pdf>

MAESE i FIDALGO, Xavier; CASANOVAS i MIRÓ, Jordi (2002-2003). Nova aproximació a la cronologia del cementiri jueu de Montjuic (Barcelona). «Tamid». 4, 7-25.

MARTÍN VISO, Iñaki (2007). Tumbas y sociedades locales en el centro de la Península Ibérica en la Alta Edad Media: el caso de la comarca de Riba Côa (Portugal). «Arqueología y Territorio Medieval». 14, 21-47.

MARTÍN VISO, Iñaki (2008). Una periferia creativa: la articulación del territorio en la comarca de Riba Côa, Portugal (siglos VI-XI). «Territorio, Sociedad y Poder». 3, 85-109.

MARTÍN VISO, Iñaki (2011). La organización espacial de los espacios funerarios alto-medievales en los territorios al Sur del Duero. In GOMES, M.; GOMES, R.; TENTE, C. coord. Cristãos e Muçulmanos na Idade Média Peninsular. Encontros e Desencontros. Lisboa: Instituto de Arqueologia e Paleociências, pp. 225-238.

MARTÍN VISO, Iñaki (2012a). Enterramientos, memoria social y paisaje en la Alta Edad Media: propuestas para un análisis de las tumbas excavadas en roca en el centro-oeste de la Península Ibérica. «Zephyrus». 69, 165-187.

MARTÍN VISO, Iñaki (2012b). Paisajes sagrados, paisajes eclesiásticos. De la necrópolis a la parroquia en el centro de la Península Ibérica. «Reti Medievali». 13: 2, 3-45.

MARTÍN VISO, Iñaki (2014a). El espacio del más acá: las geografías funerarias entre la Alta y la Plena Edad Media. In LÒPEZ OJEDA, E., ed. De la Tierra al Cielo. Ubi sunt qui ante nos in hoc mundo fuere? Actas XXIV Semana de Estudios Medievales. Logroño: Instituto de Estudios Riojanos, pp. 75-140

MARTÍN VISO, Iñaki (2014b). Datar tumbas o datar procesos? A vueltas con la cronología de las tumbas excavadas en roca en la Península Ibérica. «Debates de Arqueología Medieval». 4, 29-65.

MARTÍN VISO, Iñaki (2016). Comunidades locales, lugares centrales y espacios funerarios en la Extremadura del Duero altomedieval: las necrópolis de tumbas excavadas en la roca alineadas. "Anuario de Estudios Medievales». 46: 2, 859-898.

MATTEI, Luca (2014). Poblado y necrópolis mozárabe del Conjunto Arqueológico de Tózar. Un proyecto de investigación y puesta en valor. «Debates de Arqueología Medieval». 4, 181-196.

MATTEI, Luca (2018). Los montes occidentales de Granada en los tiempos de al-Andalus: Territorio, paisaje y sociedad. «Boletín del Instituto de Estudios Giennenses». 217, 499-527.

MATTOSO, José (2002). O Monaquismo ibérico e Cluny. Lisboa: Círculo de Leitores.

NAVARRO PÉREZ, Mercedes (2017). La ocupación del entorno de las ciudades islámicas en época omeya. Marroquies Bajos. Jaén. Jaén: Universidad de Jaén. Tese de Doutoramento. 
NAVARRO PÉREZ, Mercedes (2018) - La maqbara del camino de Bayyāsa (Marroquíes Bajos, Jaén). «Lucentum». 37, 281-303.

PERPÉTUO, João et al. (1999). Tabuaço, um passado presente. Tabuaço: Câmara Municipal.

PONCE, Mónica et al. (2017a). Relatório Final dos Trabalhos Arqueológicos. Diagnóstico, Acompanhamento e Escavação arqueológica. Rua doa Lagares, 74, Lisboa. Lisboa: ERA-Arqueologia, S.A.

PONCE, Mónica et al. (2017b). O sítio dos Lagares (Lisboa): um espaço pluricultu(r)al. In ARNAUD, J.; MARTINS, A. coord. Arqueologia em Portugal. 2017, Estado da questão. Lisboa: Associação dos Arqueólogos Portugueses, pp. 1703-1714.

RIU, Manuel (1977). La arqueologia medieval en España. Apêndice. In DE BOÜARD, Michel - Manual de Arqueología Medieval. De la prospección a la historia. Barcelona: Teide, pp. 375-490.

RUBIO DÍEZ, Rubén (2018). Las tumbas excavadas en la roca: una evidencia del paisaje rural posromano. In MARTÍN VISO, Iñaki coord. Fortificaciones, poblados y pizarras: la raya en los inícios del Medievo. Ciudad Rodrigo: Ayuntamiento, pp. 286-295.

SANTOS, Maria José (2005). A Terra de Penafiel na Idade Média. Estratégias de Ocupação do Território (875-1308). «Cadernos do Museu». 10.

SEMPLE, Sarah; WILLIAMS, H. (2015). Landmarks for the dead: exploring Anglo-Saxon mortuary geographies. In HYER, M.; OWEN-CROCKER, G., ed. The Material Culture of the Built Environment in the Anglo-Saxon World [The Material Culture of Daily Living in the Anglo-Saxon World, 2]. Liverpool: Liverpool Univ. Press, pp. 1-26.

SERRANO PEÑA, J. L.; CASTILLO ARMENTEROS, J. C. (2000). Las necrópolis medievales de Marroquíes Bajos, (Jaén). Avance de las investigaciones arqueológicas. «Arqueología y Territorio Medieval». 7, 93-120.

SILVA, António Manuel S. P. (2007). Revisão do Plano Diretor Municipal de Vila Nova de Gaia. Relatório 2.11: Património Arqueológico e Geomorfológico. Vila Nova de Gaia: Câmara Municipal/Gaiurb, EM. Disponível em <https://www.gaiurb.pt/revpdm/rel/11/11_1.pdf >.

SILVA, António Manuel S. P. (2013). Arqueologia do Castelo de Crestuma (Vila Nova de Gaia). Resultados preliminares da campanha de 2013. «Revista de Portugal». 10, 5-13.

SILVA, António Manuel S. P. (2014). El Castillo de Crestuma (Vila Nova de Gaia, Portugal). Entre la romanidad tardia y la edad media: los retos de un sítio complejo. In Las fortificaciones en la tardoantigüedad: Elites y articulación del territorio (siglos V-VIII d.C.). Madrid: La Ergástula, pp. 389-399.

SILVA, António Manuel S. P. (no prelo). A sepultura do Castelo de Crestuma (V. N. Gaia, Portugal) e as sepulturas de dupla fossa em contextos tardo-antigos e medievais cristãos, muçulmanos e judaicos. «Portvgalia». Nova Serie. 42.

SILVA, António Manuel S. P., GUIMARÃES, J. Gonçalves (2011). O Castelo de Crestuma revelado pela Arqueologia. As principais fases de ocupação do sítio arqueológico. «Boletim da Associação Cultural Amigos de Gaia». 73, 5-13.

SILVA, António Manuel S. P.; CARVALHO, T. (2014). Originalidade e tradição clássica na cerâmica local e regional tardo-antiga do castelo de Crestuma (V. N. Gaia, Portugal). In MORAIS, R.; FERNÁNDEZ, A.; SOUSA, M., ed. As produções cerâmicas de imitação na Hispania. [Porto-Madrid]: FLUP; Ex Officina Hispana, pp. 381-396.

SILVA, António Manuel S. P.; GUIMARÃES, J. Gonçalves (2013a). Castelo de Crestuma: a Arqueologia em busca da História. Vila Nova de Gaia: Águas e Parque Biológico de Gaia, EM;ASCR-CQ

SILVA, António Manuel S. P.; GUIMARÃES, J. Gonçalves (2013b) - O Castelo de Crestuma (Vila Nova de Gaia e a ocupação tardo-antiga no Baixo Douro. In Arqueologia em Portugal. 150 Anos. Lisboa: Associação dos Arqueólogos Portugueses, pp. 883-893. 
SILVA, António Manuel S.P. et al. (2017). O projeto CASTR'UÍMA (Vila Nova de Gaia, 2010-2015): elementos e reflexões para um balanço prospetivo. In ARNAUD, J.; MARTINS, A. coord. Arqueologia em Portugal. 2017, Estado da questão. Lisboa: Associação dos Arqueólogos Portugueses, pp. 137-154.

SILVA, António Manuel S. P.; PEREIRA, P.; CARVALHO, T. (2015a). Conjuntos cerâmicos do Castelo de Crestuma (Vila Nova de Gaia, N. Portugal): primeiros elementos para uma sequência longa (Sécs. IV-XI). In Actas do X Congresso Internacional A Cerâmica Medieval no Mediterrâneo (Silves, 2012). Silves: Câmara Municipal; Campo Arqueológico de Mértola, pp. 401-419.

SILVA, António Manuel S. P. et al. (2015b). O Castelo de Crestuma (Vila Nova de Gaia): um contexto estratigráfico tardo-antigo no extremo noroeste da Lusitania. In QUARESMA, J.; MARQUES, J. coord. Contextos estratigráficos na Lusitania (Do Alto Império à Antiguidade Tardia). Lisboa: Associação dos Arqueológos Portugueses, pp. 149-167.

SILVA, António Manuel S. P.; REAL, Manuel L. (no prelo). Arqueologia e história da cidade do Porto no período tardo-antigo e alti-medieval. In Atas do Encontro Internacional «A Península Ibérica entre os séculos V a X: continuidade, transição e mudança». Lisboa: Associação dos Arqueólogos Portugueses.

SILVA, António Manuel S. P.; SOUSA, L. (2014). Cerâmica do período da "Reconquista" (séculos X-XI) proveniente do Castelo de Crestuma (V. N. Gaia). In DE MAN, Adrian; TENTE, Catarina coord. Estudos de Cerâmica Medieval. O Norte e Centro de Portugal - séculos XI a XII. Lisboa: IEM, pp. 205-222.

SILVA, António Manuel S. P.; SOUSA, L.; PINTO, F. (2018). Materiais proto-históricos do Castelo de Crestuma (Vila Nova de Gaia). In HERNÁNDEZ GUTIÉRREZ, N.; LARRAZABAL GALARZA, J.; PORTERO HERNÁNDEZ, R. coord. Arqueologia en el valle del Duero: del Paleolítico a la Edad Media 6 - Actas de las VI Jornadas de Arqueología del valle del Duero (Oporto, 2016). Valladolid: Glyphos, pp. 327-340.

SOUSA, Arlindo de (1945). Nótulas arqueológico-históricas. Vila-da-Feira Lusitano-Romana: Do antigo castro ao castelo actual. Origens dos nomes: Civitas, Terra de Santa Maria, Vila e Feira. «Anales de la Asociación Española para el Progreso de las Ciencias». Ano 10. 2, 399-412.

SOUSA, Arlindo de (1957). Estudos de Arqueologia, Etnologia e História. Antiguidades do Município de Gaia: Civilizações Pré-romanas, Romana e Romana Portuguesa. Rio de Janeiro: [s.e.].

TEIXEIRA, Ricardo (1996). De Aquae Flaviae a Chaves. Povoamento e organização do território entre a Antiguidade e a Idade Média. Porto: Faculdade de Letras da Universidade do Porto. Dissertação de Mestrado.

TEIXEIRA; Ricardo; FONSECA, J. (2017). Intervenção arqueológica. Mosteiro de Paço de Sousa. Penafiel. 2017. Relatório Final. $2^{a}$ Fase. Matosinhos: Arqueologia e Património, vol. I.

TENTE, Catarina (2007). A ocupação alto-medieval da Encosta Noroeste da Serra da Estrela. Lisboa: Instituto Português de Arqueologia. (Trabalhos de Arqueologia; 47).

TENTE, Catarina (2010). Arqueologia Medieval Cristã no Alto Mondego. Ocupação e exploração do território nos séculos $V$ a XI. Lisboa: Faculdade de Ciências Sociais e Humanas da Universidade Nova de Lisboa. Tese de Doutoramento.

TENTE, Catarina (2015). Tumbas rupestres en el Alto Mondego (Guarda, Portugal). Patrones de distribución, significados y construcción del paisaje rural altomedieval. «Munibe. AntropologiaArkeologia». 66, 271-290.

TENTE, Catarina (2017). Rock-cut graves and cemeteries in the medieval rural landscape of the Viseu region (central Portugal). In BIS-WORCH, Christiane; THEUNE, Claudia, ed. Religions, cults and rituals in the medieval rural environment. Ruralia XI. Leiden: Sidestone Press, pp. 215-226.

TENTE, Catarina, LOURENÇO, Sandra (1998). Sepulturas medievais escavadas na rocha dos concelhos de Carregal do Sal e Gouveia: estudo comparativo. «Revista Portuguesa de Arqueologia». 1: 2, 191-217. 
TENTE, Catarina, LOURENÇO, Sandra (2002). Sepulturas medievais do distrito de Évora. "Revista Portuguesa de Arqueologia». 5: 1, 239-258.

TENTE, Catarina; CARVALHO, António (2015). Sepulturas e necrópoles alto-medievais na investigação arqueológica portuguesa: metodologias, problemáticas e perspetivas. In QUIRÓS CASTILLO, J.; CASTELLANOS, S., dir. Identidad y etnicidad en Hispania. Propuestas teóricas y cultura material en los siglos V-VIII. [Bilbau]: Univ. del País Vasco, pp. 125-144.

VELÁZQUEZ SORIANO, Maria Isabel (2017). Tegula con inscripción de Vila Nova de Gaia. In LÓPEZ QUIROGA, Jorge; MARTÍNEZ TEJERA, A. coord. In tempore Sueborum. El tiempo de los Suevos en la Gallaecia (411-585). El primer reino medieval de Occidente. Ourense: Deputación Provincial, p. 256.

VIEIRA, Marina (2004). Alto Paiva. Povoamento nas épocas romana e alto-medieval. "Trabalhos de Arqueologia». 36. .

VIGIL-ESCALERA GUIRADO, Alfonso (2013). Comunidad política aldeana y exclusión. Una revisión de las formas de inhumación altomedievales (ss. V-VIII d.C.). «Reti Medievali». 14: 1, 1-32.

VIGIL-ESCALERA GUIRADO, Alfonso (2015). La identidad de la comunidad local y las afiliaciones individuales en necropolis de la Alta Edad Media (400-900 AD). In QUIRÓS CASTILLO, J.; CASTELLANOS, S., dir. Identidad y etnicidad en Hispania. Propuestas teóricas y cultura material en los siglos V-VIII. [Bilbau]: Univ. del País Vasco, pp. 249-274.

WILLIAMS, Howard (2006). Death and Memory in Early Medieval England. Cambridge: Cambridge University Press. 


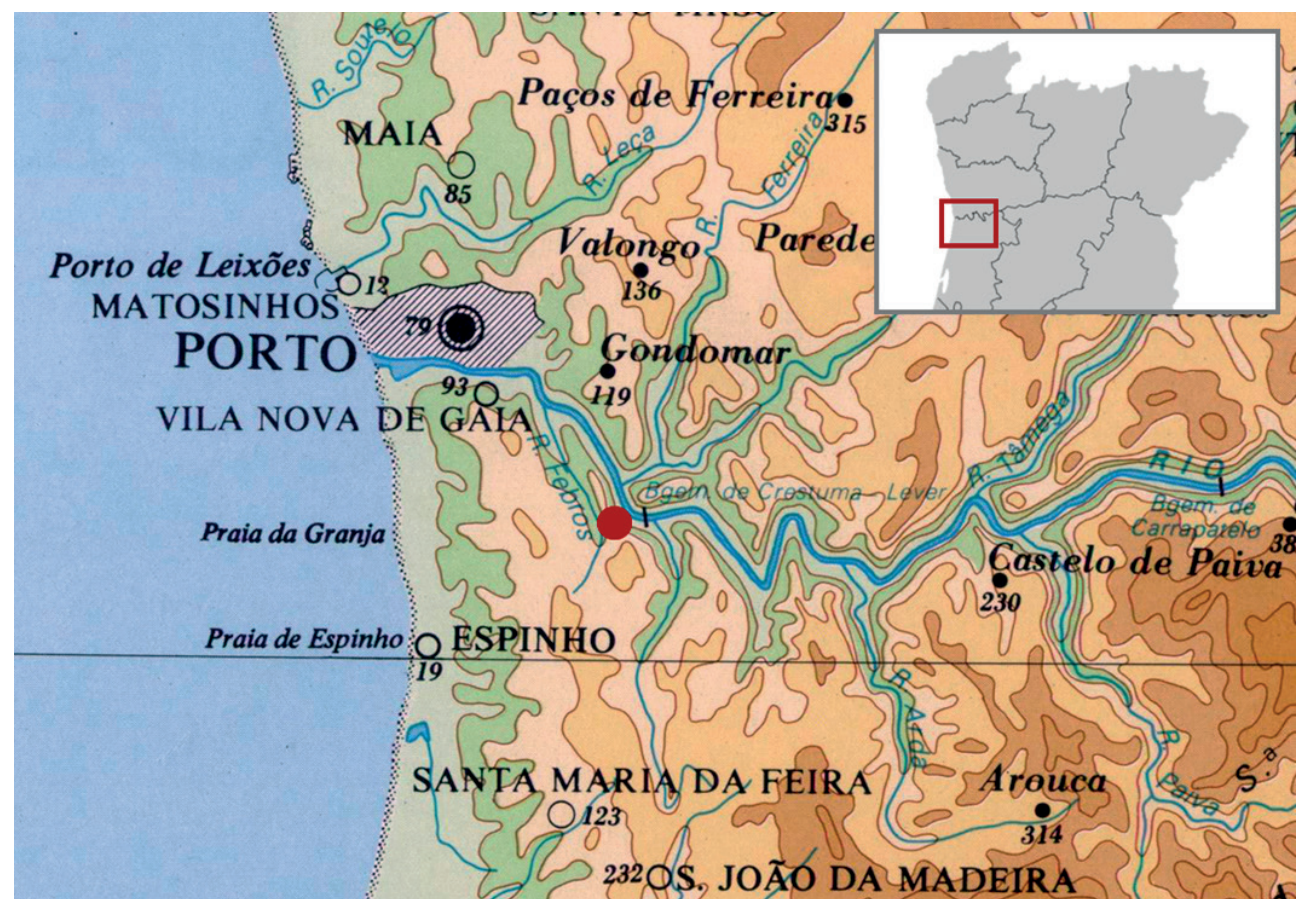

Fig. 1. Localização do complexo arqueológico de Crestuma, Vila Nova de Gaia

Fonte: Base cartográfica: Carta Hipsométrica de Portugal na escala 1:600 000 do Instituto Geográfico e Cadastral

Fig. 2.

Vista aérea do complexo arqueológico, com localização dos dois relevos que o constituem

Fonte: Google Earth; infografia dos AA

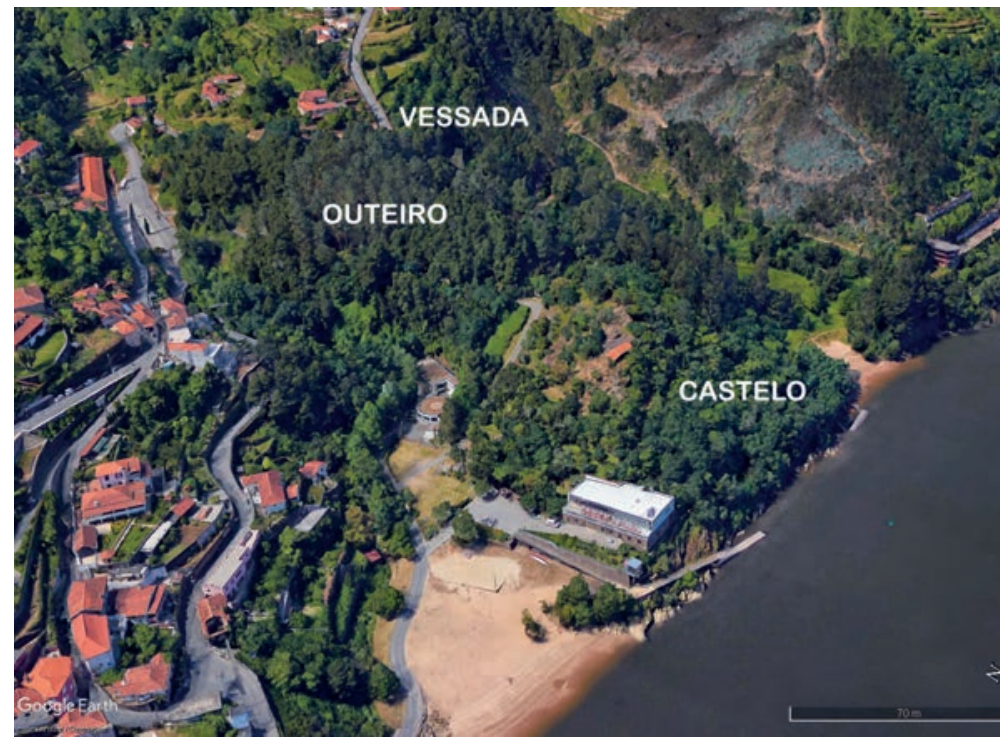




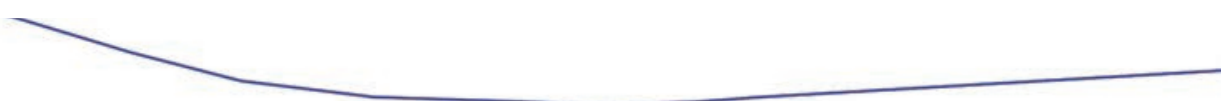

Rio Douro

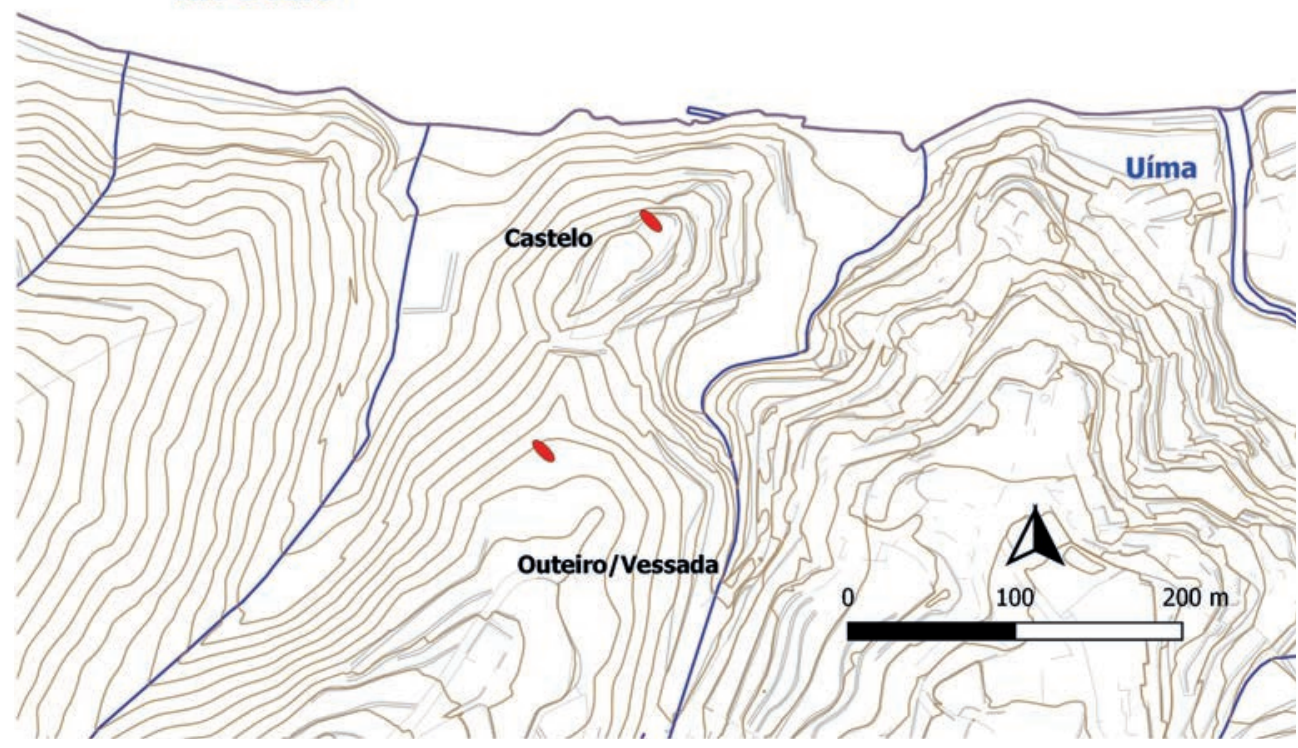

Fig. 3. Esboço topográfico de implantação das sepulturas do Castelo e do Outeiro/Vessada Fonte: Base cartográfica: Gaiurb - EM; Cartograma dos AA (ícones das sepulturas sem escala)

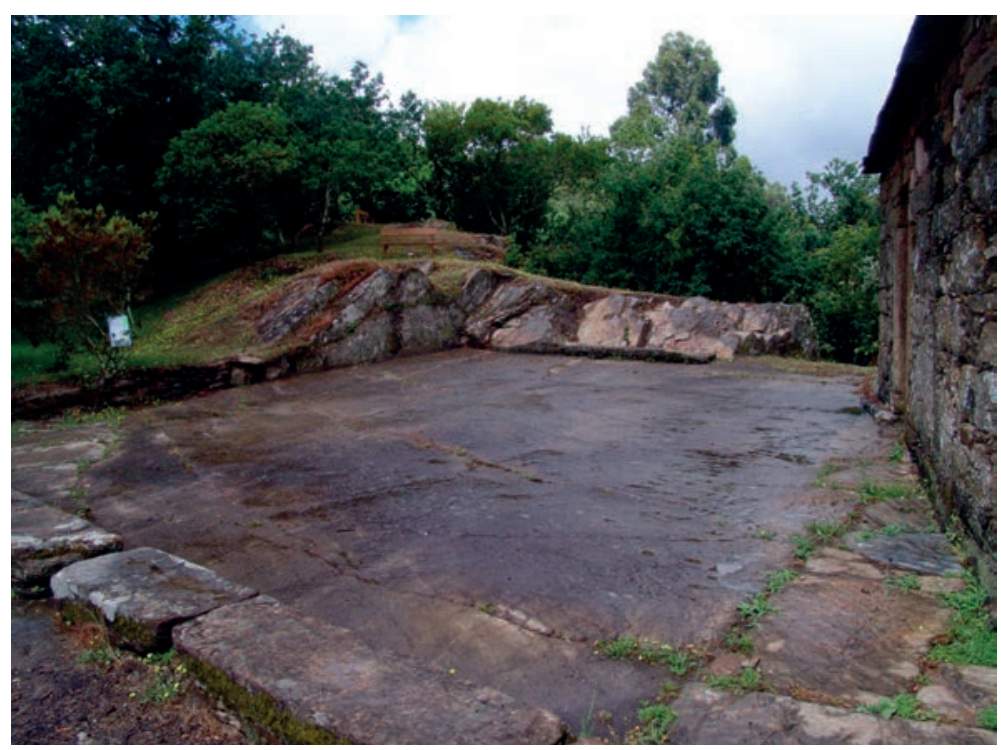

Fig. 4.

A «eira» do Castelo de Crestuma, vista a partir do ângulo nascente Fonte: António Manuel Silva - Gabinete de História, Arqueologia e Património 


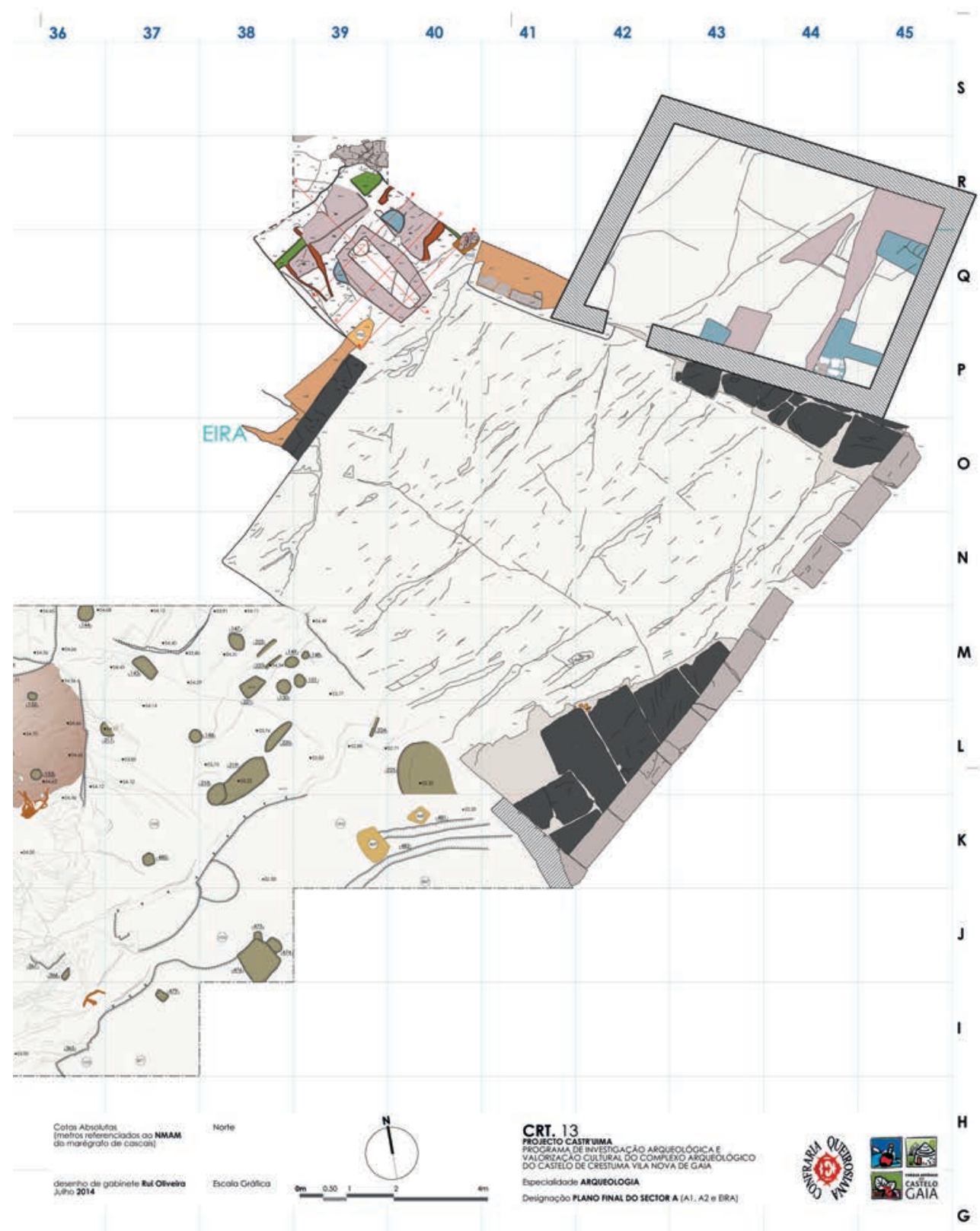

Fig. 5. Recorte da planta da parte superior do Castelo, vendo-se a «eira» e a sepultura Fonte: P. Lemos e R. Oliveira, sobre levantamento de Multimapa 


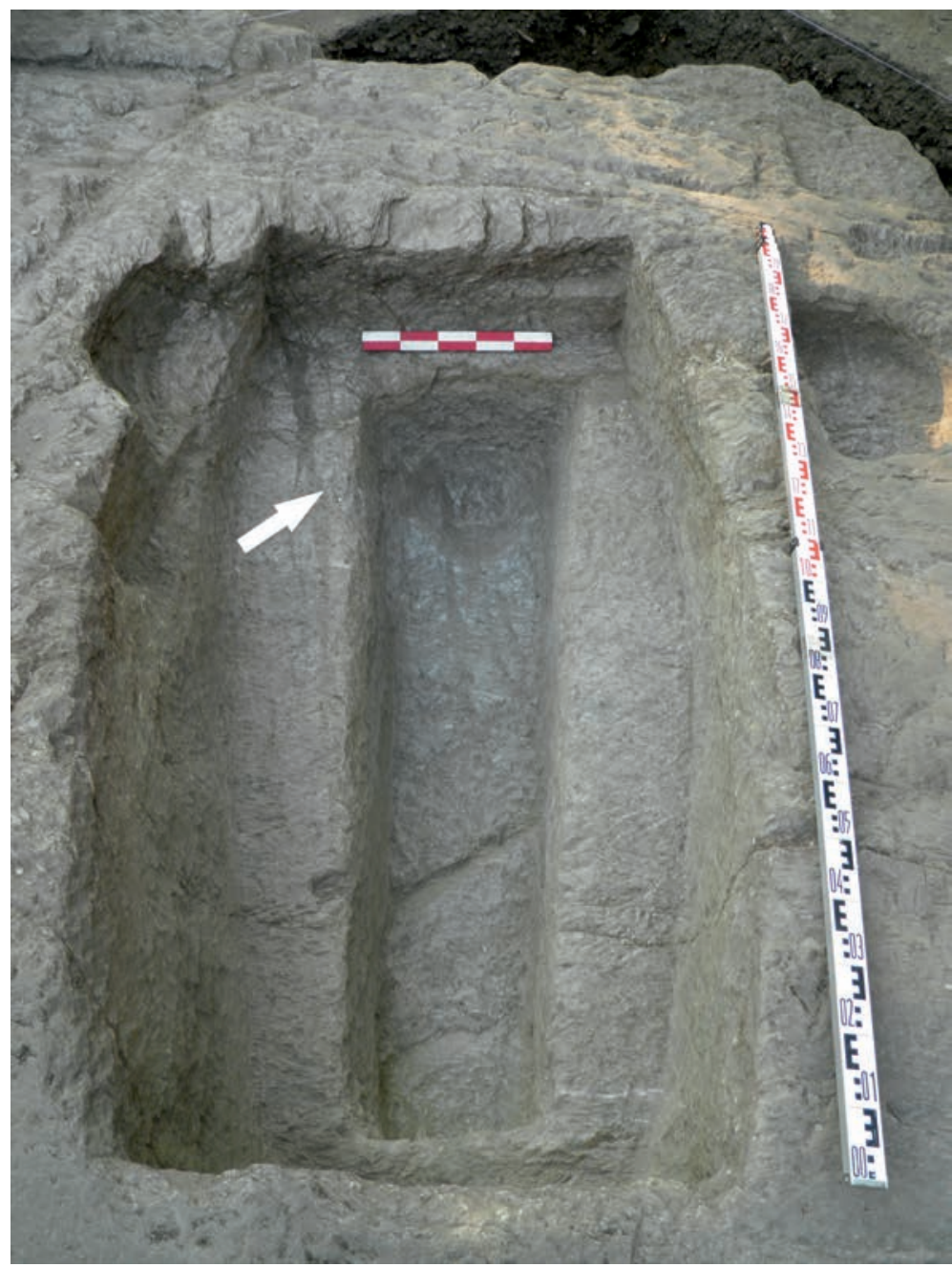

Fig. 6.

Sepultura 1 do Castelo, vista de SSE

Fonte: Gabinete de História, Arqueologia e Património 


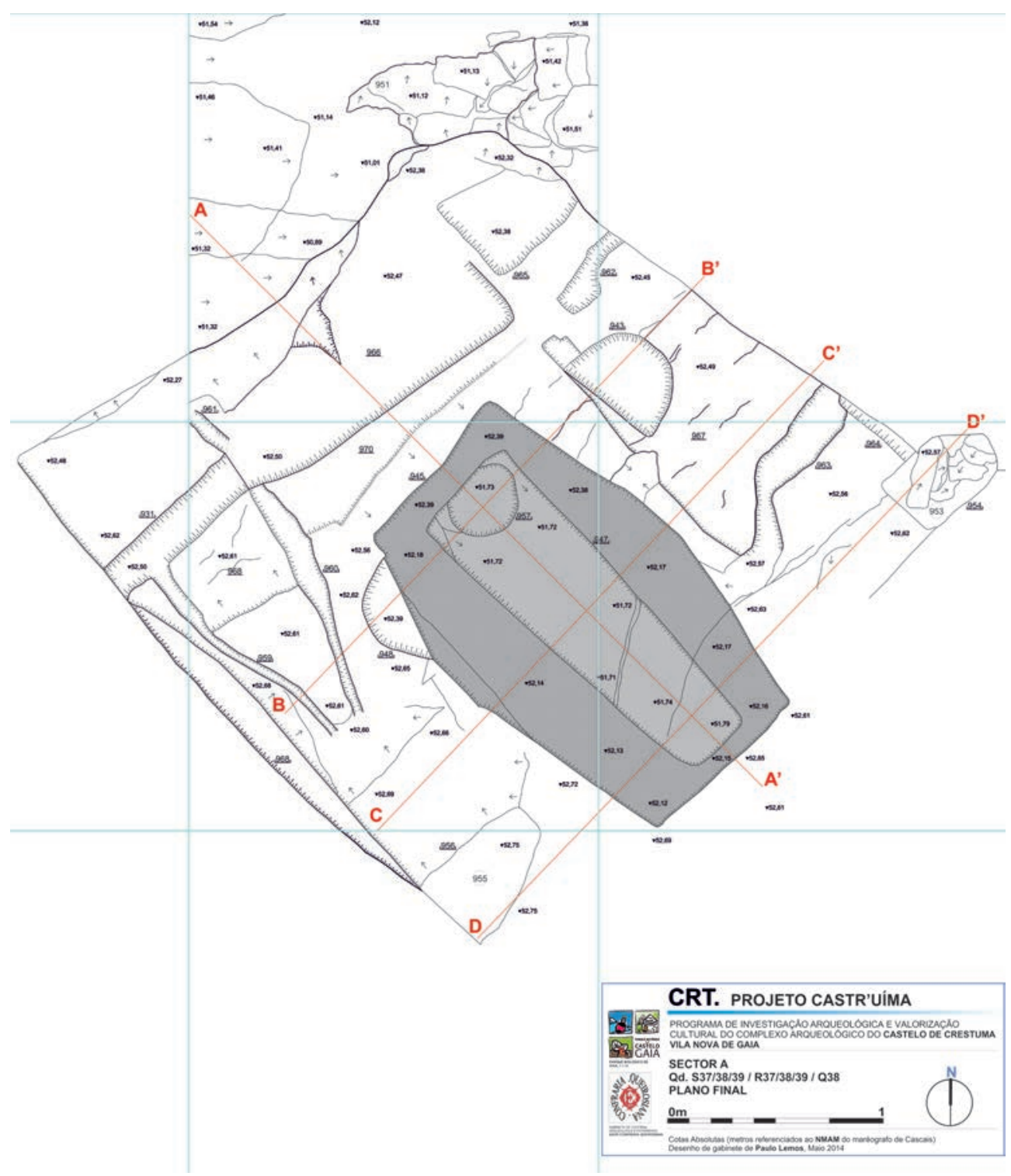

Fig. 7a. Sepultura 1 do Castelo: planta e secções longitudinal e transversais Fonte: P. Lemos — Gabinete de História, Arqueologia e Património 
NO

$52,63-$

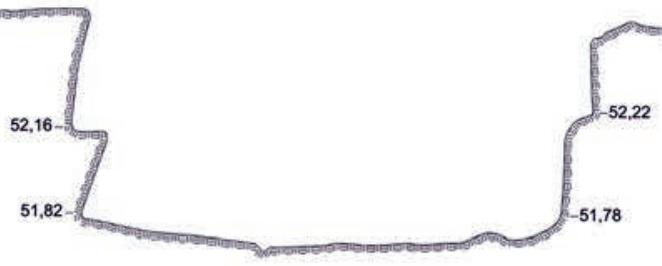

Secção A-A'

so NE

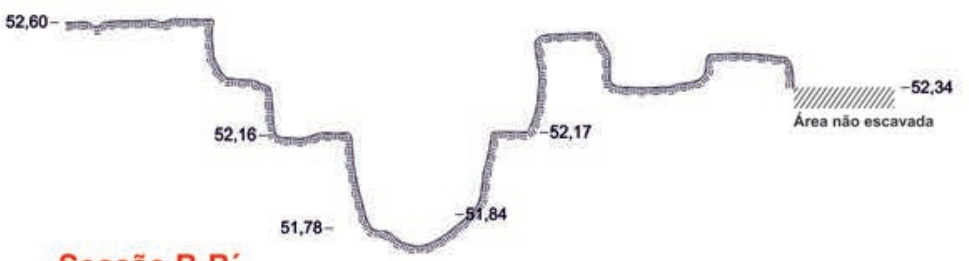

Secção B-B'

so

NE

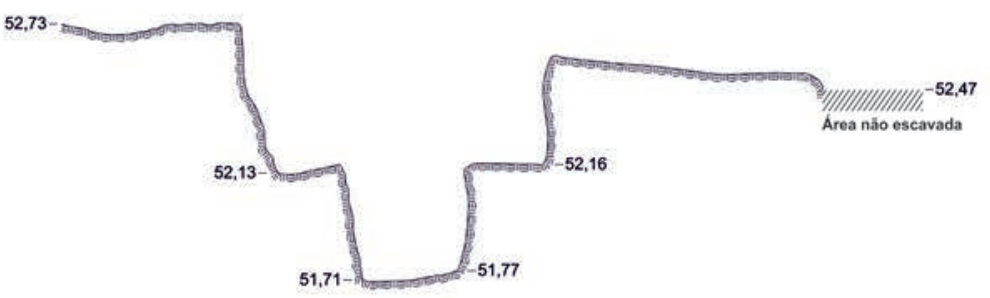

Secção C-C'

so

NE

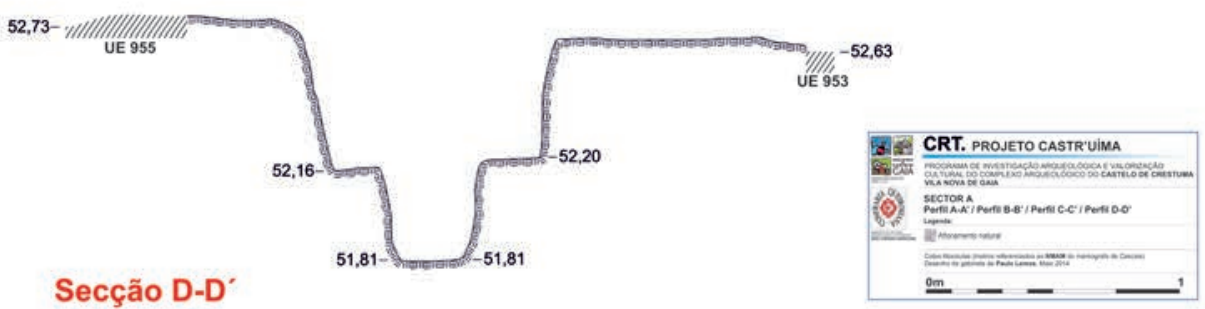

Fig. 7b. Sepultura 1 do Castelo: secção longitudinal e secções transversais Fonte: P. Lemos - Gabinete de História, Arqueologia e Património 
Fig. 8.

Sepultura 1 do Outeiro, vista sensivelmente de NNE Fonte: António Manuel Silva - Gabinete de História, Arqueologia e Património
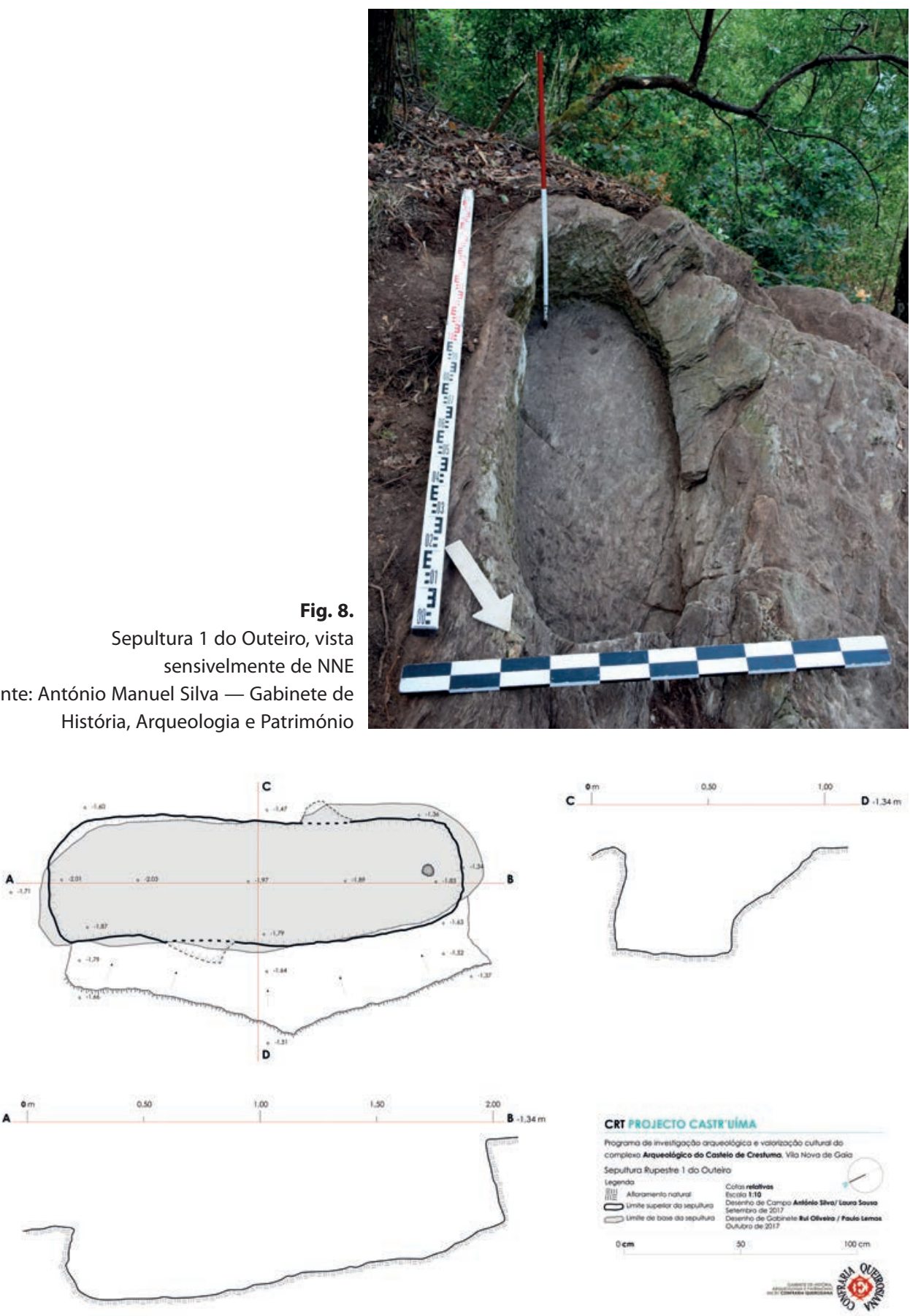

Fig. 9. Sepultura 1 do Outeiro: planta e secções axiais

Fonte: A. Silva, L. Sousa, R. Oliveira e P. Lemos - Gabinete de História, Arqueologia e Património 


\title{
TUMBAS EN PIEDRA, TUMBAS DE PIEDRA. SANTIAGO DE COMPOSTELA Y LOS RITUALES FUNERARIOS EN LA ALTA EDAD MEDIA
}

\author{
JOSÉ SUÁREZ OTERO*
}

Resumo: Os túmulos escavados na rocha constituem uma das fórmulas funerárias predominantes na grande necrópole medieval que se desenvolveu entre os séculos IX e XII ao redor da igreja de Santiago. Antropomórficos e quase exclusivos em um primeiro estágio (ss. IX-X), tornam-se trapezoidais e, embora coexistam com os túmulos de laje, não menos representativos na fase final do cemitério (ss. XI-XII). Substituem os grandes sarcófagos e dão lugar a outra concepção do túmulo, mais diversificada no formal e estratificada no social, na qual a monumentalidade será substituída pela epigrafia, a abstração simbólica pela concretização textual.

Palavras-chave: Cemitério; Ritual funerário; Tumba; Compostela; Altomedieval.

Abstract: The tombs carved into the rock constitute one of the predominant funerary formulas in the great early medieval necropolis developed between the 9th and 12th centuries around the church of Santiago. Anthropomorphic and almost exclusive in a first stage (IX-X centuries), they become trapezoi$\mathrm{dal}$ and, although coexisting with the flagstone tombs, no less representative in the final phase of the cemetery (XI-XII centuries). They replace the great sarcophagi and give way to another conception of the tomb, more diversified in the formal and stratified in the social, in which monumentality will be replaced by epigraphy, symbolic abstraction by textual concretion.

Keywords: Cemetery; Funerary Ritual; Tomb; Compostela; High Medieval.

\section{INTRODUCCIÓN}

Uno de los tipos de tumbas de la necrópolis compostelana que, sin duda, más interés despertaron fue aquel que se caracteriza por estar realizado directamente en la roca. Una de las razones de ese interés fue el integrarse en esa cronológicamente problemática y geográficamente extendida costumbre de realizar la inhumación no sobre tierra, sino sobre roca, estando bajo tierra o al descubierto. Otra, fue la convicción e insistencia, por parte de quienes las descubrieron y dieron a conocer, en una cronología antigua para esas tumbas en Compostela, sino la cantidad y riqueza de la propia muestra. Como todo lo perteneciente al registro arqueológico bajo la catedral, las informaciones conservadas resultan escasas y en muchas ocasiones confusas. Los datos se nos ofrecen previamente interpretados, por lo que tenemos como en tantas

\footnotetext{
* ANTE (Grupo de Investigación de Análise Territorial), Universidade de Santiago. Email: jsuarezotero@gmail.com.
} 
ocasiones realizar un proceso de deconstrucción de esas informaciones para entresacar los datos objetivos que puedan contener. En lo referente a la necrópolis tenemos un problema añadido, el derivado de que buena parte de esta fue exhumada en las últimas campañas de la intervención de Manuel Chamoso en el subsuelo de la basílica y los resultados de esas campañas nunca fueron publicados. Otra limitación que no debemos olvidar es la que se deriva de la condición de las tumbas que ahora vamos a tratar, el estar realizadas sobre el substrato rocoso y por lo tanto en el horizonte más bajo del registro estratigráfico, horizonte al que no siempre se accedió: la preservación in situ de restos, funerarios o constructivos, situados en niveles superiores impidió la constatación de la existencia o no de tumbas excavadas en la roca bajo esos restos.

Tendremos que reconstruir el conjunto de lo hallado a partir fundamentalmente de José Guerra Campos ${ }^{1}$, añadiendo, allí donde sea posible, las informaciones contenidas en las partes sí publicadas por Manuel Chamoso Lamas². El primero nos permite conocer la globalidad de la necrópolis descubierta, el segundo nos permitirá matizar algunos detalles de aspectos concretos de la misma. Finalmente, la planimetría de Francisco Pons Sorolla en su exhaustividad nos permite contrastar las informaciones de Chamoso y de Guerra, lo que adquiere mayor importancia dadas las contradicciones que a veces existen entre esos dos autores ${ }^{3}$. Una revisión actual de los hallazgos de las distintas campañas de M. Chamoso en el subsuelo de la Catedral sólo es posible allí donde estos son accesibles, algo que solo ocurre bajo el brazo sur del Crucero y la nave mayor del occidental; no así en los brazos menores de ese último, el brazo Norte o la Girola ${ }^{4}$.

\section{FORMAS, CONTEXTOS Y EVOLUCIÓN}

La evolución de las sepulturas excavadas en la roca compostelanas expresa cambios en la concepción de la propia tumba; cambios que llevaran del sarcófago tardoantiguo a la tumba bajo lápida medieval. El primer grupo de tumbas, aquellas que preceden a la iglesia de Alfonso III se manifiestan diversas en lo tipológico y dispersas en lo espacial. La tumba se excava en la roca, pero su conformación aún acude a las lajas para definir paredes y cubiertas. Lo hace además en una forma simple, como mero contenedor del cadáver, pero sin reproducir los contornos como ocurría en los sarcófagos tardoantiguos, o en los que todavía conviven con estas primeras tumbas en la piedra y que, también y como ocurría en alguno de aquellos, incluyen una epigrafía que individualiza, personifica, el enterramiento. Es, pues, un grupo que

\footnotetext{
${ }^{1}$ GUERRA CAMPOS, 1982: 443-486, esp. 483-486.

${ }^{2}$ CHAMOSO LAMAS, 1956a, 1956 b, 1957.

${ }^{3}$ Sobre F. Pons Sorolla, cf. CASTRO, 2013.

${ }^{4}$ En las últimas décadas se ha llevado a cabo una revisión conjunta de todas esas informaciones y restos arqueológicos (SUÁREZ OTERO, 1999, 2003, 2012), cuyos últimos resultados, de los que estas páginas son una breve síntesis, se recogen en nuestra Tesis Doctoral (SUÁREZ OTERO, 2015).
} 
representa un momento de transición, en el que tanto la tumba, como el cementerio mismo, parecen expresar una cierta indefinición. La primera, por su variabilidad; el segundo por su dispersión en pequeños grupos, cuando no tumbas aisladas (Fig. 1: Círculos $)^{5}$. Una cronología claramente anterior a la construcción de la basílica de Alfonso III, lo sitúa cronológicamente con anterioridad a fines del siglo IX: el año del 899, fecha de consagración de esa iglesia, es un término ante quem seguro ${ }^{6}$, pero es posible que el cambio tuviese lugar incluso algo antes, cuando la iglesia ya estaba arquitectónicamente definida, ca. 880-890.

El segundo grupo responde a criterios tanto formales, con la tumba excavada en la roca de configuración antropomorfa, como espaciales, con la iglesia como elemento vertebrador del cementerio, más homogéneos. La tumba no simplemente se encuentra con la roca, sino que, aunque ahora más alejada por la elevación del nivel de suelo, parece buscarla en un aparente intento de reproducir el sarcófago, pero evitando las dificultades y costes que ocasionaban en este, tanto la materia prima: el granito, ajeno a la geología local; como la elaboración de una pieza exenta: extracción, labrado de paredes externas y realización de cubierta monolítica. Las tumbas se sitúan próximas a las fachadas de la iglesia, la norte, la sur y, especialmente, a la occidental (Fig. 1: Rectángulos; Figs. 2 y 3), donde libre de otras arquitecturas, el cementerio se expande, ladera abajo, en dirección suroeste (Fig. 4 A; y 4 B, fase I; Fig. 5). Acompañan a ese tipo de sepultura, otras que, con fórmulas distintas, siguen insistiendo en la configuración antropomorfa del hueco, al tiempo que acentúan la calidad de las propias tumbas. Nos referimos a las tumbas de ladrillo o de mampostería concertadas, bien elaborados y con los interiores revestidos. Ambas posiblemente presentes ya en la etapa anterior. Al tiempo que parece constatarse un abandono del sarcófago monolítico, pues los preexistentes aparecen amortizados en la fábrica de la iglesia.

El tercer grupo continúa las características del anterior, pero se sitúa exclusivamente en la fachada meridional de la basílica alfonsina, proyectando en esa dirección una parte del cementerio que en la etapa anterior se ceñía a las inmediaciones del muro sur de la iglesia (Fig. 1: Elipse; Fig. 6). Y en él asistimos a la atenuación o desaparición del carácter antropomorfo de la caja (Fig. 7). La ubicación entre arquitecturas de esa parte del cementerio exige la perdida de la función de estas, liberando el espacio para su nuevo uso (Fig. 8). Dado que esas construcciones correspondían al primitivo palacio episcopal, la construcción de uno nuevo, que aparece reflejado en el muro reaprovechado como cimentación del muro oriental del brazo sur del crucero románico, se convierte en la referencia post quem para este grupo. La construcción de ese nuevo

\footnotetext{
${ }^{5}$ A esta etapa podrían corresponder una tumba bajo la actual girola, hacia el NE (CHAMOSO LAMAS, 1956b), otra fuera y al SE de esta (CHAMOSO, 1971); o las aparecidas ya alejadas del edificio, hacia el NE y bajo la muralla del s. X (REY SEARA, RODRÍGUEZ PUENTES, 1989; SUÁREZ OTERO, 2003).

${ }^{6}$ SÁNCHEZ ALBORNOZ, 1981; DÍAZ BUSTAMANTE, LÓPEZ PEREIRA, 1990.
} 
palacio cabe atribuirla al obispo Sisnando II (951-968), pues existe una referencia explícita a la construcción de un palacio en un pontificado que se caracterizó, además, por una importante actividad edilicia en la que se menciona la presencia incluso de arquitectos y cuya mayor consecuencia será la fortificación del Locus Sanctus. Si esa identificación resulta cierta, nos situamos a mediados del siglo X: ca. 960, para esta nueva expansión del cementerio y, más relevante en los objetivos de estas páginas, para el cambio en la configuración de las tumbas excavadas en la roca, con la pérdida paulatina del carácter antropomorfo en su configuración.

En paralelo a esa expansión meridional del cementerio, en el área occidental asistimos a un proceso similar de expansión, pero no tanto en superficie, como en profundidad, pues aquí el terreno se elevará por encima de las antiguas tumbas en roca, generando un nivel de sepulturas de lajas, a las que se añade ahora el reaprovechamiento de antiguos sarcófagos que además proyectan el cementerio un poco más hacia el Oeste. Esa elevación de nivel necesita de muros de contención hacia el extremo occidental, así como aportes de tierras y escombros, elementos ambos que no de devuelven a la actividad edilicia de Sisnando II, pues la mencionada muralla del Locus cierra al cementerio por todos sus lados, también el occidental, y las nuevas construcciones supusieron una amplia remoción en las áreas circundantes, así como la destrucción de las viejas estructuras a sustituir (Fig. 2: B, fase II) ${ }^{7}$. Esa reutilización de sarcófagos en una parte en la que no se podía acceder a la roca para la construcción de nuevas tumbas, parece señalar que la componente pétrea monolítica en la construcción de la tumba todavía era importante, aunque ahora acompañada de una presencia incipiente de las tumbas de lajas o muretes, de forma trapezoidal simple y elaboración tosca.

También a partir de ese momento nos encontramos con la aparición, y cada vez mayor importancia, de las cubiertas monolíticas epigráficas, en tumbas excavadas en la roca que expresan los cambios en la concepción de la sepultura, ahora no antropomorfa e incorporando las lajas en la definición de sus paredes; sepulturas que casi siempre buscan la proximidad a los muros de la iglesia. Esa asociación de tumbas excavadas en la roca, laudas epigráficas y posición preminente en el cementerio, implica que, todavía y hasta bien avanzado el siglo XI, la tumba pétrea sigue teniendo un valor especial, tanto que al final parece quedar relegada a la parte más importante del cementerio: el lado sur de la iglesia, donde la existencia de pórtico funerario y la propia calidad de algunas de las tumbas, laudas incluidas, sitúan la parte más noble de un cementerio que aún perdurará hasta la construcción de la catedral románica que, en esa parte, tiene una fecha ante quem de inicios del siglo XII ${ }^{8}$. Qué esa era

\footnotetext{
${ }^{7}$ Sobre la cerca y el cementerio, SUÁREZ OTERO, 2004: 308-312 y 316-319. Sobre los edificios, LÓPEZ ALSINA, 1995.

${ }^{8}$ De la amplia bibliografía sobre el inicio ahí de la construcción románica, cf. OTERO TÚÑEZ, 1965; SUÁREZ OTERO, 1994; MORALEJO ÁLVAREZ, 1983; WILLIAMS, 1984.
} 
la parte privilegiada lo indica también el que hacia occidente, las tumbas sean ya exclusivamente de lajas, salvo la reutilización de algún viejo sarcófago, aunque asistimos a una nueva ampliación tanto en superficie como en altura del cementerio, donde, además, tendrá una mayor perduración, pues ahí la construcción románica fue más lenta, y podría alcanzar hasta mediados del siglo XII (Fig. 2, B, fase III) los inicios de la construcción de la fachada occidental, con el Pórtico de la Gloria, por el Maestro Mateo - ca. 1168 - podría ser la fecha ante quem para ese último desarrollo de la necrópolis?.

\section{HACIA UNA LECTURA SOCIAL DEL CEMENTERIO}

Esa evolución de un cementerio que, recordemos, perdurará cerca tres siglos - desde la construcción de la iglesia de Alfonso III, a fines del siglo IX, hasta un momento avanzado en la construcción románica a situar entorno a mediados del siglo XII — va a contener y reflejar todos los cambios que afectaron al Locus Sanctus Iacobi en ese dilatado periodo (Fig. 9). Cambios que llevarán desde el santuario monástico-martirial inicial a la formación de la ciudad medieval, la Civitas Iacobi ${ }^{10}$. $\mathrm{Y}$ las sepulturas excavadas en la roca van a tener un papel destacado en tanto que expresión funeraria de esos cambios (Fig. 10).

\subsection{Del siglo IX al X}

Las primeras tumbas tienen un carácter exclusivamente antropomorfo, son la fórmula funeraria dominante, sino exclusiva, de una también primera etapa estrechamente relacionado con la iglesia de Alfonso III. Se trata de un conjunto escaso, del que se han descubierto cerca de veinte tumbas y cuya extensión hace pensar que no fueron muchas más, en el que destaca la uniformidad en forma y calidad, así como su concentración entorno a los muros o las proximidades de la iglesia. Respondería bien a una fase en la que el Locus tiene un significado exclusivamente religioso y este aún incipiente fue aglutinado en torno a la preminencia del templo dedicado al culto a Santiago y de quien lo regía, el obispo de Iría Sisnando I (ca. 880-920) ${ }^{11}$. Será la necrópolis de la Magna Congregatio, que aunaba la curia episcopal y los monjes de San Paio de Antealtares y de Santa María da Corticela ${ }^{12}$. No caben más diferencias que, quizá, el enterramiento de Teodomiro y algún otro de quienes tenían un papel destacado en ese pequeño pero abigarrado grupo eclesiástico. No aparecen tumbas

\footnotetext{
${ }^{9}$ Esa datación queda al margen de la problemática existencia previa de la cripta, pues ese espacio fue cerrado y delimitado con la oclusión de la puerta occidental de la muralla de Sisnando II, reformada por el obispo Cresconio (1037-1067), cf. SUÁREZ OTERO, 2003: 66; 2004: 312-317.

${ }^{10}$ LÓPEZ ALSINA, 1988; SUÁREZ OTERO, 2003: 68-77.

${ }^{11}$ LÓPEZ FERREIRO, 1899-1905: II, 163-252.

12 LÓPEZ ALSINA, 1990: 747-753.
} 
que, por su tamaño, puedan remitirnos a enterramientos infantiles, presentes en la necrópolis anterior, como también en los estadios más avanzados de esta.

Pronto asistimos a una ampliación del cementerio, clara frente a la fachada occidental de la iglesia, pero ahí esa ampliación coincidirá con un recrecimiento del terreno que oculta definitivamente a las tumbas excavadas en la roca existentes, al tiempo que impide la creación de otras nuevas. Es posible que la reutilización ahora de los viejos sarcófagos pétreos de interior antropomorfo supla a la tumba en roca, manifestando una continuidad en el ritual funerario y en las características del cementerio mismo. Ese recrecimiento del terreno podría estar en relación de la construcción de la muralla del Locus, que cierra el espacio del cementerio por el Norte y Oeste, donde se abría una de sus puertas. Circunstancia que nos lleva a mediados del siglo X, durante el pontificado de Sisnando II (951-968)13. Podría ser de este momento la expansión meridional de la necrópolis, donde volvemos a encontrar tumbas excavadas en la roca, posible por ser un área más alejada de la muralla y donde no se constata la mencionada elevación del terreno. Pero, aquí las tumbas van a perder su carácter antropomorfo, todavía insinuado al principio y ya sustituido por la tumba trapezoidal simple, al final. En un momento que el enterramiento en tierra conllevará también la aparición de las primeras tumbas de lajas, rompiéndose así la homogeneidad de la primera fase y derivando en ese cementerio más amplio y diverso que se desarrollará a partir de la segunda mitad del siglo X.

Una variedad que refleja un grupo humano entorno a la iglesia de Santiago también diversificado, en el que, a los clérigos, todavía dominantes, se van a unir los laicos que se establecen en los vicus que surgen alrededor del Locus Sanctus ${ }^{14}$, así como también los primeros peregrinos de fuera del reino astur-leonés. ${ }^{15}$ Diversificación que derivará en jerarquización. Si el cementerio se expande hacia el Oeste mediante nuevas fórmulas tumulares que sustituyen a las tumbas excavadas en la roca antropomorfas, en lado sur de la iglesia asistimos al desarrollo de un espacio cementerial privilegiado entorno a dos pórticos funerarios sucesivos que discurrían paralelos y adyacentes al muro sur de la basílica. Espacio caracterizado por tumbas de especial calidad, de paredes de ladrillo o mampostería concertada, revestidas interiormente, o tumbas cubiertas con laudas epigráficas, como la Anastasius (985) o la de Vandila (978), esta última constatando la continuidad del cementerio también en torno a la entrada norte de la iglesia ${ }^{16}$. Y aquí la tumba excavada en la roca parece seguir teniendo un

\footnotetext{
${ }^{13}$ LÓPEZ FERREIRO, 1899-1905: II, 317-334.

${ }^{14}$ LÓPEZ ALSINA, 1988:242-258.

15 SUÁREZ OTERO, 2009: 82-92.

${ }^{16}$ CHAMOSO LAMAS, 1957 [2006: 144-146]; 1956b [2006: 86-87]; GUERRA CAMPOS, 1982: 451-452; SUÁREZ OTERO, 1999: 314-315.
} 
papel destacado - la de Vandila lo era, aunque vaya perdiendo el primitivo carácter antropomorfo.

\subsection{Entre el siglo X y el XII}

Será, sin embargo, a partir de inicios del siglo XI, cuando esa expansión y diversificación tumular del cementerio se haga más evidente. Ahora ya no estamos ante el cementerio del Locus Sanctus, sino de la Civitas que se está empezando a desarrollar en torno a él. La pérdida de función de la vieja cerca, así como la remodelación de los edificios que lo conformaban, necesaria después de la razzia de Almanzor en el 997, libera nuevos espacios que acogerán una población también en crecimiento ${ }^{17}$. Unas condiciones que implican que el cementerio dejará definitivamente de alojar de manera exclusiva a los grupos eclesiásticos, secular o regular - por otra parte ahora más distanciados entre sí18, para integrar a la nueva población laica y a aquellos de los cada vez más numerosos peregrinos que no regresen a sus lugares de origen. Una amalgama creciente de muertos de diferente condición y origen que provocará la fragmentación social del cementerio. Y de nuevo los sepulcros excavados en la roca van a jugar un papel importante como expresión funeraria de esa diferenciación social.

El uso cada vez más frecuente de las tumbas de lajas no va a hacer desaparecer al sepulcro en la roca, ahora ya definitivamente perdida su condición antropomorfa. Incluso asistimos a una expansión de su uso en la extensión meridional del cementerio, aquella que se desarrolla frente a la fachada sur del templo y entre restos de antiguos edificios, o la presencia también en torno a la entrada principal del lado norte. Esa relación con las entradas apunta ya al carácter privilegiado de este tipo de enterramiento, como también el que su interior esté a veces reforzado por paredes de lajas, pero, sobre todo, porque va a recibir el elemento más expresivo de las tumbas más ricas: las laudas epigráficas. El hecho que su desarrollo, con formas aparentemente más simples, arranque de esas tumbas ricas, en relación directa con la iglesia y más aún con el espacio funerario creado exprofeso para acogerlas: pórticos funerarios, indica que el conjunto de tumbas excavadas en la roca del siglo XI siguen manteniendo una especial significación en el conjunto del cementerio.

Las tumbas excavadas en la roca van a romper su uniformidad anterior para mostrarse diversas en su conformación y dispersas en su disposición. En lo primero, la pérdida del carácter antropomórfico parece compensada con una mayor calidad en la elaboración y una también mayor riqueza formal: tumbas trapezoidales levemente antropomorfas, tumbas trapezoidales simples de lados rectos o curvos, tumbas de trapezoidales poco acentuadas y de lados curvos, tumbas excavadas, pero

\footnotetext{
${ }^{17}$ LÓPEZ ALSINA, 1988: 259-273; 1995; SUÁREZ OTERO, 2003: 73-75.

${ }^{18}$ LÓPEZ ALSINA, 1990: 757.
} 
con paredes de lajas. Pero ambas condiciones otorgan al cementerio un carácter de heterogeneidad, acentuado porque esa mejor elaboración de las tumbas es también en sí variable, y porque, por otra parte, esa nueva riqueza de formas lleva aparejada una mayor variabilidad de las dimensiones. En consecuencia, elaboración, forma y dimensiones expresan en sus variadas combinaciones el carácter marcadamente individual de estos enterramientos, como, por otra parte, señalan las cubiertas monolíticas epigráficas.

En lo segundo, la disposición, asistimos a una fragmentación del cementerio, con tumbas conformando pequeños grupos o dispersas entre estos, siempre con la orientación canónica y por tanto desviadas de la que presenta la iglesia. Lejos de las tumbas estructuradas en hileras entorno a las paredes de la iglesia y con la orientación de esta, ahora las tumbas se alejan del templo y adoptan una disposición en la que hay otros factores que influyen más decisivamente que la relación con la propia iglesia.

Cabría pensar que la elección de esa fórmula en un espacio recién liberado de su uso arquitectónico se debiera simplemente a la inmediatez de la roca base en un suelo que no posibilitó la acumulación de tierras. Sin embargo, la presencia de alguna tumba de lajas contradice esa posibilidad, y el acarreo de tierras siempre sería una opción en un marco en el que las viejas estructuras servirían de muros de contención frente a la pendiente o la lejanía del muro de la cerca. Aunque más relevante sería la condición jurídica, de propiedad, de un suelo que albergaba el antiguo palacio episcopal, y que va a seguir en relación con el que lo sustituye. En definitiva, un espacio entre la iglesia y el palacio episcopal que proyecta un ámbito funerario privilegiado, en el que la fórmula funeraria dominante se materializará intencionalmente en la tumba excavada en la roca, continuando una tradición que estaba unida a una etapa de predominio, sino exclusividad, de los enterramientos del estamento eclesiástico. Cabe pensar que ahora se busca una continuidad en la relación del tipo de sepultura y la condición, sino el estatus, del enterrado.

\section{DE LA LECTURA CONCEPTUAL A LA INTERPRETACIÓN HISTÓRICA}

Parece claro que la implantación de las tumbas excavadas en la roca de caja antropomorfa supuso un cambio radical en la conformación del cementerio, ahora con un espacio y disposición estrictamente definidos y en relación con la nueva iglesia. Una caracterización que tuvo que responder a criterios de orden religioso también definidos, tanto en la construcción de lo funerario como en su relación con lo cultual. Sin embargo, esa relación genérica no agota la clave ideológica en la construcción a fines del siglo IX de este cementerio. Hay otro detalle, que se aparta de la sepultura excavada en la roca y que podría pasar - lo ha hecho - desapercibido: el aparente rechazo de los 
sarcófagos pétreos. Reutilizados en la etapa previa y vueltos a reutilizar en momentos posteriores de esta, ahora aparecen amortizados en los cimientos o bajo los pavimentos de la iglesia, sin que en ningún caso parezcan ni tan siquiera cumplir alguna función estructural. Viejas sepulturas en sarcófagos bien visibles y obstruyendo una necesaria reorganización del terreno, tapas y cajas disociadas, producto de la destrucción de esa área cementerial anterior, fueron absorbidos o desperdigados en los rellenos sobre los que se iba a asentar el nuevo edificio, y en el único ejemplo de reutilización esta solo afectará a la tampa, cuyo sarcófago original será sustituido por una tumba excavada en la roca, todavía antropomorfa como aquel ${ }^{19}$. Extraño, cuando las nuevas tumbas se hacen excavando la roca para reproducir una caja antropomorfa que los sarcófagos ofrecían ya hecha y de mejor calidad. O se cubrían con toscas cubiertas a base de lajas irregulares, frente a las laudas monolíticas de cuidada elaboración. En consecuencia, más que desaprovechados, parecen rechazados. Eliminados intencionalmente, porque alguna razón los hacía inadecuados en el nuevo cementerio.

Una actitud más extraña, cuando los sarcófagos parecían todavía jugar un papel relevante en el cementerio preexistente, no solo por el reaprovechamiento de piezas antiguas, sino por la elaboración de otros nuevos, o al menos sus tampas, como es el caso del de Aroaldo, fechado en el $885^{20}$, o el posible de Teodomiro que atendiendo a la fecha del óbito habría que llevarlo incluso más atrás, al $847^{21}$, pero cuyos rasgos apuntan una elaboración posterior, cuando menos a la donación de la cruz de Alfonso III (año 874) ${ }^{22}$, referente iconográfico de la que aparece grabada en el propio epitafio, y quizá ya en relación con la construcción de la nueva basílica. Y no es que deje de existir la diferenciación por la calidad entre las tumbas del nuevo cementerio. Esta, aunque escasa, aparece reflejada en las tumbas, con paredes bien elaboradas en mampostería concertada o con ladrillos, dentro de lo que fue un primer pórtico funerario en el lado sur de la basílica. Como también es posible que aparezcan las primeras laudas epigráficas. Sin embargo, todo insiste en el aparente rechazo a los sarcófagos y sus tampas con decoración de doble estola, que definen la tradición local y que en Compostela eran relativamente abundantes y accesibles, como evidencia su reutilización en los tiempos inmediatamente anteriores al cementerio de la basílica de Alfonso III, o incluso en una etapa posterior del que estamos tratando. Una basílica que paradójicamente destaca por su vocación de recuperar el pasado, tanto estética como ideológicamente, a través de las columnas de mármol tardoantiguas traídas de Portucale, o más de las placas decorativas de

\footnotetext{
19 SUÁREZ OTERO, 1999: 310-311.

${ }^{20}$ CHAMOSO LAMAS, 1956b; GUERRA CAMPOS, 1982: 450; SUÁREZ OTERO, 1999: 312-313.

${ }^{21}$ CHAMOSO LAMAS, 1957; GUERRA CAMPOS, 1982: 447-450.

${ }^{22}$ LÓPEZ FERREIRO, 1899-1905: II, 169-173; BARRAL IGLESIAS, 1998: 59-63.
} 
ese y otros materiales procedentes de la Coria romano-visigótica ${ }^{23}$. Un pasado ya alejado en el tiempo, el romano, que se reivindica expresamente como propio, aunque en gran medida coetáneo de los sarcófagos que, sin embargo, ahora parecen rechazarse. En definitiva, se apela como sostén ideológico a un pasado, alejado en el tiempo y ajeno en el espacio, pero al mismo tiempo parece rechazarse otro no tan alejado, en cierta medida incluso aún presente, en lo temporal, y propio, incluso coincidente, en lo espacial.

Solo dos posibles causas podrían estar detrás de esa oposición sepultura excavada en la roca - sarcófago pétreo. La primera, la necesidad de absorber el conflicto que la plural composición de la Magna Congregatio podría generar. Integrar a monjes de varios cenobios y clero secular vinculado a la curia episcopal en una sola realidad eclesiástica necesitaba de una expresión funeraria que invocase esa unidad, no posibilitando la diferenciación en la relación post-mortem con el santuario, al tiempo que señala la preminencia de una sola autoridad en el control del Locus Sanctus, en este caso, el obispo en la persona de Sisnando I. La segunda, la intención de evidenciar una ruptura con el pasado inmediato, reflejado en una necrópolis preexistente, pero también en unos sarcófagos que llevan incluso más atrás, al tiempo que expresan una tradición en el ritual funerario, sino en el de las creencias en general, con un marcado carácter local: la Gallaecia sueva ${ }^{24}$. Y se hace al tiempo que se reivindica un pasado aún más lejano y de carácter supralocal: la Hispania romana. En definitiva, el nuevo cementerio de tumbas excavadas en la roca parece un reflejo de los cambios en la organización eclesiástica, pero también en lo político, promovidos por la monarquía asturiana en tiempos de Alfonso III y materializados en el que, en ese mismo momento y a través de esos mismos cambios, se convierte en el principal santuario del reino.

\section{BIBLIOGRAFÍA}

BARRAL IGLESIAS, A. (1998). A ourivería sagrada na Compostela medieval. As doazóns e a devoción a Santiago nos séculos IX-XV. In SINGUL, F., ed. Pratería e acibeche en Santiago de Compostela. Obxetos litúrxicos e devocionais para o rito sacro e a peregrinación. Santiago: Xunta de Galicia, pp. 55- 98.

CASTRO, B. (2013). Francisco Pons Sorolla. Arquitectura y restauración en Compostela (1945-1985). Santiago de Compostela: Consorcio de la Ciudad de Santiago.

CHAMOSO LAMAS, M. (1956a). Noticias de las excavaciones arqueológicas en la Catedral de Santiago. «Compostellanum». I: 2, 349-376.

CHAMOSO LAMAS, M. (1956b). Noticias de las excavaciones arqueológicas en la Catedral de Santiago (Segunda Fase). «Compostellanum». I: 4, 803-856.

\footnotetext{
${ }^{23}$ SÁNCHEZ ALBORNOZ, 1981; LÓPEZ PEREIRA, 1993.

${ }^{24}$ SUÁREZ OTERO, 2020.
} 
CHAMOSO LAMAS, M. (1957). Noticias de las excavaciones arqueológicas en la Catedral de Santiago (Tercera Fase). «Compostellanum». II: 4, 575-624.

CHAMOSO LAMAS, M. (1971). Noticias sobre los recientes descubrimientos arqueológicos y artísticos efectuados en Santiago de Compostela. «Principe de Viana». 32, 35-48.

DAGENAIS, John et al. (2014). New perspectives on the romanesque cathedral of Santiago de Compostela, en Santiago de Compostela. In NICOLAI, B.; RHEIDT. K., ed. Santiago de Compostela Colloquium, Pilgerarchitektur und bildliche Repräsentation in neuer Perspektive. Berna: Peter Lank International Academic Publishers, pp. 90-103.

DÍAZ BUSTAMANTE, J. M.; LÓPEZ PEREIRA, E. (1990). El acta de consagración de la catedral de Santiago: edición y estudio crítico. "Compostellanum». 35, 377-400.

GUERRA CAMPOS, J. (1982). Exploraciones arqueológicas en torno al sepulcro del Apóstol Santiago. Santiago de Compostela: Cabildo de la S. A. M. Iglesia de Santiago.

LÓPEZ AlSINA, F. (1988). La ciudad de Santiago de Compostela en la Alta Edad Media. Santiago: Universidad de Santiago.

LÓPEZ ALSINA, F. (1990). De la magna congregatio al cabildo e Santiago: reformas del clero catedralicio (830-1110). In VV.AA. - O Bispo D. Pedro e o Ambiente Político-Religioso do Século XI, Actas Congresso Internacional IX Centenário da Dedicaçao da Sé de Braga. Braga: UCP, vol. 1, pp. 735-762. .

LÓPEZ ALSINA, F. (1995). Implantación urbana de la Catedral románica de Santiago de Compostela (1070- 1150). In VV.AA. - La meta del Camino de Santiago (Catálogo de la Exposición). Santiago de Compostela: Xunta de Galicia, pp. 37-56.

LOPÉZ FERREIRO, A. (1899-1905). Historia de la S. A. M. Iglesia de Santiago. Santiago de Compostela. LÓPEZ PEREIRA, J. E. (1993). Mármoles romanos de la iglesia de Alfonso III: determinación de su origen. «Madrider Mitteilungen». 34, 275-281.

MORALEJO ÁLVAREZ, S. (1983). Notas para una revisión de la obra de K. John Conant. In CONANT, K. John, ed. Arquitectura románica da Catedral de Santiago. Santiago: Colegio Oficial de Arquitectos.

OTERO TÚÑEZ, R. (1965). Problemas de la Catedral románica de Santiago. «Compostellanum». X, 605-640.

REY SEARA, E.; RODRÍGUEZ PUENTES, E. (1989). Azabachería 29 (Santiago de Compostela). In VV.AA. - Arqueoloxía / Informes 1. Santiago de Compostela: Xunta de Galicia, pp. 104-107.

SÁNCHEZ ALBORNOZ, C. (1981). Mármoles romanos en la iglesia alfonsí de Compostela. In SÁNCHEZ ALBORNOZ, C., ed. Estudios sobre Galicia en la Temprana Edad Media. A Coruña: Fundación Pedro Barrié de la Maza, pp. 511-516.

SÁNCHEZ ALBORNOZ, C. (1981). Sobre el acta de consagración de la iglesia de Compostela en 899. In SÀNCHEZ ALBORNOZ, C., ed. Estudios sobre Galicia en la Temprana Edad Media. A Coruña: Fundación Pedro Barrié de la Maza.

SUÁREZ OTERO, J. (1994). La moneda de Alfonso VI en la catedral de Santiago. «Numisma». 235, 47-59. SUÁREZ OTERO, J. (1999). Construyendo Compostela: la necrópolis altomedieval. In VV. AA., Santiago. Xelmírez. Santiago de Compostela: Xunta de Galicia, pp. 306-319.

SUÁREZ OTERO, J. (2003). El locus Sancti Iacobi. Compostela en la Alta Edad Media. In PORTELA, E., ed. Historia de Santiago de Compostela. Santiago: Universidad de Santiago, pp. 53-81.

SUÁREZ OTERO, J. (2004). Altaria Sancti Benedicti et Sancti Antonini fuerant in turribus... Santiago de Compostela: definición y significado de la puerta en un santuario fortificado. In SHATTNER, Th. G.; VALDÉS, F., ed. Stadtore. Bautyp und Kunstform. Iberia Archaeologica, Mainz, pp. 305-323.

SUÁREZ OTERO, J. (2009). Moneda, Peregrinación y Comercio. Una nueva perspectiva del Camino de Santiago en la Edad Media. In VIII Memorial Filgueira Valverde. Reflexos da peregrinación e do culto a Santiago. Pontevedra: Diputación de Pontevedra, pp. 81-114. 
SUÁREZ OTERO, J. (2012). Galicia, la crisis del siglo VIII y la transición al mundo medieval. Nuevas propuestas para viejos problemas. In CABALLERO, L.; MATEOS; P.; GARCÍA DE CASTRO, C., ed. Asturias entre visigodos y mozárabes. Anejos de «Archivo Español de Arqueología». LXIII, 415-442.

SUÁREZ OTERO, J. (2015). Locus Iacobi. Orígenes de un santuario de peregrinación. Santiago de Compostela: Facultade de Xeografía e Historia da Universidade de Santiago. Tese de Doutoramento.

SUÁREZ OTERO, J. (2020). Santiago, entre Suevos y Visigodos. Territorio, conflicto y poder en los orígenes del enigma jacobeo. In LÓPEZ QUIROGA, Jorge, ed. Conversion, Religious Leadership and the Christianization of the Landscape in Late Antiquity. Oxford: BAR International Series.

WILLIAMS, J. (1984). La arquitectura del Camino de Santiago. "Compostellanum». XXIX, 3-4. 


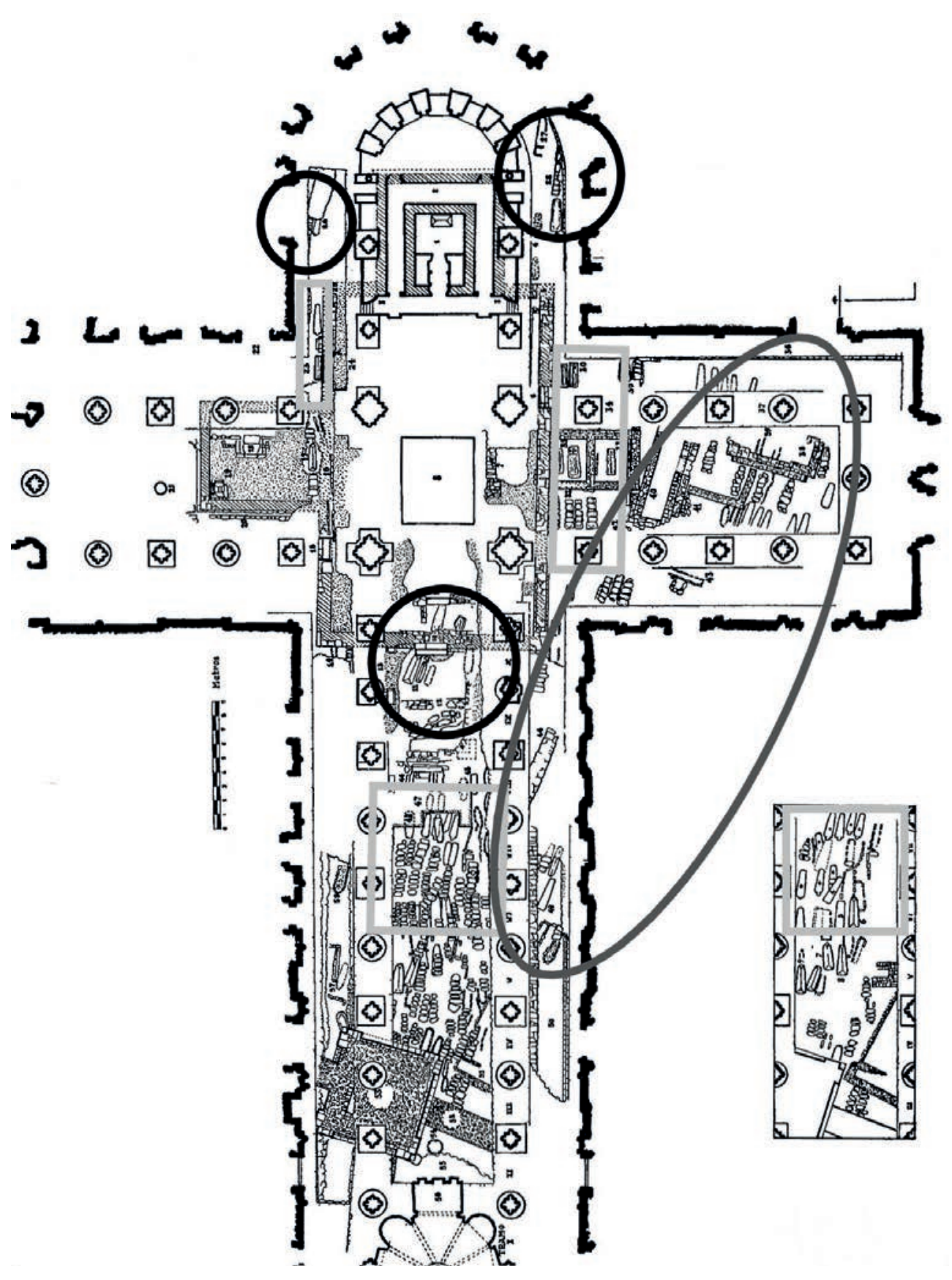

Fig. 1. Lectura evolutiva da necrópolis altomedieval compostelana. Círculos: Fase I. Antes ca. 880; Retângulos: Fase II. Siglo. X; Elipse: Fase III. Siglo XI

Fuente: Planimetría de F. Pons Sorolla, en Guerra Campos (1982) 

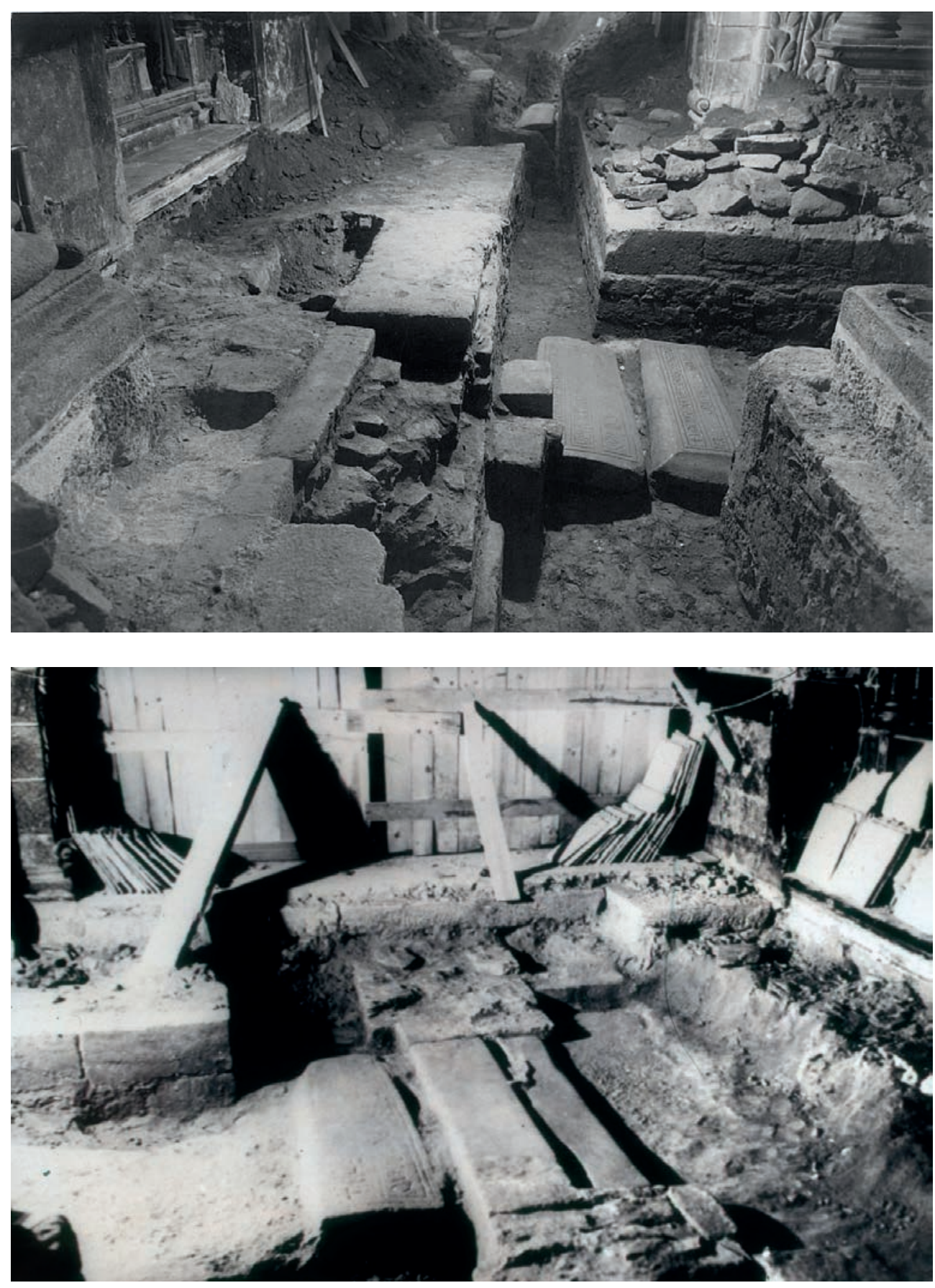

Fig. 2. Tumbas excavadas en la roca con lápida epigráfica. Puerta meridional (arriba) y puerta norte (abajo) Fuente: M. Chamoso Lamas (Arquivo Museo Catedral de Santiago) 

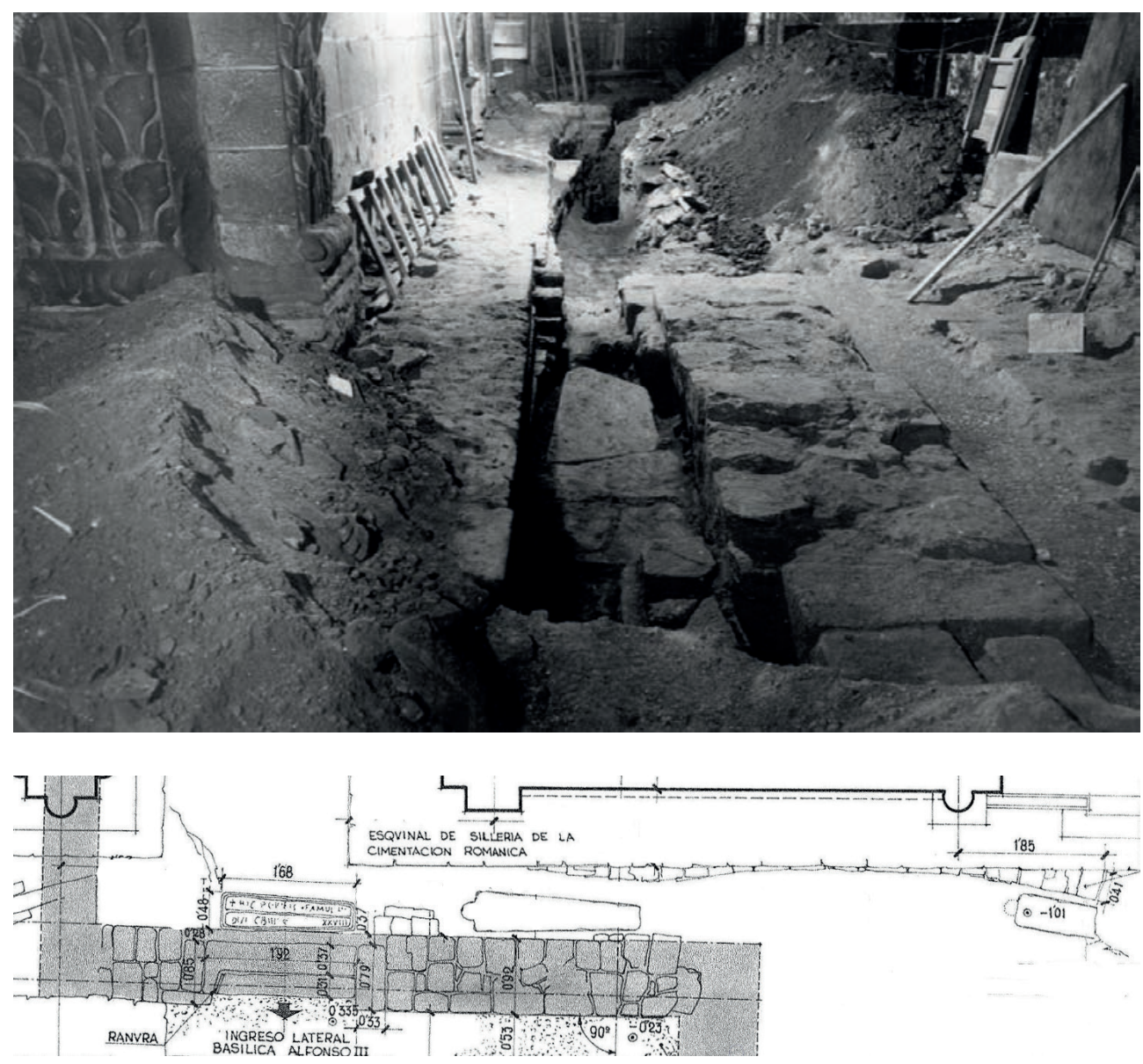

Fig 3. Tumbas en el sector norte de la Girola de la Catedral, próximas a la cabecera y entrada norte de la basílica de Alfonso III

Fuente: M. Chamoso Lamas (Arquivo Museo Catedral de Santiago) 


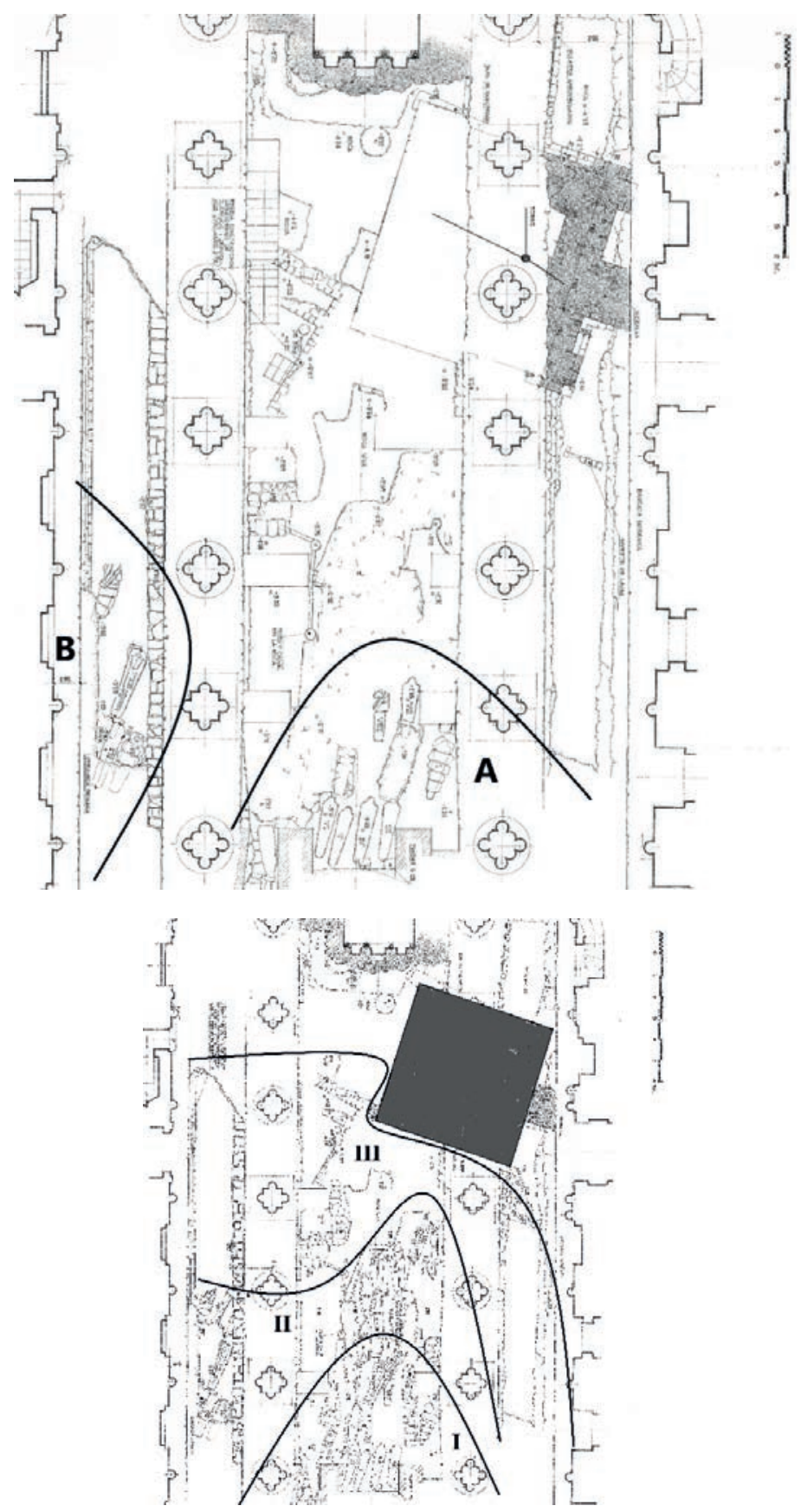

Fig. 4. Necrópolis bajo el Brazo Occidental de la catedral. Arriba, tumbas excavadas en la roca al Oeste de la iglesia de Alfonso III: A núcleo occidental. B. Proyección del núcleo Meridional. Abajo. Evolución de la necrópolis: I - s. IX-X; II - s. X-XI; III - s. XI-XII

Fuente: Planimetría de F. Pons Sorolla, en Guerra Campos (1982) 

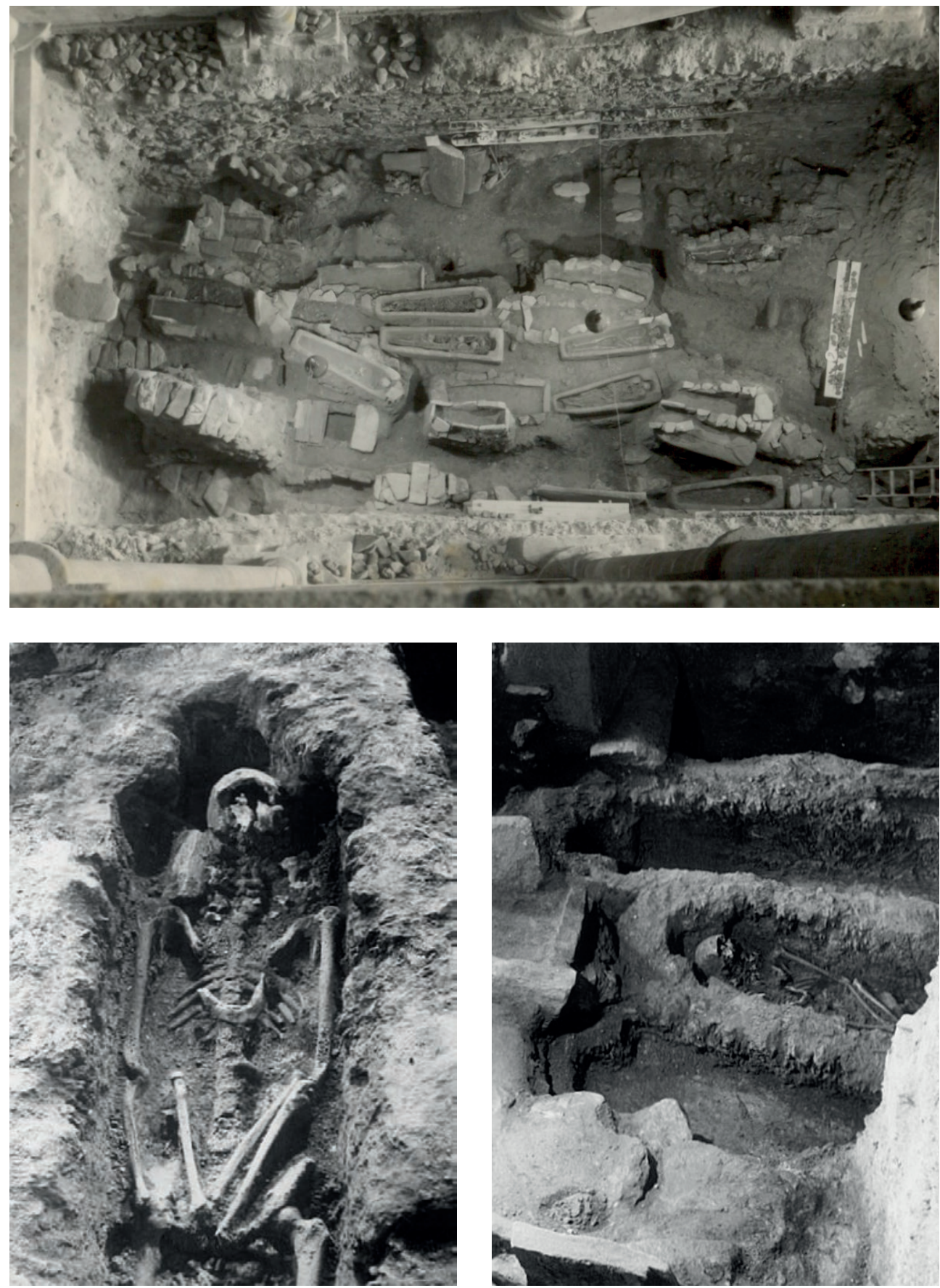

Fig. 5. Necrópolis bajo la Nave central del Brazo Mayor del Crucero. Arriba, vista general. Abajo, tumbas frente a la fachada occidental de la Iglesia de Alfonso III Fuente: M. Chamoso Lamas (Arquivo Museo Catedral de Santiago) 

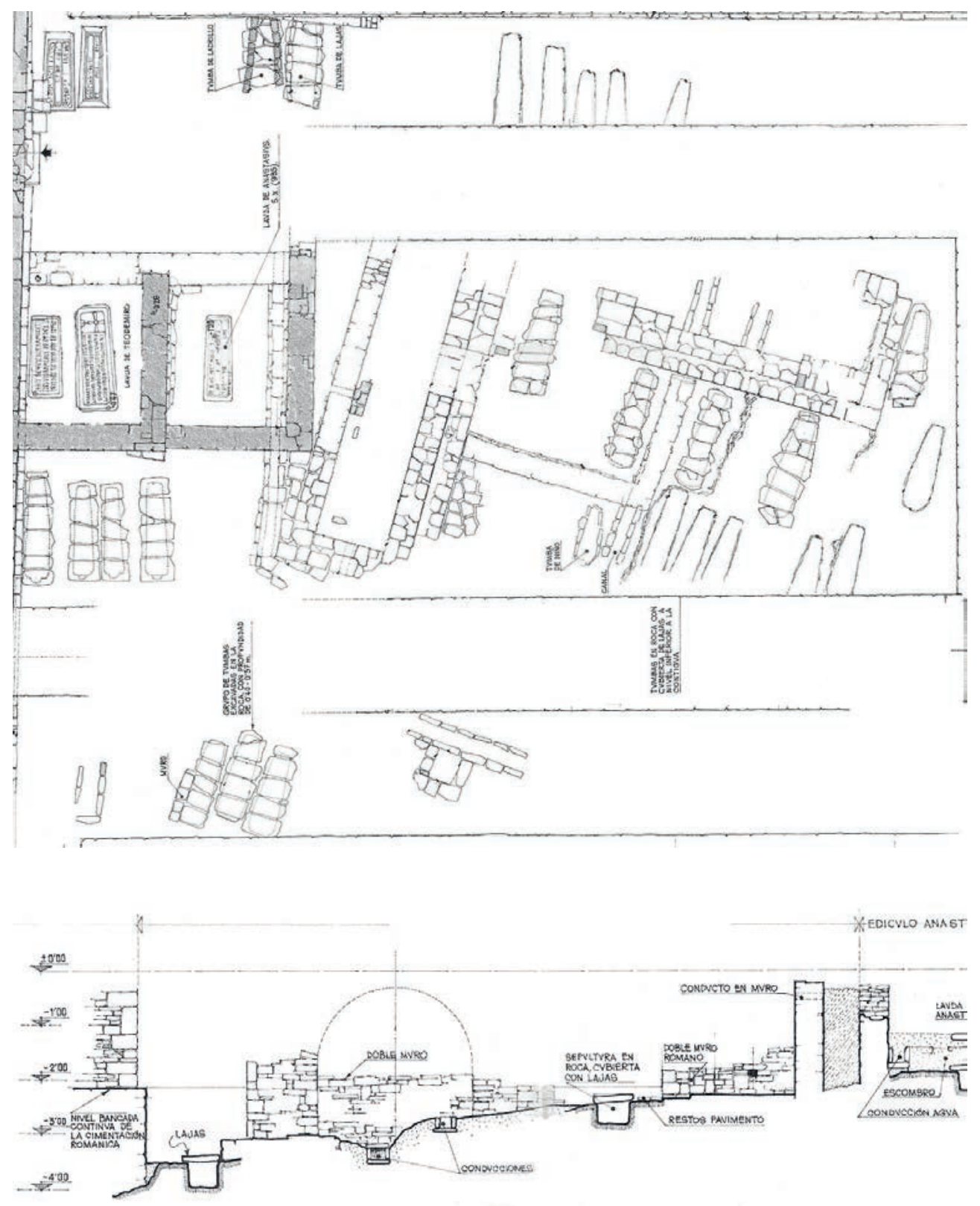

Fig. 6. Tumbas Excavadas en la roca. Brazo Sur del Crucero

Fuente: Planta y alzado, a partir de la planimetría de F. Pons Sorolla, en Chamoso Lamas (1957) 

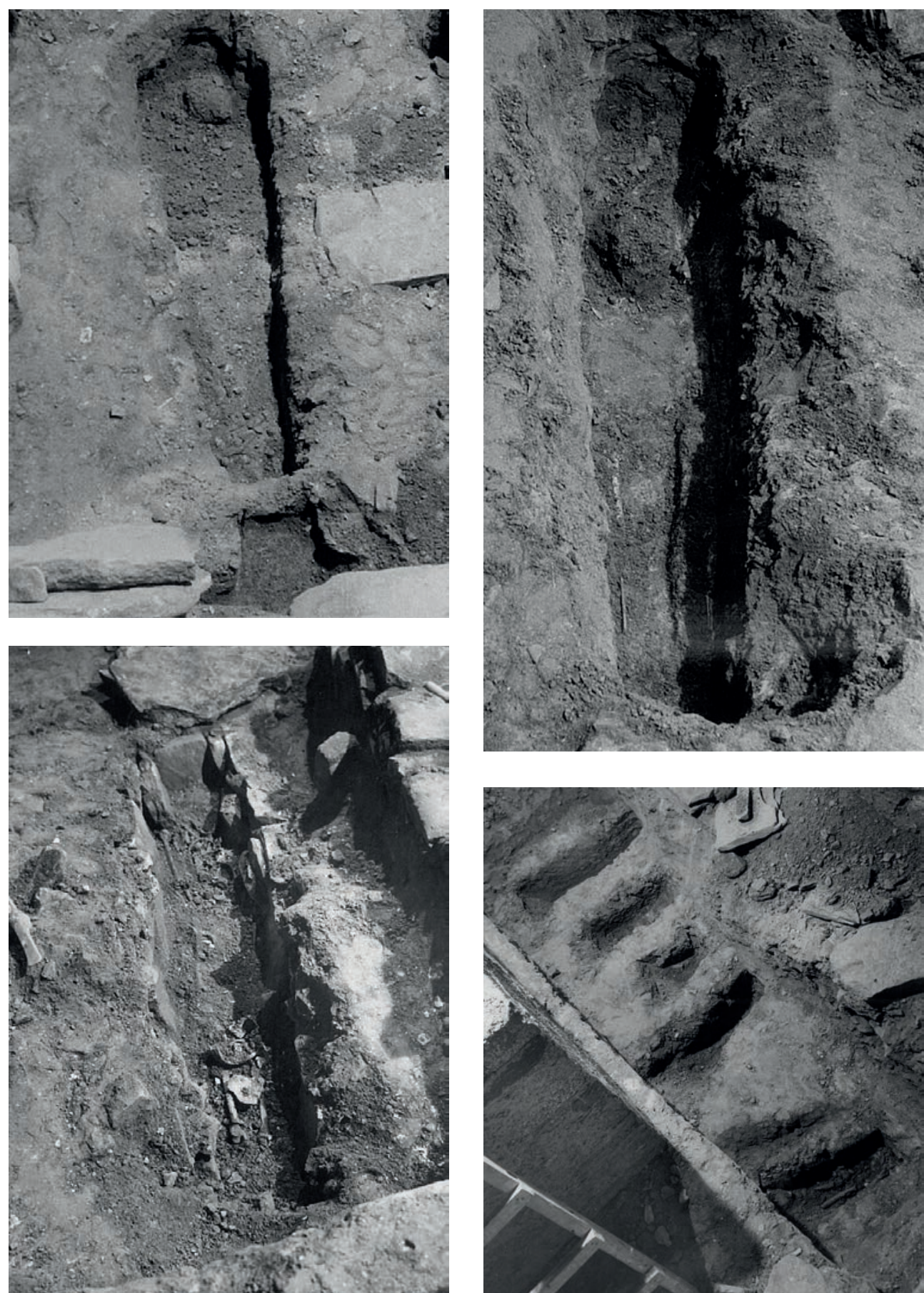

Fig. 7. Tumbas excavadas en la roca. Brazo Sur del Crucero: Nave central (1-3) y grupo en la nave menor Este Fuente: M. Chamoso Lamas (Arquivo Museo Catedral de Santiago 

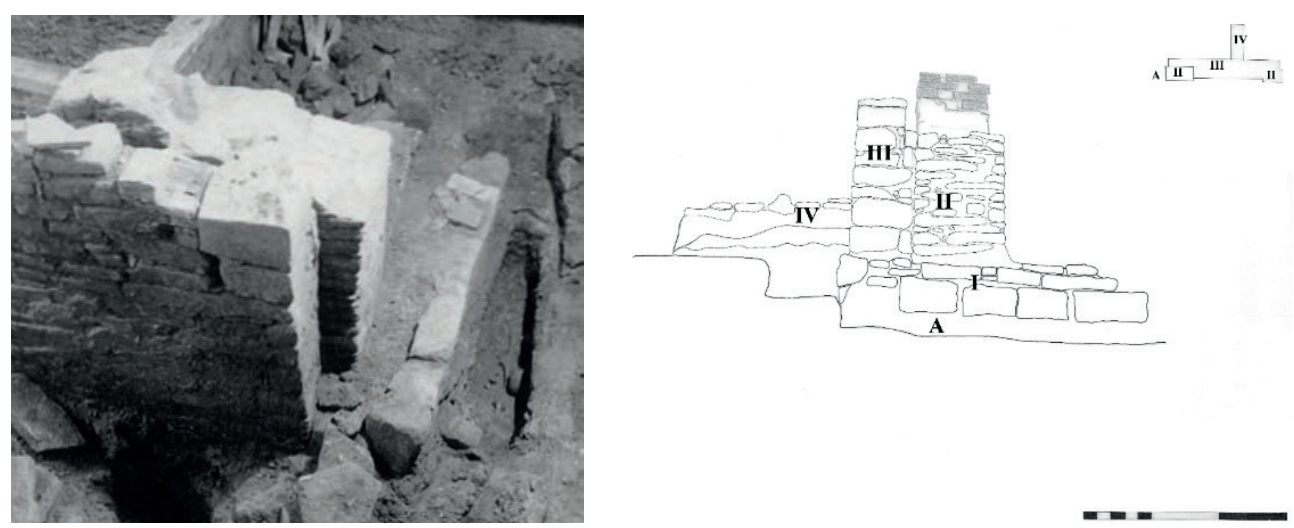

A

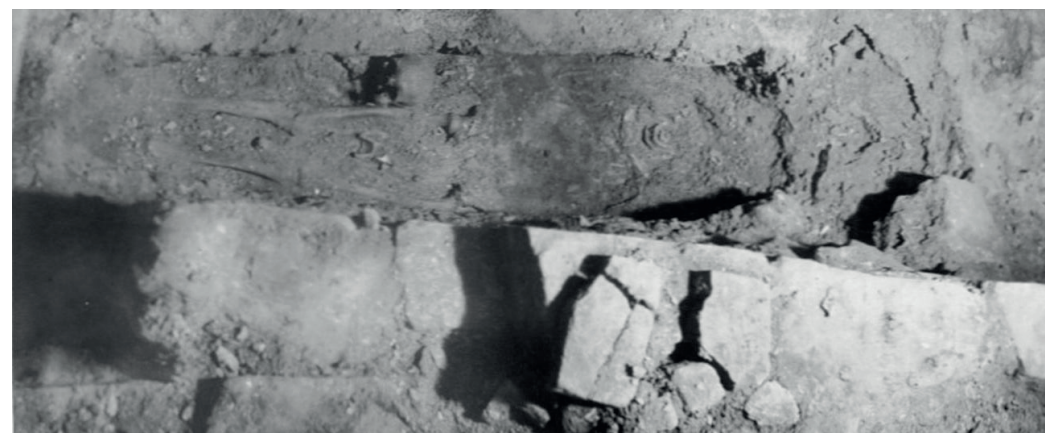

B

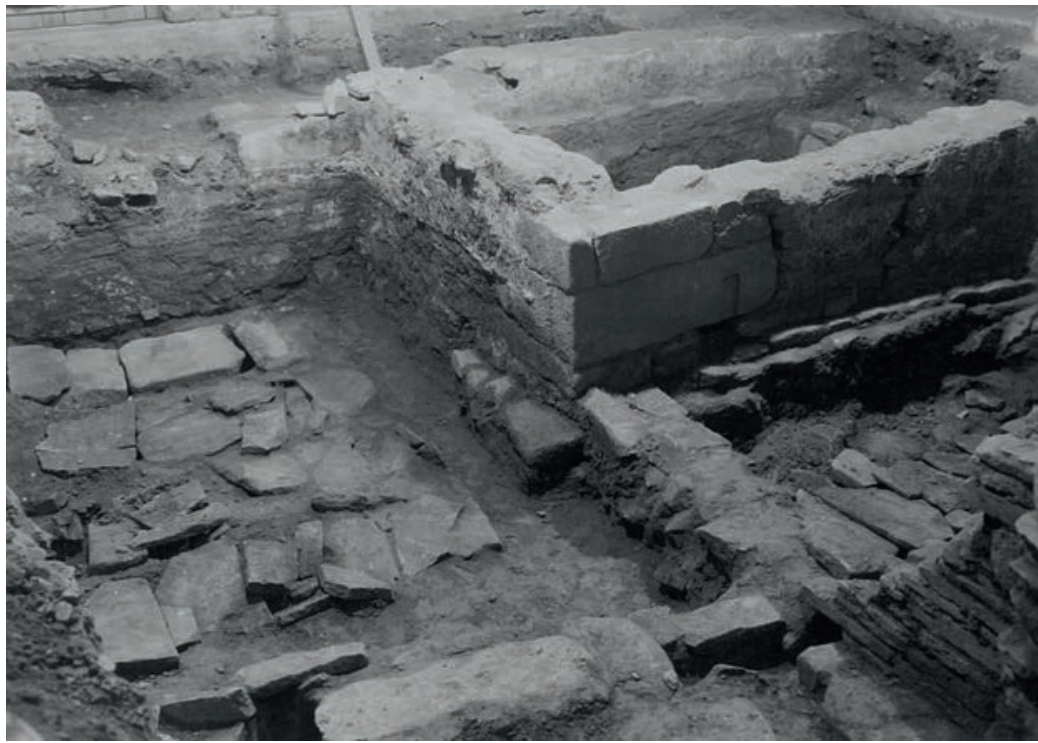

Fig. 8. Tumbas excavadas en la roca. Brazo Sur del Crucero. Estratigrafía y contexto: A. Tumba y muros del primitivo palacio episcopal (I-IV). B. Tumbas entre la basílica de Alfonso III y el «edículo de Teodomiro» Fuente: M. Chamoso Lamas, Arquivo Museo Catedral 


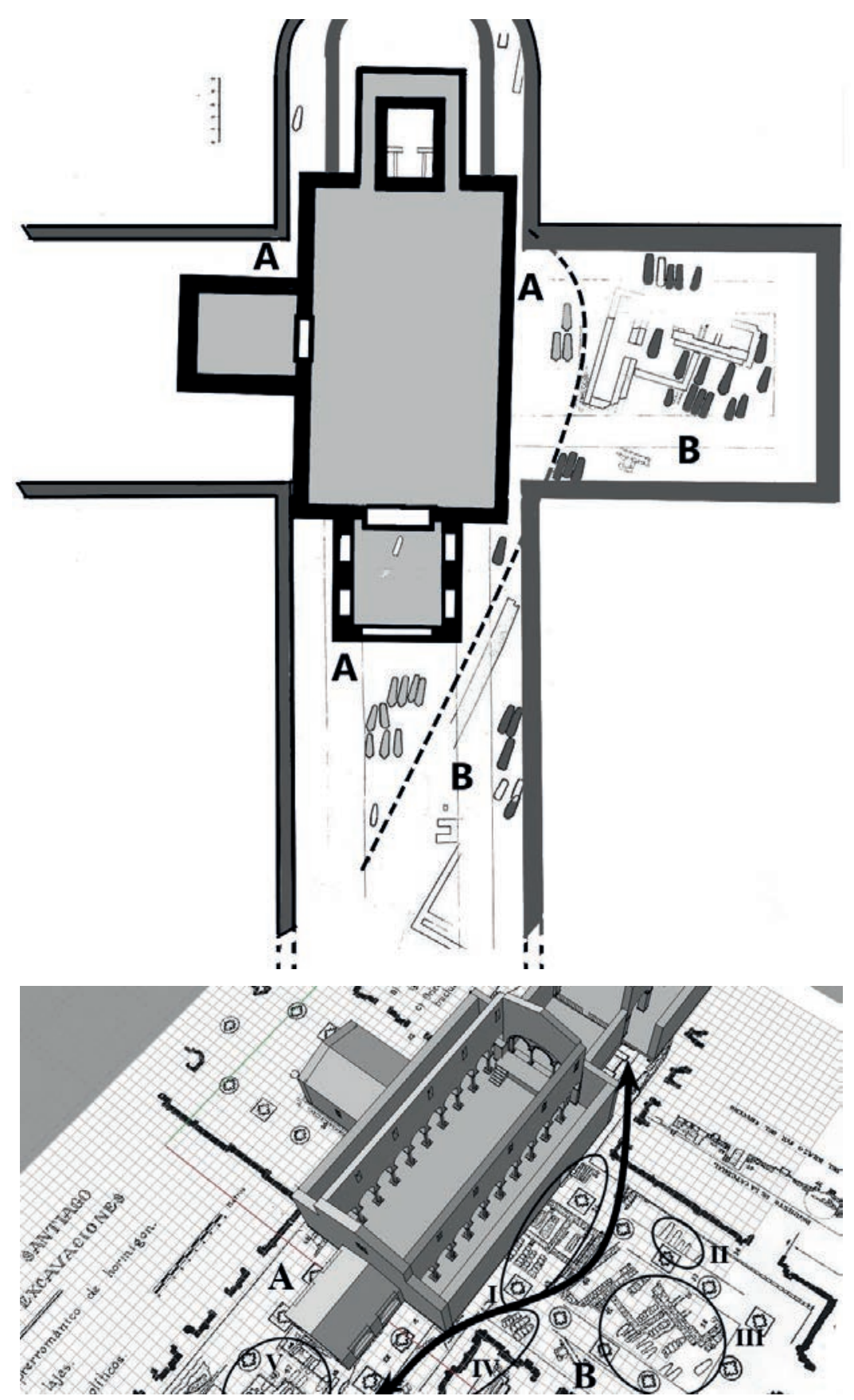

Fig. 9. Grupos de tumbas excavadas en la roca en el cementerio altomedieval compostelana. A. Fase II. Tumbas antropomorfas (ss. IX-X). B. Fase III. Tumbas trapezoidales (Ss. X-XI)

Fuente: Planta a partir de croquis en J. Guerra Campos, 1982; Reconstrucción virtual: UCLA Project (๔ Regents of the University of California) 
I.

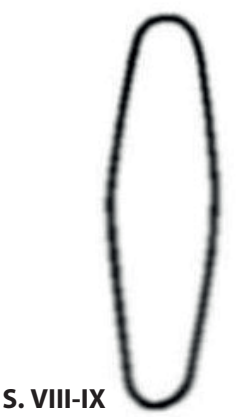

II. Ss. IX-X

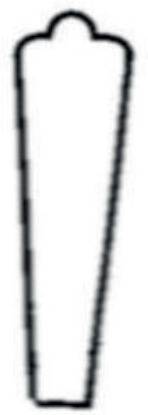

III. Ss. X-X
IV.

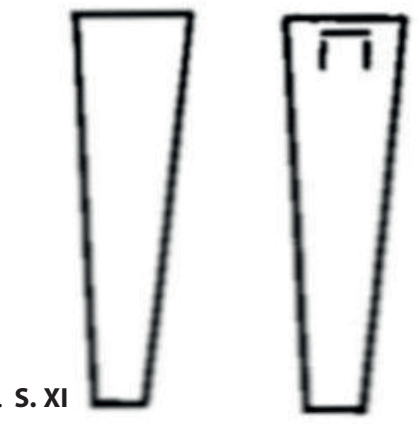

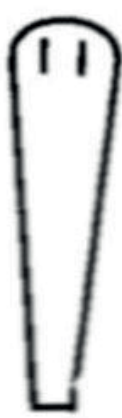

Fig. 10. Evolución formal, con datación contextual, de los sepulcros en roca compostelanos Fuente: Elaboración propia 


\title{
SEPULTURAS ESCAVADAS NA ROCHA NA BEIRA INTERIOR DURANTE A ALTA IDADE MÉDIA. SOCIEDADES E PAISAGENS RURAIS
}

\author{
CATARINA TENTE* \\ TOMAS CORDERO RUIZ** \\ JOÃO LUIIS VELOSO****
}

\begin{abstract}
Resumo: O presente trabalho aborda de forma muito sintética a problemática das sepulturas escavadas na rocha da região beirã partindo de duas escalas de análise: a microescala, que corresponde à escala do sítio arqueológico; e a macroescala, que, neste caso, corresponde à análise de toda a região. Na primeira abordagem tem sido fundamental a escavação de sítios com sepulturas, como o Penedos dos Mouros e São Gens, o que veio permitir uma nova compreensão deste fenómeno funerário. A segunda abordagem mostra-se também essencial pois começam a emergir claras diferenças na distribuição dos sítios com sepulturas à escala da região que nem sempres se podem explicar pela desigualdade no investimento da investigação arqueológica. Um desses casos é o território de Lafões aqui discutido sucintamente.
\end{abstract}

Palavras-chave: Comunidades locais medievais; Povoamento; Organização familiar; Necrópoles rupestres.

\begin{abstract}
This paper is a synthetic approach to the rock-cut graves known in Beira region. The analysis is made in two different scales: a micro-scale, corresponding to the scale of the archaeological site; and the macro-scale, which, in this case, is related with the analysis of the entire region. In the first approach has been fundamental the excavation of sites with graves, such as Penedo dos Mouros and São Gens, which allowed a new understanding of this funerary phenomenon. The second approach is also essential because some differences are beginning to emerge in the distribution of burial sites at regional scale. These differences cannot always be explained by the lack of investment in archaeological research. One such case is the territory of Lafões discussed briefly in the text.
\end{abstract}

Keywords: Local medieval communities; Settlement; Household organization; Rupestrian necropolis.

\section{INTRODUÇÃO}

As sepulturas escavadas na rocha são um dos mais visíveis e abundantes vestígios da Alta Idade Média em Portugal, com áreas com particulares concentrações, como ocorre na região beirã. A sua constante presença nas paisagens do centro e

\footnotetext{
* IEM/NOVA FCSH. Email: catarina.tente@fcsh.unl.pt.

${ }^{* *}$ IEM/NOVA FCSH. Email: tomascordero@fcsh.unl.pt.

*** IEM/NOVA FCSH. Email: joaoluisveloso@gmail.com.
} 
norte do país estimularam vários estudos realizados nos últimos 30 anos, inspirados na seminal tese de Mário J. Barroca ${ }^{1}$. Nesse trabalho foi proposto um modelo de categorização dos sítios com sepulturas que abria a porta para a vinculação das sepulturas rupestres com o povoamento, o que foi um passo em frente na forma de abordar arqueologicamente a ocupação alto medieval dos espaços rurais. Este mesmo modelo foi também avançado por Bolós y Pagés $^{2}$ e aplicado a inúmeros outros trabalhos levados a cabo na década de 90 do século XX e inícios da nova centúria em Portugal, especialmente nos territórios situados entre os rios Douro e o Mondego ${ }^{3}$.

Nos últimos 10 anos, a escavação de sítios de habitat correlacionáveis com as sepulturas escavadas na rocha levados a cabo na região beirã ${ }^{4}$, na área da barragem do Alqueva ${ }^{5}$ e na raia, quer do lado espanhol quer português, nomeadamente na La Genestosa ${ }^{6}$, e, mais a sul, em Castelo de Vide ${ }^{7}$, possibilitou um aporte de informação muito importante para a compreensão do fenómeno da construção das sepulturas escavadas na rocha. Parece ser agora mais clara a relação entre as sepulturas escavadas na rocha e a ocupação do espaço, ainda que não seja possível desenhar modelos interpretativos. A evolução da investigação sobre esta temática tem também permitido perceber que as sepulturas rupestres refletem a organização social das comunidades que as construíram e usaram, podem ter tido um papel significativo na construção da memória das famílias e comunidades e até na legitimação do direito à propriedade ${ }^{8}$. Um dos mais importantes pontos de viragem na investigação dos últimos anos ocorre com a publicação do artigo de I. Martín Viso publicado na revista "Zephyrus»" ${ }^{9}$ O trabalho não só propõe um novo modelo de categorização, como avança para uma leitura social dos diferentes padrões de associação e distribuição das sepulturas. O modelo acaba por superar as questões estritamente relacionadas com a tipologia e cronologia das sepulturas, problemáticas que dominavam (e em certa medida ainda dominam) o debate sobre as necrópoles rupestres na Península Ibérica desde os estudos de Alberto del Castillo ${ }^{10}$.

\footnotetext{
${ }^{1}$ BARROCA, 1987, 2010-2011.

2 BOLÒS i MASCLANS, PAGĖS i PARETAS, 1982

${ }^{3}$ LOPES, 2002; LOURENÇO, 2007; MARQUES, 2000; TENTE, LOURENÇO, 1998; TENTE, 2000, 2007; VALERA, 1990; VIEIRA, 2004, 2006.

${ }^{4}$ TENTE, 2010, 2015, 2017.

${ }^{5}$ FERREIRA, 2013.

${ }^{6}$ MARTÍN VISO et al., 2017; RUBIO DÍEZ, 2015.

${ }^{7}$ PRATA, 2012, 2014a, 2014b, 2017, 2018.

${ }^{8}$ MARTÍN VISO, 2008, 2011, 2012a, 2012b, 2017; MARTÍN VISO, BLANCO-GONZALEZ, 2016.

${ }^{9}$ MARTÍN VISO, 2012a.

${ }^{10}$ CASTILLO, 1970.
} 
O modelo proposto por I. Martín Viso foi aplicado em outras ocasiões às realidades da Beira Interior tendo, todavia, sido adaptado na medida em que se considera que a categoria de sepulturas isoladas deste autor comporta duas realidades diferentes: a sepulturas efetivamente únicas e isoladas e os pequenos grupos de sepulturas, que conjuntamente com as necrópoles desordenadas ou desarrumadas parecem refletir uma organização social de base familiar ${ }^{11}$. Deste modo, a abordagem patente no presente artigo aplica o modelo adaptado categorizando os sítios com sepulcros rupestres em 4 tipos: sepulturas isoladas (sepultura única); grupos desordenados que comportam 2 a 10 sepulturas; necrópoles desordenadas, que agregam mais de 10; e necrópoles ordenadas, onde se deteta um padrão espacial organizado.

No presente artigo, retoma-se a questão da organização social que as sepulturas parecem atestar, através da abordagem a casos estudos concretos que foram alvo de escavações arqueológicas. Procura-se ainda discutir a análise dos padrões de distribuição dos sítios desde uma perspetiva da macro escala, uma vez que é evidente que há áreas com grandes concentrações de sítios com sepulturas e outras em que as sepulturas escasseiam na paisagem. Para abordar esta questão usaremos o conhecimento disponível para a Beira Interior. Certos de que nesta área vasta haverá várias explicações para os diferentes padrões e densidades de distribuição, intenta-se, todavia, avançar na interpretação para o caso da região lafonense.

\section{ANÁLISE NA MICROESCALA}

Tal como referido, o estudo das sepulturas rupestres tem beneficiado dos avanços trazidos pelos resultados das escavações arqueológicas de sepulturas, como foram os casos na região beirã da sepultura do Alto da Quintinha - Mangualde ${ }^{12}$ e das sepulturas do Aljão - Gouveia ${ }^{13}$, e de sítios associados espacialmente a sepulturas, como o Penedo dos Mouros (Gouveia) e São Gens (Celorico da Beira). Para discutir a importância das escavações de sítios correlacionados para a interpretação deste fenómeno ao nível da cronologia e na sua relação com espaços habitados abordam-se de seguida dois casos-estudo.

\subsection{O Penedo dos Mouros e a sua sepultura isolada}

O estudo do Penedo dos Mouros revelou um povoado cercado, que se implanta em redor e um grande tor que suportava uma superestrutura de madeira, cujos restos foram recuperados nos trabalhos arqueológicos realizados em três campanhas (1998, 2008 e 2009). O sítio domina o pequeno, mas fértil, vale da Ribeira do Boco, afluente da margem esquerda do Mondego, cujas gentes que o habitavam deviam

\footnotetext{
11 TENTE, 2015, 2017.

12 NÓBREGA, NETO, TENTE, 2012.

13 TENTE, 2010.
} 
cultivar, já que várias sementes carbonizadas foram aqui identificadas. Um incêndio destrutivo que ocorreu na segunda metade do século $\mathrm{X}$ ditou o abandono definitivo deste sítio, tendo-se apenas identificado ocupações pastoris esporádicas de época contemporânea ${ }^{14}$.

O Penedo dos Mouros tem a particularidade de possuir uma única sepultura que foi escavada no topo mais alto do tor granítico que domina o sítio (Fig. 1). Ainda que não seja possível garantir que os vestígios arqueológicos do povoado do século $\mathrm{X}$ sejam contemporâneos da sepultura, a localização da mesma e a sua associação ao maior tramo de degraus escavados no tor permite correlacionar de forma singular estas evidências. A explicação mais plausível é a de que a sepultura foi escavada após a destruição e abandono do povoado. Se assim foi, então devemos considerar que a mesma foi construída e usada num momento em que a memória do sítio e, eventualmente do evento destrutivo, estava ainda bem viva. A sepultura do Penedo dos Mouros teria sido escavada para garantir que a memória coletiva deste lugar e da sua comunidade através da inumação de um indivíduo especial. Neste raciocínio seria lógico que esta personagem tenha tido um vínculo especial, direto ou familiar, com aquele espaço e a sua comunidade.

Não obstante serem comuns as sepulturas isoladas na Beira Interior, o caso do Penedo dos Mouros destaca-se pela excecionalidade do contexto em que terá sido construída, usando um espaço antes habitado em que se destaca pela sua implantação no topo do tor. Os dados disponíveis até ao momento mostram que esta situação não se parece repetir em mais nenhum caso, o que não significa que não possam vir a aparecer realidades semelhantes com a ampliação da investigação.

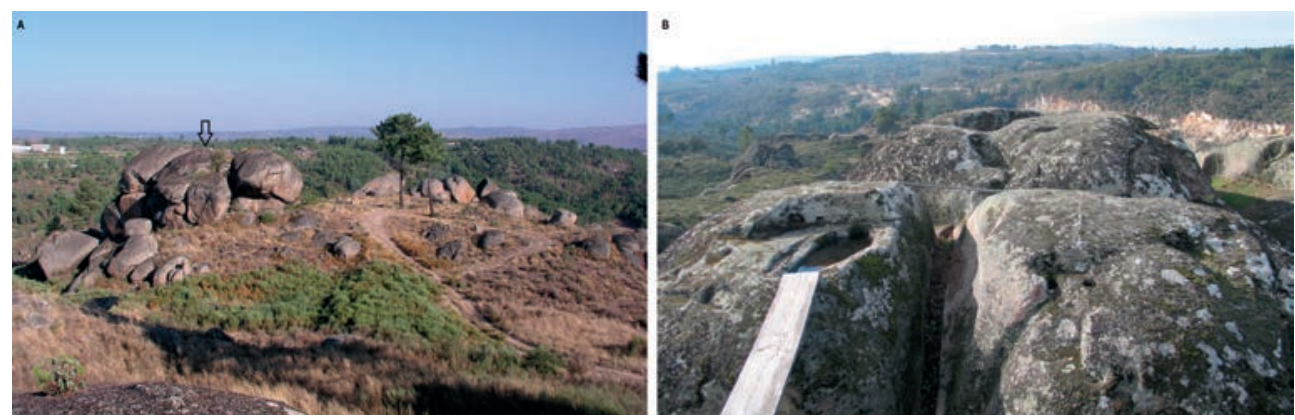

Fig. 1. Penedo dos Mouros: a) vista geral nordeste com indicação da localização da sepultura; b) Pormenor do topo do tor onde se localiza a sepultura

Fonte: Catarina Tente

14 TENTE, 2010, 2015; TENTE, CARVALHO, 2011. 


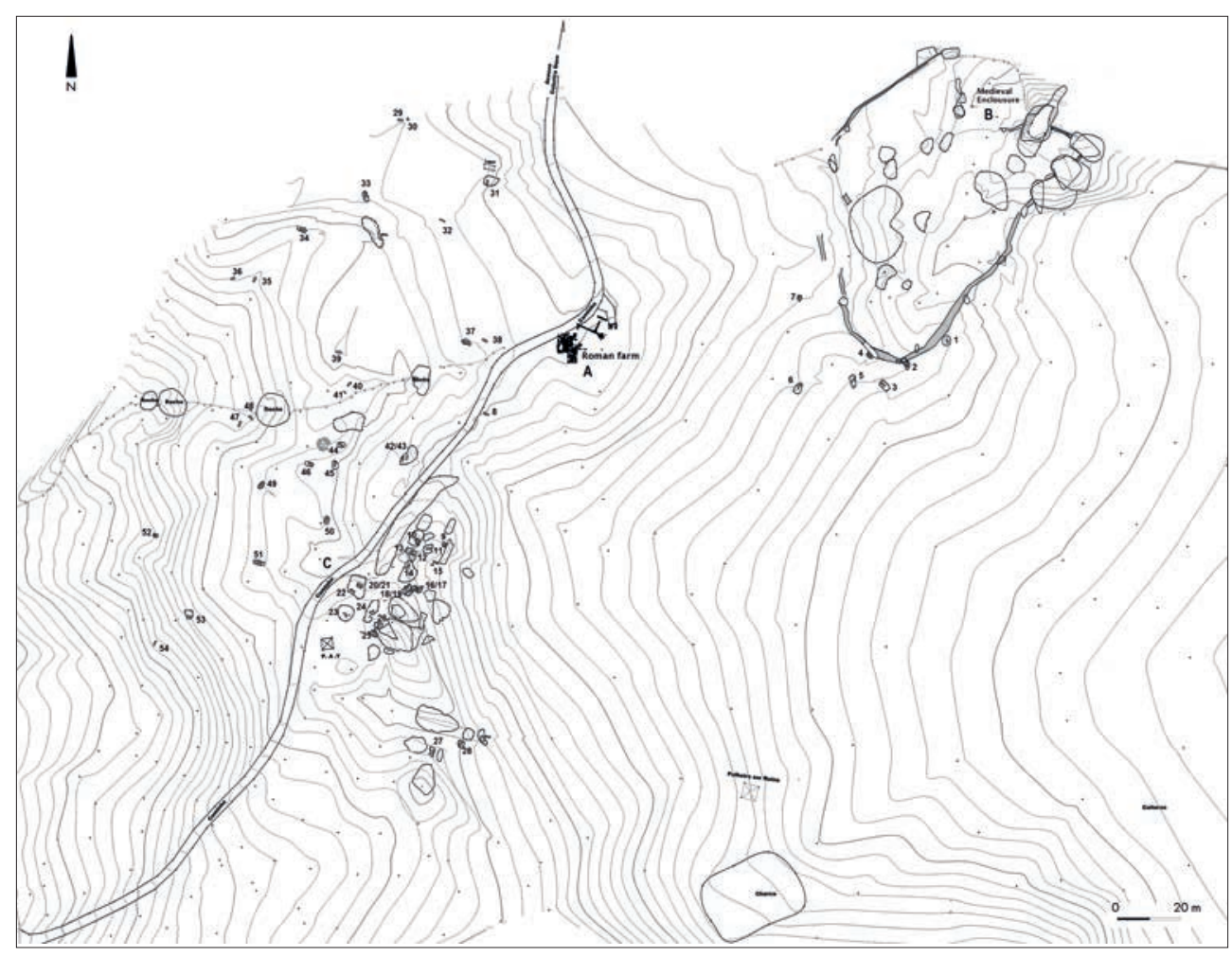

Fig. 2. Planta do sítio arqueológico de São Gens: a) quinta romana; b) povoado alto medieval; c) núcleo principal da necrópole

Fonte: Tomás Cordero, João Luís Veloso e Catarina Tente

\subsection{As necrópoles desordenadas ou desarrumadas - o caso de São Gens}

As necrópoles desordenadas são uma minoria na realidade funerária rupestre alto medieval, ainda que possam agregar um significativo número de sepulturas. $\mathrm{Na}$ maior parte dos casos estudados trata-se de necrópoles com um número de sepulturas em torno da vintena. Apesar de agruparem mais de 10 sepulturas e de comumente se associarem sepulturas infantis e juvenis, estes espaços não aparentam ter uma coerência organizativa interna, resultando na realidade de uma soma de vários núcleos funerários mais pequenos que se organizam por proximidade face ao seu grupo e pelo afastamento em relação a outros. Na prática resultaria da soma de vários núcleos de sepulturas, dispostos em clusters o que parece expressar uma organização familiar do espaço funerário ${ }^{15}$.

Entre as necrópoles desordenadas da Beira Interior destaca-se a de São Gens (Fig. 2) não só por ser a que agrega maior número de sepulturas, mas também por- 
que o povoado que se localiza nas suas proximidades foi alvo de várias campanhas de escavação entre 2008 e 2012. A necrópole, de que se conhecem 56 sepulturas, foi disposta em torno a uma antiga quinta romana abandonada no final do século IV ou início do século $\mathrm{V}^{16}$. É possível que as sepulturas fossem originalmente em maior número, já que informações orais relatam a destruição de algumas no âmbito da extração de pedra para a construção de um lagar em meados do século XX. O sítio arqueológico ocupa um vale e não tem domínio visual sobre a sua envolvente. As escavações aqui realizadas permitiram a identificação de um povoado delimitado por uma cerca de pedra e paliçada que definia uma área ovalada com cerca de 0,5 ha. As datações de radiocarbono e o estudo das suas estruturas evidenciam uma ocupação que se restringe fundamentalmente ao século $\mathrm{X}$. $\mathrm{O}$ sítio é abandonado após um incêndio destruidor ocorrido nessa centúria ${ }^{17}$. As estruturas domésticas ali identificadas eram construídas inteiramente em materiais perecíveis e estavam restritas ao interior do povoado.

Apesar de a área habitada estar concentrada, a necrópole, pelo contrário, está dispersa por 6 ha. Algumas sepulturas aparecem relativamente isoladas, mas a maioria está integrada em pequenos núcleos semelhantes aos grupos desordenados, não evidenciando em geral uma organização formal do espaço funerário. A necrópole apresenta ainda uma grande diversidade de tipologias e de orientações, ainda que haja uma tendência para as dispor nos quadrantes este, nordeste e sudeste. Unicamente baseado no seu comprimento, conseguem-se individualizar seis sepulturas infantis, com comprimentos entre os 64 e os $125 \mathrm{~cm}^{18}$. Este número não deve representar a realidade da mortalidade infantil, pelo que se deve considera que algumas das crianças defuntas desta comunidade possam ter partilhado sepulturas com adultos.

Para a análise espacial da necrópole usou-se o método de Densidade Kernel, que serve precisamente para definir clusters, o que possibilitou a agregação de 13 a 20 sepulturas em dois grandes grupos e a identificação de outros menos concentrados e mais periféricos (outliners).

Quer a análise espacial quer os dados arqueológicos do povoado sugerem que a necrópole era o espaço funerário da comunidade que habitava o povoado, que era constituída por três ou quatro grupos autoidentificados e que ocuparam este espaço durante cerca de quatro gerações. A não existência de uma diferenciação espacial no seio do cemitério (e também no interior do povoado) mostra que uma certa igualdade social entre os seus membros o que indica, uma vez mais, uma organização baseada nas relações familiares ${ }^{19}$.

\footnotetext{
${ }^{16}$ MARQUES, 2011; LOBÃO, MARQUES, TENTE, 2013.

${ }^{17}$ TENTE et al., 2018.

${ }^{18}$ BROOKES, TENTE, PRATA, 2017.

${ }^{19}$ BROOKES, TENTE, PRATA, 2017.
} 


\section{ANÁLISE NA MACROESCALA - O CASO DA BEIRA INTERIOR}

\subsection{Os dados disponíveis}

Ao longo dos últimos anos tem vindo a ser recolhida e sistematizada a informação sobre os sítios com sepulturas escavadas na rocha da Beira Interior. Esta tarefa tem sido realizada no âmbito de vários projetos de investigação e com a participação de alunos de licenciatura e mestrado da NOVA FCSH.

Para a recolha destes dados, o primeiro passo consistiu em fazer a listagem de todos os sítios com sepulturas rupestres já conhecidos na área em estudo. O primeiro passo foi a realização da pesquisa sistemática na Base de Dados Endovélico. Nesta análise levou-se em conta não só as estruturas manifestamente identificadas como sepulturas escavadas na rocha, mas também aquelas que pudessem ter sido erradamente identificadas como lagares. Esta pesquisa foi complementada pela exaustiva pesquisa bibliográfica e pela consulta de alguns processos do Arquivo da Arqueologia Portuguesa.

Estes dados foram compilados numa Base de Dados (BD) que possibilita as pesquisas cruzadas e a contabilização dos sítios (Gráfico 2), tipo de sítios (Gráfico 1), do número de sepultura (Gráfico 2), das cronologias (quando conhecidas), associação a outros vestígios, bibliografia, etc. Para a contabilização do número de sepulturas foi estabelecido um número mínimo de sepulcros, pois nem sempre os dados disponíveis no Endovélico ou na bibliografia informam especificamente do número de sepulturas por cada sítio. Portanto, os números apresentados são os que há a certeza da sua existência, mas estão claramente sub-representados. Conforme se vai aumentando a informação (por via de novas publicações ou visitas aos locais) a BD é atualizada.

Gráfico 1. Distribuição dos sítios com sepulturas de acordo com os tipos de agrupamentos de sepulturas escavadas na rocha

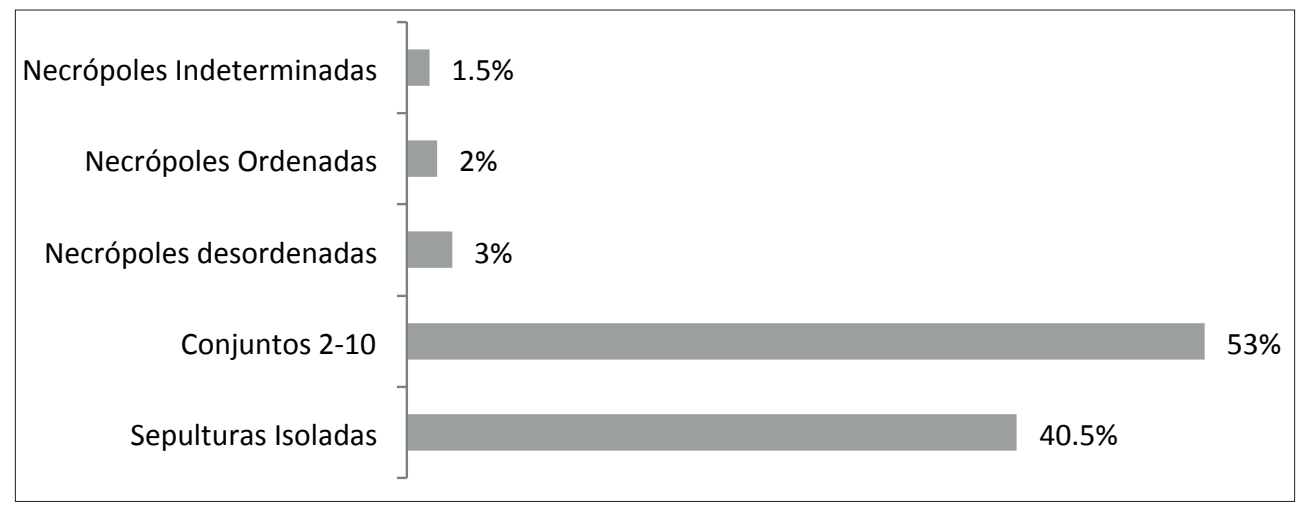

Fonte: José Tomás e Catarina Tente 
Gráfico 2. Número de sítios com sepulturas por concelho e de número mínimo de sepulturas por concelho

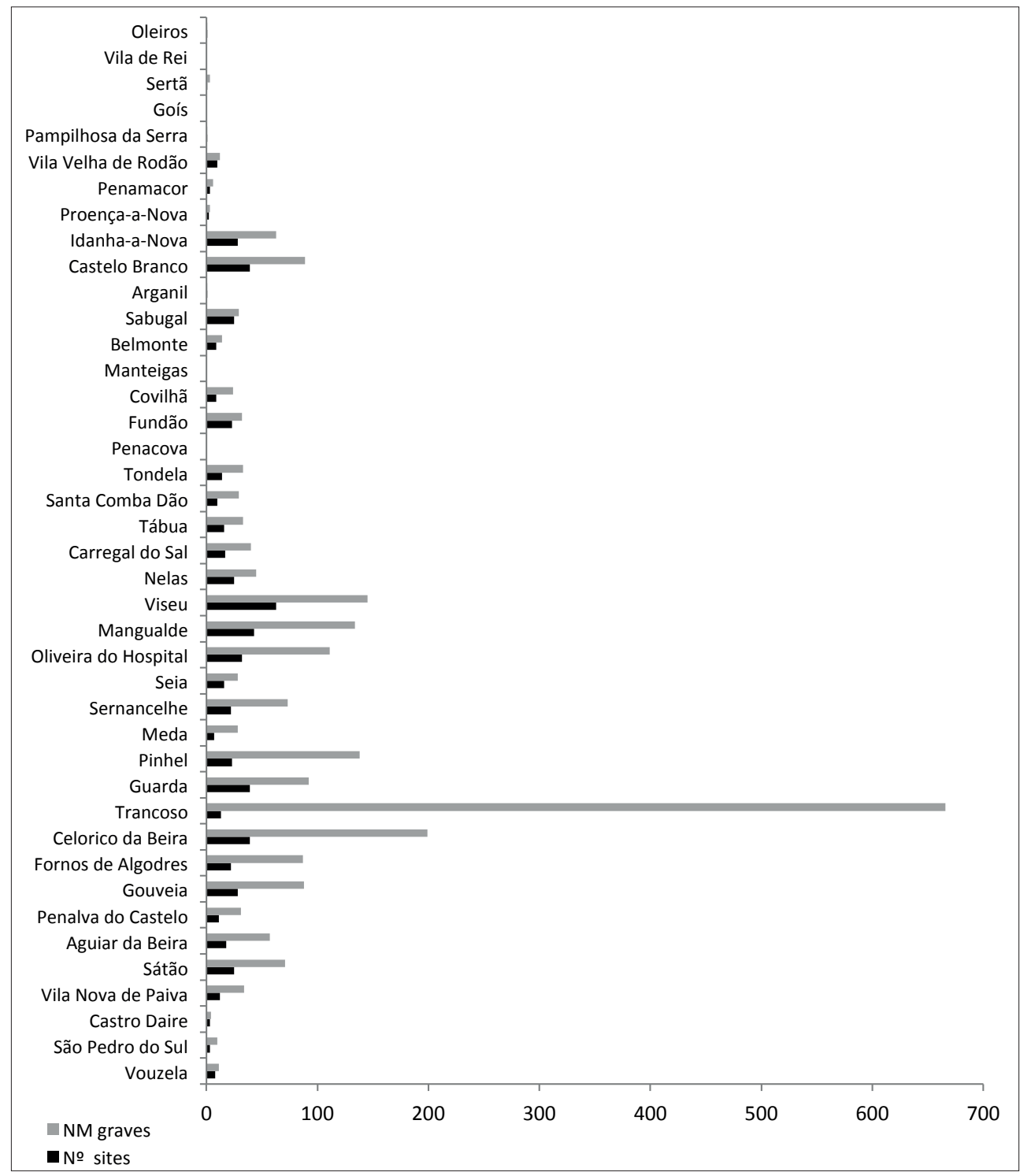

Fonte: José Tomás e Catarina Tente

À BD associou-se um SIG, do qual resulta o mapa síntese e que se apresenta no Mapa 2 A georreferenciação foi feita com vários graus de fiabilidade. Num primeiro nível estão todos os sítios com coordenadas conhecidas e confirmadas, num segundo nível fez-se a aproximação geográfica através da descrição da toponímia e dos acessos, e num último nível agregaram-se todos os sítios cuja informação era mínima e onde só foi possível referenciar em relação à freguesia. 
Obviamente que se trata de um trabalho que nunca pode ser dado por acabado, pois frequentemente são identificados mais sepulcros ou escavadas novas necrópoles como ocorre com a escavação em curso em Moreira de Rei (c. Trancoso, informação pessoal de João Lobão) onde foram já identificadas mais de 560 sepulturas escavadas na rocha integradas numa necrópole ordenada.

Atualmente estão inventariados 664 sítios com sepulturas escavadas na rocha distribuídos por 42 dos atuais concelhos e que agregam um número mínimo de 2472 sepulturas (Gráfico 2). Este inventário inclui sepulturas de várias tipologias, tamanhos e localizações que comportam desde áreas de vale, como no caso de São Gens, áreas de encosta, de alta montanha, zonas junto a zonas irrigadas, mas também em plataformas mais rochosas e secas. Não é assim possível vislumbrar nem um padrão de implantação na paisagem, nem nas tipologias das sepulturas ou nas suas orientações.

Os sítios com sepulturas isoladas representam mais de $40 \%$, os grupos de 1 a 10 sepulturas mais de $50 \%$, e juntos somam quase $94 \%$ dos sítios. Inversamente, as necrópoles estão em menor número, mas agregam bastantes sepulturas, basta que nos relembremos da necrópole ainda em escavação de Moreira de Rei (c. Trancoso).

No que se refere aos grupos, é comum as sepulturas terem orientações semelhantes por se disporem lado a lado, mas existem situações em que se orientam em direções opostas, como no caso das sepulturas de Tapada da Serra (c. Celorico da Beira). É igualmente comum a associação entre sepulturas de adultos com infantis. Estas relações espaciais são consideradas desde Alberto del Castillo como sepulturas pertencentes a familiares próximos (filho/a-/progenitor, esposos) o que continua a fazer sentido. Normalmente as sepulturas infantis estão integradas em grupos com sepulturas de adultos, mas há situações em que ocorrem sozinhas, como no caso da sepultura isolada de S. Pedro (c. Gouveia) ou em que aparecem associadas entre si como em Três Rios (concelho de Tondela). Não obstante, nestes casos não parece haver dúvidas de que estes pequenos grupos de sepulturas estão maioritariamente relacionados com núcleos familiares. $\mathrm{O}$ mesmo parece ocorrer com as necrópoles desordenadas tal como se evidencia pela análise de São Gens, onde se agrupariam vários grupos familiares.

Como evidencia o Gráfico 1, os cemitérios ordenados ou organizados representam uma percentagem muito diminuta, mas cremos que este número está sub-representado, já que muitas destas necrópoles estão ainda por identificar por estarem associadas a espaços onde existem ainda hoje igrejas. Consequentemente, estas antigas necrópoles acabam por estar subterradas e apenas obras de remodelação dos edifícios e espaços adjacentes têm permitido a sua identificação, tal como correu com Moreira de Rei, São Pedro da Lourosa (c. Oliveira do Hospital) ou em Algodres (c. Fornos 


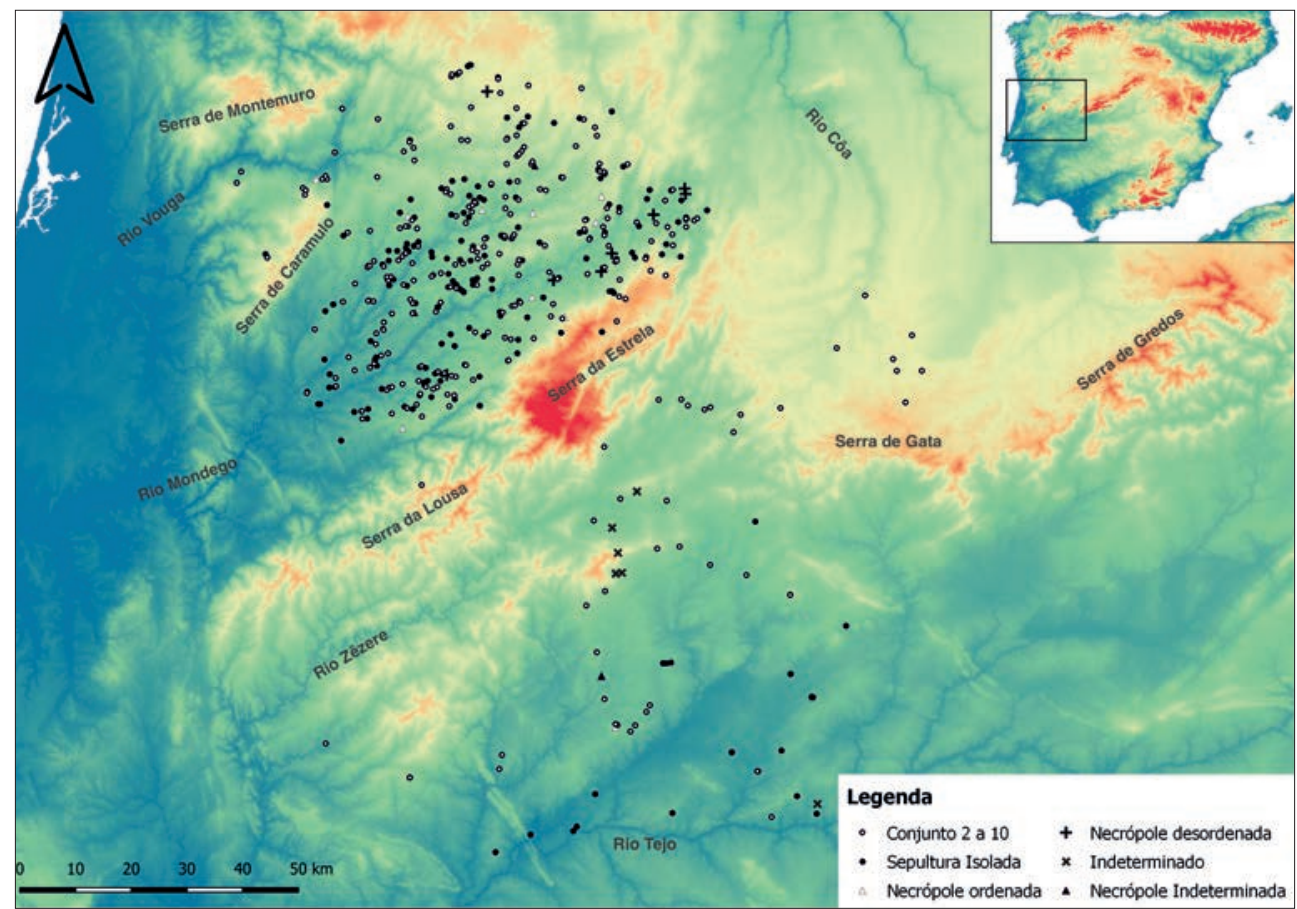

Mapa 1. Distribuição dos sítios arqueológicos com sepulturas escavadas na rocha da Beira Interior Fonte: José Tomás e Catarina Tente

de Algodres $)^{20}$. Certamente que o futuro trará ao conhecimento mais deste tipo de necrópoles e ao aumento do número de sepulturas a elas associadas.

A principal característica destas necrópoles reside no facto de concentrarem um grande número de sepulturas num espaço relativamente reduzido e circunscrito e, em geral, as sepulturas apresentarem uma orientação dominante que, em regra, está determinada pela orientação do edifício religioso a que se associam. Outro traço que as caracteriza é a recorrente (mas não exclusiva) associação a templos. Ainda que reconheçamos algumas necrópoles mais antigas, como parece ser o caso de São Pedro da Lourosa ${ }^{21}$ ou mesmo da primeira fase de Moreira de Rei, este tipo de cemitério tende a difundir-se a partir da segunda metade do século XII no âmbito da implantação do sistema $^{22}$. Este processo implicou a construção de igrejas que agregavam cemitérios, o que veio a alterar o comportamento das comunidades e famílias face aos rituais funerários. Estes novos cemitérios vieram agregar os paroquianos defuntos durante séculos resultando na grande concentração de sepulturas, nas sobreposições e reuti-

\footnotetext{
20 TENTE, 2010: 343-346; PEREIRA, 2013.

${ }^{21}$ REAL, 2014; FERNANDES, 2015.

${ }^{22}$ MATTOSO, 1985: 401-405.
} 
lizações sistemáticas, que são uma marca distintiva destas necrópoles. O processo de paroquialização teve como consequência o abandono progressivo dos grupos e necrópoles desordenadas e parece ter sido acompanhado de uma certa despersonalização da última morada, que se reflete na sobreposição e corte de sepulturas anteriores. A identidade dos mortos e as relações de familiaridade e de ancestralidade parecem perder a importância que tinham na fase anterior, em favor da ideia de pertença a uma comunidade alargada que partilha o mesmo templo e a mesma fé.

\subsection{A sua distribuição e as diferenças entre territórios - o caso de Lafões}

Ainda que o estudo de casos específicos tenha impulsionado a investigação, a abordagem na macroescala é igualmente fundamental para o entendimento destas realidades. Com os dados atualmente disponíveis, é evidente que as sepulturas escavadas na rocha não se distribuem no território da mesma forma; há áreas com concentrações muito significativas e outras áreas onde são escassas. E esta constatação não está relacionada com eventuais padrões que se poderiam definir sobre a sua localização numa mesoescala, como estarem mais próximas de caminhos, de vales, de antigos sítios romanos, junto a castelos ou a igrejas. A distribuição dos sítios patente no Mapa 2 não é homogénea, tendo, contudo, presente de que estamos a lidar com níveis de profundidade de conhecimento diferenciados. Conhecemos hoje muito

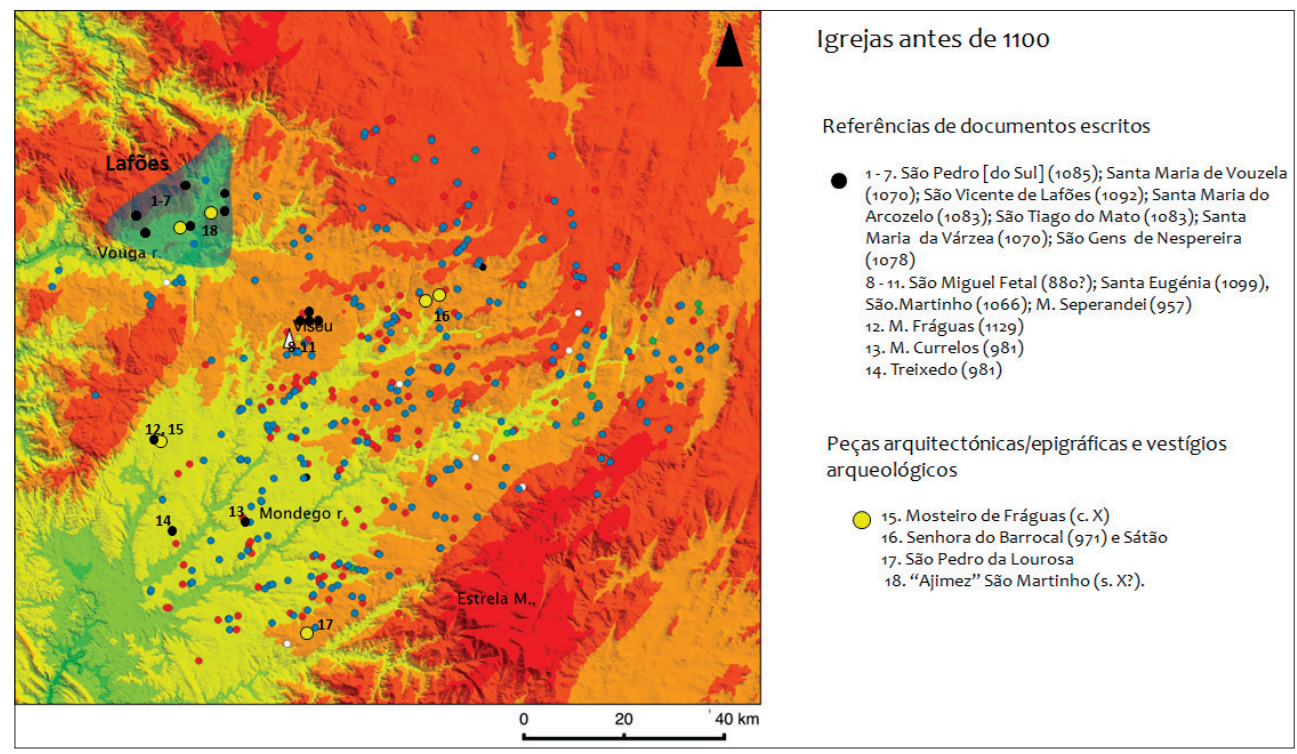

Mapa 2. Mapa da distribuição das sepulturas e das igrejas mencionadas na documentação escrita e dos elementos arquitetónicos de cronologia anterior a 1100

Fonte: José Tomás e Catarina Tente 
melhor o Alto Mondego, a região de Viseu, de Lafões e da Egitânia, do que zonas como o médio Mondego, Penacova ou o Pinhal Interior. Não obstante essa limitação, alguns padrões já emergem com alguma clareza, mas no futuro importa analisar este fenómeno e a sua relação com a ocupação do espaço e com a evolução dos contextos históricos de cada uma das sub-regiões.

Um dos casos que temos vindo a analisar é o da área de Lafões (atuais concelhos de Oliveira de Frades, S. Pedro do Sul e Vouzela) onde é notória a baixa concentração de sepulcros rupestres. Trata-se de uma área que já foi bastante prospetada pelo que o baixo número de sepulturas não pode ser explicado pela falta de investigação. Aliás, os incêndios florestais de outubro de 2017 que assolaram aquela região possibilitaram a identificação de muitos vestígios arqueológicos que estavam ocultados, mas não houve um significativo aumento das ocorrências funerárias rupestres alto medievais. Não se identificaram neste território quaisquer necrópoles desordenadas e os conjuntos agrupam genericamente apenas 2 a 3 sepulturas. Esta realidade contrasta bastante com a restante região da Beira Alta, nomeadamente com a região vizinha de Viseu.

Coincidentemente para a região de Lafões conhece-se um significativo número de documentos que datam entre os séculos IX a XI ${ }^{23}$ e que atestam a existência de várias igrejas e mosteiros. Mais recentemente, têm vindo a ser conhecidos mais alguns elementos arquitetónicos e inscrições que documentam outras igrejas que não aparecem nesta documentação (como a inscrição encontrada em Figueiredo das Donas, Vouzela) e que vêm confirmar a singularidade deste território no panorama beirão. Tal como tem sido sublinhado por Manuel L. Real, nesta região estabeleceu-se uma corte condal ligada inicialmente a Bermudo Ordonhes em redor do qual se terão instalado outros aristocratas entre os quais Diogo Fernandes e Onega, pais de Mumadona Dias ${ }^{24}$. Estas elites terão sido responsáveis pela fundação das igrejas e dos mosteiros referenciados na documentação. Provavelmente a presença destes edifícios religiosos, que refletem a presença destes grupos sociais dominantes, terá implicado um controlo restritivo das práticas funerárias das famílias e comunidades rurais. Inversamente, nas áreas rurais afastadas dos poderes dominantes as igrejas seriam raras e as comunidades e famílias teriam mais liberdade para organizar os seus espaços de habitat e as suas necrópoles.

\section{CONCLUSÕES}

Numa primeira leitura, as sepulturas rupestres são buracos escavados na rocha onde se depositavam defuntos. Todavia, a investigação tem vindo a mostrar que o estudo destes buracos, maioritariamente vazios, expressam funções que ultrapassam

\footnotetext{
${ }^{23}$ LP, 1999.

${ }^{24}$ REAL, 2014, 2018.
} 
o lugar do morto. Foram memória dos antepassados, símbolos de identidade familiar e funcionaram como locais de memória coletiva, tal como parece suceder com o caso do Penedo dos Mouros. As sepulturas são, acima de tudo, elementos estruturais na vida das comunidades rurais alto medievais e é por isso que ao contrário dos sítios de habitação, as sepulturas foram contruídas para durar. Ainda que não possamos compreender a totalidade do seu significado, a durabilidade e a localização dos sepulcros era deliberada e não deve ser dissociada da antropização e apropriação da paisagem e dos recursos rurais e florestais ${ }^{25}$.

A investigação na região beirã tem evidenciado que a investigação em temáticas como a orientação dos sepulcros integrados em grupos ou necrópoles desordenadas não tem levado à identificação de padrões dominantes. Pelo contrário, a diversidade marca esta região. Também qualquer tentativa de relação entre tipos de sepulturas e cronologia, na linha do que havia defendido Alberto del Castillo, não parece fazer qualquer sentido face aos dados disponíveis, São as escavações dos locais de habitação associados às sepulturas a melhor forma e datar grupos e necrópoles desordenadas, isso é bastante evidente quer em São Gens, quer nos casos escavados em Castelo de Vide (e alvo de artigo neste mesmo volume), onde as sepulturas antropomórficas se relacionam com espaços datados dos séculos VI a VIII.

A investigação tem também sublinhado o papel das sepulturas como guias orientadoras para a identificação de locais de habitação (casais, quintas e povoados) ou de espaço de poder (igrejas e castelos). Há efetivamente uma relação das sepulturas com o povoamento tal como sugeriu M. J. Barroca ${ }^{26}$, ainda que não a entendamos ainda em toda a sua amplitude, e emergem igualmente relações com espaços agrários e florestais.

Por fim, devemos ainda sublinhar que a durabilidade deste fenómeno funerário e a dificuldade em se datar singularmente cada sepultura implica que as abordagens, como a macro análise que aqui se apresentou, tenham de lidar com realidades anacrónicas. Se há necrópoles que se construíram e usaram durante o século X, há outras que apenas surgem no século XI e foram usadas por várias centúrias, mas haverá também sepulturas que se integram entre os séculos V e VIII. É uma limitação incontornável que apenas pode ser minimizada com o aumento de escavações em sítios espacialmente correlacionados com as sepulturas (ou com escavações de sepulturas que conservam vestígios osteológicos).

Uma outra linha de investigação fundamental para a região beirã será compreender a significativa concentração de locais com sepulturas a norte da Serra da Estrela em oposição com a dispersão de sítios a sul desta. Mas ainda não temos os dados

\footnotetext{
${ }^{25}$ MARTÍN VISO, 2014.

${ }^{26}$ BARROCA, 1987.
} 
suficientes para avançar algumas hipóteses de trabalho, esperamos que o tempo e a investigação possam trazer mais luz a esta óbvia diferença.

\section{BIBLIOGRAFIA}

BARROCA, Mário Jorge (1987). Necrópoles e sepulturas medievais de Entre-Douro-e-Minho (Séculos V $a \mathrm{XV}$ ). Porto: Faculdade de Letras da Universidade do Porto. Dissertação para Provas Públicas de Aptidão Pedagógica e Capacidade Científica.

BARROCA, Mário Jorge (2010-2011). Sepulturas escavadas na rocha de Entre Douro e Minho. «Portvgalia». Nova Serie. 31-32, 115-182.

BOLÓS MASCLANS, Jordi; PAGÉS PARETAS, Montserrat (1982). Les sepultures excavades a la roca. In RIU, Manuel, dir. Necropolis i sepultures medievals de Catalunya. Barcelona: Departament d'Historia Medieval, pp. 59-103.

BROOKES, Stuart; TENTE, Catarina; PRATA, Sara (2017). Interpreting Rock-Cut Grave Cemeteries: the early medieval necropolis and enclosure of São Gens. «Medieval Archaeology». 61: 2, 215-238.

CASTILLO, Alberto del (1970). Cronología de las tumbas llamadas "olerdolanas". In XI Congreso Nacional de Arqueología. Zaragoza: Secretaría General de los Congresos Arqueológicos Nacionales, pp. 835-845.

FERNANDES, P. A. (2015). Ecletismo. Classicismo. Regionalismo. Os caminhos da arte cristã no Ocidente peninsular entre Afonso III e al-Mansur. In BARROCA, M.J.; FERNANDES, I.C. coords. Muçulmanos e Cristãos entre o Tejo e o Douro (Sécs. VIII a XIII). Porto/Palmela: FLUP / Câmara Municipal de Palmela, pp. 293-310.

FERREIRA, F. E. R. (2013). Arqueologia alto-medieval no regolfo do Alqueva. Vestígios de uma ocupação judaica nas margens do Guadiana no século VII. Évora: EDIA.

LOBÃO, J.; MARQUES; A.; TENTE, C. (2013). S. Gens, Através da História e do Tempo. Celorico da Beira/Forno Telheiro.

LOPES, Isabel Alexandra Resende Justo (2002). Contextos Materiais da Morte durante a Idade Média: as necrópoles do Douro Superior. Porto: Faculdade de Letras da Universidade do Porto. Dissertação de Mestrado. 2 vols.

LOURENÇO, S. (2007). O povoamento alto-medieval entre os rios Dão e Alva. «Trabalhos de Arqueologia». 50. Lisboa: Instituto Português de Arqueologia.

LP: Livro Preto: cartulário da Sé de Coimbra. Ed. Manuel Augusto Rodrigues. Coimbra: Arquivo da Universidade, 1999.

MARQUES, A. (2011). A ocupação romana na Bacia de Celorico. Coimbra: Faculdade de Letras da Universidade de Coimbra. Dissertação de Mestrado.

MARQUES, J. A. (2000). Sepulturas escavadas na rocha na região de Viseu. Viseu: Edição do Autor.

MARTÍN VISO, Iñaki (2008). Una periferia creativa: la articulación del territorio en la comarca de Riba Côa (Portugal) (siglos VI-XI). «Territorio, Sociedad y Poder». 3, 85-109.

MARTÍN VISO, Iñaki (2011). La organización espacial de los espacios funerarios altomedievales en los territorios al Sur del Duero. In GOMES, R. V., GOMES, M. V.; TENTE, C., ed. Cristãos e Muçulmanos na Idade Média Peninsular: encontros e desencontros. Lisboa: Instituto de Arqueologia e Paleociências, pp. 225-238.

MARTÍN VISO, Iñaki (2012a). Enterramientos, memoria social y paisaje en la Alta edad Media: propuestas para un análisis de las tumbas excavadas en roca en el centro-oeste de la Península Ibérica. «Zephyrus». 69, 165-187.

MARTÍN VISO, Iñaki (2012b). Paisajes sagrados, paisajes eclesiásticos: de la necrópolis a la parroquia en el centro de la Península Ibérica. «Reti Medievali Rivista». 13: 2, 3-45.

MARTÍN VISO, Iñaki (2014). El espacio del más acá: las geografías funerarias entre la Alta y la Plena Edad Media. In LÒPEZ OJEDA, E., ed. De la Tierra al Cielo. Ubi sunt qui ante nos in hoc mundo 
fuere? Actas de XXIV Semana de Estudios Medievales. Logroño: Instituto de Estudios Riojanos, pp. $75-140$.

MARTÍN VISO, Iñaki (2017). A place for ancestors: early medieval burial ites in central area of Iberian Peninsula. In THEUNE-VOGT, C.; BIS-WORCH, C., ed. Ruralia XI Conference: Religious places, cult and rituals in medieval rural environment. Leiden: Sidestone, pp. 227-240.

MARTÍN-VISO, Iñaki. et al. (2017). La formación de un nuevo paisaje en el centro de la Península Ibérica en el periodo post romano: el yacimiento de La Genestosa (Casillas de Flores, Salamanca). «Archivo Español de Arqueología». 90, 7-28.

MARTÍN-VISO, Iñaki; BLANCO-GONZÁLEZ, A. (2016). Ancestral Memories and Early Medieval Landscapes: the case of Sierra de Ávila (Spain). «Early Medieval Europe». 24: 4, 393-422.

NÓBREGA, Pedro Pina; NETO, Filipa; TENTE, Catarina (2012). A sepultura medieval do Alto da Quintinha (Mangualde). «Arqueologia Medieval». 12, 203-210.

PEREIRA, T. (2013). Algodres (Fornos de Algodres). In Aspetos da Romanização das terras Beirãs de Entre Tejo e Douro. Guarda: C. M. Celorico da Beira/ARA, pp. 32.

PRATA, Sara (2012). As necrópoles alto-medievais da Serra de São Mamede (concelhos de Castelo de Vide e Marvão). Lisboa: Faculdade de Ciências Sociais e Humanas da Universidade Nova de Lisboa. Dissertação de Mestrado.

PRATA, Sara (2014a). Espaços funerários alto-medievais no Norte da Serra de São Mamede (Portalegre, Portugal): uma proposta de organização espacial. «Arkeogazte». 4, 261-279.

PRATA, Sara (2014b). Espaço, rituais e morte na Alta Idade Média: o caso das necrópoles da Serra de São Mamede (Concelhos de Castelo de Vide e Marvão). In CUNHA, A., PINTO, O.; MARTINS, R., ed. Atas do I Encontro Ibérico de Jovens Investigadores em Estudos Medievais - Arqueologia, História e Património. Braga: Universidade do Minho, pp. 43-60.

PRATA, Sara (2017). Sobre o estudo das necrópoles alto-medievais da Serra de São Mamede (Castelo de Vide e Marvão, Portugal): uma perspetiva metodológica. In TEIXEIRA, C.; CARNEIRO, A., ed. Arqueologia da transição: entre o mundo romano e a Idade Média. Coimbra: Imprensa da Universidade de Coimbra, pp. 415-432.

PRATA, Sara (2018). Arqueologia do povoamento rural alto-medieval no território de Castelo de Vide (ss. V-VIII). Salamanca: Universidade de Salamanca. Tese de Doutoramento.

REAL, Manuel L. (2014). A dinâmica cultural em "Portucale" e "Colimbriae" nos séculos VIII a XI. In DE MAN, A.; TENTE, C., ed. Estudos de Cerâmica Medieval. O Norte e o Centro de Portugal. Séculos IX a XII. Lisboa: IEM, pp. 110-139.

REAL, Manuel L. (2018). O papel das elites na definição progerssiva do território: sua presença na senhoralização da "fronteira beirã" (séculos IX-XII). In TENTE, C., ed. Do Império ao Reino. Viseu e o território entre os séculos IV a XII. Viseu: C. M. Viseu, pp. 297-340.

RUBIO DÍEZ, Rubén (2015). Arqueología, paisaje y territorio post-romano. Las tumbas excavadas en roca en el Occidente del Campo de Ciudad Rodrigo (Salamanca). Ciudad Rodrigo: Centro de Estudios Mirobrigenses.

TENTE, Catarina (2007). A ocupação alto-medieval da Encosta Noroeste da Serra da Estrela. Lisboa: Instituto Português de Arqueologia. (Trabalhos de Arqueologia; 47).

TENTE, Catarina (2010). Arqueologia Medieval Cristã no Alto Mondego, Ocupação e exploração do território nos séculos $V$ a XI. Lisboa: Faculdade de Ciências Sociais e Humanas da Universidade Nova de Lisboa. Tese de Doutoramento.

TENTE, Catarina (2015). Tumbas rupestres en el Alto Mondego (Guarda, Portugal). Patrones de distribución, significados y construcción del paisaje rural altomedieval. «Munibe. AntropologiaArkeologia». 66, 271-290. 
TENTE, Catarina (2017). Rock-cut graves and cemeteries in the medieval rural landscape of the Viseu region (central Portugal). In THEUNE, C.; BIS-WORCH, C., ed. Religion, cults \& rituals in medieval rural environment. Ruralia XI. Leiden: Sidestone Press, pp. 215-226.

TENTE, Catarina et al. (2018). Povoamento e modos de vida no limite oriental do território viseense durante o século X. O Povoado de S. Gens. In TENTE, C., ed. Do Império ao Reino. Viseu e o território entre os séculos IV a XII. Viseu: C. M. Viseu, pp. 197-228.

TENTE, Catarina; CARVALHO, A. F. (2011). The establishment of radiocarbon chronologies for early medieval sites: a case study from the upper Mondego Valley (Guarda, Portugal). «Munibe Antropologia-Arkeologia». 62, 461-468.

TENTE, Catarina; CARVALHO, A. F. (2015). Sepulturas e necrópoles alto medievais na investigação portuguesa. Metodologías, problemáticas e perspectiva. In QUIRÓS CASTILLO, J. A.; CASTELLANOS, S., ed. Seminario internacional "Quienes fueron, qué fueron y qué hacían. Identidad y arqueología funeraria entre los siglos V y VIII”. Vitória: Gasteiz, pp. 125-144.

TENTE, Catarina; LOURENÇO, S. (1998). Sepulturas medievais escavadas na rocha dos concelhos de Carregal do Sal e Gouveia: estudo comparativo. «Revista Portuguesa de Arqueologia». 1: 2, 191-217.

VALERA, António Carlos (1990). Sepulturas Escavadas na Rocha do Concelho de Fornos de Algodres. Fornos de Algodres: G.A.F.A.L.

VIEIRA, M. A. (2004). Alto Paiva, povoamento nas épocas romana e alto-medieval. «Trabalhos de Arqueologia». 36.

VIEIRA, M. A. (2006). Alguns aspectos do povoamento Tardo Antigo e Alto Medieval do curso superior do rio Paiva. As sepulturas escavadas na rocha. «Conimbriga». 45, 311-335.

\section{AGRADECIMENTOS}

À Sofia Pereira, ao Gabriel de Souza, à Ana Esmeraldo, ao Afonso Leão, à Rosa Cruz, ao Iñaki Martín Viso, ao Stuart Brookes, à Sara Prata, ao João Lobão, ao António Carlos Marques e ao Dário Neves pelo seu trabalho e discussão destas temáticas. 


\title{
O GRUPO DE SEPULTURAS ESCAVADAS NA ROCHA DE MONTEDOURO (PERAFITA, MATOSINHOS)
}

\author{
JOSÉ MANUEL VARELA* \\ CONCEIÇÃO PIRES**
}

Resumo: A necrópole rupestre de Montedouro (Perafita, Matosinhos) é constituído por um conjunto de cinco sepulturas escavadas na rocha. Pela sua situação geográfica serão um dos grupos de sepulturas escavadas na rocha de implantação mais litoral no território português, sendo que uma das sepulturas tem uma posição dominante de visibilidade sobre a orla costeira e o mar desta zona. Por toda a área envolvente tem vindo a recolher-se diverso material arqueológico, de cronologia diversa, com uma presença significativa de peças de cronológica enquadrável no período tardorromano e Antiguidade Tardia e eventualmente da Alta Idade Média. Neste trabalho fazemos uma revisão do conhecimento deste sítio arqueológico e apresentam-se ainda outras referências conhecidas na bibliografia arqueológica de sepulturas escavadas na rocha na região, mas que terão sido já destruídas.

Palavras-chave: Sepulturas rupestres; Litoral Atlântico; Antiguidade Tardia.

Abstract: The rock-cut necropolis of Montedouro (Perafita, Matosinhos) consists of a set of five graves excavated in the rock. Due to its geographical situation will be one of the groups of rock-cut graves of more coastline implantation in the territory. One of the graves has a dominant position of visibility in the landscape. Throughout the surrounding area has been collecting various archaeological material, of diverse chronology, with a significant presence of pieces of chronological framed in the late-Roman period and Late Antiquity and eventually of the High Middle Ages. In this paper we make a review of the knowledge about this archaeological site and also present other references known in the archaeological bibliography of similar rock-cut graves in the region, but which have already been destroyed.

Keywords: Rock-cut graves; Atlantic Coast; Late Antiquity.

\section{INTRODUÇÃO}

Referidas pela primeira vez, de forma muito breve, por Francisco Martins Sarmento, formam um conjunto cinco sepulturas dispersas por um campo situado no lugar de Montedouro, a pouca distância da aldeia do Cabo do Mundo (Perafita, Matosinhos $)^{1}$. Posteriormente Rocha Peixoto ${ }^{2}$, Joaquim Neves dos Santos ${ }^{3}$, Mário

\footnotetext{
* Gabinete Municipal de Arqueologia e História da Câmara Municipal de Matosinhos. Email: jose.varela@ cm-matosinhos.pt.

** Gabinete Municipal de Arqueologia e História da Câmara Municipal de Matosinhos.

${ }^{1}$ Este lugar atualmente está administrativamente integrado na União de Freguesias de Lavra, Perafita e Santa Cruz do Bispo, no Concelho de Matosinhos. Até 1836 esta freguesia pertenceu à Terra da Maia.

2 PEIXOTO, 1906.

${ }^{3}$ SANTOS, 1956, 1959.
} 
Barroca $^{4}$, Diana Bencatel ${ }^{5}$ e Conceição Pires ${ }^{6}$ descreveram de forma mais pormenorizada estas sepulturas. Foram classificadas como Imóvel de Valor Concelhio em 1974, sendo reclassificadas, em 2001 como Imóvel de Interesse Municipal.

Pela sua situação geográfica serão um dos grupos de sepulturas escavadas na rocha de implantação mais litoral no território português, sendo que uma das sepulturas tem uma posição dominante de visibilidade sobre a orla costeira e o mar desta zona. Apresentam alguma diversidade tipológica, destacando-se pela sua posição topográfica e estado de conservação, uma sepultura cuja cabeceira e pés têm um contorno ligeiramente ovalado.

Por toda a área envolvente tem vindo a recolher-se diverso material arqueológico, de cronologia diversa, com uma presença significativa de peças cuja cronologia se enquadra no período romano e da Antiguidade Tardia, estendendo-se eventualmente até à Alta Idade Média.

Para além deste grupo de sepulturas escavadas na rocha, são conhecidas ainda referências antigas a outras sepulturas na região, provavelmente do mesmo tipo, mas que até ao momento não foi possível localizar, que terão sido mesmo destruídas durante o século XX pela exploração de pedreiras e de novas edificações. São também conhecidos na região envolvente vestígios arqueológicos, identificados em prospeções de superfície, relacionados com o período tardorromano e Alta Idade Média, que contribuem para contextualizar melhor a ocupação do território envolvente durante este período.

\section{O GRUPO DE SEPULTURAS ESCAVADAS NA ROCHA DE MONTEDOURO}

O grupo de sepulturas escavadas na rocha de Montedouro, ocupa um grande afloramento granítico, entre o lugar de Pampelido Velho a norte e o Cabo do Mundo a sul, sobranceiro à planície litoral da freguesia de Perafita, no concelho de Matosinhos. O conjunto é composto por cinco sepulturas, dispersas por uma área de 1 hectare, onde se podem distinguir duas sepulturas isoladas e um subgrupo de três outras sepulturas agrupadas. O acesso a este sítio é realizado pela Travessa do Cabo do Mundo.

O espaço onde se implanta este conjunto de sepulturas rupestres é dominado por um pequeno outeiro, que atualmente se encontra significativamente alterado pela intensa exploração de pedreiras que, um pouco por todo o concelho de Matosinhos, desbastou diversos afloramentos graníticos durante os finais do século XIX e os inícios do século XX. Em muitos sítios deste outeiro, a que chamam o Monte

\footnotetext{
${ }^{4}$ BARROCA, 1987, 2011

${ }^{5}$ BENCATEL, 2009.

${ }^{6}$ PIRES, 2012.
} 
das Pedras ${ }^{7}$, são visíveis os cortes realizados no afloramento rochoso para a extração dos blocos graníticos. Quando, por volta de 1899, Rocha Peixoto visitou este local ainda a extração de pedra estava a funcionar em pleno neste local, uma vez que ele refere que «andavam a extrahir pedra do logar, muito perto da sepultura aludida» ${ }^{8}$. No entanto, pelo menos a sepultura rupestre localizada no topo deste outeiro acabou por ser preservada, mas desconhecemos se teriam existido outras no mesmo local que possam ter sido destruídas pela exploração desta pedreira.

As restantes sepulturas localizam-se a uma cota mais baixa, num pequeno plateau granítico, situado a nordeste do referido outeiro, numa bouça a que chamam o «Monte da Parede». Contíguo a esta bouça fica um campo de cultivo que quando Martins Sarmento visitou este local era conhecido popularmente como o "Campo das Antinhas» ou ainda por «Campo das Santinhas». Neste campo Martins Sarmento recolheu a informação oral de «uma mulher, que o lavrador que o fazia encontrava muito caco. Ao pé de um penedo e não muito longe da segunda campa, encontrei eu também pedaços de telha com rebordo» ${ }^{9}$. Também é referido por algumas pessoas da zona que existe por aqui a crença de que neste local teria existido, em tempos remotos, uma igreja ${ }^{10}$.

Este grupo de sepulturas apresenta diversas orientações, não seguindo assim a chamada orientação canónica, com a cabeceira voltada para nascente, parecendo que o critério utilizado para a sua implantação se deveu mais a motivos práticos de adequação ao substrato rochoso do que a uma intencionalidade ritual.

A sepultura n. ${ }^{\circ} 1$ distingue-se claramente das restantes, quer pela sua tipologia, quer ainda pela sua localização topográfica. Trata-se de uma sepultura do tipo "banheira», cujos topos são arredondados e as paredes retas, com uma cavidade sepulcral relativamente estreita. É cercada a toda a volta por uma moldura de rebordo subcircular, bastante saliente, onde encaixaria a respetiva tampa e que apresenta ainda, no seu topo norte, um sulco bem marcado. O interior da cavidade sepulcral apresenta um tratamento da superfície rochosa muito cuidado, com uma picagem muito fina, que lhe confere uma superfície muito lisa e uniforme, quase sem se notar as marcas de ação do pico no desbaste da rocha. No interior do topo sul da cavidade é ainda visível uma depressão circular, supostamente destinada a melhor segurar a posição da cabeça do defunto. A base interior da sepultura apresenta ainda uma ligeira inclinação para norte.

Mas o que é mais interessante nesta sepultura é a sua localização topográfica, no topo de um outeiro que permite uma visão de $360^{\circ}$ sobre toda a paisagem em

\footnotetext{
${ }^{7}$ SARMENTO, 1970: 44.

${ }^{8}$ PEIXOTO, 1906: 288.

${ }^{9}$ SARMENTO, 1970: 45.

${ }^{10}$ PIRES, 2012: 90, 108.
} 


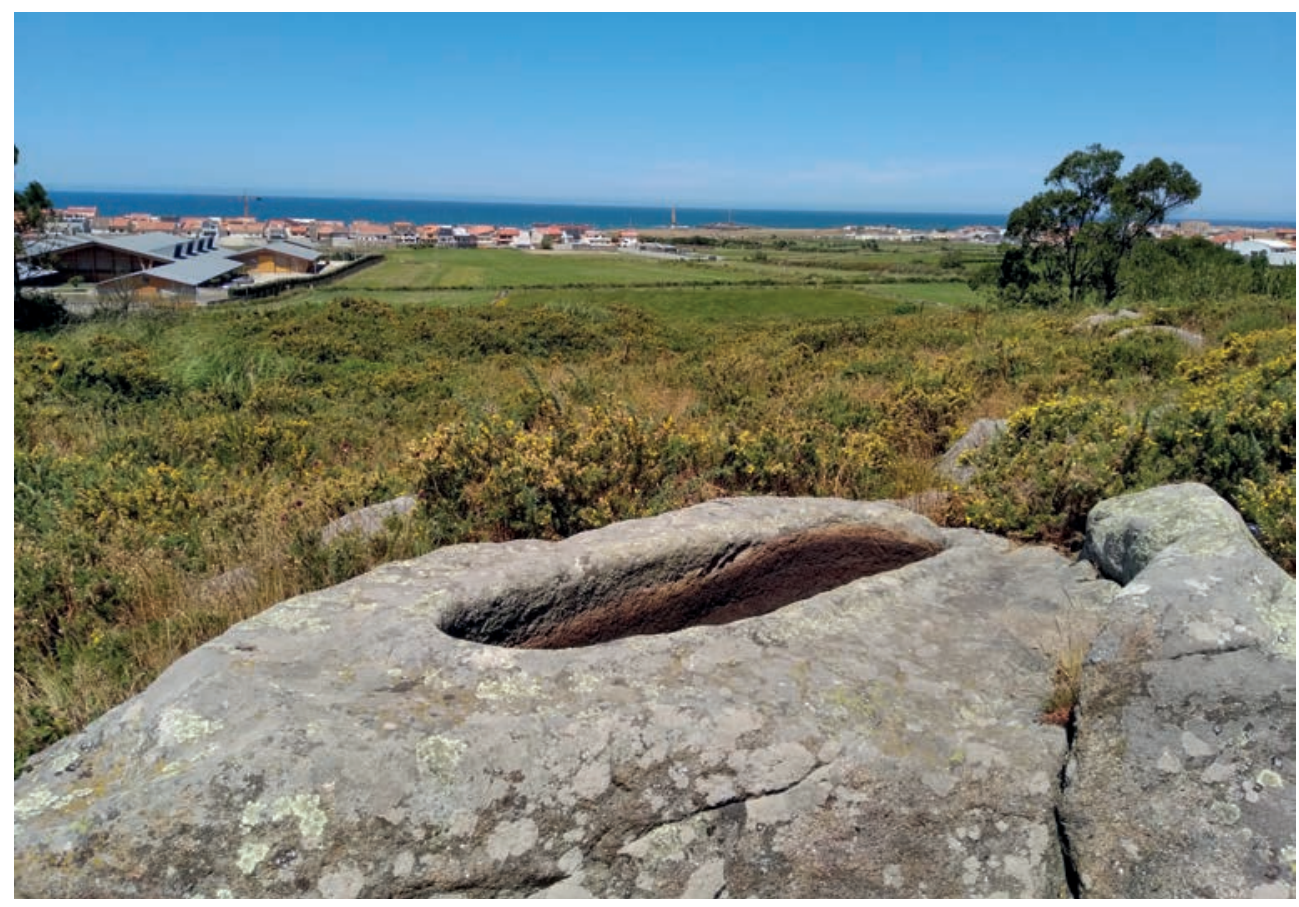

Fig. 1. Sepultura n. 1 da necrópole rupestre de Montedouro

Fonte: José Varela

redor e particularmente sobre a faixa marítima, a Poente, uma vez que a praia fica apenas a uma distância de 900 metros da praia de Arnosa de Pampelido ${ }^{11}$, com alcance visual sobre todo o território da freguesia de Perafita, quer para norte, como para nascente e sul. Esta posição topográfica dominante sobre o território distingue esta sepultura das restantes deste núcleo e parece ter resultado de uma escolha deliberada de diferenciação simbólica relativamente às restantes sepulturas deste núcleo. No entanto, no estado atual dos nossos conhecimentos, não conseguimos determinar se esta diferenciação se deverá a uma questão cronológica ou se terá por base uma diferença de estatuto social na personalidade que aqui terá sido inumada.

As restantes sepulturas deste grupo são muito diferentes da que foi atrás referida. Situam-se numa cota mais baixa, com pouca visibilidade. A sepultura n. ${ }^{\circ} 2$ é de formato sub-retangular, com parte do largo rebordo saliente preservado num dos topos e ausente no resto da sepultura. Possui ainda a particularidade de dispor de um

\footnotetext{
${ }^{11}$ Atualmente esta praia é vulgarmente conhecida como «Praia da Memória», devido ao obelisco que assinala a memória do desembarque de D. Pedro IV e do «Exército Libertador» aqui ocorrido em 1832. Até esta época era também designada como «Praia dos Ladrões».
} 
orifício subcircular, na base da cavidade sepulcral, no topo do lado sul, que atravessa o rochedo, possivelmente para drenagem de líquidos do interior da cavidade. Apesar de apresentar uma forma não-antropomórfica, deve-se salientar que o rebordo aparece circunscrito apenas ao topo da sepultura do lado norte e aparentemente não ocuparia todo o contorno da sepultura, pelo que poderemos pensar que poderia ter como intenção indicar a localização da cabeceira.

A sepultura n. 3 apresenta-se danificada, conservando-se cerca de $50 \%$ da totalidade, uma vez que é cortada por um caminho de «pé-posto» que a deve ter destruído parcialmente. Além disso o próprio afloramento rochoso apresenta sinais de fragmentação e destacamentos, que também devem ter contribuído para a sua degradação. Tem a particularidade de a cavidade sepulcral estar em plano significativamente inclinado. Também possui um rebordo, parcialmente destruído, que marca a zona a zona da cabeceira da sepultura.

A sepultura n. 4 é na realidade uma protossepultura inacabada, onde apenas é visível o esboço das linhas de desbaste delineadas na rocha para se iniciar a abertura da sua sepultura. Apresenta uma forma retangular não-antropomórfica. Observa-se um ligeiro rebaixamento num dos seus topos, sendo igualmente patente que, por motivos desconhecidos, este trabalho terá sido abandonado muito pouco tempo depois de se ter iniciado. É patente que nesta sepultura houve a intenção inicial de a orientar canonicamente no sentido nascente-poente.

A sepultura n. 5 implanta-se na borda de um afloramento rochoso situado a uma cota mais baixa e contíguo às sepulturas 3 e 4 . É de formato retangular, sem antropomorfismo e apresenta um rebordo muito saliente, apesar de ter sido parcialmente destruído devido a ter-lhe sido adossado um muro moderno e uma habitação na zona imediatamente contígua deste afloramento. Tem a particularidade de ser a única destas sepulturas que está orientada canonicamente no sentido nascente-poente. 


\section{Descrição das sepulturas ${ }^{12}$}

\section{Sepultura $n .^{\circ} 1$}

Coordenadas: $41^{\circ} 13^{\prime} 43^{\prime \prime} \mathrm{N}$ | $8^{\circ} 42^{\prime \prime} 40^{\prime \prime} \mathrm{O}$

Altitude: $37 \mathrm{~m}$

Dimensões:

Comprimento máximo: 2,07 m (incluindo o rebordo); Largura máxima: 0,76 $\mathrm{m}$ (incluindo o rebordo);

Comprimento da cavidade sepulcral:1, $87 \mathrm{~m}$;

Largura da cavidade sepulcral: $0,55 \mathrm{~m}$;

Profundidade da cavidade sepulcral: 0,40 m;

Orientação: $20^{\circ}$
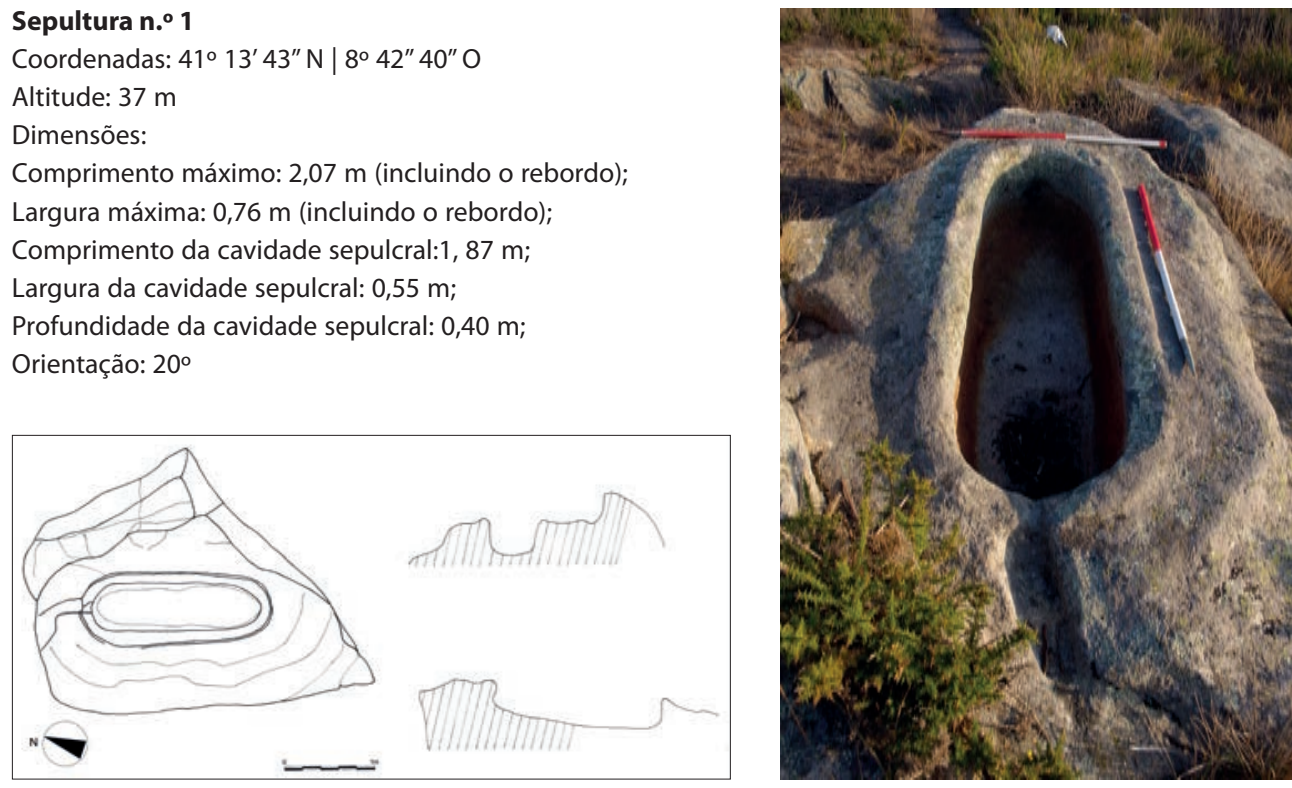

\section{Sepultura $\mathbf{n} \cdot{ }^{\circ} \mathbf{2}$}

Coordenadas: $41^{\circ} 13^{\prime} 48^{\prime \prime} \mathrm{N}$ | $8^{\circ} 42^{\prime} 39^{\prime \prime} \mathrm{O}$

Altitude: $31 \mathrm{~m}$

Dimensões:

Comprimento máximo: 2,00 m (incluindo o rebordo);

Largura máxima: 0,63 m;

Comprimento da cavidade sepulcral: $1,79 \mathrm{~m}$;

Largura da cavidade sepulcral: 0,63 m;

Profundidade máxima da cavidade sepulcral: 0,27 m;

Orientação: $30^{\circ}$
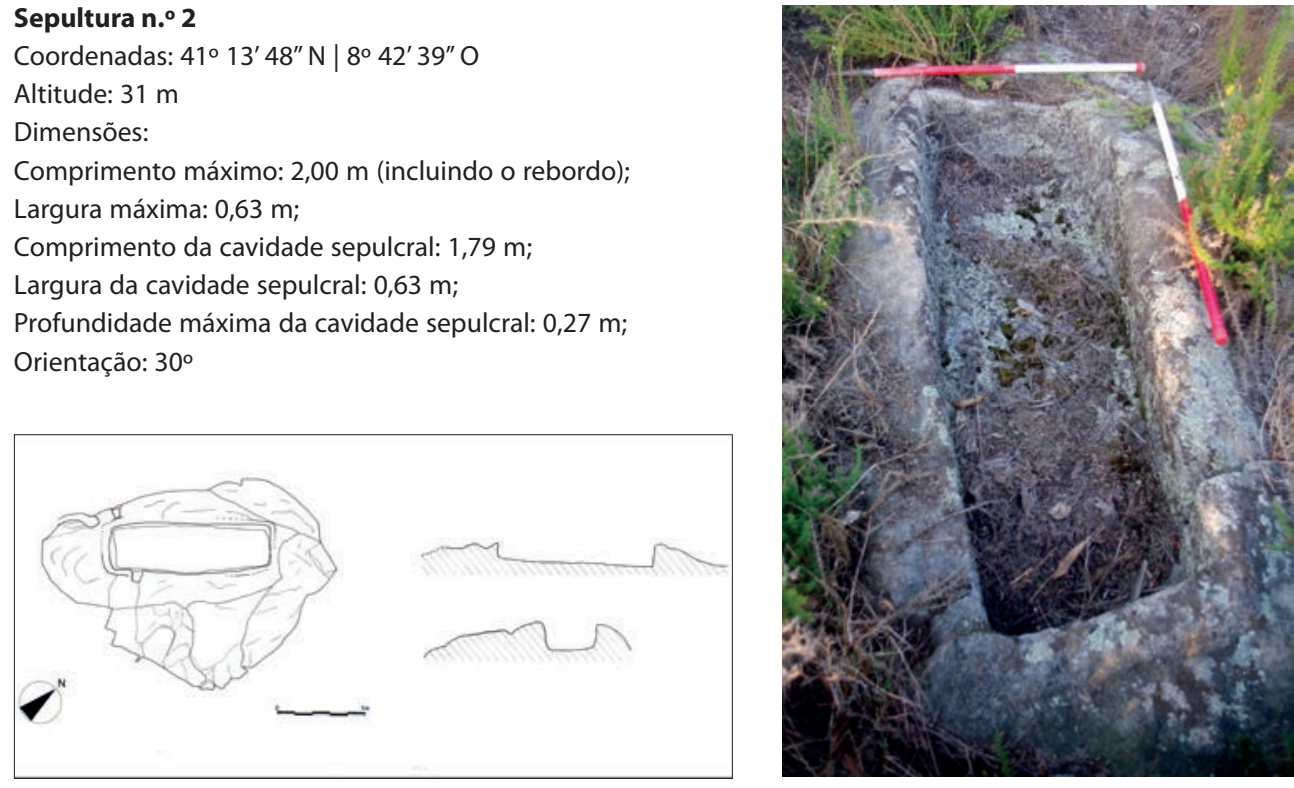

${ }^{12}$ As figuras das sepulturas (n. ${ }^{\circ}$ 1, 2, 3, 4 e 5) são da autoria de José Varela - Gabinete Municipal de Arqueologia e História de Matosinhos. 


\section{Sepultura $\mathbf{n} .^{\circ} 3$}

Coordenadas: $41^{\circ} 13^{\prime} 47^{\prime \prime} \mathrm{N} \mid 8^{\circ} 42^{\prime} 37^{\prime \prime} \mathrm{O}$

Altitude: $24 \mathrm{~m}$

Dimensões:

Comprimento máximo: 1,81 m (incluindo o rebordo); Largura máxima: 0,80 m (incluindo rebordo); Comprimento da cavidade sepulcral: 1,68 m; Largura da cavidade sepulcral: 0,69 m;

Profundidade máxima da cavidade sepulcral: 0,24 m; Orientação: $304^{\circ}$
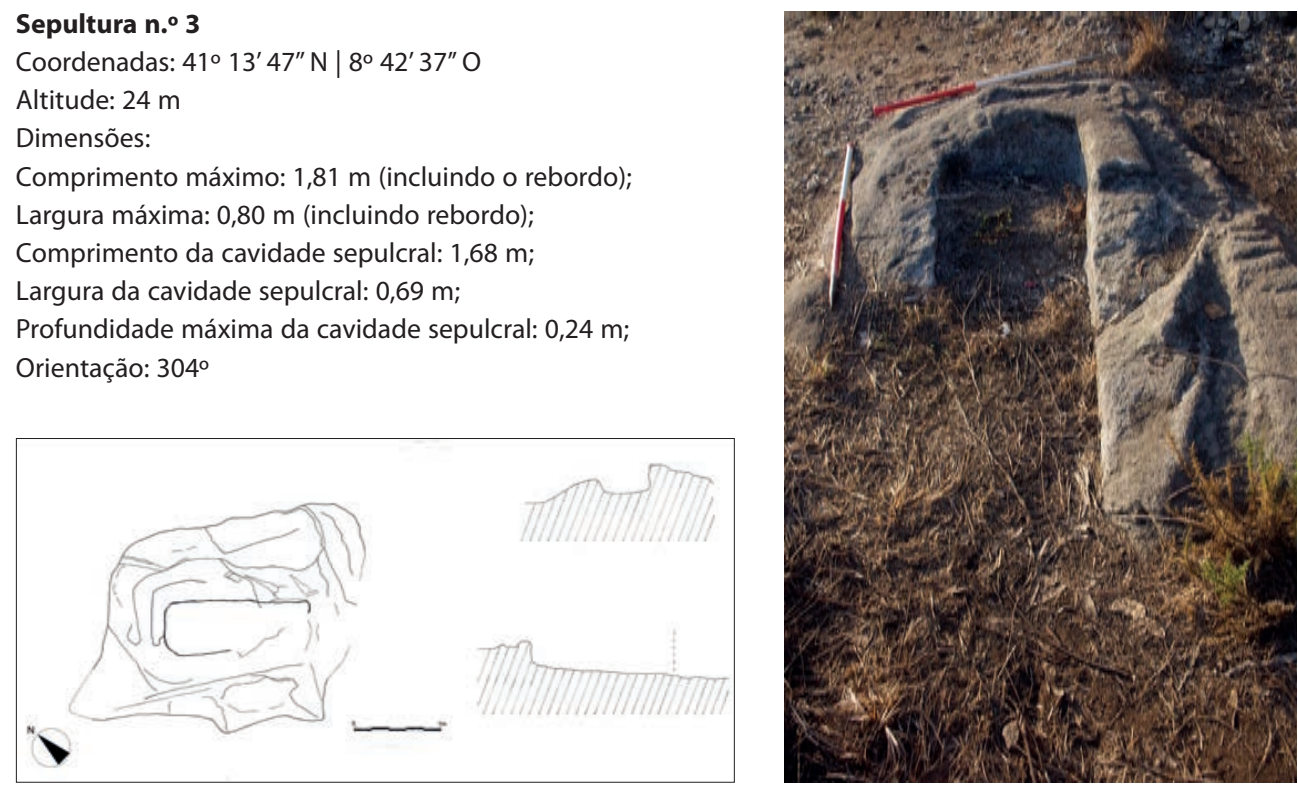

\section{Sepultura $n .^{\circ} 4$}

Coordenadas: $41^{\circ} 13^{\prime} 48^{\prime \prime} \mathrm{N} \mid 8^{\circ} 42^{\prime} 37^{\prime \prime} \mathrm{O}$

Altitude: $24 \mathrm{~m}$

Proto-sepultura inacabada, onde apenas é visível o esboço das linhas de desbaste delineadas na rocha para se iniciar a abertura da sua sepultura. Observa-se um ligeiro rebaixamento num dos seus topos, sendo igualmente patente que, por motivos desconhecidos, este trabalho terá sido abandonado muito pouco tempo depois de se ter iniciado.

Orientação: $214^{\circ}$
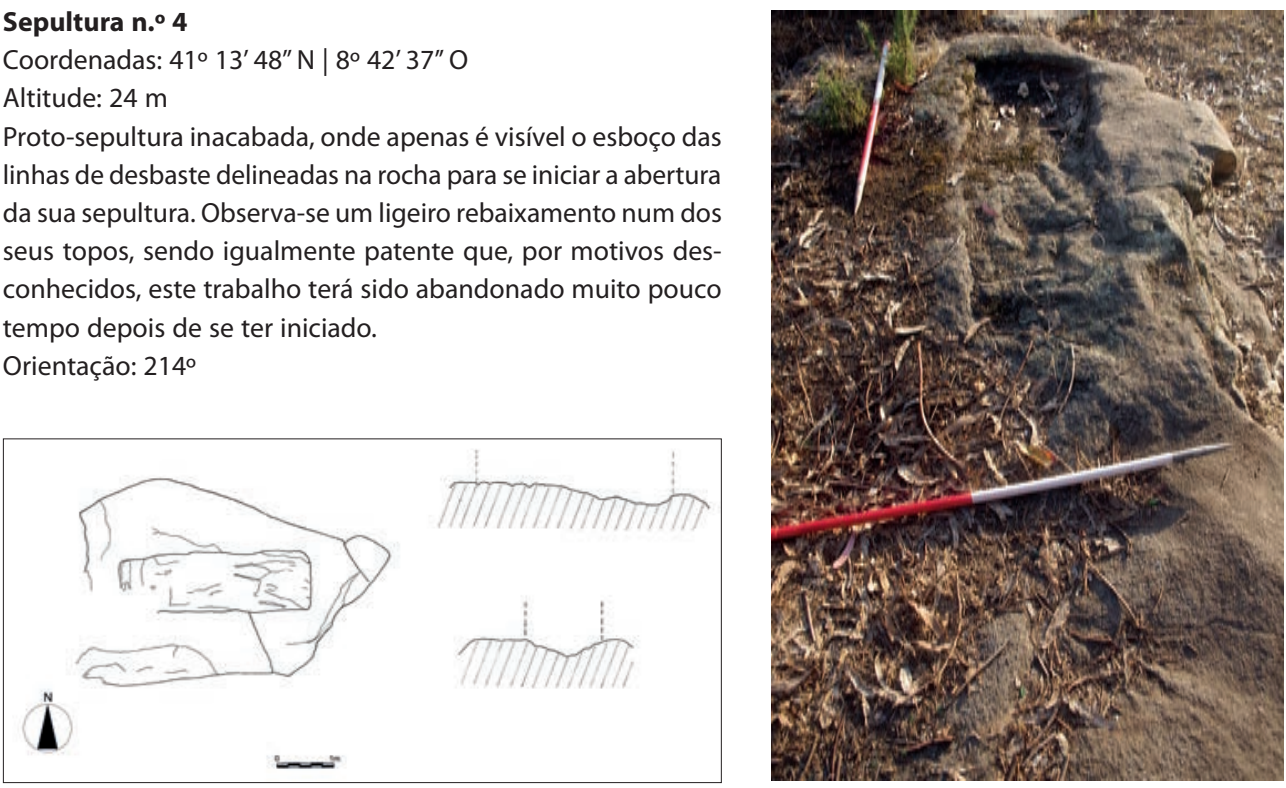


\section{Sepultura $n .^{\circ} 5$}

Coordenadas: $41^{\circ} 13^{\prime} 47^{\prime \prime} \mathrm{N} \mid 8^{\circ} 42^{\prime} 37^{\prime \prime} \mathrm{O}$

Altitude: $22 \mathrm{~m}$

Dimensões:

Comprimento máximo: 2,03 (incluindo o rebordo);

Largura máxima: 0,94 m (incluindo rebordo);

Comprimento da cavidade sepulcral: $1,74 \mathrm{~cm}$;

Largura da cavidade sepulcral: 0,57 m;

Profundidade da cavidade sepulcral: 0,32 m;

Orientação: $290^{\circ}$
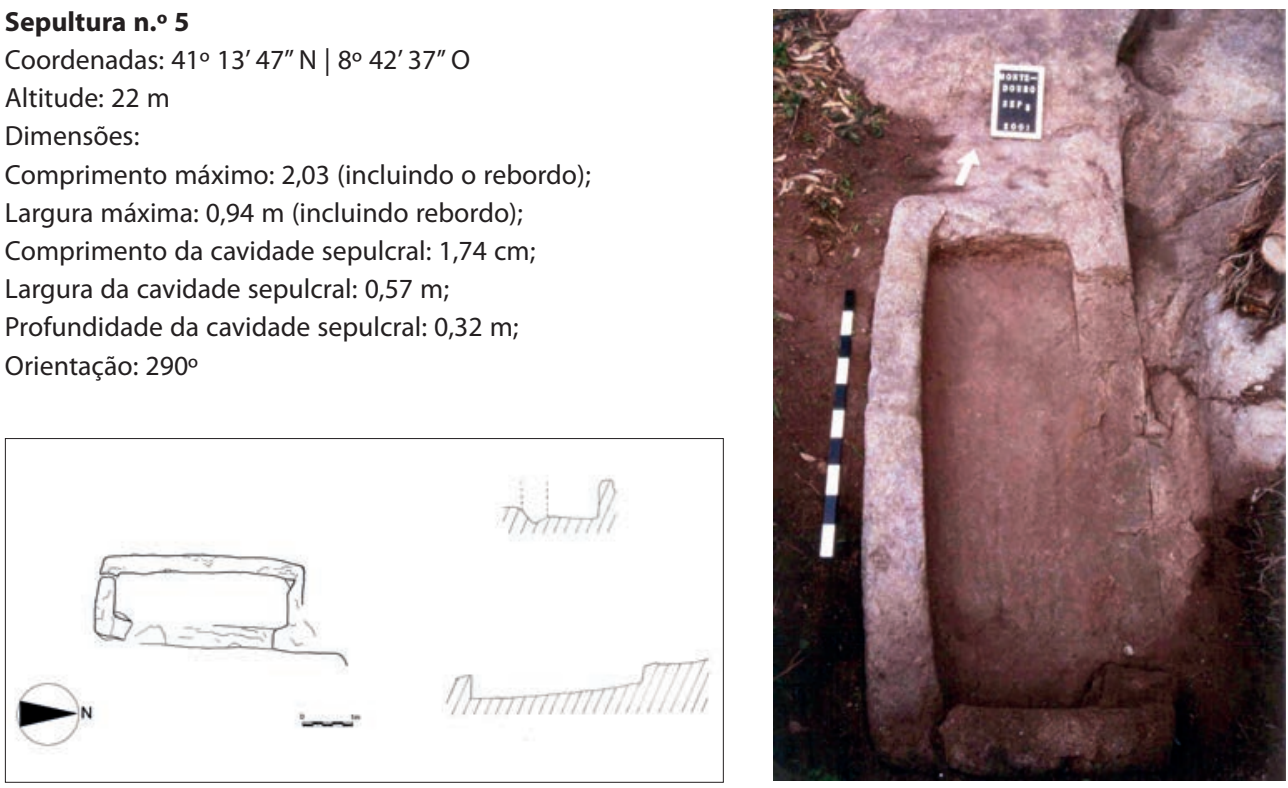

A primeira referência bibliográfica relativa à existência de sepulturas rupestre neste local é de Francisco Martins Sarmento que, aqui vem em 1878 enquanto veraneava por Matosinhos, relatando em carta que escreve a Possidónio da Silva os resultados das suas prospeções. Tendo-se deslocado a Perafita para averiguar a existência na freguesia de antiguidades arqueológicas, acaba por entrar em contacto com o padre José, antigo pároco da freguesia, que residia no lugar do Cabo do Mundo. O sacerdote mostrou-lhe então um local, perto da sua residência, onde existiam umas «sepulturas abertas em penedos». Nesta visita Martins Sarmento identificou três sepulturas, descrevendo que eram « 3 sepulturas abertas em rocha, mas em forma de canoa, com ângulos arredondas, duas quadrilongas, estando uma dellas já partida e metida por baixo da parede dum pequeno campo. Perto desta última encontrei fragmentos de telha romana e perguntando a umas mulheres se por alli apareciam muit(os) cacos como aquelles, uma dellas respondeu-me que o dono do campo, quando lavrava, encontrava muita cacaria. O campo chama-se campo das Antinhas» ${ }^{13}$. Em outro apontamento Martins Sarmento deixa ainda mais indicações sobre este sítio dizendo que «Ao pé de um penedo, e não longe da segunda campa, encontrei eu também pedaços de telha com rebordo. Houve, pois, em Perafita uma povoação que não deixou de si nenhuma memória, nem tradição» ${ }^{14}$.

\footnotetext{
${ }^{13}$ SARMENTO, 1933: 29-30.

${ }^{14}$ SARMENTO, 1970: 43-45.
} 
Anos mais tarde também Rocha Peixoto fará referência à existência destas sepulturas $^{15}$, na sua tentativa de inventariação das sepulturas em abertas em rocha do norte de Portugal. As observações que Martins Sarmento tinha feito duas décadas antes tinham-se mantido inéditas, vindo apenas a ser publicadas muitos anos mais tarde. Por esse motivo Rocha Peixoto apenas faz referência a uma informação sobre a existência de uma das sepulturas, a que identificamos como sepultura n. ${ }^{\circ} 1$. Comunicava-lhe o informador que «distante dois kilómetros da costa e no cimo d'uma collina, via-se uma espécie de pia estreita e comprida, onde caberia deitado um homem de estatura mediana, era aberta na rocha e a contorna-la observava-se um rebordo saliente, da largura duma mão travessa. Numa das cabeceiras uma depressão como indicava o logar da cabeça; ao fundo um sulco» ${ }^{16}$.

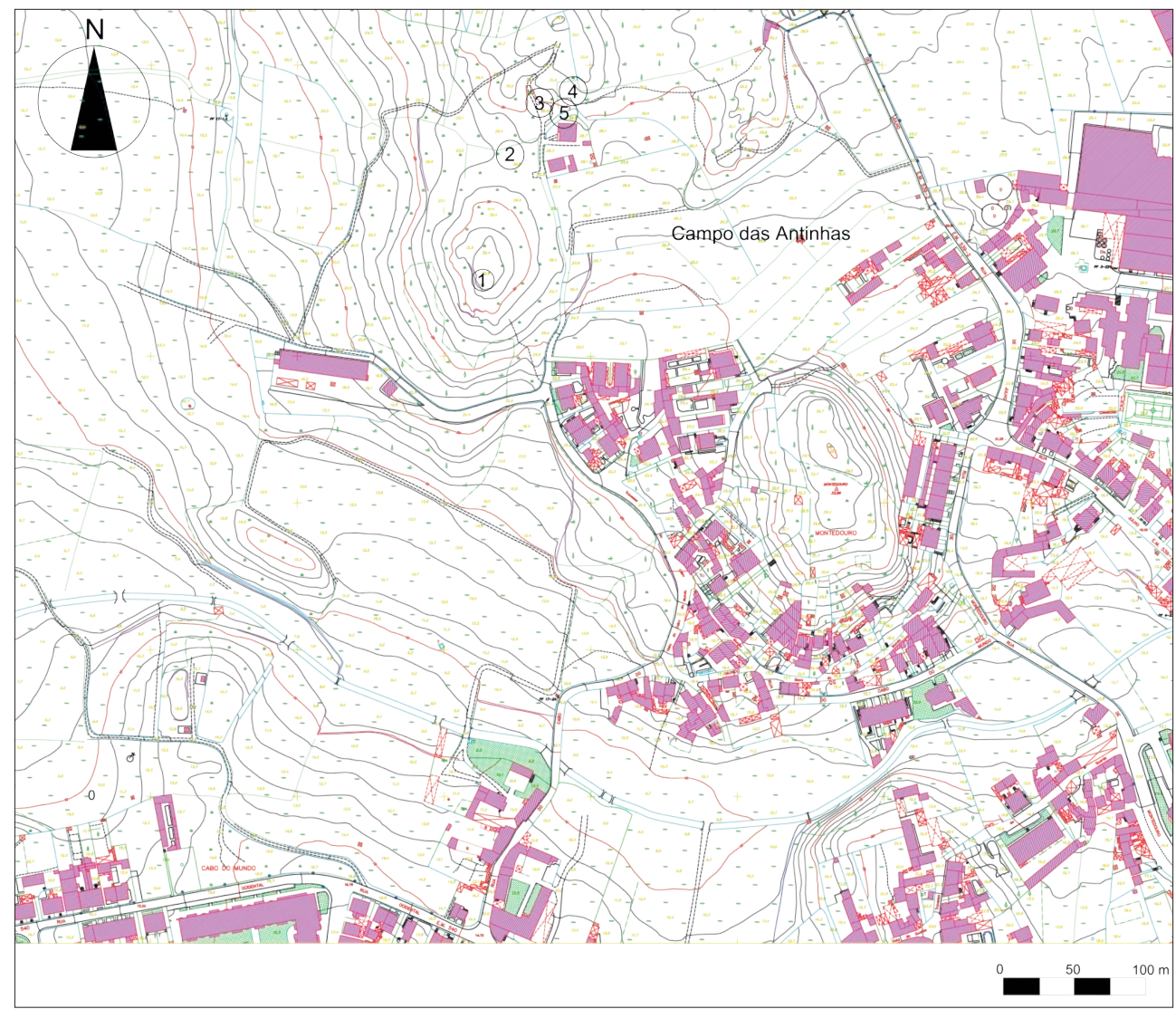

Fig. 2. Planta do Concelho de Matosinhos à escala 1:1000, Folha nº 52 (109.44) Fonte: Câmara Municipal de Matosinhos (Março de 2003) 


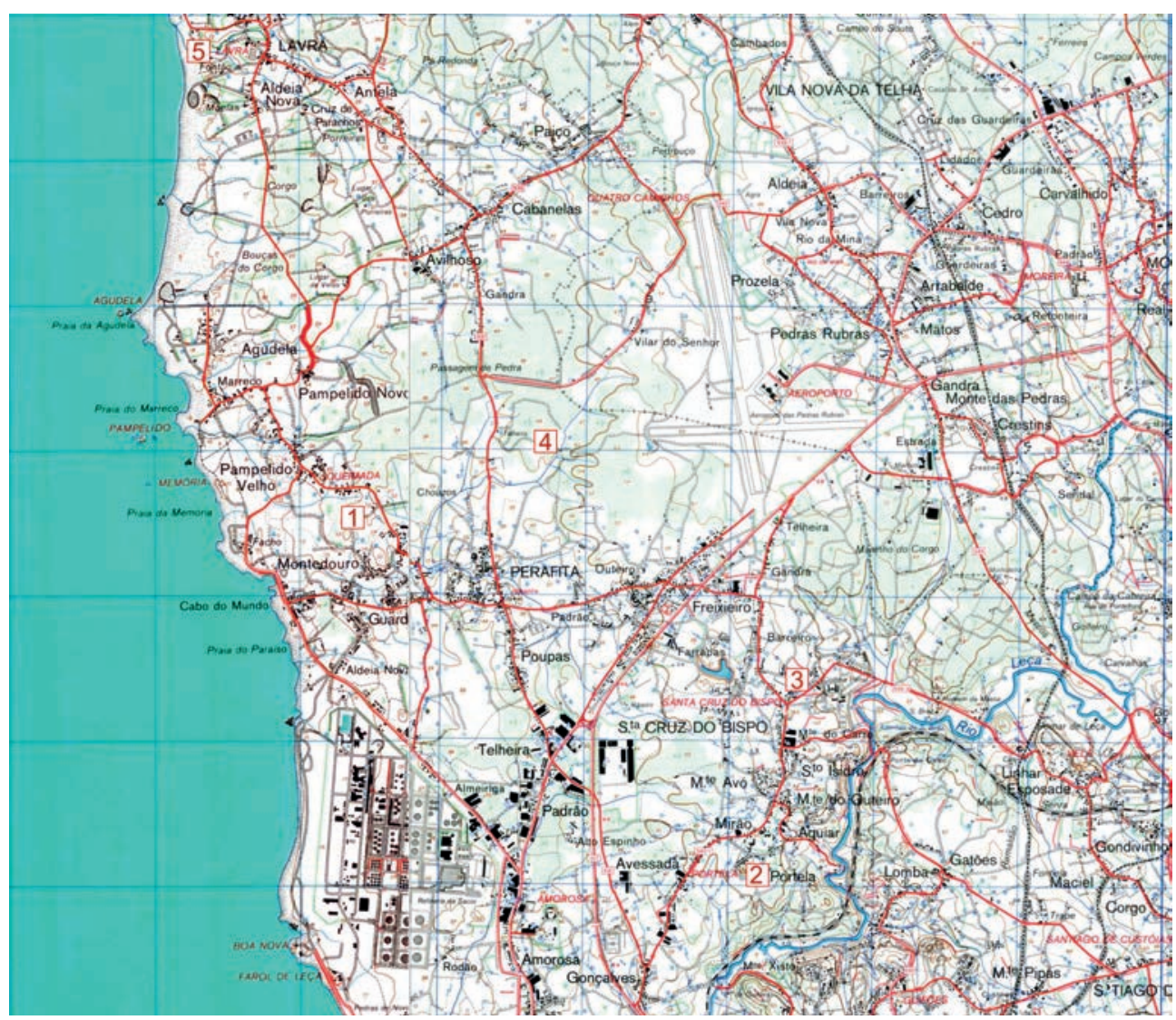

Fig. 3. Localização dos sítios referidos no texto na carta militar 1:25000 Fonte: Serviços Cartográficos do Exército, 1975. Folhas 109 e 110

Joaquim Neves dos Santos, em 1954, relocaliza e regista fotograficamente duas sepulturas deste grupo que, pela descrição, serão as correspondentes às sepulturas n. ${ }^{\circ} 1$ e n. ${ }^{\circ} 3$, mas acrescenta que «a segunda sepultura, voltada para sueste, de acabamento mais tosco [...] fazia parte de um grupo de seis sepulturas, que foram destruídas pelos montantes que extraíram pedra no local. Pelos muros de vedação dos campos vizinhos foram encontrados restos de sepulturas metidas nas paredes» ${ }^{17}$. Relativamente à outra sepultura, a descrição coincide com a sepultura n. ${ }^{\circ} 1$ como «de acabamento muito perfeito, [...] de formas arredondadas, fundo semicilíndrico, cabeceiras circulares, com cavidade para a cabeça do defunto. Está voltada a norte [...] sendo mais profunda para os pés» ${ }^{18}$. Portanto, de acordo com a descrição de Joaquim Neves dos Santos, este grupo de sepulturas deveria assim ser maior, havendo

\footnotetext{
${ }^{17}$ SANTOS, 1955: 158

${ }^{18}$ SANTOS, 1955: 158.
} 
pelo menos uma sepultura em falta, ou porque terá sido destruída pela extração de pedra ou porque ainda não se conseguiu localizar. A existência de outras sepulturas reaproveitadas nas paredes dos muros de vedação dos campos, é também significativa da importância arqueológica deste sítio não se resumir apenas a este grupo de sepulturas abertas em rocha.

A este sítio arqueológico referiram-se também os estudos realizados por Mário Barroca ${ }^{19}$ sobre a problemática das sepulturas abertas em rocha, que menciona a existência no local de cinco sepulturas, embora a quinta estivesse oculta pela vegetação e pela acumulação de detritos. Também os trabalhos realizados por Diana Bencatel ${ }^{20}$ e Conceição Pires ${ }^{21}$ apresentam a descrição desta necrópole.

\section{CONTEXTO ARQUEOLÓGICO DAS SEPULTURAS DE MONTEDOURO}

No final da década de 1990, o Gabinete Municipal de Arqueologia e História da Câmara Municipal de Matosinhos ao fazer a relocalização deste grupo de sepulturas escavadas na rocha identificou as cincos sepulturas que são atualmente conhecidas, nomeadamente a sepultura $n .^{\circ} 4$, exemplo de uma obra que teria sido interrompida, pouco tempo depois de se iniciar, assim como a sepultura n. 5 que, devido a estar a uma cota mais baixa, esteve durante muitos anos tapada por um grande eucalipto, que tombou durante uma tempestade, pondo assim à vista esta sepultura. Ao mesmo tempo a prospeção e a recolha de superfície na área em volta vieram confirmar as indicações de Martins Sarmento sobre a ocorrência de materiais cerâmicos à superfície. $\mathrm{Na}$ área envolvente apareciam superficialmente numerosos fragmentos de tégula romana, assim como fragmentos de cerâmica comum tardia e ânfora, por vezes misturados com outros materiais atribuíveis à Idade do Bronze.

Em 2009, no âmbito de trabalhos de acompanhamento arqueológico para a instalação de um ramal de gás, foi realizado uma sondagem arqueológica, por Carlos Batata, ao serviço da empresa OZECARVS, que estava a realizar o acompanhamento arqueológico da empreitada ${ }^{22}$. A sondagem, numa área de $2 \times 12 \mathrm{~m}$, foi implantada na área entre a sepultura $n .^{\circ} 1$ e a sepultura $n .^{\circ} 2$. A potência estratigráfica da zona era diminuta, uma vez que a capa de terra que cobria o substrato rochoso tinha em média menos de 50 centímetros de espessura, além de que o próprio afloramento se apresentava em processo de desagregação. No entanto nesta sondagem foi recolhida uma quantidade significativa de materiais arqueológicos, nomeadamente cerâmica de construção romana (tégula e ímbrice), cerâmica comum romana, cerâmica alto-me-

\footnotetext{
${ }^{19}$ BARROCA, 1987: 156-157; 2011: 161-162.

${ }^{20}$ BENCATEL, 2009: 233-237.

${ }^{21}$ PIRES, 2012: 90; 2016.

22 BATATA, 2009.
} 
dieval muito fragmentada e cerâmica manual pré-histórica. Estes materiais encontravam-se misturados, em deposição secundária, não tendo sido aqui identificadas estruturas arqueológicas.

Tabela 1. Materiais cerâmicos recolhidos em Montedouro em 2009

\begin{tabular}{l|c|c}
\hline \multicolumn{1}{c|}{ Classificação } & N. ${ }^{\circ}$ fragmentos & $\%$ \\
\hline Cerâmica Pré-Histórica & 20 & $9.01 \%$ \\
\hline Material de construção romano & 22 & $9.91 \%$ \\
\hline Cerâmica Romana & 100 & $45.05 \%$ \\
\hline Cerâmica Visigótica & 22 & $9.91 \%$ \\
\hline Cerâmica alto-medieval & 26 & $11.71 \%$ \\
\hline Indeterminada & 32 & $14.41 \%$ \\
\hline Total & 222 & $100.00 \%$ \\
\hline
\end{tabular}

Fonte: BATATA, 2009. (adaptado)

Considerando os resultados apresentados pela sondagem e outras informações recolhidas no local, concluiu que

No topo do monte, entre as sepulturas espalhadas, encontram-se muitos fragmentos de tégulas e imbrices, a denunciar um povoamento romano e visigótico. Segundo algumas pessoas locais, o campo a Sul/Poente da sepultura principal chama-se o "campo das panelas" e há referência a aparecerem potes de barro (informação do Dr. José Varela). Donos de propriedades adjacentes, que nos visitaram durante a escavação, referiram o aparecimento de telhas e potes de barro também a noroeste da escavação e a existência de uma capela ${ }^{23}$.

\section{OUTRAS SEPULTURAS ABERTAS NA ROCHA NO TERRITÓRIO DO CONCELHO DE MATOSINHOS}

$\mathrm{Na}$ região envolvente à necrópole de Montedouro terão existido, de acordo com as referências antigas registadas na bibliografia arqueológica, outros grupos de sepulturas escavadas na rocha. Trata-se, no entanto, de um território que foi sujeito a uma profunda transformação, primeiro devido à exploração intensiva de numerosas pedreiras e posteriormente pela instalação de grandes infraestruturas industriais e de transportes. Estas sepulturas não se conseguiram, até ao momento relocalizar, embora tenhamos uma ideia aproximada da sua localização.

\footnotetext{
${ }^{23}$ BATATA, 2009: 5-6.
} 


\subsection{Souto da Portela (Santa Cruz do Bispo)}

Rocha Peixoto refere que na vizinha freguesia de Santa Cruz do Bispo existiriam diversas sepulturas escavadas na rocha. Refere a existência de duas sepulturas no lugar do Souto da Portela, sendo que que uma tinha «a profundidade da fossa de pouco mais de 0,10 , o comprimento 1,80 , voltada para nascente e ligeiramente mais larga no logar onde deviam ter repousado os hombros. Acima encontra-se metade d'outra com orientação diferente: NE-SO» ${ }^{24}$. Em 1955 Joaquim Neves dos Santos consegue relocalizar o local onde se situava a referida sepultura, cuja existência já era desconhecida dos habitantes locais, mas já não refere a existência da segunda sepultura ${ }^{25}$. No âmbito da elaboração da Carta Arqueológica do Concelho de Matosinhos tentou-se proceder à localização desta sepultura. Na zona indicada, entre a Rua da Portela e a Rua do Souto, terá existido um grande afloramento rochoso, que foi desmontado e onde atualmente se encontra um conjunto de habitações construídas posteriormente à data em que Joaquim Neves dos Santos refere este local. Apenas subsiste o topo do afloramento rochoso onde se implanta um marco geodésico. Supomos assim que será este o local onde ficariam as duas sepulturas referidas por Rocha Peixoto e Joaquim Neves dos Santos ${ }^{26}$.

\subsection{Lugar de Santa Cruz (Santa Cruz do Bispo)}

Rocha Peixoto também refere que em Santa Cruz existiam outras sepulturas, especificando que «algumas com a forma da cabeça» ${ }^{27}$, ou seja, seriam já sepulturas totalmente antropomórficas e portanto posteriores aos finais do século IX. O lugar de Santa Cruz corresponde aproximadamente ao espaço situado entre a atual igreja paroquial e o Monte de São Brás, onde se localizaria o primitivo templo paroquial medieval, no espaço onde atualmente está a Quinta dos Bispos. A existência de um eremitério e de uma comunidade de eremitas no século XII, ou mesmo anteriormente, está documentada na doação da ermida de Santa Cruz, realizada em 1140 pela prioresa de S. Cristóvão de Rio Tinto, D. Ermesenda Guterres, a uma comunidade de frades eremitas $^{28}$. Atualmente este espaço está integrado na área do Estabelecimento Prisional de Santa Cruz do Bispo, não estando acessível ao público. Existem, contudo, ali alguns elementos pétreos medievais, nomeadamente um sarcófago monolítico proveniente da área onde se presume que tenha sido a localização da antiga igreja medieval ${ }^{29}$.

\footnotetext{
${ }^{24}$ PEIXOTO, 1906: 288.

${ }^{25}$ SANTOS, 1955: 159.

${ }^{26}$ PIRES, 2012: 110.

${ }^{27}$ PEIXOTO, 1906: 288.

${ }^{28}$ SANTOS, 1959: 75.

${ }^{29}$ PIRES, 2016.
} 


\subsection{Bouça do Corgo (Perafita)}

Referido pela primeira vez por Joaquim Neves dos Santos em 1959, este grupo de sepulturas abertas na rocha, terá sido destruído pela extração de pedra dos afloramentos rochosos da região ${ }^{30}$.

Joaquim Neves dos Santos faz apenas a descrição de uma das sepulturas, mas refere que seriam inicialmente em maior número, tendo sido destruídas pela exploração da pedreira. A última destas sepulturas estaria «voltada de Norte para Sul (com a cabeceira para Norte) e tinha um orifício sangrador aos pés e voltado para nascente. Muito perto destes sepulcros existe um outeiro chamado o Alto das Velas» ${ }^{31}$. Não é referido se a mesma teria, ou não, indícios de antropomorfismo, mas a indicação da existência de um «orifício sangrador» aproxima-a da tipologia da sepultura $n .^{\circ} 2$ de Montedouro.

No âmbito da elaboração da Carta Arqueológica do Concelho de Matosinhos procuramos relocalizar este grupo de sepulturas rupestres. Pela descrição deixada por Joaquim Neves dos Santos, identificamos um local que corresponde a um afloramento granítico localizado numas bouças junto da Rua do Monte do Corgo e Rua Central do Corgo, perto do Ribeiro de Montagaia e do lugar do Alto do Cão. Trata-se de um sítio que, nas últimas décadas, foi muito alterado, uma vez que é parcialmente cortado pela autoestrada A28, tem uma zona de grandes armazéns industriais e uma pequena zona urbanizada. Segundo informações de um residente local existe ainda uma memória de que os antigos diziam que terá existido um cemitério muito antigo num campo marginado a Nascente pelo ribeiro da Montagaia ${ }^{32}$.

Deverá ser também a este grupo de sepulturas que se refere Mário Barroca quando menciona as sepulturas do «Monte de Gaia» ${ }^{33}$.

\section{CONSIDERAÇÕES FINAIS}

O conjunto de sepulturas escavadas na rocha de Montedouro (Perafita) apresenta dois tipos diferentes. O primeiro é o representado pela sepultura n.$^{\circ} 1$, com os seus topos redondos, a indicação da cabeceira através de uma depressão interior e um tratamento fino do interior da cavidade. $\mathrm{O}$ rebordo em volta é subcircular. O segundo tipo é constituído pelas sepulturas n. ${ }^{\circ} 2$, n. ${ }^{\circ} 3$ e n. ${ }^{\circ} 5$, de tipologia retangular ou sub-retangular, com rebordos largos. Em comum apenas serem de tipo não-antropomórfico.

Outra distinção é a implantação topográfica destas sepulturas. Enquanto a sepultura $n .^{\circ} 1$ se localiza no alto de um outeiro, com uma abrangência visual de

\footnotetext{
${ }^{30}$ SANTOS, 1959: 63.

${ }^{31}$ SANTOS, 1959: 64.

32 PIRES, 2012: 109-110.

${ }^{33}$ BARROCA, 2011: 162.
} 
$360^{\circ}$ sobre o território da freguesia, as restantes sepulturas implantam-se numa cota mais baixa e discreta, sem uma grande amplitude visual.

A sepultura n. ${ }^{\circ} 4$ enquadra-se no conjunto das poucas sepulturas deste género inacabadas pouco tempo depois de se ter iniciado o trabalho de desbaste do afloramento rochoso.

Pensamos assim que estaremos em presença de dois momentos distintos de utilização funerária deste espaço, sendo a sepultura n. ${ }^{\circ} 1$ presumivelmente mais antiga do que as restantes. A ausência de indícios de antropomorfismo aponta para uma cronologia entre o século VII e o século IX $^{34}$.

$\mathrm{O}$ aspeto mais interessante, já intuído inicialmente por Francisco Martins Sarmento, mais tarde confirmado pelas prospeções realizadas pelo Gabinete Municipal de Arqueologia e História de Matosinhos, assim como pela sondagem realizada por Carlos Batata em 2009, é a existência de uma possível utilização deste espaço durante a Antiguidade Tardia e a Alta Idade Média. Apesar de ainda não se terem identificado estruturas arqueológicas neste local os materiais recolhidos apontam para uma utilização deste espaço entre a Antiguidade Tardia e a Alta Idade Média, com a presença de cerâmica tardorromana, visigótica e altimedieval ${ }^{35}$. Deverá ser na área contígua às sepulturas, que Francisco Martins Sarmento registou como o «Campo das Antinhas», atualmente um campo agrícola, que se deverá situar a zona com maior potencialidade arqueológica.

O historiador Armando Almeida Fernandes numa tentativa de identificação das igrejas mencionadas no documento de finais do século VI conhecido como Parochiale Suevum, aponta a possibilidade de a igreja da diocese portucalense mencionada na lista como Menturio possa corresponder a este lugar de Montedouro. A hipótese proposta por Almeida Fernandes é totalmente baseada numa análise filológica da evolução deste topónimo. Esta proposta de Almeida Fernandes é, contudo, rejeitada por Jorge de Alarcão, que considera que este topónimo, derivando de Monte Aureo, estaria relacionado com a exploração aurífera romana. Entende por isso que a primitiva paróquia de Menturio se deveria localizar na região de Valongo $^{36}$. No entanto, ambos os autores apenas têm em conta argumentos de natureza filológica, mas desconhecem totalmente os elementos de natureza arqueológica que corroboram uma ocupação deste local durante a Antiguidade Tardia. A hipótese de o atual topónimo de Montedouro poder estar associado à antiga Menturio mencionada no Parochiale Suevum poderá assim ser uma nova linha de investigação decorrente da cronologia das sepulturas escavadas na rocha e de outros elementos arqueológicos recolhidos nesta zona.

\footnotetext{
${ }^{34}$ BARROCA, 2010-2011: 123.

${ }^{35}$ BATATA, 2009.

${ }^{36}$ ALARCÃO, 2001: 40.
} 
No território da atual freguesia de Perafita, para além das já referidas sepulturas da Bouça do Corgo, foram ainda identificados outros locais com uma possível ocupação contemporânea. A cerca de 800 metros para nascente de Montedouro, no sítio conhecido como Vinha da Bouça / Campo do Cardeal, foram recolhidos numerosos fragmentos de cerâmica romana, incluindo cerâmica comum, ânfora e material de construção romano ${ }^{37}$. Um pouco mais longe, também para nascente, a cerca de 800 metros a sul das sepulturas da Bouça do Corgo, foi identificada a Mota de Madoufe numa prospeção realizada em 2008 pelo Gabinete Municipal de Arqueologia e História de Matosinhos. Mencionada num documento datado do ano de $1038^{38}$, corresponde a uma estrutura defensiva característica dos séculos $\mathrm{X}$ e $\mathrm{XI}^{39}$. No entanto, devido à escassez de elementos descritivos sobre este grupo de sepulturas da Bouça do Corgo não nos é possível aferir se poderão, ou não, partilhar a mesma cronologia. Apenas registamos a relativa proximidade entre os dois locais.

A três quilómetros a norte de Montedouro, já na vizinha freguesia de Lavra, fica o Fontão de Antela, onde foram recolhidos no ano de 1900 diversos elementos arqueológicos tardorromanos, nomeadamente restos de mosaicos tardios e fustes de colunas ${ }^{40}$. Este sítio tem sido interpretado como uma antiga villa romana, tendo mais tarde sido transformada em mosteiro. Um documento datado de $897^{41}$ refere-se ao Mosteiro de Lavra dizendo «que o monasterio labra que est fundato ab antiquo in ripa maris comodo est conclusa de aqua in aqua et de Karia antiqua usque in mare....» Este Mosteiro de Lavra, que ficava entre o mar e o "Caminho Antigo» era já no século IX considerado de fundação antiga e a sua origem tem sido associada à igreja mencionada na listagem do Parochiale Suevum com o nome de Labrencio. A designada «Karia antiqua» será a antiga estrada que atravessava o Rio Leça pela Ponte de Guifões, junto ao Castro do Monte Castêlo e prosseguia para norte pelo lugar de Gonçalves, passando a pouca distância deste lugar de Montedouro em direção a Lavra.

É interessante notar que a sepultura n. ${ }^{\circ} 1$ de Montedouro, que está implantada no ponto de maior abrangência visual, está perfeitamente orientada na direção do local onde terá existido este antigo Mosteiro de Lavra.

O sítio de Montedouro apresenta assim novas possibilidades de aprofundamento da investigação arqueológica que vão muito além da simples descrição de inventário de mais um grupo de sepulturas abertas na rocha.

\footnotetext{
${ }^{37}$ PIRES, 2012: 90.

${ }^{38}$ PMH, DC, Doc. 303.

${ }^{39}$ MARQUES, BARROCA, AMARAL, 2018: 176-178.

${ }^{40}$ SANTOS, 1953.

${ }^{41} \mathrm{PMH}, \mathrm{DC}$, Doc. 12.
} 


\section{FONTES}

PMH, DC: Portugaliae Monumenta Historica: a saecvlo octavo post Christvm vsqve adqvintvmdecimvm. Diplomata et chartae. Lisboa: Academia das Ciências de Lisboa. Vol. 1, pp. 1867-1873.

\section{BIBLIOGRAFIA}

ALARCÃO, Jorge de (2001). As paróquias suévicas no território actualmente português. In VILLAR, F.; FERNANDÉZ ALVARÉZ, M. P. ed. Religión, Lengua Y Cultura Prerromanas de la Península Ibérica, Salamanca: Ediciones Universidad de Salamanca, pp. 29-59.

BARROCA, Mário Jorge (1987). Necrópoles e Sepulturas Medievais de Entre-Douro-e-Minho (Séc. V a $X V)$. Porto: Faculdade de Letras da Universidade do Porto. Dissertação para Provas Públicas de Aptidão Pedagógica e Capacidade Científica.

BARROCA, Mário Jorge (2009). Rocha Peixoto e a cronologia das sepulturas escavadas na rocha. A propósito de uma polémica recensão à revista Portugália. «Póvoa de Varzim Boletim Cultural». 43, 221-233.

BARROCA, Mário Jorge (2010-2011). Sepulturas escavadas na rocha de Entre Douro e Minho. «Portvgalia». Nova Serie, 31-32, 115-182.

BATATA, Carlos (2009). Sondagens arqueológicas em Pampelido/ sepultura 1 de Montedouro (cns 783) (Perafita) no âmbito da empreitada de construção do Ramal de Leça-TRP - 02-40-001 Relatório Final, Abrantes (policopiado).

BENCATEL, Diana Ornelas (2009). Sarcófagos e sepulturas medievais (Maia e Matosinhos): Análise tipológica e cronológica. «Revista Portuguesa de Arqueologia». 12: 2, 209-238.

FERNANDES, A. de Almeida (1997). Paróquias Suevas e Dioceses Visigóticas, Arouca, [s. n.].

MARQUES, A. M.; BARROCA, M. J.; AMARAL, L. C. (2018). As incursões vikings no norte de Portugal. In BARROCA, M. J.; SILVA, Armando Coelho coord. Mil Anos da Incursão Normanda ao Castelo de Vermoim. Porto: CITCEM, pp. 143-184.

PEIXOTO, Rocha (1906). Sepulturas abertas em rocha. «Portvgalia: Materiaes para o estudo do povo portuguez». Tomo II. 2, 287-288.

PIRES, Conceição (2012). Contributos para o estudo do povoamento de Matosinhos da Pré-História ao Séc. VIII. Porto: Faculdade de Letras da Universidade do Porto. Dissertação de Mestrado.

PIRES, Conceição (2016). Carta Arqueológica do Concelho de Matosinhos. Matosinhos: Câmara Municipal de Matosinhos.

SANTOS, Joaquim Neves dos (1953). Um mosaico romano de Lavra - Matosinhos. In Temas Regionais de Arqueologia e Etnografia. Guifões-Matosinhos: [Edição de autor], vol. I.

SANTOS, Joaquim Neves dos (1955). Castrum Quiffiones: Notas Arqueológicas, Históricas e Etnográficas. Matosinhos: [Edição de autor], vols. I e II.

SANTOS, Joaquim Neves dos (1959). A Torre de Linhares na época romana. Guifões-Matosinhos: Edição do Autor.

SARMENTO, Francisco Martins (1933). Cartas inéditas de Francisco Martins Sarmento a Joaquim Possidónio da Silva. «Boletim de Trabalhos Históricos». 1, 13-50.

SARMENTO, Francisco Martins (1970). Antiqua. «Revista de Guimarães». 80: 1-2, 11-72.

TEIXEIRA, Ricardo (2009). Idade Média: dados e perspectivas arqueológicas sobre o território do Leça no período medieval (sécs. IX - XIV). In VARELA, José; PIRES, Conceição, ed. Rio da Memória: Arqueologia no Território do Leça. Matosinhos: Câmara Municipal de Matosinhos, pp. 199-232. 


\section{SEPULTURAS ESCAVADAS NA ROCHA DA FACHADA ATLÂNTICA DA PENINSULA IBERICA ATAS DO CONGRESSO INTERNACIONAL}

COORD.

MARIO JORGE BARROCA 